\title{
FEDERALISMO NO BRASIL E NA ALEMANHA: \\ ESTUDO COMPARATIVO DA REPARTIÇÃO DE COMPETÊNCIAS LEGISLATIVAS E DE EXECUÇÃO
}

\author{
Tese de doutorado
}

Orientador: Professor Titular Dr. Fernando Dias Menezes de Almeida

UNIVERSIDADE DE SÃO PAULO

FACULDADE DE DIREITO

SÃO PAULO

2016 


\section{MARIANA AUGUSTA DOS SANTOS ZAGO}

\section{FEDERALISMO NO BRASIL E NA ALEMANHA: \\ ESTUDO COMPARATIVO DA REPARTIÇÃO DE COMPETÊNCIAS LEGISLATIVAS E DE EXECUÇÃO}

Tese apresentada à Banca Examinadora do Programa de Pós-Graduação em Direito, da Faculdade de Direito da Universidade de São Paulo, como exigência parcial para obtenção do título de Doutor em Direito, na área de concentração Direito do Estado, sob a orientação do Professor Titular Dr. Fernando Dias Menezes de Almeida.

FACULDADE DE DIREITO DA UNIVERSIDADE DE SÃO PAULO

SÃO PAULO 
Zago, Mariana Augusta dos Santos

Federalismo no Brasil e na Alemanha: estudo

comparativo da repartição de competências

legislativas e de execução / Mariana Augusta dos

Santos Zago; orientador Fernando Dias Menezes de

Almeida -- São Paulo, 2016.

550

Tese (Doutorado - Programa de Pós-Graduação em

Direito do Estado) - Faculdade de Direito,

Universidade de São Paulo, 2016.

1. Federalismo. 2. Repartição de competências legislativas. 3. Repartição de competências de execução. 4. Estudo comparativo. 5. Brasile

Alemanha I. Menezes de Almeida, Fernando Dias, orient. II. Título. 
Mariana Augusta dos Santos Zago

\section{FEDERALISMO NO BRASIL E NA ALEMANHA: \\ ESTUdO COMPARATIVO DA REPARTIÇ̃̃̃O DE COMPETÊNCIAS LEGISLATIVAS E DE EXECUÇÃO}

Aprovado em:

Banca examinadora:

Professor Titular Fernando Dias Menezes de Almeida - Orientador

Titulação, nome e instituição à qual está vinculado

Titulação, nome e instituição à qual está vinculado

Titulação, nome e instituição à qual está vinculado

Titulação, nome e instituição à qual está vinculado 
Aos meus pais, por tudo o que eu sou e por tudo o que eu ainda quero ser. 


\section{AGRADECIMENTOS}

Muitos colocam o doutorado como uma das etapas mais importantes da vida de um pesquisador. Não se costuma chamar tanto a atenção para a grande jornada de conhecimento, principalmente de auto-conhecimento, que ele proporciona. Mais do que uma experiência acadêmica e profissional, ele significa a superação de medos, inseguranças e também a certeza de que ideias podem ganhar o mundo, mas nunca vão embora sem deixar algo de especial para o seu criador. Nestes agradecimentos gostaria de lembrar de todos que me acompanharam nesta caminhada de cinco anos, às vezes meio dolorida e desesperada, mas normalmente muito divertida e instigante.

Em primeiro lugar, gostaria de agradecer ao meu orientador, Professor Fernando Dias Menezes de Almeida. Nele tenho um exemplo de pesquisador, professor e de humildade. Sou muito grata por todas as vezes em que ele se dispôs a discutir as minhas ideias, por todo o auxílio em momentos de impasse em relação aos rumos da pesquisa, e também por todas as dicas e sugestões sobre como conduzir um trabalho acadêmico.

Agradeço também aos Professores Tiago Marrara, Roger Stiefelmann Leal, José Levi Mello do Amaral Junior e Jorge Bacelar Gouveia, pelos comentários e sugestões por ocasião da realização do exame de qualificação.

À FAPESP, agradeço pelo auxílio financeiro prestado para a realização desta tese. Neste ponto, também gostaria de deixar consignado o meu agradecimento ao DAAD - que não só custeou o intercâmbio que eu fiz durante a minha graduação em Munique, ocasião em que eu tive contato pela primeira vez com o tema da repartição de competências federativas - mas que também forneceu, por meio do Fachliteraturprogramm, algumas das obras imprescindíveis para a realização desta pesquisa. Pelo mesmo motivo, não poderia deixar de expressar minha gratidão à Cátegra Martius DAAD-USP e principalmente ao Professor Hans Vorländer, que me recebeu na Universidade Técnica de Dresden para estágio de pesquisa realizado em janeiro e fevereiro de 2013 no âmbito do SFB 804 - Transzendez und Gemeinsinn. Nesta ocasião tive a oportunidade de consultar boa parte das obras em alemão utilizadas na elaboração desta tese.

Aos meus pais, a quem dedico esta tese, dedico a minha incondicional gratidão. Neste meio tempo tive muitas dúvidas sobre a minha capacidade, sobre as minhas escolhas. Eles, em nenhum momento, duvidaram de mim. À minha mãe, agradeço por incutir em mim o gosto pelo conhecimento e pelo exemplo de mulher que luta pelos seus ideais. Ao meu pai, por todo o amor e compreensão que uma filha poderia ter. À minha tia, que participou ativamente da minha criação, muito obrigada por me tornar a sua filha de coração.

À minha família, que sempre me deu apoio para eu perseguir os meus sonhos. Agradeço especialmente o meu irmão, Stanislaw, à Marina e aos meus sobrinhos lindos e amados, Ana Beatriz e Guilherme, que nunca negaram um abraço carinhoso a esta tia meio ausente. Ao meu tio José, pelo auxílio na realização de partes desta pesquisa.

Ao Ivan, minha especial e eterna gratidão. Esta tese simplesmente não teria sido possível sem a sua ajuda. Não falo isso só pelo auxílio na elaboração e conclusão da pesquisa. Mas principalmente por todo o companheirismo, comprometimento e por todo o amor que você 
demonstrou por mim. Agradeço por todas as vezes em que você desconstruiu inseguranças e pessimismos com palavras, brincadeiras e gestos. Você também acreditou em mim, quando eu mesma duvidei. Não há palavra suficiente que expresse o quanto eu me considero contemplada pelo destino e por Deus, simplesmente por ter você em minha vida.

Aos amigos que eu fiz na pós-graduação - em especial, à Fabiana Oliveira Pinho, ao Fábio Gomes dos Santos, e ao Vitor Monteiro - agradeço por todas as conversas e todas as risadas proporcionadas. Com vocês pude dividir momentos importantes desta trajetória e também alguns problemas pessoais.

Aos amigos que eu fiz na graduação, muito obrigada simplesmente por estarem ao meu lado estes anos todos. Alguns deles estão mais próximos, outros mais distantes. De todo modo, tenho a absoluta certeza de que eles estarão sempre torcendo por mim. Em especial, agradeço ao Alex Hardt, à Marina Natalini, à Larissa Foelker, ao José Gladston Vianna Correia, ao João Múcio Amado Mendes, à Maybi Mota e à Michele Corbi pelos momentos especiais que eu pude dividir com vocês. Aos amigos da vida, Beatriz Brichta, Deniz Jordão, Carla Luvezuto, Camila Matias, Alessandra Domingues, dentre outros, agradeço pelo mesmo motivo. Guardo todos vocês no meu coração. 
Esta pesquisa foi possível graças ao financiamento da Fundação de Amparo à Pesquisa do Estado de São Paulo - FAPESP (Processo no ${ }^{\circ}$ 2013/03885-3) 
"Os males da federação e os da Republica são males que se curam, não pela abolição de uma ou de outra, mas pela reorganização de uma e outra. Temos praticado mal essas duas grandes instituições. Mas não melhoraríamos, acabando com ellas, senão praticando-as melhor, o que será exequível, se o quizermos" (Ruy BARBOSA.

Commentarios á Constituição Federal Brasileira. I Volume - Das disposições preliminares. São Paulo: Saraiva \& Cia, 1932, p. 71) 
ZAGO, Mariana Augusta dos Santos. Federalismo no Brasil e na Alemanha: Estudo comparativo da repartição de competências legislativas e de execução. 2016 Tese (Doutorado). Faculdade de Direito da Universidade de São Paulo. 2016

\section{RESUMO}

A federação consiste em forma de Estado caracterizada essencialmente pela repartição do poder político entre um governo central, a União, e governos regionais, os Estados-membros. O Direito, contudo, não trabalha com todas as facetas deste fenômeno eminentemente político. Ao contrário, as atenções nesta área do conhecimento se voltam para a repartição constitucional de competências, a qual é erigida por alguns autores à "questão central" do federalismo. Alinhando-se a esta premissa, a presente tese propõe um estudo comparativo do modo pelo qual a Constituição Federal de 1988 e a Lei Fundamental alemã de 1949 distribuem competências legislativas e de execução entre os entes federativos. Tal análise, por sua vez, foi estruturada a fim de responder dois grandes questionamentos: em primeiro lugar, quais são as reais semelhanças e diferenças entre os ordenamentos jurídicos brasileiro e alemão neste ponto? Em segundo lugar, existem soluções concebidas pela doutrina e pela jurisprudência alemãs para problemas envolvendo a distribuição de competências legislativas e de execução e que poderiam ser transplantadas para o ordenamento brasileiro, a fim de resolver litígios domésticos sobre estes temas? Antes de adentrar nesta análise, contudo, julgou-se necessário responder outros questionamentos menores, porém imprescindíveis dos pontos de vista teórico e metodológico. Deste modo, dedicou-se o primeiro capítulo da tese à exposição das premissas teóricas, as quais contemplaram desde noções de federalismo e federação, passando por considerações teóricas sobre a centralização e a descentralização em um Estado Federal, até a definição do que é uma competência federativa e as classificações de competência mais importantes para a pesquisa. No segundo capítulo, por sua vez, as federações brasileira e alemã foram contextualizadas segundo alguns prismas pré-selecionados, dando cumprimento, assim, a uma etapa inerente ao método comparativo. No terceiro capítulo promoveu-se uma análise integrada destes aspectos teóricos e metodológicos. Após uma apresentação dos sistemas brasileiro e alemão de repartição de competências legislativas e de execução no quarto e no quinto capítulos respectivamente, o primeiro grande questionamento da pesquisa foi respondido no sexto capítulo a partir das regras gerais em matéria de repartição de competências previstas pela Constituição Federal de 1988 e pela Lei Fundamental de 1949, do modo pelo qual estas constituições distribuem competências legislativas e da disciplina que elas dão à repartição de competências de execução. Finalmente, no sétimo capítulo o debate alemão em torno da subsunção de uma lei à norma de competência, da lealdade federal e de algumas questões municipais foi retomado a partir da sua aplicabilidade a conflitos brasileiros envolvendo a repartição de competências legislativas e de execução.

Palavras-chave: federalismo; repartição de competências legislativas; repartição de competências de execução; estudo comparativo; Brasil e Alemanha. 
ZAGO, Mariana Augusta dos Santos. Federalism in Brazil and Germany: comparative study of the constitutional allocation of legislative and executive competences. 2016. Dissertation (Doctorate). Faculty of Law - University of Sao Paulo. 2016

\section{ABSTRACT}

The federation is a form of state characterized in general terms by the division of political power between one central government, the federal government, and regional governments, the member states. The Law, however, does not comprise all the aspects of this eminently political phenomenon. On the contrary, in this area of knowledge the focus consists of the constitutional division of competences (powers), which is considered by some authors the "main question" of federalism. From this perspective, this work proposes a comparative study of how the Brazilian Federal Constitution of 1988 and the German Basic Law of 1949 allocate legislative and executive competences between the federal and regional governments. This research, in turn, was structured in order to answer two main questions: first, what are the real similarities and differences between the Brazilian and the German legal systems regarding to this aspect? Secondly, are there solutions conceived by the German jurisprudence and case-law for problems concerning the constitutional division of powers that could be transplanted to Brazilian legal system in order to solve domestic disputes on this matter? Before addressing these issues, however, it was important to answer some minor, though indispensable questions from a theoretical and methodological point of view. Thus, the first chapter of the dissertation was devoted to the explanation of the theoretical foundations of the research, which encompasses from notions of federalism and federation, theoretical appointments about centralization and decentralization in a federal state, up to a concept of federal competence and its most significant classifications with regard to this research. In the second chapter, both Brazilian and German federations were contextualized according to some preselected angles, fulfilling this important step of comparative analysis. In the third chapter both theoretical and methodological aspects were confronted. After some enlightenments about the Brazilian and German systems of division of legislative and executive powers in the fourth and fifth chapters, the first major question of this research could be answered in the sixth chapter from the perspective of the general rules of division of powers provided in the Brazilian Federal Constitution of 1988 and the German Basic Law of 1949, how these two constitutions distribute legislative competences, and the discipline theses constitutions provide for the division of executive competences. Finally, in the seventh chapter the German debate on the subsumption of a statute under the rule of competence, on the Bundestreue principle and on some municipal questions is examined from its applicability to Brazilian disputes over the constitution distribution of legislative and executive powers.

Keywords: federalism; division of legislative competences; division of administrative competences; comparative study; Brazil and Germany 
ZAGO, Mariana Augusta dos Santos. Föderalismus in Brasilien und Deutschland: vergleichende Untersuchung der Gesetzgebungs- und Verwaltungskompetenzverteilung. 2016. Dissertation (Doktorat). Juristisches Fakultät - Universität von Sao Paulo. 2016.

\section{ZUSAMMENFASSUNG}

Der Bundesstaat ist im Wesentlichen eine durch die Verteilung der politischen Macht zwischen dem Bund und den Bundesländern gekennzeichnete Staatsform. Das Recht begreift jedoch nicht jede Facette dieses höchst politischen Phänomens. Auf diesem Wissenschaftsgebiet wird vielmehr die verfassungsrechtliche Kompetenzverteilung hervorgehoben, die von einigen Autoren sogar als ,grundlegende Frage“ des Föderalismus betrachtet wird. Von dieser Prämisse ausgehend legt diese Dissertation eine vergleichende Untersuchung über die von der brasilianischen Verfassung von 1988 und dem deutschen Grundgesetz von 1949 durchgeführte Gesetzgebungs- und Verwaltungskompetenzverteilung dar. Die Forschung wurde ihrerseits aufgebaut, um zwei Hauptfragen zu beantworten: zuerst welche die echten Ähnlichkeiten und Unterschiede zwischen den Rechtssystemen Brasiliens und Deutschlands in diesem bestimmten Aspekt sind. Zweitens: gibt es in der deutschen Lehre und Gerichten ausgearbeitete Lösungen für kompetenzrechtliche Probleme, die zum brasilianischen Rechtssystem übertragen werden können, um einheimische Rechtsstreite über dieses Thema zu lösen? Bevor diese Problematik behandelt werden konnte, war es erforderlich, sich mit einigen wichtigen Nebenfragen von einem theoretischen und methodologischen Standpunkt aus zu beschäftigen. Auf dieser Weise wurde im ersten Kapitel besondere Aufmerksamkeit zu den theoretischen Prämissen der Untersuchung gewidmet, welche Begriffe des Föderalismus und Bundesstaats, theoretische Erwägungen zur Zentralisierung und Dezentralisierung in einem Bundesstaat, bis zum Zuständigkeitsbegriff und den wichtigsten Kompetenzklassifizierungen umfassen. In dem zweiten Kapitel wurden die brasilianischen und deutschen Bundesstaaten in einen Kontext gesetzt, um einen wichtigen Arbeitsschritt der vergleichenden Methode zu erfüllen. In dem dritten Kapitel wurden die zuvor diskutierten theoretischen und methodologischen Aspekte sich gegenübergestellt. Nach einer Erklärung der brasilianischen und deutschen Gesetzgebungs- und Verwaltungskompetenzverteilung in den vierten und fünften Kapiteln wurde die erste Hauptfrage in dem sechsten Kapitel beantwortet, und zwar aus der Perspektive der durch brasilianische und deutsche Verfassungen vorgesehenen Grundregeln der Kompetenzverteilung, der Gesetzgebungskompetenzverteilung und der verfassungsrechtlichen Disziplin der Verwaltungskompetenzen. Schließlich wurde die deutsche Debatte über die kompetenzrechtliche Qualifizierung eines Gesetzes, über die Bundestreue und über einige kommunale Angelegenheiten aus der Sicht ihrer Anwendung auf brasilianische Rechtsstreiten über die Kompetenzverteilung geprüft.

Stichwörter:

Föderalismus;

Gesetzgebungskompetenzverteilung; Verwaltungskompetenzverteilung; vergleichende Untersuchung; Brasilien und Deutschland 


\section{LISTA DE ABREVIATURAS E SIGLAS}

Abs. - Absatz (Parágrafo)

ADC - Ação Declaratória de Constitucionalidade

ADI - Ação Direta de Inconstitucionalidade

ADO - Ação Direta de Inconstitucionalidade por Omissão

ADPF - Argüição de Descumprimento de Preceito Fundamental

Art. - Artigo

BRD - Bundesrepublik Deutschland (República Federal da Alemanha)

BVerfG - Bundesverfassungsgericht (Tribunal Constitucional Federal)

BVerfGE - Entscheidungen des Bundesverfassungsgerichts (Decisões do Tribunal

Constitucional Federal

BVerfGG - Gesetz über das Bundesverfassungsgericht (Lei do Tribunal Constitucional Federal)

CDU - Christlich Demokratische Union Deutschlands (União Democrata Cristã da Alemanha)

CF/1891 - Constituição da República dos Estados Unidos do Brasil de 24 de fevereiro de 1891

CF/1934 - Constituição da República dos Estados Unidos do Brasil de 16 de julho de 1934

CF/1937 - Constituição dos Estados Unidos do Brasil de 10 de novembro de 1937

CF/1946 - Constituição dos Estados Unidos do Brasil de 18 de setembro de 1946

CF/1967 - Constituição da República Federativa do Brasil de 1967

CF/1967-69 - Constituição da República Federativa do Brasil de 1967, com redação dada pela Emenda Constitucional n ${ }^{\circ} 1$, de 17.10.1969

CF/88 - Constituição da República Federativa do Brasil de 1988

Coord. - Coordenador, Coordenadores, Coordenadora, Coordenadoras

CSU - Christlich-Soziale Union in Bayern (União Social-Cristã na Baviera)

DDR - Deutsche Demokratische Republik (República Democrática Alemã)

DEM - Democratas

DÖV - Die Öffentliche Verwaltung (revista alemã)

EC - Emenda Constitucional 
EGV - Vertrag zur Gründung der Europäischen Gemeinschaft (Tratado que institui a Comunidade Europeia)

FUNDEB - Fundo de Manutenção e Desenvolvimento da Educação Básica e de Valorização dos Profissionais da Educação

FUNDEF - Fundo de Manutenção e Desenvolvimento do Ensino Fundamental e de Valorização do Magistério

GG - Grundgesetz (Lei Fundamental de 1949)

Hrsg. - Herausgeber (Coordenador, Editor ou Organizador)

INAMPS - Instituto Nacional de Assistência Médica da Previdência Social

INPS - Instituto Nacional de Previdência Social

JuS - Juristische Schulung (revista alemã)

NOB - Norma Operacional Básica do Sistema Único de Sáude

$\mathrm{Nr}$ - Nummer (Número)

NSDAP - Nationalsozialistische Deutsche Arbeiterpartei (Partido dos Trabalhadores Nacional-Socialista)

NVwZ - Neue Zeitschrift für Verwaltungsrecht

Org. - Organizador, Organizadores, Organizadora, Organizadoras.

p. - Página

PAB - Piso de Atenção Básica

PCdoB - Partido Comunista do Brasil

PDT - Partido Democrático Trabalhista

PEN - Partido Ecológico Nacional

PHS - Partido Humanista da Solidariedade

PMDB - Partido do Movimento Democrático Brasileiro

PMN - Partido da Mobilização Nacional

PP - Partido Progressista

pp. - Páginas

PPS - Partido Popular Socialista

PR - Partido da República

PRB - Partido Republicano Brasileiro 
PROS - Partido Republicano da Ordem Social

PRP - Partido Republicano Progressista

PSB - Partido Socialista Brasileiro

PSC - Partido Social Cristão

PSD - Partido Social Democrático

PSDB - Partido da Social Democracia Brasileira

PSDC - Partido Social Democrata Cristão

PSL - Partido Social Liberal

PSOL - Partido Socialismo e Liberdade

PT - Partido dos Trabalhadores

PTB - Partido Trabalhista Brasileiro

PTC - Partido Trabalhista Cristão

PTdoB - Partido Trabalhista do Brasil

PTN - Partido Trabalhista Nacional

PV - Partido Verde

ReDAC - Revista de Direito Administrativo Contemporâneo

REDE - Rede Sustentabilidade

S. - Satz (Período)

SD - Solidariedade

SPD - Sozialdemokratische Partei Deutschlands (Partido Social-Democrata da Alemanha)

ss. - Seguintes

STF - Supremo Tribunal Federal

SUS - Sistema Único de Saúde

TCF - Tribunal Constitucional Federal

WRV - Weimarer Reichsverfassung (Constituição Imperial de Weimar) 


\section{SUMÁRIO}

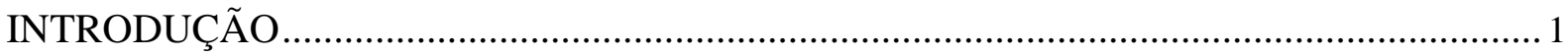

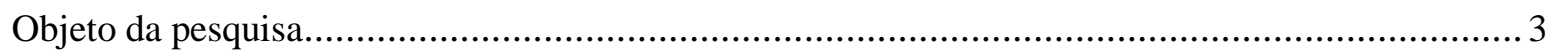

Importância da presente tese para a ciência jurídica ............................................................... 6

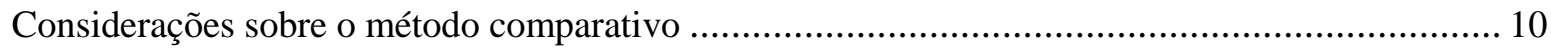

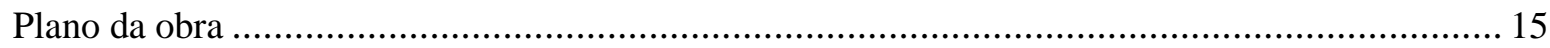

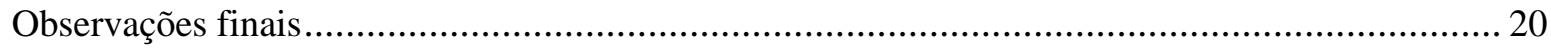

PARTE I - FEDERALISMO NO BRASIL E NA ALEMANHA: NOÇÕES GERAIS ......... 23

Primeiro Capítulo - Algumas premissas teóricas ........................................................... 23

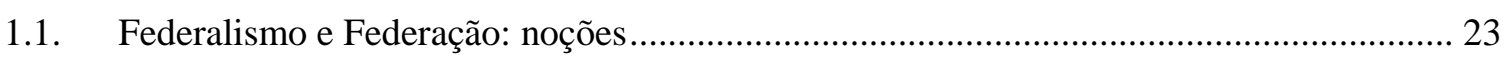

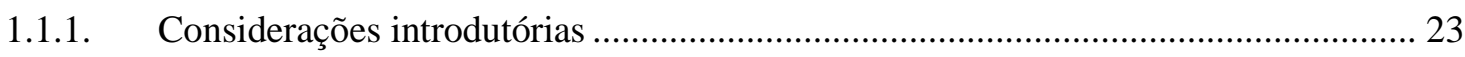

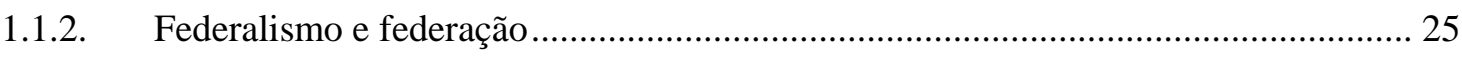

1.1.3. Federação para os fins do presente estudo comparativo ........................................... 27

1.2. A questão da cooperação no Estado Federal. $\mathrm{O}$ federalismo dualista e o federalismo

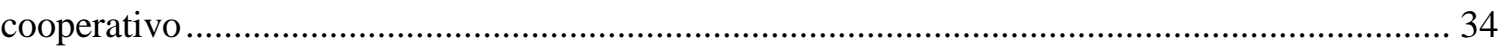

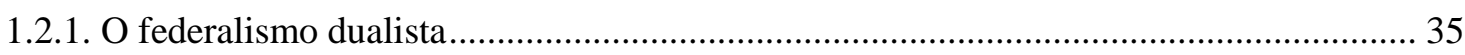

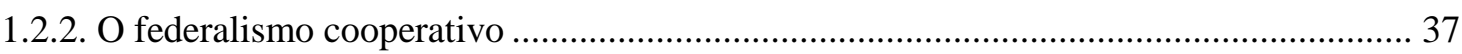

1.2.3. Aspectos dogmáticos da cooperação federativa ............................................................ 41

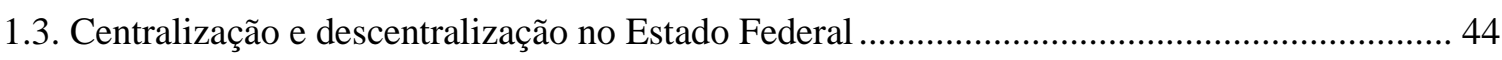

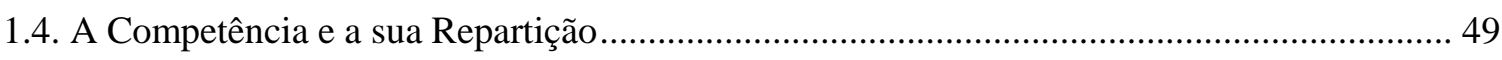

1.5. Classificações das competências e de sua repartição ........................................................... 55

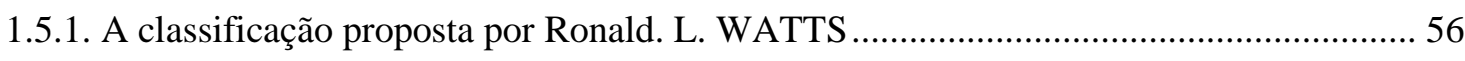

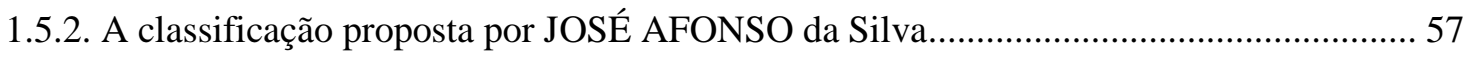

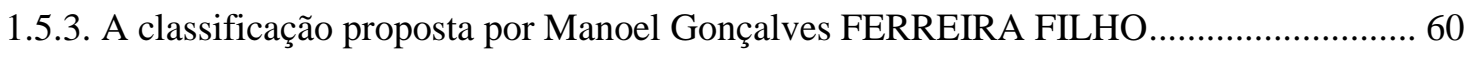

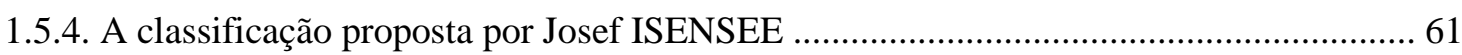

1.5.5. Nossa classificação: competências legislativas e de execução; competências privativas e

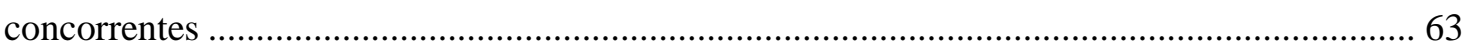

1.6. Instituições essenciais do Estado Federal: a câmara representativa dos Estados-membros e a Corte Constitucional

1.6.1. A Câmara representativa dos Estados-membros .............................................................. 70

1.6.2. O papel da corte constitucional em um Estado Federal .................................................. 74

Segundo Capítulo - Notas distintivas da Federação no Brasil e na Alemanha ................ 83

2.1. A federação brasileira sob a égide da Constituição Federal de 1988 ....................................... 85 
2.1.1. Breve histórico da federação brasileira

2.1.2. A federação brasileira a partir da Constituição Federal de 1988 ...................................... 97

2.1.3. A autonomia do Município na Constituição de 1988 ………………………………..... 105

2.1.4. A representação dos Estados-membros no Senado Federal e na Câmara dos Deputados

2.2. A federação alemã sob a égide da Lei Fundamental de 1949 .............................................. 123

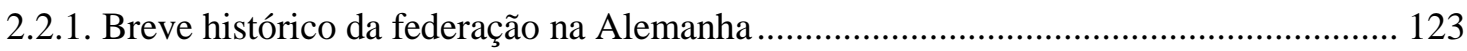

2.2.2. Breve histórico da federação alemã durante a vigência da Lei Fundamental de 1949.. 137

2.2.3. A autonomia do Município sob a égide da Lei Fundamental de 1949 .......................... 149

2.2.4. A representação dos Länder no Conselho Federal (Bundesrat) ...................................... 161

Terceiro capítulo - A experiência federativa no Brasil e na Alemanha ...................... 166

3.1. A federação diante do fenômeno da centralização .................................................................. 167

3.2. A evolução das federações brasileira e alemã .................................................................... 171

3.2.1. A questão da formação da federação brasileira........................................................... 171

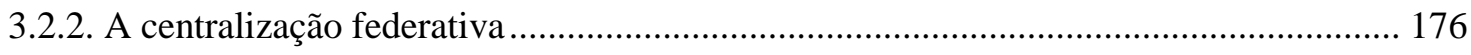

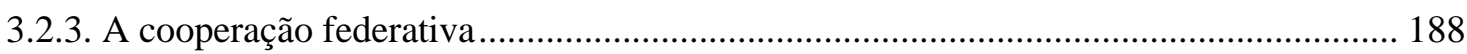

3.3. A repartição de competências como o elemento central da teoria jurídica do federalismo 210

PARTE II - ESTUDO COMPARATIVO: O SISTEMA CONSTITUCIONAL DE REPARTIÇÃO DE COMPETÊNCIAS LEGISLATIVAS E DE EXECUÇÃO NO BRASIL E

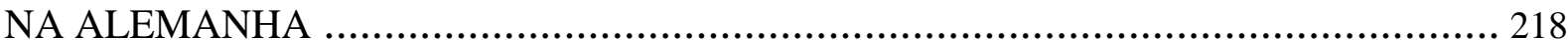

Quarto capítulo - A repartição de competências legislativas e de execução no Brasil:

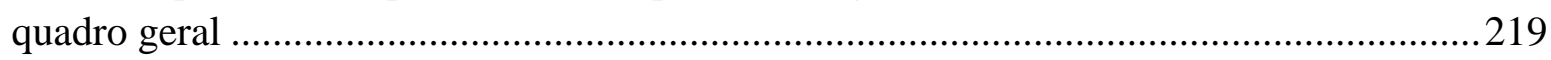

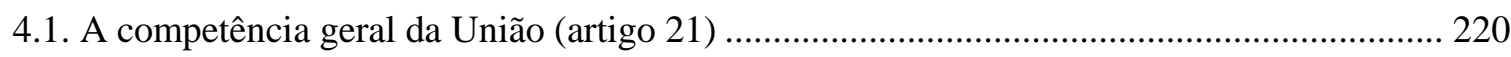

4.2. A competência legislativa privativa da União (artigo 22) ................................................... 224

4.3. A competência comum da União, Estados e Municípios (artigo 23) ................................... 229

4.4. A competência legislativa concorrente da União e dos Estados-membros (artigo 24) ........ 235

4.5. A competência privativa dos Estados-membros (parágrafos do artigo 25) .......................... 250

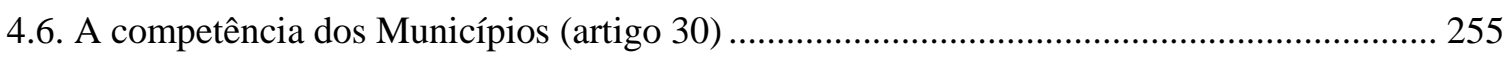

Quinto capítulo - A repartição de competências legislativas e de execução na Alemanha:

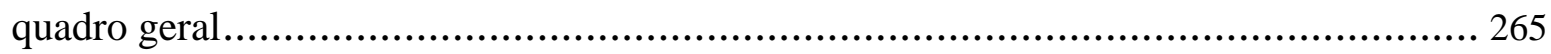

5.1. Regra geral em matéria de repartição de competências legislativas (artigo 70) ................... 267

5.2. A competência legislativa privativa da União (artigo 71) ..................................................... 273

5.3. A competência legislativa concorrente da União e dos Estados-membros (artigos 72 e 75) 278

5.3.1. A competência legislativa concorrente do artigo 72 GG............................................... 279

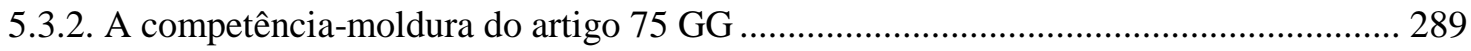

5.4. Regra geral em matéria de repartição de competências administrativas (artigo 83) ............ 295 
5.5. A execução de leis federais pelos Länder como assunto próprio e sob as ordens do Bund (artigos 84 a 85).

5.5.1. A execução de leis federais pelos Länder como um assunto próprio (artigo 84 GG) ... 303

5.5.2. A execução de leis federais pelos Länder sob as ordens do Bund (artigo 85 GG)........ 315

5.6. A competência administrativa da União (artigos 86 e seguintes) ........................................ 320

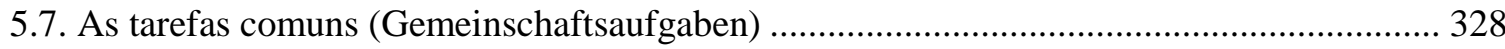

Sexto capítulo - Confrontação da repartição de competências legislativas e de execução no Brasil e na Alemanha ..................................................................... 338

6.1. Transplantes e recepções: as possíveis interações entre a Constituição Federal de 1988 e a

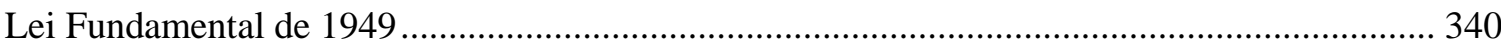

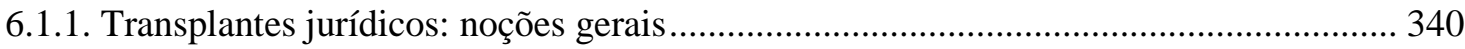

6.1.2. A possível influência da Lei Fundamental de 1949 sobre a Constituição Federal de 1988

6.1.3. Como a noção de transplante jurídico aproveita à presente tese .................................... 349

6.2. Regras gerais em matéria de repartição de competências ........................................................ 354

6.2.1. As regras gerais previstas pela Lei Fundamental de 1949 ............................................ 354

6.2.2. As regras gerais previstas pela Constituição Federal de 1988 ....................................... 363

6.3. Competências legislativas e competências de execução ………………………………....... 379

6.3.1. A repartição de competências legislativas e de execução na Alemanha .......................... 380

6.3.2. A repartição de competências legislativas e de execução no Brasil............................... 386

6.4. Competências privativas e competências concorrentes............................................................ 404

6.4.1. As competências privativas na Lei Fundamental e na Constituição Federal de 1988 ... 405

6.4.2. As competências concorrentes na Lei Fundamental e na Constituição Federal de 1988

Sétimo capítulo - Algumas questões da repartição de competências analisadas sob uma perspectiva comparada ................................................................ 421

7.1. A qualificação competencial da lei e questões afetas......................................................... 422

7.1.1. A questão da interpretação da norma de competência ................................................... 425

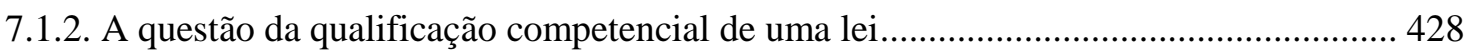

7.1.3. Alguns apontamentos sobre a interpretação da repartição de competências legislativas e

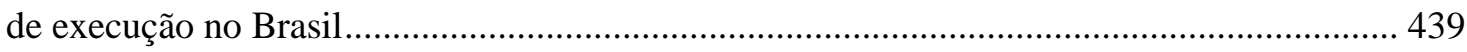

7.2. O princípio da lealdade federal aplicado à repartição de competências ................................ 450

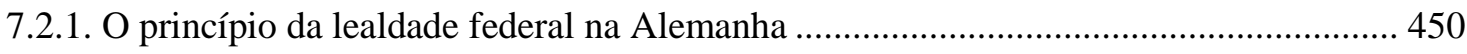

7.2.2. O princípio da lealdade federal e suas implicações para o exercício de competências

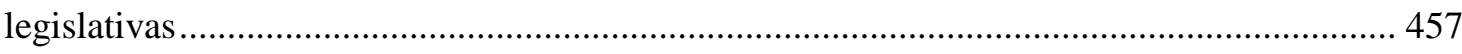

7.2.3. Aplicações do princípio da lealdade federal no Brasil .................................................... 461

7.3. Algumas questões municipais sob uma perspectiva comparada ............................................ 468 
7.3.1. As tarefas municipais em uma perspectiva comparada 471

7.3.2. Os instrumentos políticos e jurisdicionais para assegurar a autonomia municipal ....... 481

7.3.3. A autonomia das associações de Municípios 486

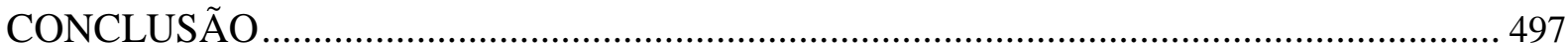

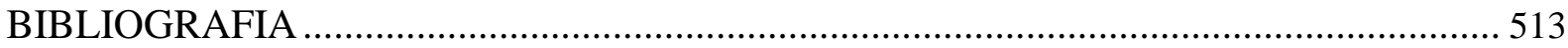

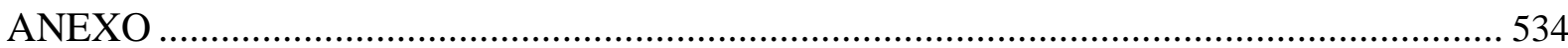




\section{INTRODUÇÃO}

A federação, como forma de Estado Moderno que combina distribuição do poder entre um governo central e diversos governos periféricos regulada por uma constituição, é uma criação do século XVIII. Mais precisamente, trata-se de fórmula forjada pelos norteamericanos para lidar com alguns problemas específicos, que não recebiam tratamento adequado no âmbito da Confederação formada pelas treze ex-colônias britânicas então soberanas.

Desde então, esta forma de organização estatal difundiu-se em escala mundial. De fato, os séculos XIX e XX conheceram uma proliferação sem precedentes de Estados Federais. É certo que alguns deles, mesmo antes de 1787, já adotavam fórmulas associativas próximas ao federalismo norte-americano: é o caso da Suíça, que era uma confederação desde 1291 e tornou-se uma federação em 1848, após um breve período de guerra civil em $1847,{ }^{1}$ ou da Alemanha, cujas "raízes" federativas remontam ao Sacro Império RomanoGermânico, segundo alguns autores. ${ }^{2}$ No entanto, a maioria das federações formadas nesse período possuem em comum o fato de serem ex-colônias dos grandes impérios europeus, sendo que virtualmente todas se inspiraram, em maior ou menor medida, no modelo norteamericano de federalismo. ${ }^{3}$

O federalismo não é, contudo, uma panaceia para todos os males e nem pode se adaptar a todos os contextos políticos e sociais. ${ }^{4}$ Justamente por isso, alguns Estados

\footnotetext{
* Sobre o modo pelo qual obras repetidamente mencionadas por esta tese serão citadas, vide as considerações tecidas no último tópico desta introdução.

${ }^{1}$ Ronald L. WATTS. Comparing Federal Systems. 3ạ Ed. Montreal \& Kingston: McGill-Queen's University Press, 2008, p. 30.

2 Nesse sentido, Klaus SCHLAICH e Stefan KORIOTH apontam como uma das raízes do controle de constitucionalidade alemão o controle de índole federativa realizado já na época do Sacro Império RomânicoGermânico (Klaus SCHLAICH; Stefan KORIOTH. Das Bundesverfassungsgericht: Stellung, Verfahren, Entscheidungen. 7ạ Ed. Munique: C. H. Beck, 2007, pp. 67-68).

${ }^{3}$ A influência do modelo norte-americano na formação das federações modernas a partir do século XIX é investigada em William H. RIKER. Federalism. In: Fred I. GREENSTEIN, Nelson W. POLSBY (Eds.). Handbook of Political Science. Volume 5: Governmental Institutions and Processes. Massachusetts: Addison-Wesley, 1975 pp. 108 e ss. Segundo este autor, a invenção do federalismo centralizado (ou moderno) pelos norteamericanos é uma condição necessária para a difusão mundial desta fórmula de organização estatal. Já o fato de a maioria das federações surgidas a partir desse período serem resultado da desintegração de grandes impérios (tais como o britânico, o espanhol ou mesmo o português, no caso do Brasil) também é levado em consideração por RIKER, embora não o considere uma condição política para a adoção do federalismo (RIKER. Federalism, p. 97).

${ }^{4}$ Diagnóstico elaborado por Ronald L. WATTS em relação às federações criadas a partir da década de 1960, como se pode perceber no seguinte trecho: "between 1960 and the late 1980s, however, it became increasingly clear that federal systems were not a panacea that many had imagined them to be. Many of the post-war federal experiments experienced difficulties and a number of them were temporarily suspended or abandoned outright. These experiences suggested that, even when undertaken with the best of motives, there are limits to
} 
organizados inicialmente sob a forma de federações tornaram-se Estados Unitários após um curto lapso de tempo; outros desmembraram-se nas suas unidades constituintes, as quais adotaram a forma de Estado Federal ou Unitário a depender das suas particularidades locais. ${ }^{5}$ Após uma nova onda de expansão posterior à Segunda Guerra Mundial, atualmente o federalismo encontra expressão em apenas 25 Estados dos 192 reconhecidos pela Organização das Nações Unidas (ONU): África do Sul; Alemanha; Argentina; Austrália; Áustria; Bélgica; Bósnia Herzegovina; Brasil; Canadá; Comores; Emirados Árabes Unidos; Espanha; Estados Unidos da América; Etiópia; Índia; Malásia; México; Micronésia; Nepal; Nigéria; Paquistão; Suíça; Rússia; São Cristóvão e Neves, e; Venezuela. ${ }^{6}$ Por óbvio, essa lista pode se tornar maior ou menor a depender da definição de federalismo e de federação que se adote: noções mais restritas tendem a deixar de fora Estados Federais marcados por uma maior centralização, como é o caso do México, da Venezuela ou mesmo do Brasil; por outro lado, noções mais abrangentes tendem a englobar os chamados Estados autonômicos - como é o caso da Espanha ${ }^{7}$ - ou Estados cujo funcionamento se assemelha mais ao de uma confederação - como é o caso dos Emirados Árabes Unidos. De todo modo, é de se ressaltar o sucesso desta fórmula de organização estatal: afinal, embora adotada por cerca de 25 Estados, os seus cidadãos representam aproximadamente $40 \%$ da população mundial, espalhados por cinco continentes. ${ }^{8}$

Uma comparação que leve em consideração a totalidade das federações modernas certamente conduz a resultados interessantes; há estudos bem conhecidos que corroboram esta afirmação, inclusive. ${ }^{9}$ A presente tese, embora também proponha uma comparação entre federações, possui uma proposta mais restrita: em primeiro lugar, não opta por comparar diversas manifestações do fenômeno federativo, mas apenas o Brasil e a Alemanha de acordo com as feições delineadas pela Constituição Federal de 1988 e pela Lei Fundamental alemã

the appropriateness of federal solutions or particular federal forms in certain circumstances" (WATTS. Comparing Federal Systems, p. 4). Considera-se possível aplicar este mesmo raciocínio à expansão do número de federações verificada já no século XIX, como se verá a seguir.

${ }^{5}$ Apenas para ficar com exemplos no continente americano, citam-se os casos do Chile e da Colômbia, que adotaram inicialmente a forma de Estado Federal e depois migraram para a forma de Estado Unitário, e o caso dos Estados Unidos da América Central, que se desmembraram nas suas unidades constituintes Nicarágua, Costa Rica, Honduras, El Salvador e Guatemala (RIKER. Federalism, p. 93).

${ }^{6}$ http://www.forumfed.org/en/federalism/federalismbycountry.php, acesso em 12/05/2013. Para um breve panorama de todas as federações atuais, vide WATTS. Comparing federal systems, pp. 29-61.

${ }^{7}$ Cf. JOSÉ AFONSO da Silva. Curso de Direito Constitucional Positivo. 24a Ed. Malheiros: São Paulo, 2004, p. 98. O Estado autonômico espanhol e o Estado regional italiano são abordados com maiores detalhes, em uma perspectiva comparativa com o Estado Federal, em Raul Machado HORTA. Direito Constitucional. 5a Ed (atualizada por Juliana Campos Horta). Belo Horizonte: Del Rey, 2010, pp. 433 e ss.

${ }^{8}$ http://www.forumfed.org/countries. Acesso: 13/03/2016.

${ }^{9}$ Como, por exemplo, os estudos empreendidos por Willian RIKER e por Ronald L. WATTS, já citados nesta tese. 
de 1949; além do mais, não envereda em uma comparação global - isto quer dizer, uma comparação que leve em consideração as principais instituições federativas desses dois Estados Federais - mas apenas os seus respectivos sistemas constitucionais de repartição de competências legislativas e de execução.

É de admitir que esta não é uma opção tão óbvia: afinal, por que comparar Brasil e Alemanha? Por que não comparar Brasil e Estados Unidos ou então Alemanha e Estados Unidos? Por que levar em consideração somente as normas constitucionais que distribuem competências legislativas e de execução entre os entes federativos?

Todos estes questionamentos são pertinentes e devem ser suficientemente elucidados antes mesmo de se iniciar a tese, sob pena de se principiar um estudo sem fornecer informações fundamentais sobre os problemas que se pretende enfrentar e quais os resultados que podem ser obtidos. A fim de solucionar esse primeiro impasse, esta introdução será dedicada a uma breve exposição do objeto desta tese, da sua importância acadêmica e da metodologia empregada, os quais são profundamente influenciados pelo viés jurídico-dogmático que esta pesquisa assume, na acepção bem trabalhada no Brasil por Tércio Sampaio FERRAZ JUNIOR. ${ }^{10}$ Ao final, pretende-se traçar um breve plano da obra, a fim de apresentar quais e como os argumentos se sucederão no decorrer do trabalho, além de tecer algumas observações de índole eminentemente formal.

\section{OBJETO DA PESQUISA}

O objeto da presente tese é delimitado de três formas, as quais se encontram bem resumidas quando se enuncia a proposta de trabalho do seguinte modo: uma análise comparativa dos sistemas brasileiro e alemão de repartição de competências legislativas e de execução, com foco nas regras e princípios que orientam o exercício de uma competência por um ou mais entes federativos, analisando primordialmente as normas constitucionais sobre o tema e também a jurisprudência pertinente nos dois ordenamentos considerados.

Depreende-se, deste modo, que o objeto da pesquisa engloba, em primeiro lugar, somente os sistemas brasileiro e alemão de repartição de competências legislativas e de competências de execução. ${ }^{11}$ Isso significa dizer que o primeiro substrato desta pesquisa

\footnotetext{
10 Em especial, nas seguintes obras: Tércio Sampaio FERRAZ JUNIOR. A ciência do direito. 2a Ed. São Paulo: Atlas, 1980 e Tércio Sampaio FERRAZ JUNIOR. Introdução ao estudo do direito. Técnica, decisão, dominação. 4a Ed. São Paulo: Atlas, 2003.

11 O conteúdo da expressão "competência de execução" será esclarecido no item 1.5.5. Por ora, basta deixar
} 
serão primordialmente as normas contidas nos artigos 21 a 25 e 30 da Constituição Federal Brasileira e nos artigos 28 II, 30, 31, 70 a 72, 75, 83 a 87, 91a e 91b da Lei Fundamental alemã, que concentram o cerne da repartição de competências nos dois ordenamentos jurídicos considerados. Ocasionalmente, porém, poder-se-á fazer menção a outros dispositivos esparsos nos dois textos constitucionais, que também tratem do objeto desta tese. $^{12}$

Ficam excluídos da análise, portanto, os dispositivos constitucionais que tratam da chamada repartição constitucional de rendas, expressão que engloba as normas constitucionais que disciplinam a distribuição dos recursos financeiros disponíveis entre as entidades subnacionais nesses dois países ${ }^{13}$. Com este corte, não se pretende negar a importância desta temática na teoria do federalismo ou mesmo na seara da repartição das competências legislativas e de execução. Acredita-se apenas que é possível chegar a resultados interessantes mesmo sem adentrar em minúcias do federalismo fiscal, o qual possui tantas peculiaridades em relação ao tema deste trabalho que costuma ser estudado por outro ramo do Direito, mais precisamente, pelo Direito Financeiro.

Em segundo lugar, a pesquisa não se debruçará sobre toda e qualquer norma constitucional que trate das competências legislativas e de execução, mas apenas sobre as regras e princípios constitucionais que orientam como estas competências (legislativas ou de execução, privativas ou concorrentes) devem ser exercidas pelas entidades subnacionais. ${ }^{14}$ Portanto, não serão objeto de análise - apenas para ficar com alguns poucos exemplos - os incisos do artigo $22 \mathrm{CF} / 88$ ou do artigo $73 \mathrm{GG}$, que trazem as matérias que são objeto da competência legislativa privativa da União no Brasil e na Alemanha, mas sim o parágrafo único do artigo $22 \mathrm{CF} / 88$ e a contrario sensu o artigo $71 \mathrm{GG}$, os quais autorizam os Estados a legislarem sobre as matérias inscritas no rol de competências privativas da União. Nesse mesmo sentido, servirão de substrato à investigação os parágrafos do artigo 24

consignado que a doutrina brasileira também emprega as expressões "competência geral", "competência material" para designar o mesmo fenômeno, ao passo que a doutrina alemã prefere a expressão "competência administrativa" (Verwaltungskompetenz ou Verwaltungszuständigkeit).

12 Por exemplo, o caso do artigo 211 da Constituição Federal brasileira, que reparte competências entre União, Estados e Municípios em matéria de educação ou então do artigo 32, § 10 do mesmo diploma, que trata da competência legislativa e material do Distrito Federal.

13 Aqui um esclarecimento importante: não se pretende tratar da repartição de recursos financeiros na segunda parte da tese, dedicada ao estudo comparativo propriamente dito. Porém, como se considera este um aspecto fundamental para a compreensão das relações federativas, ele será analisado, em linhas gerais, ao longo do segundo capítulo da tese.

${ }^{14}$ Esta segunda delimitação parte do pressuposto que há uma distinção relevante e perceptível entre normas que de qualquer modo atribuem uma determinada matéria à atuação legislativa ou administrativa de um ente federativo, de um lado, e normas que disciplinam de que modo se dará essa atuação por parte do ente que está investido desta capacidade, de outro. Esta distinção será retomada no tópico 1.4 da tese. 
CF/88 e do revogado artigo 75 GG, os quais circunscrevem a atuação da União à edição de normas gerais e dos Estados à legislação suplementar, entre outras disposições, e não as matérias que os referidos dispositivos repartem entre União e Estados-membros.

Nesta segunda delimitação estão englobadas ainda aquelas normas que orientam a prevalência da competência de um ente federativo sobre a competência de outra entidade subnacional, as quais compreendem não só as chamadas "regras de colisão" - previstas no texto constitucional, da qual o brocardo alemão Bundesrecht bricht Landesrecht (direito federal "quebra" direito estadual) positivado no artigo 31 da Lei Fundamental Alemã é um famoso exemplo - mas também normas que eventualmente possam ser extraídas das soluções concebidas pela jurisprudência e doutrina alemãs para lidar com litígios competenciais.

Em terceiro e último lugar, a presente tese levará em consideração as normas previstas pelas constituições brasileira e alemã e a jurisprudência das respectivas cortes constitucionais. Contudo, não é um objetivo desta tese perquirir como o Supremo Tribunal Federal (STF) e o Tribunal Constitucional Federal alemão (Bundesverfassungsgericht - BVerfG) julgam em matéria de repartição de competências. Ou seja, não se pretende, por meio de análises quantitativas ou estatísticas - principalmente no caso do STF, diante do volume de julgados proferidos por este tribunal - obter o posicionamento das cortes brasileira e alemã sobre determinados litígios competenciais. Quando se faz menção à jurisprudência constitucional brasileira e alemã, tem-se em mente algo mais singelo. Mais precisamente, almeja-se utilizar algumas decisões para precisar o conteúdo das normas constitucionais que serão consideradas no estudo comparativo. $\mathrm{O}$ foco reside, de todo modo, na explicitação do possível sentido e abrangência destas normas constitucionais, sendo que a jurisprudência constitucional se coloca apenas como um instrumento para atingir tal fim.

É de se ressaltar, finalmente, esta última delimitação acaba por excluir do objeto do estudo comparativo as práticas legislativa e administrativa que decorrem dessas previsões constitucionais, muito embora se reconheça que estas podem revelar aspectos relevantes de como uma competência é concretamente exercida pelos entes federativos. ${ }^{15}$

\footnotetext{
${ }^{15}$ No âmbito da ciência jurídica, há poucos estudos que se propõem a analisar empiricamente a produção legislativa dos Estados-membros. À guisa de exemplo, cita-se Denise C. VASQUES. Competências Legislativas concorrentes: prática legislativa da União e dos Estados-membros e jurisprudência do Supremo Tribunal Federal. Dissertação de mestrado - Faculdade de Direito da Universidade de São Paulo (FDUSP). São Paulo, 2007.
} 
Exposto o objeto da pesquisa com os seus devidos delineamentos, é preciso agora justificar a sua importância para a ciência jurídica, o que será feito em duas etapas a seguir: em primeiro lugar, é preciso fundamentar a opção pelo sistema constitucional de repartição de competências e a pela comparação entre Brasil e Alemanha; em segundo lugar, em que medida estes traços característicos da presente pesquisa podem trazer uma contribuição original à análise jurídica do federalismo e da federação.

A repartição de competências, por um lado, consiste em uma temática tradicional da teoria jurídica do federalismo: a ela é atribuído o papel de "chave da estrutura do poder federal" ou então de "grande questão do federalismo" 16 , pois (i) garante a autonomia das entidades federativas; (ii) promove uma ordenação das relações e os interesses intrafederativos, proporcionando eficiência e racionalidade à prática federativa; (iii) viabiliza a identificação de tendências de centralização e de descentralização em uma determinada estrutura federativa. ${ }^{17}$ Embora seja esta uma afirmação que se deixe relativizar em outras áreas do conhecimento, o foco no sistema constitucional de repartição de competências parece ser uma opção frutífera para o pesquisador do Direito que deseja se debruçar sobre o fenômeno federativo.

Já a escolha dos sistemas constitucionais de repartição de competências brasileiro e alemão como objetos da comparação pode ser bem compreendida ao se retomarem dois questionamentos que foram colocados nos primeiros parágrafos desta tese: mas afinal, por que Brasil e Alemanha? Por que não comparar Brasil e Estados Unidos?

A pertinência desta segunda pergunta justifica-se pela própria importância do modelo centralizado de federalismo forjado pelos americanos no fenômeno para a proliferação de Estados Federais, percebida a partir do século XIX e já mencionada nesta introdução. No caso do Brasil, a influência dos Estados Unidos é comumente atribuída à influência de Ruy BARBOSA, jurista que participou ativamente de todo o processo que antecedeu a queda do Império e culminou com a promulgação do primeiro texto constitucional republicano, e que nutria nítida simpatia pelo direito norte-americano. ${ }^{18}$

\footnotetext{
${ }^{16}$ HORTA. Direito Constitucional, p. 276, citando neste ponto expressões de Karl LOEWENSTEIN e Jean François AUBERT.

17 Sobre a importância da repartição de competências para a teoria jurídica do federalismo, vide o item 3.3.

18 Conforme relatam Paulo BONAVIDES e PAES DE ANDRADE, RUY BARBOSA participou tão ativamente da elaboração do texto constitucional que veio a ser aprovado em 1891 que chegou a reivindicar a autoria desta Constituição, ao que se sucedeu intenso debate sobre a legitimidade ou não de tal pleito. Para um breve resumo desta controvérsia, vide Paulo BONAVIDES, PAES DE ANDRADE. História Constitucional do Brasil. 3a Ed.
} 
No entanto, com o passar dos anos o Brasil foi assimilando influências do direito europeu - sobretudo da França, Espanha e Portugal e, posteriormente, da Alemanha tendência esta que também se verificou no Direito Constitucional e, mais especificamente, no sistema constitucional de competências. Portanto, se fazia sentido afirmar que o Brasil, por ocasião da promulgação da Constituição Federal de 1891, havia incorporado um “modelo norte-americano", também é razoável asseverar que as sucessivas constituições aproximaram o Brasil gradualmente de um "modelo europeu" de partilha de competências. ${ }^{19}$

É importante observar que a Alemanha é o único país, dentre aqueles cujos ordenamentos jurídicos que tradicionalmente influenciam o direito brasileiro, que efetivamente se organiza como uma federação moderna desde 1871 - com exceção do período que coincide com a ascensão do nacional-socialismo ao poder (1933-1945). Além do mais, abalizada doutrina nacional costuma citar a Lei Fundamental alemã como uma das fontes de inspiração para a Constituição Federal de $1988 .{ }^{20}$ Para além desse argumento de índole histórica, no entanto, a comparação entre Brasil e Alemanha também se justifica por razões de possibilidade e de utilidade acadêmica.

A possibilidade da comparação remete à existência de semelhanças e diferenças suficientes entre os institutos a serem comparados. Por óbvio, o que é uma semelhança ou uma diferença - e mais, o que é uma semelhança ou uma diferença suficiente - consiste em uma avaliação em certa medida subjetiva. $\mathrm{O}$ que se pretende excluir com esta exigência é apenas aquela comparação que leve em conta somente uma correspondência nominal entre institutos - afinal, uma mesma expressão pode designar institutos completamente distintos em diferentes ordenamentos jurídicos - ou então aquela pesquisa que opta por comparar objetos idênticos, pois frequentemente não conduz a resultados interessantes do ponto de

Rio de Janeiro: Paz e Terra, 1991, pp. 217 e ss. A predileção de RUY BARBOSA pelo direito estadunidense pode ser percebida em diversos trechos de seus Commentarios à Constituição Federal Brasileira: ao tratar do Senado Federal, por exemplo, o referido autor faz questão de expor os principais contornos do que ele chama de "teoria da Constituição Americana" (Ruy BARBOSA. Commentarios à Constituição Federal Brasileira. I/ Volume - Arts 16 a 40 - Do poder legislativo. São Paulo: Saraiva, 1933, pp. 133 e ss); em outra passagem, ao tratar da incompatibilidade entre a presença do Governo Federal no Distrito Federal e um poder municipal, o eminente jurista novamente invoca o caso americano, recorrendo às ponderações de Madison em O Federalista e também ao self-government que é tão marcante naquele país (Ruy BARBOSA. Commentarios à Constituição Federal Brasileira V Volume - Arts. 63 a 72, § 23. São Paulo: Saraiva, 1934, pp. 77 e ss).

${ }^{19}$ A dicotomia "modelo norte-americano" e "modelo europeu" de repartição de competências é trabalhada em Eduardo GARCIA DE ENTERRIA. El proyecto de constitución europea. Revista Española de Derecho Constitucional, ano 15, no 45, set/dez 1995, p. 25

${ }^{20}$ Nesse sentido, vide Fernanda Dias Menezes de ALMEIDA. Competências na Constituição de 1988. 3a Ed. São Paulo: Atlas, 2005, p. 76, JOSÉ AFONSO da Silva. um pouco de Direito Constitucional Comparado. São Paulo: Malheiros, 2009, p.264 e HORTA. Direito Constitucional, p. 280. 
vista acadêmico. Deve haver, deste modo, um certo equilíbrio entre semelhanças e diferenças na escolha da base de comparação, pois ambas são necessárias a um estudo comparativo. ${ }^{21}$

Nesse sentido, acredita-se que os dois sistemas constitucionais de repartição de competências considerados nessa pesquisa apresentam semelhanças suficientes a ponto de justificar a pertinência de um estudo comparado, ao mesmo tempo que possuem diferenças sensíveis entre si. Conforme observa Fernanda Dias Menezes de ALMEIDA, ${ }^{22}$ ambos os textos constitucionais em comento operaram uma separação entre competências legislativas e não legislativas. Na constituição brasileira, essa distinção é mais bem percebida pela análise conjunta dos artigos 21 e 22, dedicados respectivamente à competência geral e à competência legislativa privativa da União, e dos artigos 23 e 24, que tratam da competência comum e da competência legislativa concorrente da União, dos Estados-membros e dos Municípios. Na constituição alemã, todavia, essa divisão assume uma amplitude maior e só pode ser corretamente compreendida por meio de um confronto entre a parte que cuida das competências legislativas (artigos 70 a 75) e aquela que cuida da execução das leis federais e da administração federal (artigos 84 a 91), do qual se extrai a não coextensividade entre a titularidade das competências legislativas e de execução nesse ordenamento jurídico. ${ }^{23}$ Há, por outro lado, uma grande semelhança nas redações dos artigos 22, parágrafo único, $\mathrm{CF} / 88$ e 71 GG, uma vez que estes dois dispositivos permitem que uma lei autorize os Estados a

\footnotetext{
21 A ideia trabalhada nesse parágrafo encontra alguma correspondência na ideia de comparabilidade, trabalhada no Brasil por JOSÉ AFONSO da Silva. Segundo este autor, "a comparabilidade é um pressuposto básico da comparação jurídico-constitucional, porque sem ela esta não tem cabimento. Ela se fundamenta na existência de elementos comuns relativamente às instituições, às funções, aos resultados, pertencentes aos ordenamentos objeto da comparação (...) 'não se deve jamais partir de uma identidade ou equivalência existente no plano linguístico para concluir por uma identidade ou equivalência no plano jurídico, pois, com efeito, numerosas diferenças de natureza técnica, estrutural, conceptual ou de efeito jurídico e até semânticas intervêm para separar entre si as funções equivalentes" (JOSÉ AFONSO. um pouco de Direito Constitucional Comparado, pp. 39-40). Em outras palavras, a comparabilidade remete à necessidade de uma uniformidade dos objetos selecionados para comparação (ou simplesmente, base de comparação), como forma de facilitar e viabilizar a análise comparativa. Conforme observa Gerhard DANNEMANN, quanto mais parecidos são os objetos comparados, maior a possibilidade e o número de relações de causa e efeito que poderão ser traçadas (Gerhard DANEMANN. Comparative Law: study of similarities or differences? In: Reinhard ZIMMERMANN, Mathias REIMANN (Coord.). The Oxford Handbook of comparative law. Oxford: Oxford University Press, 2006, p. 408).

22 ALMEIDA. Competências na Constituição de 1988, p. 76.

${ }^{23}$ Ou seja, o fato de a União ser competente para legislar privativamente sobre uma matéria não significa que ela será competente para a sua execução por intermédio de estrutura administrativa própria, já que esta é uma atribuição dos Estados-membros nos termos do artigo 83 GG (com a seguinte redação: "os Estados executam das leis federais como assunto próprio, à medida que esta Lei Fundamental não determine ou permita de outro modo" - tradução livre). São, na verdade, poucas matérias atribuídas à Administração Pública Federal, como se pode perceber da leitura do artigo 86 e seguintes GG.
} 
legislarem sobre matérias de competência legislativa privativa da União. ${ }^{24}$ Existe, ainda, alguma correspondência entre o artigo $24 \mathrm{CF} / 88$, que trata das competências concorrentes, e o artigo 75 GG, revogado em 2006, que dispunha sobre a legislação-moldura (Rahmengesetzgebung). Note-se, todavia, que os artigos alemães mencionados são mais detalhados que os artigos brasileiros, o que pode trazer algumas consequências relevantes do ponto de vista do exercício dessas competências.

Além disso, a comparação proposta nesta tese também se justifica do ponto de vista da sua utilidade acadêmica. Por certo, a Alemanha consiste em um bom parâmetro para se avaliar o federalismo brasileiro recente. Ao erigir a Alemanha a "parâmetro" não se pretende considerar este ordenamento jurídico, no que tange a repartição constitucional de competências, um modelo que deve ser seguido pelo Brasil a qualquer custo. Muito pelo contrário, esta avaliação se revela especialmente frutífera não só porque a federação brasileira padece de problemas, mas principalmente porque a federação alemã também enfrenta as suas dificuldades, entre elas a excessiva centralização e a intensa interdependência política oriunda de um complexo sistema de distribuição e partilha de atribuições entre os entes federativos. Pretende-se, deste modo, combater uma percepção razoavelmente difundida no meio jurídico brasileiro de que a "excessiva" centralização, em especial no plano normativo, teria "descaracterizado" a federação brasileira como tal e que, por isso, o federalismo brasileiro teria se tornado um objeto de estudo irrelevante ou de importância reduzida para a ciência jurídica. A Alemanha, que é uma federação centralizada e vive às voltas com os problemas oriundos de uma excessiva cooperação federativa, demonstra que o debate brasileiro não pode ser conduzido a partir desta premissa de desnaturação da federação. ${ }^{25}$

A despeito disso, não se pode deixar de reconhecer que o ordenamento jurídico alemão concebeu soluções interessantes para litígios que envolvem a repartição de competências - como, por exemplo, o princípio da lealdade federal (Bundestreue) e a qualificação competencial de uma lei (kompetenzrechtliche Qualifikation eines Gesetzes) as quais poderiam ser de alguma utilidade para resolver problemas brasileiros. E como a busca de soluções estrangeiras para problemas domésticos é outra finalidade comumente

\footnotetext{
24 É importante lembrar que o dispositivo brasileiro exige uma lei complementar e autoriza os Estados a legislarem somente sobre questões específicas das matérias nele especificadas, ao passo que a regra inscrita no texto alemão parece autorizar os Estados a legislarem sobre todas as questões arroladas no artigo 73 GG, caso a lei federal autorize expressamente. Esta é, contudo, uma confrontação que será levada a cabo somente no item 6.4.1 da tese.

${ }^{25}$ Este, por sua vez, é um argumento que será desenvolvimento com maiores detalhes no terceiro capítulo da tese.
} 
atribuída à comparação jurídica, a presente tese investiga em que medida algumas dessas construções alemãs poderiam solucionar problemas brasileiros em matéria de repartição de competências. Aliás, na exposição das linhas gerais destes institutos e na análise da sua aplicabilidade ao caso brasileiro reside, por sua vez, a principal contribuição original que a presente tese traz à ciência jurídica brasileira.

Acredita-se ainda que a análise comparativa nos termos propostos nesta introdução fornecerá alguns subsídios importantes para a construção de uma teoria geral da repartição de competências. Afinal, como observa Josef ISENSEE, embora uma parte razoável das constituições que adotam a forma de Estado Federal seja dedicada ao tema da repartição de competências, são poucas as disposições de caráter geral ou mesmo as disposições que determinam como as competências devem ser exercidas. Assim, do mesmo modo como aconteceu com os direitos fundamentais, seria necessária a criação de uma teoria dogmática da repartição de competências, que seja capaz de fornecer um tratamento unitário e integrado às diversas normas esparsas que tratam deste tema na constituiç̧ão, a fim de fornecer uma solução comum a problemas como: colisão de competências; limites da interpretação das competências; a possibilidade de disposição unilateral ou concertada de uma competência por parte de um ente federativo e assim por diante. ${ }^{26}$

\section{CONSIDERAÇÕES SOBRE O MÉTODO COMPARATIVO}

De todo o exposto, é possível deduzir a filiação da presente tese ao método comparativo, razão pela qual torna-se necessário um breve diálogo com alguns problemas que um estudo jurídico-comparativo costuma suscitar.

Ao se debruçar sobre o direito comparado, percebe-se que este não é um ramo monolítico, informado na sua totalidade pelas mesmas premissas e pelos mesmos objetivos. Ao contrário, atualmente o direito comparado comporta pelo menos quatro abordagens distintas - o funcionalismo, a história jurídica comparada (comparative legal history), o estudo dos transplantes e recepções jurídicas (transplants and receptions) e o estudo

\footnotetext{
${ }^{26}$ Josef ISENSEE. § 133. Die bundesstaatliche Kompetenz. In Josef ISENSEE, Paul KIRCHHOF (Hrsg). Handbuch des Staatsrechts der Bundesrepublik Deutschland. Volume VI: Bundesstaat. 3a Ed. Heidelberg: C. F. Müller, 2008, pp. 458-460. Por óbvio, a presente tese propõe um estudo comparativo das normas que disciplinam a repartição de competências legislativas e materiais no Brasil e na Alemanha e não uma teoria geral da repartição de competências. Ao contrário, o objeto escolhido e os problemas aos quais a presente tese deseja dar uma solução inviabilizam tal empreitada. Deseja-se apenas deixar consignado que os resultados desta investigação podem fornecer subsídios à criação de tal teoria, uma vez que o direito comparado é considerado pelo próprio Josef ISENSSE um caminho propício ao seu desenvolvimento ( $\S 133$. Die bundesstaatliche Kompetenz, p. 459).
} 
comparado das culturas jurídicas (comparative legal culture $)^{27}$ - sendo que o funcionalismo é certamente a mais conhecida e a mais debatida delas. Nesse ponto, concordamos com Ralf MICHAELS ao afirmar que "o método funcional tornou-se tanto o mantra quanto a bête noire do direito comparado" 28 ; talvez por isso, qualquer pesquisa que pretenda se utilizar de noções desse ramo do Direito se vê invariavelmente às voltas com as noções de função ou de presumptio similitudinis, ainda que seja para refutá-las.

A presente tese, contudo, não se filia de um modo expresso a nenhum destes enfoques do direito comparado e, portanto, não adota nenhum dos mecanismos explicativos das semelhanças e diferenças que normalmente lhes acompanham. ${ }^{29}$ Propõe-se, portanto, a

${ }^{27}$ Como observa Ralf MICHAELS. The functional method of comparative law. In: Reinhard ZIMMERMANN, Mathias REIMANN (Coord.). The Oxford Handbook of comparative law. Oxford: Oxford University Press, 2006, p. 341. Para um panorama dos debates mais atuais do direito comparado, vide Reinhard ZIMMERMANN; Mathias REIMANN (Coord). The Oxford Handbook of comparative law. Oxford: Oxford University Press, 2006.

${ }^{28}$ MICHAELS. The functional method, p. 340. Como o próprio nome sugere, é a ideia de função que ocupa o papel de destaque no enfoque funcionalista do direito comparado. Nesse sentido, Konrad ZWEIGERT e Hein KÖTZ, considerados os maiores expoentes desta corrente, partem do pressuposto de que todos os ordenamentos jurídicos vivenciariam basicamente os mesmos problemas e produziriam os mesmos resultados na sua resolução, embora quase nunca o fizessem pelos mesmos meios; caberia ao comparatista então se debruçar sobre problemas concretos e pesquisar, nos sistemas legais comparados, institutos que desempenhassem a mesma função. Segundo estes autores, somente instituições que tenham a mesma funcionalidade - isto quer dizer, que possuam entre si uma equivalência de funções - podem ser comparados entre si: afinal, "coisas incomparáveis não podem comparadas de forma útil, e no Direito as únicas coisas que são comparáveis entre si são aquelas que desempenham a mesma função" (Konrad ZWEIGERT, Hein KÖTZ. Introduction to Comparative Law. 3a Ed. Oxford: Clarendon Press, 1998, p. 34). É interessante notar que esta similitude de problemas e soluções também ocupa um papel de destaque na metodologia desenvolvida por ZWEIGERT e KÖTZ, tornando-se verdadeira praesumptio similitudinis ou presunção de similitude, com pelo menos duas utilidades práticas. A primeira delas, bem razoável, seria informar ao comparatista onde procurar semelhanças entre os ordenamentos jurídicos considerados. A segunda delas, mais controversa, transforma esta presunção em uma forma de testar os resultados obtidos pelo estudo comparativo: assim, caso o pesquisador "encontre diferenças substanciais ou resultados diametralmente opostos, ele deveria ficar alerta e checar novamente se os termos nos quais ele propôs a questão eram realmente puramente funcionais, e se ele alargou as suas pesquisas de forma abrangente e suficiente." (ZWEIGERT, KÖTZ. Introduction to Comparative Law, p. 40).

${ }^{29}$ É de se admitir, afinal, que a aproximação da presente tese à abordagem funcionalista do direito comparado seria de pouca ou nenhuma utilidade. Com efeito, um dos objetivos deste estudo comparativo consiste na avaliação crítica da federação brasileira à luz do caso alemão, o que implica necessariamente na valorização das semelhanças e também das diferenças entre os dois ordenamentos considerados e, consequentemente, em um aumento na complexidade da pesquisa. Já o funcionalismo - porque introduz a noção de função justamente para reduzir a complexidade existente e encontrar, deste modo, uma semelhança entre objetos e que é representada na equivalência de funções - não serve, entretanto, nem à avaliação e nem à crítica de sistemas jurídicos, como bem observa Ralf MICHAELS (The functional method, pp. 374-375). Outro enfoque de direito comparado cuja filiação poderia, em tese, conduzir a presente pesquisa a alguns resultados interessante é aquele que estuda os transplantes e as recepções jurídicas. Segundo Michele GRAZIADEI, a ideia de transplantes e recepções está sempre relacionada à transformação de um sistema jurídico, a qual pode se dar de três maneiras: (i) novos significados, oriundos de um ordenamento, podem ser atribuídos a instituições antigas de outro ordenamento; (ii) a apropriação de elementos estrangeiros, que passam a ser incorporados e associados a institutos domésticos e; (iii) finalmente, a apropriação de elementos estrangeiros, em relação aos quais se impõe a adoção de nova terminologias no sistema jurídico que incorpora a recepção ou o 


\section{retomada de uma concepção mais minimalista da comparação jurídica, preocupada} primordialmente com a análise das semelhanças e das diferenças entre os dois ordenamentos jurídicos considerados, sem a pretensão de valorá-las e compreendê-las à luz de construções teóricas forjadas no âmbito de uma das supramencionadas vertentes da comparação jurídica e sem a pretensão de forjar um novo enfoque ou vertente neste ramo do direito.

Quando se fala em minimalista, não se quer referir a uma versão empobrecida ou desguarnecida da comparação jurídica, tendo em vista que a confrontação dos ordenamentos jurídicos considerados pelo presente estudo continua, de todo modo, a se conformar a algumas das finalidades normalmente atribuídas ao direito comparado.

Nesse ponto, a doutrina que se debruça sobre o tema costuma atribuir à comparação as seguintes finalidades: (i) unificação da lei; (ii) resolução de problemas particulares; (iii) aplicação da lei estrangeira; (iv) escolha entre ordenamentos jurídicos; (v) compreensão do Direito. ${ }^{30}$ Três destes desígnios - mais precisamente, a unificação da lei, a aplicação da lei estrangeira, e a escolha entre ordenamentos jurídicos - apresentam extrema aderência às disciplinas do Direito Privado, razão pela qual são consideradas incompatíveis com a pesquisa. Contudo, as outras duas finalidades correspondem exatamente às questões principais do estudo comparativo proposto pela presente tese.

Em primeiro lugar, almeja-se compreender melhor o direito interno a partir de um direito alienígena ${ }^{31}$ : nesse sentido, já se afirmou alhures que um dos objetivos da pesquisa é

\footnotetext{
transplante (Michele GRAZIADEI. Comparative Law as the study of transplants and receptions. In: Reinhard ZIMMERMANN, Mathias REIMANN. The Oxford Handbook of comparative law. Oxford: Oxford University Press, 2006, pp. 461-463). Deve-se admitir que as inspirações do presente estudo comparativo, em um primeiro momento, foram as ponderações de alguns nomes proeminentes do direito constitucional brasileiro no sentido de que o sistema de repartição de competências legislativas e de execução inaugurado pela Constituição Federal de 1988 (CF/88) teria se inspirado na Lei Fundamental alemã de 1949. Porém, após se debruçar sobre estas considerações com mais calma e de analisar a evolução da competência legislativa concorrente - que teria sido o instituto brasileiro transplantado do direito alemão pelo direito brasileiro concluiu-se que não se poderia afirmar a ocorrência de um transplante ou de uma recepção. De todo modo, diante da difusão deste argumento na doutrina brasileira, optou-se por dedicar algumas linhas ao assunto no tópico 6.1 desta tese. Finalmente, as outras correntes do direito comparado mostraram-se igualmente inadequadas à pesquisa, ou porque nada acrescentavam ao desenvolvimento com as suas questões centrais, ou porque eram com elas incompatíveis.

30 Sobre os possíveis propósitos da comparação jurídica, vide DANNEMANN. Comparative Law, pp. 401 e ss.

${ }^{31}$ A compreensão acerca do direito interno a partir de um ordenamento alienígena é, aliás, uma finalidade comumente atribuída à comparação independentemente da corrente à qual se filia. Konrad ZWEIGERT e Hein KÖTZ, por exemplo, consideram que "o objetivo primordial da comparação jurídica, como ocorre com todas as ciências, é o conhecimento" (ZWEIGERT, KÖTZ. Introduction to Comparative Law, p. 15). No âmbito da doutrina jurídica brasileira - apenas para ficar com um dos estudos mais conhecidos que maneja a comparação em uma temática de Direito Constitucional - cita-se OSCAR VILHENA Vieira. Supremo Tribunal Federal: Jurisprudência Política. 2a Ed. São Paulo: Malheiros, 2002, p. 48.
} 
justamente avaliar o federalismo no Brasil - especialmente, a federação brasileira vigente à luz do caso alemão, levando em consideração tanto as semelhanças quanto as diferenças entre os ordenamentos jurídicos nesse ponto.

Em segundo lugar, pretende-se buscar no caso alemão alguns subsídios para a superação do que, em nossa opinião, é uma das grandes insuficiências do modelo jurídicodogmático de repartição de competências no Brasil: embora seja este relativamente sólido, ele não se coloca a serviço da resolução dos problemas concretos que são colocados aos Poderes Legislativos federais e estaduais (e municipais, no caso do Brasil) no momento da edição de leis de sua competência e, principalmente, ao Poder Judiciário quando julga questões afetas.

Note-se que a afirmação da compatibilidade das questões principais da pesquisa com as finalidades normalmente atribuídas ao direito comparado não resolve todos os impasses que cercam um estudo comparativo. Ao contrário, é preciso esclarecer ainda o que é a semelhança e a diferença a ser averiguada no confronto entre os ordenamentos jurídicos brasileiro e alemão.

Na linguagem corrente, semelhança é conceito que exprime, entre outras coisas, uma "relação entre seres, coisas ou ideias que apresentam entre si elementos conformes, além daqueles comuns à espécie". ${ }^{32}$ Percebe-se, portanto, que semelhança é noção que busca sempre traçar uma relação de objetos, a qual é intermediada por um parâmetro - que pode ser uma propriedade ou um elemento constitutivo - com base na qual dois ou mais objetos são confrontados. Na seara do direito comparado, este parâmetro é denominado comumente de tertium comparationis: pode-se afirmar, nesse sentido, que Brasil e Alemanha (objetos de comparação) assemelham-se quanto à forma de Estado, porém não quanto à forma de governo (tertia comparationis). Contudo, há de se reconhecer, com Nils JANSEN, que para se afirmar uma semelhança não basta verificar a ocorrência do parâmetro nos objetos comparados, pois esta semelhança ainda contém em si o germe da diferença: com efeito, se é verdade que dois objetos $a$ e $b$ podem ser semelhantes porque comungam de uma mesma propriedade, a intensidade desta última em $a$ e $b$ também pode variar. Portanto, a genuína semelhança somente aparece se, além de $a$ e $b$ possuírem a propriedade erigida a tertium comparationis, eles também a possuírem no mesmo grau. ${ }^{33}$

\footnotetext{
${ }^{32}$ AURÉLIO Buarque de Holanda Ferreira, Margarida DOS ANJOS, Marina Baird FERREIRA. Aurélio século XXI: o dicionário da língua portuguesa. 3a Ed. Rev. Rio de Janeiro, 1999, p. 1832.

33 Nils JANSEN. Comparative Law and Comparative Knowledge. In Reinhard ZIMMERMANN, Mathias REIMANN (Coord.). The Oxford Handbook of comparative law. Oxford: Oxford University Press, 2006, p. 311-312.
} 
O presente estudo comparativo aproxima-se destas noções do que é semelhante e diferente e trabalha com uma similaridade fundamental que revela ao mesmo tempo o tertium comparationis escolhido, a saber: o fato de os dois ordenamentos considerados possuírem um sistema de repartição de competências que trabalha com as dicotomias competência legislativa/competência de execução, de um lado, e competência privativa/competência concorrente, de outro. A partir desta constatação, parte-se para a elaboração de relações menores de semelhança e de diferença, as quais levarão em conta por vezes a maior ou menor aptidão para a descentralização política, para a coordenação federativa, ou qualquer outra qualidade que se mostre relevante para a pesquisa, sendo certo que os critérios utilizados para aferi-las serão fornecidos caso a caso.

Feitas estas considerações, parte-se finalmente para a elaboração de algumas considerações acerca das etapas ou fases da comparação jurídica. Há, de certo modo, um consenso na doutrina de que uma análise comparativa comporta três momentos distintos: no primeiro deles, o pesquisador seleciona os objetos que serão comparados entre si; após, ele analisa cada objeto separadamente, com a finalidade de compreender seus diversos aspectos e contextos; na terceira e mais importante fase, o pesquisador procede à análise das semelhanças e das diferenças encontradas de acordo com os propósitos por ele erigidos (p. ex. a elaboração de um sistema, a explicação das diferenças e das semelhanças encontradas ou a constatação de que parte de um sistema jurídico foi recepcionado por outro). ${ }^{34}$

Alguns pretendem enxergar nestas fases um rígido modelo a ser seguido; outros preferem, contudo, tratá-las com alguma elasticidade, adaptando-as aos objetos selecionados e aos objetivos da pesquisa ${ }^{35}$. De todo modo, estas etapas parecem um norte seguro àquele que inicia um estudo comparativo: afinal, não se pode iniciar um estudo comparativo sem antes realizar uma opção a respeito de quais objetos serão confrontados; também não se

\footnotetext{
${ }^{34}$ Como observa DANNEMANN. Comparative Law: study of similarities or differences?, p. 406.

35 O primeiro destes posicionamentos é encampado no Brasil por JOSÉ AFONSO da Silva, para quem "o método do direito constitucional comparado, como o de qualquer outro ramo do direito comparado, 'consiste em conduzir um estudo comparativo por três fases sucessivas', que a doutrina chamada de 'regra dos três C', que são: Conhecer, Compreender e Comparar. As três fases devem desenvolver-se na ordem indicada, porque são solidárias e complementares, cada uma delas constitui a preparação necessária e etapa preliminar da fase seguinte" (um pouco de Direito Constitucional Comparado, p. 42). Já Gerhard DANNEMANN parece se filiar ao segundo posicionamento ao discutir a questão da semelhança e da diferença nos estágios ou passos da investigação comparativa. Segundo este autor, "não pode existir obviamente nenhuma estrutura uniforme que se adapta a todos os tipos, mas a maioria das investigações comparativas envolverá três grandes estágios: seleção (do que será comparado), descrição (da lei e do seu contexto nos sistemas legais levados em consideração), e análise (...) Nem todos esses passos aplicam-se a qualquer investigação" (DANNNEMANN. Comparative law: study of similarities or differences?, p. 406)
} 
afigura razoável valorar semelhanças e diferenças sem antes compreender cada objeto, analisando seus pormenores e peculiaridades.

A presente pesquisa não foge à regra e também segue estes passos apontados pela literatura de direito comparado. Todavia, é de se reconhecer que estes passos não estão refletidos no texto da tese. Ou seja, não se dedica uma parte da tese à análise isolada dos sistemas brasileiro e alemão de repartição de competências, contextualizando-os, para ao final realizar uma valoração das semelhanças e das diferenças encontradas. Ao contrário, opta-se primeiro por contextualizar as federações brasileira e alemãs, confrontando-se aspectos desta análise já no terceiro capítulo, para então tratar cada sistema de repartição de competências primeiro de forma separada, no quarto e no quinto capítulos. Somente a partir do sexto capítulo é que serão expostas as semelhanças e as diferenças no que diz respeito ao modo pelo qual a Constituição Federal de 1988 e a Lei Fundamental de 1949 repartem competências legislativas e de execução entre União, Estados e Municípios. Nesse ponto, acolheu-se sugestão da comissão julgadora do exame de qualificação realizado em 11 de outubro de $2012 .{ }^{36}$ Note-se, contudo, que esta é uma opção que se faz somente no plano da exposição dos resultados obtidos pela pesquisa, e não reflete uma alteração no modo de proceder da pesquisa, o qual segue as mencionadas etapas da comparação.

Feitas estas considerações, parte-se para a exposição do plano da obra, com a apresentação das principais teses a serem desenvolvidas em cada capítulo e dos motivos que nortearam a sua elaboração.

\section{PLANO DA OBRA}

A presente tese é o resultado de uma análise comparativa que se debruça sobre dois problemas centrais, que encontram estreita correspondência com as finalidades ou propósitos da pesquisa e também com o seu viés dogmático. $\mathrm{O}$ primeiro deles corresponde ao modo pelo qual é avaliado o federalismo brasileiro quando se trata da repartição de competências legislativas e de execução: trata-se de uma promessa não concretizada de descentralização legislativa e administrativa, como pretendem alguns? Em segundo lugar, há no ordenamento alemão construções doutrinárias e/ou jurisprudenciais que podem ser aplicadas ao caso brasileiro com alguma vantagem do ponto de vista da decidibilidade de conflitos?

A fim de responder a estes questionamentos, estruturou-se exposição dividida em duas partes, sendo que a primeira delas tem três capítulos e a segunda parte contará com

\footnotetext{
${ }^{36}$ Agradecemos especialmente ao Prof. Dr. Roger Stiefelmann Leal, pelos comentários feitos sobre as diferentes possibilidades de exposição dos resultados do estudo comparativo.
} 
quatro capítulos. A primeira parte será dedicada à exposição de alguns pressupostos teóricos que permearão toda a pesquisa e das notas distintivas das federações brasileira e alemã, ao passo que a segunda parte inaugura o estudo comparativo propriamente dito, com o confronto dos sistemas brasileiro e alemão de repartição de competências.

A primeira parte da tese justifica-se diante da constatação de que o federalismo é um tema multidisciplinar e cujas características e condições são objeto de discussão em diversas áreas do conhecimento. Tal fato torna imprescindível, por um lado, a explicitação dos pressupostos teóricos dos quais a pesquisa parte e, por outro lado, a contextualização de cada uma das federações analisadas, o que pode ser feito do ponto de vista político, social, econômico, cultural, entre outros. Neste último ponto, optou-se nesta tese por traçar um panorama das federações brasileira e alemã sem se aprofundar em um ou outro contexto, embora se privilegie considerações de índole histórica, tendo em vista a especial ligação entre direito constitucional e história constitucional. Admite-se que tal enfoque pode deixar muitos aspectos importantes de lado. Contudo, tal como ocorre com as premissas teóricas, não se trata de destrinchar cada um dos contextos nos quais as federações consideradas estão envoltas: ao contrário, como esta também é uma temática cercada de discussões e controvérsias, trata-se apenas de explicar o posicionamento desta tese em relação a um ou outro debate.

No primeiro capítulo, portanto, pretende-se trabalhar com alguns conceitos, noções, categorias e classificações da teoria do federalismo que são fundamentais para a compreensão do raciocínio desenvolvido nos próximos capítulos em seis tópicos ou itens. No primeiro deles serão retomados alguns aspectos do debate conceitual em torno das expressões federalismo e federação, a fim de traçar a distinção entre uma e outra e forjar o conceito de federação que será utilizado nesta tese. Já o tópico 1.2, por sua vez, será dedicado à exposição dos principais contornos do que se convencionou chamar de federalismo dualista e federalismo cooperativo, uma vez que consistem em duas tipologias que influenciam tanto o debate brasileiro quanto o alemão. A seguir, a tese de debruça sobre o tema da centralização e da descentralização a partir da distinção entre federalismo e federação traçada no primeiro item: de fato, existe uma diferença substancial, por um lado, entre a centralização e a descentralização que efetivamente se deseja em uma federação e, por outro lado, entre a centralização e a descentralização que são objetivamente observáveis em um Estado Federal.

O cerne do primeiro capítulo, contudo, concentra-se nos tópicos 1.4 e 1.5, dedicados ao estudo da competência e das suas classificações de um ponto de vista teórico. Assim, a competência será tratada não só como uma forma de delimitar a atuação estatal e atribuí-la a um ente federativo em detrimento de outros, mas também a partir da sua função de 
contenção do poder estatal e de internalização de litígios federativos pelo Direito. As classificações, por sua vez, não serão consideradas tipologias meramente didáticas, tendo em vista que tanto a constituição brasileira quanto a alemã manejam algumas delas, em especial, as competências legislativas e de execução (ou competências administrativas, como são conhecidas no direito alemão) bem como as competências privativas e concorrentes. Finalmente, o tópico 1.6 é dedicado à exposição de algumas considerações sobre a representação das unidades regionais (os Estados-membros no caso da federação brasileira e os Länder do caso da federação alemã) no plano federal, e também sobre as cortes constitucionais, como instituições que podem influenciar e até mesmo conformar o relacionamento dos atores políticos em uma federação.

O segundo capítulo, por sua vez, será dedicado à contextualização das federações brasileira e alemã a partir de alguns prismas previamente selecionados, quais sejam: (i) sua evolução histórica; (ii) seus principais aspectos constitucionais; (iii) a questão da autonomia municipal, e; (iii) a representação dos Estados-membros no Poder Legislativo federal. Seguindo esta diretriz, a federação brasileira será analisada a partir da Constituição Federal de 1967/1969 e dos trabalhos da Assembleia Nacional Constituinte de 1987/1988. A seguir, parte-se para o estudo das linhas gerais da federação sob a égide da Constituição Federal de 1988. O terceiro tópico dedicado à contextualização da federação brasileira tratará da autonomia municipal, tanto em uma perspectiva histórica quanto a partir do atual tratamento constitucional do Município. Finalmente, encerra-se a exposição das linhas gerais do federalismo brasileiro com breves considerações sobre o papel do Senado Federal, em especial a crítica que lhe é dirigida no sentido de que as suas funções federativas restaram completamente descaracterizadas.

No que tange à federação alemã, a análise se inicia a partir da Constituição Imperial de 1871, que foi a primeira a consagrar uma federação nos moldes modernos, e da Constituição Imperial de 1919 (também conhecida como Constituição de Weimar), que representou um momento de centralização da estrutura federativa alemã mesmo antes da ascensão dos nazistas ao poder. Em seguida, a atenção se volta à federação forjada pela Lei Fundamental de 1949, com especial atenção na evolução do seu tratamento constitucional. Por fim, também se pretende examinar a questão da autonomia municipal na federação alemã e o papel de proeminência assumido pela instância representativa dos Länder neste país.

O terceiro capítulo promoverá um breve balanço do que foi discutido até o momento ao retomar alguns pressupostos teóricos discutidos no primeiro capítulo à luz do que foi discutido no segundo capítulo, e também ao analisar a experiência federativa no Brasil e na Alemanha em uma perspectiva comparada. Deste modo, no tópico 3.1 pretende- 
se contextualizar a federação, de um ponto de vista teórico, diante do fenômeno da centralização. Embora este último seja verificado em muitas federações atualmente existentes, ele conduziu a um discurso negacionista por parte da doutrina jurídica brasileira: defende-se, assim, que o Brasil vivenciaria um federalismo nominal, pois o que se verificaria na prática seria um verdadeiro Estado Unitário. Entretanto, como se terá a oportunidade de expor, esta é uma concepção que se baseia em um modelo dualista de federação, bastante criticado pela literatura especializada, mas que infelizmente está na base do relativo desinteresse com o qual o federalismo é tratado por uma vertente mais contemporânea do direito constitucional. No tópico 3.2, por sua vez, procura-se efetivamente confrontar alguns aspectos da evolução das federações brasileira e alemã, a fim de verificar semelhanças e diferenças que podem influir na compreensão dos dois sistemas de repartição de competências considerados. Em especial, pretende-se analisar a questão da formação das federações brasileira e alemã, a centralização e a cooperação federativas nelas verificadas. Finalmente, no tópico 3.3 a repartição de competências será situada como o elemento central da teoria jurídica do federalismo. Embora este seja um argumento que se deixa subentender no tópico 1.4, acredita-se ser importante desenvolvê-lo antes de adentrar no estudo comparativo propriamente dito. Afinal, a repartição de competências consiste no tertium comparationis elegido pela presente pesquisa e corresponde, para falar com Nils JANSEN, a uma escolha do pesquisador sobre aquilo que efetivamente importa ser comparado em uma federação. ${ }^{37}$

O quarto capítulo inaugura o estudo comparativo propriamente dito e pretende fornecer um panorama da repartição de competências legislativas e de execução levada a cabo pela Constituição Federal de 1988, artigo por artigo. Deste modo, o que efetivamente se propõe é a análise dos seguintes temas, sendo que cada um deles corresponde a um subtópico: (i) a competência geral da União (artigo 21 CF/88); (ii) a competência legislativa privativa da União (artigo $22 \mathrm{CF} / 88$ ); (iii) a competência comum da União, Estadosmembros e Municípios (artigo $23 \mathrm{CF} / 88$ ); (iv) a competência legislativa concorrente da União e dos Estados-membros (artigo 24 CF/88); (v) a competência privativa dos Estadosmembros (parágrafos do artigo $25 \mathrm{CF} / 88$ ), e; (vi) a competência dos Municípios (artigo 30 $\mathrm{CF} / 88)$.

O quinto capítulo, por sua vez, repete a proposta do capítulo anterior ao propor um quadro da repartição de competências legislativas e administrativas na Alemanha, estruturando-se em sete subitens, nos quais serão abordados as seguintes temáticas: (i) regra

37 JANSEN. Comparative Law and comparative knowledge, pp. 314-315. 
geral em matéria de repartição de competências legislativas (artigo 70 GG); (ii) a competência legislativa privativa da União (artigo 71GG); (iii) a competência legislativa concorrente do Bund e dos Länder (artigos 72 e 75 GG); (iv) regra geral em matéria de repartição de competências administrativas (artigo 83 GG); (v) a competência administrativa dos Estados (artigos 84 e 85 GG); (vi) a competência administrativa da União (artigos 86 e seguintes ,GG), e; (vii) as tarefas comuns (Gemeinschaftsaufgaben).

Note-se que, nos subitens tanto do quarto quanto do quinto capítulo, se objetiva efetivamente fornecer uma compreensão dos dispositivos constitucionais analisados dentro do seu próprio contexto. Isto, por sua vez, significa que, de acordo com as delimitações já enunciadas nesta introdução, cada norma competencial terá o seu sentido e o seu alcance explicitado a partir das considerações da doutrina que se debruça sobre o tema e, ocasionalmente, da jurisprudência constitucional pertinente. Uma compreensão global dos sistemas brasileiro e alemão de repartição de competências em uma perspectiva comparada é algo que, por sua vez, será empreendido em um momento posterior, mais precisamente, no sexto e no sétimo capítulos da tese.

No sexto capítulo confrontam-se pela primeira vez os sistemas brasileiro e alemão de repartição de competências em quatro subitens. O primeiro deles, contudo, é dedicado a uma importante questão preliminar, vale dizer, de saber como o enfoque dos transplantes e das recepções influencia a presente tese. Nesta introdução já se teve a oportunidade de ressaltar a opção por uma vertente mais minimalista da análise comparativa, preocupada primordialmente com a identificação de semelhanças e diferenças entre os ordenamentos jurídicos considerados. Contudo, não se pode deixar de reconhecer que a partir do momento em que se analisa a aplicabilidade de soluções alemãs ao caso brasileiro não está a se propor outra coisa que um transplante jurídico, surgindo então a necessidade de estudar com maior afinco este enfoque do direito comparado. Propõe-se esta análise já no início do sexto capítulo, pois se está diante de um pressuposto teórico relevante para a compreensão dos resultados discutidos a seguir. Já no tópico 6.2 pretende-se discutir a importância das regras gerais em matéria de repartição de competências, as quais são abundantes no direito alemão em comparação com o brasileiro, ponderando o seu papel na interpretação das demais normas que atribuem competência e o seu papel no preenchimento de lacunas. A seguir, estrutura-se a confrontação propriamente dita dos sistemas brasileiro e alemão de repartição de competências em dois subtópicos a partir das duas dicotomias que informam o estudo comparativo de um ponto de vista teórico. Deste modo, no item 6.3 pretende-se analisar o modo pela qual a Constituição Federal de 1988 e a Lei Fundamental de 1949 delimitam e 
repartem competências legislativas e de execução, ao passo que no item 6.4 o foco residirá nas competências privativas e concorrentes.

O sétimo e último capítulo, por sua vez, é dedicado à análise de algumas questões da repartição de competências sob uma perspectiva comparativa. Note-se que o objetivo aqui é analisar apenas algumas e não todas as questões que comportam tal enfoque, mesmo porque isso demandaria esforços que certamente extrapolam os limites de uma pesquisa individual, como é o caso de uma tese de doutorado. Reconhece-se que a seleção contém algo de subjetivo, mas não se deixa de contemplar aspectos importantes, os quais efetivamente prestam uma contribuição original à pesquisa jurídica brasileira. Estruturou-se a exposição em seis subtópicos, cada um dedicado ao estudo dos seguintes temas: (i) a qualificação competencial da lei e questões afetas; (ii) o princípio da lealdade federal aplicado à repartição de competências, e; (iii) algumas questões municipais sob uma perspectiva comparada.

\section{OBSERVAÇÕES FINAIS}

Antes de se adentrar na pesquisa propriamente dita, é necessário fazer as seguintes ponderações de índole eminentemente formal.

Em primeiro lugar, as obras mencionadas repetidas vezes ao longo da tese serão sempre citadas de forma completa a primeira vez e, nas demais vezes, apenas por meio do prenome ou sobrenome pelo qual o autor é mais conhecido, acrescido de uma parte do título. Evitam-se, assim, expressões como op. cit, idem, ibidem, passim..., as quais por vezes dificultam a compreensão acerca do autor e da obra que são citados.

Em segundo lugar, as traduções de textos em inglês e em alemão foram feitas de forma livre, de modo a deixar o texto em português o mais harmônico possível. Esta é uma observação importante principalmente em relação à língua alemã, que trabalha com algumas estruturas gramaticais e linguísticas estranhas à língua portuguesa. Por isso, não é de se esperar nas traduções um espelho, uma tradução palavra por palavra do texto original. A despeito disso, preservou-se o sentido que o autor citado pretendeu imprimir no trecho traduzido. ${ }^{38}$

\footnotetext{
${ }^{38}$ Quanto a este ponto, a presente tese se alinha às ponderações feitas por António Francisco de SOUSA no seguinte trecho de sua obra: "nunca uma tradução literal assegurará uma boa tradução, especialmente em certas áreas do direito. Isso não impede, no entanto, que o texto de chegada se mantenha o mais possível leal ao texto de partida no que ele diz expressamente e no que o seu autor pretendeu dizer por meio dele. Mesmo tendo de assegurar a maior fidelidade ao texto de partida, em muitos casos o trabalho de 'reformulação e
} 
Em todo caso, a fim de sanar quaisquer dúvidas sobre este assunto, optou-se por transcrever no original, em nota de rodapé, todas as citações diretas em alemão que foram por nós traduzidas no corpo do texto. Prescinde-se deste procedimento nas traduções feitas do inglês, porque se considera que esta última oferece menores dificuldades. Quando o texto se referir a traduções oficiais ou empreendidas por outrem, tal fato também será elucidado em nota de rodapé.

Em terceiro lugar, a tese trabalha com diferentes redações de alguns dispositivos da Lei Fundamental de 1949. Ao invés de traduzi-los e transcrevê-los toda vez que são citados em nota de rodapé, elaborou-se um anexo no qual constam os artigos mais importantes, suas sucessivas redações e a tradução de cada um deles, e que poderá ser consultado a cada vez que a tese a eles se referir.

Aliás, cumpre fazer um esclarecimento importante sobre o modo pelo qual os dispositivos da Lei Fundamental alemã serão citados. Trata-se de um diploma estruturado em artigos, os quais se subdividem, por sua vez, em parágrafos, sendo comum ainda a menção aos períodos contidos nestes últimos. A doutrina e jurisprudência alemãs, quando querem fazer referência a uma norma contida em um período específico, costumam citá-lo do seguinte modo: Art. 84 Abs. 1 S. 1 GG, sendo que Abs. consiste em uma abreviação de Absatz (que pode ser traduzido para o português como parágrafo) e S. remete à palavra Satz (traduzível como frase ou período). Outra forma de citar o mesmo dispositivo - que não é tão comum, mas pode ser encontrada em textos jurídicos alemães ${ }^{39}$ - utiliza numerais romanos para designar os parágrafos e algarismos arábicos para indicar os períodos. Deste modo, o Art. 84 Abs. 1 S. 1 GG também pode ser citado como Art. 84 I 1 GG. A presente tese optou por esta segunda forma de citar os dispositivos da Lei Fundamental por considerala mais palatável ao leitor brasileiro, preservando-se de todo modo a abreviatura GG, que corresponde à abreviatura de Grundgesetz (ou Lei Fundamental, em português).

Em quarto lugar, o $\S 1^{\circ}$ do artigo $32 \mathrm{CF} / 88$ atribui ao Distrito Federal "as competências legislativas reservadas aos Estados e Municípios”. Ou seja, a cada vez que se faz referência a uma competência dos Estados-membros, o correto seria dizer competência

adequação' terá de ser significativo. O caso da tradução de textos sobre a organização administrativa na Alemanha para o português (...) é disto um bom exemplo (neste caso, 'adequação'). Porém, em caso algum o tradutor do texto jurídico pode cair no erro de trair o pensamento do autor, apenas pelo seu desejo de comunicar em um estilo mais acessível ao leitor. O tradutor não cumpre a sua obrigação quando não se mantém leal ao sentido e, quanto possível, à letra e a ao estilo do texto de partida" (António Francisco de SOUSA. Fundamentos da tradução jurídica alemão-português. São Paulo: Saraiva, 2014, p. 226).

39 Por exemplo, os comentários à Lei Fundamental organizados por Horst DREIER (Horst DREIER (Hrsg.). Grundgesetz - Kommentar. 2a Ed. Tübingen: Mohr Siebeck, 2008), que serão muito utilizados no decorrer desta tese, utilizam esta forma de citação. 
legislativa dos Estados-membros e do Distrito Federal. O mesmo ocorre em relação aos poderes legislativos reservados aos Municípios: ao invés de falar em competências legislativas dos Municípios tão somente, deve-se fazer também fazer a referência às competências dos Municípios e do Distrito Federal. Todavia, é de se reconhecer que, como o Distrito Federal, enquanto ente federativo dotado de competências, não assume uma maior relevância para a presente tese, opta-se por excluir a sua menção a cada oportunidade em que competências dos Estados-membros e dos Municípios brasileiros são analisadas, partindo-se do pressuposto de que esta observação será suficiente para deixar implícita a menção a este ente federativo onde se localiza a Capital Federal.

Em quinto e último lugar, como os julgados da corte constitucional alemã utilizados nesta tese foram extraídos do repertório Entscheidungen des Bundesverfassungsgerichts (BVerfGE), optou-se por citá-los do modo como fazem a doutrina e a jurisprudência alemãs, vale dizer, iniciando-se com a expressão $B V e r f G E$ seguida de três números separados por vírgulas e por parênteses. O primeiro destes números refere-se ao volume em que o julgado citado se encontra, ao passo que o segundo remete ao número da página em que a decisão utilizada se inicia. Finalmente, o terceiro número refere-se ao número da página em que é efetivamente encontrado o trecho mencionado pela tese ${ }^{40}$.

\footnotetext{
40 Por exemplo, BVerfGE 3, 407 (421) refere-se à página 421 do julgado que começa na página 407 do volume
} no 3 do referido repertório. 


\section{PARTE I - FEDERALISMO NO BRASIL E NA ALEMANHA: NOÇÕES GERAIS}

\section{PRIMEIRO CAPÍTULO - AlguMAS PREMISSAS TEÓRICAS}

\subsection{FEderalismo E FEDERAÇÃO: NOÇÕES}

\subsubsection{Considerações introdutórias}

À época da aprovação da Constituição norte-americana de 1787 pela população dos Estados, a expressão "federal" era utilizada para designar formas de associação federativa mais próximas da Confederação de Estados - em especial, a Confederação norte-americana de 1771. Um exemplo deste uso pode ser extraído da leitura do número 39 de $O$ Federalista, no qual James MADISON propõe uma discussão acerca das características federativas (vale dizer, confederativas) ou nacionais (isto é, federativas no sentido atual do vocábulo) do então novo governo a partir de cinco prismas. Assim, no tocante ao modo pelo qual seria criado, o governo a ser instaurado seria federal e não nacional, uma vez que a Constituição seria ratificada pela população de cada Estado considerado como entidade soberana e independente dos demais Estados, e não pela população dos Estados Unidos considerada como nação. Quanto às fontes dos poderes do novo governo, este apresentaria características tanto federativas quanto nacionais: enquanto que a Câmara Federal receberia seus poderes da nação norte-americana - seria nacional, portanto - os poderes do Senado decorreriam dos Estados-membros, como "sociedades políticas e com situações semelhantes", assumindo feições tipicamente federativas; o Poder Executivo reuniria tanto elementos federativos quanto nacionais, já que a sua eleição seria feita pelos Estados e também por meio de representantes nacionais. $\mathrm{O}$ governo ainda seria genuinamente nacional quanto ao exercício dos seus poderes, pois exerceria sua autoridade sobre os indivíduos e não sobre os Estados, como seria de se esperar em uma Confederação. No entanto, tal característica seria mitigada pela extensão desses poderes, os quais embora nacionais, seriam limitados a apenas alguns assuntos. Finalmente, no que tange à autoridade para efetuar emendas, o governo reuniria tanto características federativas - ao exigir mais do que a maioria e computar votos por Estados - como nacionais - ao não exigir unanimidade de votos para aprovação das alterações ao texto constitucional. ${ }^{41}$

${ }^{41}$ James MADISON. 39 - Republicanismo, nacionalismo e federalismo. In: Alexander HAMILTON; James MADISON; John JAY. O Federalista, Trad. Heitor Almeida Herrera. Brasília: Universidade de Brasília, 1984, pp. 331 ess. 
É certo que parte desta confusão terminológica inicial se encontra intrinsecamente ligada a um argumento perspicaz e bem desenvolvido pelos autores de O Federalista, qual seja, de que a Constituição norte-americana de 1787, apesar de significar uma grande centralização em relação à sistemática anterior, não teria ofendido o texto dos Artigos da Confederação de 1771 , como acusavam os seus opositores. ${ }^{42}$ De todo modo, o tempo consagrou a utilização da expressão "federal" - quando muito, seguida do adjetivo "moderno" ou "centralizado" - para designar o fenômeno surgido nos Estados Unidos da América a partir de 1787 e que se alastrou pelo mundo a partir do século XIX. Entretanto, no que consiste este "federalismo" - e, nesse ponto, pode-se dizer o mesmo das expressões correlatas "Federação" e "Estado Federal" - permanece uma questão polêmica na literatura especializada. A tentativa empreendida por James MADISON em O Federalista, embora louvável por ter sido pioneira, pode ser considerada no máximo um ponto de partida para as discussões que envolvem a definição do que seja federalismo - ou do que seja o federalismo moderno ou centralizado, como pretendem alguns.

Entre os autores que se dedicam ao estudo do federalismo, percebe-se uma certa relutância em se trabalhar com definições fechadas, tendo em vista a diversidade que o fenômeno federativo pode assumir na prática, o que certamente dificulta generalizações ínsitas à elaboração de qualquer definição. Todavia, este impasse inicial não obsta que estes autores efetivamente se debrucem sobre o federalismo; ao fazê-lo, estes mesmos autores não deixam de considerar algumas características e práticas comuns aos casos de estudo escolhidos. $^{43}$

De nossa parte, acreditamos ser impossível levar a cabo uma análise comparativa de federações sem ao menos expor as suas linhas gerais e notas distintivas. Contudo, como a presente tese propõe uma análise comparativa relativamente restrita - como já se teve oportunidade de explicitar, trata-se apenas da comparação entre os sistemas constitucionais de repartição de competências legislativas e de execução no Brasil e Alemanha - não temos a pretensão de oferecer uma definição universal, que englobe toda e qualquer federação, mas apenas de forjar uma noção em relação à qual Brasil e Alemanha possam se subsumir.

\footnotetext{
42 É o que se extrai inclusive da leitura do número 39 de O Federalista, cujos contornos foram expostos no parágrafo supra.

${ }^{43}$ Como observa Preston KING. Federalism and Federation. Baltimore: The John Hopkins University Press, 1982, p. 71. Para uma breve análise crítica das debate anglo-americano sobre o conceito de federalismo, vide Michael BURGESS. Comparative Federalism: Theory and Practice. Londres e Nova York: Routledge, 2006, pp. 10-49. Uma breve discussão acerca das definições mais difundidas na ciência política brasileira pode ser vista em Celina SOUZA. Federalismo: Teorias e Conceitos Revisitados. Revista Brasileira de Informação Bibliográfica em Ciências Sociais - BIB, São Paulo, no 65, 1o semestre/2008, pp. 27-48.
} 
Contudo, antes de adentrar nesta análise, deseja-se tecer algumas considerações sobre o sentido das expressões federalismo e federação. Com efeito, embora ambas tenham a descentralização territorial do poder como algo que lhes é ínsito, elas designam fenômenos distintos e, exatamente por isso, não podem ser usadas como sinônimos.

\subsubsection{Federalismo e federação}

A distinção entre federalismo e federação é algo instintivo, principalmente para aqueles que se debruçam sobre um ou sobre o outro como objeto de estudo. Contudo, colocar esta impressão em termos teóricos tem se revelado, no mais das vezes, uma tarefa um tanto quanto complexa. Sem a pretensão de esgotar o tema ou mesmo de desqualificar outras propostas oriundas da literatura especializada, a presente tese se vale do raciocínio desenvolvido por Preston KING em livro dedicado ao tema.

Segundo este autor, o federalismo seria uma noção a ser cindida em pelo menos dois aspectos. O primeiro deles, a ser designado pela expressão "federalismo", traduzir-seia em uma ideologia (tanto no sentido fraco quanto no sentido forte da expressão ${ }^{44}$ ), uma "filosofia política de diversidade-na-unidade", a qual poderia orientar a ação política no sentido da centralização, da descentralização ou mesmo da obtenção de um balanço federativo. ${ }^{45}$ Neste ponto, o pensamento de KING está em consonância com o de outros teóricos conhecidos do federalismo, como Ronald L. WATTS, para quem federalismo "é usado basicamente não como um termo descritivo e sim como um termo normativo e refere-se à defesa de governos em diferentes níveis, combinando elementos de shared-rule e regional self-rule". ${ }^{46}$ Já o segundo aspecto do federalismo, para o qual se reservaria a expressão federação, estaria relacionado a "uma questão de fato institucional, sem qualquer preocupação particular com promover ou criticar esta forma de unidade" 47, mais especificamente, "um arranjo institucional, sob a forma de um Estado soberano, e que se distingue de outros Estados somente pelo fato de que o seu governo central incorpora as unidades regionais no seu processo de decisão de acordo com algumas bases

\footnotetext{
${ }^{44}$ Para Preston KING, ideologia no sentido amplo ou fraco seria "um conjunto de ideias amplo e razoavelmente coerente que é invocado com a finalidade de mobilizar e direcionar a ação política de forma a servir um propósito relativamente específico" (KING. Federalism and Federation, p. 19), ao passo que ideologia em sentido restrito ou forte seria "um estilo de argumento universal o qual, enquanto é logicamente inume a criticismos, procura assegurar na prática tanto a mudança quanto a estagnação social (KING. Federalism and Federation, p. 20).

45 KING. Federalism and Federation, pp. 20-21.

46 WATTS. Comparing Federal Systems, p. 8.

${ }^{47}$ KING. Federalism and Federation, pp. 20-21.
} 
constitucionalmente consolidadas"48. Deste modo, é de se concluir que para KING, "federação" assume um viés eminente descritivo e fático, muito embora o autor não considere possível expurgar todos os elementos normativos de uma análise eminentemente fática e empírica. ${ }^{49}$

Note-se que empregar a expressão "federação" nos termos preconizados por KING oferece algumas dificuldades em uma pesquisa jurídica e dogmática, como a proposta por esta tese. Afinal, independentemente de como a realidade federativa se desenvolve, neste ramo do conhecimento a federação costuma ser enxergada a partir de pressupostos irrenunciáveis que pretendem descrever como a realidade deve ser. Se o jurista sempre tende a compreender a realidade em termos normativos, do mesmo modo, a "federação" também tende a se tornar uma noção revestida de normatividade, muito embora não possa ser por isso equiparada a uma ideologia - daí a necessidade de se persistir nesta cisão conceitual.

Este é, contudo, um impasse que pode ser resolvido de forma relativamente simples a partir da ligação que Preston KING traça entre federalismo e federação e que é bem resumida no seguinte trecho:

\begin{abstract}
"Nós consideraremos que federalismo é uma ou muitas variedades da filosofia política ou ideologia, e que federação é algum de tipo de instituição política. A intenção não é que tal distinção seja totalmente aceita, mas apenas que seja útil. Também não se pretende que filosofias/ideologias, de um lado, e instituições, de outro, sejam completamente diferentes, já que parece razoável pressupor que instituições são ou oriundas de filosofias/ideologias, ou as reflitam em um sentido mais vago (...) Bastará para os presentes propósitos dizer que uma instituição é apenas um complexo de práticas, que práticas são governadas por regras, que todas regras recomendam tipos de comportamento, e que tais recomendações são de vez em quando (e indiscriminadamente) rotuladas de 'ideológicas' ou 'filosóficas'."50
\end{abstract}

\footnotetext{
${ }^{48}$ KING. Federalism and Federation, p. 77.

${ }^{49}$ Nesse sentido, transcreve-se um trecho interessante do pensamento deste autor, em que ele argumenta como proposições normativas e empíricas não são e nem podem ser mutuamente excludentes: "to say that we ought to perform an act presupposes that we can. If the 'ought' is taken to be normative, and the 'can' to be empirical, it will be obvious that we cannot intelligibly issue normative pronouncements where we have no grasp of their related empirical underpinnings. On the other hand, if we seek only to describe the 'facts' whether in the singular on in general or universally - it is essential to recognize that facts are infinite, that none is self-evident, and that all are and can only be perceived within and in contrast to established perceptive categories. (We cannot meaningfully discuss the 'fact' of Everest without some prior convention about the meaning of 'mountain', nor the victory of President Reagan without some prior convention about the meaning of 'election'.). Categories of perception, however, are selective. They include, but also exclude. To apply them is to choose. Any act of choice may be subject to the pronouncement that it ought or ought not to be exercised. No newspaper prints all the facts. It prints some of the facts. It does not even have access to 'all the facts'. It has access only to some but must still choose which of these its editors regard as 'fit to print' The pursuit of any discovery, or pronouncement of any 'fact', in as far as it is necessarily subject to choice, cannot escape moral involvement merely by virtue of being 'factual'. It is not logically possible, therefore, to engage in normative or empirical pursuits in such a manner that he one may entirely exclude the other" (KING. Federalism and Federation, pp. 9-10).

50 KING. Federalism and Federation, p. 76.
} 
Assim, é possível dizer que a federação, para os fins da presente tese, consistirá no conjunto de regras que informam e conformam a federação enquanto instituição. Desta opção decorre uma série de consequências, algumas delas analisadas ainda neste capítulo introdutório; porém, é de se admitir que a distinção entre federalismo e federação não só persiste, como ainda se reveste de grande utilidade. ${ }^{51}$

\subsubsection{Federação para os fins do presente estudo comparativo}

Transposta esta primeira questão, resta ainda saber o que seria uma federação ou, mais precisamente, quais regras jurídicas poderiam ser reconduzidas a esta noção. Como o objetivo não é forjar um conceito universal, ao qual toda e qualquer federação pode ser reconduzida, e sim uma noção que contemple de forma satisfatória os casos brasileiro e alemão, torna-se importante atentar para as constituições das duas federações consideradas. Por óbvio, nestes dois diplomas há uma série de dispositivos que dizem respeito ao Estado Federal, como é o caso daqueles que distribuem competências entre o ente central e as entidades regionais e que consistem no objeto do presente estudo comparativo. Porém, há algumas disposições que tratam daquilo que não pode ser afastado, sob pena de não poder se falar mais em uma federação. Estamos falando das cláusulas pétreas, especialmente da disposição contida no artigo 79 III GG, que possui o seguinte teor:

\footnotetext{
"Uma alteração desta Lei Fundamental, por meio da qual a divisão da União em Estados, a participação fundamental dos Estados-membros na legislação ou os princípios contidos nos artigos 1 e 20 é afetada, é inadmissível."
}

Embora este dispositivo não forneça propriamente uma definição - nem seria recomendável que o fizesse, aliás - ele certamente esclarece quais os elementos que necessariamente devem constar de uma federação na Alemanha e, portanto, uma federação para os fins desta tese: em primeiro lugar, uma organização política composta necessariamente por União formada por Estados-membros; em segundo lugar, deve-se assegurar aos Estados a participação no processo legislativo (federal). A Constituição Federal brasileira, por sua vez, não fornece maiores subsídios neste ponto, prevendo apenas no artigo $60, \S 4^{\circ}$, inciso I, que não poderá "ser objeto de deliberação a proposta de emenda tendente a abolir: I - a forma federativa de Estado".

Deste modo, e admitindo-se que existem outras proposições doutrinárias e teóricas igualmente válidas, define-se federação como uma forma de Estado que promove uma

\footnotetext{
${ }^{51}$ A seguir, parte-se para a definição de federação para os fins do presente estudo comparativo. O federalismo será objeto de maior aprofundamento no item 1.3 desta tese.
} 


\section{divisão territorial do poder político entre um ente central e unidades regionais autônomas, e que é estruturada por uma constituição rígida, a qual garante aos entes regionais a participação na formação da vontade do ente federal. A seguir, cada um dos} elementos desta definição será destrinchado a partir de cinco observações.

Em primeiro lugar, a federação é uma forma de Estado. Nos manuais brasileiros de direito constitucional é atribuído um sentido relativamente específico à expressão "forma de Estado", mais precisamente, o de um "modo de exercício do poder político em função de um território" 52 ou de uma tipologia de Estados que é forjada "em função da descentralização". ${ }^{53}$ Embora estas sejam ideias que são levadas em consideração quando se elaborou a definição de federação que é objeto de análise, a menção a um arranjo específico de Estado serve para chamar a atenção para um dado importante. Com efeito, o federalismo, enquanto filosofia da "unidade na diversidade", pode encontrar expressão em uma multiplicidade de arranjos institucionais, como é o caso das confederações e de outros sistemas agrupados sob a insígnia de sistemas políticos federativos. ${ }^{54} \mathrm{~A}$ federação, por outro

\footnotetext{
52 JOSÉ AFONSO. Curso de Direito Constitucional Positivo, p. 98.

53 Manoel Gonçalves FERREIRA FILHO. Curso de Direito Constitucional. 30ā Ed. São Paulo: Saraiva, 2003, p. 51. A partir da ideia de forma de Estado a doutrina brasileira traça a distinção entre Estado Federal, caracterizado justamente pela divisão territorial do poder político, e Estado Unitário, que é modalidade em que o poder político encontra-se concentrado em uma única esfera, ainda que seja possível cogitar alguma descentralização administrativa. Entretanto, ainda é importante diferenciar Estado Federal de outras associações federativas, em especial da Confederação. Como bem pondera Josef ISENSEE, o Estado Federal, enquanto tipo ideal, diferencia-se em relação à Confederação e também ao Estado Unitário. Em relação à Confederação, a grande distinção reside no fato de os Estados-membros desta última possuírem qualidade de Estado, sendo que o mesmo não se pode afirmar em relação à União deles, que persiste somente como uma organização do Direito Internacional. Já no Estado Federal, tanto a União quanto os Estados são considerados Estados pela própria constituição. No Estado Unitário, por sua vez, somente o ente central é dotado de "estatalidade", sendo que esta característica não se estende às suas subdivisões. A Confederação, enquanto tipo ideal, representaria a forma pura do princípio federativo, enquanto que o Estado Unitário, por sua vez, representaria a concretização do princípio do unitarismo. O Estado Federal ficaria no meio termo entre estes dois tipos, caracterizando uma convergência entre estes dois princípios, de forma que "sem o elemento federal, não há nenhum Estado Federal, sem o unitário, não há Estado" (Josef ISENSEE. § 98 Idee und Gestalt des Föderalismus im Grundgesetz. In: Josef ISENSEE, Paul KIRCHHOF (Hrsg). Handbuch des Staatsrechts der Bundesrepublik Deutschland. Band IV - Finanzverfassung - Bundesstaatliche Ordnung. 2a Ed. Heidelberg: C. F. Müller Juristischer Verlag, 1999, pp. 520-521). Lastreando-se neste raciocínio, Matthias JESTAEDT pondera que embora seja comum caracterizar o Estado Federal "como a forma estatal do federalismo", é preciso tomar cuidado com esta afirmação, pois não se pode deixar obscurecer o fato de que o Estado Federal congrega tanto elementos federais quanto unitários (Matthias JESTAEDT. \& 29 Bundesstaat als Verfassungsprinzip. In: Josef ISENSSE, Paul KIRCHHOF (Hrsg). Handbuch des Staatsrechts der Bundesrepublik Deutschland. 3a Ed. Heidelberg: C. F. Müller, 2004, pp. 793-794).

${ }^{54}$ Segundo Ronald L. WATTS, o termo 'sistema político federal' refere-se a uma ampla categoria de sistemas políticos nos quais, ao contrário da única fonte central de autoridade política e legal nos sistemas unitários, existem dois (ou mais) níveis de governo combinando elementos de shared-rule (parceria colaborativa) por meio de um governo comum e regional self-rule (autonomia da unidade constituinte) para os governos das unidades constituintes. Este gênero amplo engloba todo um espectro de formas não-unitárias específicas, i. e., espécies que se estendem desde 'quase-federações' e 'federações' a 'confederações' e mais" (Comparing
} 
lado, consiste de uma forma específica de conciliar o ideário federativo com a ideia de soberania estatal, na forma como esta era concebida pela doutrina francesa do século XVII. ${ }^{55}$ Como observa Daniel J. ELAZAR,

"O Estado Nação moderno pretendia que a sua combinação de território, governo e povo era abrangente - ao menos sob uma perspectiva política - e, portanto, deveria ser considerada exclusiva, abarcando um único povo unido e possuindo um centro comum. $\mathrm{O}$ federalismo moderno reflete esta pretensão no seu esforço de lidar com o problema de criar e manter a unidade no governo onde a diversidade deve ser acomodada e, ao mesmo tempo, é uma expressão do interesse e do esforço de tentar prevenir a simples concentração do poder em um centro único [de poder] ou, em alguns casos, a amálgama de povos preexistentes em um único [povo]"56

É interessante observar, aliás, como o advento da federação nos moldes formulados pelos norte-americanos em 1787 promoveu uma inflexão na própria ideia de soberania. Afinal, os americanos entendiam que este atributo tão caro à própria definição do Estado residia no povo e era por ele titularizado, sendo que a ele caberia delegar poderes ao governo, podendo fazê-lo inclusive a esferas distintas de governo. Consequentemente, a questão da justificação e do exercício do poder político se colocaria necessariamente em termos mais democráticos, ao menos em comparação com os Estados europeus que lhe eram contemporâneos. ${ }^{57}$ Seja como for, o que é importante deixar consignado é que federação é necessariamente um Estado na acepção que o Direito costuma empregar ao termo - vale dizer, uma organização política que exerce sua soberania sobre um povo e sobre um território determinado - e que se caracteriza por um arranjo institucional específico, que é exposto a seguir.

Em segundo lugar, a federação também consiste em um método de divisão territorial do poder político. Este aspecto do conceito proposto faz lembrar a famosa passagem da obra de Kenneth WHEARE em que ele define o princípio federal como um "método de divisão do poder de forma que o governo central e os governos regionais sejam cada um, dentro de sua respectiva esfera, coordenados e independentes" 58 . Entretanto, a tese não se filia e nem pode se filiar ao pensamento deste autor. Neste ponto, deve-se aceitar a crítica que costuma lhe ser dirigida e reconhecer que se trata de uma proposta

Federal Systems, p. 8). Neste ponto da sua obra, WATTS refere-se expressamente à classificação proposta por Daniel ELAZAR, que decompõe os diferentes arranjos federais nas seguintes espécies: (i) federações; (ii) uniões; (iii) consociações; (iv) confederações; (v) arranjos federais assimétricos; (vi) ligas, e; (vii) federalismo local e não-governamental. Para maiores detalhes acerca de cada um destes fenômenos, vide Daniel ELAZAR. Exploring Federalism. Tuscaloosa: The University of Alabama Press, 1987, pp. 38-64.

55 ELAZAR. Exploring Federalism, pp. 33, 34 e 41.

${ }^{56}$ ELAZAR. Exploring Federalism, p. 40.

57 ELAZAR. Exploring Federalism, p. 41.

58 Kenneth C. WHEARE. Federal Government. Nova York: Oxford University Press, 1947, p. 11. 
demasiadamente restritiva. Tão restritiva que exclui Brasil e Alemanha do rol de federações. Afinal, "independente" para WHEARE remete à possibilidade de cada ente atuar, em relação a matérias predefinidas, de forma isolada e sem qualquer interferência de outra esfera de governo, ao passo que "coordenado" expressaria a ausência de relações de subordinação e de controle entre os entes federativos ${ }^{59}$. Já as federações brasileira e alemã, porque manejam instrumentos de cooperação federativa em maior ou menor medida, além de prever mecanismos pelos quais um nível federativo pode exercer sua influência sobre outro nível, não assegurariam uma atuação independente e coordenada nos termos propugnados pelo autor.

Não obstante isso, acredita-se que o mais adequado ainda seja falar em uma repartição do poder político, ainda que em uma pesquisa jurídica isso possa causar algum estranhamento. Com efeito, poderia se fazer menção à descentralização jurídica típica da federação, em que diferentes ordenamentos jurídicos convivem e encontram-se subordinados a uma ordem jurídica central, para falar com Hans $\operatorname{KELSEN}^{60}$, ou então à divisão de poderes operada pela constituição ao repartir competências entre União e Estadosmembros, como sugere Karl LOEWENSTEIN ${ }^{61}$. Embora sejam estas propostas satisfatórias quando adotadas por análises jurídicas do federalismo, elas obscurecem o fato de que se está diante de um objeto de estudo multidisciplinar e que não pode ser compreendido satisfatoriamente por meio de premissas exclusivamente jurídicas. Por isso, opta-se por uma formulação mais aberta, mas ao mesmo tempo apta para receber o influxo de outras áreas do conhecimento, em especial da ciência política. ${ }^{62}$

Em terceiro lugar, no âmbito de uma federação o poder deve ser repartido entre um poder central, com jurisdição sobre todo o território do Estado, e entidades regionais autônomas, que possuem a sua atuação limitada a uma porção deste mesmo território ${ }^{63}$.

\footnotetext{
59 É o que se extrai de WHEARE. Federal Government, pp. 2-5.

60 Hans KELSEN. Teoria Geral do Direito e do Estado. Trad. Luís Carlos Borges. São Paulo: Martins Fontes, 2000, pp. 451-453.

61 Karl LOEWENSTEIN. Teoria de la Constitución. Trad. Alfredo Gallego Anabitarte. Barcelona: Ediciones Ariel, 1969, pp. 355-356.

62 Como ressalta Ronald L. WATTS, "para entender sistemas federais e federações nas suas minúcias é necessário estudar tanto o direito constitucional e suas políticas quanto como estas interagem" (WATTS. Comparing Federal Systems, p. 9). Com efeito, trabalhos oriundos sobretudo da ciência política prestam um auxílio incomensurável na compreensão da federação enquanto objeto de estudo, ainda que o foco desta pesquisa resida exclusivamente nas normas constitucionais que a conformam e mesmo que os estudos da ciência política coloquem em um segundo plano normas constitucionais tão caras à análise jurídica do federalismo.

63 Neste ponto, cumpre fazer uma observação terminológica sobre as expressões "ente central" e "ente federal". Como se analisará a seguir, no Brasil predomina o entendimento de que o Estado brasileiro, que é o único que pode ser chamado de soberano, é formado pela União, Estados e Municípios, os quais possuem
} 
Neste ponto reside uma diferença importante entre Brasil e Alemanha. Naquele a federação é formada nos termos do artigo $1^{\circ} \mathrm{CF} / 88$ pela "união indissolúvel dos Estados e Municípios e do Distrito Federal". Ou seja, concebe-se uma diferenciação entre o Estado brasileiro, que é o único efetivamente dotado de soberania, e os entes federativos propriamente ditos, dotados exclusivamente de autonomia federativa e organizados em três planos: no primeiro deles está a União, que está legitimada a atuar em todo o território brasileiro por ser o ente federal; a seguir estão os Estados-membros, que são os entes regionais por excelência e que exercem os poderes que lhe foram atribuídos pela constituição sobre uma porção relativamente grande, porém sempre determinada, do território nacional, e; finalmente, o terceiro plano é ocupado pelos Municípios, considerados os entes locais da federação brasileira, exercendo poderes jurídicos sobre uma porção ainda menor do território. ${ }^{64} \mathrm{Na}$ Alemanha, por sua vez, não se concebe uma distinção entre União (ou Bund) e Estado total: ao contrário, o Estado total é a União, ente soberano e formado pelas unidades regionais e autônomas denominadas Länder. ${ }^{65}$

Tanto em um caso quanto no outro, os entes regionais são dotados de autonomia e, portanto, detentores das quatro capacidades que são inerentes a este conceito: a capacidade de auto-organização; a capacidade de autolegislação; a capacidade de autogoverno, e; a capacidade de auto-administração. ${ }^{66}$ Além disso, a autonomia também possui uma função de garantia: mais precisamente, ela assegura a preservação das unidades regionais (e no caso

apenas autonomia. De acordo com esta especial configuração, "ente central" remete sempre ao Estado brasileiro, ao passo que "ente federal” se refere à União. Já na Alemanha predomina o entendimento que o Estado alemão é composto pelos Estados e pela União, a qual se consubstancia no Estado total. Neste contexto, "ente central" e "ente federal" referem-se à União. Nesta tese, opta-se por se adotar as expressões "ente central" e "ente federal" como sinônimos toda vez que a federação for adotada sob uma perspectiva mais geral, ou então quando se mencionar especificamente o caso alemão. Todavia, quando o texto se referir especificamente ao caso brasileiro, "ente central" remeterá sempre ao Estado brasileiro, como Estado total, e "ente federal" será sempre utilizado para se referir à União.

64 É de se ressaltar que esta peculiar organização da federação brasileira está em conformidade com as considerações de Hans KELSEN sobre a organização do Estado Federal. Segundo este autor, uma particularidade do Estado consistiria justamente no fato de este ser composto por ordens jurídicas de três níveis, cada qual encabeçada pela sua respectiva constituição. Haveria, assim, a ordem jurídica do Estado Federal total, a qual seria composta: (i) pela ordem jurídica da Federação ou ordem jurídica central, com normas que valem para o território do Estado, e; (ii) por ordens jurídicas parciais, com normas que valem apenas em porções deste mesmo território. Consequentemente, haveria uma distinção entre Estado Federal - que seria o único dotado de "estatalidade" no sentido que o Direito Internacional empresta ao termo - e Federação - à qual a presente tese se refere como União, tendo em vista que Estado Federal e Federação são tomados como sinônimos (KELSEN. Teoria Geral do Direito e do Estado, pp. 451-453).

65 Note-se que Land pode significar tanto país quanto estado-federado (cf. http://pt.pons.com/tradu\%C3\%A7\%C3\%A3o?q=Land\&l=dept\&in=\&lf=de. Acesso: 25/06/2015). Como não há nenhuma distinção entre estado-federado e Estado-membro, opta-se por empregar a segunda destas expressões nas traduções do alemão para o português, pois é mais conhecida dos leitores brasileiros.

66 Para maiores detalhes sobre o conteúdo destas capacidades, vide JOSÉ AFONSO. Curso de Direito Constitucional positivo, pp. 608-609. 
do Brasil, também da União) como entes federativos. Nesse sentido, não pode uma emenda constitucional dissolver os Estados-membros, ou então transformá-los em órgãos administrativos a serviço da União ou do Bund. Ao contrário, deve-se garantir a posição daqueles como componentes da federação - vale dizer, como entes que se regem pela sua própria constituição e por suas próprias leis (ainda que cumpram leis provenientes de outras esferas), que executam serviços de sua competência e que são governados por agentes políticos eleitos, sob pena de não se poder falar em uma federação, mas sim de um Estado Unitário descentralizado. ${ }^{67}$

\section{Em quarto lugar, a federação deve ser estruturada por uma constituição rígida.}

Como ressalta Raul Machado HORTA, “o Estado Federal é criação jurídico-política e pressupõe na sua origem a existência da Constituição Federal, para instituí-lo. Há uma relação de causalidade entre Constituição Federal e Estado Federal" ${ }^{68}$. Esta é, contudo, uma colocação que deve ser complementa sob dois aspectos. Primeiro, não é qualquer constituição que viabiliza de um ponto de vista jurídico-positivo a federação. Ao contrário, esta é uma forma de Estado que deve ser necessariamente estruturada por uma constituição rígida - vale dizer, uma constituição submetida a um processo mais dificultoso para a sua alteração - e ser assegurada como cláusula pétrea. Com efeito, não haveria sentido a exigência de que se submeter a estrutura de uma federação à regulamentação constitucional, se uma simples lei federal pudesse alterá-la ou mesmo se uma emenda constitucional pudesse aboli-la ${ }^{69}$.

\footnotetext{
${ }^{67}$ A relação entre soberania do Estado central e a necessidade de preservação dos direitos dos Estadosmembros encontra-se colocada em termos bem perspicazes em LOEWENSTEIN. Teoria de la Constitución, p. 358.

68 HORTA. Direito Constitucional, p. 273.

69 Admite-se que este nosso último posicionamento enseja maiores esclarecimentos. Poder-se-ia cogitar, afinal, que a federação fosse assegurada por uma constituição flexível, ou então semi-rígida, em que somente a federação fosse revestida de uma imutabilidade. Ou seja, bastaria que a federação fosse prevista e regulamentada por uma constituição, pouco importando se fosse rígida, semi-rígida ou flexível. Esta é, contudo, uma linha de argumentação que deve ser afastada por dois motivos. Primeiramente, a federação frequentemente é vislumbrada como um pacto de natureza imutável entre unidades constituintes, que concordam em abrir mão de parte de sua soberania em virtude dos benefícios que a criação de um poder central pode proporcionar. Sabe-se que esta é uma representação de federação que não corresponde, por exemplo, à formação da federação brasileira, muito embora se aplique, ainda que parcialmente, à formação da federação alemã. Não obstante isso, nos parece que a ideia de que a constituição como um pacto imutável serve para fundamentar a defesa de uma constituição rígida. Explique-se. Na doutrina brasileira, costuma-se associar a qualidade de ente federativo à titularidade de autonomia, o que engloba, por sua vez, quatro capacidades fundamentais, analisadas supra. Porém, a autonomia e, consequentemente, estas capacidades, não são exclusividades dos entes integrantes de uma federação. Ao contrário, é possível encontrar exemplo de entidades com tais características em Estados Unitários e até mesmo em federações. Os Municípios na Alemanha, como ainda se terá a oportunidade de analisar nesta tese, são entes dotados de autonomia política, administrativa e financeira, mas não se qualificam como entes federativos e sim como entidades da administração indireta dos Estados-membros. Há de se procurar, portanto, um outro fundamento para a
} 
Além do mais, esta especial ligação faz com que a federação seja, tal como a constituição que a conforma, um produto historicamente situado. Neste ponto, a tese se filia a uma linha doutrinária que pode ser considerada majoritária na Alemanha, que tende a situar o Estado Federal como uma "individualidade concreto-histórica" ou nas palavras de Konrad HESSE,

\begin{abstract}
“Ordem estatal-federal experimenta, em consequência de limitações históricas, políticas, sociais e econômicas diferentes, e, em consequência das tarefas diferentes, que ela tem de cumprir, também cunhos totalmente diferentes. Já por isso a consideração jurídico-constitucional não pode ligar-se a um conceito de estado federal 'pré-constitucional'. Uma tal ligação lhe é proibida, tanto mais que o conceito, para ela decisiva, de estado federal é um conceito normativo. Tampouco como a compreensão da democracia e do estado de direito social, deixa-se, por isso, a compreensão da ordem estatal-federal da Lei Fundamental desatar da sua forma pela Constituição"70
\end{abstract}

Ou seja, embora seja interessante manusear definições teóricas acerca do Estado Federal, o fato é que o verdadeiro material de trabalho para quem pretende investiga-lo a partir de uma perspectiva jurídico-constitucional são as normas inscritas na constituição. Por óbvio, diante de tudo o que foi exposto até o presente momento, não se defende que esta é um estudo que deve ser empreendido ignorando-se as demais facetas do fenômeno federal; o que se quer dizer apenas é que as normas constitucionais que conformam a estrutura

caracterização de um ente federativo como tal. Defende-se aqui que um ente pode ser considerado integrante da federação quando a sua autonomia é assegurada de tal modo que: (i) não pode ser abolida, nem mesmo com o consentimento do seu titular; (ii) não pode ser restringida ou ampliada por ato exclusivo de uma outra esfera federativa. Ou seja, o Estado Federal permanece como o resultado de um pacto sobre aquilo que não pode ser retirado das entidades que a compõem, sendo que os termos mais fundamentais deste pacto são verdadeiramente imutáveis, ao passo que em relação a outras partes exige-se apenas que não se trate de uma decisão arbitrária de uma das partes deste pacto, como ocorreria caso a constituição fosse alterada no âmbito do processo legislativo ordinário. Por isso, tem-se que a federação se relaciona necessariamente com a ideia de rigidez constitucional, sendo, portanto, incompatível com a ideia de uma constituição flexível. Porém, é preciso explicar também porque esta forma de Estado também não se compatibiliza com a adoção de uma constituição semi-rígida, sendo este o segundo motivo que nós desejamos trazer à consideração do examinador. A federação, quando prevista em uma constituição, possui um efeito irradiante em relação aos demais preceitos constitucionais, em um fenômeno muito parecido com o dos direitos fundamentais. A partir do momento em que se consagra a existência de União indissolúvel de Estados (e Municípios, no caso brasileiro), deve-se perguntar sempre quem será o ente responsável por executar cada prestação estatal, por garantir cada direito assegurado pela constituição. Estas outras previsões constitucionais, a partir do momento em que garantem direitos ou impõem deveres aos entes federativos, acabam por integrar a autonomia destes últimos, sendo, deste modo, englobadas pela ideia de federação. Portanto, a decisão constituinte de prever esta forma de Estado acaba afetando a constituição como um todo, razão pela qual ela também se mostra incompatível com a ideia de constituição semi-rígida.

70 Konrad HESSE. Elementos de Direito Constitucional da República Federal da Alemanha (Grundzüge des Verfassungsrechts der Bundesrepublik Deutschland. Trad. Luís Afonso Heck. Porto Alegre: Sergio Antonio Fabris Editor, 1998, pp. 178-179. A versão original, em alemão, pode ser consultada em Konrad HESSE. Grundzüge des Verfassungsrechts der Bundesrepublik Deutschland. 20aㅡ. Heidelberg: C. F. Müller, 1999, p. 96.0 mesmo raciocínio é encampado por outros autores alemães citados nesta tese, como, por exemplo, Walter RUDOLF. $\S 141$ Kooperation im Bundesstaat. In: Josef ISENSEE, Paul KIRCHHOF (Hrsg.). Handbuch des Staatsrechts der Bundesrepublik Deutschland. Band VI: Bundesstaat. 5a Ed. Heidelberg: C. F. Müller, 2008, p. 1006. 
federativa não podem ser ignoradas ou mesmo subestimadas em uma análise jurídica - em especial, em uma análise jurídico-dogmática, com a proposta nesta tese - do federalismo e da federação.

Finalmente, aos entes regionais é garantida a participação na formação da vontade do ente federal, o que se dá essencialmente por meio de uma câmara representativa dos Estados-membros no Poder Legislativo federal. Embora se trate de uma característica apontada por grande parte dos autores citados até o presente momento - entre eles Preston KING, Ronald L. WATTS, Hans KELSEN, Karl LOEWENSTEIN, Raul Machado HORTA $^{71}$ - opta-se por não adentrar em considerações mais aprofundadas neste momento, tendo em vista que se trata de um assunto que será retomado nos itens 1.6.1, 2.1.4 e 2.2.4 desta tese.

\subsection{A questão da cooperaçÃo no Estado Federal. O federalismo DUALISTA E O FEDERALISMO COOPERATIVO}

Uma questão importante diz respeito à cooperação na federação. Seria ela um elemento integrante da própria definição desta forma de Estado? Em outras palavras, a divisão territorial do poder político que lhe é tão ínsita deve necessariamente se dar entre União, Estados-membros e Municípios autônomos e que cooperam entre si?

Diante do exposto no tópico anterior, a presente tese tende a responder a esta pergunta negativamente. Com isso não se pretende negar a importância que a cooperação efetivamente possui nas federações modernas, inclusive nas federações brasileira e alemã. Considera-se apenas que se trata de uma característica que não pode ser incorporada ao próprio conceito de Estado Federal, tendo em vista que ele pressupõe ações coordenadas, mas também ações independentes por parte dos entes federativos.

Admite-se, contudo, que a cooperação federativa é um tema caro aos teóricos do federalismo, dando ensejo inclusive a uma importante classificação do federalismo que contrapõe, de um lado, o chamado federalismo dualista e, de outro lado, o federalismo cooperativo.

Por óbvio, existem diversas classificações e tipologias do federalismo. Entretanto, algumas classificações revelam-se mais úteis ou importante que outras, uma vez que possibilitam não só uma melhor compreensão do tema, mas principalmente porque revelam

\footnotetext{
${ }^{71}$ KING. Federalism and Federation, p. 77; WATTS. Comparing Federal Systems, p. 9; KELSEN. Teoria Geral do Direito e do Estado, p. 454; LOEWENSTEIN. Teoria de la Constitución, p. 358, e; HORTA. Direito Constitucional, p. 275.
} 
as principais proposições teóricas que pautam, ou pautaram o debate acadêmico em um determinado momento histórico. Acredita-se que é exatamente este o caso da dicotomia federalismo dualista versus federalismo cooperativo, que por isso será objeto de breves considerações a seguir.

\subsubsection{O federalismo dualista}

O federalismo dual ou dualista consiste em uma tipologia manejada tanto por autores brasileiros como alemães. No Brasil, é possível encontrar referências a ela na obra de Manoel Gonçalves FERREIRA FILHO, Fernanda Dias Menezes de ALMEIDA e José Alfredo de Oliveira BARACHO, por exemplo. ${ }^{72}$ Já na Alemanha é certo que as menções são bem mais modestas, mas ela está na base das considerações desenvolvidas, entre outros, por Christian CALLIESS. ${ }^{73}$

Parece-nos, contudo, que a sua gênese reside no direito norte-americano e é na doutrina deste país que se deve buscar as suas linhas gerais. Bernard SCHWARTZ, por exemplo, considerava o federalismo dualista como uma doutrina, segundo a qual "tanto o Governo federal quanto os estaduais se atribuem uma área de poder rigorosamente circunscrita. Desde que permaneçam dentro de seus respectivos limites, os seus atos são válidos e não serão contestados pelos tribunais." 74 Prossegue o referido autor ao afirmar que, de acordo com este modo, União e Estados se colocariam em um plano de igualdade e se comportariam como rivais. O equilíbrio entre eles seria atingido, por sua vez, por meio da demarcação rigorosa entre as suas respectivas atribuições. ${ }^{75}$

Mais recentemente, Joseph ZIMMERMANN, baseando-se no pensamento de Edward Samuel CORWIN, atribui as seguintes características ao federalismo dual:

"1. O governo federal tem somente poderes enumerados;

2. Também os propósitos que este [governo federal] pode constitucionalmente promover são poucos;

3. Dentro das suas respectivas esferas, os dois centros de governo são 'soberanos' e, portanto, iguais;

4. A relação entre os dois centros entre si é mais de tensão do que de colaboração.

\footnotetext{
72 FERREIRA FILHO. Curso de Direito Constitucional, pp. 54-55; Fernanda Dias Menezes de ALMEIDA. Considerações sobre os rumos do federalismo nos Estados Unidos e no Brasil. Revista de Informação Legislativa, ano 24, no 96, out./dez. 1987, pp. 57-64 e José Alfredo Oliveira BARACHO. Novos Rumos do Federalismo. Doutrinas Essenciais de Direito Constitucional, vol. 3, maio/2011, pp. 91 e ss.

${ }^{73}$ Christian CALLIESS. Die Justitiabilität des Art. 72 Abs. 2 GG vor dem Intergrund von kooperativem und kompetitivem Föderalismus. Die öffentliche Verwaltung (DÖV), ano 50, Novembro 1997, Caderno 21, p. 898.

${ }^{74}$ Bernard SCHWARTZ. Direito Constitucional Americano. Trad. Carlos Nayfeld. São Paulo: Ed. Forense, 1966, p. 63.

${ }^{75}$ SCHWARTZ. Direito Constitucional Americano, p. 63.
} 
Um quinto postulado poderia ser adicionado: um plano de governo não aplica poderes coercitivos contra o outro plano" 76

Historicamente, o federalismo dualista é um modelo que concebe Estadosmembros fortalecidos em detrimento de uma União, cuja atuação encontra-se limitada a um pequeno rol de competências. ${ }^{77}$ Como se depreende do texto transcrito, a técnica de repartição de competências a ser manejada é necessariamente a da repartição horizontal de competências - vale dizer, uma repartição que pretende operar uma separação radical entre as atribuições da União e dos Estados-membros, enumerando competências privativas a um ente (normalmente, a União) e reservando ao outro as demais competências por meio de uma cláusula geral - o que garante um viés estático e não coordenado às relações federativas.

Percebe-se, portanto, que se trata de uma categoria que consegue, quando muito, explicar o desenvolvimento da federação norte-americana desde a sua fundação até o advento do New Deal. Com efeito, alguns dos pressupostos deste modelo dual encontram-se ultrapassados, como é o caso da tese da "dupla soberania" apontada por ZIMMERMANN no item 3 do trecho supracitado. Mesmo a tese da completa independência das esferas de governo é objeto de veemente crítica diante das dificuldades de ser obtida na prática. ${ }^{78}$ Além do mais, costuma-se ressaltar que mesmo neste período inicial da federação norte-americana seria possível observar o desenvolvimento de relações intergovernamentais por meio de subvenções, ainda que de uma forma incipiente. ${ }^{79}$

\footnotetext{
76 Joseph F. ZIMMERMAN. Contemporary American Federalism: The Growth of National Power. 2a Ed. Nova York: State University of New York Press, 2008, p. 7. Note-se que os quatro pontos citados por ZIMMERMAN consistem em uma citação literal de Edward CORWIN. The passing of dual federalism. Virginia Law Review, vol. 36, no 1, fev/1950, p. 4.

77 Note-se que Estados-membros fortalecidos em detrimento de uma União limitada em suas atribuições, é uma característica que se apresenta historicamente, principalmente nos Estados Unidos desde a sua fundação até o advento do New Deal. Porém, do ponto de vista teórico, considera-se que as características mais relevantes do federalismo dual consistem na separação estrita entre as esferas federativas e relações federativas informadas pela competição. Admite-se, portanto, que o federalismo dualista, enquanto tipologia, abranja federações marcadas por uma União mais fortalecida, ainda que semelhante configuração não tenha se verificado na prática.

78 SCHWARTZ. Direito Constitucional Americano, p. 63.

79 Nesse sentido, Bernard SCHWARTZ pondera que "a concessão de subvenções pelo Govêrno federal aos estados não é uma coisa nova no sistema americano. Durante os primeiros tempos dos Estados Unidos, o Governo central deu enormes extensões de terras públicas aos estados para a construção de escolas e de universidades, estradas de rodagem e de ferro, canais e fins de saneamento. A generosidade federal atingiu 0 clímax em 1837, quando uma verba de 28 milhões de dólares acumulados no tesouro federal foi dada aos estados em proporção à sua representação no Congresso. Êsses casos antigos envolviam simples concessões sem condições; não houve tentativa nem sequer de se regulamentar a maneira pela qual as subvenções federais poderiam ser usadas" (SCHWARTZ. Direito Constitucional Americano, p. 220).
} 
Em virtude de considerações deste tipo, prevalece o entendimento de que esta categoria teria perdido parte do seu poder explicativo. ${ }^{80}$ Isso não significa que ela não seja mais manejada doutrinariamente, muito pelo contrário: como se exporá oportunamente, uma visão dual de federalismo parece estar na base de uma crítica que é frequentemente dirigida ao federalismo brasileiro. Ademais, o fato de ser possível encontrar referências ao federalismo dualista em doutrinadores que pretendem descrever o direito brasileiro e alemão sob uma perspectiva atual corrobora a importância que esta tipologia ainda desempenha de um ponto de vista teórico.

\subsubsection{O federalismo cooperativo}

O federalismo cooperativo, por sua vez, é uma tipologia dotada de maior prestígio na literatura especializada. Há quem entenda que toda federação pressupõe um mínimo de coordenação. Neste contexto, o federalismo cooperativo surgiria como um modelo caracterizado por uma maior coordenação e cooperação entre os entes federativos em comparação com o modelo dualista. ${ }^{81}$ De todo modo, parece-nos irrefutável que se está diante de uma categoria relevante para explicar as federações atualmente vigentes - e, em especial, as federações brasileira e alemã - ou, pelo menos, as discussões que se se desenvolvem a seu respeito no âmbito da literatura especializada destes dois países.

Contudo, é de se admitir que definir os contornos gerais deste federalismo cooperativo não é tarefa fácil. No que consistiria, afinal, esta cooperação que lhe é tão ínsita? A fim de oferecer uma resposta adequada a este questionamento, considera-se importante analisar algumas ponderações desenvolvidas tanto pela literatura norteamericana quanto pela doutrina alemã, para então compreender como elas influenciam, com as suas devidas paticularidades, o debate desenvolvido no Brasil.

No âmbito do direito estadunidense, Joseph ZIMMERMANN pondera que o federalismo cooperativo também conceberia duas esferas de governo, mas que não seriam mais entendidas como entidades isoladas e rivais entre si diante da extensa coordenação que passa a se verificar entre elas. Na verdade, a cooperação seria nada mais do que a constatação

\footnotetext{
${ }^{80}$ Como observa ZIMMERMANN. Contemporary American Federalism, pp. 6-7.

${ }^{81}$ No Brasil, este é o posicionamento esposado por Gilberto BERCOVICl, para quem "não é plausível, contudo, um Estado Federal em que não haja um mínimo de colaboração entre os diversos níveis de governo. Faz parte da própria concepção de federalismo esta colaboração mútua. Portanto, no federalismo cooperativo, não se traz nenhuma inovação com a expressão 'cooperação'. Na realidade, a diferença é o que se entende por cooperação, que, no federalismo cooperativo, é bem diferente do modelo clássico de colaboração mínima e indispensável" (Gilberto BERCOVICI. Desigualdades regionais, Estado e Constituição. São Paulo: Max Limonad, 2003, pp. 150-151).
} 
da necessidade de programas nacionais e multifacetados para lidar com problemas que, em razão da sua amplitude e complexidade, não poderiam ser considerados nem predominantemente nacionais nem exclusivamente regionais. ${ }^{82}$

Embora o referido autor não o diga expressamente, o advento do federalismo neste país coincide com o advento da concepção de um Bem-Estar Social, e instrumentalizouse principalmente por um incremento das transferências de recursos tributários por parte da União aos Estados em troca da assunção de tarefas estatais específicas. Como ressalva Bernard SCHWARTZ, ao tratar deste mesmo fenômeno em meados do século XX:

\begin{abstract}
"Um sistema intensivo de subvenções federais para ajudar os estados a reabilitarem a sua economia e auxiliar os indivíduos incapazes de se manter constituiu grande parte das medidas do New Deal. Mas a dádiva do Governo federal não era mais concedida sem condições. Washington impunha condições substanciais aos estados que aceitavam as suas subvenções, as quais, com efeito, redundavam na supervisão federal rigorosa dos planos de restauração econômica empreendidos pelos estados.

Um bom exemplo da legislação do New Deal que fazia uso intensivo da subvenção foi a Lei de Previdência Social de 1935. Segundo ela, o Govêrno federal fazia concessões aos estados para imediata assistência à velhice, aplicação de leis de remuneração aos desempregados do estado, auxílio aos filhos dependentes, bemestar maternal e infantil, saúde pública e assistência aos cegos. O contrôle federal, porém, era em troca impôsto às atividades estaduais, pois a legislação do estado bem como a sua engrenagem e os métodos de administração deviam adaptar-se aos padrões estabelecidos pelo estatuto federal e o Conselho de Previdência Social, o órgão criado para administrá-10",83
\end{abstract}

Em tese, os Estados-membros podiam recusar o auxílio federal e preservar a sua independência, mas na prática eles se viam diante de uma situação financeira difícil. À medida que eles aceitavam a subvenção, contudo, os Estados deveriam também consentir com a ingerência federal no campo da legislação de sua competência e até mesmo em questões administrativas. O resultado deste processo foi um incremento do poder da União, ainda que no plano da repartição de competências legislativas não tenha ocorrido nenhuma alteração formal. ${ }^{84}$

Já o federalismo cooperativo na Alemanha é caracterizado por uma especial interdependência política entre as esferas de governo, o que acaba por diferenciá-lo da vertente norte-americana analisada supra. Como aponta Fritz SCHARPF, no federalismo estadunidense, o governo federal pode atuar nos âmbitos regional e local por meio de um corpo administrativo próprio, o que serviria para lhe conferir, ao menos no plano formal,

\footnotetext{
82 ZIMMERMAN. Contemporary American Federalism, p. 8.

83 SCHWARTZ. Direito Constitucional Americano, pp. 220-221.

$84 \mathrm{O}$ incremento dos poderes da União em razão das subvenções federais condicionadas é brevemente abordado em SCHWARTZ. Direito Constitucional Americano, p. 223.
} 
alguma independência em relação aos Estados-membros. A cooperação norte-americana seria substancialmente voluntária, o que possibilitaria ao governo federal voltar atrás conforme o momento político. Já na federação alemã, a administração federal é substancialmente limitada e, por isso, dependeria da administração estadual para a consecução da legislação federal. Isso significaria que à União resta a opção de compartilhar muitas decisões importantes com os Estados. Por outro lado, um especial arranjo de competências restringiria o espaço de atuação dos Estados-membros, de forma que estes ficariam novamente sujeitos à União. ${ }^{85}$ Em um contexto como este, a cooperação traduzir-se-ia em um fenômeno crescente de tomada de decisões conjuntas (Politikverflechtung) até o ponto de se criar uma verdadeira armadilha contra a solução eficiente dos problemas de redistribuição. ${ }^{86}$ Voltaremos a esta questão oportunamente, quando da análise das principais características da evolução da federação alemã sob a égide da Lei Fundamental de 1949.

Uma questão especialmente interessante diz respeito ao modo pelo qual estas diferentes acepções de federalismo cooperativo foram incorporadas no Brasil. Por um lado, parte da doutrina parece ser influenciada pelas discussões da literatura norteamericana. Nesse sentido, ao comparar as federações norte-americana e brasileira, pondera Fernanda Dias Menezes de ALMEIDA:

\begin{abstract}
"24. Embora tenha se originado a partir de processo de formação diverso, fruto que foi da descentralização política de um Estado Unitário, a Federação brasileira plasmou-se à imagem e semelhança da matriz norte-americana.

25. Também no Brasil, portanto, tivemos inicialmente o 'dual federalism', com esferas de competências estanques, enumeradas as da União, remanescentes as dos Estados, o poder central abstendo-se de interferir nos assuntos estaduais.

26. Em ordem cronológica praticamente coincidente com a norte-americana, transmudou-se em cooperativo o nosso federalismo, basicamente a partir da Constituição de 1934. De um lado, devido à iniciativa dos próprios Estados, mais precisamente por força do apelo dos Estados mais pobres que não conseguiam prover as suas necessidades sem o concurso da União. De outro lado, como era da época, em razão da ascendência do intervencionismo estatal, com sensível acréscimo das competências da União, principalmente no plano econômico e com consequente restrição das competências estaduais, comprimidas, em outra frente, pelo reconhecimento de um campo de autonomia própria dos Municípios" 87
\end{abstract}

\footnotetext{
${ }^{85}$ Fritz W. SCHARPF. The joint-decision trap: lessons from German Federalism and European Integration. Public Administration, v. 66, outono/1988, pp. 242-243. Deve-se ressaltar que o autor também inclui nesta análise o fato de o Poder Legislativo federal norte-americano ser eleito diretamente pelos cidadãos, ao passo que o Poder Legislativo federal alemão ser em parte eleito por meio de eleições diretas (mais especificamente, o Bundestag) e em parte composta por representantes dos governos estaduais (no caso, o Bundesrat ou Conselho Federal).

86 Joachin Jens HESSE. República Federal da Alemanha: do federalismo cooperativo à elaboração de política conjunta. Traduções: o federalismo na Alemanha, ano 1995, no 7, pp. 121.

${ }^{87}$ ALMEIDA. Considerações sobre o rumo do federalismo, p. 63. Poder-se-ia argumentar que esta assimilação do debate norte-americano se deve apenas ao fato de a autora se propor a fazer neste trecho específico uma
} 
Por outro lado, também é possível encontrar autores que se debruçam sob o federalismo cooperativo a partir de premissas mais próximas do enfoque alemão. Gilberto BERCOVICI, por exemplo, afirma que o federalismo cooperativo seria a modalidade adequada ao Estado Social e rebate a crítica que aquele conduziria à centralização. Segundo este autor, o que seria peculiar a esta espécie de federalismo não seria a centralização, mas sim a homogeneização:

"Esta unidade de atuação não significa, necessariamente, centralização.
Precisamos, antes de mais nada, diferenciar centralização de homogeneização.
Com a centralização há a concentração de poderes na esfera federal, debilitando
os entes federados em favor do poder central. Já a homogeneização
(Unitarisierung, uniformização) é baseada na cooperação, pois se trata do
processo de redução das desigualdades regionais em favor de uma progressiva
igualação das condições sociais de vida em todo o território nacional. A
homogeneização não é imposta pela União, mas é resultado da vontade de todos
os membros da Federação.
As tensões do federalismo contemporâneo, situadas basicamente entre a exigência
da atuação uniformizada e harmônica de todos os entes federados e o pluralismo
federal, são resolvidas em boa parte por meio da colaboração e atuação conjunta
das diversas instâncias federais. A cooperação se faz necessária para que as
crescentes necessidades de homogeneização não desemboquem na
centralização."

De nossa parte, acreditamos que a homogeneização proposta por BERCOVI não pode significar outra coisa senão a unitarização do Estado - vale dizer, a convergência para um Estado Unitário - conclusão esta que se mantém mesmo que sejam as próprias unidades subnacionais que voluntariamente se disponham a atingir tal objetivo. A própria expressão em alemão correlata - Unitarisierung - corrobora esta assertiva. Seja como for, o fato é que definição de homogeneização defendida por BERCOVICI incorpora a expressão "igualação das condições sociais de vida em todo o território nacional”, a qual até 1994 era empregada pela Lei Fundamental alemã em alguns de seus dispositivos que institucionalizam o federalismo cooperativo naquele país, a saber: o artigo 72, que trata das competências legislativas concorrentes; o artigo 91a, que prevê as chamadas tarefas comuns (Gemeinschaftsaufgaben), e; o artigo 106, que dispõe sobre a repartição do produto da

análise do federalismo à luz do caso estadunidense. Contudo, na sua tese de doutorado, que não é dedicada à análise comparada do federalismo, Fernanda Dias Menezes de ALMEIDA retoma o mesmo raciocínio ao tratar das transformações do Estado Federal: "... surgido num contexto histórico completamente distinto, ao tempo do liberalismo clássico, do État-gendarme, transpôs o federalismo os mais de duzentos anos que desde então se passaram, mostrando-se também eficiente em face das concepções de Welfare State, das imposições intervencionistas dos novos tempos. Na adaptação que ao longo desses dois séculos conheceu, mudou, sim, a conformação primeira do Estado Federal. Tanto em sua pátria como alhures, passou-se do que se convencionou designar por federalismo dual para o chamado federalismo cooperativo, basicamente mediante uma alteração das relações entre a União e os Estados, com o fortalecimento da autoridade federal e consequente retração da autoridade estadual" (Competências na Constituição de 1988, p. 33).

${ }^{88} \mathrm{BERCOVICI}$. Desigualdades regionais, p. 156-157. 
arrecadação do imposto que incide sobre vendas (Umsatzsteuer) entre União e Estados. É interessante ressaltar, contudo, que atualmente apenas o artigo 106 fala atualmente em uniformização ou igualação das condições de vida. $\mathrm{O}$ artigo 72 , que possibilitou ao longo dos anos uma forte centralização legislativa da federação alemã, como se terá a oportunidade de analisar no item 5.3.1, foi alterado neste ponto, passando a falar no estabelecimento de condições de vida equivalentes (Herstellung gleichwertiger Lebensverhältnisse), o que demonstra, de certo modo, uma mudança na compreensão dos limites da cooperação e da homogeneização no âmbito do federalismo alemão. ${ }^{89}$

Por óbvio, considerações deste tipo revelam somente as influências dos teóricos que analisam a questão da cooperação no Brasil, e não propriamente como ela é efetivamente concretizada nas relações federativas pátrias. Diante dos objetivos propostos para a presente tese e devidamente expostos na introdução, é de se admitir que transcende o escopo da presente tese a análise do modo pelo qual os entes federativos brasileiros efetivamente atuam de modo concertado em assuntos que demandam uma maior ou menor união de esforços. Isto, por sua vez, não implica nenhum juízo acerca da importância ou da urgência desta questão para o federalismo no Brasil. Deseja-se apenas ressaltar que esta é uma problemática que o presente estudo apenas pode tomar como um pressuposto, tendo em vista que a investigação que se propõe aqui versa sobre a repartição de competências legislativas e de execução a partir de um ponto de vista eminentemente jurídico-dogmático. Ou seja, mais importante do que entender como a cooperação efetivamente se desenvolve na federação brasileira é compreender aspectos normativos que influenciam o modo pelo qual atribuições legislativas e administrativas são desempenhadas pelos entes federativos. Esta é, por sua vez, uma análise que só poderá ser empreendida de forma satisfatória depois de expostas as linhas gerais das federações brasileira e alemã no segundo capítulo desta tese.

\subsubsection{Aspectos dogmáticos da cooperação federativa}

Não obstante isso, considera-se oportuno tecer já neste momento algumas observações a respeito da cooperação federativa de um ponto de vista eminentemente teórico. Novamente, não se pretende aqui um aprofundamento em aspectos descritivos do fenômeno; ao contrário, objetiva-se aqui apenas retomar e discutir alguns de seus aspectos dogmáticos. Um bom ponto de partida para tanto consiste em retomar a distinção entre

\footnotetext{
89 Já o artigo 91a, por sua vez, fala em uma melhora das condições de vida (Verbesserung der Lebensverhältnisse).
} 
coordenação e cooperação nos moldes sugeridos por Gilberto BERCOVICI a partir da obra de Enoch ROVIRA. ${ }^{90}$

Segundo estes autores, a coordenação seria uma forma de atuação conjunta, que envolveria a participação de vários entes federativos e se traduziria na tomada de uma decisão comum, em nível federal, adaptada e executada conforme as peculiaridades de cada ente federativo. É importante ressaltar que cada entidade poderia, em tese, optar pela atuação isolada e autônoma; não obstante isso, unem-se para a consecução de um objetivo comum.

Já a cooperação, por sua vez, seria uma forma de atuação conjunta que também é caracterizada pela tomada de uma decisão comum em âmbito federal. Entretanto, em relação às matérias em que a cooperação é prevista, seria vedada a atuação autônoma e isolada por parte de um ente federativo. Como propugna Enoch ROVIRA:

\begin{abstract}
"La cooperación, en sentido estricto, se diferencia cualitativamente de estas anteriores relaciones, al consistir propiamente en una toma conjunta de decisiones, en un coejercicio de las competencias, y, consiguientemente, en una corresponsabilización de las actuaciones realizadas bajo tal régimen. Una determinada función o competencia no se realiza ya de forma autónoma y separada por cada instancia, con todos los límites externos de aplicación al caso, sino de forma conjunta, de modo que tal función o competencia, para que se traduzca en concretas actuaciones, solo puede ser ejercida conjuntamente por varias partes, que deben actuar mancomunadamente.

De este modo, se rompe el principio de atribución alternativa de las diversas competencias en que se divide e poder estatal y el de separación, autonomía e independencia en su ejercicio, que constituyen los principios ordinarios y generales sobre los que se asientan los sistemas de distribución de poderes y de relación entre las diversas instancias territoriales del poder estatal, y se sustituyen por un principio de atribución conjunta, que da lugar a la exigencia de un ejercicio asimismo conjunto de las mismas. En este terreno, ninguna parte ostenta los poderes suficientes para actuar autónomamente, por separado, sino que necesariamente debe ejercer la competencia en cuestión conjuntamente con las demás $" 91$
\end{abstract}

Embora não se trate propriamente de uma estipulação conceitual a ser encampada nesta tese, é de se admitir que ela possui o mérito de sistematizar modos distintos pelos quais cooperação pode ser institucionalizada. Note-se que, segundo esta visão, a coordenação seria observada no artigo $24 \mathrm{CF} / 88$ - e, por extensão, à competência prevista no artigo 75 GG ao passo que a cooperação encontraria expressão nas competências enumeradas no artigo 23

\footnotetext{
90 Sem dúvida, existem outras aproximações possíveis. Novamente, não se trata aqui de trazer uma inovação ao debate teórico acerca do federalismo cooperativo, ou mesmo de resumir o seu estado atual, mas sim de explicitar ao examinador o nosso posicionamento acerca desta discussão. Nesse sentido, não se tem a pretensão de manejar a concepção mais moderna ou mais arraigada nas doutrinas brasileira e alemã, mas sim de utilizar aquela que permite uma compreensão mais apurada do objeto da presente pesquisa.

91 Enoch Alberti ROVIRA. Federalismo y Cooperación en la Republica Federal Alemana. Madrid: Centro de Estudios Constitucionales, 1986, p. 369.
} 
$\mathrm{CF} / 88 .{ }^{92}$ Ou seja, haveria uma certa correspondência entre coordenação e cooperação, da forma como concebidas por BERCOVICI e ROVIRA, e um determinado modo de se exercer competências federativas.

Uma outra aproximação teórica interessante é defendida por Alessandra SILVEIRA, para quem o fenômeno da cooperação poderia ser bem compreendido sob a ótica de um compromisso constitucional de cooperação, que se consubstancia historicamente em uma série de normas constitucionais com alguns conteúdos específicos, os quais podem ser adequadamente entendidos a partir de uma dimensão passiva e de uma dimensão ativa.

Do ponto de vista passivo, o compromisso de cooperação implicaria "a moderação recíproca, a abstenção do exercício de competências formalmente acometidas (quando tal comprometa o sucesso sistémico), a proibição da omissão de auxílio", ${ }^{93}$ com o objetivo de obter a "fidelização sistémica (ou para a aceitação e conservação das normas que mantém unidas as diversas partes do todo), e imped[ir] que os distintos poderes públicos frustrem a prossecução dos interesses alheios ou se recusem a ajudar [outras entidades subnacionais]." Esta vertente estaria subjacente a institutos específicos como a lealdade federal, mas também a um especial arranjo de repartição de rendas que promova o equilíbrio financeiro entre as unidades da federação e a sua substancial homogeneização. ${ }^{95}$

Já a dimensão ativa deste compromisso constitucional implicaria "atores políticos decididamente empenhados em acções concertadas e na prestação conjunta de serviços" $" 96$, em uma clara correspondência aos conceitos de coordenação e, principalmente, de cooperação apresentados por Enoch ROVIRA e introduzidos no debate brasileiro por Gilberto BERCOVICI. Ainda, note-se que esta vertente ativa pode se apresentar na Constituição não apenas como um princípio norteador, mas também pode se desdobrar em regras bem específicas, como bem analisa Alessandra SILVEIRA. ${ }^{97}$

Apesar de o aspecto passivo do compromisso constitucional ser de alguma importância para a presente tese, o seu foco residirá justamente nas disposições constitucionais que fomentam a cooperação sob um viés ativo, à medida que estas

\footnotetext{
92 BERCOVICl. Desigualdades Regionais, Desigualdades e Constituição, pp. 151 e ss

93 Alessandra SILVEIRA. Cooperação e compromisso constitucional nos Estados Compostos: Estudo sobre a teoria do federalismo e a organização jurídica dos sistemas federativos. Coimbra: Almedina, 2007, p. 10.

94 SILVEIRA. Cooperação e compromisso constitucional nos Estados Compostos, p. 97.

95 SILVEIRA. Cooperação e compromisso constitucional nos Estados Compostos, p. 97.

96 SILVEIRA. Cooperação e compromisso constitucional nos Estados Compostos, p. 11.

97 São interessantes, aliás, as considerações dessa autora sobre os desdobramentos deste compromisso constitucional sob a égide da CF/88 em SILVEIRA. Cooperação e compromisso constitucional nos Estados Compostos, p. 96.
} 
frequentemente se materializam em um arranjo específico de competências legislativas e de execução.

\subsection{CentralizaçÃo e descentralização no Estado Federal}

A federação figura como cláusula pétrea nas constituições dos Estados que adotam esta forma de Estado. É o que ocorre com a Constituição Federal de 1988, conforme se extrai do inciso I do $\S 4^{\circ}$ do seu artigo 60, e com a Lei Fundamental alemã, consoante seu artigo 79 III.

Além desta previsão genérica, o Estado Federal encontra desdobramentos em outras normas constitucionais, que são responsáveis por desenhar o cerne da estrutura federativa, ao regularem as atribuições de cada ente federativo, a forma de participação dos Estadosmembros na formação da vontade federal, a repartição de recursos entre as diferentes esferas de governo e assim por diante. Note-se que as disposições devem gozar de relativa estabilidade, sujeitando-se a um processo de alteração mais dificultoso do que o das leis ordinárias, mais resistente às maiorias momentâneas e conjunturas políticas específicas. ${ }^{98}$

Contudo, é de se admitir que o princípio federativo comporta algumas acomodações a despeito da sua imutabilidade, apresentando uma feição dinâmica, aberta e sensível a alterações legislativas e políticas. ${ }^{99}$ Estas alterações podem se dar tanto em nível constitucional quanto infraconstitucional, mas o fato é que elas normalmente ocorrem, fazendo com que o Estado Federal assuma feições mais ou menos centralizadas com o passar do tempo, ainda que sob a vigência de uma única constituição. A federação alemã, por exemplo, sofreu uma grande centralização - ou uma forte homogeneização, para falar com Gilberto BERCOVICI - sob a vigência da Lei Fundamental alemã, tendência esta que passou a ser revertida a partir da década de 90 do século XX por meio de algumas reformas constitucionais. A federação brasileira, por sua vez, também teria vivenciado um processo de centralização desde a promulgação da Constituição Federal de 1988, sobretudo nos mandatos do Presidente Fernando Henrique Cardoso. ${ }^{100}$

\footnotetext{
98 Não por outro motivo, Raul Machado HORTA afirma que há uma relação de causalidade entre federação e a adoção de uma constituição rígida (HORTA. Direito Constitucional, p. 273). Porém, deve-se ressaltar que, como a federação figura como cláusula pétrea, não são permitidas alterações que tenham o condão de abolir esta forma de Estado, ainda que a Constituição continue a afirmar formalmente que se esteja diante de um Estado Federal.

99 Peter SELMER. Die Föderalismusreform - Eine Modernisierung der bundesstaatlichen Ordnung. Juristische Schulung - JUS, caderno 12, 2006, p. 1052.

${ }^{100}$ Retomaremos este argumento no item 3.2.2.
} 
Neste ponto, é preciso fazer uma importante observação: não é um objetivo desta tese identificar e avaliar tendências de centralização e de descentralização existentes nas federações brasileira e alemã, pois se entende que a análise das normas constitucionais e da respectiva jurisprudência constitucional nos moldes propostos fornece poucos subsídios para tanto. Não obstante isso, acredita-se que situar Brasil e Alemanha como Estados Federais centralizados ou descentralizados permanece uma questão imprescindível ao estudo comparativo. Até porque a análise da aplicabilidade de construções doutrinárias ou jurisprudenciais concebidas no direito alemão para mitigar ou resolver problemas brasileiros pressupõe que se saiba, em primeiro lugar, se as soluções alemãs tendem a fomentar uma centralização ou uma descentralização e, em segundo lugar, se os problemas brasileiros estão a ensejar uma solução centralizadora ou descentralizadora.

A contextualização das federações brasileira e alemã é uma tarefa que será levada a cabo apenas no segundo capítulo desta tese, sendo que a caracterização de ambas como estruturas mais ou menos centralizadas será realizada somente no terceiro capítulo da tese. De todo modo, ainda faz sentido traçar neste capítulo, dedicado à exposição das premissas teóricas da pesquisa, algumas considerações de índole eminentemente teórica a respeito da centralização e da descentralização, a partir de argumentos trazidos por alguns autores que se debruçam sobre o assunto.

Em primeiro lugar, é importante cindir, por um lado, a análise entre a centralização e a descentralização que se deseja obter em uma federação e, por outro lado, a centralização e a descentralização que efetivamente são observadas ou observáveis em um Estado Federal. Note-se que esta proposta encontra-se intimamente ligada à distinção entre federalismo enquanto ideologia e federação enquanto arranjo institucional de fato, trabalhada no primeiro tópico deste capítulo: nesse sentido, federalismo é expressão que reúne ideias mais ou menos coerentes entre si que orientam a ação política de governos e de indivíduos no sentido de uma maior ou menor centralização ou descentralização, ao passo que federação, por sua vez, remete à instituição no âmbito da qual a centralização ou descentralização pode ser constatada ou verificada.

Segundo Preston KING, a vertente ideológica do federalismo reuniria três orientações de mobilização, por assim dizer: o federalismo centralista, o federalismo descentralista e o federalismo de balanço. A primeira delas, como o próprio nome sugere, reuniria uma série de argumentos em favor de um certo tipo de centralização e está presente, por exemplo, em $O$ Federalista. De fato, como ressalta o referido autor: 
oferecidos para tal aumento da centralização eram muitos e variados, mas os mais importantes eram no sentido de que uma união mais estreita asseguraria uma melhor defesa contra ameaças externas, contra guerra entre Estados-membros, e contra a 'facção doméstica e a insurreição', enquanto promoveria uma base mais sólida para o comércio exterior e a prosperidade privada"101

Ainda que se sustente que há também uma defesa da descentralização em $O$ Federalista, é de se admitir com Preston KING que este é um argumento secundário no raciocínio de Alexander HAMILTON, James MADISON e John JAY. ${ }^{102}$ De todo modo, é necessário ressaltar que ínsito à defesa da centralização está a ideia de eficiência governamental: em outras palavras, propugna-se que a centralização seria capaz de um promover uma solução mais eficiente de problemas no âmbito de uma federação.

Já a segunda orientação do federalismo estaria relacionada com a defesa de uma maior descentralização no âmbito de uma federação, sob o argumento de que a descentralização seria um fator de democratização, de promover a justiça ou mesmo uma maior eficiência governamental. ${ }^{103} \mathrm{Em}$ alguns casos, a descentralização chega a ser defendida como um valor em si mesmo, como um fator de incremento da autonomia local. ${ }^{104}$

Finalmente, haveria um federalismo de balanço ou balanço federalista, o qual frequentemente apareceria ligado às teorias contratualistas de Estado. É sob a égide desta terceira corrente que o federalismo é visto como foedus, um pacto pelo qual entidades outrora soberanas abrem mão de parcela do seu poder político em prol de alguma vantagem ${ }^{105}$, ou então como um compromisso entre forças centrípetas e centrífugas, ${ }^{106}$ entre diversidade e unidade e assim por diante.

Novamente, quando se faz referência a orientações centralizadora ou descentralizadora do federalismo não se quer fazer referência à centralização ou à descentralização objetivamente verificáveis em um determinado Estado Federal. Note-se que nem mesmo as justificativas apontadas em prol de uma ou de outra orientação podem ser traduzidas em relações que se verificam na prática. De fato, viu-se que a eficiência governamental é reivindicada tanto pelo federalismo centralista quanto pelo descentralista. No que toca à orientação descentralista, embora ela seja com alguma frequência relacionada

\footnotetext{
101 KING. Federalism and Federation, p. 24.

102 KING. Federalism and Federation, p. 28.

103 KING. Federalism and Federation, p. 55.

${ }^{104}$ KING. Federalism and Federation, p. 54.

105 KING. Federalism and Federation, p. 56.

106 Sobre forças centrípetas e centrífugas na federação, vide Michael BOTHE. Federalismo - Um conceito em transformação histórica. Federalismo na Alemanha e no Brasil: Traduções. São Paulo: Konrad-AdenauerStiftung, 1995, pp. 6 e ss.
} 
a uma democracia qualificada e à promoção de direitos, o fato é que a única certeza que se pode ter em relação a ela é que ela protege os interesses do grupo que controla uma determinada localidade, o que frequentemente prejudica os direitos de minorias ali situadas, como ressalta o próprio Preston KING. ${ }^{107}$ Finalmente, a ideia de um equilíbrio entre forças em uma federação não é muito viável na prática, o que significa dizer que sob o manto de um federalismo balanceado pode-se defender tanto a centralização quanto a descentralização. ${ }^{108}$

Já no que tange à centralização e à descentralização efetivamente observadas em uma federação, optou-se por se debruçar sobre um estudo mais recente, de autoria de Jonathan RODDEN ${ }^{109}$ tendo em vista que ele se propõe a discutir a análise empírica da descentralização do federalismo sob um viés crítico, expondo os principais estudos que lhe antecederam e debatendo as suas insuficiências.

Observa RODDEN que nos últimos anos se observou uma proliferação de teorias para determinar as causas e as consequências da descentralização federativa, mas que não foram acompanhadas de esforços no sentido de uma comprovação empírica. Quando existem, os testes empíricos normalmente apontam para uma tensão entre teoria e prática. ${ }^{110}$ A fim de superar este impasse, o autor propõe uma discussão sobre definições e medidas, distinguindo e estabelecendo relações entre tipos de descentralização e federalismo.

No que toca à descentralização fiscal, destaca o autor a relevância de se perquirir não só sobre a distribuição de despesas e receitas entre o governo central e governos subnacionais, mas de determinar o que ele chama de "fonte de financiamento da descentralização do gasto", vale dizer, "se ela provém de transferências intergovernamentais,

\footnotetext{
107 KING. Federalism and Federation, p. 54.

108 KING. Federalism and Federation, p 44.

109 Jonathan RODDEN. Federalismo e descentralização em perspectiva comparada: sobre significados $e$ medidas. Revista de Sociologia e Política, no 24, junho 2005, pp. 9-27.

110 Referida tensão pode ser compreendida a partir das seguintes considerações: "Teorias otimistas, começando por Montesquieu e continuando ao longo da moderna economia do bem-estar social (OATES, 1972), enfatizaram as vantagens de revelação da informação e de accountability das estruturas governamentais mais descentralizadas. As teorias da escolha pública exploraram a possibilidade de que a mobilidade, em contextos descentralizados e de jurisdição múltipla, possa facilitar a adequação entre as preferências dos cidadãos e as políticas governamentais (TIEBOUT, 1956; BRETON \& SCOTT, 1978), produzir governos menores, mais eficientes e menos corruptos (HAYEK, 1939; BRENNAN \& BUCHANAN, 1980), bem como, sob determinadas condições, mercados mais seguros e crescimento econômico mais rápido (WEINGAST, 1995). Porém, estudos empíricos recentes contestam essas teorias, apresentando evidências que associam a descentralização e o federalismo a níveis mais altos de percepção da corrupção (TREISMAN, 2000a), governos maiores (STEIN, 1999), instabilidade macroeconômica (WIBBELS, 2000) e, sob determinadas condições, menor crescimento (DAVOODI \& ZOU, 1998). Tais estudos frequentemente apresentam conclusões que põem em dúvida os benefícios da descentralização e do federalismo" (RODDEN. Federalismo $e$ descentralização em perspectiva comparada, p. 10)
} 
receita compartilhada com o centro de acordo com uma fórmula fixa ou da arrecadação de receitas próprias, tais como impostos ou tarifas pagas por usuários, ou ainda empréstimos."111 Já no campo das políticas públicas, RODDEN observa que a descentralização normalmente resulta em uma prevalência de "autoridade compartilhada", submetendo a sua mensuração a algumas particularidades. ${ }^{112}$ No que toca à descentralização política, a despeito da utilidade dos estudos que acompanham a existência ou não de eleições para autoridades regionais e locais, o autor ressalta a necessidade de avaliar também "a relação entre arenas eleitorais de nível local e central", analisando, por exemplo, se a lista dos candidatos que competem regionalmente é determinada em âmbito regional ou federal ou se a lista de candidatos para as eleições federais é de algum modo influenciada pelas autoridades ou pelos eleitores subnacionais. ${ }^{113}$

Quanto ao federalismo, RODDEN ressalta a importância da representação dos Estados-membros na elaboração de políticas do âmbito federal e propõe um critério de medição contínua, que leve em consideração alguns critérios, tais como: (i) se a decisão é tomada por indivíduos, seus representantes eleitos, ou representantes nomeados pelos governos regionais; (ii) se na representação distrital há ou não a sobre-representação dos Estados pequenos, e; (iii) se as mudanças nas políticas públicas devem ser aprovadas por maiorias simples ou qualificadas. ${ }^{114}$

O referido autor ressalta a importância de articular a mensuração do federalismo e da descentralização ao argumento teórico escolhido, propondo uma análise a partir das: “1) limitações dos estudos existentes; 2) formas de melhoras as conexões entre teoria e dados; 3) novos rumos para teoria."115 Não é o caso de destrinchar todo o raciocínio desenvolvido por RODDEN no sentido de melhor articular as teorias existentes sobre federalismo e descentralização e análise empírica do federalismo, mesmo porque o exposto até aqui já serviu para demonstrar em que medida a presente pesquisa se distancia de estudos que se propõem a observar a centralização e da descentralização em uma federação.

De todo modo, é relevante constatar que a partir do momento em que se define federação como um conjunto de normas que regulam uma série de práticas federativas - e a partir do momento em que o foco da pesquisa reside principalmente nas normas constitucionais e na jurisprudência pertinente, consoante delimitações expostas na

\footnotetext{
111 RODDEN. Federalismo e descentralização em perspectiva comparada, p. 13.

112 RODDEN. Federalismo e descentralização em perspectiva comparada, pp. 15-16.

${ }^{113}$ RODDEN. Federalismo e descentralização em perspectiva comparada, p. 16.

114 RODDEN. Federalismo e descentralização em perspectiva comparada, pp. 18-20.

${ }^{115}$ RODDEN. Federalismo e descentralização em perspectiva comparada, p. 20.
} 
introdução - a presente tese distancia-se tanto da análise da descentralização e da centralização que se deseja obter em uma federação, quanto da análise da descentralização e da centralização nela efetivamente observadas.

É de se admitir que um foco na ratio destas normas poderia fornecer subsídios para a compreensão deste aspecto mais normativo e ideológico da centralização e da descentralização, ao passo que um aprofundamento nos efeitos concretos destas mesmas normas poderia ser alguma utilidade na verificação e descrição da centralização e da descentralização. Contudo, e como já se teve a oportunidade de ressaltar em mais de uma oportunidade, o presente estudo comparativo debruça-se sobre as normas em si - seu sentido e alcance, suas possíveis interpretações - o que certamente relega a análise da centralização e da descentralização, seja de um ponto normativo, seja de um ponto de vista descritivo, a um segundo plano.

Mais uma vez, isso não quer dizer que situar o Brasil e Alemanha como federações centralizadas ou descentralizadas não assume qualquer importância na presente pesquisa. Ao contrário, isso significa apenas que tal análise se coloca no plano dos pressupostos e não dos resultados do estudo comparativo: por este motivo, ela será desenvolvida ainda no terceiro capítulo da tese, dedicado a um breve balanço dos pressupostos teóricos e da contextualização do Brasil e da Alemanha como Estados Federais, e não no sexto capítulo, destinado à exposição dos resultados do estudo comparativo propriamente dito.

\subsection{A COMPETÊNCIA E A SUA REPARTIÇÃO}

A federação já foi definida nesta tese essencialmente como uma forma de Estado caracterizada pela divisão territorial do poder político. Contudo, é de se reconhecer que entre esta ideia de divisão do poder político e a ideia de repartição de competências legislativas e materiais, que consiste no objeto desta tese, há um caminho a ser percorrido.

A competência, afinal, é um conceito eminentemente jurídico, manejado tanto pela teoria geral do direito quanto pelo direito constitucional. No âmbito da teoria geral do Direito, são dignas de menção as considerações de Hans KELSEN, para quem a competência seria apenas uma forma de regulamentação positiva da conduta humana, ao lado do “ordenar" e do "permitir". ${ }^{116}$ Nesse sentido, pondera o autor em sua famosa obra Teoria Pura do Direito que

\footnotetext{
${ }^{116}$ Hans KELSEN. Teoria Pura do Direito. Trad. João Baptista Machado. 7ạ Ed. São Paulo: Martins Fontes, 2006, pp. 16 e ss.
} 


\begin{abstract}
"A conduta humana é ainda regulada num sentido positivo quando a um indivíduo é conferido, pelo ordenamento normativo, o poder ou a competência para produzir, através de uma determinada atuação, determinadas consequências pelo mesmo ordenamento normadas, especialmente - se o ordenamento regula a sua própria criação - para produzir normas ou para intervir na produção de normas. O caso é ainda o mesmo quando o ordenamento jurídico, estatuindo atos de coerção atribui a um indivíduo poder ou competência para estabelecer esses atos coercitivos sob as condições estatuídas pelo mesmo ordenamento jurídico"117
\end{abstract}

Na sua obra Teoria Geral do Direito e do Estado, Hans KELSEN analisa mais uma vez sobre o tema, conferindo-lhe novos contornos. Em um primeiro momento, a competência surge como o elo que liga o elemento material da conduta humana regulada pela norma jurídica - "a coisa que deve ser feita ou evitada" - e o seu elemento pessoal - "o indivíduo que tem que fazê-la ou deixar de fazê-la”. Nesse sentido, dizer que um indivíduo é competente seria o mesmo que dizer que "à ação é conferida a qualidade de condição jurídica ou consequência jurídica apenas se ela for executada por este indivíduo". ${ }^{118} \mathrm{Em}$ um segundo momento, o autor trata da competência em um contexto de Estado Federal, porém sem oferecer exatamente uma definição. No trecho analisado, KELSEN se limita a afirmar que o que caracteriza a federação em contraposição ao Estado Unitário é o fato de que as competências legislativas dos Estados-membros naquele serem mais "numerosas e importantes", ou então que as competências da União em uma federação são mais numerosas do que em uma confederação, e assim por diante. ${ }^{119}$

Uma outra definição de competência oriunda da teoria geral do Direito foi formulada por Herbert L. HART. Segundo este autor, a complexidade do sistema jurídico só poderia ser captada por meio da diferenciação entre dois tipos de normas jurídicas. As normas do primeiro tipo, denominadas de normas primárias, seriam aquelas que preveem a obrigatoriedade de uma ação ou uma abstenção por parte dos seres humanos, ao passo que as normas do segundo tipo, chamadas de normas secundárias, seriam "normas sobre normas", regulando o modo pelo qual uma norma primária poderia ser: (i) reconhecida como tal; (ii) criada, extinta ou modificada, e (iii) aplicada em um caso concreto. Nesse sentido, estas não seriam normas que efetivamente impõem deveres, e sim normas que "outorgam poderes, sejam estes públicos ou privados". 120

Dentro deste raciocínio, as normas secundárias que preveem a forma pela qual normas primárias podem ser introduzidas no ordenamento jurídico ou dele retiradas podem

\footnotetext{
117 KELSEN. Teoria Pura do Direito, p. 17.

118 KELSEN. Teoria Geral do Direito e do Estado, pp. 129-130.

${ }^{119}$ KELSEN. Teoria Geral do Direito e do Estado, pp. 451 e ss.

120 Herbert L. A. HART. O conceito de Direito. Trad. Antônio de Oliveira Sette-Câmara. São Paulo: Martins Fontes, 2009, p. 105
} 
ser associadas à ideia de competência, muito embora HART as denomine de "normas de modificação" e não de "normas de competência". De todo modo, a ideia que subjaz uma ou outra parece ser a mesma, qual seja, o poder (jurídico) conferido a alguém para produzir, modificar ou revogar normas primárias. ${ }^{121}$

É de se admitir, contudo, que o objetivo principal das propostas de KELSEN e de HART não consiste exatamente em explicar como o poder político que caracteriza a federação se relaciona com a atribuição de uma competência a um ente federativo determinado. ${ }^{122}$ Tal fenômeno é analisado somente pela doutrina que se ocupa precipuamente do tema da competência em um contexto de Estado Federal. Neste sentido, observa Josef ISENSEE:

\begin{abstract}
"A competência federal é a medida jurídica do poder estatal. Ela dosa e disciplina o poder. Consequentemente ela constrói um momento de separação vertical do poder. Ela é determinada pela constituição, de forma a distribuir o poder estatal entre dois níveis dotados de estatalidade e assim limitar os campos de atuação dos detentores do poder. A repartição de competências cobre todo o potencial de atuação com uma rede jurídica, capturando-o, organizando-o, subjugando-o. Por meio da sua transcrição em termos jurídico a posição de poder é transladada em condição agregada do Direito. Questões de poder tornam-se juridicamente maleáveis por meio da definição de competências. Um litígio sobre competência pode ser discutido por um caminho jurídico, fora da luta política pelo poder. (...) A regulamentação sistemática, completa e integrada das competências garante que a diferenciação federativa não ameace a unidade do poder estatal e confere ao regime dúplice uma res publica composita. A constituição jurídica do Estado Federal constrói-se a partir da repartição de competências. Aqui repousa, do ponto de vista jurídico, o 'núcleo duro' do direito do Estado Federal”123
\end{abstract}

\footnotetext{
${ }^{121}$ Note-se que as normas de modificação são destinadas a solucionar um defeito das normas primárias, qual seja, o seu caráter estático. Sobre as crises ou defeitos das estruturas sociais simples e que são solucionadas por tipos específicos de normas secundárias, vide HART. O conceito de Direito, pp. 118 e ss.

122 Há ainda outras propostas oriundas da teoria geral do Direito. Tercio Sampaio FERRAZ JUNIOR, por exemplo, retoma o raciocínio desenvolvido por Alf ROSS para elaborar a seguinte noção de competência: "principiemos pela noção de competência. Trata-se de uma forma de poder jurídico, isto é, de exercício impositivo de comportamentos e relação de autoridade regulado por normas. Estas normas, segundo Alf Ross (Logica de las Normas, 1968) são 'normas de competência', em oposição a 'normas de conduta'. Ao estabelecer esta forma de poder jurídico, a norma de competência enuncia também (ou lhes alude) as condições necessárias para o exercício: as que delimitam qual o sujeito qualificado (competência pessoal), qual o procedimento (competência procedimental) e o alcance possível em face dos sujeitos passivos, sua situação e seu tema (competência material). Fora destes limites, os atos de exercício são nulos e a norma criada por força deles é inválida" (Tércio Sampaio FERRAZ JUNIOR. Normas Gerais e Competência Concorrente: Uma exegese do art. 24 da Constituição Federal. Revista Trimestral de Direito Público, no 7, 1994, p. 17). Como se pode perceber, trata-se de uma estipulação conceitual bem precisa, mas que não incorpora algo essencial quando se está diante de uma competência federativa: a transição de um poder político para um poder eminentemente jurídico. Isso, por sua vez, é algo que só é bem apreendido pelos autores que se propõem a estudar no âmbito do direito constitucional, como será analisado a seguir.

123 ISENSEE. § 133 Die bundesstaatliche Kompetenz, p. 457. No original: „Die bundesstaatliche Kompetenz ist das rechtliche Gefäß staatlicher Macht. Mithin bildet sie ein Moment vertikaler Gewaltenteilung. Sie ist von Verfassungs wegen dazu bestimmt, die Staatsgewalt den beiden Ebenen der Staatlichkeit zuzuteilen und so die Handlungsräume der Machtinhaber zu begrenzen. Die Kompetenzordnung überzieht das gesamte Handlungspotential mit einem rechtlichen Netz, das es einfängt, gliedert, zähmt. Durch ihre rechtliche
} 
Em outras palavras, a competência é noção intrinsecamente ligada a ideia de poder estatal, este de viés eminentemente político, e possui duas funções precípuas. Em primeiro lugar, ela opera a disciplina e contenção do poder estatal, instrumentalizando um genuíno controle vertical do poder para falar com Karl LOEWENSTEIN ${ }^{124}$ e alinhandose às finalidades do constitucionalismo moderno. Em segundo lugar, a competência permite que a divisão do poder típica da federação seja apreendida em termos jurídicos e que eventuais conflitos também sejam solucionados conforme critérios jurídicos.

Esta última função da competência reveste-se de especial importância, pois é ela quem viabiliza a transição da federação, enquanto organização política que divide o poder político de forma a assegurar a coexistência da diversidade na unidade, para a federação, como forma de Estado caracterizada pela repartição de competências entre União e Estadosmembros (e Municípios, no caso do Brasil). Ao fazê-lo, ela promove o enquadramento e a solução de problemas típicos da federação conforme normas jurídicas, viabilizando a decisão e orientando a ação dos atores políticos envolvidos. ${ }^{125}$

Contudo, precisar as funções que a noção de competência desempenha não significa exatamente um esforço no sentido de sua definição, consistindo esta em uma tarefa que só pode ser desempenhada a partir de mais algumas ponderações extraídas do direito constitucional.

No direito brasileiro é corrente a definição de JOSÉ AFONSO da Silva, para quem competência seria "a faculdade juridicamente atribuída a uma entidade ou órgão ou agente do Poder Público para emitir decisões", ao passo que competências seriam "as diversas modalidades de poder de que se servem os órgãos ou entidades estatais para realizar suas

\footnotetext{
Umschreibung wird die politische Machtlage in den Aggregatzustand des Rechts überführt, Machtfragen werden in der kompetenzrechtlichen Definition jurisdisch handhabbar. Ein Streit um die Kompetenz kann auf jurisdischem Wege ausgetragen werden, außerhalb des politischen Machtkampfes. (...) Die systematische, vollständige und nahtlose Regelung der Kompetenzen gewährleistet, daß die bundesstaatliche Differenzierung die rechtliche Einheit der Staatsgewalt nicht sprengt und das duplex regimen eine res publica composita hervorbringt. Die rechtliche Verfaßtheit des Bundesstaates baut auf der Kompetenzordnung auf. Hier liegt, jurisdisch gesehen, der ,harte Kern' des Bundesstaatsrechts"

124 Segundo Karl LOEWENSTEIN, os controles verticais do poder seriam de três tipos: (i) o federalismo; (ii) os direitos individuais; (iii) o pluralismo (Teoria de la Constitución, p. 353)

125 Neste ponto, a ideia de competência aproxima-se do viés eminentemente dogmático, preocupado com a decidibilidade, que a presente tese assume. É de ressaltar, com Tércio Sampaio FERRAZ JUNIOR, que o fenômeno da positivação modificou o status científico daquilo que "materialmente sempre foi direito com o fito de descrever aquilo que, então pode ser direito (relação causal), para ocupar-se com a oportunidade de certas decisões, tendo em vista aquilo que deve ser direito (relação de imputação). Nesse sentido, seu problema não é propriamente uma questão de verdade, mas de decidibilidade", isto quer dizer, de criar condições para a decisão e de, assim, orientar a ação (FERRAZ JUNIOR. Ciência do Direito, p. 43)
} 
funções." ${ }^{126}$ Esta é uma proposta certamente influenciada pela teoria geral do direito, em especial pelo pensamento de Hans KELSEN; nela faltam, contudo, algumas especificidades que a ideia de competência apresenta em um contexto de federalismo e de federação.

Josef ISENSEE, com razão, observa que tentativas de definição do que seja competência - lembrando que em alemão é possível utilizar tanto a expressão “Zuständigkeit" quanto a expressão "Kompetenz" - são raras na doutrina. Após comentar as propostas de Norbert ACHTERBERG e de Rupert STETTNER ${ }^{127}$, apontando os seus defeitos e insuficiências, ISENSEE forja a sua própria definição em trecho que é citado na sua integralidade pela importância que reveste para a presente tese:

\begin{abstract}
"A definição de competência deve cobrir o aspecto objetivo, a parcela do campo de atuação, e a o aspecto pessoal, o destinatário da autorização de atuação. Do mesmo modo deve ser visível o limite dúplice que a competência implica: em relação a outras parcelas e em relação àqueles que poderiam figurar como destinatários e são por conseguinte excluídos. A competência deixa-se definir, portanto, como o segmento circunscrito de um campo de atuação, o qual é atribuído a destinatários determinados para a defesa sob sua própria responsabilidade. Quando relacionada ao Estado Federal a competência deixase definir apenas como a parte, balizada juridicamente, pertencente à União ou aos Estados no potencial de atuacão do Estado como um todo" (grifo nosso) $)^{128}$
\end{abstract}

Note-se que esta definição de competência engloba três aspectos fundamentais da ideia de competência. Em primeiro lugar, ela põe em evidência o caráter dúplice da limitação que a competência impõe: se, por um lado, ela circunscreve um campo de atuação, por outro lado, ela põe em evidência que este, devidamente delimitado, é somente uma parte de um todo correspondentes a todas as tarefas e funções estatais. Em segundo lugar, ela ressalta uma decisão constitucional de atribuir a responsabilidade por uma determinada tarefa estatal a um destinatário em detrimento de outro (mesmo

\footnotetext{
${ }^{126}$ JOSÉ AFONSO. Curso de Direito Constitucional Positivo, p. 479. A fim de sanar quaisquer dúvidas, transcrevese o trecho em que a tese se baseia: "Competência é a faculdade juridicamente atribuída a uma entidade ou a um órgão ou agente do Poder Público para emitir decisões. Competências são as diversas modalidades de poder de que se servem os órgãos ou entidades estatais para realizar suas funções."

${ }^{127}$ Note-se que, para Rupert STETTNER, competência deve ser entendida como "o poder de atuação distribuído e concedido às repartições e órgãos das três funções estatais, para editar atos imperativos de uma forma bem precisa e determinada na busca de missões estatais do bem comum e no cumprimento de tarefas estatais atribuídas" (Rupert STETTNER. Grundfragen einer Kompetenzlehre. Berling: Dunckler \& Humblot, 1983, p. 35). 128 ISENSEE. § 133. Die bundesstaatliche Kompetenz, p. 463. No original: "die Definition der Kompetenz muss die gegenständliche Seite, die Parzelle des Handlungsbereichs, und die persönliche Seite, den Adressaten der Handlungsermächtigung, abdecken. Zugleich muss die zwiefache Grenze sichtbar werden, welche die Kompetenz zieht: gegenüber den anderen Parzellen und gegenüber denjeningen, die an sich als Adressaten in Betracht kämen und somit ausgeschlossen werden. Die Kompetenz lässt sich somit bestimmen als der rechtlich umschriebene Ausschnitt eines Handlungsbereichs, der einem bestimmten Adressaten zu eigenverantwortlicher Wahrnehmung rechtlich zugewiesen ist. Auf den Bundesstaat bezogen lässt sich Kompetenz knapp definieren als der rechtlich zugemessene Anteil des Bundes oder der Länder am Handlungspotential des Gesamtstaates."
} 
que esta ideia seja mitigada em parte no caso da repartição vertical de competências, como se verá a seguir). Em terceiro lugar, ela explicita que a competência também significa uma autorização para que o destinatário da norma de competência efetivamente atue em relação às tarefas que lhe foram atribuídas, embora isto não signifique uma obrigação de atuar, ao menos em tese. ${ }^{129}$ Por estes motivos esta parece ser a definição mais adequada e será a adotada nesta pesquisa, com todos os desdobramentos que lhe são ínsitos.

Feitas estas considerações, é importante deixar consignado que o objeto da presente tese não consiste exatamente nas normas de competência propriamente ditas, e sim nas normas que disciplinam o exercício de competências legislativas e de execução pelos entes federativos, consoante delimitação exposta na introdução desta tese. Na doutrina alemã, tal distinção é mais difundida, sendo que as normas de competência geralmente são referidas como Kompetenznormen e as normas que disciplinam o exercício de competências são designadas como Kompetenzausübung. Segundo ISENSEE, o exercício de uma competência "é, por sua vez, dirigido por diretivas jurídicas, por exemplo por meio da cláusula de barreira (artigo 72 II GG), por meio da ingerência da União na administração estadual na execução de leis federais (artigo 84 e 85 GG), sobretudo por meio do mandamento válido para os dois lados da lealdade federal". Todos estes institutos - e também outros institutos com este mesmo viés - serão abordados em detalhes oportunamente. Note-se, todavia, que esta pesquisa adota uma noção mais elástica de normas que disciplinam o exercício de uma competência, dado que que considera inclusive normas que preveem que uma determinada competência deve ser exercida privativa ou concorrentemente, ou que determinam que a atuação do ente federativo deve se limitar à elaboração de uma legislação ou à execução de uma legislação. Estas, por sua vez, são normas que os alemães tendem a considerar como Kompetenznormen e não como Kompetenzausübung. Na verdade, o que se pretende excluir do objeto do estudo comparativo são apenas aquelas disposições que preveem que um determinado ente federativo é competente em relação a uma matéria específica. Ou seja, objetiva-se eliminar do objeto da pesquisa os chamados títulos competenciais, vale dizer, as alíneas ou os números que arrolam matérias ou situações da vida que competem a um ente federativo com exclusão dos demais. Porém, os outros aspectos de uma norma de competência não só serão contemplados como também confrontados oportunamente. Exatamente por isso, precisar a função e o conteúdo de uma norma de competência permanece uma questão fulcral à presente tese, razão pela qual se empreendeu uma análise tal como a desenvolvida neste tópico.

\footnotetext{
${ }^{129}$ Note-se que as ideias desenvolvidas neste parágrafo apresentam correspondência com as três funções que Josef ISENSEE atribui à norma de competência em ISENSEE. § 133 -Die bundesstaatliche Kompetenz, p. 471.
} 


\subsection{CLASSIFICAÇÕES DAS COMPETÊNCIAS E DE SUA REPARTIÇÃO}

Depois de tratar da função e da definição de competência em um Estado, é chegado o momento de analisar as diversas técnicas de repartição de competências, além de algumas classificações relacionadas que são importantes para a análise comparativa que se propõe nesta tese. Para tanto, empreende-se uma breve incursão no pensamento de alguns representantes da ciência política e das ciências jurídicas brasileira e alemã. Ao término, será exposta a nossa própria classificação, elaborada a partir de elementos das classificações discutidas anteriormente.

Antes, contudo, considera-se importante tecer duas observações preliminares. Em primeiro lugar, nem as classificações aqui reunidas e discutidas possuem o mesmo propósito. Como se perceberá a seguir, Ronald L. WATTS leva em consideração o modo pelo qual as federações modernas repartem competências, para ao final elaborar uma sistematização das modalidades de competências federativas normalmente observadas. Já JOSÉ AFONSO da Silva e Josef ISENSEE propõem classificações lastreadas no direito constitucional positivo do Brasil e da Alemanha, respectivamente. Finalmente, Manoel Gonçalves FERREIRA FILHO propõe uma classificação eminentemente teórica, levando em consideração, ao mesmo tempo, as grandes linhas de evolução da federação.

Em segundo lugar, a nossa classificação, exposta no item 1.5.5, possui uma índole mais teórica. Porém, não se objetiva forjar categorias às quais todas as competências legislativas e de execução previstas pela Constituição Federal de 1988 e pela Lei Fundamental de 1949 podem ser subsumidas. O que se tem em mente com semelhante proposta é algo mais singelo, mais precisamente, pretende-se apenas forjar um arcabouço teórico que ajude a compreender os sistemas brasileiro e alemão de repartição de competências federativas, reduzindo um pouco a complexidade que lhes é inerente. É como se as categorias forjadas e discutidas neste último subitem fornecessem um resumo do que se pode ou não extrair da norma constitucional que prevê uma competência legislativa, uma competência concorrente, e assim por diante. Mais adiante, esta mesma classificação será retomada para sistematizar os resultados obtidos na confrontação dos sistemas brasileiro e alemão de repartição de competências. As razões que informaram tal escolha e as consequências que dela podem ser extraídas são questões que serão elucidadas no sexto capítulo da tese. 


\subsubsection{A classificação proposta por Ronald. L. WATTS}

O capítulo dedicado da conhecida obra Comparing Federations de Ronald WATTS dedicado à análise da repartição de competências começa com a constatação de que se está diante da característica institucional fundamental da federação, sendo que a distinção em relação a outras fórmulas estatais - em especial, a confederação e as uniões descentralizadas - reside justamente na "garantia constitucional de autonomia sobre uma certa área de funções assinaladas para cada ordem de governo" ${ }^{130}$. Como fatores que influenciam na alocação de competências ao poder central ou às unidades subnacionais, o referido autor arrola o grau de homogeneidade da sociedade, o processo de formação da federação, o período em que as competências foram repartidas pela constituição, a adoção do common law ou do civil law e, finalmente, a adoção do presidencialismo ou do parlamentarismo como sistemas de governo. ${ }^{131}$

A seguir, WATTS utiliza este último fator para analisar o relacionamento entre competências legislativas e competências de execução. Observa este autor que na maioria das federações de tradição anglo-saxônica a distribuição das competências de execução segue a divisão das competências legislativas, o que asseguraria uma maior autonomia por parte dos entes federativos, além de promover uma maior accountability ao deixar explícito qual ente é responsável por uma determinada política pública. Já as federações que adotam o parlamentarismo e de matiz europeu seriam caracterizadas pela não-coextensividade entre competências legislativas e competências administrativas: ou seja, o fato de um ente ser competente para editar uma lei não significa que ele será competente para executar as suas disposições por meio da sua administração. Tal fenômeno, mais marcante nas federações alemã, austríaca e suíça, demandaria uma maior colaboração e coordenação entre os níveis de governo, levando em alguns casos inclusive a um "entrelaçamento de relações entre os diferentes tipos de governo" e que já foi referida nesta tese como interdependência política (Politikverflechtung). ${ }^{132}$

No que toca ao modo pelo qual competências legislativas são repartidas, WATTS observa as seguintes variações: (i) competência legislativa exclusiva; (ii) competência legislativa concorrente; (iii) competência comum; (iv) competência residual, e; (v) competências de emergência. Observa este autor que a totalidade das federações trabalham com competências legislativas exclusivas, sendo que o mais comum é que elas sejam

\footnotetext{
130 WATTS. Comparing Federal Systems, p. 83

131 WATTS. Comparing Federal Systems, pp. 84-85.

132 WATTS. Comparing Federal Systems, pp. 86-87.
} 
atribuídas em maior ou menor medida à União, ao passo que às unidades constituintes é assegurada uma competência residual. Contudo, é possível encontrar federações em que a competências das unidades constituintes também seja enumerada: é o caso da Suíça, Canadá, Bélgica, Índia e Malásia. ${ }^{133}$

Já a competência legislativa concorrente seria responsável por promover "uma maior flexibilidade na distribuição de poderes, possibilitando que o governo federal adie o exercício de uma competência potencial em um campo específico até que ele se revele um assunto de importância federal," relegando o assunto à iniciativa das entidades periféricas. Note-se que, embora WATTS não exclua desta categoria aquelas hipóteses que a doutrina brasileira chama de competência concorrente cumulativa, ele certamente parece enfocar a chamada competência concorrente limitada, na qual a União se resume à edição de normas gerais, deixando às entidades periféricas a iniciativa de adaptar a legislação federal às particularidades locais. A competência comum, por sua vez, não se confundiria com a competência concorrente e ocorreria naqueles casos em que ambos os níveis de governo detêm competência exclusiva sobre um assunto, mas necessitam um do consentimento do outro para atuar. ${ }^{134}$

A competência residual, por sua vez, seria caracterizada pela atribuição, a um ou outro nível de governo, das competências legislativas não expressamente enumeradas na constituição, e seria normalmente atribuída às unidades constituintes em federações formadas por agregação, ao passo que nas federações formadas por segregação a competência residual seria atribuída à União. ${ }^{135}$

Finalmente, a competência de emergência assegura à União a possibilidade de regulamentar matérias normalmente inseridas na competência das unidades constituintes em algumas situações, representando o resultado dos temores do legislador constituinte em relação a uma possível balcanização ou desintegração. É prevista nas constituições da Malásia, Argentina, Canadá, dentre outros. ${ }^{136}$

\subsubsection{A classificação proposta por JOSÉ AFONSO da Silva}

No âmbito da doutrina brasileira é bem difundida a classificação proposta por JOSÉ AFONSO da Silva, a qual pode ser sistematizada nos seguintes termos: ${ }^{137}$

\footnotetext{
133 WATTS. Comparing Federal Systems, p. 87.

134 WATTS. Comparing Federal Systems, p. 87-89

135 WATTS. Comparing Federal Systems, pp. 89-90.

136 WATTS. Comparing Federal Systems, p. 90.

137 JOSÉ AFONSO. Curso de Direito Constitucional Positivo, pp. 479-482.
} 


\begin{tabular}{|c|c|}
\hline CRITÉRIO & ESPÉCIES DE COMPETÊNCIAS \\
\hline $\begin{array}{l}\text { Sistematização } \\
\text { grandes grupos }\end{array}$ & $\begin{array}{l}\text { - Competência material: } \\
\text { - Exclusiva; } \\
\text { - Comum, cumulativa ou paralela; } \\
\text { - Competência legislativa: } \\
\text { - Exclusiva; } \\
\text { - Privativa; } \\
\text { - Concorrente; } \\
\text { - Suplementar. }\end{array}$ \\
\hline $\begin{array}{l}\text { Quanto à forma ou } \\
\text { processo de distribuição }\end{array}$ & $\begin{array}{l}\text { - Enumerada ou expressa; } \\
\text { - Reservada ou remanescente e residual; } \\
\text { - Implícita ou resultante (ou inerente ou decorrente). }\end{array}$ \\
\hline Quanto ao conteúdo & $\begin{array}{l}\text { - Econômica; } \\
\text { - Social; } \\
\text { - Político-administrativa; } \\
\text { - Financeira; } \\
\text { - Tributária. }\end{array}$ \\
\hline Quanto à extensão & $\begin{array}{l}\text { - Exclusiva; } \\
\text { - Privativa; } \\
\text { - Comum, cumulativa ou paralela; } \\
\text { - Concorrente; } \\
\text { - Suplementar. }\end{array}$ \\
\hline Quanto à origem & $\begin{array}{l}\text { - Originária; } \\
\text { - Delegada. }\end{array}$ \\
\hline
\end{tabular}

Dentre as espécies mencionadas por JOSÉ AFONSO, merecem algum esclarecimento a distinção traçada entre competências exclusiva, privativa, comum, concorrente e suplementar, tendo em vista que ela difere um pouco da classificação proposta por WATTS.

Segundo este constitucionalista brasileiro, tanto na modalidade exclusiva quanto na privativa, uma competência seria atribuída a um ente com exclusão de todos os outros; contudo, nesta última seria possível a figura da delegação e da competência suplementar. A competência concorrente, por sua vez, seria caracterizada, nos dizeres do próprio JOSÉ AFONSO, pela "possibilidade de disposição sobre o mesmo assunto ou matéria por mais de uma entidade federativa" e pela "primazia da União no que tange à fixação de normas gerais", ao passo que a competência comum ou cumulativa expressaria a faculdade atribuída a mais de um entidade federativa de atuar em uma determinada matéria, sem que a concretização da competência por parte de um deles venha a excluir a competência do outro. Finalmente, a competência suplementar seria a competência conferida aos Estados para 
desdobrar as normas gerais da União ou suprir a sua falta, consistindo, portanto, em uma complementação da competência concorrente. ${ }^{138}$

Também difere um pouco da proposta de WATTS a distinção que JOSÉ AFONSO traça entre competências enumeradas, reservadas (ou remanescente), residuais e implícitas. Segundo este autor as competências enumeradas são estabelecidas de modo direto e explícito pela constituição, pouco importando se são competências privativas ou concorrentes. Já as competências reservadas e as competências residuais designam competências não expressamente previstas na constituição. Contudo, as competências reservadas são atribuídas genericamente a uma entidade federativa após outras competências serem enumeradas a outra; já as competências residuais consistem em um "resíduo" competencial, que resta após todas as competências da União e das unidades periféricas serem enumeradas. Finalmente, competência implícita é uma competência não expressa no texto constitucional, mas que é atribuída a um ente pois é logicamente necessária à concretização de uma competência expressamente atribuída ao mesmo ente federativo. ${ }^{139}$

JOSÉ AFONSO também traça uma distinção entre sistemas de execução de serviços digna de menção. Haveria, assim, um sistema imediato de execução de serviços, segundo o qual União e Estados-membros manteriam, “cada qual, sua própria administração, com funcionários próprios, independentes uns dos outros e subordinados aos respectivos governos": seria o caso dos EUA, da Argentina e também do Brasil. Haveria ainda um sistema mediato de execução de serviços, caracterizado pela execução dos serviços federais pela administração dos Estados-membros, e um sistema misto, no qual parte dos serviços federais seriam executados pela administração dos Estados-membros e parte pela administração pública federal. ${ }^{140}$ Embora o autor não mencione expressamente, esta diferenciação parte do pressuposto de que o titular de uma competência administrativa sobre um determinado assunto pode não ser o mesmo da respectiva competência legislativa. Assim, se a um ente for atribuída tanto a competência legislativa quanto a competência administrativa sobre o mesmo assunto, estamos falando de um sistema imediato; porém, se não houver esta correspondência, estaremos diante ou de um sistema mediato ou de um sistema misto.

\footnotetext{
138 JOSÉ AFONSO. Curso de Direito Constitucional Positivo, p. 481.

139 JOSÉ AFONSO. Curso de Direito Constitucional Positivo, p. 480.

140 JOSÉ AFONSO. Curso de Direito Constitucional Positivo, p. 482.
} 


\subsubsection{A classificação proposta por Manoel Gonçalves FERREIRA FILHO}

Manoel Gonçalves FERREIRA FILHO, por sua vez, propõe uma sistematização acerca das técnicas de repartição de competências que também conta com muitos adeptos na doutrina brasileira. Haveria, assim, uma técnica denominada horizontal, caracterizada pela separação radical das atribuições dos entes federativos, por meio da atribuição privativa de uma matéria, dos seus aspectos mais gerais aos particulares, a um ente federativo, com a exclusão dos demais. Já a segunda técnica de repartição de competência, denominada vertical ou concorrente, dividiria uma competência entre dois ou mais entes localizados em níveis diferentes na estrutura federativa, podendo ser do tipo cumulativa ou nãocumulativa. ${ }^{141}$ Como pondera FERREIRA FILHO em trecho que vale a transcrição literal:

"A cumulativa existe sempre que não há limites prévios para o exercício da
competência, ou por parte de um ente, seja a União, seja o Estado-membro. Claro
está que, por um princípio lógico, havendo choque entre norma estadual e norma
federal num campo de competência cumulativa, prevalece a regra da União. É o
que exprime o brocardo alemão: Bundesrecht bricht Landesrecht.
A não-cumulativa é que propriamente estabelece a chamada repartição 'vertical'.
Com efeito, dentro de um mesmo campo material (concorrência 'material' de
competência), reserva-se um nível superior ao ente federativo mais alto, a União
- que fixa os princípios e normas gerais, deixando-se ao ente federativo que é o
Estado-membro uma competência 'complementar'. Admite-se até, que à falta
dessas normas gerais, o Estado-membro possa suprir essa ausência (competência
'supletiva')." 142

Segundo este autor, a técnica da repartição horizontal seria típica de um federalismo dualista, ao passo que a repartição vertical seria própria do federalismo cooperativo, ambos já analisados nos tópicos 1.2.1 e 1.2.2. ${ }^{143}$ Como já se teve a oportunidade de ressaltar, tanto um quanto outro possuem outras particularidades que lhe seriam ínsitas; um especial modo de repartição de competências seria apenas um dos fatores que serviriam para reconduzir uma federação a um ou outro tipo de federalismo.

Esta classificação proposta por FERREIRA FILHO entre técnicas de repartição de competências não abrange uma distinção extremamente relevante para os fins desta tese, qual seja, aquela que contrapõe competências legislativas e competências de execução; porém, possui o mérito de inserir as competências enumeradas, remanescentes e concorrentes em um contexto de técnicas de divisão do poder em uma federação, o que certamente se dá conforme alguns objetivos e princípios específicos. De fato, qualquer

\footnotetext{
${ }^{141}$ Manoel Gonçalves FERREIRA FILHO. O Estado Federal brasileiro à luz da Constituição de 1988. Revista da Faculdade de Direito da Universidade de São Paulo, vol. 86, 1991, pp. 124-125.

142 FERREIRA FILHO. O Estado Federal brasileiro, p. 125.

${ }^{143}$ FERREIRA FILHO. O Estado Federal brasileiro, p. 124.
} 
competência privativa ou concorrente, legislativa ou administrativa, só pode ser corretamente compreendida em função de um todo e esta é uma consequência que se extrai do próprio conceito de competência adotado nesta tese, qual seja: de uma dupla limitação, que circunscreve e delimita um campo de atuação, atribuindo-o a um ente federativo e que, por outro lado, evidencia que este campo de atuação devidamente delimitado consiste apenas em uma parcela de um todo e que poderia ter sido atribuído a outros entes igualmente legitimados. Em outras palavras, não basta enquadrar uma competência em uma ou outra categoria, mas contextualizá-la em um sistema de repartição de competências e explicar a sua função dentro deste sistema.

\subsubsection{A classificação proposta por Josef ISENSEE}

No âmbito do direito constitucional alemão, merece menção a tipologia proposta por Josef ISENSEE, ${ }^{144}$ também sistematizada em um quadro a fim de facilitar a compreensão:

\begin{tabular}{|c|c|c|}
\hline $\begin{array}{l}\text { Tipologias redacionais } \\
\begin{array}{lrr}\text { (conforme } & \text { a } & \text { sua } \\
\text { formulação } & & \text { na } \\
\text { constituição) } & & \end{array}\end{array}$ & $\begin{array}{l}\text { (i) } \\
\text { (ii) }\end{array}$ & $\begin{array}{l}\text { Competências enumeradas e competências residuais; } \\
\text { Competências expressas e competências não expressas. }\end{array}$ \\
\hline $\begin{array}{l}\text { Tipologias substanciais } \\
\text { (conforme a forma e o } \\
\text { conteúdo da } \\
\text { distribuição de poder } \\
\text { entre União e Estados) }\end{array}$ & $\begin{array}{l}\text { (i) } \\
\text { (ii) } \\
\text { (iii) } \\
\text { (iv) } \\
\text { (v) }\end{array}$ & $\begin{array}{l}\text { Competências privativas e competências concorrentes; } \\
\text { Competências completas e competências parciais; } \\
\text { Competências independentes e competências acessórias; } \\
\text { Competências materiais e competências de execução } \\
\text { material } \\
\begin{array}{l}\text { Competências separadas, competências mistas e } \\
\text { competências de colaboração. }\end{array}\end{array}$ \\
\hline
\end{tabular}

As competências enumeradas e residuais já foram comentadas em mais de uma oportunidade neste tópico e não serão objeto de nova análise, tendo em vista que o referido autor alemão pouco inova no tratamento deste assunto. Cumpre apenas ressaltar uma importante observação que ISENSEE faz em relação às competências residuais, mais precisamente, o fato de estas não serem enumeradas não significa que elas sejam indefinidas. Com efeito, elas não constituem uma "massa jurídica amorfa" para falar com o referido constitucionalista alemão; ao contrário, o seu objeto é determinado pelo confronto com as competências enumeradas, sejam elas privativas ou concorrentes. ${ }^{145}$

\footnotetext{
144 ISENSEE. § 133 Die bundesstaatliche Kompetenz, pp. 465 e ss.

145 ISENSEE. § 133 Die bundesstaatliche Kompetenz, p. 466.
} 
Ou seja, embora seja corrente a utilização da expressão "competência enumerada" para se referir à competência privativa - em regra - da União, isso se deve ao fato de que as "competências privativas" da União serem normalmente "competências enumeradas". Porém, competência enumerada pode ser tanto privativa quanto concorrente, sendo certo que o seu contraposto são as competências residuais, as quais também podem ser privativas ou concorrentes.

As competências expressas e as competências não-expressas, embora não tenham sido tratadas até o presente momento, também não oferecem maiores dificuldades. As primeiras seriam aquelas previstas textualmente na constituição ao passo que as últimas não o são. Nesse sentido, elas encontram alguma correspondência com a ideia de competência implícita desenvolvida por JOSÉ AFONSO e brevemente tratada supra. Contudo, ISENSEE dá a esta última categoria os contornos do direito alemão ao nela incluir a competência por força da natureza da coisa, a competência por força do contexto da coisa e competênciaanexa. ${ }^{146}$

A competência privativa, por sua vez, seria a competência que é atribuída ou à União ou aos Estados-membros (ou aos Municípios, no caso do Brasil), com exclusão de outros possíveis legitimados. Tratar-se-ia, portanto, de delimitar um campo de atuação e atribuí-lo com exclusividade a um ente federativo em detrimento dos demais. Já a competência concorrente, segundo ISENSEE, seria aquela que estaria aberta tanto à atuação da União quanto dos Estados-membros. Diante da possibilidade de atuações concomitantes e contraditórias, tal modalidade exigiria uma decisão sobre qual direito deve prevalecer. Nesse ponto, é de se ressaltar que o direito alemão tradicionalmente consagrou a prevalência do direito federal sobre o direito estadual, conforme disposto no artigo 31 GG. Contudo, a reforma constitucional de 2006, ao instituir uma nova modalidade de competência denominada de competência de divergência (Abweichungsgesetzgebung) acabou por inverter esta regra, consagrando a primazia da legislação estadual em algumas hipóteses. ${ }^{147}$

Por meio da dicotomia que contrapõe competências completas e competências parciais, Josef ISENSEE pretendeu dar um tratamento diferenciado às competências concorrentes e concorrentes limitadas apontadas no Brasil por JOSÉ AFONSO e FERREIRA FILHO. Uma competência completa seria aquela que cobre toda a matéria ao qual se refere, ao passo que uma competência parcial ou incompleta seria aquela que cobre

\footnotetext{
${ }^{146}$ ISENSEE. § 133 Die bundesstaatliche Kompetenz, p. 466. Para maiores detalhes, acerca destas modalidades de competência não-escrita, vide o item 5.1 .

147 ISENSEE. § 133 Die bundesstaatliche Kompetenz, p. 467-468. A legislação de divergência será tratada em detalhes nos itens 5.3.1 e 5.5.1.
} 
apenas parte da matéria à qual se refere. A título de exemplo, o autor cita a competência de princípios da União, a qual seria necessariamente incompleta uma vez que princípios sempre necessitam de complementação. Esta, por sua vez, viria somente a partir da legislação dos Estados-membros. ${ }^{148}$

As demais tipologias citadas por ISENSEE parecem ser bem condicionadas ao caso alemão e não possuem reflexos para ao argumento que se pretende resolver aqui, razão pela qual não serão abordadas com mais detalhes neste tópico dedicado a considerações de índole mais geral.

\subsubsection{Nossa classificação: competências legislativas e de execução; competências privativas e concorrentes}

Percebe-se do exposto que as classificações das competências convergem em muitos pontos mas também divergem em alguns aspectos essenciais, como é o caso das competências concorrentes. Isso, por si só, já tornaria necessário a tomada de uma decisão acerca do sentido em que uma determinada espécie de competência é compreendida nesta tese. Além do mais, as duas constituições analisadas neste estudo comparativo manejam competências que elas denominam de exclusivas, privativas, concorrentes, legislativas e assim por diante, sem oferecer muitas indicações sobre o que se deve entender por uma ou outra. Nesse sentido, o artigo $73 \mathrm{GG}$, assim como o artigo $22 \mathrm{CF} / 88$, dispõem apenas que a União detém a competência privativa para legislar sobre os assuntos arrolados nos seus incisos, sem contudo esclarecer o que seria esse "privativo" que qualifica a referida competência federal. Não se defende nesta tese que essas constituições deveriam fazê-lo. Acredita-se que tal solução seria impraticável, inclusive. O que se pretende ressaltar apenas é que alguns destes adjetivos que costumam as acompanhar as competências, quando manejados por constituições, deixam de ser meras classificações e passam a exprimir o modo pelo qual uma competência deve ser exercida. Tornam-se, portanto, normas que disciplinam o exercício da competência.

Neste cenário, torna-se importante refletir sobre as classificações propostas pela doutrina jurídica à luz das constituições que serão objeto do estudo comparativo a ser desenvolvido a partir da segunda parte desta tese. E porque tanto a Constituição brasileira de 1988 quanto pela Lei Fundamental de 1949 trabalham com competências legislativas e competências de execução, de um lado, competências privativas e competências

148 ISENSEE. § 133 Die bundesstaatliche Kompetenz, p. 469. 
concorrentes, de outro, acredita-se que é necessário se aprofundar em cada uma dessas dicotomias, a fim de forjar um referencial teórico mínimo para empreender a análise comparativa proposta.

Comecemos pelas competências legislativas e pelas competências de execução, cuja diferenciação oferece maiores dificuldades em um plano conceitual. Apesar de se tratar de uma distinção intuitiva para qualquer jurista, ela traz consigo a tormentosa diferenciação entre função legislativa e função administrativa, bem como a sua atribuição a poderes independentes entre si. Acredita-se, contudo, que se possa optar por um caminho mais simples, mesmo porque a pesquisa se debruça sobre a federação e não sobre a teoria da separação de poderes.

A competência legislativa, a princípio, consiste na autorização constitucional conferida a um ente federativo para editar lei em sentido formal sobre a matéria à qual se refere a norma de competência. Ou, como bem ressalta Hans-Werner RENGELING, trata-se da

\footnotetext{
“(...) promulgação de leis (formais) dentro do procedimento parlamentar que a Constituição estipula. 'Lei' é, neste contexto, a lei formal, a qual é determinada tão somente pela forma da sua elaboração, e não - como a lei material - pelo conteúdo ou alcance, por meio da sua 'generalidade'."'149
}

Em outras palavras, competência legislativa não se relaciona necessariamente com a faculdade de criar ou editar normas dotadas de abstração e generalidade, ou leis em sentido material. É bem verdade que as leis em sentido formal costumam veicular normas gerais e abstratas, mas também podem ter efeitos eminentemente concretos, como é o caso da lei orçamentária. O que efetivamente esta modalidade de competência autoriza é a criação de normas oriundas do processo legislativo, elaboradas no âmbito do Poder Legislativo.

Já a competência de execução ou administrativa pode ser definida basicamente de dois modos. Em primeiro lugar, ela pode ser definida como a autorização conferida a um ente federativo para executar uma lei em sentido formal ou então a própria Constituição, em hipóteses determinadas. ${ }^{150}$ Dito de outro modo, esta seria uma competência que englobaria

\footnotetext{
149 Nesse mesmo sentido: Hans-Werner RENGELING. § 135 - Gesetzgebungszuständigkeit. In: Josed ISENSEE; Paul KIRCHHOF (Hrsg.). Handbuch des Staatsrechts der Bundesrepublik Deutschland. Band VI - Bundesstaat. 3a Ed. Heidelberg: C. F. Müller, 2008, p. 569. No original: "Sie bezeichnet den Erlass von (förmlichen) Gesetzen im parlamentarischen Verfahren, das die Verfassung vorgibt. ,Gesetz' ist in diesem Zusammenhang das förmliche Gesetz, das allein durch die Form seines Zustandekommens bestimmt wird, dagegen nicht - wie das materielle Gesetz - durch Inhalt und Reichweite, durch seine ,Allgemeinheit".

150 Neste ponto, reproduzem-se as considerações de Fernando Dias MENEZES DE ALMEIDA sobre a possibilidade de edição de regulamentos que vêm dar execução diretamente a algum dispositivo constitucional: "Ainda sobre a comparação entre regulamentos autônomos e de execução, cabe ressaltar uma situação nem sempre suficientemente notada quando se pensa, redutoramente, em regulamentos de
} 
todas as ações e os instrumentos necessários à execução de uma lei, sendo esta última o resultado de uma competência legislativa. Em segundo lugar, a competência de execução pode ser definida como as atribuições estatais que não seriam nem de titularidade do Poder Legislativo e nem do Poder Judiciário. Em outras palavras, seriam aquelas atribuições desempenhadas precipuamente pelo Poder Executivo. Assim, ela seria um conceito a ser determinado por exclusão, mais precisamente, consistiria naquelas atribuições e tarefas que restam depois de se retirar as atribuições que são objeto de competências legislativas e de competências judiciárias.

A presente pesquisa adota estas duas propostas e opta por definir competência de execução como aquela que envolve, em linhas gerais, a execução de uma lei em sentido formal - em alguns casos, da própria Constituição - e que é desempenhada precipuamente pelo Poder Executivo. Aqui três observações fazem-se necessárias. Em primeiro lugar, atenta-se para uma questão terminológica importante. No âmbito da doutrina brasileira, é possível encontrar referências a uma competência material ou então a uma competência geral; já entre os autores alemães o mais comum é a utilização da expressão competência administrativa. Com exceção da competência geral, que engloba tanto a atividade de execução de uma lei formal quanto atividades de cunho eminentemente político, é possível afirmar que existe uma coextensividade entre "competência de execução", "competência material" e "competência administrativa". Optou-se nesta tese por utilizar a expressão "competência de execução" por considerá-la mais precisa, com maior aderência ao raciocínio a que se pretender fazer referência quando da sua utilização, vale dizer: a autorização para promover a execução de uma lei em sentido formal. Com isso não se pretende excluir ou rechaçar a utilização das outras expressões, mesmo porque costumam ser muito utilizadas pelas obras consultadas. No caso da competência administrativa, é de se admitir que se trata de uma expressão que simplesmente não pode ser

execução de leis. Tal situação diz respeito à edição de regulamentos que vêm dar execução diretamente a algum dispositivo constitucional autoexecutável. Num caso assim, a regra constitucional já poderia - e, mais, deveria - ser posta em prática pela Administração, independentemente da atuação do legislador infraconstitucional. Ao agir para cumprir dispositivo autoexecutável da Constituição, nada impede que a Administração, para melhor organizar sua ação, estabeleça parâmetros normativos gerais e abstratos, ou seja, edite regulamentos. Os regulamentos editados nessa circunstância não terão conexão direta com nenhuma lei, mas tão somente com a Constituição. E, em que pese não dependam de lei, tais regulamentos não comumgam da mesma natureza dos regulamentos autônomos. Isso porque potencialmente são subordinados à lei: caso uma lei, ainda que desnecessariamente, venha a ser editada, o regulamento terá de adaptar-se também a ela. Tais regulamentos, cuja existência, com as peculiaridades apontadas, merece ser ressaltada, têm, entretando, a mesma natureza dos regulamentos de execução, não justificando tratamento como espécie distinta" (Fernando Dias MENEZES DE ALMEIDA. Atos administrativos normativos: algumas questões. In: Odete MEDAUAR, Vitor Rhein SCHIRATO (Coord.). Os caminhos do ato administrativo. São Paulo: Revista dos Tribunais, 2012, pp. 226-227). 
deixada de lado, tendo em vista que ela é empregada pela própria Lei Fundamental de 1949. Já a "competência material" é uma locução que tende a ser evitada nesta tese, tendo em vista a confusão que ela enseja entre a modalidade competencial em questão e a matéria à qual se refere a norma de competência.

Em segundo lugar, existe uma relação entre competências legislativas e de execução, mais precisamente: competências legislativas resultam na edição de lei em sentido formal, e competências administrativas têm por objeto as atividades, funções e instrumentos necessários à execução desta lei. Sem competência legislativa não há que se falar em competência de execução e sem competência de execução a competência legislativa perde grande parte da sua razão de ser. ${ }^{151}$

Em terceiro lugar, a titularidade das competências legislativas e das competências de execução podem não coincidir. No Brasil há uma certa correspondência entre titularidade de competências legislativas e competências administrativas, mas é somente uma decorrência do sistema de execução de serviços, para falar com JOSÉ AFONSO da Silva, que teria sido adotada por este ordenamento jurídico. Na Alemanha, contudo, as competências legislativas costumam ser titularizadas pela União, mas a execução de leis federais costuma ser um assunto dos Estados-membros. Nesse sentido, não só é possível como também é normal que o Estado execute uma lei editada pela União, sendo isto uma decorrência do sistema mediato de execução de serviços adotado neste país.

Esquematicamente, a distinção entre competências legislativas e de execução pode ser colocada nos seguintes termos:

\begin{tabular}{|l|l|l|}
\hline \multicolumn{2}{|c|}{ CLASSIFICAÇÃO DAS COMPETÊNCIAS (em função da atividade estatal) } \\
\hline $\begin{array}{l}\text { Competência } \\
\text { legislativa }\end{array}$ & $\begin{array}{l}\text { - consiste na autorização constitucional conferida a um ente federativo para } \\
\text { editar lei em sentido formal sobre uma determinada matéria; }\end{array}$ \\
\hline $\begin{array}{l}\text { Competência } \\
\text { execução } \\
\text { administrativa }\end{array}$ & de & $\begin{array}{l}\text { - consiste na autorização conferida pela constituição a um ente federativo } \\
\text { para promover a execução de uma lei em sentido formal e que se dá } \\
\text { precipuamente no âmbito do Poder Executivo }\end{array}$ \\
\hline
\end{tabular}

\footnotetext{
151 Fernanda Dias Menezes de ALMEIDA chama a atenção para o mesmo ponto ao tratar da competência material da União inscrita no artigo 21 CF/88. Segundo esta autora, "nesse artigo, confere-se a competência à União para desempenhar certas atividades de cunho político, administrativo, econômico ou social que, por sua natureza, inserem-se na órbita do Poder Executivo, pressupondo o seu exercício a tomada de decisões governamentais e a utilização da máquina administrativa. (...) como observa ANNA CÂNDIDA DA CUNHA FERRAZ (1989:65), 'embora se cogite, na espécie, de exercício de 'poder', de execução de atividade ou desempenho de encargo, as competências gerais não excluem ação normativa precedente, emanada da própria esfera de poder. Assim, por exemplo, a prestação pelo município, de serviços públicos de interesse local, inclusive o de transportes coletivos (art. 30, V), demandará, com certeza, legislação municipal disciplinadora dessa atividade local'”' (ALMEIDA. Competências na Constituição de 1988, p. 84).
} 
Competência privativa, por sua vez, consiste na atribuição, pela constituição, de uma matéria previamente delimitada a um ente federativo, com a exclusão dos demais. ${ }^{152}$ Embora esta seja uma definição cujos principais contornos são fáceis de apreender, é preciso tecer aqui três considerações importantes.

Em primeiro lugar, a competência privativa pode ser tanto legislativa quanto de execução. Existe uma tendência em se afirmar que competência privativa seria sempre legislativa, e que a competência administrativa privativa seria uma consequência lógica daquela. Todavia, esta é uma afirmação verdadeira apenas em relação às federações que adotam um sistema imediato de execução de serviços. Por outro lado, em sistemas de execução mediata ou mista, é perfeitamente possível que a uma competência legislativa privativa da União se contraponha a uma competência administrativa privativa dos Estados. É o que se extrai da leitura do artigo 83 GG quando este dispõe que “os Länder executam as leis federais como assunto próprio, desde que esta Lei Fundamental não determine ou permita de outro modo".

Em segundo lugar, competência privativa não se confunde com competência enumerada. Como já se teve e oportunidade de ressaltar, embora haja uma tendência de utilizar a expressão "competência enumerada" para se referir às competências privativas da União, este é um uso equivocado, uma vez que enumeração se refere à previsão de uma competência em títulos competenciais, o que efetivamente pode ser dar tanto em uma competência privativa quanto em uma competência concorrente.

Em terceiro lugar, apesar de se afirmar que a competência privativa é aquela que é atribuída a um ente federativo com exclusão de qualquer outro, admite-se que, na verdade, o que geralmente ocorre é a atribuição do tratamento de uma matéria a um nível federativo com exclusão de outros níveis. Nesse sentido, uma competência legislativa privativa em regra é atribuída a todos os Estados-membros em detrimento da União ou a todos os Municípios, no caso do Brasil, em detrimento de todos os Estados-membros e da União.

A competência concorrente, por fim, é a categoria que oferece mais dificuldades por uma razão bem simples: no Brasil, ela remete a um instituto, porém na Alemanha ela remete a outro. Com efeito, enquanto que a competência legislativa concorrente do artigo 24

\footnotetext{
152 Tal noção parece excluir, em um primeiro momento, as competências municipais para legislar e prestar serviços de interesse local, prevista no artigo 30, I e V, CF/88, que são privativas, porém delimitadas com base no critério da predominância do interesse. Esta é, contudo, uma impressão que se desfaz quando se constata que o exercício destas competências depende invariavelmente da recondução de matérias determinadas ao conceito de interesse local. Ou seja, são competências privativas que, indiretamente, podem ser entendidas como atribuições de determinadas matérias a um nível federativo - no caso, o dos Municípios - em detrimento dos demais.
} 
CF/88 prevê a competência da União para edição de normas gerais e uma competência suplementar dos Estados-membros em relação à legislação federal, a competência concorrente disciplinada pelo artigo 72 GG confere aos Estados a prerrogativa de legislar plenamente sobre uma matéria enquanto e desde que a União não faça uso da sua competência.

A fim de solucionar este impasse, adota-se a definição de Manoel Gonçalves FERREIRA FILHO ao tratar da repartição vertical de competências, com algumas mitigações. Deste modo, as referências deste trabalho ao conceito de competência concorrente devem ser entendidas enquanto gênero que abarca tanto as competências concorrentes previstas na Lei Fundamental alemã quanto as competências concorrentes previstas na Constituição brasileira de 1988. A fim de diferenciá-las, elas serão sempre qualificadas com algum adjetivo, por exemplo: competência concorrente alemã, competência concorrente cumulativa, ou mesmo; competência concorrente de normas gerais.

Assim, competência concorrente, para os fins desta tese, consiste na autorização conferida pela constituição para que tanto União quanto Estadosmembros (e Municípios, no caso brasileiro) atuem em relação a algumas matérias previamente definidas. Como gênero que é, ela comporta duas grandes espécies. A primeira delas é a competência concorrente cumulativa, caracterizada pela ausência de limites a um ou outro ente federativo quanto à extensão da matéria regulada: ou seja, todos os entes são legitimados a legislar ou promover a execução de todos os aspectos referentes à matéria prevista na norma de competência. Isso não significa dizer que esta seja uma competência desprovida de qualquer limitação. Como se terá a oportunidade de analisar a seguir, a Lei Fundamental prevê algumas condições ao exercício de uma competência concorrente pela União (artigo 72 GG). Porém, preenchidas estas condições, a atuação da União pode abranger toda a matéria prevista na norma.

A segunda espécie é a competência concorrente não-cumulativa ou limitada, que se caracteriza justamente por prever uma limitação quanto à extensão da matéria referida pela norma de competência, restringindo a atuação da União, dos Estadosmembros, e dos Municípios. Geralmente, a União fica adstrita à edição de normas gerais ou uma legislação de princípios, e aos Estados-membros e Municípios é conferida a faculdade de adaptá-las às peculiaridades regionais.

Esquematicamente, a distinção entre competências privativas e competências concorrentes a ser adotada pela presente tese pode ser apresentada na seguinte tabela: 


\section{CLASSIFICAÇÃO DAS COMPETÊNCIAS}

\section{(quanto ao modo e à extensão de atribuição aos entes federativos)}

\begin{tabular}{|l|l|l|}
$\begin{array}{l}\text { Competências } \\
\text { privativas }\end{array}$ & $\begin{array}{l}\text { - consiste na atribuição pela constituição de uma matéria previamente delimitada } \\
\text { a um ente federativo, com exclusão dos demais }\end{array}$ \\
\begin{tabular}{l|l} 
Competências \\
concorrentes
\end{tabular} & $\begin{array}{l}\text { - consiste na autorização conferida pela } \\
\text { constituição para que tanto União quanto } \\
\text { Estados-membros atuem em relação a } \\
\text { matéria previamente definidas. Trata-se de } \\
\text { gênero, que comporta duas espécies: }\end{array}$ & $\begin{array}{l}\text { Competência } \\
\text { cumulativa: não há limites } \\
\text { materiais impostos a um ou outro } \\
\text { ente (embora seja possível a } \\
\text { imposição de limites temporais ou } \\
\text { mesmo condicionar a atuação de } \\
\text { um outro ente ao preenchimento de } \\
\text { certos requisitos) }\end{array}$ \\
& $\begin{array}{l}\text { Competência concorrente não- } \\
\text { cumulativa ou limitada: há limites }\end{array}$ \\
& $\begin{array}{l}\text { materiais aos entes federativos - } \\
\text { vale dizer, quanto à extensão da } \\
\text { matéria atribuída a um ou outro } \\
\text { ente - sendo que à União } \\
\text { competente normalmente editar } \\
\text { normas gerais e aos Estados- } \\
\text { membros compete complementar a } \\
\text { legislação federal de normas gerais }\end{array}$ \\
& &
\end{tabular}

Uma questão importante diz respeito à necessidade de estabelecer a prevalência da norma ou ato da União ou dos Estados-membros na hipótese de colisão. Tradicionalmente o critério adotado é o da prevalência do direito federal; contanto, esta é uma regra que tem sido relativizada ${ }^{153}$ mesmo na Alemanha, de onde advém o famoso brocardo "Bundesrecht bricht Landesrecht”, razão pela qual não se pode adotá-la na presente tese de um ponto de vista teórico.

\subsection{INSTITUIÇÕES ESSENCIAIS DO ESTAdO FEDERAL: A CÂMARA REPRESENTATIVA DOS ESTADOS-MEMBROS E A CORTE CONSTITUCIONAL}

O último item deste capítulo dedicado à exposição das principais premissas teóricas da pesquisa versa sobre duas instituições consideradas por muitos autores essenciais ao Estado Federal: a câmara representativa dos Estados-membros, e a corte constitucional.

\footnotetext{
153 Por meio da previsão da denominada Abweichungsgesetzgebung ou legislação de divergência, modalidade em que o direito estadual posterior prevalece sobre o direito federal anterior.
} 
É importante ressaltar que neste ponto da exposição não se pretende traçar considerações mais concretas acerca de como funcionam estas estruturas no Brasil e na Alemanha, tendo em vista que esta será uma análise empreendida no segundo capítulo da tese em relação à câmara representativa dos Estados e durante todo a segunda parte da tese, ainda que implicitamente, no caso das cortes constitucionais.

\subsubsection{A Câmara representativa dos Estados-membros}

No Número 62 de $O$ Federalista, James MADISON defendia a existência de um Senado Federal com algumas características específicas. Em primeiro lugar, ele seria composto por membros com "uma idade mais avançada e um período mais longo de cidadania”, em virtude da natureza do cargo exercido, que exigiria maior experiência política do que o ocupado pelos membros da Câmara dos Representantes. ${ }^{154}$ Em segundo lugar, estes membros deveriam ser escolhidos pelos poderes legislativos estaduais, sendo esta a solução que mais se adequava à opinião pública da época no entender do referido autor. Em terceiro lugar, deveria existir uma igualdade de representação no Senado, a qual se justificava diante do fato de que se estava diante de uma união de Estados outrora independentes e soberanos e que demandariam por uma "participação 'igual' nos conselhos comuns, por mais desiguais que sejam as partes”. Segundo MADISON, a igualdade de representantes dos Estadosmembros seria, a bem da verdade, "reconhecimento constitucional da porção de soberania que permanece em cada um deles, bem como um instrumento para a preservação desta soberania residual". ${ }^{155}$ Em quarto e último lugar, o Senado deveria ter um número reduzido de membros em comparação com a Câmara de Representantes, os quais teriam um mandato de maior duração, diante da necessidade de se conferir alguma estabilidade ao governo e de mitigar as súbitas e violentas paixões que poderiam dominar a maioria dos representantes do povo em um determinado momento histórico. ${ }^{156}$ Segundo este federalista,

“(...) tudo o que precisa ser registrado é que um órgão destinado a corrigir aquele mal deve logicamente não sofrer dele e, consequentemente, ser menos numeroso, além de possuir grande firmeza - o que exige que sua autoridade seja mantida ininterruptamente durante um período de tempo mais longo." 157

\footnotetext{
154 James MADISON. 62 - A natureza e a influência estabilizadora do Senado. In: Alexander HAMILTON; James MADISON; John JAY. O Federalista, Trad. Heitor Almeida Herrera. Brasília: Universidade de Brasília, 1984, p. 479.

155 MADISON. 62 - A natureza e a influência estabilizadora do Senado, p. 480.

156 MADISON. 62 - A natureza e a influência estabilizadora do Senado, p. 482.

157 MADISON. 62 - A natureza e a influência estabilizadora do Senado, p. 482.
} 
Com o passar do tempo, contudo, esta fórmula teria se afigurado inadequada ao regime democrático norte-americano, até que em 1913 foi ratificada a 17 a Emenda à Constituição de 1787, pela qual os membros do Senado passavam a ser eleitos pelo voto direto. ${ }^{158} \mathrm{O}$ número de representantes por Estado e a duração do mandato permaneceram inalterados desde então.

A despeito das críticas que lhe possam ser dirigidas, o fato é que o bicameralismo estadunidense influenciou virtualmente todas as federações instauradas posteriormente. Existe em razão disto uma discussão acerca da essencialidade do bicameralismo à federação, tendo em vista que a grande maioria dos países que adota esta forma de Estado conta com duas casas legislativas no âmbito federal. ${ }^{159}$ De todo modo, deve-se ressaltar que não se verifica exatamente uma uniformidade entre as câmaras representativas dos Estadosmembros em uma perspectiva comparada. Como ressalta Ronald L. WATTS, somente sete federações escolhem atualmente os representantes das suas segundas câmaras legislativas por meio do voto direto, quais sejam: Austrália, Estados Unidos da América, Suíça, México, Argentina, Brasil e Nigéria. A maioria, contudo, optou pelo voto indireto - é o caso da Áustria, da Índia, da Bélgica, da Rússia, entre outros - sendo possível também encontrar casos de nomeação pelo governo federal e pelos governos estaduais. Onde os representantes dos Estados são escolhidos pelo voto popular, a tendência é que eles permaneçam menos compromissados com os interesses regionais do que com as linhas gerais do partido ao qual pertencem, sendo que o oposto se verifica nas federações em que a segunda câmara legislativa é composta por representantes eleitos pelas assembleias ou governos estaduais. ${ }^{160}$

Também há diferenças marcantes no tocante ao papel e à importância desempenhada pelas câmaras representativas dos Estados-membros em uma perspectiva

\footnotetext{
158 SCHWARTZ. Direito Constitucional Americano, pp. 76-77.

${ }^{159}$ A difusão de federações bicameralistas pelo mundo é afirmada em WATTS. Comparing Federal Systems, p. 147. A discussão acerca da imprescindibilidade do bicameralismo em uma federação pode ser encontrada, entre outros, em KING. Federalism and Federation, pp. 94-95.

160 WATTS. Comparing Federal Systems, pp. 147-152. O fato de o Brasil seguir as linhas gerais do Senado estadunidense pode dar a errônea impressão de que neste ponto se está diante de uma regra geral, quando na verdade a maioria das federações estruturam as câmaras representativas dos Estados-membros com base em outros parâmetros. É preciso ter atenção quanto à diversidade de soluções possíveis, a fim de evitar generalizações que não se sustentam. Outro aspecto que normalmente dá ensejo à generalizações equivocadas diz respeito ao número de representantes por Estados. Quanto a este ponto é comum a assertiva de que os Estados seriam considerados como partes iguais, tendo em vista que a federação pressupõe sempre a união de unidades outrora soberanas. Porém, como bem observa WATTS, apenas nove federações atualmente possuem uma câmara representativa composta por um número igual de representantes por Estado. O mais comum é que haja alguma proporcionalidade entre número de representantes e população, favorecendo-se ao mesmo tempo os estados menores e minorias significativas (WATTS. Comparing Federal Systems, p. 152).
} 
comparada. Em regimes presidencialistas, normalmente as duas câmaras legislativas possuem os mesmos poderes, ao passo que nos regimes parlamentaristas o papel de proeminência por definição fica com a câmara representativa do povo, o que acaba por enfraquecer a posição da instância que representa as unidades subnacionais no Poder Legislativo federal. No primeiro caso, as câmaras altas tendem a exercer maiores poderes de veto do que no segundo caso. ${ }^{161}$

Para os fins da presente tese, contudo, importa ressaltar a existência de dois modelos de instância representativa dos Estados: em primeiro lugar, o Senado Federal, que é o adotado pelo Brasil, e; o Conselho Federal, que corresponde ao seguido na Alemanha. Novamente, não se trata aqui de conformar todas as peculiaridades verificadas nas federações atualmente existentes, mas sim de forjar um arcabouço teórico em relação ao qual Brasil e Alemanha possam ser subsumidos. Note-se que, no caso deste último país, falar em um modelo é um pouco equivocado. Com efeito, a Alemanha representa a exceção de tudo o que foi dito até agora: ao passo que a maioria das federações se antagonizam quanto à escolha dos seus membros entre o voto popular e o voto da maioria dos membros dos legislativos estaduais, o Conselho Federal alemão é composto por representantes escolhidos pelos governos estaduais; apesar de se tratar de uma república parlamentarista, a segunda câmara legislativa alemã possui um papel especialmente relevante, com poderes de veto significativos. Ainda assim, acredita-se que é importante pensar este caso particularíssimo em termos abstratos, uma vez que este é um raciocínio que pode ser encontrado em obras alemãs que se dedicam a este tema. ${ }^{162}$

O Senado Federal, por um lado, apresenta quatro características principais. Em primeiro lugar, no seu âmbito a representação dos Estados-membros se dá em termos igualitários, conferindo-se a cada Estado igual número de representantes e votos. Costumase justificar esta especial configuração pelo fato de esta forma de Estado implicar, ao menos em um plano teórico, a união de Estados outrora soberanos e formalmente iguais, muito embora seja este um raciocínio que não pode se aplicar, por razões históricas, ao caso brasileiro.

\footnotetext{
${ }^{161}$ WATTS. Comparing Federal Systems, pp. 153 e 155.

162 Nesse sentido, vide INFORMATIONEN ZUR POLITISCHEN BILDUNG. O Conselho Federal. Traduções: o federalismo na Alemanha, ano 1995, no 7, pp. 75-76. Peter BADURA, por sua vez, discute as distinções entre o Conselho Federal e a segunda câmara legislativa em Staatsrecht: Systematische Erläuterung des Grundgesetzes. 5a Ed. Munique: C. H. Beck, 2012, p. 566.
} 
Em segundo lugar, os membros do Senado são escolhidos pelo sufrágio universal, do modo parecido com os membros da representação do povo ${ }^{163}$. Não é, portanto, o governo estadual ou o poder legislativo estadual que envia emissários por eles escolhidos para zelar pelos seus interesses no âmbito federal, mas sim o povo do respectivo Estadomembro que escolhe um ou mais representantes em eleições majoritárias.

Em terceiro lugar, os senadores costumam ser livres em suas opiniões, responsabilizando-se somente perante o seu eleitorado. Isto, por sua vez, tende a desnaturar a função precípua da câmara alta - vale dizer, como uma instância representativa dos interesses dos Estados-membros - pois os seus membros tendem a se fidelizar mais aos interesses da população e às posições partidárias em um âmbito federal do que aos interesses do Estado-membro ao qual em tese deveriam representar.

Em quarto e último lugar, o Senado tende a desempenhar o papel de uma segunda casa legislativa, possuindo funções parecidas com a câmara representativa do povo, em muitos casos, inclusive, atuando como uma instância revisora dos projetos aprovados por esta última. ${ }^{164}$

Já o Conselho Federal, por outro lado, também apresenta quatro notas distintivas, que se colocam em uma relação de oposição às analisadas no modelo anterior. Em primeiro lugar, a representação dos Estados-membros não se dá em termos exclusivamente igualitários, pois a população de cada ente regional é levada em consideração para conferir mais ou menos cadeiras. Não se chega ao extremo de se adotar exclusivamente o critério proporcional do "one man, one vote", mas trata-se de um modelo que tende a levar a quantidade da população dos Estados em consideração.

Em segundo lugar, os membros deste Conselho são escolhidos pelo governo dos Estados-membros. Como o termo "governo" às vezes é impropriamente utilizado para se referir a um ente federativo como um todo e não em seu sentido próprio, esclarece-se que a escolha neste modelo é feita pelo Poder Executivo do Estado-membro dentre pessoas que compõem este Poder. Exatamente por isso, não são realizadas eleições periódicas e nem possui esta câmara legislativa uma legislatura, como ocorre no modelo senatorial.

\footnotetext{
${ }^{163}$ No caso brasileiro, a diferença reside no fato de a eleição dos Senadores se dar pelo princípio majoritário (artigo 46, caput, CF/88), ao passo que a eleição dos Deputados Federal obedece ao sistema proporcional (artigo 45, caput, CF/88).

${ }^{164} \mathrm{~A}$ representação igualitária, a eleição dos membros por sufrágio universal e a liberdade no que tange às decisões são características referidas em INFORMATIONEN ZUR POLITISCHEN BILDUNG. O Conselho Federal, p. 75 .
} 
Em terceiro lugar e como uma consequência da última característica analisada, os representantes dos Estados-membros respondem perante os governos estaduais e representam os seus interesses perante o Poder Legislativo federal. Não há que se falar em representação popular aqui, ao menos diretamente.

Em quarto lugar, as atribuições do Conselho Federal tendem a diferir das atribuições da câmara representativa do povo, embora ambos os órgãos desempenhem funções legislativas. Note-se que isto não significa dizer que a instância representativa dos Estados-membros desempenhe um papel menor no processo legislativo. Como se terá a oportunidade de expor oportunamente, o Conselho Federal alemão é um órgão de extrema importância para a compreensão da dinâmica do federalismo neste país, exatamente porque tradicionalmente exerce um papel relevante na elaboração das leis federais. O que se pretende ressaltar com esta última observação é que no modelo em questão a câmara alta não funciona como instância revisora dos projetos que tramitam na câmara baixa. ${ }^{165}$

\subsubsection{O papel da corte constitucional em um Estado Federal ${ }^{166}$}

No item 1.1.3 definiu-se a federação, em linhas gerais, como um método de repartição do poder político entre entes autônomos e que é regulamentada por uma constituição rígida. Embora esta repartição pretenda forjar uma situação de harmonia entre os níveis federativos, não é difícil imaginar que surjam na prática controvérsias relacionadas ao alcance dos poderes conferidos à União ou aos Estados pela constituição, ou mesmo conflitos relacionados ao exercício desses poderes, por exemplo, quando um governo estadual toma uma medida que prejudica determinados interesses de outros Estados. Por isso, a federação sempre deve contar com um árbitro, que decidirá nestes casos a qual ente federativo assiste razão, o qual poderá ser um tribunal, o próprio povo por meio de referendos ou a câmara representativa dos Estados. ${ }^{167}$ Atualmente, a fórmula que tem

\footnotetext{
165 O fato de a representação por Estado-membro levar em consideração a sua respectiva população, a escolha dos representantes pelo governo dos Estados e o fato de os representantes responderem aos governos estaduais, aos quais se encontram vinculados, são características referidas em INFORMATIONEN ZUR POLITISCHEN BILDUNG. O Conselho Federal, p. 76.

${ }^{166}$ Alguns dos argumentos que serão expostos neste tópico, especialmente no que tange à legitimidade para a provocar o controle de constitucionalidade, consistem em conclusões obtidas em Fernando Dias MENEZES DE ALMEIDA, Mariana Augusta dos Santos ZAGO. Breves considerações sobre o papel das cortes constitucionais em uma federação (no prelo).

167 Como ressalta WATTS. Comparing Federal Systems, p. 9. Note-se que tal autor aponta a existência de um árbitro, em quaisquer das variações citadas no corpo do texto, como uma das características estruturais comuns geralmente observadas em uma federação, ao lado da: (i) existência de pelo menos duas ordens de governo; (ii) distribuição de competências legislativas e de execução e repartição de rendas operada por uma constituição formal; (iii) representação dos interesses regionais nas instituições responsáveis pela elaboração
} 


\section{prevalecido em uma perspectiva comparada consiste na instituição de tribunais}

responsáveis por dar à constituição sua interpretação final, tanto nos moldes de uma Suprema Corte norte-americana quanto de um Tribunal Constitucional Federal alemão ${ }^{168}$. Talvez por isso seja corrente a afirmação de que estas cortes são instituições essenciais ao Estado Federal, ao menos no meio jurídico ${ }^{169}$. De todo modo, em textos clássicos do federalismo já é possível encontrar a defesa de um tribunal jurisdicional superior, responsável por decidir litígios deste tipo. Por exemplo, Alexander HAMILTON apontava como uma grave falha do modelo confederativo então adotado pelos Estados Unidos a ausência de um "Tribunal Supremo". Segundo este autor, a possibilidade de haver diferentes decisões sobre uma mesma matéria já recomendaria tal providência em qualquer Estado, a fim de evitar decisões conflitantes. Mas ela seria ainda mais premente "onde a estrutura do governo é tão complexa que as leis do conjunto corram o risco de conflitarem com as das partes", sob pena de permitir que tendências e preconceitos locais fizessem com que "os dispositivos das leis estatuais prevalecessem sobre os das leis gerais". ${ }^{170}$

Considera-se oportuno, todavia, incluir um novo elemento nesta análise. Para tanto, parte-se de dois dados que são conhecidos por qualquer jurista que se debruça sobre a federação enquanto objeto de estudo. O primeiro deles consiste no princípio da inércia da

de políticas públicas no plano federal; (iv) a existência de uma constituição suprema e escrita, e; (v) processos para facilitar a colaboração intergovernamental nos casos de autoridades partilhadas ou sobrepostas (WATTS. Comparing Federal Systems, p. 9).

${ }^{168}$ WATTS. Comparing Federal Systems, p. 159. Segundo o mesmo autor, o único país que optou por uma outra fórmula, conferindo a função de guarda de constituição à câmara representativa dos estados, foi a Etiópia. De todo modo, a prevalência do modelo das cortes constitucionais faz com que alguns autores a considerem o árbitro, por excelência dos conflitos federativos. Nesse sentido, Herbert OBINGER, Stephan LEIBFRIED e Francis G. CASTLES posicionem cortes constitucionais como instituições federais secundárias, que "atuam como um árbitro para apaziguar conflitos entre os diferentes ramos de governo" (Introduction, In: Herbert OBINGER, Stephan LEIBFRIED, Francis G. CASTLES (Org.). Federalism and the Welfare State: New World and European Experiences. Cambridge: Cambridge University Press, 2005, p. 10).

169 Apenas para ficar com uma referência tradicional sobre o assunto no direito brasileiro, assinala Raul Machado HORTA que "a construção normativa do Estado Federal pressupõe a adoção de determinados princípios, técnicas e de instrumentos operacionais que podemos condensar na seguinte relação, recolhendo os subsídios da contribuição doutrinária e da organização constitucional dominante do federalismo: (...) 8. A existência no Poder Judiciário Federal de um Supremo Tribunal ou Corte Suprema, para interpretar e proteger a Constituição Federal, e dirimir litígios ou conflitos entre a União, os Estados e outras pessoas jurídicas de direito interno" (HORTA. Direito Constitucional, p. 275).

170 Alexander HAMILTON. 22 - A confederação: carência de poderes e de oportuna ratificação. In: HAMILTON, MADISON, JAY. O Federalista, pp. 229-230. Os outros defeitos da confederação norte-americana, segundo HAMILTON, seriam: (i) a inexistência de sanções para o descumprimento de leis da Confederação; (ii) falta de um compromisso mútuo dos Estados entre si e com a União a respeito das facções; (iii) o fato de a contribuição dos governos estaduais à União ser feita por quotas; (iv) a inexistência de um poder único para regular o comércio; (v) ausência de competência da União para mobilizar exércitos; (vi) a igualdade dos Estados e a necessidade de unanimidade nas votações. O tema é tratado, por sua vez, em dois números de $O$ Federalista: no número 21, intitulado "defeitos da confederação", e no número 22 supra. 
jurisdição, o qual impede que não só as cortes constitucionais, mas que os juízes como um todo atuem ex officio. Ou seja, estes devem necessariamente aguardar a provocação de um interessado ou legitimado, o qual trará ao seu conhecimento uma controvérsia previamente delimitada. Esta constatação não se altera quando se está diante de um conflito federativo. Por pior que ele seja, por maior que seja o risco que ele imponha à própria existência da federação, as cortes constitucionais nada poderão fazer enquanto não forem provocadas para tanto. O segundo dado, por sua vez, consiste no fato de que nem todos os conflitos federativos comportam uma solução jurisdicional. Ao contrário, muitos deles resolvem-se no plano político, pelos próprios atores envolvidos. Somente uma parcela - em regra, uma pequena parcela - destes conflitos é levada ao conhecimento das cortes constitucionais e será resolvida consoante critérios eminentemente jurídicos. Portanto, há um movimento de migração de alguns litígios federativos para o plano jurisdicional e que deve ser compreendido, ainda que minimamente, quando se pretende discutir o papel que cortes constitucionais, por meio de suas decisões, desempenham em uma federação.

No âmbito da ciência política é possível encontrar algumas proposições que auxiliam na compreensão deste fenômeno. Nesse sentido, ponderam Herbert OBINGER, Stephen LEIBFRIED e Francis G. CASTLES que cortes constitucionais são poderosos atores que detém poderes de veto significativos no que tange à federação. Em especial nas federações em que a oposição parlamentar possui legitimidade para provocar a atuação jurisdicional, é possível que conflitos políticos sobre o formato do Welfare State - tema do estudo promovido por estes autores - sejam transferidos para o âmbito das cortes constitucionais $^{171}$. Em outras palavras, segundo estes autores o que é decisivo para este movimento de migração de conflitos são os atores políticos legitimados a provocar a atuação das cortes constitucionais. Ocupemo-nos deste argumento com mais cuidado, tendo por parâmetro os dois tribunais que interessam para a tese: o Supremo Tribunal Federal (STF) e o Bundesverfassungsgericht (BVerfG), também conhecido como Tribunal Constitucional Federal (TCF).

Em seu momento fundacional, o STF, até em virtude do forte influxo da experiência norte-americana sobre Constituição Federal de 1891, exercia somente o controle difuso de constitucionalidade. Porém, com o passar dos anos este tribunal passou a exercer gradualmente também o controle abstrato de constitucionalidade, fenômeno este que alcançou sua amplitude máxima sob a égide da Constituição Federal de 1988. Atualmente, são quatro as ações nas quais o STF analisa, em tese, a compatibilidade de leis e atos

${ }^{171}$ OBINGER, CASTLES e LEIBFRIED. Introduction, p. 37. 
normativos com a Constituição: (i) a ação direta de inconstitucionalidade (ADI); (ii) a ação declaratória de constitucionalidade (ADC); (iii) a arguição de descumprimento de preceito fundamental (ADPF), e; (iv) a ação direta de inconstitucionalidade por omissão (ADO). Porém, ao se analisar o número de ações julgadas pelo STF, percebe-se que a ADI - que é justamente o instrumento mais tradicional de controle abstrato de constitucionalidade do direito brasileiro, previsto pela primeira vez pela Constituição Federal de 1946 - permanece como a ação mais julgada pelo STF, seguida da ADPF. ${ }^{172}$

Note-se que o STF detém ainda uma competência originária para julgar "as causas e conflitos entre a União e os Estados, a União e o Distrito Federal ou o Território" (artigo 102, I, f, CF/88). Atualmente, contudo, é de se reconhecer que a maioria dos conflitos federativos têm tomado a forma de ações de controle abstrato ${ }^{173}$, razão pela qual a exposição se concentrará no rol de legitimados para a sua propositura. Nos termos do artigo $103 \mathrm{CF} / 88$, podem propor estas ações: (i) o Presidente da República; (ii) a Mesa do Senado Federal; (iii) a Mesa da Câmara dos Deputados; (iv) a Mesa de Assembleia Legislativa ou da Câmara Legislativa do Distrito Federal; (v) o Governador de Estado; (vi) o Procurador-Geral da República; (vii) o Conselho Federal da Ordem dos Advogados do Brasil; (viii) partido político com representação no Congresso Nacional, e; (ix) confederação sindical ou entidade

\footnotetext{
172 Como é ressaltado em MENEZES DE ALMEIDA, ZAGO. Breves considerações sobre o papel das cortes constitucionais, especificamente no capítulo sobre o Supremo Tribunal Federal. Sobre a influência norteamericana sobre o STF em seu momento fundacional, vide OSCAR VILHENA Vieira. Supremo Tribunal Federal: jurisprudência política. 2a Ed. São Paulo: Malheiros, 2002, p. 118. Para um breve histórico do controle de constitucionalidade no Brasil, vide Gilmar Ferreira MENDES, Inocêncio Mártires COELHO, Paulo Gustavo Gonet BRANCO. Curso de Direito Constitucional. 5a Ed. São Paulo: Saraiva, 2010, pp. 1193-1220 e Ingo Wolfgang SARLET, Luiz Guilherme MARINONI, Daniel MITIDIERO. Curso de Direito Constitucional. São Paulo: Revista dos Tribunais, 2012, pp. 740-758. Apesar de esta evolução não ser analisada por esta tese, é possível afirmar, com Gilmar Ferreira MENDES, que a combinação dos sistemas difuso e abstrato de constitucionalidade acabou por "outorgar ao Supremo Tribunal Federal uma peculiar posição tanto como órgão de revisão de uma última instância, que concentra suas atividades no controle das questões constitucionais discutidas nos diversos processos, quanto como Tribunal Constitucional, que dispõe de competência para aferir a constitucionalidade direta das leis estaduais e federais no processo de controle abstrato de normas" (Gilmar Ferreira MENDES. Jurisdição Constitucional: o controle abstrato de normas no Brasil e na Alemanha. 5a Ed. São Paulo: Saraiva, 2005, pp. 11-12). Por este motivo, reconhece-se a impropriedade de se referir ao STF como uma legítima corte constitucional, vale dizer, de um tribunal que exerce precipuamente a jurisdição constitucional; porém, tratase de uma terminologia empregada pelos textos de ciência política consultados para se referir, como um todo, aos tribunais que se ocupam da interpretação da constituição em uma instância final. Chegou-se à conclusão, por isso, de que adotar uma outra expressão ou mesmo especificar em cada caso de qual modelo de tribunal se está fazendo referência causaria mais transtornos do que esclarecimentos, razão pela qual se persiste na expressão "corte constitucional".

173 Neste sentido, basta lembrar que as controvérsias que envolvem o exercício da competência legislativa concorrente inscrita no artigo 24 CF/88 e o exercício de competências legislativas como um todo, além dos inúmeros casos da chamada "guerra fiscal" costumam ser arguidos perante o STF por meio de ADIs.
} 
de classe de âmbito nacional ${ }^{174}$. Percebe-se, portanto, que a legitimidade para a propositura deste tipo de ação é ampla e abrange praticamente todos os atores políticos relevantes para a compreensão do jogo federativo brasileiro. Note-se que no caso dos partidos políticos, basta que eles detenham um representante em uma das casas do Poder Legislativo Federal isto é, um deputado ou um senador - para que se tornem legitimados a provocar a atuação do STF. Atualmente, 28 partidos cumprem este requisito ${ }^{175}$. Apenas os Prefeitos e as Câmaras Municipais não podem provocar o controle abstrato de constitucionalidade, devendo representar ao Procurador Geral da República. Ainda assim, é razoável esperar que, diante da amplitude do referido rol, conflitos federativos sejam levados à apreciação do Supremo Tribunal brasileiro com alguma frequência, ainda que se revistam de uma controvérsia acerca da constitucionalidade, em tese, de uma lei federal ou estadual ${ }^{176}$.

Já o BVerfG foi forjado nos moldes de uma legítima corte constitucional, vale dizer, de uma corte que exerce a jurisdição constitucional de forma exclusiva. ${ }^{177}$ Sua competência encontra-se disciplinada no $§ 13$ da Lei sobre o Bundesverfassungsgericht (BVerfGG) em 19 números ${ }^{178}$; para a análise que propõe neste tópico, contudo, interessam somente dois

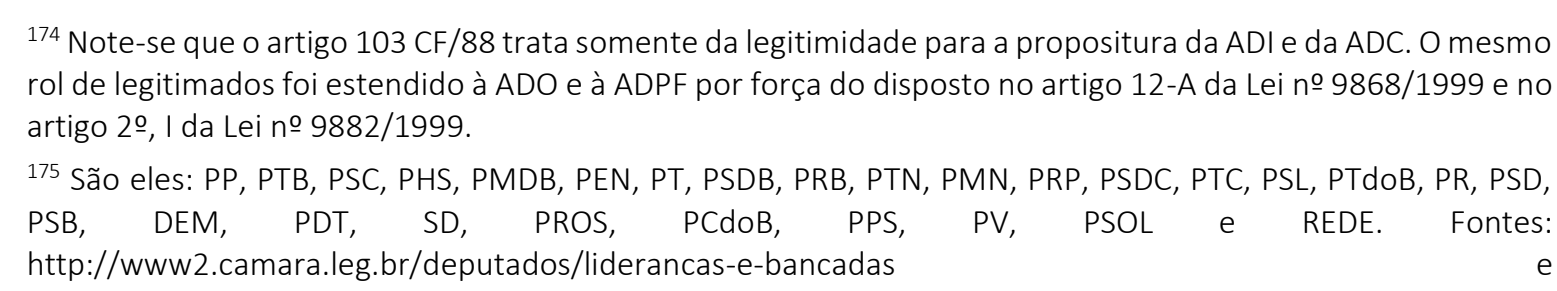
http://www.senado.gov.br/senadores/senadoresPorPartido.asp. Acesso: 08/10/2015.

176 Esta afirmação continua verdadeira mesmo em uma ação em que se questione a constitucionalidade de uma lei federal em virtude de violação a direito fundamental, quando, por exemplo, a inconstitucionalidade é arguida por um governador e a lei questionada encontra-se fundamentada em uma competência legislativa concorrente da União e dos Estados-membros. Caso uma ação como essa seja julgada procedente e a lei federal for julgada inconstitucional, o fato é que os Estados poderão legislar plenamente sobre a matéria com fulcro no artigo $24, \S 3$ 으 CF/88.

${ }^{177}$ Como ressalta Oscar VILHENA Vieira, "no que se refere à jurisdição constitucional, a Lei Fundamental optou por um sistema semelhante ao austríaco, corrigindo-lhe, porém, os mais graves defeitos. Foi criado um Tribunal Constitucional Federal, como órgão constitucional encarregado pela preservação dos direitos fundamentais e da própria Lei Fundamental" (Supremo Tribunal Federal, p. 91). A despeito desta aproximação do modelo austríaco, não é possível afirmar a influência do pensamento de Hans KELSEN nos trabalhos que culminaram com a aprovação dos artigos 93 e 94 GG. Como ressalta Gilmar Ferreira MENDES, "sustenta-se, ainda, que as concepções de Kelsen teriam contribuído para consagração de uma Corte Constitucional na Lei Fundamental de Bonn. Kelsen defendia a instituição de uma Corte Constitucional especial, a outorga do direito de ação, no controle abstrato de normas, a uma minoria qualificada; considerava que determinadas decisões do Tribunal Constitucional deveriam ser dotadas de força de lei e recomendava a publicação, tal como posteriormente consagrado na Lei do Bundesverfassungsgericht, das decisões do Tribunal no Diário Oficial. Os registros constantes dos trabalhos da Assembleia Constitucional não confirmam, porém, essa influência direta (...) Inequívoca influência exerceu o modelo da Suprema Corte Constitucional americana, que marcou, de forma decisiva, os debates na Assembleia Constitucional" (MENDES. Jurisdição Constitucional, pp. 11-12).

178 O artigo 93 GG também trata da competência do BVerfG, mas não promove exatamente uma reunião de todas as competências deste tribunal, como faz o artigo 102 CF/88 em relação ao STF. Por este motivo, optou- 
procedimentos nele previstos. O primeiro deles consiste no litígio entre União e Estadosmembros (Bund-Länder-Streitigkeiten), procedimento contraditório por meio do qual o Tribunal Constitucional Federal alemão analisa "medidas ou omissões, que dentro de uma relação material de direito constitucional entre União e Estados violaram ou colocaram em perigo diretamente uma posição jurídica de direito constitucional do Estado ou da União", tendo por base "os preceitos sobre competências da lei fundamental e o princípio não escrito da lealdade federal"179. As legitimidades ativa e passiva, como observa Leonardo MARTINS, "não foram definidas de maneira clara pelo $§ 68$ BVerfGG. Com efeito, este dispõe apenas que serão partes ativa ou passiva, respectivamente, para a União, o Governo Federal e para um Estado-membro, o correspondente Governo Estadual que, no regime parlamentarista de governo, lembre-se, é composto por deputados membros do parlamento estadual" $" 180$.

É de se ressaltar, contudo, que este é um procedimento que perdeu sua importância ao longo da vigência da Lei Fundamental de 1949. Klaus SCHLAICH e Stefan KORIOTH indicam três razões para tanto, entre elas, o fato de a supervisão federal (que é expressamente mencionada pelo artigo 93 I Nr. 3 GG como uma das hipóteses nas quais o litígio entre União e Estados poderá ser proposto perante o BVerfG) ter caído em desuso, e o fato de o próprio Tribunal Constitucional Federal alemão ter se negado durante muitas décadas a exercer qualquer influência sobre a atuação do Bund em matéria de competências legislativas concorrentes. Em especial, os referidos autores apontam para o fato de que muitos conflitos federativos passaram a ser levados à apreciação desta corte alemã pelo procedimento do controle abstrato de normas, o qual possuiria um número maior de legitimados, não seria submetido a nenhum prazo específico, além de propiciar decisões com efeitos mais amplos. ${ }^{181}$ Em outras palavras, para compreender como conflitos federativos são levados, por assim dizer, ao BVerfG, é necessário se debruçar com maior atenção sobre os legitimados para provocar o controle abstrato de constitucionalidade perante esta corte.

\footnotetext{
se por fazer referência somente ao $\S 13$ BVerfGG, o qual efetivamente arrola todas as competências da corte constitucional alemã.

179 Klaus SCHLAICH; Stefan KORIOTH. Das Bundesverfassungsgericht: Stellung, Verfahren, Entscheidungen. 7ạ Ed. Munique: C. H. Beck, 2007, p. 61.

180 Leonardo MARTINS. Direito Processual Constitucional Alemão. São Paulo: Atlas, 2011, p. 47.

$181 \mathrm{SCHLAICH}, \mathrm{KORIOTH}$. Das Bundesverfassungsgericht, pp. 62-63. Neste mesmo sentido caminham as ponderações de Leonardo MARTINS, que acrescenta um dado novo nesta evolução: "não obstante, o contencioso entre União e Estados-membros ganhou novamente relevo a partir do início da década de 1990, como consequência, talvez, do ingresso dos cinco Estados orientais, mas principalmente tendo em vista a execução de leis federais pelos Estados-membros em atendimento ao prescrito nos Arts. 83 et seq. GG" (Direito Processual Constitucional Alemão, p. 47).
} 
Nos termos do artigo 93 I Nr 2 GG, este tribunal decidirá sobre "divergências de opiniões ou dúvidas sobre a compatibilidade formal e material do direito federal ou do direito estadual com a Lei Fundamental ou a compatibilidade do direito estadual com outro direito federal a requerimento do governo federal, de um governo estadual ou de um quarto dos representantes do parlamento federal"182. O Conselho Federal, instância representativa dos Estados-membros nos termos do artigo 50 GG, não está legitimado, por sua vez, a provocar o controle abstrato de constitucionalidade na Alemanha. Está-se diante, portanto, de uma legitimidade razoavelmente mais restrita em comparação com a prevista no artigo 103 $\mathrm{CF} / 88$, o que leva a crer que, nesta federação, litígios entre os entes federativos sejam levados com uma frequência menor à apreciação do tribunal constitucional do que no Brasil. Esta é, contudo, somente uma hipótese e não propriamente uma assertiva corroborada por dados ou mesmo por estudos comparativos. Este breve tópico, inserido no capítulo dedicado à exposição das principais premissas teóricas da presente tese, tampouco não é o local adequado para semelhante análise. ${ }^{183}$

\footnotetext{
182 No original: "Das Bundesverfassungsgericht entscheidet: (...) 2. Bei Meinungsverschiedenheiten oder Zweifeln über förmliche und sachliche Vereinbarkeit von Bundesrecht oder Landesrecht mit diesem Grundgesetze oder die Vereinbarkeit von Landesrecht mit sonstigem Bundesrechte auf Antrag der Bundesregierung, einer Landesregierung oder eines Viertels der Mitglieder des Bundestages". Acerca do controle abstrato de constitucionalidade, ponderam SCHLAICH e KORIOTH que ainda que a oposição como tal não detenha legitimidade para propor tal requerimento, ela sempre pode fazê-lo ao recolher a assinatura de um terço do Parlamento Federal ou por meio de um dos "seus" governos estaduais, o que faz com que o controle abstrato de constitucionalidade também esteja submetido, de um ponto de vista político, às maiorias e à oposição parlamentar. E finalizam este raciocínio afirmando: "a propositura do requerimento ocorre de forma legítima frequentemente conforme a oportunidade política (e deve, por isso, também ser responsabilizada politicamente)." (SCHLAICH, KORIOTH. Das Bundesverfassungsgericht, pp. 75-76). Em outra passagem, ponderam os mesmos autores que, a despeito de o controle abstrato ser, em tese, um "procedimento objetivo de controle e constatação da validade ou invalidade da norma em questão (...) os debates perante o BVerfG neste procedimento costumam ser extremamente controvertidos e são tratados consequentemente, de forma não diferente do litígio entre órgãos, ocasionalmente como vitórias ou derrotas de posições políticas" (SCHLAICH, KORIOTH. Das Bundesverfassungsgericht, p. 74).

183 É de se ressaltar ainda que litígios com repercussões federativas relevantes tendem a ser suscitados em sede de controle concreto de constitucionalidade. Dois casos paradigmáticos que serão analisados no quinto capítulo desta tese, inclusive, foram levados ao julgamento da corte constitucional alemã por esta via (são eles: BVerfGE 2, 213 e BVerfGE 8, 274). Porém, é importante atentar para uma diferença importante em relação ao controle concreto realizado no Brasil, que é realizado de forma difusa - vale dizer, por todos os juízes desde a primeira instância até o STF, que proferirá a palavra final sobre a constitucionalidade de uma lei. Na Alemanha, a controvérsia surge a partir de um caso concreto, mas o controle de constitucionalidade permanece concentrado: se um juiz de qualquer instância estiver em dúvida sobre a constitucionalidade de uma lei que deva ser por ele aplicada, paralisará o feito e suscitará a questão perante o BVerfG, que analisará a constitucionalidade da lei em tese. Ou seja, também aqui se está diante de um processo objetivo; os legitimados para provocá-los são exclusivamente os juízes e os tribunais alemães, cabendo às partes envolvidas no caso concreto somente alegar a inconstitucionalidade da lei em suas respectivas manifestações (como se extrai de MARTINS. Direito Processual Constitucional Alemão, pp. 18-20). Contudo, como juízes não participam propriamente do jogo político da federação, tem-se que esta modalidade de controle de constitucionalidade não é relevante para explicar como conflitos eminentemente políticos envolvendo o Estado Federal alemão são levados à apreciação do BVerfG, razão pela qual ela não será tratada no corpo do texto.
} 
Feitas estas considerações, parte-se para uma outra importante questão que decorre daqueles dois dados de conhecimento de qualquer um que eleja a federação como objeto de estudo. Mais precisamente: ainda que nem todos os conflitos de índole federativa comportem solução jurisdicional, é de se admitir que quando isso ocorre, a corte constitucional - pela importância que ela necessariamente adquire em Estados que adotam constituições rígidas, mas também pela função de árbitro de federação mencionada supra - acaba por influenciar o desenvolvimento da estrutura federativa, conformando a atuação dos entes federativos às normas constitucionais pertinentes. Ou seja, da mesma forma que se mostra relevante compreender em que medida conflitos políticos envolvendo a federação "migram" para a jurisdição constitucional, é preciso também entender minimamente quais os efeitos que a decisão de uma corte constitucional produz sobre o plano político.

Este, por sua vez, é um problema de difícil abordagem. Considera-se um equívoco, por um lado, pretender compreender a centralização e a descentralização presentes em uma estrutura federativa como um todo contemplando somente os julgados dos tribunais constitucionais. Com efeito, muitas relações federativas desenvolvem-se de modo harmônico, de forma que nenhum dos envolvidos deseje obter um posicionamento do tribunal constitucional a respeito. Ao contrário, litígios federativos chegam às cortes constitucionais somente na hipótese de existir algum conflito ou controvérsia, e provavelmente somente se uma ou outra não puder ser resolvida no plano político. Por isso, a análise das decisões das cortes constitucionais, por mais completa que ela seja, apreende no máximo as relações federativas que não deram certo por algum motivo. Consequentemente, tentar apreender as tendências de centralização e de descentralização da estrutura federativa como um todo a partir de tais decisões seria como estudar profundamente uma exceção na tentativa de dela extrair alguma regra geral.

Por outro lado, é possível cogitar uma investigação sobre como decisões influenciam o comportamento dos atores políticos engajados no jogo federativo. Porém, esta é uma análise que transcende o escopo de uma pesquisa jurídica, como é o caso da presente tese, para ser desenvolvida somente no âmbito da ciência política. Deste ramo do conhecimento vem, contudo, uma outra proposição que se aproxima de uma solução deste imbróglio, ao menos para os fins da presente tese. Ponderam Herbert OBINGER, Stephan LEIBFRIED e Francis G. CASTLES que a capacidade da União de impor uma legislação sobre políticas públicas requer que ela primeiro adquira a competência para tanto. Para tanto, ela poderia propor uma emenda constitucional, porém este caminho em algumas federações 
- especialmente, na federação norte-americana - afigura-se demasiadamente difícil, em razão da necessidade de aprovação por parte dos Estados-membros. Por isso, "a habilidade de o governo federal de atuar depende frequentemente de como a corte constitucional interpreta a alocação de jurisdição" ${ }^{184}$, ou em outras palavras:

“As iniciativas de política social por parte do governo federal podem ser
bloqueadas se uma corte constitucional poderosa atua como um guardião dos
poderes das unidades constituintes. Se uma corte constitucional está inclinada para
uma interpretação restrita do mandato constitucional federal, as perspectivas de
iniciativas de políticas sociais federais são acentuadamente reduzidas. Por outro
lado, os julgamentos da corte também podem aumentar a capacidade do governo
central de atuar se 'poderes implícitos' são reconhecidos ou se as
responsabilidades existentes sobre políticas públicas federais são interpretadas de
uma forma ampla."

Trata-se de um argumento que se aplica especialmente à federação americana durante o período do New Deal, ocasião em que a expansão dos poderes federais com base na chamada "cláusula de comércio" foi referendada pela Suprema Corte ${ }^{186}$. Porém, é possível encontrar outros exemplos em uma perspectiva comparada. Nesse mesmo sentido, Francis G. CASTLES e John UHR apontam que a Suprema Corte da Austrália a partir de 1920 passou a adotar um posicionamento que ampliou sensivelmente os poderes da União, o que favoreceu a centralização fiscais vivenciada por esta federação na primeira metade do século XX e a criação de um Welfare State em âmbito nacional. ${ }^{187} \mathrm{Na}$ própria Alemanha, o BVerfG também exerceu um papel relevante na centralização vivenciada pela federação a partir da década de 60 do século XX, neste caso não por interpretar uma determinada competência de forma ampla, mas sim por se negar a apreciar a atuação da União no campo das competências legislativas concorrentes. ${ }^{188}$ No âmbito do STF não é possível vislumbrar casos paradigmáticos com certa facilidade em função do volume de ações julgadas por esta corte. Não obstante isso, é possível perceber um posicionamento favorável à União, por exemplo, no que diz respeito às normas gerais da União (artigo $24, \S 1^{\circ}, \mathrm{CF} / 88$ ). Em tese, elas deveriam ser quase que uma legislação de princípios, fixando somente parâmetros para a atuação do

\footnotetext{
184 OBINGER, CASTLES, LEIBFRIED. Introduction, p. 40.

185 OBINGER, CASTLES, LEIBFRIED. Introduction, p. 40.

186 De acordo com a Seção 8.3 do artigo 1ㅇ da Constituição norte-americana, compete ao Congresso "regular o comércio com nações estrangeiras, e entre diversos Estados, e com as tribos indígenas". No próprio sítio eletrônico do Senado norte-americano consta a informação de que esta é uma das competências mais abrangentes do Congresso, abrangendo, ao longo da história, "desde a regulação do comércio até a ilegalidade da segregação racial" (http://www.senate.gov/civics/constitution_item/constitution.htm. Acesso: 08/09/2014). O assunto será retomado com maiores detalhes no item 3.1.

187 Francis G. CASTLES; John UHR. Australia: Federal constraints and institutional innovations. In: OBINGER, CASTLES, LEIBFRIED. Federalism and Welfare States, p. 57-58.

${ }^{188}$ Conforme se analisará no tópico 5.3.1 desta tese.
} 
legislador estadual. Porém, muitas vezes elas descem às minúcias, o que naturalmente prejudica a autonomia estadual no plano legislativo, mas nem por isso têm sido invalidadas por este tribunal brasileiro ${ }^{189}$.

Ainda assim, não se propõe exatamente uma análise de como decisões das cortes constitucionais propiciaram ou não determinados processos políticos de centralização ou descentralização, mesmo porque o que se propõe aqui é uma confrontação das normas constitucionais que regulam a repartição de competências no Brasil e na Alemanha. Consequentemente, as grandes questões a serem trabalhadas nesta tese devem se conformar às exigências e às finalidades do método comparativo. Por isso, pretende-se apenas utilizar os julgados do STF e do BVerfG a fim de compreender o real sentido e alcance das normas constitucionais sobre a partilha de competências. Por vezes, far-se-ão referências a determinadas interpretações que, segundo a literatura especializada, barraram ou contribuíram para a centralização ou a descentralização em um dado momento histórico.

\section{Segundo CAPÍtUlo - Notas distintivas dA Federação no BRASIL E NA ALEMANHA}

Este segundo capítulo dedica-se, como o próprio título sugere, a uma exposição das principais características das federações brasileira e alemã, com o objetivo de empreender uma contextualização adequada dos sistemas constitucionais de repartição de competências no Brasil e na Alemanha.

Note-se que a contextualização é considerada uma etapa fundamental de qualquer análise comparativa, pois permite ao pesquisador uma compreensão mais acurada dos fatores e relações que informam a interpretação que se dá às normas que serão confrontadas.

Este esforço de contextualização é, no mais das vezes, o que se afigura mais complexo ao comparatista, porque exige - caso seja levado a cabo de modo exaustivo - a sua imersão em ao menos duas culturas jurídicas, o que no mais das vezes somente será possível caso ele efetivamente se dedique ao estudo dos ordenamentos jurídicos considerados por um período de tempo razoável. Contudo, esta é somente uma etapa preliminar à comparação propriamente dita, razão pela qual não pode assumir um destaque maior do que a própria confrontação dos objetos de estudo selecionados. Por este motivo, considera-se que esta contextualização se dá satisfatoriamente caso ela seja capaz de

\footnotetext{
${ }^{189}$ Este argumento será retomado no tópico 4.4.
} 
apreender - e até de explicar, grosso modo - adequadamente as relações que subjazem às instituições jurídicas que serão confrontadas a partir da segunda parte desta tese.

A partir destas considerações concebeu-se este segundo capítulo dividido em duas partes, sendo que em cada uma delas se subdividirão em quatro blocos temáticos considerados relevantes à compreensão do sistema de repartição de competências brasileiro e alemão. Na primeira parte, dedicada ao estudo da federação brasileira sob a égide da Constituição de 1988, pretende-se abordar os seguintes temas: (i) breve evolução histórica da federação no Brasil; (ii) linhas gerais da federação brasileira na Constituição Federal de 1988; (iii) a autonomia do Município sob a égide da Constituição de 1988, e; (iv) a questão da representação dos Estados-membros no Senado Federal e, em alguma medida, na Câmara dos Deputados. Já a segunda parte, dedicada ao estudo da federação alemã sob o influxo da Lei Fundamental, subdivide-se em quatro tópico, dedicados à análise dos seguintes temas: (i) evolução histórica da federação na Alemanha; (ii) principais aspectos constitucionais da federação na Lei Fundamental de 1949; (iii) aspectos da autonomia municipal na Alemanha, e; (iv) a representação dos Estados-membros (Länder) no Conselho Federal (Bundesrat).

Optou-se por um certo paralelismo no que tange aos temas abordados em cada parte deste capítulo, a fim de evidenciar e comparar quais aspectos efetivamente exercem ou não influência sobre os sistemas brasileiro e alemão de repartição de competências. Espera-se, por exemplo, que a autonomia municipal no Brasil tenha um peso maior no modo como as competências são repartidas do que na Alemanha. Acredita-se, do mesmo modo, que a questão da representação dos Estados-membros no Conselho Federal alemão seja mais significativa para a compreensão da repartição de competências neste país do que no Brasil, onde a câmara de representação dos Estados-membros encontra-se relativamente desfigurada no tocante à sua função de instância representativa estadual.

Finalmente, é de se ressaltar que a perspectiva histórica adquire uma posição de proeminência neste capítulo, embora não ele não se dedique exclusivamente a traçar um histórico das federações brasileira e alemã. Tal enfoque encontra-se intimamente relacionado a um pressuposto teórico da pesquisa e que está devidamente contemplado na seguinte passagem do pensamento de Konrad HESSE:

\footnotetext{
"Parte do reconhecimento de que a constituição de uma comunidade política concreta, seu conteúdo, a singularidade de suas normas e seus problemas devem ser compreendidos a partir de uma perspectiva histórica. Somente a consciência desta historicidade permite a compreensão total e o ajuizamento acertado das questões jurídico e político-constitucionais. Isso é algo que não pode oferecer uma teoria geral e abstrata insensível, que não emoldura a constituição na realidade político-social e suas peculiaridades históricas. Tampouco a compreensão histórica pode prescindir sem mais da justificação e da configuração teórica. Mas
} 
semelhante teoria deve estar referida ao ordenamento constitucional concreto e à realidade que a Constituição está chamada a ordenar."190

Feitas estas breves ponderações, parte-se para a análise do modo pelo qual questões jurídicas e políticas informam a federação no Brasil e Alemanha, sob uma perspectiva historicamente situada, para falar com o referido constitucionalista alemão.

\subsection{A FEDERAÇÃO BRASileira SOB a ÉGIDE dA CONSTituiçÃo Federal de 1988}

\subsubsection{Breve histórico da federação brasileira}

Há quem afirme que o Brasil nunca vivenciou o federalismo, ou então que esta é uma forma de Estado transplantada do direito estrangeiro sem maiores preocupações e, consequentemente, fadada ao insucesso mesmo passados mais de 120 anos de sua implementação. ${ }^{191}$

A fim de rebater este tipo de crítica mais apressada, seria interessante uma análise histórica mais aprofundada, desde o advento do Império até a promulgação da Constituição de 1988. Contudo, em virtude do volume de trabalho que tal análise inexoravelmente envolve e das finalidades que norteiam a confrontação do Brasil e da Alemanha no que tange a repartição de competências, decidiu-se por restringir a análise ao regime que antecedeu a Constituição Federal de 1988 e os processos políticos e sociais que culminaram com a sua promulgação, analisados a seguir. ${ }^{192}$

\footnotetext{
190 Konrad HESSE. CAPÍTULO PRIMERO - Constitución y Derecho Constitucional. In: Ernst BENDA, Werner MAIHOFER, Hans-Joachim VOGEL (Coord.). Manual de Derecho Constitucional. 2a Ed. Madrid: Marcial Pons, 2001, p. 1. Em outras palavras, a perspectiva histórica é extremamente útil à compreensão do direito constitucional vigente. Não é por outro motivo que Werner FROTSCHER e Bodo PIEROTH entendem que "a função e o significado da história constitucional no presente" é justamente servir como "auxílio imprescindível à compreensão e a interpretação do direito constitucional vigente e da ordem jurídica atual" (Werner FROTSCH; Bodo PIEROTH. Verfassungsgeschichte. 6a Ed. Munique: C. H. Beck, 2007, p. 1).

191 Embora não defenda exatamente este argumento, é possível encontrar na obra de Paulo BONAVIDES posicionamento no sentido de que a adoção da forma de Estado Federal pela Constituição Federal de 1891 teria significado a importação de uma fórmula alienígena e que o Brasil teria vivenciado um Estado Unitário de fato durante um período razoável de sua história (nesse sentido, vide Paulo BONAVIDES. O caminho para um federalismo das regiões. Revista de Informação Legislativa, ano 17, no 65, jan./mar. 1980, pp. 118-119).

192 De todo modo, considera-se oportuno mencionar algumas obras imprescindíveis para a compreensão do federalismo no Brasil. Há, assim, algumas obras jurídicas que se propõem a analisar o federalismo brasileiro sob uma perspectiva histórica, como, por exemplo, JOSÉ AFONSO da Silva. O Constitucionalismo brasileiro: evolução institucional. São Paulo: Malheiros, 2011, pp. 276 e ss, Fernando Luiz ABRUCIO. Os barões da Federação: os governadores e a redemocratização brasileira. São Paulo: Hucitec, 1998 e Luís Roberto BARROSO. Direito constitucional brasileiro: o problema da federação. Rio de Janeiro: Forense, 1982, pp. 28-76, muito embora nesta última obra a análise se estenda até a Constituição Federal de 1967. Acredita-se, contudo,
} 


\subsubsection{A Constituição Federal de 1967}

Segundo Paulo BONAVIDES e PAES DE ANDRADE, a Constituição Federal de 1967 cumpriu uma dupla função. Em primeiro lugar, ela traduziu mais um estágio de institucionalização do Movimento Militar de 1964, tanto que o próprio Ato Institucional no 4, de 7 de dezembro de 1966, que convocou o Congresso Nacional para aprovar o novo projeto de Constituição, dispunha que esta deveria representar "a institucionalização dos ideais e princípios da Revolução". Em segundo lugar, por meio da promulgação de uma nova Constituição, o Regime Militar buscava transmitir a impressão de que o Brasil vivenciava um autêntico Estado de Direito. Contudo, o modo como se levou a cabo a sua aprovação já denunciava a realidade de recrudescimento político que dominava o cenário brasileiro. Afinal, o novo texto constitucional deveria ser aprovado pelo que se convencionou chamar de Poder Constituinte Congressual, o qual nada mais era do que o Congresso Nacional já alijado de muitas de suas lideranças políticas, cujos mandatos foram cassados. Além do mais, os trabalhos da Constituinte foram submetidos a um rígido calendário, o que impossibilitava

que o melhor seja examinar algumas obras importantes para a compreensão da federação brasileira sob a égide de cada Constituição e das discussões que envolviam a sua adoção ou concretização em cada período considerado. Durante o período imperial, o Estado brasileiro organizou-se sob a forma de um Estado Unitário. Não obstante isso, ele vivenciou um período de descentralização política durante a vigência do Ato Adicional de 1834. Os méritos e desméritos deste diploma normativo gerou um debate interessante entre o Visconde do Uruguay e Aureliano Cândido Tavares Bastos, que pode ser conferido em Visconde do URUGUAY. Ensaio sobre o Direito Administrativo. Tomo II. Rio de Janeiro: Typographia Nacional, 1862, pp. 159-276 e Aureliano Cândido TAVARES BASTOS. A Província: estudo sobre a descentralização no Brasil. Brasília: Senado Federal, 1996, pp. 61-79. A descentralização política no Império também é objeto de análises mais atuais, como em Gabriela Nunes FERREIRA. Centralização e descentralização no Império: o debate entre Tavares Bastos e visconde de Uruguai. São Paulo: Editora 34, 1999, José Murilo de CARVALHO. Pontos e bordados: escritos de história e política. Belo Horizonte: Editora UFMG, 2005, pp. 155-188. No que se refere ao período compreendido pelo que se costuma denominar de República Velha, acredita-se que é imprescindível a leitura: (i) da obra de Ruy Barbosa, em especial os seus Commentarios á Constituição Federal Brasileira (colligidos e ordenados por Homero Pires). São Paulo: Saraiva, 1934, onde se pode vislumbrar a forte influência no direito norte-americano no pensamento de este que se considerou o artífice da Constituição Federal de 1891, e; (ii) dos comentários feitos por João Barbalho Uchôa CAVALCANTI em Constituição Federal Brasileira (1891): comentada. Brasília: Senado Federal, 2002 (Ed. fac-similar). Já compreendendo a época do Estado Novo é importante ressaltar o argumento desenvolvido por Francisco José de OLIVEIRA VIANNA em O idealismo da Constituição. 2a Ed. São Paulo, Rio de Janeiro, Recife, Porto Alegre: Companhia Editora Nacional, 1939, pp. 7 178. Sob a égide da Constituição Federal de 1946, importante atentar para as obras de Oswaldo Aranha BANDEIRA DE MELLO. Natureza jurídica do Estado Federal. São Paulo: Prefeitura do Município de São Paulo, 1948, Rual Machado HORTA (et. Al). Perspectivas do federalismo brasileiro. Belo Horizonte: Universidade de Minas Gerais, 1958 e A. de Sampaio DÓRIA. Direito Constitucional. Volume 1, Segundo Tomo. 5a Ed. São Paulo: Max Limonad, 1962, pp.476-527. Todas estas obras foram reunidas e discutidas no âmbito de um grupo de estudos organizado pelo Prof. Fernando Dias Menezes de ALMEIDA, e composto por Vitor Monteiro, Ágata Bobbio Ferraz, Carolina Castro Andrade, Renata Nadalini Meireles e Renata Gomes da Silva, além da autora da presente tese, e que se reuniu no ano de 2011 na Faculdade de Direito da USP. Sem as discussões promovidas neste grupo, certamente a elaboração deste capítulo dedicado à análise histórica da federação brasileira (e também esta nota de rodapé) não teriam sido possíveis, razão pela qual se deixam consignado os nossos agradecimentos. 
o aprofundamento em discussões importantes ao futuro de um país, para não falar dos dispositivos que, por serem considerados caros ao governo, simplesmente não poderiam ser emendados. ${ }^{193}$

Posteriormente, a Emenda Constitucional no 01/1969 deu novo teor à integralidade do texto constitucional de 1967 e se tornou de fato a nova Constituição do Brasil, embora não tenha sido considerada de forma autônoma pelos juristas da época, como ressaltam mais uma vez Paulo BONAVIDES e PAES DE ANDRADE. ${ }^{194}$ Tal cenário evidencia uma preocupação relativamente difundida à época de conferir alguma legitimação constitucional ao regime instaurado a partir de 1964, o que poderia ser feito com um grande esforço a partir do texto promulgado em 24/01/1967, mas em nenhuma hipótese a partir do texto da EC $\mathrm{n}^{\mathrm{o}}$ 01/1969, se considerado de forma autônoma.

Fiquemos, contudo, com a terminologia consagrada no meio jurídico e tratemos das linhas gerais da federação sob a égide da Constituição Federal de 1967, com as alterações introduzidas pela Emenda Constitucional no 01 de 1969. Segundo Luís Roberto BARROSO, a referida constituição teria operado um "quase monopólio do poder político e econômico para a União", e, embora observe que a concentração dos poderes na órbita federal fosse uma tendência mundial neste momento da história, existiriam no caso brasileiro dois outros fatores de particular importância. Em primeiro lugar, a questão da segurança nacional - que era, inclusive, uma das matérias sobre as quais o Presidente da República poderia expedir Decretos-Leis (artigo 55, I, da CF/1967-69) - “de conceituação amplíssima e, invariavelmente, desvirtuada" e, em segundo lugar, a necessidade de promover o

\footnotetext{
193 BONAVIDES, PAES DE ANDRADE. História Constitucional do Brasil, pp. 431 e ss. Como ressaltam os referidos autores, "Ridícula a alternativa em que se colocava um Congresso que havia sido escolhido pelo voto popular, obrigado a aprovar uma Constituição que não foi feita por ele e que nem poderia sê-lo porque o eleitorado não havia escolhido constituintes, mas parlamentares para uma legislação ordinária. Era o Congresso mutilado que ia aprovar e promulgar um texto deformado pela pressão do arbítrio oficial. De 1964 a 1966 eram cassados os mandatos parlamentares de Abelardo Jurema, Adahil Barreto, Almino Affonso, Bocaiuva Cunha, (...) e de tantos outros que foram arrancados do Legislativo para facilitar a ação do Governo junto à Constituinte congressual que deveria votar o projeto oficial e promulgá-lo, como o fez. A oposição estava profundamente enfraquecida com as cassações de mandatos e de direitos políticos que haviam ceifado grande parte de suas lideranças no Congresso. Os atos institucionais eram a própria contestação de uma Carta democrática como a de 1946 e seria impossível a convivência dos atos de arbítrio com um texto constituinte de efetiva representação popular" (História Constitucional do Brasil, p. 435).

194 BONAVIDES, PAES DE ANDRADE. História Constitucional do Brasil, pp. 443-444. A fim de corroborar este argumento, basta a leitura do primeiro e único artigo da Emenda Constitucional no 1/1969, cujo caput possui a seguinte redação: "A Constituição de 24 de janeiro de 1967 passa a vigorar com a seguinte redação". A seguir, o que se tem é efetivamente uma nova constituição e não a nova redação de alguns dispositivos constitucionais, como seria de se esperar de uma emenda constitucional.
} 
desenvolvimento econômico por meio de uma política financeira integrada, que harmonizasse "a atuação dos estados e municípios com as diretrizes da União."195

À época denominou-se este federalismo de feição extremamente centralizada, calcado nos imperativos de segurança nacional e de desenvolvimento econômico, de federalismo de integração, expressão cunhada pelo então Ministro de Estado dos Negócios da Justiça Alfredo BUZAID. Segundo este jurista,

"Esta tendência de política legislativa dá lugar à formação de novo tipo de federalismo. A forma, que veio a receber, contém o federalismo cooperativo, porque dêle recebeu importantes conquistas; mas o supera, ao atribuir à União maior soma de poderes para dirigir a política nacional. O propósito do constituinte não foi o de destruir as unidades federadas, cuja autonomia respeita, mas sim o de construir o novo Brasil, cuja grandeza depende do desenvolvimento integrado de tôdas as regiões. Estas não se confinam dentro dos limites territoriais de um Estado; abrangem amplas áreas que incluem vários Estados. A êsse novo tipo, que promove o desenvolvimento econômico com o máximo de segurança coletiva, ousamos denominar federalismo de integração. O federalismo dualista se fundava no princípio do equilíbrio entre a União e Estados; o federalismo cooperativo formula o princípio da suplementação das deficiências dos Estados; o federalismo de integração representa o triunfo do bem estar de tôda a nação. Êle busca, portanto, reencontrar-se com a realidade nacional, traduzindo os anseios do povo, que cria um país economicamente forte, socialmente justo e eticamente digno.

Dentro deste novo tipo de federalismo, os Estados não entram em choque com a União; são beneficiários desta na medida em que as regiões menos desenvolvidas se recuperam economicamente. A política de integração não se limita às relações intergovernamentais; atinge o país em todas as direções, proporcionando progresso ordenado e racional." 196

Por óbvio, este "federalismo de integração" que é exaltado por BUZAID contém algo de eufemístico, como bem lembra Fernanda Dias Menezes de ALMEIDA. Afinal, não se tratava de forjar uma nova etapa do federalismo brasileiro, mas sim de justificar uma União extremamente fortalecida em detrimento dos Estados-membros e dos Municípios, aquinhoada "com extenso e significativo rol de competências - as mais importantes, sem dúvida - que lhe permitiram amplamente condicionar, planejar, dirigir e controlar a atuação dos Estados"197.

Uma breve análise do artigo $8^{\circ} \mathrm{CF} / 1967-69$, e sua comparação com os artigos 13 , § $1^{\circ}$, fornecem uma compreensão de quão extenso e significativo era este rol de competências. $\mathrm{O}$ artigo $8^{\circ}$, que tratava da competência da União, concentrava tanto competências legislativas e não-legislativas quanto competências privativas e competências concorrentes. As competências gerais privativas desdobravam-se nos primeiros dezesseis incisos, ao passo

\footnotetext{
195 Luís Roberto BARROSO. Direito Constitucional Brasileiro: O problema da Federação. Rio de Janeiro: Forense, pp. 51-54.

${ }^{196}$ Alfredo BUZAID. O Estado Federal Brasileiro. Brasília: Ministério da Justiça, 1971, pp. 40-41.

197 ALMEIDA. Competências na Constituição de 1988, p. 43.
} 
que o inciso XVII tratava da competência legislativa da União, em sua maioria do tipo privativa. A competência legislativa concorrente da União e dos Estados-membros, por sua vez, restringia-se às matérias indicadas no parágrafo, de menor importância em comparação com a competência legislativa conferida privativamente àquele ente federativo. Já a competência privativa dos Estados (tanto legislativa quanto de execução) era prevista em termos genéricos no artigo $13, \S 1^{\circ}$, de amplitude inegavelmente restrita diante do número de matérias atribuídas à União no artigo $8^{\circ} .198$

É importante ressaltar ainda que, no âmbito da União, os poderes também se apresentavam concentrados no Poder Executivo, de forma que se é possível afirmar que a centralização observada no período não se deu apenas em um plano vertical, que abarca a relação entre União, Estados-membros e Municípios, mas também em um plano horizontal, que diz respeito à relação dos Poderes Legislativo, Executivo e Judiciário entre si. ${ }^{199}$ Ao analisar este fenômeno, Fernando Luiz ABRUCIO acaba por decompô-lo em três pilares financeiro, administrativo e político - cuja compreensão, ainda que em linhas gerais, fornece um retrato da correlação de forças entre União, Estados-membros e Municípios durante o período que se inicia em 1964 e se estende até promulgação da Constituição Federal de 1988.200

\footnotetext{
198 É de se ressaltar ainda o teor do artigo 15 CF/1967-69, que assegurava a autonomia municipal, entre outras coisas, "pela administração própria, no que respeite ao seu peculiar interesse, especialmente quanto: a) à decretação e arrecadação dos tributos de sua competência e à aplicação de suas rendas, sem prejuízo da obrigatoriedade de prestar contas e publicar balancetes nos prazos fixados em lei, e; b) organização dos serviços públicos locais". Apesar de esta constituição atestar textualmente a autonomia do Município, ele ainda não era considerado um ente federativo e, por esta razão, não detinha competências legislativas e materiais. Ao menos, a existência destas competências não era reconhecida de forma unânime, razão se optou por não as abordar neste parágrafo do corpo da tese, dedicado a uma breve exposição da repartição de competências sob a égide da Constituição Federal de 1967, com as alterações promovidas pela Emenda Constitucional no 1/1969. Em sentido contrário, vale dizer, de que a autonomia municipal compreendia o exercício de competências, inclusive do tipo legislativas, vide Victor Nunes LEAL. Leis Municipais. In: Victor Nunes LEAL. Problemas de Direito Público. Rio de Janeiro: Forense, 1960, pp. 160-178.

${ }^{199}$ Como é bem observado em BARROSO. Direito Constitucional Brasileiro, p. 54 e em Fernando Luiz ABRUCIO. Os barões da Federação: os governadores e a redemocratização brasileira. São Paulo: Hucitec, 1998, pp. 6263.

200 Faz-se referência especificamente ao raciocínio desenvolvido por este autor no segundo capítulo da sua conhecida obra Os barões da Federação, já citada. Isso não significa necessariamente uma concordância com a tese defendida por ABRUCIO nesta mesma obra, a saber, de que os processos que culminaram com a promulgação da Constituição Federal de 1988 deram origem a um ultrapresidencialismo estadual, o qual apresenta duas características fundamentais: "o Executivo detinha um forte domínio do processo de governo e controlava os órgãos que deveriam fiscalizá-lo. Além disso, no Executivo, o poder era extremamente concentrado nas mãos do governador" (ABRUCIO. Os barões da Federação, p. 109). É de se ressaltar, além do mais, que a tese do ultrapresidencialismo estadual é objeto de críticas, como por exemplo em BERCOVICI. Desigualdades regionais, pp. 149-150.
} 
O pilar financeiro erigido pelo regime militar decompunha-se basicamente em duas reformas. A primeira delas consistiu em restringir a possibilidade de emendas ao orçamento pelo Poder Legislativo, como uma forma de diminuir a influência regional (por meio dos deputados e senadores) nas finanças federais e conferir ao Poder Executivo um controle total do orçamento federal. A segunda reforma, por sua vez, orientou uma centralização de receitas tributárias na órbita federal, em comparação com a sistemática da Constituição Federal de 1946. Como compensação, a União passou a transferir mais recursos aos Estadosmembros e Municípios, tanto por meio de transferências voluntárias quanto por meio de um Fundo de Participação dos Estados e Municípios (FPEM) ${ }^{201}$. Lembra Fernando ABRUCIO que, neste fundo, "a maior parte das transferências, no entanto, obedecia a vinculações estabelecidas pelo Poder Central. Os critérios de rateio eram população e renda per capita, beneficiando as Regiões mais pobres do país" ${ }^{202}$. A fim de oferecer uma contrapartida aos Estados mais ricos, que eram prejudicados por este mecanismo, os militares mantiveram "um modelo econômico com investimentos extremamente concentrados nos conglomerados industrias do Sudeste", especialmente aqueles localizados em São Paulo. ${ }^{203}$

Já por meio do pilar administrativo o regime militar buscava a harmonização e a homogeneização da atuação administrativa nos três níveis de governo. Os instrumentos para atingir tal fim foram muitos, dentre os quais se ressaltam a atuação da União nos Estados e nos Municípios por meio da sua Administração Direta e Indireta, os incentivos dados aos

\footnotetext{
${ }^{201}$ ABRUCIO. Os barões da Federação, pp. 65-67. Este autor, ao comentar a centralização de receitas tributárias sob a égide da Constituição Federal de 1967, pondera que "na nova ordem fiscal, a União ficou com dez impostos e os estados e os municípios com dois cada. O Governo Federal adquiriu dois impostos que na estrutura anterior pertenciam às unidades subnacionais - o de exportação, que era importantíssimo para os estados, e o imposto sobre a propriedade rural, que era dos municípios" (ABRUCIO. Os barões da Federação, p. 66). Tal interpretação é questionada, por sua vez, por autores como Marta ARRETCHE, que constata que "esta transferência teve bem menos impacto do que se lhe atribui. Nos anos 60, o Imposto de Exportação havia perdido importância das receitas estaduais para o Imposto sobre Vendas e Consignações. Já em 1942, este Imposto representava menos de $6 \%$ do total da receita tributária dos estados, ao passo que o IVC representava 43,5\% desta (Lopreato, 2002:26)s. Na reforma do regime militar, o IVC foi transformado em ICM, permanecendo sob autoridade exclusiva dos estados. Logo, a reforma não significou uma imposição significativa de perda de áreas de tributação exclusiva para os estados." (Marta Tereza da Silva ARRETCHE. A Centralização no Estado Federativo Brasileiro. Tese (Livre-Docência) - Faculdade de Filosofia, Letras e Ciências Humanas. São Paulo, 2007, p. 85. Aliás, é muito interessante a análise que esta autora traça sobre a evolução da centralização da repartição de rendas no terceiro capítulo desta obra, cuja leitura se mostra imprescindível para a compreensão deste aspecto da centralização federativa no Brasil.

202 ABRUCIO. Os barões da Federação, p. 67.

${ }^{203}$ ABRUCIO. Os barões da Federação, p. 69. O resultado deste processo foi, como aponta o referido autor nas páginas seguintes de sua obra, o enfraquecimento financeiro principalmente dos Estados-membros, ao menos em um primeiro momento. Contudo, este quadro foi se revertendo ao longo dos anos, com o gradual aumento das transferências da União ao FPEM, à medida que o regime militar precisou ceder às pressões dos governadores para continuar no poder. A corroborar este argumento, vide as sucessivas redações conferidas ao artigo $25 \mathrm{CF} / 1967-1969$.
} 
Estados a fim de que estes reproduzissem estrutura administrativa semelhante à federal e a celebração de convênios pelos quais a União prestava assistência técnica e transferia recursos financeiros. ${ }^{204}$ Do ponto de vista jurídico, o instrumento mais importante manejado pelos militares foi o Decreto-Lei $n^{\circ}$ 200/1967, o qual pretendia não só dispor sobre a organização da Administração Federal, mas efetivamente lançar as bases de uma Reforma Administrativa que substituísse as diretrizes lançadas por Getúlio Vargas. ${ }^{205}$ Retornaremos a este ponto oportunamente, prosseguindo por ora com a exposição do terceiro pilar do regime militar a que se refere Fernando ABRUCIO em sua obra: o político.

Como observa este autor, a centralização pretendida pelo regime militar no plano político foi obtida não só por meio das eleições indiretas para governador de Estado - o que passou a ocorrer já a partir de 1966 com a edição do Ato Institucional no 03 (artigo $1^{\circ}$ ) - mas pela eleição de governadores de confiança dos militares nos Estados mais importantes da Federação. E não obstante tenha sido neste aspecto em que o regime militar tenha mostrado toda a sua arbitrariedade - com cassações, perseguições políticas e afins - foi no plano político que o objetivo de centralização vertical e horizontal do poder começou a apresentar os primeiros sinais de desgaste. ${ }^{206}$

Fernando ABRUCIO aponta as eleições realizadas em 1974 como o grande ponto de inflexão não só do processo de liberalização política, mas de transformação da estrutura federativa vigente instituída a partir de $1967 .{ }^{207}$ Por meio de uma série de manobras - entre

\footnotetext{
${ }^{204}$ ABRUCIO. Os barões da Federação, p. 71.

205 Como observa Gilberto BERCOVICI. "O Direito Constitucional passa, o Direito Administrativo permanece": a persistência da estrutura administrativa de 1967. In: Edson TELES; Vladimir SAFATLE (Orgs.). O que resta da ditadura: a exceção brasileira. São Paulo: Boitempo, 2010, pp. 81 e ss. É de se ressaltar, contudo, que este autor enfoca a questão da utilização das empresas públicas pelos militares, viabilizada pelo Decreto-Lei no 200/67, e seus desdobramentos após 1988.

${ }^{206}$ Como observa ABRUCIO. Os barões da Federação, pp. 73 e ss.

${ }^{207}$ ABRUCIO. Os barões da Federação, p. 80. Relata este autor que o ano de 1974 marca a volta dos "castelistas" ao poder e uma primeira tentativa de liberalização do regime, por meio do isolamento da chamada "linha dura" dos militares e da realização de alianças com lideranças regionais nos Estados-membros. Contudo, o resultado das eleições de 1974 demonstrou que a estratégia do regime militar não havia sido bem sucedida: "o resultado final representou um aumento dos votos e das cadeiras do MDB no Congresso, ocorrendo o contrário com a Arena. O MDB quase dobrou sua representação na Câmara passando de 87 para 165, ao passo que a Arena caiu de 223 para 199. No Senado, o MDB aumentou de 7 para 20 senadores, e a Arena perdeu 13 cadeiras, caindo sua representação de 59 para 46 senadores. Embora a Arena permanecesse ainda com a maioria nas duas Casas Legislativas, o impacto simbólico da eleição foi muito grande, especialmente porque o MDB venceu no total de votos para senador, que era o melhor indicador da opinião nacional" (ABRUCIO. Os barões da Federação, p. 83). Como consequência, o governo federal resolveu tornar o processo de liberalização ainda mais lento, ao passo que lidava com o poder de barganha cada vez maior dos governadores de Estado aliados. Apesar de adotar uma série de medidas com a finalidade de eleger aliados nos Estados e Municípios, o regime militar amargou nova derrota nas eleições municipais de 1976, embora tenha obtido relativo sucesso nas eleições de 1978. Para maiores detalhes vide ABRUCIO. Os barões da Federação, pp. 82-90 e também
} 
elas, o pacote de Abril de 1977 e a Lei Falcão - o governo federal ainda logrou obter uma significativa vitória nas eleições de 1978. Contudo, o avanço da oposição nas eleições não poderia mais ser contido nas eleições de 1982, mesmo diante de uma série de medidas tomadas pelo governo federal, a oposição - e, em especial o PMDB - voltou a crescer, aumentando sua representação no Senado e conquistando os governos dos Estados de São Paulo, Minas Gerais e Rio de Janeiro. 208

Na sociedade civil, por sua vez, as demandas pela redemocratização do país só cresciam. Como bem resume Lênio Luiz STRECK,

\begin{abstract}
"desde a década de 70, enfim, movimentos da sociedade civil reivindicavam a convocação de uma Assembleia Nacional Constituinte, mormente no período em que Raimundo Faoro ocupou a presidência da OAB. Os primeiros anos da década de 80 , já com o funcionamento dos novos partidos políticos, foram marcados pelo movimento que visava à realização de eleições diretas para Presidente da República. A emenda constitucional das 'diretas já' foi derrotada no Congresso Nacional, mas marcou indelevelmente a política brasileira, uma vez que, a partir dela, surge a ideia de derrotar o regime militar a partir das próprias regras do jogo por ela impostas: as eleições indiretas. Com efeito, a campanha de Tancredo Neves à presidência trazia em seu bojo o compromisso da convocação de uma Assembleia Constituinte"209
\end{abstract}

Tancredo Neves faleceu pouco depois de realizadas as eleições, de forma que foi José Sarney quem efetivamente exerceu a Presidência da República durante o período que vai de 15 de março de 1985 até 15 de março de 1990, tornando-se o primeiro presidente a governar sob a égide da Constituição Federal de 1988. O período correspondente ao seu mandato costuma ser lembrado como um período de instabilidade econômica, mas também de forte efervescência política por conta dos trabalhos a Assembleia Nacional Constituinte de 1987/1988 (ANC), que serão objeto de breves considerações no tópico a seguir.

\title{
2.1.1.2. A Assembleia Nacional Constituinte de 1987/1988
}

A Assembleia Nacional Constituinte (ANC), composta pelos membros da Câmara dos Deputados e do Senado Federal eleitos em 1986, passou a se reunir a partir do dia $1^{\circ}$ de fevereiro de 1987. Restava o problema de saber como se organizariam os trabalhos da Assembleia, tendo em vista que ela não partia de um Anteprojeto de Constituição. ${ }^{210}$ Após

Thomas SKIDMORE. Brasil: de Castelo a Tancredo. Trad. Mário Salviano Silva. 8a Ed. São Paulo: Paz e Terra, 1988, pp. 335 e ss.

${ }^{208}$ ABRUCIO. Os barões da Federação, p. 91-93.

${ }^{209}$ Lenio Luiz STRECK. Jurisdição constitucional e decisão jurídica. 4ạ ed. São Paulo: Revista dos Tribunais, 2013, p. 522

210 Havia um anteprojeto de Constituição elaborado pela "Comissão Provisória de Estudo Constitucionais", também conhecida como "Comissão Afonso Arinos" em referência a Afonso Arinos de Melo Franco, que a presidiu. Relata Paula BONAVIDES e PAES DE ALMEIDA que tal comissão teria sido instituída com o interesse 
algum impasse, optou-se por distribuir os trabalhos em 24 Subcomissões temáticas, cujos anteprojetos e propostas convergiriam para 8 Comissões temáticas. Finalmente, uma Comissão de Sistematização seria responsável por condensar os anteprojetos oriundos das Comissões, a fim de elaborar o projeto de Constituição que seria efetivamente submetido à votação. $^{211}$

Por óbvio, o federalismo e a repartição de competências figuraram nas discussões de várias subcomissões e comissões. ${ }^{212}$ Foi, contudo a Comissão de Organização do Estado composta pela Subcomissão da União, Distrito Federal e Territórios, pela Subcomissão dos Estados e pela Subcomissão dos Municípios e Regiões - que se debruçou sobre estas temáticas de forma precípua. Ao analisar os trabalhos destas Subcomissões, Celina SOUZA relata uma tendência de promover a descentralização, muito embora não houvesse maiores preocupações com o tipo de descentralização que seria levada a cabo e como isso seria feito. Como ressalta a referida autora, no âmbito das Subcomissões era possível observar as seguintes características:

\begin{abstract}
“a) decisões foram tomadas baseadas em argumentos que não se sustentavam em evidências empíricas; b) não se discutiu as consequências da descentralização proposta; c) as subcomissões não sofreram pressões em assuntos vinculados às relações intergovernamentais e seus conflitos, sinalizando que a disputa intergovernamental se reduzia à área tributária. Essa falta de pressão mostrou
\end{abstract}

de desenvolver apenas pesquisas e estudos, mas efetivamente se "empenhou na missão de elaborar um anteprojeto constitucional, documento ultimado e entregue ao presidente da República em 18 de setembro de 1986. (...) Em verdade, o trabalho da Comissão recebeu do governo o tratamento de um relatório ou documentário e não propriamente de um anteprojeto, qual fora concebido por Afonso Arinos. Ao invés de remetê-lo à futura Constituinte, como era de esperar, Sarney simplesmente o enviou, por despacho presidencial, datado em 24 de setembro de 1986, ao Ministério da Justiça, onde provavelmente ficou arquivado" (História Constitucional do Brasil, pp. 453-454). É possível encontrar nos anais da ANC algumas referências ao Anteprojeto Afonso Arinos, o que leva a crer que ele teve sim influência nos trabalhos desta Assembleia; porém, esta influência se deu de modo informal. Com efeito, os legisladores constituintes brasileiros não partiram de um Anteprojeto de Constituição oficial.

${ }^{211}$ A divisão da Assembleia Nacional Constituinte de 1987/1988 em comissões e subcomissões temáticas foi disciplinada pelo artigo 15 do seu Regimento Interno, disponível no seguinte link: http://www2.camara.leg.br/atividade-legislativa/legislacao/Constituicoes_Brasileiras/constituicaocidada/publicacoes/regimento-interno-da-assembleia-nacional/resolucao-2-1987. Acesso: 01/12/2014.

Para além deste problema de organização dos trabalhos da Assembleia Nacional, é de se ressaltar, com Lênio Luiz STRECK, que a própria emenda constitucional que a convocou padecia de vícios que comprometiam o objetivo principal de renovação democrática das instituições, quais sejam: (i) o fato de a Assembleia Constituinte não ser exclusiva, mas composta pelos deputados e senadores eleitos em 1986, e; (ii) o fato de que uma parte destes senadores serem "biônicos", vale dizer, não eleitos por meio de eleições diretas. Diante deste cenário, conclui o autor "a Assembleia Constituinte, ao derivar dos integrantes políticos do Congresso Nacional, não estaria comprometida tão somente com a renovação democrática das instituições políticosociais, mas guardaria também, no seu âmago, a (in)consciente tendência de manutenção do status quo ante desenvolvido no regime autocrático militar-empresarial vivido até então" (STRECK. Jurisdição constitucional e decisão jurídica, pp.522 e 523).

212 É o caso, por exemplo, da Subcomissão de Tributos, Participação e Distribuição das Receitas, da Subcomissão de Saúde, Seguridade e do Meio Ambiente, e da Subcomissão da Educação, Cultura e Esportes. 
que questões como a descentralizacão de competências, bem como o novo papel do governo federal em um sistema descentralizado, não estavam na agenda dos constituintes. No entanto, cada uma dessas subcomissões tinha uma prioridade e seus relatores foram escolhidos por apoiarem essas prioridades; d) $\underline{\mathbf{a}}$ defesa da descentralização baseava-se em argumentos normativos extraídos das teorias de desenvolvimento, em especial a de que a descentralização aumenta a eficiência e promove a democracia; e) a opcão pelo intenso uso das competências concorrentes tem sido apontada, até hoje, como um dos principais problemas enfrentados pelo governo federal. Nas diversas tentativas de mudar a Constituição, essa falta de clareza é indicada como um dos principais problemas a serem resolvidos; f) o resultado dos trabalhos dessas subcomissões trouxe um paradoxo: a bandeira anticentralista dos seus membros não se refletiu nas competências e responsabilidades da União, que foram ampliadas, em especial na área social.

A temática das relações intergovernamentais, principal responsabilidade das duas subcomissões, não foi considerada, assim como a defesa da descentralização não foi precedida de debates sobre seu impacto na Federação, nas relações intergovernamentais e nas políticas públicas." 213

Esta análise contempla dois aspectos importantes da descentralização desejada e levada a efeito pelos membros da Assembleia Nacional Constituinte: em primeiro lugar, ela não foi suficientemente planejada, vale dizer, acompanhada de mecanismos que viabilizassem a coordenação federativa; em segundo lugar, ela ocorreu de forma desigual, pois não refletiu em todos os aspectos das autonomias estaduais e municipais. Com efeito, a

\section{Constituição Federal de 1988 robusteceu a União no que tange à repartição de} competências legislativas em detrimento principalmente dos Estados-membros; foi sobretudo no campo político e da repartição de rendas que se verificou alguma

descentralização. No que tange às competências de execução, optou-se por um meio termo, como será discutido a seguir.

De todo modo, é importante compreender as razões que levaram a esta descentralização. Nesse sentido, Celina SOUZA arrola algumas razões para esta decisão de descentralizar, entre elas: (i) a "reação contra o regime autoritário, já que a centralização e autoritarismo sempre estiveram associados no Brasil"; (ii) um "ambiente favorável aos governos subnacionais, abrindo caminho para assunções normativas sobre a descentralização, como por exemplo seu potencial para promover eficiência, democracia e accountability", e; (iii) o fato de que " $54 \%$ dos membros da ANC que tinham experiência político-partidária anterior tinham sido governadores, prefeitos, vereadores ou deputados estaduais, além de serem sempre potenciais candidatos aos Executivos subnacionais.”214

\footnotetext{
213 Celina SOUZA. Federalismo e Descentralização na Constituição de 1988: Processo Decisório, Conflitos e Alianças. DADOS - Revista de Ciências Sociais, Rio de Janeiro, Vol. 44, no 3, 2001, p. 525 (grifo nosso).

214 SOUZA. Federalismo e Descentralização na Constituição de 1988, pp. 546. Estas mesmas razões são repetidas e acrescidas de outras em Celina SOUZA. Constitutional Engineering in Brazil: The Politics of Federalism and Decentralization. Basingstoke: Macmillan Press, 1997, pp. 92-94.
} 
Todas estas razões, por sua vez, podem ser de algum modo ser reconduzidas à união das demandas por redemocratização com as demandas por descentralização observada nesse período. Em primeiro lugar, porque se autoritarismo e centralização sempre andaram juntos no Brasil - como se pôde observar no período do Estado Novo e da Ditadura Militar - é natural que democracia a descentralização também se tornem noções próximas, ao menos no plano ideológico. Em segundo lugar, porque a redemocratização começou pelos Estadosmembros e Municípios. Estes, à época da Constituinte contavam com governantes eleitos pelo voto direto, ao passo que o governo federal ainda era chefiado pelo último presidente brasileiro eleito pelo voto indireto: era natural, portanto, que aqueles contassem com maior legitimidade do que este, e que as suas pretensões de descentralização fossem igualmente dotadas de maior legitimidade. ${ }^{215}$

Em suma, estas são as razões que nortearam uma nova descentralização da federação brasileira, após algumas décadas de centralização nas mãos do Poder Executivo Federal. Resta apenas saber como esta decisão informou e conformou o sistema constitucional de repartição de competências (tendo em vista que repartição de poder político não corresponde exatamente à ideia juridicamente situada de repartição de competências, principalmente de competências legislativas e competências de execução - como, aliás, já se teve a oportunidade de analisar no item 1.4). Para tanto, opta-se por analisar dois aspectos dos Anteprojetos forjados no âmbito das Subcomissões e das Comissões pertinentes da ANC. ${ }^{216}$

Em primeiro lugar, ao se examinar os Anteprojeto elaborado pelas Subcomissão da União e sobre o seu incluso relatório, percebe-se a nítida intenção de manejar as

\footnotetext{
${ }^{215}$ A união entre descentralização e democratização durante o processo que culminou com a promulgação da Constituição Federal de 1988 é analisada em Rui AFFONSO. Os Municípios e os desafios da Federação no Brasil. São Paulo em Perspectiva, 10 (3), 1996, p. 5, Fernando Luiz ABRUCIO. A coordenação federativa no Brasil: a experiência do período FHC e os desafios do governo Lula. Revista de Sociologia e Política, Curitiba, no 24, jun/2005, p. 46 e mais brevemente em SOUZA. Constitutional Engineering in Brazil, p. 93. É Maria Hermínia Tavares de ALMEIDA que expõe de forma mais acurada esta relação, no seguinte trecho: "A descentralização foi um tema central da agenda da democratização, nos anos 1980, como reação à concentração de decisões, recursos financeiros e capacidade de gestão no plano federal, durante aos 20 anos de autoritarismo burocrático. Nessas circunstências, a descentralização foi defendida tanto em nome da ampliação da democracia quanto ao aumento da eficiência do governo e da eficácia de suas políticas. Supunha-se que o fortalecimento das instâncias subnacionais, em especial dos municípios, permitiria aos cidadãos influenciar as decisões e exercer controle sobre os governos locais, reduzindo a burocracia excessiva, o clientelismo e a corrupção. No crepúsculo do autoritarismo, estabeleceu-se um consenso entre os formadores de opinião e os movimentos sociais, bem como entre políticos estaduais e locais acerca das virtudes da descentralização de recursos fiscais e de responsabilidades governamentais" (Maria Hermínia Tavares de ALMEIDA. Recentralizando a federação? Revista de Sociologia e Política, no 24, jun/2005, p. 29 - o mesmo argumento é retomado na p. 32 de forma ainda mais enfática).

216 Para uma abordagem sistemática dos Anteprojetos elaborados e discutidos no âmbito da Assembleia Nacional Constituinte, com foco no tema da repartição de competências, vide ALMEIDA. Competências na Constituição de 1988, p. 63-73.
} 


\title{
competências concorrentes com a finalidade de se promover uma descentralização
}

mais gradual. Nesse sentido, o seguinte trecho do relatório que acompanha o referido Anteprojeto:

\begin{abstract}
"Ao longo do tempo, mas sobretudo na vigência da Constituição de 1967, o modelo federativo brasileiro tornou-se acentuadamente concentrador de poderes e competências na União.

A autonomia dos Estados-membros e dos Municípios, formalmente assegurada, não se concretiza na prática, como resultado da intensa concentração de rendas nas mãos da União.

(...)

3. Não obstante a procedência dos argumentos e a legitimidade da pretensão dos Estados e dos Municípios, é preciso ter em vista que a centralização federativa constitui um processo histórico ao longo do tempo. Esta realidade não pode ser nem escamoteada, nem desconsiderada na avaliação da estratégia de recuperação das autonomias periféricas.

Pretende-se dizer, com isso, que, da mesma forma como se processou o federalismo centralizado, é de bom senso que a mudança do modelo obedeça a mecanismos que possam viabilizar uma descentralização federativa gradual, no processo de reconquista das autonomias subtraídas.

Não é crível que a mudança instantânea da centralização à descentralização federativa corresponda, na prática, ao automatismo que se imagina. Não se desconheça que a União agigantou-se demasiadamente e essa avultação não pode ser achatada de uma hora para outra sem os riscos inerentes a qualquer processo traumático, os quais, no caso, poderiam confluir à própria inviabilidade da mudanca.

4. Com a mesma percepcão, certamente, a Comissão Provisória de Estudos Constitucionais sugere, no seu Anteprojeto, a criacão de uma esfera comum de competência material e legislativa como instrumento adequado a propiciar a alteração gradual do modelo

O Relator, reconhecendo que o referido Anteprojeto consubstancia um texto seguro e bastante satisfatório no capítulo da Organização do Estado, toma-o como base de sua proposta." 217
\end{abstract}

É questionável se as competências concorrentes (ou uma esfera comum de competências legislativas e materiais, para ficar com a terminologia empregada pelo relator desta Subcomissão) efetivamente poderiam de algum modo contribuir com este objetivo proclamado pelo constituinte. Esta foi, contudo, a solução que efetivamente prevaleceu, como se pode extrair da dicção do artigo $23 \mathrm{CF} / 88$, que cuida da competência comum da União, Estados e Municípios, e do artigo $24 \mathrm{CF} / 88$, que trata da competência legislativa concorrente da União e dos Estados-membros.

Em segundo lugar, é importante atentar para a separação entre competências legislativas e competências de execução que permeou todos os Anteprojetos ${ }^{218}$ e que foi

\footnotetext{
217 Assembleia Nacional Constituinte. Subcomissão da União, do Distrito Federal e Territórios: Relatório e Anteprojeto, $\quad$ p. $2 . \quad$ Disponível em: http://www.camara.gov.br/internet/constituicao20anos/DocumentosAvulsos/vol-87.pdf. Acesso: 13/12/2014 (grifo nosso).

218 Nesse sentido, vide: (i) artigo F, incisos I a XIX e artigo F, inciso XX, artigo G, incisos I a XII e artigo G, inciso XIII do Anteprojeto da Subcomissão da União, do Distrito Federal e dos Territórios; (ii) artigo 9o, caput, inciso I
} 


\section{incorporada ao texto da Constituição Federal de 1988 de uma forma não tão refletida quanto a distinção entre competências privativas e competências concorrentes. A fim}

de corroborar este argumento basta verificar como competências legislativas e de execução foram unidas e novamente reunidas em artigos distintos no decorrer dos trabalhos da constituinte. A própria competência concorrente foi cindida em uma competência comum e uma competência concorrente, cujos títulos não apresentam uma correspondência exata.

\subsubsection{A federação brasileira a partir da Constituição Federal de 1988}

Não obstante todas as contradições que permearam os trabalhos da Assembleia Nacional Constituinte, a doutrina constitucional à época da promulgação da Constituição Federal de 1988 afirmava que havia se logrado obter um federalismo de equilíbrio, vale dizer, um federalismo que consagra um "sistema de repartição de competências que tenta refazer o equilíbrio das relações entre o poder central e os poderes estaduais e municipais" 219 por meio da ampliação das hipóteses de competência concorrente.

A inspiração para tanto era a Lei Fundamental alemã de 1949, considerada um modelo em matéria de repartição de competências, como se extrai do seguinte trecho da obra de Raul Machado HORTA:

"Concebeu a Lei Fundamental da República Federal da Alemanha
(Grundgesetz Für Die Bundesrepublick Deutschland), de 1949, a forma mais
evoluída de repartição de competências do moderno Estado federal. Ao
contrário de sua famosa antecessora, a Constituição de Weimar de 1919, da qual
se disse ter aplainado o caminho para a transformação do Estado federal
(Bundesstaat) em Estado unitário (CHARLES EISENMAN. Bonn et Weimar - Deux
Constitutions de l'Allemagne - Notes et Études Documentaires no 1337 - 1950),
a Lei Fundamental se caracteriza pelo estilo federalista que imprimiu às
instituicões do Estado alemão. (...) A repartição de competências do novo
federalismo alemão compreende dois segmentos fundamentais: o da legislação
exclusiva da Federação e o da legislação concorrente ou comum, uma competência
mista, a ser explorada pela Federação e pelos Estados, conforme regras
estabelecidas na Lei Fundamental. A legislação concorrente é a mais numerosa,
abrangendo 23 (vinte e três) casos, enquanto a legislação exclusiva da Federação
é limitada a onze competências (...) A Lei Fundamental da Alemanha contém o
modelo constitucional do federalismo de equilíbrio, que se completa, ainda, na
distribuição da competência tributária entre a Federação e os Estados (Lei
Fundamental, arts. 105/108), na previsão das subvenções financeiras aos Estados

e artigo 9o, § 1으, I do Anteprojeto da Subcomissão dos Municípios e Regiões; (iii) artigo 8으, incisos I a XVIII e artigo 8o, inciso XIX do Anteprojeto da Comissão de Organização do Estado; (iv) artigo 21 a 25 e 30, incisos I e $\checkmark$ do Projeto de Constituição elaborado pela Comissão de Sistematização, e; (ii) finalmente, os artigos 21 a 25 e 30, incisos I e V da CF/88. Todos os referidos Anteprojetos e Projetos encontram-se disponíveis em http://www2.camara.leg.br/atividade-legislativa/legislacao/Constituicoes_Brasileiras/constituicao-cidada/oprocesso-constituinte/lista-de-comissoes-e-subcomissoes. Acesso: 13/12/2014.

219 JOSÉ AFONSO. Curso de Direito Constitucional Positivo, p. 102. Nesse mesmo sentido, vide também ALMEIDA. Competências na Constituição Federal de 1988, p. 77. 
(art. 107. (2) e na colaboração federal para realização de planos estaduais de interesse comum (Lei Fundamental, art. 91, a).

4. É nesse federalismo de equilíbrio que deverá inspirar-se o constituinte federal brasileiro, para que possa levar a bom termo a restauração do federalismo brasileiro, de forma que o indispensável exercício dos poderes federais não venha inibir o florescimento dos poderes estaduais.

HORTA, como é bem sabido, é um dos grandes expoentes da análise jurídica do federalismo e não por outro motivo influenciou uma geração de constitucionalistas que se dedicaram ao tema. Contudo, é de se admitir que no trecho transcrito supra ele parte de duas premissas equivocadas.

A primeira delas consiste em erigir o caso alemão à categoria de um modelo ideal, ou pelo menos de um exemplo a ser seguido. Afinal, como ainda se terá a oportunidade de analisar nesta tese, a repartição de competências legislativas e de execução sob a égide da Lei Fundamental de 1949 conduziu, ao longo dos anos, a uma forte centralização federativa, a ponto de se falar em um "Estado Federal-Unitário" alemão. Não por outro motivo, ela foi objeto de importantes e extensas reformas constitucionais ao longo dos anos. A repartição de competências na Alemanha, portanto, merece ser estudada em virtude de todas as interessantes discussões que suscita, mas somente com muita dificuldade pode ser considerada um modelo a ser seguido.

A segunda premissa da qual parte HORTA é a de que a competência concorrente seria um mecanismo hábil a promover o equilíbrio federativo. Contudo, o que a prática demonstra é que a competência concorrente, em quaisquer das suas modalidades, enseja muitos problemas de difícil solução, além de favorecer a centralização de atribuições nas mãos da União. ${ }^{221}$ A corroborar este argumento basta lembrar que a Rahmengesetzgebung a competência-moldura prevista no artigo 75 GG, que permitia a União legislar sobre normas gerais e aos Länder suplementar estas previsões, e tão comemorada pela doutrina brasileira

\footnotetext{
220 Raul Machado HORTA. Organização constitucional do federalismo. Revista de Informação Legislativa. Brasília, ano 22, n. 87, jul/set. 1985, pp. 13-14 (grifo nosso). É de se ressaltar que em sua obra Direito Constitucional, HORTA reitera este raciocínio e afirma a sua positivação pela Constituição Federal de 1988, ao ponderar que "a repartição de competências, estruturada na Constituição Federal de 1988, reflete as novas tendências do federalismo e na concepção constitucional é visível a influência recebida da técnica de repartição de competências da Lei Fundamental da Alemanha, de 1949, que o Ante Projeto de Constituição Federal da Comissão Afonso Arinos incorporou. A Constituição de 1988, ultrapassando o dualismo dos poderes enumerados e dos poderes reservados, poderosa criação do federalismo clássico, acrescentou a desenvolveu na repartição de competências a competência comum, de caráter cooperativo, da União, dos Estados, do Distrito Federal e dos Municípios (art. 23, I até XII) e a competência concorrente, de natureza legislativa, da União, dos Estados e do Distrito Federal (...)" (HORTA. Direito Constitucional, p. 449).

${ }^{221}$ Em virtude da especial configuração da federação brasileira, admite-se que a centralização também possa ser verificada em favor dos Estados em detrimento dos Municípios, ainda que esta não ocorra com muita frequência na prática. Por isso, fez-se referência no corpo do texto a uma "centralização de atribuições nas mãos da União".
} 
- foi revogada em 2006 em prol de uma estrutura federativa mais descentralizada e definida. Por sua vez, a competência concorrente alemã (konkurrierende Gesetzgebung), referida por HORTA no trecho transcrito supra, foi a grande responsável pela intensa centralização legislativa verificada naquele país. Isso não significa que competências concorrentes não deveriam existir, muito pelo contrário: afirma-se apenas que esta é uma modalidade de repartição que suscita alguns problemas que devem ser devidamente considerados e ponderados.

\title{
Em suma, é de se questionar se este "federalismo de equilíbrio" algum dia existiu
} ou se algum dia teve condições de existir. Afinal, do ponto de vista ideológico ele nada mais é do que uma variante do que Preston KING chama de "federalismo de balanço", o qual, enquanto filosofia política, costuma ser ou instável ou incoerente ${ }^{222}$. Como pondera este autor.

\begin{abstract}
"no plano teórico, ele [o federalismo de balanço] traduz-se como um argumento tanto para uma maior centralização quanto para uma maior descentralização. No plano prático, o feito pode ser igualmente ambivalente. $\mathrm{O}$ fato é que o discurso do balanço é um instrumento retórico, no mais das vezes difícil de resistir. Se alguém procura tanto por maior centralização quanto por maior descentralização, é tentador fazer isso de tal modo a sugerir que o que este alguém procura não é novo, mas normal; não é absurdo, mas sólido; e este alguém pode invocar a metáfora do 'balanço' para atingir isso." 223
\end{abstract}

Além do mais, a afirmação de que a federação brasileira tende ou tendia a uma descentralização, ainda que gradual, neste momento da sua história consiste em uma versão razoavelmente simplificada dos fatos. Afinal, como bem pondera Maria Hermínia Tavares de ALMEIDA, “o andamento da descentralização não foi nem simples nem linear. Tendências centralizadoras poderosas também estiveram presentes, aumentando a complexidade do processo de redefinição das relações intergovernamentais" ${ }^{224}$. Em outras palavras, o que se observa a partir de 1988 são "movimentos contraditórios no sentido da descentralização e da centralização" no Estado Federal brasileiro. A referida autora pretende investigar este movimento em duas áreas, mais precisamente: (i) a repartição de receitas tributárias entre União, Estados e Municípios, e; (ii) as políticas sociais. ${ }^{225}$ Acredita-se que, para os fins desta tese, esta análise deve ser expandida, a fim de abarcar um verdadeiro panorama do federalismo brasileiro pós-1988.

\footnotetext{
222 KING. Federalism and federation, p. 44. O federalismo de balanço como uma das variantes possíveis do federalismo, ao lado do federalismo centralista e do federalismo descentralista, foi trabalhado no item 1.3 desta tese.

223 KING. Federalism and federation, p. 44.

${ }^{224}$ ALMEIDA. Recentralizando a federação?, p. 29

${ }^{225}$ ALMEIDA. Recentralizando a federação?, p. 29
} 
No plano político, a Constituição Federal de 1988 representou o ápice de um movimento de descentralização iniciado ainda no período da ditadura militar, como se teve a oportunidade de analisar supra. Atualmente, governadores, deputados estaduais, prefeitos e vereadores são eleitos pelo sufrágio universal. Aliás, a própria decisão de erigir o Município a ente federativo ao lado da União e dos Estados-membros representou uma descentralização importante no plano político, mesmo que a autonomia municipal não seja propriamente um dado novo da federação brasileira e ainda que a afirmação de que o federalismo favorece a democracia ao aproximar os cidadãos das estruturas de poder seja algo que encontre respaldo sobretudo no plano ideológico.

\section{No plano da repartição de rendas também se pôde verificar alguma} descentralização. Como ressalta Celina SOUZA, "a distribuição dos recursos tributários, apesar de hoje muito mais concentrada na União do que quando da promulgação da Constituição de 1988, assegura às esferas subnacionais cerca de $32 \%$ de todos os impostos coletados no país. Com as transferências, elas recebem $43 \%$ das receitas totais" 226 . Isso faz com que o Brasil se situe, em uma perspectiva comparada, como o país em desenvolvimento mais descentralizado do ponto de vista fiscal. ${ }^{227}$ Contudo, há dois dados a serem acrescentados a este diagnóstico, os quais fornecem uma dimensão mais apurada da complexidade que envolve esta descentralização. Em primeiro lugar, ressalta a enorme desigualdade de Estados e Municípios na arrecadação dos tributos de sua competência ${ }^{228}$. Como ressalta Marta ARRETCHE,

\footnotetext{
"A razão entre os Estados com maior e menor capacidade de arrecadação tributária própria em 1997 foi de 9,4 (Prado, 2001:50). No interior de cada Estado, municípios de mesmo tamanho apresentam enorme diversidade de arrecadação. Excetuando-se as capitais - com arrecadação até dez vezes superior à dos demais municípios de seu próprio Estado -, os municípios de maior porte não revelam melhor desempenho do que os pequenos, independentemente do nível de renda do Estado em que estão localizados.",229
}

Tradicionalmente tenta-se mitigar este cenário por meio da transferência de recursos da União para Estados e Municípios, dos Estados para os Municípios, e entre os

\footnotetext{
${ }^{226}$ Celina SOUZA. Federalismo, desenho constitucional e instituições federativas no Brasil pós-1988. Revista de Sociologia e Política, no 24, jun/2005, p. 116. Prossegue a autora afirmando que "do lado das despesas, os governos subnacionais são responsáveis por $70 \% * 10,1 \%$ do produto interno bruto (PIB) da despesa com pessoal e por $80 \%$ da formação bruta de capital fixo (2,2\% do PIB) (AFONSO, 2004, p. 5)".

${ }^{227}$ ABRUCIO. A coordenação federativa no Brasil, p. 48.

${ }^{228}$ Marta ARRETCHE. Federalismo e políticas sociais no Brasil: problemas de coordenação e autonomia. São Paulo em Perspectiva, 18 (2), 2004, p. 18.

${ }^{229}$ ARRETCHE. Federalismo e políticas sociais no Brasil, p. 18.
} 
Estados $^{230}$. As primeiras duas modalidades vêm regulamentadas nos artigos 157 a 159 $\mathrm{CF} / 88$. O artigo $157 \mathrm{CF} / 88$ prevê a participação estadual nos impostos criados pela União no exercício de sua competência residual; porém, como a partir de 1988 a União só criou contribuições sociais, a referida regra constitucional em favor dos Estados perdeu grande parte da sua utilidade. $\mathrm{O}$ artigo $158 \mathrm{CF} / 88$, por sua vez, trata da participação do Município nos impostos federais e estaduais, principalmente nestes últimos. Com efeito, de acordo com este dispositivo os Estados deverão entregar aos Municípios 50\% da arrecadação do IPVA e 25\% do ICMS incidente sobre serviços de transporte interestadual e intermunicipal e de comunicação. Porém, o dispositivo mais relevante para compreender a magnitude das transferências verticais é o artigo 159 CF/88. Segundo este dispositivo, $49 \%$ da arrecadação do IR e do IPI - que são os dois impostos federais de maior arrecadação - deve ser entregue aos Fundos de Participação dos Estados e dos Municípios, à proporção de 21,5\% e 24,5\% 231 . Além do mais, 29\% da arrecadação da CIDE-combustíveis e 10\% do IPI incidente sobre exportações devem ser entregues aos Estados, sendo que estes últimos deverão entregar aos seus respectivos Municípios 25\% da arrecadação do IPI que lhes foram transferidas pela União. Já as transferências entre os Estados se dão basicamente por meio da repartição da arrecadação do ICMS entre os Estados produtores e Estados destinatários nos termos do artigo $155 \mathrm{CF} / 88$, promovendo um fluxo de recursos dos Estados com maior arrecadação para os de menor arrecadação. ${ }^{232}$

\footnotetext{
${ }^{230}$ Como observa ARRETCHE. Federalismo e políticas sociais no Brasil, p. 18. Como ressalta a autora no referido trecho, "desde a Constituição de 1946, esta desigualdade horizontal de capacidade de arrecadação tem sido compensada por um sistema de transferências fiscais. Transferências obrigatórias de caráter constitucional distribuem parte das receitas arrecadadas pela União para Estados e municípios, bem como dos Estados para seus respectivos municípios (Varsano, 1996). Assim, os convencionalmente chamados de ciclos de centralização (Reforma Tributária de 1965-68) e descentralização (Constituições Federais de 1946 e 1988) do sistema fiscal brasileiro não se referem a processos de mudanças na distribuição da autoridade para tributar, mas estão diretamente associados às alíquotas aplicadas aos impostos de repartição obrigatória, bem como à autonomia de gasto dos governos locais sobre os recursos recebidos".

231 Os 3\% restantes devem ser aplicados, conforme artigo 150, I, c, CF/88, "em programas de financiamento ao setor produtivo das Regiões Norte, Nordeste e Centro-Oeste, através de suas instituições financeiras de caráter regional, de acordo com os planos regionais de desenvolvimento, ficando assegurada ao semi-árido do Nordeste a metade dos recursos destinados à Região".

232 Porém, é importante atentar para as seguintes ponderações de Marta ARRETCHE sobre o sistema de transferências consagrado pela Constituição Federal de 1988: "no plano vertical, o atual sistema de transferências fiscais permite que quase todos os ganhos relativos sejam apropriados pelos municípios, uma vez que seus resultados são neutros para os Estados (Serra; Afonso, 1999). Em 2002, a receita disponível (arrecadação própria + transferências) da União foi de 60\% do total das receitas, ao passo que os municípios se apropriaram de 15\%, permanecendo os Estados no mesmo patamar que estavam anteriormente à redistribuição (...). Além disso, este sistema favorece os municípios de pequeno porte. Gomes e MacDowell (1997) estimaram ser de 91\% a participação das receitas de transferência nos municípios de menos de 5.000 habitantes. Em 22 Estados brasileiros, quanto menor a população do município, maior o seu ganho de receita derivado das transferências constitucionais, vale dizer, maior a disponibilidade de recursos per capita com liberdade alocativa, uma vez realizadas as transferências (Prado, 2001:68). No plano horizontal, este sistema
} 
Em segundo lugar, deve-se ressaltar que a Constituição Federal de 1988, na sua sistemática original, conferiu aos entes federativos uma razoável autonomia no que tange à alocação de seus respectivos recursos. É verdade que esta liberdade tem sido cerceada no decorrer dos anos por meio da edição de legislação federal e de emendas constitucionais que vinculam a renda a determinadas finalidades ou a determinados patamares. ${ }^{233}$ De todo modo, persiste um cenário em que Estados e Municípios possuem a liberdade para fixar suas próprias agendas, ou pelo menos, agendas relativamente independentes do plano nacional. ${ }^{234}$ Como ressalta novamente Marta ARRETCHE,

\begin{abstract}
"Estados e municípios, por sua vez, contam com recursos garantidos, independentemente tanto de lealdade política ou adesão a políticas federais quanto de seu esforço tributário. Sistemas tributários e fiscais caracterizados por elevado nível de dependência de transferências fiscais e ausência de vínculo entre quem taxa e quem gasta tendem a produzir baixo compromisso com o equilíbrio fiscal por parte dos governos subnacionais (Rodden, 2001), tendência esta que no caso brasileiro foi limitada pela Lei de Responsabilidade Fiscal. Além disso, a autoridade do governo federal para induzir as decisões dos governos locais, no sentido de que estas venham coincidir com as suas próprias prioridades, permanece limitada, uma vez que estes detêm autonomia fiscal e política, tendo, portanto, condições institucionais para não aderir às políticas federais." ${ }^{235}$
\end{abstract}

Como uma consequência deste fenômeno, para a União torna-se mais difícil de promover a coordenação federativa, pois é necessário forjar mecanismos que tornem atraente a adesão de Estados e Municípios a programas nacionais. Retornaremos a este argumento oportunamente. ${ }^{236}$ Por ora, prosseguimos com a elaboração do panorama da federação brasileira, partindo para a análise da descentralização e da centralização no plano da legislação e da administração.

No campo da legislação, é possível verificar um movimento de centralização. O rol de competências legislativas privativas da União não só incorpora a maioria das matérias previstas no artigo $8^{\circ}$, XVII, CF/1967-69, como amplia a atuação legislativa da União a áreas não previstas pela constituição anterior. Seria até possível vislumbrar alguma

redistribui receita dos Estados mais desenvolvidos para os menos desenvolvidos (Rezende; Cunha, 2002). Entretanto, as regras que acabaram por reger as transferências constitucionais têm por consequência recriar novas desigualdades entre as Unidades da Federação (Prazo, 2001:54). É enorme a variação na receita disponível entre os municípios e Estados brasileiros. A razão entre a receita média per capita dos municípios com mais de um milhão de habitantes, na Região Sudeste, e dos Municípios com menos de 20 mil habitantes, nas Regiões Norte e Nordeste, pode ser de até 46 vezes (Gomes; MacDowell, 1997:11). Uma vez realizadas as transferências constitucionais, a receita disponível per capita do Estado de Roraima foi de duas vezes a de São Paulo, em 1997" (Federalismo e políticas sociais no Brasil, p. 19).

${ }^{233}$ Esta restrição da autonomia das unidades subnacionais na alocação de seus respectivos recursos é relatada em ALMEIDA. Recentralizando a federação?, pp. 35-36.

234 Nesse sentido, vide ARRETCHE. Federalismo e políticas sociais, p. 20

${ }^{235}$ ARRETCHE. Federalismo e políticas sociais, p. 20.

${ }^{236}$ Mais precisamente, no tópico 3.2.3, que trata da cooperação federativa no Brasil e na Alemanha. 
descentralização no que diz respeito às competências legislativas concorrentes previstas no artigo $24 \mathrm{CF} / 88$ - como, aliás, propugna a doutrina do federalismo de equilíbrio - porém, a prática em torno deste dispositivo constitucional não confirmou semelhante pretensão. Não se pode efetivamente afirmar, no entanto, que este é um dado não esperado, uma fatalidade que acometeu o federalismo brasileiro pós-1988. Afinal, a competência concorrente da União e dos Estados-membros era prevista pela ordem constitucional anterior e já nesta época as legislações federais editadas com base neste fundamento eram quase que exaustivas, deixando pouco ou nenhum espaço para a atuação dos Estados-membros. A Constituição Federal de 1988 pode até ter disciplinado o exercício desta modalidade de competência com um maior detalhamento, mas ao circunscrever a atuação da União à edição de normas gerais, acabou por abrir um flanco rumo à centralização. ${ }^{237}$

\section{No âmbito das competências de execução, a constituição brasileira vigente} optou por um meio termo. A chamada competência geral da União inscrita no artigo 21 $\mathrm{CF} / 88$, por um lado, também incorporou boa parte das matérias arroladas no artigo $8^{\circ}$, I a XVI, CF/1967-69. Algumas delas, é bom que se deixe claro, não poderiam ser atribuídas aos Estados ou aos Municípios sem grandes prejuízos à federação: é o caso, por exemplo, das relações com Estados estrangeiros e a participação de organizações internacionais, a declaração de guerra e a celebração da paz, a defesa nacional, a emissão de moeda (artigo 21, I, II, III e VII, CF/88). Porém, em outros incisos percebe-se a decisão de promover determinadas políticas públicas em um âmbito nacional, ou ao menos, a decisão de enquadrar determinadas políticas públicas forjadas e realizadas pelas unidades subnacionais em programas nacionais. Nesse sentido, menciona-se a competência da União para "planejar e promover a defesa permanente contra as calamidades públicas, especialmente as secas e as inundações", "instituir diretrizes para o desenvolvimento urbano, inclusive habitação, saneamento básico e transportes urbanos" e "elaborar e executar planos nacionais e regionais de ordenação do território e de desenvolvimento econômico e social" (artigo 21, XVIII, XX e IX, CF/88). ${ }^{238}$ Neste ponto, percebe-se claramente uma tendência centralizadora.

\footnotetext{
237 Os aspectos dogmáticos da competência legislativa concorrente prevista no artigo 24 CF/88 e o seu potencial para promover uma maior ou menor centralização serão retomados no quarto e no sexto capítulos da tese.

238 No meio jurídico é possível encontrar posicionamentos críticos a esta decisão constituinte, como, por exemplo, no seguinte trecho da obra de Fernanda Dias Menezes de ALMEIDA, “(...) a Constituição de 1988 ainda reserva destacado papel à União em relação ao planejamento. Na verdade até amplia significativamente sua atuação nessa área ao atribuir-Ihe competência em tema de planejamento urbanístico. Como já referido, incumbe hoje à União elaborar a executar planos nacionais e regionais de ordenação do território, instituir diretrizes para o desenvolvimento urbano, inclusive quanto a habitação, saneamento básico e transportes urbanos e estabelecer princípios e diretrizes para o sistema nacional de viação. O que se lamenta, numa linha de democracia participativa, é que se tenha perdido a oportunidade de tornar necessária a audiência dos
} 
Por outro lado, o artigo $23 \mathrm{CF} / 88$ parece ter um viés descentralizante. De acordo com este dispositivo - cujos aspectos dogmáticos serão destrinchados no tópico 4.3 compete à União, Estados-membros e Municípios, de modo comum, a execução de uma série de políticas públicas importantes como saúde, educação, meio ambiente e habitação, além da consecução de um objetivo da República Federativa do Brasil por meio do combate às "causas da pobreza e os fatores de marginalização, promovendo a integração social dos setores desfavorecidos". ${ }^{239}$ Perceba-se, porém, como este dispositivo efetivamente não responsabiliza um plano federativo pela execução destas políticas. Como ressalta Marta ARRETCHE, "qualquer ente estava constitucionalmente autorizado a implementar programas nas áreas de saúde, educação, assistência social, habitação e saneamento. Simetricamente, nenhum ente federativo estava constitucionalmente obrigado a implementar programas nestas áreas" ${ }^{240}$. Com efeito, parece-nos que a questão da distribuição de tarefas e responsabilidades entre os entes federativos foi simplesmente relegada para um momento posterior. Nesse sentido, o parágrafo único do artigo $23 \mathrm{CF} / 88$ prevê que leis complementares, no caso leis complementares federais, fixarão "normas para a cooperação entre a União e os Estados, o Distrito Federal e os Municípios, tendo em vista o equilíbrio do desenvolvimento e do bem-estar em âmbito nacional". Note-se que também aqui a União acaba por assumir um papel de indutor ou planejador da coordenação federativa, tendo em vista que ela é competente para criar as normas que nortearão - em alguns casos, forjarão a cooperação entre os entes federativos nas áreas referidas supra.

Em suma, por meio deste breve panorama pode-se visualizar que a

Estados e dos organismos regionais ou municipais interessados, quando da elaboração dos diversos planos nacionais e regionais. Nesse sentido constava, por exemplo, no anteprojeto da Comissão Afonso Arinos, que competia à União planejar e promover o desenvolvimento nacional, ouvidos os Estados e os órgãos interessados (art. 72, XII)" (ALMEIDA. Competências na Constituição de 1988, p. 96, sendo que o mesmo posicionamento pode ser encontrado em BERCOVICl. Desigualdades regionais, Estado e Constituição, pp. 155156). Deve-se fazer um adendo importante a este posicionamento. O fato de a União não ser compelida a ouvir Estados e Municípios no momento da elaboração destes planos nacionais e regionais não significa que ela não possa efetivamente chamar os entes estaduais e municipais à participação. Também não significa que Estados e Municípios não possam se mobilizar para ver seus interesses representados em planos nacionais ou em políticas públicas planejadas em um âmbito nacional. Além do mais, deve-se perquirir sobre o tipo de audiência que se deveria conferir aos Estados e aos "organismos regionais ou municipais interessados", para falar com Fernanda Dias Menezes de ALMEIDA: eles devem necessariamente manifestar o seu consentimento para que efetivamente haja um plano nacional? Ou eles simplesmente seriam ouvidos pura e simplesmente, sem que a União tivesse o dever de considerar os pleitos estaduais e municipais em sua decisão? Na primeira hipótese, Estados e Municípios deteriam um forte direito de veto, colocando em xeque a capacidade de atuação da União. No segundo caso, este dever de audiência seria algo meramente formal, sem que Estados e Municípios pudessem exercer qualquer influência sobre a elaboração de planos nacionais e regionais pela União.

${ }^{239}$ Faz-se referência ao objetivo inscrito no artigo 3ํ, III, CF/88 ("erradicar a pobreza e a marginalização e reduzir as desigualdades sociais e regionais").

240 ARRETCHE. Federalismo e políticas sociais, p. 22. 


\section{Constituição Federal de 1988 incorporou tendências de descentralização e de} centralização. A descentralização pode ser percebida especialmente nos planos político e fiscal, ao passo que a centralização pode ser percebida sobretudo no âmbito da legislação e, em menor medida, no da administração. Certamente essa especial configuração da federação brasileira apresenta contradições. Não se pode afirmar que ela não foi quista pelo legislador constituinte. Afinal, "propostas para combinar descentralização fiscal com descentralização de competências foram estrategicamente derrotadas na ANC 1987-88", consoante ARRETCHE. $^{241}$ Além do mais, ela suscita questões importantes no que tange às relações federativas: tem-se, afinal, que políticas públicas relevantes executadas pelos Estadosmembros e Municípios têm suas principais decisões tomadas no plano federal, tendo em vista que a União é competente para legislar, em maior ou menor medida, sobre quase todas as matérias na federação brasileira.

No decorrer da vigência da Constituição Federal de 1988, em especial durante os mandatos do Presidente Fernando Henrique Cardoso, este cenário alterou-se sensivelmente. Durante este período foram aprovadas leis e emendas constitucionais que aumentaram a arrecadação da União e que restringiram a liberdade das unidades subnacionais ao fixarem limites rígidos de gasto e vincularam suas receitas a determinadas políticas sociais, como saúde e educação. Alguns analistas falam de um novo movimento de centralização da federação brasileira, ao passo que outros traçam um diagnóstico mais cauteloso em relação a este fenômeno. A presente tese filia-se ao entendimento de que esta centralização representa nada mais do que uma continuidade de decisões tomadas pelo legislador constituinte de 1988 e, em certos aspectos, de decisões tomadas em outros momentos da história brasileira, sobretudo na época da ditadura militar, neste ponto encampando a análise deste fenômeno empreendida por Marta ARRETCHE. Mesmo em áreas descentralizadas pela Constituição Federal de 1988 pode-se perceber uma decisão pela centralização, ainda que ela tenha permanecido latente por alguns anos. Retomaremos este argumento no tópico 3.2.3, prosseguindo por ora com o esforço de contextualização da federação brasileira ao tratar da autonomia municipal sob a égide da Constituição Federal de 1988.

\subsubsection{A autonomia do Município na Constituição de 1988}

A questão da autonomia municipal no Brasil adquiriu novos contornos com a promulgação da Constituição Federal de 1988. Com efeito, o seu artigo $1^{\circ}$ dispõe que "a República Federativa do Brasil, formada pela união indissolúvel dos Estados e Municípios

\footnotetext{
${ }^{241}$ ARRETCHE. Federalismo e políticas sociais, p. 22.
} 
e do Distrito Federal", alçando os Municípios a entes integrantes da Federação brasileira, ao lado da União, dos Estados-membros e do Distrito Federal. Neste mesmo sentido, o seu artigo 18 dispõe que "a organização político-administrativa da República Federativa do Brasil compreende a União, os Estados, o Distrito Federal e os Municípios, todos autônomos, nos termos desta Constituição", tornando inconteste a estatura de ente federativo que ostenta o Município, a despeito das crises que lhe são dirigidas. ${ }^{242}$

Contudo, é de se admitir que o Município sempre gozou de alguma autonomia no Brasil, o que se deve ao próprio modo pelo qual se deu a colonização portuguesa no Brasil. As sucessivas Constituições brasileiras reconheciam esta posição diferenciada do Município, assegurando-lhe tradicionalmente a autonomia em tudo o que lhe disse respeito ao seu "peculiar interesse", ainda que o conteúdo real desta autonomia tenha variado ao longo do tempo ${ }^{243}$. Nesse sentido, o artigo 28 da Constituição de 1891 previa que "os Estados organizar-se-ão de forma que fique assegurada a autonomia dos Municípios em tudo quanto respeite ao seu peculiar interesse”. A Constituição de 1934, por sua vez, destrinchou o conteúdo da autonomia municipal ao prever, no seu artigo 13, o seguinte:

\footnotetext{
"Artigo 13. Os Municípios serão organizados de forma que lhes fique assegurada a autonomia em tudo quanto respeite ao seu peculiar interesse, e especialmente: I - a eletividade do Prefeito e dos Vereadores da Câmara Municipal, podendo aquele ser eleito por esta;

II - a decretação dos seus impostos e taxas, a arrecadação e a aplicação das suas rendas; III - a organização dos serviços de sua competência"
}

Note-se como este dispositivo assegurava a autonomia no que se refere ao peculiar interesse do Município, destrinchando o seu conteúdo nos seus incisos, a saber: (i) a

\footnotetext{
242 JOSÉ AFONSO da Silva discorda deste posicionamento, afirmando que "não é porque uma entidade territorial tenha autonomia político-constitucional que necessariamente integre o conceito de entidade federativa. Nem o Município é essencial ao conceito de federação brasileira. Não existe federação de Municípios. Existe federação de Estados. Estes é que são essenciais ao conceito de federação brasileira" (Curso de Direito Constitucional positivo, p. 475). Em sentido parecido, Paulo Gustavo Gonet BRANCO pondera que embora predomine o entendimento de que os Municípios teriam se tornado entes federativos com o advento da Constituição Federal de 1988, há algumas "razões ponderosas em contrário", entre elas o fato de os Municípios não encontrarem representação no Senado Federal e de eles não contarem com um Poder Judiciário, tal como ocorre com a União e com os Estados-membros (MENDES, COELHO, BRANCO. Curso de Direito Constitucional, p. 948). Para uma análise crítica da elevação do Municípios à categoria de ente federativo pela Constituição Federal de 1988, vide Fernando Dias MENEZES DE ALMEIDA. Crítica ao tratamento constitucional do Município como ente da federação brasileira. Doutrinas Essenciais de Direito Constitucional, v. 3, maio/2011, pp. 929 e ss.

${ }^{243}$ A evolução do conceito de autonomia municipal nas sucessivas constituições brasileiras é analisada com maiores detalhes no seguinte artigo de nossa autoria: Mariana Augusta dos Santos ZAGO. O interesse local do Município sob a égide da Constituição Federal de 1988: alguns apontamentos. Revista de Direito Administrativo Contemporâneo, ano 2, volume 9, junho/2014, pp. 177-199. Remete-se, de todo modo, à análise clássica empreendida por Victor Nunes LEAL em Coronelismo, enxada e voto: o Município e o regime representativo no Brasil. 7ạ Ed. São Paulo: Companhia das Letras, 2012.
} 
eletividade do Prefeito e dos Vereadores; (ii) a decretação e arrecadação dos impostos e taxas de sua competência, e; (iii) a organização dos serviços de sua competência.

As constituições que se seguiram adotaram fórmula idêntica - como ocorreu na Constituição Federal de 1937 - ou parecida - como foi o caso das Constituições de 1946 e 1967/1969. ${ }^{244}$ Nestas duas últimas constituições, a autonomia municipal circunscrevia-se ao autogoverno (dado pela eleição do Prefeito e dos Vereadores) e à auto-administração, esta última delimitada pelo peculiar interesse e decomposta em alíneas. De um modo ou de outro, é possível concluir que a questão do alcance e dos limites da autonomia do Município era resolvida em grande parte pelo próprio texto constitucional, que dizia o que poderia se extrair do "peculiar interesse". Porém, com o advento da Constituição Federal de 1988, este cenário se alterou de forma substancial.

Por um lado, a autonomia municipal robusteceu-se, a fim de abarcar as quatro capacidades ínsitas a um ente federativo: a capacidade de auto-organização foi consagrada por meio da elaboração de uma lei orgânica própria, nos termos do caput do artigo 29; a capacidade de autogoverno foi assegurada por meio da eletividade do Prefeito e dos Vereadores, assegurada no inciso I do mesmo artigo 29; a capacidade de autolegislação, por sua vez, encontra respaldo no artigo 30, e; por fim; a capacidade de auto-administração, também encontra previsão no artigo 30 CF/88.

Por outro lado, há pelo menos dois outros fatores que retiram ou tornam indefinida esta autonomia. Em primeiro lugar, a Constituição de 1988 confere um tratamento demasiadamente minucioso a alguns aspectos da autonomia municipal. É o caso do número de vereadores e dos limites de gastos das Câmaras Municipais. Sabe-se que a Constituição Federal de 1988 neste caso específico não desceu a minúcias à toa, tendo em vista os inúmeros disparates que se verificavam na prática em matéria de proporção de vereadores por habitante nos quase 6.000 Municípios brasileiros. Entretanto, é impossível não se espantar com o tamanho do artigo 29 - especialmente o seu inciso IV, que possui nada mais, nada menos, do que 24 alíneas - e não se perguntar se tudo o que nele consta precisava realmente figurar em um texto constitucional.

No que tange a outros aspectos da autonomia municipal, porém, a Constituição peca pela indefinição. Neste ponto, chama-se a atenção para a redação dos incisos I e V do

\footnotetext{
244 O artigo 28 da Constituição de 1946 regulava a autonomia municipal nos seguintes termos: "Artigo 28. A autonomia dos Municípios será assegurada: I - pela eleição do Prefeito e dos Vereadores; II - pela administração própria, no que concerne ao seu peculiar interesse e, especialmente: a) à decretação e arrecadação dos tributos de sua competência e à aplicação das suas rendas; b) à organização dos serviços públicos locais."
} 
artigo $30 \mathrm{CF} / 88$, que consagram o cerne da autolegislação e da auto-administração do Município, ao prever a sua competência para "legislar sobre assuntos de interesse local” e para "organizar e prestar, diretamente ou sob regime de concessão ou permissão, os serviços públicos de interesse local, incluído o de transporte coletivo, que tem caráter essencial". Perceba-se como o interesse local - expressão que, segundo a doutrina majoritária, equivale ao "peculiar interesse" empregado pelas constituições anteriores ${ }^{245}$ - deixa de qualificar a autonomia municipal como um todo, tal como ocorria sob a égide das constituições anteriores, e se torna cláusula que delimita as competências legislativa e administrativa do Município, sem que se forneça qualquer pista sobre o que é efetivamente a especificidade deste interesse que legitima a atuação do Município. Antes, o peculiar interesse era preenchido pela competência para cobrar e arrecadar impostos ou pela própria eletividade do Prefeito e dos Vereadores; atualmente, todavia, o interesse local é um conceito que deve ser preenchido unicamente pela via da interpretação, tanto por parte dos seus aplicadores quanto por parte dos tribunais. ${ }^{246}$ Retornaremos a este tema oportunamente, quando da análise da competência legislativa e administrativa do Município no item 4.6; por ora, parte-se para análise de outros dois aspectos da autonomia municipal relevantes neste esforço de contextualização da federação brasileira.

Em primeiro lugar, chama-se a atenção para a desigualdade entre os Municípios brasileiros no plano fático, o que contrasta, em um primeiro momento, com a ausência de distinções entre os Municípios no que tange à repartição de competências legislativas e de execução. Não há no texto constitucional, por exemplo, previsão no sentido de que apenas os Municípios urbanos ou então com um número determinados de habitantes podem executar serviços de interesse local. Ao contrário, o artigo 30, V, CF/88 prevê tão somente que os Municípios serão competentes para promover a execução dos serviços locais, sem distinção. Afirma-se "em um primeiro momento", porque a indefinição que é ínsita aos incisos I e V do artigo $30 \mathrm{CF} / 88$ pode fundamentar algum tratamento constitucional diferenciado entre os

\footnotetext{
245 Para uma breve exposição dos principais posicionamentos doutrinários acerca do "peculiar interesse" sob a égide das constituições anteriores à 1988 e a sua recepção pela ordem constitucional vigente sob a forma de um "interesse local", vide ALMEIDA. Competências na Constituição de 1988, pp. 113 e ss. Note-se que, segundo esta autora neste mesmo tracho, "muito embora a renúncia a essa tradicional expressão autorize supor que tenha desejado alterar o critério definidor do 'interesse' que delimita as competências municipais, parece-nos válido sustentar, na espécie, que a mudança da letra não equivale a uma mudança no espírito da Constituição". De nossa parte, acreditamos que a mudança operada pela Constituição Federal de 1988 no que diz respeito à função desempenhada pelo interesse local faz com que a aplicabilidade de posicionamentos exarados sob a égide de constituições anteriores reste comprometida. Este nosso posicionamento é retomado com maiores detalhes na nota de rodapé no 608.

${ }^{246}$ Conforme analisamos em ZAGO. O interesse local do Município sob a égide da Constituição Federal de 1988, pp. 179/199.
} 
Municípios. Esta é, contudo, mais uma questão que se relega para o tópico 4.6. Concentremo-nos neste momento no argumento da desigualdade, o qual pode ser colocado em termos esquemáticos a partir de algumas informações extraídas do sítio eletrônico do Instituto Brasileiro de Geografia e Estatística - IBGE:

\begin{tabular}{|l|l|l|l|l|}
\hline \multicolumn{5}{|c|}{ CENSO 2000 } \\
\hline $\begin{array}{l}\text { Unidades da Federação e classes } \\
\text { de tamanho da população dos } \\
\text { municípios (habitantes) }\end{array}$ & $\begin{array}{l}\text { Número de } \\
\text { municípios }\end{array}$ & \multicolumn{3}{|c|}{ População residente } \\
\hline Brasil & 5.561 & 169.799 .170 & 137.953 .959 & 31.845 .211 \\
\hline Até 5.000 & 1.382 & 6.617 .749 & 3.308 .128 & 3.309 .621 \\
\hline De 5.001 até 10.000 & 1.308 & 9.346 .280 & 5.080 .633 & 4.265 .647 \\
\hline De 10.001 até 20.000 & 1.384 & 19.654 .828 & 11.103 .602 & 8.551 .226 \\
\hline De 20.001 até 50.000 & 963 & 28.831 .791 & 19.132 .661 & 9.699 .130 \\
\hline De 50.001 até 100.000 & 299 & 20.786 .695 & 16.898 .508 & 3.888 .187 \\
\hline De 100.001 até 500.000 & 194 & 39.754 .874 & 37.572 .942 & 2.181 .932 \\
\hline Mais de 500.000 & 31 & 46.806 .953 & 45.857 .485 & 949.468 \\
\hline
\end{tabular}

\begin{tabular}{|c|c|c|c|c|}
\hline \multicolumn{5}{|c|}{ CENSO $2010^{248}$} \\
\hline \multirow{3}{*}{$\begin{array}{l}\text { Classes de tamanho da } \\
\text { população dos } \\
\text { municípios (habitantes) }\end{array}$} & \multirow{3}{*}{$\begin{array}{l}\text { Número de } \\
\text { Municípios }\end{array}$} & \multicolumn{3}{|c|}{ População residente } \\
\hline & & \multirow[t]{2}{*}{ Total } & \multicolumn{2}{|c|}{$\begin{array}{l}\text { Situação do domicílio } \\
\text { distribuição percentual }(\%)\end{array}$} \\
\hline & & & Urbana & Rural \\
\hline Brasil & 5.565 & 190.755 .799 & 84,4 & 15,6 \\
\hline Até 5.000 & 1.301 & 4.374 .345 & 56,3 & 43,7 \\
\hline De 5.001 até 10.000 & 1.212 & 8.541 .935 & 60,0 & 40,0 \\
\hline
\end{tabular}

\footnotetext{
${ }^{247}$ Fonte: INSTITUTO BRASILEIRO DE GEOGRAFIA E ESTATÍSTICA - IBGE. Indicadores Sociais Municipais. Tabela 1 - Número de municípios, população residente, por situação do domicílio, taxa de crescimento, razão de dependência, segundo as Unidades da Federação e classes de tamanho da população dos municípios - Brasil 2000. Disponível

em: http://www.ibge.gov.br/home/estatistica/populacao/indicadores_sociais_municipais/tabela1a.shtm. Acesso: 07/01/2015.

248 Fonte: INSTITUTO BRASILEIRO DE GEOGRAFIA E ESTATÍSTICA - IBGE. Indicadores sociais municipais. Tabela 1 - População residente, total e respectiva distribuição percentual, por situação do domicílio e sexo, e razão de sexo, segundo as Grandes Regiões e as classes de tamanho da população dos municípios - 2010. Disponível em:

http://www.ibge.gov.br/home/estatistica/populacao/censo2010/indicadores_sociais_municipais/tabelas_pdf /tab1.pdf. Acesso: 07/01/2015. Os números de municípios foram extraídos da Sinopse do Censo Demográfico 2010. Tabela 1.19 - Número de municípios e população nos Censo Demográficos, segundo as Grandes Regiões $e$ as classes de tamanho da população dos municípios - 1960/2010. Disponível em: http://www.ibge.gov.br/home/estatistica/populacao/censo2010/sinopse/sinopse_tab_brasil_zip.shtm. Acesso: 11/10/2015.
} 


\begin{tabular}{|l|l|l|l|l|}
\hline De 10.001 até 20.000 & 1.401 & 19.743 .967 & 60,9 & 39,2 \\
\hline De 20.001 até 50.000 & 1.043 & 31.344 .671 & 70,3 & 29,7 \\
\hline De 50.001 até 100.000 & 325 & 22.314 .204 & 81,0 & 19,0 \\
\hline De 100.001 até 500.000 & 245 & 48.565 .171 & 94,5 & 5,5 \\
\hline Mais de 500.000 & 38 & 55.871 .506 & 99,1 & 0,9 \\
\hline
\end{tabular}

Como se pode perceber, a maioria dos Municípios brasileiros é de pequeno porte, sendo que neles a população rural praticamente se equipara à população urbana nas localidades com até $\mathbf{1 0 . 0 0 0}$ habitantes. Porém, a grande maioria da população brasileira concentra-se nas cidades de médio e grande porte - com efeito, em 2010, 104.436.677 moravam em cidades com mais de 100.000 habitantes - e é essencialmente urbana. Nas cidades com mais de 500 mil habitantes, por exemplo, apenas $0,9 \%$ da população morava na zona rural em 2010.

Estas considerações, por sua vez, colocam em evidência uma questão interessante em relação à opção do legislador constituinte de 1988 de erigir os Municípios a entes da federação brasileira. Sabe-se que esta decisão suscitou - e suscita até os dias de hoje - uma série de críticas na doutrina brasileira, sob o argumento de que a grande maioria dos Municípios não estaria efetivamente preparada para exercer esta autonomia robusta do ponto de vista formal, mas ainda assim não reivindicada. Este é um julgamento que se aplicaria sobretudo aos Municípios menores, aos quais faltariam, no mais das vezes, capacidades técnica e administrativa mínimas para gerir os serviços públicos e editar as leis de sua competência. Porém, parece irrefutável que, em um país de proporções continentais como o Brasil, dotar certas localidades de condições institucionais para prover suas necessidades públicas, caso elas se organizem para tanto, é algo necessário. Esta assertiva - que se aplica a qualquer Município, independentemente do seu tamanho ou localização - aproveita ainda mais às médias e grandes cidades, onde o número de habitantes geralmente impõe uma prestação de serviços públicos mais complexa. Embora sejam relativamente poucos os Municípios deste porte, o fato é que eles concentram uma porção razoável da população brasileira: segundo dados do Censo de 2010, somente 283 Municipalidades, de um total de 5.565, tinham população de mais de 100 habitantes; porém, nestas cidades moravam 104.436.677 brasileiros, o que equivalia a aproximadamente metade da população brasileira no mesmo período. Portanto, a quantidade de pessoas que são diretamente beneficiadas pela opção de se conferir uma maior autonomia político-administrativa ao Município torna a opção do legislador constituinte de 1988 no mínimo compreensível.

Do outro lado da equação estão os outros 5.282 Municípios, que concentravam 
86.319.122 habitantes em 2010. Entre eles predomina a mais absoluta heterogeneidade. Afinal, trata-se de um grupo que contempla localidades com menos de 2.000 habitantes até municípios com 100.000 habitantes, sendo que parte deles possui população rural em percentuais relevantes ao passo que outros são essencialmente urbanos, isso sem mencionar outras diferenças socioeconômicas relevantes. Por óbvio, a muitos deles efetivamente aplicase a crítica mencionada supra, não há como negar. De todo modo, acredita-se que estas considerações já servem para demonstrar a impossibilidade de acolher críticas ou mesmo posicionamentos generalizantes em relação aos Municípios - como, por exemplo, o de que todos os Municípios não deveriam ser entes da federação brasileira ou, a contrario sensu, o de que todos os Municípios, independentemente do caso concreto, fazem por merecer a autonomia político-administrativa que lhes foi conferida pela Constituição Federal de 1988 - pois a complexidade com que as coisas se apresentam na realidade tende a desconfirmar este tipo de argumento.

O segundo aspecto relevante para a compreensão da autonomia municipal sob a égide da Constituição Federal de 1988 consiste na proliferação de Municípios no final da década de 1980 e ao longo da década de 1990, a qual foi facilitada pela redação permissiva do artigo $18, \S 4^{\circ}, \mathrm{CF} / 88$. Novamente, recorre-se a dados do IBGE para demonstrar as suas reais dimensões deste fenômeno:

\begin{tabular}{|l|l|l|l|l|}
\hline \multicolumn{5}{|c|}{ NÚMERO DE MUNICÍPIOS E POPULAÇÃO NOS CENSOS DEMOGRÁFICOS } \\
\hline
\end{tabular}

\footnotetext{
249 Fonte: INSTITUTO BRASILEIRO DE GEOGRAFIA E ESTATÍSTICA - IBGE. Sinopse do Censo Demográfico 2010. Tabela 1.19 - Número de municípios e população nos Censos Demográficos, segundo as Grandes Regiões e as classes de tamanho da população dos municípios. Disponível em: http://www.ibge.gov.br/home/estatistica/populacao/censo2010/sinopse/sinopse_tab_brasil_zip.shtm. Acesso: 11/10/2015.
} 


\begin{tabular}{|c|c|c|c|c|}
\hline Mais de 500.000 & 18 & 25 & 31 & 38 \\
\hline & \multicolumn{4}{|c|}{ População nos municípios } \\
\hline & Censo 1980 & Censo 1991 & Censo 2000 & Censo 2010 \\
\hline Brasil - total & 121.150 .573 & 146.917 .459 & 169.590 .693 & 190.755 .799 \\
\hline Até 2.000 & 88.183 & 91.431 & 172.231 & 197.429 \\
\hline De 2.000 a 5.000 & 2.228 .112 & 2.451 .222 & 4.316 .217 & 4.176 .916 \\
\hline De 5.001 a 10.000 & 7.069.211 & 7.687.121 & 9.376 .707 & 8.541 .935 \\
\hline De 10.001 a 20.000 & 15.937 .703 & 18.453 .189 & 19.654 .601 & 19.743.967 \\
\hline De 20.001 a 50.000 & 26.728 .931 & 28.005 .202 & 28.700 .747 & 31.344 .671 \\
\hline De 50.001 a 100.000 & 15.937 .465 & 19.379 .111 & 20.911 .053 & 22.314.204 \\
\hline Mais de 100.000 & 53.160 .968 & 70.850 .183 & 86.459 .137 & 104.436 .677 \\
\hline De 100.001 a 500.000 & 23.631 .329 & 32.073 .626 & 39.576 .864 & 48.565 .171 \\
\hline Mais de 500.000 & 29.529 .639 & 38.776 .557 & 46.882 .273 & 55.871 .506 \\
\hline
\end{tabular}

Em suma, 1.574 dos 5.565 dos novos entes foram criados entre 1980 e 2000, sendo que aproximadamente 1000 deles foram criados entre 1991 e 2000. Percebe-se um crescimento mais acentuado entre os Municípios de até 5.000 habitantes, os quais efetivamente dobraram de número e em população no período. Com efeito, as Municipalidades com até 2.000 habitantes saltaram de 58, em 1991, para 105, em 2000, ao passo que os Municípios com população entre 2.000 até 5.000 habitantes cresceram de 682, em 1991, para 1.225, em 2000. Ao todo, eles correspondem a 58\% dos Municípios criados no período. A seguir, há os Municípios entre 5.000 a 10.000 habitantes, que eram 1.055 em 1991 e saltaram para 1.312 em 2000. Embora não se trate de um crescimento tão expressivo, não se pode deixar de ressaltar que estes novos entes, somados aos novos Municípios com população de até 5.000, respondem por 83\% dos casos de criação de Municípios entre 1991 a 2000. Ou seja, o que se teve no período foi a proliferação de pequenas Municipalidades, embora não se possa extrair dos dados supramencionados que elas sejam o resultado do desmembramento de outros pequenos Municípios e também não seja possível afirmar que a redação originária do artigo $18, \S 4^{\circ}, \mathrm{CF} / 88$ tenha privilegiado somente pequenos Municípios, tendo em vista que o número de médias e grandes cidades também aumentou no período considerado.

Aliás, é de se ressaltar que, a despeito do susto que a criação de tantos novos entes municipais em um espaço tão curto de tempo provocou, o Brasil possui um número relativamente pequeno de Municípios em uma perspectiva comparada. Como ressalta Marta ARRETCHE, 


\begin{abstract}
"tornou-se comum afirmar que o Brasil tem um número excessivo de municípios, o que impactaria negativamente o gasto público e a gestão nacional de políticas. O número de municípios no Brasil é em parte função de suas dimensões governamentais. A Suíça, com seus 7 milhões de habitantes, tem 3.000 governos locais, 4,3 para cada 10.000 habitantes. Os EUA, com 270 milhões de habitantes, têm 70.500 governos locais, 2,6 para cada dez mil habitantes. Na comparação internacional das federações, o Brasil está no extremo mais baixo da escala, com 0,3 governos para cada dez mil habitantes (World Bank, 1999)”250
\end{abstract}

De todo modo, parece que a criação de tantos novos entes federativos em tão curto espaço de tempo foi percebida de uma forma negativa no plano político. Em 1996 foi aprovada a $\mathrm{EC} \mathrm{n}^{\circ} 15$, a qual efetivamente veio a colocar um freio neste fenômeno, ao dispor que a criação, incorporação, fusão ou desmembramento de Municípios só poderia acontecer durante o período determinado por lei complementar federal, dentre outros requisitos (artigo $18, \S 4^{\circ}, \mathrm{CF} / 88$, nova redação). Como esta lei nunca chegou a ser aprovada, tem-se que atualmente se encontra vedada a criação de novos entes municipais no Brasil. ${ }^{251}$ Porém, a situação já havia se tornado irreversível: os novos entes federativos criados não poderiam retornar à situação anterior, pois, diante da nova redação do texto constitucional, a incorporação também restou proibida até o advento da referida lei complementar federal.

\title{
2.1.4. A representação dos Estados-membros no Senado Federal e na Câmara dos Deputados
}

Uma das características fundamentais da federação consiste justamente na participação dos Estados-membros na formação da vontade do poder central, o que se dá essencialmente por meio da sua representação em uma das casas que compõem o Poder Legislativo federal, como se teve a oportunidade de analisar nos itens 1.1.3 e 1.6.1 desta

\footnotetext{
250 ARRETCHE. A Centralização no Estado Federativo Brasileiro, p. 62 (nota de rodapé no 6).

251 Entretanto, mesmo depois do advento da EC no 15/1996, alguns municípios foram criados ao arrepio do que dispunha a nova redação do artigo 18, § 4으 CF/88. Um caso paradigmático, porque foi submetido à apreciação do STF, envolveu a criação do Município de Luís Eduardo Magalhães na Bahia (curiosamente, foi o único Município criado na Bahia no período que vai entre 1991 até 2010). Apesar de reconhecer a contrariedade com a Constituição, a corte considerou "a existência de fato do Município, decorrente da decisão política que importou na sua instalação como ente federativo dotado de autonomia" ao declarar a inconstitucionalidade da lei estadual que o criou. Por isso, optou por não pronunciar a nulidade deste diploma pelo prazo de 24 meses, dentro do qual o Congresso Nacional deveria elaborar a lei complementar a que se refere o artigo 18, §4으 CF/88, o que possibilitaria a regularização do Município baiano em questão nos 6 meses seguintes (ADI 2240, Relator Ministro Eros Grau, Tribunal Pleno, julgado em 09/05/2007 - o trecho citado literalmente nesta nota foi extraído da ementa do acórdão). O Congresso Nacional brasileiro optou por uma outra via ao editar a Emenda Constitucional no 57, de 2008, que inseriu o artigo 96 ADCT, com a seguinte redação: "ficam convalidados os atos de criação, fusão, incorporação e desmembramento de Municípios, cuja lei tenha sido publicada até 31 de dezembro de 2006, atendidos os requisitos estabelecidos na legislação do respectivo Estado à época de sua criação". Até o presente momento a Lei Complementar a que se refere o artigo 18, § 4 으 CF/88 não foi aprovada.
} 
tese. Porém, é de se admitir que, no Brasil, o Senado Federal - a instituição que atualmente desempenha este papel, ao menos em tese - é uma instituição bem antiga, precedendo até mesmo à adoção da forma federativa de Estado em 1891. Ao longo de sua história, o Senado flertou com diferentes modelos e encontrou justificação teórica e política em argumentos de matizes diversos, sendo também uma instância criticada por muitos doutrinadores brasileiros. Por este motivo, considera-se indispensável a elaboração de um breve histórico desta instância legislativa, com base nos principais marcos jurídico-constitucionais e também nas ponderações trazidas pela doutrina pertinente.

Foi a Constituição de 1824 que instituiu o Senado pela primeira vez no Brasil. Segundo o seu artigo 14, a Assembleia Geral, à qual o Poder Legislativo era delegado nos termos do artigo 13, era composto de duas Câmaras: (i) a Câmara dos Deputados, e; (ii) a Câmara de Senadores ou Senado. A primeira era composta por membros eleitos para um mandato de prazo temporário (artigo 35), ao passo que a segunda era composta por membros vitalícios e eleitos (artigo 40) por meio de listas tríplices, cabendo ao Imperador nomear um terço dos candidatos destas listas (artigo 43). Finalmente, o artigo 45 arrolava os requisitos para ser Senador, entre eles, a idade mínima de quarenta anos e rendimento anual superior a oitocentos mil réis. Ao comentar a divisão do Poder Legislativo em duas Câmaras, José Antônio PIMENTA BUENO, o Marquês de São Vicente, considerava ser ela "uma das mais importantes e sólidas garantias que a sabedoria de nossa lei fundamental deu ao país e ao seu porvir" ${ }^{252}$. Segundo este autor, cada uma das Casas possuiria características distintas, as quais, combinadas, conduziriam à aprovação de leis realmente úteis ao interesse geral. A Câmara dos Deputados, por um lado, seria "a representação ativa do progresso, dos interesses locais e móveis", possuindo, portanto, um viés mais liberal, ao passo que o Senado deveria, "sem opor-se àquela representação quando suas vistas forem bem fundadas (...) fora disso ser o representante das idéias conservadoras, e do interesse geral, como predominantes" 253 . O Poder Legislativo do Império corresponderia, assim, a um certo compromisso entre liberalismo e conservadorismo, o qual pode ser aplicado, enquanto chave analítica, à Constituição de 1824 como um todo ${ }^{254}$. De todo modo, o que parece importante

\footnotetext{
252 Eduardo KUGELMAS (Org.). José Antônio Pimenta Bueno, Marques de São Vicente. São Paulo: Editora 34, 2002, p. 110.

253 KUGELMAS (Org.). José Antônio Pimenta Bueno, pp. 116-117.

${ }^{254}$ Nesse sentido, observam Paulo BONAVIDES e Paes de ANDRADE que "a Constituição do Império, objeto agora de consideração, não foi na história do País a Constituição-modelo do nosso liberalismo. Com efeito, em matéria de texto só houve liberalismo na plenitude com o advento da República. Teve a Constituição, contudo, um alcance incomparável, pela força de equilíbrio e compromisso que significou entre o elemento liberal, disposto a acelerar a caminhada para o futuro, e o elemento conservador, propenso a referendar o status quo e, se possível, tolher indefinidamente a mudança e o reformismo nas instituições. O primeiro era descendente
} 
ressaltar aqui é que o Senado surgiu no Brasil apartado do ideário federativo, sendo sustentado, do ponto de vista normativo-ideológico, pelas virtudes normalmente atribuídas ao bicameralismo ${ }^{255}$.

Com a promulgação da República e a adoção da forma federativa de Estado, o Senado ressurge sob novo fundamento. Mais precisamente, ele deixa de se relacionar com a representação de ideais conservadores para se tornar a instância representativa dos Estadosmembros da federação brasileira, como se extrai das seguintes ponderações de JOÃO BARBALHO Uchôa Cavalcanti:

\begin{abstract}
"Entretanto, na constituição do poder legislativo federal, menos como garantia de ordem e maturidade das deliberações, do que como condição do federalismo, não cabe mal uma segunda câmara. O regimen federal é um regimen de dualismo, estado composto de Estados. E devendo funccionar pelo systema representativo, preciso é n'elle haver duas representações, a do Estado federal ou da União e a dos Estados particulares, - a câmara dos deputados para aquelle representando o povo de toda a nação - o senado para representar cada uma das partes componentes da União (os Estados), em pé de igualdade e todas como unidades de que ella é somma" 256
\end{abstract}

De acordo com a Constituição Federal de 1891, o Senado era composto por “cidadãos elegíveis nos termos do art. 26 e maiores de 35 anos, em número de três Senadores por Estado e três pelo Distrito Federal, eleitos pelo mesmo modo por que forem os Deputados" (artigo 30). Nos termos do seu artigo 31, o mandato do Senador duraria 09 anos - três vezes mais do que o do Deputado, portanto - renovando-se o Senado pelo terço trienalmente. Ao comentar a questão da paridade de representação entre os Estadosmembros, Ruy BARBOSA ponderava que "tamanha importância tem, neste regimen, a

da Revolução Francesa, o segundo, da Santa Aliança e do absolutismo" (História Constitucional do Brasil, p. 95).

${ }^{255}$ Ao elogiar o sistema bicameral adotado pela Constituição do Império, PIMENTA BUENO asseverava que "se as paixões políticas, o erro, a força de uma idéia, o fanatismo predominante, o interesse do momento ou de partido, a influência de um ministro ou de um favorito da maioria, a eloquência, o entusiasmo, o temor, a violência, ou desejo de popularidade, leva uma Câmara a adotar precipitada ou indevidamente um projeto porventura perigoso, a outra câmara opõe um dique, um veto constitucional que neutraliza a precipitação, ou o perigo; evitam-se, assim, os males que uma oligarquia onipotente, por sua unidade, pudera lançar sobre o país. As minorias adquirem mais meios de expor à sociedade as suas idéias, por isso mesmo que não estão sujeitas ao capricho, ou injustiça, de uma só maioria; a Constituição é mais respeitada porque cada uma das Câmaras é fiscal da outra no sentido desse grande interesse (...)" (KUGELMAS (Org.). José Antônio Pimenta Bueno, pp. 110-111). Percebe-se, neste trecho, uma clara menção a uma das virtudes normalmente atribuídas ao bicameralismo, vale dizer, a contenção ou a correção de paixões momentâneas, eleitas como prioridade por uma maioria ocasional. Diante da proeminência deste constitucionalista na época do Império - não por outro motivo, Eduardo KUGELMAS intitula a introdução à obra supracitada de "Pimenta Bueno, o jurista da Coroa" - é de se admitir que argumentos deste tipo tenham encontrado prestígio entre os políticos e juristas desta época. Note-se, contudo, que este mesmo argumento encontra-se na base da defesa de um Senado em o Federalista. Para maiores detalhes, vide o item 1.6.1 desta tese.

256 JOÃO BARBALHO Uchôa Cavalcanti. Constituição Federal brasileira (1891) [comentada]. Ed. Fac-Similar. Brasília: Senado Federal, 2002, p. 55. 
representação dos Estados no Senado, que nem por meio constituinte admitte o Pacto Federativo alterar-se-lhe a igualdade", equiparando os membros desta instância a embaixadores reunidos em Congresso Diplomático ${ }^{257}$. Em outras palavras, assim como Estados soberanos são representados de forma igualitária perante o direito internacional, os Estados-membros da federação brasileira seriam representados no Senado, considerado pelo referido autor uma "Dieta Federal". Em virtude disso, disporia o senador de uma "inviolabilidade representativa", considerada incompatível com pressões e insatisfações populares em torno de determinada ideia. ${ }^{258}$ Porém, neste ponto, é de se admitir que o modo de escolha dos Senadores colocava este raciocínio em cheque, pois, como ponderava JOÃO BARBALHO, "si deve haver as duas câmaras, é preciso que não sejam em tudo homogêneas, que haja entre ellas diferenças características e a principal destas deve se achar no modo porque são constituídas, estará na eleição" ${ }^{259}$. Não havia, portanto, como tornar os Senadores imune às reivindicações populares, como pretendia Ruy BARBOSA, tendo em vista que eles eram eleitos pelo povo e a ele respondiam politicamente.

A partir da Constituição Federal de 1934, o Senado começou a passar por interessantes transformações, ainda que muitas delas não tenham sequer entrado em vigor. De acordo com o artigo 22 CF/1934, o Poder Legislativo deveria ser exercido "pela Câmara dos Deputados com a colaboração do Senado Federal" - neste ponto, a Constituição parece ter conferido uma posição de primazia do primeiro sobre o último - sendo que ao Senado competia exclusivamente a iniciativa de leis sobre intervenção federal e que interessassem um ou mais Estados, consoante o artigo 41, § $3^{\circ}, \mathrm{CF} / 1934 .{ }^{260}$ Conforme Paulo BONAVIDES e Paes de ANDRADE, o enfraquecimento do Senado Federal sob a égide desta constituição evidenciava o indício de uma tendência unitarizante, contrabalanceada por uma "fixação mais literalmente federativa da função exercida por aquela entidade, nascida aliás para ser a casa dos Estados, a moradia do princípio federativo" ${ }^{261}$. Um dado importante escapa a esta análise: afinal, o artigo $88 \mathrm{CF} / 1934$ conferia ao Senado a função de "promover a

\footnotetext{
257 BARBOSA. Commentarios à Constituição Federal Brasileira. I/ Volume, p. 138.

258 BARBOSA. Commentarios à Constituição Federal Brasileira. I/ Volume, pp. 138-139.

259 JOÃO BARBALHO. Constituição Federal brasileira, p. 92.

${ }^{260}$ Comentando o fato de o Poder Legislativo ter sido conferido à Câmara dos Deputados "em colaboração com o Senado" sob a égide da Constituição Federal de 1934, Raul ARAÚJO CASTRO ponderava que a Constituição Federal de 1934 não teria optado nem pelo unicameralismo, tendo em vista que a aprovação de certas leis dependia da manifestação do Senado, e nem pelo bicameralismo, pois muitas leis eram votadas exclusivamente pela Câmara dos Deputados. A Constituição Federal de 1937, por sua vez, teria consagrado expressamente o bicameralismo ao dispor, no seu artigo 38, § 1으, que o parlamento nacional era composto de duas câmaras: (i) a Câmara dos Deputados, e; (ii) o Conselho Federal (Raul de ARAÚJO CASTRO. A Constituição de 1937. Rio de Janeiro: Freitas Bastos, 1938, pp. 139-140.

261 BONAVIDES, ANDRADE. História Constitucional do Brasil, p. 326.
} 
coordenação dos Poderes federais entre si, manter a continuidade administrativa, velar pela Constituição, colaborar na feitura de leis e praticar os demais atos da sua competência”. Ao examinar este papel de coordenador, Renato PAES DE BARROS refuta a crítica no sentido de que a Constituição não teria conferido ao Senado qualquer instrumento para exercê-lo, enumerando, para tanto, algumas funções por ele consideradas de coordenação, tais como: (i) a iniciativa de leis sobre intervenção federal; (ii) o exame da legalidade dos decretos do Poder Executivo; (iii) a proposição de revogação de atos administrativos ilegais, dentre outros $^{262}$. Deixa-se, contudo, o estudo das repercussões desta nova função conferida ao Senado Federal de lado - mesmo porque a curta e atribulada vigência da Constituição Federal de 1934 evidencia que tenham sido limitadas - a fim de se analisar as transformações sofridas pela instância representativa dos Estados sob a égide da Constituição Federal de 1937, a começar pelo nome: de "Senado Federal", esta instituição passou a se chamar "Conselho Federal".

Segundo o artigo $50 \mathrm{CF} / 1937$, este Conselho Federal era composto por representantes dos Estados - aliás, foi a primeira constituição a dizer isso textualmente - e dez membros nomeados pelo Presidente da República. Os senadores representantes dos Estados, à proporção de um por Estado, eram originalmente escolhidos pelas Assembleias Legislativas estaduais. Contudo, aos Governadores do Estado era facultado vetar os nomes escolhidos pelas Assembleias, sendo que estas últimas só poderiam derrubar o veto pelo voto de dois terços de seus membros (artigo 50, parágrafo único, CF/1937). Note-se, portanto, como esta constituição operou uma alteração substancial na forma de escolha dos membros desta instância legislativa, de modo que estes últimos passaram a responder politicamente às assembleias estaduais e também aos governos estaduais. Contudo, estas são observações que são feitas apenas em tese, tendo em vista que o Parlamento não chegou sequer a funcionar até o término da ditadura de Getúlio Vargas. Como ressalta JOSÉ AFONSO da Silva, a Constituição de 1937

"não fora submetida ao referendo popular (via plebiscito), conforme previa seu
art. 187. Por conseguinte, não se realizaram também as eleições ao Parlamento
Nacional, que seriam marcadas depois da realização do dito plebiscito (art. 78).
Vale dizer: houve Ditadura pura e simples, com os Poderes Executivo e

\footnotetext{
262 Renato PAES DE BARROS. Da conceituação jurídica do Senado na Constituição de 16 de Julho. São Paulo: Revista dos Tribunaes, 1937, pp. 95-96. Em outro trecho desta mesma obra, este autor analisa as discussões travadas na Assembleia Constituinte, comentando que se cogitou em um primeiro momento extinguir o Senado, considerado "orgam bastardo, de acção perturbadora". Porém, no decorrer dos trabalhos optou-se por the conferir feições de "órgão técnico consultivo" e de "aparelho coordenador da acção dos poderes" (Da conceituação jurídica do Senado, pp. 44-45).
} 
Legislativo concentrados nas mãos do presidente da República. Liquidou-se também o Federalismo, pela eliminação da autonomia dos Estados." 263

A Constituição Federal de 1946 marca a volta ao sistema senatorial, em moldes que seriam adotados posteriormente pelas Constituições de 1967, 1967-69 e 1988. Deste modo, o Senado passou a ser instância legislativa composta de representantes dos Estados e do Distrito Federal, eleitos pelo povo segundo o princípio majoritário (artigo 60 CF/1946, artigo 43 CF/1967, artigo 41 CF/1967-69 e artigo 46 CF/88). A representação das unidades federativas, por sua vez, foi garantida em termos igualitários, sendo que cada Estado conta com três vozes (artigo 60, § $1^{\circ}, \mathrm{CF} / 1946$, artigo 43, § $1^{\circ}, \mathrm{CF} / 1967$, artigo 41, § 1º $\mathrm{CF} / 1967$ 69 e artigo 46, § $\left.1^{\circ}, \mathrm{CF} / 88\right)$. Somente durante o período compreendido entre 1977 e 1985 um dos três senadores por Estado passou a ser eleito pelo sufrágio do colégio eleitoral constituído para a eleição do Governador de Estado" (artigo 41, § 2 , CF/1967-69, com redação dada pela $\mathrm{EC} \mathrm{n}^{\circ}$ 8/1977), em uma clara tentativa do regime militar de aumentar a representação do seu partido de sustentação. ${ }^{264}$

No âmbito da doutrina é possível notar uma justificação da existência do Senado a partir da necessidade de haver uma representação dos interesses estaduais no âmbito federal, muito embora seja possível encontrar posicionamentos críticos à estrutura e à função de fato exercida por esta instância legislativa. Nesse sentido, Francisco Cavalcanti PONTES DE MIRANDA, comentando a Constituição de 1946, ponderava a intenção do legislador constituinte em conferir uma representação aos Estados no Senado Federal, de um lado, e a decisão constituinte de dotar a população de uma representação no âmbito da Câmara dos Deputados também por Estado ${ }^{265}$. Afinal, nos termos do artigo 56 CF/1946, a Câmara dos

\footnotetext{
263 JOSÉ AFONSO. O constitucionalismo brasileiro, p. 71.

${ }^{264}$ Esta alteração na forma de eleição dos senadores é uma das várias manobras tomadas pelo regime militar para frear o avanço do MDB nas eleições que seriam realizadas em 1978, e que ficaram conhecidas como "Pacote de Abril". Como ressalta Thomas SKIDMORE, ao invés de usar a força para controlar o resultado das eleições - como havia feito Médici nas eleições de 1970, "Geisel preferiu a solução de uma emenda constitucional através do Al-5, e em 1 de abril de 1977, fechou o Congresso. O pretexto para o fato de força foi um ambicioso projeto de reforma judiciária que o MDB rejeitava, pois, segundo afirmava, a reforma pleiteada pelo governo não fazia sentido sem que antes fossem revogadas leis arbitrárias como o Al-5 e a Lei de Segurança Nacional. Invocando os poderes arbitrários do Al-5, Geisel anunciou uma série de importantes reformas constitucionais (apelidadas de 'pacote de abril'), todas visando direta ou indiretamente tornar a ARENA imbatível nas próximas eleições. Doravante as emendas constitucionais exigiriam maioria simples apenas; todos os governadores de estado e um terço dos senadores seriam escolhidos indiretamente em 1978 por colégios eleitorais estaduais (que incluiriam os vereadores, ficando assegurado o controle da ARENA); os deputados federais teriam o seu número fixado à base da população e não do total de eleitores registrados (como fora nas eleições de 1970 e 1974); e o acesso dos candidatos ao rádio e ou à televisão ficava rigorosamente limitado nos termos da lei Falcão já aprovada pelo Congresso em 1976 (SKIDMORE. Brasil: de Castelo a Tancredo, p. 373).

${ }^{265}$ Francisco Cavalcanti PONTES DE MIRANDA. Comentários à Constituição de 1946. Tomo II (Arts. 60 - 72). 2은 Ed. Rio de Janeiro: Borsoi, 1960, pp. 455-456.
} 
Deputados era composta por "representantes do povo, eleitos, segundo o sistema de representação proporcional, pelos Estados, pelo Distrito Federal e pelos Territórios”. Por este motivo, considerava este autor ser falho o objetivo de "representação das unidades da federação, porque se dá, em relação à Câmara dos Deputados, bis in idem"266. Themístocles Brandão CAVALCANTI, também escrevendo sob a égide da Constituição Federal de 1946, associa o Senado Federal à necessidade de prover a representação dos Estados ${ }^{267}$, mas dirige duras críticas à estrutura bicameralista. Segundo este autor, "a Câmara Alta, o Senado, foi sempre, neste país, um estágio para novos postos políticos e uma aposentadoria honrosa para aqueles que já haviam ocupado elevadas posições. Isto, porém, não compensa as desvantagens do sistema", ponderando ainda que "quanto à representação dos Estados em uma câmara alta, já hoje não constitui elemento essencial do sistema federativo" ${ }^{268}$. Por fim, Manuel Gonçalves FERREIRA FILHO, analisando a Constituição de 1967-69, tecia as seguintes considerações sobre o Senado Federal:

"O bicameralismo brasileiro é, ostensivamente de tipo federativo. A segunda
Câmara, o Senado Federal, se destina a representar os Estados-membros, enquanto
a primeira, a Câmara dos Deputados, representa o povo em geral. Na verdade, a
doutrina considera essencial ao Estado Federal a estrutura bicameral do
Legislativo.
Um exame realista, porém, mostra que o Senado brasileiro, como o de outros
Estados federais, pouco ou nada representa os Estados federados. Não passa de
uma segunda Câmara de representação do povo. Com efeito, os senadores são
eleitos por intermédio de partidos. Estão vinculados a estes, inclusive no Brasil,
pela obrigação de fidelidade partidária (...), e de nenhuma forma à representação
dos interesses dos Estados enquanto Estados. Para que verdadeiramente
representassem os Estados, deveriam ser designados por aqueles que devem zelar
pelos interesses destes, isto é, pelos Governos estaduais (...)
Em verdade, no Brasil, o Senado assume, pronunciadamente, o caráter de Câmara
de moderação. É uma assembleia de mais velhos, de chefes de largo prestígio e
experiência, que põem a prudência acima de tudo, usando-a como freio aos
impulsos da Câmara dos Deputados"269

Tratam-se de críticas que são repetidas, em maior ou menor medida, por doutrinadores que escrevem sobre a Constituição Federal de 1988, como, por exemplo, Paulo Gustavo Gonet BRANCO, JOSÉ AFONSO da Silva e Fernando Dias MENEZES DE

\footnotetext{
266 PONTES DE MIRANDA. Comentários à Constituição de 1946, p. 456. Crítica que o mesmo autor repete em Francisco Cavalcanti PONTES DE MIRANDA. Comentários à constituição de 1967. Tomo III (Arts. 34-112). São Paulo: Revista dos Tribunais, 1967, p. 75.

267 Themistocles Brandão CAVALCANTI. A Constituição Federal Comentada. Volume II. 2a Ed. Rio de Janeiro: José Konfino, 1952, p. 107.

${ }^{268}$ CAVALCANTI. A Constituição Federal Comentada. Volume II, pp. 12 e 14.

${ }^{269}$ Manoel Gonçalves FERREIRA FILHO. Comentários à Constituição brasileira: Emenda Constitucional no 1, de 17 de outubro de 1969. 1o Volume: Artigos 1o a 45. 2a Ed. São Paulo: Saraiva, 1977, p. 216.
} 
ALMEIDA $^{270}$. Em razão disso, alguns defendem a sua extinção, ao passo que outros defendem a sua transformação em um Conselho Federativo, como faz Dinorá Adelaide Musetti GROTTI ${ }^{271}$. Considera-se oportuno, de todo modo, analisar algumas censuras comumente dirigidas ao Senado Federal, verificando a sua pertinência diante de algumas considerações trazidas pela ciência política.

Comecemos sobre a crítica elaborada por PONTES DE MIRANDA. Não há como negar que a Câmara dos Deputados, a despeito de ser a câmara representativa do povo, tem a sua composição influenciada pela necessidade de se promover uma certa igualação entre os Estados. O próprio artigo $45 \mathrm{CF} / 88$, ao tratar da escolha dos seus membros, dispõe que esta se dará "pelo sistema proporcional, em cada Estado". Isso é feito, por sua vez, por meio do estabelecimento de um número mínimo e um número máximo de Deputados por Estado, nos termos do $\S 1^{\circ}$ deste mesmo dispositivo constitucional. São Paulo, que é o Estado mais populoso da federação, conta com 70 representantes populares, ao passo que Estados menos populosos, como Acre, Roraima e Rondônia, contam com 8 representantes cada um ${ }^{272}$. Ocorre que esta limitação gera uma situação no mínimo curiosa, pois a proporção entre o número de representantes do Estado mais populoso e do Estado menos populoso é de 8,75, ao passo que a proporção entre os eleitores de São Paulo e Roraima, por exemplo, é de $89,29^{273}$. Colocada a mesma questão de outro modo, na prática o voto do cidadão de São Paulo conta muito menos - mais precisamente, 10 vezes menos - na hora de eleger um representante seu na Câmara dos Deputados do que o de um cidadão de Roraima. Diante deste cenário, há quem considere que o brocardo one man, one vote consiste em um verdadeiro pilar das modernas democracias, não podendo ser afastado ou mitigado sem prejuízo a esta forma de exercício de poder. Por isso, o número de Deputados por Estado-

\footnotetext{
270 MENDES, COELHO, BRANCO. Curso de Direito Constitucional, p. 933, JOSÉ AFONSO. Curso de Direito Constitucional Positivo, p. 511 e Fernando Dias MENEZES DE ALMEIDA. Comentários aos artigos 44 a 46. In: J. J. Gomes CANOTILHO; Gilmar Ferreira MENDES; Ingo Wolfgang SARLET; Lenio Luiz STRECK; Léo Ferreira LEONCY (Coord). Comentários à Constituição de Brasil. São Paulo: Saraiva, 2013, p. 998.

${ }^{271}$ Segundo a referida autora, "a Câmara dos Deputados tornou-se um representante do povo e dos Estados, tal é a força que os Estados menores têm, e o Senado Federal tornou-se um órgão excrescente, sem função própria e antidemocrático. Assim, não faria mal nenhum para o processo legislativo brasileiro se o Senado não ficasse como uma segunda Casa de revisão dos projetos de leis provindos da Câmara dos Deputados, mas fosse substituído por um Conselho Federativo, que cuidaria apenas de matéria legislativa da Federação Brasileira (Dinorá Adelaide Musetti GROTTI. A federação brasileira como força de descentralização do poder. Cadernos de Direito Constitucional e Política, ano 5, no 18, jan/mar. 1997, p. 133). A forma de eleição dos membros deste Conselho Federativo e a duração do seu mandato, dentre outras questões, não são abordadas por esta autora 272 O número atualizado de Deputados por Estado-membro pode ser consultado em http://www2.camara.leg.br/a-camara/conheca/quantos-sao-e-de-que-forma-e-definido-o-numero-dedeputados. Acesso: 21/01/2015.

273 A proporção foi calculada a partir dos votos válidos, obtidos em http://www.tse.jus.br/eleicoes/estatisticas/estatisticas-eleitorais-2014-resultado. Acesso: 21/01/2015.
} 
membro brasileiro deveria ser adaptado de modo que o voto de todos os cidadãos brasileiros tenha o mesmo valor na hora de estes últimos elegerem seus representantes no Poder Legislativo. Por outro lado, é possível arrazoar que a democracia também pressupõe a participação, ainda que por representação, de todos os cidadãos, o que, em uma federação tão desigual inclusive no que tange à distribuição da população pelos Estados-membros, somente é possível por meio de mecanismos tais como os manejados pela constituição. De um modo ou de outro, o que parece ser importante ressaltar aqui é que, ainda que se considere que o objetivo de tal medida tenha sido igualar materialmente a representação da população de um país de proporções continentes como o Brasil, ela acaba por promover uma igualação dos Estados-membros brasileiros na Câmara dos Deputados. ${ }^{274}$

Parte-se então para a crítica desenvolvida por Manoel Gonçalves FERREIRA FILHO no trecho supracitado. Com efeito, Ronald L. WATTS constata em uma perspectiva comparada que, onde os senadores são eleitos pelo voto direto, eles tendem a votar de acordo com os seus respectivos partidos, ao passo que, em países onde eles são eleitos pelas assembleias estaduais, eles tendem a se ver como representantes dos interesses regionais ${ }^{275}$. Os senadores brasileiros inserem-se na primeira das tendências apontadas por este autor canadense, de forma que acabam por se orientar de forma partidária, distanciando-se de questões federativas. E aqui cumpre fazer um adendo importante: não se trata de qualquer orientação partidária, mas sim de uma orientação partidária definida nacionalmente. Afinal, os senadores poderiam se alinhar a orientações partidárias locais ou estaduais, mas não parece ser este o caso. Como observa Marta ARRETCHE, em emendas constitucionais que afetam interesses estaduais, os senadores de um mesmo Estado votaram reiteradamente de forma separada. Não se pode falar, por isso, em coesão das bancadas estaduais no Senado. Porém, em relação a estas mesmas votações observa a autora "a disciplina partidária no

\footnotetext{
274 Note-se que há argumentos a favor e contra a fixação de patamares mínimos e máximos de representantes por Estado pelo artigo 45, § 1ํ, CF/88, a partir de considerações de índole federativa. Nesse sentido, há quem argumente que a fixação destes patamares pelo legislador constituinte teria sido salutar, tendo em vista que evitaria que os Estados mais populosos - em especial São Paulo, que possui o maior colégio eleitoral obtivessem o controle da agenda da Câmara dos Deputados, aprovando ou vetando medidas conforme os seus interesses. Por outro lado, costuma-se argumentar também que os Estados menos populosos, sobrerepresentados, contariam com uma vantagem indevida e artificial na discussão de seus interesses na Câmara dos Deputados, sendo-Ihes lícito não só aprovar projetos em detrimento de outros componentes da federação como rejeitar outras medidas contrárias ao seu interesse. Perceba-se, contudo, como estes são posicionamentos que só fazem sentido quando se parte do pressuposto de que os parlamentares desta Casa Legislativa votem conforme os interesses de seus respectivos Estados, vale dizer, de que eles se comportem e se agrupem em bancadas estaduais. Isto, porém, não é o que se verifica na prática, como já demonstrou Marta ARRETCHE em Continuidades e Descontinuidades da Federação Brasileira: De como 1988 Facilitou 1995? DADOS - Revista de Ciências Sociais, Rio de Janeiro, vol. 52, no 2, 2009, pp. 377-423.

275 WATTS. Comparing Federal Systems, p. 151.
} 
Senado é sistematicamente elevada para todos os sete maiores partidos nacionais" 276 . Cenário parecido se repete na Câmara dos Deputados, a qual, apesar de composta por representados eleitos por Estados, também aprova sistematicamente leis e emendas que influenciam negativamente os interesses estaduais ${ }^{277}$. Ou seja, os interesses estaduais não parecem, com efeito, ser devidamente representados no âmbito federal. Diante da centralização normativa vivenciada pela federação brasileira - e que será discutida com maior profundidade no tópico 3.2.2 e no quarto capítulo da tese - este dado se torna especialmente preocupante.

Diante disto, ganha força o argumento de que o Senado brasileiro teria assumido o papel de uma segunda câmara de representação do povo. Mas não se trata exatamente de uma câmara simétrica à Câmara dos Deputados na sua composição, pois os seus membros costumam contar com razoável experiência política. Nesse sentido, é possível encontrar dentre os senadores brasileiros ex-governadores e até mesmo ex-presidentes da República. Não se vai ao extremo de afirmar, como fazia Themistocles Brandão CAVALCANTI, que o Senado seria uma "aposentadoria honrosa para aqueles que já haviam ocupado elevadas posições", embora se admita que pode se tratar, como qualquer cargo político, de "um estágio para novos postos políticos". Pode-se cogitar de todo modo, como faz Manoel Gonçalves FERREIRA FILHO em sua crítica, que o fato de os seus membros serem mais velhos, mais experientes, acabaria por conferir ao Senado o viés de uma câmara de moderação, freando os impulsos da Câmara dos Deputados. Esta é, contudo, uma característica - ou mesmo uma vantagem, como pretende alguns - que costuma ser associada com o bicameralismo e não propriamente com a representação de entes estaduais no âmbito federal $^{278}$.

Finalmente, nenhuma das críticas discutidas neste tópico tangencia a opção do legislador constituinte brasileiro de submeter todos os Estados-membros a uma igualdade formal ao prever que cada Estado conta com apenas com três representantes eleitos (artigo $46, \S 1^{\circ} \mathrm{CF} / 88$ ). Neste ponto, parece haver um apego tão forte a um modelo ideal de Senado

\footnotetext{
276 Marta ARRETCHE. Democracia, federalismo e centralização no Brasil. Rio de Janeiro: FGV e Fiocruz, 2012, pp. 137-138.

${ }^{277}$ Conforme demonstrado por ARRETCHE. Continuidades e Descontinuidades da Federação Brasileira, pp. 392 e ss.

278 No que tange à discussão e aprovação de projetos de lei, é possível enxergar uma simetria entre Senado Federal e Câmara dos Deputados. Todos os projetos aprovados em uma casa legislativa devem seguir para a outra casa, sendo que só entrará em vigor após a aprovação em ambas as casas. Não há, portanto, uma distinção entre projetos que são submetidos e que não são submetidos a sua apreciação, tal como ocorre na Alemanha, de forma que nos projetos que não guardam relação com os interesses dos Estados-membros, o Senado Federal brasileiro exerce a função de uma segunda casa legislativa, ao lado da Câmara dos Deputados.
} 
que impede que se leve em consideração um fato essencial à federação brasileira, qual seja, a discrepância de território e de população existente entre os Estados brasileiros. Note-se que esta discrepância é tão grande no Brasil que leva Ronald L. WATTS a considerar o Brasil como um exemplo extremo de como segundas câmaras restringem a democracia, tendo em vista que senadores representando apenas $43 \%$ da população brasileira controlam mais de $74 \%$ dos votos do Senado. Em razão disso, avalia o referido autor que "a representação desproporcional das unidades constituintes menores talvez tenha sido levada muito longe"279. Não seria nocivo, portanto, que o número de senadores por Estado contemplasse uma variação, a fim de contemplar os Estados mais populosos da federação, tal como ocorre com o Bundesrat alemão, o qual será objeto de considerações mais detidas ainda neste capítulo.

\subsection{A federação AlemÃ sob A ÉGIDE dA LeI Fundamental de 1949}

\subsubsection{Breve histórico da federação na Alemanha}

A parte do segundo capítulo dedicada à análise da federação alemã sob o influxo da Lei Fundamental de 1949 também começa com um breve histórico. Este, porém, abrange um espectro temporal maior e assume um viés de descrição das instituições federativas do ponto de vista constitucional. Justifica-se esta opção diante do fato de que aspectos históricos desta federação não são tão difundidos na literatura jurídica brasileira, em virtude da dificuldade de acesso às obras pertinentes.

De todo modo, discorrer sobre a história da Alemanha pode se transformar em uma tarefa hercúlea caso não haja qualquer delimitação temporal. Por isso, adotou-se como marco inicial da análise a Constituição alemã de 1871, uma vez que este costuma ser o ponto de partida de alguns textos que tratam da repartição de competências na Lei Fundamental de 1949 ao abordarem seus antecedentes históricos. ${ }^{280}$ Deixa-se de abordar, portanto,

\footnotetext{
279 WATTS. Comparing Federal Systems, p. 155.

280 Vide RENGELING. $\$ 135$ - Gesetzgebungszuständigkeit. In: ISENSEE, KIRCHHOF (Hrsg.). Handbuch des Staatsrechts. Band VI, pp. 586-588 e Winfried KLUTH. Die deutsche Föderalismusreform 2006: BeweggründeZielsetzungen - Veränderungen. In: Winfried KLUTH (Hrsg). Föderalismusreformgesetz - Einführung und Kommentierung. Baden-Baden: Nomos, 2007, pp. 45-47 e, de um modo geral, todos os comentários à Lei Fundamental citados no quinto capítulo desta tese. Nesse mesmo sentido, ponderam Werner FROTSCHER e Bodo PIEROTH que "para uma formulação mais próxima do federalismo (princípio federativo) um 'olhar para atrás' sobre as relações constitucionais da Confederação Germânica (Deutscher Bund) e do Império alemão de 1871 é tão importante quanto a análise do direito comparado. A regulamentação das competências legislativa da União e dos Estados na Lei Fundamental (vide artigo 30 e 70 e ss GG) relaciona-se aproximadamente com o catálogo de competências da Constituição do Império de 1871" (FROTSCHER, PIEROTH. Verfassungsgeschichte, p. 2).
} 
experiências federativas anteriores à unificação alemã - tais como o Rheinbund, o Deutscher Bund e o Norddeutscher Bund - remetendo-se a leitura, também neste ponto da tese, à literatura pertinente. ${ }^{281}$

\subsubsection{A Constituição do Império de 1871}

A Constituição alemã de 1871 é melhor compreendida, em linhas gerais, à luz dos acontecimentos que culminaram com a unificação deste país, em 1870.

Desde 1866 a Prússia havia logrado reunir 22 Estados alemães em uma organização de índole federativa, conhecida como Confederação da Alemanha do Norte (Norddeutscher Bund), e regida por uma constituição, a qual previa, em linhas gerais: (i) a existência de um Conselho Federal (o Bundesrat), composto por representantes dos governos estaduais; (ii) a existência de uma câmara de representação da população (o Reichstag), e; (iii) uma Presidência (o Präsidium), ocupada pelo Rei da Prússia. ${ }^{282}$

Pouco tempo depois surgiu um desentendimento entre a França e a Prússia acerca da sucessão da coroa espanhola. De um lado, a Prússia entendia que o posto deveria ser ocupado pelo príncipe prussiano Leopold von Hohenzollern-Sigmarinen; por outro lado, os franceses viam com muita desconfiança o fato de que a fronteira sudoeste do seu território fosse governada por um governante prussiano. Este impasse finalmente levou à Guerra FrancoPrussiana de 1870, da qual participaram também os Estados alemães do Sul, compelidos a lutar do lado da Prússia em virtude de compromissos anteriormente assumidos. ${ }^{283}$

\footnotetext{
${ }^{281}$ A maioria dos livros de história constitucional ou história do direito alemães citados neste tópico contemplam, ainda que brevemente, o período anterior à Constituição Imperial de 1871. Para uma análise mais detalhada deste período, vide Klaus STERN. Das Staatsrecht der Bundesrepublik Deutschland. Band V: Die geschichtlichen Grundlagen des deutschen Staatsrechts. Munique: C. H. Beck'sche Verlagsbuchhandlung, 2000.

${ }^{282}$ Reinhold ZIPPELIUS. Kleine deutsche Verfassungsgeschichte: vom frühen Mittelalter bis zur Gegenwart. 7a Ed. Munique: C. H. Beck, 2006, p. 120. Interessante ressaltar que este autor atribui ao Norddeutscher Bund a natureza jurídica de Estado Federal (Bundesstaat) e não de uma confederação. A presente tese não pretende adentrar nesta problemática, pois não a considera de grande relevância para a compreensão do argumento a ser desenvolvido neste item. Opta-se, por isso, pela terminologia pela qual esta forma de associação estatal é conhecida em português, vale dizer, Confederação da Alemanha do Norte.

${ }^{283}$ FROTSCHER, PIEROTH. Verfassungsgeschichte, p. 199. Como ressalta Klaus STERN, „, declaração de guerra à Prússia significava de acordo com a constituição da Confederação da Alemanha do Norte automaticamente uma guerra contra ela e o casus foederis para os Estados alemães do sul em virtude das alianças de proteção. A guerra foi consequentemente de acordo com o direito internacional uma guerra franco-alemã e foi entendida pelo povo [alemão] como uma guerra nacional" (Das Staatsrecht der Bundesrepublik Deutschland. Band V, p. 322). Ressalta o referido autor neste mesmo trecho que Otto von Bismarck manejou e utilizou esta guerra para o seu objetivo de unificar alemã, muito embora não seja possível afirmar que ele desejou promoveu uma "Kriegspolitik", ou uma política de guerra. Segundo STERN, Bismarck apenas teria aceitado a perspectiva da guerra.
} 
Com a capitulação da França, o sentimento nacionalista alemão encontrava-se fortalecido e o caminho para a unificação alemã e para a hegemonia da Prússia sobre todos os territórios alemães encontrava-se finalmente aberto. Pouco tempo depois, os quatro Estados alemães do Sul - quais sejam, Baviera, Baden, Württemberg e Hessen-Darmstadt assinaram tratados com a Confederação da Alemanha do Norte, por meio dos quais aqueles aderiram a esta organização, inclusive submetendo-se a sua constituição. Finalmente, consentiram os envolvidos em se transformar em um Império Alemão, a ser comandado pelo Rei da Prússia, o qual passaria a se chamar Imperador (Kaiser). ${ }^{284}$

A Constituição do Império de 1871 surge ao cabo deste processo e não poderia deixar de refletir a hegemonia da Prússia. ${ }^{285}$ Segundo o seu artigo 11, o monarca prussiano era também o Imperador Alemão, sendo que a ele competia declarar a guerra e a paz, celebrar tratados com outros Estados e enviar e receber representantes diplomáticos, dentre outras atribuições. Além do mais, a Prússia detinha um número desproporcional de representantes no Conselho Federal em comparação com os outros Estados: ao total, ela possuía 17 votos, seguido da Baviera, com 6 votos; a grande maioria dos Estados detinha, todavia, apenas 1 voto. ${ }^{286}$ Este cenário, que já revela uma desproporção na participação dos Estados na sua representação no nível federal, tornava-se ainda mais significativa tal disparidade entre seus membros diante da disposição contida no artigo 78, segundo o qual uma proposta de alteração da Constituição considerava-se rejeitada quando recebesse 14

\footnotetext{
284 FROTSCHER, PIEROTH. Verfassungsgeschichte, pp. 199-200. Ressalta Ulrich EISENHARDT que a própria "constituição da Confederação da Alemanha do Norte era configurada de tal modo que não era necessário um novo processo constituinte para que a Confederação da Alemanha do Norte fosse ampliada para um Império Alemão. Era suficiente um ato simples do Poder Legislativo" (Ulrich EINSENHARDT. Deutsche Rechtsgeschichte. 3a Ed. Munique: Beck'sche Verlagsbuchhandlung, 1999, p. 391), que foi o que efetivamente aconteceu por meio da assinatura dos chamados tratados de novembro com os Estados do Sul e por meio de uma deliberação do Parlamento Imperial da Confederação da Alemanha do Norte em dezembro de 1870. Relatam Werner FROTSCHER e Bodo PIEROTH que a Constituição de 1871 consistiu em um esforço de sistematização da Constituição do Império - que era composta pela Constituição da Confederação da Alemanha do Norte e os tratados e protocolos assinados por ocasião da unificação alemã - em um único documento (Verfassungsgeschichte, p. 205). Nesse mesmo sentido, ZIPPELIUS. Kleine Deutsche Verfassungsgeschichte, p. 120-121.

${ }^{285}$ A versão da Constituição Imperial de 1871 que foi utilizada na elaboração deste tópico pode ser consultada em Günter DÜRIG; Walter RUDOLF (Org). Texte zur deutschen Verfassungsgeschichte vornehmlich für den Studiengebrauch. 3a Ed. Munique: C. H. Besk'sche Verlagsbuchhandlung, 1996, pp. 153-175.

${ }^{286}$ Nos termos do artigo 6ㅇ da Constituição de 1871, a distribuição de cadeiras por Estado no Conselho Federal (Bundesrat) era feita do seguinte modo: Hannover, Kurhessen, Holstein, Nassau e Frankfurt - 17; Bayern - 6; Sachsen - 4; Württemberg - 4; Baden - 3; Hessen - 3; Mecklenburg-Schwerin - 2; Sachsen-Weimar - 1; Mecklenburg-Strelitz - 1; Oldenburg - 1; Braunschweig - 2; Sachsen-Meinigen -1; Sachsen-Alterburg - 1; Sachsen-Koburg-Gotha - 1; Anhalt - 1; Schwarburg-Rudolstadt - 1; Schwarzburg-Sonderhausen - 1; Waldeck -1; Reuß älterer Linie - 1; Reuß jüngerer Linie - 1; Schaumburg-Lippe - 1; Lippe - 1; Lübeck - 1; Bremen - 1; Hamburg -1 .
} 
votos desfavoráveis no Conselho Federal. Portanto, a Prússia podia, isoladamente, vetar qualquer proposta de emenda à Constituição contrária aos seus interesses. ${ }^{287}$

Traçava-se, portanto, um cenário de sensível desigualdade jurídica entre os Estados-membros, o qual se completava pela existência de direitos especiais (Sonderrechte) e direitos de exceção (Ausnahmerechte), geralmente conferidos aos

Estados maiores, os quais efetivamente pactuaram o seu ingresso nesta federação inaugurada a partir de 1871. Direitos especiais eram, como explica Heiko HOLSTE, direitos que colocavam alguns Estados em uma posição privilegiada na organização federal, ao passo que direitos de exceção representavam exceções a uma competência do Império em favor de um ou mais Estados-membros. Era o caso, por exemplo, da Baviera, que detinha presidência da comissão do Conselho Federal para assuntos exteriores, como um direito especial, e a competência para legislar, nos termos do artigo 35, sobre aguardente e cerveja ao lado de Baden e de Württemberg, como um direito de exceção. ${ }^{288}$

No plano fático, os Estados também eram marcados pela mais profunda disparidade, bem resumida no seguinte trecho da obra de Heiko HOLSTE:

\begin{abstract}
"O Império era composto por 25 Estados-membros ao todo. Destes eram quatro reinados (Prússia, Baviera, Saxônia e Württemberg), seis grão-ducados (Baden, Hessen, Mecklenburg-Schwerin, Mecklenburg-Strelitz, Oldenburg e SaxôniaWeimar), 5 ducados (Braunschweig, Saxônia-Meinigen, Saxônia-Altenburg, Saxônia-Coburg-Gotha e Anhalt), sete principados (Schwarzburg-Rudolstadt, Schwarzburg-Sondershausen, Waldeck, Reuß-Greiz, Reuß-Gera, SchaumburgLippe e Lippe) bem como as três cidades livres Lübeck, Bremen e Hamburgo. Uma posição especial de terra imperial possuía a Alsácia-Lorena, anexado em 1870 e anteriormente território francês.

Nem todos os Estados-membros possuíam um território fechado (...). Também as relações de grandeza entre os Estados-membros eram extremamente díspares. A Prússia compreendia quase dois terços do território do Império e contava ao tempo da fundação do Império com 24 milhões de pessoas, cerca de 60 por cento de todos os habitantes. Somente os Estados do sul da Alemanha Baviera, Baden e Württemberg, além da Saxônia, possuíam dimensão e população dignos de menção, que ultrapassavam a fronteira dos milhões. O principado Reuß- Greiz correspondia ao uma porção de cerca de 0,05 $\%$ do território do Império, Schaumburg-Lippe contabilizava ao todo 32.000 habitantes. A Prússia era 750 vezes maior do que estes Estados-membros
\end{abstract}

\footnotetext{
287 Por conta de normas deste tipo, Kenneth WHEARE pondera que a Constituição alemã de 1871 não teria instituído uma federação nos termos por ele propugnados, tendo em vista não haver uma independência do poder central em relação aos governos subnacionais, em especial da Prússia (Federal Government, p. 7). Contudo, a maioria da doutrina consultada adota entendimento diverso e tende a considerar o período em que vigeu a Constituição de 1871 como a primeira experiência federativa, na acepção mais moderna do termo, da Alemanha.

288 Heiko HOLSTE. Der deutsche Bundesstaat im Wandel (1867-1933). Berlin: Dunckler \& Humblot, 2002, p. 149-150. Note-se que a autora fornece outros exemplos de direitos especiais e de exceção neste trecho da sua obra, a cuja leitura se remete.
} 
menos populosos. Estas diferencas também tinham consequências na divisão do poder político (...) bem como no desempenho econômico" 289

No que tange a repartição de competências legislativas e administrativas, o artigo $2^{\circ}$ da Constituição de 1871 previa que "dentro do território federal o Império exerce o seu direito ao processo legislativo de acordo com as estipulações do conteúdo desta Constituição e com o efeito de que as leis imperiais preferem às leis estaduais", consagrando a técnica das competências enumeradas ao Império e, implicitamente, de competências residuais aos Estados-membros. ${ }^{290}$

O artigo $4^{\circ}$, por sua vez, previa um rol de matérias em relação as quais o poder central poderia exercer a competência legislativa e a supervisão (Beaufsichtigung), esta última de índole eminentemente administrativa. Neste figuravam alguns temas fundamentais ao projeto de unificação alemã, como é o caso da alfândega, do sistema monetário e da emissão de moeda, do sistema de pesos e medidas, isso sem mencionar o direito comercial e o direito civil. Também se afigurava importante que o Império pudesse implementar os serviços de correios e telégrafos e também ferrovias, o que foi viabilizado por meio da sua previsão nas alíneas de $n^{\circ} 8$ e 10 . Outras matérias diziam respeito à própria organização do governo federal, sendo compreensível a previsão de uma competência legislativa federal. Era o caso, por exemplo, da competência para legislar sobre o Exército e a Marinha (alínea de $\left.n^{\circ} 14\right) .{ }^{291}$ Note-se que o artigo $4^{\circ}$ continha o cerne da competência legislativa do Reich, mas era possível encontrar outras previsões em artigos espalhados no texto da Constituição de 1871 (como é o caso do artigo 35).

\footnotetext{
289 HOLSTE. Der Deutsche Bundesstaat im Wandel, pp. 129-130 (grifo nosso). No original: „Das Reich bestand aus insgesamt 25 Gliedstaaten. Dies waren vier Königreiche (Preußen, Bayern, Sachsen und Württemberg), sechs Großherzogtümer (Baden, Hessen, Mecklenburg-Schwerin, Mecklenburg-Strelitz, Odenburg und SachsenWeimar), fünf Herzogtümer (Braunschweig, Sachsen-Meinigen, Sachsen-Altenburg, Sachsen-Coburg-Gotha und Anhalt), sieben Fürstentümer (Schwarzburg-Rudolstadt, Schwarzburg-Sonderhausen, Waldeck, Reuß ältere Linie, Reuß jüngere Linie, Schaumburg-Lippe und Lippe) sowie die die Freien Städte Lübeck, Bremen und Hamburg. Eine Sonderstellung als, Reichsland' besaß das 1870 annektierte, vormals französische Gebiet ElsaßLothringen. Nicht alle Gliedstaaten besaßen ein geschlossenes Territorium (...) Auch die Größenverhältnisse zwischen den Gliedstaaten waren höchst verschieden. Preußen umfasste nahezu zwei Drittel der Fläche des Reiches und stellte zur Zeit der Reichsgründung mit 24 Millionen Menschen ca. 60 Prozent aller Einwohner. Nennenswert Ausmaße und eine Bevölkerungszahl, die die Millionengrenze überschritt, hatten nur noch die süddeutschen Staaten Bayern, Württemberg und Baden sowie Sachsen. Das Fürstentum Reuß ältere Linie brachte es auf einen Anteil von rund 0,05 Prozent des Reichsterritoriums, Schaumburg-Lippe zählte ganze 32.000 Einwohner. Preußen war 750 mal größer als dieser bevölkerungsschwächste Gliedstaat. Diese Unterschiede hatten auch Folgen für die Verteilung der politischen Macht - dies hat sich im Vorherigen schon deutlich gezeigt - sowie für die wirtschaftliche Leistungsfähigkeit."

290 Dispunha a primeira parte do artigo 2o da Constituição de 1871, no original: "Innerhalb dieses Bundessgebiet übt das Reich das Recht der Gesetzgebung nach Maßgabe des Inhalts dieser Verfassung und mit der Wirkung aus, daß die Reichsgesetze den Landesgesetzen vorgehen."

291 HOLSTE. Der deutsche Bundesstaat im Wandel, p. 165.
} 
Da análise destes dois dispositivos extraem-se três considerações interessantes. Em primeiro lugar, o fato de o artigo $2^{\circ}$ dispor que as competências do Reich seriam enumeradas não significava que estas competências seriam necessariamente privativas. Ao contrário, como ressalta Heiko HOLSTE, o Império contava com algumas competências privativas, mas a grande maioria das suas competências eram do tipo concorrente cumulativa (naquela época denominadas de competências facultativas do Reich), franqueando-se a possibilidade aos Estados de legislar inclusive sobre as matérias previstas no artigo $4^{\mathbf{0}}$, enquanto não editada lei federal sobre o mesmo assunto. Prevalecia o entendimento, afinal, de que se a própria constituição conferia ao poder central de forma expressa a competência privativa para legislar sobre uma determinada matéria - era o caso do artigo 35 , que tratava da competência privativa do Império para legislar sobre aduana - nos demais casos, em que não havia esta previsão explícita, não poderia se supor que a competência federal também fosse privativa. Além do mais, o artigo $2^{\circ}$ tratava de uma prevalência do direito federal sobre o direito estadual, o que só fazia sentido se as competências em questão fossem concorrentes e não privativas. ${ }^{292}$

Em segundo lugar, as competências enumeradas e expressas ao Reich não consubstanciavam um óbice ao reconhecimento de competências não expressas (ou não escritas - ungeschriebene Kompetenzen). Estas últimas, por sua vez, poderiam resultar tanto de um raciocínio próximo ao da doutrina norte-americana dos poderes implícitos, quanto de uma interpretação demasiadamente extensiva das competências legislativas expressas do Império. Tanto em um caso quanto no outro o Reich acababa por englobar matérias cuja normatização, em um primeiro momento, não poderia ser feita em nível federal. ${ }^{293}$

Em terceiro lugar, a Constituição de 1871 já concebia uma diferenciação no que diz respeito à repartição de competências legislativas e à repartição de competências administrativas, de forma que poucos assuntos eram objeto de normatização e de execução pelo mesmo nível de governo. Afinal, ao Império não competia a execução das leis de sua competência, mas somente a supervisão desta execução, nos termos do artigo $4^{\circ}$. E como o texto da Constituição não continha uma regra geral no tocante à distribuição das competências administrativas, prevalecia o disposto no artigo $2^{\circ}$, vale dizer: a execução das

\footnotetext{
292 HOLSTE. Der deutsche Bundesstaat im Wandel, pp. 163-165. A partir de considerações desta mesma autora, chega-se à conclusão que esta competência concorrente da Constituição de 1871 é bem parecida com a competência concorrente prevista no artigo $24 \mathrm{CF} / 88$, uma vez que era lícito ao Império não regular inteiramente uma determinada matéria, deixando uma margem para a atividade legislativa dos Estadosmembros. Era possível ao Império inclusive "restringir-se ao estabelecimento de normas gerais e deixar o preenchimento das particularidades ao poder legislativo dos Estados", o que reforça a semelhança entre as duas constituições em apreço (HOLSTE. Der deutsche Bundesstaat im Wandel, p. 164).

293 HOLSTE. Der deutsche Bundesstaat im Wandel, p. 160.
} 
leis era, em regra, um assunto que dizia respeito aos Estados-membros. Pondera Heiko HOLSTE, contudo, que este espaço de autonomia dos Estados-membros restava sensivelmente restringido em virtude da regra inscrita na alínea $\mathrm{n}^{\circ} 2$ do artigo $7^{\circ}$ da Constituição de 1871, segundo o qual competia ao Conselho Federal emitir preceitos administrativos obrigatórios de caráter geral e organização administrativa. ${ }^{294}$

Em suma, a Constituição Federal de 1871 já trabalhava com as duas dicotomias em matéria de competências federativas adotadas pela presente tese - de um lado, competências privativas e competências concorrentes; de outro lado, competências legislativas e competências administrativas - sendo que, já nesta época, não se podia falar em uma coextensividade quanto à titularidade das competências legislativas e administrativas. Contudo, em virtude do disposto no artigo 78, este era um arranjo que tendia a não sobreviver às maiorias políticas momentâneas: não havia, afinal, um processo mais dificultoso de emenda à Constituição; ao contrário, pela dicção do referido dispositivo, as alterações da Constituição deveriam seguir o trâmite do processo legislativo comum no âmbito do Poder Legislativo Federal. Por isso, falava-se que o Reich detinha a competência sobre a competência - ou a Kompetenz-Kompetenz - vale dizer, o poder de decidir sobre a própria competência. ${ }^{295}$ As únicas disposições que escapavam ao poder reformador do Império eram os direitos especiais e os direitos de exceção, já mencionados supra. Estes últimos, aliás, nada mais eram do que competências a serem exercidas por alguns Estados-membros em detrimento do Reich $^{296}$.

\subsubsection{A Constituição alemã de 1919 (República de Weimar)}

A partir da publicação da Constituição alemã de 1919 tem início a um período conturbado da história alemã, conhecido como República de Weimar. Tal como a constituição que a antecedeu, não há como explicá-la sem retomar os acontecimentos imediatamente anteriores, em especial, a Primeira Grande Guerra Mundial. ${ }^{297}$

\footnotetext{
294 HOLSTE. Der deutsche Bundesstaat im Wandel, p. 172.

295 HOLSTE. Der Deutsche Bundesstaat im Wandel, p. 160.

296 HOLSTE. Der Deutsche Bundesstaat im Wandel, p. 160.

297 Este confronto, sem precedentes em números e dimensões, marcou de maneira indelével toda uma geração, como bem ressalta Eric HOBSBAWM: "Não surpreende que na memória dos britânicos e franceses, que travaram a maior parte da Primeira Guerra Mundial na Frente Ocidental, esta tenha permanecido como a 'Grande Guerra', mais terrível e traumática na memória que a Segunda Guerra Mundial. Os franceses perderam mais de $20 \%$ de seus homens em idade militar, e se incluirmos os prisioneiros de guerra, os feridos e os permanentemente estropiados e desfigurados - os 'gueules cassés' ['caras quebradas'] que se tornaram parte tão vívida da imagem posterior da guerra -, não muito mais de um terço dos soldados franceses saiu da guerra incólume. As possibilidades do primeiro milhão de soldados britânicos sobreviver à guerra incólume
} 
Embora tivesse lutado ao lado de outras potências europeias, igualmente perdedoras, não é exagero nenhum afirmar que a Alemanha foi quem mais perdeu neste confronto. $\mathrm{O}$ Tratado de Versalhes de 1919, que colocou fim à Primeira Grande Guerra, impôs aos alemães perdas territoriais relevantes - entre elas, o importante território da Alsácia-Lorena, conquistado da França em 1870 (artigo 27) - além de um dever de indenizar todos os prejuízos causados às potências aliadas (artigo 231 e 232). Os termos em que este acordo foi assinado foram mal recebidos pela população alemã, que os considerava humilhantes e excessivamente prejudiciais - gerando um sentimento de insatisfação habilmente manejado pela extrema direita para ascender ao poder, no começo da década de 30 do século XX. ${ }^{298}$ Um efeito mais imediato da guerra foi, contudo, a Abdicação do Imperador Guilherme II, o que abriu espaço para a proclamação da República e para a elaboração e aprovação de uma nova Constituição em 11 de agosto de 1919 em Weimar. ${ }^{299}$

Contudo, entre as forças que comandavam o jogo político na Alemanha neste período não havia muito consenso, mesmo sobre as questões fundamentais de um sistema político. ${ }^{300}$ Nesse sentido, relatam Werner FROTSCHER e Bodo PIEROTH que

eram de mais ou menos 50\%. Os britânicos perderam uma geração - meio milhão de homens com menos de trinta anos (Winter, 1986, p. 83) -, notadamente entre suas classes altas, cujos rapazes, destinados como gentleman a ser os oficiais que davam o exemplo, marchavam para a batalha à frente de seus homens e em consequência eram ceifados primeiro. Um quarto dos alunos de Oxford e Cambridge com menos de 25 anos que serviam no exército britânico em 1914 (Winter, 1986, p. 98) foi morto. Os alemães, embora contassem ainda mais mortos que os franceses, perderam apenas uma pequena proporção de seus contingentes em idade militar, muito mais numerosos que os franceses: $13 \%$ deles. Mesmo as baixas aparentemente modestas dos EUA (116 mil, contra 1,6 milhão de franceses, quase 800 mil britânicos e 1,8 milhão de alemães) na verdade demonstram a natureza assassina da Frente Ocidental, a única onde estes lutaram" (Eric HOBSBAWM. Era dos Extremos: o breve século XX: 1914-1991. Trad. Marcos Santana. São Paulo: Companhia das Letras, 1995, pp. 33/34).

298 FROTSCHER, PIEROTH. Verfassungsgeschichte, p. 272. A dimensão da reparação devida pela Alemanha ao término da Primeira Guerra Mundial pode ser dimensionada a partir do teor dos artigos 231 e 232: "Article 231. The Allied and Associated Governments affirm and Germany accepts the responsibility of Germany and her allies for causing all the loss and damage to which the Allied and Associated Governments and their nationals have been subjected as a consequence of the war imposed upon them by the aggression of Germany and her allies"; "Article 232. The Allied and Associated Governments recognize that the resources of Germany are not adequate, after taking into account permanent diminutions of such resources which will result from other provisions of the present Treaty, to make complete reparation for all such loss and damage. The Allied and Associated Governments, however, require, and Germany undertakes, that she will make compensation for all damage done to the civilian population of the Allied and Associated Powers and to their property during the period of the belligerency of each as an Allied or Associated Power against Germany by such aggression by land, by sea and from the air, and in general all damage as defined in Annex I hereto." (http://avalon.law.yale.edu/imt/partviii.asp. Acesso: 11/02/2015).

${ }^{299}$ FROTSCHER, PIEROTH. Verfassungsgeschichte, pp. 250 e ss. A versão da Constituição Imperial de 1919 que foi utilizada na elaboração deste tópico pode ser consultada em DÜRIG, RUDOLF. Texte zur deutschen Verfassungsgeschichte, pp. 176-212.

$300 \mathrm{O}$ argumento de que na República de Weimar não existia um consenso entre as forças políticas sobre questões fundamentais merece maiores esclarecimentos. Como bem ressalta Karl KROESCHELL, tanto direita quanto esquerda política não aprovavam a República, a qual só veio a ser efetivamente adotada por um esforço 
não se logrou obter um acordo definitivo sequer sobre as cores da bandeira nacional. Conforme o artigo $3^{\circ}$ da Constituição de Weimar, as suas cores eram preto, vermelho e amarelo, em alusão às cores adotadas pela Constituição de Paulskirche de 1849 e como forma de se desvincular da monarquia que vigorou entre 1871 até 1918. Porém, a bandeira com as cores preta, branca e vermelha, adotada pelo regime anterior, permaneceu como bandeira mercante, em um sinal de compromisso entre as forças políticas responsáveis pela elaboração da Constituição de Weimar. Em um momento posterior, o Presidente Paul von Hinderburg, que se apegava mais à tradição inaugurada em 1871 do que a de 1848/1849, chegou a determinar que as repartições consulares e enviadas a lugares fora da Europa utilizassem a bandeira com as cores preta, branca e vermelha ao lado da bandeira oficial. ${ }^{301}$

Porém, em nenhum outro aspecto a falta de um consenso se afigurou mais deletéria do que no plano da democracia. $O$ fato é que a democracia em Weimar era povoada por atores antidemocráticos, que utilizaram seus instrumentos para conquistar o poder político e dele não mais abdicar. É preciso lembrar, afinal, que o Nationalsozialistische Deutsche Arbeiterpartei (NSDAP), partido de Adolf Hitler, teve a chance de surgir, crescer e se consolidar em 1932, como um dos partidos de maior representação no Parlamento, pela via da eleição direta e universal..$^{302}$

dos sociais-democratas, que conduziram o processo de elaboração da Constituição de Weimar a partir de uma coalização com o centro católico e a esquerda liberal (Karl KROESCHELL. Deutsche Rechtsgeschichte. Band 3: Seit 1650. 3a Ed. Wiesbaden: Westdeutsche Verlag, 2001, p. 234). A necessidade de dialogar com diferentes correntes políticas fez com que a Constituição assumisse um viés de compromisso, o qual não foi o suficiente para garantir a sua estabilidade frente à radicalização que caracterizou a política alemã durante as décadas de 20 e 30 do século XX. Com efeito, os sociais-democratas perderam espaço no cenário político alemão e a Constituição de Weimar efetivamente não pôde resistir em meio a atores que questionavam a todo o instante seus postulados mais básicos. A despeito desta fragilidade, é de se ressaltar que a Constituição alemã de 1919 também é bem conhecida pelo seu extenso catálogo de direitos fundamentais e pelo seu viés socializante, sendo considerada neste ponto uma predecessora das constituições atualmente vigentes.

${ }^{301}$ FROTSCHER, PIEROTH. Verfassungsgeschichte, pp. 287-289. Nesse mesmo sentido, relatam os autores que a Constituição de Weimar no seu artigo 128 determinava o livre ingresso dos cidadãos alemães aos cargos públicos, conforme a sua capacidade e o seu desempenho. Contudo, ela se viu obrigada a herdar e lidar com o funcionalismo público oriundo da Constituição de 1871, de índole eminentemente monárquica e antidemocrática. Em um ponto, a situação chegou a níveis tão despropositados que o governo federal se viu obrigado a editar uma lei, proibindo a utilização da função e do aparato públicos com a finalidade de depreciar forma republicana de Estado, as cores da bandeira nacional ou a administração federal/estadual, entre outras proibições. Por óbvio, semelhante disposição não surtiu os efeitos desejados entre os agentes públicos, os quais continuaram ostentando uma feição eminentemente antidemocrática, contribuindo em certa medida para a derrocada da República com a ascensão do nacional-socialismo (FROTSCHER, PIEROTH. Verfassungsgeschichte, pp. 290-292). Note-se que o compromisso em torno das cores da bandeira nacional e expresso no artigo 3 WRV também é alvo de breves comentários em STERN. Das Staatsrecjt der Bundesrepublik Deutschland. Band V, p. 560.

302 Como ressaltam FROTSCHER, PIEROTH. Verfassungsgeschichte, p. 284. Ao comentar as eleições de 31/07/1932, Klaus STERN pondera que, embora os nazistas tivessem logrado obter 230 das 608 cadeiras do parlamento alemão e terem se tornado o partido de maior representação ao lado da KPD, eles utilizavam o seu poder mais para sabotar leis do que para formar um governo operacional. Em agosto deste mesmo ano, o 
Contudo, isso não seria possível se a própria Constituição de 1919 não contivesse algumas falhas de ordem institucional que permitiram a erosão da democracia em direção ao autoritarismo para, finalmente, mergulhar no totalitarismo. Com efeito, o seu artigo 48 permitia ao Presidente, no caso de violação ou perigo à ordem e à segurança pública, tomar as medidas cabíveis para o restabelecimento da normalidade, o que incluía a edição dos chamados decretos de emergência (Notverordnungen). Em tese, o Parlamento poderia até retirar a validade destes atos normativos, mas como ao Presidente era facultado simplesmente dissolver esta casa legislativa (artigo 25), a relação entre Poder Legislativo e Poder Executivo acabava por se desenvolver sempre em favor deste último. ${ }^{303}$

A partir do momento que o Presidente Hindenburg passou a fazer uso desta prerrogativa, o sistema parlamentarista ruiu. O papel de proeminência, que antes era ocupado pelo Parlamento, passou a ser ocupado pelo Poder Executivo, em especial pelo Presidente, em relação ao qual o Chanceler passou a responder politicamente a partir de $1930 .{ }^{304}$ Como um reflexo deste fenômeno, o número de leis aprovadas por esta casa legislativa caiu drasticamente. Lembram FROTSCHER e PIEROTH que "em 1930 o Parlamento aprovou ainda 98 leis, em 1931 foram 34 [leis aprovadas] e em 1932 apenas 5"305. Em suma, antes mesmo do cataclismo totalitário que dominou a Alemanha em 1933 com a ascensão de Hitler, o sistema político alemão já padecia de tendências antidemocráticas, além de um autoritarismo na figura do seu Presidente.

No plano da federação também se pôde notar a falta de um consenso entre os atores envolvidos sobre algumas questões relevantes. Por exemplo, relata Heiko HOLSTE que, durante os trabalhos da assembleia constituinte, cogitou-se uma nova organização territorial dos Estados (os quais passaram a se chamar Länder, ao invés de Bundes- ou Gliedstaaten, como ocorria sob a égide da Constituição anterior), a fim de eliminar aqueles demasiadamente pequenos, mas principalmente para conter e mitigar a hegemonia da

presidente alemão chegou a oferecer alguns postos no governo a Hitler, mas a ele só interessava a sua condução, o que só viria a ocorrer em janeiro de 1933 (STERN. Das Staatsrecht der Bundesrepublik Deutschland. Band V, pp. 732-733).

303 FROTSCHER, PIEROTH. Verfassungsgeschichte, p. 266.

${ }^{304}$ FROTSCHER, PIEROTH. Verfassungsgeschichte, pp. 277-279.

${ }^{305}$ FROTSCHER, PIEROTH. Verfassungsgeschichte, p. 279. Note-se que, para Heiko HOLSTE, esta diminuição do número de leis federais a partir do começo da década de 30 pode ser explicada pelas dificuldades em encontrar um consenso em relação a alguns temas englobados na competência legislativa do Reich, e também pela crise no próprio parlamentarismo, evidenciada pela troca de governo e de coalizões do poder (HOLSTE. Der Deutsche Bundesstaat im Wandel, p. 346). De todo modo, o fato é que eram esses decretos de emergência que passaram a conformar a atuação do Reich. Como ressalta Ulrich EISENHARDT, "as leis federais eram editadas sob a forma de decretos de emergência". Consequentemente, a posição de proeminência do Presidente no sistema político alemão se tornou ainda maior, a ponto de este ser caracterizado como um Imperador-substituto (Ersatzkaiser) (EISENHARDT. Deutsche Rechtsgeschichte, p. 426). 
Prússia. Este último objetivo, contudo, só poderia ser efetivamente concretizado com o desmembramento do território prussiano em Estados menores; porém, a ideia encontrou fortes objeções durante o processo de elaboração da Constituição, razão pela qual se acabou optando pela solução compromissória do artigo 18 WRV (Weimarer Reichsverfassung), segundo o qual a organização dos Estados obedeceria a um critério de "melhor desempenho econômico e cultural do povo" (wirtschaftliche und kulturelle Höchstleistung). Ou seja, a Prússia permaneceu com um território e população desproporcionalmente grandes em relação aos outros Estados, cabendo ao governo federal, em um momento posterior e diante das circunstâncias políticas adequadas, alterar este estado de coisas. ${ }^{306}$

É bem verdade que aquela hegemonia prussiana institucionalizada, tal como sob a égide da Constituição Imperial de 1871 e que provocou um verdadeiro entrelaçamento entre Prússia e Império, foi efetivamente desmantelada. O rei da Prússia não era mais, afinal, o Imperador alemão e nem detinha este Estado um poder de veto isolado no Conselho Imperial (Reichsrat). Todavia, as suas dimensões ainda lhe garantiam um papel de proeminência fática em relação a outros Estados alemães, permanecendo este como um desequilíbrio que não foi devidamente equacionado pela ordem constitucional então vigente. $^{307}$

O Conselho Imperial (Reichsrat), aliás, foi objeto de uma substancial reformulação pelo legislador constituinte de 1919. Em primeiro lugar, o número de representantes por Estado passou a ser contabilizado com base na sua respectiva população, abstendo-se a Constituição de fixá-lo em números, tal como fazia o texto constitucional anterior. Nesse sentido, o artigo 61 WRV estabelecia o mínimo de um representante por Estado, sendo este número ampliado à razão de um representante a cada um milhão de habitantes, até o máximo de dois quintos de todos os membros daquela câmara representativa. Em segundo lugar, nos termos do artigo 63, os Estados seriam representados por membros do seu governo (Mitglieder ihrer Regierungen), o que é uma inovação em relação à ordem constitucional anterior, que falava apenas em representantes dos membros

\footnotetext{
306 HOLSTE. Der Deutsche Bundesstaat im Wandel, pp. 276-278.

${ }^{307}$ HOLSTE. Der Deutsche Bundesstaat im Wandel, p. 282. Ressalta a referida autora neste trecho da sua obra que, por meio da separação entre União e Estados - especialmente, pela separação entre União e Prússia pretendeu-se firmar um federalismo com igualdade de tratamento entre os Estados. Contudo, a despeito de esta igualdade entre os Estados existir no plano formal - a qual englobava inclusive a inexistência de direitos especiais e de exceção aos Estados maiores da federação - o fundamento fático sob o qual se assentava a hegemonia jurídica da Prússia sob a égide da Constituição de 1871 - consubstanciado no seu vasto território e na sua população numerosa - permaneceu intocado.
} 
da União (Vertreter der Mitglieder des Bundes). ${ }^{308}$ Contudo, é mais importante observar que, em comparação com Constituição de 1871, o Conselho Imperial passou a exercer um papel relativamente modesto, mais precisamente, o de instância de representação dos Estados, com limitada influência perante os Poderes Legislativo e Executivo do Império (artigo 60 WRV). A corroborar este argumento, basta lembrar que o Conselho Federal não aprovava leis federais, como ocorria sob a égide da constituição anterior; ao contrário, esta era uma atribuição a ser exercida primordialmente pelo Parlamento Federal, conforme se extrai do parágrafo segundo do artigo $68 \mathrm{WRV}$. Ao Conselho competia somente um direito de objeção, o qual poderia ser revertido por decisão de $2 / 3$ da câmara representativa do povo (artigo $74 \mathrm{WRV}) .{ }^{309}$

No que tange à repartição de competências, a Constituição de Weimar também trabalhava com as dicotomias competências privativas e concorrentes, de um lado, e competências legislativas e administrativas, de outro. A primeira delas pode ser bem contemplada pela análise do artigo $6^{\circ} \mathrm{WRV}$, que tratava da competência legislativa privativa do Reich, e dos artigos $7^{\circ}$ e $12 \mathrm{WRV}$, que disciplinava a competência legislativa concorrente entre o Império e os Estados. É interessante ressaltar que a constituição ainda não falava expressamente de uma competência concorrente. Ao contrário, optou o legislador constituinte por tratar da legislação privativa do Império (ausschließliche Gesetzgebung des Reiches) em um artigo (artigo $6^{\circ}$ ) e das competências do Império (introduzidas pela expressão “das Reich hat die Gesetzgebung” ou "o Império detém a legislação") em outro $\operatorname{artigo}\left(\operatorname{artigo} 7^{\circ}\right) .{ }^{310} \mathrm{~A}$ concorrência entre Império e Estados é enunciada apenas no artigo 12, com o seguinte teor:

\footnotetext{
308 O estabelecimento de um patamar máximo de representantes era uma das disposições que visavam acabar com a hegemonia da Prússia nesta câmara. Com este mesmo objetivo, o artigo 63 da Constituição de 1919 previa que a metade dos representantes da Prússia não seriam membros do seu governo, e sim das administrações provinciais deste Estado.

${ }^{309}$ Cf. FROTSCHER, PIEROTH. Verfassungsgeschichte, p. 268. Esta alteração na estatura constitucional do Conselho Federal era um reflexo de uma transformação no fator legitimador da Constituição de 1919: se a unificação alemã que antecedeu a Constituição de 1871 fez com que esta ostentasse um predomínio do componente federativo, em Weimar privilegiou-se o componente democrático e nacional, consubstanciado no papel de proeminência da câmara representativa do povo e no parlamentarismo (como observa HOLSTE. Der Deutsche Bundesstaat, p. 281). De todo modo, nesta peculiar conformação da Câmara representativa dos Estados os elaboradores da Lei Fundamental de 1949 também foram buscar inspiração.

310 Neste ponto, deve-se fazer apenas uma observação quanto à tradução da palavra "Gesetzgebung". Em muitos dicionários pode se encontrar o equivalente à "legislação" em português, mas não se pode deixar que reconhecer, com Hans-Werner RENGELING, que se está diante de um termo equívoco. Porém, como ressalta o referido autor, quando "Gesetzgebung" é utilizada em um contexto de repartição de competências federativas, ela adquire um significado preciso, qual seja, o de uma lei em sentido formal, que é aprovada por meio de um processo legislativo-parlamentar (RENGELING. § 135 Gesetzgebungszuständigkeit. In: ISENSEE, KIRCHHOF (Hrsg.). Handbuch des Staatsrechts, p. 569).
} 
“Artigo 12. Enquanto e à medida que o Império não fizer uso do seu direito de legislar, detêm os Estados o direito a elaborar legislação. Tal não vale para a legislação privativa do Império., 311

Ou seja, em relação a todas as competências legislativas do Império que não fossem expressamente qualificadas como privativas, os Estados poderiam exercer a competência legislativa concorrente. Perceba-se como este artigo não limitava de nenhum modo o exercício da competência por parte do ente federal, ao contrário do que passou a ocorrer com a vigência da Lei Fundamental de 1949. Contudo, em relação a algumas matérias, o legislador constituinte optou por colocar algumas limitações. Era o caso da legislação de necessidade (Bedarfgesetzgebung), prevista no artigo $9^{\circ} \mathrm{WRV}$, segundo a qual o Reich podia legislar à medida que houvesse uma necessidade da adoção de preceitos uniformes (ou "soweit ein Bedürfnis für den Erlaß einheitlicher Vorschriften vorhanden ist”). A legislação de princípios (Grundsatzgesetzgebung), com previsão nos artigos 10 e 11 WRV, também impunha uma limitação de ordem material à competência do Império, ao prever que em determinadas matérias este só estaria autorizado a legislar sobre princípios.

Como se terá a oportunidade de analisar oportunamente, a imposição de condições e de limitações materiais para o exercício de competências legislativas por parte da União é uma das características marcantes da competência concorrente sob a égide da Lei Fundamental de 1949. Contudo, como relata Heiko HOLSTE, na vigência da Constituição de Weimar prevaleceu o entendimento de que tanto a necessidade que justificaria a legislação uniforme por parte do Império quanto a legislação de princípios não estavam sujeitos a qualquer controle jurisdicional. No caso da legislação de necessidade, a situação era ainda mais grave, tendo em vista que ela abarcava temas amplos como Wohlfahrtspflege - algo como a proteção do bem estar social - e a proteção da ordem pública e da segurança, os quais acabaram por receber uma interpretação bem extensiva por parte da doutrina na época. Neste contexto, o poder central tinha a seu dispor uma competência quase que ilimitada - uma cláusula geral, que justificaria a sua atuação em qualquer área. ${ }^{312}$

No que diz respeito à distinção entre repartição de competências legislativas e repartição de competências de execuçao, é importante atentar para o disposto nos artigos 14 e 15 da Constituição de Weimar. O primeiro deles dispunha que as leis federais deveriam ser executadas pela administração estadual, ao passo que o segundo autorizava o

\footnotetext{
311 No original: „Artikel 12. Solange und soweit das Reich von seinem Gesetzgebungsrechte keinen Gebrauch macht, behalten die Länder das Recht der Gesetzgebung. Dies gilt nicht für die ausschließliche Gesetzgebung des Reiches." Note-se que o artigo 13 WRV previa ainda que "direito imperial revoga direito estadual" (ou „Reichsrecht bricht Landrecht“), dando origem à expressão que atualmente é empregada no artigo 31 GG.

312 HOLSTE. Der deutsche Bundesstaat im Wandel, p. 340-342.
} 
Império a exercer uma supervisão em relação aos assuntos nos quais este último tivesse exercido a competência legislativa. Porém, é de se ressaltar que a própria Constituição facultava ao ente federal, por meio de processo legislativo comum, alterar esta partilha de atribuições. Em outras palavras, o próprio texto constitucional autorizava a União a expandir sua competência administrativa, em detrimento da autonomia a princípio assegurada aos Estados-membros. ${ }^{313}$ Na prática, como ressalta Heiko HOLSTE, o Poder Central utilizou esta faculdade conferida pela constituição para ampliar a sua própria estrutura administrativa, além de utilizar a sua competência legislativa para intervir e influir sobre as administrações dos Estados-membros, inclusive por meio da criação de poderes federais de controlar e de dar instruções. Em determinado momento, os Estados chegaram a até a ceder o exercício de algumas competências ao Reich, além de celebrar acordos, sob influência do governo federal, com o intuito de promover uma uniformização da atuação administrativa no âmbito estadual. Porém, é de se admitir que os Länder também cooperavam entre si por meio de reuniões e acordos, ainda que não houvesse incentivos federais para tanto. ${ }^{314}$

De um modo geral, pode-se afirmar que a Constituição de Weimar possuía uma tendência homogeneizadora, o que se extrai de uma série de dispositivos que visavam conferir uma uniformidade na atuação dos entes federados: é o caso, por exemplo, dos supramencionados artigos 10 e $11 \mathrm{WRV}$, que facultavam ao Império editar princípios gerais que serviriam, ao menos em tese, para conferir uma maior uniformidade à legislação dos Estados. Contudo, o que parece mais importante ressaltar é o espírito centralizador desta Constituição, diante da ausência de mecanismos que impedissem a ampliação dos poderes do centro em prejuízo das unidades subnacionais. Não se pode afirmar que este foi um dado não desejado pelo legislador constituinte de Weimar, o qual possuía uma nítida preferência pela adoção de um Estado Unitário e somente persistiu na fórmula federativa diante da impossibilidade de fazê-lo de outro modo. ${ }^{315}$

\footnotetext{
313 Com efeito, dispunha o artigo 14 da Constituição de Weimar que as leis imperiais seriam executadas pelas autoridades estaduais, à medida que as leis imperiais não dispusessem de outro modo (no original: "Die Reichsgesetze werden durch die Landesbehörden ausgeführt, soweit nicht die Reichsgesetze etwas anderes bestimmen").

314 HOLSTE. Der Deutsche Bundesstaat im Wandel, pp. 360-368.

${ }^{315}$ Como ressalta HOLSTE. Der deutsche Bundesstaat im Wandel, pp. 275-276 e também Juan Joaquín VOGEL. Capitulo XII - El régimen federal de la Ley Fundamental. In: Ernst BENDA; Wener MAIHOFER, Hans-Jochen VOGEL; Konrad HESSE, Wolfgang HEYDE. Manual de Derecho Constitucional. Trad. Antonio López Pina. 2a Ed. Madrid e Barcelona: Marcial Pons, 2001, pp. 616-617.
} 


\subsubsection{Breve histórico da federação alemã durante a vigência da Lei Fundamental de $1949^{316}$}

Uma série de fatores contribuíram para a catástrofe que foi a Segunda Guerra Mundial. Seus exatos contornos escapam os limites desta exposição, razão pela qual se remete à literatura pertinente. ${ }^{317}$ Os seus efeitos para a Alemanha, contudo, merecem ser retomados, ainda que brevemente.

Sabe-se que após a sua capitulação, em maio de 1945, a Alemanha foi dividida em quatro zonas de ocupação - sob responsabilidade dos Estados Unidos da América, da União Soviética, do Reino Unido e da França - que seriam administradas conjuntamente por meio de um Conselho de Controle dos Aliados (alliierte Kontrollsrat) até que se encontrasse uma decisão acerca do futuro deste país. Contudo, antes que tal objetivo fosse efetivamente atingido, a tensão entre Estados Unidos e União Soviética fez com que o território alemão restasse cindido em dois Estados. ${ }^{318}$

Por mais que não tenha sido este o fator determinante desta ruptura, é interessante ressaltar como este conflito entre capitalismo e comunismo se manifestou em um impasse acerca da forma de Estado a ser adotada pela Alemanha após sua unificação. Com efeito, relata Reinhard MUßGNUG que a União Soviética insistia pela adoção de um Estado Unitário, por meio do qual os comunistas, utilizando a sua zona de ocupação e em conjunto com o partido comunista das zonas de ocupação ocidentais, pudessem controlar. Já as potências ocidentais desejavam evitar este cenário e por isso propunham a estruturação da Alemanha em moldes federativos, em uma clara tentativa de aumentar a representação dos

\footnotetext{
${ }^{316}$ O foco deste tópico obviamente reside na evolução da estrutura federativa alemã durante a vigência da Lei Fundamental de 1949, deixando-se de lado outros temas igualmente interessantes, mas que não se relacionam diretamente com a presente tese, como é o caso dos direitos fundamentais e da integração europeia. Além do mais, deve-se ressaltar que muitos dos fatos relatados neste tópico serão retomados em momentos posteriores desta tese. Considerou-se oportuno, contudo, a elaboração de um tópico exclusivamente dedicado a um histórico da estrutura federativa alemã sob a égide da Lei Fundamental de 1949, no qual os acontecimentos mais relevantes para a compreensão desta evolução fossem dispostos cronologicamente, como forma de facilitar a exposição de outros argumentos a respeito da federação alemã, também desenvolvidos sob uma perspectiva histórica, em outras passagens da tese, ainda que isto implique em alguma redundância.

317 Existem diversas abordagens dos fatores e das consequências da Segunda Guerra Mundial. Para uma exposição relativamente sucinta, mas que enxerga este verdadeiro cataclismo em uma perspectiva mais global - em especial, por meio de uma análise conjunta com a Primeira Guerra Mundial cita-se HOBSBAWM. A era dos extremos, pp. 29-219 (parte dedicada ao que ele chama de "era da catástrofe").

318 Como ressaltam Werner FROTSCHER e Bodo PIEROTH, "O conflito leste-oeste como uma confrontação global de blocos na verdade não se limitou à Alemanha, mas ela foi - como a Coréia - atingida de forma peculiar, porque por conta das tensões crescentes, a própria unidade estatal foi colocada dúvida. A coalização de guerra anti-Hitler dos Aliados foi destruída, os aliados de antes figuravam como forças ocupantes inimigas em relação umas às outras" (FROTSCHER, PIEROTH. Verfassungsgeschichte, p. 377).
} 
Estados-membros ocidentais em relação aos Estados-membros da porção oriental, comandados pelos soviéticos. Como uma solução a este impasse afigurava-se impossível, as potências ocidentais acabaram por renunciar temporariamente o objetivo da reunificação alemã e passaram a orientar seus esforços na criação de um Estado Federal. ${ }^{319}$ A zona de ocupação soviética seguiu um rumo próprio e tornou-se em 1949 a República Democrática Alemã (ou Deutsche Demokratische Republik - DDR).

Ainda segundo MUßGNUG, a federação também foi a solução desejada pelos alemães da parte ocidental, na medida em que ela representava a continuação de uma "tradição federativa da história constitucional alemã". ${ }^{320}$ Contudo, o fato é que, mesmo que os alemães da porção ocidental quisessem outra coisa, ainda assim eles estariam adstritos à forma de Estado Federal, pois esta foi uma imposição feitas pelos poderes aliados por meio do Documento de Frankfurt $\mathrm{n}^{\circ}$ 1, que autorizava a convocação de uma assembleia constituinte. Além do mais, é de se admitir que esta tradição federativa se encontrava sensivelmente abalada no período que antecedeu à formação do Conselho Parlamentar responsável pela aprovação do novo texto constitucional alemão: os Aliados, afinal, haviam dividido a Alemanha em novos Estados, sendo que apenas em relação a Baviera, Bremen e Hamburgo poderia se falar em uma continuidade cultural e histórica de suas fronteiras. Seja como for, esta nova divisão territorial da Alemanha, ainda que imposta pelos poderes aliados, serviu para pôr fim a um grande problema da federação alemã sob a égide da Constituição de Weimar: a Prússia, afinal, havia sido dissolvida em 1946/1947 e não mais viria a se reunir nos contornos anteriores à Segunda Grande Guerra. ${ }^{321}$

\footnotetext{
319 Reinhard MUßGNUG. § 8 - Zustandekommen des Grundgesetzes und Entstehen der Bundesrepublik Deutschland. In: Josef ISENSEE; Paul KIRCHHOF (Coord). Handbuch des Staatsrechts der Bundesrepublik Deutschland. Band 1: Historische Grundlagen. 3a Ed. Heidelberg: C. F. Müller, 2003, pp. 317-320. Como anotam Werner FROTSCHER e Bodo PIEROTH, os Estados Unidos - e nesse ponto eram apoiados pelo Reino Unido eram a favor da formação de um Estado Alemão Ocidental forte para fazer oposição e servir de proteção em relação ao Estado Alemão Oriental e ao bloco socialista como um todo. Porém, a França, que havia sofrido por duas vezes as consequências de ter uma Alemanha forte e unida como vizinha, propugnava pela criação de uma confederação de Estados (Staatenbund), formada a partir dos Estados em que foram divididas as zonas de ocupação. Depois de alguns debates, a opção pelo Estado Federal surgiu como uma solução de compromisso entre estas potências vencedoras, e foi imposta aos alemães no momento da elaboração da sua constituição, juntamente com a exigência de um poder central adequado e de um rol de garantias e direitos individuais (FROTSCHER, PIEROTH. Verfassungsgeschichte, pp. 378-379). A preferência da França por um Estado alemão fraco e descentralizado, e a sua oposição à criação de uma administração alemã central também é mencionada em EISENHARDT. Deutsche Rechtsgeschichte, p. 505.

320 MUßGNUG. $\& 8$ - Zustandekommen des Grundgesetzes In: ISENSEE, KIRCHHOF (Hrsg). Handbuch des Staatsrechts, p. 340. Nesse mesmo sentido, Klaus STERN. Das Staatsrecht der Bundesrepublik Deutschland. Band I: Grundbegriffe und Grundlagen des Staatsrechts, Strukturprinzipien der Verfassung. 2a Ed. Munique: C. H. Beck'sche Verlagsbuchhandlung, 1984, pp. 666-667.

${ }^{321}$ Como ressalta Hans-Jochen VOGEL, "Además, Prusia fue expresamente disuelta. En 1946/1947 se crearon cinco Länder en la zona de ocupación soviética, compuestos en parte por antiguos territorios prusianos, cuya
} 
A Lei Fundamental de 1949 - ou Lei Fundamental de Bonn, como também é conhecida - surge como uma constituição transitória, que persistiria até a reunificação alemã, quando então seria elaborada uma verdadeira constituição para todo o povo alemão. ${ }^{322}$ Aprovada por um Conselho Parlamentar e criticada pela sua falta de legitimidade originária - foi, afinal, ratificada pelos poderes legislativos estaduais e não pelo povo diretamente $^{323}$ - ela se tornou de fato a Constituição alemã, regulando e conformando o jogo político e respeitada pelos seus atores. A federação por ela instaurada, por sua vez, coloca-se em uma relação de continuidade às Constituições de 1871 e 1919, não obstante tenha introduzido algumas inovações importantes.

existencia fue, sin embargo, muy breve. En 1952, la República Democrática de Alemania creada en 1949 se dividió en 14 distritos. Berlín-Este se convirtió, como capital de la República Democrática Alemana en el 150 distrito. Los territorios de Prusia pertenecientes a la zona británica fueron divididos en los Länder Renania del Norte-Westfalia, Baja Sajonia y Schleswig-Holsten, y los demás Länder que habían existido sobre dicho territorio se fundieron con estos tres nuevos Länder. Hamburgo se mantuvo en las lindes de la reforma territorial de 1937, y lo propio sucedió con Bremen, como puerto de la zona americana. En la zona francesa se creó el Land de Renania-Palatinado, a partir de territorios anteriormente habían pertenecido a Prusia, Hesse, Oldemburgo y Baviera. La parte de Baden y la parte de Wurtemberga incorporando también antiguos territorios prusianos. Las partes de Baden y Wurtemberga que quedaban en la zona americana fueron unificadas para crear el Land de Baden-Wurtemberga. El nuevo Land de Hesse, además de mantener el territorio del antiguo Estado de Hesse, se extendió también a territorios prusianos. Por tanto, como unidades de inquebrantada tradición histórica y territorial sólo quedaran Baviera - aunque perdió el Palatinado - y las ciudades hanseáticas de Hamburgo y Bremen. También Hesse y Wurtemberga-Baden preservaron - con algunas restricciones - su integridad. Por su parte, Berlin siguió una evolución singular." (VOGEL. Capítulo XII - El Régimen federal de la Ley Fundamental, pp. 617-618. Na versão original, em alemão: Hans-Jochen VOGEL. $\S 22$ Die bundesstaatliche Ordnung des Grundgesetzes. In: Ernst BENDA; Werner MAIHOFER; Hans-Jochen VOGEL; Konrad HESSE; Wolfgang HEYDE (Coord.) Handbuch des Verfassungsrechts der Bundesrepublik Deutschland. 2o Volume. 2a Ed. Berlin: Walter de Gruyter, 1994, p. 1046).

322 Porém, como ressalta Ulrich EISENHARDT, "a despeito do seu caráter provisório, o qual foi cunhado pelo preâmbulo e artigo 146 GG, a Lei Fundamental de 23 de maio de 1949 foi desde o começo uma verdadeira constituição e não um estatuto de organização transitório. Sobretudo no que tange aos direitos fundamentais e aos princípios estruturantes da democracia, do Estado Social de Direito e do Estado Federal contém a Lei Fundamental elementos materiais duradouros" (Deutsche Rechtsgeschichte, p. 541).

323 É importante ressaltar que a Lei Fundamental de 1949 não foi o fruto de uma Assembleia Constituinte, tal como ocorreu sob a égide da Constituição de Weimar, mas de um Conselho Parlamentar, composto por membros dos parlamentos estaduais, estes sim eleitos pelo povo. Os trabalhos deste Conselho, por sua vez, foram orientados por um projeto de constituição elaborado por especialistas do direito constitucional (o chamado Herrenchiemseer Verfassungskonvent), que tinha por objetivo deliberado justamente evitar os erros cometidos pela Constituição de Weimar, sem, contudo tomar partido sobre questões políticas, as quais deveriam ser deliberadas durante o processo constituinte. Depois de aprovada, a Lei Fundamental foi analisada pelas forças aliadas ocidentais e submetida a um processo de ratificação perante os parlamentos estaduais. Originariamente, as forças aliadas pretendiam que a aprovação da constituição para o Estado alemão ocidental se desse por meio de referendo. Contudo, os alemães de todo modo evitaram utilizar esta via, tendo em vista a sua utilização por Adolf Hitler para fins eminentemente anti-democráticos. É de se ressaltar que neste ponto reside uma das principais críticas à legitimidade da Lei Fundamental, tendo em vista que o povo apenas de forma mediata participou de sua elaboração e aprovação. Estas e outras informações sobre o processo de elaboração da Lei Fundamental de 1949 podem ser obtidas tanto na supracitada obra de Reinhard MUßGNUG quanto em obras de história constitucional alemã, especialmente aqueles citadas nesta tese. 
No que tange ao Conselho Federal (Bundesrat), optou-se por um meio termo entre a Constituição de 1871 e a Constituição de 1919: trata-se, portanto, de um órgão com papel relevante sobre matérias que dizem respeito aos interesses dos Estados - em relação às quais é necessária sua aprovação - e de influência limitada sobre outras matérias - sobre as quais ele pode manifestar a sua objeção, exercendo, portanto, um poder de veto. Em uma perspectiva mais genérica, pode-se afirmar que é uma instituição extremamente importante ao federalismo alemão pós-1949; esta é, contudo, uma constatação cujo alcance será devidamente explicitado somente no item 2.2.4 desta tese.

Já no tocante à repartição de competências legislativas e de execução, a Lei Fundamental também trabalha com as dicotomias competências legislativas e competências administrativas, de um lado, e competências privativas e competências concorrentes, de outro. Contudo, o Conselho Parlamentar acabou optando por uma redação mais técnica, o que dissipou algumas omissões e incertezas que existiam nos textos constitucionais anteriores. Optou-se, assim, por consagrar uma regra geral no artigo $30 \mathrm{GG}$ - que é repetida, segundo a doutrina alemã, nos artigos 70 e 83 em relação à repartição das competências legislativas e das competências administrativas - qual seja: os Estados detêm a competência, desde que e à medida que a própria Lei Fundamental - e não a lei federal, como acontecia sob a égide da Constituição de Weimar no que tange às competências de execução - não disponha de outro modo. ${ }^{324}$ A seguir, o diploma em questão divide as competências legislativas, disciplinadas nos artigos 70 a 75 , e as competências administrativas ou de execução, previstas no artigo 83 e seguintes, para então tratar das competências privativas e das competências concorrentes. Nesse sentido, os artigos 71 e 73 tratam da competência legislativa privativa da União (ou Bund), os artigos 72 e 74 versam sobre a competência legislativa concorrente do Bund e dos Estados (ou Länder), e o artigo 75 (revogado pela Reforma do Federalismo de 2006) disciplinava a chamada competênciamoldura do Bund. Já os artigos 84 e 85 cuidam das competências administrativas a serem exercidas pelos Estados no campo da execução da lei federal, ao passo que os artigos 86 e seguintes da competência administrativa privativa do Bund. ${ }^{325}$

Neste momento de nova fundação da federação alemã, pretendeu-se assegurar uma maior descentralização, além de uma separação entre as atribuições da União e

\footnotetext{
324 Para um breve panorama das demandas por descentralização e por centralização no que tange à repartição de competências legislativas e de execução, vide o item 3.2.1 desta tese.

325 Retornaremos a este tema no quarto capítulo da tese, dedicado especificamente à confrontação dos sistemas brasileiros e alemão de repartição de competências. Por ora, prosseguiremos com o esforço de contextualização da federação alemã.
} 
dos Estados - um sistema de separação (Trennsystem), para ficar com a expressão utilizada pelos doutrinadores alemães ${ }^{326}$. Este sistema, embora não encontrasse uma previsão constitucional explícita, poderia ser extraído da forma pela qual a Lei Fundamental reparte competências entre os níveis federativos, vale dizer, circunscrevendo o campo de atuação do nível federal a algumas matérias, deixando ao nível estadual a responsabilidade pelas demais áreas. Em outras palavras, a Lei Fundamental manejava basicamente a técnica horizontal de repartição de competências para falar com Manoel Gonçalves FERREIRA FILHO. Mesmo a competência legislativa concorrente, que já despontava como a modalidade de maior repercussão prática em virtude da sua extensão temática, não previa propriamente uma atuação conjunta do Bund e dos Länder, tendo em vista que, de acordo com o artigo 72 GG, eventual regulamentação de um tema por lei federal tem o condão de impedir a edição de legislações estaduais sobre este mesmo tema, como se terá a oportunidade de analisar no quinto capítulo desta tese. Somente no caso da competência-moldura (Rahmengesetzgebung, prevista no artigo $75 \mathrm{GG}$ ) é que se poderia conceber um ponto de contato entre os planos federal e estadual no que tange à legislação. Porém, tratava-se de uma modalidade restrita a poucas matérias; além do mais, na sua redação originária, a Lei Fundamental tratava apenas da competência do Bund para legislar sobre preceitos-moldura, silenciando-se sobre o papel a ser desempenhado pelos Estados. Já a proposta descentralizante da constituição alemã poderia ser extraída dos dispositivos com vocação geral - em especial, dos artigos 30, 70 e $83 \mathrm{GG}$, os quais davam a entender uma proeminência dos Estados-membros vis-à-vis uma contenção do poder federal - e principalmente das limitações impostas pelo artigo 72 GG à atuação federal em sede de competências legislativas concorrentes. Segundo a redação originária deste último dispositivo, a União tinha direito de legislar "se e à medida que existe uma necessidade de regulamentação federal, porque: (i) uma matéria não pode ser regulamentada de forma eficiente pela legislação dos Estados isoladamente, ou; (ii) a regulamentação de uma matéria por uma lei estadual poderia prejudicar os interesses de outros Estados ou da coletividade, ou; (iii) o estabelecimento da unidade jurídica e econômica, especialmente a salvaguarda da unidade das condições de vida além dos limites

\footnotetext{
326 Como, por exemplo, faz Peter SELMER. Die Föderalismusreform - Eine Modernisierung der bundesstaatlichen Ordnung? Juristiche Schulung (JuS), 2006, Caderno 12, p. 1053, Christian CALLIESS. Die Justitiabilität des Art. 72 Abs. 2 GG vor dem Intergrund von kooperativem und kompetitivem Föderalismus. Die öffentliche Verwaltung (DÖV), ano 50, Novembro 1997, Caderno 21, p. 890 e Hasso HOFMANN. $\S 9$ Die Entwicklung des Grundgesetzes von 1949 bis 1990. In: Josef ISENSEE, Paul KIRCHHOF. Handbuch des Staatsrechts der Bundesrepublik Deutschland. Band I: Historische Grundlagen. 3a Ed. Heidelberg: C. F. Müller, 2003, p. 405.
} 
do território de um Estado a exigirem". Ou seja, estava-se diante de uma redação que parecia restringir sensivelmente a edição de leis federais, privilegiando a posição dos Länder $^{327}$

Entretanto, o que se verificou com o passar dos anos foi uma forte centralização federativa, fundamentada no plano do discurso pela necessidade de promover uma igualação das condições de vida em todo o território alemão. Sem dúvida, a maior responsável por este fenômeno foi a profusão de leis federais sobre as matérias submetidas à competência concorrente, o que foi viabilizado juridicamente pelo entendimento esposado pelo Tribunal Constitucional Federal alemão no sentido de que o preenchimento dos pressupostos contidos no artigo 72 GG era uma decisão puramente discricionária do legislador. ${ }^{328}$

Outro traço bem característico da federação instaurada pela Lei Fundamental de 1949 é a cooperação, concretizada em especial por meio da tomada de decisões conjuntas e que levou, ao longo dos anos, a uma homogeneização da atuação dos entes federativos mesmo naquelas áreas que não foram atingidas pela centralização. Alguns pesquisadores veem nesta forma de coordenação intergovernamental uma verdadeira armadilha, como, por exemplo, Fritz W. SCHARPF em famoso artigo intitulado não por outro motivo de "the joint-decision trap" (ou a armadilha da decisão conjunta) ${ }^{329}$. Note-se que, embora o objetivo deste autor seja analisar o processo de tomada de decisões no âmbito da União Europeia a partir de elementos do caso alemão, ele não deixa de retomar as principais características e as críticas a este modo de conduzir políticas públicas. De todo modo, o que parece ser interessante compreender neste momento da exposição - o assunto será retomado com maiores detalhes oportunamente - é que os entes federativos alemães, aqui incluindo-se União e todos os Estados-membros, encontram-se frequentemente vinculados à tomada de decisões conjuntas, por consenso ou então por uma maioria qualificada, sob pena de não poderem adotarem uma nova política pública ou então de não promoverem alterações importantes em políticas públicas já existentes. Dito de outro modo, os entes federativos ficam reféns de decisões anteriormente tomadas, as quais permanecem em muitos casos simplesmente pela dificuldade de se obter um novo consenso sobre a mudança a ser promovida.

\footnotetext{
327 O caráter aparentemente descentralizante do artigo 72 ॥ GG e a sua incapacidade para reverter o viés unitarizante vivenciado pela federação alemã, mesmo após a entrada em vigor da Lei Fundamental, é alvo de breves comentários em Fritz W. SCHARPF. Die Föderalismusreform: kein Ausweg aus der Politikverflechtungsfalle?. Frankfurt e Nova lorque: Campus, 2009, p. 19.

328 Retornaremos a esta questão, com todos os seus delineamentos jurídicos, no item 5.3.1 desta tese.

329 Fritz W. SCHARPF. The joint-decision trap: lessons from German Federalism and European Integration. Public Administration, v. 66, outono/1988, pp. 239-278.
} 
Tanto a centralização quanto a cooperação federativas são características que serão analisadas com mais afinco e sob uma perspectiva comparada no terceiro capítulo da tese. De todo modo, considera-se oportuno traçar algumas considerações de índole histórica, que ajudarão a compreender a evolução - sobretudo a evolução constitucional - da estrutura federativa alemã. Para tanto, retrocede-se um pouco na análise, a fim de retomar os desafios colocados à federação alemã no momento da sua nova fundação. Segundo Hasso HOFMANN, a então Alemanha Ocidental iniciava sua existência jurídica com o desafio de assentar quase nove milhões de refugiados ou pessoas deslocadas oriundas do leste, de promover a assistência de 200.000 ex-soldados e a 250.000 servidores expulsos do serviço público. ${ }^{330}$ Além do mais, era preciso restabelecer a infraestrutura do país, que havia sido sensivelmente destruída após a Segunda Grande Guerra.

Originariamente, a constituição alemã não previa a ajuda da União aos Estados ou dos Estados-membros alemães entre si. Na verdade, ela não continha exatamente um projeto acabado de constituição financeira (Finanzverfassung), como bem anota Fritz W. SCHARPF $^{331}$, tendo em vista que a repartição da competência concorrente em matéria de tributos foi postergada para um momento posterior à entrada de vigor da Lei Fundamental (artigo 107, redação originária, GG), tendo sido resolvida somente em 1955 por meio de uma reforma constitucional. ${ }^{332}$ De todo modo, a despeito de se ter consagrado também aqui um sistema de separação, na prática o que se verificou foi um incremento de modalidades de financiamento misto (Mischfinanzierung), por meio das quais o Bund transferia recursos

\footnotetext{
330 HOFMANN. \& 9 Die Entwicklung des Grundgesetzes von 1949 bis 1990 In: ISENSEE, KIRCHHOF (Hrsg). Handbuch des Staatsrechts, p. 364. Sobre este momento da história alemã e os seus reflexos sobre a federação alemã, pondera Fritz W. SCHARPF que "por outro lado, a força de ligação dos novos Estados, frequentemente delimitados de acordo com os interesses das forças de ocupação, até porque as identidades de 'compatriotismo' - nunca congruentes completamente com os territórios dentro da Alemanha - haviam sido apagadas por meio das novas fronteiras estaduais, pela evacuação e pelos fluxos de refugiados. Resumindo, dos escombros do Império não surgiu nenhuma consciência de Estado dos Länder. Ao contrário: precisamente porque o peso das consequências da guerra - pessoas em situação de rua, fome e refugiados - estavam divididas regionalmente de forma extremamente desigual, a defesa da unidade jurídica e a demanda por uma solidariedade nacional para a redução das 'disparidades regionais' surgiram como irrefutável moral e politicamente, ao passo que todos os esforços dirigidos à autonomia política dos Länder eram interrompidos como suspeitas de separatismo" (SCHARPF. Föderalismusreform: kein Ausweg aus der Politikverflechtugsfalle?, p. 18).

${ }^{331}$ Conforme SCHARPF. Föderalismusreform: kein Ausweg aus der Politikverflechtungsfalle?, p. 23. Apenas a título de esclarecimento, a constituição financeira é um conceito que abrange, segundo Peter BADURA, a repartição de competências para a legislação político-financeira, sobretudo no que tange a criação de tributos, a repartição das receitas tributárias, as decisões sobre a administração financeira federal e estadual, e as principais decisões sobre o relacionamento do orçamento da União e dos Estados (BADURA. Staatsrecht, p. 854).

${ }^{332}$ Note-se que esta mesma reforma incluiu um sistema de compensação financeira entre Estados com melhor desempenho e Estados com pior desempenho no aspecto financeiro, por meio de inclusão de um segundo parágrafo ao artigo 107 GG.
} 
para a realização de atividades a serem desenvolvidas pelos Länder, desde a construção de moradias sociais e hospitais até a criação e expansão de instalações científicas conjuntas, como o Max-Planck-Gesellschaft. ${ }^{333}$ Tal cenário, por sua vez, suscitou muitas críticas por parte dos Länder, as quais são bem resumidas por Hasso HOFMANN no seguinte trecho:

“contra este sistema de transferências da União não previsto constitucionalmente,
contra este financiamento misto como o 'cavalo de Troia do Estado Federal
moderno' (R. Herzog) levantou-se, sem dúvidas, resistência federativa. Na sua
deliberação de junho de 1963 os ministros-presidentes dos Estados dirigiram-se
contra 'a promoção não-sistemática das mais diferentes tarefas nos orçamentos da
União e dos Estados' ou exigiriam uma 'ordenação duradoura das relações
financeiras' - porém, não no sentido da volta a uma práxis estritamente conforme
à constituição, mas sim com o objetivo de esclarecer para o futuro quais tarefas
que somente poderão ser exercidas conjuntamente por União e Estados e quais
tarefas inequivocamente recaem na competência da União ou dos Estados, a fim
de restabelecer uma (nova) 'paz constitucional duradoura'."’334

Atendendo a estes anseios, em 1969 foi finalmente aprovada uma reforma constitucional, conhecida como a Reforma Financeira de 1969, justamente por ter introduzido uma série de alterações na parte da Lei Fundamental dedicada à regulamentação da constituição financeira. Dentre elas, menciona-se a inclusão do artigo 104a GG, cujo parágrafo quarto autorizava a ajuda financeira da União no caso de investimentos relevantes dos Estados e dos Municípios, de promoção do crescimento econômico, de igualação das condições econômicas no território nacional, ou de perturbação do equilíbrio global da economia. ${ }^{335}$ Também é digna de menção a expansão da competência concorrente da União aos tributos em relação aos quais ela tivesse direito ao produto da arrecadação, viabilizada pela nova redação conferida ao parágrafo segundo do artigo 105 GG. Porém, é de se admitir que alterações relevantes em matéria financeira já vinham sendo introduzidas deste 1967. Neste ano, o artigo 109 GG, que até então previa somente que União e Estados eram

\footnotetext{
333 HOFMANN. \& 9 Die Entwicklung des Grundgesetzes von 1949 bis 1990 In: ISENSEE, KIRCHHOF (Hrsg). Handbuch des Staatsrechts, pp. 406-407.

334 HOFMANN. \& 9 Die Entwicklung des Grundgesetzes von 1949 bis 1990 In: ISENSEE, KIRCHHOF (Hrsg). Handbuch des Staatsrechts, p. 407. No original: "Gegen diese verfassungsrechtlich nicht vorgesehene Fondswirtschaft des Bundes, gegen diese Mischfinancierung als das, trojanische Pferd des modernen Bundesstaates' (R. Herzog) regte sich freilich föderalistischer Widerstand. In ihrer Entschließung vom Juni 1963 wandten sich die Ministerpräsidenten der Länder gegen die, unsystematischer Förderung der verschiedensten Aufgaben in den Haushalten des Bundes und der Länder' und verlangten eine, dauerhafte Ordnung der Finanzverhältnisse' - aber nicht im Sinne der Rückkehr zu einer strikt verfassungsmäßigen Praxis, sondern mit dem Ziel, für die Zukunft zu klären, welche Aufgaben nur gemeinschaftlich von dem Bund und Ländern wahrgenommen werden können und welche Aufgaben eindeutig in die Zuständigkeit des Bundes oder der Länder fallen, um so einen (neuen), Verfassungsfrieden von Dauer' herzustellen".

335 O parágrafo primeiro deste dispositivo consagra, por sua vez, a regra geral sobre o tema ao prever que União e Estados arcam com as despesas resultantes da realização de suas respectivas tarefas. Atualmente, a ajuda financeira da União vem regulamentada no artigo 104b GG, incluído pela Reforma Constitucional de 2006.
} 
autônomos e independentes entre si no que tange à gestão de suas finanças, foi alterado a fim de autorizar a União a editar legislação de princípios sobre gestão financeira, além de estabelecer um planejamento financeiro com duração plurianual, restringindo, assim, a autonomia financeira dos Estados $^{336}$.

Uma grande novidade trazida pela Reforma Financeira de 1969 consistiu na introdução das chamadas tarefas conjuntas (Gemeinschaftsaufgaben), previstas a partir daquele momento nos artigos 91a e 91b GG. Consoante se extrai da exposição de motivos do projeto de alteração da Lei Fundamental, posteriormente aprovado em 1969, consistia em um objetivo do legislador constituinte de 1969 o acréscimo de um regramento de direito constitucional - ao lado e excepcionando o sistema de separação de tarefas estatais disciplinando a atuação conjunta da União e dos Estados-membros em determinadas tarefas, em relação às quais "somente por meio do planejamento e financiamento comum da União e dos Estados poderão ser preenchidas de forma totalmente eficaz" ${ }^{\text {"37. }}$. Note-se que estas tarefas se encontravam abrangidas pela competência estadual e deveriam, em tese, ser financiadas somente pelos Estados. Contudo, diante da importância de que se revestiam, foram escolhidas pelo legislador constituinte para serem submetidas a um sistema de planejamento e financiamento conjunto e compulsório. Com isso estavam lançadas as bases constitucionais da cooperação que é tão característica a esta federação. Esta é, porém, uma questão que será analisada somente a partir do terceiro capítulo desta tese ${ }^{338}$, de forma a prosseguir com a análise da evolução histórica da federação alemã sob uma perspectiva constitucional.

Como ressalta Hasso HOFMANN, as alterações promovidas pela Reforma Financeira de 1969 devem ser olhadas em conjunto com outras reformas constitucionais aprovadas logo após, as quais tiveram o condão de ampliar ainda mais a competência concorrente da União. A primeira delas, ocorrida ainda em 1969, estendeu a competência legislativa federal a áreas como subsídios educacionais, hospitais e ensino superior (neste último caso, a atuação federal se restringiria à adoção de preceitos-moldura, nos termos do artigo 75 GG). Em 1971, acrescentou-se o artigo 74a à Lei Fundamental, o qual conferiu ao

\footnotetext{
${ }^{336}$ Conforme HOFMANN. § 9 Die Entwicklung des Grundgesetzes von 1949 bis 1990 In: ISENSEE, KIRCHHOF (Hrsg). Handbuch des Staatsrechts, p. 411.

337 DEUTSCHER BUNDESTAG 5. WAHLPERIODE. Entwurf eines Gesetzes zur Änderung und Ergänzung des Grundgesetzes (Finanzreformgesetz). Drucksache V/2861, p. 11. No original: „2. Die Regelung über die Trennung der Aufgaben von Bund und Ländern ist durch eine verfassungsrechtliche Ordnung für das Zusammenwirken bei solchen Aufgaben zu ergänzen, die nur durch gemeinsame Planung und Finanzierung von Bund und Ländern wirkungsvoll erfüllt werden können".

338 Os aspectos jurídico-dogmáticos das tarefas comuns serão analisados somente no item 5.7 desta tese.
} 
Bund a competência concorrente do Bund para legislar sobre remuneração e previdência dos servidores públicos e juízes estaduais, competência que era até então restrita à edição de preceitos-moldura nos termos do artigo 75 GG. Em terceiro e último lugar, HOFMANN cita as alterações promovidas em 1971 e 1972, as quais autorizaram o Bund a legislar sobre questões relativas proteção do meio ambiente. ${ }^{339}$ Embora relevantes para a compreensão do aumento da importância da legislação da União, é importante ressaltar que o avanço da atuação legiferante da União deu-se sobretudo pela via da interpretação constitucional. Porém, o que ocorreu - como, aliás, se teve a oportunidade de discutir no item 1.6.2 - não foi exatamente o Tribunal Constitucional Federal alemão interpretando extensivamente as normas que atribuíam competências ao Bund, mas sim esta corte se negando a analisar a constitucionalidade das leis federais, sobretudo, o seu enquadramento aos pressupostos enunciados no artigo 72 II GG. O resultado, como já se sabe, foi uma intensa centralização no plano normativo, a qual permaneceu contrabalanceada por uma proeminência dos Länder na atividade de execução das leis, inclusive leis federais.

Com a unificação alemã em 1990, abriu-se uma nova oportunidade para a reforma da estrutura federativa alemã. Como ressalta Armin DITTMANN, as bases fáticas da federação alemã haviam sido substancialmente alteradas com o ingresso dos cinco Länder formados pouco antes a partir do território da República Democrática Alemã: a homogeneização dos Estados-membros e a unificação das condições de vida cuidadosamente construídas nas décadas anteriores na porção ocidental do território alemã - haviam sido substancialmente modificadas por um aumento de aproximadamente $40 \%$ do território e de $25 \%$ da população, cujas condições de vida diferiam drasticamente daquelas então vigentes no território alemão. Apenas para se ter uma ideia, em 1991 o PIB per capita na porção oriental era de apenas $30 \%$ da verificada nos Länder da parte ocidental ${ }^{340}$. Porém, em um primeiro momento não se optou por uma reformulação da estrutura federativa da República Federal da Alemanha. $\mathrm{O}$ artigo $5^{\circ}$ do Tratado de Unificação previa apenas uma recomendação dos governos da DDR e da BRD, “aos órgãos legislativos da Alemanha unificada, de se ocuparem dentro de dois anos das questões levantadas no contexto da unificação alemã sobre a alteração ou complementação da Lei Fundamental”, entre elas, "o relacionamento entre União e Estados conforme a deliberação conjunta dos ministros-

\footnotetext{
339 HOFMANN. \& 9 Die Entwicklung des Grundgesetzes von 1949 bis 1990 In: ISENSEE, KIRCHHOF (Hrsg). Handbuch des Staatsrechts, pp. 410-411.

340 Armin DITTMANN. \& 205 Föderalismus in Gesamtdeutschland. In: Josef ISENSEE, Paul KIRCHHOF (Hrsg). Handbuch des Staatsrechts der Bundesrepublik Deutschland. Band IX - Die Einheit Deutschlands - Festigung und Übergang. Heidelberg: C. F. Müller, 1997, p. 232.
} 
presidentes de 5 de julho de 1990"341, o que significava conferir à futura organização estatal alemã um viés mais federativo, vale dizer, que melhor contemplasse a posição dos $\operatorname{Länder}^{342}$, enfraquecida após anos de nítido predomínio do plano federal. Tal objetivo deveria ser atingido, por sua vez, por meio de uma "reorganização das relações financeiras entre União e Estados, um retorno das competências legislativas aos Estados, uma expansão dos seus direitos de consentimento por meio do Conselho Federal e um fortalecimento dos seus direitos no tratamento das relações exteriores" ${ }^{343}$. A Reforma Constitucional de 1994 surge ao cabo deste processo e consiste na concretização de alguns destes objetivos, principalmente do retorno de competências legislativas aos Estados-membros. Com efeito, o artigo 72 II GG ganhou uma nova redação, segundo a qual o Bund teria o direito de legislar "se e à medida que o estabelecimento de condições de vida equivalentes no território federal ou a salvaguarda da unidade jurídica ou econômica no interesse da totalidade do Estado tornar necessária (erforderlich) uma regulamentação por lei federal". Além do mais, logrouse incluir um Número 2a no artigo 93 I GG (que disciplina a competência do BVerfG), que tornava plenamente justiciável a questão da necessidade da regulamentação da lei federal, a qual a passou a ser decidida pela via do controle abstrato de normas. Como ressalta Winfried KLUTH, "ainda que esta reforma tenha se restringido a alguns pontos, estes correspondem a uma importante função inicial sob um olhar mais atual, pois elas levaram nos últimos cinco anos a uma série de decisões espetaculares do Tribunal Constitucional Federal, as quais influenciaram de forma considerável a discussão sobre o federalismo"344.

A despeito disso, permaneceu uma percepção negativa acerca da estrutura federativa alemã, que informaria alterações posteriores da Lei Fundamental. Em 2003 foi instituída uma comissão para a modernização da estrutura federativa (Kommission zur Modernisierung der bundesstaatlichen Ordnung), conduzida pelo então líder da bancada da SPD, Franz Münterfering, pelo então Ministro-Presidente da Baviera e líder da bancada da CSU, Edmund Stoiber, e composta de 16 membros. Após ouvir representantes do governo federal, dos poderes legislativos estaduais e especialistas, dentre outros, esta comissão terminou seus trabalhos de forma frustrante, pois não logrou obter um consenso acerca de

\footnotetext{
${ }^{341}$ http://www.gesetze-im-internet.de/einigvtr/art_5.html. Acesso: 20/11/2015.

342 DITTMANN. § 205 Föderalismus in Gesamtdeutschland, p. 240.

343 DITTMANN. \& 205 Föderalismus in Gesamtdeutschland, p. 240.

${ }^{344}$ KLUTH. Die Deutsche Föderalismusreform 2006, p. 53. No original: "Auch wenn diese Reform sich auf wenige Punkte beschränkte, kommt ihr aus heutiger Sicht eine wichtige Initialfunktion zu, da sie in den letzten fünf Jahren zu einer Reihe von spetakulären Entscheidungen des Bundesverfassungsgerichts führte, die die Föderalismusdiskussion erheblich beeinflusst haben."
} 
um conceito comum. ${ }^{345}$ Não obstante isso, seus trabalhos influenciaram a grande coalização formada pela CDU, CSU e SPD a partir do ano de 2005, cujo acordo englobou os principais resultados obtidos pela comissão. ${ }^{346}$ Em março de 2006 logrou-se aprovar a chamada Reforma do Federalismo I, a maior alteração da Lei Fundamental desde o início da sua vigência. No foco estavam a repartição de competências legislativas e administrativas, que restaram substancialmente alteradas, com a revogação da competência-moldura (Rahmengesetzgebung) do artigo 75 GG, com a inclusão de uma competência de divergência (Abweichungsgesetzgebung) no artigo 73 III GG e com a nova redação conferida ao artigo 84 I GG. Porém, os objetivos desta reforma eram mais amplos, conforme se extrai do discurso da Chanceler Angela Merkl em 14/12/2005, citado pela exposição de motivos da proposta de alteração da Lei Fundamental que foi enviada ao Parlamento Federal: (i) uma repartição mais clara das competências legislativas e revogação da competência-moldura; (ii) uma reformulação da necessidade de aprovação das leis federais pelo Conselho Federal; (iii) supressão do financiamento conjunto e a reelaboração das possibilidades de ajuda financeira da União, e; (iv) fortalecimento da adequação da estrutura federativa alemã à União Europeia. ${ }^{347}$ Entretanto, se tal reforma efetivamente logrou alcançar tais objetivos, é algo questionável. Com efeito, a necessidade de aprovação de leis federais pelo Conselho Federal não foi efetivamente eliminada, mas parcialmente substituída por um modelo de legislação de divergência ${ }^{348}$, o financiamento conjunto não foi eliminado, mas somente restringido, e assim por diante. Tratou-se, portanto, de uma reforma que ficou no meio do caminho no que diz respeito às finalidades por ela perseguidas.

Em 2009, os esforços de alteração e de modernização da estrutura federativa alemã tiveram por objeto a chamada constituição financeira em uma reforma que ficou conhecida como Reforma do Federalismo II. A bem da verdade, esta reforma abrange duas leis de alteração da Lei Fundamental, as quais se ocuparam de temas como as relações financeiras entre Bund e Länder, endividamento público. Em razão da delimitação exposta na introdução desta tese, estes temas deixam de ser abordados aqui com maior profundidade ${ }^{349}$. De todo

\footnotetext{
345 SELMER. Die Föderalismusreform - Eine Modernisierung der bundesstaatlichen Ordnung?, p. 1055.

${ }^{346}$ Christian STARCK. 1. Teil. Einführung. In: Christian STARCK (Hrsg). Föderalismusreform. Munique: C. H. Beck e Franz Vahlen, 2007, p. 3.

${ }^{347}$ DEUTSCHER BUNDESTAG 16. WAHLPERIODE. Gesetzentwurf der Fraktionen der CDU/CSU und SPD: Entwurf eines Gesetzes zur Änderung des Grundgesetzes (Artikel 22, 23, 33, 52, 72, 73, 74, 74a, 75, 84, 85, 87c, 91a, 91b, 93, 98, 104a, 104b, 105, 107, 109, 125a, 125b, 125c, 143c). Drucksache 16/813, p. 7-8.

348 Conforme será analisado no item 5.5.1.

349 Neste ponto, remete-se à leitura de artigos acadêmicos que tratam desta temática, entre eles, Peter SELMER. Die Föderalismusreform II - Ein verfassungsrechtliches monstrum simile. Neue Zeitschrift für Verwaltungsrecht (NVwZ), 2009, pp. 1256-1262.
} 
modo, cumpre mencionar que esta reforma, assim como fez a Reforma do Federalismo de 2006, buscou alterar o regramento constitucional das tarefas comuns. Porém, se em 2006 buscou-se restringir as áreas submetidas à atuação conjunta e compulsória da União e dos Estados-membros, em 2009 os esforços parecem ter se concentrado na criação de áreas de colaboração administrativa (Verwaltungszusammenarbeit) por meio do acréscimo dos artigos 91c e 91d GG. Finalmente, em 2010 logrou-se incluir o artigo 91e GG no tex to da constituição alemã, o qual também se refere a esta colaboração administrativa.

Em suma, são estes os principais acontecimentos que marcaram a estrutura federativa alemã de um ponto de vista constitucional. Muitos deles serão retomados no decorrer da tese, pois são necessários à compreensão do argumento desenvolvido. Não obstante isso, considerou-se relevante a elaboração de uma exposição cronológica, tal como a empreendida neste item, tendo em vista que a evolução histórica da federação alemã sob a égide da Lei Fundamental não é tão conhecida pelos doutrinadores brasileiros como é a evolução da federação brasileira sob a vigência da Constituição Federal de 1988.

\subsubsection{A autonomia do Município sob a égide da Lei Fundamental de 1949}

Neste tópico, propõe-se um breve estudo da autonomia municipal na Alemanha, tendo por base as normas consagradas na Lei Fundamental de 1949. Começa-se esta exposição, tal como feito quando da análise da autonomia do Município no Brasil, com um breve histórico.

A doutrina alemã consultada costuma adotar como marco inicial desta análise a lei prussiana sobre cidades (preußische Städteordnung vom 19.11.1808), de autoria do Ministro de Estado Freiherr vom und zum Stein, razão pela qual esta lei também é conhecida como Stein'sche Städteordnung. ${ }^{350}$ São duas as informações importantes sobre este diploma. Em primeiro lugar, embora ele não utilizasse ainda a expressão auto-administração $(\text { Selbstverwaltung })^{351}$, que viria a ser consagrada pelos diplomas posteriores, esta lei conferia

\footnotetext{
350 Como ressaltam Andreas J. KRELL. Diferenças do conceito, desenvolvimento e conteúdo da autonomia municipal na Alemanha e no Brasil. Revista de Informação Legislativa, Brasília, ano 32, no 128, out/dez. 1995, p. 107, Thorsten Ingo SCHMIDT. Kommunalrecht. 2a Ed. Tübingen: Mohr Siebeck, 2014, p. 7 e Martin BURGI. Kommunalrecht. 4a Ed. Munique: C. H. Beck, 2012, p. 21. Note-se que este último autor, no trecho citado, também relata experiências anteriores de auto-administração e auto-determinação durante a Idade Média.

${ }^{351}$ A expressão "Selbstverwaltung" é de difícil tradução. Por um lado, "Verwaltung" significa administração e quanto a isto não há maiores dúvidas, ao passo que "Regierung" é a palavra alemã para governo. Portanto, "Selbstverwaltung" nada mais é do que auto-administração. Porém, ao se analisar o histórico deste instituto, principalmente quando se considera a tradicional dualidade entre sociedade e Estado que ele pressupõe, conclui-se que ele está mais próximo do self-government norte-americano. Optou-se, aqui, por uma tradução mais literal, mas espera-se que, com as ponderações que se seguirão servirão para afastar associações
} 
às cidades "o direito de resolver os seus assuntos sob sua própria responsabilidade e em seu próprio nome" ${ }^{, 352}$, partindo, para tanto, de uma dualidade entre a sociedade, organizada nestes entes locais, e o Estado prussiano ${ }^{353}$. Em segundo lugar, esta iniciativa tinha como objetivo promover um envolvimento da população com os assuntos da administração municipal, diminuindo, assim, o distanciamento entre Estados e cidadãos. Indiretamente, contudo, procurava-se fortalecer o próprio Estado da Prússia, enfraquecido diante da ameaça representada por Napoleão Bonaparte ${ }^{354}$.

Com o advento do período conhecido como Restauração, novas leis deste tipo foram editadas, desta feita reduzindo a liberdade das entidades locais. Porém, já em 1849 a autonomia municipal ganha um novo impulso por meio da previsão contida no $§ 184$ da Constituição de Paulskirche. Previa tal dispositivo que "cada município tem como direitos fundamentais da sua constituição: a) a escolha dos seus dirigentes e representantes; b) a administração independente dos assuntos municipais, com a inclusão da polícia local, sob a supervisão superior, organizada legalmente, do Estado; c) a publicação do seu orçamento municipal; d) a publicidade das audiências, como regra"355. É de se ressaltar a opção constituinte de posicionar a auto-administração municipal como um direito fundamental, o que pressupõe um certo dualismo entre sociedade e Estados nos termos supramencionados. Sabe-se que esta constituição sequer entrou em vigor; não obstante isso, ela motivou a elaboração de uma nova legislação prussiana restauradora, além de um intenso debate acadêmico. ${ }^{356}$

A próxima previsão constitucional digna de menção consiste no artigo 127 WRV tendo em vista que a Constituição Imperial de 1871 silenciou-se a respeito, deixando o assunto para ser regulamentado pelos Estados-membros - o qual assegurava a autonomia municipal nos seguintes termos: "Municípios e associações de Municípios possuem o direito

apressadas com a noção brasileira de auto-administração, inegavelmente mais restrita que a expressão alemã em comento.

352 BURGI. Kommunalrecht, p. 21.

${ }^{353}$ Como ressalta Andreas J. KRELL, "o criador deste diploma legal histórico, Freiherr von Stein, ainda partiu da premissa da distinção estrita entre a administração do poder público, encarnado no Rei da Prússia e os órgãos de um estado de polícia (Polizeistaat) e, por outro lado, as atividades administrativas e iniciativas políticas dos próprios cidadãos nos seus respectivos municípios" (Diferenças do conceito, desenvolvimento e conteúdo da autonomia municipal, p. 107).

${ }^{354}$ SCHMIDT. Kommunalrecht, pp. 7-8 e BURGI. Kommunalrecht, p. 21.

355 No original: "Jede Gemeinde hat als Grundrechte ihrer Verfassung: a) die Wahl ihrer Vorsteher und Vertreter; b) die selbständige Verwaltung ihrer Gemeindeangelegenheiten mit Einschluss der Ortspolizei, unter gesetzlich geordneter Oberaufsicht des Staates; c) die Veröffentlichung ihres Gemeindehaushaltes; d) Oeffentlichkeit der Verhandlungen als Regel". A versão da Constituição de Paulskirche utilizada neste tópico pode ser consultada em DÜRIG, RUDOLF. Texte zur deutschen Verfassungsgeschichte, pp. 94-134.

${ }^{356}$ Como ressalta SCHMIDT. Kommunalrecht, pp. 9-10. 
de auto-administração dentro dos limites da lei”357. Em mais uma manifestação clara da influência da Constituição de Paulskirche, esta previsão foi inserida na parte da Constituição de Weimar dedicada aos direitos fundamentais ${ }^{358}$, dando a entender que a autonomia municipal seria novamente assegurada nestes termos. Porém, prevaleceu o entendimento de que se estava diante de uma garantia institucional de auto-administração. Em virtude disso, como ressalta Thorsten Ingo SCHMIDT, os Municípios não gozariam de uma proteção subjetiva individual contra medidas do legislador, e nem possuiriam o direito de executar determinadas tarefas. Porém, o legislador também não poderia limitar a auto-administração municipal de tal modo a retirar destes entes locais a oportunidade de uma atuação efetiva ${ }^{359}$. No decorrer da vigência desta constituição alemã, a forte crise econômica acabou por esgotar financeiramente os Municípios, levando muitos deles ao colapso. Somente na Prússia, mais de 600 comissários estatais foram enviados aos Municípios, como ressalta Martin BURGI, o que certamente levou a uma restrição os poderes de auto-administração. ${ }^{360}$ Finalmente, com a ascensão do nacional-socialismo, a autonomia municipal, juntamente com grande parte das instituições do Estado de Direito, caiu por terra. ${ }^{361}$

A Lei Fundamental de 1949 trata da auto-administração municipal no seu artigo 28 GG, dentro do capítulo sobre "a União e os Estados"362. Conforme o parágrafo primeiro deste dispositivo, "nos Estados, nas circunscrições e nos Município o povo deve ter uma representação, que é resultante do voto geral, direto, livre, igual e secreto". Além do mais,

\footnotetext{
357 No original: "Gemeinden und Gemeindeverbände haben das Recht der Selbstverwaltung innerhalb der Schranken der Gesetze".

358 Mais precisamente, na seção dedicada à disciplina da vida comunitária, inserida dentro da parte intitulada "direitos fundamentais e deveres fundamentais dos alemães".

359 SCHMIDT. Kommunalrecht, p. 12.

360 BURGI. Kommunalrecht, p. 25.

361 A evolução do direito municipal durante o nacional-socialismo é brevemente relatada em BURGI. Kommunalrecht, pp. 25-25 e SCHMIDT. Kommunalrecht, pp. 13-14.

362 Sobre a evolução promovida pela Lei Fundamental de 1949, ressalta Andreas J. KRELL que "no final da República de Weimar, com o surgimento da teoria da 'garantia institucional' do município, a doutrina jurídica começou a abandonar dogmaticamente a teoria do dualismo rígido entre a sociedade e os entes locais num lado, e o Estado com os órgãos governamentais no outro. Essa ideia foi totalmente superada em 1949 pela Lei Fundamental (Grundgesetz) de Bonn que consagrou a auto-administração municipal como um dos princípios constitucionais básicos da estrutura organizacional do novo Estado alemão" (Diferenças do conceito, desenvolvimento e conteúdo da autonomia municipal, p. 109). Atualmente, é pacífico o entendimento de que auto-administração municipal é uma garantia institucional e não um direito fundamental. Nesse sentido, vide Horst DREIER. Artikel 28 [Homogenitätsgebot; kommunale Selbstverwaltung]. In: Horst DREIER (Hrsg.). Grundgesetz - Kommentar. Band II: Artikel 20-82. 2a Ed. Tübingen: Mohr Siebeck, 2006, p. 645, Michael NIERHAUS. Artikel 28 [Verfassungsmässige Ordnung in den Ländern, Wahlrecht, kommunale Selbstverwaltung, Gewährleistung durch den Bund]. In: Michael SACHS (Hrsg.). Grundgesetz - Kommentar. 7ạ Ed. Munique: C. H. Beck, 2014, p. 1048. Nos manuais de direito municipal consultados, referido posicionamento é mencionado em BURGI. Kommunalrecht, p. 49 e SCHMIDT. Kommunalrecht, p. 22.
} 
"nos municípios, uma assembleia municipal pode tomar o lugar do corpo eleito". Percebase como a constituição não faz exatamente uma opção sobre o modo pelo qual o componente político dos municípios, resultante do voto popular, e a administração dos seus respectivos serviços se relacionam. Exatamente por isso, os Estados alemães, a quem a regulamentação deste relacionamento específico foi relegado, optaram por uma multiplicidade de arranjos. Como observa Andreas J. KRELL,

"Na Alemanha existem nada menos do que quatro tipos diferentes de organização política municipal, dos quais alguns foram reformados durantes os últimos anos. Em alguns estados alemães, o prefeito (Bürgermeister) e os vereadores (Räte conselheiros) são diretamente eleitos pelo povo; em outros, os cidadãos votam apenas nos vereadores, os quais, por sua vez, elegem um integrante do conselho para ser o prefeito. Além disso, há estados onde o prefeito possui os plenos direitos de chefe do Executivo local; em outros, ele somente exerce funções representativas, enquanto a administração do município cabe a um diretor executivo (Stadtdirektor). No estado economicamente mais importante da Alemanha, na Renânia-Norte/Westfália, o governo das comunas e cidades é atribuído a uma comissão executiva (Magistrat) eleita pelo Conselho, e o prefeito é somente o diretor dessa comissão, um primus inter pares." 363

Já o artigo 28 II GG dispõe que "aos municípios deve ser garantido o direito de regulamentar todos os assuntos do interesse da comunidade local, nos limites da lei e sob sua própria responsabilidade", sendo este direito estendido, com algumas adaptações, às associações de municípios. Prossegue referido dispositivo afirmando que a autoadministração abrange a sua autonomia financeira, inclusive com a previsão de uma fonte de impostos relacionada à capacidade econômica e do direito de estabelecer a alíquota respectiva. Centremos a nossa exposição nas normas contidas neste parágrafo do artigo 28 GG, mesmo porque são elas que apresentam uma proximidade maior com as previsões contidas no artigo $30 \mathrm{CF} / 88$. Antes, contudo, são necessárias breves considerações sobre quais são efetivamente os entes municipais na Alemanha, que certamente não se resumem às Gemeinden, traduzidas aqui como Municípios ${ }^{364}$. Além do mais, é importante ter uma

\footnotetext{
363 KRELL. Diferenças do conceito, desenvolvimento e conteúdo da autonomia municipal, p. 116.

364 Aqui uma observação importante sobre a correta tradução de Gemeinde. Nos dicionários jurídicos consultados, esta palavra alemã é traduzida como comunidade, município, freguesia, entre outros (nesse sentido, vide Erik JAYME, Jobst-Joachim NEUSS. Wörterbuch Recht und Wirtschaft. Band 2: DeutschPortugiesisch. 2a Ed. Munique: C. H. Beck, 2013, p. 185). Uma tradução mais literal resultaria na escolha da palavra comunidade. Com efeito, Gemeinde vem de Gemein, que remete a algo comum. Porém, é de se admitir que comunidade é vocábulo de sentido bem equívoco, não possuindo um sentido técnico-jurídico preciso, ao contrário do que ocorre com a expressão Município. Por isso, optou-se por traduzir Gemeinde como Município, o que pode gerar alguns equívocos iniciais, tendo em vista que esta palavra portuguesa, no seu sentido técnicojurídico, remete a um ente federativo, dotado de autonomia política, administrativa e financeira. Porém, como ainda se terá a oportunidade de analisar nesta tese, a auto-administração das Gemeinden, garantida pelo artigo 28 ॥ GG, apresenta muitos pontos em comum com a autonomia federativa conferida ao Município brasileiro.
} 
visão geral sobre quantos são, qual o seu tamanho em regra, e como estão distribuídos os Municípios na Alemanha.

Quanto à primeira destas questões, ao se procurar por manuais de direito municipal depara-se com a expressão Kommunalrecht, que pode ser traduzida como "direito das comunas" (Kommunen - comunas; Recht - direito). Não obstante isso, a Lei Fundamental e também as constituições estaduais ${ }^{365}$ referem-se às Gemeinden e às Gemeindeverbände, traduzidas nesta tese como "Municípios" e "associações de Municípios". Finalmente, a constituição alemã também se refere às Kreise, ou Landkreise, as quais podem ser traduzidas como "circunscrições estaduais". Todas estas expressões revelam fenômenos distintos, o que naturalmente enseja alguns esclarecimentos.

Segundo Thorsten Ingo SCHMIDT, comuna (Kommune) consiste em um gênero, que abarca os Municípios, as circunscrições estaduais, e outras associações de Municípios. Os Municípios (Gemeinde), por sua vez, são as organizações comunais do grau mais baixo. Consistem normalmente em agrupamentos de pequeno porte; não obstante isto, já são agraciados com a garantia de auto-administração nos termos do artigo 28 II GG. Os Municípios, por sua vez, costumam ser agrupados em circunscrições estaduais (Landkreise), que são as organizações comunais de grau intermediário, caracterizando-se tanto como entidades territoriais de pessoas quanto entidades territoriais de municípios. Na prática, uma circunscrição estadual costuma compreender entre dez e trinta Municípios. No nível intermediário também se situam as cidades livres de circunscrição (kreisfreie Städte), que exercem simultaneamente as tarefas de um Município e de uma circunscrição estadual, o que acaba por lhes conferir maiores possibilidades de decisão. Há ainda outras associações de Municípios dignas de menção, como as associações conhecidas como Stadt-UmlandVerbände, que seriam compostas por uma grande cidade e os Municípios vizinhos ${ }^{366}$. Seria, portanto, o instituto mais próximo das regiões metropolitanas brasileiras, previstas no artigo $25, \S 3^{\circ}, \mathrm{CF} / 88$.

As circunscrições estaduais e as cidades livres de circunscrição, enquanto associações de Municípios (Gemeindeverbände), também possuem a garantia da autoadministração em virtude da disposição contida no artigo 28 II 2 GG. O tema será retomado

\footnotetext{
365 Neste sentido, vide os artigos 10 a 12 da Constituição da Baviera, disponíveis na internet no seguinte endereço: http://gesetze-bayern.de/Content/Document/BayVerf/true. Acesso: 21/01/2016.

${ }^{366}$ SCHMIDT. Kommunalrecht, pp. 1 e 66-69. Quando se afirma que as circunscrições são entidades territoriais tanto de pessoas quanto de municípios, quer-se chamar a atenção para o fato de que, embora consistente no agrupamento de municípios, estas circunscrições caracterizam-se como associações de pessoas. Os seus membros, como ressalta Martin BURGI, são as pessoas que moram no território da circunscrição e não os Municípios que a ela pertencem (Kommunalrecht, pp. 305-306).
} 
oportunamente. De todo modo, considera-se importante ressaltar dois dados importantes sobre o assunto. Em primeiro lugar, em virtude de os Municípios na Alemanha serem regulamentados por legislação estadual, existem associações de Municípios não contempladas pelos manuais de direito municipal com uma pretensão mais geral, que foram os manuais consultados para a elaboração deste tópico. Em segundo lugar, nem todas estas associações são agraciadas com a garantia da auto-administração prevista no artigo 28 II GG e complementada pelas legislações estaduais. Os distritos governamentais (Regierungsbezirke), por exemplo, são considerados meras circunscrições administrativas, e não organizações municipais propriamente ditas ${ }^{367}$. Mesmo as Stadt-Umland-Verbände podem ou não administrar os assuntos sob sua própria responsabilidade, conforme ainda será analisado nesta tese $\mathrm{e}^{368}$.

Atualmente, a Alemanha possui 11.116 Municípios e 402 circunscrições estaduais e cidades livres de circunscrição. A fim de fornecer uma compreensão geral dos Municípios alemães, elaborou-se a seguinte tabela a partir de dados extraídos do sítio do Departamento Federal de Estatística:

\begin{tabular}{|l|r|r|r|r|}
\hline \multicolumn{4}{|c|}{ MUNICÍPIOS ALEM ÃES E SUA POPULAÇÃO, CONFORME O CENSO DE 2011 } \\
\hline Faixas de habitantes & $\begin{array}{c}\text { Número de } \\
\text { Municípios }\end{array}$ & $\begin{array}{c}\text { Número de } \\
\text { Municípios (\%) }\end{array}$ & Habitantes & \multicolumn{1}{|c|}{$\begin{array}{r}\text { Habitantes } \\
(\%)\end{array}$} \\
\hline Abaixo de 100 & 202 & 1,82 & 13.089 & 0,02 \\
\hline De 100 a 200 & 466 & 4,19 & 71.175 & 0,09 \\
\hline De 200 a 500 & 1.547 & 13,92 & 535.074 & 0,66 \\
\hline De 500 a 1.000 & 1.859 & 16,72 & 1.364 .927 & 1,68 \\
\hline De 1.000 a 2.000 & 1.903 & 17,12 & 2.727 .435 & 3,36 \\
\hline De 2.000 a 3.000 & 1.050 & 9,45 & 2.584 .363 & 3,18 \\
\hline De 3.000 a 5.000 & 1.191 & 10,71 & 4.626 .071 & 5,70 \\
\hline De 5.000 a 10.000 & 1.344 & 12,09 & 9.550 .951 & 11,76 \\
\hline De 10.000 a 20.000 & 877 & 7,89 & 12.185 .891 & 15,01 \\
\hline
\end{tabular}

\footnotetext{
367 SCHMIDT. Kommunalrecht, p. 69.

${ }^{368}$ A autonomia das associações de Municípios será analisada com maiores detalhes no item 7.4.3 desta tese. 369 Fonte: STATISTISCHES BUNDESAMT. Gemeindeverzeichnis: Gemeinde nach Bundesländern und Einwohnergrösserklassen am 31.12.2014. Disponível em: https://www.destatis.de/DE/ZahlenFakten/LaenderRegionen/Regionales/Gemeindeverzeichnis/Administrativ /Aktuell/08GemeindenEinwohnergroessen.html. Acesso: 21/01/2016.
} 


\begin{tabular}{|l|r|r|r|r|}
\hline De 20.000 a 50.000 & 493 & 4,44 & 14.864 .611 & 18,31 \\
\hline De 50.000 a 100.000 & 107 & 0,96 & 7.305 .633 & 9,00 \\
\hline De 100.000 a 200.000 & 38 & 0,34 & 5.174 .873 & 6,37 \\
\hline De 200.000 a 500.000 & 25 & 0,22 & 6.738 .385 & 8,30 \\
\hline Mais de 500.000 & 14 & 0,13 & 13.455 .059 & 16,57 \\
\hline TOTAL & $\mathbf{1 1 . 1 1 6}$ & $\mathbf{1 0 0}$ & $\mathbf{8 1 . 1 9 7 . 5 3 7}$ & $\mathbf{1 0 0}$ \\
\hline
\end{tabular}

Da tabela extrai-se que parte relevante dos alemães - mais precisamente, $45,13 \%$ reside em localidades com população entre 5.000 a 50.000 habitantes. A porção que reside em Municípios com mais de 500.000 habitantes é relevante (16,57\%), mas não é algo desproporcional (como ocorre no caso brasileiro). É de se atentar ainda para o número total de Municípios alemães, o que confirma o argumento de Marta ARRETCHE, exposto no item 2.1.3, de que o número de Municipalidades brasileiras não é, de fato, tão elevado, principalmente quando se leva em consideração as proporções continentais do Brasil.

Prosseguindo com a exposição, esta concentração da população alemã em Municípios pequenos ou médios pode ser verificada na maioria dos Länder. Na Baviera, por exemplo, 59,08\% reside em Municípios com população entre 5.000 e 50.000 habitantes; em Baden-Württemberg este percentual é de 57,72; em Hessen, de 53,04. Já o número de Municípios por Länder varia bastante. A Renânia-Palatinado é o Estado com o maior número de Municípios, 2.305, seguido da Baviera, com 2.056 Municípios, Schleswig-Holstein, com 1.110 Municípios, e Baden-Württemberg, com 1.101 Municípios. Não é possível observar uma proporção entre população e número de Municípios: com efeito, a Renânia-Palatinado possui 4.011.582 habitantes, ao passo que a Baviera possui 12.691.568; o Estado mais populoso da Alemanha, Renânia do Norte-Westfália, possui uma população de 17.638.098 habitantes e apenas 396 Municípios. ${ }^{370}$

No que diz respeito às circunscrições estaduais e cidades livres de circunscrições, não se obtiveram dados organizados como na tabela supra. Porém, ao se analisar os dados disponíveis no Departamento Federal de Estatística, constata-se que em poucos casos a população destas organizações é inferior a 50.000 habitantes ${ }^{371}$, sendo que o normal é encontrar circunscrições com número de habitantes entre 100.000 e 300.000 , chegando em

\footnotetext{
370 Fonte: STATISTISCHES BUNDESAMT. Gemeindeverzeichnis: Gemeinde nach Bundesländern und Einwohnergrösserklassen am 31.12.2014. Disponível em: https://www.destatis.de/DE/ZahlenFakten/LaenderRegionen/Regionales/Gemeindeverzeichnis/Administrativ /Aktuell/08GemeindenEinwohnergroessen.html. Acesso: 21/01/2016.

${ }^{371}$ A maioria situada na Baviera, que possui 96 circunscrições e cidades livres.
} 
alguns casos a 500.000 habitantes. Ultrapassam 1.000.000 de habitantes somente as grandes cidades alemãs, como Munique, Hannover, Colônia e Berlin. O número de Kreise e de kreisfreie Städte também variam de Estado para Estado. Schleswig-Holstein, por exemplo, conta com apenas 15 organizações deste tipo, ao passo que a Renânia do Norte-Westfália com 22 cidades livres de circunscrição e 31 circunscrições estaduais. ${ }^{372}$

Feito este panorama das organizações municipais na Alemanha, é chegado o momento de tecer algumas considerações sobre a garantia de auto-administração consagrada no artigo 28 II GG. Para tanto, utiliza-se de uma construção forjada por Klaus STERN ${ }^{373}$ e que foi encampada pela doutrina alemã, a qual divide a referida garantia em três níveis ou planos. Em primeiro lugar, a garantia institucional prevista no dispositivo constitucional em comento seria uma garantia institucional de personalidade jurídica (institutionelle Rechtssubjektsgarantie), ou em outras palavras, uma garantia de existência de Municípios como pessoas jurídicas de direito público integrantes da organização administrativa dos Estados-membros. Municípios não podem ser completamente suprimidos ou então transformados em simples estruturas administrativas sem qualquer independência, como explica Horst DREIER. ${ }^{374}$ Porém, não se pode extrair destas considerações uma garantia de existência dos Municípios individualmente considerados, pois fusões, desmembramentos e outras alterações são consideradas possíveis, desde que fundamentadas no bem comum e desde que ouvido o Município atingido. ${ }^{375}$ Não se está diante, portanto, de uma garantia individual, mas sim de uma garantia do Município enquanto instituição fundamental e basilar do Estado alemão.

Em segundo lugar, a auto-administração do Município também se desdobra em uma garantia objetiva de instituição jurídica (objektive Rechtsintitutionsgarantie), a qual abrange "todos os assuntos do interesse da comunidade local, nos limites da lei e sob sua própria responsabilidade" (artigo 28 II GG). Está-se, portanto, diante do cerne da garantia conferida pela Lei Fundamental alemã aos Municípios, razão pela qual ela merece maior detalhamento.

\footnotetext{
372 Fonte: STATISTISCHES BUNDESAMT. Gemeindeverzeichnis: Kreisfreie Städte und Landkreise nach Fläche, Bevölkerung und Bevölkerungsdichte am 31.12.2014. Disponível em: https://www.destatis.de/DE/ZahlenFakten/LaenderRegionen/Regionales/Gemeindeverzeichnis/Administrativ /Aktuell/04Kreise.html. Acesso: 21/01/2016.

373 Klaus STERN. Das Staatsrecht der Bundesrepublik Deutschland. Band I - Grundbegriffe und Grundlagen des Staatsrechts, Strukturprinzipien der Verfassung. 2a Ed. Munique: C. H. Beck'sche Verlagsbuchhandlung, 1984, p. 409. Na literatura brasileira, referida construção teórica é mencionada em Thiago MARRARA. Do modelo municipal alemão aos problemas municipais brasileiros. Revista brasileira de Direito Municipal-RBDM, ano 9, n. 27, jan./mar. 2008, pp. 38-39.

${ }^{374}$ DREIER. Artikel 28. In: DREIER (Hrsg.). Grundegesetz, p. 653.

${ }^{375}$ Como ressalta DREIER. Artikel 28. In: DREIER (Hrsg.). Grundegesetz, p. 653 e 667.
} 
Percebe-se, primeiramente, que a constituição alemã também circunscreve a atuação dos Municípios aos assuntos de interesse local, ou como consta do texto constitucional, "aos assuntos da comunidade local". Segundo o Tribunal Constitucional Federal alemão, em trecho que é citado por muitos dos autores consultados, "assuntos da comunidade local são aquelas necessidades e interesses que se enraízam na comunidade local ou que tenham com ela uma referência específica, que são comuns aos moradores da comunidade como tais, posto que eles dizem respeito à vida em comum e ao morar junto na comunidade política" ${ }^{376}$. Trata-se de uma definição que confere aos Municípios um campo de atuação amplo, ao mesmo adaptável a alterações fáticas e jurídicas ${ }^{377}$. Não podia ser outro modo, aliás, pois como ressalta Michael NIERHAUS, “em virtude da diferença no número de habitantes, extensão territorial, bem como nas estruturas econômica e social dos Municípios, os assuntos locais não se deixam explicar em um círculo de tarefas válido para todos os tempos" ${ }^{378}$ Não há, portanto, um rol taxativo de atividades consideradas de interesse local. De todo modo, é importante atentar para como este conceito consagra uma presunção de competência, como ressalta Horst DREIER, a partir de uma decisão da corte constitucional alemã. Nesse sentido, a garantia consubstanciada no artigo 28 II GG não contempla um catálogo determinado e exaustivo de tarefas municipais; porém, ela autoriza o Município a exercer todas aquelas tarefas que não tenham sido atribuídas por lei a outros entes da administração, sem a necessidade de se lastrear em um título competencial específico $^{379}$. Finalmente, embora a Lei Fundamental fale apenas nas atividades de interesse da comunidade local, muitas constituições estaduais estabelecem a competência dos Municípios sobre toda a administração pública nos seus respectivos territórios ${ }^{380}$. Isso é possível, por sua vez, porque os entes municipais compõem a própria administração estadual. Neste caso, ao invés de o Estado instituir uma estrutura própria para a execução de determinados serviços - o que compreende a criação de autoridades (Behörden) tanto

\footnotetext{
376 BVerfGE 79, 127 (151-152). No original: "Hiernach sind Angelegenheiten der örtlichen Gemeinschaft diejenigen Bedürfnisse und Interessen, die in der örtlichen Gemeinschaft wurzeln oder auf sie einen spezifischen Bezug haben, die also den Gemeindeeinwohnern gerade als solchen gemeinsam sind, indem sie das Zusammenleben und -wohnen der Menschen in der (politischen) Gemeinde betreffen". Definição citada por DREIER. Artikel 28. In: DREIER (Hrsg.). Grundegesetz, p. 657, NIERHAUS. Artikel 28. In: SACHS (Hrsg.). Grundgesetz, pp. 1050 e Hans D. JARASS, Bodo PIEROTH. Grundgesetz für die Bundesrepublik Deutschland: Kommentar. 12a Ed. Munique: C. H. Beck, 2012, p. 627.

377 NIERHAUS. Artikel 28. In: SACHS (Hrsg.). Grundgesetz, p. 1051

378 NIERHAUS. Artikel 28. In: SACHS (Hrsg.). Grundgesetz, p. 1051. No original: „Wegen der unterschiedlichen Einwohnerzahl, flächenmässigen Ausdehnung sowie Wirtschafts- und Sozialstruktur der Gemeinden lassen sich die örtlichen Angelegenheiten nicht als ein für alle Zeit festsehender Aufgabenkreis umschreiben".

379 DREIER. Artikel 28. In: DREIER (Hrsg.). Grundegesetz, p. 658, neste ponto citando a ementa da BVerfGE 79, 127.

380 DREIER. Artikel 28. In: DREIER (Hrsg.). Grundegesetz, p. 658.
} 
regionais quanto locais, as chamadas Mittelbehörden e Unterbehörden - ele transfere aos Municípios as atribuições que seriam executadas pelos níveis locais de sua administração, e permanece somente com as estruturas regionais. ${ }^{381}$

A garantia objetiva de instituição jurídica abrange ainda a execução dos assuntos de interesse local do Município sob sua própria responsabilidade (in eigener Verantwortung). Ou como bem resume Thiago MARRARA, "no tocante às atividades de competência municipal, o ente local decidirá ainda se, quando e como as executará’382. Porém, a intensa regulamentação legal de determinadas atividades executadas pelos Municípios por parte da União e dos Estados pode reduzir esta margem de liberdade; além do mais, em relação às chamadas tarefas obrigatórias, os Municípios detêm autonomia para determinar apenas o modo pelo qual elas serão levadas a cabo, tendo em vista que o "se" a tarefa será executada é uma questão que sequer se coloca ${ }^{383}$.

Tradicionalmente alguns poderes municipais (Gemeindehoheiten) ${ }^{384}$ são associados à gestão dos assuntos de interesse local sob sua própria responsabilidade. Entre eles, estão o poder de exercer direitos de soberania sobre o próprio território, inclusive sobre as pessoas que nele se situam (Gebietshoheit); o poder de estabelecer a organização de sua própria estrutura interna e o modo pelo qual determinadas tarefas serão levadas a cabo (Organisationshoheit), e de estabelecer quais serão os seus funcionários (Personalhoheit); o poder de planejar as suas atividades em geral, em especial, a ocupação do seu território (Plannungshoheit); o poder de conduzir as suas receitas e despesas sob sua própria responsabilidade (Finanzhoheit), entre outros. ${ }^{385}$

\footnotetext{
${ }^{381}$ Conforme Hans Peter BULL e Veith MEHDE, os Estados contam com poucas estruturas locais próprias, pois os Municípios e as associações de Municípios tendem a colocar as suas instituições à disposição dos Estados (Hans Peter BULL, Veith MEHDE. Allgemeines Verwaltungsrecht mit Verwaltungslehre. 8a Ed. Heidelberg: C. F. Müller, 2009, p. 54).

382 MARRARA. Do modelo municipal alemão aos problemas municipais brasileiros, p. 39. Definição semelhante pode ser encontrada em NIERHAUS. Artikel 28. In: SACHS (Hrsg.). Grundgesetz, p. 1055, DREIER. Artikel 28. In: DREIER (Hrsg.). Grundegesetz, p. 659 e Peter J. TETTINGER, Kyrill-A. SCHWARZ. Artikel 28. In: Hermann von MANGOLDT, Friedrich KLEIN, Christian STARCK (Hrgs). Kommentare zum Grundgesetz. Band II: Artikel 20-82. 6a Ed. Munique: Franz Vahlen, 2010, p. 613.

${ }^{383}$ Como ressalta DREIER. Artikel 28. In: DREIER (Hrsg.). Grundegesetz, p. 659.

384 Note-se que a expressão Hoheit costuma ser traduzida como soberania em português. Porém, neste contexto, tendo em vista ainda a percepção generalizada no Brasil que soberania é um poder que se confere apenas ao Estado brasileiro e não aos seus entes federativos, optou-se por utilizar a palavra poder, por ser mais genérica.

385 Os poderes municipais citados e as suas respectivas definições foram retirados de TETTINGER, SCHWARZ. Artikel 28. In: von MANGOLDT, KLEIN, STARCK (Hrsg.). Kommentare zum Grundgesetz, pp. 613 e ss, sendo que neste trecho é possível encontrar uma lista completa e sistematizada de todos os poderes que costumam ser atribuídos ao Município. Para considerações mais detalhadas acerca de cada um destes poderes, vide DREIER. Artikel 28. In: DREIER (Hrsg.). Grundegesetz, pp. 667 e ss.
} 
Não se pode olvidar que estes assuntos de interesse da comunidade local e que são conduzidos sob a própria responsabilidade dos Municípios encontram-se delimitados pela lei. Afinal, o artigo 28 II GG garante aos Municípios o "direito de regulamentar todos os assuntos do interesse da comunidade local nos limites da lei e sob sua própria responsabilidade". Ou seja, está-se diante de uma garantia que ganha os seus contornos definitivos pela atuação do legislador - daí ela ser adjetivada de institucional ${ }^{386}$. Quanto a isto não há maiores dúvidas, tendo em vista que é a própria Lei Fundamental que assim estabelece. A grande questão aqui consiste em saber qual lei é essa. Tendo em vista que a organização e a atividade dos Municípios não consta figura dentre as matérias atribuídas à União, tanto privativa quanto cumulativamente, tem-se que a competência legislativa aqui reside basicamente com os Estados-membros, em virtude da previsão contida no artigo 70 GG. Não poderia ser de outro modo, aliás, pois os Municípios são pessoas de direito público integrantes da administração estadual, ainda que dotadas de uma razoável autonomia. Notese apenas que a lei a que se refere o artigo 28 II GG compreende qualquer "norma jurídica estatal com eficácia exterior, leis formais federais e estaduais, bem como regulamentos; incluídos estão além disso programas de ordenação do território, estatutos de outros entes da administração e regras do direito costumeiro" 387 . Portanto, uma regulamentação federal não resta completamente excluída; porém, ela se dá somente nos casos determinados ou permitidos pela Lei Fundamental ${ }^{388}$.

O terceiro nível proposto por STERN consubstancia-se em uma garantia subjetiva de posição jurídica (subjektive Rechtsstellungsgarantie). Com efeito, os conteúdos das garantias institucionais expostos supra não consistem em meras recomendações ao legislador estadual; ao contrário, caso um Município seja atingido em sua autonomia, ele poderá invocar proteção jurisdicional, tanto das cortes estaduais quanto do próprio Tribunal Constitucional Federal. Nesse sentido, o artigo 93 I Nr. 4b GG autoriza a corte constitucional alemã a julgar "a reclamação constitucional de Municípios e associações de Municípios devido a violação do direito de auto-administração conforme artigo 28 por lei”. No caso de

\footnotetext{
${ }^{386}$ Como ressalta Martin BURGI, uma garantia é qualificada como institucional quando ela ganha forma e é concretizada pela atividade do legislador, o qual encontra-se submetido aos limites impostos pela própria garantia constitucional (Kommunalrecht, p. 49).

387 DREIER. Artikel 28. In: DREIER (Hrsg.). Grundegesetz, p. 661. No original: „Gesetz meint jede staatliche Außenrechtsnorm, förmliche Bundes- und Landesgesetze ebenso wie Rechtsverordnungen; eingeschlossen sind des weiteren Raumordnungsprogramme, Satzungen anderer Verwaltungsträger und gewohnheitsrechtliche Regeln".

${ }^{388}$ Conforme DREIER. Artikel 28. In: DREIER (Hrsg.). Grundegesetz, p. 663.
} 
a lei ser estadual, exige o referido dispositivo que uma reclamação não possa ser apresentada perante o tribunal estadual.

Neste tópico não serão abordadas todas as questões que dizem respeito aos Municípios alemães, mesmo porque isto certamente transcenderia o seu escopo, que consiste somente em fornecer uma compreensão dos principais aspectos da autonomia municipal neste país. Esta temática será novamente retomada - e novos componentes importantes serão acrescidos - no tópico derradeiro desta tese. Por ora, considera-se oportuno terminar este item com algumas considerações sobre a autonomia financeira dos entes locais na Alemanha. Sabe-se que o artigo 28 II GG assegura aos Municípios "fundamentos de sua autonomia financeira", o que abrange inclusive uma fonte de impostos relacionadas à capacidade econômica e o direito de estabelecer alíquotas sobre esta fonte de impostos. Segundo Thorsten Ingo SCHMIDT, tal previsão assegura aos entes municipais o direito de estabelecer as alíquotas do imposto predial (Grundsteuer) e do imposto industrial (Gewerbesteuer). Deve-se ressaltar que os Municípios participam ainda das receitas de impostos federais e comuns, como o imposto sobre valor agregado (Umsatzsteuer) e o imposto de renda (Einkommenssteuer). Finalmente, muitas constituições estaduais estabelecem que aos Municípios só podem transferidas tarefas, quando estas transferências vêm acompanhadas de determinações sobre o seu financiamento. É o que se convenciona chamar de princípio da conexão (Konnexitätsprinzip). ${ }^{389}$ Porém, os autores consultados costumam fazer referência às dificuldades financeiras dos Municípios, oriundas sobretudo do aumento de atribuições sem uma respectiva fonte de financiamento. Nesse sentido, as observações de Andreas J. KRELL, bem atuais mesmo depois de transcorridas quase duas décadas:

\footnotetext{
"Aliás, é frequente os municípios se queixarem que o reembolso estadual não costuma chegar a cobrir, de fato, as despesas que acarretam para os entes locais. O município alemão tem, pois, um 'duplo caráter': é entidade da autoadministração e, ao mesmo tempo, órgão executor do seu respectivo estado federado.

$\mathrm{Na}$ verdade, o volume das funções delegadas exercidas pelo município alemão, tornam-se cada vez maior, convertendo o município, cada vez mais, em instância local do estado. Por outro lado, os municípios preferem executar tarefas estaduais com seus próprios servidores a admitir a instituição de uma série de órgãos estaduais específicos no seu território, o que certamente iria destruir a unidade de administração pública"390
}

\footnotetext{
389 SCHMIDT. Kommunalrecht, pp. 29-30.

390 KRELL. DIferenças do conceito, desenvolvimento e conteúdo da autonomia municipal, p. 118.
} 


\subsubsection{A representação dos Länder no Conselho Federal (Bundesrat)}

No tópico 1.6.1 posicionou-se a Câmara representativa dos Estados-membros no Poder Legislativo federal como uma instituição essencial do Estado Federal e propuseramse dois modelos teóricos: o Senado Federal e o Conselho Federal. Longe de ser meramente didática, esta foi uma distinção que informou as discussões do Conselho Parlamentar que aprovou a Lei Fundamental alemã. Como ressalta MUßGNUG, a SPD era favorável à adoção de um Senado, cujas atribuições compreenderiam somente um direito de veto em relação aos projetos de lei aprovados pelo Parlamento Federal (Bundestag) e era neste ponto seguido em parte pelos representantes da CDU do norte da Alemanha, os quais desejavam que o órgão de representação dos Länder fosse chamado a aprovar as leis federais, e não a apresentar somente uma objeção a elas. Já os representantes da CDU do sul da Alemanha e da CSU eram a favor de um Conselho Federal e da necessidade da sua aprovação em relação a todos os projetos votados no Parlamento Federal. Após alguma divergência, prevaleceu uma solução intermediária, qual seja: como regra geral, o Conselho Federal poderia apenas manifestar a sua objeção em relação aos projetos aprovados pela Câmara representativa do povo; em relação a algumas matérias expressamente determinadas pela Constituição, contudo, a aprovação do Conselho Federal seria essencial para a entrada em vigor da lei. ${ }^{391}$ Em outras palavras e levando em consideração o que já foi exposto na parte relativa ao histórico da federação alemã, pode-se afirmar que o atual Conselho Federal foi forjado como um meio termo entre o poderoso Bundesrat da Constituição Imperial de 1871 e o enfraquecido Reichsrat da Constituição de Weimar. ${ }^{392}$

Conforme o artigo 51 I GG, o Conselho Federal é composto por membros pertencentes e escolhidos pelos governos estaduais, podendo ser exonerados, substituídos ou mesmo fazerem representar-se por outrem. Ou seja, não há que se falar em eleição direta pelo povo, ou mesmo de eleição indireta, quando se trata do órgão de representação dos Estados-membros na federação alemã: o meio pelo qual se passa a fazer parte deste Conselho é a nomeação por parte do Poder Executivo de um Land, sendo que cabe a cada constituição estadual definir quem será considerado membro do seu governo ou

\footnotetext{
391 MUßGNUG. \& 8 - Zustandekommen des Grundgesetzes In: ISENSEE, KIRCHHOF (Hrsg). Handbuch des Staatsrechts, pp. 339-340. O mesmo impasse é brevemente relatado em Diether POSSER. CAPÍTULO XIII Significado del Bundesrat. In: Ernst BENDA; Wener MAIHOFER, Hans-Jochen VOGEL; Konrad HESSE, Wolfgang HEYDE. Manual de Derecho Constitucional. Trad. Antonio López Pina. 2aㅡ. Ed. Madrid e Barcelona: Marcial Pons, 2001, p. 681.

${ }^{392}$ A afirmação de que o Conselho Federal é um meio termo entre as Constituições alemãs de 1871 e 1919 é relativamente frequente na doutrina alemã, muito embora dela não se possa extrair uma influência direta destas duas constituições sobre o texto da Lei Fundamental de 1949. À guisa de exemplo, cita-se Peter BADURA e Diether POSSER, citados a seguir.
} 
não para este fim. Como decorrência, o funcionamento deste Conselho não compreende legislaturas, sendo um órgão constitucional permanente, como bem ressalta Dieter POSSER. ${ }^{393}$

É importante observar - e neste ponto reside uma diferença importante em relação ao sistema senatorial - que o número de representantes por Estado varia conforme a população. Nos termos do artigo 51 II GG, “cada Land tem pelo menos três votos [no Conselho Federal], Länder com mais de dois milhões de habitantes tem quatro [votos], Länder com mais de seis milhões de habitantes cinco [votos], Länder com mais de sete milhões de habitantes seis [votos]." ${ }^{394}$ Nos dias atuais, isso significa dizer Bremen, Hamburgo, Mecklenburg-Vorpommern e Saarland têm três vozes no Conselho Federal; Berlin, Brandenburgo, Hessen, Rheinland-Pfalz, Saxônia, Saxônia-Anhalt, SchleswigHolstein, Thüringen são representados por quatro vozes, e finalmente; Baden-Württemberg, Baviera, Niedersachsen, Nordhein-Westfalen têm seis vozes no Conselho Federal. Como ressalta Peter BADURA, esta é uma norma que privilegia os menores Estados-membros em relação aos Estados maiores no que tange a sua representação no âmbito federal e, neste ponto, representa uma justificável predominância do componente federativo em detrimento do democrático. ${ }^{395}$

As atribuições do Conselho Federal, por sua vez, são enunciadas em termos genéricos no artigo 50 GG. Segundo este dispositivo da Lei Fundamental alemã, "por meio do Conselho Federal os Länder participam do Poder Legislativo e na Administração do Bund e nos assuntos da União Europeia." ${ }^{396} \mathrm{Na}$ sua redação originária, o artigo 50 GG tratava

\footnotetext{
393 POSSER. Capítulo XIII - Significado del Bundesrat, p. 682.

${ }^{394}$ No original: "Artikel 51 (2) GG. Jedes Land hat mindestens drei Stimmen, Länder mit mehr als zwei Millionen Einwohners haben vier, Länder mit mehr als sechs Millionen Einwohner fünf, Länder mit mehr als sieben Millionen Einwohnern sechs Stimmen."

395 BADURA. Staatsrecht, p. 568. O número atual de representantes por Estado mencionado neste parágrafo também foi retirado deste mesmo trecho citado e também pode ser visualizado no próprio sitio eletrônico do Conselho Federal (http://www.bundesrat.de/DE/bundesrat/laender/laender-node.html. Acesso: 17/03/2015). Note-se, ademais, que o artigo 51 (2) não promove uma igualação ou uma equiparação entre os maiores e os menores Estados da federação alemã, mas deseja apenas aproximá-los no que tange à sua representação - e, consequentemente, a sua possibilidade de influência - no processo legislativo federal.

${ }^{396}$ No original: "Artikel 50. Durch den Bundesrat wirken die Länder bei der Gesetzgebung und Verwaltung des Bundes und in Angelegenheiten der Europäischen Union mit." Ao comentar este dispositivo, Roman HERZOG Ihe dirige duas críticas. A primeira delas consiste no fato de que ele, mesmo contando com uma redação genérica, não abarca todas as tarefas que são atribuídas ao Conselho Federal - a possibilidade de este participar da escolha dos juízes do Tribunal Constitucional Federal e desta forma exercer uma influência sobre o Poder Judiciário, por exemplo, não se encontra compreendida na redação do artigo 50 GG - além de restringir o conceito de Poder Executivo à ideia de Administração. Em segundo lugar, o artigo 50 GG diz muito pouco sobre a intensidade e a forma pela qual o Conselho Federal participa dos Poderes Legislativo e Executivo do Bund. Estes são dados que só podem ser efetivamente visualizados por meio de uma análise sistemática das diversas normas da Lei Fundamental que tratam das atribuições deste órgão constitucional (Roman
} 
apenas da participação dos Estados nos Poderes Legislativo e Executivo da União. Contudo, em virtude do aumento das normatizações advindas da comunidade europeia e da sua influência sobre os Estados-membros, estes últimos lograram finalmente obter o direito de integrarem o processo decisório no que tange aos assuntos da União Europeia, o que se dá essencialmente nos termos do artigo $23 \mathrm{GG} .{ }^{397}$

A participação do Conselho Federal no processo legislativo federal se dá, como já se anteviu, pela necessidade de sua aprovação em relação a algumas leis (as chamadas Zustimmungsgesetze) ou a possibilidade de exercer o seu veto ou a sua objeção em relação às demais (denominadas de Einspruchsgesetze). Note-se que todas as leis devem ser aprovadas pelo Parlamento Federal e posteriormente encaminhadas à instância de representação dos Estados-membros nos termos do artigo 77 GG, para que esta aprove ou vete o texto aprovado pela câmara de representação popular, conforme o caso. ${ }^{398}$

HERZOG. § 58 Aufgaben des Bundesrates. In: Josef ISENSEE; Paul KIRCHHOF (Coord). Handbuch des Staatsrechts der Bundesrepublik Deutschland. 3ㅇVolume: Demokratie - Bundesorgane. 3a Ed. Heildelberg: C. F. Müller, 2003, p. 966).

397 De acordo com o artigo 23 I GG, a transferência de "direitos de soberania" (Hoheitsrechte) à União depende da aprovação do Conselho Federal. Já o artigo 23 IV GG dispõe que "o Conselho Federal deve participar da formação de vontade da União, à medida que ele devesse participar em uma medida interna correspondente ou à medida que os Länder fossem competentes internamente". O artigo 23 V GG determina, por sua vez, que "à medida que os interesses dos Länder em uma área de competência privativa do Bund são afetados ou à medida que, de resto, a União detenha o direito à legislação, o governo federal deve considerar a posição do Conselho Federal. Se os poderes legislativos dos Länder, a instituição de autoridades estaduais ou seu procedimento administrativo forem afetados em seu núcleo, deve a formação de vontade do Bund neste ponto considerar a opinião do Conselho Federal de modo decisivo".

398 Diether POSSER traça uma visão bem esquemática das possibilidades de tramitação de uma lei no Conselho Federal e que é transcrita aqui, pois ajuda a compreender o papel que este órgão constitucional pode desempenhar na aprovação de uma lei: „Respecto de leyes aprobadas por el Bundestag, el Bundesrat tiene las siguientes posibilidades: aa) El Bundesrat presta su expresa conformidad a un proyecto de ley aprobado en el Bundestag que requiere su acuerdo; en ningún caso bastaría con su silenciosa pasividad. Cuando el proyecto consiste en una reforma constitucional, es necesaria una mayoría de dos tercios del Bundesrat (art. 79.2 GG). La conformidad del Bundesrat es condición de la aprobación de la ley. bb) El Bundesrat rehúsa su conformidad e un proyecto de ley que requiere su acuerdo. En tal caso, tanto el Bundestag como el Gobierno federal - cada uno una vez - pueden solicitar la convocatoria de la Comisión de mediación. Si luego del trámite de la Comisión de mediación mantiene el Bundesrat su rechazo, la ley no prospera. (...) cc) Cuando el Bundesrat no desea ni prestar su conformidad ni resusarla a um proyecto de ley que requiera su acuerdo, pero en cambio sí quiere enmendarla, puede convocar la Comisión de mediación. Para ello dispone de tres semanas desde que le es presentado el proyecto de ley (art. 77.2 G). Cuando discurre el plazo sin que el Bundesrat haya decidido convocar la Comisión, deberá optar entre prestar su conformidad o rehusarla. dd) En el caso de proyectos de ley que no requieran el acordó del Bundesrat, puede expresamente decidir en el plazo de tres semanas no convocar la Comisión mediadora (de ordinario), dejar correr el plazo sin decidir o retirar la solicitud de convocatoria de la Comisión - ejemplo de resolución del Bundesrat de 10 de julio de 1981 (Drucksache 288/81) -. En tales casos, la ley aprobada por el Bundestag es considerada conforme a Derecho. ee) Si el Bundesrat ha rogado la actuación de la Comisión mediadora con ocasión de una ley que no requiere la propia conformidade, quedará el resultado del trámite de mediación: las deliberaciones de la Comisión mediadora concluyen bien con una propuesta de acuerdo bien sin resultado - en los casos n que después de tres sesiones el empate bloquea una propuesta de acuerdo-." (POSSER. Capítulo XIII - Significado del Bundesrat, p. 686). 
Em tese, as leis que necessitam da aprovação do Conselho Federal deveriam ser minoria, tendo em vista que se restringem às hipóteses enumeradas na Lei Fundamental, e as leis com possibilidade de veto por parte deste Conselho deveriam corresponder à maioria da sua atuação legislativa. Contudo, não foi isso que se observou durante a vigência da constituição alemã: durante os anos de 1949 e 2013, 51\% das leis apreciadas pela câmara representativa dos Estados eram Zustimmungsgesetze e 49\% eram Einspruchgesetzte, sendo que em alguns momentos esta proporção chegou a $60 \%$ contra $40 \%$, como ressalta Diether POSSER. ${ }^{399}$

As consequências deste fenômeno são especialmente importantes, uma vez que, como os membros do Bundesrat devem observar as orientações do partido do seu respectivo governo, a maioria partidária neste órgão constitucional pode não coincidir com a maioria partidária no Parlamento Federal (Bundestag). Em um cenário como este, é completamente diferente ter que obter a maioria dos votos para conseguir aprovar uma lei e ter que obter a maioria para conseguir exercer o seu direito de veto sobre uma legislação - lembrando que, caso esta última maioria não seja obtida, a lei em questão restará aprovada.

Ressalta Fritz W. SCHARPF que este aumento do número de leis que dependem da aprovação do Conselho Federal não decorreu de uma alteração do texto da Lei Fundamental de 1949, mas sim pela via da interpretação constitucional, em especial do artigo 84 I GG, que previa a aprovação da instância representativa dos Estados na hipótese de a lei federal dispor sobre a instituição de autoridades administrativas (Einrichtung der Behörden) e sobre procedimento administrativo dos Estados-membros. ${ }^{400}$ Mais especificamente, o Tribunal Constitucional Federal decidiu que, caso um projeto de lei contivesse algum dispositivo que dissesse respeito a alguma matéria submetida à imprescindível aprovação pelo Conselho Federal, ele deveria ser aprovado como um todo por este órgão do Poder Legislativo Federal. Ou seja, mesmos as normas estranhas a sua competência deveriam aprovadas pelo Conselho Federal, de forma que a sua importância para o processo legislativo federal se tornou ainda maior. $^{401}$

Embora houvesse na doutrina quem considerasse esta sistemática uma verdadeira compensação aos Estados pela perda de competências legislativas importantes ${ }^{402}$, o fato é

\footnotetext{
399 http://www.bundesrat.de/DE/dokumente/statistik/statistik-node.html. Acesso: 17/03/2015 e POSSER. Capítulo XIII - Significado del Bundesrat, p. 683.

${ }^{400}$ SCHARPF. Föderalismusreform: kein Ausweg aus der Politikverflechtungsfalle?, p. 22. O artigo 84 I GG será objeto de maiores aprofundamentos do quinto capítulo da tese.

${ }^{401}$ Como restou decidido em BVerfGE 8, 274 (294 e ss). Para maiores detalhes, vide o item 5.5.1 desta tese.

${ }^{402}$ Como, por exemplo, HESSE. Der unitarische Bundesstaat, p. 23 e POSSER. Significado del Bundesrat, p. 683.
} 
que ela ensejava alguns aspectos negativos que não podiam ser desprezados. Em especial, menciona-se a dificuldade de o governo federal empreender inovações em políticas públicas nas quais os interesses dos Estados se agrupavam, tendo em vista que o sistema do Conselho Federal permite que interesses particularísticos e burocráticos dos governos estaduais se contraponham, quase de igual para igual, aos interesses nacionais. ${ }^{403}$

Em suma, estas e outras desvantagens informaram uma percepção negativa acerca da importância que o Conselho Federal assumiu no processo legislativo federal, e foi por isso um dos alvos da Reforma do Federalismo de 2006. Embora esta não tenha solucionado definitivamente a questão, ela efetivamente promoveu uma diminuição do número de leis que necessitam a aprovação desta instância de representação dos Länder: com efeito, de 2006 até o momento presente $39 \%$ das leis promulgadas foram Zustimmungsgesetze ao passo em $61 \%$ foram Einspruchsgesetze, segundo informações extraídas do próprio sítio eletrônico do Conselho Federal. ${ }^{404}$

Por último, cumpre apenas tratar brevemente da participação dos Länder na Administração Federal, o que também se dá por meio do Bundesrat e nas hipóteses delimitadas pela Lei Fundamental em várias passagens. Roman HERZOG sistematiza estas hipóteses em seis grupos: (i) em primeiro lugar, o Conselho Federal deve manifestar a sua aprovação em relação aos regulamentos editados pelo governo federal ou pelos seus ministros nas matérias arroladas no artigo 80 II GG e também nos casos em que os Estados executam lei federal por delegação ou mediante a supervisão federais (artigos 84 e 85 GG); (ii) o Conselho Federal deve ainda aprovar os preceitos administrativos de caráter geral editados pelo Bund previstos no artigo 84 II, 85 II, entre outros; (iii) em terceiro lugar, o Conselho Federal deve necessariamente expressar o seu consentimento em algumas situações que envolvem a supervisão e a coerção exercida pela União sobre os Estadosmembros (Bundesaufsicht e Bundeszwang), como por exemplo no caso em que o governo federal envia representantes aos órgãos públicos estaduais contra a vontade dos Estadosmembros; (iv) em quarto lugar, o Conselho Federal também deve manifestar a sua concordância em relação aos tratados internacionais que cuidem de matérias que seriam submetidas à sua aprovação na hipótese de serem regulamentadas por lei federal (artigo 59

\footnotetext{
${ }^{403}$ Conforme se extrai de SCHARPF. The joint-decision trap, p. 254. Em relação a este último aspecto negativo, é interessante atentar para as considerações de Fritz W. SCHARPF no sentido de que estes interesses particularísticos e burocráticos não se encontram representados no Conselho Federal, tão somente. Ao contrário "eles são participantes diretos dos processos centrais de decisão. Neste sentido, o que nós temos é um sistema de democracia direta, 'participativa', sem quaisquer salvaguardas para uma reverberação isolada do interesse geral" (SCHARPF. The joint-decision trap, p. 254), o que se torna mais patente quando se tem em mente que os membros do Bundesrat estão adstritos às instruções do seu respectivo governo estadual.

${ }^{404}$ http://www.bundesrat.de/DE/dokumente/statistik/statistik-node.html. Acesso: 28/03/2015.
} 
II GG); (v) em quinto lugar, é necessária a aprovação dos Estados, por meio de sua instância representativa, para que a União possa declarar o Estado de Defesa (artigo 115a GG), e (vi) finalmente, o Conselho Federal pode ser chamado a manifestar a sua aprovação em outras situações determinadas pela legislação infraconstitucional. ${ }^{405}$

\section{TERCEIRO CAPÍTULO - A EXPERIÊNCIA FEDERATIVA NO BRASIL E NA} ALEMANHA

Este terceiro capítulo será dedicado à exposição de algumas conclusões importantes que já podem ser extraídas a partir do que foi discutido no primeiro e no segundo capítulos da tese. Trata-se, portanto, de um capítulo mais curto, ainda que em algumas partes se pretenda trazer novos dados e informações à apreciação do examinador, em especial no que tange à análise da centralização e da cooperação nas federações brasileira e alemã.

Para tanto, propõe-se exposição dividida em três tópicos, sendo que dois deles serão dedicados a questões mais teóricas acerca da federação e um deles a considerações acerca das federações brasileira e alemã em uma perspectiva comparada. Deste modo, no item 3.1 se analisará a federação diante do fenômeno da centralização. Embora a centralização seja verificada em virtualmente todos os Estados Federais, no âmbito da doutrina jurídica brasileira ela conduziu a um desinteresse sobre o tema, sob o argumento de que o Brasil vivenciaria um Estado Unitário de fato que desautorizaria a federação instituída no plano normativo. A presente tese, ao propor um estudo comparativo da repartição de competências legislativas e de execução em duas federações centralizadas, coloca-se em contrariedade a este argumento. Considera-se, de todo modo, oportuno também refutá-lo de um ponto de vista teórico.

Já no tópico 3.2 pretende-se promover uma comparação entre as federações brasileira e alemã. Para tanto, foram selecionados alguns aspectos analisados nos tópicos 2.1 e 2.2, acrescendo-se as questões da centralização e da cooperação, as quais foram propositalmente relegadas para este capítulo a fim de que elas pudessem ser analisadas conjuntamente. Não se objetiva, portanto, realizar uma confrontação global, exaustiva, entre Brasil e Alemanha no que tange a esta forma de Estado, mas apenas de traçar algumas considerações importantes que nortearão o estudo comparativo da repartição de

\footnotetext{
405 HERZOG. \& 58 Aufgaben des Bundesrates In: ISENSEE, KIRCHHOF (Hrsg). Handbuch des Staatsrechts, pp. 973-978.
} 
competências legislativas e de execução a ser empreendido a partir da segunda parte desta tese.

Finalmente, o tópico 3.3 promove uma retomada da repartição de competências ainda de um ponto de vista teórico, a fim de justificar a escolha da presente tese pelo que efetivamente importa ser comparado. Por óbvio, esta é uma assertiva que se deixa relativizar em outras áreas do conhecimento que também se ocupam da federação, mas tendo em vista que se propõe aqui é uma investigação jurídica e dogmática, é de admitir que a análise das normas constitucionais necessariamente assume uma posição de destaque.

\subsection{A FEDERAÇÃO DIANTE DO FENÔMENO DA CENTRALIZAÇÃO}

No tópico 1.1.3 definiu-se federação como "a forma de Estado que promove uma divisão territorial do poder político entre um ente central e unidades regionais autônomas, e que é estruturada por uma constituição rígida, a qual garante aos entes regionais a participação na formação da vontade do ente central". Como se teve a oportunidade de ressaltar naquela ocasião, trata-se de uma proposta de escopo relativamente modesto, pois não pretende englobar todas as federações atualmente vigentes, mas somente contemplar os casos brasileiro e alemão.

É importante notar, contudo, como a federação não foi definida como a forma de Estado que promove uma divisão territorial do poder político entre um ente central e unidades regionais autônomas, de forma que estas últimas permaneçam com a maior parte das atribuições e faculdades e assumam uma posição de proeminência em relação ao ente central. Há duas razões para tanto. Em primeiro lugar, porque se trataria de uma noção que não se aplicaria ao Brasil e à Alemanha, os quais são, como já se pôde antever diante de tudo que foi exposto até o momento, federações sensivelmente centralizadas. Em segundo lugar, porque as federações atualmente vigentes costumam lidar ou então lidaram com um processo de centralização, de forma que caso se adotasse semelhante definição, poucos seriam os Estados em que se poderia considerar presente esta forma de Estado.

A corroborar esta constatação, basta lembrar que mesmo os Estados Unidos vivenciaram uma expansão dos poderes federais na época do New Deal. Como já afirmava Bernard SCHWARTZ em meados do século XX,

“(...) Há coisa de um século, o Estado atuava principalmente como polícia, soldado e juiz. Hoje, o Estado atua também como médico, enfermeiro, professor, organizador de seguro, construtor de casas, engenheiro sanitário, químico, inspetor ferroviário, fornecedor de gás, água e eletricidade, planejador de cidades, distribuidor de pensões, fornecedor de transporte, organizador de hospital, 
construtor de estrada de rodagem, exercendo ainda um grande número de outras atividades'.

Se o Estado deve efetivamente executar as inúmeras funções que a opinião pública moderna exigiu que ele efetuasse, só pode fazê-lo pela intervenção nos negócios sociais e econômicos numa escala nacional. A ação governamental limitada ao plano local raramente se pode mostrar eficaz quando os problemas a serem tratados são de âmbito nacional." ${ }^{406}$

É verdade que demorou algum tempo até que este tratamento de problemas em âmbito nacional - em especial, a crise econômica que assolava a Estados Unidos desde 1929 - efetivamente fosse referendado pela Suprema Corte deste país. Com efeito, em um primeiro momento ela se mostrou reticente não só à ampliação dos poderes federais necessários à consecução do New Deal proposto por Franklin D. Roosevelt, como também à própria regulação da economia pelo Estado, seja por meio de leis federais, seja por meio de leis estaduais. ${ }^{407}$ A doutrina aponta o julgamento do caso "United Sates v. Darby", em 1941, como o grande momento de inflexão no posicionamento deste tribunal sobre o assunto $^{408}$. Porém, como assevera OSCAR VILHENA Vieira, já em 1937 esta corte havia reconhecido a constitucionalidade de lei estadual que propunha alguma regulação do mercado em "West Coast Hotel Co. v. Parrish". No mesmo ano, "a Suprema Corte cede também ao governo federal o direito de intervir na esfera econômica, ao declarar constitucional o National Labor Relations Act (Ato Nacional das Relações de Trabalho), por ocasião do julgamento do caso NLRB v. Jones \& Laughin Steel Corp" ${ }^{409}$. Contudo, foi somente a partir de "United States v. Darby" que a Suprema Corte abriu "mão de rever os motivos e propósitos que levaram o Congresso a legislar com base na cláusula de comércio. Julgar se o ato é compatível com a justificativa dada pelo Congresso para sua emanação é função do próprio Congresso: 'o judiciário não pode prescrever limitações ao setor legislativo do governo sobre o exercício de poderes reconhecidamente seus'. A partir de Darby, o Congresso estava livre para interferir na esfera econômica, sem que a Corte pusesse qualquer tipo de obstáculo." ${ }^{410}$.

Note-se que, mesmo com a União atuando e regulando aspectos importantes do mercado, os Estados-membros continuaram a desempenhar papel relevante nesta federação,

\footnotetext{
406 SCHWARTZ. Direito Constitucional Americano, p. 207.

${ }^{407}$ Como se pode extrair do breve histórico traçado por OSCAR VILHENA sobre o federalismo e a expansão dos poderes federais em Supremo Tribunal Federal, pp. 69-72.

${ }^{408}$ Como, por exemplo, SCHWARTZ. Direito Constitucional Americano, pp. 210 e ss. Note-se que o autor neste trecho pondera que "a Corte Suprema começou a eliminar as restrições à ação federal impostas pela sua rigorosa observância do federalismo dualista" já em 1937. Porém, somente em 1941 a Suprema Corte teria expressamente revogado a decisão anteriormente proferida por ela sobre o assunto.

${ }^{409}$ VILHENA. Supremo Tribunal Federal, pp. 75-76.

${ }^{410}$ VILHENA. Supremo Tribunal Federal, p. 77.
} 
legislando sobre aspectos importantes da vida cotidiana dos seus cidadãos, como adverte Bernard SCHWARTZ. ${ }^{411}$ Porém, a partir de então não era mais possível afirmar que a União desempenhava naquele país apenas um papel subsidiário, concentrando os seus esforços apenas naquelas áreas restritas que foram objeto de considerações de Alexander HAMILTON, James MADISON e John JAY em Ofederalista. $^{412}$

Fenômenos similares podem ser observados na Austrália, na Alemanha e até mesmo no Brasil, conforme ressaltado no item 1.6.2. De todo modo, parece ser importante observar que tanto a descentralização quanto a centralização são fenômenos inerentes ao federalismo e à federação. No âmbito da ciência política, esta percepção levou a algumas construções teóricas interessantes como a de William H. RIKER - apenas para ficar com uma das referências mais clássicas - que define federalismo como "uma organização política na qual as atividades de governo são divididas entre governos regionais e um governo central de tal modo que cada tipo de governo detenha algumas atividades em que ele toma decisões finais" ${ }^{413}$. Trata-se de uma definição propositalmente ampla, que pretende a acomodação de todas as federações em um "contínuo do que diz respeito à centralização" ${ }^{414}$, dentro de um limite mínimo e um limite máximo. No primeiro deles, "os governantes da federação podem tomar decisões em apenas uma categoria de ação estreitamente restrita", ao passo que no segundo deles "os governantes da federação podem tomar decisões sem consultar os governantes dos governos-membros em todos [os assuntos] com exceção de uma categoria de ação estreitamente restrita" 415 .

\section{No âmbito da ciência do direito, a percepção da centralização tem conduzido}

a um certo desinteresse sobre o tema. Por óbvio, há boas obras e teses que se dedicam sobre aspectos jurídicos da federação nos dias atuais. Contudo, as atenções da doutrina parecem ter se voltado para outras temáticas do direito constitucional, como é o caso dos

\footnotetext{
${ }^{411}$ Assevera este autor que "apesar da constante expansão da autoridade federal ocorrida nas últimas décadas, são ainda os estados que executam muitas das funções mais essenciais, no sistema americano. Assim, para citar apenas alguns exemplos importantes, a educação pública está quase inteiramente a cargo dos estados e de suas subdivisões políticas, o mesmo acontecendo com o que diz respeito à saúde pública e às atividades sociais até agora realizadas pelo Governo dos Estados Unidos. O amparo aos necessitados, o seguro de desemprego, a indenização dos trabalhadores, uma grande variedade de atividades de saúde pública, os serviços em benefício da agricultura e a proteção dos recursos naturais - tudo isso está sob a responsabilidade dos estados americanos, embora, é verdade, sujeito, nos últimos anos, a um aumento crescente da supervisão federal em alguns dêsses campos" (Direito Constitucional Americano, pp. 57-58).

412 Neste ponto, refere-se especificamente aos números 41 a 45 da referida obra (HAMILTON, MADISON, JAY. O federalista, pp. 343-384).

413 RIKER. Federalism, p. 101.

${ }^{414}$ RIKER. Federalism, p. 101.

415 RIKER. Federalism, p. 102.
} 
direitos fundamentais e do controle de constitucionalidade, que também são importantes, mas que não justificam um esquecimento da federação enquanto objeto de estudo. Afinal, ela costuma ser apreciada pelo Supremo Tribunal Federal com uma certa frequência, possuindo também uma relevância prática muito grande.

A embasar este desinteresse também está o argumento relativamente difundido no meio jurídico de que, no Brasil, a centralização seria de tal monta que teria conduzido a uma descaracterização da federação enquanto tal, verificando-se na prática um Estado Unitário. ${ }^{416}$ Trata-se, contudo, de um entendimento que incorre em dois equívocos. Em primeiro lugar, embora se verifique no Brasil uma intensa centralização legislativa, é de se admitir que em outras áreas se operou uma sensível descentralização a partir de 1988, como inclusive já se teve a oportunidade de analisar no tópico 2.1.2 desta tese. Pode-se discutir se esta descentralização foi suficiente ou mesmo adequada, com alguma razão até. Mas o fato de um imposto tão expressivo quanto o ICMS pertencer aos Estados no Brasil ou de políticas importantes como a segurança pública serem executadas primordialmente pela esfera estadual de governo ${ }^{417}$, por exemplo, é algo que só pode ser explicado pela vigência de uma federação.

\footnotetext{
${ }^{416}$ No sentido de que o Brasil teria vivenciado um Estado Unitário de fato desde a proclamação da República, vide nota de rodapé no 191. Sobre o assunto, é interessante atentar para as seguintes considerações de José CRETELLA JUNIOR sobre a competência da União sob a égide da Constituição Federal de 1988: "com efeito, sob o aspecto formal de Federação, o Brasil é, na realidade, Estado Unitário fortemente centralizado, situação que o legislador constituinte de 1988 procurou atenuar, transferindo às unidades federadas e às entidades municipais uma série de atribuições, antes, em 1937, em 1967 e em 1969, detidas pelo poder central (...) Notase, ainda, pela leitura deste artigo da Constituição [no caso, o artigo 21 CF/88], que o nosso país é mais Estado Centralizado (aproximando-se, por esse lado, do Estado Unitário) do que Federação, pois a competência do Poder Central é tão grande que muito pouco resta para os Estados-membros, situação bem diversa daquilo que preceituaram as Constituições de 1891, de 1934 e de 1946" (José CRETELLA JUNIOR. Comentários à Constituição Brasileira de 1988. Volume III: Arts. 18 e 22. 2a Ed. Rio de Janeiro: Forense Universitária, 1991, p. 1286).

417 O artigo $144 \mathrm{CF} / 88$, em seu caput, dispõe que "a segurança pública, dever do Estado, direito e responsabilidade de todos, é exercida para a preservação da ordem pública e da incolumidade das pessoas e do patrimônio", passando a seguir a arrolar tanto órgãos federais quanto estaduais responsáveis pela consecução desta política pública. Contudo, ao se analisar o teor dos parágrafos $\S 4$ o e $\S 5$ o deste mesmo dispositivo constitucional percebe-se que uma parte razoável - e porque não dizer, a mais parte importante das atividades tipicamente de segurança pública são atribuídas as polícias civis e às polícias militares dos Estados-membros. Situação diversa ocorre com a legislação sobre esta matéria, que permanece centralizada nas mãos da União, como se extrai dos $\S 7$ o do artigo 144, artigo 22, XXI, e artigo 24, XVI, CF/88. O enquadramento das guardas municipais como órgãos de segurança pública e a competência legislativa sobre o tema em virtude do disposto no § 8o do artigo $144 \mathrm{CF} / 88$ permanecem questões indefinidas, mesmo com a edição do Estatuto das Guardas Municipais (Lei no 13.022/2014). Sobre a constitucionalidade deste diploma, com especial foco nos argumentos ventilados na ADI no 5156, vide Mariana Augusta dos Santos ZAGO, Guilherme Siqueira de CARVALHO. O Estatuto Geral das Guardas Municipais (Lei no 13.022/2014): considerações sobre sua constitucionalidade à luz da repartição federativa de competências. Revista de Direito Administrativo Contemporâneo (ReDAC), São Paulo, ano 3, vol. 21, nov./dez. 2015, pp. 169-198.
} 
Em segundo lugar, esta percepção da federação brasileira parece partir do pressuposto teórico de que o federalismo dual - ou ao menos uma característica que lhe acompanha historicamente, que é a existência de Estados-membros fortalecidos em contraposição a uma União limitada em suas atribuições - é o modelo ideal e preferencial de federação, do qual todos os outros seriam uma mera corruptela. Como já se teve a oportunidade de ressaltar no item 1.2.1, o federalismo dual explica no máximo o caso norteamericano desde 1787 até o advento do New Deal, sendo que a limitação da atuação da União a poucas áreas de atuação, característica deste modelo, serve no máximo para explicar o desenvolvimento das relações federativas nos Estados Unidos neste período específico. Por ser historicamente situada, ela simplesmente não pode ser erigida a condição essencial da federação de um ponto de vista teórico.

O que se verifica mais comumente em uma federação são tendências de descentralização combinadas com tendências centralizadoras, o que pode colocar ora as unidades subnacionais ora o poder central em posição de destaque, muito embora o que se verifique historicamente seja a assunção de uma gama cada vez maior de atribuições pela União. Por óbvio, não se defende aqui que a centralização seja um fenômeno isento de críticas, muito pelo contrário. O que se deseja pontuar é um tanto mais singelo, qual seja, a ideia de que a centralização deve ser discutida, e até mesmo combatida caso seja considerada excessiva, mas não deve levar a um desinteresse pela federação como objeto de estudo, tendo em vista que se trata de um tema com repercussões relevantes na política, no direito e, o que é mais importante, na vida dos cidadãos.

\subsection{A EVOLUÇÃO DAS FEDERAÇÕES BRASILEIRA E ALEMÃ}

\subsubsection{A questão da formação da federação brasileira}

A partir das contextualizações promovidas nos tópicos 2.1 e 2.2, em especial dos aspectos históricos trabalhos nos subitens 2.1 .1 e 2.2.2, é possível rebater uma outra crítica bem comum à federação brasileira. Defende-se de uma forma relativamente corriqueira que ela assumiria uma feição mais centralizada em decorrência do seu processo de formação. Nesse sentido, as seguintes ponderações de Valerio de Oliveira MAZZUOLI:

\footnotetext{
"O Brasil é exemplo típico de Estado Federal, mas que nasceu de um Estado unitário (Império), ao contrário dos Estados Unidos da América do Norte (que também é Estado Federal), que nasceram sob a forma de Confederação, sendo transformado depois em regime federativo, quando entrou em vigor a Constituição de 1787. O fato de o Brasil derivar de um Estado unitário e os Estados Unidos da América de um Estado confederado traz algumas implicações práticas, dentre elas a de que a autonomia interna dos Estados federados nos Estados Unidos (nos campos político, tributário, legislativo, econômico etc.) é mais ampla que a dos
} 
Estados federados brasileiros. Lembre-se da possibilidade que alguns Estados federados norte-americanos têm de legislar sobre pena de morte, o que não é possível no sistema da Federação brasileira." 418

Em cursos de Direito Constitucional é possível encontrar este mesmo raciocínio enunciado em termos mais teóricos, vale dizer, de que Estados Federais formados por agregação (como é o caso dos Estados Unidos da América e também da Alemanha) seriam menos propícios à centralização do que as federações formadas por desagregação (como é o caso do Brasil e da grande maioria das federações). ${ }^{419}$

Parece-nos, contudo, que o processo de formação da federação brasileira explica muito pouco sobre a centralização percebida nos dias atuais, por quatro razões.

A primeira delas, de índole mais teórica, remete à impossibilidade de se estabelecer uma regra geral que relacione o processo de formação de federações e a centralização federativa. Embora seja normal definir a federação como a forma de Estado formada pela agregação de Estados outrora independentes, o fato é que a maioria das federações vigentes desde o século XIX são oriundas da desagregação de grandes impérios, como o britânico e o espanhol. Existem poucas federações formadas por agregação, sendo que as mais emblemáticas certamente são os Estados Unidos, a Suíça e a Alemanha. Poderse-ia até argumentar que há duas federações relativamente descentralizadas neste rol e que somente a Alemanha seria centralizada. O problema é que o argumento de que federações formadas por agregação resistem melhor à centralização tem uma outra face, qual seja, de que federações formadas por desagregação costumam ser mais centralizadas por este motivo, o que é bem difícil de ser comprovado na prática, tendo em vista a heterogeneidade das federações envolvidas.

Em segundo lugar, mesmo durante o Império o Brasil vivenciou um período de descentralização política sob a vigência do Ato Adicional de 1834, o que deu ensejo a um caloroso debate sobre as vantagens e as desventuras da descentralização em um país como o Brasil. Paulino José de Souza Soares, o Visconde de URUGUAY, era um dos críticos deste diploma, embora entendesse que alguma descentralização administrativa seria salutar ao Império brasileiro, como se pode extrair do seguinte trecho de sua obra:

“A decentralisação administrativa que trouxe o acto adicional era, pelas razões que acima forão expostas, até certo ponto jusitificável.

\footnotetext{
${ }^{418}$ Valerio de Oliveira MAZZUOLI. Curso de Direito Internacional Público. 4ạ Ed. São Paulo: Revista dos Tribunais, 2010, p. 425.

${ }^{419}$ Nesse sentido, vide FERREIRA FILHO. Curso de Direito Constitucional, p. 54 e JOSÉ AFONSO. Curso de Direito Constitucional Positivo, p. 102, lembrando apenas que as federações formadas por agregação são aquelas que resultam da união de Estados outrora independentes ao passo que federações por segregação são aquelas que resultam da desagregação de Estados Unitários.
} 
Decentralisando porém as atribuições que passou para as Assembléas Provinciaes, era indispenavel fazê-lo de modo que cada um dos Poderes Geral e Provincial se pudesse mover na sua orbita, sem encontrar no mesmo terreno, e pôr-se em conflito com o outro. Era indispensável que essa decentralisação fosse meramente administrativa, e não embaraçasse a direção politica dos Poderes Geraes, que não póde deixar de ser única; nem he possível que hajão tantas politicas quantas Assembléas Proviniciaes. Seria uma completa anarchia." 420

Por outro lado, Aureliano Cândido TAVARES BASTOS, citando o trecho supracitado da obra do Visconde de URUGUAY para se referir ao "preconceito com que se defende a reação de 1837”, ponderava que a implantação do sistema descentralizador do Ato Adicional era razoavelmente mais complexa do que o sistema federal estadunidense, tendo em vista não ter o diploma brasileiro instaurado a federação "mas um regímen que participava de ambos os sistemas, centralizador e descentralizador" ${ }^{\text {" } 21}$. O relativo insucesso do Ato teria sido resultado, portanto, "da inexperiência dos homens públicos, a exageração com que fazia-se avultar os erros de funcionários ignorantes, o cálculo dos que viram com tristeza arrebatar-se da capital grande soma de poder e de influência", entre outros fatores. ${ }^{422}$

É de se ressaltar que a própria adoção da monarquia teria sido o resultado de uma opção consciente da elite brasileira à época da independência brasileira, a fim de evitar uma fragmentação do novo Estado que viria a surgir e a manutenção da ordem econômica escravocrata. ${ }^{423}$ Porém, como bem ressalta JOSÉ MURILO de Carvalho, "o ideal de unidade da elite esbarrava na realidade da ausência de uma tradição de governo central na colônia e na ausência de fortes laços de união, econômicos ou políticos, entre as antigas capitanias" ${ }^{424}$.

\footnotetext{
420 URUGUAY. Ensaio sobre o Direito Administrativo, p. 205.

421 TAVARES BASTOS. A província, pp. 64-65.

422 TAVARES BASTOS. A província, p. 65. Perceba-se, portanto, que existia um debate em torno da descentralização político-administrativa mesmo no tempo em que o Brasil se organizava sob a forma de um Estado Unitário. Nesse sentido, VIRGÍLIO AFONSO da Silva pondera que "embora o Brasil, durante todo o período monárquico, tenha adotado a forma unitária de Estado, os ideais federalitas estiveram presentes nos debates políticos desde a independência. A tensão entre centralização e descentralização (não apenas administrativa), seja no primeiro reinado, seja, sobretudo, durante o período regencial, relembrava a cada instante que a opção pelo unitarismo, embora tivesse razões estratégicas não desprezíveis, nunca fora uma opção consensual (Ferreira, 1999)" (VIRGÍLIO AFONSO da Silva. Capítulo 25 - Federalismo e articulação de competências no Brasil. In: B. Guy PETERS, Jon PIERRE (Orgs.). Administração Pública: Coletânea. São Paulo: UNESP; Brasilia: ENAP, 2010, p. 552).

423 JOSÉ MURILO. Federalismo e centralização no Império brasileiro, p. 162

424 JOSÉ MURILO. Federalismo e centralização no império brasileiro, pp. 162-163. Note-se que alguns autores consideram as pretendem inclusive situar das capitanias hereditárias a origem da federação que seria formada apenas em 1891. Nesse sentido, Alessandra SILVEIRA pondera que "mas não seria despropositado afirmar que o Brasil de hoje é produto da federação das Capitanias separadas e autónomas que se reuniram - ou foram reunidas - numa só nação e institucionalmente num só Estado. Como explica João Camillo de Oliveira Torres, até a sua Independência em 1822, o Brasil não passava da justaposição de unidades política, administrativa, económica e culturalmente estanques, sem comunicação interna ou outra sujeição comum que não o governo d’El Rei. Se as circunstâncias económicas em certa medida agrupavam as Capitanias do Norte, o certo é que o
} 
Assim, conclui-se que a mesma crítica que se pode fazer à adoção de um federalismo sob forte influência norte-americana em 1889 em virtude da sua pouca aderência com a realidade brasileira à época da proclamação da República pode ser feita em relação à adoção de uma monarquia centralizada em 1824 diante da forte descentralização que vigeu durante o período da Colônia. De um modo ou de outro, o fato é que centralização e descentralização eram tendências verificáveis no Império brasileiro e que reuniram defensores e críticos durante este período da história brasileira.

Em terceiro lugar, a federação é a forma de Estado adotada pelo Brasil há mais de 120 anos e é razoável que neste meio tempo outros fatores mais determinantes para a centralização tenham entrado em cena, como, por exemplo, as leis editadas e as estruturas administrativas implantadas durante os períodos autoritários e centralizadores do Estado Novo e da Ditadura Militar. ${ }^{425}$ Algumas delas continuam em vigor até os dias de hoje, e embora não se possa falar propriamente de recepção de normas constitucionais, é de se admitir que disposições importantes da Constituição Federal de 1988 sobre a federação tem a sua inspiração na constituição anterior. Este é, contudo, um argumento que será melhor desenvolvido somente no tópico a seguir.

O quarto e último motivo resulta de uma comparação da evolução da federação brasileira com a federação alemã. Viu-se que esta última foi instaurada pela Constituição Imperial de 1871 foi o resultado de um processo de agregação de Estados outrora independentes, o que se deu em parte por meio de tratados internacionais. Em um primeiro momento e como uma consequência do objetivo de unificação, o Império alemão comportou e tolerou uma série de diferenças quanto à forma e ao regime de governo: havia, afinal, desde repúblicas até regimes absolutistas no território alemão, contanto que todos se submetessem ao Kaiser alemão, Rei da Prússia. Como ressalta Heiko HOLSTE em passagem da sua obra, dos 25 Estados da federação instituída pela Constituição Imperial de 1871, 22 eram monarquias. Embora a maioria delas pudesse ser classificada como monarquias

Sul e o Norte ignoravam-se cordialmente" (SILVEIRA. Compromisso Constitucional nos Estados Compostos, p. 43).

${ }^{425} \mathrm{~A}$ centralização de recursos fiscais durante a ditadura militar e de programas sociais durante a Era Vargas é, aliás, referida no seguinte trecho da análise de Maria Hermínia Tavares de ALMEIDA: "Com efeito, a concentração de recursos fiscais na esfera federal foi a marca do autoritarismo burocrático no Brasil. De outra parte, desde os anos 1930, o crescimento da ação do governo no domínio social correu paralelo à centralização política e à concentração de poderes no poder Executivo federal. Mais do que isso, o sistema de proteção social brasileiro foi criado, expandiu-se e adquiriu seus traços centrais durante os dois ciclos de autoritarismo, sob Vargas (1930-1945) e sob os militares (1964-1984). Em consequência, as políticas sociais estiveram associadas ao crescimento da atividade da administração federal. Elas foram marcadas por concepções autoritárias materializadas na predominância das agências do Executivo federal, dos procedimentos fechados de tomada de decisões e da gestão feita por burocracias centrais" (ALMEIDA. Recentralizando a federação?, p. 30). 
constitucionais, duas (Mecklenburg-Strelitz e Mecklenburg-Schwerin) estruturavam-se em um modelo antigo para a época, tendo permanecido inertes à evolução políticoconstitucional verificada nos séculos anteriores. Parte de uma delas (Mecklenburg-Strelitz) era inclusive governada em moldes absolutistas. Somente as cidades-livres Lübeck, Bremen e Hamburgo eram repúblicas. ${ }^{426}$

A partir de 1919 o que se viu, contudo, foi um Estado Federal propositalmente centralizado, sendo que o Reich detinha meios de concentrar ainda mais atribuições em suas mãos. Ou seja, o fato de a federação alemã ter se formado por agregação 50 anos antes desempenhou um papel bem limitado de resistência contra a "universal tendência para a centralização", para falar com Manoel Gonçalves FERREIRA FILHO. ${ }^{427}$

Quando da entrada em vigor da Lei Fundamental de 1949, por sua vez, é de se admitir que não existiam mais os antigos Estados alemães. A ocupação pelas potências aliadas e a formação de novos Estados dentro das suas respectivas zonas de ocupação fez com que a tradição federativa alemã restasse sensivelmente abalada. ${ }^{428} \mathrm{~A}$ federação de feições descentralizadas foi, com efeito, uma imposição das potências ocidentais vencedoras da Guerra e não resistiu ao processo de centralização legislativa verificado já a partir da década de 50 do século XX.

Pode-se argumentar que o fato de os governos estaduais terem antecedido a formação do governo federal após a $2^{\mathrm{a}}$ Grande Guerra indicaria um novo processo de agregação federativa. É possível inclusive reconhecer que, durante o processo de elaboração da Lei Fundamental de 1949, a fidelização de certos membros do Conselho Parlamentar a interesses regionais fez com que a estrutura federativa alemã assumisse feições mais descentralizadas, como ocorreu, aliás, com a repartição de competências legislativas e de execução. Nesse sentido, ressalta Reinhard MUßGNUG que a SPD, tal quando da elaboração da Constituição de Weimar, era favorável a uma maior concentração de atribuições na esfera federal, e nesse ponto era seguida por parte da CDU. Contudo, a outra parte deste último partido aliou-se com a CSU no sentido de garantir uma proeminência dos Länder em relação ao Bund. Embora fossem minoria, estes representantes do sul da Alemanha poderiam impedir a aprovação da Lei de Bonn, razão pela qual se optou por um meio termo: embora a União restasse favorecida por meio de um extenso rol de competência legislativas (ela passou a contar com competências privativas, competências concorrentes e competências-

\footnotetext{
${ }^{426}$ HOLSTE. Der Deutsche Bundesstaat im Wandel, pp. 138-139.

${ }^{427}$ FERREIRA FILHO. Curso de Direito Constitucional, p. 54.

428 Neste sentido, vide HESSE. Der unitarische Bundesstaat, p. 12. Sobre o assunto, vide também as considerações de Hans-Jochen VOGEL expostas na nota de rodapé no 321.
} 
moldura - a chamada Rahmengesetzgebung), os Estados puderam assumir um papel de proeminência no tocante às competências administrativas ou de execução. ${ }^{429}$ Porém, estes dois argumentos somente reforçam o raciocínio que se desenvolve aqui, qual seja, de que o modo pelo qual federações são originalmente formadas - e, em especial, as federações brasileira e alemã - não é tão determinante para a centralização ou a descentralização federativa posteriormente verificadas.

Por derradeiro, não se pode deixar de ressaltar que Estados-membros brasileiros possuem fronteiras mais antigas do que muitos Estados alemães. Alguns deles, como como Rio Grande do Sul, o Rio de Janeiro e o Maranhão, possuem dimensões inalteradas desde os tempos do Império. Não obstante isso, parcela da doutrina jurídica brasileira frequentemente aborda com maior naturalidade a tradição federativa alemã do que a tradição federativa brasileira, mesmo o Brasil sendo uma federação há mais de 120 anos.

\subsubsection{A centralização federativa}

No tópico 1.3 asseverou-se que a identificação e a avaliação da centralização e da descentralização nas federações brasileira e alemã não consistem em um objetivo da tese, tendo em vista que a análise das normas constitucionais - e, em alguns casos, da jurisprudência pertinente - não fornece muitos subsídios para tanto. Não obstante isso, ponderou-se que posicionar Brasil e Alemanha como Estados Federais mais ou menos centralizados permanece como uma questão imprescindível ao estudo comparativo que será desenvolvido a partir da segunda parte da tese. É de se admitir, afinal, que a determinação dos possíveis sentidos e alcances das normas sobre o exercício de competências legislativas e de execução pode assumir matizes mais ou menos descentralizantes e, neste caso, deve-se saber por qual deles optar.

Comecemos a análise pelo caso brasileiro. Afirma-se, por um lado, que a Constituição Federal de 1988 teria promovido uma razoável descentralização em comparação com a ordem constitucional anterior, tendência esta que começaria a ser revertida com o passar dos anos, em especial a partir do primeiro mandato do Presidente Fernando Henrique Cardoso. ${ }^{430}$ Como se teve a oportunidade de ressaltar no item 2.1.2, na

\footnotetext{
${ }^{429}$ MUßGNUG. \& 8 - Zustandekommen des Grundgesetzes. In: ISENSEE, KIRCHHOF (Hrsg). Handbuch des Staatsrechts, p. 341-342.

430 Como ressalta Maria Hermínia Tavares de ALMEIDA, não são poucos que respondem afirmativamente à questão de se a federação brasileira estaria "passando por um processo de recentralização, depois de uma década e meia de experiência descentralizadora" (Recentralizando a federação?, p. 29). A autora, no entanto, mostra-se reticente a este respeito. Ao contrário, afirma no término de sua investigação que "o governo
} 
verdade a Constituição brasileira congregou tanto tendências centralizadoras quanto descentralizadoras, o que certamente gerou algumas contradições, além de conferir uma complexidade peculiar às relações federativas. De todo modo, é possível afirmar que a atual constituição brasileira possuiria, de modo geral, um viés descentralizante em relação à sua antecessora e que o período FHC teria representado um turning point neste cenário, com a consequente recentralização da federação brasileira. Existe, todavia, uma interpretação alternativa sobre este fenômeno defendida por Marta ARRETCHE e encampada pela presente tese, a qual enxerga elementos de continuidade entre as decisões tomadas pelo legislador constituinte de 1988 e a centralização federativa percebida a partir da década de 1990. Estes elementos, que podem ser resumidos em uma "centralização decisória", já estavam "presentes na Constituição de 1946 e coincidiram com o Estado Desenvolvimentista". ${ }^{431}$ Esta interessante análise acerca da centralização federativa no Brasil pode ser decomposta em dois argumentos menores, a saber: (i) percebe-se uma centralização decisória no Brasil a partir da Constituição Federal de de 1946, sendo que esta centralização teria informado importantes decisões do legislador constituinte de 1988; (ii) é possível traçar uma relação de continuidade em relação às decisões tomadas em 1988 e o fenômeno de centralização percebido a partir do primeiro mandato do Presidente Fernando Henrique Cardoso. A seguir, cada um destes argumentos será detalhado e complementado.

Em primeiro lugar, depreende-se do raciocínio desenvolvido pela referida autora que a centralização decisória é um vetor presente na federação brasileira desde a Constituição Federal de 1946 e teria informado as decisões do legislador constituinte de 1988. Iniciemos a nossa análise na Constituição Federal de 1967/1969, mesmo porque foi este o marco inicial escolhido quando da elaboração de um breve histórico da federação brasileira, e concentremos na centralização da normatização, que é o aspecto da

\footnotetext{
federal foi importante na criação dos mecanismos que possibilitaram o redesenho das relações intergovernamentais para o provimento de serviços sociais. Ele também foi crucial para alcançar e garantir a estabilidade da moeda e algum equilíbrio fiscal, ainda que frágil. As escolhas de políticas fiscais e sociais, em alguns casos, circunscreveram a autonomia de estados e municípios. Mas elas não são suficientes para avalizar o diagnóstico de que está em curso um processo de recentralização" (ALMEIDA. Recentralizando a federação?, pp. 38-39). Fernando Luiz ABRUCIO, por sua vez, deixa o argumento da recentralização em segundo plano, ao analisar as medidas implementadas durante o período FHC como mitigadoras de um padrão de federalismo predatório, ao mesmo tempo em que elas fomentariam a coordenação federativa. Não obstante isso, não deixa de caracterizar este momento como um turning point das relações federativas brasileiras, diante do fortalecimento da União e do enfraquecimento dos Estados (ABRUCIO. A coordenação federativa no Brasil, pp. 41-67). Parece-nos que o governo FHC representou sim um momento de centralização federativa importante. Ela pode ter se manifestado sobretudo nos planos fiscal e das políticas públicas. Contudo, como são estes justamente os planos em que se logrou obter alguma descentralização em 1988 (como se teve a oportunidade de ressaltar no item 2.1.2, a produção legislativa permaneceu extremamente centralizada), este novo movimento de recentralização não pode ser ignorado em uma análise do federalismo brasileiro pós-1988.

431 ARRETCHE. A centralização no Estado Federativo Brasileiro, p. 1.
} 
centralização decisória referida por ARRETCHE que mais guarda pertinência com as competências legislativas e de execução. ${ }^{432}$

Uma breve leitura do artigo $8^{\circ} \mathrm{CF} / 1967-69$ é o suficiente para constatar que a União detinha muitas competências privativas sob a égide da ordem constitucional anterior, o que naturalmente contribuía para a centralização do Estado Federal brasileiro e, consequentemente, para o enfraquecimento dos Estados-membros e Municípios. Seria de se esperar, portanto, que parte desta estrutura fosse desmantelada pelo legislador constituinte de 1988, caso o intuito fosse efetivamente promover uma descentralização da estrutura federativa brasileira como um todo. Porém, não foi exatamente isto que aconteceu. Ao contrário, ao se analisar as matérias arroladas nos artigos 21 e $22 \mathrm{CF} / 88$, percebe-se que estes dois dispositivos incorporaram a maioria - senão a totalidade - das disposições do artigo $8^{\circ}$ CF/1967-69, e foram além, atribuindo ao poder central competências que lhe eram estranhas sob a ordem constitucional anterior.

Neste ponto, é interessante notar como disposições da Constituição Federal de 1967/1969 simplesmente são repetidas pela Constituição vigente na sua literalidade. É o caso, por exemplo, a competência da União para legislar privativamente sobre "direito civil, comercial, penal, processual, eleitoral, agrário, marítimo, aeronáutico, espacial e do trabalho", prevista no artigo $8^{\circ}$, XVII, alínea b, da CF/1967-69 e que foi repetida pelo artigo 22, I, CF/88 nesta mesmíssima ordem; ou da competência de "organizar a defesa permanente contra as calamidades públicas, especialmente as secas e as inundações" (artigo $8^{\circ}$, XIII, CF/1967-69 e artigo 21, XVIII, CF/88) e da competência para legislar privativamente sobre "sistema monetário e de medidas, títulos e garantia dos metais" (artigo $8^{\circ}$, XVII, alínea j, CF/1967-69 e artigo 22, VI, CF/88), que possuem redação quase idêntica nos dois textos constitucionais. Por óbvio, os elaboradores da Constituição atualmente vigente não tinham a obrigação de inovar completamente em tal rol e nem seria recomendável que o fizessem. Com estas observações pretende-se apenas afirmar o caráter de continuidade que a Constituição Federal de 1988 certamente possui em relação à Constituição Federal de

\footnotetext{
432 Neste ponto, apenas um breve esclarecimento sobre as noções de centralização decisória e de centralização normativa, trabalhada por Marta ARRETCHE na sua obra A Centralização no Estado Federativo Brasileiro. Como já se teve a oportunidade de ressaltar, a centralização decisória é expressão que sintetiza, nas palavras da própria ARRETCHE, "elementos de continuidade na trajetória do federalismo brasileiro". No capítulo primeiro, dedicado à análise das transformações na estrutura federativa e comportamento das bancadas estaduais, ela acaba por decompor esta centralização decisória em pelo menos quatro vetores: (i) recuperação de receitas da União, por meio da criação de tributos não sujeitos à repartição; (ii) centralização da autoridade tributária, por meio da edição de legislação federal sobre impostos estaduais e municipais; (iii) centralização da normatização, por meio da edição de leis federais disciplinando competências de Estados e Municípios, e; (iv) centralização fiscal, isto é, quando a União passou a limitar a autonomia decisória nos gastos estaduais e municipais (ARRETCHE. A centralização no Estado Federativo Brasileiro, pp. 1, 13-38).
} 
1967/69 no que tange às competências que foram atribuídas de forma privativa ao ente federal, confirmando neste ponto o argumento desenvolvido por Marta ARRETCHE.

Apesar de ampliar a competência da União sobre determinadas matérias, não se pode dizer que o legislador constituinte de 1987/1988 não pretendeu descentralização alguma no plano das competências legislativas e de execução. Ocorre que esta deveria ser levada a cabo de forma gradual, por meio de uma ampliação das competências concorrentes, dentro de um paradigma de "federalismo de equilíbrio". Em outras palavras, a decisão de descentralizar nos planos legislativo e administrativo foi instrumentalizada por meio das competências concorrentes, buscando conferir àquela um caráter mais gradual e objetivando um maior equilíbrio no que tange às atribuições da União, dos Estados-membros e Municípios ao término deste processo. Porém, é de se admitir que o modo como esta modalidade de competência foi regulamentada pela Constituição Federal de 1988 favorece mais a centralização do que a descentralização, tendo em vista a fragilidade das limitações impostas à atuação da União. Nos termos do artigo $24 \mathrm{CF} / 88$, a única exigência que se impõe à União é que ela legisle sobre normas gerais, sendo que até os dias atuais não se logrou obter exatamente um consenso sobre o que são exatamente estas normas gerais ${ }^{433}$.

Em comparação com a ordem constitucional anterior, a Constituição Federal de 1988 inovou em pelo menos um aspecto: a possibilidade de a União legislar tanto sobre aspectos importantes das administrações estaduais e municipais quanto sobre políticas públicas que são executadas primordialmente pelas esferas estadual e municipal de governo. Com efeito, a partir de 1988 o ente federal brasileiro passou a ter competência para legislar sobre "normas gerais de licitação e contratação, em todas as modalidades, para as administrações públicas diretas, autárquicas e fundacionais da União, Estados, Distrito Federal e Municípios, obedecido o disposto no artigo 37, XXI, e para as empresas públicas e sociedades de economia mista, nos termos do artigo 173, $\S 1^{\circ}$, III" (artigo 22, XXVII $\mathrm{CF} / 88$ ), sobre "normas gerais de organização, efetivos, material bélico, garantias, convocação e mobilização das Políticas Militares e Corpos de Bombeiros Militares” (artigo 22, XXI CF/88) e "organização, garantias, direitos e deveres das polícias civis" (artigo 24, XVI CF/88), que são corporações pertencentes à administração dos Estados-membros, entre outros. Isto, por sua vez, acabou por restringir ainda mais a autonomia estadual - e a

\footnotetext{
433 O debate doutrinário e jurisprudencial em torno das normas gerais da União será retomado com maiores detalhes no tópico 4.4 da tese.
} 
autonomia municipal, em menor medida - no que diz respeito à organização da sua própria administração, não bastassem as limitações contidas nos artigos 37 a 40 CF/88. ${ }^{434}$

Além do mais, a Constituição Federal de 1988 ainda atribuiu à União a competência para legislar sobre "trânsito e do transporte" (artigo 22, XI, CF/88), educação (artigo 22, XXIV, e artigo 24, IX, CF/88), saúde (artigo 24, XII e artigo 198 CF/88) e segurança pública (artigo $144 \mathrm{CF} / 88$ ), que são políticas públicas executadas em maior ou menor medida pelas unidades subnacionais, seja por expressa disposição constitucional (como é o caso da saúde, da educação e da segurança pública) seja por determinação de lei federal (como é o caso da política de trânsito). Nestas áreas, portanto, os governos estaduais e municipais encontramse vinculados às disposições contidas na legislação federal, o que inevitavelmente restringe a atuação destes entes federativos, ainda que a normatização federal lhes confira alguma margem de liberdade.

Note-se, contudo, que neste ponto a Constituição Federal de 1988 apenas incorporou e consolidou uma visão centralizadora presente na estrutura federativa brasileira desde a ordem constitucional anterior. Por óbvio que a execução pelos Estados e Municípios de programas governamentais forjados na órbita federal ocorre hoje sob um novo paradigma, tendo em vista que este especial arranjo de atribuições e forjado e legitimado pela própria constituição. Contudo, não se pode deixar de vislumbrar um paralelo com o modo pelo qual o regime militar concebia a descentralização e que foi positivado no artigo 10 do DecretoLei $\mathrm{n}^{\circ}$ 200/1967, transcrito a seguir:

\footnotetext{
"Artigo 10, $\S 1^{\circ}$. A descentralização será posta em prática em três planos principais:

a) dentro dos quadros da Administração Federal, distinguindo-se claramente o nível de direção do de execução;

b) da Administração Federal para a das unidades federadas, quando estejam devidamente aparelhadas e mediante convênio;

c) da Administração Federal para a órbita privada, mediante contratos ou concessões.

(...)

$\S 4^{\circ}$ Compete à estrutura central de direção o estabelecimento de normas, critérios, programas e princípios, que os serviços responsáveis pela execução são obrigados a respeitar na solução dos casos individuais e no desempenho de suas atribuições.

$\S 5^{\circ}$ Ressalvados os casos de manifesta impraticabilidade ou inconveniência, a execução de programas federais de caráter nitidamente local deverá ser delegada, no todo ou em parte, mediante convênio, aos órgãos estaduais ou municipais incumbidos de serviços correspondentes.
}

$\S 6^{\circ}$ Os órgãos federais responsáveis pelos programas conservarão a autoridade normativa e exercerão controle e fiscalização indispensáveis sobre

\footnotetext{
434 Sobre a regulamentação de aspectos importantes da organização administrativa da União, dos Estadosmembros e dos Municípios pela Constituição Federal de 1988, vide o tópico 6.3 desta tese.
} 
a execução local, condicionando-se a liberação dos recursos ao fiel cumprimento dos programas e convênios." ${ }^{435}$

Isto é, já nesta época Estados e Municípios se colocavam como executores de programas federais, sendo este papel formalizado por convênio e estimulado pela liberação dos recursos federais. Ao fazê-lo, segundo disposições do próprio Decreto-Lei $\mathrm{n}^{\circ} 200$, os entes estaduais e municipais submetiam-se à normatização e à fiscalização do governo federal, o que certamente contribuiu para submeter as relações federativas brasileiras a uma lógica de hierarquia administrativa, a qual em virtude da forte influência francesa assume concomitantemente um viés centralizador. ${ }^{436}$ Optou-se por denominar este regime de descentralização, o que poderia ser interpretado em tom irônico caso isso não revelasse uma confusão entre o que se costuma denominar de descentralização no âmbito do direito administrativo e a descentralização federativa.

Verificada uma relação de continuidade entre a centralização normativa presente já sob a égide da ordem constitucional anterior e disposições contidas na Constituição Federal de 1988, é chegado o momento de se debruçar sobre o segundo argumento desenvolvido por Marta ARRETCHE, qual seja, o de que há também uma continuidade entre as decisões tomadas pelo legislador constituinte de 1988 e a centralização percebida a partir da segunda metade da década de 1990. No que tange à centralização da normatização, aspecto mais interessa à presente tese, pondera a referida autora que durante o governo do Presidente Fernando Henrique Cardoso foram aprovadas leis relevantes como a Lei $\mathrm{n}^{\mathrm{o}}$ 8987/1995 (sobre concessões), a Lei nº 9394/1996 (Lei de Diretrizes e Bases da Educação), a Lei $\mathrm{n}^{\circ}$ 10.257/2001 (Estatuto da Cidade), que disciplinam aspectos importantes da atuação dos Estados e dos Municípios. Porém, esta profusão de leis não pode ser interpretada como uma ruptura em relação à estrutura federativa forjada pela Constituição brasileira vigente, pelo contrário: o que se observa é uma continuidade das decisões tomadas em 1988, pois as referidas leis consistem simplesmente em uma concretização de regras constitucionais que preveem competências legislativas à União. ${ }^{437}$ Como ressalta ARRETCHE,

"Em resumo, os governos Fernando Henrique de fato aprovaram extensa legislação que regulamentou com razoável grau de detalhamento as regras

\footnotetext{
435 Grifo nosso. Para uma análise dos antecedentes e dos objetivos propugnados pelos atores envolvidos na elaboração e aprovação do Decreto-Lei no 200/1967, vide Natasha Schmitt Caccia SALINAS. Reforma administrativa de 1967: a reconciliação do legal com o real. In: Carlos Guilherme MOTA, Natasha Schmitt Caccia SALINAS (Coord). Os juristas na formação do Estado-Nação brasileiro: 1930 - dias atuais. São Paulo: Saraiva, 2010, pp. 453-482.

${ }^{436}$ Sobre a visão administrativista dos militares sobre o "federalismo cooperativo", a importância do DecretoLei no 200 para a estrutura administrativa desenvolvida no governo militar e o papel dos convênios na subordinação de Estados e Municípios às diretivas federais, vide ABRUCIO. Os barões da Federação, pp. 70-73. ${ }^{437}$ ARRETCHE. A centralização no Estado Federativo brasileiro, pp. 28-29.
} 
segundo as quais estados e municípios exercem suas competências. Esta tem como efeito limitar sua autonomia decisória nestas questões específicas. Entretanto, esta centralização decisória em nada contraria os princípios fundamentais da $C F 88$, representando, na verdade, desenvolvimento e continuidade de seus dispositivos centrais. Estes já previam, sob a forma de competências privativas da União, que um amplo campo de ações descentralizadas seriam implementadas de forma homogênea no território nacional, razão pela qual seria necessária a prévia autorização ou regulamentação da União. Se isto é verdade, não há razões para afirmar que houve mudança nesta dimensão da estrutura federativa." ${ }^{338}$

A bem da verdade, a descentralização federativa promovida com a promulgação da Constituição Federal de 1988 se deu sobretudo no plano fiscal. Com efeito, a constituição brasileira na sua redação originária conferia aos Estados - e, em menor medida, aos Municípios brasileiros - alguns tributos importantes, além de lhes dar uma razoável autonomia no que tange à alocação das suas receitas. $\mathrm{E}$ é em relação a este último aspecto que se pode falar que a centralização verificada na década de 90 representou uma ruptura, à medida que a União passou a editar legislação e aprovar emendas constitucionais que vincularam a utilização de verbas estaduais e municipais para determinados fins. Em relação à legislação federal que disciplina os impostos estaduais e municipais também não se pode falar exatamente em descontinuidade em relação a 1988, tendo em vista que ela se lastreia em competência inscrita no artigo 146, III, a, CF/88, inalterado desde então. ${ }^{439}$

Mas se há uma relação de continuidade entre as decisões tomadas pelo legislador constituinte de 1988 no que tange à estrutura federativa brasileira e a centralização verificada posteriormente, como explicar o fato de esta última ter se manifestado somente a partir do primeiro governo do Presidente Fernando Henrique Cardoso? Segundo Marta ARRETCHE, esta mudança não pode ser explicada por uma alteração do comportamento das bancadas estaduais na Câmara dos Deputados, pois estas sempre se mostraram pouco coesas durante

\footnotetext{
${ }^{438}$ ARRETCHE. A centralização no Estado Federativo brasileiro, p. 33.

439 É o que conclui Marta ARRETCHE em A centralização no Estado Federativo brasileiro, pp. 23-28 e 33-38. A referida autora inclui a aprovação de emendas constitucionais entre uma das medidas tomadas pela União para restringir a autonomia dos Estados e dos Municípios na alocação de suas receitas. Tal afirmação pode causar algum estranhamento a um jurista, tendo em vista que emendas à Constituição diferem substancialmente de simples leis ordinárias ou complementares. Afinal, as primeiras destinam-se a alterar o texto da Constituição, o que em um Estado Federal significa concomitantemente alterar o pacto entre União e unidades constituintes. Contudo, no caso brasileiro, as emendas constitucionais não requerem uma participação ativa dos Estados-membros e dos Municípios. Elas não precisam ser aprovadas pelas assembleias estaduais, tal como ocorre nos Estados Unidos da América. A necessidade da aprovação pela instância representativa dos Estados-membros poderia indicar alguma participação das unidades subnacionais - como, aliás, ocorre na Alemanha - porém, como no Brasil os senadores tendem a votar conforme os seus partidos e não em atenção aos seus respectivos Estados, conclui-se que a aprovação de emendas à Constituição desenvolve-se somente no plano federal, revelando-se na prática como uma das medidas colocadas à disposição da União, ainda que seja a mais difícil delas do ponto de vista procedimental, para realizar os seus objetivos.
} 
o governo de todos os presidentes pós-1988. Por outro lado, "para o período 1989-2006, a disciplina em relação à orientação dos líderes partidários nas matérias de interesse federativo é o comportamento regular, confirmando os achados de Cheibub et alii (2006). A diferença entre as taxas de disciplina em relação aos partidos é sistematicamente bem superior à disciplina em relação ao partido do governador". ${ }^{440}$ No Senado observa-se o mesmo fenômeno de forma ainda mais acentuada: nesta casa legislativa os índices de coesão partidária são superiores a 75\% para os sete maiores partidos, ao passo que a coesão em relação às bancadas estaduais é mínima. "A bancada estadual de senadores votar juntamente é antes uma exceção que a regra", segundo a referida autora. ${ }^{441}$ Portanto, a profusão de leis federais que afetam interesses estaduais e municipais só pode ser explicada pelo fato de esta questão ter assumido uma centralidade na agenda do presidente Fernando Henrique Cardoso, que usou a capacidade que os presidentes normalmente têm de obter aprovação no legislativo para ver concretizada esta agenda. ${ }^{442}$

Já a Alemanha, por sua vez, também vivenciou um período acentuado de centralização federativa a partir da década de 50. A fim de analisar este fenômeno de uma forma didática, retoma-se o pensamento de Konrad HESSE sobre as tendências unitarizantes verificadas na federação alemã sob a égide da Lei Fundamental de $1949^{443}$.

Segundo HESSE, o primeiro fenômeno que determinaria uma convergência de um Estado Federal-Unitário seria a concentração de tarefas estatais na esfera federal. No campo da legislação, o aumento da importância da União decorreria sobretudo da ineficácia dos condicionantes impostos pelo artigo 72 II GG à competência concorrente do Bund. Esta

\footnotetext{
${ }^{440}$ ARRETCHE. A centralização no Estado Federativo brasileiro, p. 41.

${ }^{441}$ ARRETCHE. Democracia, federalismo e centralização no Brasi, pp. 136-138. Lembrando apenas que no caso do Senado Federal, a referida autora concentrou a sua análise na aprovação de emendas constitucionais nesta casa legislativa, ao contrário do estudo promovido em relação à Câmara dos Deputados, que levou em consideração tanto leis quanto emendas constitucionais que podem ser vistas como prejudiciais aos interesses dos Estados-membros e Municípios.

442 ARRETCHE. A centralização no Estado Federativo brasileiro, pp. 50-51.

443 Deve-se ressaltar que o objetivo de Konrad HESSE não é exatamente analisar a centralização federativa, mas sim demonstrar como as tendências unitarizantes por ele identificadas acabaram por determinar uma alteração na própria concepção de Estado Federal. Para maiores detalhes, vide HESSE. Der unitarische Bundesstaat, pp. 12 e ss. De todo modo, parece-nos que a utilização destas tendências como vetores de análise da centralização federativa verificada na Alemanha é algo bem pertinente em uma pesquisa que se debruça exclusivamente sobre competências legislativas e competências de execução. Mas há outras alternativas possíveis, é importante deixar isto bem claro. À título de exemplo, Fritz W. SCHARPF analisa o aumento do entrelaçamento político sob a égide da Lei Fundamental de 1949 a partir: (i) da repartição de competências; (ii) da aprovação do Conselho Federal em determinados casos; (iii) da constituição financeira (Föderalismusreform, pp. 21-26).
} 
é uma questão que será analisada com todas as suas nuanças jurídicas somente no tópico 5.3.1 desta tese, mas desde logo cumpre fazer duas observações importantes.

Em primeiro lugar, é interessante atentar para o histórico legislativo deste dispositivo. Segundo Stefan OETER, o Conselho Parlamentar responsável pela elaboração e aprovação da Lei Fundamental de 1949 tinha optado por uma redação mais genérica para o artigo 72 II GG. Com efeito, o texto aprovado em um primeiro momento dizia apenas que a União deveria regular o que efetivamente devesse ser regulado de forma uniforme (em alemão: "Der Bund soll nur das regeln, was einheitlich geregelt werden muss"). Porém, o governo militar instituído na Alemanha pelos poderes aliados considerou tal previsão pouco favorável à posição dos Länder, tendo sugerido a sua eliminação do texto final da Lei Fundamental e a sua substituição por outro texto. ${ }^{444}$ Após diversas tratativas logrou-se finalmente obter a fórmula que constava da redação originária do artigo 72 II GG, que impunha três condicionantes relativamente precisos à atuação da União. Porém, tratava-se de um dispositivo considerado estranho à tradição federativa alemã, uma imposição das tropas de ocupação. A fim de mitigar os efeitos deste dispositivo na prática, os políticos alemães envolvidos na elaboração do artigo 72 II GG teriam até inserido expressões com o nítido escopo de restringir a sua eficácia na prática. Foi o caso da menção à "necessidade da regulamentação por lei federal" (das Bedürfnis nach bundesgesetzlicher Regelung), que já sob a égide da Constituição de Weimar era interpretada como uma decisão discricionária do legislador. ${ }^{445}$

Como ressalta o próprio Stefan OETER, sob estas condições não seria de se esperar

\footnotetext{
444 Stefan OETER. Artikel 72. In: Hermann von MANGOLDT, Friedrich KLEIN, Christian STARCK (Hrgs). Kommentare zum Grundgesetz. Band II: Artikel 20-82. 6a Ed. Munique: Franz Vahlen, 2010, pp. 1874-1875. Transcreve-se a seguir o trecho em que o referido autor comenta as "sugestões" feitas pelos poderes aliados ao texto da Lei Fundamental de 1949, não só pelo interesse que uma curiosidade histórica como esta suscita, mas sobretudo para se ter uma ideia de como o poder constituinte alemão se encontrava restringido em decorrência da capitulação em 1945: "Die Alliierten Militärgoverneure waren mit dieser Formulierung äußerst unzufrieden, da sie sie für nicht länderfreundlich hielten. Ihre Bedenken fassten sie im Memorandum zum vorläufigen Entwurf des Grundgesetzes (unter Nr. 3) mit den Worten zusammen: ,In the first place, we would like to point out that the powers of the federal government as now set forth in Article 36 are not defined with sufficient clarity adequately to safeguard the position of the states in a federal system. To correct this we suggest that you delete present Articles 36 and 36 a and substitute therefore a new Article 36 based very largely upon your own language...' und schlugen in der Folge die Grundzüge einer Neufassung vor. Als Grundbestandteil formulierten sie dabei: 'The Laender shall retain the right to legislate in the fields hereinafter enumerated except where it is clearly impossible for a single Land to enact effective legislation or where the legislation if enacted would be detrimental to the rights of interests of other Laender; in such cases, and provided that the interests of several Laender are clearly, directly and integrally affected, the Federation shall have the right to enact such legislation as may be necessary or appropriate...' Das Bemühen um eine möglichst scharfe und justitiable Fassung der Bestimmung war dabei unverkennbar" (OETER. Artikel 72. In: von MANGOLDT, KLEIN, STARCK (Hrsg.). Kommentare zum Grundgesetz, pp. 1874-1875).

${ }^{445}$ OETER. Artikel 72. In: von MANGOLDT, KLEIN, STARCK (Hrsg.). Kommentare zum Grundgesetz, p. 1876.
} 
um cumprimento fiel do compromisso firmado com os aliados em relação ao artigo 72 II GG. ${ }^{446}$ Com efeito, o que se verificou nos anos seguintes foi uma profusão de leis federais sobre os temas arrolados no artigo 74 GG, a qual, somada à ausência de controle sobre o preenchimento dos requisitos previstos no artigo 72 II GG por parte do Tribunal Constitucional Federal, foi responsável por uma intensa centralização legislativa. ${ }^{447} \mathrm{Ou}$ seja, também neste caso pode-se asseverar que a centralização representou apenas uma decorrência das decisões tomadas em 1949, verificando-se aqui também uma continuidade decisória. ${ }^{448}$

Em segundo lugar, é importante observar com o passar dos anos as condicionantes impostas à legislação concorrente da União não só se demonstraram ineficazes, como também passaram a impulsionar o fenômeno da centralização legislativa. Especialmente o terceiro requisito originalmente imposto pelo artigo 72 II GG, que autorizava a União a legislar caso existisse necessidade de estabelecer uma unidade jurídica e econômica especialmente para garantir a "uniformidade das condições de vida", foi erigido a fundamento da unitarização legislativa. Em outras palavras, a atuação da União em sede de competências concorrentes, que deveria ser restrita aos casos em que houvesse necessidade de se promover uma uniformização das condições de vida, passou a ser embasada pela necessidade de se promover a igualação destas condições. ${ }^{449}$ Por óbvio, este foi um entendimento que se desgastou ao longo dos anos, mas só logrou ser revertido em 1994, ainda em decorrência dos tratados de unificação alemã.

\footnotetext{
${ }^{446}$ OETER. Artikel 72. In: von MANGOLDT, KLEIN, STARCK (Hrsg.). Kommentare zum Grundgesetz, p. 1877.

447 O tema será abordado com maiores detalhes no item 5.3.1. Por ora, basta observar que as matérias compreendidas na competência concorrente da União e dos Estados-membros encontram-se arroladas no artigo 74 GG. O artigo 72 GG contém apenas regras sobre o exercício desta modalidade de competência.

${ }^{448}$ Fritz SCHARPF também enxerga uma continuidade entre as decisões tomadas em 1949 e a centralização verificada posteriormente no campo das competências legislativas concorrentes, embora se valha de uma argumentação um pouco distinta. Este autor também parte do texto aparentemente restritivo do artigo 72 ॥ GG, em comparação com a produção legislativa posteriormente verificada por parte do Bund. Porém, ele acrescenta à análise o disposto no artigo 125 GG, o qual determinava que o direito editado até aquele momento fosse recepcionado como direito federal sem a necessidade de preenchimento dos pressupostos previstos pelo artigo 72 ॥ GG, desde que subsistisse ao processo de desnazificação (SCHARPF. Föderalismusreform: kein Ausweg aus der Politikverflechtungsfalle?, p. 19). Em sentido contrário, defende Klaus STERN que a proeminência da União no que tange às competências legislativas concorrentes não teria sido desejada pelo Conselho Parlamentar, tendo resultado de fatores políticos, econômicos, técnicos e sociais (STERN. Das Staatsrecht der Bundesrepublik Deutschland. Band I, p. 679). Em sentido parecido com o de STERN, Reinhard MUßGNUG entende que o fato de o BVerfG ter decidido pela não justiciabilidade do artigo 72 ॥ GG, derrubando assim às barreiras impostas pelo legislador constituinte à atuação legiferante da União, não poderia ser prevista de antemão (MUßGNUG. § 8 - Zustandekommen des Grundgesetzes. In: ISENSEE, KIRCHHOF (Hrsg). Handbuch des Staatsrechts, pp. 340-341).

${ }^{449}$ Como ressalta Rupert STETTNER. Artikel 72. In: Horst DREIER (Hrsg.). Grundgesetz - Kommentar. Band II: Artikel 20-82. 2a Ed. Tübingen: Mohr Siebeck, 2006, p. 1606.
} 
A concentração de tarefas estatais na esfera federal a que se referia HESSE também encontrava expressão, ainda que em menor medida, na repartição de competências administrativas. ${ }^{450}$ No item 2.2.2 ressaltou-se que a Lei Fundamental de 1949 promove uma distinção entre competências legislativas e competências de execução. As primeiras encontram-se disciplinadas nos artigos 70 a 75 e subdividem-se em privativas e concorrentes; as últimas por sua vez, são regulamentadas nos artigos 83 a 91 GG e, a rigor, são privativas da União ou dos Estados-membros. No campo da legislação, a União possui um papel de proeminência, como pode ser apreendido diante de tudo o que já foi exposto até aqui. Porém, na federação alemã a execução das leis em geral, mesmo as leis federais, costuma ser promovida pelas administrações estaduais, o que acaba por fortalecer a posição dos Estados-membros. ${ }^{451}$ Esta é, por sua vez, mais uma discussão que será desenvolvida com todas as suas peculiaridades dogmáticas na segunda parte da tese. Por ora, basta ressaltar que a repartição de competências legislativas e de execução na Alemanha normalmente não coincidem, e que o fato de os Estados, em regra, executarem as leis federais, confere uma especial conformação às relações federativas neste país.

Segundo HESSE, no campo da execução das leis o avanço do Bund poderia ser observado tanto pela expansão da Administração Pública federal quanto do aumento da influência federal sobre a Administração dos Estados-membros. No primeiro caso, isso seria obtido por meio do permissivo contido no artigo 87 III GG, segundo o qual a União poderia instituir, "para os assuntos nos quais a União detém a competência legislativa, autoridades federais superiores independentes e novas pessoas e entes de direito público ligados diretamente à União". Ainda que esta expansão da administração federal se restringisse exclusivamente a órgãos de cúpula, sem que houvesse uma estrutura administrativa própria para a execução de serviços, era contrabalanceado por meio de uma política auxílios. ${ }^{452}$ Já a influência do Bund sobre as administrações estaduais deu-se sobretudo nos termos do artigo 84 GG. Este dispositivo, que autoriza a União a supervisionar a execução de leis federais pelos Estados-membros, autorizava a Poder Legislativo federal a dispor sobre temas relevantes à autonomia administrativa dos Estados-membros - mais precisamente, a organização dos órgãos públicos e o procedimento administrativo - além autorizar a edição

\footnotetext{
450 HESSE. Der unitarische Bundesstaat, pp. 16 e ss.

451 Por este motivo, aliás, é que se costuma encontrar em manuais de direito constitucional alemão que, na federação alemã, há uma ênfase da União no campo da competência legislativa, ao passo que na competência de execução se percebe uma ênfase dos Estados-membros. Nesse sentido, vide Christoph DEGENHART. Staatsrecht I -Staatsorganisationsrecht: mit Bezügen sum Europarecht. 28ạ Ed. Heidelberg: C. F. Müller, 2012, p. 184.

452 HESSE. Der unitarische Bundesstaat, p. 17.
} 
de normas administrativas de caráter geral. Como contraponto, a Lei Fundamental impunha a aprovação por parte do Conselho Federal.

$O$ intenso manejo da faculdade contida no artigo 84 I GG conduziu, por sua vez, a um aumento da importância do Conselho Federal, sendo esta a segunda tendência unitarizante identificada por Konrad HESSE. Quanto a este ponto, alguns esclarecimentos são necessários.

Conforme analisado no item 2.2.4, o Conselho Federal foi concebido como uma poderosa instância representativa dos interesses estaduais, mas deve manifestar a sua aprovação somente nos assuntos determinados pela própria Lei Fundamental. Em relação aos demais assuntos, a atuação deste Conselho se resume ao exercício de um poder de veto. Falou-se em Zustimmungsgesetze, que são as leis que devem ser aprovadas pelo Conselho Federal, e Einspruchgesetze, que são as leis que somente podem ser vetadas por esta casa legislativa e que deveriam corresponder à maioria das leis de acordo com a sistemática originalmente prevista pela Lei Fundamental. Contudo, o que se verificou foi um aumento substancial das Zustimmungsgesetze até o ponto em que elas passaram a representar a regra e não mais a exceção.

Segundo HESSE, este fenômeno apresenta-se intrinsicamente ligado à interpretação segundo a qual, se houvesse na lei uma parte que dependesse do assentimento do Conselho Federal, a lei como um todo deveria ser aprovada por esta instância legislativa. Caso esta lei fosse alterada posteriormente, seria necessária uma nova aprovação do Conselho Federal, ainda que a parte alterada não necessitasse, em tese, da sua anuência. Embora fosse este um entendimento aplicável a todas as Zustimmungsgesetze, ele tinha como elemento fundamental o artigo 84 I GG. ${ }^{453}$ Fritz W. SCHARPF também parece se posicionar neste sentido, ao atribuir este aumento de leis que necessitam de aprovação do Conselho Federal a uma determinada interpretação do artigo 84 I GG. ${ }^{454}$

De todo modo, deve-se observar que a importância adquirida pelo Conselho Federal ao longo dos anos encontra-se intimamente relacionada com o aumento da regulamentação federal sobre temas relevantes da administração estadual. Em outras palavras, também na federação alemã a União legisla sobre competências administrativas dos Estadosmembros. ${ }^{455}$ Contudo, ao contrário do que ocorre no Brasil, legislações deste tipo dependem

\footnotetext{
453 HESSE. Der unitarische Bundesstaat, p. 22.

${ }^{454}$ SCHARPF. Föderalismusreform: kein Ausweg aus der Politikverflechtungsfalle?, p. 22.

${ }^{455}$ A complementar este cenário, ressalta-se ainda a competência federal para estabelecer preceitos-moldura sobre "o regime jurídico das pessoas que estão no serviço público dos Estados, Municípios e outras corporações de direito público" (artigo 75 Nr. 1 GG) e para legislar sobre a remuneração e sobre as pensões
} 
da aprovação do Conselho Federal, o qual por sua própria composição permite uma representação efetiva dos interesses dos Estados-membros perante o Poder Legislativo Federal.

Finalmente, a última tendência unitarizante referida por Konrad HESSE consiste na coordenação entre União e Estados-membros e entre os próprios Estadosmembros, o que teria conduzido a uma uniformização da prática administrativa. Segundo este autor, os Länder passaram a uniformizar a sua atuação por meio de contratos e acordos e também no âmbito de conferências ministeriais, mesmo em tarefas compreendidas na sua esfera de atuação e que, portanto, não estariam submetidas a uma influência do Bund. Apenas para se ter uma ideia, entre os anos de 1949 e 1960 foram celebrados 339 contratos e acordos e mais de 500 encontros entre ministros da educação. ${ }^{456}$

Sabe-se que a cooperação - por meio especialmente da tomada de decisões conjuntas - é um dado marcante da federação alemã. Por isso, optou-se por abordá-la de forma autônoma no tópico a seguir, também dedicado à análise da cooperação e da coordenação federativas no Brasil.

\subsubsection{A cooperação federativa}

Embora tanto Brasil ${ }^{457}$ quanto Alemanha possam ser reconduzidos ao que se costuma denominar de federalismo cooperativo, é de se admitir que há uma diferença substancial no modo pelo qual a cooperação é levada a cabo nestes dois países, razão pela qual se julga pertinente traçar uma breve análise comparativa dos instrumentos e mecanismos de cooperação.

Comecemos a exposição pelo caso brasileiro, mais especificamente, pelos aspectos jurídico-constitucionais da cooperação. No tópico 2.1.2 fez-se referência a um papel coordenador da União, o que se extrai sobretudo de um conjunto de competências inscritas

dos servidores públicos (artigo 74a GG). Note-se que estes dois dispositivos ou foram inseridos ou substancialmente reformados nas reformas constitucionais de 1969 e 1971, as quais foram responsáveis por inserir mecanismos importantes do federalismo-unitário no texto da Lei Fundamental.

456 HESSE. Der unitarische Bundesstaat, p. 19.

457 No caso do Brasil também se fez referência ao "federalismo de equilíbrio" supostamente incorporado pela Constituição Federal de 1988, segundo parcela relevante da doutrina jurídica. Contudo, ele parece ser mais relevante para a compreensão das tendências de centralização e descentralização da federação brasileira, mais especificamente, o discurso jurídico em defesa destas tendências. Este tema foi abordado de forma suficiente nos tópicos 2.1.2 e 3.2.2, de forma que se considera despiciendo persistir na sua análise neste tópico dedicado à cooperação federativa. De todo modo, deixa-se consignado que o "federalismo de equilíbrio" não parece, de um ponto de vista teórico, conflitar com o "federalismo cooperativo", que será objeto de considerações a seguir. 
nos artigos 21 e $22 \mathrm{CF} / 88$. Além do mais, chamou-se a atenção para o papel relevante desempenhado pela União no que tange às competências comuns da União, dos Estados e dos Municípios, tendo em vista que a cooperação necessária à consecução de programas nas matérias arroladas no artigo $23 \mathrm{CF} / 88$ deve ser disciplinada em lei complementar federal. Neste momento, considera-se oportuno tratar das normas constitucionais que preveem a cooperação federativa.

Ao se analisar a Constituição brasileira, percebe-se que ela faz expressa menção à cooperação, à coordenação e à colaboração federativas em poucas passagens, mais precisamente: (i) no artigo $23 \mathrm{CF} / 88$, que será analisado em seus aspectos dogmáticos na segunda parte desta tese; (ii) no incisos VI e VII do artigo $30 \mathrm{CF} / 88$, segundo os quais compete ao Município "manter, com a cooperação técnica e financeira da União e do Estado, programas de educação infantil e ensino fundamental" e "prestar, com a cooperação técnica e financeira da União e do Estado, serviços de atendimento à saúde da população"; (iii) no artigo 216-A, caput e $\S 1^{\circ}$, VI, CF/88, que disciplina do Sistema Nacional de Cultura; (iv) no artigo $241 \mathrm{CF} / 88$, que trata dos consórcios públicos e convênios de cooperação entre os entes federados para a gestão associada de serviços públicos; (v) no artigo 204, I, CF/88, que trata de uma das diretrizes das ações governamentais na área da assistência social, e; (vi) nos artigos 205, 211 e $214 \mathrm{CF} / 88$, os quais fornecem a disciplina constitucional da política pública de educação. Não obstante isso, é possível extrair destas referências pelo menos duas consequências importantes.

A primeira destas consequências consiste na existência de um compromisso constitucional de cooperação, na acepção trabalhada por Alessandra SILVEIRA, cujos contornos foram expostos no tópico 1.2.3 desta tese. Este compromisso, que se revela em um verdadeiro princípio que orienta a cooperação - tanto na sua vertente ativa quanto na sua vertente passiva - entre União, Estados e Municípios, pode ser extraído não só das normas constitucionais supramencionadas, mas principalmente da decisão de repartir atribuições relacionadas a uma mesma matéria entre os entes federativos. Afinal, na federação brasileira a competência legislativa apresenta-se concentrada no plano federal, ainda que esta legislação venha a ser executada por Estados e Municípios. É o que ocorre, por exemplo, com a educação, com a saúde, com a segurança pública e assim por diante. Em um cenário como esse, a coordenação federativa torna-se necessária, ainda que em patamares mínimos, a fim de que os programas governamentais gestados em âmbito nacional sejam implementados de forma uniforme do território brasileiro.

Este compromisso constitucional naturalmente se direciona à consecução de determinados objetivos. Neste ponto, uma observação importante. Percebe-se em certa 
parcela da doutrina a tendência de elogiar a cooperação federativa, como um modo preferencial de atingir decisões e forjar políticas públicas melhores do que aquelas oriundas da ação individual dos entes federativos. Contudo, é de se admitir que a cooperação não é um fim em si mesmo: os entes federativos não coordenam a sua atuação de determinado modo por ser este supostamente um modo natural ou correto de levar a cabo as suas atribuições. Ao contrário, uma das vantagens que normalmente se atribui à federação consiste justamente na preservação da diversidade das entidades subnacionais, ao mesmo tempo em que se atinge a unidade necessária para a condução dos negócios de interesse comum. Por este motivo, a diversidade de soluções para um mesmo problema não deve ser encarada, em um primeiro momento, como uma distorção a ser mitigada e sim como uma decorrência lógica da adoção da forma de Estado Federal. A coordenação e a cooperação federativas surgem quando a atuação isolada dos entes federativos não é capaz de solucionar um problema, ou porque as soluções individuais por parte dos Estados e dos Municípios colocam-se em contrariedade com o interesse nacional.

No caso brasileiro, embora exista uma série de problemas cuja solução demanda essa conjugação de esforços típica do federalismo cooperativo, parece-nos que a Constituição Federal de 1988 quis orientar a cooperação federativa, de um ponto de vista mais geral, para a mitigação de uma das grandes mazelas - senão a maior - do Estado brasileiro, que é a questão das desigualdades sociais e regionais. Não por outro motivo a sua redução é erigida a objetivo fundamental da República Federativa do Brasil, conforme artigo $3^{\circ}$, III, da CF/88. ${ }^{458}$ Além do mais, o parágrafo único do artigo 23 , que prevê a edição de normas de cooperação em relação às políticas sociais mais relevantes, menciona expressamente "o equilíbrio do desenvolvimento e do bem-estar em âmbito nacional". Vale dizer, na federação brasileira, soluções individuais por parte de Estados e Municípios somente encontram amparo caso sejam capazes de mitigar o cenário de desigualdade e contribuam para o atingimento de um "bem-estar em âmbito nacional", ou ao menos quando não prejudiquem tais objetivos, colocando em uma posição de neutralidade em relação a estes últimos.

A segunda consequência importante diz respeito à existência de políticas públicas constitucionalmente descentralizadas e cooperativamente orientadas. Os casos mais emblemáticos neste ponto certamente são o da educação e da saúde, não só em virtude das normas constitucionais que mencionam expressamente a coordenação e a cooperação federativa nestas áreas e mencionadas supra. Com efeito, nestas duas políticas o

${ }^{458}$ Conforme SILVEIRA. Cooperação e Compromisso Constitucional nos Estados Compostos, p. 96. 
relacionamento entre os entes federativos e as atribuições de cada um vêm disciplinados de forma relativamente minuciosa pela própria Constituição Federal. No que tange à educação, dispõe o artigo $211 \mathrm{CF} / 88$ que a "União, os Estados, o Distrito Federal e os Municípios organizarão em regime de colaboração seus sistemas de ensino", sendo que: (i) a União organizará o sistema federal de ensino, financiará as suas instituições de ensino, e exercerá "em matéria educacional, função redistributiva e supletiva, de forma a garantir equalização de oportunidades educacionais e padrão mínimo de qualidade de ensino mediante assistência técnica e financeira aos Estados, ao Distrito Federal e aos Municípios"459; (ii) “os Estados e Distrito Federal atuarão prioritariamente no ensino fundamental e médio", e; (iii) "os Municípios atuarão prioritariamente no ensino fundamental e na educação infantil." Além do mais, dispõe o referido artigo que "na organização de seus sistemas de ensino, a União, os Estados, o Distrito Federal e os Municípios definirão formas de colaboração, de modo a assegurar a universalização do ensino obrigatório". Temos, assim, não só uma previsão da repartição da competência legislativa e de execução para a educação - mais precisamente, nos artigos 24, IX e 23, V, $\mathrm{CF} / 88$ - mas uma determinação constitucional de que o seu exercício deve ser coordenado - ou em caráter de colaboração, para utilizar a expressão empregada pelo texto constitucional.

Em matéria de saúde, o artigo 198 CF/88 dispõe que "as ações de serviços públicos de saúde integram uma rede regionalizada e hierarquizada e constituem um sistema único, organizado de acordo", entre outras diretrizes, com a "descentralização, com direção única em cada esfera de governo". Embora o seu $\S 2^{\circ}$ preveja o financiamento conjunto deste sistema único por parte da União, Estados, Distrito Federal e Municípios, o detalhamento das competências de cada nível de governo é feita somente nos artigos 16 a 18 da Lei $\mathrm{n}^{\circ}$ 8.080/1990, sendo que a descentralização federativa se deu nos termos das Normas Operacionais Básicas (NOBs) editadas pelo Ministério da Saúde. De todo modo, é a Constituição que determina que cada uma dessas atribuições deve ser realizada de forma coordenada, ao prever que todas elas devem necessariamente se integrar em um sistema único.

Nas áreas da saúde e da educação, portanto, não é necessário recorrer a um compromisso constitucional, de índole eminentemente principiológica, para se afirmar a necessidade de resolução concertada e pactuada de problemas, pois existem regras constitucionais que assim o determinam. Mas estas previsões contemplam um outro

\footnotetext{
459 Neste ponto, percebe-se nitidamente uma manifestação do legislador constituinte a fim de orientar a coordenação e a cooperação a fim de promover uma redução das desigualdades sociais e regionais.
} 
aspecto normativo importante, a saber: diante de regras jurídicas que impõem a cooperação e a coordenação nestas políticas públicas, não podem os entes federativos se furtarem de uma ação concertada. Não pode um Estado, por exemplo, organizar seu regime de ensino de outra forma que não envolva a colaboração com a União e com os Municípios que se localizem em seu território, sob pena de afrontar a Constituição. Também não pode um Estado ou um Município criar o seu próprio sistema de saúde, a ele destinando os recursos reservados ao Sistema Único de Saúde, pois tal programa se colocaria em total contrariedade ao disposto pela Constituição. Em outras palavras, onde a constituição determina de forma específica a atuação concertada da União, dos Estados e dos Municípios, está-se diante da cooperação federativa propriamente dita para falar com Gilberto BERCOVICI, ao passo que a colaboração fundamentada unicamente no compromisso constitucional de cooperação revela somente hipóteses de coordenação federativa. ${ }^{460}$

Contudo, é de se admitir que a cooperação e a coordenação federativas não se desenvolvem na prática única e exclusivamente porque normas constitucionais assim determinam. Por certo, esta é uma afirmação que pode causar algum estranhamento no meio jurídico, mas o fato é que, a despeito de a constituição efetivamente prescrever a atuação concertada dos entes federativos em determinadas políticas públicas, a coordenação no Estado Federal brasileiro é um fenômeno complexo, submetido a uma série de condicionamentos além daqueles eminentemente jurídicos. É chegado o momento, portanto, de tratar de alguns aspectos políticos da coordenação federativa no Brasil. Neste ponto, analisam-se dois vetores importantes para a compreensão da coordenação federativa no Brasil, ambos também referidos por Marta ARRETCHE. Deste modo, tem-se que (i) a coordenação entre os entes federativos varia, no Brasil, conforme cada política setorial (ii) sendo que cada política permanece influenciada, em maior ou menor medida, pelas estruturas criadas anteriormente, em especial, durante o regime militar $^{461}$. Ou seja, neste ponto também se verifica uma continuidade decisória, para falar com a referida autora. Destrinchemos este argumento a partir da análise das políticas públicas de saúde e de educação.

\footnotetext{
${ }^{460}$ A distinção que BERCOVICI traça entre cooperação e coordenação foi devidamente elucidada no item 1.2.3 desta tese. Deve-se ressaltar, contudo, que para o referido autor, a cooperação seria visualizada sobretudo no arranjo competencial previsto pelo artigo $23 \mathrm{CF} / 88$, ao passo que a coordenação federativa encontraria respaldo sobretudo nas competências legislativas concorrentes previstas no artigo 24 CF/88. A intersecção realizada neste tópico entre a referida distinção e a ideia de compromisso constitucional de cooperação consiste em uma conclusão obtida a partir da confrontação das considerações de Gilberto BERCOVICl e de Alessandra SILVEIRA sobre o tema da cooperação federativa.

${ }^{461}$ ARRETCHE. Federalismo e políticas sociais, p. 22.
} 
Segundo Sônia Miriam DRAIBE, embora as primeiras iniciativas reconduzíveis ao que se convenciona chamar de Welfare State tenham sido introduzidas no Brasil já na década de 30, foi durante o período da ditadura militar que um sistema de proteção social se consolidou institucionalmente, vale dizer, com a criação de "organismos e mecanismos institucionais e financeiros asseguradores da reprodução do conjunto das políticas sociais" $" 462$. Nos dizeres da referida autora,

“(...) sob as características autoritárias e tecnocráticas do regime que se instalou
em 1964, que se completa o sistema de welfare no Brasil; define-se o núcleo duro
da intervenção social do Estado; arma-se o aparelho centralizado que suporta tal
intervenção; são identificados os fundos e recursos que apoiarão financeiramente
os esquemas de políticas sociais; definem-se os princípios e mecanismos de
operação e, finalmente, as regras de inclusão/exclusão social que marcam
definitivamente o sistema. A expansão maciça que se verifica a partir de meados
dos anos 70 far-se-á sob esse padrão organizado desde 1964 e que já no final dos
70 apresenta indícios de esgotamento e crise (nos seus aspectos organizacionais,
financeiros e sociais)." ${ }^{\circ 63}$

Portanto, analisar as iniciativas tomadas nesse período parece ser um ponto de partida seguro quando se busca compreender as continuidades e descontinuidades da descentralização e da coordenação das políticas sociais. No que diz respeito à política de educação, em especial a política de educação básica, o primeiro paradigma importante reside na antiga Lei de Diretrizes e Bases da Educação (Lei n 5.692/1971), a qual propunha uma descentralização na prestação especialmente para a esfera municipal, acompanhada de uma ação uniformizadora por parte do governo federal ${ }^{464}$. Dispunha o seu artigo 58, caput, que "a legislação estadual supletiva (...) estabelecerá as responsabilidades do próprio Estado e dos seus Municípios no desenvolvimento dos diferentes graus de ensino e disporá sobre medidas que visem a tornar mais eficiente a aplicação dos recursos públicos destinados à educação", sendo que, nos termos do parágrafo único deste mesmo dispositivo, "as providências de que trata este artigo visarão à progressiva passagem para a responsabilidade municipal de encargo e serviços de educação, especialmente de $1^{\circ}$ grau, que pela sua natureza possam ser realizados mais satisfatoriamente pelas administrações locais". Por fim, o artigo 59 da Lei $n^{\circ} 5.692 / 1971$ previa que os Municípios deveriam aplicar pelo menos “20\% da receita tributária municipal no ensino de $1^{\circ}$ grau”, o que posteriormente foi aumentado para " $20 \%$ das transferências que lhes couberem no Fundo de Participação". Esta tentativa de municipalização do ensino básico teve, contudo, resultados limitados. Como

\footnotetext{
462 Sônia Miriam DRAIBE. As políticas sociais do regime militar brasileiro: 1964-84. In: Gláucio Ary Dillon SOARES, Maria Celina D’Araújo (Org.). 21 anos de regime militar: balanços e perspectivas. Rio de Janeiro: Fundação Getúlio Vargas, 1994, p. 275.

463 DRAIBE. As políticas sociais do regime militar brasileiro, p. 276.

${ }^{464}$ Como observa DRAIBE. As políticas sociais do regime militar brasileiro, p. 281.
} 
observa Marta ARRETCHE, na prática Estados e Municípios possuíam suas próprias redes de ensino, o que fez com que "a oferta de ensino tenha se consolidado de forma nitidamente dual; isto é, tanto Estados quanto municípios prestam serviços educacionais nos níveis infantil, fundamental e médio, dado que não havia legalmente nenhuma espécie de 'divisão de trabalho’ entre estes dois níveis de governo(...)"465.

Com o advento da Constituição Federal de 1988, este cenário não restou substancialmente alterado: o $\S \S 2^{\circ}$ e $3^{\circ}$ do seu artigo 212 preveem somente que Municípios atuarão "prioritariamente no ensino fundamental e educação infantil" e Estados “prioritariamente no ensino fundamental e médio"; a União, por sua vez, exerce uma "função redistributiva e supletiva, de forma a garantir equalização de oportunidades educacionais e padrão mínimo de qualidade de ensino mediante assistência técnica e financeira aos Estados, ao Distrito Federal e aos Municípios". Ou seja, persistiu-se um regime dual de oferta de ensino, com todos os seus problemas de superposição de competências e inconsistências, tendo em vista que aos Estados e Municípios é lícito, ainda que não desejável de um ponto de vista constitucional, atuar da educação infantil até o ensino médio. A União também continua a exercer um importante papel normatizador, além de se responsabilizar pela igualação da prestação deste serviço público em âmbito nacional.

Ocorre que neste ponto a ação coordenadora da União sofre uma limitação importante. Trata-se, afinal, de uma política pública financiada principalmente por Estados e Municípios ${ }^{466}$. Nos termos do artigo 212 CF/88, “a União aplicará, anualmente, nunca menos de dezoito, e os Estados, o Distrito Federal e os Municípios vinte e cinco por cento,

\footnotetext{
${ }^{465}$ Marta ARRETCHE. Estado Federativo e políticas sociais: determinantes da descentralização. Rio de Janeiro: Revan; São Paulo: FAPESP, 2000, p. 137. Prossegue a referida autora, neste mesmo trecho, afirmando que "a noção de dualidade das redes também é caracterizada pelo fato de que não se construíram, entre Estados e seus municípios, formas de planejamento, para além do respeito a uma definição curricular dos serviços oferecidos por cada um deles. A carreira, o salário e o pagamento dos professores, a natureza e qualidade dos serviços educacionais oferecidos, bem como os padrões de avaliação, foram sempre executados - na esmagadora maioria dos Estados - de modo independente para uma mesma série em uma mesma cidade por suas redes, que tenderam a operar de modo inteiramente paralelo". Note-se que, do ponto de vista qualitativo, as críticas que se pode fazer à política de educação desenvolvida durante o regime militar são ainda mais contundentes. Como observa Sonia Miriam DRAIBE, “(...) quanto ao grau de escolaridade das pessoas com mais de 10 anos, cerca de $23 \%$ não tinham logrado completar um ano de instrução e apenas 18,3\% haviam conseguido atingir ou superar oito anos de escolaridade. Se o acesso à escola básica havia quase se generalizado, mais da metade dos alunos, entretanto, não lograva completar as suas primeiras séries, e menos de $25 \%$ completavam o primeiro grau, seja por evasão, seja sobretudo pela repetência. As baixas taxas de cobertura da educação pré-escolar (7\%) e principalmente infantil (creches) mas sobretudo a tão insignificante cobertura do segundo grau - cerca de $15 \%$ da faixa etária correspondente - completam este quadro de insuficiências e atrasos sociais" (DRAIBE. As políticas sociais do regime militar brasileiro, p. 292).

466 Como ressalta Marta ARRETCHE, o governo federal desempenha uma função supletiva no que tange ao financiamento da política de educação, custeando programas de alimentação para estudantes e construção de unidades escolares (Federalismo e políticas sociais no Brasil, p. 24).
} 
no mínimo, da receita resultante de impostos, compreendida a proveniente de transferências, na manutenção e desenvolvimento do ensino". Note-se que alguns Estados aumentaram inclusive este patamar nas suas respectivas constituições, como é o caso de São Paulo, que adota o patamar mínimo de "30 por cento da receita resultante de impostos, incluindo recursos provenientes de transferências" (artigo 255 da Constituição Estadual). Além do mais, há os recursos do salário-educação - instituído já no período da ditadura militar com o intuito de financiar ações de educação ${ }^{467}$ - os quais consistem em uma fonte adicional de financiamento desta política pública, a serem repartidos com Estados e Municípios (artigo $\left.212, \S 5^{\circ}, \mathrm{CF} / 88\right)$. Em um cenário como este, a União deve forjar mecanismos hábeis a promover a adesão dos Estados e dos Municípios, pois na ausência destes mecanismos estes entes tendem a utilizar os recursos disponíveis conforme suas próprias prioridades, ainda que na área da educação se submetam às disposições da legislação federal, como já ressaltado alhures.

A fim de contornar este problema, o então Presidente Fernando Henrique Cardoso logrou aprovar a EC $\mathbf{n}^{0}$ 14/96, conhecida por ter instituído o Fundo de Manutenção e Desenvolvimento do Ensino Fundamental e de Valorização do Magistério (FUNDEF). Consoante o artigo 60 ADCT, com redação dada pela referida emenda, foram instituídos fundos estaduais para os quais eram vertidos determinados porcentuais das receitas estaduais e municipais. Posteriormente, estes valores eram redistribuídos ao Estado e aos Municípios "proporcionalmente ao número de alunos nas respectivas redes de ensino fundamental”. À União cabia complementar os recursos dos fundos estaduais "sempre que, em cada Estado e no Distrito Federal, seu valor não alcançar o mínimo definido nacionalmente". Embora seja possível extrair deste dispositivo e também da Lei $n^{\circ}$ 9424/1996, que regulamentou o FUNDEF, alguns objetivos da política de educação, como um compromisso de ajustar o valor mínimo por aluno de forma que ele fosse compatível com um padrão mínimo da qualidade de ensino, a remuneração dos professores do ensino fundamental, a erradicação do analfabetismo, o fato é que o principal efeito deste programa foi uniformizar a aplicação dos recursos destinados à educação. Como ressalta Fernando Luiz ABRUCIO, "o objetivo do governo federal com o Fundef foi corrigir a má distribuição de recursos entre as diversas regiões e dentro dos próprios estados, diminuindo as desigualdades presentes na rede pública de ensino. Trata-se, nesse sentido, de uma política vertical e horizontal de redistribuição de recursos, o que a faz única no

\footnotetext{
467 O salário-educação foi instituído pela Lei no 4.440/1964, tendo sido revogado posteriormente pelo DecretoLei $n$ o 1.422/1975. A sua inserção dentro de um modo específico de financiamento do gasto social durante o regime militar é empreendida em DRAIBE. As políticas sociais do regime militar brasileiro, pp. 288-290.
} 
federalismo brasileiro"468. É verdade que o FUNDEF, ao condicionar a transferência de recursos ao número de alunos matriculados pelos Estados e pelos Municípios, acabou por promover uma expansão na oferta de matrículas, indo ao encontro do objetivo de universalização do ensino previsto no artigo $211, \S 4^{\circ}, \mathrm{CF} / 88 .{ }^{469}$ Porém, persiste um cenário de desigualdade na prestação deste serviço público em âmbito nacional, o que não tem sido devidamente equacionado pelas sucessivas iniciativas do governo federal. $\mathrm{O}$ FUNDEB, instituído pela EC n ${ }^{\circ} 53 / 2006$ e regulamentado pela Lei no $11.494 / 2007$, por consistir quase que em uma reedição do FUNDEF, não alterou este cenário.

A política pública de saúde, por sua vez, também se caracterizava por uma dualidade de regimes durante o período da ditadura militar, como bem ressalta Sonia Miriam DRAIBE:

\begin{abstract}
"Mas o que de fato ocorreu foi a organização, no Brasil, de duas estruturas: a de saúde pública, desenvolvida pelo ministério [da saúde] e por ações de estados e municípios, e a de medicina previdenciária, realizada pelos serviços médicos associados primeiramente aos institutos de aposentadorias e pensões e, após 1967, pelo INPS/Inamps. Nessa estrutura desintegrada, cabia à rede ministério/secretarias estaduais e municipais a assistência coletiva, principalmente a de caráter médico-sanitário de orientação preventiva. Aos serviços previdenciários cabia prover assistência médica aos segurados, individualmente e apoiada na rede hospitalar e ambulatorial" ${ }^{\prime 470}$
\end{abstract}

Contudo, a proeminência certamente residia na segunda destas estruturas, a qual era financiada por contribuições oriundas da Previdência Social e possuía três características importantes. Em primeiro lugar, só podiam usufruir dos serviços custeados pelo INPS/Inamps aqueles que eram empregados formalmente. Com efeito, estava-se diante de um sistema previdenciário e contributivo, de forma que, para auferir os seus benefícios, era necessário verter contribuições para o sistema, o que em regra se dava apenas pelo emprego formal. Em segundo lugar, tratava-se de uma estrutura com nítida ênfase na medicina curativa, o que implicava a existência de uma rede hospitalar, própria ou conveniada. Neste ponto, o regime militar acabou optando por parcerias com o regime privado, inclusive subsidiando a construção de hospitais privados ${ }^{471}$, o que acabou funcionando como uma "forte alavanca para a constituição e o fortalecimento dos interesses ligados ao complexo médico-empresarial privado, que nos anos 80 chega a responder por $70 \%$ da oferta de serviços médicos no país" ${ }^{\# 72}$. Estes poderosos interesses subsistem até os

\footnotetext{
${ }^{468}$ ABRUCIO. A coordenação federativa no Brasil, p. 60.

${ }^{469}$ ARRETCHE. A centralização no Estado Federativo Brasileiro, p. 71.

470 DRAIBE. As políticas sociais do regime militar brasileiro, pp. 283-284.

${ }^{471}$ Como ressalta ARRETCHE. A centralização no Estado Federativo Brasileiro, p. 104.

472 DRAIBE. As políticas sociais do regime militar brasileiro, p. 284.
} 
dias de hoje, consistindo em um elemento importante para a compreensão da atual política de saúde e em um dos grupos de sua sustentação política. ${ }^{473}$ Em terceiro lugar, sendo o que mais interessa para a análise desenvolvida aqui, o regime administrado pelo INPS/Inamps possuía feições eminentemente centralizadas, concentrando recursos financeiros e políticos, e, como se tratava da estrutura predominante da política de saúde desenvolvida neste período, é de se reconhecer que as principais decisões sobre esta política pública eram tomadas no nível federal. ${ }^{474}$

Já as medidas de medicina preventiva, conduzidas pela primeira das estruturas referidas por DRAIBE supra, descentralizaram-se no decorrer dos anos. Nesse sentido, ressalta Marta ARRETCHE que "os grandes provedores já eram os estados e municípios no final dos anos 80, assim como o governo federal já não era mais um provedor importante, na medida em que apenas 5,2\% dos estabelecimentos de atenção primária à saúde estavam sob sua responsabilidade. $" 475$

A partir da crise econômica vivenciada pelo Brasil durante a década de 70, que se estendeu durante a década de 80 do século XX, este modelo apresentou sinais de desgaste. Afinal, a sua principal fonte de financiamento eram contribuições oriundas de relações de emprego formal. Com o crescente desemprego, o regime militar viu-se diante de um duplo problema: em primeiro lugar, um decréscimo nos recursos disponíveis para o financiamento desta política pública; em segundo lugar, a incapacidade de fornecer aos desempregados - e também aos trabalhadores sem vínculo formal como um todo - uma prestação de saúde em moldes minimamente dignos.

Neste mesmo período surge o chamado movimento sanitarista, que possuía uma postura crítica ao sistema de saúde instituído pelo regime militar e propunha uma série de reformas que visavam conferir a esta política pública um viés mais redistributivo ${ }^{476}$. E o que é mais importante, foi o movimento de mais influenciou os principais delineamentos constitucionais e legais do Sistema Único de Saúde (SUS) ${ }^{477}$. Deste modo, a saúde foi prevista como um "direito de todos e dever do Estado, garantido mediante políticas sociais e econômicas que visem à redução do risco de doença e de outros agravos e ao acesso

\footnotetext{
${ }^{473}$ Conforme ARRETCHE. A centralização no Estado Federativo Brasileiro, pp. 104 e 109-110.

${ }^{474}$ Conforme DRAIBE. As políticas sociais do regime militar brasileiro, p. 284.

${ }^{475}$ ARRETCHE. A centralização no Estado Federativo brasileiro, p. 104.

${ }^{476}$ ARRETCHE. A centralização no Estado Federativo brasileiro, p. 106.

477 Deve-se ressaltar que a corrente sanitarista acabou por conduzir o processo que culminou com a aprovação do SUS, mas a ele se agregava uma série de outros interesses, como o dos hospitais privados já mencionados neste item. Embora se trate de uma análise muito interessante, opta-se neste ponto por se remeter à literatura pertinente, como, por exemplo, ARRETCHE. A centralização no Estado Federativo brasileiro, pp. 106 e ss.
} 
universal e igualitário às ações e serviços para sua promoção, proteção e recuperação" (artigo 196, caput, CF/88), embora livre à iniciativa privada (artigo 199 CF/88). Além do mais, "as ações e serviços públicos de saúde integram uma rede regionalizada e hierarquizada e constituem um sistema único" (artigo 198 CF/88), organizado segundo algumas diretrizes como a descentralização federativa e o atendimento integral, com prioridade para as atividades preventivas.

Em outras palavras, o que se propunha era uma reforma ambiciosa na política de saúde brasileira, praticamente uma inversão de paradigmas em relação ao sistema do INPS/Inamps: ao invés de um sistema contributivo, pretendia-se instaurar um sistema gratuito, financiado por recursos do orçamento da União; ao invés de um direito limitado a um grupo delimitado de titulares, propugnava-se por um "direito de todos", mais precisamente, por um direito fundamental nos termos do artigo $6^{\circ} \mathrm{CF} / 88$; ao invés de focar no tratamento de doenças por meio principalmente de um rede hospitalar e ambulatorial, o que se preconizava era "um atendimento integral, com prioridade para as ações preventivas"; ao avesso da centralização federativa verificada sob a égide da ordem constitucional anterior, o paradigma que deveria orientar as relações federativas nesta política pública a partir de 1988. Naturalmente, mudanças de tamanha magnitude demoraram para ser efetivadas. Tanto que cientistas políticos como Marta ARRETCHE entendem que a construção desta política pública somente terminou em 2000, quando 99\% dos Municípios brasileiros aderiram ao SUS. ${ }^{478}$ De nossa parte, embora não seja o nosso objetivo traçar um histórico da política de saúde, acredita-se que é relevante retomar alguns fatos importantes para compreender a coordenação entre União, Estados e Municípios nesta seara.

Embora a questão do financiamento da saúde tenha sido resolvida somente ao cabo do seu processo de formação, o fato é que se está diante de uma política pública custeada em grande medida pela União, o que dá a este ente federativo um recurso valioso no momento de promover a descentralização e a coordenação federativas. $O$ instrumento jurídico pelo qual estas duas últimas têm sido promovidas consiste nas Normas Operativas Básicas (NOBs), editadas pelo Ministério da Saúde. A NOB SUS 01/93 (Portaria $n^{\circ} 545 / 1993$ ), editada ainda sob o governo Itamar Franco, foi a primeira a tentar promover uma descentralização compatível entre receitas e encargos. Porém, as dificuldades em torno do financiamento desta política pública acabaram por comprometer os seus resultados. ${ }^{479}$

\footnotetext{
478 ARRETCHE. A centralização no Estado Federativo brasileiro, p. 101

${ }^{479}$ Como é possível extrair de ARRETCHE. A centralização no Estado Federativo brasileiro, pp. 113-115. Notese que, apesar dos problemas enfrentados durante a implementação da NOB SUS 01/1993, é possível atestar
} 
A NOB SUS 1/96 (Portaria $\left.n^{\circ} 2.223 / 1996\right)$, por sua vez, obteve maior sucesso no seu objetivo de descentralizar a prestação dos serviços de saúde. Como observa Fernando Luiz ABRUCIO, "segundo dados de dezembro de 2001, 99\% dos municípios estavam habilitados a uma das condições de gestão, sendo 89\% em Gestão Plena da Atenção Básica, e $10,1 \%$ na Gestão Plena do Sistema Municipal"480. É de se ressaltar que esta norma ministerial criou um mecanismo interessante para não só induzir a adesão da esfera municipal à política nacional, mas também para fazer com que os Municípios executassem programas específicos definidos em âmbito nacional por meio de um Piso Assistencial Básico (PAB). Novamente segundo ABRUCIO,

\begin{abstract}
"O PAB é composto de uma parte fixa e outra variável. A primeira destina-se à atenção básica da saúde e garante a transferência automática, fundo a fundo, de um mínimo de R $\$ 10$ por habitante/ano para todos os municípios brasileiros. A ideia era reduzir as desigualdades existentes entre as municipalidades, uma vez que aquelas com maior 'capacidade produtiva' tendiam a receber mais recursos, ao passo que as pequenas, com rede incipiente ou nenhuma rede de atenção à saúde, pouco recebiam. A parte variável do PAB é uma das invenções mais frutíferas do federalismo nos anos FHC. Sua distribuição de recursos só ocorria se os governos locais aderissem aos programas nacionais definidos como prioritários. Além disso, para receber tais recursos era preciso passar por todo o sistema de conselhos, que procura fiscalizar o uso adequado dos recursos públicos.

Foram seis os programas nacionais incluídos no PAB variável: Saúde da FamíliaAgentes Comunitários de Saúde, Saúde Bucal, Assistência Financeira Básica, Combate às Carências Nutricionais, Combate a Endemias e Vigilância Sanitária. A característica básica dessas políticas era a ênfase na prevenção e não na cura, lema histórico do movimento sanitarista. O município podia aderir a quantos quisesse e recebia os recursos de acordo com o estipulado em cada programa. Tais ações governamentais, ademais, envolvem capacitação dos gestores locais e a avaliação dos resultados, seja pelo sistema federal, seja pelo controle social ligado aos mecanismos de accountability intrínsecos ao SUS. Os resultados foram bastante satisfatórios no que se refere à adesão e, consequentemente, ao número de pessoas atingidas. No caso do Programa de Agentes Comunitários de Saúde (PACS), por exemplo, houve um aumento de $30 \%$ na população coberta entre 1994 e 1998 (SINGER, 2002, p. 517)"481
\end{abstract}

Note-se que, a despeito desta descentralização ordenada de recursos e de encargos promovida pelo governo federal por meio da NOB SUS 1/1996, ainda hoje é possível observar diferenças substanciais no que tange à qualidade e à quantidade de serviços prestados em âmbito nacional. De todo modo, a referida norma teve o mérito não só de promover uma racionalização do gasto público na área da saúde - como fez o FUNDEF e o FUNDEB na área da educação - mas obteve efetivamente uma municipalização da prestação deste serviço público, ao encontro da diretriz constitucional da descentralização (artigo 198,

o sucesso de alguns dos instrumentos por ela previstos, como é o caso das Comissões Intergestoras Bipartites e Tripartite, as quais permanecem até os dias atuais, como importante mecanismo de inflência de Estados e Municípios sobre o processo decisório em âmbito federal.

${ }^{480}$ ABRUCIO. A coordenação federativa no Brasil, p. 58.

${ }^{481}$ ABRUCIO. A coordenação federativa no Brasil, p. 59. 
I, CF/88), além de induzir os Municípios brasileiros a concretizar programas específicos, considerados importantes pelo Ministério da Saúde. Sem dúvida, o fato de a União ser a grande responsável pelo financiamento nesta área desempenhou um papel importante neste fenômeno, tendo em vista que a saúde é um tema importante para Estados e Municípios do ponto de vista político e estes últimos necessitam de recursos federais para levar a cabo seus programas de saúde. Por isso, o governo federal - mais especificamente, o Ministério da Saúde - conseguiu conferir uma certa uniformidade às atuações estaduais e municipais, ao condicionar o recebimento de verbas federais à execução de certas prestações específicas.

No caso da educação, a utilização de repasses federais produziria resultados limitados, tendo em vista que Estados e Municípios já custeavam as suas respectivas redes de ensino. Por isso, a técnica empregada pelo governo federal foi vincular, por meio de emenda constitucional, a utilização das receitas estaduais e municipais a parâmetros ditados por lei federal. Ou seja, limitou-se a liberdade de Estados e Municípios para alocar os seus respectivos recursos, o que representa, por sua vez, um elemento importante da centralização verificada a partir da década de 90, como se analisou no item 3.2.2. Já no caso da política de saúde é possível se vislumbrar uma centralização, sobretudo no plano normativo. Além do mais, também aqui se utilizou a técnica da emenda constitucional para vincular recursos federais, estaduais e municipais. As EC no 29/2000 e, mais recentemente, a EC no 86/2015, são indicativas deste fenômeno. Porém, esta foi uma medida tomada a partir dos anos 2000, quando a descentralização da prestação do serviço de saúde já havia sido iniciada. De um modo ou de outro, coordenação e centralização andam juntas nestas políticas públicas, o que se coloca em conformidade com a opção constitucional, já analisada nesta tese, de conferir à União um papel proeminente na coordenação das relações federativas brasileiras.

Já o estudo da cooperação na federação alemã também pode ser cindido em aspectos jurídicos e políticos. Comecemos a exposição pelo primeiro destes aspectos, retomando a distinção feita pela doutrina alemã entre coordenação diretiva (direktive Koordination) e coordenação cooperativa (kooperative Koordination). Segundo Walter RUDOLF, a coordenação diretiva tem lugar quando a União detém, dentre as competências que lhe foram atribuídas pela Lei Fundamental, uma posição de coordenação tal que lhe permita decidir de forma diretiva. Já a coordenação cooperativa ocorre quando não é conferido semelhante papel à União, de forma que caberá ao Bund e aos Länder, com o ente central ou entre si, conformarem a sua atuação a premissas estabelecidas conjuntamente. ${ }^{482}$

\footnotetext{
482 RUDOLF. \& 141 Kooperation im Bundesstaat. In: ISENSEE, KIRCHHOF (Hrsg.). Handbuch des Staatsrechts, p. 1016. Neste ponto, o autor retoma o raciocínio desenvolvido em Gunter KISKER. Kooperation im Bundesstaat:
} 
Instrumentos de coordenação diretiva podem ser visualizados, por exemplo, na execução estadual de leis federais, tanto como assunto próprio quanto sob as ordens da União $^{483}$. Como já se teve a oportunidade de analisar alhures, uma das características do federalismo alemão desde a Constituição de 1871 e que foi acolhida pela Lei Fundamental consiste na não-coextensividade da titularidade das competências legislativas e de execução. Ou seja, é possível e é esperado que os Länder executem leis do Bund. Em razão disso, ao governo federal são conferidos alguns mecanismos para garantir que esta atividade de execução se dê de modo satisfatório, mas aos governos estaduais, por meio do Conselho Federal, também são garantidos meios para interferir na utilização destes mecanismos pelo Bund. Esta é uma análise que será desenvolvida com a devida profundidade no quinto e no sexto capítulos da tese. Por ora, cumpre apenas ressaltar que se está falando, entre outros, do artigo 84 GG, o qual é extremamente importante para a compreensão do aumento da importância do Conselho Federal sob a égide da Lei Fundamental de 1949. Afinal, a possibilidade de a União legislar sobre a instituição de autoridades administrativas e sobre procedimento administrativo estaduais, como autoriza o parágrafo primeiro do referido dispositivo, nada mais é do que um instrumento de coordenação diretiva conferido à União, em relação ao qual o Conselho Federal deve manifestar o seu consentimento. Porém, neste caso prevaleceu a interpretação de que o Conselho Federal deveria consentir com todo o conteúdo da lei federal que contivesse semelhante instrumento, sendo este um elemento importante para compreender a centralização federativa verificada na federação alemã a partir de $1949^{484}$.

Outros instrumentos de cooperação diretiva ressaltados por Walter RUDOLF consistem no dever da União de ouvir os Estados-membros em determinados assuntos, como no caso de uma nova organização do território federal (artigo 29 II 2 GG) e no caso de tratados internacionais que afetem "relações especiais de um Land" 485 . Segundo este mesmo autor, a coordenação diretiva não envolveria exatamente desdobramentos do chamado federalismo cooperativo. Somente os instrumentos de coordenação federativa poderiam ser reconduzidos a este paradigma, razão pela qual sua exposição se concentra nestes

\footnotetext{
Eine Untersuchung zum kooperativen Föderalismus in der Bundesrepublik Deutschland. Tübingen: J. C. B. Mohr (Paul Siebeck), 1971, pp. 3 e 7 e ss.

${ }^{483}$ Como ressalta RUDOLF. $§ 141$ Kooperation im Bundesstaat. In: ISENSEE, KIRCHHOF (Hrsg.). Handbuch des Staatsrechts, p. 1016.

${ }^{484}$ Conforme analisado no item anterior.

${ }^{485}$ RUDOLF. $\S 141$ Kooperation im Bundesstaat. In: ISENSEE, KIRCHHOF (Hrsg.). Handbuch des Staatsrechts, p. 1016.
} 
últimos $^{486}$. A presente tese, a partir deste momento, também foca na apresentação dos principais instrumentos de coordenação cooperativa, deixando aqui consignada a importância que a modalidade diretiva de coordenação desempenha nas relações federativas alemãs.

Ao se analisar o texto da Lei Fundamental alemã, percebe-se - tal como na Constituição Federal de 1988 - que as referências à colaboração ou à atuação coordenada dos entes federativos são escassas. ${ }^{487}$ Com efeito, somente no artigo 91a II GG, que trata de uma das tarefas comuns (Gemeinschaftsaufgaben), se encontra uma referência à Koordinierung, ou coordenação. A palavra Vereinbarung ou acordo, por sua vez, é mencionada mais vezes, não só no capítulo dedicado às tarefas comuns e à colaboração administrativa (Verwaltungszusammenarbeit), como também em outros dispositivos esparsos. Ainda assim, não se pode afirmar que se esteja diante de um texto constitucional impregnado de menções à coordenação federativa. Porém, isso não significa que a constituição alemã não seja informada por um paradigma de federalismo cooperativo: ao contrário, sabe-se que o caso alemão é caracterizado pela intensa cooperação entre os entes federativos, em especial por meio da tomada de decisões conjuntas. Ocorre que estas decisões são tomadas em diferentes instâncias, formais e informais, e estendem-se a áreas não contempladas pela Lei Fundamental de 1949, como ocorre nas propostas de uniformização da legislação estadual. Ao analisar a questão, Walter RUDOLF distingue cinco formas de coordenação cooperativa. Três delas assumem especial destaque para a presente tese, razão pela qual serão brevemente expostos a seguir. ${ }^{488}$

Em primeiro lugar estão as reuniões (Besprechungen), que se situam em um plano mais informal. Elas podem se destinar à mera obtenção de informações - por exemplo, um Estado-membro alemão deseja saber como outro Estado lidou com um determinado assunto - ou até à elaboração ou à obstrução de projetos de lei. Neste último caso, as reuniões são especialmente úteis quando a questão não puder ser tratada nas conferências dos Ministros ou por uma das comissões do Conselho Federal. De todo modo, deve-se ressaltar que elas consistem basicamente em um "meio de colaboração na área

\footnotetext{
${ }^{486}$ RUDOLF. § 141 Kooperation im Bundesstaat. In: ISENSEE, KIRCHHOF (Hrsg.). Handbuch des Staatsrechts, pp. 1016-1017.

${ }^{487}$ Como observa RUDOLF. § 141 Kooperation im Bundesstaat. In: ISENSEE, KIRCHHOF (Hrsg.). Handbuch des Staatsrechts, p. 1017.

${ }^{488}$ As outras duas formas apontadas por Walter RUDOLF consistem na transferência de competências - a qual pode ser instrumentalizada de diversas formas, inclusive por meio da celebração de contratos estatais, lembrando apenas que a transferência definitiva somente pode se dar por meio de reforma constitucional -e a colaboração do Bund e dos Länder nos assuntos da União Europeia (RUDOLF. \& 141 Kooperation im Bundesstaat. In: ISENSEE, KIRCHHOF (Hrsg.). Handbuch des Staatsrechts, pp. 1034 e ss).
} 
administrativa e no campo político. Se acordos são obtidos, então eles são sem vinculação jurídica", com exceção de acordos tomados por escrito, e que são reconhecidos como vinculantes. ${ }^{489}$

Em segundo lugar vêm as conferências (Konferenzen) e as comissões (Ausschüsse). Aqui se situam as conferências dos ministros-presidentes (Ministerpräsidentenkonferenz), que ocorrem três ou quatro vezes ao ano e que se ocupam de questões estaduais ou federais que afetam todos os Länder, e as famosas conferências ministeriais (Fachministerkonferenz), as quais, consistem no "mais importante instrumento da colaboração intrafederativa para a coordenação dos interesses estaduais”. Estas últimas, por sua vez, contam em regra com a presença do ministro federal competente para a matéria, o qual atua ativamente nas decisões tomadas no âmbito destas comissões, ao passo que nas conferências de ministros-presidentes não há um representante federal. As comissões, por sua vez, situam-se abaixo do nível ministerial e podem ser instituídas inclusive pelas conferências de ministros, hipótese em que elas se ocuparão de preparar as conferências e, de um modo geral, da coordenação de assuntos de interesse comum das administrações estaduais. ${ }^{490}$ Neste ponto, RUDOLF faz uma observação importante:

\begin{abstract}
"Porque nas comissões e nas comunidades de trabalho participam os respectivos especialistas dos Estados e geralmente também da União, a sua influência na prática da sua área de competência não deve ser subestimada. Aqui são desenvolvidas propostas para leis estaduais idênticas, coordenados regulamentos ou preceitos administrativos nos Estados e sugeridos preceitos administrativos da União conforme artigo 84 II e 85 II GG. Estas comissões e comunidades de trabalho constituem um instrumento essencial para a unificação jurídica na República Federal”491
\end{abstract}

As deliberações no âmbito das conferências e das comissões podem ser tomadas por maioria ou então por unanimidade. No caso das conferências, prevalece atualmente a tomada das decisões por maioria, sobretudo quando se tratam de questões organizatórias e

\footnotetext{
489 RUDOLF. § 141 Kooperation im Bundesstaat. In: ISENSEE, KIRCHHOF (Hrsg.). Handbuch des Staatsrechts, pp. 1020-1022. A citação direta encontra-se na página 1021.

490 RUDOLF. § 141 Kooperation im Bundesstaat. In: ISENSEE, KIRCHHOF (Hrsg.). Handbuch des Staatsrechts, pp. 1022-1025. A citação direta encontra-se na página 1022.

${ }^{491}$ RUDOLF. \& 141 Kooperation im Bundesstaat. In: ISENSEE, KIRCHHOF (Hrsg.). Handbuch des Staatsrechts, p. 1025. No original: "Da in den Ausschüssen und Arbeitsgemeinschaften die jeweiligen Fachspezialisten der Länder und meist auch des Bundes mitarbeiten, ist deren Einfluss auf die Praxis in ihrem Kompetenzbereich nicht zu unterschätzen. Hier werden die Entwürfe für gleichlautende Landesgesetze erarbeitet, Rechtsverordnungen oder Verwaltungsvorschriften in den Ländern koordiniert und die Verwaltungsvorschriften des Bundes gemäß Art. 84 Abs. 2 und 85 Abs. 2 GG entworfen. Diese Ausschüsse und Arbeitsgemeinschaften bilden ein wesentliches Instrument für die Rechtsvereinheitlichung in der Bundesrepublik". Note-se que os preceitos administrativos do Bund são típicos instrumentos da coordenação diretiva, os quais acabam por receber o influxo da coordenação cooperativa quando seus termos são discutidos ou propostos em conferências ou comissões.
} 
de recomendações ao Bund. Porém, quando se tratam de recomendações dirigidas a um Estado, considera-se necessário o seu consentimento. No caso das comissões, as deliberações são tomadas pela maioria dos votos, exceto quando foi fixada a regra da unanimidade. $^{492}$

Em terceiro lugar surgem as formas contratuais de coordenação cooperativa, em especial, os contratos estatais (Staatsverträge) ${ }^{493}$, acordos administrativos (Verwaltungsabkommen) e os acordos de coordenação (Koordinationsabsprachen).

Konrad HESSE, quando tratou da cooperação como uma das tendências unitarizantes da federação alemã, referiu-se também às conferências ministeriais, mas principalmente à celebração de contratos e acordos pelos Estados em áreas de sua própria competência ${ }^{494}$. Porém, é de se admitir que existem diferenças sensíveis entre os modelos contratuais no que tange ao seu procedimento de celebração e aos seus efeitos. Os contratos estatais e os acordos administrativos, por um lado, destinam-se a produzir efeitos independentemente de quaisquer medidas ulteriores por parte dos Estados contratantes e diferenciam-se entre si pelo fato de os primeiros necessitarem da aprovação dos poderes legislativos estaduais para serem celebrados. Com efeito, os contratos estatais versam sobre matérias cuja regulação deve se dar por meio de lei editada pelo Parlamento. Por este motivo, aliás, que os contratos estatais, quando aprovados, assumem o status de lei. Em tese, eles poderiam até ser revogados por uma outra lei posterior; porém, como isto representa uma violação do que foi acordado, tem-se que o meio correto para fazer cessar os efeitos contratuais consiste na denúncia ou então na celebração de um novo contrato. Já os acordos administrativos regulamentam matérias inseridas no âmbito de atuação do Executivo e, por isto, uma manifestação do Poder Legislativo torna-se despicienda. Já os acordos de coordenação, por outro lado, caracterizam-se por não serem auto-executáveis - ou seja, necessitam de medidas que os tornem aplicáveis nos territórios dos entes federativos que os celebram - e visam à adoção de práticas administrativas e legislativas uniformes. ${ }^{495}$ Como exemplos desta última modalidade, RUDOLF cita as deliberações tomadas no âmbito de conferências que, por

\footnotetext{
492 Conforme RUDOLF. § 141 Kooperation im Bundesstaat. In: ISENSEE, KIRCHHOF (Hrsg.). Handbuch des Staatsrechts, pp. 1024 e 1025.

493 Note-se que alguns dicionários jurídicos (em especial, JAYME, NEUSS. Wörterbuch Recht und Wirtschaft. Band 2, p. 529) traduzem Staatsvertrag como tratado. Optou-se aqui, contudo, por uma tradução mais literal (Staat - Estado; Vertrag - contrato), pois "tratado", em português, possui um sentido bem delimitado, qual seja, o de um acordo celebrado entre Estados soberanos e regido por regras de direito internacional. Procurouse, assim, evitar associações errôneas no que diz respeito à natureza jurídica, escopo e limites deste instituto alemão.

${ }^{494}$ HESSE. Der unitarische Bundesstaat, p. 19.

495 Conforme RUDOLF. \& 141 Kooperation im Bundesstaat. In: ISENSEE, KIRCHHOF (Hrsg.). Handbuch des Staatsrechts, pp. 1030-1032.
} 
representarem meras diretivas ou não, precisam de uma lei ou de um regulamento para serem aplicadas. $^{496}$

Perceba-se como estes três instrumentos acabam por se entrelaçar no caso concreto. Afinal, no âmbito das conferências e das comissões - ou mesmo no âmbito das reuniões podem ser gestados contratos, acordos administrativos ou de coordenação. Qualquer um destes instrumentos contratuais, por sua vez, pode visar à adoção de práticas legislativas e administrativas uniformes, além da transferência temporária de competências, dentre outros temas $^{497}$. Esta percepção não explica, porém, como as relações federativas alemãs efetivamente se desenvolvem de um modo coordenado ou não. É chegado o momento, portanto, de adentrar nos aspectos políticos da cooperação. Para tanto, retoma-se uma noção utilizada de forma recorrente para descrever o caso alemão: o processo de tomada de decisões conjuntas (joint-decision making ou Politkverflechtung) ${ }^{498}$.

Conforme Sabine KROPP, parte da ciência política alemã toma as expressões federalismo cooperativo e Politikverflechtung por sinônimas, ao passo que outra parte opta por traçar uma distinção entre estes dois conceitos. A presente tese, ao considerar o federalismo cooperativo como um modelo teórico ao qual tanto Brasil quanto a Alemanha, dentre outras federações, podem ser subsumidos ${ }^{499}$, deve necessariamente optar por este segundo caminho. Para tanto, alinha-se ao raciocínio proposto por KROPP, para quem ${ }^{500}$ a palavra Politikverflechtung deve ser reservada a uma estrutura decisória específica inserida, por óbvio, em um paradigma de federalismo cooperativo - na qual os entes situados no nível estadual são obrigados a trabalhar conjuntamente. ${ }^{501}$

\footnotetext{
${ }^{496}$ RUDOLF. § 141 Kooperation im Bundesstaat. In: ISENSEE, KIRCHHOF (Hrsg.). Handbuch des Staatsrechts, p. 1033.

497 Sobre as transferências de competências, vide as considerações de RUDOLF. $\S 141$ - Kooperation im Bundestaat. In: ISENSEE, KIRCHHOF (Hrsg.). Handbuch des Staatsrechts, pp. 1034-1038.

498 Neste ponto, um esclarecimento importante. Aa expressão alemã Politkverflechtung poderia ser traduzida de um modo mais literal como entrelaçamento político (Politik - política; Verflechtung - entrelaçamento). Acreditamos inclusive que esta seria uma tradução mais apropriada, tendo em vista que ela apresenta uma maior correspondência ao fenômeno retratado. Com efeito, Politikverflechtung não se traduz somente um processo de tomada de decisões conjuntas, mas sim de atores políticos compelidos a tomar decisões de forma conjunta, em um verdadeiro fenômeno de entrelaçamento decisório. Optou-se, contudo, por aderir à tradução propugnada por Fritz W. SCHARPF (The joint-decision trap, p. 239), um dos maiores expoentes da análise deste fenômeno, que traduz Politikverflechtung como joint decision making, ou processo de tomada de decisões conjuntas.

${ }^{499}$ Conforme analisado no item 1.2.

500 Sabine KROPP. Kooperativer Föderalismus und Politikverflechtung. Wiesbaden: VS Verlag für Sozialwissenschaften, 2010, pp. 11-12.

${ }^{501}$ KROPP. Kooperativer Föderalismus und Politikverflechtung, p. 12.
} 
Do ponto de vista institucional, há dois elementos importantes para a compreensão desta estrutura de tomada de decisões conjuntas, ambos referidos por Fritz W. SCHARPF: (i) em primeiro lugar, as decisões tomadas pelo governo federal devem depender do consentimento das unidades constituintes; (ii) em segundo lugar, este consentimento deve ser ou unânime ou obtido pela maioria qualificada das unidades constituintes. $^{502}$ Em outras palavras, o governo federal não pode decidir de forma independente, devendo sempre colher o consentimento de todos os Länder, ou então de grande parte deles. Não é preciso dizer que, em que um mecanismo como este, cada Estadomembro alemão detém um poder de veto muito grande, pois a sua discordância pode colocar em xeque decisões sobre políticas públicas de interesse tanto da União quanto dos outros Estados-membros envolvidos. Porém, há um terceiro elemento importante a ser acrescentado nesta equação, também referido por SCHARPF, que consiste na prevalência de um estilo de decisão caracterizado pela barganha, vale dizer, pelo "apelo a interesses individualísticos de todos os participantes (necessários) e pelo recurso a incentivos", em casos menos frequentes substituído ou combinado a um estilo de solução de problemas (problem-solving), caracterizado pelo apelo a "valores comuns (solidários) e pelo recurso ao ostracismo e à exclusão como sanções coletivas finais"

A fim de compreender estes elementos de uma forma mais acurada é preciso analisar a questão sob uma perspectiva histórica. Conforme exposto no item 2.2.2, após o término da Segunda Grande Guerra, os Länder e, posteriormente, os Länder e o Bund passaram a colaborar entre si com a finalidade de reconstruir o país, em especial, estruturas de infraestrutura que foram destruídas durante o conflito ${ }^{504}$. Por parte do governo federal, esta colaboração se dava por meio da concessão de subsídios federais, os quais objetivavam também incrementar a coordenação dos Estados-membros e impor alguns parâmetros federativamente uniformes. Porém, tratava-se de uma cooperação não institucionalizada e que era questionada quanto à sua constitucionalidade, tendo em vista que a Lei Fundamental de 1949 teria consagrado, ainda que implicitamente, um sistema de separação (Trennsystem),

\footnotetext{
502 SCHARPF. The joint-decision trap, p. 254. KROPP se refere a características institucionais fundamentais parecidas às mencionadas por SCHARPF em Kooperativer Föderalismus und Politikverflechtung, p. 13. A única diferença que se nota é a opção desta autora em focar nas consequências da adoção da regra de unanimidade ou de maioria qualificada, especialmente os altos custos políticos envolvidos na obtenção de uma decisão, tendo em vista que todos os atores políticos envolvidos possuem um poder de vetar isoladamente a adoção de uma política pública desejada pelos demais.

503 SCHARPF. The joint-decision trap, pp. 258 e seguintes. Note-se que os estilos de decisão concebidos pelo autor são apresentados nas páginas 258-259, ao passo que os estilos mais frequentemente observados na tomada de decisões conjuntas são discutidos a seguir.

${ }^{504}$ KROPP. Kooperativer Föderalismus und Politikverflechtung, p. 126.
} 
de acordo com o qual uma atuação conjunta por parte da União e dos Estados-membros alemães seria possível somente nas hipóteses autorizadas pela própria constituição. Em virtude disso, em 1969 a Lei Fundamental foi reformada, a fim de incluir três institutos: (i) as tarefas comuns (Gemeinschaftsaufgaben), previstas nos artigos 91a e 91b GG, por meio das quais União e Estados colaborariam em áreas inseridas primordialmente na competência federativa destes últimos; (ii) os subsídios federais aos programas de investimento estaduais também em áreas determinadas (artigo 104a GG), e; (iii) os acordos de colaboração entre Bund e Länder sobre ensino fundamental e ensino médio (artigo 91b GG). ${ }^{505}$ Relata Fritz W. SCHARPF que o artigo 91b GG foi, dentre os institutos incluídos em 1969, o de aplicação mais problemática. De um lado, o governo federal desejava implementar um programa progressista de ensino fundamental e médio; porém, como ele não era responsável pela fatia mais relevante do financiamento desta política pública, os Estados-membros se sentiam livres para defender suas concepções ideologizadas de ensino. Ao término, embora tivesse forjado um plano nacional de ensino, o governo federal simplesmente não conseguiu implementa-lo pois não obteve o consentimento do número necessário de Estados. A fim de evitar novas derrotas como esta, buscou-se a partir daquele momento o desenvolvimento de regras decisórias próximas da unanimidade, mesmo em áreas onde decisões por maioria simples seriam possíveis. ${ }^{506}$

Extrai-se deste breve histórico que a tomada obrigatória de decisões conjuntas se restringia, em um primeiro momento, a algumas áreas determinadas pela própria Lei Fundamental. Além do mais, o texto da constituição alemã previa somente a regulamentação da colaboração por meio de lei submetida à aprovação do Conselho Federal, o que em si já contém uma certa dose de entrelaçamento político dada a composição deste órgão constitucional ${ }^{507}$, mas não ao ponto de ter de se obter, forçosamente, o consentimento de todos os Estados-membros alemães, como posteriormente se verificou. De todo modo, o que parece ser importante observar é que a expressão Politikverflechtung designaria uma explicação satisfatória para uma parcela importante, embora restrita tematicamente, da

\footnotetext{
505 Conforme SCHARPF. The joint-decision trap, pp. 245-246. Este breve histórico é elaborado com maiores no item 2.2.2 da tese. Neste momento da exposição, é suficiente uma retomada dos acontecimentos mais importantes, de modo a contextualizar o argumento que será desenvolvido a seguir. Observe-se, finalmente, que, a despeito de o processo de tomada de decisões conjuntas ser explicado a partir dos acontecimentos que sucederam a Segunda Grande Guerra, Fritz SCHARPF enxerga elementos importantes da Politikverflechtung já durante o período da República de Weimar, conforme se extrai de SCHARPF. Föderalismusreform: kein Ausweg aus der Politikverflechtungsfalle?, p. 17.

506 SCHARPF. The joint-decision trap, p. 246.

507 Conforme analisado no tópico 2.2.4 desta tese
} 
cooperação federativa alemã, tendo em vista que apenas nela se verificaria uma colaboração juridicamente obrigatória por parte dos Estados-membros.

\section{Ao lado desta modalidade obrigatória de cooperação situam-se formas} voluntárias ou espontâneas de coordenação cooperativa, por meio das quais os entes federativos alemães se unem para a superação de problemas comuns. Ainda que estes problemas sejam de tal monta que a cooperação se torne imperiosa no plano fático, estas formas de cooperação não são propriamente obrigatórias do ponto de vista jurídico ${ }^{508}$. Porém, também nestes casos é possível vislumbrar o fenômeno da tomada de decisões conjuntas e a adoção da unanimidade e da maioria qualificada como regras de julgamento, ainda que sob outro fundamento. Com efeito, como se está diante de uma modalidade voluntária de cooperação, por princípio, uma decisão não pode ser imposta a um ente federativo que não concorda com o posicionamento da maioria, daí a tendência de sempre se buscar o seu consentimento. Exemplo desta tendência pode ser visualizado no âmbito das conferências de ministros-presidentes e de ministros apontadas por Walter RUDOLF. Nelas se discutem os mais variados temas de interesse dos Länder, sendo que muitos deles certamente não se subsumem às hipóteses de obrigatoriedade de uma decisão conjunta. Porém, até pouco tempo atrás também as deliberações nestas instâncias se davam por meio do consenso de todos os entes envolvidos. Como ressalta Sabine KROPP, até 2004 prevalecia a regra da unanimidade nas conferências de ministros-presidentes. Porém, para que um sistema como este fosse factível na prática seria necessária uma lógica de compromisso por parte dos envolvidos, o que nem sempre era viável em virtude da existência de polarizações político-partidárias. Por isso, optou-se por substituir a regra da unanimidade por uma maioria qualificada de 13 Länder. As decisões sobre o regulamento interno e sobre medidas que afetem o orçamento interno e sobre instalações conjuntas ainda demandam a concordância de todos os Länder. Relata a mesma autora ainda fenômeno parecido no âmbito da conferência dos ministros de educação. Nas outras conferências ministeriais eventuais decisões permanecem sendo tomadas pela unanimidade dos Estados. ${ }^{509}$

Note-se que a lógica da tomada de decisões conjuntas é tão forte que impregna inclusive a utilização dos instrumentos de coordenação diretiva pelo Bund. Como se terá a oportunidade de analisar na segunda parte desta tese, instrumentos como a supervisão federal e as instruções dadas aos Estados, ambos previstos nos artigos 84 e 85 GG, são raramente manejados pela União, pois a cooperação entre os governos federal e estaduais costuma dar

\footnotetext{
${ }^{508}$ Conforme KROPP. Kooperativer Föderalismus und Politikverflechtung, p. 125.

${ }^{509}$ KROPP. Kooperativer Föderalismus und Politikverflechtung, pp. 136 e 138.
} 
conta das questões surgidas no âmbito da execução da lei federal pelos Estados e que justificariam a aplicação destes institutos. Já outros instrumentos também previstos pelos artigos 84 e 85 GG e manejados com frequência pelo Bund - como é o caso dos preceitos administrativos de caráter geral - podem ser forjados no âmbito das comissões e das conferências, como sugere o próprio Walter RUDOLF no trecho transcrito supra ${ }^{510}$, o que acaba por lhe conferir um caráter consensuado, ainda que no final a sua vigência dependa de um ato jurídico da União.

De todo modo, deve-se ressaltar que não se trata de uma estrutura decisória isenta de críticas, muito pelo contrário. Como ressaltava Fritz W. SCHARPF já no final da década de 1980, os resultados oriundos do processo de tomada de decisões conjuntas, diante de todas as características institucionais e políticas já comentadas neste tópico, eram frequentemente avaliados como inferiores ao desejado. Com efeito, se a realização de determinadas tarefas estatais por meio de programas conjuntos foi bem recebida e avaliada em um momento inicial, com o passar dos anos esta iniciativa passou a ser vista como ineficiente, inflexível, desnecessária e, em certos casos, até antidemocrática. ${ }^{511}$ Destas objeções chama a atenção a questão do caráter antidemocrático das políticas forjadas de acordo com esse processo decisório. Os parlamentos, afinal, confrontar-se-iam "com faits accomplis das negociações burocráticas entre dois níveis de governo" e poderiam apenas "ratificar ou refutar o resultado, mas eles raramente poderão exercitar controle direto sobre o próprio processo de negociação" 512 . É de ressaltar, afinal, que a cooperação tão característica do federalismo alemão é um fenômeno que se desenvolve sobretudo no âmbito do Poder Executivo. Não é por outro motivo, aliás, que se costuma utilizar a expressão federalismo de execução (Executivföderalismus) - a qual, segundo Sabine KROPP, remete justamente ao "papel de

\footnotetext{
510 Vide nota de rodapé no 491.

511 SCHARPF. The joint-decision trap, p. 239 e ss. A forma de distribuição de competências legislativas e administrativas na Alemanha - vale dizer, de uma forma em que as segundas necessariamente não encontrem uma estreita correspondência com as primeiras - e o seu papel na conformação de um modelo cooperativo de atuação também é ressaltada pela literatura que se ocupa do federalismo em uma perspectiva comparada. Nesse sentido, vide WATTS. Comparing Federal Systems, p. 86

512 SCHARPF. The joint-decision trap, p. 249. Além do mais, ressalta o referido autor que "o fato de certos programas serem financiados conjuntamente por dois (ou às vezes três) níveis de governo reduz os seus custos de oportunidade em cada nível. Em comparação com programas que competem entre si, os quais deveriam ser financiados inteiramente por uma única fonte, os programas conjuntos por conseguinte parecem ter uma vantagem 'injusta' em cada nível. Uma das consequências é a tendência de gastar demais em programas conjuntos (...). Outra é a distorção das preferências políticas 'reais' nos níveis local e do Land, toda vez que alguns programas, mas não todos, são fortemente subsidiados pelo governo federal. Sob estas condições, os programas conjuntos podem se tornar ofertas às quais o Land ou a cidade 'não podem se dar ao luxo de rejeitar' e, consequentemente, e representar uma séria restrição ao controle democrático local e regional” (SCHARPF. The joint decision trap, p. 249).
} 
dominância dos Executivos nas estruturas de autocoordenação existentes" ${ }^{\text {513 }}$ - para caracterizar o caso alemão. Os parlamentos, sobretudo os parlamentos estaduais, realmente restam desprestigiados neste modelo, tendo em vista que em alguns casos sequer a recusa do que foi negociado pelos seus respectivos governos é faticamente possível, diante dos custos políticos que decisões deste tipo costumam impor.

Durante a vigência da Lei Fundamental de 1949 pelo menos três reformas constitucionais pretenderam mitigar não só os problemas trazidos por este modelo de cooperação, mas também pela acentuada centralização legislativa e pelo aumento da importância do Conselho Federal, analisados no tópico anterior. São elas: (i) a Reforma Constitucional de 1994; (ii) a Reforma do Federalismo I, de 2006, e; (iii) a Reforma do Federalismo II, de 2009. Seus exatos contornos deixam de ser desenvolvidos neste momento, seja porque já foram abordados no tópico 2.2.2 seja porque serão destrinchados com maior detalhamento a partir da segunda parte da tese.

\subsection{A REPARTIÇÃO DE COMPETÊNCIAS COMO O ELEMENTO CENTRAL DA TEORIA JURÍDICA DO FEDERALISMO}

Até o presente momento tem-se dedicado à análise das federações brasileira e alemã sob uma perspectiva mais geral, além da explicitação de alguns pressupostos teóricos relevantes. Mesmo os outros tópicos deste terceiro capítulo pretendem promover uma confrontação entre as estruturas federativas brasileira e alemã de um ponto de vista mais geral. Neste tópico, portanto, busca-se esclarecer em que medida todo o esforço empreendido até agora se relaciona com a análise dogmática da repartição de competências legislativas e de execução que se pretende desenvolver partir da segunda parte da tese.

Por um lado, a contextualização é uma etapa prévia e imprescindível a qualquer estudo comparativo, segundo já se teve a oportunidade de ressaltar em mais de uma oportunidade nesta tese. Por outro lado, é de se admitir que o estudo da federação envolve uma particularidade que deve ser devidamente contemplada, qual seja: a complexidade do objeto de estudo. Com efeito, está-se diante de um fenômeno sobretudo político e que só pode ser apreendido de forma plena por um enfoque interdisciplinar. Por este motivo, aliás, no tópico 1.1.3 se conceituou a federação como um método de repartição do poder político e não uma forma de Estado caracterizada por uma repartição constitucional de competências, como faz comumente a doutrina brasileira. Isso, por sua vez, representou o reconhecimento

513 KROPP. Kooperativer Föderalismus und Politikverflechtung, p. 127. 
de que a dimensão política da federação não pode ser obscurecida ou desconsiderada sem que se deixe de lado aquilo que lhe é mais característico.

Embora até o presente momento se tenha levado em consideração o conhecimento produzido em outras áreas do conhecimento, esta pesquisa não objetiva propriamente uma análise interdisciplinar do fenômeno federativo. Ao contrário, o que se propõe aqui é uma investigação eminentemente jurídica da federação a partir do sistema constitucional de competências, o que não é necessariamente problemático do ponto de vista metodológico, desde que os resultados almejados correspondam ao que costumam obtidos em uma pesquisa eminentemente jurídica. Não obstante isso, é de se admitir que tal escolha exige uma explicação sobre o modo como a pesquisa se relaciona com aqueles elementos da federação que não são devidamente internalizados pelo Direito. Além do mais, tratando-se de uma investigação que não se debruça sobre todos os aspectos jurídicos da federação, torna-se necessário também justificar a escolha pela repartição de competências como algo que efetivamente importa ser comparado em uma federação.

Quando se afirma a necessidade de explicitar como a pesquisa se relaciona com aspectos da federação que não devidamente internalizados pelo Direito, reconhece-se que este último muitas vezes se limita a regulamentar alguns elementos que envolvem a federação, com a finalidade de fornecer balizas para a solução de alguns conflitos surgidos no seu âmbito. A cooperação, por exemplo, é um aspecto importante das federações estudadas, mas que só é internalizada pelo ordenamento jurídico quando minimamente institucionalizada pelos atores políticos envolvidos. Mesmo as reuniões (Besprechungen) a que se refere Walter RUDOLF e brevemente comentadas no tópico anterior não são propriamente encontros previstos e disciplinados pelo Direito, embora os resultados deles possam se traduzir em normas jurídicas que vinculam os entes federativos.

Também a repartição de competências representa somente um aspecto - relevante, deve-se reconhecer - da repartição do poder político que caracteriza a federação. É importante recordar que a competência, afinal, nada mais é do que a medida jurídica do poder estatal, vale dizer, o meio pelo qual o direito dosa e disciplina o poder em um Estado Federal, viabilizando a solução de eventuais impasses no que tange à sua titularidade e ao seu exercício segundo critérios eminentemente jurídicos. ${ }^{514}$ É bem verdade que, a partir do advento do Estado de Direito, não é mais possível se pensar em uma atuação estatal que não esteja amparada minimamente pela lei e em conformidade com a constituição. A

\footnotetext{
514 ISENSEE. § 133 Die bundesstaatliche Kompetenz, p. 457. A função que a norma de competência desempenha foi objeto de estudo no item 1.4.
} 
competência - por representar basicamente uma autorização conferida pela constituição à União, aos Estados e aos Municípios para atuar de um determinado modo, englobando inclusive a aprovação de leis - desempenha um desdobramento fundamental do Estado de Direito em uma federação. Não obstante isso, deve-se admitir que critérios jurídicos podem desempenhar um papel limitado em determinadas questões de poder. Cite-se, à título de exemplo, as discussões realizadas no âmbito do Poder Legislativo federal acerca da divisão de atribuições, entre as esferas de governo, em uma política pública descentralizada. Por óbvio que os atores políticos podem e devem levar em consideração as regras jurídicas pertinentes, mas somente é possível verificar a compatibilidade do que foi acordado no plano político com o ordenamento jurídico depois que uma lei é aprovada. ${ }^{515}$

É possível adotar três posturas diante da constatação de que o ordenamento jurídico não pode abarcar toda a complexidade inerente à federação. A primeira delas consiste em desconsiderar o que é estranho ao Direito, preocupando-se apenas com aquilo que pode ser apreendido por meio do estudo das normas jurídicas. Trata-se de uma perspectiva relativamente difundida na ciência jurídica brasileira e que é frequentemente atribuída à influência do pensamento de Hans KELSEN no Brasil. Nas primeiras linhas de seu famoso Teoria Pura do Direito, este autor asseverava que

“(...) quando a Teoria Pura empreende delimitar o conhecimento do Direito em face destas disciplinas, fá-lo não por ignorar ou, muito menos, por negar essa conexão, mas porque intenta evitar um sincretismo metodológico que obscurece a essência da ciência jurídica e dilui os limites que lhe são impostos pela natureza do seu objeto" 516

Note-se, entretanto, que KELSEN efetivamente propunha somente a compreensão do Direito como fenômeno distinto de outras ordens que também pretendem disciplinar a conduta humana e a produção de um conhecimento científico a partir desta delimitação. A desconsideração do que não pode ser abrangido pelo Direito e o consequente descolamento do conhecimento jurídico daquele produzido em outras áreas do conhecimento, por outro lado, foi um passo que parte da doutrina brasileira deu com suas próprias pernas. As críticas a este posicionamento são muitas, mas não serão retomadas aqui, de modo a seguir com a exposição.

Já a segunda postura consiste em simplesmente desconsiderar os aspectos jurídicos da federação. Trata-se de algo que não é visto - ou, ao menos não, é visto com alguma

\footnotetext{
515 Ressalvado o controle da obediência do devido processo legislativo pelo Supremo Tribunal Federal. Sobre este assunto, vide as ponderações Luiz Guilherme MARINONI em SARLET, MARINONI, MITIDIERO. Curso de Direito Constitucional, pp. 768-769.

516 KELSEN. Teoria Pura do Direito, pp. 1-2.
} 
facilidade - em pesquisas que pretendem se filiar a algum ramo do Direito por razões óbvias, mas existem investigações empreendidas em outras áreas do conhecimento que conferem um papel muito limitado à análise de regras jurídicas. Parece-nos, contudo, que do mesmo modo que não se pode deixar de lado a dimensão política da federação, conforme ressaltado supra, também não se pode obscurecer a sua dimensão jurídica, sem que se deixe de analisar algo que é ínsito a este fenômeno. Afinal, a federação pode até representar o resultado de uma barganha política ${ }^{517}$, mas que é necessariamente sacramentada em uma constituição escrita, cujas disposições são interpretadas e garantidas por uma suprema corte.

Finalmente, é possível vislumbrar uma postura intermediária, que prioriza a análise de questões eminentemente jurídicas, mas que sempre tem em mente os elementos extrajurídicos inerentes à federação. É a postura adotada pela presente tese, ao propor uma primeira parte dedicada à exposição de questões mais gerais das federações no Brasil e na Alemanha e uma segunda parte voltada à análise dogmática da repartição de competências legislativas e de execução nestes dois países. Pretendeu-se, deste modo, contemplar as principais características e tendências dos Estados Federais brasileiro e alemão e também confrontá-las - o que foi feito ao longo deste terceiro capítulo - a fim de forjar alguns vetores de análise importantes para o estudo comparativo a ser empreendido a partir do quarto capítulo. Estes consistem, por sua vez, na análise da formação das federações (a qual remete necessariamente a uma compreensão histórica do fenômeno), na centralização (em especial, nos elementos de continuidade decisória, para falar com Marta ARRETCHE) e na cooperação.

Muitos dos institutos que serão estudados a partir da segunda parte terão os seus possíveis sentidos elucidados a partir da sua capacidade de promover uma maior centralização ou descentralização ou a partir dos impactos que determinada interpretação provoca para uma estrutura federativa mais ou menos coordenada, e assim por diante. Por outro lado, alguns dos fenômenos analisados nesta primeira parte, principalmente aqueles que são limitados ou viabilizados por uma interpretação que se dá a determinadas normas constitucionais, terão sua explicação complementada pelo estudo dos aspectos jurídicodogmáticos destas normas na segunda parte da tese. Percebe-se, portanto, que embora o caminho natural seja utilizar o que foi discutido nesta primeira parte para melhor compreender o sentido e o alcance das normas constitucionais que disciplinam a repartição de competências legislativas e de execução, também deve-se esperar que as possíveis interpretações destas normas também ajudem a compreender determinados acontecimentos

${ }^{517}$ Como sugere RIKER. Federalism, p. 116. 
e fenômenos do federalismo brasileiro e alemão analisados sob uma perspectiva mais geral nesta primeira parte.

Feitas estas considerações, é chegado o momento de esclarecer as razões que informaram a escolha da repartição de competências como objeto de comparação. Afinal, a análise jurídica da federação compreende outros aspectos importantes, como a aplicação do princípio da simetria, a intervenção federal e a chamada constituição financeira. Por que então se debruçar somente sobre as regras constitucionais que distribuem atribuições legislativas e de execução entre os entes da federação?

Sem negar a importância destas outras temáticas, optou-se pela análise da repartição de competências diante da posição de centralidade no âmbito da teoria jurídica do federalismo. Pelo menos, é o que se constata a partir da análise da doutrina brasileira e alemã. Nesse sentido, Fernanda Dias Menezes de ALMEIDA, em obra que é referência sobre o tema no Brasil, entende que a repartição de competências dá substância à descentralização em unidades subnacionais e preserva, por um lado, a autonomia - já que as capacidades de auto-organização e de autolegislação dos entes federativos restariam esvaziadas caso não lhes fossem atribuídas matérias passíveis de normatização - e, por outro, mantém o relacionamento harmônico entre União e Estados-membros. 518

JOSÉ AFONSO da Silva é mais enfático ao afirmar que "a distribuição constitucional de poderes é o ponto nuclear da noção de Estado Federal" ${ }^{\text {"519 }}$, deixando entender que ela garante uma feição mais ou menos descentralizada à estrutura federativa. Nesse mesmo sentido vão as ponderações de Raul Machado HORTA, ao afirmar que

“a Constituição Federal como responsável pela repartição de competências, que
demarca os domínios da Federação e dos Estados-Membros, imprimirá ao modelo
federal que ela concebeu ou a tendência centralizadora, que advirá da amplitude
dos poderes da União, ou a tendência descentralizadora, que decorrerá da
atribuição de maiores competências aos Estados-Membros. Por isso, a repartição
de competências é encarada como a 'chave da estrutura do poder federal', 'o
elemento essencial da construção federal', a 'grande questão do federalismo', 'o
problema típico do Estado Federal'.',

Paulo Gustavo Gonet BRANCO, em curso em coautoria com GILMAR Ferreira MENDES, reitera uma das funções atribuídas por Fernanda Dias Menezes de ALMEIDA à repartição de competências (vale dizer, a manutenção de um relacionamento harmônico entre os entes federativos), considerando-a "mecanismo que favorece a eficiência da ação

\footnotetext{
518 ALMEIDA. Competências na Constituição de 1988, p. 29. Note-se que a relação entre repartição de competências e autonomia também é apontada por FERREIRA FILHO. Curso de Direito Constitucional, p. 53.

519 JOSÉ AFONSO. Curso de Direito Constitucional Positivo, p. 477.

520 HORTA. Direito Constitucional, p. 276.
} 


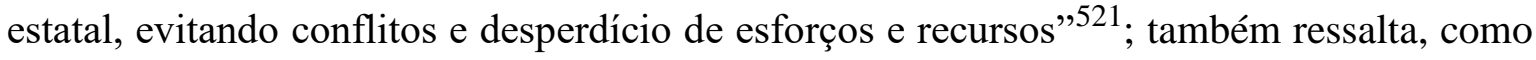
faz JOSÉ AFONSO da Silva, o papel desta distribuição constitucional na adoção de um modelo mais centralizador (por meio da concentração de competências) ou descentralizador (por meio atribuição de um rol mais amplo de competências aos Estados-membros) de federalismo $^{522}$.

Alessandra SILVEIRA, em pesquisa sobre a cooperação nos Estados compostos (dentre os quais certamente se inclui o Estado Federal), defende que a alocação de competências entre os entes subnacionais seria a forma de captar o próprio funcionamento de um Estado Federal, já que nela que se vai "procurar a fórmula mais idônea à composição dos interesses gerais com aqueles regionais em cada ordenamento concreto, ou noutros termos, a solução técnica que vai informar todo o complexo das relações entabuladas entre as diversas esferas de poder num Estado composto",523.

No âmbito da literatura alemã, é importante ressaltar o posicionamento de Karl LOEWENSTEIN, para quem a repartição de competências é o tema mais delicado da técnica constitucional justamente por ser "a chave da estrutura do poder federal"524. Após enumerar o mínimo de competências que devem ser atribuídas ao poder central em um Estado Federal, e relatar o fenômeno de expansão do rol de atribuições à União em virtude do advento do Estado de Bem Estar Social, pondera o autor que na "relação das competências enumeradas e residuais se pode apreciar o caráter da estrutura federal, isto é, se tende a uma preponderância do Estado central ou do Estado-membro" ${ }^{\text {,525. }}$.

Josef ISENSEE também ressalta a centralidade da repartição de competências dentro da temática do Estado Federal. Segundo este autor, a repartição de competências seria o que permitiria que regime jurídico dúplice típico do Estado Federal funcionasse propriamente, comparando-a ainda ao esqueleto do Estado Federal, porque carregaria e organizaria o poder estatal como um todo. Nesse sentido, a repartição de competências consistiria em um momento estático - não obstante essencial do ponto de vista jurídico - do federalismo ${ }^{526}$.

\footnotetext{
521 Gilmar Ferreira MENDES, Inocêncio Mártires COELHO, Paulo Gustavo Gonet BRANCO. Curso de Direito Constitucional. 5a Ed. São Paulo: Saraiva, 2010, p. 931.

522 MENDES, COELHO, BRANCO. Curso de Direito Constitucional, pp. 931-932.

523 SILVEIRA. Cooperação e Compromisso Constitucional nos Estados Compostos, p. 267.

524 LOEWENSTEIN. Teoria de la Constituición, p. 356.

525 LOEWENSTEIN, Teoria de la Constituición, p. 357.

526 ISENSEE. \& 133 Die bundesstaatliche Kompetenz, pp. 456-457.
} 
Ingolf PERNICE afirma claramente que a distribuição de atribuições entre União e entidades subnacionais seria o cerne de cada estrutura federativa, dado que que indicaria o modo pelo qual o ideário federativo seria concretizado e promoveria ainda o "balanço federativo" entre independência das entidades subnacionais e o desempenho de tarefas pela União. ${ }^{527}$

Rupert STETTNER assevera, por sua vez, que

"no Estado Federal com seus níveis de Estado Central e Estados-Membros, a distribuição das tarefas e poderes entre União e Estados é uma dos mais importantes problemas a se resolver. O Tribunal Constitucional Federal indica a repartição de competências como importante processo de formação do princípio federativo e como elemento de uma adicional separação de poderes funcional" ${ }^{\prime 528}$

Percebe-se deste pequeno incurso pela literatura que a repartição de competências assume posição central dentro do Estado Federal a partir de: (i) sua função de garantia da autonomia das entidades subnacionais; (ii) seu papel na ordenação das relações e dos interesses intrafederativos, proporcionando, pelo menos em tese, eficiência e racionalidade à prática federativa e; (iii) sua utilidade na identificação de tendências de centralização ou de descentralização em uma determinada estrutura federativa.

Note-se que situar a competência e sua repartição como os pontos centrais da análise jurídica do federalismo torna-se especialmente importante nesta tese. Afinal, elas consistem no tertia comparationis e representam uma escolha do pesquisador sobre aquilo que realmente importa ser comparado em uma federação do ponto de vista jurídico. Como bem ressalta Nils JANSEN, análises comparativas não são puramente objetivas ou mesmo "neutras". Ao contrário, ao erigirem um aspecto como termo que orientará a comparação (o chamado tertium comparationis), estas traduzem uma verdadeira escolha "por aquilo que efetivamente importa". A percepção do que é importante, por sua vez, muitas vezes é tomada de forma quase que subconsciente ou, em alguns casos, como algo que se reveste de alguma obviedade; no entanto, elas são, como bem aponta JANSEN, "frequentemente influenciadas por um entendimento conceitual e cultural do direito que é herdado". Nesse sentido, a própria escolha do tertium comparationis reveste-se de uma certa normatividade - sendo que aqui normatividade é empregada no sentido de um ato de vontade e não no sentido de uma

527 Ingolf PERNICE. Artikel 30 [Kompetenzverteilung zwischen Bund und Länder]. In: Horst DREIER (Hrsg.). Grundgesetz - Kommentar. 2a Ed. Tübingen : Mohr Siebeck, 2006, p. 718.

528 Rupert STETTNER. Artikel 70 [Gesetzgebung des Bundes und der Länder]. In: Horst DREIER (Coord). Grundgesetz - Kommentar. 2a Ed. Tübingen : Mohr Siebeck, 2006, p. 1549 - grifos no original. No original : "Im Bundesstaat mit seinen Ebenen des Gesamtstaates und der Gliedstaaten ist die Verteilung der staatlichen Aufgaben und Befugnisse zwischen Bund und Ländern eine der wichtigsten zu lösenden Aufgaben. Das Bundesverfassungsgericht hat die Kompetenzaufteilung als wichtige Ausformung des bundesstaatlichen Prinzips und als Element zusätzlicher funktionaler Gewaltenteilung bezeichnet". 
normatividade jurídica - porque é direcionada por suposições normativas acerca do que a lei deve ou não ser e, principalmente, porque estas suposições são seletivas: elas servem tanto para incluir quanto para excluir dados relevantes do universo considerado pelo comparatista. Por isso, como um postulado metodológico de sinceridade e claridade, todo estudo comparativo deve explicar os motivos e as razões que nortearam a sua escolha. ${ }^{529}$

Espera-se que as considerações supra tenham cumprido esta função ao elucidar em que medida a ideia de competência reflete a divisão de poder político típica do federalismo e porque focar na sua repartição em um estudo comparativo reflete uma escolha sobre o que realmente importa em uma análise jurídica da federação.

\footnotetext{
529 JANSEN. Comparative Law and Comparative Knowledge, pp. 314-315. Note-se que a normatividade que Nils JANSEN atribui à escolha do tertium comparationis é muito próxima das considerações que Preston KING traça sobre a normatividade ínsita a qualquer análise ou pesquisa, mesmo aquelas que se pretendem exclusivamente empíricas. De fato, como explica o referido autor "if we seek only to describle the 'facts' whether in the singular or in general or universally - it is essential do recognize that facts are infinite, that none is self-evident, and that all are and can only be perceived within and in contrast to established perceptive categories (We cannot meaningfully discuss the 'fact' of Everest without some prior convention about the meaning of 'mountain', nor the victory of President Reagan without some prior convention about the meaning of 'election'.) Categories of perception, however, are selective. They include, but also exclude. To apply them is to choose. Any act of choice may be subject to the pronouncement that it ought or ought not to be exercised. No newspaper prints all the facts. It prints some of the facts (...) It is not logically possible, therefore, to engage in normative or empirical pursuits in such a manner that the one may entirely exclude the other" (KING. Federalism and Federation, pp. 9-10).
} 


\section{PARTE II - ESTUDO COMPARATIVO: O SISTEMA CONSTITUCIONAL DE REPARTIÇÃO DE COMPETÊNCIAS LEGISLATIVAS E DE EXECUÇÃO NO BRASIL E NA ALEMANHA}

Após a apresentação das premissas teóricas da pesquisa e dos diferentes contextos que envolvem as federações brasileira e alemã, parte-se para o estudo comparativo do sistema constitucional de repartição de competências legislativas e de execução nesses dois países.

Trata-se de análise cindida em quatro capítulos. O primeiro deles, o quarto capítulo, será dedicado à exposição das linhas gerais da repartição de competências legislativas e de execução no Brasil. O quinto capítulo repete a mesma proposta em relação à repartição de competências legislativas e de execução na Alemanha. Como o foco reside nas normas que de algum modo disciplinam o exercício de competências pelos entes federativos, consoante considerações feitas na introdução deste trabalho, não se pretende dedicar um espaço específico ao estudo das matérias que são atribuídas a um ente em detrimento ou em concorrência com outros. Por óbvio, serão feitas referências a um ou outro título competencial, mas sempre com a intenção de elucidar como competências legislativas e de execução, privativas e concorrentes são repartidas pelos dois textos constitucionais em comento. Além do mais, é importante deixar consignado que os artigos selecionados tanto da Constituição Federal de 1988 quanto da Lei Fundamental de 1949 não englobam todas as normas que tratam de algum modo da repartição de competências. Para a análise que se pretende desenvolver, entretanto, basta o enfoque nos dispositivos que concentram o cerne desta matéria nas duas constituições consideradas.

No quarto e no quinto capítulos ainda ainda não se fornecerá uma compreensão global dos sistemas brasileiro e alemão de repartição de competências em uma perspectiva comparada, algo que só será feito a partir do sexto capítulo. Deste modo, o que se propõe no quarto e no quinto capítulos é somente um estudo de cada espécie de competência legislativa ou de execução, privativa ou concorrente existente nos ordenamentos jurídicos brasileiro e alemão, estruturando-se a exposição artigo por artigo. Para tanto, retomam-se algumas importantes discussões jurisprudenciais e doutrinárias a respeito de cada dispositivo constitucional analisado.

O sexto capítulo, por sua vez, concentra o cerne do estudo comparativo, pois é nele que se pretende expor os resultados obtidos da confrontação dos sistemas constitucionais de repartição de competências no Brasil e na Alemanha. Esta é, por sua vez, uma análise que 
será conduzida a partir das duas dicotomias examinadas no item 1.5.5 desta tese, vale dizer: competências legislativas e competências de execução, de um lado, e; competências privativas e competências concorrentes, de outro. Além do mais, considera-se importante dedicar algumas linhas ao estudo da importância e da pertinência das regras gerais e das regras de colisão em matéria de repartição de competências, tendo em vista que esta é uma característica marcante do sistema alemão, ainda que a constituição brasileira também contenha algumas previsões nesse sentido.

O sétimo capítulo é dedicado a algumas questões acerca da repartição de competências que são melhor elucidadas sob a perspectiva comparada. Para tanto, propõese uma breve incursão nos seguintes temas: (i) a qualificação competencial da lei e questões afetas; (ii) o princípio da lealdade federal aplicado à repartição de competências, e; (iii) algumas questões municipais sob uma perspectiva comparada.

\section{QUARTO CAPÍTULO - A REPARTIÇÃO DE COMPETÊNCIAS LEGISLATIVAS E DE EXECUÇÃO NO BRASIL: QUADRO GERAL}

Quando da análise dos antecedentes e das linhas gerais da Constituição Federal de 1988, afirmou-se que ela operou uma sensível descentralização federativa em comparação com a ordem constitucional anterior - esta última marcada por uma centralização vertical, no âmbito da União em detrimento de Estados e Municípios, e também horizontal, no âmbito do Poder Executivo federal em detrimento principalmente do Poder Legislativo federal. Contudo, esta não foi uma descentralização que se operou em todos os planos, como também já se teve a oportunidade de examinar: não se pode afirmar, portanto, que a Constituição brasileira operou uma descentralização que fortaleceu Estados-membros e Municípios em todos os aspectos de sua autonomia. Ao contrário, estamos diante de um fenômeno que se verificou sobretudo nos planos político e de repartição de receitas - embora a afirmação possa ser estendida à repartição de competências de execução, se comparada com a Constituição Federal de 1967/1969. As competências legislativas, entretanto, permaneceram concentradas na União, com exceção das competências concorrentes previstas no artigo 24 $\mathrm{CF} / 88$. Estas últimas, por sua vez, seriam as grandes responsáveis por promover uma descentralização gradual da federação brasileira, após décadas de uma intensa centralização legislativa.

Mais uma vez, é algo bem questionável se a descentralização gradual pretendida pelo legislador constituinte de 1988 era um escopo que poderia ser alcançado precipuamente por meio de um incremento das competências concorrentes, principalmente quando se tem 
em mente o desenvolvimento da estrutura federativa brasileira nestes quase 30 anos de vigência. Contudo, não se pode negar que o manejo intensivo das competências concorrentes foi a grande novidade trazida Constituição Federal de 1988, e que merece ser estudado com maior profundidade em uma pesquisa que se debruça sobre o tema.

A seguir, propõe-se uma breve análise dos artigos 21 a 25 e $30 \mathrm{CF} / 88$, sem a pretensão de esgotar todas as discussões que estes dispositivos suscitam, mesmo porque o objetivo consiste apenas em traçar um panorama da repartição de competências legislativas e de execução no Brasil. Para maiores esclarecimentos sobre cada competência contida nos dispositivos analisados, remete-se à leitura da literatura pertinente. ${ }^{530}$

\subsection{A COMPETÊNCIA GERAL DA UNIÃO (ARTIGO 21)}

Embora não seja a única solução possível, tradicionalmente a repartição de competências tem sido levada a cabo de forma que a União conte com poderes enumerados que lhe são privativos. A Constituição Federal de 1988 não foge desta regra e arrola nos seus artigos 21 e 22 matérias que competem à União com exclusão das demais esferas federativas.

O artigo $21 \mathrm{CF} / 88$ trata da competência geral da União ou competência da União em sentido estrito, para utilizar a terminologia empregada por José CRETELLA JUNIOR e clássica entre os doutrinadores brasileiros. Segundo este autor, esta competência abrange "“a capacidade genérica ou possibilidade de desempenhar serviços públicos federais, de editar atos administrativos e atos políticos', ora pelo desempenho do Chefe do Executivo, só; ora pelo desempenho do Legislativo, só; ora por meio do ato complexo ou ato conjugado do qual participam os dois Poderes, o Executivo Federal e o Legislativo Federal." ${ }^{31}$

Estamos diante, portanto, de um artigo que arrola outras competências, além daquelas que denominamos de competências de execução. Embora não seja o objetivo da presente tese se aprofundar na análise dos seus incisos, não se pode deixar de citar a sistematização proposta por Raul Machado HORTA, que agrupa os poderes atribuídos à União pelo artigo $21 \mathrm{CF} / 88$ do seguinte modo: (i) poderes soberanos (art. 21, I a VII); (ii) poderes de defesa do Estado e da estrutura federal (art. 21, V); (iii) poderes de administração e fiscalização econômico-financeira (artigo 21, VIII); (iv) poderes de planejamento de

\footnotetext{
530 Embora existam outras obras com a mesma proposta, recomenda-se, pela sua qualidade e atualidade, a leitura dos comentários feitos por Fernanda Dias Menezes de ALMEIDA em J. J. Gomes CANOTILHO; Gilmar Ferreira MENDES; Ingo Wolfgang SARLET; Lenio Luiz STRECK; Léo Ferreira LEONCY (Coord). Comentários à Constituição de Brasil. São Paulo: Saraiva, 2013.

${ }^{531}$ CRETELLA JUNIOR. Comentários à Constituição Brasileira de 1988. Volume III, p. 1285.
} 
desenvolvimento (art. 21, IX, XVIII, XIX e XX); (v) poderes de comunicação, telecomunicação e transporte (art. 21, X, XI, XII-a-f, XXI); (vi) poderes de polícia e segurança federais (arts. 21, XIV, XXII e 144); (vii) poderes de organização (art. 21, XIII, XV e XXIV); (viii) poderes de explorar serviços nucleares e monopolizar minérios nucleares e seus derivados (artigo 21, XXIII, a, b e c); (ix) poder de anistiar (artigo 21, XXV), e; (x) poder de regular (artigo 21, XI e XXV). ${ }^{532}$

Enquadram-se no conceito de competência de execução proposto por esta tese os grupos (iii) a (viii) e (ix) relacionados por HORTA. Por óbvio, há outras competências deste tipo esparsas no texto da Constituição Federal de 1988, como é o caso da pesquisa e da lavra de jazidas de petróleo, que constitui monopólio da União nos termos do artigo 177, I, CF/88. Porém, é o artigo $21 \mathrm{CF} / 88$ que contém o cerne da competência da União que não é classificada expressamente como legislativa, razão pela qual se opta por focar a análise neste dispositivo, estruturando a exposição a partir de quatro considerações de índole geral. ${ }^{533}$

Em primeiro lugar, como bem ressalta Fernanda Dias Menezes de ALMEIDA, embora o caput do artigo 21 não o diga de forma expressa, as competências arroladas nos seus incisos são privativas. Não é correto o raciocínio de que somente são atribuídas com exclusividade à União as competências que são qualificadas pelos advérbios "privativamente" ou "exclusivamente". É bem verdade que a Constituição brasileira opta por dizer textualmente que a competência legislativa da União inscrita no seu artigo 22 é do tipo privativa. Porém, como bem ressalta ALMEIDA, é despicienda a expressão "privativamente" que qualifica o advérbio "competir" neste dispositivo, servindo somente para antagonizar com o teor do artigo $24 \mathrm{CF} / 88$, que trata das competências legislativas concorrentes da União e dos Estados-membros. ${ }^{534}$

Em segundo lugar, as competências inscritas no artigo 21 que se qualificam como

\footnotetext{
532 HORTA. Direito Constitucional, pp. 317-319. Note-se que a expressão “competência geral da União" que dá título a este tópico, também é empregada por este autor.

533 Para uma breve exposição das competências de execução da União esparsas pelo texto constitucional, vide ALMEIDA. Competências na Constituição de 1988, p. 90.

534 ALMEIDA. Competências na Constituição de 1988, p. 84. Prossegue a referida autora neste mesmo trecho afirmando que "na Federação, a regra primeira manda que a cada partícipe se confiram competências privativas, o que é indispensável para se dar substância à autonomia de cada órbita de poder. Assim, basta dizer que determinada competência assiste a uma entidade para que, automaticamente, não seja das outras, salvo previsão de atuação concorrente que, esta sim, há de ser expressa." Neste ponto, é preciso fazer um reparo. Esta é uma afirmação que certamente se aplica ao caso norte-americano e também ao caso brasileiro, que tem no modelo norte-americano de competências a sua primeira inspiração. Ela não se aplica, porém, à federação alemã. Como se teve a oportunidade de ressaltar no item 2.2.1 desta tese, sob a égide da Constituição Imperial de 1871 predominou o entendimento de que as competências da União que não eram expressamente qualificadas de privativas permitiriam a competência concorrente dos Estados-membros.
} 


\section{competências de execução pressupõem, em regra, uma normatização prévia do Poder}

Legislativo. Conforme analisado no item 1.5.5, porque consistem na autorização atribuída a um ente federativo de executar uma lei em sentido formal, as competências de execução se colocam em uma relação de dependência em relação às competências legislativas correspondentes. Ou seja, só há que falar em exercício de uma competência de execução desde que já se tenha sido editada a lei em sentido formal no exercício de uma competência legislativa. Excepcionalmente, admite-se que a execução da própria Constituição, sobretudo quando se está diante de disposições constitucionais autoexecutáveis. Nesse sentido, pondera Fernando Dias MENEZES DE ALMEIDA que, nestes casos, a Administração deve dar execução à norma constitucional, “independentemente da atuação do legislador infraconstitucional", inclusive por meio da edição de atos administrativos normativos ${ }^{535}$.

É importante ressaltar, além do mais, que uma competência de execução pode encontrar respaldo em mais de uma competência legislativa. A título de exemplo, pode-se citar a competência da União para "explorar, diretamente ou mediante autorização, concessão ou permissão, os serviços de telecomunicações, nos termos da lei, que disporá sobre a organização dos serviços, a criação de um órgão regulador e outros aspectos institucionais" contida no inciso XI do artigo $21 \mathrm{CF} / 88$, que é devidamente balizada pela Lei $n^{\circ} 9.472 / 1997$, sendo que esta encontra o seu fundamento constitucional na competência da União para legislar privativamente sobre "águas, energia, informática, telecomunicações e radiofusão", prevista no artigo $22, \mathrm{IV}, \mathrm{CF} / 88$. Porém, é de se admitir que nem todos os aspectos da competência do artigo 21, XI, CF/88 encontram-se compreendidos pela competência legislativa do artigo 22, IV, CF/88. Por exemplo, as concessões realizadas nesse setor também sofrem o influxo da Lei $n^{\circ}$ 8.987/1995 e a contratação de obras e serviços de engenharia civil está sujeita ao procedimento das licitações previsto em lei geral para a Administração Pública, nos exatos termos do artigo 54 da Lei no 9.472/1997.

Em terceiro lugar, existe uma correspondência entre as competências de execução inscritas no artigo $21 \mathrm{CF} / 88$ e as competências legislativas privativas da União, concentradas em sua maioria no artigo 22 CF/88, mas que também podem ser encontradas em outros dispositivos esparsos pela Constituição brasileira. À título de exemplo, cita-se a competência privativa da União para legislar sobre serviço postal (artigo 22, V) e para manter o serviço postal e o correio aéreo nacional (artigo 21, X); a competência federal para legislar sobre telecomunicações (artigo 22, IV) e para explorar, diretamente ou mediante autorização, concessão ou permissão, os serviços de telecomunicações (artigo 21,

535 MENEZES DE ALMEIDA. Atos administrativos normativos, p. 226. 
XI); a competência para legislar sobre "sistema estatístico, sistema cartográfico e de geologia nacionais" (artigo 22, XVIII) e de "organizar e manter os serviços oficiais de estatística, geografia, geologia e cartografia de âmbito nacional (artigo 21, XV), e; a competência privativa para legislar sobre "atividades nucleares de qualquer natureza" (artigo 22, XXVI) e para explorar, também de modo exclusivo "os serviços e instalações nucleares de qualquer natureza" (artigo 21, XXIII). ${ }^{536}$

Em relação a estas matérias, a decisão do legislador constituinte por centralizar o tratamento de uma matéria foi efetivamente levada a cabo. Ou seja, a normatização legislativa é feita no âmbito federal e a execução desta normatização é levada a cabo pela administração federal. Neste ponto, pode-se afirmar que a Constituição Federal de 1988 adere ao sistema imediato de execução de serviços, para falar com JOSÉ AFONSO da Silva, segundo o qual "União, Estados, Distrito Federal e Municípios mantêm, cada qual, seu corpo de servidores públicos, destinados a executar os serviços das respectivas administrações (artigo 37 e 39)."537

Também é possível afirmar que, neste ponto específico, a repartição de competências brasileira aponta uma certa aderência ao modelo norte-americano de federalismo tal como definido por Fritz W. SCHARPF, no âmbito do qual "o exercício das funções do governo federal é formalmente independente dos governos dos Estados norteamericanos, e aquelas funções que são assumidas pelo governo federal são efetivamente nacionalizadas." ${ }^{, 538}$ Note-se, contudo, que esta é uma constatação que não se aplica a todos

\footnotetext{
536 Outros exemplos: a competência da União para legislar privativamente sobre "política de crédito, câmbio, seguros e transferência de valores" (artigo 22, VII) e "sistemas de poupança, captação e garantia da poupança popular" (artigo 22, XIX) e de administrar, também de modo exclusivo, "as reservas cambiais do País e fiscalizar as operações de natureza financeira, especialmente as de crédito, câmbio e capitalização, bem como as de seguro e previdência privada" (artigo 21, VIII); a competência para legislar de modo privativo sobre radiodifusão (artigo 22, IV) e "explorar, diretamente ou mediante autorização, concessão ou permissão os serviços de radiodifusão sonora e de sons e imagens" (artigo 21, X); a competência privativa da União tanto para legislar sobre energia (artigo 22, IV) quanto para explorar "os serviços e instalações de energia elétrica e o aproveitamento energético dos cursos de água", neste caso "em articulação com os Estados onde se situam os potenciais hidroenergéticos" (artigo 21, X), entre outros exemplos. Como ressalta Fernanda Dias Menezes de ALMEIDA, "o exercício das competências materiais pressupõe, no Estado de Direito, a existência de disciplina legal, considerando-se o primado do princípio da legalidade, que, para a Administração Pública, significa poder fazer apenas o que a lei permite. É natural, portanto, que haja uma estreita correlação entre o art. 22, que engloba a maior parte das competências legislativas privativas da União, e o art. 21, onde se encontram relacionadas as correspondentes competências materiais. Isso poderá ser constatado ao se compararem com os incisos do art. 21, os do art. 22, examinados na sequência" (Fernanda Dias Menezes de ALMEIDA. Comentários ao artigo 22, caput. In: J. J. Gomes CANOTILHO; Gilmar Ferreira MENDES; Ingo Wolfgang SARLET; Lenio Luiz STRECK; Léo Ferreira LEONCY (Coord). Comentários à Constituição de Brasil. São Paulo: Saraiva, 2013, p. 737).

537 JOSÉ AFONSO. Curso de Direito Constitucional Positivo, p. 482.

538 SCHARPF. The joint decision trap, p. 242.
} 
os aspectos da competência legislativa privativa da União no Brasil, como se terá a oportunidade de analisar a seguir.

Em quarto e último lugar, o artigo 21 CF/88 não contém nenhuma disposição geral sobre o modo como as competências nele arroladas devem ser exercidas pela União. Apenas em alguns incisos se pode extrair alguma disposição sobre o modo como uma competência específica deve ser executada. É o caso da competência para executar "os serviços e instalações de energia elétrica e o aproveitamento energético dos cursos de água, em articulação com os Estados onde se situam os potenciais hidroenergéticos" (inciso XII, alínea "b"), vale dizer, em regime de colaboração e cooperação com esses Estados-membros; ou da competência para "explorar os serviços e instalações nucleares de qualquer natureza e exercer o monopólio estatal sobre a pesquisa, a lavra, o enriquecimento e reprocessamento, a industrialização e o comércio de minérios nucleares e seus derivados", que deverá ser exercida consoante diretrizes e princípios discriminados nas alíneas do inciso XXIII.

\subsection{A COMPETÊNCIA LEGISLATIVA PRIVATIVA DA UNIÃO (ARTIGO 22)}

O artigo 22 CF/88 disciplina a competência legislativa da União em termos bem abrangentes. Com efeito, são 29 incisos que atribuem ao Poder Central o poder de legislar, de forma exclusiva, sobre temas importantes, tais como "direito civil, comercial, processual, eleitoral, agrário, marítimo, aeronáutico, espacial e do trabalho" (inciso I), "trânsito e transporte" (inciso XI) e "seguridade social" (inciso XXIII). Em outras palavras, o Brasil é uma federação bem centralizada no que diz respeito às competências legislativas, mas este dado isoladamente não serve para desnaturá-lo como tal, como aliás se teve a oportunidade de ressaltar no item 3.1 .

Neste tópico pretende-se traçar algumas breves considerações sobre o artigo 22 também sob uma perspectiva mais geral, como já se teve a oportunidade de fazer em relação ao artigo 21.

Em primeiro lugar, se é verdade que as competências administrativas privativas da União possuem uma relação de correspondência com as competências legislativas privativas atribuídas a este ente, não se pode dizer a mesma coisa quando se invertem os termos desta equação. Ou seja, nem toda competência legislativa que é atribuída com exclusividade à União é executada privativamente por órgãos federais. A título exemplificativo, podese citar a legislação sobre desapropriação, que calcada na competência do artigo 22, II, também é aplicada por Estados-membros, Distrito Federal e Municípios, ou a legislação sobre registros públicos, com fundamento constitucional no artigo $22, \mathrm{XXV}$, mas que é 
executada precipuamente por serviços notariais e registrais, mediante delegação dos Tribunais de Justiça dos Estados-membros.

Esta constatação aplica-se ainda às competências previstas nos incisos IX, XXI, XXIV, XXVII do artigo 22, que são rotuladas nesta tese de "competências privativas para legislar sobre normas gerais". Com efeito, de acordo com esses dispositivos, a União detém competência para legislar sobre: (i) "diretrizes da política nacional de transportes"; (ii) "normas gerais de organização, efetivos, materiais bélicos, garantias, convocação e mobilização das polícias militares e corpos de bombeiros militares"; (iii) "diretrizes e bases da educação nacional", e; (iv) normas gerais de licitação e contratação, em todas as modalidades, para as administrações públicas diretas, autárquicas e fundacionais da União, Estados, Distrito Federal e Municípios.” A redação empregada pelo legislador constituinte em relação a estas competências causou uma perplexidade inicial na doutrina brasileira. A celeuma é bem resumida no seguinte trecho dos comentários que Fernanda Dias Menezes de ALMEIDA faz sobre a competência inscrita no artigo 22, IX:

\footnotetext{
"Mas há, em termos técnicos, uma impropriedade a registrar quanto ao fato de se haver incluído entre as competências legislativas privativas da União a de estabelecer diretrizes da política nacional de transportes. É que, quando se trata de competência legislativa privativa, cabe a seu titular a disciplina integral da matéria, ou seja, a normatização de todos os seus aspectos, gerais e específicos. Já o estabelecimento apenas de normas gerais (assim consideradas, entre outras, as que assentam princípios, bases, diretrizes), a cargo de um dos entes federados, cabendo aos demais suplementá-las com a edição de normas específicas, é típico da competência legislativa concorrente. E como quer a posição doutrinária que aqui se aceita, quando a Constituição confere a um ente o estabelecimento de normas gerais sobre uma matéria, automaticamente está admitindo que a hipótese é de competência concorrente.

Assim sendo, se o constituinte destinou à União a fixação de diretrizes da política nacional de transportes, pode-se interpretar que o fez porque quis automaticamente que os demais integrantes da Federação estabelecessem as regras específicas pertinentes, para atender às respectivas peculiaridades.

Se foi esta a intenção, melhor teria sido, tecnicamente, incluir a matéria no art. 24, que congrega os temas de competência legislativa concorrente. Já se a ideia foi a de deixar que o poder central normatizasse integralmente o assunto, então mais adequado teria sido dizer, tout court, que compete privativamente à União legislar sobre a política nacional de transportes." 539
}

\footnotetext{
${ }^{539}$ Fernanda Dias Menezes de ALMEIDA. Artigo 22, IX. In: CANOTILHO, MENDES, SARLET, STRECK, LEONCY, Comentários à Constituição do Brasil, pp. 740-741. Na sua clássica obra Competências na Constituição de 1988, a referida autora relata que, com base no entendimento de que a competência arrolada no artigo 22, XXVII era do tipo privativa, o Tribunal de Contas do Estado de São Paulo chegou a recomendar que a administração deixasse de utilizar a lei paulista de licitações (Lei Estadual no 6544/89), pois não haveria autorização para que os Estados-membros legislassem sobre a matéria. Com efeito, entendeu esta corte que, como se estava diante de uma competência privativa, os Estados-membros só poderiam legislar sobre a matéria no caso de haver uma autorização constitucional nos termos do parágrafo único do artigo 22 CF/88 (ALMEIDA. Competências na Constituição de 1988, p. 104-105). Por óbvio, não foi este o entendimento que prevaleceu, mas demonstra que a questão das "competências privativas da União para legislar sobre normas gerais", longe de ser uma celeuma doutrinária, possui implicações práticas importantes.
} 
Concordamos com o entendimento de que a melhor técnica constitucional seria incluir estas matérias no artigo que versa sobre a competência legislativa concorrente da União e dos Estados-membros. Porém, ousamos discordar da referida autora no que diz respeito às consequências desta falha na redação da constituição. Afinal, a competência privativa não significa necessariamente que o ente à qual ela é atribuída deve disciplinar de toda uma matéria, mas sim que esta normatização ou execução se dê com a exclusão dos demais entes federativos. Com efeito, tradicionalmente uma competência privativa envolve a capacidade de dispor sobre todos os aspectos de uma matéria, mas isto é apenas algo que normalmente se verifica, entretanto não algo ínsito ao conceito de competência privativa. Portanto, é perfeitamente possível uma competência privativa para legislar apenas sobre um aspecto de uma matéria, como a Constituição Federal de 1988 faz e como deve reconhecer o intérprete da norma constitucional, sob pena de admitir que a constituição contém disposições inúteis.

Em virtude disso, temos dúvidas se a previsão de que a União está autorizada a legislar privativamente apenas sobre normas gerais pode ser considerada automaticamente uma competência legislativa concorrente nos termos do artigo $24 \mathrm{CF} / 88$. Das previsões contidas no artigo 22, IX, XXI, XXIV, XXVII, CF/88 é possível extrair apenas que o legislador constituinte quis retirar dos Estados-membros a possibilidade de estes últimos legislarem sobre normas gerais ou diretrizes. A partir desta primeira constatação surgem dois cenários. No primeiro deles, reconhece-se a inaplicabilidade das disposições contidas nos parágrafos do artigo $24 \mathrm{CF} / 88$ e a legislação estadual que complementa as normas gerais editadas pela União passa a se fundamentar na competência residual dos Estados-membros contida no artigo $25, \S 1^{\circ}, \mathrm{CF} / 88$. Em um segundo cenário, admite-se que os referidos incisos do artigo 22 CF/88 consagram efetivamente hipóteses de competência legislativa concorrente, mas a eles aplicam-se somente as regras contidas nos $\S \S 1^{\circ}$ e $2^{\circ}$ do artigo 24 $\mathrm{CF} / 88$. Em ambos os casos, a consequência é a mesma: os Estados nunca exercem a competência legislativa plena sobre a matéria, pois as suas normas gerais, as suas diretrizes e bases, encontram-se abrangidas pela competência privativa da União.

De todo modo, deve-se reconhecer que estas competências legislativas consideradas privativas pela Constituição, é bom frisar - são executadas primordialmente pelos Estados. É o caso, por exemplo, da atribuição contida no inciso XXI do artigo 22 $\mathrm{CF} / 88$, que prevê a edição de normas gerais sobre aspectos relevantes da Polícias Militares e Corpos de Bombeiros Militares, sendo certo que estas instituições se encontram inseridas no âmbito das administrações estaduais; ou da competência para legislar sobre diretrizes e bases da educação nacional (artigo 22, XXIV), que será executada primordialmente por 
Estados e Municípios nos termos do artigo $211 \mathrm{CF} / 88$. Portanto, é correto afirmar apenas que existe uma correspondência das competências gerais da União em relação às competências legislativas que são atribuídas exclusivamente a este ente, mas não o contrário.

Em segundo lugar, dispõe o parágrafo único do artigo 22 que "lei complementar poderá autorizar os Estados a legislar sobre questões específicas das matérias relacionadas neste artigo". Dois aspectos desta autorização legislativa aos Estados em matéria de competência privativa da União chamam a atenção, quais sejam: (i) as condicionantes impostas pela própria Constituição Federal de 1988, e; (ii) a relevância prática deste instituto.

Ao se analisar a redação do parágrafo único do artigo $22 \mathrm{CF} / 88$, percebe-se que a referida autorização foi limitada de pelo menos duas formas. Primeiramente, o referido dispositivo exige que a autorização se dê por meio de lei complementar, que se caracteriza justamente por ter um quórum de aprovação mais elevado que o da lei ordinária. Em segundo lugar, nos termos do parágrafo único, os Estados poderão ser autorizados a legislar somente sobre "questões específicas das matérias relacionadas neste artigo". Por isso, em nenhuma hipótese poderá a União autorizar os Estados a normatizarem sobre todos os aspectos de uma competência legislativa que lhe foi privativamente atribuída. Estas, por sua vez, consistem em limitações importantes, pois restringem a possibilidade de que este dispositivo efetivamente opere uma descentralização legislativa na federação brasileira. ${ }^{540}$

Outra questão interessante diz respeito à possibilidade de esta delegação ser feita a somente alguns Estados ou se, ao contrário, ela deve sempre abranger todos os Estadosmembros da federação brasileira indistintamente. Logo após a promulgação da Constituição Federal de 1988, Anna Cândida da Cunha FERRAZ se manifestou no sentido de que "a transferência da competência privativa para os estados, mesmo para questões específicas, não poderá ser desigual em número, profundidade ou complexidade, sequer para atender à diversidade entre os estados, em face do princípio da igualdade de tratamento tradicionalmente assegurado às entidades federadas no Brasil e não suprimido ou

\footnotetext{
540 Ainda sobre os limites materiais desta delegação legislativa aos Estados-membros, pondera José CRETELLA JUNIOR que "o parágrafo único do art. 22 não tem o condão de transformar 'questões específicas de todas as matérias do artigo' em objeto da lei complementar. Por exemplo, nenhuma lei complementar pode autorizar os Estados a legislar sobre questões específicas de direito penal, de direito eleitoral, de direito civil, de direito comercial, de direito marítimo, de direito aeronáutico, de direito do trabalho, de direito espacial. Nem sobre questões específicas de mobilização geral, nacionalidade, naturalização, cidadania, emigração, imigração, extradição de estrangeiros, expulsão e entrada, nem sobre polícias federais, nem sobre atividades nucleares. Entretanto, sobre trânsito e transporte, havendo lei complementar que autorize o Estado a legislar, nada há que Ihe impeça a função legislativa a respeito" (Comentários à Constituição de 1988, pp. 1678-1679).
} 
excepcionado pelo texto vigente. ${ }^{541}$ Fernanda Dias Menezes de ALMEIDA concorda com este posicionamento, mas não deixa de dirigir críticas à redação do dispositivo em comento, pois, como bem ressalta a autora, nem sempre a igualdade de tratamento tem se revelado benéfica de uma federação, sobretudo na federação brasileira, que é caracterizada por profundas desigualdades sociais e regionais. A possibilidade de delegação assimétrica - vale dizer, dirigida a alguns Estados-membros somente - seria, no entender desta autora, uma ferramenta adequada para fazer frente às disparidades no âmbito estadual. ${ }^{542}$

\title{
Já do ponto de vista prático, este é um dispositivo sem maiores repercussões.
}

Existe apenas uma lei complementar que faculta aos Estados legislar sobre matéria de competência privativa da União: a Lei Complementar n $n^{\circ}$ 103/2000, que autoriza os Estados e o Distrito Federal a instituir piso salarial para os empregados que não tenham piso salarial definido em lei federal, convenção ou acordo coletivo de trabalho (artigo $1^{\circ}$ ). Ao analisar a jurisprudência do Supremo Tribunal Federal sobre o parágrafo único do artigo $22 \mathrm{CF} / 88$, por sua vez, constata-se que pelo menos uma lei estadual editada com base neste permissivo foi considerada inconstitucional por extrapolar os limites da delegação, como se pode extrair do trecho de ementa transcrita a seguir:

\begin{abstract}
"2. A competência legislativa do Estado do Rio de Janeiro para fixar piso salarial decorre da Lei Complementar federal $\mathrm{n}^{\circ}$ 103, de 2000, mediante a qual a União, valendo-se do disposto no artigo 22, inciso I e parágrafo único, da Carta Maior, delegou aos Estados e ao Distrito Federal a competência para instituir piso salarial para os empregados que não tenham esse mínimo definido em lei federal, convenção ou acordo coletivo de trabalho. Trata-se de lei estadual que consubstancia um exemplo típico de exercício, pelo legislador federado, da figura da competência privativa delegada.

3. A expressão 'que o fixe a maior' contida no caput do artigo $1^{\circ}$ da Lei estadual $\mathrm{n}^{\circ} 5627 / 09$ tornou os valores fixados na lei estadual aplicáveis, inclusive, aos trabalhadores com pisos salariais estabelecidos em lei federal, convenção ou acordo coletivo de trabalho inferiores a esse. A inclusão da expressão extrapola os limites da delegação legislativa advinda da Lei Complementar $n^{\circ}$ 103/2000, violando, assim, o art. 22, inciso I, e parágrafo único, da Constituição Federal, por invadir a competência da União para legislar sobre direito do trabalho.

4. Não há no caso mera violação indireta ou reflexa da Constituição. A lei estadual que ultrapassa os limites da lei delegadora de competência privativa da União é inconstitucional, por ofensa direta às regras constitucionais de repartição da competência legislativa. Existindo lei complementar federal autorizando os Estados-membros a legislar sobre determinada questão específica, não pode a lei estadual ultrapassar os limites da competência delegada, pois, se tal ocorrer, o diploma legislativo estadual incidirá diretamente no vício da inconstitucionalidade. Atuar fora dos limites da delegação é legislar sem competência, e a usurpação da competência legislativa qualifica-se como ato de transgressão constitucional." ${ }^{543}$
\end{abstract}

\footnotetext{
${ }^{541}$ Anna Cândida da Cunha FERRAZ. União, Estado e Município na nova Constituição: enfoque jurídico-formal. In: A nova constituição paulista: perspectivas. São Paulo: Fundap, 1989, p. 71.

542 ALMEIDA. Competências na Constituição de 1988, pp. 111-113.

543 ADI 4.391, Relator Ministro Dias Toffoli, Tribunal Pleno, julgada em 02/03/2011.
} 
É de se reconhecer que a decisão do STF não merece reparo algum, pois de fato a lei estadual extrapolou os limites estabelecidos pela LC n 103/2000. Porém, não se pode deixar de ressaltar quão restrita foi esta autorização legislativa e o quanto ela desprestigia a atividade legiferante por parte do Estado-membro: com efeito, não se tratava de permitir legislação estadual divergente ou mesmo de permitir a complementação da normatização federal por lei estadual, mas apenas de autorização para instituir piso salarial na hipótese de a questão não ser tratada por lei federal, convenção ou acordo coletivo.

Também é possível encontrar na jurisprudência da suprema corte brasileira julgados que abordam o parágrafo único do artigo $22 \mathrm{CF} / 88$ para declarar inconstitucionais leis estaduais que tratam de aspectos de trânsito e transporte, sob o argumento de que aos Estados-membros só seria possível legislar sobre o tema no caso de haver uma delegação legislativa pela União. ${ }^{544}$ É compreensível que as entidades subnacionais desejem legislar sobre estas matérias, sobretudo porque participam ativamente da execução das normas de trânsito e transporte. Contudo, como se trata de uma competência legislativa conferida à União com exclusão dos demais entes federativos, é de se admitir, tal como fez o STF, que somente com o advento de uma lei complementar nos termos do parágrafo único do artigo $22 \mathrm{CF} / 88$ a atividade legiferante dos Estados poderá ser considerada constitucional.

\subsection{A COMPETÊNCIA COMUM DA UnIÃO, ESTAdOS E MUNICÍPIOS (ARTIGO 23)}

A competência comum da União, Estados e Municípios, prevista atualmente no artigo $23 \mathrm{CF} / 88$, consiste em uma inovação trazida pela Constituição Federal de 1988, a partir de um desmembramento da competência concorrente atualmente prevista no artigo 24 CF/88. Com efeito, o Anteprojeto da Subcomissão da União, Distrito Federal e Territórios previa somente uma competência comum da União, Estados-membros e Municípios no seu artigo $8^{\circ}$ e uma competência comum da União e dos Estados-membros no seu artigo 10, sendo que a ambas se aplicava o disposto nos artigos 12 e 13 , segundo os quais competia à União a edição de normas gerais e aos Estados e Municípios a elaboração de leis

\footnotetext{
544 Nesse sentido, as seguintes ADIs: ADI 874, Relator Ministro Gilmar Mendes, Tribunal Pleno, julgada em 03/02/2011; ADI 3625, Relator Ministro Cezar Peluso, Tribunal Pleno, julgada em 04/03/2009; ADI 3049, Relator Ministro Cezar Peluso, Tribunal Pleno, julgada em 04/06/2007; ADI 2402, Relatora Ministra Cármen Lúcia, Tribunal Pleno, julgada em 31/05/2007; ADI 2432, Relator Ministro Eros Grau, Tribunal Pleno, julgada em 09/03/2005. Todos estes julgados citados nesta nota de rodapé, por sua vez, foram retirados do documento "A Constituição e o Supremo", disponível em http://www.stf.jus.br/arquivo/cms/publicacaoLegislacaoAnotada/anexo/constituicao.PDF. Acesso: 06/03/2016.
} 
suplementares. Já o Anteprojeto da Comissão de Organização do Estado optou por reagrupar todas as competências da União - legislativas e de execução, privativas e concorrentes - em um único artigo, sem fazer menção a uma competência comum aos três níveis federativos. Porém, era possível visualizar uma competência legislativa concorrente nos moldes previstos pela Constituição Federal de 1967-69, vale dizer, pela menção à legislação sobre normas gerais sobre algumas matérias arroladas no artigo que tratava da competência privativa da União. Foi somente nos trabalhos da Comissão de Sistematização que a competência comum do artigo $23 \mathrm{CF} / 88$ foi separada da competência atualmente prevista no artigo 24 CF/88 e ganhou feições substancialmente distintas desta última: ${ }^{545}$ trata-se, afinal, uma competência administrativa e sua a concorrência se dá em termos diversos do disposto nos parágrafos do artigo $24 \mathrm{CF} / 88$. Há, por outro lado, um elemento comum entre essas duas modalidades: ambas são competências concorrentes, no sentido que a presente tese emprega ao termo (devidamente explicitado no item 1.5.5), e, portanto, contemplam situações em que a Constituição confere a mais de uma esfera de poder a faculdade de atuar em determinadas matérias. A seguir, propõe-se um aprofundamento de cada uma dessas características da competência comum.

Em primeiro lugar, o artigo 23 CF/88 contempla competências de execução ou administrativas. Ao menos, este é o entendimento predominante, esposado por autores como Fernanda Dias Menezes de ALMEIDA, Manoel Gonçalves FERREIRA FILHO, JOSÉ AFONSO da Silva, José CRETELLA JUNIOR, Paulo Gustavo Gonet BRANCO, Luís Roberto BARROSO, Andreas J. KRELL e Paulo Luiz NETO LOBO. ${ }^{546}$ A exceção é dada por Diogo de Figueiredo MOREIRA NETO, para quem a competência comum seria uma espécie de competência concorrente clássica, caracterizada pela indiferenciação entre

\footnotetext{
545 Os anteprojetos das Subcomissões e Comissões da Assembleia Nacional Constituinte podem ser consultados no link: seguinte http://www2.camara.leg.br/atividadelegislativa/legislacao/Constituicoes_Brasileiras/constituicao-cidada/o-processo-constituinte/lista-decomissoes-e-subcomissoes. Acesso: 30/04/2015.

546 ALMEIDA. Competências na Constituição de 1988, p. 129 e ss; FERREIRA FILHO. Curso de Direito Constitucional, p. 60; JOSÉ AFONSO. Curso de Direito Constitucional Positivo, p. 480; CRETELLA JUNIOR. Comentários à Constituição, p. 1740-1741; MENDES, COELHO, BRANCO. Curso de Direito Constitucional, pp. 953/954; Luís Roberto BARROSO. Federação, transportes e meio ambiente: interpretação das competências federativas. In: André Ramos TAVARES; George Salomão LEITE; Ingo Wolfgang SARLET (Org.). Estado constitucional e organização do poder. São Paulo: Saraiva, 2010, p. 500; Andreas J. KRELL. As competências administrativas do artigo 23 da CF, sua regulamentação por lei complementar e o "poder-dever de polícia". Interesse Público, ano 5, no 20, julho/agosto 2003, p. 59; Paulo Luiz NETO LOBO. Competência legislativa concorrente dos Estados-Membros na Constituição de 1988. Revista de Informação Legislativa, Brasília, ano 26, no 101, janeiro/março 1989, p. 99
} 
competência legislativa e competência administrativa. ${ }^{547}$ Fiquemos, contudo, com o posicionamento majoritário, com todos os desdobramentos que lhe são ínsitos.

Em segundo lugar, sabe-se que competências de execução ou administrativas referem-se ao poder juridicamente conferido a um ou mais entes federativos para promover a execução de leis em sentido formal, em regra, colocando-se deste modo em uma relação de dependência com as competências legislativas. Tendo em vista este liame entre os dois elementos desta dicotomia, surge então a interessante questão de saber com quais competências legislativas as competências do artigo 23 CF/88 se relacionam.

Segundo Fernanda Dias Menezes de ALMEIDA, as competências comuns refletem uma opção do legislador constituinte de separar as competências concorrentes em competências legislativas e de execução, tal como fez com as competências privativas da União. ${ }^{548}$ Contudo, ao se analisarem os incisos do artigo 23 e do artigo $24 \mathrm{CF} / 88$, percebese que não há propriamente uma relação de correspondência entre as matérias arroladas nestes dispositivos. As competências comuns, por um lado, podem ser agrupadas nas seguintes áreas setoriais, conforme sistematização proposta por Andreas J. KRELL:

“- Saúde: cuidar da saúde (II); promover a melhoria das condições de saneamento básico (IX).

- Educação e Cultura: proporcionar os meios de acesso à educação (V); proporcionar os meios de acesso à cultura $(\mathrm{V})$; proporcionar os meios de acesso à ciência (V); implantar política de educação para a segurança do trânsito (XII).

- Assistência social: cuidar da assistência pública (II); combater as causas da pobreza e os fatores de marginalização (X); proteger pessoas portadoras de deficiência (II).

- Segurança alimentar: organizar o abastecimento alimentar (VIII); fomentar produção agropecuária (VIII).

- Moradia: promover programas de construção de moradias e a melhoria das condições de habitação (IX).

- Meio ambiente e patrimônio histórico: proteger o meio ambiente e combater a poluição (VI); preservar as florestas, a fauna e a flora (VII); fiscalizar as concessões de direitos de pesquisa e exploração de recursos hídricos e minerais (XI); proteção dos bens de valor histórico, artístico, cultural e paisagístico, impedindo sua destruição (III, IV)",549

Já as competências legislativas concorrentes, por outro lado, contemplam algumas destas áreas setoriais, como é o caso da competência para legislar sobre "florestas, caça,

\footnotetext{
547 Diogo de Figueiredo MOREIRA NETO. Competência concorrente limitada: o problema da conceituação das normas gerais. Revista de Informação Legislativa, Brasília, ano 25, no 100, outubro/dezembro 1988, p. 139.

548 ALMEIDA. Competências na Constituição de 1988, p. 129.

${ }^{549} \mathrm{KRELL}$. As competências administrativas do artigo 23 da CF, p. 59. Faz-se apenas a ressalva de a área setorial "Educação e Cultura" restou ampliada por meio da Emenda Constitucional no 85 de 2015, que deu ao inciso V do artigo 23 novo teor. A competência comum da União, dos Estados, do Distrito Federal e dos Municípios agora compreende proporcionar "os meios de acesso à cultura, à educação, à ciência, à tecnologia, à pesquisa e à inovação."
} 
pesca, fauna, conservação da natureza, defesa e dos recursos naturais, proteção do meio ambiente e controle da poluição" (artigo 24, inciso VI); "proteção ao patrimônio histórico, cultural, artístico, turístico e paisagístico" (artigo 24, inciso VII); "responsabilidade por dano ao meio ambiente, ao consumidor, a bens e direitos de valor artístico, estético, histórico, turístico e paisagístico" (artigo 24, inciso VIII); "educação, cultura, ensino, desporto, ciência, tecnologia, pesquisa, desenvolvimento e inovação" (artigo 24, IX), e; "proteção e integração social das pessoas portadoras de deficiência” (artigo 24, XIV). Em todos estes casos, pode-se afirmar que há uma correspondência entre a competência comum e a competência legislativa concorrente. Porém, há tanto competências comuns não abrangidas pelo catálogo do artigo 24 CF/88 quanto competências legislativas
concorrentes sem qualquer correspondência com os incisos do artigo $23 \mathrm{CF} / 88$.

Há quem considere esta discrepância apenas uma crítica que pode ser feita ao sistema de repartição de competências legislativas e de execução inaugurado pela Constituição Federal de 1988. Existem autores, contudo, que enxergam neste ponto uma mitigação do princípio da execução imediata ou do sistema imediato de execução de serviços. ${ }^{550}$ Como observa Andreas J. KRELL,

"É evidente que o art. 23 regulamenta a competência material, a qual abrange a
realização de medidas administrativas. Com isso, a Constituição brasileira pela
primeira vez atribui separadamente competências administrativas que eram antes
automaticamente incluídas nas competências legislativas concorrentes. (...)
Podemos observar que a Constituição de 1988 teve a intenção de abandonar - pelo
menos parcialmente - a estrita separação administrativa entre os diferentes entes
federativos quando passou a discriminar, separadamente, as competências
administrativas das três esferas estatais, que não são mais coincidentes
(congruentes) com as competências legislativas, o que acontecia antes de 1988." 551

${ }^{550}$ Esclarece Andreas J. KRELL que "o sistema administrativo brasileiro tem a sua base no princípio da execução imediata. Os quadros de funcionários mantidos pela União, pelos Estados e pelos municípios, respectivamente, executam - com poucas exceções - exclusivamente os dispositivos legais da própria esfera. No passado, os órgãos de uma prefeitura municipal, por exemplo, podiam fundamentar os seus atos somente nas leis produzidas pela câmara local ou nos decretos do prefeito. Sob o regime da Constituição Federal anterior, de 1967/69, a competência administrativa resultava direta e necessariamente da respectiva competência legislativa. Portanto, uma Administração não podia agir para executar as normas de uma outra esfera pública. Por outro lado, nenhum Estado poderia - por exemplo - prescrever aos seus municípios o procedimento administrativo a observar em seus atos. Segundo a teoria dominante no Brasil, tal regulamentação iria abusar das prefeituras, reduzidas a 'intermediários burocráticos'. Apenas em casos de emergência foi concedido às prefeituras o direito de executar também leis superiores. Um exemplo é o impedimento de infrações iminentes de normas dos Códigos Florestal ou de Minas, através de funcionários municipais, quando os órgãos federais competentes não estejam presentes. Além dos casos de urgência, a execução planejada de leis de uma outra esfera estatal, no Brasil, sempre tem sido a celebração de convênios administrativos, que, até hoje, representam o principal instrumento de colaboração entre a União, os Estados e os municípios" (KRELL. As competências administrativas do artigo 23 da CF, p. 55). Já o sistema imediato de execução de serviços referese a tipologia elaborada por JOSÉ AFONSO da Silva (Curso de Direito Constitucional Positivo, p. 482), brevemente exposta no item 1.5.2 desta tese.

${ }^{551}$ KRELL. As competências administrativas do artigo 23 da CF, pp. 59-60. 
Note-se apenas que, se é possível falar em uma parcial derrogação desta separação administrativa entre os entes federativos (ou do princípio da execução imediata), ela não se dá somente pelo fato de existir uma competência administrativa comum distinta da competência legislativa concorrente. Ao contrário, ela decorre da própria distinção feita pela Constituição de 1988 entre competências legislativas e competências de execução e da atribuição destas modalidades, em alguns casos, a esferas federativas distintas. Com efeito, na federação brasileira o poder de legislar e o poder de administrar nem sempre são atribuídos aos mesmos entes federativos, o que significa dizer que nem sempre quem edita uma legislação será quem efetivamente promoverá a sua execução. KRELL chama a atenção para este fenômeno no que diz respeito à repartição vertical de competências, mas é de se reconhecer que ele também encontra expressão na repartição horizontal de competências como um todo, como ainda se terá a oportunidade de analisar no item 6.3.1.

Em terceiro lugar, durante uma parte dos trabalhos da Assembleia Nacional Constituinte a competência atualmente inscrita no artigo 24 foi denominada de "comum". Posteriormente optou-se por qualificá-la de "concorrente", reservando-se o adjetivo “comum" para a competência do artigo 23. Contudo, esta questão de nomenclatura não obscurece o fato de que se está diante de uma competência concorrente na acepção que a presente tese empresta ao termo, vale dizer: de uma autorização conferida pela Constituição no sentido de que tanto a União quanto Estados-membros e Municípios atuem em relação a determinadas matérias.

Entretanto, trata-se de uma modalidade que não se enquadra, a princípio, em uma das subespécies de competência concorrente analisadas no item 1.5.5. Com efeito, não se está diante de poderes que foram atribuídos de modo cumulativo, pois não se pode extrair do artigo $23 \mathrm{CF} / 88$ que qualquer um dos entes poderá promover a execução integral das matérias nele arroladas e que isto poderá eventualmente impedir que outros entes façam o mesmo. Ao contrário, o parágrafo único deste artigo fala em "normas para a cooperação entre a União e os Estados, o Distrito Federal e os Municípios”, o que significa que se deseja promover, de algum modo, a atuação conjunta de todos os níveis de governo. Do mesmo modo, não se pode extrair, seja do caput do artigo 23, seja do seu parágrafo único, alguma limitação material à ação de quaisquer das esferas federativas envolvidas, razão pela qual também não se pode considerar o artigo $23 \mathrm{CF} / 88$ uma competência concorrente limitada.

A bem da verdade, parece que o legislador constituinte optou por não tomar nenhuma decisão a respeito do modo como esta competência comum deveria ser exercida. Ao contrário, optou por uma solução compromissória no parágrafo único do artigo 23 CF/88 ao mencionar a necessidade de cooperação entre União, Estados-membros e 
Municípios. Esta "solução cooperativa" pode se dar de diversas formas, que vão desde algo próximo a uma concorrência cumulativa, passando pela concorrência limitada até uma indesejável, não obstante possível superposição de atribuições. Também é possível conceber mecanismos de atuação concertada e até de decisão conjunta a fim de concretizar a disposição contida no parágrafo único do artigo 23, como propõe Gilberto BERCOVICI. ${ }^{552}$

Contudo, a despeito de a cooperação a que se refere o dispositivo constitucional em comento abrir muitas possibilidades sobre a forma pela qual estas competências administrativas devem ser concretizadas, deve-se reconhecer que a distribuição das competências legislativas correspondentes conduz a uma centralização das decisões sobre a execução das políticas públicas previstas no artigo $23 \mathrm{CF} / 88$. Com efeito, como ressalta Fernanda Dias Menezes de ALMEIDA,

\footnotetext{
"as leis que servirão de embasamento para a execução das tarefas comuns serão, em sua maior parte, fruto da competência legislativa concorrente, em que caberá à União editar normas gerais e às demais esferas a legislação suplementar (...) Isto quando a competência material comum não se tiver de exercer de acordo com lei federal editada no uso de competência legislativa privativa, hipótese em que a União estabelecerá normas gerais e específicas, legislando integralmente sobre a matéria." ${ }^{553}$
}

Tendo em vista esta centralização no âmbito legislativo, é natural que as competências de execução também se orientem no sentido de conferir um maior protagonismo à União em detrimento dos Estados-membros e Municípios. Ao menos, é de se esperar que a cooperação necessária para a execução adequada das políticas públicas arroladas no artigo $23 \mathrm{CF} / 88$ seja delineada e até mesmo controlada pelo poder central, cabendo aos Estados e aos Municípios simplesmente aderir ao plano elaborado em nível nacional. O próprio fato de o parágrafo único do referido dispositivo constitucional determinar que as "normas para a cooperação entre a União e os Estados, o Distrito Federal e os Municípios, tendo em vista o equilíbrio do desenvolvimento e do bem-estar em âmbito nacional" serão estabelecidas por leis complementares - discutidas e aprovadas pelo Poder Legislativo federal - corroboram esta constatação.

Esta tendência não impede uma "solução cooperativa" mais descentralizada, calcada na participação de Estados e Municípios no processo decisório, como defende Gilberto BERCOVICI, ou mesmo a adoção de outros mecanismos para viabilizar uma cooperação efetiva entre as três esferas federativas. Porém, estas são possibilidades que dependem de uma decisão, tomada invariavelmente pela União, no sentido de descentralizar a execução

\footnotetext{
552 BERCOVICl. Desigualdades regionais, Estado e Constituição, pp. 152-154.

553 ALMEIDA. Competências na Constituição de 1988, p. 133.
} 
das políticas públicas abrangidas pela competência comum. É, aliás, o que parece ter ocorrido na área do meio ambiente, por meio da Lei Complementar no 140 de 2011.

\subsection{A COMPETÊNCIA LEGISLATIVA CONCORRENTE DA UNIÃO E DOS ESTADOS- MEMBROS (ARTIGO 24)}

Conforme ressaltado em mais de uma oportunidade, a previsão de um ambicioso catálogo de competências legislativas concorrentes consistiu em uma das grandes apostas da Assembleia Nacional Constituinte de 1987/1988 para obter uma descentralização no plano legislativo. ${ }^{554}$ Contudo, não se está diante de uma inovação trazida pela Constituição Federal de 1988: ao contrário, esta é uma técnica manejada - de forma tímida, é verdade - desde a Constituição brasileira de 1934. Foi somente a partir de 1988, porém, que esta modalidade de competência deixou de ser restrita a algumas poucas matérias e passou a rivalizar, em importância, com a competência privativa da União. De certo modo, a presente tese parte do pressuposto que esta opção do legislador constituinte brasileiro significou mais a generalização de um problema do que de uma solução, como bem ressalta Diogo de Figueiredo MOREIRA NETO. ${ }^{555}$ A fim de melhor desenvolver este argumento, é imprescindível traçar um breve histórico deste instituto no direito brasileiro, a começar pela Constituição Federal de 1934.

Por um lado, sabe-se que esta foi uma constituição que ficou pouquíssimo tempo em vigor. Por outro lado, ela inaugurou redação que foi repetida pelas demais constituições brasileiras, além de ser considerada uma das inspirações da Constituição Federal de 1988 na parte em que esta trata da repartição de competências, ${ }^{556}$ razão pela qual as suas disposições merecem algum aprofundamento. Começa-se a análise pela transcrição do $\S 3^{\circ}$ do artigo $5^{\circ}$ da Constituição Federal de 1934:

\footnotetext{
“Artigo $5^{\circ}, \S 3^{\circ}$ - A competência federal para legislar sobre as matérias dos números XIV e XIX, letras $c$ e $i$, in fine, e sobre registros públicos, desapropriações, arbitragem comercial, juntas comerciais e respectivos processos; requisições civis e militares, radiocomunicação, emigração, imigração e caixas econômicas; riquezas do subsolo, mineração, metalurgia, águas, energia hidrelétrica, florestas, caça e pesca, e sua exploração não exclui a legislação estadual supletiva ou complementar sobre as mesmas matérias. As leis estaduais,
}

\footnotetext{
554 Este mesmo raciocínio também é esposado por Fernanda Dias Menezes de ALMEIDA em seus comentários ao caput do artigo 24 (CANOTILHO, MENDES, SARLET, STRECK, LEONCY, Comentários à Constituição do Brasil, p. 751).

555 MOREIRA NETO. Competência concorrente limitada, p. 135 e ss.

556 Nesse sentido, vide ALMEIDA. Competências na Constituição de 1988, p. 76.
} 
nestes casos, poderão atendendo às peculiaridades locais, suprir as lacunas ou deficiências da legislação federal, sem dispensar as exigências desta”

Apesar da redação truncada, este dispositivo consagrava quatro aspectos dignos de menção. Em primeiro lugar, ele não fazia referência a uma competência legislativa concorrente da União e dos Estados-membros, mas apenas à possibilidade de estes últimos legislarem de forma supletiva e complementar em relação a algumas matérias atribuídas privativamente à União pelo caput do artigo $5^{\circ} \mathrm{CF} / 1934$. Não obstante isso, este dispositivo efetivamente consagrava uma dupla concorrência entre União e Estados-membros no campo legislativo. Com efeito, o adjetivo "supletiva" que caracteriza a legislação estadual editada com base neste artigo remete a algo "que supre ou se destina a suprir", ao passo que o adjetivo "complementar" se refere a algo "que serve de complemento", que completa outra coisa. ${ }^{557}$ Ora, uma legislação estadual só pode ser supletiva em relação a uma competência da União quando supre a ausência de uma lei federal, e só pode complementar esta mesma competência quando completa uma lei federal que não disciplina todos os aspectos de uma matéria. Por este motivo, conclui-se que o artigo em comento consagrava, ao mesmo tempo, competências legislativas concorrentes cumulativas e limitadas, no sentido que a tese empresta a estes dois termos.

Em segundo lugar, embora isto não fosse dito de uma forma textual pela Constituição Federal de 1934, estas duas modalidades de competência concorrente não incidiam sobre as mesmas matérias. Deste modo, os Estados estariam legitimados a legislar supletivamente vale dizer, cumulativamente - em relação aos assuntos discriminados no próprio $\S 3^{\circ}$ do artigo $5^{\circ}$, ao passo que em relação às matérias referidas nos incisos XIV e XIX, alíneas "c" e "i”" a legislação da União deveria se restringir a normas gerais - sendo, portanto limitada e aos Estados caberia complementá-la por meio de lei estadual. ${ }^{558}$

Em terceiro lugar, é importante atentar para a técnica utilizada pelo legislador constituinte de 1934 ao manejar a competência concorrente limitada. Ao invés de dizer expressamente que a União deveria se restringir à edição de normas gerais em determinados temas, ele optou por atribuir à União "competências privativas para legislar sobre normas gerais ou normas fundamentais", em relação às quais a competência dos Estados-membros deveria ser necessariamente complementar.

\footnotetext{
557 Definições de "supletiva" e "complementar" retiradas de AURÉLIO, FERREIRA. Aurélio século XXI: o dicionário da língua portuguesa, pp. 1631 e 440.

558 Para uma visão esquemática das matérias que competiam cumulativamente e de forma limitada à União e aos Estados-membros sob a égide da Constituição Federal de 1934, vide MOREIRA NETO. Competência concorrente limitada, pp. 132-133.
} 
Em quarto lugar e último lugar, a parte final do $\S 3^{\circ}$ do artigo $5^{\circ}$ estabelecia a lei federal como um parâmetro a ser seguido pelas legislações estaduais, ao dispor que "as leis estaduais, nestes casos [vale dizer, nos casos de legislação estadual supletiva ou complementar], poderão, atendendo às peculiaridades locais, suprir as lacunas ou deficiências da legislação federal, sem dispensar as exigências desta”. Em outras palavras, a legislação federal deveria ser utilizada como parâmetro para a atuação legiferante dos Estados-membros, mesmo nos casos em que a União, em tese, estivesse adstrita à edição de normas gerais.

A Constituição Federal de 1937, por sua vez, previa no seu artigo 18 que os Estados poderiam legislar independentemente de autorização "no caso de haver lei federal sobre a matéria, para suprir-lhes as deficiências ou atender às peculiaridades locais, desde que não dispensem ou diminuam as exigências da lei federal, ou não havendo lei federal e até que esta regule" sobre os assuntos arrolados nos seus incisos.

Embora este dispositivo não falasse em uma legislação estadual supletiva ou complementar, aos Estados-membros também era facultado legislar tanto para suprir a ausência de lei federal e para atender as peculiaridades locais, quanto para complementar a lei federal existente. Ou seja, mais uma vez competências legislativas concorrentes cumulativas e limitadas foram disciplinadas de forma conjunta, quase que indiferenciadas. Há, contudo, uma grande diferença em comparação com a regulamentação com a ordem constitucional anterior: como a Constituição Federal de 1937 não restringia atuação da União à edição de normas gerais em nenhuma matéria, todas as alíneas do seu artigo 18 admitiam tanto a concorrência cumulativa quanto a concorrência limitada.

Em relação à modalidade limitada da competência concorrente, é de se admitir que a Constituição de 1937 continha um verdadeiro jogo de palavras: com efeito, a legislação estadual poderia suprir as deficiências da lei federal ou atender às peculiaridades locais; porém, não havia nenhuma demarcação à atuação da União, o que possibilitava que esta descesse a minúcias e regulasse inclusive para atender às peculiaridades locais, sem deixar qualquer espaço para a autonomia estadual. Além do mais, o parágrafo único do artigo 18 CF/1937 dispunha que não só a lei federal mas também o regulamento expedido pelo Presidente da República serviam de parâmetro às leis estaduais, revogando-as em caso de incompatibilidade.

A Constituição Federal de 1946 marcou um retorno à fórmula empregada em 1934, fazendo referência à legislação estadual supletiva ou complementar, sendo esta última delimitada aos casos em que a competência privativa da União era restrita à edição de normas 
gerais. Tem-se, assim, que havia concorrência legislativa cumulativa entre União e Estadosmembros nos seguintes temas: (i) registros públicos e juntas comerciais; (ii) organização, instrução, justiça e garantias das polícias militares e condições gerais da sua utilização pelo Governo federal nos casos de mobilização ou de guerra; (iii) requisições civis e militares em tempo de guerra; (iv) tráfego interestadual; (v) riquezas do subsolo, mineração, metalurgia, águas, energia elétrica, floresta, caça e pesca; (vi) emigração e imigração; (vii) incorporação dos silvícolas à comunhão nacional. Já a competência concorrente limitada à edição de normas gerais por parte da União estendia-se às seguintes matérias: (i) direito financeiro; (ii) seguro; (iii) previdência social; (iv) defesa e proteção da saúde; (v) regime penitenciário, e; (vi) educação nacional.

Havia, portanto, um certo equilíbrio entre as hipóteses de concorrência cumulativa e concorrência limitada no texto constitucional de 1946. Contudo, a partir da Constituição Federal de 1967/1969 percebe-se uma preferência pela limitação da atuação da União na competência legislativa concorrente. ${ }^{559}$ Com efeito, o seu artigo $8^{\circ}$ consagrava apenas quatro hipóteses de competência concorrente cumulativa, ao mesmo tempo a concorrência limitada se estendia a nove hipóteses: (i) orçamento, despesa e gestão patrimonial e financeira de natureza pública; (ii) taxa judiciária, custas e emolumentos remuneratórios dos serviços forenses, de registros públicos e notariais; (iii) direito financeiro; (iv) seguro; (v) previdência social; (vi) defesa e proteção da saúde; (vii) regime penitenciário; (viii) educação nacional, e; (ix) desportos. Porém, como observa Diogo de Figueiredo MOREIRA NETO,

\begin{abstract}
"o legislador constitucional brasileiro tem demonstrado, nos últimos vinte anos, acentuada simpatia pela técnica da competência concorrente limitada, parecendo preferir a sua problemática definição dos limites de atuação da União e dos Estados e abrir mão das vantagens que ela proporciona, mantendo uma solução que venha a possibilitar a tessitura de uma malha legislativa que, nacional, teria condições de mais adequadamente alcançar as peculiaridades políticas, econômicas, sociais e geográficas encontradas em nosso imenso País. Embora faça sentido esse objetivo político de unificar o essencial sem prejuízo da diversificação do secundário, o problema foi ampliado, nas Cartas de 1967 e 1969, sem que se tivesse avançado substancialmente em doutrina, seja na formulação de um conceito apriorístico de normas gerais ou, pelo menos, de uma orientação empírica razoavelmente segura." ${ }^{560}$
\end{abstract}

É bem verdade que, já sob a égide da Constituição Federal de 1967/1969, alguns doutrinadores já se debruçavam sobre assunto, forjando algumas proposições interessantes sobre o conteúdo e alcance destas normas gerais. Nesse sentido, Geraldo ATALIBA defendia que normas gerais teriam por função "completar a Constituição onde e quando seja previsível - ou efetivamente venha a ocorrer - conflito entre as pessoas tributantes" e seriam

\footnotetext{
${ }^{559}$ Como observa MOREIRA NETO. Competência concorrente limitada, p. 134

560 MOREIRA NETO. Competência concorrente limitada, p. 134.
} 
necessariamente veiculadas por uma lei nacional. ${ }^{561}$ Interessante, aliás, é a distinção que este autor fazia entre lei federal e lei nacional, a qual encontra atualmente ampla aceitação da doutrina pátria: lei federal seria aquela que vincularia somente a administração federal e as pessoas a ela subordinadas; a lei nacional, por sua vez, seria aquela oriunda do Estado total - estrutura que, por definição, abarca União, Estados-membros e Municípios - e, como tal, poderia vincular as administrações federais, estaduais e municipais às suas disposições. ${ }^{562}$ É, contudo, Diogo de Figueiredo MOREIRA NETO, já no ocaso da ordem constitucional inaugurada em 1967, quem resume o "estado da arte" no que tange ao conteúdo e ao alcance destas normas:

\author{
"Sintetizando-as, a partir dessas características, as normas gerais seriam institutos \\ que: \\ a) estabelecem princípios, diretrizes, linhas mestras e regras jurídicas gerais \\ (BÜHLER, MAUNZ, BURDEAU, PONTES, PINTO FALCÃO, CLÁUDIO \\ PACHECO, SHAID MALUF, JOSÉ AFONSO DA SILVA, PAULO DE \\ BARROS CARVALHO, MARCO AURÉLIO GRECCO);
}

561 Geraldo ATALIBA. Normas gerais de direito financeiro e tributário e autonomia dos Estados e Municípios: Limites à norma geral - Código Tributário Nacional. Revista de Direito Público, ano 3, vol. 10, out./dez. 1969, pp. 47-48. Estas normas gerais de direito financeiro e tributário a que se refere ATALIBA possuem, em especial, uma gênese legislativa bem curiosa e que é relembrada por Rubens Gomes de SOUZA no seguinte trecho da sua obra: "eu teria que verificar esta afirmativa, mas creio que esta confissão não ficou nos limites do confessionário. Algo existe naquele livrinho Andaimes da Constituição, em que ele confessa que sua primeira ideia, primeira e última, era atribuir à União competência para legislar sobre direito tributário, amplamente e sem a limitação contida no conceito de normas gerais, desde que esta legislação tivesse a feição de uma lei nacional, de preceitos endereçados ao legislador ordinário dos três poderes tributantes: União, Estados e Municípios. A única limitação, que ele próprio enxergava, era a de se tratar de preceitos comuns aos três legisladores. Afora isto, ele não via e não achava necessário delimitar, de outra maneira, a competência que queria fosse atribuída ao Legislador da União, que já então ele concebia, neste setor e em outros paralelos, não como federal, mas sim nacional. Entretanto, ele encontrou resistência política, de se esperar e muito forte, em nome da autonomia dos Estados e da autonomia dos Municípios, em nome de temores, justificados ou não, de se abrir uma porta, pela qual se introduzisse o fantasma da centralização legislativa. Falou-se nada menos do que na própria destruição do regime federativo, todos os exageros verbais que o calor do debate político comporta e o próprio Aliomar encontrou uma solução de compromisso, que foi a de delimitar-se essa competência, que ele queria ampla, pelas normas gerais, expressão que, perguntado por mim quanto ao sentido que ele lhe dava, no intuito de ter uma forma de interpretação autêntica, ele me confessou que não tinha nenhuma, que nada mais fora do que um compromisso político, que lhe havia ocorrido e que tinha dado certo. O importante era introduzir na Constituição a ideia; a maneira de vestir a ideia, a sua roupagem era menos importante do que o seu recebimento no texto constitucional e o preço deste recebimento foi a expressão 'normas gerais', delimitava, sem dúvida, do âmbito da competência atribuída, mas em termos que nem ele próprio, Aliomar, elaborara ou raciocinara. Era o puro compromisso político. E a partir dessa política, juridicamente espúria, nós tivemos uma enorme produção bibliográfica, que até hoje continua a respeito do que sejam normas gerais." (Rubens Gomes de SOUZA; Geraldo ATALIBA; Paulo de Barros CARVALHO. Comentários ao Código Tributário Nacional (Parte Geral). 2a Ed. São Paulo: Malheiros, 1985, pp. 4-5). Contudo, é de se ressaltar que este histórico legislativo ajuda a explicar apenas o sentido e o alcance das normas gerais de direito financeiro e tributário, dado que a delimitação da competência da União à edição de normas gerais é anterior aos acontecimentos relatados por Rubens Gomes de SOUZA. De todo modo, esta enorme produção bibliográfica sobre o que seriam estas normas gerais no âmbito do direito financeiro e do direito tributário constituem um ponto de partida interessante para quem deseja se debruçar sobre a competência legislativa concorrente.

${ }^{562}$ ATALIBA. Normas gerais de direito financeiro e tributário, p. 49. 
b) não podem entrar em pormenores ou detalhes nem, muito menos, esgotar o assunto legislativo (MATZ, BÜHLER, MAUNZ, PONTES, MANOEL GONÇALVES FERREIRA FILHO, PAULO DE BARROS CARVALHO E MARCO AURÉLIO GRECCO);

c) devem ser regras nacionais, uniformemente aplicáveis a todos os entes públicos (PINTO FALCÃO, SOUTO MAIOR BORGES, PAULO DE BARROS CARVALHO, CARVALHO PINTO e ADILSON ABREU DALLARI);

d) devem ser regras uniformes para todas as situações homogêneas (PINTO FALCÃO, CARVALHO PINTO e ADILSON ABREU DALLARI);

e) só cabem quando preencham lacunas constitucionais ou disponham sobre áreas de conflito (PAULO DE BARROS CARVALHO e GERALDO ATALIBA);

f) devem referir-se a questões fundamentais (PONTES e ADILSON ABREU DALLARI);

g) são limitadas, no sentido de não poderem violar a autonomia dos Estados (PONTES, MANOEL GONÇALVES FERREIRA FILHO, PAULO DE BARROS CARVALHO e ADILSON ABREU DALLARI);

h) não são normas de aplicação direta (BURDEAU e CLAUDIO PACHECO)"563

A despeito desta multiplicidade de proposições doutrinárias, a Constituição Federal de 1988 persistiu na fórmula genérica "normas gerais" para circunscrever o campo de atuação legislativa da União. Muitos problemas práticos decorrem desta opção, tendo em vista que ela passou a se aplicar a todas as matérias em relação às quais subsiste a competência concorrente legislativa da União e dos Estados-membros. Nesse sentido é que se fala que a atual constituição vigente generalizou um problema já existente nas constituições anteriores, mas esta é uma crítica que certamente se aplica a outros aspectos da atual competência legislativa concorrente da União e dos Estados-membros. Com efeito, a previsão contida no artigo $24 \mathrm{CF} / 88$ é mais ampla e intricada do que a das constituições que lhe antecederam, dotando-a de uma complexidade sem precedentes.

Com efeito, é corrente a afirmação de que o artigo 24 CF/88 teria consagrado uma concorrência limitada entre União e Estados-membros no campo legislativo. ${ }^{564}$ Porém, ao se analisar os parágrafos supratranscritos, percebe-se que, novamente, o legislador constituinte optou por tratar conjuntamente competências concorrentes limitadas e cumulativas. ${ }^{565}$ Por um lado, os $\$ \S 1^{\circ}$ e $2^{\circ}$ consagram a modalidade limitada da

\footnotetext{
563 MOREIRA NETO. Competência concorrente limitada, pp. 149-150. Esta análise também é empreendida por Fernanda Dias Menezes de ALMEIDA, já sob a égide da Constituição Federal de 1988, em Competências na Constituição de 1988, pp. 146-151.

564 Nesse sentido ALMEIDA. Competências na Constituição de 1988, p. 141, MENDES, COELHO, BRANCO. Curso de Direito Constitucional, pp. 954-955, FERREIRA FILHO. Curso de Direito Constitucional, p. 60, LOBO. Competência legislativa concorrente dos Estados-membros, p. 97.

${ }^{565}$ Neste mesmo sentido Tércio Sampaio FERRAZ JUNIOR. Normas gerais e competência concorrente: uma exegese do art. 24 da Constituição Federal. Revista Trimestral de Direito Público, oo 7, 1994, p. 18. Note-se que o referido autor enxerga uma competência legislativa concorrente cumulativa apenas no § 40 do artigo 24 $\mathrm{CF} / 88$, ao passo que na presente tese se defende que os $\S \S 3$ e e 4 o do referido dispositivo constitucional consagrariam a modalidade cumulativa da competência concorrente. Este mesmo argumento também é encampado pelo STF, ainda que seja em um julgado isolado, na ADI no 3098, Relator Ministro Carlos Velloso, Tribunal Pleno, julgado em 24/11/2005.
} 
concorrência legislativa, ao prever a competência da União para legislar sobre normas gerais e a competência dos Estados-membros para suplementar a legislação da União. ${ }^{566}$ Neste ponto, há que se ressaltar uma alteração do ponto de vista da técnica constitucional, em comparação com as constituições anteriores. Com efeito, a Constituição Federal de 1988 qualifica a competência dos Estados-membros de "suplementar" e não de "supletiva" ou "complementar", como faziam os textos constitucionais anteriores. Ao se consultar o dicionário, tem-se que "suplementar" significa tanto "fornecer suplemento para; acrescer alguma coisa" quanto "suprir ou compensar a deficiência de"567; em outras palavras, suplementar pode significar tanto complementar quanto suprir, razão pela qual a doutrina considera que ocorreu apenas uma alteração da terminologia empregada. ${ }^{568}$ Contudo, devese fazer uma ressalva a este raciocínio: embora se possa afirmar que a competência legislativa concorrente do Estado-membro inscrita no artigo $24 \mathrm{CF} / 88$ possa se qualificar como "suplementar" nas duas acepções da palavra, o $\S 2^{\circ}$ deste dispositivo constitucional trata somente da competência complementar, i.e., da competência que acresce conteúdo normativo à legislação de normas gerais da União. ${ }^{569}$

Por outro lado, os $\$ \S 3^{\circ}$ e $4^{\circ}$ do artigo $24 \mathrm{CF} / 88$ consagram a modalidade cumulativa de concorrência legislativa entre União e Estados-membros, ao prever que os Estados poderão legislar plenamente, caso não exista lei federal, sobre quaisquer das matérias arroladas nos incisos do referido dispositivo constitucional, sendo que na hipótese de União efetivamente legislar sobre o tema, a lei estadual terá sua eficácia suspensa em tudo o que contrariar a lei federal. Ou seja, enquanto a União não fizer uso da sua competência, os Estados poderão legislar sem qualquer limitação material. Apenas o Poder Legislativo Federal encontra-se limitado à edição de normas gerais, não só pelo disposto no $\S 1^{\circ}$, mas também porque o $\S 4^{\circ}$ fala da "superveniência de lei federal sobre normas gerais" em expressa referência à situação descrita no $\S 3^{\circ}$. Corrobora esta constatação ainda o fato de o $\S 4^{\circ}$ do artigo $24 \mathrm{CF} / 88$ consagrar uma prevalência do direito federal, a qual é aplicável somente nas hipóteses de competência concorrente cumulativa; ${ }^{.70}$ na competência

\footnotetext{
566 Há ainda a competência do Município para suplementar a legislação federal e estadual no que couber, inscrita no artigo 30, II, CF/88 e que será oportunamente analisada no item 4.1.6 desta tese.

${ }^{567}$ AURÉLIO, FERREIRA. Aurélio século XXI: o dicionário da língua portuguesa, p. 1631.

568 Nesse sentido, vide ALMEIDA. Competências na Constituição de 1988, p. 152.

${ }^{569}$ Como também reconhece ALMEIDA. Competências na Constituição de 1988, p. 152.

570 Como ressalta Manoel Gonçalves FERREIRA FILHO. Comentários à Constituição Brasileira (Emenda Constitucional no 1, de 17 de outubro de 1969). 1o Volume - Artigos 1 a 45. São Paulo: Saraiva, 1972, p. 109. Em sentido contrário, CRETELLA JUNIOR. Comentários à Constituição de 1988, pp. 1775 e ss.
} 
concorrente limitada, cada ente legisla dentro do campo material determinado pela própria Constituição, sob pena de inconstitucionalidade formal. ${ }^{571}$

É certo que, por meio da inclusão dos $\S \S 3^{\circ}$ e $4^{\circ}$ do artigo $24 \mathrm{CF} / 88$ (os quais não encontram paralelo em nenhuma constituição brasileira anterior), o legislador constituinte não pretendeu criar uma competência concorrente cumulativa ao lado da tão prestigiada modalidade limitada de concorrência legislativa, mas sim resolver uma celeuma doutrinária acerca da possibilidade (ou não) de os Estados legislarem quando não houvesse lei federal sobre o tema, que existia sob a égide da Constituição Federal de 1967/1969. Com efeito, apontava Manoel Gonçalves FERREIRA FILHO a existência de corrente doutrinária que sustentava, sob a vigência das Constituições Federais de 1946 e de 1967/1969, que somente depois que a União fizesse uso da sua competência legislativa é que os Estados restariam autorizados a legislar nos temas de competência concorrente. O referido autor, por sua vez, discordava deste posicionamento, sob o argumento de que "a competência de complementar as normas ordinárias federais está em paralelo com a competência de complementar a Constituição, suprindo a ausência de lei federal". 572

Não obstante esta intenção, o que efetivamente se forjou no artigo 24 CF/88 foi uma dupla concorrência: a primeira delas concebe limites material à atuação da União e dos Estados-membros; a outra, por sua vez, confere competência legislativa plena aos Estadosmembros, limitando somente a atuação normativa do Poder Legislativo federal à edição de normas gerais. Ambas modalidades, por óbvio, aplicam-se à totalidade das matérias arroladas nos incisos do artigo $24 \mathrm{CF} / 88$. A rigor, a Constituição Federal de 1988 só prevê competências legislativas concorrentes limitadas, sem associá-las a uma competência legislativa plena por parte dos Estados-membros, no artigo 22 CF/88, mais precisamente, naquelas competências por nós denominadas de "competências privativas da União para legislar sobre normas gerais" quando da análise deste dispositivo constitucional ${ }^{573}$. A questão consiste em saber como interpretar corretamente este grande emaranhado normativo que a Constituição brasileira vigente criou ao manejar a

\footnotetext{
${ }^{571}$ Esta afirmação de que o artigo 24 CF/88 consagra duas modalidades de competência legislativa concorrente é, a bem da verdade, uma conclusão que se extrai do raciocínio desenvolvido por Diogo de Figueiredo MOREIRA NETO no seu artigo sobre competência concorrente limitada, citado neste item. Porém, ao descrever a competência inscrita atualmente no artigo 24 CF/88, o referido autor enxerga somente uma competência concorrente legislativa limitada (cf. MOREIRA NETO. Competência concorrente limitada, p. 139).

572 FERREIRA FILHO. Comentários à Constituição Brasileira, pp. 110-111. Esta mesma polêmica doutrinária é retratada em ALMEIDA. Competências na Constituição de 1988, pp. 153-154.

573 Esta constatação só se aplica, por sua vez, quando se considera que estas "competências privativas da União para legislar sobre normas gerais" é uma espécie de competência legislativa concorrente. Sobre esta questão, vide as considerações tecidas no tópico 4.2.
} 
técnica vertical de repartição de competências. Objetiva-se, por meio das considerações que se seguirão, expor alguns vetores que ajudarão a promover uma melhor compreensão do artigo $24 \mathrm{CF} / 88$.

Em primeiro lugar, cumpre ressaltar que a legislação de normas gerais da União permanece, a rigor, como uma faculdade e não como uma imposição constitucional. ${ }^{574}$

Com efeito, a União pode não julgar oportuno ou necessário editar normas gerais sobre um tema, ainda que a prática revele não só que o poder federal exerce ativamente esta competência legislativa, como também legisla de forma a deixar pouco espaço para a atuação dos poderes legislativos estaduais. Esta é, por sua vez, uma conclusão que se extrai do exposto nos $\S \S 3^{\circ}$ e $4^{\circ}$ do artigo $24 \mathrm{CF} / 88$ : afinal, se o Poder Legislativo federal efetivamente devesse editar normas gerais, o $\S 3^{\circ}$ não faria referência expressa à inexistência da lei federal e nem o $\S 4^{\circ}$ falaria em superveniência de lei federal.

Se normas gerais são faculdade a ser exercida por razões de necessidade ou conveniência, deve-se perquirir em quais hipóteses a União está autorizada a editá-las ou, ao contrário, se a simples edição destas normas pelo Poder Legislativo federal já é o suficiente para atestar esta necessidade ou conveniência. De um lado, poder-se-ia sustentar que a União deveria fazer uso desta competência legislativa somente nos casos em que há necessidade de se promover uma regulamentação nacional de uma determinada matéria. Neste contexto, normas gerais seriam normas que promoveriam um tratamento federativo uniforme de determinados temas, por óbvio, quando esta uniformização fosse imperiosa. Nos demais casos, os Estados deveriam exercer a sua competência legislativa plena. Por outro lado, é possível argumentar que o juízo acerca da necessidade e da oportunidade destas normas já teria sido feito pelo legislador constituinte ao atribuir esta competência à União, tendo em vista que se trata de um dos instrumentos por ele concebidos para fomentar a coordenação federativa. ${ }^{575}$

Em segundo lugar, é preciso se debruçar sobre o alcance da competência legislativa plena conferida aos Estados-membros pelo $\S 3^{\circ}$ do artigo $24 \mathrm{CF} / 88$. Afinal, ela abrange ou não abrange a elaboração de normas gerais por parte dos Estados-membros? Fernanda Dias Menezes de ALMEIDA responde afirmativamente a esta questão, neste ponto sendo seguida

\footnotetext{
574 Neste sentido, LOBO. Competência legislativa concorrente dos Estados-membros, p. 98.

575 A competência legislativa concorrente costuma ser considerada um típico instrumento do federalismo cooperativo por parte da doutrina. Sobre a relação entre esta modalidade de competência e a figura da coordenação federativa, vide BERCOVICI. Desigualdades regionais, p. 151.
} 
pela maioria da doutrina brasileira. ${ }^{576}$ Contudo, parece-nos que este não é o modo mais correto de interpretar as disposições contidas no referido dispositivo constitucional. Com efeito, o $\S 3^{\circ}$ dispõe que "os Estados exercerão a competência legislativa plena, para atender a suas peculiaridades" no caso de não existir lei federal sobre normas gerais, deixando claro que esta competência dos Estados, por um lado, é plena - o que significa dizer que ela autoriza os Poderes Legislativos estaduais a promoverem a regulamentação integral de uma matéria - e, por outro, dirige-se ao atendimento das peculiaridades locais - o que, em outras palavras, equivale ao regramento das relações jurídicas desenvolvidas em seu respectivo território. Aos Estados-membros não é lícito, portanto, regulamentar situações ou relações que se desenvolvam no território de outro Estados, porque esta é uma função precípua da norma geral da União. Em outras palavras, legislar plenamente para atender às peculiaridades contrapõe-se, por princípio, a legislar sobre normas gerais e é por isso que aos Estados-membros não é permitido editar este tipo de norma. Por óbvio, esta é uma conclusão que tem por pressuposto uma diferenciação entre o regramento integral e a edição de normas gerais sobre um tema. Quando estas duas categorias indevidamente se confundem - e a prática pós-1988 demonstra que esta confusão é a regra - os Estados acabam legislando sobre o que se convenciona chamar de normas gerais e a União invariavelmente desce ao regramento de peculiaridades regionais. Diferentemente da práxis sobre o tema, a presente tese defende a importância de se conceber um conceito mais restrito e suficientemente delimitado de normas gerais, que não se confunde com o regramento integral da matéria referido pelo $\S 3^{\circ}$ do artigo $24 \mathrm{CF} / 88$, sendo esta a terceira observação que se deseja fazer sobre a competência inscrita no artigo $24 \mathrm{CF} / 88$.

Existem na doutrina e na jurisprudência diversas noções do que são normas gerais. Para os fins desta tese, acolhe-se definição forjada por Diogo de Figueiredo MOREIRA NETO:

\footnotetext{
"chegamos, assim, em síntese, a que normas gerais são declarações principiológicas que cabe à União editar, no uso de sua competência concorrente limitada, restrita ao estabelecimento de diretrizes nacionais sobre certos assuntos, que deverão ser respeitadas pelos Estados-Membros na feitura das suas respectivas legislações, através de normas específicas e particularizantes que as detalharão, de modo que possam ser aplicadas, direta e imediatamente, às relações e situações concretas a que se destinam em seus respectivos âmbitos políticos"577
}

\footnotetext{
576 ALMEIDA. Competências na Constituição de 1988, p. 155 e também FERREIRA FILHO. O Estado Federal brasileiro à luz da Constituição de 1988, p. 128; FERRAZ JUNIOR. Normas gerais e competência concorrente, p. 19 (esclarecendo-se apenas que, para este autor, o Estado pode "legislar sobre normas gerais naquilo em que elas constituem condições de possibilidade para a legislação própria sobre normas particulares"), MENDES, COELHO, BRANCO. Curso de Direito Constitucional, p. 955.

577 MOREIRA NETO. Competência concorrente limitada, p. 159.
} 
Colocando esta proposta em termos mais esquemáticos, tem-se que normas gerais: (i) são declarações principiológicas, vale dizer, declarações dotadas de um maior nível de abstração, que não descem a particularismos; (ii) estabelecem diretrizes nacionais sobre certos assuntos, ou seja, são normas que promovem uma uniformização legislativa de uma matéria, e; (iii) dirigem-se aos Estados-membros na elaboração de suas respectivas legislações. Como se extrai da citação supra, são os Poderes Legislativos estaduais quem editarão "normas específicas e particularizantes", aplicáveis "direta e imediatamente às relações e situações concretas a que se destinam em seus respectivos âmbitos políticos". Consequentemente, à União cabe somente regulamentar de forma indireta e mediata estas relações, dirigindo-se direta e imediatamente apenas aos Poderes Legislativos dos Estados. ${ }^{578}$

Todavia, é de se admitir que tanto doutrina quanto jurisprudência costumam trabalhar com construções mais concisas. No âmbito da doutrina, é possível encontrar definições no sentido de que normas gerais são "princípios, bases, diretrizes, que hão presidir todo um sistema jurídico" (Manoel Gonçalves FERREIRA FILHO), "princípios, diretrizes, bases, a serem pormenorizados, detalhados, esmiuçados, pelos titulares da competência legislativa suplementar" (Fernanda Dias Menezes de ALMEIDA), "normas não exaustivas, leis-quadro, princípios amplos, que traçam um plano, sem descer a pormenores" (Paulo Gonet BRANCO), bem como "normas não exaustivas, normas incompletas, de modo a não esgotar a competência a matéria da legislação concorrente" (Raul Machado HORTA). ${ }^{579}$ Em apertada síntese, normas gerais consistiriam em princípios ou diretrizes dotados de uma maior generalidade, a fim de não esgotar as possibilidades da legislação suplementar dos Estados-membros. O problema desta proposta, entretanto, é que o modo pelo qual ela é enunciada acaba por criar uma confusão, de um lado, entre "norma geral" que delimita a competência da União nos termos do $\S 1^{\circ}$ do artigo $24 \mathrm{CF} / 88$ e, de outro, o caráter geral e abstrato que as normas jurídicas normalmente possuem (inclusive a norma estadual que

\footnotetext{
578 Para maiores detalhamentos, vide MOREIRA NETO. Competência concorrente limitada, pp. 160-162.

579 FERREIRA FILHO. O Estado Federal brasileiro, p. 127; Fernanda Dias Menezes de ALMEIDA. Comentários ao artigo 24, § 1‥ In: CANOTILHO, MENDES, SARLET, STRECK, LEONCY, Comentários à Constituição do Brasil, p. 757; MENDES, COELHO, BRANCO. Curso de Direito Constitucional, p. 954-955; HORTA. Direito Constitucional, p. 326. Poucos autores parecem trabalhar com construções mais elaboradas em torno das normas gerais. Neste segundo grupo enquadra-se a definição proposta por Alice Gonzalez BORGES em artigo dedicado ao estudo das normas gerais em matéria de licitações e contratos administrativos (Alice Gonzalez BORGES. Normas gerais nas licitações e contratos administrativos (Contribuição para a elaboração de uma lei nacional). Revista de Direito Público, ano 24, no 96, out./dez.1990, pp. 81-93).
} 
atende a peculiaridades locais), além de conduzir a um subjetivismo muito grande, como aliás reconhece parte da doutrina analisada. ${ }^{580}$

No Supremo Tribunal Federal, ${ }^{581}$ por sua vez, são escassas as definições de normas gerais, muito embora a competência legislativa concorrente seja, em si, um tema sobre o qual esta Corte constitucional se manifesta com frequência. Entretanto, é possível encontrar em alguns julgados ponderações no sentido de que normas gerais "se caracterizam por definirem diretrizes gerais e princípios amplos sobre dado tema", ${ }^{582}$ ou então por serem uma "legislação nacional de princípios". ${ }^{583}$ Há julgados, ainda, que remetem a definições doutrinárias conhecidas, como aquela elaborada por Paulo Gonet BRANCO no Curso de Direito Constitucional que este escreve juntamente com o Ministro Gilmar MENDES. ${ }^{584}$ Uma das tentativas de aproximação conceitual mais elaboradas - e também uma das mais citadas - no âmbito da jurisprudência do STF foi elaborada pelo Ministro Carlos Velloso no julgamento da ADI 927-MC/RS, cujo excerto se transcreve:

"A formulação do conceito de 'normas gerais' é tanto mais complexa quando se
tem presente o conceito de lei em sentido material - norma geral, abstrata. Ora, se
a lei, em sentido material, é norma geral, como seria a lei de 'normas gerais'
referida na Constituição? Penso que essas 'normas gerais' devem apresentar
generalidade maior do que apresentam, de regra, as leis. Penso que 'norma geral',
tal como posta na Constituição, tem o sentido de diretriz, de princípio geral. A
norma geral federal, melhor será dizer nacional, seria a moldura do quadro a ser
pintado pelos Estados e Municípios no âmbito de suas competências. Com

580 Nesse sentido, ALMEIDA. Competências na Constituição de 1988, pp. 954-955.

581 Os julgados que serão citados a seguir foram obtidos por meio de consulta à ferramenta de busca de jurisprudência do sítio eletrônico do Supremo Tribunal Federal, inserindo-se o seguinte termos: "normas e gerais e competência e concorrente". A pesquisa retornou 43 acórdãos em 24/05/2015, sendo que apenas 27 guardavam pertinência direta com o tema analisado.

582 ADI 4423, Relator Ministro Dias Toffoli, Tribunal Pleno, julgada em 24/09/2014, p. 11.

${ }^{583}$ ADI 2903, Relator Ministro Celso de Mello, Tribunal Pleno, julgada em 01/12/2005, p. 95. Prossegue o Ministro Relator ao afirmar que "a União federal, ultrapassando o domínio normativo das regras gerais, não pode, sob pena de transgredir domínio constitucionalmente reservado ao Estado-membro, editar legislação que desça a pormenores, que minudencie condições específicas ou que se ocupe de detalhamentos que descaracterizem o coeficiente de maior generalidade e abstração que se requer das normas gerais referidas no texto da Constituição, pois estas, mais do que as fórmulas simplesmente genéricas contidas nas leis em sentido material, hão de veicular princípios, diretrizes e bases essenciais à regulação de determinada matéria especificada no art. 24 da Carta Política" (p. 96, grifos no original). É de se ressaltar que, para André Ramos TAVARES, haveria ainda mais um conceito de norma geral presente no STF, mais precisamente, a de que "a sua generalidade decorreria de sua (i) possível aplicação federativa uniforme" (André Ramos TAVARES. Aporias acerca do "condomínio legislativo" no Brasil: uma análise a partir do STF. In: André Ramos TAVARES, George Salomão LEITE, Ingo Wolfgang SARLET (Org.). Estado constitucional e organização do poder. São Paulo: Saraiva, 2010, p. 165).

584 Nesse sentido, a ADI 4060, Relator Luiz Fux, Tribunal Pleno, julgada em 25/02/2015, pp. 8-9 e a ADI 4423, Relator Ministro Dias Toffoli, Tribunal Pleno, julgada em 24/09/2014, p. 10-11. Tal constatação parece ir ao encontro do posicionamento de VIRGÍLIO AFONSO da Silva, no sentido de que o Supremo Tribunal Federal "na maior parte dos casos, repete apenas os critérios apontados por textos jurídicos, sem construir, a partir destas, um desenho mais claro da relação entre União, estados e Distrito Federal no que diz respeito às competências concorrentes (VIRGÍLIO AFONSO. Capítulo 25 - Federalismo e articulação de competências no Brasil, p. 562). 
propriedade, registra a professora Alice Gonzalez Borges que as 'normas gerais', leis nacionais, 'são necessariamente de caráter mais genérico e abstrato do que as normas locais. Constituem normas de leis, direito sobre direito, determinam parâmetros, com maior nível de generalidade e abstração, estabelecidos para que sejam desenvolvidos pela ação normativa subsequente das ordens federais', pelo que 'não são normas gerais as que se ocupem de detalhamentos, pormenores, minúcias, de modo que nada deixam à criação própria do legislador a quem se destinam, exaurindo o assunto de que tratam. Depois de considerações outras, no sentido da caracterização de 'norma geral', conclui: 'são normas gerais as que se contenham no mínimo indispensável ao cumprimento dos preceitos fundamentais, abrindo espaço para que o legislador possa abordar aspectos diferentes, diversificados, sem desrespeito a seus comandos genéricos, básicos.' (Alice Gonzalez Borges, 'Normas gerais das Licitações e Contratos administrativos', RDP 96/81)"585

Embora esta proposta efetivamente adicione um elemento novo - qual seja, de que as normas gerais se destinariam a estabelecer parâmetros à atuação normativa subsequente dos Estados-membros, qualificando-se como "normas sobre leis" e dirigidas sobretudo aos Poderes Legislativos dos Estados-membros - ela persiste na enunciação de normas gerais como "princípios gerais", “diretrizes", o que pode embasar tanto posicionamentos no sentido de uma maior centralização legislativa na órbita federal quanto posições que prestigiem a autonomia dos Estados-membros. Com efeito, o STF julgou uma série de leis estaduais inconstitucionais em um passado recente e agora parece se inclinar no sentido de prestigiar a autonomia dos Estados-membros, utilizando praticamente o mesmo arcabouço teórico acerca do sentido e do alcance das normas gerais. ${ }^{586}$

585 ADI 927 MC, Relator Ministro Carlos Velloso, Tribunal Pleno, julgado em 03/11/1993, pp. 46-48. Note-se que este não foi um julgado selecionado consoante o procedimento exposto na nota de rodapé no 581 . Contudo, o trecho supratranscrito foi citado textualmente em dois julgados selecionados, mais precisamente, na ADI 3670, Relator Ministro Sepúlveda Pertence, julgada em 02/04/2007, pp. 118-119 e na ADI 3098, Relator Ministro Carlos Velloso, Tribunal Pleno, julgada em 24/11/2005, pp. 105-107.

${ }^{586}$ Embora esta noção de norma geral, mais aberta a subjetivismos, seja o substrato teórico desta tendência, acredita-se que o seu mecanismo explicativo seja basicamente uma conversão institucional, para falar com James MAHONEY e Kathleen THELEN, principalmente quando se leva em consideração a aposentadoria de Ministros com posições centralistas (é o caso, p. ex., da Ministra Ellen Gracie) e a posse de Ministros que defendem francamente uma maior descentralização federativa (como é o caso dos Ministros Luiz Fux e Dias Toffoli) Nesse sentido, no julgamento da ADI 4060, o Ministro Luiz Fux ponderou que "a federação brasileira ainda se revela altamente centralizada, muitas vezes beirando o federalismo meramente nominal. Vislumbro dois fatores essenciais para esse quadro. O primeiro é de índole jurídico-positiva: a engenharia constitucional brasileira, ao promover a partilha de competências entre os entes da federação (CRFB, arts. 21 a 24), concentra grande quantidade de matérias sob a autoridade privativa da União. O segundo fator é de natureza jurisprudencial. Não se pode ignorar a contundente atuação do Supremo Tribunal Federal ao exercer o controle de constitucionalidade de lei ou ato federal e estadual, especialmente aquele inspirado no 'princípio da simetria' e numa leitura excessivamente inflacionada das competências normativas da União (...) Acredito que seja o momento de a Corte rever sua postura prima facie em casos de litígios constitucionais em matéria de competência legislativa, passando a prestigiar as iniciativas regionais e locais, a menos que ofendam norma expressa e inequívoca da Constituição. Essa diretriz parece ser a que melhor se acomoda à noção de federalismo como sistema que visa a promover o pluralismo nas formas de organização política" (ADI 4060, Relator Ministro Luiz Fux, julgada em 25/02/2015, pp. 7-9). Para maiores detalhes sobre a conversão institucional e de outros mecanismos de mudança institucional, vide James MAHONEY; Kathleen THELEN. $A$ 
Por meio destas críticas, não se pretende negar que normas gerais efetivamente sejam proposições normativas dotadas de uma maior generalidade, como defende a doutrina e jurisprudência supracitadas. Considera-se apenas que esta aproximação conceitual é insuficiente. Como pondera Tércio Sampaio FERRAZ JUNIOR, a correta delimitação do alcance e do sentido da previsão contida no $\S 1^{\circ}$ do artigo 24 , também deve levar em conta os possíveis destinatários da norma - neste contexto, uma norma é geral "quando se aplica à universalidade deles, sem distinções" e particular "quando se destina a uma coletividade ou categoria de destinatários" ${ }^{\$ 87}$ - mas sobretudo uma interpretação teleológica, orientada ao "interesse prevalecente na organização federativa" sob um paradigma de federalismo cooperativo, ${ }^{588}$ como é o caso do federalismo brasileiro. Em outras palavras, é preciso perquirir se há uma necessidade de uniformizar a legislação em todo o território nacional, como forma de obter uma maior coordenação entre os entes da Federação em assuntos que demandam um esforço conjunto ou então com a finalidade de evitar conflitos que poderiam surgir na hipótese de o assunto ser regulado por uma multiplicidade de leis estaduais. Caso uma norma geral não se justifique do ponto de vista da sua finalidade de uniformização federativa, é de se franquear aos Estados-membros a competência legislativa plena, e não apenas a competência suplementar, nos exatos limites fixados pela legislação federal.

Porém, a adoção de um conceito mais restrito de norma geral, como aquela que é precipuamente dirigida ao legislador estadual e que, no mais, só possui aplicabilidade indireta e mediata às relações jurídicas concretas - como propugna Diogo de Figueiredo MOREIRA NETO - oferece uma dificuldade prática importante. Como bem ressalta Carlos Ari SUNDFELD, a previsão no sentido de que a União limitar-se-á à edição deste tipo de norma "não é, contudo, absoluta, valendo-se apenas para as leis que regulem exclusivamente: a) atividade estadual ou municipal; ou; b) atividade privada". ${ }^{589}$ Quando se trata de regular a atuação da administração pública federal em uma das matérias previstas nos incisos do artigo 24, a União não só editará normas gerais como também estará legitimada a descer a minucias. ${ }^{590} \mathrm{O}$ grande problema é que nem todos os diplomas legislativos promovem uma distinção exata entre as disposições aplicáveis a todos os entes da Federação, porque gerais, e aquelas aplicáveis somente à estrutura administrativa federal.

Theory of Gradual Institutional Change. In: James MAHONEY; Kathleen THELEN. Explaining Institutional Change: Ambiguity, Agency, and Power. Cambridge: Cambridge University Press, 2010.

587 FERRAZ JUNIOR. Normas gerais e competência concorrente, p. 18.

588 FERRAZ JUNIOR. Normas gerais e competência concorrente, p. 19.

${ }^{589}$ Carlos Ari SUNDFELD. Sistema constitucional das competências. Revista Trimestral de Direito Público, no 1, 1993, p. 276.

590 Como ressalta SUNDFELD. Sistema constitucional das competências, pp. 276-277. 
O exemplo mais emblemático deste fenômeno é o a Lei ${ }^{\circ}$ 8.666/1993, que sob o pretexto de traçar as normas gerais em matéria de licitação e contratos administrativos (conforme autoriza o artigo 22, XXVVII, CF/88), prevê um apertado esquema normativo também aos Estados-membros e Municípios, que ficam quase tolhidos da possibilidade de regulamentar o tema de outro modo. É certo que o referido diploma surgiu em um contexto de moralização da Administração Pública ${ }^{591}$, porém é difícil imaginar como, por exemplo, uma contratação de copos descartáveis em uma distante localidade possui envergadura política e econômica suficiente a justificar a sua regulamentação por norma geral federal, como acontece atualmente. Já a Lei n ${ }^{\circ} 11.079 / 2004$, promove esta diferenciação entre normas aplicáveis às três esferas e aquelas cujo destinatária é a União. Contudo, mesmo algumas normas que a lei considera como de vocação geral deveriam ser aplicadas à União tão somente, uma vez que limitam a autonomia dos governos estaduais e municipais nas suas contratações sem que esta restrição se justifique do ponto de vista da "prevalência do interesse federativo", para falar com Tércio Sampaio FERRAZ JUNIOR. É o caso, por exemplo, da norma contida no artigo $2^{\circ}, \S 4^{\circ}$, I, Lei $n^{\circ} 11.079 / 2004$, que pró́be a realização de parcerias público-privadas a contratos de valor inferior a $\mathrm{R} \$ 20.000 .000,00$ ou então das disposições contidas nos artigos 10 e seguintes da mesma lei, as quais regulam o processo de licitação destas parcerias em termos relativamente minuciosos. Neste ponto, concorda-se com as ponderações de Carlos Ari SUNDFELD no sentido de que "são impróprios para as normas gerais problemas como: a fixação de prazos, a definição das autoridades competentes para tal ou qual ato, o estabelecimento de valores exatos de multas, o detalhamento dos procedimentos administrativos, e assim por diante". ${ }^{592}$ Contudo, esta é uma proposição que pode ser utilizada apenas como um dos possíveis vetores de interpretação dos diplomas legislativos editados com fulcro no artigo 24 CF/88, pois a Constituição Federal de 1988, em si, não contém nenhuma previsão sobre o modo pelo qual estas normas gerais devem ser veiculadas nas leis editadas pela União no âmbito de sua competência. ${ }^{593}$

A título de considerações finais, cumpre apenas ressaltar que, tal como ocorre com a competência legislativa privativa da União (artigo $22 \mathrm{CF} / 88$ ) e a competência comum da União, Estados e Municípios (artigo $23 \mathrm{CF} / 88$ ), também no artigo $24 \mathrm{CF} / 88$ é possível vislumbrar uma dissociação entre a titularidade da competência legislativa sobre um tema e

\footnotetext{
591 Sobre as demandas que cercavam a aprovação da Lei no 8.666/1993, vide as considerações de Alice Gonzalez BORGES em Aplicabilidade de normas gerais de lei federal dos Estados. Revista de Direito Administrativo, Rio de Janeiro, vol. 194, out./dez. 1993, pp. 97 e ss.

592 SUNDFELD. Sistema constitucional das competências, p. 276.

${ }^{593}$ Como reconhece ALMEIDA. Competências na Constituição de 1988, pp. 150-151.
} 
a da competência para promover a execução desta normatização. $\mathrm{O}$ exemplo mais patente deste fenômeno é a competência para legislar concorrentemente sobre juntas comerciais, inscrita no inciso III do artigo $24 \mathrm{CF} / 88$, embora as juntas comerciais propriamente ditas estejam inseridas na estrutura administrativa dos Estados-membros. Há outros exemplos interessantes, como é o caso da competência para legislar concorrentemente sobre "organização, garantias, direitos e deveres das polícias civis", prevista no inciso XVI, e "proteção à infância e juventude" inscrita no inciso XV, cuja execução compete, em regra, a instituições estaduais e, no último caso, também municipais.

\subsection{A COMPETÊNCIA PRIVATIVA DOS ESTADOS-MEMBROS (PARÁGRAFOS DO ARTIGO 25)}

A competência privativa dos Estados-membros vem enunciada nos três parágrafos do artigo 25 da $\mathrm{CF} / 88$. A competência para "explorar diretamente, ou mediante concessão, os serviços locais de gás canalizado", prevista no $\S 2^{\circ}$ do referido dispositivo constitucional, não oferece maiores dificuldades. ${ }^{594} \mathrm{O} \S 3^{\circ}$ deste mesmo dispositivo, por sua vez, será tratado com maiores detalhes no tópico 7.3.3 desta tese. Por isso, as atenções neste tópico naturalmente se voltam para as disposições contidas no $\S 1^{\circ}$ do artigo $25 \mathrm{CF} / 88$, que consagra o que se convenciona chamar de competência reservada, residual ou remanescente dos Estados-Membros. ${ }^{595}$

No número 45 de $O$ Federalista, James MADISON, ao rebater as críticas dos antifederalistas no sentido de que os poderes conferidos à União poderiam ameaçar a soberania e a importância dos governos estaduais, esclarecia que

“os poderes delegados ao governo federal pela Constituição proposta são poucos e definidos; os que permanecem com os governos estaduais são numerosos e

\footnotetext{
594 É de se ressaltar, contudo, que a "pesquisa e a lavra das jazidas de petróleo e gás natural e outros hidrocarbonetos fluidos" constituem monopólio da União, nos termos do artigo 177, I, CF/88. A fim de compatibilizar esta disposição com o artigo 25, § 2ำ, CF/88, "deve-se entender que a União, após pesquisar e lavrar as jazidas de gás natural, que são de sua propriedade (art. 176), outorgará aos Estados a exploração dos serviços locais de gás canalizado" (ALMEIDA. Competências na Constituição de 1988, p. 125). Neste ponto, ALMEIDA cita o posicionamento de JOSÉ AFONSO da Silva, para quem "não é fácil compreender a lógica do constituinte que, ao mesmo tempo que dá monopólio de pesquisa e lavra de gás natural à União, confere aos Estados aquela exploração direta ou por concessão, como se fosse dele; a conciliação será a União pesquisar e lavrar e depois outorgar aos Estados, que tenham condições, a distribuição; esta é que os Estados poderão explorar diretamente ou mediante concessão (JOSÉ AFONSO. Curso de Direito Constitucional Positivo, p. 619).

595 A presente tese considera sinônimas as expressões "reservada", "residual" e "remanescente". Sobre os possíveis significados de cada uma destas expressões que costumam qualificar a competência atribuída privativamente aos Estados-membros pelo artigo 25, §1ำ, CF/88, vide ALMEIDA. Competências na Constituição de 1988, pp. 81-82. Para uma compreensão acerca do posicionamento de JOSÉ AFONSO da Silva sobre o tema, vide o item 1.5 .2 desta tese.
} 
imprecisos. Aqueles serão exercidos principalmente sobre tópicos externos, tais como guerra, paz, negociações e comércio exterior, com o qual o poder de taxação estará mais intimamente ligado. Os poderes reservados aos Estados se estenderão sobre todos os tópicos que, no curso normal da vida do país, dizem respeito às liberdades e bens do povo, à ordem interna e aos aperfeiçoamentos e progresso do Estado.

A atuação do governo federal será mais abrangente e importante em tempo de guerra e de ameaças; a dos governos estaduais, em tempo de paz e tranquilidade. Uma vez que aqueles períodos serão provavelmente bem menores que estes, os governos estaduais desfrutarão de mais essa vantagem sobre o federal. Na verdade, quanto mais eficazmente os poderes federais assegurarem a defesa nacional, menos frequente será a ocorrência de ameaças que poderiam favorecer a ascendência dos referidos poderes sobre os governos dos Estados." 596

Note-se que, na sua versão original, a Constituição norte-americana somente enumerava os poderes da União. Foi somente a partir da Décima Emenda, em 1791, que a cláusula dos poderes reservados aos Estados foi expressamente incorporada ao texto constitucional, declarando um entendimento a respeito da repartição de competências entre União e Estados-membros que já era predominante desde 1787. ${ }^{597}$ De todo modo e como já se teve a oportunidade de ressaltar em mais de uma oportunidade, com o passar dos anos a federação norte-americana passou a vivenciar um período de centralização federativa, o que foi viabilizado no plano da repartição de competências por meio de uma leitura expansiva da cláusula de comércio inscrita na oitava seção do artigo $1{ }^{\circ}{ }^{598}$ Portanto, a prática acabou por desconfirmar o prognóstico de James MADISON.

No Brasil, a despeito da influência que o constitucionalismo estadunidense exerceu sobre a primeira Constituição Republicana, foi somente a partir da Constituição Federal de 1934 que se passou a consagrar poderes remanescentes aos Estados, dando início a uma tradição que foi repetida por todas as constituições brasileiras, inclusive a Constituição Federal de $1988 .{ }^{599}$ Com efeito, o $\S 1^{\circ}$ do artigo $25 \mathrm{CF} / 88$ prevê que "são reservados aos Estados as competências que não lhes sejam vedadas por esta Constituição". Porém, se em um momento pretérito esta previsão garantia aos entes estaduais ampla autonomia nos campos legislativo, financeiro e administrativo, hoje ela também tem a sua importância sensivelmente diminuída por dois fatores.

\footnotetext{
596 James MADISON. 45 - Poderes e prerrogativas que permanecem com os Estados. In: HAMILTON, MADISON, JAY. O federalista, p. 383.

597 https://www.law.cornell.edu/anncon/html/amdt10_user.html\#amdt10_hd4. Acesso: 30/05/2015.

598 Vide, neste sentido, as ponderações desenvolvidas nos itens 1.2 .2 e 3.1 desta tese.

599 Nos termos do artigo 7ㅇ, IV, CF/1934 competia aos Estados "exercer, em geral, todo e qualquer poder ou direito, que lhes não for negado explícita ou implicitamente por cláusula expressa desta Constituição”, o que foi repetido, com pequenas alterações, pelo artigo 21, II, CF/1937, artigo 18, § 1으, CF/1946 e artigo 13, § 1으, CF/1967-1969.
} 
Em primeiro lugar, costuma-se mencionar as numerosas competências que são atribuídas à União, o que invariavelmente restringe esta competência estadual. ${ }^{600}$ Sabe-se, afinal, que a extensão dos poderes que são reservados aos Estados deve ser aferida por meio de um raciocínio de exclusão: ou seja, é preciso primeiro verificar as competências conferidas aos outros entes federativos pelo texto constitucional para só então apurar as competências que restam aos Estados-membros, porque não conferidas à União ou aos Municípios. Por óbvio, quanto mais competências são atribuídas às esferas federal e municipal, menor o espaço de atuação da esfera estadual. No caso brasileiro, é preciso atentar também para a extensão do catálogo das competências concorrentes, pois se com uma mão ele contempla os Estados-membros com alguma autonomia legislativa e administrativa, com a outra mão ele restringe ainda mais o campo de competências que lhes são privativas. A título de exemplo, cita-se a competência privativa da União para legislar sobre "normas gerais de organização, efetivos, material bélico, garantias, convocação e mobilização das polícias militares e corpos de bombeiros militares" (artigo 22, XXI) e a competência concorrente para legislar sobre "organização, garantias, direitos e deveres das polícias civis" (artigo 24, XVI), que permitem à União fixar parâmetros de atuação e organização de instituições pertencentes aos Estados-membros, ainda que confiram aos Estados-membros, ao menos em tese, uma margem razoável de atuação legiferante.

Em segundo lugar, o fato de os Municípios terem se tornado entes federativos, com competências que lhe são próprias, também retirou competências privativas importantes dos Estados-membros. Nesse sentido, relata Fernanda Dias Menezes de ALMEIDA que os Estados-membros perderam para os Municípios a competência para criar distritos e para legislar sobre organização municipal. ${ }^{601}$ É certo que em ambos os casos a legislação municipal deverá obedecer às disposições da lei ou da constituição estaduais, conforme o caso. Ainda assim, não se pode deixar de se reconhecer que a autonomia conferida aos Municípios pela Constituição Federal de 1988, em especial no que tange à auto-legislação e a auto-administração, operou-se principalmente em detrimento da autonomia estadual.

Deste modo, pode-se afirmar que a competência privativa do Estado-membro foi sensivelmente tolhida em duas frentes: por um lado, a extensa enumeração de competências privativas e concorrentes à União; de outro lado, a não tão extensa, mas ainda assim significativa enumeração de competências privativas aos Municípios. Entretanto, não se vai tão longe a ponto de afirmar que o artigo $25, \S 1^{\circ}, \mathrm{CF} / 88$ teria perdido

\footnotetext{
600 Nesse sentido, vide os comentários feitos por Fernanda Dias Menezes de ALMEIDA em CANOTILHO, MENDES, SARLET, STRECK, LEONCY. Comentários à Constituição do Brasil, p. 759.

${ }^{601}$ ALMEIDA. Competências na Constituição de 1988, pp. 127-128.
} 
a sua utilidade, representando uma reminiscência histórica que comprova o quão nominal o federalismo brasileiro teria se tornado. Ao contrário, parece-nos que esta previsão constitucional não tem sido interpretada com o devido alcance. De todo modo, cumpre tecer algumas considerações sobre a técnica constitucional que está por trás desta competência, a fim de se desfazerem alguns equívocos comuns.

Em primeiro lugar, é importante não tratar a competência residual como uma competência indefinida. Com efeito, quando da análise das classificações das competências e de sua repartição (item 1.5.4 desta tese), ressalvou-se a importante observação feita por Josef ISENSEE no sentido de que as competências residuais, embora não enumeradas, não seriam propriamente competências indefinidas, uma vez que são determinadas pelo confronto com as competências enumeradas privativas e concorrentes. Em outras palavras, a competência residual é uma competência determinável a partir do confronto com as competências enumeradas, sendo que o critério de distinção entre ambas é a discriminação ou não das matérias que competem a um ente federativo. Caso ocorra este detalhamento da competência com base na matéria ou em outro critério (por exemplo, a competência do Município para prestar serviços de interesse local inscrita no artigo 30, V, CF/88), a competência será enumerada. Caso se atribua os poderes não enumerados a um ente federativo - no caso do Brasil e também da Alemanha, aos Estados-membros - se está diante de uma competência residual, remanescente ou reservada.

Em segundo lugar, não se deve confundir competência residual com competência implícita. A competência implícita é uma modalidade de competência não expressa, a qual se contrapõe, por definição, à competência expressa, prevista de modo textual na Constituição Federal. Ora, tanto a competência enumerada quanto a competência residual são competências expressas, sendo que apenas a competência enumerada pode ser acrescida por algo que lhe é implícito. Com efeito, a redação genérica da competência reservada a torna incompatível com a ideia de competência implícita, pois ela acaba por englobar, a título de competência remanescente, qualquer assunto que com ela se relacione. Por isso, é de se admitir que a competência implícita - e de um modo geral, qualquer competência nãoexpressa - opera necessariamente no sentido de restringir a competência residual. ${ }^{602}$

\footnotetext{
602 Em sentido parecido, sob a perspectiva dos poderes atribuídos aos Municípios, ponderava Victor Nunes LEAL sob a égide da Constituição Federal de 1946 que a constituição havia estabelecido "três esferas de competência, e não deu ao município podêres remanescentes, como aos Estados. Em relação aos municípios, prevalece, portanto, o mesmo princípio aplicável à União: a União e os municípios têm os podêres que se acham enumerados na Constituição, e também os podêres que nestes estejam implícitos. Os Estados, além de podêres expressos, têm todos os mais que não Ihes sejam negados: são os poderes remanescentes." (Victor Nunes LEAL. Alguns problemas municipais em face da Constituição. In: Victor Nunes LEAL. Problemas de Direito Público. Rio de Janeiro: Forense, 1960, p. 324). Note-se, contudo, que sob a égide da Constituição de 1988 o
} 
Em terceiro lugar, também é importante não confundir competência reservada com as dicotomias que contrapõem, de um lado, competências legislativas e competências de execução, e de outro lado, competências privativas e competências concorrentes. Extrai-se da Constituição Federal de 1988 que a competência reservada pode ser tanto legislativa quanto administrativa, porque 0 $\$ 1^{\circ}$ do artigo $25 \mathrm{CF} / 88$ não faz nenhuma reserva a este respeito. Porém, é de se admitir que se o referido dispositivo consagra uma hipótese de competência privativa do Estado, tendo em vista que a competência concorrente dos Estados-membros encontra-se disciplinada em termos autônomos nos artigos 23 e 24 CF/88. Em tese, seria possível se cogitar uma competência residual concorrente; esta não foi, contudo, a solução pela qual optou o legislador constituinte brasileiro.

Feitas estas considerações, parte-se para a análise do sentido e do alcance desta competência do Estado-membro. Segundo Fernanda Dias Menezes de ALMEIDA, trata-se de uma competência restrita a assuntos de natureza administrativa e financeira competências materiais, segundo esta autora - os quais já se encontram devidamente delimitados pelo próprio texto constitucional. ${ }^{603}$ Esta é uma constatação que não merece reparo algum, mas que deve ser complementada com algumas ponderações importantes.

Primeiramente, o fato de as competências legislativas privativas do Estado-membro serem demasiadamente restritas - é difícil, aliás, imaginar um aspecto das relações dos indivíduos entre si que seja regulada privativamente pelos Poderes Legislativos estaduais não significa que os Estados-membros simplesmente não contam com competências legislativas importantes na federação brasileira. Ocorre que elas se encontram inseridas sobretudo no artigo $24 \mathrm{CF} / 88^{604}$. Por isso, defende-se a necessidade de se conferir à legislação de normas gerais da União feições que possibilitem uma ampla margem de atuação aos Poderes Legislativos estaduais, sob pena de retirar dos Estados-membros grande parte da sua competência legislativa.

Em segundo lugar, é preciso perquirir quais competências de execução permanecem na órbita dos Estados-membros por força do artigo $25, \S 1^{\circ}, \mathrm{CF} / 88 .{ }^{605}$ Representaria mesmo

posicionamento esposado por Victor Nunes não pode persistir, tendo em vista que esta constituição não mais restringe a competência residual a todas as competências não atribuídas expressa ou implicitamente a outros entes federativos. Retornaremos a esta interessante questão no sexto capítulo da tese.

603 ALMEIDA. Competências na Constituição de 1988, p. 128.

${ }^{604}$ Este, aliás, é o posicionamento defendido em FERRAZ. União, estado e município na nova Constituição, p. 72.

${ }^{605}$ As competências financeiras não compõem o objeto do presente estudo comparativo, razão pela qual não serão analisadas. Quanto às competências administrativas, concorda-se com as ponderações de Fernanda Dias Menezes de ALMEIDA, no sentido de que a Administração dos Estados sofre o influxo de uma série de disposições constitucionais, às quais acabam por restringir a autonomia estadual no âmbito de sua 
este dispositivo constitucional apenas uma autorização para que os Estados-membros organizem a sua própria administração e os seus próprios serviços dentro das estritas balizas delineadas pela Constituição Federal de 1988, como sugere Fernanda Dias Menezes de ALMEIDA, ou seria possível conferir ao $\$ 1^{\circ}$ do artigo $25 \mathrm{CF} / 88$ o caráter de uma regra geral, capaz de conferir uma leitura específica acerca do sistema brasileiro de repartição de competências como um todo? Apesar de o primeiro destes posicionamentos ser o mais alardeado pela doutrina brasileira, acredita-se que o segundo deles também não é desprovido de fundamento. Retornaremos ao tema com a devida profundidade no tópico 6.2.2 desta tese. Por ora, prossegue-se com o esforço de compreensão da repartição de competências legislativas e de execução no Brasil.

Antes, contudo, cumpre fazer uma breve menção ao artigo $25, \S 3^{\circ} \mathrm{CF} / 88$, segundo a qual "os Estados poderão, mediante lei complementar, instituir regiões metropolitanas, aglomerações urbanas e microrregiões, constituídas por agrupamentos de municípios limítrofes, para integrar a organização, o planejamento e a execução de funções públicas de interesse comum". Esta foi, com efeito, a única competência legislativa expressa que os Estados receberam, à título privativo, da União com a promulgação da Constituição Federal de 1988, como ressalta Fernanda Dias Menezes de ALMEIDA. ${ }^{606}$ Uma vez que a região metropolitana e afins se destinam a promover um exercício conjunto de competências, inclusive dos Municípios nela abrangidos, também se posterga a sua análise para o sétimo capítulo desta tese. Por ora, parte-se para o último tópico desta parte dedicada exclusivamente ao estudo da repartição de competências legislativas e de execução promovida pela Constituição Federal de 1988, com a análise das competências do Município.

\subsection{A COMPETÊNCIA DOS MUNICÍPIOS (ARTIGO 30)}

A competência dos Municípios vem enunciada no artigo $30 \mathrm{CF} / 88$ em nove incisos, que agregam competências privativas e concorrentes e competências legislativas, de execução e tributárias. ${ }^{607}$ As competências tributárias não serão objeto de considerações neste tópico, em virtude da delimitação exposta na introdução desta tese. Com isso, a análise se concentrará nas competências para "legislar sobre assuntos de interesse local" (artigo 30,

competência privativa de execução (Competências na Constituição de 1988, pp. 126-127). Contudo, este é um fenômeno que também se aplica à União e aos Municípios, tendo em vista que estas previsões constitucionais também se aplicam às suas respectivas administrações

${ }^{606}$ ALMEIDA. Competências na Constituição de 1988, p. 127.

${ }^{607}$ Neste mesmo sentido, ALMEIDA. Competências na Constituição de 1988, p. 116. 
I, CF/88) e para “organizar e prestar, diretamente ou sob regime de concessão ou permissão, os serviços públicos de interesse local” (artigo 30, V, CF/88), que são as que mais interessam à presente tese. No item 2.1.3 ponderou-se como a autonomia municipal foi tradicionalmente assegurada no que dizia respeito ao seu peculiar interesse e se desdobrava, conforme as sucessivas constituições brasileiras: (i) na eletividade do Prefeito; (ii) na arrecadação de tributos de sua competência, e; (iii) na prestação de serviços de sua competência. A partir da Constituição de 1988, contudo, essa "cláusula do interesse local" deixou de qualificar a autonomia municipal e passou a delimitar duas competências do Município, o que gerou uma série de dificuldades. ${ }^{608}$ Não se pode afirmar, contudo, que a fórmula empregada pelo legislador constituinte é o resultado de um equívoco. Ao contrário, quando se debruça sobre os trabalhos da Assembleia Nacional Constituinte de 1987/1988 percebe-se que até o término dos trabalhos da Subcomissão dos Municípios e Regiões prevaleceu uma redação que discriminava em termos relativamente precisos os serviços a serem prestados pelos entes locais, como se depreende da análise do inciso I do artigo $9^{\circ}$ do seu Anteprojeto:

"§ $1^{\circ}$ - As atribuições dos Municípios poderão variar segundo as particularidades locais, sendo, entretanto, de sua competência exclusiva os serviços e atividades que digam respeito ao seu peculiar interesse, tais como:

I - prestação dos seguintes serviços públicos:

a) abastecimento de água potável e esgotos sanitários;

b) transportes coletivos urbanos e intramunicipais;

c) mercados, feiras e matadouros;

d) distribuição de gás natural ou obtido por processo técnico;

e) construção e conservação de estradas vicinais;

f) cemitérios e serviços funerários;

g) iluminação pública;

h) prevenção de acidentes naturais;

i) atenção primária de saúde;

j) limpeza urbana" 609

A competência legislativa do Município, por sua vez, já se estendia aos "assuntos de interesse local", sendo a fórmula que prevaleceu com a promulgação da Constituição de

\footnotetext{
608 Exatamente por isso acreditamos que não seja possível transpor com alguma facilidade os posicionamentos doutrinários acerca do conteúdo do interesse local elaborados sob a égide das constituições anteriores. Embora tanto a Constituição Federal de 1988 quanto as constituições anteriores façam referência a um interesse que é peculiar ou de titularidade do Município, deve-se reconhecer que a função que esta referência desempenha atualmente difere sensivelmente de outrora. Reconhecemos, contudo, que este é um entendimento minoritário. Para uma breve exposição do entendimento majoritário sobre o assunto - inclusive acerca do sentido e do alcance do peculiar interesse sob a égide da Constituição Federal de 1967-1969 e a sua recepção pela Constituição Federal de 1988 - vide ALMEIDA. Competências na Constituição de 1988, pp. 114116.

609 Assembleia Nacional Constituinte. Subcomissão dos Municípios e Regiões: Anteprojeto. Disponível em: http://www.camara.gov.br/internet/constituicao20anos/DocumentosAvulsos/vol-99.pdf.

Acesso: 13/12/2014.
} 
1988; porém, era possível definir os seus contornos a partir do rol de serviços de interesse local, de caráter exclusivo, transcrito supra. Como anota Celina SOUZA, no âmbito da Comissão de Organização do Estado, tal lista de serviços que "seriam de competência do município 'para que o cidadão saiba a quem cobrar a realização do serviço público, mesmo correndo o risco de ser muito detalhe para uma constituição" encontrou fortes objeções, de forma que prevaleceu a "necessidade de deixar flexível a alocação de funções entre os níveis de governo em um sistema federal" ${ }^{610}$, o que se deu, em relação aos Municípios, justamente por meio do manejo desta "cláusula do interesse local". 611

Porém, o conteúdo desta cláusula de fato tem se demonstrado questão das mais tormentosas. Arrisca-se afirmar que se está, com efeito, diante do problema de mais difícil solução no sistema brasileiro de repartição de competências legislativas e de execução, rivalizando com a definição da extensão da legislação das normas gerais da União nos termos do artigo $24, \S 1^{\circ}, \mathrm{CF} / 88$. Não obstante isso, acredita-se que uma solução para este impasse deve ser ao mesmo tentada neste momento da exposição, não só porque se está diante do cerne da competência legislativa e da competência de execução do Município, mas sobretudo porque os incisos $\mathrm{I}$ e $\mathrm{V}$ do artigo $30 \mathrm{CF} / 88$ apresentam interfaces importantes com competências dos Estados-membros.

Principiemos esta análise pela correspondência, ainda que parcial, entre o interesse local do Município e o princípio da predominância do interesse, que, conforme JOSÉ AFONSO da Silva norteia a repartição de competências em um Estado

Federal e, "segundo o qual à União caberão aquelas matérias e questões de predominante interesse geral, nacional, ao passo que aos Estados tocarão as matérias e assuntos de predominante interesse regional, e aos Municípios concernem os assuntos de interesse local". ${ }^{612}$ É de se ressaltar que este é um princípio manejado, em tese, somente pelo legislador constituinte no momento em que este elabora as regras constitucionais sobre a distribuição de competências, pois as competências, quando postas em um texto constitucional, costumam ser enunciadas em termos razoavelmente definidos, com menção a matérias ou atividades que são da atribuição de um ou outro ente. O intérprete do direito,

\footnotetext{
610 SOUZA. Federalismo e Descentralização na Constituição de 1988, p. 523. A opção por uma fórmula variável em função das inúmeras particularidades dos Municípios em detrimento de um catálogo fixo de serviços que seriam considerados de interesse local do Município também é abordada em Andreas J. KRELL. Diferenças do conceito, desenvolvimento e conteúdo da autonomia municipal na Alemanha e no Brasil. Revista de Informação Legislativa, Brasília, a. 32, n. 128, out./dez. 1995, p. 122.

${ }^{611}$ A análise dos artigos 30, I e V, CF/88 à luz dos anteprojetos forjados nas subcomissões e comissões da Assembleia Nacional Constituinte de 1987/1988 também é por nós empreendida em ZAGO. O interesse local do Município, pp. 190-191.

612 JOSÉ AFONSO. Curso de Direito Constitucional Positivo, p. 478.
} 
por sua vez, pode se valer deste princípio somente para melhor compreender a repartição de competências posta em uma Constituição. Nesse sentido é que se pode afirmar que a competência para legislar sobre "sistema monetário e de medidas, títulos e garantias dos metais" (artigo 22, VI, CF/88) foi atribuída à União porque corresponde a um interesse predominantemente geral da federação brasileira.

Entretanto, no que tange à competência do Município, o legislador constituinte optou simplesmente por enunciar um desdobramento deste princípio, deixando a definição dos seus possíveis conteúdos ao intérprete da Constituição. Em outras palavras, é como se ele tivesse manejado o referido princípio somente para fixar a competência da União e dos Estados-membros, mas deixado a competência dos Municípios a ser preenchida em um momento posterior, segundo a evolução e as necessidades da estrutura federativa brasileira. Esta situação de indefinição, por sua vez, não pode obscurecer o fato de que a competência, em um Estado Federal, tem a função precípua de delimitar a atuação dos entes federativos e exatamente por isso, o interesse local deve ser interpretado no sentido de se deliminar a competência do Município. Neste contexto, surge a importante questão de saber quem são os legitimados a fazê-lo. ${ }^{613}$ Parece-nos, em primeiro lugar, que se deve franquear aos Municípios a possibilidade de definir o interesse local, pois são os titulares desta competência ${ }^{614}$. Também o Supremo Tribunal Federal é um intérprete legítimo deste interesse municipal, na qualidade de intérprete final da Constituição Federal de 1988, e sobre esta possibilidade também não pairam maiores dúvidas. E aos Estados-membros: a eles também deve ser permitido opinar sobre o alcance desta competência municipal?

No tópico anterior se teve a oportunidade de ressaltar como a ascensão do Município à categoria de ente federativo retirou dos Estados-membros competências privativas

\footnotetext{
${ }^{613}$ A discussão sobre os possíveis sentidos do interesse local e os atores legitimados a interpretá-lo é por nós desenvolvida em termos similares, porém não coextensivos, em ZAGO. O interesse local do Município, pp. 177199.

614 É o que se extrai, por exemplo, das ponderações de ALMEIDA. Competências na Constituição de 1988, p. 119 na parte em que esta autora menciona que a competência para legislar sobre interesse local não é "enumerada na própria Constituição e que deverá conhecer maior detalhamento nas leis de organização municipal”, e também de Martonio Mont'Alverne Barreto LIMA. Artigo 30. In: J. J. Gomes CANOTILHO, Gilmar Ferreira MENDES, Ingo Wolfgang SARLET, Lenio Luiz STRECK, Léo Ferreira LEONCY (Coord.). Comentários à Constituição do Brasil. São Paulo: Saraiva/Almedina, 2013, p. 787. Pondera este segundo autor no trecho supracitado que "entendeu a jurisprudência do Supremo Tribunal Federal que a competência a que se referem os incisos I e II do art. 30 da Constituição Federal traduzem o sentido de que, neste âmbito, a atividade legislativa municipal submete-se aos ditames das leis orgânicas municipais, que por sua vez acham-se submetidas às Constituições Federal e Estadual respectiva. Assim, a espécie normativa municipal não poderá ir aonde não foram legislação federal, estadual, no limite de suas competências". Note-se, portanto, que o instrumento jurídico por meio do qual o Município dirá quais são os temas inseridos no seu interesse local é a sua lei orgânica, a qual deve obedecer ao disposto na Constituição Federal e na Constituição Estadual, conforme artigo $29 \mathrm{CF} / 88$.
} 
importantes. Como anota Fernanda Dias Menezes de ALMEIDA, com a promulgação da Constituição de 1988, os Estados perderam a competência de criar distritos, agora atribuída ao Município pelo artigo 30, IV, e também a competência "de legislar sobre a organização municipal, passando a Lei Orgânica dos Municípios a ser elaborada pelas Câmaras de Vereadores" 15 , sendo que esta última constitui uma importante competência estadual em uma perspectiva comparada. Complementando este raciocínio, pode-se afirmar que, a depender do sentido que se empreste à expressão "interesse local", os Estados podem perder outras competências importantes, por um motivo bem simples. As competências inscritas no artigo 30, I e V, CF/88 são competências privativas, vale dizer, competências que são exercidas com exclusão das demais esferas de governo. A indefinição que lhes é característica, por sua vez, deve-se ao interesse local, o qual pode ser delimitado de vários modos, inclusive em detrimento da autonomia estadual. Esta é uma conclusão que se extrai não só do fato de a atuação destes entes ser remanescente ou residual, mas principalmente porque a interface primeira do interesse municipal, de índole local, é o interesse estadual, de índole eminentemente regional. É como se houvesse uma tensão entre competências dos Estados e dos Municípios, cuja solução permanecesse em constante transformação. De qualquer modo, como sempre está em jogo a autonomia estadual, nada mais recomendável que eles sejam intérpretes legítimos da chamada "cláusula do interesse local”, ainda que não sejam os únicos.

No âmbito da doutrina nacional são poucos que efetivamente discutem os meios pelos quais os Estados podem concretizar esta participação. Andreas J. KRELL pondera, por exemplo, que

\footnotetext{
"também ficou difícil, no sistema da Carta de 1988, entender o papel das Constituições estaduais em relação aos municípios, 'visto que os entes locais acham os parâmetros e limites definidores da sua autonomia diretamente na Carta Federal, sobrando, portanto, pouco espaço para o estado cuidar do município. Mesmo assim, poderíamos atribuir aos textos estaduais, que tratam das competências municipais, o seguinte significado: onde a Carta estadual declara os municípios a serem competentes para determinadas tarefas, o próprio estado reconhece, de maneira indireta, que tais funções - salvo raras exceções - não são de interesse predominantemente regional (estadual) e que, portanto, estão os municípios facultados e 'exortados' a editar suas próprias legislações nessas áreas, podendo incluí-los, desde o início, nas suas Leis Orgânicas municipais.”616
}

Concorda-se com esta proposição, e acredita-se que ela seria, aliás, uma forma adequada de franquear aos Estados a possibilidade de influir na delimitação do interesse

\footnotetext{
${ }^{615}$ ALMEIDA. Competências na Constituição de 1988, pp. 127-128.

616 KRELL. Diferenças do conceito, desenvolvimento e conteúdo da autonomia municipal, p. 123. Ressaltandose apenas que, no entender deste autor, o Município não deve ser único intérprete do interesse local, sendo esta uma tarefa que deve ser compartilhada com os Estados-membros.
} 
local do Município. Infelizmente, como observa o próprio KRELL ${ }^{617}$, não prevaleceu o teor do $\S 4^{\circ}$ do artigo $9^{\circ}$ do Anteprojeto da Subcomissão dos Municípios e Regiões, que permitia aos Estados definir "as particularidades locais, para efeito da variação a que se refere o $\S$ $1^{\circ}$ ”, de forma que resta aos Estados-membros apenas esta via indireta. Por óbvio, poderão surgir excessos no caso concreto, mas estes poderão ser apreciados e, conforme o caso, corrigidos pelo Supremo Tribunal Federal, inclusive pela via do controle abstrato. ${ }^{618}$

Outra questão importante consiste em como “preencher” este interesse do Município com competências e serviços que lhe sejam privativos. Neste ponto, é de se reconhecer que a Constituição não contém nenhuma orientação explícita nesse sentido, a não ser que o transporte coletivo está incluído no conceito de serviço público de interesse local e que "tem caráter essencial". Porém, o confronto dos incisos I e V do artigo $30 \mathrm{CF} / 88$ e destes com o histórico de sua elaboração pela Assembleia Nacional Constituinte pode fornecer pelo menos dois subsídios importantes.

Em primeiro lugar, deve-se decidir se os incisos do artigo 30 CF/88 relacionamse ou não em termos de correspondência. Caso se afirme esta correspondência - o que faz algum sentido, já que a expressão "interesse local" é utilizada apenas duas vezes pela Constituição Federal de 1988, justamente para delimitar as competências inscritas nos incisos I e V do artigo $30 \mathrm{CF} / 88$ - há duas consequências importantes a serem observadas. Primeiro: porque a competência para legislar sobre assuntos de interesse local corresponde

\footnotetext{
${ }^{617}$ KRELL. Diferenças do conceito, desenvolvimento e conteúdo da autonomia municipal, p. 122.

${ }^{618} \mathrm{Na}$ jurisprudência do Supremo Tribunal Federal é possível encontrar um caso interessante, que diz respeito justamente à delimitação do interesse local por uma constituição estadual. Trata-se da ADI 2077/MC, por meio da qual se impugnava - entre outros dispositivos - os artigos 59, V da Constituição do Estado da Bahia, o qual dispunha que "cabe ao Município, além das competências previstas na Constituição Federal: (...) organizar e prestar os serviços públicos de interesse local, assim considerados aqueles cuja execução tenha início e conclusão no seu limite territorial, e que seja realizado, quando for o caso, exclusivamente com seus recursos naturais, incluindo o transporte coletivo, que tem caráter emergencial". Os Ministros entenderam que este artigo impunha uma limitação indevida à autonomia municipal, ao circunscrever os assuntos de interesses locais a questões resolvidas inteiramente no âmbito do território do Município. Nesse sentido, entendeu o Ministro Ilmar Galvão em seu voto, no que foi acompanhado pelos demais Ministros, que "trata-se de dispositivos que, desenganadamente, tiveram o efeito de limitar a autonomia municipal, no que concerne à organização e prestação de serviços públicos de interesse local, ao restringir o conceito de interesse da espécie em que se baseia a competência municipal, à hipóteses de serviços 'cuja execução tenha início e conclusão no seu limite territorial, e que seja realizado..., exclusivamente, com seus recursos naturais'. Afastou-se a possibilidade de o Município, por via de instrumentos jurídicos de larga utilização pelas pessoas de direito público, como o convênio, organizar serviços públicos gerados ou concluídos fora de seu território ou que demandem a utilização de recursos naturais de outros Municípios, do próprio Estado ou, mesmo, da União, restrição que não se contém na Carta da República" (ADI 2077 MC, Relator Min. Ilmar Galvão, Relator para o Acórdão Ministro Joaquim Barbosa, Tribunal Pleno, julgado em 06/03/2013, p. 8). Note-se que esta não consiste na proposta formulada por Andreas KRELL, que sugere que as constituições estaduais incluam assuntos e serviços no interesse local do Município, e não restrinjam este conceito por meio de previsões como a da constituição baiana.
} 
à competência para prestar os serviços de interesse local, é de se admitir que aos Municípios não é permitido legislar sobre serviços que não sejam de interesse local. Nesse sentido, as Câmaras Municipais não poderiam, por exemplo, legislar sobre serviços que são prestados direta e primordialmente pelos Estados-membros ou pela União, como o transporte intermunicipal ou os correios. Segundo: os Municípios não podem prestar, ao menos não com base na cláusula do interesse local, serviços sobre os quais não possam exercer sua competência legislativa. Por este motivo, não é permitido ao Município criar Ofícios de Registro Público municipais, uma vez que ele é englobado pela competência legislativa da União (artigo 22, XXV, CF/88) e dos Estados-membros (artigo 236, § 1º, CF/88 e artigo 25, $\left.\S 1^{\mathrm{o}}, \mathrm{CF} / 88\right)$.

Por óbvio, este é um entendimento restritivo das competências inscritas no artigo 30, I e $\mathrm{V}, \mathrm{CF} / 88$; porém, ele não conduz necessariamente a uma limitação expressiva da capacidade de legislar dos Municípios. Afinal, os entes locais ainda detêm competência legislativa suplementar nos termos do artigo 30, II, CF/88. E embora o dispositivo em questão não faça nenhuma referência ao artigo $24 \mathrm{CF} / 88$, associá-los faz todo o sentido: afinal, de acordo com o artigo 30, II, CF/88 a legislação do Município deverá suplementar as legislações federal e estadual, do mesmo modo como a legislação dos Estados suplementa a legislação federal de normas gerais conforme o $\S 2^{\circ}$ do artigo $24 \mathrm{CF} / 88$. Ou seja, o inciso II do artigo $30 \mathrm{CF} / 88$ atribui aos Municípios competência legislativa concorrente que se estende sobre as matérias arroladas nos incisos do artigo $24 \mathrm{CF} / 88^{619}$, o que certamente confere um espaço de atuação relevante.

Também é possível partir de uma não-correspondência entre os incisos I e $\mathrm{V}$ do artigo $30 \mathrm{CF} / 88$. Afinal, quando se constata que as competências legislativas da União são mais numerosas e extensas que as suas competências de execução, deve-se reconhecer forçosamente que Estados e Municípios também são executores de leis federais. Quais serviços serão executados pelos Estados e quais serviços serão executados pelos Municípios são questões resolvidas a partir da correta interpretação dos artigos $25, \S 1^{\circ}$ e 30, V, CF/88. Retornaremos a esta importante questão no tópico 6.2.2, partindo-se agora para o segundo

\footnotetext{
${ }^{619}$ Nesse mesmo sentido, ALMEIDA. Competências na Constituição de 1988, p. 156. Em sentido contrário, Manoel Gonçalves FERREIRA FILHO. Comentários á Constitutição Brasileira de 1988. Volume 1: Arts. 10 a 43. São Paulo: Saraiva, 1990, p. 219. Note-se que este último autor, no referido trecho, não sustenta que os Municípios não poderiam atuar de modo alguns nas áreas contempladas pelo artigo 24 CF/88. Ocorre que o Município poderia apenas "regulamentar as normas legislativas federais ou estaduais, para ajustar sua execução a peculiaridades locais. Destarte, aqui, a competência não seria propriamente legislativa, mas administrativa: a competência de regulamentar leis".
} 
subsídio para a compreensão do conteúdo do interesse local, que é o mais controverso, sem sombra de dúvidas.

Do histórico de elaboração e aprovação dos incisos I e V do artigo 30 CF/88 - mais especificamente, pelo fato de uma enumeração dos serviços de interesse local ter sido substituída por uma redação mais genérica, a fim de conferir uma maior maleabilidade e adaptabilidade às transformações históricas - decorre que o interesse local é um conceito que deve se adaptar às peculiaridades sociais, econômicas, administrativas e financeiras dos entes locais, sendo esta uma conclusão que se extrai do histórico da elaboração e aprovação dos incisos I e V do artigo 30 CF/88. Como se teve a oportunidade de analisar no item 2.1.3, os Municípios brasileiros são muito díspares entre si. E embora não exista nada na Constituição que imponha um tratamento diferenciado aos diferentes Municípios, também não existe nada que vede esta diferenciação, desde que consentânea com o princípio da igualdade em sua vertente material, o que necessariamente envolve um juízo de proporcionalidade. Afinal, existe uma série de disparidades que devem ser levadas em consideração na hora de definir as responsabilidades dos governos municipais, sob pena de sujeitar os cidadãos com serviços públicos de péssima qualidade ou mesmo com a simples omissão na sua prestação. Não se pode pretender que um Município sem qualquer capacidade técnica e administrativa preste os mesmos serviços que cidades como São Paulo, Salvador ou Porto Alegre colocam à disposição de seus cidadãos. Por outro lado, não se deve privar estas grandes cidades de competências para legislar sobre assuntos e prestar serviços que afetem sensivelmente a população que nelas vivem, quando não atribuídas expressamente à União ou ao respectivo Estado-membro. Em outras palavras, a cláusula do interesse local deve restringir o escopo de atuação do Município, quando as suas particularidades prejudiquem a fruição de políticas públicas por parte dos seus cidadãos, e deve embasar políticas públicas mais audaciosas àqueles entes locais que podem efetivamente implementá-las. ${ }^{620}$

\footnotetext{
${ }^{620}$ Não se pode deixar de reconhecer que o que se propõe aqui é justamente uma assimetria constitucional, a qual consiste, conforme Ronald L. WATTS "nas diferenças no status ou nos poderes legislativos e executivos atribuídos às diferentes unidades regionais" (Comparing Federal Systems, p. 127). Neste ponto faz-se menção especificamente à terceira espécie de assimetria constitucional apontada por WATTS, a qual se caracteriza, nos dizeres deste autor, pelo fato de existir uma "constituição formalmente simétrica em dar a todos os Estados-membros a mesma jurisdição, mas inclui previsões que permitem que os Estados-membros optem, em certos casos, por aderir ou não a estas atribuições. Estas previsões possibilitam governos a assumir o pleno exercício de sua autonomia em diferentes velocidades. Arranjos assim preservam a aplicação simétrica formal da distribuição de poderes a todos os Estados-membros, mas proporcionam meios específicos para acomodar dentro desta estrutura uma assimetria de fato entre Estados-membros no exercício destes poderes" (Comparing Federal Systems, p. 128).
} 
Admite-se que este entendimento não corresponde à jurisprudência dominante no

\title{
Supremo Tribunal Federal. Ao se analisar os julgados desta corte, percebe-se que eles
} tendem a emprestar ao interesse local uma interpretação uniformizante, a fim de englobar todos os Municípios brasileiros independentemente das suas particularidades locais. Nesse sentido, é de se ressaltar o teor das Súmulas 419 e 645, que autorizam as Câmaras Municipais a regular o horário de funcionamento do comércio local ${ }^{621}$, mas também e principalmente o entendimento esposado na ADI $1842^{622}$, que reconheceu ao Município a competência para o serviço de saneamento básico, ainda que a sua prestação seja dotada de particularidades que normalmente transbordam o território e as possibilidades municipais. Nesse sentido, o seguinte trecho do voto do Ministro Gilmar MENDES:

\begin{abstract}
"Não há dúvida quanto à complexidade e à importância da prestação de serviços de saneamento básico.

Por um lado, as próprias circunstâncias naturais e o elevado custo para a adequada prestação do serviço público e, principalmente, para a instalação e manutenção da infra-estrutura necessária - como canais e tubos em paralelo para amplo abastecimento de água e recolhimento de esgoto, estruturas de drenagem de águas pluviais, estações de tratamento etc. - demandam expressivos aportes financeiros, além de condições técnicas, que nem sempre estão ao alcance da maioria dos municípios brasileiros.

Além disso, o serviço de saneamento básico constitui monopólio natural, pois os custos fixos de implantação e manutenção do sistema são tão elevados que uma única fornecedora pode atender a toda demanda com custo menor que múltiplas fornecedoras (...)

Assim, a configuração de monopólio natural revela não só ser inexequível o estabelecimento de concorrência na prestação de serviço de saneamento básico, como também indica que a reunião da demanda de municípios limítrofes pode reduzir custos e tornar o serviço mais atrativo para concessionários privados.

Notoriamente, poucos são os municípios que por si sós têm condições de atender adequadamente à função pública de saneamento básico. Normalmente, o próprio acesso aos recursos hídricos depende da instituição das redes de abastecimento entre diversos municípios." ${ }^{.623}$
\end{abstract}

\footnotetext{
${ }^{621}$ Prevê a Súmula 419 STF que "os Municípios têm competência para regular o horário do comércio local, desde que não infrinjam leis estaduais ou federais válidas". Já a Súmula 645 STF dispõe que "é competente o Município para fixar o horário de funcionamento de estabelecimento comercial". O Município também é competente, segundo entendimento consolidado nesta corte, para legislar sobre conforto, segurança e rapidez aos usuários de serviços bancários (nesse sentido, vide Al 768666 AgR, Relator Ministro Roberto Barroso, Primeira Turma, julgado em 26/11/2013). Embora o STF fundamente este entendimento no interesse local, parece-nos que o que fundamenta a atuação municipal nestes casos é a competência suplementar para legislar sobre direito econômico e sobre produção e consumo, nos termos do artigo 24, I e V c/c artigo 30, II, CF/88).

622 Há ainda outras duas ADIs importantes para a compreensão do posicionamento do STF em matéria de saneamento básico: a ADI 1841 e a ADI 2077. A ADI 2077 foi objeto de breves considerações na nota de rodapé no 618. Já a ADI 1841 será tratada no item 7.3.3, que versa sobre regiões metropolitanas

623 Voto do Ministro Gilmar Mendes da ADI no 1842, Rel. Ministro Maurício Corrêa (Relator para o acordão Ministro Luiz Fux), Tribunal Pleno, julgada em 13/09/2013, pp. 170-171
} 
O Ministro Nelson Jobim também faz referências às peculiaridades da prestação do saneamento básico no seu extenso voto, em que ele aborda o histórico desta política pública, levando ainda alguns dados importantes à apreciação dos seus pares:

\footnotetext{
"Nesse último caso, é muito comum que se integrem sistemas de abastecimento de água ou que adutoras tragam água de outras bacias próximas.

É, mais uma vez, o caso da REGIÃO METROPOLITANA DO RIO DE JANEIRO.

A água vem, basicamente (83\%), do Rio Paraíba do Sul e do Rio Piraí. É armazenada em reservatórios localizados nos municípios de PIRAÍ e RIO CLARO - municípios que não fazem parte da REGIÃO METROPOLITANA na configuração da LC 87/97. É distribuída a partir do SISTEMA GRANDU, localizado no Município de NOVA IGUAÇU - município fundador da região metropolitana.

O abastecimento de água na região é completado a partir do SISTEMA PRODUTOR ACARI (um conjunto de pequenas captadoras localizadas no norte da região) e do SISTEMA LARANJAL, localizado em SÃO GONÇALO.

A REGIÃO METROPOLITANA DO RIO DE JANEIRO é exemplo típico de transposição de bacia hidrográfica adjacente para um região geográfica que não oferece oferta de água suficiente.

Outro exemplo contundente é SÃO PAULO, maior região metropolitana do Brasil, com 17,8 milhões de pessoas.

A demanda por água é muito maior do que suporta sua bacia mais próxima (Bacia do Alto Tietê).

Tal demanda faz com que metade da água ofertada tenha que vir do SISTEMA CANTAREIRA (48,7\%), a partir de 6 barragens na BACIA dos rios PIRACIBABA, CAPIVARI e JUNDIAÍ, localizado no limite com o Estado de Minas Gerais." ${ }^{624}$
}

Contudo, tanto o Ministro Gilmar Mendes quanto o Ministro Nelson Jobim entendem que a solução para este impasse consiste no agrupamento de Municípios em regiões metropolitanas, aglomerações urbanas, microrregiões ou até mesmo em consórcios públicos. O Ministro Nelson Jobim se posiciona inclusive no sentido de que "a delimitação política das fronteiras de uma REGIÃO, AGLOMERADO OU MICRORREGIÃO deverá, necessariamente, respeitar a lógica da distribuição das bacias hidrográficas dentro de cada ESTADO sob risco de inviabilização na prestação do serviço de abastecimento de água" "625. Com a devida vênia, se o saneamento básico é uma política pública que normalmente transcende as capacidades técnicas e econômicas de um Município, e que é prestada, ainda que por meio de concessão, majoritariamente pelos Estados-membros, não faz muito sentido reconduzi-la ao interesse local do Município. Com efeito, o que há no caso é um interesse tipicamente regional e que deveria ser titularizado pelos Estados-membros com base no artigo $25, \S 1^{\circ}, \mathrm{CF} / 88$, ao menos como regra geral. Excepcionalmente, os poucos Municípios brasileiros que estão aptos a executar a política de saneamento básico poderiam fazê-lo com base na competência inscrita no artigo $30, \mathrm{~V}, \mathrm{CF} / 88$, porque neste caso se poderia vislumbrar

\footnotetext{
${ }^{624}$ Voto do Ministro Nelson Jobim na ADI 1842, pp. 92-93.

625 Voto do Ministro Nelson Jobim na ADI 1842, p. 91.
} 
um interesse local predominante. De um modo ou de outro, o que se afigura mais criticável no posicionamento do STF, no nosso sentir, é equiparar os Municípios brasileiros no momento de lhe atribuir competências com base no disposto no artigo 30, I e V, CF/88. Com isso, a Corte perde uma oportunidade de utilizar a noção de interesse local, historicamente situada e adaptável às disparidades municipais, para forjar um arranjo competencial mais adequado a este cenário de diversidade.

\section{QUINTO CAPÍTULO - A REPARTIÇÃO DE COMPETÊNCIAS LEGISLATIVAS E DE EXECUÇÃO NA ALEMANHA: QUADRO GERAL}

Depois de se debruçar sobre as principais questões que cercam a repartição de competências legislativas e de execução no Brasil, é chegado o momento de analisar o sistema alemão de repartição de competências, em especial os artigos 70 a 72, 75, 83 a 86, 91a e 91b GG, que concentram o cerne das disposições constitucionais a esse respeito. Antes, é importante retomar algumas características marcantes da federação alemã analisadas no item 2.2 e no terceiro capítulo desta tese, uma vez que elas são importantes para melhor compreender as discussões doutrinárias e jurisprudenciais expostas a seguir.

Em primeiro lugar, a Lei Fundamental de 1949 trabalha deliberadamente com as duas dicotomias que norteiam o presente estudo comparativo de um ponto de vista teórico. As competências legislativas, por um lado, subdividem-se em privativas e concorrentes e concentram-se nos artigos 70 a 75 GG (lembrando que o artigo 75 GG foi revogado em 2006). Já as competências de execução - que serão denominadas neste capítulo preferencialmente de competências administrativas, tendo em vista que é esta a terminologia utilizada pela doutrina constitucional alemã - são reguladas pelos artigos $83 \mathrm{GG}$ e seguintes e subdividem-se em competências privativas da União e dos Estados-membros. Uma administração mista - vale dizer, uma estrutura em que a administração estadual encontrese subordinada ao corpo burocrático federal, ou mesmo que suponha alguma forma de trabalho conjunto entre órgãos federais e estaduais, para falar com Peter BADURA ${ }^{626}$, não é admitida pela Lei Fundamental, a não ser nas hipóteses por ela determinadas, segundo entendimento mais tradicional.

Note-se que esta forma de estruturar a repartição de competências na federação alemã é antiga e remonta pelo menos à Constituição Imperial de 1871, passando pela Constituição de Weimar, como já se teve a oportunidade de analisar. No entanto, é a partir de 1949 que

${ }^{626}$ BADURA. Staatsrecht, p. 686. 
tal opção é conduzida em termos mais técnicos, ainda que não tenham logrado evitar o processo de centralização federativa que ocorreu neste país sobretudo a partir da década de 1960.

Aliás, centralização é um dado que, na Alemanha, encontra estreita correspondência com a cooperação e a interdependência política. Com efeito, a Lei Fundamental não só distingue entre competências legislativas e de execução, como atribui as primeiras em grande parte ao Bund e as segundas primordialmente aos Länder. Este dado, por sua vez, confere uma especial conformação às relações federativas alemãs, precisamente porque a execução de leis federais depende substancialmente da colaboração e da cooperação das entidades estaduais. Ao fazê-lo, as administrações estaduais devem se conformar em maior ou menor medida aos preceitos administrativos gerais editados pela União, sendo que estes últimos devem, em regra, ser aprovados pelo Conselho Federal (Bundesrat), como forma de garantir o respeito aos interesses e à autonomia dos Länder.

Todas estas informações serão destrinchadas com as devidas nuanças dogmáticas nos itens a seguir. Por ora, cumpre apenas ter em mente duas relações que ajudarão a compreender o sistema alemão de repartição de competências sob uma perspectiva global: (i) a cooperação federativa alemã tem como um dos seus fatores explicativos a especial conformação de competências legislativas e de execução; (ii) a centralização que se observa sobretudo no plano normativo, mas também presente no plano administrativo, tem como contraponto - embora não se trate propriamente de uma compensação - a participação da instância representativa dos Länder no Poder Legislativo Federal, por meio da aprovação das leis e atos administrativos que são submetidos à sua apreciação.

Em segundo lugar, é importante colocar o tema da distribuição de competências na federação alemã em uma perspectiva histórica. Afinal, trata-se de tema que foi objeto de algumas reformas constitucionais importantes ao longo dos mais de 60 anos de vigência da Lei Fundamental de 1949. Contudo, não se pretende abrir neste capítulo um item específico que contemple esta evolução, mesmo tal análise já foi empreendida no item 2.2.2. Não se descarta menção a esta evolução constitucional nos tópicos a seguir, como um modo de tornar a exposição mais clara.

Em terceiro e último lugar, tal como no tópico dedicado ao estudo da partilha de competências no Brasil, não se tem a pretensão de esgotar todas as discussões que estes dispositivos constitucionais estudados a seguir suscitam, mas apenas abordar os pontos que efetivamente acrescentam algo em uma comparação com os artigos 20 a 25 e 30 CF/88. Para 
maiores esclarecimentos sobre cada competência contida nos dispositivos analisados, também se remete à leitura da literatura pertinente. ${ }^{627}$

\subsection{Regra geral em matéria de REPARTIÇÃO dE COMPETÊNCIAS LEGISLATIVAS (ARTIGO 70)}

Feitas estas considerações introdutórias, parte-se para o estudo da distribuição das competências legislativas e administrativas na federação alemã, a começar pelo artigo 70 GG. Uma leitura mais superficial deste dispositivo constitucional pode conduzir à errônea impressão de que ele consagra somente uma competência residual dos Länder, tal como faz o artigo $25, \S 1^{\circ}, \mathrm{CF} / 88$, segundo o entendimento majoritário. Todavia, quando se analisa com maior atenção o seu teor, percebe-se que o artigo 70 GG consagra, a bem da verdade, duas regras gerais em matéria de repartição de competências legislativas: (i) os Estados têm o direito de legislar, à medida que a Lei Fundamental não confira à União competências legislativas (artigo 70 I GG), e; (ii) a delimitação de competências legislativas entre União e Estados rege-se pelos preceitos da Lei Fundamental sobre legislação privativa e concorrente (artigo 70 II GG) ${ }^{628}$ Concentremos a exposição na primeira destas normas, mesmo porque é ela quem costuma ser qualificada de regra fundamental (Grundregel) pela doutrina alemã que se debruça sobre o tema. ${ }^{629}$ Para tanto, é importante atentar para os seus possíveis significados para a repartição de competências, sob uma perspectiva geral, e também para a autonomia dos Estados-membros alemães, a partir de um prisma particular. Esta é, por sua vez, uma análise que pode ser bem estruturada a partir de duas considerações mais gerais sobre as possíveis funções desempenhadas pelo artigo 70 I GG.

\footnotetext{
627 Em especial, recomenda-se a leitura dos comentários à Lei Fundamental de 1949 citados a seguir. Como alguns dos dispositivos analisados foram alterados ao longo dos mais de 60 anos de vigência da Lei Fundamental de 1949, é importante consultar diferentes edições destes comentários. Comentários sobre o artigo 75 GG, por exemplo, são encontrados somente em edições anteriores a 2006.

${ }^{628}$ Ou seja, trata-se de um assunto que deve ser regulamentado por norma constitucional, não havendo que se falar em atribuição de um poder de legislar por meio de legislação infraconstitucional. Note-se que, nos termos do artigo 71 GG, é possível se cogitar que um Poder Legislativo estadual seja autorizado a legislar sobre assunto submetido à competência privativa da União. Contudo, esta autorização não possui o condão de atribuir uma competência que era do Bund, por disposição constitucional, a um Land, mesmo porque isto significaria um verdadeiro deslocamento de competência de uma esfera federativa para outra, o que é vedado pela ordem constitucional alemã. Para maiores detalhes, vide o tópico 5.2 desta tese.

629 Nesse sentido, BADURA. Staatsrecht, p. 629, Jochen ROZEK. Artikel 70. In: Hermann von MANGOLDT, Friedrich KLEIN, Christian STARCK (Hrgs). Kommentare zum Grundgesetz. Band II: Artikel 20-82. 6a Ed. Munique: Franz Vahlen, 2010, pp. 1804-1805 e Christoph DEGENHART. Artikel 70 [Gesetzgebung des Bundes und der Länder]. In: Michael SACHS (Hrsg). Grundgesetz - Kommentar. 7ạ Ed. Munique: C. H. Beck, 2014, pp. 1489 e ss.
} 
Por um lado, a despeito de se qualificar o artigo 70 I GG como regra geral em matéria de repartição de competências legislativas, é de se admitir que possui um caráter especializante em comparação com a regra contida no artigo 30 GG, segundo o qual "o exercício de poderes e tarefas estatais compete aos Estados, à medida que esta Lei Fundamental não edite ou permita outra regulamentação". Note-se como este último dispositivo fala em poderes (Befugnisse) e tarefas estatais (staatliche Aufgaben) e não em competência (Zuständigkeit ou Kompetenz), como faz os artigos 70 GG e seguintes. Ao comentar esta diferença na terminologia empregada, Rupert STETTNER considera que poderes seriam sinônimos de competências, sendo que ambos se colocam como meio à realização das tarefas estatais. ${ }^{630}$ Já Bodo PIEROTH entende que poderes remeteriam ao meio que autoriza a intervenção do Estado na liberdade e na propriedade, ao passo que tarefas estatais corresponderiam às áreas de atuação material do Estado, sendo que ambos poderiam ser reconduzidos ao conceito de competência. ${ }^{631}$ Seja como for, é de se reconhecer que o artigo 30 GG promove uma repartição de atribuições em um nível mais amplo que o artigo $70 \mathrm{GG}$, uma vez que parece contemplar não só poderes e deveres de agir da União e dos Estados-membros, mas também as próprias áreas em que esta atuação pode se dar. O artigo 70 I GG, portanto, coloca-se como regra geral apenas em relação à partilha e distribuição de competências legislativas. Para a repartição de competências administrativas, como ainda se analisará nesta tese, vige outra regra geral, com outra ratio.

Por outro lado, o artigo 70 I GG também funciona como uma competência residual. Exatamente por isso, as competências que ele atribui aos Länder devem ser determinadas, tal como ocorre com o artigo $25, \S 1^{\circ}, \mathrm{CF} / 88$, por meio de um raciocínio de exclusão. ${ }^{632}$ Ou seja, primeiro deve-se determinar quais competências são atribuídas à União para só então precisar quais matérias recaem na competência privativa estadual. Neste ponto, é de se ressaltar uma imprecisão técnica do dispositivo constitucional em comento. Com efeito, ele prevê que os Estados serão competentes "à medida que esta Lei Fundamental não confira à União poderes legislativos". Porém, é de se admitir que não é sempre que a atribuição de uma competência à União pela constituição tem o condão de subtrair automaticamente a competência legislativa estadual. Nesse sentido, observa Jochen ROZEK que

\footnotetext{
${ }^{630}$ Rupert STTETNER. Artikel 70. In: Horst DREIER (Hrg). Grundgesetz - Kommentar. Band II: Artikel 20-82. 2a Ed. Tübingen: Mohr Siebeck, 2006, pp. 1.558.

631 Hans D. JARASS, Bodo PIEROTH. Grundgesetz für die Bundesrepublik Deutschland: Kommentar. 12a Ed. Munique: C. H. Beck, 2012, p. 642.

632 Nesse mesmo sentido, ROZEK. Artikel 70. In: von MANGOLDT, KLEIN, STARCK (Hrsg.). Kommentare zum Grundgesetz, p. 1805.
} 


\begin{abstract}
"somente no campo da competência legislativa privativa do Bund a Lei Fundamental determina uma outra regulamentação no sentido do artigo 30 (artigo 71), segundo o qual os Länder são excluídos tão somente pela previsão da competência federal, e não por meio da lei federal editada com base neste fundamento. Por outro lado, para o campo da legislação concorrente (Art. 72) a Lei Fundamental permite apenas, nos termos do artigo 30, uma outra regulamentação: leis federais podem suprimir leis estaduais."633
\end{abstract}

Seja como for, o fato de a competência estadual ser precisada depois de identificadas e excluídas as competências federais suscita a importante questão de como interpretar a norma constitucional que atribui competência legislativa ao Bund. Ao se analisar questão parecida no item 4.1.5 desta tese, dedicado ao estudo da competência privativa do Estado-membro sob a égide da Constituição Federal de 1988, não se teceram maiores considerações sobre o tema, mesmo porque ele não costuma suscitar maiores celeumas entre a doutrina brasileira. Ao contrário, no Brasil parece ser óbvia a afirmação de que uma competência pertence à União e, por isso, não se pode permitir ao Estado determinada atuação em um caso concreto, ainda que não se saiba ao certo qual o conteúdo da lei federal e como ele pode ser subsumido à competência do ente federal. Entretanto, é possível na doutrina alemã encontrar algumas proposições interessantes sobre a interpretação da norma competencial e sobre o que se costuma denominar de qualificação competencial de uma lei (kompetenzrechtliche Qualifikation eines Gesetzes), muito embora não se perceba ainda um consenso sobre questões fundamentais. Este assunto será retomado com todos os seus principais desdobramentos no item 7.1. Por ora, prossegue-se a exposição com principais contornos da competência inscrita no artigo 70 I GG, com a análise das competências não-escritas.

Com efeito, quando se tem em mente a competência federal que deve ser excluída a fim de que de se possa aferir o conteúdo do artigo 70 I GG, deve-se levar em consideração que ela pode ser escrita ou não escrita. ${ }^{634} \mathrm{~A}$ competência escrita concentrase sobretudo nos artigos 73 e 74 GG, que contêm o rol de poderes privativos do Bund e concorrentes entre Bund e Länder. Entretanto, é possível encontrar outras previsões esparsas

\footnotetext{
${ }^{633}$ ROZEK. Artikel 70. In: von MANGOLDT, KLEIN, STARCK (Hrsg.). Kommentare zum Grundgesetz, p. 1809. No original: „Nur für den Bereich der ausschließlichen Gesetzgebungszuständigkeit des Bundes trifft das Grundgesetz i.S.d. Art. 30 eine andere Regelung (Art. 71), nach welcher die Länder schon durch die Bundeszuständigkeit selbst, nicht erst durch das auf ihrer Grundlage ergangene Bundesgesetz ausgeschlossen sind. Für den Bereich der konkurrierenden Gesetzgebung (Art. 72) lässt das Grundgesetz i.S.d. Art. 30 dagegen lediglich eine andere Regelung zu: Bundesgesetze können Landesgesetze verdrängen."

${ }^{634}$ Como se teve a oportunidade de expor no item 1.5., competências escritas e não escritas correspondem a uma tipologia redacional, na acepção trabalhada por Josef ISENSEE, que leva em consideração o fato de a competência encontrar previsão expressa ou não no texto da constituição. Note-se que, mesmo no caso de a competência ser do tipo não escrita, isso não significa que se trate de uma norma sem qualquer lastro constitucional, como se terá a oportunidade de analisar a seguir.
} 
na Lei Fundamental, quando esta prevê, por exemplo, que determinado assunto deve ser regulado por lei federal, consagrando uma competência privativa ao ente federal. ${ }^{635}$ Já a competência não escrita, conforme doutrina e jurisprudência alemãs, pode ser de três tipos: (i) competência não escrita por força da natureza da coisa (ungeschriebene Kompetenz kraft Natur der Sache); (ii) competência não escrita por força de conexão fática (ungeschriebene Kompetenz kraft Sachzusammenhangs), e; (iii) competência anexa (Annexkompetenz).

A primeira modalidade de competência não escrita surge, como o próprio nome sugere, quando se está diante de uma matéria cuja regulamentação só pode se dar, pela sua própria natureza, por meio de lei federal. Ou seja, trata-se de uma modalidade que serve essencialmente para fundamentar uma competência privativa da União, como sugere Jochen ROZEK, em casos em que a própria matéria regulada torna inviável uma regulamentação por parte dos Estados-membros. ${ }^{636}$ É o que acontece, por exemplo, com os símbolos e feriados nacionais e com a determinação da sede dos órgãos constitucionais do Bund, que simplesmente não poderiam ser regulamentados por lei estadual porque dizem respeito à própria representação e organização do ente federal. ${ }^{637}$

Deve-se ressaltar que a competência por força da natureza da coisa, embora não se apresente em uma relação de dependência com um título competencial específico - como ocorre com as demais modalidades de competência não escrita analisadas a seguir - deve necessariamente encontrar respaldo na Lei Fundamental de 1949. A necessidade de uma legislação federal não deve se fundamentar, portanto, unicamente em considerações supralegais ${ }^{638}$ ou práticas, ou mesmo em detrimento de previsão constitucional expressa que assegure a competência dos Estados-membros em um caso concreto. A questão é saber como encontrar este necessário ponto de contato com a constituição alemã: como ressalta Rupert STETTNER, "existe um amplo consenso sobre as competências por força da natureza da

\footnotetext{
635 Para uma visão geral das diversas competências federais espalhadas pelo texto da Lei Fundamental de 1949, vide ROZEK. Artikel 70. In: von MANGOLDT, KLEIN, STARCK (Hrsg.). Kommentare zum Grundgesetz, pp. 18261827.

${ }^{636}$ ROZEK. Artikel 70. In: von MANGOLDT, KLEIN, STARCK (Hrsg.). Kommentare zum Grundgesetz, p. 1828.

637 Estes são, aliás, os exemplos mais citados pelos comentadores da Lei Fundamental de 1949, entre eles: RENGELING. § 135 - Gesetzgebungszuständigkeit. In: ISENSEE, KIRCHHOF (Hrsg.). Handbuch des Staatsrechts, p. 601, ROZEK. Artikel 70. In: von MANGOLDT, KLEIN, STARCK (Hrsg.). Kommentare zum Grundgesetz, pp. 18291830 e DEGENHART. Artikel 70. In: SACHS (Hsrg.). Grundgesetz, p. 1498.

${ }^{638}$ Como ressalta Hans-Werner RENGELING, "de acordo com opinião difundida, as chamadas competências não-escritas por força da natureza da coisa devem ser determinadas a partir do sentido total da Lei Fundamental, da estrutura federativa por ela cunhada ou da analogia a um artigo competecial individual, portanto, por meio de uma interpretação no sentido mais amplo, e não a partir de um direito suprapositivo, efetivamente não escrito (RENGELING. § 135 - Gesetzgebungszuständigkeit. In: ISENSEE, KIRCHHOF (Hrsg.). Handbuch des Staatsrechts, p. 600).
} 
coisa, no entanto menos sobre a sua fundamentação jurídico-teorética do que sobre a sua existência e grupos de casos". ${ }^{639}$ Parece prevalecer o entendimento de que esta é uma modalidade competencial que se extrai tanto de uma interpretação sistemática da Lei Fundamental de 1949 quanto do princípio federativo. Como ressalta Jochen ROZEK, a natureza da coisa surge um "argumento de evidência", que nada mais é do um "abreviativo para o resultado de uma interpretação sistemática da Lei Fundamental sob os auspícios do Estado Federal. Por isso, uma competência legislativa do Bund por força da natureza da coisa só pode ser aceita, caso a necessidade de regulamentação nacional por meio do Bund colocarse na própria Lei Fundamental com suficiente evidência". 640

Já a competência for força de conexão fática possui contornos substancialmente distintos. Nesta modalidade existe uma matéria cuja legislação compete expressamente à União ou aos Estados-membros. Porém, não é possível fazer uso desta competência sem regulamentar também outras matérias, em relação às quais o ente federativo em questão não está legitimado a atuar. Em outras palavras, há uma conexão fática entre a matéria prevista pela norma competencial e outra matéria não abrangida pela competência legislativa do ente federativo, conferindo-lhe poderes para legislar inclusive sobre os temas aos quais ele originalmente não era competente. De acordo com Tribunal Constitucional Federal alemão, não basta que esta conexão se dê em termos de uma mera conveniência acerca de uma regulamentação conjunta das matérias; ao contrário, é necessário que "uma matéria expressamente atribuída ao Bund não possa ser regulamentada de modo razoável, sem que ao mesmo tempo uma outra matéria não atribuída expressamente seja regulamentada conjuntamente, quando, portanto, uma invasão nesta matéria não expressamente prevista representar uma pressuposto para a regulamentação de uma matéria atribuída à legislação federal." ${ }^{641}$ Conforme ressalta Rupert STETTNER, o contexto fático necessário ao

\footnotetext{
${ }^{639}$ STETTNER. Artikel 70. In: DREIER (Hrsg.). Grundgesetz, p. 1578. No original: “Weitgehender Konsens herrscht über die Kompetenzen kraft Natur der Sache, allerdings weniger über ihre rechtstheoretische Begründung als über Existenz und Fallgruppen".

${ }^{640}$ ROZEK. Artikel 70. In: von MANGOLDT, KLEIN, STARCK (Hrsg.). Kommentare zum Grundgesetz, p. 1829. No original: "sie ist ebenso wie die 'Begriffsnotwendigkeit' - als Evidenzargument - lediglich Abbreviativ für das Ergebnis einer systematischen Auslegung des Grundgesetzes unter bundesstaatlichen Vorzeichen. Eine Gesetzgebungskompetenz des Bundes kraft Natur der Sache kann daher nur dann angenommen werden, wenn das Erfordernis einer gesamtstaatlichen Regelung gerade durch den Bund im Grundgesetz selbst mit hinreichender Evidenz angelegt ist".

${ }^{641}$ BVerfGE 3, 407 (421). No original: "Soviel steht jedenfalls fest, dass die bloße Erwägung, es sei zweckmäßig, mit einer dem Bund ausdrücklich zugewiesenen Materie gleichzeitig auch eine verwandte Materie zu regeln, nicht zur Begründung einer Gesetzgebungszuständigkeit des Bundes ausreicht. Ein sogenannter Sachzusammenhang vermöchte vielmehr eine Zuständigkeit nur dann zu stützen, wenn eine dem Bund ausdrücklich zugewiesene Materie verständigerweise nicht geregelt werden kann, ohne dass zugleich eine nicht ausdrücklich zugewiesene andere Materie mitregelt wird, wenn also ein Übergreifen in nicht ausdrücklich
} 
reconhecimento desta competência já foi reconhecido por esta corte no direito de estabelecer taxas para autenticação judicial em procedimentos de jurisdição voluntária em relação ao direito civil, em partes do direito de radiofusão em relação aos partidos políticos e aos direitos autorais, no enquadramento da profissão de cuidador de idosos em relação às profissões da área da saúde, dentre outros exemplos. ${ }^{642}$ De todo modo, esta modalidade de competência não escrita parece fluir para o instituto da qualificação competencial da lei ${ }^{643}$, o qual será objeto de maiores considerações no item 7.1.2 desta tese.

Note-se que esta modalidade acresce competências tanto à esfera federal quanto à esfera estadual ${ }^{644}$, ao contrário do que ocorre na competência por força da natureza da coisa. Além do mais, trata-se de uma competência acessória, de acordo com a tipologia elaborada por Josef ISENSEE e exposta no item 1.5.4 desta tese, uma vez que está sempre ancorada em uma outra norma competencial expressa, que é complementada por esta outra regra não escrita. Exatamente por isso, a invasão na matéria em relação ao qual o ente federativo não está legitimado a atuar deve ser pontual e restringir-se ao necessário para possibilitar a regulamentação da matéria prevista expressamente como sujeita à legislação pelo referido ente.

A competência anexa, que é a terceira modalidade de competência não escrita, também possui este viés de acessoriedade e é muito parecida com a competência por força de conexão fática, principalmente no que tange aos seus pressupostos ${ }^{645}$, a ponto de ser tratada em conjunto com ela tanto pela doutrina quanto pela jurisprudência alemã. De um ponto de vista conceitual, contudo, é possível vislumbrar uma distinção no fato de a competência anexa ser relacionada aos "estágios de preparação e execução da implementação de regulamentações materiais" e colocar-se, quanto à competência escrita cuja implementação se provê, em uma relação de "conexão funcional e insolúvel"646.

\footnotetext{
zugewiesene Materien unerlässliche Voraussetzung ist für die Regelung einer der Bundesgesetzgebung zugewiesenen Materie."

642 STETTNER. Artikel 70. In: DREIR (Hrsg.). Grundgesetz, p. 1582.

${ }^{643}$ STETTNER. Artikel 70. In: DREIER (Hrsg.). Grundgesetz, p. 1581.

${ }^{644}$ Conforme RENGELING. § 135 - Gesetzgebungszuständigkeit. In: ISENSEE, KIRCHHOF (Hrsg.). Handbuch des Staatsrechts, p. 600 e STETTNER. Artikel 70. In: DREIER (Hrsg.). Grundgesetz, p. 1581.

${ }^{645}$ Conforme RENGELING. § 135 - Gesetzgebungszuständigkeit. In: ISENSEE, KIRCHHOF (Hrsg.). Handbuch des Staatsrechts, p. 599

${ }^{646}$ ROZEK. Artikel 70. In: von MANGOLDT, KLEIN, STARCK (Hrsg.). Kommentare zum Grundgesetz, p. 1834. Como ressalta este autor neste mesmo trecho, o poder de polícia e as medidas policias, desde que relacionadas às matérias atribuídas ao Bund são consideradas de sua competência anexa. Porém, quando o poder de polícia e o direito de polícia e a segurança pública são regulamentadas de forma autônoma, elas recaem na competência legislativa dos Estados.
} 
Finalmente e encerrando o raciocínio de exclusão necessário para se precisar o real conteúdo do artigo 70 I GG, tem-se que, a despeito de seu texto garantir uma proeminência dos Estados, o volume e a extensão das competências federais fazem com que na prática o papel de destaque seja assumido pelo Bund. Ou seja, também na Alemanha se verifica uma forte centralização legislativa.

Todavia, aos Länder ainda compete legislar privativamente sobre algumas matérias importantes com base no artigo $70 \mathrm{I}$, ao contrário do que ocorre no Brasil, onde praticamente só se consegue vislumbrar legislação estadual em matéria de competência concorrente. Nesse sentido, pode-se afirmar que os poderes legislativos estaduais alemães são competentes tradicionalmente para legislar sobre direito municipal, polícias e segurança pública, educação e o que se convenciona chamar neste país de direito de radiofusão. ${ }^{647}$ Com a Reforma do Federalismo de 2006, novas matérias foram acrescidas à competência privativa estadual, como, por exemplo, a competência para execução penal, para determinar o horário de fechamento do comércio (Ladenschlussrecht) e a competência para dispor sobre a remuneração e a pensão dos servidores públicos estaduais. ${ }^{648}$

\subsection{A COMPETÊNCIA LEGISLATIVA PRIVATIVA DA UNIÃO (ARTIGO 71)}

O artigo 71 GG trata, como o próprio título deste tópico sugere, da competência legislativa privativa da União. Contudo, nele não se encontrarão as matérias efetivamente abrangidas pela competência legislativa federal, mas somente normas que disciplinam o seu exercício. Quem deseja verificar “o quê” efetivamente compete com exclusividade à União deve atentar para os números do artigo $73 \mathrm{GG}$, que contemplam alguns temas importantes, como é o caso do "tráfego aéreo" (artigo 73 I Nr. 6 GG), dos "correios e telecomunicação" (artigo 73 I Nr. 7 GG), e a "produção e a utilização da energia atômica para fins pacíficos" (artigo 73 I Nr. 14 GG). ${ }^{649}$ Existem ainda outras normas esparsas na Lei

\footnotetext{
647 BADURA. Staatsrecht, p. 631.

648 Para uma exposição de todas as competências legislativas dos Estados-membros, inclusive aquelas acrescidas pela Reforma do Federalismo de 2006, vide RENGELING. $\S 135$ - Gesetzgebungszuständigkeit. In: ISENSEE, KIRCHHOF (Hrsg.). Handbuch des Staatsrechts, pp. 723 e ss.

649 De um modo geral, pode-se afirmar que o artigo 73 GG prevê uma lista parecida com aquela contida no artigo 22 CF/88, com dois grandes diferenciais: (i) a Constituição Federal de 1988 neste ponto confere à União competência para legislar sobre muitos ramos do Direito, sendo que na Lei Fundamental estes encontram-se submetidos à competência legislativa concorrente da União e dos Estados-membros, e; (ii) a constituição alemã contempla muitos títulos competenciais ligados à instrução e investigação criminal - como a competência para legislar sobre "a defesa contra perigos do terrorismo internacional por meio dos órgãos da polícia criminal federal" (artigo 73 (1) Nr. 9a), sobre o trabalho conjunto da União e dos Estados em matéria de polícia criminal" (artigo 73 (1) Nr10 a) GG), além da competência para legislar sobre armas e explosivos
} 
Fundamental que conferem o tratamento legislativo de determinada matéria de forma privativa ao Bund. Algumas o fazem por meio da atribuição ao ente federal de uma competência legislativa privativa propriamente dita; porém, a maioria remete a regulamentação de um tema específico à lei federal, extraindo-se desta previsão uma competência exclusiva pela via da interpretação. ${ }^{650}$

Não consiste em um objetivo da presente tese - como já se teve a oportunidade de ressaltar em mais de uma passagem - analisar cada título competencial, cada matéria submetida à legislação privativa do Bund, mas sim as regras que disciplinam o exercício destas competências. Exatamente por isso elegeu-se o artigo 71 GG e não o artigo 73 GG para ser objeto de maiores aprofundamentos a seguir, o que será feito a partir de três observações.

Em primeiro lugar, é corrente a afirmação de o dispositivo em questão conteria uma definição legal da competência legislativa privativa do Bund. ${ }^{651} \mathrm{Com}$ efeito, ao dispor que "na área da competência privativa da União os Estados terão o poder de legislar se e à medida que eles são expressamente autorizados por uma lei federal", o artigo 71 GG também deixa claro que a competência privativa é aquela em que os Estados-membros, em tese, não estão autorizados a legislar. Excepcionalmente, se houver uma autorização e nos termos desta autorização, os Estados poderão editar legislação sobre uma ou algumas questões específicas atribuídas privativamente à União. ${ }^{652}$

No âmbito da doutrina alemã fala-se muito em um efeito de barreira (Sperrwirkung), que é bem definido por Markus HEINTZEN nos seguintes termos:

"Efeito de barreira é um conceito da dogmática do Estado Federal, por trás do qual está um princípio de todo direito competencial estatal: o princípio da exclusividade das atribuições de competência. Cada alocação de competência desencadeia um

(artigo 73 (1) Nr. 12 GG), os quais não são disciplinados de um modo tão detalhado pela constituição brasileira, muito embora a União também detenha competências importantes nesta seara.

650 Markus HEINTZEN. Artikel 71. In: Hermann von MANGOLDT, Friedrich KLEIN, Christian STARCK (Hrgs). Kommentare zum Grundgesetz. Band II: Artikel 20-82. 6a Ed. Munique: Franz Vahlen, 2010, p. 1850. É de se ressaltar ainda as competências não escritas da União por força da natureza da coisa, que são necessariamente privativas, e as competências por força do contexto fático, que podem ser tanto privativas quanto concorrentes.

${ }^{651}$ Nesse sentido, RENGELING. § 135 - Gesetzgebungszuständigkeit. In: ISENSEE, KIRCHHOF (Hrsg.). Handbuch des Staatsrechts, p. 602; HEINTZEN. Artikel 71. In: von MANGOLDT, KLEIN, STARCK (Hrsg.). Kommentare zum Grundgesetz, p. 1846; JARASS, PIEROTH. Grundgesetz, p. 805.

652 Nesse sentido, Hans-Werner RENGELING afirma que o artigo 71 GG possui uma dupla função: em primeiro lugar, consiste em uma definição legal da competência legislativa privativa; em segundo lugar, contempla uma exceção à regra geral (RENGELING. § 135 - Gesetzgebungszuständigkeit. In: ISENSEE, KIRCHHOF (Hrsg.). Handbuch des Staatsrechts, p. 602). Já Markus HEINTZEN entende que o artigo 71 GG contém quatro proposições, sendo três de conteúdo normativo e a última de conteúdo declaratório, embora atribua pouco significado ao dispositivo mencionado. Para maiores detalhes, vide HEINTZEN. Artikel 71. In: von MANGOLDT, KLEIN, STARCK (Hrsg.). Kommentare zum Grundgesetz, p. 1846. 
efeito de barreira para aquelas unidades organizacionais do Estado que não são destinatárias dela. A sua atuação é proibida, mesmo a repetição do conteúdo da atividade do detentor da competência." 653

Embora tal expressão soe um tanto estranha aos juristas brasileiros, ela exprime nada mais do que uma decorrência da própria ideia de competência. Afinal, conforme já se ressaltou no item 1.4. desta tese, a competência consiste em uma norma que inclui, mas que também exclui. Por um lado, ela atribui um poder a um destinatário específico, legitimandoo a atuar em relação a uma matéria também determinada. Por outro lado, ela exclui potenciais destinatários e possíveis matérias que também poderiam ter sido contempladas por esta mesma norma. Em outras palavras, enquanto que para uns (vale dizer, para os seus destinatários) a competência tem o condão de uma autorização, para outros (isto é, para os outros que poderiam ser destinatários da norma competencial, mas não o são) ela significa uma proibição de atuar, ou um efeito de barreira para utilizar a expressão empregada pelos autores alemães.

O grande diferencial da competência privativa é que nela o efeito de barreira é produzido pela própria norma constitucional. Ou seja, basta a atribuição de uma competência específica, no caso ao Bund, para que os Estados-membros fiquem proibidos de atuar em relação à matéria por ela contemplada. ${ }^{654}$ Estes últimos não se tornam competentes diante da inércia da União, ainda que se esteja diante de uma omissão prejudicial aos interesses estaduais e dos cidadãos. Nesse sentido, os autores alemães costumam frisar que a Lei Fundamental, por meio de uma competência legislativa, confere a um ente federativo apenas uma faculdade de atuar, não uma obrigação. No caso de uma competência privativa - e, em especial, uma competência privativa do Bund - a mera concessão desta faculdade pela constituição já tem o condão de proibir a atuação por parte dos Länder, ao contrário do que ocorre com a competência legislativa concorrente. Nesta última, é necessário que a União efetivamente faça uso da sua competência e edite uma lei para que se possa falar em um efeito de barreira em relação aos Estados-membros.

\footnotetext{
653 HEINTZEN. Artikel 71. In: von MANGOLDT, KLEIN, STARCK (Hrsg.). Kommentare zum Grundgesetz, p. 1852. No original: "Sperrwirkung ist ein Begriff der Bundesstaatsdogmatik, hinter dem ein Grundsatz allen staatlichen Kompetenzrechts steht: der Grundsatz der Ausschließlichkeit von Kompetenzzuweisungen. Jede Kompetenzzuweisung entfaltet Sperrwirkung für diejenigen Organisationseinheiten des Staates, an die sie nicht adressiert ist. Verboten ist deren Tätigwerden, auch inhaltsgleiche Wiederholung von Aktivitäten des Kompetenzinhabers".

654 Nesse sentido, HEINTZEN. Artikel 71. In: von MANGOLDT, KLEIN, STARCK (Hrsg.). Kommentare zum Grundgesetz, p. 1852; RENGELING. § 135 - Gesetzgebungszuständigkeit. In: ISENSEE, KIRCHHOF (Hrsg.). Handbuch des Staatsrechts, p. 603; Rupert STETTNER. Artikel 71. In: Horst DREIER (Hrg). Grundgesetz Kommentar. Band II: Artikel 20-82. 2a Ed. Tübingen: Mohr Siebeck, 2006, p. 1592; JARASS, PIEROTH. Grundgesetz, p. 806.
} 
Em segundo lugar e como uma consequência do que foi exposto, a previsão de uma competência em termos privativos ao ente federal tem o condão de tornar nula qualquer legislação estadual sobre o tema. Contudo, como bem ressalta Rupert STETTNER, tal efeito é neutralizado na hipótese de haver uma autorização nos termos do artigo 71 GG, a qual deve se dar por lei federal nos termos do referido artigo. ${ }^{655}$ Nesta hipótese, os Estados-membros tornam-se legitimados a legislar em matéria de competência legislativa do Bund; contudo, não há propriamente uma transferência de competência por meio de lei federal, o que se afigura absolutamente vedado pela Lei Fundamental de 1949.

Nos termos do artigo 71 GG, esta autorização deve se dar por lei federal - vale dizer, ela deve constar de uma lei formal do Bund, a qual deve fixar a extensão da atuação do Estado-membro ${ }^{656}$ - e deve ser dirigida ao Poder Legislativo estadual. Tal ponderação é importante para diferenciar o permissivo contido no artigo 71 GG da possibilidade de delegação legislativa prevista no artigo $80 \mathrm{GG}$, uma vez que se está diante de institutos submetidos a regimes jurídicos distintos. O artigo 80 I GG, por um lado, dispõe que "por meio de lei o governo federal, um ministro federal ou o governo estadual podem ser autorizados a editar regulamentos. O conteúdo, a finalidade e a extensão da autorização conferida devem ser definidos em lei”. Embora se utilize a expressão regulamento, é de se admitir que o instituto em questão está mais próximo de uma lei delegada prevista no artigo $68 \mathrm{CF} / 88$, tendo em vista que há no caso uma delegação de poderes legislativos. Fiquemos, contudo, com a tradução mais corrente do termo. O que deve ser ressaltado é que a delegação do artigo 80 GG é dirigida ao Poder Executivo, tanto federal quanto estadual, e deve ser delimitada quanto ao seu conteúdo, finalidade e extensão. A Rechtsverordnung, ou o regulamento que é o produto desta delegação, é um ato do Poder Executivo, muito embora possa se revestir de uma lei estadual nos termos do artigo 80 V GG. Já a delegação contida no artigo 71 GG, por outro lado, compreende o poder de edição de uma lei em sentido formal pelo Poder Legislativo Estadual, o qual possui uma margem razoável de atuação, considerando que ele não se encontra adstrito a disposições federais acerca do conteúdo, da finalidade e da extensão da delegação, como ocorre no artigo 80 GG. ${ }^{657}$

\footnotetext{
655 STETTNER. Artikel 71. In: DREIER (Hrsg.). Grundgesetz, p. 1593.

656 RENGELING. § 135 - Gesetzgebungszuständigkeit. In: ISENSEE, KIRCHHOF (Hrsg.). Handbuch des Staatsrechts. p. 604.

657 Bodo PIEROTH entende, todavia, que a autorização do artigo 71 GG tem a mesma extensão da delegação prevista no artigo $80 \mathrm{GG}$, muito embora a ela não se aplique as demais exigências contidas no artigo 80 I S 2 GG (JARASS, PIEROTH. Grundgesetz, p. 806). Já Markus HEINTZEN entende que as disposições do artigo 80 GG não podem ser aplicadas analogicamente ao artigo 71 GG (Artikel 71. In: von MANGOLDT, KLEIN, STARCK (Hrsg.). Kommentare zum Grundgesetz, p. 1859).
} 
Além do mais, como a autorização contida no artigo 71 GG tem o objetivo de obter uma diferenciação regional ${ }^{658}$, a doutrina alemã entende ela pode ser dirigida a um, alguns ou a todos os Estados da federação. Conforme observa Markus HEINTZEN,

\begin{abstract}
"Destinatádios da autorização são, de acordo com o teor do artigo 71, os Estados. Isto pode ser tanto todos quanto alguns Estados. A opinião de que a União poderia autorizar somente alguns Estados é irreconciliável com a ratio do artigo 71, porque uma necessidade de diferenciação regional pode certamente existir em âmbito federal; ela [a opinião] não é mais defendida atualmente. Conferindo a União a autorização não a todos os Estados, o tratamento desigual deve ser fundamentado pela igualdade federativa como uma característica do princípio do Estado Federal. Como exemplos de diferenciações permitidas podem ser ressaltados: os Estados com costa marítima, os Estados com fronteiras externas, os Estados que se juntaram à federação depois de 1949." ${ }^{\prime 659}$
\end{abstract}

Em qualquer destes cenários, contudo, a norma editada com base no autorizativo do artigo 71 é considerada "lei estadual" e não uma "lei federal por delegação", conforme jurisprudência do Tribunal Constitucional Federal alemão ${ }^{660}$. Nada mais óbvio, afinal, pois o que a permissão prevista no dispositivo constitucional em questão faz é remover o efeito de barreira imposto aos Estados-membros quando uma competência é atribuída privativamente à União. Ou seja, os Länder, que eram proibidos a legislar sobre uma determinada matéria, passam a ser autorizados a atuar nesse sentido. ${ }^{661}$ Note-se que se está diante de uma autorização e não de uma obrigação imposta aos poderes legislativos estaduais, que podem simplesmente quedar-se inertes no caso concreto.

No que tange às matérias que podem ser objeto da autorização, há alguma controvérsia na doutrina alemã. Alguns autores, por um lado, defendem a existência de matérias ou campos de atuação "inimigos" ao permissivo contido no artigo 71 GG

\footnotetext{
${ }^{658}$ Conforme decidiu o Tribunal Constitucional Federal alemão em BVerfGE 8, 407 (418). Segundo esta corte, "a razão para a autorização nos termos do artigo 71, segunda parte, GG, bem como aquela do artigo 80 I S 1 GG é a mesma: a necessidade ou a oportunidade de uma regulamentação material regionalmente diferenciada"

659 HEINTZEN. Artikel 71. In: von MANGOLDT, KLEIN, STARCK (Hrsg.). Kommentare zum Grundgesetz, p. 1860. No original: "Adressat der Ermächtigung sind nach dem Wortlaut von Art. 71 die Länder. Dies können entweder alle oder einzelne Länder oder ein bestimmtes Land sein. Die Ansicht, der Bund dürfte nur einzelne Länder ermächtigen, ist mit der ratio des Art. 71 unvereinbar, weil ein Bedürfnis nach regionaler Differenzierung durchaus bundesweit bestehen kann; sie wird heute nicht mehr vertreten. Erteilt der Bund die Ermächtigung nicht allen Ländern, so muss die Ungleichbehandlung sich vor dem föderalen Gleichheitssatz als Ausprägung des Bundesstaatsprinzips rechtfertigen lassen. Als Beispiele für zulässige Differenzierungen werden genannt: die Küstenländer, Länder mit Außengrenzen, Länder, die dem Bund nach 1949 beigetreten sind."

660 BVerfGE 8, 407 (415).

${ }^{661}$ É interessante ressaltar como a doutrina alemã não costuma falar propriamente de uma delegação de competência legislativa, muito embora seja possível encontrar referências a este termo na literatura pesquisada. Seja como for, o fato é que a autorização a que o artigo $71 \mathrm{GG}$ se refere tem o condão de legitimar a atuação dos Estados-membros, razão pela qual deve ser objeto de maiores esclarecimentos. Nesse sentido, vide HEINTZEN. Artikel 71. In: von MANGOLDT, KLEIN, STARCK (Hrsg.). Kommentare zum Grundgesetz, pp. 1852 e ss.
} 
(ermächtigungsfeindliche Sachgebiete), principalmente naqueles casos em que seria de se reconhecer uma competência não escrita por força da natureza da coisa. Nesse sentido, Rupert STETTNER cita como exemplos de matérias que não poderiam ser regulamentadas por lei estadual: as eleições para o parlamento federal, regulamentações pertinentes aos órgãos do Bund, o serviço militar e sistema monetário. ${ }^{662}$ Em outro sentido, Markus HEINTZEN entende que mesmo as competências por força da natureza da coisa podem ser delegadas. ${ }^{663}$ Porém, todos os autores consultados sustentam que, embora o dispositivo constitucional em apreço não contenha nenhuma restrição nesse sentido, não é possível à União autorizar os Poderes Legislativos estaduais a regulamentar a totalidade de uma matéria submetida à competência privativa federal, tendo em vista que a repartição de competências é um tema ponderado e regulado pela Lei Fundamental e não pode ser submetido a um tratamento infraconstitucional. ${ }^{664}$

Finalmente, a última observação que se deseja fazer a respeito do artigo 71 GG diz respeito à sua limitada importância prática. Afinal, poucas leis federais foram editadas com base neste dispositivo da Lei Fundamental alemã, sendo que apenas uma ainda se encontra em vigor. ${ }^{665} \mathrm{O}$ tema também foi objeto de considerações mais aprofundadas pelo Tribunal Constitucional Federal alemão apenas em uma única decisão ${ }^{666}$. Não por outro motivo, aliás, a doutrina alemã, que tão frequentemente reproduz as decisões desta corte em seus comentários à constituição, neste ponto recorre a outros autores para fundamentar o seu posicionamento.

\subsection{A COMPETÊNCIA LEGISLATIVA CONCORRENTE DA UNIÃO E DOS ESTADOS- MEMBROS (ARTIGOS 72 E 75)}

A competência legislativa concorrente entre Bund e Länder possui um longo histórico, que já foi brevemente abordado no item 2.2.1 desta tese. Sob a égide da Constituição Imperial de 1871 a União contava com competências legislativas privativas,

\footnotetext{
662 STETTNER. Artikel 71. In: DREIER (Hrsg.). Grundgesetz, p. 1594. Neste mesmo sentido JARASS, PIEROTH. Grundgesetz, p. 807.

663 HEINTZEN. Artikel 71. In: von MANGOLDT, KLEIN, STARCK (Hrsg.). Kommentare zum Grundgesetz, p. 1862.

664 RENGELING. § 135 - Gesetzgebungszuständigkeit. In: ISENSEE, KIRCHHOF (Hrsg.). Handbuch des Staatsrechts, p. 605; STETTNER. Artikel 71. In: DREIER (Hrsg.). Grundgesetz, p. 1595; HEINTZEN. Artikel 71. In: von MANGOLDT, KLEIN, STARCK (Hrsg.). Kommentare zum Grundgesetz, p. 1860.

665 Nesse sentido, vide HEINTZEN. Artikel 71 In: von MANGOLDT, KLEIN, STARCK (Hrsg.). Kommentare zum Grundgesetz, p. 1863.

666 Mais precisamente, no BVerfGE 8, 407, já citado neste tópico.
} 
expressamente designadas como tais, e também com as competências legislativas enumeradas no artigo $4^{\circ}$, em relação aos quais também era lícito aos Estados-membros legislar, segundo o entendimento predominante. Falava-se à época de uma competência facultativa da União. Já a Constituição Imperial de 1919 previa, além da competência legislativa privativa da União inscrita no artigo $6^{\circ}$, uma competência legislativa da União no seu artigo $7^{\circ}$, que não era denominada de concorrente, mas em relação a qual os Estados poderiam legislar "enquanto e à medida que o Império não fizesse uso do seu direito de legislar" (artigo 12). Além do mais, a Constituição de Weimar conferia ao ente federal a possibilidade de legislar sobre determinados temas desde que houvesse uma necessidade de editar preceitos uniformizantes nos termos do artigo $9^{\circ}$ e também de editar uma legislação de princípios nos termos do artigo 10 e $11 .{ }^{667}$

A Lei Fundamental de 1949 inova, portanto, ao falar de competências concorrentes. Note-se que a constituição fala em "concorrência" apenas em relação à competência inscrita no artigo 72, que corresponde a uma típica competência concorrente cumulativa de acordo com a tipologia exposta no item 1.5.5. Até 2006, a constituição alemã previa também uma competência-moldura (Rahmengesetzgebung) no seu artigo 75, a qual podia ser enquadrada no que a presente tese chama de competência concorrente limitada. Embora tenha a primeira modalidade maior relevância prática, foi a segunda delas que chamou a atenção de doutrinadores brasileiros à época da elaboração da Constituição Federal de 1988.

A seguir, propõe-se uma exposição das linhas gerais de cada uma das modalidades de competência legislativa concorrente previstas pela Lei Fundamental de 1949. Como ambas foram afetadas de modo substancial pelas sucessivas reformas constitucionais e também pelas alterações na jurisprudência do Tribunal Constitucional Federal em resposta a estas alterações, aproveitar-se-á o ensejo para expor de forma mais detalhadas os principais aspectos desta evolução. ${ }^{668}$

\subsubsection{A competência legislativa concorrente do artigo 72 GG}

Ao se analisar o teor do artigo 72 GG percebe-se um certo paralelismo com o artigo 71 GG, considerando-se que tanto um quanto outro dispositivo não se destinam propriamente a delimitar áreas de atuação e atribuí-las privativamente à União ou

\footnotetext{
667 Este breve histórico da competência concorrente pode ser encontrado na maioria dos comentários à Lei Fundamental, entre eles: OETER. Artikel 72. In: von MANGOLDT, KLEIN, STARCK (Hrsg.). Kommentare zum Grundgesetz, pp. 1871-1872, e; STETTNER. Artikel 72. In: DREIER (Hrsg.). Grundgesetz, pp. 1599-1600.

668 Para um panorama desta evolução legislativa, vide o tópico 2.2.2 desta tese.
} 
concorrentemente à União e Estados-membros, mas sim disciplinar o exercício de competências pela União e pelos Estados-membros. ${ }^{669}$ Ou seja, quem deseja saber "o quê" efetivamente compete ao Bund e aos Länder de forma concorrente, deve analisar o catálogo contido no artigo $74 \mathrm{GG}$, que contempla matérias como: direito civil e direito penal (Art. 74 I Nr. 1); direito do trabalho e previdência social (Art. 74 I Nr. 12); trânsito (Art. 74 I Nr. 22); aspectos jurídicos de áreas da economia como mineração, indústria, energia, comércio, bancos, bolsas de valores (Art. 74 I Nr. 11). ${ }^{670}$ Diante do volume e da importância das áreas inseridas na competência concorrente da União e dos Estados-membros, há quem afirme que esta é a modalidade de maior relevância prática ${ }^{671}$. Não sem razão, aliás: apenas para se ter uma ideia da proeminência desta modalidade de competência, basta atentar para a extensão do artigo 74 I GG, que enumera a competência concorrente do Bund e dos Länder em 33 hipóteses; já o artigo 73 I GG, que discrimina a competência privativa da União, contempla, por sua vez, apenas 14 hipóteses.

O primeiro parágrafo do artigo 72 GG, que é o único que não foi alterado de uma forma substancial desde 1949, dispõe que "na área da legislação concorrente, os Estados têm a faculdade de legislar, enquanto e à medida que a União não utilizar sua competência legislativa por meio de uma lei”. Nesta previsão encontra-se o cerne da competência concorrente, pois dela se extrai quais as possibilidades de atuação da União e dos Estadosmembros. A estes últimos é facultado legislar sobre todas as matérias sobre as quais recai esta modalidade de competência, sem qualquer limitação quanto à extensão desta regulamentação. Porém, a partir do momento em que a União faz uso da sua competência - ou seja, a partir do momento em que ela legislar sobre estas mesmas áreas, também sem qualquer limitação quanto à extensão desta regulamentação - os Estados-membros perdem a faculdade supramencionada, sendo a que regulamentação estadual eventualmente editada se torna nula. ${ }^{672}$

\footnotetext{
${ }^{669}$ Não é por outro motivo, aliás, que a doutrina alemã afirma que o artigo 72 GG seria uma "norma paralela“ (Parallelnorm) ao artigo 72 GG. Nesse sentido, vide STETTNER. Artikel 72. In: DREIER (Hrsg.). Grundgesetz, p. 1604 e OETER. Artikel 72. In: von MANGOLDT, KLEIN, STARCK (Hrsg.). Kommentare zum Grundgesetz, p. 1870

670 É de se ressaltar ainda que, do mesmo modo que ocorre com as competências legislativas privativas da União, também há competências legislativas concorrentes esparsas pelo texto da Lei Fundamental, embora em menor número. Isso ocorre porque, ao contrário do que acontece com competências do primeiro tipo, as competências privativas necessitam de expressa previsão. Nesse sentido, vide HEINTZEN. Artikel 71 In: von MANGOLDT, KLEIN, STARCK (Hrsg.). Kommentare zum Grundgesetz, p. 1850.

${ }^{671}$ Nesse sentido, STETTNER. Artikel 72. In: DREIER (Hrsg.). Grundgesetz, p. 1604.

672 JARASS, PIEROTH. Grundgesetz, p. 812 e RENGELING. § 135 - Gesetzgebungszuständigkeit. In: ISENSEE, KIRCHHOF (Hrsg.). Handbuch des Staatsrechts, p. 640.
} 
Em outras palavras, a partir do momento em que a União legisla, entra em cena o "efeito de barreira" - cujos contornos foram expostos no tópico anterior - em relação aos Estados-membros. Porém, ao contrário do que ocorre com a competência privativa, este efeito não é desencadeado pela sua simples previsão por uma norma constitucional. No caso da competência concorrente é necessário que o Bund efetivamente faça uso desta faculdade por meio de lei e o faça em termos exaustivos para que uma atuação por parte dos Länder se torne proibida. Neste ponto, há um esclarecimento importante. Caso o ente federal se limite a regular parcialmente uma matéria, então aos poderes legislativos estaduais será lícito legislar sobre o que não foi abrangido pela regulamentação federal. Porém, caso a normativa federal compreenda a totalidade de uma matéria, uma atuação por parte dos Estadosmembros será vedada, ainda que se trate de uma legislação estadual que complemente apenas a legislação federal, sem qualquer contradição a esta última. ${ }^{673}$

De um modo ou de outro, o fato é que a legislação federal tem o condão de restringir total ou parcialmente a atuação dos Estados-membros. Exatamente por isso a doutrina alemã entende que o artigo 72 GG contempla na verdade uma falsa concorrência (unechte Konkurrenz), pois ela sempre se resolve em favor da União. ${ }^{674}$ Entretanto, o fato de a atuação do Bund não conceber limites quanto à extensão da matéria regulamentada não significa que ela não esteja submetida a quaisquer condicionantes. Ao contrário, a Lei Fundamental concebe desde 1949 alguns requisitos ou pressupostos à edição de leis federais no seu artigo 72 II GG. Desde que preenchidos estes requisitos, à União é facultado legislar sobre a integralidade de matéria. Neste caso, fala-se que a legislação federal esgotou o tema, sendo

673 Cf. RENGELING. § 135 - Gesetzgebungszuständigkeit. In: ISENSEE, KIRCHHOF (Hrsg.). Handbuch des Staatsrechts, p. 637 e CALLIESS. Die Justitiabilität des Art. 72 Abs. 2 GG, p. 893. Quanto ao efeito de barreira imposto aos Estados pela edição da lei federal, cumpre fazer alguns esclarecimentos importantes. Consoante a redação originária do artigo 72 I, "na área da legislação concorrente os Estados detêm o poder de legislar, enquanto e à medida que a União não utilizar seu poder de legislar". Pelo fato de o dispositivo não fazer referência a uma lei editada pela União, mas à simples utilização de um poder de legislar, havia quem defendesse que o efeito de barreira começava a partir do momento em que a União iniciasse o processo legislativo para a aprovação da lei, muito embora não tenha sido esse o entendimento que efetivamente prevaleceu. Porém, como observa Stefan OETER, o Tribunal Constitucional Federal alemão nunca se pronunciou em termos conclusivos sobre o assunto; em alguns casos, inclusive, esta corte entendeu que o efeito de barreira deveria se iniciar antes da promulgação da lei por aplicação do princípio da lealdade federal (Artikel 72, p. 1877). A partir de 1994, o artigo 72 I GG passou a contar com a seguinte redação, que dissipou eventuais dúvidas sobre o termo a quo do efeito de barreira: "na área da legislação concorrente, os Estados têm o poder de legislar, enquanto e à medida que a União não utilizar sua competência por meio de uma lei". Esta alteração, contudo, não significou propriamente uma alteração no conteúdo do referido dispositivo, mas sim um esclarecimento, conforme OETER (Artikel 72. In: von MANGOLDT, KLEIN, STARCK (Hrsg.). Kommentare zum Grundgesetz, p. 1892).

674 Como, por exemplo, OETER. Artikel 72. In: von MANGOLDT, KLEIN, STARCK (Hrsg.). Kommentare zum Grundgesetz, p. 1868 e STETTNER. Artikel 72. In: DREIER (Hrsg.). Grundgesetz, p. 1603. Com a introdução da legislação de divergência (Abweichungsgesetzgebung), em 2006, este cenário se alterou um pouco, porém somente em relação a algumas matérias 
vedado aos Estados legislar de qualquer modo sobre ele. Todavia, caso não estejam presentes no caso concreto os pressupostos para a legislação federal, então a União deve manter-se inerte, franqueando aos Estados a possibilidade de legislar sobre uma determinada matéria, também sem qualquer restrição quanto ao conteúdo ou à extensão desta regulamentação.

De acordo com a redação originária do artigo 72 II GG, a União só poderia legislar “enquanto e à medida que existisse uma necessidade (Bedürfnis) de uma legislação federal, porque: (i) uma matéria não pode ser regulamentada de forma eficiente pela legislação dos Estados isoladamente; (ii) a regulamentação de uma matéria por uma lei estadual poderia prejudicar os interesses de outros Estados ou da coletividade, ou; (iii) a proteção da unidade jurídica e econômica, especialmente a salvaguarda da unidade das condições de vida no território federal além dos limites do território de um Estado a exigirem”. No que tange aos dois primeiros condicionantes, ressalta Rupert STETTNER que eles eram quase de desprovidos de significado real, tendo em vista a jurisprudência do BVerfG no sentido de que haveria a necessidade de uma lei federal não só quando o objetivo fosse preservar uma unidade jurídica, mas também quando o objetivo fosse efetivamente estabelecer esta unidade jurídica. Diante disso, o terceiro requisito (consubstanciado na proteção da unidade jurídica e econômica, especialmente a salvaguarda da unidade das condições de vida no território federal) poderia ter assumido um maior significado entre os condicionantes impostos pelo artigo 72 II GG; porém, novamente uma interpretação bem expansiva por parte do Tribunal Constitucional Federal teria praticamente mitigado o seu fator limitante. Note-se que, segundo o referido autor, o artigo 72 II Nr. 3 GG não só teria legitimado qualquer lei federal em sede de competência concorrente, como também teria funcionado como um impulso à unitarização ao prever, ao menos de acordo com uma determinada interpretação, a necessidade de se estabelecer uma igualação das condições de vida no território alemão. ${ }^{675}$

Segundo a doutrina alemã, o que efetivamente determinou um predomínio da União no que tange às competências legislativas concorrentes foi o seguinte entendimento da Corte constitucional alemã acerca do controle judicial da necessidade (Bedürfnis) da lei federal nos termos do artigo 72 II GG:

“d) Portanto era a União competente para a edição da Lei sobre anistia de acordo com o artigo 74 Nr. 1 GG.

O exame da questão, se é de se reconhecer uma necessidade no sentido do artigo 72 II GG para a edição desta lei, não é necessário para esta constatação. A questão, se uma necessidade de uma regulamentação federal existe, é uma questão discricionária obrigatória do legislador federal, a qual de acordo com a sua natureza não é justiciável e, por isso, a [sua] revisão por parte Tribunal Constitucional Federal, a princípio, é negada. Realmente os pressupostos para o

${ }^{675}$ STETTNER. Artikel 72. In: DREIER (Hrsg.). Grundgesetz, pp. 1605-1606. 
exercício do direito à legislação concorrente pela União (Art. 72 II GG) são - ao contrário do artigo $9 \mathrm{WRV}$ - descritos em detalhes. Deste modo, a liberdade discricionária do legislador federal é restringida, mas a decisão acerca da questão da necessidade permanece com a natureza de uma verdadeira decisão discricionária. A questão de até que ponto esta decisão deveria ser revisada pelo Tribunal Constitucional Federal, caso o legislador federal desconhecesse os limites impostos à sua discricionariedade ou então abusasse da discricionariedade a ele concedida, não precisa aqui de resposta alguma; por isso a constatação de um excesso ou de um exercício abusivo desta discricionariedade na edição da Lei sobre anistia padece de quaisquer fundamentos." 676

Em apertada síntese, o BVerfG entendeu que o exercício de competências concorrentes pela União e a centralização legislativa que poderia decorrer de um uso indiscriminado desta faculdade eram questões que deveriam ser resolvidas no plano político. $\mathrm{Ou}$, em outras palavras, eram questões que não poderiam ser internalizadas pelo Direito, muito embora a própria ideia de competência tenha por base a internalização de um conflito político pelo ordenamento jurídico-constitucional e a sua solução consoante critérios eminentemente jurídicos.

Enquanto perdurou, este foi um entendimento muito criticado pela doutrina alemã, não sem razão. De todo modo, considera-se relevante traçar duas considerações a seu respeito. Em primeiro lugar, embora não se possa afirmar exatamente uma influência da ordem constitucional anterior, parece-nos que a jurisprudência da corte constitucional alemã neste ponto se coloca em uma relação de continuidade em relação à República de Weimar. Como pondera Stefan OETER, sob a égide da Constituição Imperial de 1919 a necessidade que fundamentava a competência da União inscrita no artigo $9^{\circ}$ também era considerada pela maioria uma decisão discricionária do legislador, muito embora houvesse quem defendesse que se estava diante de uma questão eminentemente jurídica. ${ }^{677}$

\footnotetext{
676 BVerfGE 2, 213 (224 e ss). No original: “d) Sonach war der Bund für den Erlass des Straffheitsgesetzes nach Art. 74 Ziff $1 G G$ zuständig. Einer Prüfung der Frage, ob für den Erlass dieses Gesetzes ein Bedürfnis im Sinne des Art. 72 Abs. 2 GG anzuerkennen ist, bedarf es zu dieser Feststellung nicht. Die Frage, ob ein Bedürfnis nach bundesgesetzlicher Regelung besteht, ist eine Frage pflichtmässigen Ermessens des Bundesgesetzgebers, die ihrer Natur nach nicht justitiabel und daher der Nachprüfung durch das Bundesverfassungsgericht grundsätzlich entzogen ist. Zwar sind - im Gegensatz zu Art. 9 WRV - die Voraussetzungen für die Ausübung des Rechts zur konkurrierenden Gesetzgebung durch den Bund (Art. 72 Abs. 2 GG) im einzelnen bezeichnet. Hierdurch wird Ermessensfreiheit des Bundesgesetzgeberns eingeengt, der Entscheidung der Bedürfnisfrage bleibt jedoch der Charakter einer echten Ermessensentscheidung. Die Frage, inwieweit diese Entscheidung vom Bundesverfassungsgericht nachzuprüfen wäre, falls der Bundesgesetzgeber die seinem Ermessen gesetzten Grenzen verkannt oder das ihm eingeräumte Ermessen missbraucht hätte, bedarf hier keiner Beantwortung; denn für die Feststellung einer Überschreitung oder missbräulichen Ausübung dieses Ermessens bei Erlass des Straffreiheitsgesetzes fehlt es an jedem Anhalt". É de se ressaltar que "Straffreiheitgesetz" é uma expressão que é traduzida somente com alguma dificuldade para o português. Segundo o dicionário jurídico consultado, trata-se de uma lei compreende institutos despenalizadores, aproximando-se, em termos gerai, à ideia de extinção de punibilidade (Carl CREIFELS. Rechtsworterbuch. 17ạ Ed. Munique: C. H. Beck, 2002, p. 1302).

677 OETER. Artikel 72. In: von MANGOLDT, KLEIN, STARCK (Hrsg.). Kommentare zum Grundgesetz, p. 1873.
} 
Em segundo lugar, é de se ressaltar o papel que esta ausência de controle jurisdicional sobre a atuação legiferante da União desempenhou na unitarização da federação alemã. Não é por outro motivo, aliás, que ela foi apontada por Konrad HESSE como uma das tendências unitarizantes - ao lado da necessidade de se garantir a uniformização das condições de vida no território alemão, mesmo em áreas inseridas na competência privativa dos Estados, e do aumento da importância do Conselho Federal - que teriam informado uma mudança na própria concepção de Estado Federal sob a égide da Lei Fundamental. ${ }^{678} \mathrm{O}$ referido autor alemão falava no advento de um Estado Federal-Unitário, cujas linhas gerais foram brevemente analisadas no item 2.2.3 e retomadas no terceiro capítulo desta tese. $\mathrm{Ou}$ seja, o que se delineava a partir do supracitado entendimento do BVerfG era uma visão extremamente centralizante de federação, que encontrava respaldo político à época, mas que com o passar dos anos passou a ser considerada inadequada pelos próprios atores políticos envolvidos. ${ }^{679}$

Em 1994, ainda como uma consequência do tratado de unificação alemã, a Lei Fundamental foi reformada em alguns pontos importantes. ${ }^{600} \mathrm{O}$ artigo 72 GG teve os seus parágrafos reformulados, além de ganhar um parágrafo terceiro, em uma clara tentativa de reverter a tendência centralizadora verificada até aquele momento. Consequentemente, o seu parágrafo segundo passou a dispor que a União somente teria o direito a legislar "se e à medida que o estabelecimento de condições de vida equivalentes no território nacional ou a salvaguarda da unidade jurídica ou econômica no interesse da totalidade do Estado tornar necessária (erforderlich) uma regulamentação por lei federal”. Embora a redação apenas pareça ter concentrado o que dizia o referido dispositivo na sua redação original, a alteração promovida foi substancial. Afinal, ela atingiu dois importantes pilares do Estado FederalUnitário: (i) a necessidade de "igualação" das condições de vida - e, consequentemente, o impulso à unitarização legislativa que ela representava - foi retirada da parte da constituição que trata da repartição de competências, e substituída pela "equivalência" de condições de vida, ${ }^{681}$ (ii) a centralização legislativa, embora não fosse de fato revertida, foi ao menos barrada pela imposição dos seguintes pressupostos à atuação da União.

\footnotetext{
678 HESSE. Der unitarische Bundesstaat, pp. 14-25.

679 Para se entender como a decisão do Bundesverfassunggericht encontrou respaldo político à época, vide nossas considerações, a partir do relato de Stefan OETER, sobre o histórico legislativo do artigo 72 GG no tópico 3.2.2 desta tese.

680 Para um histórico mais detalhado das tentativas de alteração do artigo 72 GG desde a década de 70, vide OETER. Artikel 72, p. 1884 e ss. É de se ressaltar, contudo, que a maioria dos comentários à Lei Fundamental aqui citados costumam traçar tal histórico, ainda que brevemente. Para uma visão geral das alterações da Lei Fundamental, vide BADURA. Staatsrecht, pp. 51-56.

${ }^{681}$ A menção à unidade ou melhora das condições de vida continuam no artigo 91a e artigo 106 GG.
} 
Em primeiro lugar, a partir de então o Bund só poderia fazer uso da sua competência concorrente caso a legislação federal fosse necessária. Note-se que, enquanto a redação originária do artigo 72 II GG falava em uma necessidade (Bedürfnis), a nova redação também faz menção a algo que também pode ser traduzido para o português como "necessidade", mas que na verdade se trata de uma Erforderlichkeit. Esta modificação, por sua vez, trouxe consequências importantes, tendo em vista que a Erforderlichkeit consiste em parte integrante do princípio da proporcionalidade e seria pouco provável que ela tenha sido inserido no artigo 72 GG com outro significado, como bem ressalta Rupert STETTNER. ${ }^{682}$ Ao comentar esta alteração, Christian CALLIESS ponderou que, embora o princípio da proporcionalidade tenha como âmbito de aplicação preferencial os direitos fundamentais, ele poderia ser transplantado para relação entre União e Estados-membros:

\begin{abstract}
"Assim, deve ocorrer não só um exame da adequação (pergunta: a lei federal é adequada para atingir efetivamente os fins por ela almejados?) e a observância do imperativo do meio mais moderado e igualmente eficaz (pergunta: este objetivo não pode ser alcançado por meio de uma lei estadual com conteúdo parecido?), mas também pode ser efetuado, no âmbito da proporcionalidade [em sentido estrito], uma ponderação entre o ganho de uma regulamentação federal e a perda da competência federal em um contexto de federalismo competitivo." ${ }^{683}$
\end{abstract}

Todavia, o exame da necessidade (Erforderlichkeit) não eliminava o problema de definir exatamente qual o conteúdo de cada uma das finalidades do artigo 72 II GG. ${ }^{684}$ Afinal, o que deve se entender por "estabelecimento de uma equivalência das condições de vida"? Qual o sentido da expressão "salvaguarda da unidade jurídica e econômica no interesse da totalidade do Estado"? Tal tarefa coube ao Tribunal Constitucional Federal no julgamento da lei sobre cuidados aos idosos (Altenpflegegesetz) em 2002. Com efeito, a reforma constitucional de 1994 também logrou inserir um Nr. 2a ao artigo 93 I GG, de forma que a Corte passou a decidir sobre divergências de opinião acerca do preenchimento dos requisitos do artigo 72 II GG por uma lei federal, a requerimento do Conselho Federal, de

\footnotetext{
682 STTETNER. Artikel 72. In: DREIER (Hrsg.). Grundgesetz, p. 1608. No sentido de que a "Erforderlichkeit" consiste no critério da necessidade, integrante do princípio da proporcionalidade, vide Christoph DEGENHART. Artikel 72 [Konkurrierende Gesetzgebung]. In: Michael SACHS (Hrsg.). Grundgesetz - Kommentar. 7ạ Ed. Munique: C. H. Beck, 2014, p. 1519.

683 CALLIESS. Die Justitiabilität des Art. 72 Abs. 2 GG, p. 896. No original: „Daher hat nicht nur eine Prüfung der Geeignetheit (Frage: Ist das Bundesgesetz geeignet, die mit ihm verfolgten Ziele effektiv zu erreichen?) und der Beachtung des Gebots des mildesten, gleich wirksamen Mittels (Frage: Kann dies Ziel nicht gleich wirksam durch inhaltlich ähnliche Ländergesetze erreicht werden?) zu erfolgen, sondern es kann im Rahmen der Angemessenheit auch eine Abwägung zwischen dem Gewinn einer bundesrechtlichen Regelung und dem Verlust einer landesrechtlichen Kompetenz vor dem Hintergrund des kompetitiven Föderalismus vorgenommen werden".

${ }^{684}$ Ressalta Stefan OETER, com razão, que o princípio da proporcionalidade não teria o condão de concretizar os parâmetros contidos no artigo 72 ॥ GG; ao contrário, ele desempenharia a função de deixar estes parâmetros abertos a argumentos de índole fática (OETER. Artikel 72, p. 1912).
} 
um governo estadual ou do órgão de representação judicial. Ou seja, a partir de 1994 os pressupostos previstos no referido artigo também passaram a ser objeto de controle jurisdicional por disposição constitucional expressa.

No que tange à equivalência das condições de vida, o BVerfG entendeu que ela não se encontraria preenchida com a simples entrada em vigor de uma legislação federal uniforme ou quando estaria em jogo a simples melhora nestas condições. Entendeu a corte, que "ao contrário, o bem jurídico equivalência de condições de vida está ameaçado, e a União estará autorizada a agir, somente quando as condições de vida nos Estados da República Federal tiverem se desenvolvido separadamente de forma a prejudicar a estrutura social federal ou quando uma evolução deste tipo se desenha concretamente". ${ }^{685}$ Ou seja, a referida corte alemã deixou claro que nem toda diferença em um Estado Federal, ainda que ela diga respeito às condições de vida da população, deve ser considerada nociva. Ao contrário, a própria ideia de federação pressupõe alguma diversidade de regulamentações ao consistir em fórmula apta a forjar e acomodar uma "unidade na diversidade". O que não pode ser tolerado é que estas diferenças coloquem em jogo a existência da federação enquanto unidade, e é exatamente esta a hipótese contemplada pelo primeiro dos requisitos do artigo 72 II GG. ${ }^{686}$

Já a unidade jurídica restaria prejudicada - e, neste caso, uma atuação do Bund seria legítima dos termos do parágrafo segundo do artigo 72 GG - quando as diferentes regulamentações estaduais trouxessem consequências problemáticas, especialmente quando ensejassem um cenário de insegurança jurídica ou prejudicassem a movimentação de pessoas no território alemão. ${ }^{687} \mathrm{~A}$ unidade econômica, por sua vez, diria respeito à "manutenção de uma capacidade funcional da área econômica da República Federal por meio de uma regulamentação uniforme federal". E prosseguiu o BVerfG ao afirmar:

\footnotetext{
"Uma lei federal é de todo modo necessária para a criação de um território econômico e, com isso, para a garantia da unidade jurídica, quando ela deve assegurar a unidade da formação profissional ou produzir possibilidades de ingresso iguais a profissões ou ofícios em todos os Estados, independentemente de onde os grupos profissionais devem ser ordenados competencialmente (Art. 74 I GG). Realmente cada Estado pode regulamentar tal assunto - também em altos níveis profissionais - sem prejudicar os interesses de outros Estados. Diferentes requisitos de formação e de autorização no território econômico alemão podem, contudo, erguer fronteiras inoportunas, elas podem provocar uma concentração ou
}

\footnotetext{
685 BVerfGE 106, 62 (144). No original: „das bundesstaatliche Rechtsgut gleichwertiger Lebensverhältnisse ist vielmehr erst dann bedroht und der Bund erst dann zu Eingreifen ermächtigt, wenn sich die Lebensverhältnisse in den Ländern der Bundesrepublik in erheblicher, das bundesstaatliche Sozialgefüge beeinträchtigender Weise auseinander entwickelt haben oder sich eine derartige Entwicklung konkret abzeichnet".

${ }^{686}$ STETTNER. Artikel 72. In: DREIER (Hrsg.). Grundgesetz, p. 1611.

${ }^{687}$ BVerfGE 106, 62 (145-146).
} 
uma diminuição de novas gerações em determinadas regiões, elas podem prejudicar o nível da formação e, com isso, estabelecer desvantagens consideráveis para as chances da nova geração bem como para a situação profissional em todo o Estado." 688

É de se ressaltar que, nos termos da nova redação do artigo 72 II GG, tanto a unidade jurídica quanto a unidade econômica deveriam ser preservadas "no interesse da totalidade do Estado". Tal previsão, por sua vez, representou mais uma limitação à legislação concorrente da União, tendo em vista que ela vedou a edição de lei federal para a proteção do interesse de apenas alguns Estados. ${ }^{689}$

De um modo geral, percebe-se que o Tribunal Constitucional Federal delineou os pressupostos da União de uma forma bem precisa e restrita, o que certamente levou a um fortalecimento da posição dos Estados-membros. Entretanto, não se pode ir ao extremo de afirmar que este posicionamento teve o condão de reverter a centralização operada durante o período em que a Corte se manteve inerte, por uma razão bem simples. Conforme o parágrafo $3^{\circ}$ do artigo 72 GG, acrescido ao texto da Lei Fundamental em 1994 justamente para regulamentar a situação das leis federais promulgadas até aquele momento, caberia à União determinar quando uma lei federal que não mais preenchesse os requisitos do artigo 72 II GG poderia ser substituída pelo direito estadual. Ou seja, estava-se diante novamente de uma decisão discricionária do Bund, restando aos Länder atuar no sentido obter tal liberação perante o Conselho Federal, como bem ressalta Hans-Werner RENGELING. ${ }^{690}$

De todo modo, o fato é que esta nova redação do artigo 72 II GG também não agradou a todos. Afinal, havia sempre o risco de uma lei federal ser considerada inconstitucional por desobediência aos pressupostos do artigo 72 II GG, o que poderia jogar por terra todo um intenso trabalho necessário à sua aprovação. Por isso, o artigo 72 foi alterado novamente em 2006 pela chamada Reforma do Federalismo I. ${ }^{691}$ Em apertada

\footnotetext{
688 BVerfGE 106, 62 (147). No original: "Zur Schaffung eines einheitlichen Wirtschaftsgebiets und damit zur Wahrung der Wirtschaftseinheit ist ein Bundesgesetz jedenfalls dann erforderlich, wenn es die Einheitlichkeit der beruflichen Ausbildung sicherstellen oder wenn es für gleich Zugangsmöglichkeiten zu Berufen oder Gewerben in allen Ländern sorgen muss, unabhängig davon, wo die Berufsgruppe selbst kompetentiell (Art. 74. Abs. 1GG) einzuordnen ist. Zwar kann jedes Land solche Angelegenheit - auch auf hohem professionellem Niveau - regeln, ohne die Interessen der anderen Länder zu beeinträchtigen. Unterschiedliche Ausbildungs-und Zulassungsvoraussetzungen können aber im deutschen Wirtschaftsgebiet störende Grenzen aufrichten, sie können eine Ballung oder Ausdünnung des Nachwuchses in bestimmten Regionen bewirken, sie können das Niveau der Ausbildung beeinträchtigen und damit erhebliche Nachteile für die Chancen des Nachwuchses sowie die Berufssituation im Gesamtstaat begründen."

689 STETTNER. Artikel 72. In: DREIER (Hrsg.). Grundgesetz, p. 1612.

690 RENGELING. § 135 - Gesetzgebungszuständigkeit. In: ISENSEE, KIRCHHOF (Hrsg.). Handbuch des Staatsrechts, p. 652.

${ }^{691}$ Para uma visão geral das principais alterações trazidas por esta emenda à constituição alemã, vide Christian STARCK (Hrg). Föderalismusreform: Einführung. Munique: Franz Vahlen e C. H. Beck, 2007. Para uma
} 
síntese, pode-se afirmar que foram duas as principais alterações introduzidas neste dispositivo.

Em primeiro lugar, o âmbito da cláusula de necessidade (Erforderlichkeitsklausel) foi reduzido a apenas algumas matérias discriminadas no artigo 72 II GG, quais sejam: (i) permanência e residência dos estrangeiros (Nr. 4 do artigo 74 I GG); (ii) assistência social (Nr. 7); (iii) direito da economia (Nr. 11); (iv) a regulamentação dos subsídios educacionais e incentivo à pesquisa educacional (Nr. 13); (v) a transferência de terras, recursos naturais e meios de produção para propriedade comum ou outras formas de economia comum (Nr. 15); (vi) proteção econômica dos hospitais e a regulamentação dos preços praticados pelos hospitais (Nr. 19a); (vii) direito dos gêneros alimentícios, a proteção das plantas contra doenças e pragas e a proteção dos animais (Nr. 20); (viii) trânsito (Nr. 22); (ix) responsabilidade do Estado (Nr. 25), e; (x) a criação assistida da vida humana, a investigação e alteração artificial das informações genéticas bem como regulamentação sobre transplante de órgãos, tecidos e células (Nr. 26). Em relação às demais matérias contidas no artigo 74 I GG, não é mais preciso proceder à verificação do preenchimento dos pressupostos do artigo 72 II GG; a necessidade de uma regulamentação federal nestes casos passou a ser presumida, por assim dizer. Ao comentar esta alteração a doutrina alemã defende que teriam sido criadas duas modalidades de competências. A primeira delas, denominada de competência nuclear (Kernkompetenz), seria aquela à qual só se aplica o disposto no artigo 72 I GG, sem qualquer exame acerca do preenchimento do disposto no segundo parágrafo deste dispositivo, ao menos em um plano jurisdicional. Já a segunda, chamada de competência de necessidade (Bedarfkompetenz), seria caracterizada pela incidência do disposto do artigo 72 I e II GG, com o consequente exame da necessidade (Erforderlichkeit) da lei federal. ${ }^{692}$

A estas duas modalidades acresceu-se uma terceira espécie, a segunda grande novidade trazida pela Reforma do Federalismo I ao artigo 72 GG: a competência de divergência (Abweichungsgesetzgebung). Nos termos do novo artigo 72 III GG, caso a União faça uso da sua competência legislativa concorrente, os Estados poderão editar regulamentações divergentes sobre as seguintes matérias: (i) direito da caça; (ii) proteção da natureza e a preservação da paisagem natural; (iii) a distribuição da terra (Bodenverteilung); (iv) a ordenação do território (Raumordnung); (v) o regime da água, e; (vi) a admissão e a conclusão de curso em instituições de ensino superior. É de se ressaltar que a União poderá

compreensão das novidades em sede de repartição de competências legislativas, vide Christoph DEGENHART. Die Neuordnung der Gesetzgebungskompetenzen durch die Föderalismusreform. Neue Zeitschrift für Verwaltungsrecht (NVWZ), ano 25, novembro/ 2006, Caderno 11, pp. 1209 a 1216.

692 RENGELING. § 135 - Gesetzgebungszuständigkeit. In: ISENSEE, KIRCHHOF (Hrsg.). Handbuch des Staatsrechts, p. 636. 
novamente legislar sobre o tema, sendo franqueado aos Estados novamente divergir da legislação federal, e assim por diante. Por conta desta possibilidade, a competência de divergência tem sido denominada por muitos de "modelo Ping-Pong", o que já carrega em si um juízo valorativo desfavorável à opção introduzida pelo legislador constituinte alemão. ${ }^{693}$

\subsubsection{A competência-moldura do artigo 75 GG}

Até 2006 a Lei Fundamental de 1949 previa também uma competência-moldura no seu artigo 75. Apesar de a revogação deste dispositivo estar prestes a completar 10 anos, acredita-se que é importante traçar algumas considerações a respeito desta modalidade de competência concorrente, em razão da sua relevância para a compreensão da competência inscrita no artigo $24 \mathrm{CF} / 88$. Para tanto, propõe-se aqui uma exposição sob uma perspectiva histórica, tendo em vista que também esta competência foi objeto de algumas reformas constitucionais desde a entrada em vigor da constituição alemã.

A redação originária do artigo 75 GG era relativamente concisa, sem qualquer subdivisão em parágrafos. O seu caput previa somente que a União detinha o "direito, obedecidos os requisitos do artigo 72, de editar preceitos-moldura sobre" arrolados em cinco números, assemelhando-se muito com o artigo 10 da Constituição de Weimar. Com efeito, referido dispositivo conferia ao Reich o poder de editar princípios sobre temas, aliás, muito parecidos com os estabelecidos no artigo $75 \mathrm{GG}^{694}$.

A Lei Fundamental inovou ao circunscrever a atuação da União no artigo 75 à edição de preceitos-moldura (Rahmenvorschriften) e não à edição de uma legislação de princípios (Grundsatzgesetzgebung), como fazia a Constituição de 1919. Afinal, são duas categorias que não se confundem e que conviveram até 2006 na constituição alemã vigente. ${ }^{695}$ A competência federal para a edição de princípios, por um lado, concebe uma

\footnotetext{
693 A legislação de divergência será retomada com maior aprofundamento no item 5.5.1, quando da análise na nova regulamentação conferida pela Reforma do Federalismo de 2006 ao artigo 84 I GG.

${ }^{694}$ Nesse sentido, o artigo 10 WRV conferia ao ente federal a faculdade de editar princípios sobre temas como ensino superior, funcionários públicos, direito agrário, os quais também eram compreendidos pela competência inscrita no artigo 75.

695 Em sentido contrário, o BVerfG enxergou uma relação de continuidade entre os artigos 10 e 11 WRV e o artigo 75 GG em um julgado proferido poucos anos após a entrada em vigor da Lei Fundamental. Segundo esta Corte, "o uso do conceito 'preceitos-moldura' no lugar de 'princípios' para a designação da limitação conceitual do poder legislativo da União na Lei Fundamental não significa que a medida da regulamentação federal deve ser determinada hoje diferentemente do que no tempo da Constituição Imperial de Weimar. A história do surgimento da Lei Fundamental confirma esta opinião. As negociações do Conselho Parlamentar mostram somente que por meio da designação 'preceitos-moldura' deveria ser dirimida qualquer dúvida de que preceitos federais ancorados nesta norma de competência podem conter não só diretivas ao poder legislativo
} 
restrição ainda maior à atuação federal do ponto de vista do seu conteúdo e extensão, além de ser dirigida exclusivamente ao legislador estadual. As matérias sobre a qual ela recai são bem limitadas: atualmente, somente duas matérias (previstas nos artigos 109 III GG e artigo 140 GG c/c artigo 138 I 2 WRV) comportam esta modalidade de legislação federal. ${ }^{696}$ Já a competência-moldura permitia uma atuação mais abrangente da União, inclusive com aplicação direta às relações concretas apesar de primordialmente orientadas aos legisladores estaduais.

Como ressalta Klaus STERN, “a competência-moldura da União (Art. 75 e art. 98, parágrafo $3^{\circ}$, segundo período GG) é caracterizada pelo fato de que União e Estados devem se tornar ativos um ao lado do outro, de tal modo que a União estabeleça as molduras, os contornos, as principais características, as diretivas, os princípios norteadoras, por outro lado, os Estados podem e devem preencher estas molduras por meio de direito estadual"697. Três elementos conformadores importantes podem ser extraídos desta definição.

Em primeiro lugar, estamos diante de uma modalidade de competência concorrente na acepção que a presente tese empresta ao termo, pois tanto União quanto Estados-membros são legitimados a atuar em relação a uma determinada matéria. ${ }^{698}$ Tal percepção é reforçada, por sua vez, tanto pelo fato de o artigo 70 II GG determinar que a distribuição de poderes legislativos entre União e Estados-membros se dará necessariamente com base em uma competência privativa ou em uma competência concorrente - o que força o enquadramento da competência-moldura em uma destas espécies - quanto pelo fato de o artigo 75 GG fazer desde 1949 expressa referência ao artigo 72 GG, determinando a sua aplicação às matérias nele previstas. ${ }^{699}$

estadual, mas também regras jurídicas válidas diretamente; isto já era o caso muitas vezes de leis-princípios de acordo com a Constituição Imperial de Weimar, mas contestada em sua admissibilidade (BVerfGE 4, 115 (128-129)). Neste mesmo sentido, vide Rupert STETTNER. Artikel 75. In: Horst DREIER (Hrg). Grundgesetz Kommentar. Band II: Artikel 20-82. 2a Ed. Tübingen: Mohr Siebeck, 2006, p'. 1706 e Jochen ROZEK. Artikel 75. In: Hermann von MANGOLDT, Friedrich KLEIN, Christian STARCK (Hrgs). Kommentare zum Grundgesetz. Band II: Artikel 20-82. 5a Ed. Munique: Franz Vahlen, 2005, p. 2048.

696 RENGELING. § 135 - Gesetzgebungszuständigkeit. In: ISENSEE, KIRCHHOF (Hrsg.). Handbuch des Staatsrechts, p. 720 e ROZEK. Artikel 75. In: von MANGOLDT, KLEIN, STARCK (Hrsg.). Kommentare zum Grundgesetz, p. 2041.

697 STERN. Das Staatsrecht der Bundesrepublik Deutschland. Band I, p. 680. No original: "Die Rahmengesetzgebung des Bundes (Art. 75, 98 Abs 3 Satz 2 GG) ist dadurch gekennzeichnet, dass Bund und Länder nebeneinander tätig werden müssen, und zwar dargestalt, dass der Bund den Rahmen, die Umrisse, die Grundzüge, die Richtlinien, die leitenden Prinzipien setzt, die Länder hingegen diesen Rahmen durch Landesgesetze ausfüllen können und müssen."

698 De acordo com a tipologia forjada no item 1.5.5 desta tese, estamos diante de uma competência concorrente limitada, vale dizer, de uma modalidade que impõe limites materiais à atuação dos entes federativos.

${ }^{699}$ Como ressalta ROZEK. Artikel 75. In: von MANGOLDT, KLEIN, STARCK (Hrgs). Kommentare zum Grundgesetz, 
Aliás, a aplicabilidade do artigo 72 GG ao artigo em comento sempre se afigurou problemática, em virtude da remissão genérica que o artigo 75 GG fazia. Havia quem sustentasse que somente o parágrafo segundo deste dispositivo se aplicava à competênciamoldura. Nesse sentido, Rupert STTETNER entendia pela não incidência do artigo 72 I GG, em virtude de o artigo 75 GG não contemplar nenhum efeito de barreira a uma atuação legiferante por parte dos Länder. Já Jochen ROZEK defendia entendimento oposto, qual seja, o de que o exercício de uma competência-moldura por parte da União impunha um efeito de barreira aos Estados-membros, justamente por conta da aplicação do artigo 72 I GG, não se vislumbrando a incidência do disposto no artigo 31 GG. $^{700}$ Os dois posicionamentos, todavia, convergiam no sentido de determinar a incidência do artigo 72 II GG ao artigo 75 GG, arrastando para o âmbito deste último dispositivo constitucional toda a problemática discutida no tópico anterior.

Em segundo lugar, no âmbito da competência-moldura tanto a União quanto os Estados deveriam legislar, para falar com Klaus STERN, "um ao lado do outro": a União, por um lado, deveria editar preceitos-moldura; já os Estados-membros, por outro lado, deveriam preencher esta moldura normativa por meio da edição das suas respectivas leis. Portanto, a regulamentação de uma matéria contida no artigo 75 GG só seria possível por meio e ao término de uma dupla atuação legiferante. Nesse sentido, já em 1954 o Tribunal Constitucional Federal alemão já se manifestou sobre a necessidade de uma lei-moldura federal ser passível e ser carente de preenchimento por parte de uma lei estadual:

\footnotetext{
"Quando o legislador federal edita preceitos-moldura, ele deve deixar aos Estados, no que tange à área por ela regulada, algo para regulamentar. Isso que permanece com os Estados para regular deve ser de uma importância substancial. Os preceitos estaduais devem se enquadrar na moldura dada pela União. Por outro lado, porém, deve a moldura estabelecida pela União deixar aos Estados a possibilidade de regular complementando a matéria de acordo com as relações peculiares do Estado. Preceitos-moldura da União devem, mesmo que não em todas as disposições isoladas mas como um todo, ser passíveis e carentes de preenchimento pelo poder legislativo estadual, de qualquer modo serem desenhados para tal preenchimento. Eles não precisam se restringir a normas de significado principiológico; mas por outro lado eles não podem exceder o seu propósito de representar apenas um limite para a regulamentação própria por legislação estadual. Eles devem deixar ao poder legislativo estadual espaço para vontades
}

pp. 2040-2041. Em sentido contrário, entendia o BVerfG que a Rahmengesetzgebung se colocava como uma terceira modalidade independente de competência federal, ao lado da competência privativa e da competência concorrente (BVerfGE 111, 226 (247)).

700 STETTNER. Artikel 75. In: DREIER (Hrsg.). Grundgesetz, p. 1715 e ROZEK. Artikel 75. In: von MANGOLDT, KLEIN, STARCK (Hrsg.). Kommentare zum Grundgesetz, pp. 2040-2041 e 2043-2047. Note-se que estes dois autores escrevem em 2006 e 2005, respectivamente, já no ocaso desta modalidade de competência. Como se tratam de conclusões que se referem a uma parte do artigo 75 GG que se manteve inalterada desde 1949, considera-se que elas podem ser utilizadas nas conclusões que a presente tese tece à competência-moldura de um ponto de vista mais geral. 
decisórias no tratamento jurídico do tema e não podem restringi-lo a apenas escolher entre possibilidades jurídicas predeterminadas."701

Percebe-se, portanto, como a dualidade legislativa que era inerente a esta modalidade de competência serviu para forjar uma noção do que seria um preceito-moldura. Afinal, a Lei Fundamental de 1949 nunca conteve disposição acerca do conteúdo desta norma $^{702}$ e é de se admitir que até 1994 não havia outro subsídio para defini-la a não ser aquele empregado pela corte constitucional alemã no trecho supracitado. Nesta mesma ocasião o Tribunal Constitucional Federal também entendeu que à União também era lícito editar normas diretamente aplicáveis às situações concretas, desde que estas normas devessem ter a sua eficácia combinada a de normas estaduais, a fim de atingir a regulamentação legal pretendida. ${ }^{703}$ Com base neste entendimento, a União passou a editar longas leis, inclusive com preceitos aplicáveis diretamente às relações jurídicas concretas, ainda que garantindo alguma margem de atuação ao legislador estadual como um todo. ${ }^{704} \mathrm{O}$ resultado desta prática foi novamente a centralização legislativa, em menor medida do que ocorreu com a competência concorrente analisada no tópico anterior, em virtude de o Tribunal Constitucional Federal alemão ter considerado o preceito-moldura (Rahmenvorschrift) como um conceito jurídico, sobre o qual poderia recair o controle jurisdicional. ${ }^{705}$

Em terceiro lugar e como uma manifestação do que foi dito supra, diante da necessidade de uma dupla atividade legislativa e de uma necessária harmonização entre ambas, a Rahmengesetzgebung alemã coloca-se como uma legislação cooperativa. ${ }^{706} \mathrm{E}$

\footnotetext{
701 BVerfGE 4, 115 (129-130). No original: “Wenn der Bundesgesetzgeber Rahmenvorschriften erlässt, muss er im Hinblick auf das zu ordnende Sachgebiet den Ländern noch etwas zu regeln übrig lassen. Das, was den Ländern zu regeln bleibt, muss von substantiellem Gewicht sein. Die Landesvorschriften müssen sich zwar in den vom Bund gegebenen Rahmen einpassen. Andererseits aber muss der vom Bund gezogene Rahmen dem Land die Möglichkeit lassen, die Materie entsprechend den besonderen Verhältnissen des Landes ergänzend zu regeln. Rahmenvorschriften des Bundes müssen, wenn auch nicht in allen einzelnen Bestimmungen, so doch als Ganzes durch Landesgesetzgebung ausfüllungsfähig und ausfüllungsbedürftig, jedenfalls auf eine solche Ausfüllung hin angelegt sein. Sie brauchen sich zwar nicht auf Normen von grundsätzlicher Bedeutung zu beschränken, andererseits aber dürfen sie ihre Zweckbestimmung, nur eine Grenze für landesgesetzliche Eigenregelung zu bilden, nicht überschreiten. Sie müssen dem Landesgesetzgeber Raum für Willensentscheidungen in der sachlichen Rechtsgestaltung übrig lassen und dürfen ihn nicht darauf beschränken, nur zwischen vorgegebenen rechtlichen Möglichkeiten zu wählen.

702 Nesse sentido, STETTNER. Artikel 75. In: DREIER (Hrsg.). Grundgesetz, p. 1709 e ROZEK. Artikel 75. In: von MANGOLDT, KLEIN, STARCK (Hrsg.). Kommentare zum Grundgesetz, p. 2047.

703 BVerfGE 4, 115 (130).

${ }^{704}$ Como relata STETTNER. Artikel 75. In: DREIER (Hrsg.). Grundgesetz, p. 1709

705 ROZEK. Artikel 75. In: von MANGOLDT, KLEIN, STARCK (Hrsg.). Kommentare zum Grundgesetz, p. 2051.

706 Nesse sentido, ROZEK. Artikel 75. In: von MANGOLDT, KLEIN, STARCK (Hrsg.). Kommentare zum Grundgesetz, p. 2041 e também BVerfGE 111, 226 (247).
} 
não se está diante de qualquer cooperação federativa, mas sim de uma cooperação à alemã, dentro de um paradigma de Estado Federal-Unitário e caracterizada por uma acentuada interdependência política. Afinal, fosse a competência-moldura compreendida como uma modalidade de competência concorrente ou como uma competência estadual conformada por preceitos federais, o fato era que o Bund não podia prescindir dos Länder se desejasse ver determinados parâmetros aplicados em um âmbito nacional.

Em 1969, uma reforma constitucional introduziu outro instrumento típico do federalismo-unitário no artigo 75 GG. A partir de então, este dispositivo passou a contar com um parágrafo segundo, o qual previa a necessidade de aprovação do Conselho Federal no caso de a lei federal versar sobre criação e mensuramento da remuneração e da avaliação dos órgãos públicos estaduais. Por meio desta alteração procurou-se garantir uma contrapartida aos Estados-membros, que tiveram um aspecto importante da sua autonomia restringida em virtude de uma leitura expansiva do alcance do preceito-moldura, por meio da participação da sua câmara representativa na formação da legislação federal.

Finalmente, a reforma constitucional de 1994, informada por um discurso de fortalecimento dos poderes legislativos estaduais após anos de uma prática legislativa unitarizante, buscou limitar a atuação legiferante do Bund por meio da imposição de novos parâmetros. Em primeiro lugar, para que a União pudesse editar um preceito-moldura, ele deveria ser necessário (erforderlich), em virtude da nova redação do artigo 72 GG, ao qual o artigo 75 I GG continuou a fazer expressa referência. Além do mais, neste último dispositivo passou a constar expressamente que os preceitos-moldura deveriam ser dirigidos aos poderes legislativos estaduais. Em terceiro lugar, o artigo 75 II GG passou a prever que somente em casos excepcionais a União poderia descer a minucias ou conter regulamentações de aplicabilidade ao caso concreto. Note-se que, embora tal previsão tenha sido inserida no texto da Lei Fundamental com o nítido propósito de restringir a atuação legiferante da União, ela corroborou a prática legislativa que havia sido desenvolvida até aquele momento, ao afirmar a contrario sensu que regulamentações federais aplicáveis diretamente às relações concretas, em tese, seriam possíveis. ${ }^{707}$ Em quarto e último lugar, o parágrafo terceiro do artigo 75 impôs aos Estados o dever de editar normas estaduais correspondentes no caso de a União editar preceitos-moldura, encerrando uma grande celeuma acerca do assunto.

\footnotetext{
${ }^{707}$ Como é bem ressaltado em ROZEK. Artikel 75. In: von MANGOLDT, KLEIN, STARCK (Hrsg.). Kommentare zum Grundgesetz, p. 2050.
} 
Em virtude da profunda alteração, o Tribunal Constitucional Federal promoveu uma revisão da sua jurisprudência sobre o assunto, em um caso que ficou conhecido como Juniorprofessur (BVerfGE 111, 226). É certo a Corte manteve o seu posicionamento principalmente no que diz respeito ao conteúdo típico de um preceito-moldura, referindo-se inclusive ao trecho do julgamento proferido em 1954 citado supra. ${ }^{708}$ No que tange à possibilidade de o legislador federal editar normas com aplicabilidade direta, contudo, a modificação foi substancial. Em virtude de o artigo 75 I GG a partir de então mencionar "preceitos-moldura para o poder legislativo estadual" (Rahmenvorschriften für die Gesetzgebung der Länder) e diante da nova redação do artigo 72 II GG, o referido tribunal alemão passou a esposar o entendimento de que a norma federal "dirige-se em primeiro lugar ao poder legislativo estadual" ${ }^{\text {709 }}$, superando o entendimento anterior de que o artigo 75 GG franqueava ao Bund a possibilidade de editar tanto diretivas aos poderes legislativos estaduais quanto preceitos com aplicabilidade direta. ${ }^{710}$ Diante disso, era preciso definir o que seria a situação excepcional que justificaria a edição de normas federais diretamente aplicáveis a um caso concreto. Neste ponto, o BVerfG também sepultou um outro posicionamento tradicional - segundo o qual uma regulamentação unitária por meio de lei federal seria possível "quando estivesse presente interesse particularmente forte e legítimo"711 - passando a analisar a existência de um caso excepcional com base em um critério quantitativo e um critério qualitativo. De acordo com o primeiro deles, regulamentações detalhadas e diretamente aplicáveis ao caso concreto não poderiam predominar na lei federal, vale dizer, deveriam figurar em menor número em comparação com os preceitos dirigidos ao legislador estadual. Qualitativamente, haveria uma situação excepcional somente quando um preceito-moldura não pudesse ser editado de forma compreensível se desacompanhado de um outro preceito que descesse a minúcias ou que tivesse aplicabilidade direta. ${ }^{712}$

Percebe-se, do exposto, que a reforma de 1994 e a jurisprudência constitucional que se seguiu representaram uma clara tentativa de revestir o artigo 75 GG com contornos mais federativos e cooperativos, após anos de uma prática legislativa deletéria a estes dois valores. Como ressaltava Jochen ROZEK já no ocaso desta modalidade competencial, era pouco provável que estas alterações fossem suficientes para retirá-la do fogo cruzado em que ela

\footnotetext{
708 BVerfGE 111, 226 (249).

709 BVerfGE 111,226 (248).

710 BVerfGE 4,115 (130).

711 BVerfGE 43, 291 (343).

712 BVerfGE 111, 226 (252-253).
} 
se encontrava. Ela, afinal, era colocada sob fortes críticas, pois seria muito complicada, muito demorada e muito pouco adequada às necessidades da integração europeia. ${ }^{713}$ Nesse mesmo sentido, Rupert STETTNER também ressaltava que a necessidade de uma dualidade legiferante fazia com que a competência-moldura se colocasse em conflito com o princípio segundo o qual as relações entre União e Estado deveriam ser o menos entrelaçadas possível. ${ }^{714}$ Note-se que este "princípio", que lastreou todas as reformas constitucionais desde 1994, representa nada mais do que a necessidade de desconstrução do modelo de relacionamento político típico do federalismo-unitário.

Em 2006 a competência-moldura foi finalmente revogada, aplicando-se ao direito federal editado com base no artigo 75 GG o disposto no artigo $125 \mathrm{~b} \mathrm{GG}^{715}$.

\subsection{Regra geral EM MATÉRIA de REPARTIÇÃO DE COMPETÊNCIAS DE EXECUÇÃO (ARTIGO 83)}

Feitos os devidos esclarecimentos acerca da distribuição do poder de legislar entre União e Estados-membros na federação alemã, é chegado o momento de tecer considerações mais detidas sobre o modo pelo qual a Lei Fundamental de 1949 reparte competências de execução entre os entes federativos. Note-se que, a partir deste momento, a presente tese também fará referência a "competências administrativas" como expressão sinônima a “competências de execução", tendo em vista que se trata da terminologia empregada pela doutrina e pela jurisprudência alemãs. ${ }^{716}$

Em algumas passagens desta tese já se referiu ao fato de não existir exatamente uma correspondência entre a partilha constitucional das competências legislativas e das competências de execução nesta federação. Ou seja, o ente legitimado para editar uma legislação pode não ser - e geralmente não é - o mesmo ente legitimado para a execução dos preceitos contidos nesta lei. Na doutrina brasileira, tal fenômeno é retratado sob o rótulo do

\footnotetext{
713 ROZEK. Artikel 75. In: von MANGOLDT, KLEIN, STARCK (Hrsg.). Kommentare zum Grundgesetz, p. 2042.

714 STETTNER. Arikel 75. In: DREIER (Hrsg.). Grundgesetz, p. 1709.

715 Segundo o artigo 125b I GG, na sua redação atual, "Permanece válida como direito federal a legislação editada com base no art. 75 na redação válida até 10 de setembro de 2006 e que poderia ser editada como direito federal após esta data. Os poderes e deveres dos Estados-membros relativos à legislação permanecem existentes. Nas áreas nomeadas no art. 72 III 1 os Estados-membros podem adotar regulamentações divergentes da legislação federal. Todavia, nas áreas do art. 72 III 1 Nr. 2, 5 e 6, apenas se e na medida em que a União, a partir de 10 de setembro de 2006, ter feito uso de sua competência legislativa; nos casos dos números 2 e 5, até a partir 1ㅇ de janeiro de 2010; no caso do número 6, até a partir de 1o de agosto de 2008". 716 Com efeito, é possível encontrar em textos jurídicos menção à "Verwaltungszuständigkeit", a qual é traduzida em termos literais como "competência administrativa" ou "competência de administração".
} 
sistema mediato de execução de serviços ou o princípio da execução mediata de serviços. Porém, na Alemanha ele assume dignidade constitucional no artigo $83 \mathrm{GG}$, o qual impõe aos Länder a execução das leis federais por meio de sua própria estrutura administrativa e custeada com os seus próprios recursos, em regra. Assim, se na área da legislação a posição de proeminência é ocupada pelo Bund, na seara administrativa os Länder ocupam papel de destaque. Não é por outro motivo que nos manuais de direito constitucional é possível encontrar menções a uma ênfase da União na legislação e a uma ênfase dos Estados na atividade administrativa. ${ }^{717}$

Segundo a doutrina alemã, o artigo 83 GG consiste em um desdobramento, uma concretização do artigo $30 \mathrm{GG}^{718}$, assumindo a envergadura de uma regra geral em matéria de repartição de competências administrativas. Porém, ao se confrontar o teor dos dois dispositivos em questão, percebe-se que os preceitos nele contidos não se relacionam em termos de correspondência. Com efeito, o artigo 30 confere aos Länder o exercício de poderes e tarefas estatais como regra geral, na hipótese de não haver na Lei Fundamental disposição em outro sentido. Já a primeira parte do artigo 83 GG contém uma prescrição de conteúdo diverso, mais precisamente, a de que a execução das leis federais deve ser promovida pelas administrações estaduais. Note-se como o dispositivo em questão não trata das competências administrativas como um todo, como seria de se esperar em um preceito com vocação de regra geral. A execução das leis estaduais, por exemplo, é uma questão que simplesmente não é abarcada pela norma contida no artigo $83 \mathrm{GG}$, recaindo na esfera estadual por aplicação do $30 \mathrm{GG}^{719}$. Além do mais, deste dispositivo não se depreende - ao menos, por meio de uma interpretação textual - que as competências administrativas deverão exercidas pelos Estados-membros, caso a constituição alemã não disponha de outro modo. $\mathrm{O}$ artigo 83 GG contém, a bem da verdade, uma regra específica, qual seja, a de que a execução das leis federais - não a execução de normas jurídicas como um todo, mas apenas das leis federais - compete aos Estados como um assunto próprio, sendo esta uma regra que só pode ser relativizada ou excepcionada pela própria Lei Fundamental.

\footnotetext{
717 DEGENHART. Staatsrecht I - Staatsorganisationsrecht, p. 184.

718 Nesse sentido, JARASS, PIEROTH. Grundgesetz, p.903; STERN. Das Staatsrecht der Bundesrepublik Deutschland. Band I, p. 683; Georg HERMES. Artikel 83. In: Horst DREIER (Hrsg). Grundgesetz - Kommentar. Band III: Artikel 83-146. 2a Ed. Tübingen: Mohr Siebeck, 2008, p. 13, e; Hans-Heinrich TRUTE. Artikel 83. In: Hermann von MANGOLDT, Friedrich KLEIN, Christian STARCK (Hrgs). Kommentare zum Grundgesetz. Band III: Artikel 83-146. 6a Ed. Munique: Franz Vahlen, 2010, pp. 10-11.

719 Conforme HERMES. Artikel 83. In: DREIER (Hrsg.). Grundgesetz, p. 19 e Armin DITTMANN. Artikel 83 \{Grundsatz der Länderexekutive]. In: Michael SACHS (Hrsg.). Grundgesetz - Kommentar. 7a Ed. Munique: C. H. Beck, 2014, p. 1694
} 
Fiquemos, contudo, com o que preconiza a doutrina alemã, mesmo porque o que se pretende neste capítulo é uma retomada das principais discussões jurisprudenciais e doutrinárias a respeito de cada dispositivo constitucional analisado, conforme exposto na introdução desta segunda parte. Entendem os autores alemães que o artigo 83 GG consagra, a bem da verdade, uma dupla relação de regra e exceção (doppeltes Regel-AusnahmeVerhältnis) a favor dos Länder. De acordo com a primeira delas, o Bund detém somente as competências a ele atribuídas pela Lei Fundamental (exceção), ao passo que aos Länder é atribuído todo o restante, a título de competência residual (regra). Já a segunda impõe que a execução das leis federais deve ocorrer por meio de administração estadual própria (Landeseigenverwaltung) (regra), sendo que outras formas de execução devem ser previstas ou autorizadas pelo texto constitucional (exceção). ${ }^{720}$ Estas duas regras, por sua vez, podem ser extraídas da primeira parte do artigo 83 GG, sendo que a ambas se aplica a exceção contida na segunda parte do referido dispositivo. Tem-se assim, em primeiro lugar, que "os Estados executam as leis federais, desde que a Lei Fundamental não determine ou permita de outro modo" e, em segundo lugar, que "os Estados executam leis federais como assunto próprio, desde que a Lei Fundamental não determine ou permita de outro modo". Precisemos o real conteúdo de cada uma destas normas, a partir do sentido que doutrina e jurisprudência alemãs emprestam às expressões contidas no artigo 83 GG.

Em primeiro lugar, se os Estados executam leis federais como regra geral, é preciso saber primeiramente o que são exatamente estas leis federais que deverão ser executadas pelas administrações estaduais. Segundo Janbernd OEBBECKE, "leis federais não são somente leis federais formais, mas também regulamentos ou o costume da União"721 $\mathrm{Ou}$ seja, ao contrário do que ocorre com as competências legislativas, que tem por objeto a edição de uma lei em sentido formal, a competência administrativa ou de execução abrange, no direito alemão, a execução de leis federais em um sentido amplo, abrangendo o direito federal escrito e não escrito, direito federal ainda vigente em razão de regras de transição (pois a União não detém mais a competência legislativa), regulamentos federais (desde que necessitem de alguma medida de execução) e a própria Lei Fundamental. ${ }^{722}$

\footnotetext{
720 JARASS, PIEROTH. Grundgesetz, p. 903; HERMES. Artikel 83. In: DREIER (Hrsg.). Grundgesetz, p. 13, e; TRUTE. Artikel 83. In: von MANGOLDT, KLEIN, STARCK (Hrsg.). Kommentare zum Grundgesetz, pp. 10-11.

721 Janbernd OEBBECKE. § 136 - Verwaltungszuständigkeit. In: Josef ISENSEE, Paul KIRCHHOF (Hrsg). Handbuch des Staatsrechts der Bundesrepublik Deutschland. Band VI-Bundesstaat. 3a Ed. Heidelberg: C. F. Müller, 2008, p. 745. No original: „'Bundesgesetze' sind nicht nur formelle Bundesgesetze, sondern etwa auch Verordnungen oder das Gewohnheitsrecht des Bundes".

722 TRUTE. Artikel 83. In: von MANGOLDT, KLEIN, STARCK (Hrsg.). Kommentare zum Grundgesetz, p. 27; JARASS, PIEROTH. Grundgesetz, p. 901 e Christian HEITSCH. Die Ausführung der Bundesgesetze durch die Länder.
} 
No que tange às normas oriundas da União Europeia, reina alguma controvérsia sobre a aplicabilidade do artigo 83 GG. Como ressalta Georg HERMES, existem poucas normas de direito comunitário que são executadas diretamente por funcionários desta organização supranacional. Como regra, são os Estados-membros da União Europeia que executam o direito comunitário, o que pode se dar de forma mediata ou imediata. Na execução mediata, a norma supranacional deve ser transformada em direito (lei) nacional para só então ser executada no território alemão. Como a Alemanha é um Estado Federal, são legitimados a promover esta transformação tanto o Bund quanto os Länder, aplicandose as disposições contidas nos artigos 70 e seguintes GG. Ou seja, a depender da distribuição de competências legislativas contidas na Lei Fundamental, ela pode se dar por meio de uma lei estadual quanto de uma lei federal. Neste último caso, aplica-se o disposto no artigo 83 GG, sem maiores elucubrações. Já na execução mediata o direito comunitário não precisa ser convertido em direito nacional, devendo ser executada como tal pela administração pública. Surge então um problema, pois a norma comunitária não se qualifica como direito federal ou direito estadual. Por um lado, argumenta-se que a competência seria dos Estadosmembros com base no artigo 30 GG. Contudo, prevalece o entendimento de que o artigo 83 GG aplica-se analogicamente ao caso, como uma forma de garantir a ingerência do Bund na execução levada a cabo pelos Länder nos termos do artigo 84 GG. ${ }^{723}$

Em segundo lugar, é importante saber no que consiste exatamente a atividade de execução de uma lei federal. Como observa Christian HEITSCH, a Lei Fundamental menciona a execução de leis federais nos artigos 83, 84 e $85 \mathrm{GG}$, considerando-a fundamento da supervisão federal e também do poder conferido ao Bund (artigos 84 e 85) de regular a organização das autoridades administrativas e o processo administrativo estaduais (artigo 84). Em todos os casos, a execução da lei federal possui o mesmo significado, qual seja, execução administrativa da lei federal. ${ }^{724}$ Isto engloba, segundo este mesmo autor,

Tübingen: Mohr Siebeck, 2001, pp 156-157. Note-se que, para este último autor, a Lei Fundamental não seria uma lei federal para fins de aplicação do artigo 83 GG

723 HERMES. Artikel 83. In: DREIER (Hrsg.). Grundgesetz, pp. 6-7. Neste ponto um esclarecimento importante: embora o artigo 83 GG determine que a execução das leis federais deve ser levada a cabo pelos Estadosmembros como um assunto que Ihes é próprio, o artigo 84 GG confere ao Bund a possibilidade de supervisionar a aplicação do direito federal, ainda que esta supervisão se restrinja à verificação da legalidade da atuação estadual. Já o artigo 85 GG prevê uma ingerência ainda mais forte do governo federal sobre a execução das leis federais pelos Länder, inclusive por meio de ordens dirigidas aos seus órgãos de cúpula. No caso da execução do direito comunitário, caso ela encontrasse fundamento tão somente no artigo 30 GG, a União não poderia exercer qualquer influência sobre os Estados-membros. Por outro lado, a execução norteada pela aplicação analógica dos artigos 83 e seguintes GG concebe uma ingerência do Bund sobre os Länder sobre a aplicação do direito comunitário.

${ }^{724}$ HEITSCH. Die Ausführung der Bundesgesetze durch die Länder, pp. 155-156. 
"ao lado da organização dos Behörde e do processo administrativo também a edição de regulamentos nos termos do artigo 80 GG e de preceitos administrativos bem como as demais atuações administrativas, tanto sob a forma de direito público (ato administrativo, comandos dentro do serviço administrativo, contrato de direito público, atos materiais da administração) ou de direito privado."725

Em outras palavras, a execução de uma lei federal, para os fins da Lei Fundamental, significa a organização de uma estrutura administrativa, no âmbito da qual são desempenhadas formas típicas de atuação administrativa ou então atos de direito privado, mas que são praticados pela Administração com a finalidade de concretizar o programa contido na lei. Não pode ser considerada execução, portanto, a simples observância da legislação do Bund pelos Estados, conforme entendimento majoritário. ${ }^{726}$

Em terceiro lugar, se os Länder executam leis federais, sendo esta uma regra que se extrai da primeira parte do artigo 83 GG, é preciso entender como a segunda parte deste mesmo dispositivo representa uma exceção ao prever que a Lei Fundamental pode determinar (bestimmen) ou permitir (zulassen) de outro modo. Ora, tendo em vista que a federação alemã se divide de um ponto de vista organizacional em União e Estados, tão somente, a exceção prevista pela norma constitucional em comento só pode significar a execução das leis federais pela própria União, por meio de estrutura administrativa própria. Isto, por sua vez, pode se dar de forma obrigatória - porque determinado pela própria Lei Fundamental - ou facultativamente - quando permitido pela constituição alemã. No primeiro caso se está diante da administração federal obrigatória (obligatorische Bundesverwaltung), ao passo que no segundo consubstancia a da administração federal facultativa (fakultative Bundesverwaltung) ou por força de lei (Bundesverwaltung kraft Geseztes) ${ }^{727}$ Retornaremos a este assunto no tópico 5.6, dedicado ao estudo da competência administrativa da União, retomando a análise do sentido e do alcance das normas contidas no artigo 83 GG.

Em quarto lugar, os Länder executam leis federais como assunto próprio (als eigene Angelegenheit), vale dizer, no âmbito da própria organização administrativa estadual, levada

\footnotetext{
725 HEITSCH. Die Ausführung der Bundesgesetze durch die Länder, p. 156. No original: „Dazu gehört im einzelnen neben der Einrichtung der Behörden und dem Verwaltungsverfahren auch der Erlass von Rechtsverordnungen nach Massgabe des Art. 80 GG und von Verwaltungsvorschriften sowie das übrige Verwaltungshandeln, gleich ob in den Formen des öffentlichen Rechts (Verwaltungsakt, innerdienstliche Weisung, öffentlich-rechtlicher Vertrag, schlichtes Verwaltungshandeln) oder das Privatrechts." Nesse mesmo sentido, OEBBECKE. § $136-$ Verwaltungszuständigkeit. In: ISENSEE, KIRCHHOF (Hrsg.). Handbuch des Staatsrechts, p. 745 e HERMES. In: DREIER (Hrsg.). Grundgesetz. Artikel 83, p. 21

726 Nesse sentido, JARASS, PIEROTH. Grundgesetz, p. 901, OEBBECKE. $\S 136$ - Verwaltungszuständigkeit. In: ISENSEE, KIRCHHOF (Hrsg.). Handbuch des Staatsrechts, p. 745, HERMES. In: DREIER (Hrsg.). Grundgesetz. Artikel 83, pp. 20-21, DITTMANN. Artikel 83. In: SACHS (Hrsg.). Grundgesetz, p. 1695.

727 BADURA. Staatsrecht, p. 684.
} 
a cabo por servidores estaduais e custeada por recursos dos Estados. ${ }^{728}$ Ou como pondera Georg HERMES,

\begin{abstract}
"Com a formulação de que os Estados executam as leis federais 'como assunto próprio', o artigo 83 exprime que os Estados cumprem sua tarefa de execução sob sua própria responsabilidade, nesta atividade não estão submetidos a quaisquer ordens da União e subordinam-se por meio do artigo 84 GG simplesmente a uma limitada supervisão jurídica da União. Os Estados executam o direito federal, portanto, como se fosse direito estadual. Desde que não sejam estabelecidas regras federais especiais, a execução do direito federal segue as regras do direito constitucional estadual e da legislação estadual vigentes para o direito estadual. Os Estados executam as leis federais, deste modo, com seus próprios servidores, seus próprios recursos e sua própria organização. Aos Estados pertence em especial a competência de regular a organização das autoridades administrativas que são necessárias para a execução da lei e o processo administrativo (poder de organização), desde que excepcionalmente uma lei federal com aprovação do Conselho Federal não determine de outro modo. Eles determinam, para além disso, a interpretação das normas das leis federais e preenchem o campo de atuação discricionário e de apreciação." 729
\end{abstract}

Como o próprio Georg HERMES deixa bem claro no trecho supracitado, a execução de leis federais pelos Länder sob sua própria responsabilidade não significa uma completa abstenção por parte do Bund quanto a este assunto. Ao contrário, a própria Lei Fundamental prevê alguns mecanismos pelos quais este último poderá exercer influência sobre a execução de suas leis. Ocorre que esta influência é limitada, em regra, à supervisão "se os Länder executam a lei de acordo com o direito vigente" (Artigo 84 III GG). Excepcionalmente, o governo federal poderá emitir ordens individuais dirigidas aos órgãos de cúpula da administração estadual (Artigo 84 V GG).

Como exceção a esta regra, a Lei Fundamental prevê a execução de leis federais pelos Estados sob as ordens da União, prevista no artigo $85 \mathrm{GG}^{730}$. De acordo com o parágrafo terceiro deste dispositivo, as autoridades estaduais estão subordinadas às instruções ou diretivas (Weisung) das mais altas autoridades federais competentes, vale

\footnotetext{
728 OEBBECKE. § 136 - Verwaltungszuständigkeit. In: ISENSEE, KIRCHHOF (Hrsg.). Handbuch des Staatsrechts, p. 747. Nesse mesmo sentido, TRUTE. Artikel 83. In: von MANGOLDT, KLEIN, STARCK (Hrsg.). Kommentare zum Grundgesetz, pp. 34-35 e BADURA. Staatsrecht, pp. 689-690.

729 HERMES. Artikel 83. In: DREIER (Hrsg.). Grundgesetz, p. 22. No original: "Mit der Formulierung, dass die Länder die Bundesgesetze, als eigene Angelegenheit' ausführen, bringt Art. 83 GG zum Ausdruck, dass die Länder ihre Vollzugsaufgabe in eigener Verantwortung erfüllen, dabei keinen Weisungen des Bundes unterworfen sind und lediglich durch Art. 84 GG beschränkten Rechtsaufsicht des Bundes unterstehen. Die Länder führen das Bundesrecht also so aus, als sei es Landesrecht. Soweit nicht besondere bundesrechtliche Regelungen getroffen sind, folgt die Ausführung des Bundesrechts den für das Landesrecht geltenden landesverfassungsrechtlichen und landesgesetzlichen Regeln. Die Länder führen die Bundesgesetze also mit eigenem Personal, eigenen Sachmitteln und eigener Organisation aus. Den Ländern kommt insbesondere die Kompetenz zu, die für den Gesetzesvollzug erforderliche Einrichtung der Behörden und das Verwaltungsverfahren zu regeln (Organisationsgewalt), soweit nicht ausnahmsweise ein Bundesgesetz mit Zustimmung des Bundesrates etwas anderes bestimmt. Sie bestimmen darüber hinaus die Auslegung der bundesgesetzlichen Normen und füllen Ermessens- und Beurteilungsspielräume aus."

730 Outra exceção é a execução de lei federal pelo próprio Bund e que já foi mencionada supra.
} 
dizer, do Ministério que é competente para uma determinada matéria no âmbito federal. Estas instruções, por sua vez, são dirigidas às mais graduadas autoridades estaduais, as quais ficam responsáveis pela sua execução. Nos termos do artigo 85 IV GG, a supervisão federal neste caso se estende não só à conformidade da atuação estadual à lei, mas à sua oportunidade. Por significar uma ampla ingerência da União na administração estadual, a execução por delegação só ocorre nas hipóteses determinadas ou permitidas pela própria Lei Fundamental. $^{731}$

No tópico 5.5 trataremos destas duas modalidades de execução de leis federais pelos Länder com maiores detalhes, servindo as presentes considerações apenas para elucidar como elas se relacionam com as regras (gerais) previstas no artigo 83 GG. Terminemos este tópico com mais quatro ponderações acerca deste dispositivo, que costumam ser trabalhadas pela doutrina alemã.

Em primeiro lugar, a Lei Fundamental de 1949, no seu artigo 83 GG e também os artigos seguintes, pretendeu traçar uma separação entre as administrações federal e estaduais. Por este motivo, uma administração mista (Mischverwaltung) é permitida somente nas hipóteses constitucionalmente estabelecidas, sendo vedada nos demais casos. ${ }^{732}$ Exemplos de formas mistas de administração podem ser visualizados nas disposições contidas nos artigos 91a e seguintes GG e também os artigos 84 e 85 GG, em especial no que tange à supervisão exercida sobre a execução de leis federais pelos Länder. Imaginou-se que assegurar esta especial conformação em nível constitucional - vale dizer, admitindo somente variações previstas ou permitidas pela própria constituição alemã - fosse o suficiente para assegurar uma posição favorável aos Estados. Com este mesmo propósito, limitou-se a execução das leis federais pelo próprio Bund às matérias previstas no próprio texto constitucional, vedando-se a ampliação destas hipóteses por lei federal, como ocorria sob a égide da Constituição de Weimar. Porém, o que se verificou na prática foi uma crescente interdependência entre estas duas esferas em virtude da cooperação que é típica deste país e também do intenso manejo das variações permitidas pela constituição alemã. Também ocorreu um incremento da estrutura administrativa da União por meio do permissivo contido no artigo 87 III GG, como ainda será analisado nesta tese.

Em segundo lugar, a despeito de a atuação do Bund ser restrita às hipóteses admitidas pela própria Lei Fundamental, tal fato não impediu o reconhecimento de competências administrativas não escritas ao ente federal. Do mesmo modo que no campo

\footnotetext{
${ }^{731}$ BADURA. Staatsrecht, p. 693 e HERMES. Artikel 83. In: DREIER (Hrsg.). Grundgesetz, p. 26.

732 Como é ressaltado em BVerfGE 108, 169 (182).
} 
das competências legislativas, existem competências não escritas por força do contexto fático, competência anexa e competência por força da natureza da coisa. ${ }^{733}$ Os dois primeiros tipos não encerram maiores dificuldades, tendo em vista que se encontram ligadas a alguma competência federal prevista nos artigos 86 e seguintes GG. ${ }^{734}$ Já a competência não escrita por força da natureza da coisa suscita maiores discussões e tem sido reconhecida tão somente quando as finalidades previstas pela lei federal não puderem de modo algum serem alcançadas pela atuação administrativa estadual. ${ }^{735}$ Como ressalta Georg HERMES, o reconhecimento de uma competência não escrita ao Bund é limitada de três formas, quais sejam: (i) a unidade da execução da lei não pode ser alcançada por meio da cooperação entre os Länder; (ii) a unidade não pode ser obtida por meio dos mecanismos de influência do Bund previstos no artigo 84 III e 85 III GG, e; (iii) finalmente, a unidade não pode ser obtida pela aplicação do princípio da lealdade federal. ${ }^{736}$

Em terceiro lugar, ao contrário das competências legislativas - as quais consubstanciam uma faculdade conferida a um ou mais entes federativos, e cujo exercício se torna obrigatório apenas pelo influxo de outras normas constitucionais, como diretivas ou mandamentos constitucionais ${ }^{737}$ - a competência para a execução das leis federais é interpretada como um dever imposto aos Estados-membros da federação alemã. ${ }^{738}$ Esta diferença não deixa de causar algum estranhamento e sugere, pelo menos, que o caráter facultativo não é algo que pode ser afirmado em relação às competências como um todo. De todo modo, parece-nos que a facultatividade da competência legislativa se encontra intimamente relacionada com o fato de o seu objeto ser necessariamente o resultado de um processo político, o qual pode ser balizado, porém nunca exclusivamente determinado por regras jurídicas. Já a competência para a execução de uma lei tem por objeto uma atividade que é conformada e determinada por regras jurídicas, razão pela qual se falar em um dever jurídico de promover a execução de uma legislação é algo mais natural.

\footnotetext{
733 JARASS, PIEROTH. Grundgesetz, p. 901, HERMES. Artikel 83. In: DREIER (Hrsg.). Grundgesetz, pp. 24-25, TRUTE. Artikel 83. In: von MANGOLDT, KLEIN, STARCK (Hrsg.). Kommentare zum Grundgesetz, pp. 36-40.

734 JARASS, PIEROTH. Grundgesetz, p. 901.

735 BVerfGE 11, 6 (17).

736 HERMES. Artikel 83. In: DREIER (Hrsg.). Grundgesetz, p. 25.

737 RENGELING. § 135 - Gesetzgebungszuständigkeit. In: ISENSEE, KIRCHHOF (Hrsg.). Handbuch des Staatsrechts, p. 572.

738 JARASS, PIEROTH. Grundgesetz, p. 903, BADURA. Staatsrecht, p. 690, HERMES. Artikel 83. In: DREIER (Hrsg.). Grundgesetz, p. 23, OEBBECKE. \& 136 - Verwaltungszuständigkeit. In: ISENSEE, KIRCHHOF (Hrsg.). Handbuch des Staatsrechts, p. 747, TRUTE. Artikel 83. In: von MANGOLDT, KLEIN, STARCK (Hrsg.). Kommentare zum Grundgesetz, p. 35, DITTMANN. Artikel 83. In: SACHS (Hrsg.). Grundgesetz, p. 1691 e também BVerfGE 37, 363 (385).
} 
Finalmente, a execução de leis estaduais pela administração estadual encontra respaldo no artigo 30 GG e não no artigo 83 GG, sendo um assunto que é disciplinado primordialmente pelas constituições dos Länder. Como a presente tese se restringe à análise das normas da Lei Fundamental de 1949, trata-se de um assunto que não será abordado em um ponto específico. Contudo, é importante deixar consignado que se na federação alemã a legislação federal pode e normalmente é executada os Estados-membros, a recíproca não é válida: não é lícito ao Bund executar leis estaduais, consoante doutrina e jurisprudência constitucionais. $^{739}$

\subsection{A EXECUÇÃO DE LEIS FEDERAIS PELOS LÄNDER COMO ASSUNTO PRÓPRIO E SOB AS ORDENS DO BUND (ARTIGOS 84 A 85)}

A execução de leis federais pelos Länder, enunciada em termos gerais no artigo 83 GG, é detalhada em dois outros dispositivos constitucionais, que serão objeto de considerações mais detidas neste tópico. O primeiro deles, o artigo $84 \mathrm{GG}$, representa segundo doutrina majoritária uma concretização do artigo $83 \mathrm{GG}^{740}$. Já o artigo 85 GG prevê uma outra modalidade de execução, muito embora ainda se esteja diante de execução de lei federal pelos Länder. Comecemos a análise pelo artigo 84 GG, que é um dos dispositivos mais importantes para a compreensão do funcionamento do federalismo alemão sob uma perspectiva constitucional.

\subsubsection{A execução de leis federais pelos Länder como um assunto próprio (artigo 84)}

De acordo com o primeiro período do artigo 84 I GG, caso os Länder executem leis federais como assunto próprio, então eles regulamentarão a organização dos seus respectivos Behörden ${ }^{741}$ e o procedimento administrativo (Verwaltungsverfahren). O que é uma lei

\footnotetext{
739 BADURA. Staatsrecht, p. 699, HERMES. Artikel 83. In: DREIER (Hrsg.). Grundgesetz, p. 19.

${ }^{740}$ Como, por exemplo, OEBBECKE. § 136 Verwaltungszuständigkeit. In: ISENSEE, KIRCHHOF (Hrsg.). Handbuch des Staatsrechts, p. 751; Georg HERMES. Artikel 84. In: Horst DREIER (Hrsg). Grundgesetz - Kommentar. Band III: Artikel 83-146. 2a Ed. Tübingen: Mohr Siebeck, 2008, p. 44; Hans-Heinrich TRUTE. Artikel 84. In: Hermann von MANGOLDT, Friedrich KLEIN, Christian STARCK (Hrgs). Kommentare zum Grundgesetz. Band III: Artikel 83146. 6a Ed. Munique: Franz Vahlen, 2010, p. 47, e; Armin DITTMANN. Artikel 84 [Länderverwaltung und Bundesaufsicht]. In: Michael SACHS (Hrsg.). Grundgesetz - Kommentar. Munique: C. H. Beck, 2014, p. 1697.

741 Neste ponto cumpre fazer alguns esclarecimentos importantes sobre o sentido da palavra Behörde (ou Behörden, no plural). Nos dicionários jurídicos alemão-português consultados, ela é traduzida como "repartição", "autoridade" ou mesmo "poder" (Gerhard KÖBLER. Rechtsportugiesisch: Deutsch-portugiesisches und portugiesisch-deutsches Rechtswörterbuch für jedermann. Munique: Franz Vahlen, 2007, p.23 e JAYME, NEUSS. Wörterbuch Recht und Wirtschaft. Band 2, p. 37). Em obra dedicada aos fundamentos da tradução
} 
federal para fins deste dispositivo e quais as medidas compreendidas na sua execução são questões que já foram devidamente elucidadas no tópico anterior. A organização dos Behörden, como observa Janbernd OEBBECKE, corresponde às determinações no sentido de que devem existir em um dado lugar autoridades administrativas dotadas de determinadas competências materiais e locais e de uma estrutura administrativa específica. ${ }^{742}$ Organização aqui é tomada em um sentido amplo, a fim de englobar tanto a criação, quanto a organização propriamente dita e a atribuição de determinadas tarefas ou poderes, como bem ressalta Georg HERMES. ${ }^{743}$ Behörde (ou autoridade administrativa) também deve ser tomado em um sentido abrangente, próximo à vertente funcional do conceito. ${ }^{744}$ Já o procedimento administrativo, por sua vez, diz respeito às

\begin{abstract}
"determinações, as quais contêm o tipo e o modo, bem como a forma da execução de uma lei federal, portanto a formação da vontade, a preparação e a tomada de decisões, o trato com informações, direitos de participação e obrigações de cooperação, procedimento de controle, formas de atuação, a execução de decisões, bem como as regras sobre exclusão de pessoas de determinados procedimentos" 745
\end{abstract}

jurídica do alemão para o português, além da análise da estrutura administrativa alemã e portuguesa em uma perspectiva comparada, António Franciso de SOUZA entende que "Behörde pode ser, na maior parte das vezes, traduzido para a linguagem jurídico-administrativa portuguesa como 'autoridade administrativa'” (SOUZA. Fundamentos da tradução jurídica, p. 449). Porém, acredita-se que estas expressões portuguesas não apreendem as especificidades da realidade alemã às quais Behörde pretende se referir. Como explicam Hans Peter BULL e Veith MEHDE, Behörde é um termo equívoco e que pode ser compreendido em um sentido organizacional e em um sentido funcional. De um ponto de vista organizacional, Behörden são órgãos administrativos do Estado ou de suas subdivisões que atuam de forma autônoma, sob sua própria responsabilidade, como é o caso dos Municípios (que compõem a administração direta dos Estados) ou das pessoas que compõem a administração indireta alemã. Eles são compostos por Ämter, que nada mais são do que um agrupamento de Stellen, sendo estes últimos caracterizados como o "campo de atuação ou de tarefas que é atribuído a uma pessoa abstrata", ou seja, algo próximo da ideia brasileira de cargo público. Já de um ponto de vista funcional, mais amplo e que restou acolhido pela Lei Federal de Processo Administrativo no seu $\S 1$ 으. Behörde corresponde a todo Stelle que desempenha tarefas de direito administrativo (BULL, MEHDE. Allgemeines Verwaltungsrecht mit Verwaltungslehre, pp. 167 e 164). Tendo em vista a diversidade de sentidos em que esta expressão alemã pode ser empregada, optou-se por não traduzi-la no corpo do texto como regra geral, a fim de evitar confusões que uma tradução pouco acurada pode suscitar. Em certas passagens, opta-se pela expressão "autoridade", que é a mais empregada pela literatura especializada.

742 OEBBECKE. \& 136 Verwaltungszuständigkeit. In: ISENSEE, KIRCHHOF (Hrsg.). Handbuch des Staatsrechts, p. 752.

743 HERMES. Artikel 84. In: DREIER (Hrsg.). Grundgesetz, p. 52, neste ponto citando JARASS, PIEROTH. Grundgesetz, p. 906.

744 OEBBECKE. § 136 Verwaltungszuständigkeit. In: ISENSEE, KIRCHHOF (Hrsg.). Handbuch des Staatsrechts, p. 753, HERMES. Artikel 84. In: DREIER (Hrsg.). Grundgesetz, p. 52 e também JARASS, PIEROTH. Grundgesetz, p. 906. Sobre o sentido funcional de Behörde, vide nota de rodapé no 741.

745 OEBBECKE. § 136 Verwaltungszuständigkeit, p. 753. No original: "Bei der Regelung des Verwaltungsverfahrens geht es um Bestimmungen, welche, die Art und Weise sowie die Form der Ausführung eines Bundesgesetzes, also die Willensbildung, die Vorbereitung und das Zustandekommen von Entscheidungen, den Umgang mit Informationen, Mitwirkungsrechte und -pflichten, verwaltungsinterne Kontrollvorgänge, Handlungsformen, die Durchsetzung von Entscheidungen sowie die Regeln über den Ausschluss von Personen vom einzelnen Verfahren enthalten. "É de se ressaltar que esta definição corresponde, 
Neste ponto é importante atentar também para uma observação importante feita pela doutrina: a execução de leis federais pelos Länder como um assunto próprio compreende outros assuntos além da organização da sua própria estrutura administrativa e do procedimento administrativo. A Lei Fundamental de 1949 refere-se a elas de forma específica por duas razões bem simples. Em primeiro lugar, efetivamente se está diante de duas matérias que integram o cerne da execução da legislação federal pelos Estadosmembros. Em segundo lugar, a constituição alemã traça em relação a estes dois assuntos disposições específicas nos períodos seguintes do artigo 84 I GG, daí a necessidade da sua menção em um momento anterior, quando se está a tratar da regra geral. ${ }^{746}$

De acordo com a redação originária deste dispositivo, ao Bund era lícito legislar sobre organização dos Behörden e sobre o procedimento administrativo estaduais, desde que com aprovação do Conselho Federal. Em mais de uma oportunidade ponderou-se como esta norma - e, mais especificamente, uma especial interpretação a ela conferida pelo Tribunal Constitucional Federal alemão - importou em um aumento do número de leis que dependem da aprovação do Conselho Federal (Zustimmungsgesetze) e, consequentemente, em um aumento da importância desta instituição no processo legislativo federal. É chegado o momento de se debruçar sobre este argumento com maior calma. Parte-se, para tanto, da literalidade do artigo 84 I GG, o qual dispunha que "caso os Estado executem as leis federais como assunto próprio, eles regulam a organização dos Behörden e o procedimento administrativo, desde que lei federal com a aprovação do Conselho Federal não disponha de outro modo". Note-se que o que efetivamente determinava a necessidade de aprovação da instância representativa dos Estados era o fato de a lei federal tratar de organização e processo administrativo dos Estados; entretanto, o artigo 84 I GG falava na aprovação da "lei federal" pelo Conselho Federal e não dos artigos da lei federal que regulamentassem os temas referidos por este dispositivo constitucional, tão somente, o que lançou dúvidas sobre o que seria efetivamente o objeto da aprovação desta instância representativa dos Estadosmembros. O Tribunal Constitucional Federal alemão analisou esta questão em 1958, decidindo do seguinte modo:

\footnotetext{
"Mas se a lei federal que os Estados executam como assunto próprio regulamentar o procedimento administrativo das autoridades estaduais, então necessita a lei de acordo com o artigo 84 I GG como um todo a aprovação do Conselho Federal. Necessitam de aprovação não só as disposições individuais sobre o procedimento administrativo. A expressão 'lei federal' no final do artigo 84 I GG não significa - como, por exemplo, no artigo 100 I GG - a lei no sentido de uma norma isolada,
}

\footnotetext{
em grande parte, à forjada pelo Tribunal Constitucional Federal alemão para fins de interpretação do artigo 84 I GG em BVerfGE 55, 274 (320-321).

746 Nesse sentido OEBBECKE. § 136 Verwaltungszuständigkeit. In: ISENSEE, KIRCHHOF (Hrsg.). Handbuch des Staatsrechts, pp. 751-752 e HERMES. Artikel 84. In: DREIER (Hrsg.). Grundgesetz, pp. 46-47.
} 
mas a lei como unidade técnico-legislativa (...). Isto resulta sobretudo do artigo 78 GG. A 'lei deliberada no parlamento federal' (artigo $78 \mathrm{GG}$ ) é a lei que por meio de uma deliberação legislativa do Parlamento Federal é reunida em uma unidade. Esta lei somente existe conforme o artigo $78 \mathrm{GG}$, se o Conselho Federal a aprova, desde que a sua aprovação seja necessária de acordo com o artigo 84 I GG ou outro preceito da Lei Fundamental. Uma lei somente pode, no que diz respeito ao seu processo de formação, ser vista e ser tratada como um todo. Caso alguém visse como carente de aprovação somente as normas isoladas da lei sobre procedimento, isso então resultaria em dificuldades quase que incontornáveis no processo legislativo e na promulgação das leis. Finalmente, corresponde a uma atividade permanente do Parlamento Federal, do Conselho Federal e do Governo Federal ver a totalidade da lei como dependente da aprovação do Conselho Federal"747

Konrad HESSE, ao comentar esta decisão em 1962, considerou-a lógica e dotada de um automatismo peculiar. Segundo este autor, dentro de um contexto de Estado FederalUnitário, o Bund não poderia mais se contentar em apenas legislar sobre uma matéria; ao contrário, ele deveria garantir que a execução da sua legislação também se desse de forma uniforme em todo o território nacional. Isso, por sua vez, só poderia ser feito com a edição de normas federais sobre organização e procedimento administrativo, ainda que em prejuízo da autonomia administrativa dos Estados-membros. Surge então a necessidade de incluir o Conselho Federal nos mecanismos do Estado Federal-Unitário, dotando-o de poder de decisão inclusive sobre as disposições de direito material que, a princípio, não estariam incluídas na sua competência. Não por outro motivo, HESSE termina este argumento com a seguinte observação: “então a lógica interna está ao lado do Conselho. Ela é a lógica do Estado Federal-Unitário"748.

Percebe-se, portanto, que para este autor o aumento da importância política do Conselho Federal significou uma compensação dada aos Estados da federação alemã pela perda de algumas competências legislativas e administrativas que tradicionalmente

\footnotetext{
747 BVerfGE 8, 274 (294-295). No original: "Regelt aber ein Bundesgesetz, das die Länder als eigene Angelegenheit ausführen, das Verwaltungsverfahren der Landesbehörden, so bedarf nach Art. 84 Abs. 1 GG das Gesetz als Ganzes der Zustimmung des Bundesrates. Zustimmungsbedürftig ist nicht die einzelne Vorschrift über das Verwaltungsverfahren. Der Ausdruck,Bundesgesetz' am Ende von Art 84 Abs. 1 GG meint nicht - wie etwa Art. 100 Abs. 1 GG - das Gesetz im Sinne einer einzelnen Norm, sondern das Gesetz als gesetzgebungstechnische Einheit (...) Das folgt vor allem aus Art. 78 GG. Das ,vom Bundestage beschlossene Gesetz' (Art. 78 GG) ist das durch einen Gesetzesbeschluss des Bundestages zu einer Einheit zusammengefasste Gesetz. Dieses Gesetz kommt nach Art. 78 GG zur zustande, wenn der Bundesrat zustimmt, sofern nach Art. 84 Abs. 1 GG oder anderen Vorschriften des Grundgesetzes seine Zustimmung notwendig ist. Ein Gesetz kann, was den Vorgang seiner Entstehung angeht, nur als Ganzes gesehen und behandelt werden. Sähe man als zustimmungsbedürftig lediglich die einzelnen, das Verfahren regelnden Normen der Gesetze an, so würden sich kaum überwindbare Schwierigkeiten im Gesetzgebungsverfahren und bei der Verkündung der Gesetze ergeben. Es entspricht schließlich der ständigen Übung von Bundestag, Bundesrat und Bundesregierung, das ganze Gesetz als der Zustimmung des Bundesrates bedürftig anzusehen."

748 HESSE. Der unitarische Bundesstaat, p. 23. No original: "denn die innere Logik ist hier auf der Seite des Bundesrates. Sie ist die Logik des unitarischen Bundesstaates".
} 
compunham a sua autonomia federativa, conferindo um certo balanceamento ou equilíbrio ao federalismo alemão. ${ }^{749}$ Este raciocínio deve ser visto com algumas ressalvas, contudo.

Não se nega, por um lado, que existe uma relação entre o incremento de competências legislativas da União e o aumento do número de leis que dependem de aprovação do Conselho Federal. Como se teve a oportunidade de analisar nos itens anteriores, a maioria das competências legislativas previstas pela Lei Fundamental são concorrentes cumulativas, submetendo-se, portanto, aos condicionamentos previstos no artigo 72 GG. Em razão de uma interpretação peculiar conferida ao seu parágrafo segundo pelo BVerfG e também já discutida nos tópicos antecedentes, o Bund viu-se livre para legislar sobre as matérias arroladas no artigo 74 GG. Contudo, estas leis federais continuavam a ser executadas em sua maioria pelos Länder, tendo em vista que a Lei Fundamental utiliza critérios diversos ao repartir as competências legislativas e as competências administrativas. E quanto maior o número de leis federais executadas pelos Estados, maior a probabilidade de estas leis disciplinarem, ainda que conjuntamente com disposições de direito material, questões concernentes à estrutura administrativa e ao procedimento administrativo estaduais. Com efeito, por mais que se possa distinguir, em um plano teórico, o direito material - o qual é de competência do Bund de todo modo - das disposições concernentes ao procedimento administrativo que deve ser observado e aos Behörden responsáveis pela aplicação do direito material, o fato é que na prática estas categorias podem confundir-se. Além do mais, a constituição alemã não impunha limitação alguma à edição de leis federais sobre estas duas temáticas da administração pública estadual, conferindo ao Bund a simples faculdade de fazê-lo conforme seu juízo discricionário. Entretanto, como uma condição imposta ao exercício desta faculdade, a União deveria submeter toda as matérias disciplinada na lei federal à aprovação do Conselho Federal, inclusive aquelas matérias que, em tese, não necessitariam da aquiescência deste órgão. Consequentemente, cresceu a importância da instância representativa dos Estadosmembros alemães frente o Parlamento Federal. Este último, por sua vez, passou a lidar com os riscos e consequências de ver uma legislação votada por seus membros fracassar em razão da ausência de uma aquiescência, a qual a princípio sequer seria necessária de acordo com a literalidade da Lei Fundamental. ${ }^{750}$

\footnotetext{
749 Nesse mesmo sentido caminham as ponderações de POSSER. Significado del Bundesrat, p. 683.

${ }^{750}$ Como ressalta Willi BLÜMEL, o referido entendimento do Tribunal Constitucional Federal alemão teve como consequência a invalidade da lei que não tivesse obtido a aprovação do Bundesrat, mesmo quando esta contivesse apenas algumas poucas disposições sobre organização e procedimento administrativo dos Estados (Willi BLÜMEL. \& 101 Verwaltungszuständigkeit. In: Josef ISENSEE, Paul KIRCHHOF (Hrsg). Handbuch des
} 
Não se pode concordar, todavia, que este aumento da participação dos Estadosmembros no processo legislativo federal significou efetivamente uma compensação pela perda de competências legislativas importantes, por uma razão bem simples. O Conselho Federal é composto por representantes dos governos estaduais e, portanto, tende a representar os interesses dos Poderes Executivos estaduais. Não há representação dos poderes legislativos estaduais na órbita federal, como ocorreria se os representantes dos Estados-membros no âmbito federal fossem escolhidos por eleição indireta dentre os seus membros, por exemplo. Por isso, mesmo diante de um aumento de leis federais que necessitam da aprovação do Conselho Federal, os poderes legislativos estaduais permaneciam desprestigiados diante do esvaziamento da competência legislativa dos Länder, a qual restou irremediada até 1994, pelo menos. Admitir uma compensação entre a perda de competências legislativas estaduais pelo aumento da importância do Conselho Federal seria o mesmo que afirmar que os poderes legislativos estaduais seriam prestigiados pelo aumento da importância dos respectivos governos estaduais. Ora, isto não parece fazer sentido, além de ser pouco democrático: afinal, no Conselho Federal as discussões pautamse apenas indiretamente por premissas democráticas, ao passo que os poderes legislativos estaduais contam com representantes eleitos pelo povo e, por conseguinte, dotados de maior legitimidade democrática. ${ }^{751}$

Quando este dispositivo foi alterado pela Reforma do Federalismo I, de 2006, estava em foco o fortalecimento dos poderes legislativos estaduais e da política desenvolvida no plano estadual como um todo. A regulamentação da organização e do procedimento administrativos estaduais pelo Bund foi mantida, porém ela passou a se submeter a dois modelos distintos. No primeiro deles, denominado de modelo de divergência (Abweichungsmodell), à União é facultado legislar sobre estes dois temas sem a necessidade de aprovação do Conselho Federal; porém, aos Länder é conferida a possibilidade de editar regulamentação divergente da lei federal, aplicando-se em caso de colisão o critério da lei posterior. $^{752}$

Tal como na legislação concorrente de divergência prevista no artigo 72 III GG, é possível lançar críticas a este modelo. Em primeiro lugar, também aqui se verifica a

Staatsrechts der Bundesrepublik Deutschland. Band IV - Finanzverfassung - Bundesstaatliche Ordnung. 2a Ed. Heidelberg: C. F. Müller, 1999, p. 873).

751 Nesse mesmo sentido são as ponderações de HERMES. Artikel 84. In: DREIER (Hrsg.). Grundgesetz, pp. 4950.

752 Por aplicação do disposto no artigo 72 III GG, em especial, o seu terceiro período. É de se ressaltar que o artigo 84 I GG faz expressa referência à aplicação do artigo 72 III GG. 
possibilidade de se instaurar um verdadeiro "Ping-Pong" normativo ${ }^{753}$, no qual a União legisla, os Estados divergem, a União edita nova legislação, os Estados divergem novamente e assim por diante. Em uma hipótese como essa - que é possível, ao menos em tese, de acordo com a nova redação do artigo 84 I GG, ainda que não desejada - as relações jurídicas eventualmente disciplinadas por estas sucessivas legislações restariam seriamente prejudicadas diante da insegurança jurídica gerada. A fim de mitigar este problema, estabelece o terceiro período do artigo $84 \mathrm{I} \mathrm{GG} \mathrm{-} \mathrm{repetindo,} \mathrm{neste} \mathrm{ponto,} \mathrm{o} \mathrm{disposto} \mathrm{no}$ segundo período artigo 72 III GG - que a lei federal posterior à regulamentação estadual divergente entrará em vigor apenas seis meses após a sua publicação, desde que, com a aprovação do Conselho Federal, não se determine de outro modo. Imaginou-se que, por meio desta previsão, pelo menos os danos decorrentes da troca repentina de legislação seriam mitigados, além de conferir aos Estados a possibilidade de editar nova regulamentação divergente, barrando a eficácia da nova lei federal. ${ }^{754}$

Em segundo lugar, é questionável se este modelo efetivamente trará contribuições ao fortalecimento da política desenvolvida no plano estadual. Como ressalta Janbernd OEBBECKE, não é possível esperar uma concorrência federativa digna de menção no plano do procedimento e da organização administrativa dos Länder, sendo realista esperar somente uma diminuição do número de leis que dependem da aprovação do Conselho Federal. ${ }^{755}$ Georg HERMES, por outro lado, pondera que existem elementos suficientes a indicar que a nova redação do artigo 84 I GG representaria essencialmente um deslocamento de problemas antigos, pois as discussões sobre a regulamentação da organização dos Behörden e do procedimento administrativo do Estados, que antes se desenvolviam no âmbito da comissão de negociação do Bundestag e do Bundesrat, poderiam ser transferidas para uma negociação informal entre a União e os Estados que tendem a editar regulamentações divergentes. A única novidade efetivamente trazida pela Reforma do Federalismo I com significado real

\footnotetext{
753 A título de esclarecimento, "modelo Ping-Pong" ou "sistema Ping-Pong" são expressões utilizadas pela própria doutrina alemã.

754 HERMES. Artikel 84. In: DREIER (Hrsg.). Grundgesetz, p. 63. Como ressalta este autor, esta sistemática inaugurada pela nova redação do artigo 84 I GG pode conduzir a outras incertezas. Em especial, o prazo de seis meses, em tese, somente se aplica às leis federais que pretendem derrogar regulamentação estadual divergente. Caso mais de um Estado opte por divergir da legislação federal, surgirá a importante questão de saber a qual delas a nova lei federal se refere e, consequentemente, em qual Estado ela entrará em vigor apenas seis meses após a sua publicação. A fim de evitar este cenário, HERMES se posiciona no sentido de que o legislador federal deve descrever precisamente qual o Estado e qual a regulamentação estadual ele pretende derrogar (HERMES. Artikel 84. In: DREIER (Hrsg.). Grundgesetz, p. 63).

755 OEBBECKE. § 136 Verwaltungszuständigkeit. In: ISENSEE, KIRCHHOF (Hrsg.). Handbuch des Staatsrechts, pp. 756-757. Note-se que efetivamente se observou uma diminuição do número de Zustimmungsgesetze, conforme estatísticas discutidas no tópico 2.2.4.
} 
teria consistido na proibição de transferência de tarefas ao plano municipal por lei federal, pondo fim a uma prática muito criticada sob a égide da redação originária do artigo 84 I GG. ${ }^{756}$

É importante deixar claro que a edição de lei federal com a aprovação do Conselho Federal não restou absolutamente vedada na nova sistemática do artigo 84 I GG, mas foi relegada a um segundo e excepcional plano. ${ }^{757}$ De acordo com quinto período do artigo em questão, “a União pode, em casos excepcionais devido a uma necessidade especial de regulamentação federal uniforme, regulamentar o procedimento administrativo sem que haja possibilidade de regulamentação divergente dos Estados”. Como a lei federal em questão depende da aprovação do Conselho Federal, este segundo modelo foi denominado de modelo de aprovação (ou Zustimmungsmodell). Atente-se, contudo, que leis federais aprovadas segundo este segundo modelo somente podem versar sobre procedimento administrativo. Portanto, aos Länder é sempre facultado regulamentar a organização dos seus Behörden de forma divergente da legislação federal. ${ }^{758}$

De um modo geral, esta nova sistemática inaugurada pela nova redação do artigo 84 I GG trouxe um problema relevante no que tange à determinação do alcance das faculdades conferidas ao Bund e aos Länder. Como se expôs até o presente momento, ao primeiro compete legislar sobre organização dos Behörden e procedimento administrativo, em qualquer hipótese. Porém, é de se admitir que o direito de divergir dos Estados encontrase condicionado à delimitação destes dois temas, pois somente um deles - mais precisamente, a organização dos Behörden - não poderá ser restringido pelo recurso à aprovação do Conselho Federal. Aliás, cumpre precisar o sentido de procedimento administrativo, a fim de determinar a incidência do segundo modelo previsto pelo dispositivo em comento. Estas são observações importantes, sobretudo diante da dificuldade de separar na prática o direito material, este sempre de competência da União (pois se está diante da execução de leis federais pelos Estados), das disposições sobre a estrutura que será

\footnotetext{
756 HERMES. Artikel 84. In: DREIER (Hrsg.). Grundgesetz, pp. 38-39.

${ }^{757}$ Este caráter excepcional extrai-se não só do fato de o artigo 84 I GG dizer expressamente que somente em casos excepcionais o Bund poderá regulamentar o processo administrativo sem a possibilidade de divergência por parte dos Estados, mas também de a União estar limitada à "uma especial necessidade de regulamentação federal uniforme" (wegen eines besonderen Bedurfnisses nach bundeseinheitlicher Regelung") de acordo com este mesmo dispositivo.

758 OEBBECKE. § 136 Verwaltungszuständigkeit. In: ISENSEE, KIRCHHOF (Hrsg.). Handbuch des Staatsrechts, p. 755, HERMES. Artikel 84. In: DREIER (Hrsg.). Grundgesetz, p. 48, JARASS, PIEROTH. Grundgesetz, p. 909.
} 
responsável pela sua execução e procedimento que será adotado para tal, como já mencionado. ${ }^{759}$

Os demais parágrafos do artigo 84 GG tratam dos chamados direitos de ingerência (Ingerenzrechte) do Bund, os quais não foram alterados durante a vigência da Lei Fundamental de 1949. É de se ressaltar, em primeiro lugar, que estes direitos, por representarem uma invasão na competência administrativa estadual, restringem-se às hipóteses previstas no próprio texto constitucional. ${ }^{760}$ Em segundo lugar, eles podem consistir em uma supervisão federal (Bundesaufsicht) ou se manifestar por meio de instruções (Weisungen) acerca da execução da lei federal dirigidas aos governos estaduais sendo que algumas delas são mais abstratas, ao passo que outras referem-se a um caso concreto. Comecemos pela análise deste segundo grupo de direitos.

Nos termos do artigo 84 II GG, "o governo federal pode, com a aprovação do Conselho Federal, editar preceitos administrativos de caráter geral". Preceitos administrativos de caráter geral consistem, como ensina Janbernd OEBBECKE, em “instruções gerais, portanto, uma regulamentação abstrata, que em regra não é dirigida a eficácia jurídica exterior direta"761. Percebe-se, portanto, que são duas as principais características desta espécie normativa: em primeiro lugar, ela pretende normatizar uma quantidade indeterminada de fatos, possuindo um viés eminentemente abstrato; em segundo lugar, ela não possui, em regra, eficácia externa à Administração, muito embora se trate de uma norma juridicamente vinculante. ${ }^{762}$ A sua função primordial é, conforme observa Georg

759 Como bem ressalta Georg HERMES, as problemáticas que envolviam a delimitação do direito material e o
direito formal, que já existiam sob a égide da redação originária do artigo 84 I GG não teriam sido "resolvidas
pela nova concepção do artigo 84 I GG no âmbito da Reforma do Federalismo. Elas aparecem daqui em diante
somente sob 'nova roupagem': enquanto que a resposta para a pergunta de se a regulamentação apresenta
conteúdo material ou pertence ao direito da organização dos Behörden ou do procedimento administrativo,
até 2006 decidia somente a necessidade de aprovação das leis federais, decide ela hoje - ao lado da pergunta
que persiste sobre a necessidade de aprovação das leis federais de acordo com o artigo 84 I 6 GG - no âmbito
do modelo de divergência em primeiro lugar o alcance do direito de divergência dos Länder. Se, portanto, o
alcance do novo direito de divergência dos Länder como um elemento central da Reforma do Federalismo
depende de uma pergunta de delimitação não superável, como antes, tanto de um ponto de vista prático
quanto teórico, então devem ser procurados outros auxílios de orientação para a superação das questões
concretas de interpretação" (HERMES. Artikel 84 . In: DREIER (Hrsg.). Grundgesetz, pp. 56-57).
760 OEBBECKE. § 136 Verwaltungszuständigkeit. In: ISENSEE, KIRCHHOF (Hrsg.). Handbuch des Staatsrechts, p.
759 e também BLÜMEL. § 101 Verwaltungszuständigkeit, p. 879.
761 OEBBECKE. § 136 Verwaltungszuständigkeit. In: ISENSEE, KIRCHHOF (Hrsg.). Handbuch des Staatsrechts, p.
759. Note-se que, neste ponto, o referido autor propõe definição muito semelhante à forjada pelo BVerfGE
100,249 (258), à qual ele inclusive cita neste ponto de sua obra.
762 Estas duas características podem ser extraídas da definição forjada pelo Tribunal Constitucional Federal
alemão citada supra e são apontadas por autores que seguem o posicionamento desta corte, como JARASS,
PIEROTH. Grundgesetz, p. 910 e também OEBBECKE. 136 Verwaltungszuständigkeit. In: ISENSEE, KIRCHHOF
(Hrsg.). Handbuch des Staatsrechts, p. 759, embora a última delas seja relativizada em HERMES. Artikel 84 . In: 
HERMES, garantir uma execução uniforme da lei federal, neste ponto ancorando-se na jurisprudência do Tribunal Constitucional Federal alemão. ${ }^{763}$

Na prática, estes preceitos administrativos são manejados pelo Bund com certa frequência. Nesse sentido, Willi BLÜMEL ressalta que, até a décima legislatura, 703 preceitos foram encaminhados ao Conselho Federal, sendo que somente 4 deles foram rejeitados por esta instância. Janbernd OEBBECKE, por sua vez, pondera que estes preceitos, no mais das vezes, são vistos mais como uma ajuda do que como uma limitação. Os dois autores em questão chamam atenção para o fato de que a edição destes preceitos pela União pode ser substituída pela elaboração de um modelo a ser adotado pelos governos estaduais. $^{764}$

Mais difíceis de ocorrer na prática são as instruções individuais (Einzelweisungen) previstas no artigo $84 \mathrm{~V} \mathrm{GG},{ }^{765}$ as quais consistem em "ordens juridicamente vinculantes, que são editadas para um caso concreto de execução da lei, sem que sejam dirigidas a uma eficácia jurídica direta para o exterior". ${ }^{766}$ Quatro considerações importantes podem ser

DREIER (Hrsg.). Grundgesetz, p. 70. A referência à vinculação jurídica deste tipo de norma serve, por sua vez, para diferenciá-la das simples recomendações, as quais não se qualificam como preceitos administrativo de caráter geral. Nesse sentido, JARASS, PIEROTH. Grundgesetz, p. 910, neste ponto seguindo a jurisprudência do Tribunal Constitucional Federal alemão. Outros autores entendem que, embora o artigo 84 II GG de fato não trate de meras recomendações, ele também não as proíbe, como, por exemplo, HERMES. Artikel 84, pp. 7172 e TRUTE. Artikel 84. In: von MANGOLDT, KLEIN, STARCK (Hrsg.). Kommentare zum Grundgesetz, p. 73.

763 HERMES. Artikel 84. In: DREIER (Hrsg.). Grundgesetz, p. 69, referindo-se neste ponto ao BVerfGE 11, 6 (18). Em BLÜMEL. § 101 Verwaltungszuständigkeit, p. 879 também é possível encontrar referência a esta função dos preceitos administrativos de caráter geral.

764 BLÜMEL. § 101 Verwaltungszuständigkeit, pp. 879-880 e OEBBECKE. § 136 Verwaltungszuständigkeit. In: ISENSEE, KIRCHHOF (Hrsg.). Handbuch des Staatsrechts, p. 760. Apenas a título de esclarecimento, os números mencionados por Willi BLÜMEL referem-se à 10a legislatura do Parlamento Federal alemão (Bundestag), tendo em vista que o Conselho Federal, por ser um órgão permanente, não possui legislaturas. No sítio eletrônico do Conselho Federal é possível encontrar estes números atualizados, e também compará-los com o de outras espécies normativas que são apreciadas por este órgão federal alemão. Até 2013, ao Conselho Federal foram encaminhados 1041 preceitos administrativos gerais, sendo que apenas 9 deles não lograram obter aprovação nesta instância. Para maiores detalhes, vide http://www.bundesrat.de/SharedDocs/downloads/DE/statistik/gesamtstatistik.pdf?_blob=publicationFile\&v =3. Acesso: 11/09/2015.

765 Nesse sentido BLÜMEL. § 101 Verwaltungszuständigkeit, p. 876 e OEBBECKE. $\S 136$ Verwaltungszuständigkeit. In: ISENSEE, KIRCHHOF (Hrsg.). Handbuch des Staatsrechts, p. 760. Ao contrário do que ocorre com os preceitos administrativos de caráter geral, não é possível verificar a frequência com que estas instruções individuais são submetidas ao Conselho Federal porque referida instância não fornece dados estatísticos a este respeito.

766 TRUTE. Artikel 84. In: von MANGOLDT, KLEIN, STARCK (Hrsg.). Kommentare zum Grundgesetz, p. 75. No original: "Bei den Einzelweisungen handelt es sich um für die Adressaten in den Ländern rechtsverbindliche Anordnungen, die für einen konkreten Sachverhalt des Gesetzesvollzugs ergehen, ohne auf unmittelbare Rechtswirkungen nach außen gerichtet zu sein. "Neste mesmo sentido caminham as definições propostas por JARASS, PIEROTH. Grundgesetz, p. 910, BLÜMEL. \& 101 Verwaltungszuständigkeit, p. 877 e HERMES. Artikel 84. In: DREIER (Hrsg.). Grundgesetz, p. 74. 
extraídas desta definição. Em primeiro lugar, as instruções são ordens, vale dizer, preceitos juridicamente vinculantes, de observância obrigatória pelos seus destinatários, que são as mais altas autoridades administrativas dos Estados (oberste Landesbehörden) nos termos do artigo $84 \mathrm{~V} \mathrm{GG.}{ }^{767} \mathrm{Em}$ segundo lugar, elas devem ter por objeto, como o próprio nome sugere, uma situação individual, diferenciando-se neste ponto dos preceitos administrativos de caráter geral, os quais se dirigem, também por definição, a um número indeterminado e abstrato de casos. Em terceiro lugar, este caso específico deve se originar da execução de uma lei federal pelos Estados. Como bem ressalta Hans-Heinrich TRUTE, a previsão do artigo 84 V GG não encerra uma autorização geral ao Bund de dar instruções específicas aos Estados-membros em qualquer assunto, mas somente em relação aos casos específicos que vem a surgir durante a execução da legislação federal. ${ }^{768}$ Em quarto e último lugar, tendo em vista que a eficácia destas instruções se restringem à esfera da Administração, elas não criam direitos ou deveres para terceiros. Não poderia ser de outro modo, afinal, o destinatário da instrução é a administração estadual, sendo que é esta última quem será efetivamente responsável por editar o ato administrativo que produzirá efeitos na esfera jurídica de terceiros. Note-se que, a rigor, a instrução não se qualifica como um ato administrativo, como ressalta Willi BLÜMEL. 769

Já a supervisão federal (Bundesaufsicht), que corresponde à segunda modalidade de direitos de ingerência do Bund, vem regulada nos parágrafos terceiro e quarto do artigo 84 GG. Trata-se de um instituto sem maiores repercussões práticas, segundo a doutrina consultada, sobretudo diante da importância que a proteção de direitos subjetivos e o controle da atuação administrativa estadual assumiram. Também se menciona a tendência de substituir o procedimento previsto pela constituição para a supervisão por mecanismos informais de harmonização como um fator que contribui para que a supervisão federal seja tão difícil de se verificar na prática. ${ }^{770}$ De todo modo, como o tema vem regulamentado em dois parágrafos relativamente extensos do artigo 84 GG, considera-se impossível não tecer algumas considerações sobre ele.

Nos termos do primeiro período do artigo 84 III GG, "o governo federal exerce a supervisão se os Estados executam a lei federal de acordo com o direito vigente". Note-se,

\footnotetext{
${ }^{767}$ Contudo, estas instruções poderão ser dirigidas a autoridades administrativas estaduais inferiores em casos urgentes, segundo juízo do governo federal.

768 TRUTE. Artikel 84. In: von MANGOLDT, KLEIN, STARCK (Hrsg.). Kommentare zum Grundgesetz, p. 75.

769 BLÜMEL. \& 101 Verwaltungszuständigkeit, p. 877.

770 OEBBECKE. § 136 Verwaltungszuständigkeit, pp. 761-762. In: ISENSEE, KIRCHHOF (Hrsg.). Handbuch des Staatsrechts, BLÜMEL. § 101 Verwaltungszuständigkeit, p. 881 e HERMES. Artikel 84. In: DREIER (Hrsg.). Grundgesetz, p. 76.
} 
portanto, que esta atividade de supervisão só pode dar em um contexto de execução de lei federal, na acepção que se costuma emprestar a esta expressão e que foi devidamente elucidada no tópico anterior. Neste ponto, a doutrina consultada costuma afirmar que se trata de uma supervisão acessória à lei federal, remetendo-se ao pensamento de Heinrich TRIEPEL. ${ }^{771}$ Além do mais, esta atividade de supervisão consiste na verificação da conformidade de atuação estadual ao Direito. Estamos diante, portanto, de uma mera supervisão jurídica (reine Rechtsaufsicht), que tem como parâmetro tanto o direito federal escrito e não escrito, quanto o direito internacional e o direito comunitário. ${ }^{772}$

Nos períodos seguintes do artigo 84 III e também no artigo 84 IV, a Lei Fundamental dedica-se a descrever como se dará esta supervisão, sendo possível diferenciar entre medidas destinadas à obtenção de informações, de viés preparatório, e medidas que realizam propriamente a supervisão. ${ }^{773}$ Nesse sentido, dispõe o segundo período do artigo 84 III que o governo federal pode, com a finalidade de viabilizar a supervisão "enviar delegados para as mais altas autoridades estaduais, com o seu consentimento, e caso este consentimento seja denegado, mediante consentimento do Conselho Federal, também para junto das autoridades inferiores". Estes delegados, por sua vez, funcionam como órgãos do governo federal e são responsáveis justamente por obter as informações pertinentes. Existe alguma controvérsia sobre os poderes destes delegados, vale dizer, se abrange o direito de consultar autos ou de exigir relatórios. ${ }^{774}$

771 BADURA. Staatsrecht, p. 690, JARASS, PIEROTH. Grundgesetz, p. 911, BLÜMEL. $\oint 101$ Verwaltungszuständigkeit, p. 882, OEBBECKE. § 136 Verwaltungszuständigkeit. In: ISENSEE, KIRCHHOF (Hrsg.). Handbuch des Staatsrechts, p. 762, HERMES. Artikel 84. In: DREIER (Hrsg.). Grundgesetz, p. 76 e TRUTE. Artikel 84. In: von MANGOLDT, KLEIN, STARCK (Hrsg.). Kommentare zum Grundgesetz, p. 76. A referência à obra de Heinrich TRIEPEL (mais especificamente, à obra intitulada "Die Reichaufsicht") pode ser encontrada nos comentários feitos por BADURA, BLÜMEL e TRUTE. BADURA, no trecho supracitado, traça breves comentários sobre a dicotomia forjada por TRIEPEL.

772 JARASS, PIEROTH. Grundgesetz, p. 911, OEBBECKE. § 136 Verwaltungszuständigkeit. In: ISENSEE, KIRCHHOF (Hrsg.). Handbuch des Staatsrechts, p. 762, HERMES. Artikel 84. In: DREIER (Hrsg.). Grundgesetz, p. 77 e TRUTE. Artikel 84. In: von MANGOLDT, KLEIN, STARCK (Hrsg.). Kommentare zum Grundgesetz, p. 77. Neste ponto, é importante relatar uma certa divergência doutrinária. Todos os autores consultados concordam que o direito federal seja parâmetro do controle, sendo que o mesmo se repete em relação ao direito internacional e comunitário, sendo que em relação a este último entendem que a matéria regulamentada pelo direito comunitário deve estar inserida na competência legislativa da União (nesse sentido HERMES e TRUTE, supracitados). JARASS, PIEROTH entendem, por sua vez, que funcionam como medida da supervisão jurídica também as instruções gerais e específicas previstas no artigo 84 II e V GG (neste ponto, seguidos por OEBBECKE e HERMES), mas não o direito estadual. Autores com um posicionamento mais tradicional, todavia, costumam incluir o direito estadual, inclusive o direito constitucional estadual, como parâmetro do controle (nesse sentido BLÜMEL. § 101 Verwaltungszuständigkeit, p. 883 e também BADURA. Staatsrecht, p. 691).

773 Como propõe HERMES. Artikel 84. In: DREIER (Hrsg.). Grundgesetz, p. 78

${ }^{774}$ Nesse sentido, vide as ponderações de OEBBECKE. § 136 Verwaltungszuständigkeit. In: ISENSEE, KIRCHHOF (Hrsg.). Handbuch des Staatsrechts, p. 763 e HERMES. Artikel 84. In: DREIER (Hrsg.). Grundgesetz, pp. 78-79. 
O parágrafo quarto do artigo 84 GG trata do procedimento de supervisão propriamente dito, que se inicia com a constatação por parte do governo federal de que existem falhas na execução de leis federais pelos Estados-membros alemães. Nesta hipótese, a Lei Fundamental prevê um procedimento, que é bem resumido por Georg HERMES no seguinte trecho:

\begin{abstract}
“(...) caso o Estado elimine a falha que foi objeto de censura, termina o procedimento da supervisão federal. Caso, ao contrário, o Estado considere a repreensão pela falha infundada e não corrija a falha censurada pelo governo federal, podem os dois envolvidos solicitar que o Conselho Federal declare formalmente, se o Estado violou o direito (...) Caso o Conselho Federal não conste nenhuma falha ou caso ele não siga o requerimento do governo federal em toda a sua extensão, este pode tanto invocar o Tribunal Constitucional Federal conforme artigo 84 IV 2 GG ou tomar para si a conclusão do Conselho Federal e deixar a questão assentar-se por si. Neste caso o procedimento é terminado. Caso, ao contrário, o Conselho Federal constate a falha censurada pelo governo federal, três possibilidades para a continuidade do procedimento são consideradas: se o Estado elimina completamente a falha, o procedimento é terminado. A segunda possibilidade consiste no Estado invocar o Tribunal Constitucional Federal conforme artigo 84 IV 2 GG. Caso o Estado não elimine a falha e não invoque o Tribunal Constitucional Federal, fica à disposição do governo federal o meio da coação federal conforme o artigo 37 GG bem como a possibilidade de invocar, de sua parte, o Tribunal Constitucional Federal no âmbito do procedimento de acordo com o artigo 93 I Nr. 3 GG." $" 775$
\end{abstract}

\title{
5.5.2. A execução de leis federais pelos Länder sob as ordens do Bund (artigo 85)
}

A execução de leis federais pelos Estados também pode se dar por delegação ou sob as ordens (im Auftrag) do Bund, nos termos do artigo 85 GG. Fala-se em delegação porque esta é a terminologia empregada por autores que traduzem este dispositivo da constituição alemã para o francês e para o português ${ }^{776}$. Acredita-se, contudo, que esta é uma terminologia que deve ser evitada, pois pode ensejar alguns equívocos. Delegação, em um

\footnotetext{
775 HERMES. Artikel 84. In: DREIER (Hrsg.). Grundgesetz, pp. 79-80. No original: “(..) Beseitigt das Land den gerügten Mangel, ist das Verfahren der Bundesaufsicht beendet. Hält das Land die Mängelrüge dagegen für unbegründet und beseitigt es den von der Bundesregierung gerügten Mangel nicht, können beide Beteiligte beantragen, dass der Bundesrat förmlich feststelle, ob das Land das Recht verletzt hat (...) Stellt der Bundesrat keinen Mangel fest oder folgt er dem Antrag der Bundesregierung nicht in vollem Umfang, kann die entweder gem. Art. 84 IV 2 GG das Bundesverfassungsgericht anrufen oder sich die Feststellung des Bundesrates zu eigen machen und die Sache auf sich beruhen lassen. In diesem Fall ist das Verfahren beendet. Bestätigt dagegen der Bundesrat den von der Bundesregierung gerügten Mangel, kommen für den Fortgang des Verfahrens drei Möglichkeiten in Betracht: Wenn das Land den Mangel vollständig beseitigt, ist das Verfahren beendet. Die zweite Möglichkeit besteht darin, dass das Land gem. Art. 84 IV 2 GG das Bundesverfassungsgericht anrufen. Beseitigt das Land den Mangel nicht, ohne das Bundesverfassungsgericht anzurufen, steht der Bundesregierung das Mittel des Bundeszwangs nach Art. 37 GG sowie die Möglichkeit zu Gebote, ihrerseits das Bundesverfassungsgericht im Rahmen des Verfahrens nach Art. 93 I Nr. 3 GG anzurufen."

776 Cita-se, a título exemplificativo, a tradução da Lei Fundamental de 1949 do alemão para o francês, disponível no seguinte sítio eletrônico: http://www.bijus.eu/?p=9663. Acesso: 09/03/2016.
} 
sentido técnico-jurídico, remete ao exercício de uma competência por uma pessoa distinta do seu titular, sem que se possa falar, todavia, em transferência de titularidade. $\mathrm{O}$ artigo 85 GG, por sua vez, não prevê uma hipótese de Estados atuando por delegação da União, mas sim de Estados exercendo competências que são suas por expressa previsão constitucional, como um assunto que lhes é próprio nos termos do artigo 83 GG. O grande diferencial em relação à sistemática estabelecida pelos artigos 83 e 84 GG consiste em uma maior interferência do Bund na atividade de execução da lei, o que acaba conferindo a esta modalidade um caráter excepcional, restrito às hipóteses determinadas ou permitidas pela própria Lei Fundamental. ${ }^{777}$ Nesse sentido, aliás, é que se fala em administração obrigatória por ordem da União (obligatorische Bundesauftragverwaltung) - nas hipóteses em que a Lei Fundamental efetivamente determina a sua criação e que estão consignadas nos artigos 90 II, 104a III e 108 III GG - e administração facultativa por ordem da União - nos casos em que a Lei Fundamental simplesmente faculta a sua criação, e que estão previstas nos artigos $87 \mathrm{~b}$ II, 87c, 87d II, 89 II e IV, 120a I GG. ${ }^{778}$

Durante a vigência da Lei Fundamental de 1949, o artigo 85 GG foi pouco alterado. Somente em 2006 se incluiu, até por um certo paralelismo com o artigo 84 GG, a proibição de a União transferir tarefas e atribuições diretamente aos Municípios. A despeito disso, não se pode deixar de notar um aumento da importância deste instituto sob a égide da Lei de Bonn, o que se deu basicamente por meio de uma ampliação das matérias submetidas à sistemática do artigo 85 GG. ${ }^{779}$ Com efeito, a administração (estadual) sob as ordens do Bund foi concebida com um instituto de aplicabilidade restrita a apenas algumas hipóteses. Contudo, já em 1952 a Lei Fundamental foi alterada para prever a instituição de

\footnotetext{
777 Neste sentido caminham as ponderações de BLÜMEL. § 101 Verwaltungszuständigkeit, p. 887, OEBBECKE. $\S 136$ Verwaltungszuständigkeit. In: ISENSEE, KIRCHHOF (Hrsg.). Handbuch des Staatsrechts, pp. 766-767, Georg HERMES. Artikel 85. In: Horst DREIER (Hrsg). Grundgesetz - Kommentar. Band III: Artikel 83-146. 2a Ed. Tübingen: Mohr Siebeck, 2008, p. 93, e; Hans-Heinrich TRUTE. Artikel 85. In: Hermann von MANGOLDT, Friedrich KLEIN, Christian STARCK (Hrgs). Kommentare zum Grundgesetz. Band III: Artikel 83-146. 6a Ed. Munique: Franz Vahlen, 2010, pp. 88. A doutrina consultada, neste ponto, costuma se referir a uma polêmica doutrinária sobre a natureza jurídica desta modalidade de execução de lei federal pelos Estados, mencionando posicionamentos no sentido de que ela consubstanciaria uma competência da União ou mesmo uma competência que seria comum à União e aos Estados-membros. Porém, prevaleceu o entendimento de que se trata de uma competência de titularidade dos Länder e exercida como um assunto que lhes é próprio, tendo inclusive o Tribunal Constitucional Federal decidido já esposado este entendimento no seguinte trecho: "auch diese sogenannte Auftragsverwaltung ist eine Form der Landesverwaltung; die Länder üben hierbei Landesstaatsgewalt aus, ihre Behörden handeln als Landesorgane, nicht als Bundesorgane. Das folgt ebenso aus dem Wortlaut des Art. 85 Abs. 1 GG wie aus der Systematik des 8. Abschnitts des Grundgesetzes, der der bundeseigenen Verwaltung (Art. 86) zwei Formen der Landesverwaltung voranstellt, nämlich die Ausführung der Bundesgesetze durch die Länder im Auftrag des Bundes" (BVerfGE 81, 330, (331)).

778 Distinção que é trabalhada pela maioria dos autores citados na nota de rodapé anterior. Por todos, cita-se TRUTE. Artikel 85. In: von MANGOLDT, KLEIN, STARCK (Hrsg.). Kommentare zum Grundgesetz, p. 86.

779 TRUTE. Artikel 85. In: von MANGOLDT, KLEIN, STARCK (Hrsg.). Kommentare zum Grundgesetz, p. 87.
} 
administração sob as ordens da União em relação à compensação dos encargos (Lastenausgleich); quatro anos depois, foi a vez da administração da defesa (Verteidigungsverwaltung) ser incluída no rol de matérias submetidas a esta modalidade de administração estadual; antes do fim da década de 1950, em 1959, novamente a constituição alemã foi alterada neste ponto, a fim de também submeter a energia nuclear à administração estadual sob as ordens do Bund. Em 1961, incluiu-se a administração do tráfego aéreo e, finalmente, em 1969, a administração fiscal e o pagamento de benefícios foram incluídos no rol de matérias em relação às quais facultada a criação de administração estadual sob as ordens da União. ${ }^{780}$

Em comparação com a regra geral prevista no artigo 83 GG e concretizada no artigo 84 GG, é de se admitir que o artigo 85 GG, de fato, tem o seu âmbito de aplicação restrito a algumas poucas matérias. Entretanto, são matérias de grande repercussão e, consequentemente, marcadas por um forte interesse federal. Neste sentido, como pondera Georg HERMES, matérias importantes submetidas à sistemática do artigo 85 GG dizem respeito à infraestrutura de larga-escala, de grande significado para a integração social, política e econômica da Alemanha. É o caso, por exemplo, da administração do tráfego aéreo e das rodovias federais ou mesmo da energia nuclear. Outras áreas, como por exemplo, a defesa, inclusive a proteção da população civil, revelam também um interesse que transcende os limites territoriais de um Estado específico. Em todos estes casos, embora o interesse federal seja patente, não se pode prescindir da proximidade que as administrações estaduais normalmente têm dos fatos e também dos cidadãos. Por isso, a execução da legislação federal sobre estes temas também é levada a cabo pelas administrações estaduais; porém, à União são conferidos instrumentos mais eficazes para interferir na atuação dos Länder. $^{781}$

Feitas estas considerações, parte-se para a análise das disposições contidas no artigo $85 \mathrm{GG}$, as quais de certo modo correspondem a variações da disciplina contida no artigo 84 GG, razão pela qual comparações e referências tornam-se inevitáveis.

Em primeiro lugar, dispõe o parágrafo primeiro do artigo 85 GG que "caso os Estados executem leis federais sob as ordens da União, a organização dos Behörden permanece assunto dos Estados, desde que lei federal com a aprovação do Conselho Federal

\footnotetext{
780 Cronologia de alterações constitucionais elaborada por BLÜMEL. § 101 Verwaltungszuständigkeit, pp. 885886.

781 HERMES. Artikel 85. In: DREIER (Hrsg.). Grundgesetz, p. 91. Cumpre ressaltar que, dentre as matérias supramencionadas, certamente a energia nuclear é a de maior relevância prática em virtude dos debates que costuma suscitar. Como ressalta Janbernd OEBBECKE, de sete decisões proferidas pelo Tribunal Constitucional Federal alemão entre 1990 e 2002 sobre administração estadual sob as ordens do Bund, quatro diziam respeito a este tema (§ 136 Verwaltungszuständigkeit, p. 767).
} 
não disponha de outro modo". Note-se, portanto, que este dispositivo continua a incorporar o modelo de aprovação do Conselho Federal (Zustimmungsmodell), com todos os desdobramentos que lhe são ínsitos. Além do mais, é importante ressaltar que, embora o artigo 85 GG seja silente em relação ao procedimento administrativo, prevalece o entendimento, tanto na doutrina quanto na jurisprudência, de que se trata de um mero erro redacional. Portanto, à União é lícito legislar tanto sobre organização dos Behörden quanto sobre procedimento administrativo estaduais. ${ }^{782}$

Em segundo lugar, da mesma forma que ocorre no artigo 84 II GG, o artigo 85 II GG confere ao governo federal a faculdade de editar preceitos administrativos de caráter geral, vale dizer, instruções gerais sobre a execução das leis federais, com eficácia restrita, ao menos em tese, ao âmbito interno da Administração. Além do mais, o parágrafo segundo do artigo 85 GG também prevê a possibilidade de o governo federal regulamentar a formação uniforme dos servidores públicos e empregados (einheitliche Ausbidung der Beamten und Angestellten), sendo que formação, neste contexto, deve ser entendida como formação educacional ou profissional. De acordo com este mesmo dispositivo, os diretores dos Behörden situados no meio da estrutura administrativa dos Estados devem ser nomeados com o consentimento do Bund. Estas duas últimas previsões possibilitam ao governo federal exercer influência inclusive sobre questões de pessoal, muito embora a primeira delas tenha uma importância prática limitada. ${ }^{783}$

O parágrafo terceiro do artigo $85 \mathrm{GG}$, por sua vez, dispõe que "as autoridades estaduais permanecem sob as ordens das mais altas autoridades federais. As instruções devem, exceto se o governo considerar o caso urgente, ser dirigidas às mais altas autoridades

\footnotetext{
782 No sentido de que o procedimento administrativo estadual figuraria entre as matérias sobre as quais o Bund pode legislar, vide TRUTE. Artikel 85. In: von MANGOLDT, KLEIN, STARCK (Hrsg.). Kommentare zum Grundgesetz, p. 92, HERMES. Artikel 85. In: DREIER (Hrsg.). Grundgesetz, p. 101, OEBBECKE. $\& 136$ Verwaltungszuständigkeit. In: ISENSEE, KIRCHHOF (Hrsg.). Handbuch des Staatsrechts, p. 768 e também BLÜMEL. § 101 Verwaltungszuständigkeit, p. 889. Na jurisprudência do Tribunal Constitucional Federal alemão parece ser pacífica esta mesma orientação, como pode ser conferido no BVerfGE 26, 338 (385). Quanto à questão de saber se a regulamentação federal sobre a necessidade de aprovação do Conselho Federal, a doutrina parece se dividir (em posições opostas, vide HERMES. Artikel 85. In: DREIER (Hrsg.). Grundgesetz, p. 102 e TRUTE. Artikel 85. In: von MANGOLDT, KLEIN, STARCK (Hrsg.). Kommentare zum Grundgesetz, p. 92). A corte constitucional alemã, por sua vez, possui entendimento de que somente lei federal sobre organização dos Behörden necessitam de aprovação do Conselho Federal, retirando o procedimento administrativo das matérias que necessitam do consentimento deste órgão federal (nesse sentido, BVerfGE 126, 77, (98)).

${ }^{783}$ Como ressalta Hans-Heinrich TRUTE, a União pode editar regulamentação sobre servidores públicos em geral e também sobre outras atividades que são executadas pelos Estados sob as ordens invocando fundamento constitucional diverso e sem submeter, portanto, às limitações do artigo 85 II GG (TRUTE. Artikel 85. In: von MANGOLDT, KLEIN, STARCK (Hrsg.). Kommentare zum Grundgesetz, p. 95). Deve-se ressaltar que esta influência do Bund sobre a formação dos servidores estaduais deve se restringir àqueles que exercem atividade administrativa sujeita à sistemática do artigo 85 GG e exercem poderes decisórios de forma independente (como ressalta HERMES. Artikel 85. In: DREIER (Hrsg.). Grundgesetz, p. 104).
} 
da administração estadual". Ou seja, também esta modalidade de administração estadual poderá ser conformada por instruções individuais oriundas do Bund. Contudo, é de admitir que existem diferenças marcantes entre as previsões do artigo $84 \mathrm{~V} \mathrm{GG}$ e do artigo 85 III GG. Enquanto que no primeiro deles a faculdade de dar instruções isoladas deve ser prevista em lei federal que necessita da aprovação do Conselho Federal, no segundo deles o poder de dar instruções é conferido pelo no próprio texto constitucional e nele encontra seu fundamento. Além do mais, enquanto que no artigo $84 \mathrm{~V} \mathrm{GG}$ as instruções devem ser proferidas pelo governo federal de forma colegiada, o artigo 85 III GG confere este poder ao Ministro competente, sem que haja necessidade de uma decisão colegiada. ${ }^{784}$ Há que ressaltar ainda uma distinção relevante no que tange ao escopo das instruções nestes dois dispositivos: ao passo que no artigo $84 \mathrm{~V}$ elas devem se restringir a casos especiais, dentro da sistemática estabelecida pelo artigo 85 GG as instruções consistem, de acordo com o Tribunal Constitucional Federal alemão, um meio regular pelo qual o Bund consegue impor o interesse comum na hipótese de divergência de opiniões ${ }^{785}$, sem a necessidade de invocar argumentos no sentido de sua necessidade ou conveniência.

Diante de todo o exposto, percebe-se que, sob a égide do artigo 85 GG é mais fácil - e também mais frequente - que o governo federal condicione a atuação dos Länder às suas instruções, o que faz com que o artigo 85 III GG suscite maiores polêmicas. Não se pretende adentrar em todas elas, mesmo porque este tipo de análise não se compatibiliza com o estudo que se pretende levar a cabo neste capítulo, destinado à exposição das linhas gerais da repartição de competências na Alemanha. Mas convém retomar neste ponto uma construção teórica interessante forjada pelo Tribunal Constitucional Federal alemão no intuito de distinguir e delimitar as atribuições federais e estaduais quando uma instrução é editada. Esta corte fala em competências materiais de execução (Wahrnehmungskompetenzen) e competências materiais (Sachkompetenzen). As primeiras consistiriam "no agir e na responsabilidade para fora, exercida contra terceiros", e não poderiam em hipótese nenhuma ser retirada dos Estados-membros alemães. ${ }^{786}$ Já as segundas corresponderiam ao poder de julgamento ou de decisão sob um determinado contexto fático, e estariam situadas em um primeiro momento na esfera jurídica dos Länder. Porém, em determinadas situações, o Bund

\footnotetext{
${ }^{784}$ As características das instruções isoladas previstas no artigo $84 \mathrm{~V}$ e 85 III GG e que foram confrontadas neste trecho são comentadas, entre outros, por OEBBECKE. \& 136 Verwaltungszuständigkeit. In: ISENSEE, KIRCHHOF (Hrsg.). Handbuch des Staatsrechts, pp. 760 e 768-769. A título de esclarecimento, o governo federal enquanto colégio é uma referência ao artigo 62 GG, segundo o qual "o governo federal é composto pelo chanceler federal e pelos ministros federais".

785 BVerfGE 81, 310 (332).

786 BVerfGE 81, 310 (332).
} 
poderia tomar este poder de decisão para si, e o instrumento hábil para tanto é o direito de dar instruções (Weisungsrecht). ${ }^{787}$ Não é por outro motivo, aliás, que a instrução é definida em sede doutrinária como "o instrumento, com a ajuda do qual o Ministro federal competente, como a mais alta autoridade federal, chama para si a competência de julgamento e pode exercê-la regular e simultaneamente ligada a um caso individual concreto"788 É de se ressaltar ainda que esta competência, conforme jurisprudência do Tribunal Constitucional Federal alemão, estende-se sobre toda a atividade de execução da lei federal, ${ }^{789}$ o que somada às considerações supra, dá uma percepção suficiente do alcance deste instrumento que é colocado à disposição do governo federal alemão.

Finalmente, o artigo 85 IV GG trata da supervisão federal, a qual abrange não só análise da conformidade à lei, mas também a conveniência da execução. Note-se, além do mais, que os instrumentos conferidos ao governo federal para obter as informações necessárias são mais amplos do que aqueles previstos no artigo 84 III GG. Enquanto que este menciona somente o envio de delegados aos mais altos Behörden estaduais, o artigo 85 IV GG permite o envio destes delegados a todos os Behörden estaduais, e faculta ao governo federal a solicitação de relatórios e a apresentação de documentos. ${ }^{790}$

\subsection{A COMPETÊNCIA ADMINISTRATIVA DA UNIÃO (ARTIGOS 86 E SEGUINTES)}

No tópico 5.4 analisou-se como o artigo 83 GG consagra uma dupla relação de regra-exceção a favor dos Länder, em primeiro lugar, ao conferir-lhes uma competência residual relevante, autorizando a atuação por parte do Bund somente nas hipóteses constitucionalmente enumeradas e, em segundo lugar, ao estabelecer a administração estadual própria como a forma de execução preferencial de execução das leis federais, devendo as demais formas serem previstas ou autorizadas pela Lei Fundamental. No próprio

\footnotetext{
787 BVerfGE 104, 249 (264-265). O mesmo argumento já havia sido desenvolvido em BVerfGE 81, 310 (332). Note-se que esta distinção entre competência de execução e competência de julgamento é referida por toda a literatura consultada, como por exemplo, BADURA. Staatsrecht, p. 693, OEBBECKE. § 136 Verwaltungszuständigkeit. In: ISENSEE, KIRCHHOF (Hrsg.). Handbuch des Staatsrechts, p. 767, HERMES. Artikel 85. In: DREIER (Hrsg.). Grundgesetz, pp. 94-95, TRUTE. Artikel 85. In: von MANGOLDT, KLEIN, STARCK (Hrsg.). Kommentare zum Grundgesetz, p. 89 e HEITSCH. Die Ausführung der Bundesgesetze durch die Länder, p. 249. 788 HERMES. Artikel 85. In: DREIER (Hrsg.). Grundgesetz, p. 106. No original: "Die Weisung ist das Instrument, mit dessen Hilfe der zuständige Bundesminister als oberste Bundesbehörde die Sachkompetenz an sich ziehen und regelmäßig zugleich bezogen auf einen konkreten Einzelfall ausüben kann".

789 BVerfGE 81, 310 (335).

790 Para maiores detalhes sobre este instituto, vide HERMES. Artikel 85. In: DREIER (Hrsg.). Grundgesetz, pp. 120 e ss e TRUTE. Artikel 85. In: von MANGOLDT, KLEIN, STARCK (Hrsg.). Kommentare zum Grundgesetz, p. 103 e ss.
} 
tópico 5.4 e também no item 5.5.1 pretendeu-se elucidar os principais contornos das regras gerais consagradas pelo artigo 83 GG. No item 5.5.2 analisou-se, pela primeira vez, uma disposição constitucional que pode ser classificada de excepcional, ao prever uma forma de execução distinta da administração estadual própria. Neste tópico, finalmente, pretende-se prosseguir com o estudo das disposições que excepcionam o disposto no artigo 83 GG, seja porque enumeram competências administrativas ao Bund, seja porque preveem formas de execução que são titularizadas pelo Bund.

Principiemos esta análise com algumas considerações iniciais importantes. Em primeiro lugar, é de se ressaltar que o que está em jogo aqui é a execução de leis federais. Como já se mencionou alhures, a execução de leis estaduais é levada a cabo pelos próprios Estados-membros alemães e não recebe um tratamento específico pela Lei Fundamental de 1949, muito embora esteja lastreada constitucionalmente no artigo $30 \mathrm{GG}$, o qual disciplina a repartição vertical de poderes entre Bund e Länder sob uma perspectiva mais geral. Não existe execução de leis estaduais pelo Bund, como bem ponderam doutrina e jurisprudência alemãs. ${ }^{791}$

Em segundo lugar e como uma consequência do que foi dito, o Bund deve deter a competência legislativa privativa ou, ao menos, a competência legislativa concorrente sobre a matéria cuja execução está em questão. ${ }^{792}$ Portanto, toda competência administrativa federal encontra respaldo em uma competência legislativa federal, muito embora a recíproca, por tudo o que foi exposto até o presente momento, não seja verdadeira: com efeito, leis federais podem - e normalmente são - executadas pelos Länder. Em outras palavras, a competência administrativa do Bund é menos abrangente do que a sua competência legislativa; porém, a partir do momento que se fala em execução de leis pela administração pública federal alemã, deve-se reconhecer que tem por objeto uma lei federal, oriunda do exercício de uma competência legislativa pelo Bund.

Em terceiro lugar, quando a Lei Fundamental atribui uma competência administrativa à União, ela quer excluir, ao menos a princípio, uma atuação administrativa por parte dos Estados-membros. ${ }^{793}$ Ou seja, estamos diante de uma competência do tipo

\footnotetext{
${ }^{791}$ No âmbito da doutrina alemã, cita-se BADURA. Staatsrecht, p. 699, HERMES. Artikel 83. In: DREIER (Hrsg.). Grundgesetz, p. 19 e TRUTE. Artikel 83. In: von MANGOLDT, KLEIN, STARCK (Hrsg.). Kommentare zum Grundgesetz, p. 16. No âmbito da jurisprudência do BVerfG, o mesmo entendimento pode ser encontrado, por exemplo, em BVerfGE 21, 312 (325).

792 OEBBECKE. § 136 Verwaltungszuständigkeit. In: ISENSEE, KIRCHHOF (Hrsg.). Handbuch des Staatsrechts, p. 779.

793 OEBBECKE, § 136 Verwaltungszuständigkeit. In: ISENSEE, KIRCHHOF (Hrsg.). Handbuch des Staatsrechts, p. 777 e Georg HERMES. Artikel 86. In: Horst DREIER (Hrsg). Grundgesetz - Kommentar. Band III: Artikel 83-146. 2a Ed. Tübingen: Mohr Siebeck, 2008, p. 147.
} 
privativa. Contudo, como ressalta Georg HERMES, na prática existem uma multiplicidade de formas de cooperação entre a União e os Estados-membros que colocam esta assertiva em cheque. ${ }^{794}$ Além do mais, deve-se ressaltar que a própria Lei Fundamental autoriza por vezes que a administração federal seja substituída pela administração sob as ordens da União (Bundesauftragsverwaltung), a qual se qualifica como uma administração estadual, ainda que se trate de uma forma de execução excepcional nos termos do artigo 83 GG. Em alguns casos, a administração federal pode ser substituída até pela administração estadual. ${ }^{795}$ Nesse sentido, dispõe o artigo 87d I GG que o tráfego aéreo será conduzido pela administração federal; porém, o parágrafo segundo deste mesmo dispositivo autoriza que lei federal, com a aprovação do Conselho Federal, transfira certas tarefas para os Länder na modalidade da Bundesauftragsverwaltung. Previsões parecidas podem ser encontrada nos artigos 87b II GG, sobre administração das forças armadas (especificamente no que diz respeito ao conjunto de medidas relacionadas ao serviço militar e à proteção da população civil) e 89 II GG, sobre administração dos cursos de água federais. ${ }^{796}$

Mas o que Lei Fundamental quer dizer exatamente quando prevê que a execução de leis federais sobre determinadas matérias deve se dar por um órgão da administração federal própria? Neste ponto, existem diferenças substanciais em relação à administração federal brasileira, razão pela qual é recomendável conduzir a análise em termos mais descritivos, a começar pelo artigo 86 GG. Segundo este dispositivo, “caso a União execute as leis por meio de administração federal própria ou por meio de pessoas jurídicas ou entidades de direito público ligadas diretamente à União, o governo federal então editará preceitos administrativos de caráter geral, desde que a lei não disponha de modo específico". Ainda de acordo com este mesmo artigo, "o governo federal regula, desde que a lei não disponha de outro modo, a organização dos Behörden". Percebe-se do exposto que a Lei Fundamental alemã diferencia, em um primeiro momento, entre administração federal própria e administração federal por meio de pessoas jurídicas (Körperschaften) e entes (Anstalten) de direito público. A primeira, denominada também de administração federal direta (unmittelbare Bundesverwaltung) é caracterizada pelo fato de a "estrutura organizativa que concretiza a função administrativa - portanto, os Behörden, os cargos estar diretamente ligada à pessoa jurídica da República Federal e não ser juridicamente

\footnotetext{
794 HERMES. Artikel 86. In: DREIER (Hrsg.). Grundgesetz, p. 147.

795 OEBBECKE. § 136 Verwaltungszuständigkeit. In: ISENSEE, KIRCHHOF (Hrsg.). Handbuch des Staatsrechts, pp. 788-789.

796 O fato de a administração federal ser, em regra, substituível pela administração sob as ordens do Bund demonstra, aliás, o interesse federal que está presente nesta modalidade de execução da lei federal pelos Estados, como se teve a oportunidade de mencionar no tópico anterior.
} 
independente"797. Já a segunda, também conhecida como administração federal indireta (mittelbare Bundesverwaltung), é marcada pela "maior ou menor independência jurídica das unidades administrativas". 798

Note-se que o artigo 86 GG não contém exatamente regras sobre a repartição de competências administrativas. Ao contrário, embora ele esteja inserido dentro desta grande temática da execução das leis federais (e represente ele mesmo uma exceção à regra geral prevista pelo artigo $83 \mathrm{GG}$ ), o artigo em questão possui outras duas finalidades importantes, que acabam sobrepujando o seu possível significado para a distribuição de competências de execução. Em primeiro lugar, ele atribui a edição de preceitos administrativos de caráter geral e a organização dos Behörden ao governo federal, a princípio como órgão colegiado. Em segundo lugar, ele autoriza que a lei disponha de outro modo, permitindo que o Parlamento Federal e o Conselho Federal interfiram neste assunto ${ }^{799}$. Não se trata de algo substancialmente distinto dos artigos 84 e 85 GG, aliás. Como se teve a oportunidade de se analisar nos tópicos anteriores, estes dois dispositivos não são destinados exatamente a delimitar determinadas tarefas e finalidades estatais e reparti-las entre as esferas federativas,

\footnotetext{
${ }^{797}$ HERMES. Artikel 86. In: DREIER (Hrsg.). Grundgesetz, p. 137.

798 HERMES. Artikel 86. In: DREIER (Hrsg.). Grundgesetz, p. 137. Note-se que o artigo 86 GG, ao tratar da administração federal indireta, menciona as pessoas jurídicas (Körperschaften) e os entes (Anstalten) de direito público. Como explicam Hans Peter BULL e Veith MEHDE, as Körperschaften caracterizam-se, em primeiro lugar, por serem uma associação de pessoas naturais (excepcionalmente, contudo, admite-se associações formadas por pessoas jurídicas), cuja filiação é determinada pela lei. Em outras palavras, se está diante de uma filiação compulsória, o que conduz à necessidade de delimitar precisamente as atribuições destas organizações (BULL, MEHDE. Allgemeines Verwaltungsrecht mit Verwaltungslehre, pp. 46-47). Harmut MAURER, por sua vez, acrescenta que as Körperschaften devem ser criadas por um ato soberano e "desempenham atividades estatais, em regra, com meios soberanos, sob a supervisão estatal" (Harmut MAURER. Allgemeines Verwaltungsrecht. 16a Ed. Munique: C. H. Beck, 2006, p. 605). Exemplos de Körperschaften são as associações profissionais de advogados, médicos etc, as quais no Brasil assumem normalmente a forma de autarquia. Já as Anstalten, como também esclarecerem BULL e MEHDE, são organizações dotadas de autonomia em relação à administração direta e que assumem formas variadas. Diferentemente das Körperschaften, as Anstalten não têm membros e sim usuários, sendo constituídas para a consecução de uma finalidade administrativa específica (BULL, MEHDE. Allgemeines Verwaltungsrecht mit Verwaltungslehre, p. 47). Embora o artigo 86 GG refira-se somente às pessoas jurídicas e entes de direito público, defende-se que o mesmo se aplica às fundações (Stiftungen) de direito público, por uma interpretação extensiva. Como bem pondera Martin BURGI, "no caminho de uma interpretação extensiva do suporte fático incluem-se das fundações de direito público, entendidas como organizações capazes juridicamente para a administração de um patrimônio transferido e afetado a uma finalidade por um instituidor. Pois as diferenças proporcionalmente pequenas entre fundação e ente (a diferença essencial reside na proveniência do patrimônio administrado) não são adequdas para fundamentar um tratamento diferente tendo em vista as consequências jurídicas regulamentadas pelo artigo 86" (Martin BURGI. Artikel 86. In: Hermann von MANGOLDT, Friedrich KLEIN, Christian STARCK (Hrgs). Kommentare zum Grundgesetz. Band III: Artikel 83-146. 6a Ed. Munique: Franz Vahlen, 2010, p. 132).

799 Para maiores detalhes, vide OEBBECKE. \& 136 Verwaltungszuständigkeit. In: ISENSEE, KIRCHHOF (Hrsg.). Handbuch des Staatsrechts, p. 778, JARASS, PIEROTH. Grundgesetz, p. 917, BURGI. Artikel 86, pp. 138-145 e HERMES. Artikel 86. In: DREIER (Hrsg.). Grundgesetz, pp. 153-158.
} 
mas sim conferir ao Bund e aos Länder determinados poderes jurídicos no que tange à organização e procedimento a ser observado pelos Länder na atividade de execução da lei federal. A determinação de que os Länder devem promover a execução da lei oriunda do Poder Legislativo Federal extrai-se do artigo 83 GG, no caso da administração própria dos Estados, e dos artigos 87a e seguintes GG, no que tange à administração estadual sob as ordens do Bund. Como a regulamentação da organização dos Behörden e do procedimento administrativo estaduais, dentro da sistemática do artigo 84 e 85 GG, acaba por ser repartida entre Bund e Länder, é de se admitir que estas disposições assumem fortes contornos federativos, por assim dizer. No caso do artigo 86 GG, a edição de preceitos administrativos de caráter geral e a organização dos Behörden federais são repartidas entre Poder Executivo e Poder Legislativo federais, mas como neste último os Estados-membros encontram-se fortemente representados, trata-se de uma regulamentação que também possui reflexos federativos consideráveis.

O primeiro dispositivo que efetivamente atribui competências administrativas ao Bund é o artigo 87 GG. Como ressalta Georg HERMES, trata-se do dispositivo mais importante sobre a administração federal, determinando ou permitindo exceções às regras gerais contida no artigo 83 GG. ${ }^{800}$ Ao fazê-lo, ele acaba por traçar uma nova distinção, desta feita entre administração própria com estrutura subordinada própria (bundeseigene Verwaltung mit eigenem Verwaltungsunterbau), disciplinada no artigo 87 I GG, e administração federal própria por meio de autoridades federais superiores (bundeseigene Verwaltung durch Bundesöberbehörden), regulamentada pelo artigo 87 III $^{801}$, sendo que ambas são modalidades de administração federal própria. A primeira, como o próprio nome sugere, é aquela que se subdivide em órgãos subordinados e hierarquicamente vinculados, de modo a formar uma estrutura centralizada. Neste ponto, a doutrina se refere a uma subdivisão em três níveis: o primeiro deles seria ocupado pelas mais altas autoridades federais ou autoridades federais de cúpula (os oberste Bundesbehörden), que são os ministérios; logo abaixo, viriam os Behörden medianos, com uma competência territorial ampla, e; finalmente, os Behörden inferiores, com competência territorial ainda mais restrita. ${ }^{802}$ Já as autoridades federais superiores, como elucidam Hans Peter BULL e Veith MEHDE, são "os postos ou cargos, que são imediatamente subordinados a uma autoridade

\footnotetext{
800 Georg HERMES. Artikel 87. In: Horst DREIER (Hrsg). Grundgesetz - Kommentar. Band III: Artikel 83-146. 2a Ed. Tübingen: Mohr Siebeck, 2008, p. 170.

${ }^{801}$ Note-se que o artigo 87 III GG trata de outras estruturas administrativas, além das autoridades superiores federais, como se terá a oportunidade de analisar a seguir.

802 Neste sentido, vide as ponderações de OEBBECKE. § 136 Verwaltungszuständigkeit. In: ISENSEE, KIRCHHOF (Hrsg.). Handbuch des Staatsrechts, p. 780 e HERMES. Artikel 86. In: DREIER (Hrsg.). Grundgesetz, p. 140.
} 
federal de cúpula (um Ministério), que não têm estrutura subordinada, mas são competentes sobre todo o território federal. Trata-se de Behörden, que são instituídos para tarefas especiais e, assim, ocupados por especialistas para a respectiva área". ${ }^{803}$ Como exemplos de autoridades federais superiores, cita-se o Departamento Federal de Polícia Judiciária (Bundeskriminalamt), o Serviço Federal de Controle de Carteis Econômicos (Bundeskartellamt), o Departamento Federal de Estatística (Statistisches Bundesamt), e departamento de patentes alemão (Deutsches Patentamt), entre outros. ${ }^{804}$

O parágrafo primeiro do artigo 87 GG determina, por um lado, que "os serviços de relações exteriores, a administração financeira federal e, nos termos do artigo 89, a administração dos cursos de água federais e a navegação" serão executados por uma administração federal com estrutura subordinada própria. Note-se que neste ponto a Lei Fundamental determina e não simplesmente autoriza, ou seja, está-se diante de hipóteses de administração federal obrigatória (obligatorische Bundesverwaltung). Até 1993/1994, como ressalta Harmut MAURER, os serviços federais de correios e de ferrovias também eram executados deste modo, mas foram privatizados e, atualmente, são disciplinados nos artigos 87e e $87 f$ GG. ${ }^{805}$ Por outro lado, a segunda parte do artigo 87 GG autoriza a criação, por meio de lei federal, de "órgão federais de proteção de fronteiras, entidades centrais para informação e comunicação policiais, para a polícia criminal e para a coleta de documentação com a finalidade de proteção da constituição e de proteção contra os esforços realizados no território federal que, por meio do emprego da violência ou de atos preparatórios nesse sentido ponham em perigo os interesses da República Federal da Alemanha no estrangeiro". Nestes casos, a Lei Fundamental somente faculta a execução de serviços pela administração federal, mas é necessária uma lei para que isto efetivamente ocorra. Nestes casos está-se diante da administração federal facultativa (fakultative Bundesverwaltung). ${ }^{806}$

\footnotetext{
${ }^{803}$ BULL, MEHDE. Allgemeines Verwaltungsrecht mit Verwaltungslehre, p. 51. Definições parecidas podem ser encontradas em MAURER. Allgemeines Verwaltungsrecht, pp. 568-569, OEBBECKE. $\S 136$ Verwaltungszuständigkeit. In: ISENSEE, KIRCHHOF (Hrsg.). Handbuch des Staatsrechts, p. 781, HERMES. Artikel 86. In: DREIER (Hrsg.). Grundgesetz, p. 139 e JARASS, PIEROTH. Grundgesetz, p. 922.

${ }^{804}$ Exemplos extraídos de MAURER. Allgemeines Verwaltungsrecht, p. 569. Neste ponto optou-se por utilizar algumas traduções sugeridas em JAYME, NEUSS. Wörterbuch Recht und Wirtschaft, p. 74.

805 MAURER. Allgemeines Verwaltungsrecht, p. 569.

${ }^{806}$ A distinção entre administração federal obrigatória e administração federal facultativa é bem difundida na doutrina, como, por exemplo, em BADURA. Staatsrecht, p. 700. Para um panorama do artigo 87 GG com base nesta dicotomia, vide JARASS, PIEROTH. Grundgesetz, pp. 920-924. Cumpre mencionar ainda que o parágrafo primeiro período do artigo 87 I GG não encerra todas as hipóteses de administração federal obrigatória, sendo somente o dispositivo que concentra alguns serviços obrigatoriamente executados pela União. As outras matérias que recaem na administração federal obrigatória, conforme Martin BURGI, são: (i) instituições de seguro social que transcendem o território de um Estado (art. 87 II GG); (ii) administração federal das Forças Armadas (art. 87b I 1 GG); (iii) administração do tráfego aéreo (art. 87d I 1 GG); (iv) administração do tráfego
} 
Já o artigo 87 III GG disciplina, em seu primeiro período, a criação de novas autoridades federais superiores. Conforme este dispositivo, "podem ser instituídos, para os assuntos nos quais a União detém a competência legislativa, autoridades federais superiores e novas pessoas e entes de direito público ligadas diretamente à União". Ou seja, novamente se está diante de uma hipótese de administração federal facultativa, a qual deverá assumir a forma ou de autoridades federais superiores ou de administração federal indireta. Porém, é de se admitir que a função primordial deste dispositivo não é definir os contornos de determinada parcela da administração federal, mas sim facultar ao ente federal a expansão de sua própria competência administrativa. Como bem pondera Georg HERMES, o artigo 87 III 1 GG "não pressupõe uma competência administrativa federal fundamentada por meio de outras normas da Lei Fundamental, mas é fundamento da competência", assumindo o viés de uma verdadeira cláusula geral, representando "uma exceção à separação das competências legislativas e competências materiais normatizada fundamentalmente no artigo 83 GG" ${ }^{\prime 207}$. A importância que este dispositivo para a compreensão da repartição de competências administrativas e do modo pelo qual estas se relacionam com as competências legislativas é patente.

Extrai-se da literalidade do artigo 87 III 1 GG que a criação de autoridades federais superiores e de pessoas jurídicas da administração federal somente pode se dar nos assuntos em relação aos quais o Bund detém a competência legislativa. Ou seja, é de se admitir, alinhando-se neste ponto com a jurisprudência e doutrina alemãs, que "a competência legislativa do Bund representa o limite exterior da sua competência administrativa" ${ }^{808}$ : afinal, uma competência legislativa federal faculta à União, obedecidos os demais pressupostos legais, o exercício de uma competência administrativa; porém, a competência administrativa federal nunca poderá extrapolar o limite material que é dado pela competência legislativa, estendendo-se sobre assuntos em relação aos quais o Bund não possa legislar.

Além do mais, o artigo 87 III 1 GG determina que a criação destes novos organismos deve se dar por lei federal, atribuindo, portanto, uma nova competência

\footnotetext{
ferroviário (art. 87e I 1 GG), (v) funções de administração pública nas áreas de correios e telecomunicações (art. 87f II $2 \mathrm{GG}$ ); (vi) banco federal (art. $88 \mathrm{GG}$ ); (vii) redes de conexão técnico-informacionais (art. 91c IV 1 GG); (viii) aduana, entre outros impostos (art. 108 I GG), e; (ix) artigo 130 I 1 GG (BURGI. Artikel 86, p. 115). Do mesmo modo, a administração federal facultativa não se restringe às hipóteses contidas no artigo 87 I e III GG, podendo ser encontrada nos seguintes dispositivos da Lei Fundamental relacionados por Martin BURGI: (i) art. 87b I 3 GG; (ii) art. 87b II 1 GG; (iii) art. 87e II GG; (iv) 87f III GG; (v) art. 89 ॥ 2 GG; (vi) art. 90 III GG; (vii) art. 108 IV 1 GG; (ix) art. 120a I 1 GG (BURGI. Artikel 86, pp. 115-116).

807 HERMES. Artikel 87. In: DREIER (Hrsg.). Grundgesetz, p. 195.

${ }^{808}$ HERMES. Artikel 83. In: DREIER (Hrsg.). Grundgesetz, p. 11, citando neste ponto os seguintes julgados, entre outros: BVerfGE 12, 205 (229); 15, 1 (16); 78, 374 (386).
} 
legislativa privativa ao Bund. Na literatura consultada menciona-se a função de proteção da autonomia dos Estados que esta reserva de lei federal impõe; afinal, ela "cria transparência, dá ao Conselho Federal por meio do direito de oposição uma possibilidade de controle, e cria sobre o processo legislativo custos de transação, os quais serão transpostos pelos atores por parte do Bund interessados em um novo Behörde somente pela existência de um interesse de peso" ${ }^{809}$ Neste ponto não se pode deixar de traçar um paralelo com o artigo 14 WRV, segundo o qual "as leis imperiais são executadas pelas autoridades estaduais, desde que as leis federais não disponham de outro modo". Como se teve a oportunidade de ressaltar no item 2.2.1.2, tal previsão lastreou uma expansão razoável da administração federal sob a égide da Constituição de 1919, tendo a reserva de lei federal (ou imperial, no caso) se revelado uma barreira ineficaz para barrar tal fenômeno. Do mesmo modo, o fato de o artigo 87 III 1 GG submeter a criação de autoridades federais superiores e pessoas jurídica da administração indireta à edição de lei federal representa, por si só, uma medida insuficiente para resguardar a competência administrativa dos Länder. Se ao menos esta lei fosse submetida à aprovação do Conselho Federal, mas não é o caso: trata-se, ao contrário, de uma matéria cuja aprovação a instância representativa dos Estados-membros pode somente se opor.

É possível extrair do comando do artigo 87 III 1 GG ainda outros dois pressupostos que acabam por restringir o exercício da faculdade nele contida pelo Bund. Em primeiro lugar, autoridades federais intermediárias ou inferiores não poderão ser criadas ou ser utilizadas para a execução de tarefas administrativas pelo Bund. Tal exigência extrai-se sobretudo do confronto do primeiro período do artigo 87 III GG com o segundo período deste dispositivo, o qual autoriza a criação de autoridades federais intermediárias e inferiores, desde que haja a aprovação do Conselho Federal e da maioria dos membros do Parlamento Federal e se trate de novas tarefas atribuídas ao Bund. Em segundo lugar, as matérias devem comportar execução por meio de órgãos centrais, vale dizer, com jurisdição sobre todo o território alemão. Em outras palavras, mesmo que a União efetivamente edite uma lei, ainda assim ela não estará legitimada a promover a sua execução, caso esta atividade envolva medidas que não possam ser empreendidas por estes órgãos centrais. ${ }^{810}$

\footnotetext{
809 OEBBECKE. § 136 Verwaltungszuständigkeit. In: ISENSEE, KIRCHHOF (Hrsg.). Handbuch des Staatsrechts, pp. 780-781. No original: "Vor allem dient er aber dem Schutz der Länderzuständigkeiten. Er schafft Transparenz, gibt dem Bundesrat über das Einspruchrecht eine Kontrollmöglichkeit und erzeugt über das Gesetzgebungsverfahren Transaktionskosten, die ein an einer neuen Behörde interessierter Akteur auf seiten des Bundes nur bei Vorliegen eines gewichtigen Interesses aufbringen wird". Neste mesmo sentido caminham as ponderações de HERMES. Artikel 87. In: DREIER (Hrsg.). Grundgesetz, p. 197.

${ }^{810}$ HERMES. Artikel 87. In: DREIER (Hrsg.). Grundgesetz, p. 204.
} 
Não se pode afirmar que estes pressupostos efetivamente inibiram o exercício da faculdade contida no artigo 87 III 1 GG pelo Bund. No decorrer da vigência da Lei Fundamental algumas matérias importantes foram transferidas à administração federal com fulcro neste dispositivo constitucional. É o caso, por exemplo, da repressão a cartéis, que atualmente é promovida pelo Serviço Federal de Controle de Carteis Econômicos (Bundeskartellamt), ou do direito de patentes, que é levado a cabo pelo Departamento de patentes alemão (Deutsches Patentamt). Não é por outro motivo, aliás, que Konrad HESSE, em 1962, já se referia a este dispositivo ao descrever a centralização administrativa que teria conduzido, ao lado das demais tendências analisadas no item 3.2.2. desta tese, a uma unitarização do Estado Federal alemão. Nesse mesmo sentido, ressalta Georg HERMES que o artigo 87 III 1 GG foi largamente utilizado pelo Bund de modo a criar uma "multiplicidade de instituições federais ou confiar a elas novas tarefas", o que teria diminuído sensivelmente a competência administrativa dos Länder, ${ }^{811}$ citando a seguir uma série de autoridades federais, pessoas jurídicas de direito público e de direito privado cuja existência corrobora esta afirmação.

\subsection{AS TAREFAS COMUNS (GEMEINSCHAFTSAUFGABEN)}

No tópico 3.2.3 se teve a oportunidade de analisar a cooperação no Estado Federal alemão, apontando a tomada de decisões conjuntas como algo que lhe é, ao mesmo tempo, ínsito e característico. Também se teve a oportunidade de situar as tarefas comuns (Gemeinschatsaufgaben), inseridas na Lei Fundamental pela Reforma Financeira de 1969, como uma etapa importante de institucionalização da cooperação que vinha sendo desenvolvida pela União e pelos Estados-membros alemães desde o término da Segunda Grande Guerra. Não se pretende aqui adentrar novamente nesta análise, optando-se por tratar dos aspectos jurídico-dogmáticos dos artigos 91a e 91b GG, que são os dispositivos constitucionais que regulam as tarefas comuns.

Em primeiro lugar, é importante compreender o que são efetivamente estas tarefas comuns de um ponto de vista conceitual, com base em alguns subsídios extraídos do próprio texto constitucional, sem ter a pretensão, contudo, de se fornecer uma definição legal deste instituto. Um bom ponto de partida nesse sentido consiste na delimitação das competências federais e estaduais em relação às matérias submetidas a este regramento constitucional. De acordo com a redação originária dos artigos 91a e 91b GG, as tarefas comuns incidiam sobre

${ }^{811}$ HERMES. Artikel 87. In: DREIER (Hrsg.). Grundgesetz, p. 206. 
as seguintes matérias: (i) construção e ampliação de instituições de ensino superior e clínicas de ensino superior (artigo 91a I Nr. 1 GG); (ii) melhora da estrutura econômica regional (artigo 91a I Nr. 2 GG); (iii) melhora da estrutura agrária e da proteção de costas (artigo 91a I Nr. 3 GG); (iv) planejamento da educação básica (artigo 91b), e; (v) incentivo à instituições e projetos de pesquisa científica (artigo 91b GG). Tratam-se, portanto, de áreas tradicionalmente inseridas na competência privativa dos Estados-membros. Porém, como ressalta Uwe VOLKMANN, "a particularidade desta colaboração consiste no fato de que à União são abertas possibilidades de influência e de participação em áreas que eram originalmente um domínio dos Estados" ${ }^{\text {"12 }}$. No caso do artigo 91a GG estas possibilidades de participação e influência formam um arranjo competencial específico, o qual vincula a atuação da União e dos Estados-membros nos planos legislativo, administrativo e financeiro, desde que preenchidos os pressupostos estabelecidos pela Lei Fundamental. Já o artigo 91b criou uma competência de cooperação do Bund, a fim de assegurar, do ponto de vista jurídico, os acordos que vinham firmados entre este e os Estados-membros nas áreas por ele referidas. Há, assim, dentro do conceito de tarefas comuns, simultaneamente, vinculação e espontaneidade, sendo que a primeira é reservada à colaboração prevista pelo artigo 91a GG e a segunda se aplica não só à sistemática estabelecida pelo artigo 91b GG, como as demais formas de colaboração federativa existentes.

Esta abertura à atuação da União em áreas englobadas pela autonomia estadual, por sua vez, é em grande parte decorrência da incapacidade de promover programas estatais satisfatórios de forma isolada. Tornou-se necessário, portanto, congregar esforços federais e estaduais, a fim de que o cumprimento de determinadas tarefas fosse possível. No caso do artigo 91a GG, extrai-se ainda que esta atuação concertada deve se orientar para a melhora das condições de vida (Verbesserung der Lebensverhältnisse), o que remete, por definição, a uma atuação uniformizadora da União. Conforme já analisado no decorrer desta tese, esta fórmula - e também a igualação das condições de vida (Einheitlichung der Lebensverhältnisse), prevista pelo artigo 72 II GG na sua redação originária - embasou uma centralização da estrutura federativa alemã, embora, do ponto de vista do discurso, se tenha optado, por vezes, em falar em uma mera uniformização ou homogeneização da atuação

\footnotetext{
812 Uwe VOLKMANN. Artikel 91a. In: Hermann von MANGOLDT, Friedrich KLEIN, Christian STARCK (Hrsg). Kommentar zum Grundgesetz. Band 3: Artikel 83 a 146. 5a Ed. Munique: Franz Vahlen, 2005, p. 512. No original: "Die Eigenart dieser Zusammenarbeit besteht darin, dass dem Bund auf einzelnen Sachgebieten, die ursprünglich eine Dömane der Länder waren, besondere Mitwirkungs- und Einflussmöglichkeiten eröffnet werden". Observação semelhante, sob outra base legislativa (tendo em vista a alteração promovida no artigo 91a GG pela Reforma do Federalismo de 2006) pode ser encontrada em Werner HEUN. Artikel 91a [Mitwirkungsbereiche des Bundes bei Länderaufgaben]. In: Horst DREIER (Hrsg.). Grundgesetz - Kommentar. Band III: Artikel 83-146. 2a Ed. Tübingen: Mohr Siebeck, 2008, p. 399.
} 
legislativa e administrativa. De todo modo, o que parece importante ressaltar é que esta necessidade de uniformização, ou mesmo de simples melhora, das condições de vida também informa a cooperação entre os entes federativos alemães de um modo geral, aplicando-se também ao artigo 91b GG, ainda que não haja menção expressa.

Em suma, é possível afirmar que as tarefas comuns se referem a disposições constitucionais que autorizam o Bund a atuar em áreas originariamente de competência dos Länder, seja por meio de competências específicas legislativas, administrativas e financeiras - no caso do artigo 91a $\mathrm{GG}^{813}$ - seja por meio de uma competência genérica de cooperação - como ocorre no artigo 91b - de forma a viabilizar a concretização de determinadas tarefas estaduais consideradas especialmente importantes e que não podem ser adequadamente concretizadas de modo isolado. A finalidade, como já foi dito, consiste em promover uma melhora nas condições de vida da população alemã, alinhando-se a um paradigma de federalismo cooperativo. No mais, é de se admitir que os artigos 91a e 91b GG preveem instrumentários diferentes para atingir tal desiderato, o que recomenda uma análise separada de cada um deles, a começar pelo artigo 91a GG.

De acordo com o parágrafo primeiro do artigo 91a GG, inalterado desde 1969, “a União colabora com o cumprimento de tarefas dos Estados nas seguintes áreas, se estas tarefas forem significativas para a coletividade e se a colaboração da União for necessária para a melhora das condições de vida (tarefas comuns)". Atente-se, em primeiro lugar, para o modo pelo qual este dispositivo enuncia a atuação de União e Estados. Afinal, ele não diz que a União "pode colaborar" com o cumprimento de tarefas dos Estados, e sim que a União "colabora" com o cumprimento destas tarefas ("Der Bund wirkt (...) bei de Erfüllung von Aufgaben der Länder mit” $)^{814}$. Ou seja, a colaboração aqui não se coloca como uma faculdade conferida aos entes federativos alemães; ao contrário, preenchidos os requisitos colocados pela Lei Fundamental, a colaboração se coloca como um dever, vinculando União e Estados. Exatamente por isso a doutrina alemã fala em um mandamento constitucional (Verfassungsauftrag) ${ }^{815}$. Retornaremos ao tema ainda neste tópico. Por ora, prossegue-se

\footnotetext{
813 Nesse sentido, VOLKMANN. Artikel 91a. In: von MANGOLDT, KLEIN, STARCK (Hrsg.). Kommentare zum Grundgesetz, pp. 516 e ss.

${ }^{814}$ Embora se tenha traduzido o referido dispositivo da Lei Fundamental no tempo verbal presente, tendo em vista que é a efetivamente empregada no texto em alemão, acredita-se que uma tradução mais consentânea com técnica que normalmente se costuma utilizar na redação de artigos de lei no Brasil seria algo no seguinte sentido: "a União colaborará com o cumprimento de tarefas dos Estados nas seguintes áreas (...)".

815 Nesse sentido, VOLKMANN. Artikel 91a. In: von MANGOLDT, KLEIN, STARCK (Hrsg.). Kommentare zum Grundgesetz, p. 523, HEUN. Artikel 91a. In: DREIER (Hrsg.). Grundgesetz, p. 397. JARASS, PIEROTH, por sua vez, entendem que o artigo 91a GG consagraria um dever dirigido à União no sentido de se colaborar no
} 
com a análise do artigo 91a I GG, analisando os dois requisitos ou pressupostos impostos por este dispositivo para a colaboração federativa nas áreas por ele previstas, quais sejam: (i) tarefas significativas para a coletividade; (ii) necessidade da colaboração da União para a melhora das condições de vida. Segundo Uwe VOLKMANN, uma tarefa tornar-se-ia significativa para a coletividade, para fins do artigo 91a GG, quando ela atinge a população de mais de um Estado-membro, sendo mais decisiva a necessidade de se traçar uma regulamentação que transcenda as fronteiras dos territórios estaduais do que a prioridade que a tarefa em questão possui, em tese, em relação às demais tarefas. Já a necessidade da melhora das condições de vida, segundo este mesmo autor, pressupõe uma comparação entre a situação destas condições no caso de cumprimento isolado destas tarefas e o resultado que seria obtido por meio de uma atuação cooperativamente orientada. A necessidade deve ser afirmada se "sem a colaboração da União e dos Estados uma melhora nas condições de vida não pode ou não pode adequadamente ser atingida" $\$ 16$

A análise do artigo 91a I GG termina com o exame das áreas efetivamente submetidas a este regramento constitucional. Neste ponto observa-se uma evolução importante. Sabe-se que, na sua redação originária, o artigo 91a I GG previa três áreas de atuação conjunta do Bund e dos Länder: (i) ampliação e construção de instituições de ensino superior, inclusive as clínicas de ensino superior (artigo 91a I Nr. 1 GG); (ii) melhora da estrutura econômica regional (artigo 91a I Nr. 2 GG), e; (iii) melhora da estrutura agrária e da proteção das costas marítimas (artigo 91a I Nr 3 GG). ${ }^{817}$ As duas últimas áreas - no caso do artigo 91a I GG Nr. 3, refere-se especificamente à melhora da estrutura agrária - passaram

preenchimento de tarefas estaduais, mas não conteria um mandato constitucional para os Estados no sentido de levar a cabo estas tarefas (JARASS, PIEROTH. Grundgesetz, p. 949).

816 VOLKMANN. Artikel 91a. In: von MANGOLDT, KLEIN, STARCK (Hrsg.). Kommentare zum Grundgesetz, pp. 523-524. Ponderações neste mesmo sentido podem ser encontradas em HEUN. Artikel 91a. In: DREIER (Hrsg.). Grundgesetz, p. 400. Além do mais, ressalta-se o posicionamento destes dois autores, nos trechos citados, no sentido de que a justiciabilidade destes dois pressupostos, em razão da amplitude em que são formulados, é restrita.

817 Quanto às áreas originalmente abrangidas pelos números do artigo 91a I GG, cumpre fazer duas observações. Em primeiro lugar, é de se admitir que na verdade o referido dispositivo consagrava quatro tarefas comuns, tendo em vista que o Nr. 3 previa duas áreas de atuação que guardam pouca relação entre si, a saber, melhora da estrutura agrária e proteção das costas marítimas. Fez-se referência a três áreas de atuação conjunta no corpo do texto apenas com o intuito de criar uma correspondência entre os três números do artigo 91a I GG, em sua redação originária. Em segundo lugar, reconhece-se que o artigo 91a I Nr. 1 GG, na redação aprovada em 1969, mencionava a construção e a ampliação somente das instituições científicas de ensino superior. Porém, já em 1970 esta parte do dispositivo em questão foi alterada, a fim de estender a colaboração entre União e Estados às instituições de ensino superior como um todo. E foi esta redação que permaneceu por mais de 35 anos, informando as discussões travadas tanto no âmbito político quanto no âmbito jurídico e influenciando os debates doutrinárias em torno do tema. Por este motivo, opta-se por começar a análise a partir da redação vigente em 1970, mesmo para não tornar a exposição confusa por meio de menções a alterações legislativas que pouco importam para o argumento que se pretende desenvolver. 
a ser influenciadas por normas oriundas do direito europeu, além de serem, em grande medida, financiadas pela própria União Europeia ${ }^{818}$. Note-se, porém, que o direito europeu também exerceu um papel restritivo em relação a estas tarefas comuns. Conforme o artigo 87 do Tratado que institui a Comunidade Econômica Europeia, são incompatíveis com o mercado comum a concessão de subsídios estatais que, por meio do favorecimento de determinadas empresas ou setores produtivos, falseiem ou ameacem falsear a concorrência, sendo esta uma regra excepcionada apenas em algumas hipóteses ${ }^{819}$. Relata Werner HEUN que, em virtude desta disposição, a Alemanha teve que se comprometer, em 1987, a reduzir a área abrangida pelas tarefas comuns de 33\% para 27\% do seu território a partir de 1991 e, posteriormente, para 17,6\% do seu território. Os novos Estados alemães, formados a partir do território da antiga DDR, continuaram como uma área a ser fomentada nos termos do artigo 91a I Nr. 2 GG $^{820}$. Posteriormente, a situação destes novos Länder passou a ser expressamente contemplada como uma exceção à regra de proibição de subsídios ou auxílios estatais. Nesse sentido, o artigo 107.2 do Tratado sobre o Funcionamento da União Europeia (que incorporou e atualizou as disposições contidas no Tratado que institui a Comunidade Econômica Europeia) considera compatível com o mercado interno "os auxílios atribuídos à economia de certas regiões da República Federal da Alemanha afectadas pela divisão da Alemanha, desde que sejam necessários para compensar as desvantagens económicas causadas por esta divisão". Ainda consoante este dispositivo, "cinco anos após a entrada em vigor do Tratado de Lisboa, o Conselho, sob proposta da Comissão, pode adoptar uma decisão que revogue a presente alínea"821. A única área que permaneceu relativamente imune ao influxo da União Europeia foi a construção e a ampliação das instituições de ensino superior, prevista no artigo 91a I Nr. 1 GG em sua antiga redação. Contudo, em 2006 esta tarefa comum foi revogada pela Reforma do Federalismo, de forma que atualmente encontram-se submetidas ao regramento constitucional previsto pelo artigo 91a GG somente a "melhora da estrutura econômica regional" e a "melhora da estrutura agrária e da proteção

\footnotetext{
818 VOLKMANN. Artikel 91a. In: von MANGOLDT, KLEIN, STARCK (Hrsg.). Kommentare zum Grundgesetz, p. 521.

819 Segundo VOLKMANN, algumas destes auxílios "são compatíveis, contudo, com o mercado comum já em virtude do tratado (Art. 87 Abs 2 EGV); outros podem, de acordo com o juízo discricionário da Comissão, ser reputados ou declarados como compatíveis com o mercado comum (Art. 87 Abs. 3, 88 Abs. 2 UAbs. 3 EGV). A estes pertencem nomeadamente os auxílios para o fomento da estrutura econômica de áreas com condições de vida extraordinariamente baixas ou considerável subemprego (Art. 87 Abs 3 lit. a EGV), cuja principal aplicação neste país representam as medidas para melhora da estrutura administrativa regional no âmbito da tarefa comum do artigo 91a I Nr. 2" (VOLKMANN. Artikel 91a. In: von MANGOLDT, KLEIN, STARCK (Hrsg.). Kommentare zum Grundgesetz, p. 520).

820 HEUN. Artikel 91a. In: DREIER (Hrsg.). Grundgesetz, p. 395.

821 http://www.fd.uc.pt/Cl/CEE/pm/Tratados/Lisboa/tratados-TUE-TFUE-V-Lisboa.htmI\#TFUE-PARTE-III-TITVII-CAP-1-SECCAO-2. Acesso: 29/11/2015.
} 
costeira” (antigos Nr. 2 e 3, atuais Nr. 1 e 2 do artigo 91a I GG). Embora esta alteração constitucional possa ser bem compreendida em um contexto de diminuição do entrelaçamento político tão característico ao federalismo cooperativo alemão e tão criticado pelos teóricos que se ocupam do tema ${ }^{822}$, Werner HEUN pondera que

\begin{abstract}
"a retirada da construção de instituições de ensino superior das tarefas comuns é, por isso, também certamente questionável, tendo em vista que o caráter nacional desta tarefa não foi suprimido. O perigo de um financiamento insuficiente do ensino superior aumentou por este motivo. Os programas bilionários da União editados depois da Reforma para o financiamento da educação, os quais são amparados agora pelo artigo $104 \mathrm{~b}$ GG, comprovam isto de forma evidente. Podese mesmo perguntar, se não foi suprimida verdadeiramente a tarefa comum errada, porque a necessidade de promoção das tarefas comuns restantes, em todo caso, prescinde ainda mais de plausibilidade e a fundamentação para a sua manutenção parece um pretexto." 823
\end{abstract}

Porém, não foi esta a única alteração relevante introduzida pela Reforma do Federalismo de 2006 neste dispositivo. Os demais parágrafos do artigo 91a foram reformulados ou então renumerados nesta ocasião. A redação originária do parágrafo segundo, por exemplo, previa na sua redação originária que "por meio de lei federal com a aprovação do Conselho Federal, as tarefas comuns serão reguladas em pormenores. A lei federal deve conter princípios gerais para o seu cumprimento". Da referência que este dispositivo fazia - e ainda faz - à lei federal extrai-se que ao Bund foi atribuída uma nova competência legislativa ao lado das demais previstas no artigo 70 e seguintes GG e de natureza privativa. ${ }^{824}$ A necessidade de aprovação da instância representativa dos Estados, por sua vez, parece ser óbvia neste caso, em virtude de as tarefas comuns representarem uma ingerência - ainda que necessária, diante da importância das tarefas envolvidas e da impossibilidade de uma atuação isolada - na competência legislativa e administrativa dos Estados-membros. A principal questão trazida por este dispositivo, contudo, consistia em saber exatamente o que seriam estes princípios que deveriam ser regulamentados por lei

\footnotetext{
822 Como ressalta Johannes HELLERMANN. B. Gemeinschaftsaufgabens (Art. 91a, 91b). In: Christian STARCK (Hrsg). Föderalismusreform: Einführung. Munique: C. H. Beck, Franz Vahlen, 2007, pp. 132-133.

823 HEUN. Artikel 91a. In: DREIER (Hrsg.). Grundgesetz, p. 399. No original: "Die Herausnahme des Hochschulbaus aus dem Gemeinschaftsaufgaben ist deshalb auch durchaus fragwürdig, da der gesamtstaatliche Charakter dieser Aufgabe nicht entfallen ist. Die Gefahr einer Unterfinanzierung der Hochschulen hat sich deshalb erhöht. Die unmittelbar nach der Reform aufgelegten Milliardenprogramme des Bundes zur Bildungsfinanzierung, die nun auf Art. 104b GG gestützt werden, belegen das überdeutlich. Man kann sich sogar fragen, ob nicht geradezu die falsche Gemeinschaftsaufgabe entfallen ist, da jedenfalls die Notwendigkeit der Förderung der verbliebenen Gemeinschaftsaufgaben sehr viel der Plausibilität entbehrt und die Begründung für ihre Beibehaltung vorgeschoben erscheint."

824 VOLKMANN. Artikel 91a. In: von MANGOLDT, KLEIN, STARCK (Hrsg.). Kommentare zum Grundgesetz, pp. 527-528. Observa Werner HEUN, contudo, que a maioria da doutrina, sob a vigência da redação anterior do artigo 91a II GG, posicionava-se no sentido de este dispositivo teria consagrado uma legislação de princípios (Grundsatzgesetzgebung) ao Bund (Artikel 91a. In: DREIER (Hrsg.). Grundgesetz, p. 403).
} 
federal. Segundo Uwe VOLKMANN, a lei federal deveria conter disposições que preparassem o preenchimento das tarefas e que possibilitassem a decisão sobre as consequências financeiras das tarefas, que indicassem os objetivos a serem atingidos ${ }^{825}$. Além do mais, deve-se ressaltar que, segundo a redação originária do parágrafo terceiro do artigo 91a GG, a lei federal deveria conter "determinações sobre o procedimento e sobre as instituições para um planejamento-moldura comum". Segundo este mesmo dispositivo, "a inserção de um projeto no planejamento-moldura" demandava "a aprovação do Estado em cujo território ele será executado".

Logo após a introdução do artigo 91a GG foram editadas três leis federais - uma para cada área enunciada nos números no artigo 91a I GG - as quais estabeleciam, em linhas gerais, o conteúdo e a extensão das tarefas comuns, as diretivas ou princípios para a sua consecução e, além do mais, o procedimento e conteúdo do planejamento a que se referia o parágrafo terceiro do artigo $91 \mathrm{a} \mathrm{GG}^{826}$. Porém, é de se admitir que o verdadeiro cerne das tarefas comuns, como ressaltava o próprio legislador constituinte em 1969, residia na elaboração e execução do planejamento-moldura pelos Poderes Executivos federal e estaduais $^{827}$. Afinal, era nesta etapa que se podiam ser observados os principais elementos da Politikverflechtung discutida no tópico 3.2.3 desta tese, quais sejam: (i) União e Estados vinculados a uma decisão conjunta, e; (ii) tomada de decisões por unanimidade. Note-se que o artigo 91a III, última parte, GG mencionava apenas a necessidade da aprovação do Estado em cujo território o projeto referido pelo plano fosse ser executado. Posteriormente, este consenso foi ampliado pelas leis federais posteriormente aprovadas, as quais exigiam uma maioria qualificada de três quartos votos. Porém, conforme relata Uwe VOLKMANN, uma decisão por maioria era considerada politicamente discutível, pois a União já detinha metade dos votos e poderia facilmente impor uma maioria juntamente com os Estados governados pelo mesmo partido político. Por isso, na prática prevaleceu o princípio da unanimidade da tomada de decisões sobre o planejamento das tarefas comuns. ${ }^{828}$ Por isso, o que efetivamente se tinha era União e Estados vinculados a uma colaboração - a própria redação do artigo 91a I GG, como já se teve a oportunidade de expor neste tópico, impõe um dever, um mandato

\footnotetext{
${ }^{825}$ VOLKMANN. Artikel 91a. In: von MANGOLDT, KLEIN, STARCK (Hrsg.). Kommentare zum Grundgesetz, p. 528. 826 VOLKMANN. Artikel 91a. In: von MANGOLDT, KLEIN, STARCK (Hrsg.). Kommentare zum Grundgesetz, pp. 528-529.

${ }^{827}$ Como se extrai da exposição de motivos da 21 a proposta de alteração da Lei Fundamental, aprovada em 1969 e conhecida como Reforma Financeira de 1969 (DEUTSCHER BUNDESTAG - 5. WAHLPERIODE. Entwurf eines Gesetzes zur Änderung und Ergänzung des Grundgesetzes (Finanzreformgesetz). Drucksache V/2861, p. 50 (item 271). Esta intenção do legislador constituinte também é referida por VOLKMANN. Artikel 91a. In: von MANGOLDT, KLEIN, STARCK (Hrsg.). Kommentare zum Grundgesetz, p. 530.

${ }^{828}$ VOLKMANN. Artikel 91a. In: von MANGOLDT, KLEIN, STARCK (Hrsg.). Kommentare zum Grundgesetz, p. 531.
} 
constitucional, e não uma mera faculdade - e obrigados a tomar decisões unânimes a fim de promover uma atuação concertada - o que conferia a qualquer Estado e também à União um poder de veto relevante.

Não por outro motivo, a Reforma do Federalismo de 2006, que tinha por objetivo declarado suprimir ou ao menos reduzir os processos de tomada de decisões conjuntas, alterou substancialmente os antigos parágrafos segundo e terceiro do artigo 91a GG. A partir de então, o parágrafo segundo deste dispositivo passou a prever que "por meio de lei federal, com a aprovação do Conselho Federal, as tarefas comuns, bem como os detalhes da cooperação, serão regulados em pormenores". Ampliou-se, portanto, o objeto da legislação federal, a qual não mais dispõe somente sobre princípios, podendo descer a pormenores tanto das tarefas comuns quanto da cooperação a ser desenvolvida. Deste modo, buscou-se ampliar o campo de atuação do legislador, o que acaba por restringir a importância do Poder Executivo nesta seara. Já o dispositivo que tratava do planejamento comum foi revogado, de forma que este último deixou de ser um elemento integrante das tarefas comuns, ao menos do ponto de vista constitucional. Contudo, ao legislador ordinário permanece a opção de adotar o planejamento. ${ }^{829}$ Finalmente, diante destas alterações, o antigo parágrafo quarto do artigo 91 a GG foi renumerado, de modo que agora a divisão dos encargos financeiros entre União e Estados vem regulamentada no atual parágrafo terceiro do artigo 91a GG.

Em 1969 a Lei Fundamental também foi acrescida de um artigo 91b, segundo o qual a "União e os Estados podem, em virtude de acordos, atuar conjuntamente no planejamento do ensino básico e na promoção de instituições e projetos de pesquisa científica de significado supraregional". Com isso, objetivava-se criar novas áreas de atuação conjunta de Bund e Länder, porém, como não se tratava propriamente de uma imposição constitucional como ocorre com o artigo 91a GG - o artigo 91b prevê apenas que os União e Estados "podem" atuar conjuntamente - estas áreas foram denominadas de tarefas comuns impróprias (unechte Gemeinschaftsaufgaben).

As principais características do artigo 91b GG podem ser compreendidas em confronto com o artigo 91a GG. Além do fato de a atuação concertada da União e dos Estados-membros não decorrer de uma imposição constitucional, o artigo 91b também confere uma maior elasticidade à colaboração federativa, tendo em vista que ela será regulamentada por meio de um acordo ${ }^{830}$. No caso do artigo 91a GG, a cooperação,

\footnotetext{
${ }^{829}$ Conforme HEUN. Artikel 91a. In: DREIER (Hrsg.). Grundgesetz, p. 404.

830 Uwe VOLKMANN. Artikel 91b. In: Hermann VON MANGOLDT, Friedrich KLEIN, Christian STARCK (Hrsg). Kommentar zum Grundgesetz. Band 3: Artikel 83 a 146. 5a Ed. Munique: Franz Vahlen, 2005, p. 540. Ponderações no mesmo sentido podem ser encontradas em Werner HEUN. Artikel 91b [Forschungsförderung,
} 
considerada um dever, é estruturada por meio de lei federal, sendo que até 2006 os seus pormenores deveriam ser regulamentados por meio de um planejamento comum, cuja elaboração e alteração dependia da aprovação da União e de todos os Estados alemães. Tratava-se, portanto, de uma cooperação engessada, pouco suscetível a mudanças. Já na hipótese do artigo 91b, a cooperação será estruturada e regulamentada tanto por meio de contratos estatais (Staatsverträge) quanto por acordos administrativos (Verwaltungsabkommen), do qual participam a União e todos ou alguns Estados ${ }^{831}$. Como ressalta Werner HEUN, em razão do princípio da igualdade e do princípio da lealdade federal, a União deve considerar todos os Estados como parceiros em potencial, buscando sempre a participação de todos os Länder atingidos. Isso, por sua vez, não obsta que, no caso concreto, o acordo venha a ser firmado com somente uma parte dos Estados ou mesmo com um Estado ${ }^{832}$.

Quanto às áreas submetidas à sistemática do artigo 91b GG também se percebe uma evolução legislativa. Quando da introdução deste dispositivo na Lei Fundamental, duas áreas foram contempladas, quais sejam: (i) o planejamento em matéria de ensino básico, e; (ii) a pesquisa científica. Também neste caso se estava diante de temáticas inseridas na competência dos Estados-membros, mas que eram objeto de acordos entre União e Estados desde antes. Buscava-se, com a inserção deste dispositivo constitucional, assegurar a constitucionalidade destes acordos, conferindo à União uma competência específica para celebrá- $\operatorname{los}^{833}$, desde que obedecido o requisito da "suprarregionalidade". O planejamento da educação básica, contudo, revelou-se a área mais problemática das tarefas comuns. Fritz W. SCHARPF considera inclusive que o fracasso de implementar uma política nacional nesta seara foi o antecedente político mais importante para a estruturação de um processo de tomada de decisões conjuntas informado pelo princípio da unanimidade (ou, em alguns casos, da maioria qualificada $)^{834}$. O tema já foi analisado no tópico 3.2.3 desta tese, a cuja leitura se remete. De todo modo, o que se cumpre ressaltar aqui é que durante os mais de 35

\footnotetext{
Leistungsfähigkeit des Bildungswesens]. In: Horst DREIER (Hrsg.). Grundgesetz - Kommentar. Band III: Artikel 83-146. 2a Ed. Tübingen: Mohr Siebeck, 2008, p. 412.

831 Para uma diferenciação entre contrato estatal e acordo administrativo, vide o tópico 3.2.3 desta tese.

832 HEUN. Artikel 91b. In: DREIER (Hrsg.). Grundgesetz, p. 413. Note-se que, no caso do artigo 91b I Nr.2 GG, na sua redação atual, é necessário o consentimento de todos os Länder. Retornaremos a este ponto ainda neste tópico.

833 Como é ressaltado em HEUN. Artikel 91b. In: DREIER (Hrsg.). Grundgesetz, p. 410.

${ }^{834}$ SCHARPF. The joint-decision trap, p. 246.
} 
anos em que o artigo 91b permaneceu em vigor, a cooperação nele prevista se desenvolveu sobretudo no âmbito da promoção da pesquisa científica ${ }^{835}$.

Em 2006 o artigo 91b também foi alterado. Neste caso, porém, não se promoveu uma reforma substancial das normas que dispõem sobre a cooperação: o acordo permanece como o instrumento jurídico eleito para regulamentar a atuação dos entes federativos envolvidos; além do mais, a necessidade de questão possuir um significado suprarregional subsistiu como requisito para a cooperação. Foram as áreas submetidas ao regramento do artigo 91b GG que foram alteradas. A partir de então, União e Estados poderiam celebrar acordos sobre os seguintes temas: (i) instituições e projetos de pesquisa científica fora de estabelecimentos de ensino superior; (ii) projetos de ciência e pesquisa em estabelecimentos de ensino superior, e; (iii) construções de pesquisa em estabelecimentos de ensino superior, inclusive equipamentos grandes. Percebe-se, por um lado, que a tarefa comum anteriormente designada pelo artigo 91b como "promoção da pesquisa científica" foi desdobrada e detalhada pelo legislador constituinte de 2006. Por outro lado, também se constata que parte da área antigamente prevista no artigo 91a I Nr. 1 GG foi transferida para o artigo 91b. Não se pode deixar de reconhecer, afinal, que existe uma certa correspondência entre a “construção e a ampliação de instituições de ensino superior" (antigo artigo 91a I Nr. 1 GG) e "projetos de ciência e pesquisa em estabelecimentos de ensino superior" (atual artigo 91b I Nr. 2 GG). Note-se que, em relação a esta última área, o legislador constituinte de 2006 considerou oportuno exigir a concordância de todos os Länder, trazendo para o artigo 91b a tomada de decisões por unanimidade tão característica do artigo 91 a GG. ${ }^{836}$

Em 2009 e 2010 foram incluídos três novos dispositivos nesta parte da Lei Fundamental, que passou a se chamar "tarefas comum, colaboração administrativa". Referese especificamente aos artigos 91c, 91d e 91e GG. Porém, tratam-se de previsões constitucionais que tem pouca relevância para o estudo comparativo e que, por isso, não serão objeto de considerações mais detalhadas. Parte-se então para o confronto dos sistemas brasileiro e alemão de repartição de competências legislativas e de execução.

\footnotetext{
835 Conforme VOLKMANN. Artikel 91b. In: von MANGOLDT, KLEIN, STARCK (Hrsg.). Kommentare zum Grundgesetz, pp. 539 e 543.

836 Note-se que, em 2014, o artigo 91b I GG foi novamente alterado, passando a dispor o seguinte: “União e Estados podem, em razão de acordos em casos de importância suprarregional, colaborar para a promoção da ciência, pesquisa e ensino. Acordos, que digam respeito especialmente a instituições de ensino superior, necessitam de aprovação de todos os Estados. Isto não vale para aacordos sobre construções para a pesquisa, inclusive grandes equipamentos". Retornou-se, portanto, a uma redação mais genérica, parecida porém não idêntica à redação aprovada em 1969. Os demais parágrafos do artigo 91b GG permaneceram inalterados.
} 


\section{SEXTO CAPÍTULO - CONFRONTAÇÃO DA REPARTIÇÃO DE COMPETÊNCIAS LEGISLATIVAS E DE EXECUÇÃO NO BRASIL E NA ALEMANHA}

Expostas as principais características dos sistemas brasileiro e alemão de repartição de competências legislativas e de execução, é chegado o momento de confrontá-los, buscando identificar semelhanças e diferenças entre eles. Trata-se de uma tarefa árdua, como já se mencionou em mais de uma passagem desta tese, não só em decorrência da complexidade dos objetos de comparação selecionados. Por onde começar a comparação? Como expor os resultados desta comparação? Estas são perguntas respondidas, necessariamente, com uma certa dose de subjetividade. Afinal, a comparação jurídica não é uma área com uma metodologia propriamente pronta e acabada e, em razão disso, não fornece uma resposta para todos os problemas que invariavelmente surgem em uma investigação deste tipo.

Quanto ao primeiro destes questionamentos, acreditamos que uma pesquisa que envolve a confrontação de um bloco de normas - em especial, de normas constitucionais, em razão de sua importância para a vida política de um país - só pode ser bem conduzida quando os próprios contextos em que elas são produzidas e nos quais elas devem produzir seus efeitos são compreendidos e confrontados. Esta, aliás, foi uma tarefa empreendida no segundo e no terceiro capítulos da tese, sendo que, ao final, foram constatadas semelhanças e diferenças importantes nos principais eixos temáticos selecionados para a comparação. Deste modo, foi possível verificar que tanto Brasil quanto Alemanha são federações marcadas por uma forte centralização, e que tentam ao longo dos anos reverter ou ao menos mitigar os efeitos desta tendência. Por óbvio, não se quer dizer que Brasil e Alemanha vivenciam esta centralização da mesma forma. Porém, percebe-se uma tendência comum de centralização no âmbito da legislação, ponderada por uma descentralização substancial na seara administrativa, o que é extremamente importante para a compreensão da repartição de competências legislativa e de execução nestes dois países. A fim de viabilizar a realização de políticas públicas neste contexto, tanto a federação brasileira quanto a federação alemã recorrem à cooperação federativa. E neste último ponto percebe-se uma diferença fundamental entre Brasil e Alemanha: enquanto no primeiro país a adesão das unidades federativas deve ser incentivada, sobretudo por meio de incentivos de natureza fiscal, no segundo observa-se tomada de decisões conjuntas. Esta última, por sua vez, poderia até ser considerada como algo positivo se os entes federativos pudessem vislumbrar a tomada individual de decisões, quando as circunstâncias possibilitassem uma atuação autônoma. Contudo, não é isso que acontece na prática, conforme já analisado, e por isso a cooperação 
se tornou um problema para os alemães, do qual eles tentam se desvencilhar, tanto quanto da centralização, por meio de sucessivas reformas constitucionais.

Porém, a compreensão e a confrontação dos diversos contextos em que as normas constitucionais analisadas se inserem não bastam para responder aos questionamentos colocados supra. É necessário, além do mais, forjar e aplicar um referencial teórico que permita enxergar semelhanças e diferenças que realmente importam. Poder-se-ia, por exemplo, ponderar que a emissão de moeda se encontra inserida na competência privativa da União no Brasil e Alemanha, ou como legislação sobre direito civil e direito penal compete neste primeiro país privativamente à União e, no segundo, concorrentemente à União e aos Estados. Porém, assertivas deste tipo deixam de lado algo fundamental, mais precisamente, o que é uma competência privativa e uma competência concorrente no Brasil e na Alemanha. Afinal, diante de tudo o que oi exposto até o presente momento já é possível concluir que os contornos dogmáticos destas modalidades de competências diferem - sendo que, em alguns casos, diferem substancialmente - nos dois ordenamentos considerados.

Optou-se, deste modo, por utilizar as dicotomias competências legislativas/de execução e competências privativas/concorrentes - cujos contornos foram expostos no primeiro capítulo da tese, dedicado à exposição das premissas teóricas - como uma forma de se aproximar dos objetos de comparação e de melhor entender as semelhanças e as diferenças entre eles verificadas. Já no quarto e o quinto capítulos os sistemas brasileiro e alemão de repartição de competências foram compreendidos a partir destas chaves de análise. Obviamente, a ideia destes capítulos era expor o sentido e o alcance das principais regras que disciplinam a repartição de competências no Brasil e na Alemanha, consoante a jurisprudência e a doutrina destes dois países. Não obstante isso, aproveitou-se o ensejo para introduzir alguns argumentos que serão amarrados e discutidos neste sexto capítulo. Note-se que as referidas dicotomias são utilizadas, além do mais, como um modo de expor de forma mais racional e organizada as conclusões obtidas a partir da confrontação dos ordenamentos considerados. Por este motivo, aliás, é que existe neste capítulo um tópico dedicado à análise das competências legislativas e de execução e outro tópico à análise das competências privativas e concorrentes em uma perspectiva comparada.

Antes, contudo, considera-se oportuno tratar de dois temas. Em primeiro lugar, é preciso traçar algumas considerações sobre um enfoque do direito comparado conhecido como transplantes e recepções, diante do reconhecimento de que existem algumas intersecções importantes da presente tese com esta vertente da comparação jurídica. Em segundo lugar, acredita-se que é importante tecer algumas observações sobre as chamadas regras gerais em matéria de repartição de competências. Sabe-se que elas são relativamente 
abundantes na Lei Fundamental de 1949, ao passo que a Constituição Federal de 1988 contém poucas regras com uma vocação geral. Embora a extensa enumeração de competências à União tenha diminuído o alcance de alguma destas regras - é o caso do artigo $70 \mathrm{GG}$ e certamente o caso do artigo $25, \S 1^{\circ}, \mathrm{CF} / 88$ - considera-se que constituem vetores importantes para a compreensão do sistema constitucional de repartição de competências como um todo, conformando a interpretação que se dá a outras regras que atribuem competências a um ou outro nível federativo.

\subsection{TRANSPLANTES E RECEPÇÕES: AS POSSÍVEIS INTERAÇÕES ENTRE A CONSTituiçÃo Federal de 1988 e A LeI FundamentAL DE 1949}

\subsubsection{Transplantes jurídicos: noções gerais}

A vertente da comparação jurídica conhecida como transplantes e recepções consiste em um campo relativamente recente de investigação científica ${ }^{837}$ e tem a sua fundação normalmente atrelada à conhecida obra de Alan WATSON intitulada "Legal Transplants: An Approach to Comparative Law”, editada pela primeira vez em $1974^{838}$. Para WATSON, o direito comparado não seria o estudo de um ordenamento jurídico estrangeiro ou parte dele e nem uma simples contagem dos vários sistemas jurídicos ou das famílias de sistemas. Note-se que o direito comparado não seria sequer uma questão de traçar comparações, pois seria "bem questionável se comparações são justificáveis em termos acadêmicos como direito comparado, se o ponto de partida é o problema jurídico ou o ramo do direito", pois os diferentes contextos sociais, políticos, econômicos tornam difícil crer que duas sociedades tenham o mesmo problema, a não ser em um nível técnico ${ }^{839}$. Segundo este autor, direito comparado consistiria, a bem da verdade, no estudo do relacionamento entre ordenamentos jurídicos, sendo que as razões das semelhanças e das diferenças verificadas entre eles seriam aferidas por meio de um estudo da história destes mesmos ordenamentos. Nesse sentido, o direito comparado seria "história do direito preocupada com

\footnotetext{
837 Como é observado em GRAZIADEI. Comparative Law as the study of transplants and receptions, p. 442.

${ }^{838}$ A versão consultada para a elaboração deste tópico é a segunda edição desta mesma obra, editada em 1993. A referência bibliográfica completa da versão que será citada neste tópico é a seguinte: Alan WATSON. Legal Transplants: An Approach to Comparative Law. 2a Ed. Athens e Londres: The University of Georgia Press, 1993.

839 WATSON. Legal Transplants, p. 4. Neste último ponto o autor parece inclusive refutar estudos comparativos tais como o conduzido nesta presente tese. Contudo, ao analisar o trecho com calma, principalmente diante das referências a problemas comuns a mais de uma sociedade, parece na verdade que o autor se insurge contra uma comparação conduzida em moldes funcionalistas. Sobre o funcionalismo no direito comparado, vide nota de rodapé $n$ o 28 .
} 
o relacionamento de sistemas"; porém, não se confundiria com a história do direito em função do relacionamento em questão, o qual poderia ser de três tipos: (i) quando regras de um sistema derivam de outro sistema, provavelmente com modificações; (ii) quando dois sistemas jurídicos derivam de um terceiro sistema, e; (iii) quando um sistema exerce influência sobre outro. ${ }^{840}$

A expressão transplante jurídico, por sua vez, seria reservada ao movimento, à transferência "de uma regra ou de um sistema jurídico de um país para o outro, de um povo para outro" ${ }^{841}$. Neste ponto, um parêntese importante: WATSON trata nesta obra dos transplantes jurídicos, mas a corrente do direito comparado em comento é chamada normalmente de transplantes e recepções. Michele GRAZIADEI, sobre a terminologia própria deste enfoque, toma as expressões "transplantes" e "recepções" como conceitos abrangentes e equivalentes, ao passo que a expressão "transferência" é por ele utilizada quando um termo genérico se aplica ao caso ${ }^{842}$. De certo modo, esta é uma opção encampada pela presente tese. $\mathrm{Na}$ verdade, acredita-se que as expressões transplantes e recepções revelam apenas uma mudança de perspectiva do fenômeno: enquanto transplantes, ou mesmo transferências, se referem ao movimento da norma jurídica de um ordenamento para o outro, as recepções traduzem o momento da acolhida desta norma jurídica pelo ordenamento jurídico destinatário, por assim dizer. Retomando o raciocínio, tem-se que os maiores transplantes voluntários poderiam, segundo WATSON, serem enquadrados em três categorias:

\footnotetext{
"Primeiro quando um povo muda para um território diferente onde não existe uma civilização comparável, e leva a sua lei consigo. Em segundo lugar, quando um povo muda para um território diferente onde existe uma civilização comparável, e leva a sua lei consigo. Em terceiro lugar, quando um povo voluntariamente aceita uma grande parte do sistema de outro povo ou povos" 843
}

Exemplos destes grandes transplantes voluntários são a recepção do direito romano na Europa a partir do final da Idade Média, impulsionada pelos estudos desenvolvidos e difundidos no âmbito das universidades, e a recepção do Common Law em antigas colônias britânicas, inclusive por meio inclusive de "estatutos de recepção" como aqueles editados pelos Estados norte-americanos depois da criação da União ${ }^{844}$. É certo, porém, que existem

\footnotetext{
840 WATSON. Legal Transplants, pp. 6-7.

841 WATSON. Legal Transplants, p. 21.

842 GRAZIADEI. Comparative Law as the study of transplants and receptions, pp. 443-444.

843 WATSON. Legal Transplants, pp. 29-30.

844 GRAZIADEI. Comparative Law as the study of transplants and receptions, pp. 445-447 e 451-453. Note-se que Alan WATSON trabalha com outros exemplos de grandes transplantes jurídicos, como por exemplo, a
} 
muitos transplantes voluntários de menor monta, envolvendo a transferência de regras ou institutos jurídicos específicos. É o que ocorre, por exemplo, quando o legislador de um país procura, como se costuma dizer impropriamente, "no direito comparado", soluções que ele julga adequadas para resolver problemas internos. Ele pode não querer transplantar regras, mas somente tomar decisões informadas por outras concepções de direito, e nesse caso a identificação de um transplante jurídico pode ser mais complicada, como ressalta Michele GRAZIADEI $^{845}$. De todo modo, deve-se reconhecer que transplantes jurídicos voluntários, tanto grandes quanto pequenos, são comuns e corriqueiros. Não por outro motivo, Alan WATSON chega a sugerir que "o transplante é, na verdade, a fonte mais fértil de desenvolvimento. A maioria das mudanças na maioria dos sistemas são resultado de empréstimos" $" 846$.

Porém, os transplantes também podem se dar involuntariamente, por uma imposição do vencedor de uma guerra ou do colonizador. Michele GRAZIADEI, nesse sentido, menciona que "o crescimento dos impérios coloniais na África, nas Américas, Ásia e Oceania trouxe com ele a importação de modelos ocidentais, os quais eram familiares somente para os colonizadores" ${ }^{\prime 847}$. Na verdade, não se trata de algo estranho à realidade brasileira, tendo em vista que o Brasil durante séculos foi colônia do Império português e sofreu influência profunda do direito português, a qual permaneceu muito forte mesmo depois da independência. Apenas para se ter uma ideia, até a adoção do Código Civil brasileiro, em 1916, as relações civis desenvolvidas em território brasileiro permaneciam regulamentadas pelas ordenações do Reino portuguesas. ${ }^{848}$ De todo modo, o caso brasileiro revela outros dois fenômenos importantes em sede de transplantes e recepções jurídicas.

Em primeiro lugar, o transplante jurídico em um contexto de imposição pode ser tanto uma experiência transitória e que será abandonada quando terminar a situação de

\footnotetext{
recepção do direito romano na Escócia e no direito inglês na Nova Zelândia. Para maiores detalhes, vide WATSON. Legal Transplants, pp. 31 e seguintes.

845 Michele GRAZIADEI. Legal Transplants and the Frontiers of Legal Knowledge. Theoretical Inquiries in Law, vol. 10, 2009, p. 701.

846 WATSON. Legal Transplants, p. 95.

847 GRAZIADEI. Comparative Law as the study of transplants and receptions, p. 456.

${ }^{848}$ Segundo Orlando GOMES, "A Constituição de 25 de março de 1824 prescrever, no art. 179, no XVIII, que se organizasse, quanto antes, um Código Civil, fundado nas sólidas bases da Justiça e da Equidade. A despeito de todas as tentativas fetias para o cumprimento desta determinação, sobreveio a República, em 1889, sem se ter realizado a reforma legislativa de base, aspirada desde a proclamação da Independência. As Ordenações Filipinas, embora alteradas e completadas, sobreviveram à queda do Império, conservando sua extraordinária vitalidade nos primeiros vinte e cinco anos do regime republicano. E assim completaram 314 anos de existência" (Orlando GOMES. Raízes Históricas e Sociológicas do Código Civil Brasileiro. Salvador: Livraria Progresso Editora, 1958, p. 13).
} 
dominação, ou persistir como parte do direito do país ora subjugado, quando a imposição do direito estrangeiro é respaldada por um duradouro controle militar ou político ${ }^{849}$. A influência - em um primeiro momento, a vigência - do direito português no Brasil parece se enquadrar no segundo cenário, ainda que, com o passar dos anos, seja perceptível a influência de outros ordenamentos jurídicos, tais como o francês, o norte-americano e, mais recentemente, o alemão. Aliás, nesta evolução reside o segundo fenômeno observável no direito brasileiro e que pode ser compreendido a partir das noções de transplantes e recepções.

Com efeito, o prestígio de determinados ordenamentos jurídicos também consiste em um fator importante de mudança e que pode motivar o transplante de determinadas regras e instituições jurídicas. Como ressalta Michele GRAZIADEI, "mais frequentemente, recepções e transplantes jurídicos tem ocorrido sem violência. O desejo de ter o que os outros têm, especialmente se ele é tido como superior, pode ser o suficiente para desencadear transplantes ou recepções" ${ }^{\text {" } 50}$. Note-se que esta afirmação permanece verdadeira ainda que seja transferida, afinal, uma concepção errônea e empobrecida do direito estrangeiro ${ }^{851}$. Parece ter sido este, aliás, o caso do acolhimento da teoria francesa do contrato administrativo no Brasil, como pondera Fernando Dias MENEZES DE ALMEIDA ${ }^{852}$, muito embora o referido autor não analise este fenômeno sob o enfoque do direito comparado em comento.

A identificação de um transplante jurídico na prática resta comprometida, contudo, quando apenas se acredita ter ocorrido um deles. Segundo GRAZIADEI, "alguns transplantes existem somente na crença de certa comunidade", citando, como

\footnotetext{
849 GRAZIADEI. Comparative Law as the study of transplants and receptions, p. 457.

850 GRAZIADEI. Comparative Law as the study of transplants and receptions, pp. 457-458.

${ }^{851}$ Nesse sentido, ao traçar algumas reflexões gerais sobre os transplantes por ele analisados, Alan WATSON pondera que "o direito estrangeiro pode ser influente mesmo quando ele completamente mal compreendido" (Legal Transplants, p. 99).

852 Fernando Dias MENEZES DE ALMEIDA. Contrato administrativo. São Paulo: Quartier Latin, 2012, pp. 318 320. Segundo este autor no referido trecho de sua obra, "com efeito, a teoria surgiu em contexto institucional diverso, com o sentido de sistematizar elementos da prática já adotada, progressivamente, a partir de decisões do Conselho de Estado francês, as quais, por sua própria natureza, são mais sujeitas a mudanças decorrentes da necessidade de se oferecerem soluções adaptadas a cada um dos casos concretos, em diversos momentos históricos. Porém, o tratamento dogmático dado à teoria do contrato administrativo - quando transposta ao Brasil e mesmo em sua evolução na França - acabou por the impor uma redução simplificadora e empobrecedora da construção original. Neste sentido, se se tomar o pensamento de Gaston JÈZE como pensamento fundador da teoria do contrato administrativo, verifica-se que sua construção possuía muitas sutilezas a mais do que a simplificação dogmática que, no senso comum, reduz a essência da teoria do contrato administrativo à afirmação das ditas 'cláusulas exorbitantes', ou seja, de um regime de poderes de ação autoexecutória unilateral por parte da Administração, notadamente no tocante à rescisão ou alteração unilateral dos contratos, acompanhada, como contraponto, do equilíbrio econômico-financeiro do contrato".
} 
exemplo, o caso do sistema israelita de educação jurídica, o qual seria baseado em um método problemático. Muitos acreditam que ele teria sido importado de Harvard, mas na verdade a sua origem residiria no próprio direito doméstico, a partir dos esforços de um professor chamado Joshua Weisman. Por este motivo, a identificação de um transplante jurídico deve ser conduzida de uma forma cética e meticulosa, pois uma invenção doméstica, produzida por juristas ou políticos de um determinado país, pode parecer uma importação de normas e institutos jurídicos de outros ordenamentos jurídicos. ${ }^{853}$

\subsubsection{A possível influência da Lei Fundamental de 1949 sobre a Constituição Federal de 1988}

$\mathrm{Na}$ introdução deste trabalho afirmou-se que a presente pesquisa retoma uma concepção minimalista da comparação jurídica, preocupada primordialmente com a identificação de semelhanças e diferenças dos sistemas brasileiro e alemão de repartição de competências legislativas e de execução. Os objetivos, declarados nesta mesma ocasião, consistem em uma melhor compreensão do sistema brasileiro, além da busca de alguns subsídios no direito alemão para a solução de alguns problemas brasileiros em matéria de repartição de competências. Porém, não se pode deixar de reconhecer que, em um primeiro momento, o que despertou a curiosidade para a comparação entre Brasil e Alemanha foi a afirmação de parte da doutrina brasileira de que a Constituição Federal de 1988, no que diz respeito à repartição de competências legislativas e de execução, teria se inspirado na Lei Fundamental de 1949. Note-se que esta mesma doutrina fala em inspiração e não em transplante jurídico; não obstante isso, a referida noção oriunda do direito comparado e exposta no item anterior vem à mente, intuitivamente, quando se depara, por exemplo, com o seguinte trecho do pensamento de Fernanda Dias Menezes de ALMEIDA:

\footnotetext{
"Mas o sistema de partilha de competências, como um todo, mais se aproxima do sistema alemão, com a previsão das competências legislativas e não legislativas da União em artigos distintos; com a separação, também, das competências comuns legislativas e não legislativas; com a previsão de delegação de competências legislativas da União aos Estados pelo legislador federal; com a repartição vertical de competência legislativa concorrente, cabendo as normas gerais à União e a legislação suplementar aos Estados.

Aliás, procede lembrar que o anteprojeto Afonso, tomado como base na Constituinte para a versão final do sistema de repartição de competências, praticamente reeditava a proposta apresentada por JOSÉ AFONSO DA SILVA à Comissão Afonso Arinos, proposta esta ali acolhida pelo relator da matéria, RAUL MACHADO HORTA, com aperfeiçoamentos por ele sugeridos. É mais um indicativo de que se teria feito sentir a influência da Constituição alemã, pela qual,
}

${ }^{853}$ GRAZIEDEI. Legal Transplants and the Frontiers of Legal Knowledge, p. 701. 
já se viu, RAUL MACHADO HORTA revela, não sem razão, particular simpatia." 854

Ao se debruçar sobre a obra de Raul Machado HORTA - fiquemos, para este fim, apenas com a obra intitulada "Direito Constitucional", que reúne uma série de conhecidos artigos deste autor - percebe-se, por sua vez, algumas referências à influência que a Lei Fundamental de 1949 teria desempenhado no federalismo brasileiro pós-1988, como, por exemplo:

\begin{abstract}
“A Constituição de 1988 modernizou a repartição das competências da União, dos Estados, do Distrito Federal e dos Municípios. A repartição de competências serve para identificar as tendências do federalismo constitucional. Pode ser a sede da centralização, com sacrifício da autonomia, como pode se converter na peça de fortalecimento da autonomia.

No rumo do fortalecimento é que infletiu o federalismo constitucional de 1988. Voltando-se para as fontes contemporâneas do federalismo europeu, especial o da Lei Fundamental de Bonn, a Constituição vigente diversificou a repartição de competências, para distribuí-la nos domínios da competência geral da União (art. 21, I a XXI); competência legislativa privativa da União (art. 22, I a XXIX); competência comum da União, dos Estados, do Distrito Federal e dos Municípios (art. 23, I a XII, parágrafo único); e a competência de legislação concorrente da União, dos Estados e do Distrito Federal (art. 24, I a XVI, $\S \S 1^{\circ}$ a $4^{\circ}$ )." ${ }^{\text {, } 55}$

"Inspirando-se na concepção desenvolvida na Lei Fundamental da Alemanha, de 1949, que o Anteprojeto de Constituição Federal da Comissão Afonso Arinos (1986) adotou, a Constituição de 1988, introduziu na repartição de competências a técnica da legislação concorrente da União, dos Estados e do Distrito Federal, abrandando o volume da legislação que tradicionalmente compunha nas Constituições anteriores à legislação privativa da União." ${ }^{\text {"856 }}$
\end{abstract}

“A repartição de competências, estruturada na Constituição Federal de 1988, reflete as novas tendências do federalismo e na concepção constitucional é visível a influência recebida da técnica de repartição de competências da Lei Fundamental da Alemanha, de 1949, que o Ante Projeto de Constituição Federal da Comissão Arinos incorporou. (...) No domínio da competência legislativa concorrente, a Constituição limitou a competência da União ao estabelecimento de normas gerais (art. 24, $\left.\S \S 1^{\circ}, 2^{\circ}, 3^{\circ}\right)$. Na linha da Lei Fundamental da Alemanha, que admitiu o ingresso dos Estados-Membros no domínio da competência legislativa exclusiva da Federação (art. 71), a Constituição Federal de 1988 dispõe que lei complementar poderá autorizar os Estados a legislar sobre questões específicas de matérias da competência legislativa privativa da União (art. 22, parágrafo único), em potencial ampliação da competência legislativa dos Estados no condomínio legislativo, que a Constituição implantou na competência de legislação concorrente." 857

\footnotetext{
${ }^{854}$ ALMEIDA. Competências na Constituição de 1988, p. 76.

855 HORTA. Direito Constitucional, p. 414 (grifos no original).

856 HORTA. Direito Constitucional, p. 424 (grifos no original).

857 HORTA. Direito Constitucional, p. 449 (grifos no original). Neste ponto, cumpre apenas esclarecer que estas tendências modernas a que o autor se refere no começo da sua citação encontravam-se plasmadas em algumas constituições editadas no período pós-guerra, entre elas a Lei Fundamental de 1949.
} 
Parece-nos, contudo, que a repartição de competências legislativas e de execução atualmente vigente é, sobretudo, um desdobramento das constituições anteriores, tendo em vista que a maioria das inovações supostamente forjadas sob o influxo da Lei Fundamental de 1949 já encontravam previsão na legislação constitucional anterior a 1988. O que a Constituição Federal de 1988 fez foi tornar algumas opções tradicionais em matéria de repartição de competência - em especial, no que diz respeito à competência legislativa concorrente - mais claras. Em razão disso, a afirmação de que a constituição brasileira vigente teria se inspirado da Lei Fundamental soa um pouco equivocada, muito embora isso não signifique dizer que não haja semelhanças entre estas duas constituições. Ao contrário, a presente tese parte não só do pressuposto de que estas semelhanças existem, mas de que são semelhanças suficientes para fins de elaboração de um estudo comparativo. O que não é possível, no nosso sentir, é reconduzir todas estas semelhanças à ideia de um transplante jurídico (neste caso, transplante jurídico voluntário por influência de um ordenamento jurídico sobre outro, como sugere WATSON, ou em função do prestígio de um determinado ordenamento, como propõe GRAZIADEI).

Com efeito, a separação entre competências legislativas e não legislativas da União é tradicional no Brasil e remonta à Constituição Federal de 1934. Nesse sentido, os incisos I a XVIII do seu artigo $5^{\circ}$ tratavam basicamente do que hoje se convém denominar de competência geral da União, ao passo que o inciso XIX arrolava, em alíneas, a competências legislativas da União. Esta mesma fórmula foi repetida pela Constituição Federal de 1946 nos incisos I a XIV do seu artigo $5^{\circ}$ e alíneas do artigo $5^{\circ}, \mathrm{XV}$, bem como pela Constituição Federal de 1967-69 no seu artigo $8^{\circ}$, I a XVI e alíneas do artigo $8^{\circ}$, XVII. O que a Constituição Federal de 1988 fez foi somente cindir a competência geral e a competência legislativa privativa da União em dois artigos, e não se pode afirmar que trata de algo completamente original no direito brasileiro, tendo em vista que a Constituição Federal de 1937 já fazia o mesmo nos seus artigos 15 e 16.

Já a competência legislativa concorrente também possui um longo histórico no direito brasileiro, embora tenha sido denominada de "concorrente" apenas pela Constituição Federal de 1988. O tema já foi analisado com todos os seus desdobramentos no tópico 4.4 desta tese. De todo modo, convém relembrar que a limitação da competência federal à edição de normas gerais encontra previsão no Brasil desde a Constituição Federal de 1934, tendo sido repetida pelas constituições posteriores. Além do mais, a competência suplementar dos Estados, prevista no artigo $24, \S 2^{\circ}, \mathrm{CF} / 88$, parece ser nada mais do que uma reedição da competência complementar disciplinada nas constituições anteriores, ao passo que a competência legislativa plena a que se refere o artigo $24, \S 3^{\circ}, \mathrm{CF} / 88$ apresenta-se como uma 
reformulação da competência legislativa supletiva dos Estados-membros, disciplinada pela primeira vez também pela Constituição de 1934 e repetida nas constituições posteriores.

A grande novidade efetivamente trazida pela Constituição Federal de 1988 neste ponto consistiu na expansão da competência legislativa concorrente, embora muitas das matérias arroladas atualmente nos incisos do artigo $24 \mathrm{CF} / 88$ já se encontrassem inseridas na competência legislativa complementar ou supletiva dos Estados sob a égide das constituições anteriores. É o caso, por exemplo, da competência sobre direito financeiro (artigo $6^{\circ} \mathrm{CF} / 1946$ e artigo $8^{\circ}$, parágrafo único, CF/1967-69), produção e consumo (artigo $8^{\circ}$, parágrafo único, CF/1967-69) e diretrizes e bases da educação (artigo 5, § 3º CF/1934, artigo $6^{\circ} \mathrm{CF} / 1946$ e artigo $8^{\circ}$, parágrafo único, CF/1967-69). Além do mais, pode-se vislumbrar uma alteração de terminologia: se antes se falava em competência legislativa supletiva e complementar dos Estados, a ser exercida em hipóteses de competência privativa da União - ao menos em tese, tendo em vista que as constituições anteriores restringiam a atuação legiferante da União sobre algumas matérias à edição de normas gerais - hoje se fala em competência legislativa concorrente da União e dos Estados. Tal opção parecia privilegiar a autonomia estadual em um primeiro momento; porém, esta é uma percepção que restou desconfirmada na prática. ${ }^{858}$

\footnotetext{
${ }^{858}$ Ainda em relação à competência legislativa concorrente e à influência supostamente exercida pelo direito alemão, Diogo de Figueiredo MOREIRA NETO anota que "a Constituição brasileira de 26 de junho de 1934 não só manteve a competência concorrente clássica, enumerando expressamente os casos de sua concorrência, como sob forte inspiração do referido art. 10, da Carta de Weimar, estabeleceu várias hipóteses de competência concorrente limitada (artigo 5ㅇ, § 3)" (MOREIRA NETO. Competência concorrente limitada, p. 132). Por óbvio, a confirmação desta assertiva depende da análise dos trabalhos da assembleia constituinte responsável pela elaboração desta constituição, o que certamente transcende o escopo da presente tese. Porém, ainda que tenha sido o objetivo do legislador constituinte se inspirar em Weimar, é de admitir que o resultado, vale dizer, o que efetivamente se encontrava plasmado na Constituição de 1934, era substancialmente distinto das previsões contidas na Constituição alemã de 1919. Como já analisado no tópico 2.2.1.2, referido diploma conferia à União uma competência legislativa privativa (artigo 6o WRV) e uma competência legislativa (artigo 70 WRV), que não era qualificada nem como privativa nem como concorrente, mas à qual se aplicava o disposto no artigo 12 WRV (segundo o qual os Estados poderiam legislar se e à medida que o Reich não fizesse exercício de sua competência legislativa). Além do mais, o artigo go submetia o exercício de determinas competências legislativas pelo Reich à existência de uma necessidade (Bedürfnis) de preceitos uniformizantes, ao passo que os artigos 10 e 11 WRV tratavam da competência federal para editar princípios sobre determinadas matérias. Percebe-se, portanto, que o foco da Constituição alemã consistia na enumeração e regulamentação da competência do Reich, sendo que a competência dos Länder restava assegurada por meio de uma cláusula genérica, uma verdadeira competência residual. Já o artigo 5ㅇ, § 3으, CF/1934 a que se refere MOREIRA NETO no trecho supracitado não trata da competência da União e sim da competência dos Estados, cindindo-a em competência complementar e supletiva, e arrolando as matérias submetidas a cada uma delas. Ele não previa uma competência residual e genérica aos Estados, como fazia o artigo 12 WRV. A única semelhança, em termos, que se percebe entre as duas constituições é a restrição da atuação legiferante da União em algumas hipóteses. Diz-se em termos, porque a Constituição de Weimar restringia a atuação da União à edição de princípios (Grundsätze), ao passo que a Constituição brasileira de 1934 fala em normas gerais, o que não necessariamente é a mesma coisa.
} 
As únicas normas constitucionais vigentes que não encontram nenhum paralelo em constituições anteriores e em relação às quais se vislumbra afinidades mais marcantes com a Lei Fundamental encontram-se previstas no artigo 22, parágrafo único, e no artigo 23 $\mathrm{CF} / 88$. A primeira delas, de fato, em muito se assemelha ao artigo $71 \mathrm{GG}$, o qual dispõe que lei federal pode autorizar os Länder a regulamentarem questões inseridas na competência privativa do Bund. Já a segunda delas, por sua vez, aproxima-se do artigo 91a GG, que trata das tarefas comuns, principalmente na parte em que submete a disciplina da cooperação à lei federal. Em relação ao artigo 22, parágrafo único, $\mathrm{CF} / 88$, afirmar a ocorrência de um transplante jurídico seria plausível até - deve-se lembrar, aliás, que Fernanda Dias Menezes de ALMEIDA cita este dispositivo para corroborar o argumento acerca da influência da Lei Fundamental sobre o sistema brasileiro de repartição de competências legislativas e de execução - muito embora uma previsão como esta não seja algo realmente inédito no direito brasileiro. Nesse sentido, basta verificar o teor do artigo 17 CF/1937. Já em relação ao artigo $23 \mathrm{CF} / 88$, é de se admitir que a sua elaboração não esteve vinculada à intenção de se forjar institutos similares aos das tarefas comuns alemãs. Ao contrário, como este dispositivo da constituição brasileira consiste em um desdobramento da competência legislativa concorrente, pode-se concluir que ele se encontra compreendido na mesma evolução do atual artigo $24 \mathrm{CF} / 88$ e analisada no item 4.4 desta tese.

Por este motivo, entende-se que as semelhanças e as diferenças apresentadas e discutidas ainda neste sexto capítulo não consistem propriamente em um relacionamento entre os sistemas de repartição de competências legislativas e de execução previstos pela Constituição Federal de 1988 e pela Lei Fundamental de 1949, ao menos não nos moldes propugnados pelo enfoque do direito comparado conhecido como transplantes e recepções. Ao contrário, acredita-se que as principais decisões constitucionais sobre a distribuição das competências legislativas e de execução no Brasil apresentam um elemento de continuidade muito forte em relação às constituições anteriores. Para melhor compreender estas decisões, é preciso analisar a evolução das normas constitucionais que disciplinam a distribuição de competências legislativas e de execução em uma perspectiva histórica, considerando as disposições pertinentes nas sucessivas constituições brasileiras.

A influência que a Constituição Federal de 1988 teria recebido da Lei Fundamental de 1949 coloca-se, portanto, mais como um discurso doutrinário e menos como uma realidade, aplicando-se a ela as ponderações de Michele GRAZIADEI com as quais se encerrou o tópico anterior. Note-se, finalmente, que afirmações deste tipo não pretendem desmerecer o pensamento de Fernanda Dias Menezes de ALMEIDA ou de Raul Machado HORTA. Pelo contrário, a primeira autora possui uma das melhores e mais 
influentes obras sobre repartição de competências no Brasil, resultado de uma tese de doutorado defendida já nos primeiros anos de vigência da Constituição Federal de 1988, e que influenciou de forma decisiva a percepção desta tese sobre o tema. Já Raul Machado HORTA é sem sombra de dúvida um dos grandes artífices da teoria jurídica do federalismo no Brasil. Tendo em vista que este autor escreveu sob a égide de pelo menos três constituições brasileiras, é possível inclusive compreender a evolução do pensamento jurídico sobre o federalismo a partir da análise de suas obras. Ocorre que estes autores não estão preocupados em conduzir um estudo comparativo, ao contrário da presente tese, e ponderações deste tipo traduzem um relacionamento específico entre os objetos de comparação, devidamente explicitado no item 6.1.1. É extamente este relacionamento específico - que confere um determinado sentido às semelhanças e às diferenças encontradas a partir do confronto dos sistemas brasileiro e alemão de repartição de competências legislativas e de execução - que se pretende ver afastado.

\subsubsection{Como a noção de transplante jurídico aproveita à presente tese}

As considerações traçadas supra não encerram, contudo, todas as possíveis interações da repartição de competências legislativas e de execução no Brasil e também desta tese com as noções de transplantes e de recepções jurídicas. Para tanto, é importante compreender que a referência ao direito estrangeiro como forma de reforçar e validar um argumento - enfim, como um argumento de autoridade - também pode levar a um transplante jurídico. Aliás, o próprio Alan WATSON observa este fato no seguinte trecho de sua obra:

\footnotetext{
"Em décimo lugar, as duas conclusões anteriores, na verdade quase todas até agora, mostram a importância da autoridade para os transplantes e para o direito em geral. É uma característica bem marcante dos advogados que eles não gostam de pensar que estão sozinhos ou que as suas decisões são o resultado do seu próprio poder limitado de argumentação. Portanto, a força da doutrina do precedente no direito inglês, o hábito dos juristas romanos de listar os seus companheiros em apoio, e até certo ponto a frequência dos transplantes. Mesmo quando um jurista já decidiu o que ele deseja que a lei seja, ele pode olhar (ou mesmo inventar) um precedente de um sistema respeitado para reforçar a sua opinião. Em casos extremos, a reivindicação pode ser feita de que o direito vem de um deus. Transplantes na verdade oferecem uma percepção sobre a importância decisiva acerca do papel desempenhado pela autoridade no direito" ${ }^{\prime 59}$
}

O fenômeno retratado por WATSON existe entre nós há séculos. A corroborar esta afirmação, basta lembrar das inúmeras referências dos doutrinadores brasileiros do Império e também da Primeira República a obras norte-americanas ou francesas. No caso do direito

\footnotetext{
859 WATSON. Legal Transplants, p. 99.
} 
administrativo, por exemplo, demorou um certo tempo até que se formasse no Brasil uma teoria com características próprias, como ressalta Fernando Dias MENEZES DE ALMEIDA, ainda que as citações de obras estrangeiras não tenham exatamente cessado, justamente por conta do prestígio que elas costumam gozar dentre os autores brasileiros ${ }^{860}$. Em tempos de globalização, estas referências ao direito estrangeiro tornaram-se ainda mais frequentes nos diversos ramos do direito e também no direito constitucional. Nesse sentido, há autores que se debruçam especificamente sobre a utilização do direito estrangeiro na interpretação constitucional, inclusive pelas cortes constitucionais, geralmente associado a um enfoque histórico. Sobre o assunto Vicki C. JACKSON pondera que "a obra histórica preocupada com a influência e o movimento de ideias constitucionais através das fronteiras nacionais frequentemente exibe um grau de ceticismo sobre as fortes reivindicações de

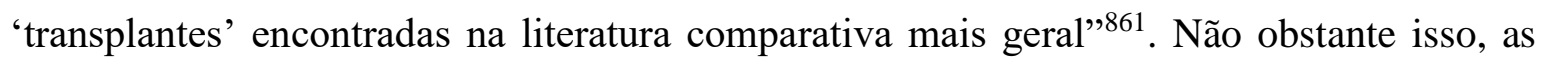
ideias de transplantes e de migração ou movimento de ideias constitucionais apresentam intersecções óbvias. O próprio objeto de estudo deste segundo enfoque nada mais é do que uma reedição dos possíveis relacionamentos entre ordenamentos jurídicos, segundo Alan

${ }^{860}$ Fernando Dias MENEZES DE ALMEIDA. Formação da Teoria do Direito Administrativo no Brasil. São Paulo: Quartier Latin, 2015. Nesta obra, o autor analisa, como o próprio nome sugere, o processo de formação da teoria brasileira do direito administrativo. Formação, neste contexto, refere-se à "formação da continuidade teórica (da teoria do direito administrativo), a partir do qual as gerações de pensadores contemporâneas (daquele período) e futuras sintam-se implidas a referir-se a certos padrões (forma de organização das ideias, temas, inspirações valorativas), ou ao menos levar em conta sua existência, seja para com eles concordar, ou deles discordar, e mesmo a eles acrescentar novos aspectos" (Formação da Teoria do Direito Administrativo, p. 39). Já teoria, por sua vez, remete à "derivação coletiva do conjunto de ideias, de pensamentos produzidos em dado contexto social e histórico, perdendo, portanto, conexão com a identidade autoral dos indivíduos" (Formação da Teoria do Direito Administrativo, p. 70). Segundo este autor, o direito administrativo brasileiro, enquanto teoria, teria se formado a partir da década de 40 do século $X X$, e nos dias atuais viveria um momento de maturidade, no qual as discussões travadas seriam caracterizadas por um "grau de adensamento, de ganho de complexidade" (Formação da Teoria do Direito Administrativo, p. 14). No que diz respeito à utilização de doutrina estrangeira por obras gerais de direito administrativo, MENEZES DE ALMEIDA constata a influência de juristas e filósofos franceses durante o Império e da doutrina francesa, italiana e norte-americana no período da Primeira República. Já a partir de 1930, momento em que ocorre a formação propriamente dita do direito administrativo, o autor ressalta que "a escassez das fontes de direito positivo fica ainda mais contrastada pelo fato de ganhar nova dimensão, muito mais extensa e detalhada, a carga conceitual dos elementos jurídicos específicos do direito administrativo - por exemplo: noção de administração, princípios da administração, ato administrativo, contrato administrativo, responsabilidade do Estado, poder de política, e serviço público. Esses elementos têm desenvolvimentos puramente doutrinários, em grande medida amparados por invocação de doutrina estrangeira" (Formação da Teoria do Direito Administrativo, p. 261). Finalmente, a partir de 1988, percebe-se uma tendência de considerar mais o direito positivo, inclusive a Constituição Federal, e a jurisprudência em torno de determinados institutos, o que faz com que o papel da doutrina, inclusive da doutrina estrangeira, se altere substancialmente. Como ressalta MENEZES DE ALMEIDA, "nas obras do período atual, diferentemente, a citação, individualizada ou em bloco, de autores reunidos pelo critério de origem nacional tende a surgir apenas em passagens nas quais está em questão a análise comparativa entre direitos de diversas nacionalidades" (Formação da Teoria do Direito Administrativo, p. 352).

861 Vicki C. JACKSON. Comparative consitutitional law: methodologies. In: Michel ROSENFELD, András SAJÓ (Ed.). The Oxford Handbook of Comparative Constitutional Law. Oxford: Oxford University Press, 2012, p. 58. 
WATSON. É o que se percebe, pelo menos, na seguinte descrição elaborada por Vicki C. JACKSON:

\begin{abstract}
"A obra histórica está preocupada com a compreensão do desenvolvimento do direito constitucional ou dos sistemas constitucionais ao longo do tempo. Podem existir tanto formas 'genéticas' de conexão entre sistemas, baseadas na influência que um tem sobre o desenvolvimento do outro, quanto formas 'genealógicas' de conexão, nas quais um (ou mais) sistemas constitucionais nascem de outro, tipicamente em países egressos de relacionamentos coloniais (...) Ela também pode examinar como um conceito jurídico que existe em um sistema influencia ou migra para outro, enfocando não só no caminho das ideias, mas também em como estas ideias são transmitidas, por exemplo, por meio de estudos de graduação no exterior." $" 862$
\end{abstract}

Note-se que o direito estrangeiro pode exercer diferentes influências na interpretação judicial da constituição, como pondera Gábor HALMAI. Segundo este autor, o grau menos influente seria quando os juízes somente mencionam o direito estrangeiro, sendo que o próximo passo seria quando os juízes passam a seguir casos ou ideias de outros sistemas jurídicos, os quais são dotados de alguma autoridade, muito embora não se possa afirmar que eles tenham um efeito vinculante. Em verdade, "a autoridade do direito estrangeiro citado é somente persuasiva no processo de interpretação judicial" ${ }^{863}$.

No âmbito do Supremo Tribunal Federal é possível perceber influências do direito estrangeiro em diversos graus. Fiquemos apenas com as referências à Lei Fundamental, em razão do interesse que esta constituição claramente possui para a presente pesquisa. Em um caso que versava sobre a constitucionalidade do exame da Ordem dos Advogados do Brasil, o Ministro Gilmar MENDES inicia seu voto expondo conceitos de uma teoria alemã dos direitos fundamentais, como o "âmbito ou núcleo de proteção (Schutzbereich)", "restrições ou limitações a esses direitos (limitações ou restrições = Schranke oder Eingriff)" e assim por diante. Em outro ponto, ele menciona expressamente artigos da Lei Fundamental de 1949, como o artigo 19 II, que garante o conteúdo essencial dos direitos fundamentais, e o artigo 1 III GG, o qual declara a vinculação do legislador a estes direitos ${ }^{864}$. Neste caso, estáse diante de uma influência forte, que orienta a própria estrutura de pensamento do referido Ministro $^{865}$. Por outro lado, também é possível encontrar referências à Lei Fundamental

\footnotetext{
862 JACSON. Comparative constitutional law: methodologies, p. 58. Note-se ainda a relação entre a migração de ideias constitucionais com o enfoque histórico, do mesmo modo que os transplantes jurídicos se relacionam com a história do Direito.

${ }^{863}$ Gábor HALMAI. The use of foreign law in constitutional interpretation. In: Michel ROSENFELD, András SAJÓ (Ed.). The Oxford Handbook of Comparative Constitutional Law. Oxford: Oxford University Press, 2012, p. 1329. ${ }^{864}$ RE no 603.583/RS, Rel. Min. Marco Aurélio, julgado em 26/10/2011, p. 70 e 74.

865 Note-se que há vários julgados no qual o Ministro Gilmar Mendes se refere à doutrina ou mesmo à jurisprudência alemã. O julgado citado consiste em apenas um exemplo da influência do direito alemão no pensamento deste Ministro e, consequentemente, no próprio Supremo Tribunal Federal.
} 
em casos que versam sobre repartição de competências, como por exemplo, na seguinte manifestação do Ministro Carlos VELLOSO nos autos da ADI nº 1007/PE:

\footnotetext{
"Esta competência suplementar é não-cumulativa, quer dizer, ela preenche vazios. Mas a Constituição não ficou aí e somente aí. Aqui, a grande contribuição da lei fundamental de Bohn (sic) - pena que o eminente Ministro Gilmar Mendes não esteja presente. É que, inexistindo normal federal, o Estado legisla sobre tudo. Agora, sobrevindo lei federal esta afasta a lei estadual. Mas afasta em quê? Naquilo que o Estado legislou em termo de diretrizes, de normas gerais, por quê? Porque a competência da União para legislar na legislação concorrente é puramente uma legislação de normas gerais, é o parágrafo $1^{\circ}$." 866
}

Neste segundo caso está-se diante de uma influência fraca do direito estrangeiro, pois neste trecho ele é somente mencionado, funcionando como um argumento de autoridade. Com efeito, diante do que foi analisado nos tópicos 4.4 e 5.3 desta tese, sabe-se que os principais contornos dogmáticos da competência legislativa concorrente diferem nestes dois países e que a grande inovação a que se refere Carlos VELLOSO é, em grande medida, uma construção brasileira. Por isso, o recurso à Lei Fundamental é meramente persuasivo, com o intuito de reforçar algo que está disciplinado expressamente pela Constituição Federal de 1988.

Em que momento esta referência deixa de ser um mero argumento de autoridade e passa a se tornar uma ideia que influencia julgadores e juristas de um modo geral? Em que momento a referência a uma suposta inspiração do legislador constituinte pode efetivamente informar um transplante de institutos ou mesmo a migração de certa compreensão a respeito de institutos de um país para o outro? Viu-se no tópico anterior que a Lei Fundamental, na obra de Fernanda Dias Menezes de ALMEIDA e Raul Machado HORTA, foi apontada como uma fonte próxima de inspiração da Constituição Federal de 1988. Na manifestação do Ministro Carlos VELLOSO percebe-se um estágio adiante, pois a Lei Fundamental passa a ser referida em termos persuasivos, a fim de reforçar os acertos do legislador constituinte. Não nos parece, contudo, que seja o caso de afirmar que a constituição alemã ou suas regras tenham influenciado o discurso jurídico brasileiro pós-1988 em matéria de repartição de competências, a ponto de se falar em um transplante ou migração de ideias.

Não se pode deixar de reconhecer, porém, que na presente tese se defende justamente a viabilidade de transplantes de institutos jurídicos alemães afetos à repartição de competências. Como este dado é importante para a compreensão dos resultados da pesquisa expostos a partir deste sexto capítulo, convém explicar esta assertiva de forma detida. No item anterior teve-se a oportunidade de se analisar como - a despeito da afirmação de parte relevante da doutrina de que a Lei Fundamental de 1949 teria funcionado

${ }^{866}$ ADI no 1007/PE, Rel. Min. Eros Grau, julgado em 31/08/2005 p. 22 
como uma fonte de inspiração para o legislador constituinte de 1987-1988 - não é possível utilizar a noção de transplantes para analisar as semelhanças e as diferenças que serão expostas e discutidas a seguir. Isso ocorre porque as principais decisões tomadas em 19871988 em matéria de repartição de competências legislativas e de execução colocam-se em uma relação de continuidade com as constituições anteriores, razão pela qual elas são melhor compreendidas a partir de uma perspectiva histórica, considerando-se as sucessivas constituições brasileiras. Por este motivo, aliás, a confrontação destes sistemas e a identificação dos pontos em comum e de divergência prescindirá deste enfoque do direito comparado, sendo conduzida em termos minimalistas, como já exposto na introdução desta tese. Do mesmo modo, a despeito de a Lei Fundamental ser invocada em alguns julgados do Supremo Tribunal Federal, acredita-se que isso tem um efeito mais persuasivo, funcionando como um argumento de autoridade. Por isso, também não é possível concluir pela utilidade da ideia de transplante jurídico para analisar a evolução constitucional sobre o tema depois de 1988. Não obstante isso, considera-se que, a partir das semelhanças encontradas e expostas ainda neste capítulo, seja possível defender o transplante de certas construções doutrinárias e jurisprudenciais alemãs para solucionar alguns litígios brasileiros nesta matéria. Não se trata, contudo, de um transplante - ou de uma migração, a depender do ponto de vista teórico que se adote - realizado de forma arbitrária ou motivado apenas pelo prestígio que o direito alemão atualmente goza dentre a doutrina constitucional brasileira, mas embasado a partir da constatação de semelhanças suficientes e, ao mesmo tempo, da confrontação das diferenças existentes. O objetivo, portanto, é ponderar e equalizar todas as variáveis desta atividade de transferência, a fim de que ela seja a mais bem-sucedida possível.

Note-se que estas ponderações se refletem na exposição dos resultados, a qual será levada a cabo em dois capítulos e não em um grande capítulo, tão somente. $O$ primeiro deles, o sexto capítulo, é dedicado à atividade de confrontação dos sistemas brasileiro e alemão de repartição de competências legislativas e de execução, a fim de identificar semelhanças e diferenças. Já no segundo deles, o sétimo e último capítulo, será analisado como e em que medida determinados institutos alemães podem ser aplicáveis a problemas brasileiros nesta seara. Em alguns trechos deste sexto capítulo, além da exposição das semelhanças e das diferenças, ponderar-se-á como o direito constitucional brasileiro poderá se beneficiar a partir da percepção alemã sobre o mesmo fenômeno. Considerações deste tipo não deixam de sugerir um transplante, mas não são o objetivo precípuo da exposição. 


\subsection{REGRAS GERAIS EM MATÉRIA DE REPARTIÇÃO DE COMPETÊNCIAS}

A exposição das semelhanças e das diferenças entre a Constituição Federal de 1988 e a Lei Fundamental de 1949 no que diz respeito à repartição de competências legislativas e de execução inicia-se com a identificação e o estudo, em uma perspectiva comparada, das regras gerais sobre o tema. No Brasil se tem dado pouca atenção ao tema, talvez porque a Constituição de 1988 possui poucas regras deste tipo, mesmo em comparação com as suas antecessoras. Na Alemanha, por sua vez, a questão é tratada com mais cuidado, já que a constituição atualmente vigente neste país contempla não só regras gerais sobre a repartição de competências propriamente ditas, mas também normas gerais de colisão, as quais decidirão o caso concreto na hipótese de não haver outra disposição.

Neste ponto não há como não dar razão aos alemães. Regras gerais são imprescindíveis para se interpretar o modo pelo qual competências são atribuídas por uma constituição de um modo sistemático. Em outras palavras, são elas que reúnem uma série de normas com esta vocação - muitas concentradas em alguns artigos, mas também esparsas pelo texto constitucional - em um sistema, a ser interpretado e desenvolvido segundo alguns critérios específicos. Não por outro motivo, aliás, se fala nesta tese reiteradamente em sistema brasileiro e alemão de repartição de competências, e não simplesmente em regras sobre este tema. Isso se dá em relação à Alemanha porque certamente a Lei Fundamental possui regras com esta vocação. Contudo, tal assertiva também pode ser repetida em relação à Constituição Federal de 1988, como se analisará a seguir.

\subsubsection{As regras gerais previstas pela Lei Fundamental de 1949}

No quinto capítulo foram analisadas algumas regras gerais em matéria de repartição de competências atualmente vigentes. Deste modo, no tópico 5.1 investigou-se o teor do artigo 70 GG, aplicável à repartição de competências legislativas e que confere aos Estados o direito de legislar, à medida que a própria Lei Fundamental não confira à União poderes legislativos. Ponderou-se sobre a necessidade de realização de um raciocínio de exclusão a fim de se precisar o real conteúdo da competência estadual, considerando-se, para isso, tanto as regras escritas quanto as normas não-escritas que conferem competências à União. Além do mais, chamou-se a atenção para o fato de que as competências conferidas aos Länder com base neste artigo eram restritas a alguns poucos temas, como organização e procedimentos dos Behörden estaduais, os Municípios, educação e cultura, segurança 
pública, construção, entre outros ${ }^{867}$. Trata-se de matérias importantes, mas ainda assim reconheceu-se que a enumeração de muitas competências à União acabou por conferir a esta última uma nítida proeminência na legislação, ao contrário do que a simples leitura do artigo 70 GG pode sugerir. Já no item 5.4 situou-se o artigo 83 GG como a regra geral em matéria de repartição de competências administrativas, expondo-se a dupla relação de regra e exceção que pode ser extraído do seu texto: (i) em primeiro lugar, os Länder detêm as competências administrativas (regra), ressalvadas as hipóteses em que a Lei Fundamental enumere competências ao Bund (exceção); (ii) em segundo lugar, os Länder executam leis federal por meio de administração estadual própria, custeada com seus próprios recursos (regra), sendo que outras formas de execução devem ser previstas ou autorizadas pelo texto constitucional (exceção).

Contudo, estas não são as únicas regras deste tipo previstas pela Lei Fundamental. Dentro do título chamado "a União e dos Estados” (“der Bund und die Länder"), é possível encontrar o artigo 30 GG - o qual dispõe que "o exercício de poderes estatais e o cumprimento de tarefas estatais compete aos Estados, à medida que a Lei Fundamental não determine ou não permita outra regulamentação" - e o artigo 31 GG que consagra o famoso brocardo "Bundesrecht bricht Landesrecht" ou "direito federal revoga direito estadual". Os artigos 70 e 83 GG, já analisados, colocam-se como regras especializantes em relação ao artigo 30 GG, mas não são os únicos: o artigo 92 GG é o terceiro dispositivo que concretiza a norma estabelecida pelo artigo $30 \mathrm{GG}$, desta feita em relação ao Poder Judiciário, ao prever que “o Poder Judiciário é confiado aos juízes; ele é exercido pelo Tribunal Constitucional Federal, pelos tribunais federais previstos pela Lei Fundamental e pelos Tribunais dos Estados" ${ }^{\prime 868}$.

Uma investigação que contemplasse os pormenores do artigo 93 GG certamente transcenderia os limites desta pesquisa, que é delimitada, consoante disposto na introdução, à análise das competências legislativas e de execução. $\mathrm{O}$ mesmo não se pode afirmar em relação aos artigos 30 e 31 GG. Com efeito, se a ideia é analisar as regras gerais sobre repartição de competências legislativas e de execução, é de admitir que estes últimos dispositivos contemplam as regras gerais por excelência, razão pela qual não só faz

\footnotetext{
${ }^{867}$ Matérias estas arroladas em PERNICE. Artikel 30. In: DREIER (Hrsg.). Grundgesetz, p. 727.

868 Note-se que todos estes dispositivos conferem - ou pretendem conferir - competência ampla aos Estados, autorizando a União a atuar somente nas hipóteses determinadas ou permitidas pela própria constituição. Em outras palavras, todos os artigos em comento estabelecem a competência residual dos Estados, a qual somente será aferida por meio da exclusão das competências enumeradas à União.
} 
sentido, como também é imperioso, que eles sejam estudados com maior afinco neste tópico. Comecemos esta análise pelo artigo 30 GG e seus possíveis significados ${ }^{869}$.

Em primeiro lugar, a doutrina alemã costuma relacionar este dispositivo à obrigatoriedade da distribuição de competências determinada na Lei Fundamental. Com efeito, as normas contidas tanto no artigo 30 GG quanto nos artigos que especializam o seu conteúdo nas áreas da legislação, da administração e da jurisdição devem ser observadas obrigatoriamente pelo Bund e pelos Länder diante do seu caráter $\operatorname{cogente}^{870}$. Os entes federativos não podem, portanto, afastar a incidência destas normas, seja por meio de delegação dos poderes que lhes são conferidos, seja por tolerar de forma silente invasões em sua competência. ${ }^{871}$ Esta mesma obrigatoriedade impede ainda o que se convenciona chamar de referência dinâmica (dynamische Verweisung), por meio da qual "uma lei estadual declara aplicável uma lei federal na sua respectiva redação vigente" Note-se que a referência a uma redação específica de uma norma editada por outro ente - o que se convenciona chamar de referência estática (statische Verweisung) - não se afigura problemática. O que é incompatível com o artigo $30 \mathrm{GG}$, e consequentemente com a repartição de competências disciplinada pela Lei Fundamental, é a menção à redação vigente de uma lei federal (ou de uma lei estadual), pois esta pode ser alterada ou revogada sem que o legislador estadual tenha controle sobre este processo. Contudo, é possível que lei federal faça uma referência dinâmica à lei estadual, pois neste caso se entende que a União se utilizou implicitamente da autorização prevista nos artigos 71 e 72 I GG $^{873}$.

Como uma decorrência da obrigatoriedade da repartição de competências também se costuma apontar a proibição de uma administração mista (Mischverwaltung). Quanto a

\footnotetext{
${ }^{869}$ Os comentaristas da Lei Fundamental consultados costumam extrair do artigo 30 GG também a estatalidade dos Länder. Como pondera Winfried ERBGUTH, esta qualidade de Estado "não é derivada da União, mas é reconhecida como poder de soberania próprio dele. O exercício de soberania ocorre nos Estados por meio de Poder Legislativo próprio, Administração e Poder Judiciário. Os Estados dispõem de território e poderiam editar leis sobre nacionalidade" (Wilfried ERBGUTH. Artikel 30 [Kompetenzverteilung zwischen Bund und Ländern]. In: Michael SACHS (Hrsg.). Grundgesetz - Kommentar. 7ạ Ed. Munique: C. H. Beck, 2014, p. 1093). Neste ponto reside uma diferença importante entre Brasil e Alemanha, tendo em vista que aqui o mesmo fenômeno é compreendido de outro modo. Porém, como não se trata de um significado do artigo 30 GG que se relaciona exatamente com a distribuição de competências - trata-se, afinal, de uma consequência do modo pelo qual a Lei Fundamental opera esta repartição - ele não será abordado no corpo da tese.

870 PERNICE. Artikel 30, p. 728. Neste mesmo sentido JARASS, PIEROTH. Grundgesetz, p. 644, Wolfgang MÄRZ. Artikel 30. In: Hermann von MAGOLDT, Friedrich KLEIN, Christian STARCK (Hrsg.). Kommentar zum Grundgesetz. Band 2: Artikel 20 bis 82. 6a Ed. Munique: Franz Vahlen, 2010, p. 689 e também Wilfried ERBGUTH. Artikel 30. In: SACHS (Hrsg.). Grundgesetz, p. 1096.

${ }^{871}$ PERNICE. Artikel 30. In: DREIER (Hrsg.). Grundgesetz, p. 728, citando neste ponto MäRZ. Artikel 30. In: von MANGOLDT, KLEIN, STARCK (Hrsg.). Kommentare zum Grundgesetz, p. 689.

872 PERNICE. Artikel 30. In: DREIER (Hrsg.). Grundgesetz, p. 728.

${ }^{873}$ MÄRZ. Artikel 30. In: von MANGOLDT, KLEIN, STARCK (Hrsg.). Kommentare zum Grundgesetz, pp. 689-691.
} 
este aspecto é possível perceber uma divergência na doutrina. Por um lado, a maioria dos autores consultados parecem partir do pressuposto de que o artigo 30 e o artigo 83 GG estabeleceram uma separação das administrações federal e estaduais, de forma que uma atuação conjunta da União e dos Estados na seara administrativa - neste ponto, refere-se constantemente a direitos de co-decisão (Mitentscheidungsrechte) da União nas administrações estaduais - deve se dar nas hipóteses determinadas ou autorizadas pela Lei Fundamental. Exemplos destas determinações ou autorizações podem ser encontrados nos artigos 91a e 91b GG, estudados no capítulo anterior. Para estes autores, é possível sim extrair dos artigos 30 e 83 a proibição de uma administração mista. ${ }^{874}$ Já Ingolf PERNICE, por outro lado, considera que, embora o artigo 30 se coloque como um obstáculo aos referidos direitos de co-decisão da União, não é possível extrair dele tal proibição. Nas palavras deste autor,

\begin{abstract}
"Os artigos 30, 83 GG opõem-se ao reconhecimento de direitos de co-decisão da União na administração estadual e vice-versa, em princípio. Uma proibição da administração mista, contudo, não resulta disso. Também não existe 'nenhum princípio geral constitucional, pelo qual tarefas administrativas devem ser levadas a cabo privativamente pela União ou pelos Estados, desde que regras constitucionais expressas não permitam outra coisa'. Os artigos 91a, 91b demonstram isso igualmente, como o artigo 108 IV GG assim como o auxílio jurídico e administrativo de acordo com o artigo 35 I GG, os quais não precisam ser delimitados a um caso concreto (...). Da função de proteção do artigo $30 \mathrm{GG}$ decorre ao menos, todavia, que a administração cooperativa entre União e Estado não deve ser, direta ou indiretamente, como por meio de correspondentes reservas nos auxílios financeiros (compare o artigo 104a GG), imposta ou obrigada por meio da diminuição dos recursos. A delegação de tarefas administrativas abrangentes, nomeadamente também a execução das leis estaduais à União, encontra ademais no artigo 30, sob o aspecto da repartição de poderes funcional, um limite objetivo." $\$ 775$
\end{abstract}

Quanto a este ponto, a razão parece assistir a PERNICE. Com efeito, a determinação de que União e Estados atuem de forma independente no campo administrativo pode até concretizar os princípios democráticos e do Estado de Direito, como sugere Bodo

\footnotetext{
${ }^{874}$ Nesse sentido, JARASS, PIEROTH. Grundgesetz, p. 645, MÄRZ. Artikel 30. In: von MANGOLDT, KLEIN, STARCK (Hrsg.). Kommentare zum Grundgesetz, p. 691 e ERBGUTH. Artikel 30. In: SACHS (Hrsg.). Grundgesetz, p. 1096. 875 PERNICE. Artikel 30. In: DREIER (Hrsg.). Grundgesetz, p. 729. No original: "Art. 30, 83 GG stehen der Einräumung von Mitentscheidungsrechten des Bundes bei der Landesverwaltung und umgekehrt grundsätzlich entgegen. Ein Verbot der Mischverwaltung folgt daraus jedoch nicht. Auch gibt es ,keinen allgemeinen verfassungsrechtlichen Grundsatz, wonach Verwaltungsaufgaben ausschliesslich vom Bund oder von den Ländern wahrzunehmen sind, sofern nicht ausdrückliche verfassungsrechtliche Regeln etwas anderes zulassen. Art. 91a, 91b zeigen dies ebenso, wie Art. 108 IV G G sowie die nach Art. 35 I GG gebotene Rechts- und Amtshilfe, die nicht auf einen Einzelfall beschränkt sein muss (...). Aus der Schutzfunktion des Art. $30 \mathrm{GG}$ ergibt sich indessen zumindest, dass kooperative Verwaltung zwischen Bund und Ländern nicht direkt oder mittelbar, etwa durch entsprechende Vorbehalte bei Finanzhilfen (vgl. Art. 104a GG), oktroyiert oder durch Verknappung der Mittel erzwungen sein darf".
} 
PIEROTH ${ }^{876}$, mas parece contrastar com a própria realidade alemã. Sabe-se, afinal, que a cooperação entre os Länder e também entre Bund e Länder é muito intensa neste país, especialmente por meio da tomada de conjunta de decisões. É certo que esta atuação conjunta nem sempre se demonstrou benéfica, razão pela qual se tenta atualmente lhe impor algumas limitações. Porém, não nos parece que esta tentativa deva ser levada a cabo por meio da imposição de uma atuação independente da União e dos Estados, por duas razões simples. Em primeiro lugar, porque a realização de determinadas tarefas pode se demonstrar complicada e custosa na prática, e neste caso uma atuação cooperativamente orientada pode se colocar como uma boa alternativa. Em segundo lugar, porque embora a Lei Fundamental tenha previsto originalmente um sistema de separação, para ficar com a terminologia utilizada pela doutrina alemã, o fato é que com o passar dos anos reformas constitucionais foram alterando e mitigando este sistema, por meio da inclusão de artigos como os artigos 91a a 91e GG, de forma que hoje a federação alemã se insere, sem sombra de dúvidas, em um paradigma de federalismo cooperativo. Mesmo as recentes alterações em prol de um federalismo competitivo (Wettbewerbföderalismus), como as reformas de 2006 e 2009, não lograram alterar este cenário.

Em segundo lugar, a doutrina alemã consultada também costuma relacionar o artigo 30 GG à função de delimitação que uma competência inexoravelmente possui, ponderando sobre a impossibilidade de uma dupla competência (Doppelzuständigkeit) - vale dizer, uma situação em que tanto União quanto Estados sejam competentes para atuar sobre uma determinada matéria ${ }^{877}$. O tema será retomado com maior profundidade no tópico 7.1. De todo, neste ponto cumpre fazer algumas considerações importantes. Já se ressaltou em mais de uma passagem nesta tese como a competência é uma norma que inclui, mas também exclui possíveis matérias e destinatários. Não faria muito sentido, portanto, que após a vigência de uma norma deste tipo tanto União quanto Estados permanecessem igualmente competentes para atuar sobre uma mesma matéria, porque neste caso a competência não teria operado delimitação alguma. Note-se que mesmo na competência legislativa concorrente prevista no artigo 72 GG os Poderes Legislativos federal e estaduais não são igualmente competentes sobre as matérias nelas compreendidas: ao contrário, em princípio compete aos Estados legislar, sendo que a União só poderá editar legislação quando cumpridos os requisitos do artigo 72 II GG. Tanto em um caso como no outro, incidem critérios para se decidir qual legislação é válida e aplicável a um caso concreto, não se

\footnotetext{
876 JARASS, PIEROTH. Grundgesetz, p. 645.

877 Nesse sentido JARASS, PIEROTH. Grundgesetz, p. 644 e MÄRZ. Artikel 30. In: von MANGOLDT, KLEIN, STARCK (Hrsg.). Kommentare zum Grundgesetz, p. 689.
} 
admitindo que uma legislação federal e uma legislação estadual regulem de forma divergente o mesmo aspecto de uma matéria. Com afirmações deste tipo não se pretende negar que na prática possam surgir pontos de contato, ou até mesmo intersecções, entre competências da União e dos Estados-membros. Porém, estes casos são resolvidos no âmbito da interpretação da norma competencial ${ }^{878}$, como se ainda terá a oportunidade de analisar nesta tese.

Em terceiro e último lugar, o artigo 30 GG normalmente é associado a uma presunção em favor dos Länder, a qual, em casos de dúvida, deveria influenciar a decisão sobre a atribuição de uma tarefa ou matéria em favor dos Estados e nunca da União $^{879}$. Os autores consultados, todavia, se insurgem contra tal posicionamento, pois uma presunção, no sentido técnico-dogmático, envolve sempre uma questão de prova, ao passo que a afirmação da competência de um ente em um determinado caso concreto é necessariamente uma questão de interpretação ${ }^{880}$. De todo modo, no artigo 30 GG estaria contida uma "diretriz de interpretação amigável aos Estados" (länderfreundliche Auslegungsrichtlinie), a incidir nos casos em que, "a despeito da utilização da metódica de interpretação, permanecessem dúvidas sobre a aceitação de uma competência federal" ${ }^{881}$. Acredita-se, porém, que não é necessário reconhecer qualquer presunção ou mesmo diretriz de interpretação diante do caráter residual da norma contida no artigo 30 GG. Tem-se, portanto e necessariamente, uma das duas situações, ambas regulamentadas de forma expressa pela própria Lei Fundamental: ou se reconduz determinado caso ou matéria a uma norma que atribui competência à União, e neste caso se estará diante de uma competência federal por aplicação da segunda parte do artigo $30 \mathrm{GG}$, ou se reconhece que semelhante procedimento não é possível, confirmando a competência dos Estados com base no artigo $30 \mathrm{GG}$, primeira parte.

Já o artigo 31 GG possui conteúdo distinto do artigo 30 GG. Com efeito, ele não busca promover uma repartição de atribuições entre União e Estados, e sim fornecer um critério a ser aplicado em caso de colisão. Não obstante isso, o artigo $31 \mathrm{GG}$ possui duas características em comum com o artigo 30 GG: (i) tal como este último dispositivo, o artigo 31 GG também se coloca como regra geral, porém, como uma regra geral de colisão; (ii) a sua aplicação a um caso concreto também é reduzida pela eficácia de

\footnotetext{
878 Como observa ERBGUTH. Artikel 30. In: SACHS (Hrsg.). Grundgesetz, p. 1098.

879 MÄRZ. Artikel 30. In: von MANGOLDT, KLEIN, STARCK (Hrsg.). Kommentare zum Grundgesetz, pp. 687-688. 880 MÄRZ. Artikel 30. In: von MANGOLDT, KLEIN, STARCK (Hrsg.). Kommentare zum Grundgesetz, p. 688, ERBGUTH. Artikel 30. In: SACHS (Hrsg.). Grundgesetz, p. 1094.

${ }^{881}$ ERBGUTH. Artikel 30. In: SACHS (Hrsg.). Grundgesetz, p. 1094. No original: "Art. 30 enthält demnach eine länderfreundliche Auslegungsrichtlinie für solche Fälle, in denen trotz Einsatzes der Auslegungsmethodik Zweifel an der Annahme einer Bundeskompetenz verbleiben".
} 
regras especializantes previstas pela própria Lei Fundamental, como é o caso dos artigos 71 e 72 GG, estudados no quinto capítulo desta tese ${ }^{882}$. Comecemos a exposição pela análise na norma contida no artigo $31 \mathrm{GG}$ para só depois tratar do seu relacionamento com algumas regras constitucionais que especializam o seu conteúdo.

Dispõe o artigo 31 GG que direito federal "quebra" (bricht) direito estadual, sendo o dispositivo mais curto da Lei Fundamental ${ }^{883}$. Direito federal neste contexto remete a normas produzidas por um órgão da União ${ }^{884}$, abrangendo, como pondera Horst DREIER, “a própria Lei Fundamental, como leis formais simples e regulamentos; para isso contam além disso a Convenção Europeia de Direitos Humanos (...) e as regras gerais do direito internacional (...). Direito federal de qualquer nível tem precedência sobre direito estadual de qualquer nível: um regulamento da União pode, portanto, quebrar direito constitucional estadual" ${ }^{\prime 85}$. Já o direito estadual, por sua vez, compreende o direito produzido por órgãos dos Länder, englobando, em razão do que foi exposto supra, também o direito constitucional estadual, mas também leis, regulamentos estaduais, estatutos (Satzungen) dos Länder e das suas pessoas jurídicas ${ }^{886}$.

Porém, a grande questão relativa à interpretação do artigo 31 GG está no verbo "quebrar", pois ele é quem dita o que acontecerá com o direito estadual na hipótese de contrariedade com o direito federal. Segundo Peter M. HUBER, “'quebrar' significa a eliminação definitiva do direito estadual existente e o impedimento de futuro direito

\footnotetext{
${ }^{882}$ Conforme JARASS, PIEROTH. Grundgesetz, p. 646, Peter M. HUBER. Artikel 31 [Vorrang des Bundesrechts]. In: Michael SACHS (Hrsg.). Grungesetz - Kommentar. 7a Ed. Munique: C. H. Beck, 2014, p. 1105, Horst DREIER. Artikel 31 [Vorrang des Bundesrechts]. In: Horst DREIER (Hrsg.). Grundgesetz - Kommentar. Band II: Artikel 20 -82. 2a Ed. Tübingen: Mohr Siebeck, 2006, pp. 748-749.

${ }^{883}$ Como observa Wolfgang MÄRZ. Artikel 31. In: Hermann von MANGOLDT, Friedrich KLEIN, Christian STARCK (Hrsg.). Kommentar zum Grundgesetz. Band 2: Artikel 20 bis 82. 6a Ed. Munique: Franz Vahlen, 2010, p. 714.

${ }^{884}$ Nesse sentido JARASS, PIEROTH. Grungesetz, p. 646, HUBER. Artikel 31. In: SACHS (Hrsg.). Grundgesetz, p. 1107, entre outros.

885 DREIER. Artikel 31. In: DREIER (Hrsg.). Grundgesetz, pp. 755-756. No original: "Damit ist einer gängigen Formel gemäß das gesamte von Organen des Bundes gesetzte Recht jeglicher Rangstufe umfaßt: also namentlich das Grundgesetz selbst sowie einfache förmliche Gesetze und Rechtsverordnungen; hierzu zählen ferner die EMRK (...) und die allgemeinen Regeln des Völkerrechts (...). Bundesrecht jeder Stufe hat Vorrang vor Landesrecht jeder Stufe: eine Rechtsverordnung des Bundes kann also Landesverfassungsrecht brechen. "Notese, contudo, que há uma certa divergência em relação às espécies de normas federais que podem "quebrar" o direito estadual. Todos os comentários consultados incluem a Lei Fundamental, leis federais, direito anterior à Lei Fundamental (eis que recepcionado como lei federal), regulamentos federais, mas discordam em relação às demais. Horst DREIER, no trecho supracitado, exclui do âmbito do artigo $31 \mathrm{GG}$ normas federais sem eficácia externa, como os regulamentos do Parlamento e do Conselho Federal, além dos preceitos administrativos e decisões sobre casos concretos tanto da Administração quanto do Judiciário. Peter M. HUBER, por outro lado, inclui os preceitos administrativos (HUBER. Artikel 31. In: SACHS (Hrsg.). Grundgesetz, p. 1107), da mesma forma como faz Wolfgang MÄRZ (Artikel 31. In: von MANGOLDT, KLEIN, STARCK (Hrsg.). Kommentare zum Grundgesetz, p. 726).

${ }^{886}$ HUBER. Artikel 31. In: SACHS (Hrsg.). Grundgesetz, p. 1107.
} 


\section{estadual. O direito estadual 'quebrado' é nulo e não repristina também depois da} eliminação do direito federal" ${ }^{887}$. Em outras palavras, o artigo 31 GG prevê a derrogação do direito estadual incompatível com o direito federal, e não a sua simples ineficácia. Além do mais, é necessário haver uma contrariedade entre o direito federal e o direito estadual, pois somente neste caso é que se pode falar em uma colisão entre normas. Esta contrariedade existe, como já decidiu o Tribunal Constitucional Federal, quando duas normas, uma federal e outra estadual, são aplicáveis aos mesmos fatos e podem conduzir a resultados diferentes. ${ }^{888}$ Portanto, no caso de o direito federal e o direito estadual regularem os mesmos fatos de forma coincidente, não há que se falar em colisão e de se cogitar a aplicação do artigo $31 \mathrm{GG}^{889}$

Feitas estas considerações, parte-se para a análise das disposições constitucionais consideradas especiais à regra geral contida no artigo $31 \mathrm{GG}$, em especial aquelas contidas nos artigos 71 e 72 GG.

No tópico 5.2 as atenções se voltaram para o artigo 71 GG, que trata da competência legislativa privativa da União. Ponderou-se como este dispositivo impunha um efeito de barreira (Sperrwirkung) à atuação legiferante por parte dos Estados, efeito este que decorria da própria previsão de uma competência à União em termos privativos pela Lei Fundamental e que só cessaria diante de uma autorização a que o próprio artigo 71 GG se refere. Porém, é de se admitir que este dispositivo possui uma dupla função, como bem ressalta Wolfgang MÄRZ:

"Ele estabelece uma barreira completa e abrangente para o legislador estadual, e ele permite exceções a este efeito de barreira por meio de lei federal ordinária.

\footnotetext{
${ }^{887}$ HUBER. Artikel 31. In: SACHS (Hrsg.). Grundgesetz, p. 1109. No original: "'Brechen' bedeutet die endgültige Beseitigung bestehenden und die Verhinderung zukünftigen Landesrechts. Das, gebrochene' Landesrecht ist nichtig und lebt auch nach einer Beseitigung des Bundesrechts nicht wieder auf".

888 BVerfGE 36, 342 (363) O mesmo posicionamento é afirmado em DREIER. Artikel 31. In: DREIER (Hrsg.). Grundgesetz, p. 757, JARASS, PIEROTH. Grundgesetz, p. 647, entre outros.

${ }^{889}$ Conforme pondera Horst DREIER, "a partir desta premissa aceita-se majoritariamente, em abandono da teoria weimariana e da opinião do conselho parlamentar, que o direito estadual de conteúdo igual não é quebrado. Isto reconheceu o Tribunal Constitucional Federal expressamente em relação ao direito constitucional estadual idêntico, neste ponto fundamentado a partir do respeito exigido à constituição estadual, mas deixou em aberto em relação a outro direito estadual. Também para este, porém, não vale outra coisa segundo a opinião acertada. Somente uma tal forma de analisar faz jus ao caráter do artigo 31 como norma de colisão (...); ela incide, note-se bem, somente diante da existência de uma colisão e deixa intocado o efeito de barreira das competências legislativas" (DREIER. Artikel 31. In: DREIER (Hrsg.). Grundgesetz, p. 759. No original: "Von diesen Prämissen ausgehend, nimmt man mittlerweile in Abkehr von der Weimarer Lehre und der Auffassung des Parlamentarischen Rates (...) überwiegend an, daß inhaltsgleiches Landesrecht nicht gebrochen wird. Das hat das Bundesverfassungsgericht für gleichlautendes Landesverfassungsrecht ausdrücklich anerkannt und insoweit mit dem gebotenen Respekt vor der Landesverfassung begründet, für sonstiges Landesrecht aber noch offengelassen. Nur eine solche Betrachtungsweise wird dem Charakter des Art. 31 GG als Kollisionsnorm und läßt die Sperrwirkung der Gesetzgebungskompetenzen unberührt."
} 
Voltando-se como norma de colisão, o artigo 71 GG evita qualquer conflito entre direito federal editado em conformidade com o Direito e direito estadual editado em conformidade com o Direito: direito estadual editado sem autorização, tanto se ele reclama vigência constitutiva ou somente repete preceitos federais, é editado em contrariedade à competência e, por isso, ineficaz." 890

Em outras palavras, o artigo 71 GG afasta a incidência do artigo 31 GG porque este último dispositivo reclama a existência de direito federal e direito estadual válidos. Já o artigo 71 GG, porque comina a nulidade a qualquer norma estadual editada sobre matérias inseridas na competência legislativa privativa da União, afasta justamente a dupla validade exigida pelo artigo 31 GG. O mesmo fenômeno ocorre, aliás, com o artigo 72 I e II GG, muito embora o fato de se estar diante de uma competência legislativa concorrente possa sugerir o contrário. Com efeito, a concorrência que adjetiva esta competência pode dar a impressão de que podem coexistir legislação federal e legislações estaduais divergentes sobre o mesmo tema ${ }^{891}$. Porém, como se teve a oportunidade de analisar no item 5.3.1, o artigo 72 GG também prevê um efeito de barreira, só que desencadeado pelo exercício, pela União, da sua competência legislativa. A partir do momento em que isto acontece, a legislação estadual anterior é derrogada e os Estados ficam impedidos de editar nova legislação. Ou seja, também aqui não existe vigência concomitante do direito federal e do direito estadual, de forma que não existe propriamente um conflito ao qual o artigo $31 \mathrm{GG}$ possa ser aplicado.

Note-se que, no final das contas, tanto o artigo 31 quanto os artigos 71 e 72 GG possuem uma consequência parecida, qual seja, a derrogação do direito estadual incompatível com o direito federal. Ou seja, nos três casos aplica-se o critério da prevalência do direito federal sobre o direito estadual. Porém, há uma diferença importante entre estes dispositivos e que é bem observada por Bodo PIEROTH: o efeito de barreira previsto pelos artigos 71 e 72 GG invalida qualquer direito estadual, mesmo que o seu conteúdo seja compatível com o da lei federal ${ }^{892}$, ao contrário do que ocorre com o artigo 31 GG.

Situação diferente ocorre com a legislação de divergência (Abweichungsgesetzgebung) prevista no artigo 72 III e também no artigo 84 I GG com

\footnotetext{
890 MÄRZ. Artikel 31. In: von MANGOLDT, KLEIN, STARCK (Hrsg.). Kommentare zum Grundgesetz, pp. 734-735. No original: "Er errichtet eine vollständige und umfassende Sperre für den Landesgesetzgeber, und er lässt Ausnahmen von dieser Sperrwirkung mittels einfachen Bundesgesetzes zu. Kollisionsrechtlich gewendet, schließt Art. 71 jeden Konflikt zwischen rechtmäßig erlassenem Bundesrecht und rechtmäßig erlassenem Landesrecht aus: Ohne Ermächtigung erlassenes Landesrecht, gleich ob es konstitutive Geltung beansprucht oder die bundesrechtlichen Vorschriften nur wiederholt, ist kompetenzwidrig erlassen und daher unwirksam."

${ }^{891}$ Como observa MÄRZ. Artikel 31. In: von MANGOLDT, KLEIN, STARCK (Hrsg.). Kommentare zum Grundgesetz, pp. 735 e seguintes.

892 JARASS, PIEROTH. Grundgesetz, p. 647.
} 
redação dada pela Reforma do Federalismo de 2006. Conforme analisado alhures, este dispositivo autorizou os Länder a legislarem sobre temas outrora inseridos na competênciamoldura da União, mesmo após a União fazer uso da sua competência legislativa, aplicandose ao caso concreto a lei posterior. A lei que regulamentará o caso concreto, frise-se, pode ser tanto estadual quanto federal, pois o critério a ser aplicado em caso de colisão é o da lei posterior e não o da prevalência do direito federal, tal como ocorre com a competência legislativa concorrente disciplinada no artigo 72 I e II GG. Note-se, portanto, que a legislação de divergência afasta o artigo 31 GG, não porque é considerada uma regra especial em relação a ele, mas sim porque estabelece conteúdo normativo diverso ao dele. $\mathrm{E}$ o faz de dois modos, aliás. Em primeiro lugar, impõe a aplicação da lei posterior ao caso concreto, como já dito. Em segundo lugar, a lei anterior não é derrogada pela lei posterior, e sim considerada ineficaz. Caso a lei posterior seja revogada, a lei anterior restabelece a sua eficácia plena ${ }^{893}$ e não poderia ser de outro modo, diga-se de passagem. Imagine-se, por exemplo, que uma lei estadual regule um assunto de forma divergente da lei federal. Ainda assim, esta mesma lei federal deverá continuar vigendo nos demais Estados que não fizeram uso da faculdade prevista no artigo 72 III GG, razão pela qual um Estado poderá determinar, no máximo, que a lei federal não será aplicada às relações jurídicas desenvolvidas no seu próprio território. Tanto é assim que o artigo 72 III dispõe que "nas áreas do primeiro período prevalece, no relacionamento entre direito federal e direito estadual, a respectiva lei posterior", optando por falar em precedência e não em revogação. Estas mesmas considerações se aplicam ao modelo de divergência previsto pelo artigo 84 GG, por expressa disposição neste sentido.

\subsubsection{As regras gerais previstas pela Constituição Federal de 1988}

A Constituição Federal de 1988 parece, em um primeiro momento, ter apenas duas regras com uma vocação mais geral. A primeira delas é o artigo $25, \S 1^{\circ}, \mathrm{CF} / 88$, que trata da competência residual dos Estados-membros e ao qual costuma ser atribuída uma eficácia muito restrita em virtude da enumeração de muitas competências à União e algumas competências importantes aos Municípios. Já a segunda delas consiste no artigo $24, \S 4^{\circ}$, $\mathrm{CF} / 88$, a princípio aplicável apenas à competência legislativa concorrente, assemelhandose, porém, a uma reedição do artigo 31 GG. Não se afirma categoricamente que estas são as únicas disposições deste tipo previstas pela constituição brasileira; não se afirma sequer que elas são efetivamente normas gerais em matéria de repartição de competências legislativas

${ }^{893}$ HUBER. Artikel 31. In: SACHS (Hrsg.). Grundgesetz, p. 1105. 
e de execução neste primeiro momento. Não obstante isso, reconhece-se que elas são um bom ponto de partida para o estudo das regras gerais em matéria de repartição de competências legislativas e de execução no direito constitucional vigente. Iniciemos a exposição pelo artigo $25, \S 1^{\circ}$, fazendo-o sob uma perspectiva histórica.

\subsubsection{O artigo 25, § 1으, da Constituição Federal de 1988}

Sabe-se que a forma de Estado Federal foi adotada pelo Brasil a partir da Constituição Federal de $1891^{894}$ sob nítida influência do direito norte-americano. Porém, tal qual a redação originária da constituição americana que lhe serviu como inspiração, esta constituição não previa expressamente a competência residual dos Estados-membros. Era algo subentendido, a partir a enumeração de poderes privativos ao Congresso Nacional pelo artigo 34. Nesse sentido, Ruy BARBOSA já afirmava em 1889, em voto separado no Congresso do Partido Liberal, que deveria competir à autoridade provincial "além do que estabelece o Acto Addicional, todos os poderes não compreendidos nas atribuições da autoridade nacional e não contrários aos direitos constitucionais dos cidadãos, e bem assim as nomeações dos juízes singulares" ${ }^{\text {} 895}$. A repartição de competências de execução, por sua vez, era regulada pelo $\S 3^{\circ}$ do artigo $7^{\circ}$, segundo o qual "as leis da União, os atos e as sentenças de suas autoridades serão executadas em todo o País por funcionários federais, podendo, todavia, a execução das primeiras ser confiada aos Governos dos Estados, mediante anuência destes". A contrario sensu, as leis estaduais eram executadas pelos Estados. Deste modo, tinha-se que as competências legislativas eram as únicas repartidas por meio da enumeração de competências privativas à União e da atribuição de uma competência residual implícita aos Estados; as competências de execução acompanhavam a distribuição das competências legislativas, de forma que União executava as suas próprias leis e os Estados faziam o mesmo em relação às suas leis, em regra. Diz-se "em regra", porque esta especial conformação das competências legislativas e de execução poderia ser alterada, de forma que os governos estaduais passariam a executar leis federais. De todo

\footnotetext{
894 Note-se que a adoção da federação, de fato, precedeu a própria Constituição Federal de 1891. Como observa JOSÉ AFONSO da Silva, "os republicanos assumiram o poder no dia 15.11.1889. Instala-se o Governo Provisório sob a presidência do Marechal Deodoro da Fonseca. A primeira afirmação constitucional da República foi o Decreto 1, expedido naquela data. Nele se traduz a velha aspiração brasileira com a adoção do Federalismo. As Províncias do Brasil, reunidas pelo laço da Federação, ficaram constituindo os Estados Unidos do Brasil, e cada um desses Estados, no exercício de sua legítima 'soberania', decretaria sua Constituição e elegeria seus corpos legiferantes e seus governos (arts. 1으. 2으 e 3ㅇ)" (JOSÉ AFONSO. O constitucionalismo brasileiro, p. 53). Porém, como a presente tese parte da indissociabilidade entre federação e constituição, optou-se por eleger a Constituição Federal de 1891 como marco inicial.

895 BARBOSA. Commentarios á Constituição Federal Brasileira. I Volume, p. 59.
} 
modo, estava-se diante de um sistema imediato de execução de serviços para falar com JOSÉ AFONSO da Silva ${ }^{896}$ ou do princípio da execução imediatas segundo Andreas J. KRELL ${ }^{897}$.

A Constituição Federal de 1934 também optou por uma enumeração das competências privativas federais (artigo $5^{\circ}$ ), além da previsão de competências concorrentes da União e dos Estados-membros no seu artigo $10^{898}$. Desta vez, a competência residual dos Estados foi consagrada expressamente no artigo $7^{\circ}$, IV, segundo o qual competia privativamente aos Estados "exercer, em geral, todo e qualquer poder ou direito, que lhes não for negado explícita ou implicitamente por cláusula expressa desta Constituição". A repartição de competências de execução era regulamentada pelo o artigo $5^{\circ}$, § $1^{\circ}, \mathrm{CF} / 1934$ em termos muito parecidos com o artigo $7^{\circ}, \S 3^{\circ}, \mathrm{CF} / 1891$. Ou seja, novamente estava-se diante de um sistema imediato de execução de serviços. A única inovação trazida por esta constituição neste ponto consistiu na possibilidade de a União executar leis estaduais do mesmo modo que era possível os Estados executar leis estaduais. Nos dois casos, a transferência da atividade de execução da lei deveria ser regulada por acordo.

A Constituição Federal de 1937 manejou igualmente a técnica horizontal de repartição de competências para falar com Manoel Gonçalves FERREIRA FILHO ao enumerar competências legislativas à União e conferir aos Estados a competência residual, nos exatos termos do artigo 21 , II. O artigo 19, por sua vez, disciplinava a repartição de competências de execução, ao prever que "a lei pode estabelecer que serviços de competência federal sejam de execução estadual; neste caso ao Poder Executivo federal caberá expedir regulamentos e instruções que os Estados devam observar na execução dos serviços”. Duas foram as inovações introduzidas por este dispositivo: em primeiro lugar, a execução de leis federais pelos Estados não dependia mais de acordo, mas ato do Poder Legislativo da União, o que necessariamente impunha uma limitação à autonomia estadual; em segundo lugar, o governo federal poderia conformar a atividade estadual de execução

\footnotetext{
${ }^{896}$ Para maiores detalhes sobre os sistemas de execução de serviços propostos por JOSÉ AFONSO, vide o tópico 1.5.2.

${ }^{897}$ Este princípio foi abordado de forma sucinta no item 4.3. De todo modo, considera-se oportuno transcrever as seguintes ponderações de Andreas J. KRELL sobre o assunto: "o sistema administrativo brasileiro tem a sua base no princípio da execução imediata. Os quadros de funcionários mantidos pela União, pelos Estados e pelos municípios, respectivamente, executam - com poucas exceções - exclusivamente os dispositivos legais da própria esfera. No passado, os órgãos de uma prefeitura municipal, por exemplo, podiam fundamentar os seus atos somente nas leis produzidas pela câmara local ou nos decretos do prefeito" (KRELL. As competências administrativas do artigo 23 da CF, p. 55).

898 Não se pode olvidar do artigo 5으 § 3o, CF/1934, que tratava da competência legislativa concorrente da União e dos Estados-membros. Para maiores detalhes sobre esta modalidade competência legislativa, vide nossas ponderações no tópico 4.4 .
} 
por meio de regulamentos e instruções, assemelhando-se neste ponto à Lei Fundamental alemã.

A Constituição Federal de 1946 restabeleceu as regras gerais em matéria de repartição de competências legislativas e de execução nos moldes das Constituições de 1891 e 1934, muito embora o modo pelo qual elas foram formuladas tenha se alterado um pouco. A competência privativa da União vinha enunciada no artigo $5^{\circ}$, ao passo que os Estados contavam com uma competência supletiva e complementar sobre alguns temas, conforme o artigo $6^{\circ}$, e a competência residual nos exatos termos do artigo $18, \S 1^{\circ}$. A repartição das competências de execução, por sua vez, era contemplada pelo artigo $18, \S 3^{\circ}$, com o seguinte teor:

\begin{abstract}
“ $§ 3^{\circ}$ - Mediante acordo com a União, os Estados poderão encarregar funcionários federais da execução de leis e serviços estaduais ou de atos e decisões das suas autoridades; e, reciprocamente, a União poderá, em matéria da sua competência, cometer a funcionários estaduais encargos análogos, provendo às necessárias despesas."
\end{abstract}

Ao permitir que, mediante acordo, a União executasse leis estaduais e os Estados executassem leis federais, este dispositivo implicitamente admitia que, como regra geral, a União deveria executar as leis federais, ao passo que os Estados deveriam executar leis estaduais. Ou seja, mais uma vez uma constituição brasileira consagrava o princípio da execução imediata. Nesse sentido, Francisco Cavalcanti PONTES DE MIRANDA ponderava que "a discriminação dos serviços em federais, estaduais e municipais é matéria constitucional: à União é que cabe prover os seus; aos Estados-membros, prover aos serviços estaduais (...); e aos Municípios, a ser turno, prover os serviços municipais"899. Porém, é de se admitir que o assunto recebia pouca atenção na doutrina da época, que preferia se debruçar sobre os requisitos e sobre a necessidade dos acordos ao qual se referia o artigo $18, \S 3^{\circ}$, CF/1946. 900

A Constituição Federal de 1967 - neste ponto centramos a exposição na versão dada pela EC n $n^{\circ}$ 01/1969 - também continha formulação muito parecida com a constituição que lhe antecedeu. Por um lado, arrolava competências privativas da União no seu artigo $8^{\circ}$ (cujo parágrafo único tratava da competência supletiva e complementar dos Estados) e atribuía aos Estados-membros a competência residual nos termos do artigo 13, $\S 1^{\circ}$. Por outro lado, o $\S 3^{\circ}$ do artigo 13 dispunha que "a União, os Estados e Municípios poderão celebrar convênios para a execução de suas leis, serviços ou decisões, por intermédio de funcionários

\footnotetext{
899 PONTES DE MIRANDA. Comentários à Constituição de 1946. Tomo II, p. 157.

900 Nesse sentido, vide os comentários de PONTES DE MIRANDA. Comentários à Constituição de 1946. Tomo II, pp. 158 e ss, CAVALCANTI. A constituição federal comentada. Volume I, pp. 278 e ss.
} 
federais, estaduais ou municipais". Note-se que o referido dispositivo falava em União, Estados e Municípios celebrando convênios para "a execução de suas leis", não deixando qualquer margem de que, em regra, a União deveria executar leis federais, Estados deveriam executar leis estaduais e Municípios deveriam executar leis municipais. Nesse sentido, pondera Andreas J. KRELL que

"sob o regime da Constituição Federal anterior, de 1967/69, a competência
administrativa resultava direta e necessariamente da respectiva competência
legislativa. Portanto, uma Administração não podia agir para executar as normas
de uma outra esfera política. Por outro lado, nenhum Estado poderia - por exemplo
- prescrever aos seus municípios o procedimento administrativo a observar em
seus atos. Segundo a teoria dominante no Brasil, tal regulamentação iria abusar
das prefeituras, reduzidas a 'intermediários burocráticos'.
Apenas em casos de emergência foi concedido às prefeituras o direito de executar
também leis superiores. Um exemplo é o impedimento de infrações iminentes de
normas dos Códigos Florestal ou de Minas, através de funcionários municipais,
quando os órgãos federais competentes não estejam presentes. Além dos casos de
urgência, a execução planejada de leis de uma outra esfera estatal, no Brasil,
sempre tem sido a celebração de convênios administrativos, que, até hoje,
representam o principal instrumento de colaboração entre a União, os Estados e os
municípios."”o1

Em apertada síntese, todas as constituições federais brasileiras até 1967/69 operavam uma repartição relativamente detalhada das competências legislativas $e$ dispunham direta ou indiretamente - em todo o caso, de forma expressa - que a titularidade das competências de execução seria a mesma da competência para legislar correspondente. Estas eram as regras gerais a serem observadas em matéria de repartição de competências legislativas e de execução, as quais poderiam ser mitigadas por meio de convênios ou acordos. Estes mesmos convênios ou acordos seriam os responsáveis, por sua vez, por viabilizar a colaboração federativa na atividade de execução das leis, como ressalta Andreas J. KRELL no trecho supracitado. Curiosamente, eles nunca receberam - como também não o recebem atualmente - um tratamento doutrinário compatível com a importância que eles possuem na prática federativa, como pondera este mesmo autor. ${ }^{902}$

\footnotetext{
901 KRELL. As competências administrativas do artigo 23 da CF, p. 55. Note-se que os comentários da época, ao analisarem a disposição contida no artigo 13, § 3으, CF/1967-69, também preferiram focar na possibilidade e na utilidade da celebração destes convênios do que se debruçar sobre a distribuição das competências de execução que o referido artigo impunha. Nesse sentido, vide as considerações de PONTES DE MIRANDA. Comentários à constituição de 1967. Tomo II, pp. 296 e ss e FERREIRA FILHO. Comentários à Constituição brasileira: Emenda Constitucional no 1. Vol. 1, pp. 124 e 125.

902 KRELL. As competências administrativas do artigo 23 da CF, pp. 55 e ss. Apenas para se ter uma ideia desta importância, o governo federal brasileiro atualmente conta com um sítio eletrônico denominado "portal dos convênios" (www.convenios.gov.br), apenas para gerenciar acordos da União com Estados, Municípios, além das entidades com o terceiro setor. Sobre as polêmicas doutrinárias que envolvem a figura do convênio no
} 
Com o advento da Constituição Federal de 1988 este cenário alterou-se substancialmente. Em primeiro lugar, observa-se um incremento das competências enumeradas, que podem ser tanto privativas quanto concorrentes. Tem-se, assim, dispositivos dedicados à disciplina da competência geral da União (artigo 21), da competência legislativa privativa da União (artigo 22), da competência comum da União, Estados e Municípios (artigo 23), da competência legislativa concorrente (artigo 24) e da competência dos Municípios (artigo 30). Em segundo lugar, os Estados-membros permaneceram com a competência residual nos termos do artigo $25, \S 1^{\circ}$, o qual dispõe que "são reservadas aos Estados as competências que não lhes sejam vedadas por esta constituição". Porém, a constituição atualmente vigente não contém qualquer regra geral no que tange à titularidade das competências de execução. Existem muitas previsões no sentido de que um ou outro serviço, ainda que regulamentados essencialmente por lei federal, devem ser executados por Estados ou Municípios. Este é o caso da saúde e da educação, aliás. E quando a constituição não atribui uma competência de execução a um ente federativo de forma expressa, como determinar a sua titularidade?

A despeito da ausência de previsão constitucional nesse sentido, autores como JOSÉ AFONSO da Silva continuam a defender que "o sistema brasileiro é o de execução imediata", o que significa dizer que "União, Estados, Distrito Federal e Municípios mantêm, cada qual, seu corpo de servidores públicos, destinados a executar os serviços das respectivas administrações (arts. 37 e 39)"903. Mesmo Andreas J. KRELL se limita a afirmar uma mitigação do princípio da execução imediata no que tange às competências inscritas no artigo $23 \mathrm{CF} / 88,{ }^{904}$ partindo do pressuposto de que a regra geral continua a ser a execução imediata de serviços.

Estas parecem, contudo, assertivas feitas a partir do que o direito constitucional brasileiro tradicionalmente consagrou, e não a partir do que ele atualmente prevê. Frise-se: não há, no direito constitucional positivo brasileiro, disposição no sentido de que a União deve executar leis federais, Estados devem executar leis estaduais e Municípios devem executar leis municipais, como regra geral. Neste caso, deve ser aplicada à repartição de competências de execução a única regra constitucional com vocação geral, que é justamente o artigo 25, $\S 1^{\circ} \mathrm{CF} / 88$.

\footnotetext{
direito administrativo brasileiro, em especial a sua aproximação com a ideia de contrato, vide MENEZES DE ALMEIDA. Contrato administrativo, pp. 242-246.

903 JOSÉ AFONSO. Curso de Direito Constitucional Positivo, p. 482.

904 KRELL. As competências administrativas do artigo 23 da CF, pp. 60 e ss.
} 
Note-se que, embora o artigo $25, \S 1^{\circ}, \mathrm{CF} / 88$ seja normalmente associado com a competência legislativa privativa e residual dos Estados, a sua literalidade permite que ele assuma um escopo bem mais amplo. Afinal, o artigo 25, $\S 1^{\circ}, \mathrm{CF} / 88$ não se destina conferir aos Estados apenas competências legislativas. Ao contrário, ele reserva aos Estados "as competências que não lhes sejam vedadas" constitucionalmente, o que pode abranger tanto competências legislativas quanto competências de execução. Partindo-se desta premissa, observa-se uma completa inversão no que tange ao sistema de execução de serviços consagrado pela Constituição Federal de 1988 em comparação com as constituições que lhe antecederam: com efeito, a constituição brasileira vigente consagrou um sistema mediato de execução de serviços - ou nos dizeres de JOSÉ AFONSO, um sistema "pelo qual os serviços federais, em cada Estado, são executados por funcionários deste, mantendo a União pequeno corpo de servidores incumbidos da vigilância e fiscalização destes serviços" $" 905$ - ou ao menos, um sistema misto. Como esta é uma das grandes conclusões deste estudo comparativo, considera-se oportuno destrinchar o seu conteúdo a partir de três observações.

Em primeiro lugar, no item 4.5 expôs-se o posicionamento de Fernanda Dias MENEZES DE ALMEIDA no sentido de que o artigo $25, \S 1^{\circ}, \mathrm{CF} / 88$ se restringiria a assuntos de competência material e financeira dos Estados-membros, os quais também sofrem o influxo de outras disposições da Constituição Federal de $1988^{906}$. Ponderou-se ainda como a competência legislativa com fulcro neste dispositivo seria demasiadamente restrita, não sendo possível cogitar uma matéria sobre a qual os Estados poderiam legislar residualmente. Nesta mesma ocasião colocou-se um questionamento importante, qual seja, o de se o artigo $25, \S 1^{\circ}, \mathrm{CF} / 88$ conteria apenas uma autorização para que os Estados organizassem sua própria administração e os seus próprios serviços ou se seria possível conferir o artigo $25, \S 1^{\circ}$ o caráter de uma verdadeira cláusula geral, a orientar a repartição de competências como um todo.

Diante de tudo o que foi exposto até o presente momento tem-se que este questionamento se resolve no sentido da afirmação e do posicionamento do artigo 25 , § $1^{\circ}, \mathrm{CF} / 88$ como regra geral em matéria de repartição de competências legislativas e de execução. Embora não se possa deixar de concordar que a eficácia deste dispositivo constitucional como competência residual é limitada, principalmente no diz respeito às competências legislativas, quando se reconhece a sua vocação geral, a sua importância se

\footnotetext{
905 JOSÉ AFONSO. Curso de Direito Constitucional Positivo, p. 482.

${ }^{906}$ ALMEIDA. Competências na Constituição de 1988, p. 128.
} 
torna enorme: colocando em termos comparativos, é como se o artigo $25, \S 1^{\circ}, \mathbf{C F} / 88$ correspondesse aos artigos 30, 70 e 83 GG somados, e ainda se colocasse como regra geral em relação ao artigo 125 CF/88, que trata da Justiça dos Estados.

Como regra geral que é, tem-se que a aplicabilidade do artigo $25, \S 1^{\circ}$ - tal como ocorre com os referidos dispositivos da Lei Fundamental alemã - é restringida por outros dispositivos constitucionais, tanto aqueles que enumeram competências à União e aos Municípios, quanto aqueles que especializam o seu conteúdo. Dado o tamanho da Constituição Federal de 1988, acredita-se que são muitos os dispositivos que operam esta restrição eficacial. Não obstante isso, é de se admitir que a repartição de competências em algumas políticas públicas importantes pode ser compreendida mais facilmente a partir desta constatação. É o caso da política de trânsito. Sabe-se que é da União a competência para legislar privativamente sobre trânsito e transporte (artigo 22, XI, CF/88), o que foi levado a cabo por meio da Lei no 9.503/1997 (Código de Trânsito Brasileiro - CTB). Lê-se no artigo $5^{\circ}$ deste diploma legislativo que "o Sistema Nacional de Trânsito é o conjunto de órgãos e entidades da União, dos Estados, do Distrito Federal e dos Municípios que tem por finalidade o exercício das atividades de planejamento, administração, normatização, pesquisa, registro e licenciamento de veículos, formação, habilitação e reciclagem de condutores, educação, engenharia, operação do sistema viário, policiamento, fiscalização, julgamento de infrações e de recursos e aplicação de penalidades". Os artigos 22 e 24 CTB, por sua vez, estabelecem as competências dos "órgãos ou entidades executivos de trânsito dos Estados e do Distrito Federal" e dos "órgãos e entidades executivos de trânsito dos Municípios", sendo que a primeira delas, nos dois dispositivos mencionados, consiste em "cumprir e fazer cumprir a legislação e as normas de trânsito" editadas, no caso, pela União. Em um caso como este, o poder legislativo federal foi o responsável pela elaboração de uma política pública nacional, que é executada com o auxílio das instâncias estaduais e municipais, e o que é mais importante: sem que haja na Constituição nenhuma previsão expressa nesse sentido, além do $\S 1^{\circ}$ do artigo $25 \mathrm{CF} / 88$, no caso dos Estados-membros, e do artigo $30 \mathrm{CF} / 88$, no caso do Município. ${ }^{907}$ Ainda que se admita que o $§ 10$ do artigo $144 \mathrm{CF} / 88$ confira aos Estados e aos Municípios expressamente a competência para ações de "segurança viária, exercida para a preservação da ordem pública e da incolumidade das pessoas e do seu patrimônio nas vias públicas" - o que certamente compreende, nos termos do seu inciso I, "a educação, a

\footnotetext{
907 Este mesmo argumento repete-se para políticas públicas importantes, como é o caso da educação (artigo 22, XXIV) e da saúde (artigo 24, XII), embora nestes casos União, Estados e Municípios tenham suas atribuições reguladas e repartidas, a grosso modo, pela própria Constituição Federal (artigos 198 a 200 e artigos 205 a 214).
} 
engenharia e fiscalização de trânsito, além de outras atividades previstas em lei, que assegurem ao cidadão o direito à mobilidade urbana eficiente" - o fato é que este dispositivo foi inserido na Constituição Federal de 1988 somente em meados de 2014 (mais precisamente, pela EC n 82/2014), aproximadamente 17 anos após a promulgação do Código de Trânsito. Até então as regras constitucionais que embasavam a atuação de Estados e Municípios eram o artigo $25, \S 1^{\circ}$ e o artigo $30, \mathrm{~V}, \mathrm{CF} / 88$.

Aliás, é importante atentar para o relacionamento do artigo $25, \S 1^{\circ} \mathrm{com}$ o artigo 30, I e V, CF/88, sendo esta a segunda observação a fazer. Para tanto, é importante retomar e desenvolver algumas considerações elaboradas no tópico 4.6. Nesta ocasião se ressaltou como o interesse local era um conceito a ser preenchido exclusivamente pela via da interpretação, o que colocava a importante questão de saber quais eram os seus legítimos intérpretes. Ponderou-se como os Municípios poderiam ser chamados a delimitar o interesse local, eis que são os seus titulares, assim como o Supremo Tribunal Federal, indubitavelmente o intérprete final da Constituição, e os Estados-membros, como o nível federativo mais afetado pela adoção de um conceito mais amplo de interesse local. Além do mais, colocou-se a importante questão de saber como "preencher" este interesse local, fornecendo-se dois subsídios para tanto. É exatamente neste ponto da exposição que se deseja retornar.

Sabe-se que os incisos I e V do artigo 30 CF/88 possuem uma redação parecida, ao autorizaram os Municípios a legislarem e a executarem serviços "de interesse local". A partir daí pode-se partir para a afirmação de uma correspondência entre estes dois dispositivos, de forma que os Municípios só poderiam legislar sobre assuntos que eles pudessem prestar a título de interesse local, e só poderiam prestar os serviços sobre os quais eles pudessem legislar a título de interesse local. Trata-se de um posicionamento mais restritivo da autonomia municipal, mas que ainda assim faz algum sentido quando se analisa a literalidade destes dois títulos competenciais. Também é possível partir de uma não-correspondência entre estas duas competências municipais, sendo esta a posição mais acertada, no nosso sentir, após levar em consideração duas características importantes da Constituição Federal de 1988. A primeira delas, já ressaltada no item 4.6, é o fato de as competências legislativas e de execução da União não serem coextensivas, o que acaba por colocar Estados e Municípios na posição de executores de programas definidos nacionalmente. A segunda característica, que se apresenta intimamente ligada à primeira, é o fato de a constituição brasileira regulamentar com maior detalhamento as competências legislativas do que as competências de execução. Por isso, a interpretação do interesse local a partir do subsistema das competências legislativas deve conduzir necessariamente a resultados diferentes da 
interpretação deste mesmo interesse no âmbito do subsistema das competências de execução. Mais precisamente, propugna-se que o interesse local que delimita a competência legislativa inscrita no inciso I do artigo 30 é invariavelmente mais restrito do que o interesse local a que se refere o inciso $\mathrm{V}$ do mesmo dispositivo: aos Municípios é lícito legislar, com fulcro no artigo 30, I, CF/88, somente sobre assuntos que não estejam inseridos na competência legislativa privativa ou concorrente da União e dos Estados-membros; já aos Municípios é lícito, lastreado na previsão do artigo 30, V, prestar serviços ainda que eles não estejam inseridos na sua competência legislativa.

Pois bem. A despeito destas considerações, e partindo ainda do pressuposto de que o interesse local é um conceito determinável pela via da interpretação, as dificuldades em atribuir uma matéria determinada à legislação ou à execução pelos Municípios não resta dissipada. Afinal, esta mesma matéria poderia ser igualmente reconduzida à competência residual dos Estados, que é mais ampla e, segundo o raciocínio que se desenvolve nesta tese, mais basilar ao federalismo brasileiro. É bem verdade que em textos clássicos de direito municipal e constitucional, a determinação e a afirmação das competências do Município sempre precede a da competência residual dos Estados. Nesse sentido, basta lembrar as regras elaboradas por Victor Nunes LEAL ao tratar da correlação entre os poderes municipais e os federais e estaduais, resumidas no seguinte trecho de sua obra:

\footnotetext{
"São quatro as regras enunciadas, tomando-se em cada um como ponto de referência os poderes dos municípios.

Segundo a primeira, os poderes municipais expressos e exclusivos afastam qualquer outra competência, seja federal, seja estadual. Lei federal ou estadual que disponha sobre matéria da competência expressa e exclusiva do município, não é válida por infringir a Constituição. É lei exorbitante da competência do poder que a promulgou. Não pode produzir efeito.

A segunda regra refere-se aos poderes municipais implícitos. Sobre eles prevalecem os poderes estaduais expressos, e também os federais expressos ou implícitos.

O mesmo, entretanto, não ocorre em relação à competência estadual remanescente. E aqui temos a terceira regra do nosso esquema: Os poderes municipais implícitos é que prevalecem sobre os poderes estaduais remanescentes. E por que? Por força do texto expresso da Constituição. A Constituição, ao definir os poderes remanescentes dos Estados, assim se exprimiu no $\S 1^{\circ}$ do art. 18: 'Aos Estados se reservam todos os poderes que, implícita ou explicitamente, não lhes sejam vedados por esta Constituição'. Os poderes que a Constituição dá implicitamente aos municípios estão vedados aos Estados; logo, diante dos poderes municipais implícitos, cede a competência residual remanescente.

A quarta regra diz respeito aos poderes concorrentes. Em muitas matérias, a competência pertence, cumulativamente, à União, aos Estados e aos municípios. Aqui, domina o princípio de que a entidade de maior categoria sobrepuja a de menor: os poderes concorrentes da União prevalecem sôbre os do Estado, que, por sua vez, prevalecem sôbre os do municípios." ${ }^{908}$
}

908 LEAL. Alguns problemas municipais, pp. 325-326 (grifos no original). Note-se que estas mesmas regras são adotadas por HELY LOPES Meirelles em Direito Municipal Brasileiro. 17ạ Ed. São Paulo: Malheiros, 2013, p.135. 
Parece-nos, contudo, que sob a égide da Constituição Federal de 1988 se operou uma inversão na terceira regra sugerida por LEAL. Isso se dá por uma razão bem simples: não há no artigo $25, \S 1^{\circ}, \mathrm{CF} / 88$ menção a competências explícitas e implícitas que afastariam a competência residual dos Estados, como faziam as Constituições Federais de 1946 e 1967/1969. Atualmente a competência residual ou reservada dos Estados é enunciada de tal modo que "são reservadas aos Estados as competências que não lhes sejam vedadas por esta Constituição", não se podendo extrair daí nenhuma regra no sentido de que competências implícitas necessariamente afastam competência residual (expressa) dos Estados.

Diante disso, defende-se que as competências não expressamente atribuídas à União e aos Municípios devem permanecer, em um primeiro momento, com os Estados a título residual. Apenas em um segundo momento é que assuntos e serviços inseridos na competência residual passam a ser de titularidade do Município com base na cláusula de interesse local, pois, embora se esteja diante de uma competência municipal expressa, a sua indeterminação faz com que ela funcione quase como uma competência implícita. Como isto será definido dependerá da articulação dos Municípios e dos Estados no sentido de definir quais competências continuarão a ser exercidas em nível estadual e quais competências poderão ser incumbidas aos Municípios com base no interesse local. Isto, por sua vez, pode se dar por disposição na constituição estadual, como sugere Andreas J. KRELL ${ }^{909}$, mas é possível cogitar outros instrumentos jurídicos, como ainda se terá a chance de expor ainda neste tópico. Em caso de litígio decidirá o Supremo Tribunal Federal ${ }^{910}$. Sabe-se que este é um posicionamento controverso, mas que deve ser se sustenta por tudo o que foi exposto até o presente momento: por um lado, os Municípios são entes federativos que devem ter a sua autonomia preservada, o que também se deve ao fato de consistirem no nível federativo mais propício para o desenvolvimento do self-government; por outro lado, os Estados-membros também são entes autônomos e não podem ter as suas

\footnotetext{
${ }^{909}$ Este posicionamento de Andreas J. KRELL foi exposto com detalhes no item 4.6. De todo modo, ele pode ser consultado em KRELL. Diferenças do conceito, desenvolvimeto e conteúdo da autonomia municipal, p. 123. 910 É de se ressaltar, afinal, que as constituições estaduais podem ser objeto de Ação Direta de Inconstitucionalidade. Portanto, em caso de conflito em torno da atribuição de competências ao Município pela constituição estadual, o STF poderá ser instado a se manifestar sobre a questão. O grande problema aqui reside no fato de que somente os Estados detêm legitimidade para ajuizar esta ação. Sobre a necessidade de se conferir também aos Municípios instrumentos para levar litígios que afetem os seus interesses à apreciação do STF, vide o tópico 7.2.2 desta tese.
} 
capacidades legislativas e administrativas diminuídas por meio de ato unilateral dos Municípios. ${ }^{911}$

Em casos especiais - isto é, nos casos em que as demandas dos cidadãos em relação ao Município tenham crescido, o que pode ocorrer em razão do difícil acesso de determinadas localidades, mas principalmente em virtude da metropolização - o interesse local do Município poderá ser ampliado $^{912}$, seja por meio de previsão específica na Constituição Estadual seja pela instituição de regiões metropolitanas as quais se refere o artigo $25, \S 3^{\circ}, \mathrm{CF} / 88$. Neste último caso, embora se esteja diante de uma competência legislativa privativa do Estado - uma das únicas, aliás - deve-se reconhecer que os Municípios não podem ser alijados do exercício das competências que são reunidas na região metropolitana, as quais deverão ser exercidas conjuntamente, ainda que não se adote o princípio da unanimidade nas decisões. ${ }^{913}$

Em terceiro e último lugar, considera-se oportuno se debruçar, ainda que sem a profundidade necessária, sobre as interações entre os artigos $25, \S 1^{\circ}$ e o artigo 241, ambos da CF/88. Poder-se-ia pensar em um primeiro momento que este último dispositivo seria uma reedição da regra geral em matéria de competências de execução prevista nas constituições anteriores, mas não é este o caso. Com efeito, prevê o artigo $241 \mathrm{CF} / 88$ que "a União, os Estados, o Distrito Federal e os Municípios disciplinarão por meio de lei os consórcios públicos e os convênios de cooperação entre os entes federativos, autorizando a gestão associada de serviços públicos, bem como a transferência total ou parcial de encargos, serviços, pessoal e bens essenciais à continuidade dos serviços transferidos”. Não é possível encontrar neste artigo nenhuma regra ou diretriz sobre o modo pelo qual competências devem ser distribuídas entre União, Estados e Municípios. O que efetivamente pode ser extraído da previsão contida no artigo 241 CF/88 é uma mitigação da repartição de competências de execução levada a cabo pela Constituição Federal de 1988 em outros artigos, na medida em que autoriza que serviços considerados tipicamente federais,

\footnotetext{
911 Questão importante diz respeito à legitimidade da União para delimitar o conteúdo do interesse local. De acordo com o entendimento esposado nesta tese, somente Estados e Municípios, além do Supremo Tribunal Federal, seriam atores legitimados para desempenhar tal tarefa. A União só poderia disciplinar e delimitar o interesse local no caso daquelas políticas públicas que são descentralizadas pela própria constituição e desde que a União assuma nestas políticas um papel relevante de coordenação. Aplicando este raciocínio à política nacional de trânsito, tem-se que a atribuição de competências diretamente aos Municípios pela lei federal é inconstitucional. Admite-se, contudo, que este raciocínio não corresponde ao posicionamento dominante no que diz respeito à repartição de competências nesta política pública.

912 Defende-se aqui que o interesse municipal deve ser ampliado e não reduzido, pois não faz muito sentido afirmar que, diante do crescimento de demandas dos cidadãos em relação ao Município, as suas possibilidades de atuação para fazer frente a estas demandas sejam reduzidas.

913 Conforme decidido na ADI 1842, aliás. Retornaremos ao tema, de todo modo, no tópico 7.3.3.
} 
estaduais ou municipais segundo estes últimos dispositivos sejam prestados conjuntamente ou por outros entes federativos. Colocando esta constatação em uma perspectiva comparada - o que é justamente o objetivo deste capítulo - o artigo 241 CF/88 mitiga a própria obrigatoriedade da repartição constitucional de competências de execução: ao contrário do que se extrai do artigo $30 \mathrm{GG}$, a partilha constitucional destas competências pode ser substituída por soluções cooperativas, o que implica necessariamente algum poder de disposição sobre os poderes conferidos constitucionalmente aos entes federativos envolvidos. Note-se que esta ponderação não se aplica à repartição de competências legislativas, à qual a ideia de obrigatoriedade forjada pela doutrina alemã e comentada no tópico anterior se aplica quase que irrestritamente.

Portanto e retornando ao problema da conciliação do artigo $25, \S 1^{\circ} \mathrm{com}$ o artigo 30, I e V, CF/88, tem-se que a determinação dos serviços de interesse local pode se dar por tanto por lei - aqui incluída constituição estadual e a lei orgânica municipal - quanto por acordo, em virtude da autorização contida no artigo 241 CF/88. Já a definição do interesse local que delimitará a competência legislativa do Município é um pouco mais complicada. No nosso sentir, o instrumento mais apropriado seria previsão específica nas constituições estaduais e nas leis orgânicas municipais, mas deve-se reconhecer que esta é uma questão deixada em aberto pela constituição brasileira vigente.

\subsubsection{O artigo 24, § 4o, da Constituição Federal de 1988}

Conforme mencionado na introdução deste tópico, o artigo $24, \S 4^{\circ}, \mathrm{CF} / 88$ pode ser vislumbrado como o segundo dispositivo com uma vocação mais geral. Afirmou-se isto em virtude da semelhança, ao menos em um plano superficial, entre o seu teor e o do artigo 31 GG, o qual, como já se sabe, é considerado a regra geral de colisão. Afinal, prevê o artigo $24, \S 4^{\circ}, \mathrm{CF} / 88$ que "a superveniência da lei federal sobre normas gerais suspende a eficácia da lei estadual, no que lhe for contrário", estabelecendo a regra da primazia da legislação federal sobre a legislação estadual, da mesma forma como faz o dispositivo da Lei Fundamental em comento. Com base nisso, seria possível afirmar que o artigo $24, \S 4^{\circ}$, CF/88 é a regra geral do direito constitucional brasileiro para solucionar situações de colisão de competências?

Acredita-se que esta pergunta deve ser respondida negativamente. A bem da verdade, o artigo $24, \S 4^{\circ}, \mathrm{CF} / 88$ é uma regra específica, com aplicabilidade restrita às competências legislativas concorrentes, o que se dá basicamente por três razões. A primeira delas, mais singela, remete à própria localização da norma em questão, vale dizer, 
nos parágrafos do artigo $24 \mathrm{CF} / 88$, dedicados precipuamente à disciplina da competência concorrente. Deste modo, tem-se que, nesta modalidade de competência legislativa, a União encontra-se adstrita à edição de normas gerais, as quais devem ser suplementadas pelas legislações estaduais, as quais concretizarão as normas gerais, além de adaptá-las às diferentes realidades regionais ( $\S 1^{\circ}$ e $2^{\circ}$ do artigo $24 \mathrm{CF} / 88$ ). Note-se que a legislação de normas gerais não é obrigatória - ou, ao menos, não deve necessariamente preceder temporalmente as legislações estaduais - porque o $\S 3^{\circ}$ do artigo $24 \mathrm{CF} / 88$ faculta aos Estados, na ausência de legislação federal, o exercício de competência legislativa plena, para atender às suas peculiaridades. Sobrevindo as normas gerais, então incide o $\S 4^{\circ}$ do artigo $24 \mathrm{CF} / 88$, cominando a ineficácia da legislação estadual em tudo no que esta última lhe contrariar. Percebe-se, portanto, que este último dispositivo se harmoniza completamente com o teor dos outros parágrafos do artigo 24 , os quais, conjuntamente, contemplam todas as situações que possam surgir no âmbito da competência legislativa concorrente da União e dos Estados, tão somente.

A segunda razão remete à própria redação do artigo $24, \S 4^{\circ}, \mathrm{CF} / 88$, o qual fala em "superveniência de lei federal sobre normas gerais" e não em "superveniência de lei federal", tão somente. A expressa referência que este dispositivo faz às normas gerais restringe o seu âmbito de aplicação à competência legislativa concorrente, não podendo dele se extrair, portanto, uma regra geral aplicável ao sistema brasileiro de repartição de competências legislativas e de execução como um todo.

O terceiro e último motivo é o mais contundente e refere-se à consequência prevista pelo $\S 4^{\circ}$ do artigo $24 \mathrm{CF} / 88$ para a incompatibilidade entre a legislação federal e as legislações estaduais. Sobre o assunto, é interessante atentar para as seguintes ponderações de Fernanda Dias Menezes de ALMEIDA:

\footnotetext{
"Sob a égide da Constituição anterior dizia PONTES DE MIRANDA (1967: v. II, 175-176) que 'a lei central excluía a lei local, 'não só na sua incidência', como 'no seu ser mesmo', concluindo, conseqüentemente, que 'por isso, a lei federal, que ab-rogou, ou derrogou, a lei local, pode ser, por sua vez, ab-rogada, ou derrogada, sem que volva à vida a lei estadual que aquela ab-rogara, ou derrogada. Quando a lei federal ab-roga outra lei federal, que sua vez ab-rogara, ou derrogara lei estadual, restitui ao Estado-membro a competência de legislar, e não a lei mesma.' (Grifos no original.)

A presente Constituição resolve a questão de outra forma. Não estabelece a revogação da lei estadual pela lei federal superveniente. Fala, isto sim, em suspensão da eficácia do diploma estadual. Por isso mesmo é que JOSÉ AFONSO DA SILVA (1989:435), discorrendo sobre a matéria, explica que 'a lei estadual, não sendo revogada nem derrogada no seu aspecto contraditório, apenas perde sua aplicabilidade, porque fica com a eficácia suspensa. Quer dizer, também, sendo
} 
revogada a lei federal pura e simplesmente, a lei estadual recobra sua eficácia e passa outra vez a incidir." 914

Note-se que a constituição anterior não continha nenhuma previsão que tratasse especificamente da situação da superveniência de norma federal nas hipóteses de competência concorrente da União e dos Estados-membros, como ocorre na constituição atual $^{915}$. O parágrafo único do artigo $8^{\circ} \mathrm{CF} / 1967-69$ previa apenas que "a competência da União não exclui a dos Estados para legislar supletivamente sobre as matérias das alíneas $c$, $d, e, n, q$ e $v$ do item XVII, respeitada a lei federal", de onde era possível extrair uma prevalência da legislação federal em virtude da exigência contida na última parte deste dispositivo. A consequência atribuída por PONTES DE MIRANDA - vale dizer, a abrogação da lei estadual - deve-se à nítida influência da doutrina alemã sobre o pensamento deste autor ${ }^{916}$, mas não encontrava previsão expressa na Constituição Federal de 1967, com as alterações introduzidas pela $\mathrm{EC} \mathrm{n}^{\circ} 01 / 1969$.

Com o advento da Constituição Federal de 1988, a questão da superveniência de lei federal editada com fulcro em uma competência concorrente recebeu tratamento específico, o qual diverge daquele conferido aos litígios competenciais em geral. É de se admitir, afinal, que no caso de desrespeito às normas constitucionais que atribuem competência a um ente federativo em detrimento de outro - ou, em outras palavras, no caso de invasão da competência de um ente federativo por outro ente - a consequência normalmente é a declaração da inconstitucionalidade da lei ou ato que infrinja a distribuição constitucional de competências. Já o artigo $24, \S 4^{\circ}, \mathrm{CF} / 88$ determina a simples

\footnotetext{
914 ALMEIDA. Competências na Constituição de 1988, p. 156. Note-se que PONTES DE MIRANDA, no trecho citado por ALMEIDA, baseia-se sobretudo na doutrina alemã para concluir pela derrogação da legislação estadual pela legislação federal, como se pode perceber do seguinte trecho transcrito a seguir: "Dissemos que, nos casos do art. 8ㅇ, XVII, d), e), n) e v), a superveniência do direito federal exclui o direito local. Dá-se o mesmo, nos casos das letras c) e q), se com a nova norma geral, diretriz ou base se chocaria o direito local. O princípio estava na Constituição de 1937, art. 18, parágrafo único, mas era desnecessário: era intrínseco, lògicamente, ao sistema da Constituïção de 1937. É o brocardo 'Direito federal corta Direito local' (em caso de competências concorrentes), que nos veio, doutrinàriamente, do direito alemão, onde já aparecia o princípio no art. 2, 1a parte, da velha Constituïção federal alemã, passando, em 1919, para o art. 13, alínea 1a a com a forma do enunciado usada na linguagem jurídica da doutrina alemã, sendo de notar-se que, linguisticamente, a velha forma era mais correta do que a que se deu ao texto de 1919. Nesse, está escrito Reichsrecht bricht Landrecht, em vez de Reichsrecht bricht Landesrecht, que era o brocardo tradicional. Na Constituïção da Alemanha ocidental, de 23 de maio de 1949, art. 31, reproduz-se o brocardo. Idem, na Constituição da Alemanha oriental, de 7 de outubro de 1949, art. 114." (PONTES DE MIRANDA. Comentários à Constituïção Federal de 1967. Tomo II, p. 174).

915 Lembrando apenas que, até o advento da Constituição Federal de 1988, não se falava em uma competência concorrente da União e dos Estados-membros e sim de uma competência supletiva e complementar dos Estados sobre temas inseridos na competência privativa da União.

${ }^{916}$ Sobre a influência da doutrina alemã sobre este posicionamento específico de PONTES DE MIRANDA, vide nota de rodapé no 914.
} 
ineficácia da legislação estadual. Com ponderações deste tipo não se deseja afirmar que onde atualmente se lê "ineficácia" deva-se entender "inconstitucionalidade superveniente". Ao contrário, é uma convicção inafastável desta tese que a interpretação constitucional não pode se dar em contrariedade ou simplesmente em desconsideração do texto constitucional. O que se deseja ponderar aqui apenas é que o artigo $24, \S 4^{\circ}, \mathrm{CF} / 88$ trata de uma situação específica - superveniência de lei federal em desconformidade com lei estadual anterior editada em obediência à repartição constitucional de competências - em relação à qual se aplica uma consequência específica - a ineficácia da legislação estadual anterior - o que se está em completa consonância com o argumento que se pretende sustentar aqui, qual seja, o de que o artigo $24, \S 4^{\circ}, \mathrm{CF} / 88$ é uma regra de colisão específica, com aplicabilidade restrita às competências legislativas concorrentes, e não uma regra geral de colisão a ser aplicada à repartição de competências legislativas e de execução como um todo.

Diante destas considerações, surge então de saber se a Constituição Federal de 1988 consagra, a bem da verdade, alguma regra geral de colisão. A resposta a este questionamento também merece ser negativa. Poder-se-ia até argumentar que, diante do papel coordenador atribuído à União e já discutido em mais de uma oportunidade nesta tese, as atuações estaduais e municipais deveriam necessariamente se harmonizar com as diretrizes definidas em nível federal. Ou seja, o direito constitucional vigente consagraria, à semelhança do direito alemão a regra da prevalência do direito federal sobre o direito estadual (e municipal), o que poderia ser obtido por uma interpretação do sistema de repartição de competências legislativas e de execução como um todo. Por outro lado, também é possível afirmar que, diante da descentralização promovida pela Constituição Federal de 1988, em caso de colisão deveria prevalecer a legislação estadual ou municipal, como uma forma de privilegiar a autonomia das unidades regionais. A presente tese tende a preferir o primeiro destes posicionamentos, mas admite que não há subsídios suficientes para erigi-lo a uma regra geral de colisão. Não há, com efeito, no direito constitucional positivo nenhuma regra de colisão com vocação geral, aplicável aos conflitos federativos na hipótese de não pode ser utilizada nenhuma regra especializante do seu conteúdo, a exemplo do que ocorre com o artigo $31 \mathrm{GG}$.

Com estas ponderações não se pretende afirmar que conflitos federativos principalmente os conflitos entre direito federal e direito estadual (e municipal) editados em conformidade com a repartição constitucional de competências - permanecem sem qualquer solução no Brasil diante da completa ausência de disciplina constitucional. Uma assertiva como esta seria falsa, porque a Constituição Federal de 1988 contém regras específicas de colisão, como é o caso do artigo $24, \S 4^{\circ}, \mathrm{CF} / 88$, já analisado neste tópico. Ou seja, 


\section{em caso de divergência entre normas válidas oriundas de níveis federativos diversos,}

deve-se buscar uma solução com base nestas regras específicas. É bem verdade que muitas delas não estão explícitas no texto da Constituição, mas podem ser obtidas pela interpretação de normas constitucionais expressas. Neste ponto, algumas construções oriundas do direito alemão poderiam prestar um auxílio imenso. É o caso do chamado efeito de barreira (Sperrwirkung), exposto nos itens 5.2 e 5.3 e retomado no tópico anterior como regra especializante em relação ao artigo $31 \mathrm{GG}$ : ora, também é possível afirmar que lei estadual sobre tema arrolado no artigo $22 \mathrm{CF} / 88$ não pode ser considerado válido pois a simples atribuição de uma competência legislativa à União a título privativo tem o condão de impedir qualquer atuação legiferante por parte dos Estados e dos Municípios; esta situação somente é alterada caso haja uma autorização por lei complementar federal nos termos do parágrafo único do artigo $22 \mathrm{CF} / 88$, o qual retira o efeito de barreira imposto pela norma que confere competência em termos privativos à União. Isso exige que normas competenciais sejam compreendidas pelo seu aspecto negativo, vale dizer, pela restrição que elas impõem em relação a potenciais destinatários e matérias. Mas ainda assim se trata de uma interpretação feita a partir do que a constituição efetivamente prevê, a partir do direito brasileiro positivo.

\subsection{COMPETÊNCIAS LEGISLATIVAS E COMPETÊNCIAS DE EXECUÇÃO}

Ao se propor um tópico sobre as competências legislativas e as competências de execução deve-se ter em mente não só como elas são distribuídas entre União, Estados e Municípios, mas também como a repartição de competências legislativas e a repartição de competências de execução se relacionam. O tema tem recebido muita atenção por parte da doutrina e jurisprudência alemãs, mas é relativamente pouco explorado no Brasil por razões diversas.

A seguir, propõe-se exposição dividida em dois tópicos. No primeiro deles objetivase apenas retomar e problematizar alguns aspectos da correlação das competências legislativas e de execução na Alemanha, a qual já foi tratada com maiores detalhes no quinto capítulo desta tese. Já o segundo tópico analisa esta mesma questão no direito constitucional brasileiro vigente, ao mesmo tempo em que expõe os resultados da confrontação entre Brasil e Alemanha neste ponto. Trata-se, portanto, de um item mais longo, no qual serão expostas e discutidas algumas das conclusões mais importantes deste estudo comparativo. 


\subsubsection{A repartição de competências legislativas e de execução na Alemanha}

Em mais de uma oportunidade nesta tese já se debruçou sobre a especial - e também tradicional, já que remonta à Constituição Imperial de 1871 - distribuição das competências legislativas e de execução na Alemanha. Sabe-se, assim, que neste país as competências legislativas apresentam-se concentradas na União, de forma que este ente federativo acaba assumindo uma proeminência nesta área. Já as competências de execução, inclusive as competências para a execução de leis federais, pertencem em sua maioria aos Estadosmembros, os quais acabam por adquirir posição de destaque nesta seara. Portanto, tem-se que, na federação alemã, Estados executam as leis federais, em regra como um assunto que lhes é próprio. Vendo o mesmo fenômeno sob uma perspectiva oposta, tem-se que a União normalmente precisa da colaboração dos Estados para ver a sua legislação executada ${ }^{917}$.

Estas, contudo, não são as únicas implicações desta não-coextensividade no que tange à titularidade das competências legislativas e de execução. Muitas delas já foram analisadas no decorrer do terceiro e do quinto capítulo, a cuja leitura se remete. Neste tópico pretende-se apenas retomá-las sob uma perspectiva mais global, com o intuito de forjar algumas conclusões que serão úteis na análise comparativa com o Brasil. Para tanto, propõese exposição estrutura a partir de três grandes observações.

\section{A primeira observação diz respeito à previsão de mecanismos de influência do} Bund sobre a atividade de execução da lei federal pelos Länder, analisados no tópico 5.5. Alguns deles são mais incisivos, como é o caso das instruções individuais previstas no artigo $84 \mathrm{~V}$ e no artigo 85 III GG. Outros parecem ser mais sutis, como a supervisão federal prevista no artigo 84 III GG, a qual se limita a uma avaliação da conformidade da atuação estadual com o Direito; em certas hipóteses, porém, esta supervisão pode abranger também a oportunidade da execução (artigo 85 IV GG), o que acaba por aumentar a influência do Bund sobre a atuação dos Länder. Chamam a atenção ainda a possibilidade de a União editar preceitos administrativos de caráter geral e, principalmente, a possibilidade de União regular, por meio de lei, o procedimento administrativo e a instituição dos Behörden estaduais. Tende-se a acreditar que tais faculdades conferidas ao Bund sejam recebidas até com algum estranhamento pela doutrina brasileira, embora algumas delas não sejam exatamente estranhas ao nosso direito, conforme ainda será discutido nesta tese.

Sabe-se que alguns destes mecanismos colocados à disposição da União são pouco manejados, pois têm sido substituídos ou incrementados por formas de cooperação

\footnotetext{
917 Este, aliás, é uma das características do modelo germânico descrito por Fritz SCHARPF em The joint-decision trap, pp. 242-243.
} 
voluntária. A supervisão federal nos moldes do artigo 84 GG, por exemplo, é um instrumento que tem sido substituído não só por mecanismos cooperativos de uniformização da atuação administrativa, mas também pelo controle exercido pelos cidadãos. Já os preceitos administrativos de caráter geral, por sua vez, são elaborados muitas vezes no âmbito das comissões e conferências analisadas no item 3.2.3, o que acaba por lhes conferir feições mais cooperativas. Em um cenário como este surge a interessante questão de saber até que ponto esta especial conformação de competências legislativas e de execução pressupõe cooperação. Poderiam União e Estados agir de forma completamente independente ou o fato de a União legislar e os Estados executarem a legislação da União faz com que alguma forma de coordenação seja necessária?

Deve-se reconhecer que esta segunda alternativa se apresenta como a mais correta, pois a atividade de execução de uma lei - qualquer lei, não só a lei federal - comporta uma margem de discricionariedade muito grande. Afinal, um mesmo preceito legal pode ser executado de várias formas e isto se coloca como uma realidade problemática quando há apenas uma lei federal - a qual, no mais das vezes, instituem as bases de políticas públicas nacionais - e vários executores. Caso não haja nenhuma forma de compatibilizar e harmonizar a atuação destes últimos, uma mesma lei federal pode traduzir diferentes direitos e deveres em âmbito nacional.

Os mecanismos de influência do Bund sobre os Länder previstos nos artigos 84 e 85 GG e analisados no tópico 5.5 desempenham, sob uma perspectiva mais geral, justamente este papel de compatibilização e harmonização, sendo imprescindíveis para que a execução da lei federal caminhe para um bom termo de um modo global. Atentese para o fato de que eles não deixam de ser uma forma de cooperação federativa, mais precisamente, do que se convenciona chamar de coordenação diretiva. O tema já foi abordado com detalhes alhures, mas por ora cumpre apenas lembrar que nesta modalidade de coordenação federativa a União detém competências de coordenação que lhe permitem decidir, em relação aos Estados-membros, de modo diretivo ${ }^{918}$. A substituição ou o incremento dos instrumentos previstos nos artigos 84 e 85 GG por mecanismos de coordenação cooperativa919 ou de cooperação voluntária revelam apenas uma

\footnotetext{
918 Definição forjada por Walter RUDOLF em $\S 141$ - Kooperation im Bundesstaat. In: ISENSEE, KIRCHHOF (Hrsg.). Handbuch des Staatsrechts, p. 1016.

919 Lembrando apenas que, dentro da classificação proposta por Walter RUDOLF, coordenação diretiva, exposta supra, contrapõe-se a coordenação cooperativa, a qual é caracterizada justamente pelo fato de uma competência ser dividida entre União e Estados de forma que os dois lados tenham que "atingir um proceder comum de forma cooperativa" (RUDOLF. § 141 - Kooperation im Bundesstaat. In: ISENSEE, KIRCHHOF (Hrsg.). Handbuch des Staatsrechts, p. 1016).
} 
preferência por soluções mais consensuadas, das quais participam União e Estadosmembros. Porém, em ambos os casos se está diante de coordenação federativa, a qual desempenha o importante papel de redução da margem de discricionariedade franqueada aos Estados na atividade de execução da lei.

A segunda observação a ser feita diz respeito à influência dos Estados-membros alemães sobre a produção legislativa federal, o que se dá essencialmente por meio do Conselho Federal. Sabe-se que este órgão - forjado como uma poderosa instância de representação dos Estados, mas que só deveria manifestar sua aprovação sobre determinadas matérias arroladas pela própria Lei Fundamental - teve o seu papel e a sua importância alterados no decorrer dos anos. O grande responsável por este fenômeno certamente foi a interpretação conferida pelo Tribunal Constitucional Federal sobre o artigo 84 GG, de modo que, se a União quisesse legislar sobre procedimento administrativo e instituição de Behörden estaduais, era necessário que o Conselho Federal manifestasse a sua aprovação em relação à lei como um todo. Como Estados normalmente executam leis federais, procedimento administrativo e instituição de Behörden são temas que aparecem com alguma frequência nestas leis, de forma que a necessidade de aprovação Conselho Federal passou a ser decisiva. Embora se negue nesta tese que este aumento da importância do Conselho Federal seja efetivamente uma compensação dada aos Estados em razão da perda de competências legislativas importantes ${ }^{920}$, não há como deixar de reconhecer que dotar os Estados de um poder de veto relevante sobre as leis que eles posteriormente terão que executar faz sentido, ao menos em um plano político. Afinal, se à União é conferido mecanismos para exercer influência sobre a execução de suas leis pelos Estados, aos Estados também devem ser garantidos instrumentos para influenciar a elaboração da lei cuja execução será por eles promovida. Forma-se, portanto, um ciclo no qual o Bund atua sobre os Länder e os Länder atuam sobre o Bund. É bem verdade que partes deste ciclo são consideradas viciosas pelos alemães, sendo que alguns deles foram inclusive desmantelados nas sucessivas reformas constitucionais relatadas no tópico 2.2.2. É o caso do artigo 84 GG, que não mais prevê a aprovação do Conselho Federal como regra geral. De todo modo, é importante compreender a interdependência entre União e Estados no que tange à execução de lei federal.

Porém, é de se admitir que esta influência recíproca também é perceptível na execução de leis estaduais pelos Estados, sendo esta a terceira grande observação a ser feita. Nesse sentido, basta lembrar das tarefas comuns (Gemeinschaftsaufgaben), cujas linhas

920 Este argumento foi exposto e refutado no item 5.5.1, a cuja leitura se remete. 
gerais foram expostas no tópico 5.7 desta tese. Conforme exposto naquela ocasião, estas tarefas incidem sobre matérias inseridas tradicionalmente na competência privativa dos Estados-membros, conferindo ao Bund competências e faculdades que lhe seriam vedadas pela Lei Fundamental na ausência de previsão expressa. No que diz respeito às matérias arroladas no artigo 91a GG, a Lei Fundamental previu inclusive que decisões deveriam ser tomadas conjuntamente, forjando uma hipótese de coordenação federativa compulsória, concretizada sobretudo na elaboração de um planejamento comum. Para completar este cenário, as leis que regulamentavam estas tarefas comuns - as quais dependiam de aprovação do Conselho Federal, é sempre bom lembrar - passaram a exigir maiorias qualificadas ou até mesmo decisões unânimes para a adoção de decisões conjuntas. Neste ponto, aliás, está a gênese da Politikverflechtung, ou da tomada de decisões conjuntas, tão ínsita ao federalismo cooperativo alemão. Note-se que a influência do Bund também pode assumir a forma de acordos, nos exatos termos do artigo 91b GG, travados bilateral ou multilateralmente. De um modo ou de outro conclui-se que também nas áreas em que Estados, em tese, deveriam legislar e executar a sua própria legislação também são conferidos mecanismos de influência ao Bund e instrumentos pelos quais os Länder conformam a atuação federal. Ou seja, também aqui se nota uma interdependência entre União e Estados.

Finalmente, é importante atentar para uma outra característica da distribuição de competências legislativas e de execução na Alemanha que se mostra útil ao argumento que se pretende desenvolver no tópico sobre a repartição de competências legislativas e de execução no Brasil. Mais precisamente, deseja-se falar da competência para legislar sobre servidores públicos. Este é um tema que não diz respeito exatamente à execução da lei, mas apresenta relações óbvias com esta temática. Ao tratar da distinção entre direito material, procedimento administrativo e instituição de Behörden para fins de incidência do artigo 84 I GG, Janbernd OEBBECKE resume a questão em três respostas e perguntas importantes: deste modo, o direito material responderia a pergunta pelo "o quê" efetivamente seria executado; a instituição dos Behörden, por sua vez, seria a resposta para a pergunta por "quem" executa a lei, e; finalmente, o procedimento administrativo ditaria o "como" esta atividade seria levado a cabo ${ }^{921}$. Os servidores públicos, por sua vez, são as pessoas que interpretam diariamente "o quê" deve ser executado, agrupados em Behörden, são responsáveis por conduzir os procedimentos administrativos que ditarão "como" leis serão executadas. Portanto, se a regulamentação do serviço público também é repartida

\footnotetext{
921 OEBBECKE. § 136 - Verwaltungszuständigkeit. In: ISENSEE, KIRCHHOF (Hrsg.). Handbuch des Staatsrechts,
} p. 752. 


\section{entre União e Estados, esta repartição possui reflexos sobre o modo pelo qual} competências administrativas são exercidas. É o que ocorre na Alemanha, sendo que também aqui se percebe uma evolução constitucional relevante.

$\mathrm{Na}$ sua redação originária, a Lei Fundamental previa apenas a competência privativa da União para legislar sobre "as relações jurídicas das pessoas a serviço da União e das pessoas jurídicas de direito público ligadas diretamente à União" (artigo 73 I Nr. 8 GG), e para editar preceitos-moldura sobre "as relações jurídicas das pessoas que integram o serviço público dos Estados, Municípios e outras pessoas jurídicas de direito público" (artigo 75 Nr. 1 GG). Todavia, já em 1969, a competência-moldura da União foi ampliada, a fim de incluir um parágrafo segundo, segundo o qual, com a aprovação do Conselho Federal, os preceitos-moldura poderiam estabelecer "parâmetros unitários para a constituição e mensuração da remuneração, inclusive da avaliação dos órgãos públicos, bem como contribuições mínimas e máximas”. Finalmente, em 1971 a constituição alemã foi emendada com a finalidade de incluir um artigo 74a GG, com o seguinte teor:

“(1) A competência legislativa concorrente estende-se, além disso, à remuneração e previdência dos membros do serviço público, que estão em uma relação de serviço e lealdade de direito público, à medida que à União não caiba a competência privativa de acordo com o artigo $73 \mathrm{Nr} .8$.

(2) Leis federais conforme o parágrafo primeiro necessitam da aprovação do Conselho Federal.

(3) Necessitam da aprovação do Conselho Federal também leis federais conforme o artigo $73 \mathrm{Nr}$. 8, à medida que elas prevejam outros parâmetros do que a lei federal nos termos do parágrafo primeiro para a constituição ou a mensuração da remuneração e da previdência, inclusive a avaliação de órgãos públicos ou outras contribuições mínimas ou máximas.

(4) Os parágrafos primeiro e segundo vigoram correspondentemente para a remuneração e a previdência dos juízes estaduais. Para leis conforme o artigo 98 I vigora o parágrafo terceiro correspondentemente" 922

Percebe-se, assim, uma restrição ainda maior à autonomia estadual, pois a atuação legislativa da União passou a se dar nos termos do artigo 72 GG, vale dizer, sem qualquer limitação quanto à extensão da matéria regulada. Por óbvio, uma previsão como esta teve a sua constitucionalidade questionada perante o Tribunal Constitucional Federal, que decidiu pela sua compatibilidade com o artigo 79 III GG, desde que fosse garantido aos Estados a

\footnotetext{
922 No original: "(1) Die konkurrierende Gesetzgebung erstreckt sich ferner auf die Besoldung und Versorgung der Angehörigen des öffentlichen Dienstes, die in einem öffentlich-rechtlichen Dienst- und Treuverhältnis stehen, soweit dem Bund nicht nach Artikel 73 Nr. 8 die ausschließliche Gesetzgebung zusteht. (2) Bundesgesetze nach Absatz 1 bedürfen der Zustimmung des Bundesrates. (3) Der Zustimmung des Bundesrates bedürfen auch Bundesgesetze nach Artikel 73 Nr. 8, soweit sie andere Maßstäbe für den Aufbau oder die Bemessung der Besoldung und Versorgung einschließlich der Bewertung der Ämter oder andere Mindest-oder Höchstbeträge vorsehen als Bundesgesetze nach Absatz 1. (4) die Absätze 1 und 2 gelten entsprechend für die Besoldung und Versorgung der Landesrichter. Für Gesetze nach Artikel 98 Abs. 1 gilt Absatz 3 entsprechend."
} 
possibilidade de realizar reformas e alterações estruturais na sua organização administrativa. ${ }^{923}$ A seguir, o que se viu foi uma profusão de leis federais com fulcro no artigo 74a GG, o que praticamente acabou com a possibilidade de os Estados legislarem sobre o tema. Como anota Stefan OETER:

\begin{abstract}
"legislação independente nas áreas da remuneração e da previdência de servidores, desde então, quase não é mais possível, o que foi reforçado por inúmeras leis sobre remuneração de servidores e previdência de servidores editadas posteriormente. Os legisladores estaduais estão hoje na prática autorizados a legislar nas matérias de remuneração e previdência dos servidores estaduais e municipais apenas à medida que o legislador federal expressamente permitiu isso em áreas delimitadas estreitamente, portanto declarou explicitamente que ele não quis regulamentar uma questão específica de forma exaustiva." ${ }^{924}$
\end{abstract}

Finalmente, em 2006 os artigos 74a e 75 foram revogados, o que não significou necessariamente que os Länder readquiriram capacidade plena para legislar sobre os seus respectivos servidores públicos. Ao contrário, foi conferido ao Bund a faculdade de legislar sobre "os direitos e os deveres de status dos servidores públicos dos Estados, Municípios e outras pessoas jurídicas de direito público bem como dos juízes nos Estados com exceção da carreira, da remuneração e da previdência"925 (artigo 74 I Nr. 27 GG), sendo esta uma competência que não se submete à verificação da necessidade (Erforderlichkeit) da legislação estadual nos termos do artigo 72 II GG. Porém, é de se admitir que foi conferido aos Estados uma margem maior de atuação, tendo em vista a ressalva feita no final no artigo 74 I Nr. 27 GG: a partir de agora, aos poderes legislativos estaduais compete privativamente legislar sobre temas importantes como carreira, remuneração e previdência dos servidores do seu respectivo Estado.

\footnotetext{
923 Stefan OETER. Artikel 74a. In: Hermann VON MANGOLDT, Friedrich KLEIN, Christian STARCK (Hrsg). Kommentar zum Grundgesetz. Band 2: Artikel 20 bis 82. 5a Ed. Munique: Franz Vahlen, 2005, p. 2030. Note-se que neste mesmo trecho o referido autor traça algumas considerações críticas sobre este posicionamento da corte constitucional alemã. O julgado citado é o BVerfGE 34,9.

924 OETER. Artikel 74a, p. 2032. No original: "Eigenständige Gesetzgebung auf den Gebieten der Beamtenbesoldung und -versorgung ist den Ländern seitdem kaum mehr möglich, was durch die im weiteren Verlauf erlassenen zahlreichen Gesetze zur Beamtenbesoldung und Beamtenversorgung noch verschärft wurde. Die Landesgesetzgeber sind heute praktisch in Materien der Besoldung und Versorgung der Landes- und Kommunalbeamten nur noch gesetzgebungsbefugt, soweit der Bundesgesetzgeber dies für eng umgrenzte Bereiche ausdrücklich zugelassen hat, also explizit erklärt hat, er habe eine bestimmte Frage nicht, erschöpfend' regeln wollen."

925 No original: "die Statusrechte und -pflichten der Beamten der Länder, Gemeinden und anderen Körperschaften des öffentlichen Rechts sowie der Richter in den Ländern mit Ausnahme der Laufbahnen, Besoldung und Versorgung". Para maiores detalhes sobre o alcance desta competência vide as considerações de Christoph DEGENHART em SACHS. Grundgesetz, pp. 1594-1597.
} 


\subsubsection{A repartição de competências legislativas e de execução no Brasil}

A repartição de competências legislativas e de execução no Brasil e, em especial o relacionamento entre a distribuição de uma e de outra, são temas que não têm sido tratados com a devida atenção no Brasil. Acredita-se que este é um equívoco com consequências graves, que acabam por obscurecer a própria natureza das relações travadas no âmbito da federação brasileira. Por meio das observações a seguir, objetiva-se trazer genuína contribuição não só para a compreensão da correlação entre competências legislativas e de execução, mas para a teoria jurídica do federalismo. Para tanto, elaborou-se exposição subdividida em dois tópicos, os quais procurarão abordar dois aspectos importantes da Constituição Federal de 1988 - a saber, a descentralização de algumas políticas públicas pela própria constituição (artigo 144 e seguintes) e a constitucionalização da Administração Pública (artigos 37 e 40) - dentro de um contexto de partilha e distribuição de competências em um Estado Federal.

\subsubsection{A relação entre a repartição de competências legislativas e a repartição de competências de execução}

No tópico 6.2.2.1 expôs-se como a Constituição Federal de 1988 promoveu uma alteração substancial na repartição de competências de execução. Com efeito, ao contrário das constituições que lhe antecederam, a constituição brasileira vigente não dispõe que a titularidade destas competências, em regra, é a mesma das competências legislativas. Portanto, não é mais possível afirmar que, no que tange à execução de serviços, a federação brasileira teria previsto um sistema imediato. Viu-se, igualmente, que a Constituição de 1988 contém apenas uma regra geral em matéria de repartição de competências, o artigo $25, \S 1^{\circ}$, $\mathrm{CF} / 88$, a qual deve ser aplicada naqueles casos em que não há previsão constitucional sobre a titularidade das competências legislativas e de execução. Com base nestas considerações, afirmou-se a transição para um sistema mediato, ou ao menos para um sistema misto de execução de serviços.

Porém, é de se admitir que estas são ilações que se colocam como regra geral, a serem aplicadas na hipótese de a Constituição Federal de 1988 não conter qualquer previsão específica. O fato é que há muitas previsões constitucionais que atribuem competências legislativas e de execução à União, Estados e Municípios. Se é comum criticar a constituição brasileira pela sua extensão e prolixidade, isso muito se deve à regulamentação de políticas públicas em nível constitucional, o que se dá essencialmente por meio do estabelecimento de diretrizes, princípios gerais e também de regras que atribuem 


\section{competências à União, Estados e Municípios. Em muitas destas políticas se percebe um} certo descolamento da titularidade da competência legislativa e da competência de execução, aplicando-se aqui a conclusão que outrora se fez em relação às regras gerais: em outras palavras, nestas políticas públicas constitucionalmente descentralizadas a competência legislativa permanece primordialmente com a União, a qual exerce também um pronunciado papel de coordenação; a competência de execução fica concentrada com os Estados e Municípios. Este fenômeno, de certo modo, já foi apreendido por alguns cientistas políticos brasileiro. Nesse sentido é que Marta ARRETCHE, por exemplo, identifica como um fator de centralização - por ela denominada de centralização da normatização - a edição de leis federais sobre competências dos Estados e dos Municípios ${ }^{926}$. Todavia, enquanto a referida autora prefere vislumbrar no fato de a União legislar sobre temas cuja execução normalmente compete aos Estados uma tendência de centralização, a presente tese opta por enxergar no fato de à União não competir a execução de leis e programas federais importantes uma tendência importante de descentralização e de interdependência federativa.

Isto não quer dizer, por sua vez, que a União não promova a execução de suas próprias leis em muitas áreas. Ao contrário, é possível observar uma coextensividade no que diz respeito à titularidade das competências legislativas e das competências de execução em algumas matérias importantes, o que faz com que a constatação anterior - vale dizer, de que na maioria das políticas públicas a constituição atribui a titularidade destas competências a níveis federativos diversos - mereça maiores esclarecimentos. ${ }^{927}$ Antes disso, contudo, propõe-se uma breve incursão nos quatro possíveis relacionamentos entre competências legislativas e de execução consagrados pela Constituição Federal de 1988.

O primeiro deles consiste em uma paridade, uma coincidência entre a competência de legislar sobre determinadas matérias e a respectiva competência de execução. Exemplos deste relacionamento podem ser extraídos do confronto dos artigos 21 e 22 CF/88. Nesse sentido, atente-se para competência privativa da União para legislar sobre telecomunicações, inscrita no artigo 22, IV , CF/88, e para prestar, diretamente ou mediante autorização, concessão ou permissão, os serviços de telecomunicação nos termos do artigo 21, XI, CF/88; a competência federal para legislar e para executar o serviço postal (artigo 22, V, e artigo 21, X, CF/88); a competência federal para legislar sobre sistema monetário e de medidas, títulos e garantias dos metais e sobre política de crédito, câmbio, seguros e transferências de valores (artigo 22, VI, e VII, CF/88) e a competência para emitir moeda

\footnotetext{
${ }^{926}$ ARRETCHE. A Centralização no Estado Federativo brasileiro, pp. 28 e seguintes.

927 Apesar de ser este um argumento já esboçado no quarto capítulo desta tese, considera-se importante retomá-lo neste momento com os desdobramentos que lhes são ínsitos.
} 
(artigo 21, VII) e para "administrar as reservas cambiais do País e fiscalizar as operações de natureza financeira, especialmente as de crédito, câmbio e capitalização, bem como as de seguros e de previdência privada" (artigo 21, VIII). Em todos estes e também em outros ${ }^{928}$ casos percebe-se a intenção de atribuir à União o poder de legislar sobre uma determinada matéria e também de promover a execução de suas próprias leis.

Em segundo lugar, há casos em que à União é atribuída somente a competência legislativa, sem que haja qualquer referência a uma competência federal de execução. Porém, na prática, sabe-se as leis federais editadas com fulcro nestas competências legislativas são executadas no âmbito da estrutura administrativa federal, o que pode se dar por razões diversas. É o caso competência para legislar sobre "nacionalidade, cidadania e naturalização" (artigo 22, XIII) e sobre "emigração e imigração, entrada, extradição e expulsão de estrangeiros" (artigo 22, XV), ambas concretizadas na Lei ${ }^{\circ}$ 6.815/1980 (Estatuto do Estrangeiro), cuja execução é promovida pelo Ministério da Justiça. É também o caso da competência legislativa federal para legislar privativamente sobre "seguridade social" (artigo 22, XXIII) e concorrentemente sobre "previdência social" (artigo 24, XII). $\mathrm{O}$ artigo $21 \mathrm{CF} / 88$ não atribui nenhuma competência privativa à União para executar os programas e ações da seguridade social, sob uma perspectiva mais geral, e da previdência social, de um ponto de vista mais específico. Contudo, o Regime Geral de Previdência Social (RGPS), que é certamente o maior e mais importante regime previdenciário, é gerido em termos privativos pelo Instituto Nacional do Seguro Social (INSS), autarquia federal cuja criação foi autorizada pela Lei $n^{\circ} 8.029 / 1990$, sem que a Constituição Federal de 1988 contenha uma previsão específica nesse sentido. Ao contrário, o artigo $194 \mathrm{CF} / 88 \mathrm{diz}$ expressamente que "a seguridade social compreende um conjunto integrado de ações de iniciativa dos Poderes Públicos e da sociedade", dando a entender, portanto, que a seguridade social é um assunto cuja execução compete tanto à União, quanto aos Estados e aos Municípios. Note-se que, em relação a outras áreas da previdência social e até mesmo da seguridade social como um todo, é possível vislumbrar uma atuação mais ou menos integrada dos Estados e dos Municípios sob a coordenação da União.

Em terceiro lugar, há casos em que à União é conferida uma competência legislativa privativa ou concorrente, mas não lhe é atribuída a competência de execução, ao menos não na mesma extensão. A título exemplificativo cita-se a

\footnotetext{
928 Nesse sentido, vide os casos da radiofusão (artigo 22, V e 21, XII, a CF/88); dos portos (artigo 22, X e 21, XXI, f CF/88); do Ministério Público do Distrito Federal e Territórios (artigo 22, XVII e 21, XIII CF/88); do Tribunal de Justiça do Distrito Federal e Territórios (artigo 22, XVII e artigo 21, XIII CF/88), e; do sistema estatístico, cartográfico e de geologia nacional (artigo 22, XVIII e 21, XV CF/88).
} 
competência da União para legislar sobre transportes e estabelecer as diretrizes da polícia nacional de transportes (artigo 22, XI e IX). Ao se analisar o artigo $21 \mathrm{CF} / 88$, constata-se que a União detém competência privativa somente para: (i) explorar, diretamente ou mediante autorização, concessão ou permissão, "os serviços de transporte ferroviário e aquaviário entre os portos brasileiros e fronteiras nacionais, ou que transponham os limites de Estado e território (inciso II, d); (ii) explorar, diretamente ou mediante autorização, concessão ou permissão, "os serviços de transporte rodoviário interestadual e internacional de passageiros" (inciso II, e); (iii) estabelecer diretrizes para o transporte urbano, e; (iii) estabelecer diretrizes para o sistema nacional de viação. O serviço de transporte intermunicipal, por sua vez, fica a cargo dos Estados com base no artigo $25, \S 1^{\circ}$, ao passo que o transporte coletivo local é prestado pelos Municípios com base na cláusula do interesse local (artigo 30, V). Fenômeno parecido ocorre na área de trânsito, que é submetido à competência legislativa privativa da União (artigo 22, XI), mas cuja execução escapa em grande medida do seu alcance. Nesse sentido, basta lembrar que a União possui apenas a competência administrativa comum para "estabelecer e implantar política de educação para a segurança do trânsito" (artigo 23, XII). Já as atividades de "segurança viária", a qual nos termos do artigo 144, § 10, abrange "a educação, engenharia e fiscalização do trânsito, além de outras atividades previstas em lei, que assegurem ao cidadão o direito à mobilidade urbana eficiente" permanecem em grande medida com os Estados e os Municípios ${ }^{929}$. Finalmente, atente-se para a competência federal para legislar em termos privativos sobre registros públicos (artigo 22, XXV). A execução desta legislação federal, por sua vez, é feita pelos Estados, mas "em caráter privado, por delegação do Poder Público", nos termos do artigo $236 \mathrm{CF} / 88$. De todo modo, o concurso público de provas e títulos para o ingresso na atividade notarial a que se refere o $\S 4^{\circ}$ deste dispositivo é organizado e aplicado pelos Tribunais de Justiça dos Estados. Trata-se, portanto, de um serviço cuja regulamentação se dá em nível estadual, ainda que por ato administrativo do Poder Judiciário. Em todo caso, está-se diante de execução estadual de lei federal.

Em quarto lugar, percebe-se uma certa tendência de relacionar competências legislativas concorrentes (artigo $24 \mathrm{CF} / 88$ ) com competências de execução comuns à União, Estados e Municípios (artigo 23 CF/88) ou então com competências privativas dos Estados e dos Municípios. Por óbvio, uma competência administrativa privativa da União não resta completamente excluída, mas é limitada a algum aspecto específico. Nesse

\footnotetext{
${ }^{929}$ Sobre o fundamento constitucional da atuação dos Estados e dos Municípios em matéria de trânsito antes do advento da EC no 82/2014, que acrescentou o artigo 144, § 10 ao texto da Constituição Federal de 1988, vide nossas considerações no tópico 6.2.2.1.
} 
sentido, cite-se a competência concorrente da União e dos Estados (e também dos Municípios, conforme entendimento esposado nesta tese e exposto no item 4.6) para legislar sobre direito urbanístico (artigo 24, I). A União detém competências administrativas privativas importantes nesta seara, como é o caso da competência para "instituir diretrizes para o desenvolvimento urbano, inclusive habitação, saneamento básico e transportes urbanos" (artigo 21, XX). Não obstante isso, os executores por excelência da política urbana são os Municípios, conforme dispõe o artigo $182 \mathrm{CF} / 88$. Já as normas relativas às pessoas com deficiência consistem em uma matéria em que uma competência legislativa concorrente - mais precisamente, a competência inscrita no artigo 24, XIV, CF/88 - se relaciona em termos de correspondência com uma competência administrativa comum (artigo 23, II), sendo escassas na constituição referências a competências privativas atribuídas à União, aos Estados ou aos Municípios ${ }^{930}$.

Resumindo o que foi dito até agora, tem-se que competências legislativas e de execução podem se relacionar basicamente de quatro modos:

(i) Um mesmo ente pode deter tanto a competência legislativa quanto a competência de execução sobre uma determinada matéria, hipótese em que ele legislará e também promoverá a execução da sua própria legislação. Nos exemplos supra, analisou-se esta correspondência quando o titular é a União, mas admite-se que ela possa existir mesmo quando os titulares são Estados e Municípios, a despeito de este ser um fenômeno menos frequente;

(ii) Pode ocorrer também que a um ente federativo seja atribuída a competência legislativa, sem qualquer previsão quanto à competência de execução respectiva. Não obstante isso, na prática a execução da lei é promovida pelo ente ou nível federativo que editou a legislação. Em casos menos frequentes, a um ente federativo é atribuída a competência de execução, sendo que a competência legislativa correspondente é vislumbrada como algo ínsito às atribuições deste ente. É o que ocorre com a competência da União para "autorizar e fiscalizar a produção e o comércio de material bélico" e a competência legislativa para tratar de questões afetas, como ocorreu com a edição da Lei n ${ }^{\circ}$ 10.826/2003 (Estatuto do Desarmamento);

\footnotetext{
930 Fala-se aqui propositalmente em referências escassas e não em referências inexistentes. Nesse sentido, atente-se para a disposição contida no artigo 227, §2으, segundo o qual "a lei disporá sobre normas de construção dos logradouros e dos edifícios de uso público e de fabricação de veículos de transporte coletivo, a fim de garantir acesso adequado às pessoas portadoras de deficiência". A lei em questão, diante da completa ausência de uma atividade ou prestação estadual ou municipal, só pode ser lei federal. Está-se diante, portanto, de uma competência legislativa atribuída à União.
} 
(iii) Também existem casos em que a Constituição atribui uma competência privativa à União, ao passo que a competência de execução respectiva é atribuída a outro nível federativo. Neste terceiro grupo, é possível incluir também aqueles casos em que a União permanece apenas com parte da competência de execução (geralmente uma competência de coordenação), ao passo que os Estados e Municípios são responsáveis por uma atuação mais concreta;

(iv) Finalmente, em algumas matérias a Constituição Federal confere uma competência legislativa concorrente à União e aos Estados nos termos do artigo $24 \mathrm{CF} / 88$, sendo que a respectiva competência de execução é atribuída de forma comum à União, Estados e Municípios, conforme o artigo $23 \mathrm{CF} / 88$, ou então em termos privativos à própria União, aos Estados e também aos Municípios.

A competência legislativa da União se estende ainda sobre temas como direito civil, direito comercial, direito do trabalho, abrangendo, enfim, quase todos os ramos do direito. Porém, nestes casos não se está diante de uma legislação federal que deve ser executada, e sim observada tanto pelo Poder Público quanto pelos cidadãos. Por óbvio, esta é uma afirmação que só se sustenta quando se acolhe - é o que a presente tese faz, aliás - a acepção de execução esposada pelos alemães e já exposta alhures, vale dizer, enquanto atividade que implica a organização de uma estrutura administrativa, no âmbito da qual são desempenhadas formas típicas da atuação administrativa ou então atos de direito privado, mas praticados com a finalidade de concretizar o programa definido em lei ${ }^{931}$. Por este motivo, não consiste em uma preocupação desta pesquisa relacionar estas competências legislativas com competências de execução.

Nas políticas públicas constitucionalmente descentralizadas há normalmente um relacionamento do terceiro ou do quarto tipo. Ou seja, a União detém uma competência legislativa pronunciada, além de desempenhar uma função de coordenação, ao passo que Estados e Municípios desempenham o papel de executores destas políticas ${ }^{932}$. Note-se que esta assertiva se mostra verdadeira mesmo naqueles casos em que a União se encontra, em tese, adstrita à edição de normas gerais, tendo em vista a amplitude com que tal norma costuma ser interpretada. A fim de corroborar esta afirmação, passa-se a analisar três políticas disciplinadas constitucionalmente: (i) segurança pública;

\footnotetext{
${ }^{931}$ A atividade de execução da lei, segundo a doutrina alemã, foi abordada no tópico 5.4, a cuja leitura se remete.

932 Este fenômeno também é observado por VIRGÍlIO AFONSO. Capítulo 25 - Federalismo e articulação de competências no Brasil, p. 564.
} 
(ii) educação, e; (iii) saúde ${ }^{933}$. Isto não significa que outras políticas públicas se desenvolvam de outro modo. A análise que se propõe aqui é meramente exemplificativa. Não obstante isso, acredita-se que ela já será suficiente para chegar a conclusões importantes, que serão expostas a seguir.

Comecemos esta análise pela política de segurança pública ${ }^{934}$. Nos termos do caput do artigo $144 \mathrm{CF} / 88$, a segurança pública é colocada como "direito do Estado, direito e responsabilidade de todos", sendo exercida "para a preservação da ordem pública e da incolumidade das pessoas e do patrimônio". Perceba-se como este dispositivo encampa diferentes acepções do que é a segurança pública, sem optar, contudo, por um modelo definido. Como bem ressalta Cláudio Pereira de SOUZA NETO, "por um lado, concebeu como finalidade das políticas de segurança a preservação da 'incolumidade das pessoas e do patrimônio'. Por outro lado, manteve parte importante da polícia militarizada"935. Não obstante isso, considera este autor não ser compatível com a Constituição Federal de 1988 a condução de políticas autoritárias, devendo a segurança pública, erigida à categoria de serviço público, se harmonizar "com o princípio democrático, com os direitos fundamentais e com a dignidade da pessoa humana" ${ }^{\prime \prime 36 . ~}$

Seja como for, o fato é que o artigo $144 \mathrm{CF} / 88$ não é o único dispositivo relevante para a compreensão da distribuição das competências legislativas e de execução nesta política pública. Com efeito, competências legislativas relevantes em matéria de segurança

\footnotetext{
933 Estas três políticas setoriais foram escolhidas por serem especialmente propícias para a compreensão da distribuição constitucional de competências em políticas públicas em geral. No caso da saúde e educação, o fato de elas já terem sido analisadas sob o prisma da ciência política no terceiro capítulo da tese somente facilita a compreensão do argumento desenvolvido neste tópico. Já a segurança pública representa uma escolha pouco ortodoxa, porque costuma ser pouco discutida tanto no âmbito da ciência política quanto no do direito. Por outro lado, esta é uma das políticas públicas em que a Constituição estabelece um arranjo competencial mais preciso, atribuindo a cada esfera federativa atribuições bem específicas, razão pela qual ela também será considerada nesta exposição.

934 A análise da política de segurança pública a partir da repartição federativa de competências foi por nós desenvolvida, em coautoria com Guilherme Siqueira de CARVALHO, em artigo publicado na Revista de Direito Administrativo Contemporâneo (ZAGO, CARVALHO. O Estatuto Geral das Guardas Municipais).

935 Cláudio Pereira de SOUZA NETO. Comentários ao artigo 144. In: J. J. Gomes CANOTILHO; Gilmar Ferreira MENDES; Ingo Wolfgang SARLET; Lenio Luiz STRECK; Léo Ferreira LEONCY (Coord). Comentários à Constituição do Brasil. São Paulo: Saraiva, 2013, p. 1586.

936 SOUZA NETO. Comentários ao artigo 144. In: CANOTILHO, MENEDES, SARLET, STRECK, LEONCY. Comentários à Constituição do Brasil, p. 1586. No nosso artigo mencionado supra, defendemos que o conceito de segurança pública estampado no artigo 144 representa um apanhado de proposições doutrinárias defendidas por autores como Diogo de Figueiredo MOREIRA NETO já no ocaso da Constituição Federal de 1967/1969. Porém, ao posicionar a segurança pública como "dever do Estado, direito e responsabilidade de todos", a Constituição Federal de 1988 acaba por posicioná-la como uma política pública, conduzida pelo Estado, da qual a população é legitimada não só a participar como também a controlar (ZAGO, CARVALHO. O Estatuto Geral das Guardas Municipais, pp. 175-177).
} 
pública encontram-se inscritas no artigo $22 \mathrm{CF} / 88$, que trata das competências privativas da União. De acordo com este dispositivo, a União pode legislar sobre "normas gerais de organização, efetivos, material bélico, garantias, convocação e mobilização das polícias militares e corpos de bombeiros militares" (inciso XXI) e sobre "competência da polícia federal e das polícias rodoviária e ferroviárias federais" (inciso XXII). Além do mais, no artigo $24 \mathrm{CF} / 88$ ainda é conferida à União a possibilidade de legislar concorrentemente sobre "organização, garantias, direitos e deveres das polícias civis" (inciso XVI). Note-se, portanto, que ao ente federal foi conferido meios de conformar, de uniformizar corporações integrantes das administrações estaduais. Mas não é só isso: o fato é que à União foi atribuída a possibilidade de uniformizar as corporações responsáveis pelas atividades mais cotidianas da segurança pública. Como se extrai dos $\S \S 4^{\circ}$ e $5^{\circ}$ do artigo $144 \mathrm{CF} / 88$, afinal, às polícias civis “incumbem, ressalvada a competência da União, as funções de polícia judiciária e a apuração de infrações penais, exceto as Militares", ao passo que às polícias militares compete "a polícia ostensiva e a preservação da ordem pública; aos corpos de bombeiros militares, além das atribuições definidas em lei, incumbe a execução de atividades de defesa civil". Ou seja, os órgãos de segurança pública que normalmente a população brasileira procura no caso de perturbação da ordem pública são órgãos estaduais, subordinados aos Governadores de Estado, mas a sua organização é ou pode ser a vir regulamentada, ainda que em linhas gerais, por legislação federal. Por óbvio que os Estados permanecem legitimados a legislar sobre as matérias inscritas no artigo 22, XXI, e no artigo 24, XVI, $\mathrm{CF} / 88$, não só porque se está diante de competências concorrentes, mas porque se está diante de um tema afeto à própria organização administrativa estadual, inerente à sua autonomia federativa. De todo modo, o que se percebe neste ponto é um descolamento, ainda que parcial, da competência legislativa e da respectiva competência de execução.

Mas também a União e os Municípios detêm competências de execução relevantes na política pública de segurança. Afinal, o artigo $144 \mathrm{CF} / 88$ arrola como órgãos de segurança também a polícia federal, a polícia rodoviária federal e a polícia ferroviária federal, as quais integram a Administração Pública Federal e tem as suas atribuições disciplinadas nos $\S \S 1^{\circ}$ e $3^{\circ}$ do artigo $144 \mathrm{CF} / 88$. A organização destas polícias, por sua vez, deve ser feita por lei federal de competência privativa da União nos termos do artigo 22, XXII, CF/88. Já a competência de execução do Município é um pouco mais nebulosa. De acordo com o $\S 8^{\circ}$ do artigo $144 \mathrm{CF} / 88$, aos Municípios é facultado "constituir guardas municipais destinadas à proteção de seus bens, serviços e instalações, conforme dispuser a lei"; todavia, o caput do artigo 144 não arrola as guardas municipais dentre os órgãos de segurança pública. Em virtude disso, muitos sustentam que estas guardas não exerceriam propriamente funções de 
segurança pública, Na prática, porém, muitas destas corporações costumam atuar como polícia ostensiva, realizando inclusive buscas pessoais. Mas esta não é a única polêmica trazida pelo artigo $144, \S 8^{\circ}, \mathrm{CF} / 88$ : a parte final deste dispositivo faz referência a uma lei, sem especificar se ela deve ser editada pela União, pelos Estados ou pelos Municípios. Há quem sustente que a lei no caso só poderia ser uma lei municipal, ao passo que outros entendem que o parágrafo em comento refere-se a uma lei federal. Tende-se a optar pelo segundo destes posicionamentos, o que acaba por promover novamente um descolamento entre competência legislativa e competência de execução. ${ }^{937}$

No que diz respeito à política pública de educação - restringindo-se novamente a análise, tal como no terceiro capítulo, à política pública de educação básica - há três competências legislativas importantes a serem consideradas. A primeira encontra-se no artigo 22, XXIV, o qual confere à União a possibilidade de legislar privativamente sobre diretrizes e bases de educação, e que aparece quase que conjugada à competência para legislar concorrentemente sobre educação inscrita no artigo 24, IX, CF/88. Finalmente, não se pode esquecer da competência da União para legislar sobre o plano nacional de educação, prevista no artigo $214 \mathrm{CF} / 88$. Percebe-se, portanto, que a União detém competências legislativas importantes nesta área - ainda que adstrita a elaboração de planos nacionais, diretrizes e bases ou normas gerais - o que não veda, mas pressupõe, uma atuação legiferante por parte dos Estados e dos Municípios. A competência de execução também se apresenta repartida entre União, Estados e Municípios; porém, enxerga-se uma proeminência destes dois últimos níveis federativos. Nesse sentido, o artigo 23, V, CF/88 consagra uma competência comum das três esferas para proporcionar os meios de acesso à educação, o que é concretizado pela disposição contida no artigo 30, VI - segundo o qual compete ao Município “manter, com a cooperação técnica e financeira da União e do Estado, programas de educação infantil e de ensino fundamental" - e pelos parágrafos do artigo 211 CF/88. Segundo estes últimos dispositivos, a União exerce primordialmente um papel de coordenação, exercendo ainda uma "função redistributiva e supletiva, de forma garantir a equalização de oportunidades educacionais e padrão mínimo de qualidade de ensino mediante assistência técnica e financeira aos Estados, ao Distrito Federal e aos Municípios", ao passo que Estados e Municípios colocam-se como verdadeiros executores da política de educação básica: os primeiros responsabilizando-se primordialmente pelo ensino fundamental e médio e os segundos pelo ensino fundamental e educação infantil. Ou seja, também nesta política se percebe um descolamento das competências legislativas e de

\footnotetext{
937 O artigo 144, § 8o, CF/88 e as polêmicas que ele suscita na doutrina e na jurisprudência foram por nós analisados em ZAGO, CARVALHO. O Estatuto Feral das Guardas Municipais, a cuja leitura se remete.
} 
execução, sendo que à União compete parcela relevante da legislação e Estados e Municípios colocam-se como executores da legislação federal, ainda que se admita a importância da sua legislação para complementar os padrões mínimos estabelecidos nacionalmente.

Finalmente, na política pública de saúde percebe-se a conjugação de uma competência legislativa concorrente - à União e aos Estados compete, nos termos do artigo 24, XII, legislar sobre "proteção e defesa da saúde" - e de uma competência administrativa comum, mais precisamente, a de "cuidar da saúde e assistência pública" (artigo 23, II). Porém, aqui a Constituição Federal de 1988 não pormenorizou este arranjo, estabelecendo competências legislativas e de execução específicas à União, aos Estados e aos Municípios. Ao contrário, no que tange à estrutura da política pública de saúde, a Constituição prevê apenas que "as ações e serviços públicos de saúde integram uma rede regionalizada e hierarquizada e constituem um sistema único" (artigo $198 \mathrm{CF} / 88$ ), o qual possui como uma de suas diretrizes a "descentralização, com direção única em cada esfera de governo" (artigo 198, I, CF/88). A fim de compreender quais as atribuições de cada nível federativo, deve-se olhar para a legislação infraconstitucional, especialmente para os artigos 16 a 19 da Lei ${ }^{\circ}$ 8.080/1990. Quando se analisam estes dispositivos legais, percebe-se um arranjo muito parecido com o estabelecido constitucionalmente para a segurança pública e a educação. A União exerce um papel de coordenação, ao formular políticas públicas, elaborar normas, critérios e mecanismos de controle. Os Estados, por sua vez, também desempenham um papel de coordenação, e executam, em caráter complementar, determinadas ações e serviços de saúde. Os Municípios, por sua vez, consistem nos grandes executores da política saúde, ao "planejar, organizar, controlar e avaliar as ações e os serviços de saúde e gerir e executar os serviços públicos de saúde" (artigo 18, I, Lei nº 8.080/1990). Em outras palavras, percebese também aqui um descolamento da normatização - desenvolvida sobretudo no âmbito do Ministério da Saúde, como se teve a chance de ressaltar no terceiro capítulo desta tese - e a sua execução propriamente dita, levada a cabo a partir da década de 90 sobretudo pela esfera municipal de governo.

Colocando o mesmo argumento em termos mais diretos, sustenta-se que nestas políticas públicas - e também em outras áreas setoriais não analisadas - ocorre um fenômeno parecido com a execução de leis federais na Alemanha. De nossa parte, acredita-se que este fenômeno é tão intenso sob a égide da Constituição Federal de 1988 que teria operado uma verdadeira inversão do paradigma de execução de serviços: se antes, como regra geral, era de se esperar uma execução imediata, a partir de 1988 se observa a execução mediata. Por óbvio, há quem discorde desta assertiva, preferindo colocar a especial conformação das competências legislativas e de execução nestas políticas 
públicas como casos isolados. Seja como for, o fato é que se está diante de áreas setoriais importantes, que afetam sobremaneira o cotidiano do cidadão. Portanto, exceção ou não, trata-se de um fenômeno que deve ser identificado, compreendido e sobre o qual faz sentido tecer duas proposições.

A primeira delas consiste na influência da União sobre os Estados e Municípios. Ao se analisar a Constituição Federal de 1988 percebe-se que esta, ao contrário da Lei Fundamental alemã de 1949, não prevê mecanismos de coordenação diretiva ${ }^{938}$, seja sob uma perspectiva mais geral, seja setorialmente. É certo que existem menções à atuação coordenadora da União em algumas políticas públicas regulamentadas constitucionalmente, como é o caso do artigo 204, I, CF/88, que se ocupa da repartição de atribuições na área da assistência social. Mas não há disposição na constituição brasileira que autoriza a União, por exemplo, a exercer supervisão sobre a conformidade da atuação dos Estados ao direito federal por eles executado, ou então a editar instruções específicas, que informarão ou em certos casos substituirão a decisão do administrador estadual no caso concreto, tal como ocorre no direito alemão.

Isso não significa que, na prática, a União não disponha de instrumentos de coordenação parecidos com aqueles previstos pelo direito alemão. Nesse sentido, basta lembrar alguns atos normativos formulados no âmbito da administração pública federal e que são observados por Estados e Municípios, como é o caso das Normas Operacionais Básicas do SUS (conforme analisado no terceiro capítulo) ou então das Resoluções do CONAMA. Embora não se trate propriamente de preceitos administrativos de caráter geral (artigo 84 II e 85 II), um paralelo é inevitável. Além do mais, é possível que a União exerça de fato, principalmente quando ela é responsável pelo financiamento, atuação próxima a uma supervisão ou então a uma instrução específica, seja pela via do controle ou mesmo politicamente. Contudo, não se considera possível que a União determine o procedimento administrativo a ser observado pelos Estados e Municípios e nem determinar como se organizará a estrutura administrativa responsável pela execução das políticas públicas em comento, como autorizam o artigo 84 I e 85 II GG, a menos que exista previsão constitucional para tanto. É o que ocorre, por exemplo, nos artigos 22, XXI, XXVII e artigo 24, XVI, CF/88.

Seja como for, o fato é que a União deve contar com meios para promover a coordenação federativa. Como esta última efetivamente ocorre já foi analisado no terceiro

\footnotetext{
${ }^{938}$ Apenas para retomar brevemente a questão, instrumentos de cooperação diretiva, neste contexto, referese sobretudo àqueles instrumentos de influência do Bund sobre os Länder previstos nos artigos 84 e 85 GG.
} 
capítulo desta tese, lembrando apenas que, no Brasil, ela costuma variar conforme a área setorial e tem o seu sucesso normalmente condicionado à necessidade do financiamento federal para a execução da política pública por Estados e Municípios. Aqui deseja-se apenas tratar da necessidade da coordenação e da cooperação federativas sob uma perspectiva comparada. Argumentou-se no tópico 6.3.1 que a execução de uma lei - neste ponto nos referíamos a qualquer lei, não só a lei federal - comporta uma margem de discricionariedade muito grande. Sabe-se, afinal, que o texto da lei pode ser interpretado de diversos modos, e também pode ser executado de diversos modos. Além do mais, ponderou-se como em um cenário em que a União legisla e os Estados executam, como ocorre na Alemanha, caso não seja tomada nenhuma medida de uniformização ou de compatibilização da atuação estadual, uma mesma lei federal poderia traduzir diferentes direitos e deveres em âmbito nacional. Estas considerações mostram-se ainda mais contundentes no contexto brasileiro, em que União, no mais das vezes, está legitimada a legislar somente sobre normas gerais. É certo que o Poder Legislativo Federal, sob o pretexto de editar normas gerais, acaba descendo a minúcias. Porém, o fato é que se espera que a legislação federal assuma em muitos casos uma abstração maior, o que acaba por aumentar a margem de discricionariedade de Estados e Municípios.

Curiosamente, esta é uma questão que não tem sido objeto de maiores considerações por parte da doutrina constitucional brasileira. Isto se deve, talvez, ao fato de que esta margem de discricionariedade é avaliada como algo salutar ao federalismo brasileiro, pois seria uma forma de prestigiar as autonomias estadual e municipal. Deve-se reconhecer que esta percepção se mostra verdadeira, ao menos em parte. Com efeito, é importante que mesmo programas definidos nacionalmente se adaptem às peculiaridades regionais e locais; todavia, quando esta adaptação dá origem a interpretações diferentes e divergentes sobre as decisões fundamentais destes programas, correções devem ser feitas. Como à União não são garantidos meios para impor uma determinada forma de execução, conforme já discutido, estas correções podem e devem ser promovidas pelo diálogo entre as esferas federativas, o qual será mais ou menos efetivo a depender da política pública em questão.

Já a segunda ponderação diz respeito à influência dos Estados e Municípios sobre a União. Sabe que, no Brasil, não há um órgão federal em que os interesses dos Estados encontrem-se fortemente representados e articulados, como é o caso do Conselho Federal alemão. Viu-se no item 2.1.4 que o Senado Federal brasileiro, que seria a instância em que os interesses estaduais em tese encontrariam expressão, há muito atua como uma segunda casa legislativa, sendo que as suas vantagens e desvantagens são atreladas mais ao 
bicameralismo do que à necessidade de se prover uma representação estadual e federativa no âmbito do Poder Legislativo federal. No mais, deve-se reconhecer que os Municípios sequer contam com uma instância de representação institucionalizada - como ocorre com os Estados-membros em relação ao Senado Federal - seja no âmbito estadual, seja no âmbito federal. ${ }^{939}$

Não obstante isso, tem-se que muitas vezes Estados e Municípios encontram-se, na sua atuação, vinculados a preceitos federais, isto quando não executam a legislação federal. Por isso, também se afigura recomendável que estes entes subnacionais participem da formulação da política pública em âmbito nacional. Como isto efetivamente ocorre na prática também é definido setorialmente. Trazemos três exemplos para ilustrar esta afirmação. No âmbito da saúde, há o exemplo bem conhecido das comissões intergestores. Nos termos do artigo 14-A da Lei n 8.080/1990, "as Comissões Intergestores Bipartite e Tripartite são reconhecidas como foros de negociação e pactuação entre gestores, quanto aos aspectos operacionais do Sistema Único de Saúde (SUS)”. Suas atribuições são discriminadas no parágrafo único deste dispositivo, entre elas, a de "definir diretrizes, de âmbito nacional, regionais e intermunicipal, a respeito da organização das redes de ações e serviços de saúde, principalmente no tocante à sua governança institucional e à integração das ações e serviços dos entes federados” (artigo 14-A, parágrafo único, II, Lei $\left.\mathrm{n}^{\circ} 8.080 / 1990\right)$.

No âmbito da política do meio ambiente, o CONAMA, vinculado ao Ministério do Meio Ambiente, é um órgão com funções normativas importantes. A corroborar esta afirmação, basta lembrar a sua Resolução $n^{\circ}$ 001/1986, que durante muitos anos regulamentou a realização do estudo de impacto ambiental e respectivo relatório de impacto ambiental (EIA/RIMA), e da sua Resolução no 237/1997, que dispõe sobre licenciamento ambiental. Conforme informações do seu sítio eletrônico, este conselho é representativo de cinco gestores: órgãos federais, estaduais e municipais, setor empresarial e social civil. Os órgãos federais representados são o Ministério do Meio Ambiente, o IBAMA, a ANA e outros Ministérios. Os governos estaduais contam com um representante por Estado. Finalmente, os Municípios contam com oito representantes ${ }^{940}$.

Finalmente, na seara da segurança pública há o Conselho Nacional de Segurança Pública (CONASP), o qual possui atribuições de coordenação relevantes como "atuar na

\footnotetext{
${ }^{939}$ Alguns autores utilizam, inclusive, o fato de os Municípios não contarem com uma representação no âmbito federal para questionar o seu status de entes integrantes da federação, como em MENDES, COELHO, BRANCO. Curso de Direito Constitucional, p. 948.

${ }^{940}$ http://www.mma.gov.br/port/conama/. Acesso: 10/01/2016.
} 
formação de diretrizes e no controle da execução da Política Nacional de Segurança Pública", "propor diretrizes para as ações da Política Nacional de Segurança Pública e acompanhar a destinação e aplicação dos recursos a ela vinculados", e "articular e apoiar, sistematicamente, os Conselho de Segurança Pública dos Estados, do Distrito Federal e dos Municípios, com vistas à formulação de diretrizes básicas comuns e à potencialização do exercício das suas atribuições legais e regulamentares" ${ }^{941}$. Figuram como membros deste Conselho, dentro outros, o Conselho Nacional de Secretários de Segurança Pública e o Conselho Nacional de Secretários e Gestores Municipais de Segurança Pública e Conselho Nacional das Guardas Municipais. ${ }^{942}$

Por óbvio, a participação efetiva de Estados e Municípios na formulação da política pública em nível nacional vai depender de quão bem estão estruturados estes Conselhos, da sua efetiva participação na tomada de decisões em âmbito federal, dos seus efetivos poderes (se deliberativos ou meramente consultivos), do modo pelo qual as deliberações são tomadas, e assim por diante.

\subsubsection{A constitucionalização da Administração Pública sob a égide da Constituição Federal de 1988}

A Administração Pública recebeu uma atenção especial do legislador constituinte de 1987/1988, o qual dedicou um capítulo inteiro da constituição à disciplina de seus aspectos fundamentais, em um total de sete extensos artigos (artigos 37 a $43 \mathrm{CF} / 88$ ). Tratase de algo sem paralelo do direito constitucional brasileiro, embora seja possível encontrar capítulos com propostas semelhantes nas constituições portuguesa (artigos 266 a 272) e espanhola (artigo 103 e seguintes). Nesta tese refere-se a este fenômeno como a constitucionalização da Administração Pública, muito embora se reconheça que esta expressão pode designar e geralmente designa um fenômeno mais amplo. Como ressalta Gustavo BINENBOJM, a constitucionalização do direito administrativo, como uma resposta "aos riscos criados pelo enfraquecimento da lei e pela multiplicidade de ordenamentos administrativos setoriais", significa uma superação do paradigma da legalidade

\footnotetext{
${ }_{941}$ http://portal.mj.gov.br/data/Pages/MJDE2A290DITEMID4D7BA2232A4E4DEA93D108413FB9B62APTB RIE.htm Acesso: 10/01/2016.

${ }^{942}$ http://portal.mj.gov.br/data/Pages/MJ337926C4ITEMID53E5AC7324014DFEB2D9520E5D7D247APT BRIE.htm. Acesso: 10/01/2016.
} 
administrativa, erigindo-se "a Constituição como cerne da vinculação administrativa à juridicidade" 943 . Segundo este autor,

\begin{abstract}
"toda a sistematização dos poderes e deveres da Administração Pública passa a ser traçada a partir dos lineamentos constitucionais pertinentes, com especial ênfase no sistema de direitos fundamentais e nas normas estruturantes do regime democrático, à vista de sua posição axiológica central e fundante no contexto do Estado democrático de direito. A filtragem constitucional do direito administrativo ocorrerá, assim, pela superação do dogma da onipotência da lei administrativa e sua substituição por referências diretas a princípios expressa ou implicitamente consagrados no ordenamento constitucional. Em tempos de deslegalização e proliferação de autoridades administrativas, sobreleva a importância dos princípios e regras constitucionais na densificação do ambiente decisório do administrador e amenização dos riscos próprios da normatização burocrática." ${ }^{944}$
\end{abstract}

A presente tese não vai tão longe ao analisar o fenômeno da constitucionalização da Administração, preferindo enfocar a análise nos artigos 37 a 40 CF/88, mesmo porque são estes os dispositivos constitucionais que se relacionam com a pesquisa ora desenvolvida. Ao analisá-los, percebe-se que eles estabelecem tanto princípios quanto normas específicas. Os princípios são arrolados sobretudo no caput do artigo 37, o qual estabelece que "a administração pública direta e indireta de qualquer dos Poderes da União, dos Estados, do Distrito Federal e dos Municípios obedecerá aos princípios de legalidade, impessoalidade, moralidade, publicidade e eficiência”. Já as regras específicas compreendem diversos assuntos, mas é possível enxergar alguns temas que recebem uma atenção especial: (i) o concurso público para ingresso no serviço público; (ii) direitos dos servidores públicos; (iii) remuneração e aposentadoria dos servidores públicos. Outros assuntos também recebem disciplina constitucional, como é o caso da responsabilidade do Estado e dos administradores ( $\operatorname{artigo} 37, \S \S 4^{\circ}$ e $5^{\circ}$ ), da contratação pública (artigo 37, XXI), e da participação dos cidadãos na administração pública (artigo $37, \S 3^{\circ}$ ); porém, é de se admitir que o foco das regras contidas no artigo 37 a $40 \mathrm{CF} / 88$ é o servidor público, o que acaba por conferir um viés corporativo a estas disposições. ${ }^{945}$

\footnotetext{
${ }^{943}$ Gustavo BINENBOJM. A constitucionalização do Direito Administrativo no Brasil: um inventário de avanços e retrocessos. Revista Eletrônica sobre a Reforma do Estado, № 13, março/abril/maio 2008, p. 14.

${ }_{944}$ BINENBOJM. A constitucionalização do Direito Administrativo no Brasil. pp. 15-16.

${ }^{945}$ Nesse sentido, assevera Gustavo BINENBOJM que "a Constituição brasileira de 1988 discorre longamente sobre a Administração Pública, descendo a minúcias que exigem uma feição corporativa muito mais nítida que qualquer preocupação garantística. A despeito disso, trouxe alguns avanços, como a enunciação expressa de princípios setoriais do direito administrativo, que na sua redação original eram os da legalidade, impessoalidade, moralidade e publicidade. A Emenda Constitucional ํo 19/98 (apelidada de Emenda da Reforma Administrativa) acrescentou ao elenco o princípio da eficiência. A propósito, a tensão entre eficiência e legitimidade democrática é uma das questões centrais da Administração Pública na atualidade" ( $A$ constitucionalização do Direito Administrativo no Brasil, p. 24).
} 
É de se ressaltar que as regras contidas nos artigos 37 a 40 CF/88 aplicam-se à União, Estados e Municípios indistintamente, retirando certas questões relevantes - como o limite máximo da remuneração dos servidores - da discricionariedade legislativa dos entes federativos brasileiros. É nesse sentido que se fala em uma constitucionalização, pois estas questões foram efetivamente constitucionalizadas, tendo sido retiradas do jogo federativo. Na Alemanha, conforme já analisado, a regulamentação de aspectos importantes do funcionalismo público estadual ocorreu, durante alguns anos, por meio de preceitos-moldura da União e, posteriormente, por meio de legislação federal editada com fulcro em uma competência legislativa concorrente (artigo 74a GG, e após 2006, artigo 74 I Nr. 27 GG). No Brasil, esta constitucionalização teria retirado este poder inclusive da União, dado que seria algo que nem mesmo ela poderia dispor. Afinal, os artigos 37 a $40 \mathrm{GG}$ podem ser alterados somente por emenda constitucional, a qual deve ser aprovada por um processo legislativo mais demorado e mais dificultoso do que o processo legislativo federal ordinário. Embora estas sejam considerações que tendem a se harmonizar com a percepção dos juristas sobre o tema, o fato é que elas não revelam todas as implicações dos dispositivos constitucionais em comento para a repartição de competências legislativas e de execução.

Destrinchemos este argumento a partir de um pressuposto importante, a saber: ao ente federativo deve ser garantido meios de dispor da sua própria autonomia administrativa ${ }^{946}$; portanto, se aspectos da sua atuação administrativa devem ser regulamentados por lei - o que se afigura como uma decorrência do princípio da legalidade - tem-se que este mesmo ente federativo detém a competência para editar esta lei, sem que seja necessária qualquer autorização ou previsão constitucional nesse sentido. Do mesmo modo, se a atuação administrativa de um ente deve ser regulamentada por decreto, então é de se admitir que o Chefe do Executivo deste ente detém a competência para tal ato, sendo despicienda qualquer previsão de uma competência de execução ao ente federativo em questão. Nesse sentido, se a criação ou a extinção de cargos no âmbito da administração federal deve se dar por lei, então esta lei deve ser federal; nas hipóteses em que estas questões podem ser disciplinadas por regulamento, então necessariamente se está diante de um regulamento federal. ${ }^{947}$ Aplicando este pressuposto à regulamentação dos

\footnotetext{
946 Segundo Anna Cândida da Cunha FERRAZ, "a autonomia administrativa é decorrência necessária da autoorganização de qualquer ente dotado de poder político, que, sem ela, não poderia exercer suas competências e perseguir e alcançar os fins que lhe são próprios. Em regra, traduz-se na capacidade que tem a entidade política para fixar, livre e autonomamente, sua estrutura administrativa, optar pelo modo (concentrado ou desconcentrado) de executar os serviços públicos inerentes, ditar as regras de funcionamento da máquina administrativa e finalmente estatuir sobre o seu funcionalismo, fixando-lhes o regime jurídico, bases de remuneração etc. (FERRAZ. União, estado e município na nova Constituição, p. 62).

947 Note-se que a exigência de lei federal para a criação e a extinção de cargos no âmbito da administração
} 
servidores públicos de um ente federativo - que é certamente um aspecto importante da sua autonomia administrativa - tem-se que ela deve se dar por lei ou então por decreto deste mesmo ente. Por este motivo, o estatuto dos servidores civis da União deve ser necessariamente uma lei federal (no caso, a Lei no 8112/1990), ao passo que o estatuto dos servidores públicos de um Estado-membro deve ser uma lei estadual ${ }^{948}$, e assim por diante.

Somente as exceções a esta regra geral devem ser expressamente disciplinadas pela Constituição Federal, sendo esta a segunda premissa do nosso argumento. Voltemos ao exemplo já debatido da competência da União para legislar privativamente sobre "normas gerais de organização, efetivos, material bélico, garantias, convocação e mobilização das Polícias Militares e Corpos de Bombeiros Militares" inscrita no artigo 22, XXI, CF/88. Sabese que estas são corporações estaduais, subordinadas aos Governadores de Estado, nos termos do artigo $42 \mathrm{CF} / 88$. Caso não houvesse nenhuma previsão neste sentido, uma lei federal sobre esta matéria seria absolutamente inconstitucional, diante do seu caráter excepcional.

Estas exceções podem ser de dois tipos. Em primeiro lugar, a Constituição pode determinar que a um ente federativo - neste caso, é de se admitir que este ente federativo só pode ser a União - compete legislar sobre aspectos da atividade administrativa de outros entes - vale dizer, dos Estados e Municípios. É o que ocorre, por exemplo, com a competência federal para legislar sobre "normas gerais de licitação e contratação, em todas as modalidades, para as administrações públicas diretas, autárquicas e fundacionais da União, Estados, Distrito Federal e Municípios" (artigo 22, XXVII, CF/88). Note-se que a atuação legiferante da União deve se restringir, em relação à licitação e à contratação, à edição de normas gerais. Por este motivo é que se fala que a autorização constitucional deve se restringir a aspectos da atividade administrativa; do contrário, a própria autonomia federativa e, consequentemente, o próprio princípio federativo, restaria vulnerado. Na prática, sabe-se que a linha divisória entre a fixação de normas gerais e normas específicas é tênue, como se pode extrair inclusive da leitura da Lei nº 8.666/1993. Fiquemos, todavia, com o modo como as coisas deveriam ser por ora.

federal encontra-se previsão expressa no artigo 48, X, CF/88, ao passo que a sua disciplina por regulamento federal é autorizada pelo artigo 84, VI, CF/88, sendo desnecessário, portanto, recorrer ao argumento de que isso seria garantido à União mesmo na hipótese de não haver qualquer previsão legal nesse sentido. Contudo, é de se admitir que o argumento que se esposa aqui revela-se útil para a compreensão das competências, legislativas ou não, relacionadas à própria autonomia administrativa dos Estados e Municípios, diante da ausência de previsão constitucional expressa.

948 À título exemplificativo, cita-se a Lei Estadual paulista no 10.261/1968, que institui o estatuto dos funcionários públicos civil do Estado de São Paulo. 
Contudo, a Constituição Federal pode não se limitar a atribuir uma competência legislativa a um ente federativo, mas sim disciplinar ela mesma as questões e os aspectos da atuação administrativa dos entes federativos considerados dignos de tal regulamentação. É precisamente este o caso dos artigos 37 a $40 \mathrm{CF} / 88$, os quais traçam regras a serem observadas pelas três esferas federativas. Neste caso, admite-se que as disposições sejam mais específicas, pois elas são estabelecidas pela própria Constituição, principalmente quando se está diante de disposições oriundas do poder constituinte originário. A intenção aqui é óbvia: retirar estes aspectos e questões dos entes federativos. Não se trata de uma questão submetida à discricionariedade da União, dos Estados e dos Municípios; ao contrário, trata-se de uma questão decidida em nível constitucional.

O grande problema deste segundo tipo de exceção é que, no Brasil, a emenda constitucional é discutida e deliberada somente no plano federal. A participação de Estados e Municípios é limitada, colocando-se somente quando estes últimos se articulam politicamente no sentido de aprovar ou de rejeitar determinada proposta de emenda. Além do mais, é de se admitir que a alteração da constituição não é submetida a um processo tão dificultoso como em outros países, como os Estados Unidos. Sobre este assunto, é importante atentar para as seguintes ponderações de Marta ARRETCHE:

"Na verdade, embora a aprovação de emendas constitucionais seja a modalidade
mais exigente de alteração do status quo da legislação brasileira, a aprovação de
emendas constitucionais no Brasil é comparativamente pouco exigente em termos
internacionais (...). Ainda que o Brasil adote a fórmula de requerer dois turnos de
votação na Câmara dos Deputados e no Senado, são necessárias apenas cinco
sessões entre uma e outra votação, na mesma legislatura. Nestes termos, a
incerteza com relação à obtenção de maioria na segunda votação é praticamente
zero. A definição de maioria parlamentar, neste caso, também é a mais baixa em
termos internacionais, de apenas $3 / 5$. Finalmente, diferentemente das estratégias
que conferem poder de veto às assembleias estaduais ou a um referendo, no Brasil,
a decisão das câmaras legislativas no plano federal é suficiente para aprovar uma
emenda constitucional, que terá imediata validade para todos os entes federativos.
A única estratégia de veto possível para os entes federativos é reunir uma 'maioria
oposicionista' de $41 \%$ de parlamentares em quatro sessões de uma mesma
legislatura. Caso, por outro lado, o presidente seja capaz de reunir uma maioria de
$61 \%$ das duas Casas, as chances de veto são praticamente nulas." ".49

Em outras palavras, é de se admitir o processo de aprovação de emendas é protagonizado pela União. Tanto é assim que, no final da década de 1990 e começo do século XXI, o governo federal logrou aprovar e implementar uma reforma administrativa e previdenciária forjada e justificada, do ponto de vista técnico e político, no âmbito do Ministério da Administração Federal e Reforma do Estado (MARE): as EC nº 19/1998 e no

${ }^{949}$ ARRETCHE. A centralização no Estado Federativo brasileiro, p. 39. 
20/1998, cujas propostas e impactos são bem comentadas. Restam aos Estados e Municípios, por meio de suas bancadas, apresentar propostas de seus interesses particularísticos - ainda assim constitucionalizados - na Câmara dos Deputados e do Senado Federal, ${ }^{950}$ o que os coloca em uma posição de inferioridade no jogo federativo. Em suma, tal como na Alemanha, ainda que por meios não tão declarados, a questão da regulamentação de aspectos importantes da atividade administrativa dos Estados e Municípios no Brasil é submetida ao jogo federativo, sendo também aqui é observada uma proeminência da União.

\subsection{COMPETÊNCIAS PRIVATIVAS E COMPETÊNCIAS CONCORRENTES}

Finalmente, o sexto capítulo da tese termina com algumas ponderações acerca da repartição das competências privativas e concorrentes no Brasil e na Alemanha. Ao contrário dos tópicos anteriores, não se propõe aqui uma análise apartada do Brasil e da Alemanha, mas sim uma análise integrada destes dois ordenamentos, dividida em duas partes. $\mathrm{Na}$ primeira delas, propõe-se um estudo acerca de como a Lei Fundamental de 1949 e a Constituição Federal de 1988 distribuem competências privativas entre União e Estados (e Municípios, no caso do Brasil). Na segunda delas realiza-se este mesmo estudo em relação às competências concorrentes. Acredita-se que, deste modo, a exposição do argumento desenvolvido neste tópico se tornará mais clara e objetiva.

Antes de iniciar a exposição, é preciso fazer duas observações importantes. Em primeiro lugar, a análise da repartição de competências privativas não pretende somente compreender melhor o caso brasileiro à luz do caso alemão, mesmo porque os contornos da competência privativa não variam muito nos dois ordenamentos considerados, mas sim propor o transplante de certas construções teóricas do direito alemão para o direito brasileiro, conforme discutido no tópico 6.1. Em segundo lugar, na parte dedicada à repartição de competências concorrentes, pretende-se estruturar a análise comparativa a partir de algumas observações gerais, tendo em vista que no quarto e quinto capítulos estas competências foram destrinchadas em quase todos os seus aspectos dogmáticos. Não se pretende, assim, trabalhar novamente a definição da norma geral no direito brasileiro, mas sim entender como o direito alemão pode responder importantes questionamentos colocados pela doutrina e jurisprudência brasileiras sobre o assunto, e assim por diante.

${ }^{950}$ ARRETCHE. A centralização no Estado Federativo brasileiro, p. 32. 


\subsubsection{As competências privativas na Lei Fundamental e na Constituição}

Federal de 1988

No tópico 1.5 .5 conceituou-se a competência privativa como a atribuição, pela constituição, de uma matéria previamente delimitada a um ente federativo, com a exclusão dos demais. Além do mais, ponderou-se que, embora seja possível que a constituição atribua uma competência privativamente a um ente federativo específico, normalmente essa atribuição é feita a um nível federativo - a todos os Estados-membros ou a todos os Municípios - sendo que a exclusão normalmente se aplica aos outros níveis federativos não contemplados pela norma de competência. Sendo assim, tem-se que uma competência privativa é normalmente atribuída a todos os Estados-membros, com a exclusão da União e de todos os Municípios, ou então aos Municípios, com exclusão de todos os Estados e da União, ou à União, com exclusão de todos os Estados e Municípios. Conforme esclarecido naquela ocasião, este é um conceito eminentemente teórico, tendo como única finalidade nortear a análise e a compreensão das principais características dos objetos de comparação, tendo em vista que estes últimos normalmente se revestem de tantas particularidades que dificultam a identificação da sua essência.

Contudo, a recondução das competências privativas previstas pela Constituição Federal de 1988 e pela Lei Fundamental de 1949 ao conceito por nós formulado, a despeito da existência de algumas peculiaridades dogmáticas em cada um dos ordenamentos considerados, não se afigura problemática. Com efeito, ambas as constituições, quando conferem uma competência em termos privativos a uma esfera federativa, pretendem autorizá-la e legitimá-la a atuar em relação a uma determinada matéria, ao mesmo tempo em que retiram das outras esferas qualquer possibilidade de atuação. A partir de agora, a exposição se centra na discussão e na confrontação das competências privativas atribuídas à União, mesmo porque são elas que costumam ser disciplinadas com maiores detalhes nas constituições federais, como um todo, e nas constituições brasileira e alemã, em particular.

Comecemos pelas competências privativas de execução, ou competências privativas administrativas como se referem doutrina e jurisprudência alemãs. Conforme analisado no item 5.6, na Alemanha elas costumam ser delimitadas pela própria Lei Fundamental; porém, ao Bund é facultado ampliar a sua própria competência, obedecidos os requisitos impostos pelo artigo 87 III GG. E, no caso brasileiro, é possível afirmar que as competências de execução atribuídas à União são limitadas àquelas expressamente previstas pela Constituição Federal de 1988? A resposta a este questionamento tende a ser positiva em um primeiro momento. Afinal, embora a constituição 
brasileira trabalhe com um extenso rol de competências concorrentes, a técnica de repartição de competências mais básica por ela manejada é a técnica horizontal, com a enumeração de competências privativas em sua esmagadora maioria à União, e a atribuição de uma competência residual aos Estados. No que diz respeito às competências de execução, tal arranjo pode ser vislumbrado no artigo $21 \mathrm{CF} / 88$, que trata da competência geral da União. Mesmo as funções de coordenação conferidas ao governo federal pela constituição brasileira parecem ter sido atribuídas em termos taxativos, tendo em vista que elas incidem sobre atividades desenvolvidas por Estados e Municípios. Porém, não se deve esquecer que a própria constituição autoriza os entes federativos a promoverem a gestão associada de serviços públicos, com "transferência total ou parcial de encargos, serviços, pessoal e bens essenciais à continuidade dos serviços transferidos" nos termos do artigo $241 \mathrm{CF} / 88$. Ou seja, a repartição de competências de execução pode ser relativizada em prol de soluções cooperativamente orientadas. Diante do permissivo constitucional, é possível que a União, por meio de seus servidores, promova a execução de leis estaduais e municipais, ao contrário do previsto pela Lei Fundamental alemã.

Já a repartição de competências legislativas privativas funciona em termos diversos, pois ela se coloca como insuscetível de ser alterada pelos entes federativos, conforme já analisado no tópico 6.2.2.1 desta tese. É certo que parte da doutrina entende que o artigo 22, parágrafo único, contempla uma possibilidade de delegação da competência legislativa atribuída originariamente à União ${ }^{951}$. Porém, considera-se que este posicionamento não é o mais acertado, tendo em vista que o referido dispositivo constitucional consagra uma simples autorização. Neste ponto, as ponderações traçadas pela doutrina alemã se mostram especialmente importantes para compreender os limites do

\footnotetext{
${ }^{951}$ Nesse sentido, vide JOSÉ AFONSO. Curso de Direito Constitucional positivo, p. 481. Sobre o assunto, atentese para as seguintes ponderações de Fernanda Dias Menezes de ALMEIDA, as quais expõem de forma precisa os problemas que envolvem o reconhecimento de que o artigo 22, parágrafo único, CF/88 teria possibilitado à União delegar, transferir sua competência aos Estados: "De nossa parte, vemos com certa reserva a possibilidade de delegação em tela. É que a repartição de competências é assunto vital na Federação e por isso entendemos que se deva resolver no âmbito da própria Constituição, salvo se houver motivos ponderáveis para, em alguns pontos, transferir à legislação infraconstitucional a definição a respeito. É do poder constituinte a responsabilidade de dizer o que compete a cada entidade federativa e o que pode ser competência comum, esclarecendo, nesse último caso, em que medida e de que forma se exercerá essa competência. Ora, se mesmo sensível aos reclamos por maior descentralização o constituinte atribuiu à União todas as competências legislativas do artigo 22, terá tido razões fortes para isso, pouco importando, para o raciocínio que se está tentando desenvolver, que discordemos dessas razões. Se assim é, ou seja, se houve motivação relevante para concentrar tais competências em mãos do legislador federal, parece ilógico facultar que este as transfira, ainda que parcialmente como ocorre na espécie. O que o constituinte fez foi permitir que um poder constituído excepcione a repartição constitucional de competências, contrariando o entendimento de que só a Constituição pode excepcionar a própria regra" (ALMEIDA. Competências na Constituição de 1988, p. 108).
} 
permissivo contido no parágrafo único do artigo $22 \mathrm{CF} / 88$. A fim de destrinchar este argumento, que é em parte descritivo ${ }^{952}$ e em parte propositivo, propõe-se exposição estruturada a partir de quatro observações, com as quais se encerra o presente tópico.

Em primeiro lugar e antes de tratar propriamente das normas contidas no artigo 22, parágrafo único, CF/88 e artigo 71 GG em uma perspectiva comparada, considera-se importante tecer algumas considerações sobre o objeto da competência legislativa privativa da União. Na Alemanha, ele certamente consiste na edição de uma lei federal. Já no Brasil, é possível afirmar que ele compreende a edição tanto de leis nacionais quanto de leis federais. Tal distinção, por sua vez, reside na própria compreensão de como se estrutura o Estado Federal. Na Alemanha, entende-se que a federação alemã é composta por Estados (Länder) reunidos em uma União (Bund). Não por outro motivo, aliás, que a expressão alemã "Bund" costuma ser traduzida como federação, pois neste país se verifica uma identidade entre federação e União. Por isso, a competência atribuída privativamente ao Bund para editar uma lei só pode ter como resultado uma lei federal. No direito brasileiro, por sua vez, vigora o entendimento de que a federação consiste no Estado total, o qual é composto pela União, pelos Estados e pelos Municípios. Semelhante configuração estatal respalda a distinção entre leis nacionais e leis federais, corrente na doutrina e na jurisprudência brasileiras: as primeiras seriam aplicáveis à União, Estados e Municípios indistintamente, ao passo que as segundas aplicar-se-iam somente à União e sua respectiva estrutura administrativa. Poder-se-ia argumentar que somente as competências que implicassem a edição de leis nacionais seriam efetivamente privativas, pois seriam as únicas que seriam aplicáveis às outras esferas legislativas. Porém, a presente tese posiciona-se contrariamente a tal compreensão, por duas razões bem simples. A primeira delas está relacionada com o próprio conceito de competência privativa encampado por esta pesquisa, qual seja, o de uma autorização para agir conferida a um nível federativo com exclusão dos demais, não sendo necessário que o produto do exercício desta competência seja aplicável aos outros níveis federativos. A segunda razão decorre da conclusão esposada nesta tese de que Estados e Municípios podem executar leis federais, o que faz cair por terra a própria distinção entre leis nacionais e leis federais, a qual reside justamente no âmbito de aplicação destas espécies legislativas. Além do mais, é de se reconhecer que tanto leis nacionais quanto leis federais são discutidas e deliberadas no âmbito do Poder Legislativo federal, o que coloca a sua produção nas mãos da União.

Já a segunda observação diz respeito propriamente à autorização contida nos

\footnotetext{
952 Mais precisamente, descritivo das semelhanças e das diferenças entre as constituições brasileira e alemã.
} 
artigos 22, parágrafo único, CF/88 e 71 GG. Perceba-se como se fala em autorização e não em delegação, como fazem a doutrina e a jurisprudência brasileiras. Com efeito, o artigo 22, parágrafo único, $\mathrm{CF} / 88$ diz expressamente que "lei complementar poderá autorizar os Estados a legislar sobre questões específicas das matérias relacionadas neste artigo". O fato de este dispositivo utilizar o verbo "autorizar" e o fato de esta autorização se limitar a questões específicas inviabiliza a afirmação de uma delegação de competência propriamente dita. Neste ponto, as ponderações da doutrina alemã discutidas no tópico 5.2 desta tese mostram-se especialmente úteis, pois elas fornecem ao mesmo tempo a finalidade e os limites deste permissivo constitucional. A finalidade consiste simplesmente em retirar o efeito de barreira criado pela norma constitucional que atribui uma competência legislativa privativa à União. Os Estados-membros, que antes eram proibidos de editar legislação sobre as matérias arroladas nos incisos do artigo 22 CF/88, passam a ser autorizados a fazê-lo. No que diz respeito aos limites, o referido dispositivo da constituição brasileira prevê que a autorização deve recair apenas sobre questões específicas, do mesmo modo como ocorre com o artigo 71 GG. Apesar de não haver nenhuma previsão nesse sentido na Lei Fundamental, entende-se que a permissão contida no artigo 71 GG não pode abranger a competência da União como um todo, pois nesse caso teria ocorrido uma delegação, o que absolutamente vedado pela constituição alemã. No caso do artigo 22, parágrafo único, $\mathrm{CF} / 88$, como a restrição da autorização a algumas questões específicas encontra-se expressa, a inexistência de uma delegação legislativa é ainda mais patente.

De todo modo, deve-se entender porque a afirmação de que o artigo 22, parágrafo único, CF/88 consagra uma simples autorização, não uma delegação de competência, é importante. Conforme defendido em mais de uma ocasião, a competência federativa é estabelecida pela própria constituição. A despeito de a federação nem sempre ser formulada em termos de um contrato, é da essência desta forma de Estado colocar certas decisões acima dos interesses mais momentâneos dos entes federativos. É certo que, na prática, no Brasil a alteração da constituição é um processo que está nas mãos da União, eis que discutido e deliberado somente pelo Poder Legislativo federal. Mas, ainda assim, se trata de um processo mais dificultoso, mais demorado, que o da aprovação de uma lei ordinária. A delegação, por sua vez, significa dotar os entes federativos de um poder de disposição sobre as competências que lhes são atribuídas pela constituição. Isso significa uma verdadeira subversão da própria ideia de Estado Federal. ${ }^{953}$

\footnotetext{
953 Para uma crítica da delegação, por lei complementar, de competências federativas previstas pela própria Constituição, vide as ponderações de Fernanda Dias Menezes de ALMEIDA transcritas na nota de rodapé no 951.
} 
Também é certo que a possibilidade da gestão associada de recursos acaba por dotar os entes federativos deste poder de disposição no que diz respeito às competências de execução. Porém, há uma autorização expressa na Constituição nesse sentido. O mesmo não se pode afirmar em relação à repartição de competências legislativas, tendo em vista que o artigo 22, parágrafo único, $\mathrm{CF} / 88$ fala em autorização e não em delegação de competência. Daí a necessidade de enquadrar corretamente a norma permissiva contida neste dispositivo constitucional como uma suspensão do efeito de barreira imposto pelo artigo 22, caput, e não de uma delegação.

Em terceiro lugar, com respaldo na doutrina alemã é possível superar uma antiga celeuma a respeito da autorização contida no parágrafo único do artigo $22 \mathrm{CF} / 88$, que diz respeito aos potenciais destinatários da "delegação" nele contida. A questão já foi analisada com todos os seus contornos no tópico 4.2. Neste momento da exposição cumpre apenas lembrar os dois posicionamentos que se antagonizam do debate: de um lado, há aqueles que entendem que a autorização poderia se dar de forma desigual, abrangendo apenas alguns Estados-membros; já do outro lado, há os que defendem que a delegação deve abranger todos os Estados de forma indistinta, tendo em vista que o direito constitucional brasileiro teria consagrado um federalismo simétrico ${ }^{954}$. Acredita-se que o primeiro destes posicionamentos seja o mais correto, mesmo porque a literalidade do dispositivo constitucional em comento não exige que a autorização seja dirigida a todos os Estados; ao contrário, ele se refere apenas "aos Estados", o que pode abranger mais de um ou todos os Estados-membros da federação brasileira. Além do mais, é de se admitir, como faz doutrina e jurisprudência alemãs ${ }^{955}$, que um dispositivo como este também possui o objetivo de promover uma diferenciação regional, o que é ainda mais importante em um Estado Federal de proporções continentais como o Brasil. Isto não significa que a autorização contida no artigo 22, parágrafo único, $\mathrm{CF} / 88$ deva necessariamente contemplar somente alguns Estados; porém, quando as condições fáticas recomendarem uma diferenciação regional no que diz respeito à legislação, a autorização poderá e deverá contemplar os Estados que comunguem destas mesmas condições fáticas. Em todo o caso, permanece a possibilidade de a lei complementar federal autorizar todos os Estados a legislarem sobre questões específicas inseridas na competência privativa da União, tendo em vista - como sugere a doutrina alemã - que "a diferenciação regional pode certamente existir em âmbito federal" ${ }^{\prime 956}$.

\footnotetext{
954 Para uma compreensão deste debate, de viés eminentemente doutrinário, vide ALMEIDA. Competências na Constituição de 1988, p. 110.

955 Referido posicionamento foi objeto de considerações no item 5.2 desta tese.

956 HEINTZEN. Artikel 71 In: von MANGOLDT, KLEIN, STARCK (Hrsg.). Kommentare zum Grundgesetz, p. 1860.
} 
A quarta e última observação diz respeito à relevância prática do instituto consagrado no artigo 71 GG e no artigo 22, parágrafo único, CF/88. Sabe-se, diante de tudo o que foi exposto até o presente momento, que ela é praticamente inexistente. Não é por outro motivo, aliás, que Fernanda Dias Menezes de ALMEIDA pondera, com razão, que "o fato é que nada indicia que os Estados devam esperar muito da regra do parágrafo único do artigo 22. Em primeiro lugar, insista-se, trata-se ali de uma mera faculdade aberta ao legislador federal, que dela, se quiser, poderá nem fazer uso" ${ }^{957}$. E embora a referida autora arrole outras restrições formais e materiais que corroboram este prognóstico, deve-se reconhecer que a grande razão para o insucesso destes dispositivos constitucionais consiste justamente em tornar a autorização neles prevista uma decisão discricionária da União. Ora, a história de quase todas as federações modernas é marcada por um movimento de centralização federativa, a qual tem como um de seus desdobramentos a centralização legislativa. Uma descentralização legislativa, no mais das vezes, tem sido obtida somente pela via da reforma constitucional. A Alemanha é um exemplo bem ilustrativo deste fenômeno. A despeito de o artigo 71 GG ter quase setenta anos de vigência, os Länder só passaram a legislar sobre competências outrora abrangidas na competência legislativa da União quando o próprio rol dos artigos 73 e 74 GG foi reformado. Nesse sentido, mencionam-se as competências estaduais para legislar sobre execução penal, direito de reunião, horário de fechamento de lojas, resultantes das alterações promovidas no artigo 74 I Nr. 1, 3 e 11 GG. ${ }^{958}$ Portanto, é de se admitir que, uma vez que a constituição atribui uma competência legislativa à União, as chances de esta última recuar no exercício desta competência em prol dos Estados são bem reduzidas.

\subsubsection{As competências concorrentes na Lei Fundamental e na Constituição Federal de 1988}

Tanto a Constituição Federal de 1988 quanto a Lei Fundamental de 1949 têm como característica central o manejo intenso das competências legislativas concorrentes. É possível afirmar que esta modalidade de competência consiste na grande aposta feita tanto pelo legislador constituinte alemão quanto pelo legislador constituinte brasileiro, no sentido de se obter uma maior descentralização legislativa. Porém, nos dois casos esta aposta restou

\footnotetext{
957 ALMEIDA. Competências na Constituição de 1988, p. 109.

958 Conforme apontado por RENGELING. § 135 - Gesetzgebungszuständigkeit. In: ISENSEE, KIRCHHOF (Hrsg.). Handbuch des Staatsrechts, p. 593. O rol completo de matérias acrescidas à competência legislativa privativa dos Estados pela Reforma do Federalismo de 2006 pode ser consultado nas páginas 593 e 594 desta mesma obra.
} 
frustrada por uma série de fatores. No caso alemão, os condicionantes impostos à atuação da União nada mais eram do que uma imposição das potências ocidentais que venceram a Segunda Guerra, em especial dos Estados Unidos. Sabe-se muito bem que normas inseridas em um ordenamento jurídico deste modo costumam gerar um movimento de repulsa, diante da sua pouca aderência ao contexto sobre o qual elas pretendem incidir. Além do mais, a reconstrução da Alemanha e implementação de um Estado de Bem-Estar Social embasou um discurso de centralização. Falava-se à época de uma necessidade de igualação das condições de vida no território nacional, em clara referência a um dos pressupostos previstos no artigo 72 II GG. Ou seja, os condicionantes outrora concebidos para conter o avanço da União passaram a justificar uma atuação por parte do ente federal. Já no que diz respeito à Constituição Federal de 1988, as competências concorrentes previstas no artigo 24 foram associadas a um discurso de descentralização gradual, como uma forma de devolver ordenadamente competências importantes aos Estados-membros após anos de centralização legislativa. Porém, a prática verificada após 1988 deixou uma sensação de frustração: embora em tese a União esteja adstrita à edição de normas gerais, a aprovação de leis federais extensas deixou pouco espaço para a legislação dos Estados e dos Municípios. Por isso, há quem entenda que a federação brasileira teria sofrido um processo de desnaturação, verificando-se um hiato entre o que a Constituição Federal de 1988 prevê e o que efetivamente se verifica na prática. De nossa parte, acreditamos que a centralização verificada nas matérias submetidas à competência legislativa concorrente possui algumas variáveis institucionais importantes, as quais passam a ser analisadas neste tópico sob uma perspectiva comparada. Antes disso, contudo, considera-se importante tecer considerações de índole mais teórica, retomando-se, para tanto, o conceito e as modalidades de competências concorrentes expostas no item 1.5.5 desta tese.

Naquela ocasião definimos competência concorrente como a autorização conferida pela constituição para que tanto União quanto Estados-membros (e Municípios, no caso brasileiro) atuem em relação a algumas matérias previamente definidas. Trata-se, portanto, de um gênero, que comporta duas espécies: a primeira é a competência concorrente cumulativa, caracterizada pela ausência de limites a um ou outro ente federativo quanto à extensão da matéria regulada; já a segunda modalidade consiste na competência concorrente não-cumulativa ou limitada, cuja nota distintiva consiste justamente em prever uma limitação quanto à extensão da matéria regulamentada por um ou outro ente, sendo que normalmente a União fica adstrita à edição de normas gerais ou a uma legislação de princípios. Mais uma vez, deve-se frisar que esta é uma proposta forjada apenas com o intuito de enfrentar a complexidade inerente aos objetos de estudo, sem a pretensão de fornecer uma 
definição em relação às quais as competências concorrentes previstas pelas constituições brasileira e alemã possam ser subsumidas perfeitamente. Portanto, é possível e também esperado que tanto a Lei Fundamental alemã quanto a Constituição Federal brasileira apresentem peculiaridades importantes que não são devidamente contempladas pela definição e pelas modalidades concebidas no item 1.5.5.

Feita esta ressalva, parte-se para a análise de como estas noções se aplicam ao caso brasileiro e alemão. Conforme analisado no tópico 5.3, a Lei Fundamental previa até 2006 as duas modalidades de competência concorrente supramencionadas. Havia, assim, a competência regulamentada pelo artigo $72 \mathrm{GG}$, que se enquadra no que chamamos de competência concorrente cumulativa, e a competência prevista no artigo 75 GG, a qual, por impor limitações à atuação da União, pode ser subsumida ao que denominamos de competência concorrente não-cumulativa. Ao artigo 75 GG aplicavam-se as disposições do artigo $72 \mathrm{GG}$, por expressa disposição constitucional. Não obstante isso, diferentes valores informavam a interpretação destes dois artigos. No caso do artigo 72 GG predomina a ideia de que a Lei Fundamental pretendeu promover uma concorrência entre os entes federativos, ainda que se trate, na grande maioria dos casos, de uma falsa concorrência (unechte Konkurrenz), tendo em vista que ela sempre se resolve pela predominância da legislação federal em relação à estadual. De todo modo, nas matérias submetidas à competência concorrente - lembre-se que a modalidade regulamentada pelo artigo 72 GG é a única denominada de concorrente pela Lei Fundamental - União e Estados competem pela possibilidade de legislar: o Bund vence quando existe uma necessidade de regulamentação federal nos termos do artigo 72 II GG; do contrário, os Länder vencem. Não é à toa, aliás, que a grande celeuma envolvendo este artigo sempre consistiu na determinação de quem é legitimado a afirmar esta necessidade no caso concreto. Durante muito tempo, o Poder Legislativo federal firmou-se como o único legitimado a interpretar os condicionamentos impostos pelo artigo 72 II GG; em 1994, esta possibilidade foi franqueada irrestritamente ao Tribunal Constitucional Federal; finalmente, a partir de 2006 optou-se por um meio termo, conferindo-se à corte constitucional alemã a possibilidade de analisar a necessidade da legislação federal em relação a algumas matérias. De um modo ou de outro, tanto União quanto Estados legislam sem qualquer restrição quanto à extensão da sua regulamentação. É possível que o Poder Legislativo Federal considere oportuno legislar apenas sobre parte da matéria referida pela norma de competência, hipótese em que aos Estados será lícito legislar sobre a parte restante. Contudo, a recíproca nem sempre é verdadeira, pois se os Estados optarem por regulamentar apenas parcialmente uma matéria, ainda assim a União só poderá legislar sobre o tema se houver a necessidade de uma regulamentação nacional. 
Já a competência inscrita no artigo 75 GG, revogado em 2006, era interpretada como uma legislação cooperativa, tendo em vista que uma legislação completa sobre os temas arrolados nos seus incisos só poderia existir após União e Estados legislarem sobre o tema. Em outras palavras, somente ao término de uma dupla ação legiferante é que se poderia vislumbrar uma regulamentação aplicável ao caso concreto. É certo que a União poderia editar preceitos aplicáveis diretamente às relações jurídicas desenvolvidas nos territórios dos Estados; todavia, aos Länder deveria ser franqueada uma margem de atuação discricionária, não podendo ter a sua atividade reduzida à simples repetição dos preceitos federais ou então à opção por uma ou outra alterativa colocada pelo legislador federal. A ideia de cooperação surge da própria necessidade de uma concatenação da legislação federal e estadual: em primeiro lugar, a União edita os preceitos-moldura; posteriormente, Estados preenchem esta moldura com a sua própria legislação. Dentro deste esquema, não há propriamente espaço para a competição, como ocorre com o artigo 72 GG.

É certo que o fato de a legislação-moldura do Bund ter sido submetida aos condicionantes impostos pelo artigo 72 II GG, consoante entendimento majoritário, altera um pouco este cenário. Afinal, caso não houvesse a necessidade de uma regulamentação federal, os Estados passariam a deter a competência legislativa plena sobre os assuntos arrolados nos incisos do artigo 75 GG. Ainda assim, aos Poderes Legislativos estaduais não seria lícito - nem faria sentido, aliás - editar preceitos-moldura; o contrário seria admitir que os Estados primeiro elaborariam a moldura, para depois eles próprios preencherem a moldura que eles mesmos forjaram. Além do mais, os problemas que cercavam a afirmação da necessidade de uma legislação federal no caso concreto, presentes no artigo 72 II GG, foram transferidos para o artigo $75 \mathrm{GG}$, de forma que uma atuação legiferante por parte da União, na prática, não sofria restrição alguma. ${ }^{959}$

Embora não tenham sido acrescentados às noções propostas no item 1.5.5, competição e cooperação são valores úteis para a compreensão das modalidades de competência concorrentes por nós forjadas. Assim, na competência concorrente cumulativa, o ente federal e os entes estaduais competem pela faculdade de legislar, ao passo que na competência concorrente limitada União e Estados se coordenam no sentido de elaborar uma única legislação, a ser aplicada as relações jurídicas concretas. Deve-se reconhecer que esta segunda modalidade também contempla diferenciações regionais; não obstante isso, no âmbito do território de um Estado, a legislação a ser obtida ao término da atuação da União e dos Estados é uma só. Tal cenário pressupõe obviamente alguma coordenação federativa,

\footnotetext{
959 Situação esta alterada pela reforma constitucional de 1994, como já se teve a oportunidade de analisar em mais de uma oportunidade nesta tese.
} 
deixando pouco espaço para a competição entre as esferas legislativas. Tendo estas considerações em mente, é possível finalmente compreender o porquê da amálgama entre competências concorrentes cumulativas e não-cumulativas feita pelo artigo $24 \mathrm{CF} / 88$. Poderse-ia até argumentar que a sistemática inaugurada por este dispositivo em muito se assemelha à prevista pelo artigo $75 \mathrm{GG}$; todavia, uma análise da evolução constitucional das competências legislativas concorrentes no Brasil afasta semelhante pretensão. Conforme exposto no tópico 4.4, a partir da Constituição Federal de 1934 o ordenamento jurídico brasileiro passou a prever competências concorrentes legislativas cumulativas e não cumulativas, mas as diferenças entre uma e outra modalidade foram sendo mitigadas até desaparecerem completamente sob a égide da Constituição Federal de 1988. Com efeito, de acordo com o artigo $24 \mathrm{CF} / 88$, União e Estados (e também os Municípios, por força do disposto no artigo 30, II) competem e cooperam em relação às mesmas matérias. Tal percepção se mostra ainda mais verdadeira quando se tem em mente que a autorização para a elaboração de normas gerais embasou e ainda embasa a edição de leis extensas pela União. Com isso, os limites materiais impostos à União caem por terra, e o que se tem inexoravelmente é uma competição em que aos Estados só resta perder em virtude da previsão contida no artigo $24, \S 4^{\circ}, \mathrm{CF} / 88$.

As únicas competências em que União e Estados se colocam, ao menos em tese, como entes que cooperam entre si, tão somente, são aquelas por nós denominadas de competências privativas da União para legislar sobre normas gerais (artigo 22, IX, XXI, XXIV e XXVII, CF/88). Nestas hipóteses, aos Estados é lícito somente complementar as normas gerais, preenchendo as molduras fornecidas pelo legislador federal, tal como no artigo 75 GG. Contudo, se o Poder Legislativo federal não se limita à edição de normas gerais, também aqui a cooperação acaba se convolando em uma relação de competição entre os entes federativos.

Feitas estas considerações, é chegado o momento de destrinchar o argumento exposto no início deste tópico, qual seja, o de que a centralização verificada em relação às competências legislativas concorrentes previstas no artigo $24 \mathrm{CF} / 88$ possui algumas variáveis institucionais importantes ${ }^{960}$. Para tanto, mais uma vez a comparação entre Brasil e Alemanha demonstra-se frutífera.

\footnotetext{
960 Embora não correspondam às variáveis institucionais da centralização comentadas neste tópico da tese, não se pode deixar de transcrever o seguinte trecho da obra de Anna Cândida da Cunha FERRAZ, que já em 1989 traçava um prognóstico bem acurado do real potencial centralizador da competência legislativa concorrente: "Esse nova fórmula de distribuição de poderes não tende, necessariamente, consoante tem sido apontado com certa frequência, a fortalecer as unidades federadas ou a aumentar o grau de descentralização política no Brasil. Na verdade, pode ela ser vista como instrumento de centralização normativa, uma vez que
} 
Comecemos pelo possível conteúdo das normas gerais da União (artigo 24, § 1º, CF/88). Há muito se criticam a sua indefinição, bem como a falta de parâmetros para definir quando a União edita normas deste tipo ou não. Neste último caso, costuma-se censurar tanto a falta de parâmetros legais quanto parâmetros jurisprudenciais, tendo em vista o conceito bem elástico com que o STF costuma trabalhar. Partindo-se destas considerações, propõe-se um breve confronto destas normas e dos preceitos-moldura editados pela União nos termos do artigo 75 GG. Acredita-se que esta opção não enseja maiores esclarecimentos, tendo em vista que o preceito-moldura alemão consiste na espécie normativa mais próxima da norma geral brasileira. Ao se analisar a redação originária do artigo 75 GG percebe-se que ele era redigido em termos tão ou mais lacônicos que o artigo $24, \S 1^{\circ}, \mathrm{CF} / 88$, ao prever somente que "a União tem o direito, obedecidos os requisitos do artigo 72, de editar preceitosmoldura" sobre as matérias arroladas em seus números. Isso, todavia, não impediu que o BVerfG forjasse um conceito que prestigiasse a autonomia legislativa dos Länder, partindo de um pressuposto simples: se a competência-moldura pressupõe uma dupla atuação legiferante, a edição de preceitos-moldura pelo Bund não pode tornar despicienda a legislação estadual. Ao longo do tempo, outros critérios foram acrescidos a esta proposta, como a exigência de que a legislação federal apenas em situações excepcionais seja aplicada diretamente às relações jurídicas concretas. ${ }^{961}$ Todos estes critérios poderiam ser aplicados às normas gerais previstas pelo artigo $24, \S 1^{\circ}, \mathrm{CF} / 88$, de modo a forjar uma definição mais favorável à autonomia dos Estados-membros brasileiro. Portanto, se a União edita uma lei de diretrizes e bases da educação que pode ser aplicada diretamente, sem a necessidade de uma complementação por parte de Estados e Municípios, deve-se admitir então que a legislação federal não se restringe à edição de diretrizes e bases.

Como já se ressaltou em mais de uma ocasião, considera-se o fortalecimento da competência legislativa concorrente dos Estados imprescindível para dotá-los de um patamar razoável de autonomia legislativa, tendo em vista que a sua competência legislativa para legislar, com fulcro no artigo $25, \S 1^{\circ}, \mathrm{CF} / 88$ encontra-se sensivelmente restringida pela extensa enumeração de competências privativas à União ou então concorrentes à União,

\footnotetext{
a maioria das principais áreas do campo legislativo fica reservada à Federação, ainda que no âmbito restrito das 'normas gerais'. Para corroborar a afirmação, observem-se: o vasto elenco de matérias submetidas á 'legislação de princípios' da União; a inclusão nesse elenco de matérias que dantes eram autonomamente regulamentadas pelos estados; a dificuldade prática de, em certos casos, fixar-se com clareza o limite do conteúdo das 'normas gerais'; e a inevitável uniformização no tratamento de certas matérias, fato esse que nem sempre poderá ser superado pelas normas específicas para atender às diversidades regionais existentes no País" (FERRAZ. União, estado e município na nova Constituição, p. 70).

961 Para maiores aprofundamentos, vide o item 5.3.2 desta tese.
} 
Estados e Municípios. Porém, deve-se atentar para um fato importante, o qual inclusive motivou a extinção da competência-moldura alemã, em 2006: o estabelecimento de uma legislação aplicável, nestes termos, é um processo custoso e demorado. Além do mais, ele incidiria sobre matérias cuja uma extensa regulamentação federal afigura-se imprescindível, como o direito econômico ou mesmo o direito penitenciário. Por isso, acredita-se que a decisão por uma maior descentralização legislativa, a despeito do discurso que lhe é favorável, deve ser discutida, ou no mínimo ponderada, pois ela certamente possui vantagens e desvantagens. ${ }^{962}$

De um modo ou de outro, não se pode deixar de reconhecer que a forma genérica como a limitação imposta à União foi redigida acaba por fundamentar, no plano jurídico, tanto interpretações como a sugerida nesta tese como a que predomina atualmente, nitidamente favorável à União. Esta é, portanto, uma variável importante para compreender a centralização legislativa verificada no que diz respeito às matérias arroladas no artigo $24 \mathrm{CF} / 88.963$

Outra variável importante consiste na ausência de regras sobre o direito federal anterior à Constituição Federal de 1988. Ora, as matérias atualmente inseridas na competência legislativa concorrente da União e Estados-membros eram arroladas dentre as competências privativas da União, franqueando-se aos Estados apenas uma competência supletiva ou complementar. Muitas leis federais foram editadas com fulcro nestas competências privativas e foram recepcionadas pela Constituição Federal de 1988. É o caso da Lei n ${ }^{\circ}$ 5.692/1971, que estabelecia as diretrizes e bases da educação nacional, e que só veio a ser substituída pela Lei $\mathrm{n}^{\text {o }}$ 9.394/1996. A grande questão é que esta mesma constituição não estabeleceu um modo específico pelo qual a adequação desta legislação

\footnotetext{
962 Acredita-se, aliás, que um passo importante para que a competência legislativa concorrente no Brasil finalmente seja revertida a favor dos Estados consistiria justamente na diminuição do rol de matérias contido no artigo $24 \mathrm{CF} / 88$. Conforme ressaltado no corpo do texto, atualmente ele compreende temas que não poderiam ser regulamentados pelos Estados-membros de forma substancial sem prejuízos para a uniformidade da normatização em âmbito federal. Nestas matérias, a regulamentação federal deve ser extensa, o que implica necessariamente uma ampliação o do conceito de normas gerais, a fim de que tal legislação seja possível do ponto de vista jurídico-constitucional. O caso mais emblemático deste argumento é a competência concorrente para legislar sobre direito econômico. Por outro lado, caso o rol seja restringido, de forma a abranger somente matérias cuja normatização por parte dos Estados não compromete interesses nacionais sensíveis, existiria então a possibilidade de União e Estados compreenderem e a vivenciarem a competência inscrita no artigo 24 CF/88 em termos mais federativos, de forma a prestigiar a competência legislativa estadual.

963 Caso, portanto, se deseje imprimir uma maior descentralização legislativas nestas matérias, restringindo a margem de atuação de legislador federal, seria mais adequado promover uma alteração do artigo $24, \S 1$ 은 CF/88, estabelecendo limites à atuação da União ou então especificando quais as características das normas gerais por ela editadas.
} 
ao conceito de normas gerais deveria ser verificada. $O$ legislador federal não estava obrigado - ou mesmo exortado - a reconhecer que a sua legislação não se enquadrava na limitação prevista pelo artigo $24, \S 1^{\circ}, \mathrm{CF} / \mathbf{8 8}^{964}$. Por outro lado, não havia um instrumento de controle abstrato de constitucional por meio do qual a questão poderia ser suscitada perante o STF. Com efeito, tal possibilidade passou a existir somente a partir do advento da Lei $\mathrm{n}^{\mathrm{o}}$ 9.882/1999, que regulamentou a propositura e o julgamento da Arguição de Descumprimento de Preceito Fundamental (ADPF) ${ }^{965}$. Ou seja, durante muito tempo a União não tinha exatamente um incentivo para recuar na sua produção legislativa, nem os Estados detinham meios adequados para fazer valer o seu direito no âmbito jurisdicional. Mesmo após a ADPF, não se tem notícia de que os Estados ou mesmo Municípios tenham feito uso desta faculdade, o que é bem sintomático de uma "cultura centralista", como se tornou corrente afirmar no meio jurídico.

A terceira variável institucional importante diz respeito à ausência de condicionantes à atuação da União. Sabe-se que a Lei Fundamental estabelece alguns pressupostos à atuação da União no artigo 72 II GG, que é certamente um dos dispositivos mais polêmicos da repartição de competências legislativas e de execução na Alemanha. ${ }^{966}$ Já a constituição brasileira partiu do pressuposto de que a edição de normas gerais pela União coloca-se como faculdade e não como obrigação. Afinal, o parágrafo terceiro do artigo 24 $\mathrm{CF} / 88$ prevê que "inexistindo lei federal sobre normas gerais, os Estados exercerão a competência legislativa plena, para atender a suas peculiaridades", partindo do pressuposto, portanto, de que a União pode não fazer uso da sua competência nos termos do parágrafo primeiro deste dispositivo. Isto, por sua vez, coloca interesse questão de saber se ou quando a União está legitimada a editar normas gerais. Seria possível extrair da Constituição Federal algum condicionante à atuação da União, tal como ocorre sob a égide da Lei Fundamental?

A resposta a esse questionamento merece ser negativa. Ao se analisarem os parágrafos do artigo $24 \mathrm{CF} / 88$ percebe-se que o Poder Legislativo federal não deve preencher nenhum pressuposto ou condição para exercer a sua competência legislativa. A edição ou

\footnotetext{
964 Foi o que a Lei Fundamental passou a prever a partir de 1994 no artigo 72 III GG. Com a Reforma do Federalismo de 2006, a disposição foi transferida para o artigo 72 IV GG.

965 Antes disso, porém, o STF costumava analisar a derrogação do direito pré-constitucional como uma preliminar, julgando improcedente a representação, posição esta que foi substituída pelo "entendimento de que o processo do controle abstrato de normas destina-se, fundamentalmente, à aferição da constitucionalidade de normas pós-constitucionais. Dessa forma, eventual colisão entre o direito préconstitucional e a nova Constituição deveria ser simplesmente resolvida segundo princípios do direito intertemporal. Assim, cabe à jurisdição ordinária, tanto quanto ao STF, examinar a vigência do direito préconstitucional, no âmbito do controle incidente de normas" (MENDES, COELHO, BRANCO. Curso de Direito Constitucional, pp. 1278-1279).

966 O outro dispositivo é o artigo 84 I GG, cujas polêmicas foram analisadas no tópico 5.5.1.
} 
não de normas gerais permanece, deste modo, como uma decisão determinada tão somente pela percepção da necessidade, a ser aferida discricionariamente pela União, da regulamentação do tema em âmbito nacional. Não é preciso discorrer como isto consiste em uma variável importante para a centralização legislativa, pois os Estados somente podem exercer a sua competência legislativa plena na hipótese de o ente federal permanecer inerte. Portanto, quando a União legisla, e principalmente quando ela legisla porque não tem nenhum impedimento em fazê-lo, a competência legislativa estadual é invariavelmente restringida.

Percebe-se, portanto, que não é apenas uma indefinição acerca do conceito de normas gerais que contribuiu para a centralização legislativa verificada após 1988. Existem outras variáveis importantes para compreender este fenômeno, embora se admita que elas sejam potenciadas pela supramencionada indefinição. Nesse sentido, se sob a égide da Constituição Federal de 1967/1969, a União, sob o pretexto de editar normas gerais, acabou editando legislações federais extensas, que deixavam pouco espaço para a atuação legiferante dos Estados-membros, estas legislações acabaram recepcionadas pela Constituição Federal de 1988 sem que houvesse mecanismos para questionar a sua adequação com o arcabouço previsto pelo artigo $24 \mathrm{CF} / 88$. De todo modo, não se deixa de enxergar aqui também fortes elementos de continuidade. Em primeiro, há uma forte continuidade da constituição brasileira vigente e a ordem constitucional anterior, não só porque o artigo $24 \mathrm{CF} / 88$ consiste em uma evolução do que previa o antigo $8^{\circ} \mathrm{CF} / 1967-69$, mas porque uma parte relevante da legislação federal editada na vigência da Constituição Federal de 1967/1969 foi recepcionada, eis que enquadrada nas competências inscritas no artigo 24 CF/88 como legislação de normas gerais da União. Em segundo lugar, há uma forte continuidade entre as decisões tomadas e cristalizadas na Constituição Federal de 1988 e o fenômeno de centralização legislativa verificado posteriormente, sobretudo a partir dos mandatos do Presidente Fernando Henrique Cardoso. Com efeito, foi o próprio legislador constituinte originário que concebeu amarras muito frágeis - quase que inexistentes, a bem da verdade - para conter o avanço da União. Como resultado, o Poder Legislativo federal não se sentiu melindrado em editar legislações extensas, mesmo porque elas eram vistas como o simples exercício de sua competência legislativa.

Poder-se-ia cogitar então se a legislação de divergência (Abweichungsgesetzgebung), introduzida na Lei Fundamental alemã pela Reforma do Federalismo de 2006, não seria uma boa solução para promover uma descentralização legislativa no Brasil. Porém, não se pode esquecer que tal inovação foi recebida com uma série de ressalvas na própria Alemanha. Conforme já ressaltado em mais de uma passagem 
desta tese, a doutrina alemã costuma associar esta nova modalidade de competência concorrente a um jogo de ping-pong - são comuns as referências a um "modelo ping-pong" ou então a um "sistema ping-pong" - o que contém, em si, algo de pejorativo, mas também de acurado. De fato, a legislação de divergência suscita algumas perplexidades em virtude da opção do critério da prevalência da legislação posterior como a regra de colisão a ser aplicada na hipótese de existir tanto uma lei federal quanto uma lei estadual aplicáveis ao caso concreto. Suponha-se, por exemplo, que a União legisle, um Estado-membro resolva divergir da legislação federal, e posteriormente a União decida legislar novamente sobre o tema. Surgem então algumas questões importantes: (i) a União deverá fazer constar na sua lei que está divergindo desta legislação estadual, ou a simples contradição entre estas legislações já torna a lei federal aplicável às relações concretas?; (ii) a legislação federal posterior revoga ou simplesmente torna ineficaz a legislação estadual divergente? (iii) como ficam as relações continuadas iniciadas sob a vigência da legislação estadual, diante da vigência da legislação federal posterior? Até que o direito alemão obtenha uma resposta definitiva a estas perguntas, qualquer tentativa de transplante seria no mínimo temerária. Não obstante isso, as perspectivas lançadas por esta nova modalidade de competências são promissoras e merecem ser acompanhadas com atenção.

Finalmente, este tópico se encerra com algumas considerações sobre as competências comuns, como uma modalidade de competência concorrente na acepção que a presente tese empresta ao termo. No tópico 4.3 foram expostas as dificuldades de posicionar as competências inscritas no artigo 23 em uma das espécies por nós forjadas no item 1.5.5. Afinal, não é possível afirmar nem a existência de limites constitucionalmente fixados à atuação de um ou de outra esfera legislativa, o que caracterizaria uma modalidade não-cumulativa de concorrência, e nem a inexistência destes limites, tendo em vista que União, Estados e Municípios devem necessariamente cooperar entre si, nos termos o parágrafo único do artigo em comento. Ponderou-se ainda que, na verdade, o artigo $23 \mathrm{CF} / 88$ possibilitaria uma série de arranjos federativos, desde uma indesejável superposição de competências, passando pela adoção de mecanismos decisórios conjuntos, até chegar a uma divisão estrita de tarefas entre os três níveis federativos. Tende-se a afirmar que, na prática, predomine a adoção de uma repartição de atribuições em virtude do número elevado de entes federativos no Brasil, ao passo que uma superposição de funções, em virtude dos problemas que ela gera, seja evitada.

De todo modo, parece-nos importante que exista esta multiplicidade de combinações no que diz respeito às competências de execução. Esta afirmação aplica-se com mais razão à execução de políticas sociais, em virtude da complexidade que envolve a sua 
prestação, o que exige, no mais das vezes, uma conjugação de esforços entre União, Estados e Municípios. É certo que a repartição de competências em uma federação possui justamente a finalidade de circunscrever um espaço de atuação de cada nível federativo, separando-o dos demais. No que diz respeito às competências legislativas, esta finalidade persiste sem grandes mitigações, pois o cidadão deve saber qual ente federativo pode lhe impor direitos e obrigações e qual lei ele deve obedecer nas suas relações jurídicas, sob pena de criar uma situação de insegurança jurídica. No tocante às competências de execução, contudo, considerações deste tipo perdem importância, embora isso não significa que elas sejam irrelevantes. O cidadão também deve saber de qual ente federativo ele deve demandar a prestação de um serviço público. Por outro lado, não é necessariamente ruim que um ente federativo esteja legitimado a prestar um serviço quando é exortado a fazê-lo pelos seus cidadãos. Note-se que tais ponderações não pretendem desconsiderar ou criticar as hipóteses em que a Constituição Federal promove uma repartição estrita de competências de execução, mas apenas de apresentar as vantagens da previsão de competências administrativas comuns à União, Estados e Municípios, as quais costumam, no mais, serem muito criticadas justamente pela situação de indefinição que geram. Porém, esta indefinição é causada mais pela ausência das leis complementares a que se refere o parágrafo único do artigo $23 \mathrm{CF} / 88$ do que por este dispositivo constitucional. Não seria de se esperar que a constituição brasileira descesse ainda mais a minúcias e detalhes as atribuições de cada ente federativo em matéria de preservação de florestas, flora e fauna (artigo 23, VII, CF/88), por exemplo. Semelhante tarefa tem que competir ao legislador ordinário, no caso, ao legislador federal.

Considerações deste tipo são importantes sobretudo em uma perspectiva comparada. Já se analisou nesta tese como a Alemanha se vê às voltas com uma proibição da administração mista (Verbot der Mischverwaltung), que nada mais é do que um desdobramento da separação estrita das competências de execução. De acordo com esta proibição, União e Estados devem prestar os seus serviços separadamente, sob sua responsabilidade e custeada pelos seus próprios recursos, o que pode até encontrar respaldo em uma percepção teórica de como uma federação deve ser. Na prática, todavia, os desafios concretos enfrentados pela federação alemã ao longo de sua história recente - a saber, a reconstrução de sua infraestrutura e o assentamento de pessoas deslocadas ou refugiadas após a Segunda Grande Guerra, a estruturação de um Estado de Bem-Estar Social, mais recentemente, a unificação da Alemanha Ocidental e da Alemanha Oriental - tornaram imprescindível uma conjugação de esforços entre União e Estados.

Embora não esteja prevista expressamente na constituição alemã, a proibição da administração mista durante um tempo foi tão arraigada que lastreou algumas reformas 
constitucionais com o intuito de autorizar - ou de legitimar no plano jurídico - a atuação conjunta de Bund e Länder. É o caso certamente da reforma de 1969 e das reformas promovidas em 2009 e 2010. O federalismo alemão é caracterizado pela cooperação e, especificamente, pela tomada de decisões conjuntas, mesmo em situações em que tal não era necessário. Criou-se, portanto, uma daquelas tensões entre direito e realidade que obscurecem tanto a percepção do fenômeno jurídico quanto dos fatos.

\section{SÉtimo capítulo - Algumas Questões dA REPARTIÇÃo dE COMPETÊNCIAS ANALISADAS SOB UMA PERSPECTIVA COMPARADA}

Neste sétimo e último capítulo propõe-se a análise de algumas questões da repartição de competências legislativas e de execução sob uma perspectiva comparada. Obviamente, não se pretende aqui contemplar todas as questões que se beneficiam deste enfoque, mas apenas algumas delas, a saber: (i) qualificação competencial da lei e questões afetas; (ii) o princípio da lealdade federal aplicado à repartição de competências, e; (iii) algumas questões municipais. Esta é, por sua vez, uma decisão que enseja alguns esclarecimentos, tendo em vista que ela necessariamente privilegia determinados debates em detrimento de outros, igualmente relevantes.

Há basicamente duas razões que nortearam a nossa escolha. Em primeiro lugar, buscou-se selecionar temas que fossem relevantes para compreender ou solucionar problemas brasileiros. Conforme ressaltado na introdução, esta tese se filia a uma das finalidades comumente atribuídas ao direito comparado, ao buscar no direito estrangeiro no caso, no direito alemão - soluções ou mesmo subsídios para resolver problemas domésticos - brasileiros, portanto. Nesse sentido é que se debruça sobre temáticas que têm sido discutidas no âmbito da doutrina e da jurisprudência alemãs, somente se e à medida que elas possam prestar relevante contribuição para solução de problemas que afetam o sistema brasileiro de repartição de competências legislativas e de execução.

Em segundo lugar, procurou-se selecionar questões que possuíssem alguma relação com as conclusões por nós obtidas no estudo comparativo e expostas no capítulo anterior. A interpretação da norma competencial e a atividade de subsunção de uma lei a esta norma, por exemplo, são assuntos muito abordados pela doutrina alemã quando da análise das regras gerais em matéria de repartição de competências, mas recebem pouca atenção por parte da doutrina e da jurisprudência brasileira. Assim, se no tópico 6.2.2 analisamos as regras gerais previstas pela Constituição Federal de 1988 em uma perspectiva comparada, o item 7.1 propõe o estudo de um desdobramento importante do reconhecimento da existência de tais 
regras no nosso ordenamento jurídico. Já a lealdade federal, por outro lado, representa um importante limitador ao exercício de competências pela União e pelos Estados, mas que não é expressamente previsto pela Lei Fundamental de 1949. Trata-se de um instituto formulado pela doutrina e pela jurisprudência a partir de uma interpretação da previsão contida no artigo 20 GG (segundo o qual a República Federal da Alemanha é um Estado Federal democrático e social), colocando-se, portanto, em uma relação de continuidade com a temática da interpretação da norma competencial. Finalmente, o tópico derradeiro trata de algumas questões municipais sob uma perspectiva comparada, com o objetivo de elaborar algumas propostas para a resolução de problemas identificados no sexto capítulo que envolvem a competência dos municípios brasileiros identificados.

\subsection{A QUALIFICAÇÃO COMPETENCIAL DA LEI E QUESTÕES AFETAS}

Os manuais e cursos de Direito Constitucional, ao comentarem a repartição de competências legislativas e de execução promovida pela Constituição Federal de 1988, normalmente se limitam a afirmar a competência da União, dos Estados e dos Municípios para legislar sobre esta ou aquela matéria. Não há, por exemplo, uma preocupação em arrolar quais problemáticas são efetivamente abrangidas pela matéria discriminada na norma de competência, exceto nos casos em que a própria norma de competência é formulada em termos bem indeterminados, como ocorre com o artigo 30, I, CF/88. Nesse sentido é que se costuma afirmar a competência do Município para legislar, como um assunto de interesse local, sobre horário de funcionamento de estabelecimento comercial ou então sobre “conforto, segurança e rapidez aos usuários de serviços bancários", respaldando-se, neste ponto, em posicionamentos tradicionais do $\mathrm{STF}^{967}$.

Não obstante isso, quando este tribunal é chamado a se manifestar sobre a repartição de competências - em especial, sobre a repartição de competências legislativas - a questão costuma vir formulada de um outro modo: no mais das vezes questiona-se se a regulamentação de uma determinada situação da vida por um ente federativo pode ser reconduzida a uma norma que lhe atribui competência para tanto. Em determinados casos é fácil afirmar a constitucionalidade ou não da legislação, porque existe uma compreensão bem precisa e arraigada no meio jurídico do que é a matéria à qual a norma de competência faz referência e do pertencimento desta regulamentação a esta matéria. Por exemplo, uma lei que trate de guarda compartilhada - mais precisamente, a Lei federal $n^{\circ}$ 13.058/2014 -

\footnotetext{
967 Estes posicionamentos, por sua vez, são objeto de breves comentários na nota de rodapé no 621, a cuja leitura se remete.
} 
claramente encontra-se inserida dentro do Direito de Família e, portanto, do Direito Civil. Está-se diante, portanto, claramente de uma lei federal editada com base na competência inscrita no artigo 22, I, CF/88. Em relação a outras leis, todavia, não é tão fácil afirmar a competência do ente federativo legiferante. Nesse sentido, qual norma poderia autorizar a União ou os Estados a legislarem sobre a comercialização (ou a proibição da comercialização) do amianto crisotila? A competência residiria com a União, em razão da sua competência para legislar privativamente sobre minas, inscrita no artigo 22, XII, CF/88, com a União e com os Estados, como uma matéria que diz respeito proteção e defesa da saúde (artigo 24, XII, CF/88)? O que dizer então de uma lei estadual que estabelece a obrigatoriedade de determinadas informações nos rótulos de produtos que sejam comercializados em seu território: está diante de uma norma constitucional, eis que amparada pela competência concorrente estadual para legislar sobre produção e consumo (artigo 24, V, CF/88) ou inconstitucional, em virtude dos reflexos sensíveis que ela invariavelmente produz sobre o comércio interestadual (artigo 22, VIII, CF/88)? ${ }^{968}$

Curiosamente, a questão da subsunção de uma lei à norma de competência não tem recebido a devida atenção no Brasil, ao contrário do que acontece na Alemanha ${ }^{969}$. Neste país, existem muitas discussões sobre os problemas que envolvem este momento da análise da constitucionalidade formal da lei. Cunhou-se, inclusive, uma expressão para designá-lo: fala-se em qualificação competencial de uma lei (kompetenzielle

\footnotetext{
968 O fato de algumas leis serem facilmente subsumidas a uma competência e outras não se deve, em grande medida, a uma diferença importante no que diz respeito à descrição da matéria à qual a norma faz referência, a qual é bem resumida por Christoph DEGENHART no seguinte trecho: "a interpretação de uma norma que atribui competência depende do tipo de descrição da matéria. Ela pode ser efetuada fático-descritivamente ou então normativo-receptivamente, portanto tanto pela designação dos fatos da vida regulamentados de acordo com critérios fáticos quanto por meio de recepção de um campo normativo preexistente como matéria a ser regulamentada na norma de competência" (DEGENHART. Artikel 70. In: SACHS (Hsrg.). Grundgesetz, pp. 1502-1503). Tomando esta distinção e aplicando-se à problemática exposta supra, tem-se que quando a descrição da matéria pela norma de competência se dá em termos normativos-receptivos, então a atividade de subsunção de uma lei à norma constitucional tende a ser facilitada pela compreensão, mais ou menos difundida no meio jurídico, do que é o complexo normativo, ao qual à norma faz referência. Além do mais, a análise da compatibilidade da lei questionada com a competência tende a se restringir a uma compatibilidade da referida lei com o que normalmente se encontra compreendido por um ramo do direito, o que normalmente oferece menos dificuldades do que a análise da compatibilidade de uma lei, que prescreve ações e omissões a seus destinatários, e uma situação da vida prevista pela norma, o que ocorre quando a matéria prevista pela norma é descrita fático-descritivamente. Por óbvio que as duas descrições mencionadas por DEGENHART podem suscitar dificuldades, mas os problemas parecem surgir com maior frequência quando a matéria é referida pela norma de competência em termos fático-descritivos.

969 Há que se ressaltar, todavia, que alguns autores brasileiros, como VIRGÍLIO AFONSO da Silva, já se debruçam sobre a problemática que envolve a afirmação da competência da União ou dos Estados em determinados casos concretos, ainda que o foco não seja exatamente a subsunção da lei à norma de competência, que é o objeto deste tópico, e sim à dificuldade de se encontrar, na jurisprudência do Supremo Tribunal Federal, critérios para saber se um ente federativo é ou não competente para regulamentar determinadas situações fáticas (VIRGÍlIO AFONSO. Capítulo 25 - Federalismo e articulação de competências no Brasil, pp. 562-563).
} 
Qualifikation eines Gesetzes), em uma tentativa de chamar a atenção para as peculiaridades que envolvem a recondução de uma regulamentação legal a uma competência inscrita na Constituição, muito embora isso não obscureça o fato de que se está diante de uma subsunção no sentido técnico-jurídico da expressão ${ }^{970}$. Na verdade, neste país existe a compreensão de que a interpretação da norma de competência e a subsunção da lei a esta norma são duas questões distintas, ainda que interligadas: com efeito, somente após interpretar a competência é que se pode determinar se uma atuação legiferante pode ser a ela conduzida e, somente ao término deste processo, é que se poderá determinar a constitucionalidade ou a inconstitucionalidade de uma lei.

Neste tópico pretende-se traçar um panorama dos debates que envolvem estas questões na Alemanha para, ao término, apontar algumas linhas de evolução para a interpretação do sistema brasileiro de repartição de competências legislativas. Antes de adentrar nesta análise, cumpre fazer três observações importantes.

Em primeiro lugar, não se observa propriamente um consenso na doutrina e na jurisprudência sobre o que deve informar a interpretação da norma de competência e sobre a qualificação competencial da lei. Obviamente existem alguns pontos já pacificados, mas há também um forte debate sobre pontos de fundamental importância. Exatamente por isso não se considera prudente defender a aplicabilidade de soluções alemãs ao caso brasileiro neste ponto, como seria de se esperar em virtude da própria proposta deste sétimo capítulo. Objetiva-se aqui algo mais singelo. Mais precisamente, deseja-se apenas chamar a atenção para a problemática que pode envolver - e geralmente envolve - a afirmação da competência de um ente federativo para legislar sobre uma determinada situação da vida e a para a necessidade de se forjar critérios adequados para se lidar com esta problemática. Nesse ponto, a Alemanha parece ser um bom exemplo a ser seguido, não porque ela efetivamente forjou critérios consistentes para lidar com os impasses que a subsunção de uma lei a uma competência legislativa pode suscitar, mas sim porque a doutrina desta país parece já ter se dado conta do quão complexa esta atividade pode ser.

Em segundo lugar, admite-se que a discussão desenvolvida neste tópico pode se distanciar em um primeiro momento do objeto da presente tese. Afinal, o foco aqui reside principalmente nas normas que atribuem competências, ao passo que o estudo comparativo desenvolvido nesta pesquisa considera as normas constitucionais que disciplinam o exercício destas competências. Porém, as conclusões que serão obtidas ao término da investigação

\footnotetext{
970 Nesse sentido, as considerações de Tobias HERBST. Gesetzgebungskompetenzen im Bundesstaat: Eine Rekonstruktion der Rechtsprechung des Bundesverfassungsgerichts. Tübingen: Mohr Siebeck, 2014, p. 109.
} 
desenvolvida neste item colocam-se em uma relação de continuidade com o que foi discutido no sexto capítulo, em especial, no tópico 6.2.2. Tratam-se, portanto, de um debate importante - imprescindível até - para que se complementar as conclusões obtidas até o presente momento.

Em terceiro e último lugar, pretende-se analisar aqui somente questões afetas à interpretação de competências legislativas. Acredita-se que, diante de tudo o que foi exposto até o presente momento, esta seria até uma observação desnecessária. De fato, a subsunção de uma lei e uma norma de competência tem como pressuposto necessário que se esteja diante de uma norma que preveja uma competência legislativa. Contudo, julgou-se oportuna a explicitação desta ressalva, a fim de evitar a extensão das conclusões obtidas neste tópico às competências de execução, o que certamente se mostraria equivocado.

\subsubsection{A questão da interpretação da norma de competência}

A interpretação de uma norma que atribui competências ao Bund ou aos Länder segue, segundo a doutrina alemã, as regras básicas da interpretação constitucional ${ }^{971}$, com

\footnotetext{
971 RENGELING. § 135 Gesetzgebungszuständigkeit. In: ISENSEE, KIRCHHOF (Hrsg.). Handbuch des Staatsrechts, p. 580, DEGENHART. Artikel 70. In: SACHS (Hsrg.). Grundgesetz, p. 1503, ROZEK. Artikel 70. In: von MANGOLDT, KLEIN, STARCK (Hrsg.). Kommentare zum Grundgesetz, p. 1836 e STETTNER. Artikel 70. In: DREIER (Hrsg.). Grundgesetz, p. 1563. Quando a doutrina consultada faz referência às regras básicas de interpretação, ela engloba tanto os métodos tradicionais de interpretação (interpretação gramatical, lógica, sistemática, histórica, genética, comparativa e teleológica) quanto os princípios da interpretação constitucional, como o da unidade da constituição, interpretação conforme a constituição, entre outros (conforme RENGELING. \& 135 Gesetzgebungszuständigkeit. In: ISENSEE, KIRCHHOF (Hrsg.). Handbuch des Staatsrechts, p. 581). Porém, as atenções parecem efetivamente se voltar para os métodos gramatical, histórico e sistemático, na medida em que eles são os métodos que assumem maior destaque na jurisprudência do BVerfG. Ao propor uma análise sistemática da Lei Fundamental, alguns autores recorrem ao princípio da unidade da constituição (nesse sentido, STETTNER. Artikel 70. In: DREIER (Hrsg.). Grundgesetz, p. 1565). Neste tópico preferimos focar nas considerações encontradas na maioria das obras consultadas e não nos deter nos princípios constitucionais de interpretação. Ao tomar esta decisão, a presente tese acolhe as conclusões formuladas por VIRGíLIO AFONSO da Silva no sentido de que tais princípios se assemelhariam muito entre si - o que coloca em xeque a própria razão de sua existência - isso sem mencionar o fato de que parte eles representariam reformulações de cânones tradicionais de interpretação (VIRGÍLIO AFONSO da Silva. Interpretação constitucional e sincretismo metodológico. In: VIRGÍlIO AFONSO da Silva (Org.). Intepretação constitucional. São Paulo: Malheiros, 2005, pp. 121 e ss). Este mesmo autor ainda formula uma crítica bem contundente a respeito da utilização integrada dos métodos, a qual teria conduzido a um verdadeiro sincretismo metodológico: "salvo engano, não há quem opte por esse ou aquele método. Ao contrário: eles são quase sempre apresentados como complementares, falando-se frequentemente em 'conjunto de métodos'. E como a discussão dos métodos costuma ser feita em conjunto com a discussão sobre os princípios acima analisados, o problema do sincretismo somente se agrava" (VIRGÍLIO AFONSO. Interpretação constitucional e sincretismo metodológico, p. 133). Prossegue VIRGÍLIO AFONSO em sua crítica, ao afirmar que "o sincretismo metodológico, característico do atual estágio da discussão sobre interpretação constitucional, impede que se avance na discussão acerca da tarefa da interpretação constitucional (...) Assim, não é de se estranhar que em trabalhos sobre métodos e princípios de interpretação constitucional não costumam ser usados exemplos concretos de sua possível aplicação prática. Não se costuma examinar, por exemplo, quando se fala desse ou daquele método, como seria uma aplicação
} 
algumas especificidades. ${ }^{972}$ Normalmente os trabalhos começam com a interpretação gramatical da regra de competência, ou seja, a interpretação que leva em consideração o conteúdo textual da norma ${ }^{973}$. Trata-se de um método normalmente insuficiente para determinar o sentido de uma norma constitucional - por conseguinte, também de uma competência federativa - em virtude da abertura que lhe é característica, daí a necessidade de complementá-la com outros métodos ou técnicas. Não obstante isto, deve-se reconhecer que o conteúdo textual da norma impõe algumas limitações importantes ao intérprete, mais precisamente: se por um lado ele não é suficiente, por si só, para precisar ou determinar um sentido específico da norma, por outro ele fornece as balizas do que pode ser considerado uma interpretação possível da norma e o que não pode. Com efeito, como ressalta Jochen ROZEK, "por outro lado, é igualmente inadmissível expandir demasiadamente o texto constitucional e dele 'espremer' assertivas que não podem de forma alguma serem abrangidas pelo conteúdo textual do título competencial." 974

Contudo, é o método histórico, dentre os métodos mais tradicionais de interpretação, que assume um destaque especial na jurisprudência do Tribunal

prática de cada um deles. As análises costumam limitar-se a expor a ideia teórica central de cada método. Isto é, obviamente, insuficiente, pois métodos não são um fim em si mesmos, mas existem para serem aplicados" (VIRGÍLIO AFONSO. Interpretação constitucional e sincretismo metodológico, pp. 135-136). Não se pode deixar de reconhecer que neste tópico incorreremos na falha apontada por este autor, pois só contextualizaremos os métodos normalmente mencionados pela doutrina alemã, sem se deter em exemplos de sua aplicação. Porém, esta é uma opção que decorre do fato de que o foco principal aqui não é tratar da interpretação de uma norma de competência e sim da subsunção de uma lei a ela, tema este que será abordado no próximo tópico e com exemplos. Para uma visão crítica dos métodos de interpretação, inclusive com menção a exemplos extraídos da jurisprudência do BVerfG, vide HERBST. Gesetzgebungskompetenzen im Bundesstaat, pp. 20 e ss).

972 STETTNER. Artikel 70. In: DREIER (Hrsg.). Grundgesetz, p. 1563.

973 ROZEK. Artikel 70. In: von MANGOLDT, KLEIN, STARCK (Hrsg.). Kommentare zum Grundgesetz, p. 1836. Rupert STETTNER, em habilitação publicada em 1983, ponderava como o BVerfG fazia referência aos métodos tradicionais de interpretação em bloco, o que, no entender deste autor, representava que este tribunal até aquele presente momento não havia decidido se estes métodos deveriam ser aplicados em uma ordem específica. Até aquele momento, percebia-se apenas uma reserva à interpretação histórico-genética, vale dizer, aquela que leva em consideração a vontade objetiva do legislador (Rupert STETTNER. Grundfragen einer Kompetenzlehre. Berlin: Dunckler \& Humblot, 1983, p. 383). Todavia, este estado de coisas parece ter se alterado com o passar do tempo. Em habilitação publicada em 2014, Tobias HERBST pondera que a interpretação gramatical exerce, no âmbito da jurisprudência do BVerfG, duas funções: em primeiro lugar, ela representa uma primeira aproximação com o sentido da norma; em segundo lugar, ela estabelece os limites às possíveis interpretações da norma (HERBST. Gesetzgebungskompetenzen im Bundesstaat, p. 23). Além do mais, nos comentários consultados afirma-se a importância do método histórico, inclusive com o recurso ao histórico legislativo da norma de competência.

974 ROZEK. Artikel 70. In: von MANGOLDT, KLEIN, STARCK (Hrsg.). Kommentare zum Grundgesetz, p. 1836. No original: "(...) andererseits ist es gleichermassen unzulässig, den Verfassungstext zu überspannen um ihm Aussagen , abzupressen', die vom Wortlaut des Kompetenztitels keinesfalls mehr umfasst sein können". Sobre os problemas metológicos desta função limitante da interpretação gramatical, vide HERBST. Gesetzgebungskompetenzen im Bundesstaat, pp. 24-25. 
Constitucional Federal e, por conseguinte, na doutrina consultada. ${ }^{975}$ Note-se que, na jurisprudência desta corte, este método não se reduz a uma interpretação genética, pois o que se busca efetivamente é compreender a competência em seus contornos atuais por meio do recurso a situações jurídicas anteriores, entre outros instrumentos. A fim de levar a cabo tal empreitada, este tribunal recorre, por exemplo, à compreensão do tema sob a égide da Constituição de Weimar, ou então ao que tradicionalmente se entende por aquela competência. Além do mais, ele também costuma contemplar a evolução constitucional em torno daquele título competencial, inclusive o seu histórico legislativo, e a prática constitucional, vale dizer, como o legislador costuma exercer esta competência em uma perspectiva histórica. ${ }^{976}$ Todavia, é de se admitir que considerações de índole histórica tendem a assumir uma importância maior somente naquelas competências cujas matérias são descritas em termos normativos - é o caso, por exemplo, do Direito Civil, do Direito Penal e assim por diante - ou então em relação àquelas competências que fazem referência a situações da vida, mas que são tradicionais no direito alemão. Quando a norma de competência delimita uma matéria levando em consideração situações fáticas novas, o método histórico acaba por exercer um papel reduzido. ${ }^{977}$

Também assume um papel de destaque na interpretação das competências legislativas o método sistemático. O Tribunal Constitucional Federal alemão formulou algumas proposições interessantes com base em uma análise sistemática do catálogo de competências previsto pela Lei Fundamental, entre elas a possibilidade de estruturar competências em grupos ou então a constatação de uma especial proximidade entre títulos competenciais, como é o caso da competência para legislar sobre "proteção social" e "direito da economia", ambas inseridas na competência concorrente da União e dos Estados. ${ }^{978}$ Porém, neste ponto da exposição, considera-se oportuno chamar a atenção para uma outra consequência deste método de interpretação, mais precisamente, o relacionamento que ele promove entre competências legislativas, direitos fundamentais e outros princípios constitucionais. Como ressalta Rupert STETTNER, as implicações desta relação ainda não

\footnotetext{
975 Nesse sentido ROZEK. In: von MANGOLDT, KLEIN, STARCK (Hrsg.). Kommentare zum Grundgesetz. Artikel 70, p. 1836, STETTNER. Artikel 70. In: DREIER (Hrsg.). Grundgesetz, p. 1564, DENGENHART. Artikel 70, p. 1503 e HERBST. Gesetzgebungskompetenzen im Bundesstaat, p. 29.

976 As presentes considerações sobre o método histórico foram extraídas de ROZEK. Artikel 70. In: von MANGOLDT, KLEIN, STARCK (Hrsg.). Kommentare zum Grundgesetz, pp. 1836-1837 e STETTNER. Artikel 70. In: DREIER (Hrsg.). Grundgesetz, pp. 1564. Para considerações críticas sobre como o BVerfG utiliza o método histórico, vide HERBST. Gesetzgebungskompetenzen im Bundesstaat, pp. 29 e ss.

977 ROZEK. Artikel 70. In: von MANGOLDT, KLEIN, STARCK (Hrsg.). Kommentare zum Grundgesetz, p. 1837. Sobre a descrição fática ou normativa de uma matéria por uma norma de competência, vide nota de rodapé no 968. 978 STETTNER. Artikel 70. In: DREIER (Hrsg.). Grundgesetz, p. 1565 e ROZEK. Artikel 70. In: von MANGOLDT, KLEIN, STARCK (Hrsg.). Kommentare zum Grundgesetz, p. 1838.
} 
estão devidamente esclarecidas, mas não pairam muitas dúvidas de que o método sistemático viabiliza semelhante interação ${ }^{979}$. De todo modo, no que diz respeito aos direitos fundamentais, deve-se admitir com Hans-Werner RENGELING, que se está diante de uma interação recíproca. De um lado, a previsão de uma competência à União ou aos Estados para legislar sobre um direito fundamental - ou mais especificamente, sobre limitações a este direito - dá a entender que estas limitações são, ao menos em tese, possíveis. Por exemplo, a previsão da competência concorrente do Bund e dos Länder para legislar sobre autorização para atuar em carreiras médicas (artigo 74 I Nr. 19 GG) sugere que semelhante restrição ao exercício destas profissões não foi descartada pelo legislador constituinte. ${ }^{980}$ Por outro lado, direitos fundamentais podem impor limitações ao exercício de uma competência ou mesmo determinar a sua obrigatoriedade. Não se pode esquecer, afinal, que competências legislativas são tradicionalmente entendidas como uma autorização conferida ao ente federativo para legislar, sendo que o "se" e o "como" isso se dá permanece, em tese, como decisões discricionárias do legislador. Porém, a necessidade de se garantir determinados direitos fundamentais pode demandar o exercício de uma competência legislativa, muito embora esta necessidade não seja suficiente per se para afirmar a existência de uma competência. ${ }^{981}$

\subsubsection{A questão da qualificação competencial de uma lei}

É, contudo, o debate sobre a qualificação competencial da lei que parece oferecer maiores contribuições para o direito brasileiro. Com efeito, não se identificam na doutrina e na jurisprudência brasileiras grandes preocupações a respeito do enquadramento de uma determinada regulamentação legal a uma competência específica. Não obstante isso, considera-se que este é um momento fundamental da análise da conformidade da atuação legiferante de um ente federativo à constituição, e que não pode ser tratado como uma questão de menor importância dentro da análise da constitucionalidade formal de uma lei.

\footnotetext{
979 STETTNER. Artikel 70. In: DREIER (Hrsg.). Grundgesetz, p. 1560.

980 RENGELING. § 135 Gesetzgebungszuständigkeit. In: ISENSEE, KIRCHHOF (Hrsg.). Handbuch des Staatsrechts, p. 578. Note-se que competências legislativas também podem desencadear efeitos jurídicos materiais, conferindo direitos ou impondo obrigações aos cidadãos alemães. É o caso, por exemplo, da competência privativa da União para legislar sobre o uso de energia nuclear para fins pacíficos, dando a entender que o exercício de atividades que utilizem energia nuclear, obedecida esta finalidade, não é proibido pela Lei Fundamental (conforme STETTNER. Artikel 70. In: DREIER (Hrsg.). Grundgesetz, p. 1560 e ROZEK. Artikel 70. In: von MANGOLDT, KLEIN, STARCK (Hrsg.). Kommentare zum Grundgesetz, p. 1838).

${ }^{981}$ RENGELING. § 135 Gesetzgebungszuständigkeit. In: ISENSEE, KIRCHHOF (Hrsg.). Handbuch des Staatsrechts, p. 579.
} 
Por isso é oportuno retomar o debate alemão sobre o enquadramento competencial de uma lei com maior detalhamento.

Em primeiro lugar, é preciso conceituar esta qualificação como um típico raciocínio de subsunção. Como ressalta Tobias HERBST, a expressão "qualificação" visa somente chamar a atenção para as especificidades da subsunção da lei à norma de competência, tendo em vista que a lei normalmente não fala exatamente a "mesma língua" do título competencial. Com efeito, a lei visa regulamentar situações e comportamentos, ao passo que a norma de competência se preocupa mais com etiquetar estas situações e comportamentos, inserindo-os em determinadas matérias ${ }^{982}$. Em outras palavras, trata-se de uma subsunção diferente por conta da matéria fática que deverá ser subsumida à norma. HERBST afirma que este objeto da subsunção deve consistir na edição de uma lei pelo legislador como um processo mais ou menos fático, e que, como tal, pode indubitavelmente ser reconduzido a uma norma jurídica. ${ }^{983}$ De nossa parte, acreditamos que o que se subsume a uma norma de competência não é propriamente a promulgação de uma lei, mas sim o seu resultado, i. e., a própria lei. Neste contexto, esta última passa a ser considerada simultaneamente um fato - mais precisamente, o produto acabado de uma ação humana e dotado de alta complexidade - e uma norma jurídica, que visa regulamentar ações humanas com finalidades específicas.

Estas considerações, todavia, não resolvem todos os problemas que cercam a subsunção de uma lei a uma competência, muito pelo contrário. Elas consistem apenas no início de uma problemática das mais interessantes. O que efetivamente deve ser levado em consideração na lei para fins de seu enquadramento à norma constitucional? Autores como Peter BADURA entendem que é o objeto da legislação, não a sua finalidade ou seu efeito, e que deve ser utilizado para qualificá-la competencialmente, sendo este um raciocínio que deve sempre ser levado a cabo com base na ênfase, no foco principal da regulamentação ${ }^{984}$. Quanto a este último aspecto, reconhece-se que não poderia ser de outro modo. Afinal, uma regulamentação legal pode tocar muitas matérias - e, consequentemente, muitas competências diferentes - por isso a necessidade de se ater ao núcleo, ao foco da lei que se pretende subsumir. Do contrário, nenhuma qualificação será possível. Porém, no tocante à primeira ponderação de BADURA, é de se admitir que se está diante de um posicionamento minoritário. Com efeito, predomina atualmente o entendimento de que a finalidade da lei (Gesetzeszweck), bem como os seus efeitos (Wirkungen), são os fatores determinantes

\footnotetext{
982 HERBST. Gesetzgebungskompetenzen im Bundesstaat, p. 109.

983 HERBST. Gesetzgebungskompetenzen im Bundesstaat, p. 109.

984 BADURA. Staatsrecht, p. 630.
} 
na subsunção de uma lei a uma competência, muito embora seja possível encontrar menção a outros possíveis critérios. ${ }^{985}$ É o que se costuma denominar de qualificação funcional (funktionelle Qualifikation) da lei.

A afirmação de que a finalidade da lei é o elemento que deve ser levado em consideração no momento de ordená-la em uma competência determinada suscita, por sua vez, quatro questões importantes. Em primeiro lugar, é preciso posicionar a legislação qualificada como ato de vontade - no caso, o ato de vontade objetiva - que promove a “ordenação finalística de áreas determinadas"986. Isto certamente exige uma reformulação da noção de lei que tem sido usado até o presente momento nesta tese; ainda assim, não se trata de algo que traga efetivamente prejuízos ao argumento desenvolvido até o presente momento. De fato, para todas as conclusões obtidas até agora bastava tomar a lei em seu sentido formal, vale dizer, como norma aprovada por meio de um processo legislativo parlamentar. Porém, a partir do momento em que se utiliza a finalidade almejada pela lei para subsumi-la a uma competência específica, é de se admitir que esta finalidade deve necessariamente compor a sua substância e, por conseguinte, o seu conceito. É preciso ressaltar, contudo, que esta finalidade não deve ser necessariamente extraída da lei como um todo e nem de cada um dos seus artigos. Retornaremos esta observação ainda neste tópico, partindo para a análise da segunda questão importante relacionada à qualificação funcional da lei.

Afinal, por que é necessário se apegar à finalidade da lei para promover o seu enquadramento à norma de competência? A fim de responder este questionamento, deve-se reconhecer que as matérias referidas pelas normas de competência não são estanques, mas acabam se relacionando tanto abstrata quanto concretamente. De fato, no mais das vezes estas matérias nada mais são do que simulacros, verdadeiras representações de situações que se apresentam na realidade, sendo que estas últimas se complementam e se interseccionam de forma mais ou menos complexa tanto do ponto de vista social quanto do ponto de vista econômico ${ }^{987}$. Mesmo quando as matérias são descritas em termos normativos-receptivos -

\footnotetext{
985 Nesse sentido, JARASS, PIEROTH. Grundgesetz, p. 801 e STETTNER. Artikel 70. In: DREIER (Hrsg.). Grundgesetz, p. 1566.

986 HERBST. Gesetzgebungskompetenzen im Bundesstaat, p. 120. Deve-se ressaltar que esta noção de lei se encontra intimamente relacionada ao argumento defendido por HERBST em seu trabalho, que consiste em uma habilitação defendida em 2010 na Universidade Humboldt de Berlin. Não se trata, portanto, de uma noção encampada pela doutrina alemã de um modo geral, a qual parece adotar o conceito formal de lei. Como neste tópico se acolhem as sugestões de HERBST no que diz respeito à qualificação competencial da lei, inclusive nas hipóteses de concorrência de competências, considerou-se oportuno acolher também a noção de lei por ele forjada.

987 HERBST. Gesetzgebungskompetenzen im Bundesstaat, p. 110.
} 
quando, por exemplo, a norma de competência faz referência a um ramo codificado do Direito - esta complexidade se apresenta, tendo em vista que elas mediatamente não deixam de incidir sobre situações concretas. Note-se que quanto mais nova ou inédita uma situação, maior será a dificuldade de reconduzi-la a uma competência, em virtude da ausência de casos anteriores que tornem a sua qualificação algo mais confortável. Tal fenômeno ocorre mesmo quando a situação é eminentemente jurídica, por exemplo, a celebração de um contrato. Afinal, trata-se de um negócio jurídico regulamentado pelo Direito Civil, pelo Direito Comercial ou então pelo Direito do Consumidor? Outro exemplo, caso uma lei deseje regulamentar a proteção da intimidade na internet, qual seria o título competencial ao qual tal lei poderia ser subsumida?

Percebe-se, do exposto, que a chance de uma regulamentação legal tocar diferentes matérias, ainda que possua um objetivo bem delimitado, não é baixa. Se estas matérias forem atribuídas a esferas federativas diversas, cria-se então um impasse, pois a afirmação de todas as competências correspondentes conduziria à situação em que um ente é competente, mas ao mesmo tempo não é competente para legislar sobre um determinado assunto. É preciso decidir, pois, quais dos efeitos possíveis de uma regulamentação devem ser utilizados para qualificá-la, e quais efeitos devem ser considerados irrelevantes para tal mister. É nesse sentido que a doutrina e, mais timidamente, também o Tribunal Constitucional Federal, elegem a finalidade da regulamentação legal como o critério determinante para o seu enquadramento competencial ${ }^{988}$, o que implica considerar a própria lei como um ato que necessariamente deve possuir uma finalidade identificável. Porém, como ressalta Tobias HERBST,

\footnotetext{
“(...) nem todos os efeitos pretendidos por uma regulamentação legal realmente ocorrem. Por isso, coloca-se a pergunta de se importa à subsunção de uma regulamentação legal a uma norma de competência o efeito querido ou então o efeito efetivamente provocado pela regulamentação legal. O último não pode, todavia, ser seriamente exigido: a classificação competencial de uma regulamentação legal deve ser possível no momento da sua promulgação, portanto, antes mesmo da existência de conhecimentos empíricos sobre o efeito da regulamentação, e conhecimentos posteriores sobre os reais efeitos não podem conduzir por razões de segurança jurídica a uma troca subsequente de competência legislativa (...).

Mas também a exposição, que é dita pela regulamentação legal, sobre os efeitos almejados não bastam por si só. Caso fosse assim, o legislador estaria livre, com a ajuda de formulações expressas de finalidades conforme uma competência, para editar regulamentações legais, em relação as quais é questionável, se seus efeitos realmente correspondem à finalidade, e que tocam, nos seus reais efeitos, possivelmente matérias competenciais atribuídas a outro nível federativo. A pergunta, se o efeito (esperado) corresponde à finalidade fixada, deve por isso ser respondida no âmbito do possível sob uma perspectiva objetiva (...) Somente
} 988 HERBST. Gesetzgebungskompetenzen im Bundesstaat, pp. 110-111 e também STETTNER. Artikel 70. In:
DREIER (Hrsg.). Grundgesetz, p. 1567. 
avaliações evidentemente errôneas sobre os efeitos esperados de uma regulamentação legal deveriam poder conduzir a uma classificação competencial não dirigida às finalidades fixadas da regulamentação, mas sim aos efeitos reais divergentes dos esperado (sob a perspectiva do observador objetivo)." 989

Ao erigir a finalidade como o critério norteador da qualificação competencial de uma lei, os alemães buscam obter uma única resposta à pergunta de qual competência lastreia constitucionalmente a atividade do legislador. Em outras palavras, eles objetivam enquadrar uma determinada regulamentação legal em um único título competencial. Tal propósito, por sua vez, encontra-se intimamente relacionado com a percepção, bem difundida no meio jurídico alemão, de que uma “'dupla competência' no sentido de que União e Estados podem regulamentar o mesmo objeto de forma diferente, é estranha ao sistema de normas de competências constitucionais e contrariaria a sua função de delimitação" 990 . De fato, competências delimitam por essência - nesse sentido, vide as considerações traçadas no tópico 1.4 - e seria muito frustrante se, após a sua incidência, elas não revelassem uma opção por um destinatário dentre outros possíveis. Além do mais, pressupõe-se que a Lei Fundamental reparte todas as competências entre União e Estados. Mesmo para aquilo que não é expressamente previsto, a constituição alemã contém uma norma de competência, pois neste caso se aplica a regra geral contida no artigo 70 GG. Não se considera compatível com a sistemática estabelecida constitucionalmente na Alemanha que sobrem matérias cuja legislação não é repartida entre União e Estados, tendo em vista que a repartição, como se disse, se dá em termos exaustivos.

\footnotetext{
989 HERBST. Gesetzgebungskompetenzen im Bundesstaat, pp. 111-112. No original: „Allerdings tritt nicht jeder von einer gesetzlichen Regelung intendierte Wirkung auch tatsächlich ein. Es stellt sich daher die Frage, ob es für die Subsumtion einer gesetzlichen Regelung unter eine Kompetenznorm auf die intendierte oder auf die durch die gesetzliche Regelung tatsächlich hervorgerufenen Wirkung ankommt. Letzteres kann aber nicht ernsthaft verlangt werden: Die kompetenzielle Zuordnung einer gesetzlichen Regelung muss zum Zeitpunkt ihres Erlasses möglich sein, also auch schon vor dem Vorliegen empirischer Erkenntnisse über die Wirkung der Regelung, und spätere Erkenntnisse über ihre tatsächliche Wirkung dürfen schon aus Gründen der Rechtssicherheit nicht zu einem nachträglichen Wechsel der Gesetzgebungskompetenzen führen (...) Aber auch die aus der gesetzlichen Regelung sprechende Vorstellung von ihrer beabsichtigten Wirkung genügt für sich genommen nicht. Wäre es so, stünde es dem Gesetzgeber frei, mit Hilfe ausdrücklicher Formulierung kompetenzgerechter Zwecksetzung gesetzliche Regelungen zu erlassen, bei denen es zweifelhaft ist, ob ihre Wirkungen tatsächlich der Zwecksetzung entsprechen, und die in ihren tatsächlichen Wirkungen möglicherweise Kompetenzmaterien berühren, die der anderen föderalen Ebene zugeordnet sind. Die Frage, ob die (erwartete) Wirkung der Zwecksetzung entspricht, muss daher im Rahmen des Möglichen aus einer objektiven Perspektive beantwortet werden (...) Nur offensichtliche Fehleinschätzungen der erwarteten Wirkungen einer gesetzlichen Regelung sollten daher dazu führen können, dass die kompetenzielle Zuordnung sich nicht nach der Zwecksetzung der Regelung, sondern nach den (aus der Sicht des objektiven Beobachters) davon abweichenden tatsächlich zu erwartenden Wirkungen richtet."

990 RENGELING. \& 135 Gesetzgebungszuständigkeit. In: ISENSEE, KIRCHHOF (Hrsg.). Handbuch des Staatsrechts, p. 584. No original: „Eine ,Doppelzuständigkeit' in dem Sinne, dass Bund und Länder denselben Gegenstand in unterschiedlicher Weise regeln können, ist dem System der verfassungsrechtlichen Kompetenznormen fremd und widerspräche ihrer Abgrenzungsfunktion".
} 
Em terceiro lugar, o reconhecimento de que a qualificação competencial deve ser única e se dá com base na finalidade da legislação, objetivamente considerada, produz ao menos uma consequência importante: o ente federativo legiferante torna-se competente para regulamentar inclusive aquelas situações que, em um primeiro momento, recairiam na competência de outro ente, desde que a referida regulamentação se coloque como imprescindível para alcançar a finalidade almejada. Em apertada síntese, o ente federativo torna-se competente em relação àqueles efeitos secundários produzidos pela sua legislação, sendo que neste contexto as competências não-escritas por força do contexto fático e as competências anexas, analisadas no item 5.1, tendem a desempenhar um papel importante, como pondera Hans-Werner RENGELING. ${ }^{991}$ Por outro lado, não é possível afirmar a competência de um ente federativo, seja União ou Estados-membros, quando os efeitos sobre outras competências não puderem ser alinhados à finalidade da legislação por ele editada.

A quarta e última questão diz respeito à extensão da regulamentação legal que deve ser subsumida à norma de competência. Afinal, deve-se promover a qualificação de uma lei como um todo, ou deve-se analisar artigo por artigo? É possível dividir uma lei em partes e enquadrá-las em títulos competenciais distintos? Não existe uma única resposta para estes questionamentos. Em tese, é possível reconduzir toda uma lei, ainda que ela seja extensa, a um único título competencial. É o que ocorre, por exemplo, com ramos codificados do Direito, como o Direito Civil e o Direito Penal. Porém, quando são agrupadas em uma única lei regulamentações de mais de uma matéria, não será mais possível subsumir a lei, como um todo, a uma única competência legislativa. ${ }^{992}$

Já a qualificação competencial de um único dispositivo legal pode se tornar inviável diante da impossibilidade de lhe atribuir uma finalidade específica na ordenação da realidade que ele pretende promover. Tobias HERBST relata um exemplo extraído da jurisprudência do BVerfG que ilustra bem esta situação. Em um determinado momento esta corte teve que apreciar a constitucionalidade de uma lei federal que determinava que a designação "engenheiro" só poderia ser utilizada obedecidos alguns requisitos, em especial, a realização

\footnotetext{
991 RENGELING. § 135 Gesetzgebungszuständigkeit. In: ISENSEE, KIRCHHOF (Hrsg.). Handbuch des Staatsrechts, p. 585. Transcreve-se, a seguir, o trecho citado, em razão da sua importância para o raciocínio desenvolvido a seguir: "Bei der Zuweisung von Gesetzen zu einer Kompetenznorm dürfen die einzelnen Vorschriften eines Gesetzes nicht isoliert betracht werden. Es kommt vielmehr auf den Regelungzusammenhang an. Handelt es sich um eine Teilregelung, die bei isolierter Betrachtung eine Materie darstellt, für die der Bundesgesetzgeber nicht zuständig ist, kann gleichwohl seine Kompetenz zu bejahen sein, wenn sie mit dem kompetenzbegründenden Schwerpunkt der Gesamtregelung derart eng verzahnt ist, dass sie als Teil dieser Gesamtregelung erscheint'. In diesem Zusammenhang kann die Frage nach Kompetenzen kraft Sachzusammenhangs bzw. Annexkompetenzen eine besondere Rolle spielen".

992 HERBST. Gesetzgebungskompetenzen im Bundesstaat, p. 113.
} 
de um ensino superior técnico ou então de uma prova de uma escola de engenharia estatal ou reconhecida pelo Estado. A União sustentava a sua competência para editar semelhante regulamentação com base no artigo $74 \mathrm{Nr} .11 \mathrm{GG}$, o qual prevê a competência da União e dos Estados para legislar concorrentemente sobre "direito da economia". Note-se que este título competencial é bem amplo, abrangendo todos os aspectos da vida e da atividade econômica, inclusive a regulamentação de profissões. Todavia, a corte constitucional alemã entendeu que a regulamentação em questão, isoladamente considerada, não poderia ser entendida como uma regulamentação da profissão "engenheiro"993. Ou como ressalta HERBST,

\begin{abstract}
"esta competência [no caso, a competência concorrente para legislar sobre direito da economia] se estenderia à ordenação jurídica e à fixação de perfis profissionais 'na economia'. Tais regulamentações normatizariam frequentemente também o direito de utilização de respectivas designações profissionais. Contudo, a lei do engenheiro teria se limitado à normatização da designação professional e não regulamentaria nem o conteúdo da atuação profissional do engenheiro, nem um perfil profissional 'engenheiro'. Para a normatização de uma ordenação abrangente da profissão de engenheiro estaria o legislador federal, na visão do Tribunal Constitucional Federal, legitimado; não estaria, contudo, para uma mera normatização da designação profissional. Esta não teria isoladamente 'nenhuma relação com o direito da economia'." 994
\end{abstract}

Note-se que o maior problema da lei federal em comentado, a bem da verdade, foi o fato de que ela era tão diminuta que não foi possível dela extrair a finalidade inequívoca de regulamentar um aspecto do "direito da economia". Com efeito, ela poderia tanto se destinar à regulamentação da profissão de engenheiro quanto do ensino técnico ou superior de engenheiro, hipótese em que os Estados-membros seriam competentes. Trata-se, portanto, de uma legislação que, isoladamente considerada, é multivalente do ponto de vista competencial. Somente a sua inserção em uma legislação maior é que poderia lhe emprestar uma finalidade precisa compatível com a competência inscrita no artigo 74 Nr. 11 GG. ${ }^{995}$

Do exposto, conclui-se que, em princípio, regulamentações legais de um tamanho intermediário podem ser subsumidas mais facilmente a um título competencial, pois delas é

\footnotetext{
993 HERBST. Gesetzgebungskompetenzen im Bundesstaat, p. 115. O julgado em questão pode ser consultado em BVerfGE 26, 246.

${ }^{994}$ HERBST. Gesetzgebungskompetenzen im Bundesstaat, pp. 115-116. No original: „Diese Kompetenz erstrecke sich auch darauf, Berufe, in der Wirtschaft' rechtlich zu ordnen und Berufsbilder zu fixieren. Solche Regelungen normierten oft auch das Recht zur Führung der jeweiligen Berufsbezeichnung. Das Ingenieurgesetz allerdings beschränke sich auf die Normierung der der Berufsbezeichnung und regele weder den Inhalt der beruflichen Tätigkeit des Ingenieurs noch ein Berufsbild "Ingenieur". Zur Normierung einer umfassenden Ordnung des Ingenieurberufes wäre der Bundesgesetzgeber nach Ansicht des Bundesverfassungsgerichts befugt; nicht jedoch zur blossen Normierung der Berufsbezeichung. Diese habe für sich, keinerlei Bezug zum Recht der Wirtschaft".

${ }^{995}$ HERBST. Gesetzgebungskompetenzen im Bundesstaat, p. 116.
} 
possível extrair uma finalidade clara e específica. Neste ponto, acolhe-se a conclusão de Tobias HERBST no sentido de que o objeto da subsunção deve ser "regulamentações que servem à ordenação finalística da matéria respectiva" (Regelungen, die dem zweckhaften Ordnen der jeweiligen Materie $)^{996}$, no caso, a matéria respectiva a uma competência. Deste modo, é a finalidade de regulamentar a matéria prevista pela competência legislativa que delimitará quais normas comporão o objeto da subsunção. Lembrando apenas que este objeto preferencialmente não pode ser muito amplo e nem muito restrito, a fim de viabilizar a identificação de um desígnio único e precípuo.

Ocorre que, mesmo diante das considerações supra, podem surgir na prática situações em que uma mesma regulamentação pode ser enquadrada, segundo a sua finalidade, em mais de uma competência. Na Alemanha esta situação é designada de concorrência de competências legislativas (Konkurrenzen der Gesetzgebungskompetenzen), a qual não se confunde de nenhum modo com a competência legislativa concorrente (konkurrierende Gesetzgebungkompetenz), modalidade regulamentada sobretudo nos artigos 72 e 74 GG, muito embora se admita uma ligação entre estes dois institutos. Com efeito, a competência legislativa concorrente, em especial a competência de divergência, representa uma hipótese de concorrência de competências legislativas prevista e disciplinada pela própria Lei Fundamental ${ }^{997}$. Porém, o que interessa neste ponto da exposição é a concorrência não disciplinada, talvez porque não vislumbrada pelo legislador constituinte alemão, entre duas competências em um caso concreto, em especial quando uma competência pertence ao Bund e a outra competência pertence aos Länder. Colocando a questão de uma forma mais apurada, o fenômeno da concorrência de competências - ou ao menos a concorrência que suscita interesse acadêmico e jurisprudencial - pressupõe que tanto União quanto Estados, lastreados em títulos competenciais distintos, possam regulamentar os mesmos fatos de forma divergente. Em uma situação como esta, aos destinatários das normas federais e estaduais não seria dada a oportunidade de se comportar conforme o Direito ${ }^{998}$. Trata-se, portanto, de uma situação que deve ser evitada, pois ela gera uma insegurança jurídica muito grande. Deve-se, portanto, decidir qual nível federativo é competente para legislar sobre os fatos em questão, declarando a incompetência do outro nível.

\footnotetext{
996 HERBST. Gesetzgebungskompetenzen im Bundesstaat, p. 121.

997 Como é bem ressaltado em Roland WAGNER. Die Konkurrenzen der Gesetzgebungskompetenzen von Bund und Ländern. Berlin: Dunckler \& Humblot, 2011, pp. 132 e 163 e ss.

998 WAGNER. Die Konkurrenzen der Gesetzgebungskompetenzen, p. 134.
} 
O grande problema é que os critérios para tanto se multiplicam. O próprio Tribunal Constitucional Federal alemão emprega diversas fórmulas quando da resolução deste tipo de litígio, como ressalta Tobias HERBST. Nesse sentido, esta corte fala em "finalidade principal" (Hauptzweck), o foco ou a ênfase (Schwerpunkt) da regulamentação, a própria essência (Wesen) da regulamentação, e assim por diante. Porém, trata-se de critérios etéreos, que "apelam finalmente somente para a evidência da atribuição da competência no caso concreto" 999 . No âmbito da doutrina, os critérios tanto para a qualificação competencial quanto para a resolução de concorrência de competências costumam vir combinados. É o que se extrai, por exemplo, das seguintes considerações de Christoph DEGENHART,

\footnotetext{
"A atribuição competencial deve ser efetuada, por conseguinte, de acordo com os seguintes critérios:

- Identidade de conteúdo do objeto imediato da regulamentação com uma regulamentação já constatada da matéria da competência;

- Acréscimo na estrutura normativa da matéria da competência;;

- Identidade da finalidade da lei em uma relação da regulamentação questionada com a norma de competência;

- Acréscimo no desenvolvimento histórico, a tradição de uma matéria;

- Especialidade da regulamentação para o tema da competência, viabilidade do suporte fático dentro da matéria da competência;

- Foco da regulamentação."1000
}

De nossa parte, acreditamos que a proposta formulada por Tobias HERBST no sentido de que o critério aplicável no caso de concorrência é o foco (Schwerpunkt) da regulamentação ${ }^{1001}$, é o que se mostra mais adequado para lidar com a complexidade do problema. Deste modo, caso uma mesma lei ou parte dela finalisticamente ordene matérias referidas por competências diferentes, então deve-se procurar onde reside a ênfase, onde está o foco central da ordenação promovida pela regulamentação. Tal análise, por sua vez, não deve ser conduzida quantitativa, mas qualitativamente, e também de acordo com a parte, também considerada qualitativa e não quantitativamente, que é regulamentada em

\footnotetext{
999 HERBST. Gesetzgebungskompetenzen im Bundesstaat, pp. 161-162.

1000 DEGENHART. Artikel 70. In: SACHS (Hsrg.). Grundgesetz, pp. 1505-1506. No original: „Die kompetenzmässige Zuordnung ist mithin nach folgenden Kriterien vorzunehmen: - inhaltliche Identität des unmittelbaren Gegenstands der Regelung mit einer vorgefundenen Regelung der Kompetenzmaterie; Einfügung in die normative Struktur der Kompetenzmaterie; - Identität des Gesetzeszwecks im Verhältnis der fraglichen Regelung zur Kompetenznorm; - Einfügung in die historische Entwicklung, die Tradition der Materie; - Spezialität der Regelung für das Kompetenzthema, Realisierbarkeit des Tatbestands innerhalb der Kompetenzmaterie; - Schwerpunkt der Regelung". Esta abordagem integrada dos critérios também pode ser observada em ROZEK. Artikel 70. In: von MANGOLDT, KLEIN, STARCK (Hrsg.). Kommentare zum Grundgesetz, pp. 1839 e ss e STETTNER. Artikel 70. In: DREIER (Hrsg.). Grundgesetz, pp. 1566 e ss.

1001 HERBST. Gesetzgebungskompetenzen im Bundesstaat, pp. 137 e ss. Note-se que a filiação desta tese ao critério defendido por este autor coloca-se como natural, em virtude da influência do seu pensamento na elaboração deste tópico, inclusive no que diz respeito à eleição da finalidade como critério norteador da qualificação competencial da lei.
} 
comparação com o total da matéria referida pela competência. ${ }^{1002}$ Reconhece-se que este critério pode parecer tão etéreo quanto os outros apontados anteriormente, mas dele é possível extrair alguns questionamentos que auxiliam na qualificação competencial única de uma regulamentação legal, por exemplo: (i) esta última ordena a matéria prevista pela competência de uma forma típica?; (ii) ela promove uma ordenação da matéria como um todo ou somente de parte dela?; (iii) ela dispõe sobre aspectos centrais da matéria, seus princípios estruturantes, ou trata apenas de aspectos marginais? ${ }^{1003}$

Feitas estas considerações, é oportuno constatar como as considerações supra podem ser utilizadas para resolver alguns litígios competenciais. No começo da vigência da Lei Fundamental, a corte constitucional alemã teve que decidir sobre a constitucionalidade de uma lei estadual que estabelecia um prazo diferenciado de prescrição nos delitos de imprensa. Note-se que, na Alemanha, a imprensa era originalmente prevista como uma competência-moldura da União e a partir de 2006 tornou-se competência exclusiva dos Estados, com base no artigo 70 GG. Já o Direito Penal encontra-se submetido à competência concorrente da União e dos Estados com base no artigo 74 I Nr. 1 GG. A prescrição dos delitos de imprensa, por sua vez, é uma regulamentação que promove uma ordenação finalística tanto da imprensa, eis que visa disciplinar as consequências de determinadas relações desenvolvidas no âmbito do chamado direito de imprensa, e também do Direito Penal, eis que trata de um instituto típico deste ramo do direito. O Tribunal Constitucional Federal, ao se debruçar sobre a questão, reconheceu a competência do Estado para editar semelhante regulamentação ao reconhecer como as especificidades das relações de imprensa podem determinar uma diminuição do prazo prescricional. O foco ou a ênfase da regulamentação residia, portanto, nas relações de imprensa e não no Direito Penal. ${ }^{1004}$

Em outra ocasião, este tribunal alemão teve que apreciar a constitucionalidade de uma lei estadual que regulamentava o direito do membro da imprensa, como testemunha, de permanecer calado. Novamente se estava diante de uma regulamentação que poderia, de acordo com a sua finalidade, ser enquadrada quanto como uma competência estadual para regulamentar relações de imprensa quanto de uma competência concorrente para legislar sobre processo penal, a qual o Bund já tinha exercido quando editou o Código de Processo Penal. Porém, neste caso o BVerfG entendeu que preceitos sobre o direito de uma testemunha de permanecer em silêncio seriam “de acordo com a sua essência, partes

\footnotetext{
1002 HERBST. Gesetzgebungskompetenzen im Bundesstaat, pp. 137-138.

1003 HERBST. Gesetzgebungskompetenzen im Bundesstaat, pp. 137-138.

1004 HERBST. Gesetzgebungskompetenzen im Bundesstaat, pp. 139-141. O julgado em questão pode ser consultado em BVerfGE 7, 29.
} 
integrantes do direito de produção de prova dos regulamentos de processo", entre outras razões, e declarou a legislação estadual em comento inconstitucional. ${ }^{1005}$ Certamente esta decisão parece contradizer o que a corte constitucional alemã havia decidido no que tocante à prescrição dos delitos de imprensa, mas um olhar mais apurado sobre a questão revela o acerto da decisão. Como ressalta HERBST mais uma vez, o decisivo aqui é o fato de que o direito de permanecer em silêncio abrange diversas profissões e representa uma mitigação importante do princípio da verdade real, que informa o processo penal como um todo. Não haveria como reconhecer uma regulamentação isolada para os membros de imprensa sem estabelecer um tratamento desigual em relação às demais profissões que também gozam do direito de permanecer em silêncio e sem alterar substancialmente a ponderação, feita pelo legislador federal, entre o interesse de se manter o sigilo em determinadas profissões e o interesse de reconstruir, no âmbito do processo penal, os fatos o mais próximo possível da verdade. Deste modo, está-se diante de uma regulamentação cuja ênfase reside no processo penal e não nas relações de imprensa. ${ }^{1006}$

Por último, cumpre tecer breves considerações sobre a aplicabilidade do artigo 31 GG, o qual foi objeto de breves comentários no tópico 6.2.1 desta tese. Alguns autores pretendem relegar este artigo a uma posição subsidiária, mais precisamente, quando não é possível, de modo algum, subsumir uma regulamentação a uma competência federal ou estadual. Este é, certamente, o posicionamento de Tobias HERBST ${ }^{1007}$, cujo argumento tem sido encampado neste tópico. Porém, outros autores conferem um maior prestígio ao referido artigo da Lei Fundamental. Christian PESTALOZZA, por exemplo, em um artigo muito citado sobre qualificação competencial de leis em um Estado Federal, defende a solução dos casos de colisão com base nos critérios do "direito especial" (Sonderrecht) e "direito geral" (allgemeines Recht). Deste modo, dever-se-ia reconhecer a competência do Bund no caso de a sua regulamentação representar um direito especial em relação à matéria referida pela norma de competência, ao passo que a competência federal deveria ser negada quando a sua regulamentação representa apenas um direito geral em relação à matéria a que se refere a competência legislativa. Porém, nos casos em que fosse identificada o que ele chama de concorrência ideal de competências - vale dizer, situações em que uma regulamentação representasse "direito especial" tanto em relação a uma competência federal quanto uma

\footnotetext{
1005 HERBST. Gesetzgebungskompetenzen im Bundesstaat, p. 141. O julgado em questão pode ser consultado em BVerfGE 36, 193.

1006 HERBST. Gesetzgebungskompetenzen im Bundesstaat, pp. 143-144.

1007 HERBST. Gesetzgebungskompetenzen im Bundesstaat, pp. 167 e ss.
} 
competência estadual - dever-se-ia aplicar o artigo $31 \mathrm{GG}^{1008}$. Pelo critério da ênfase da ordenação finalística, mesmo nestas situações apontadas por PESTALOZZA seria possível obter uma qualificação competencial única. $\mathrm{O}$ artigo 31 GG seria relegado às regulamentações individuais, das quais nem sempre é possível aplicar extrair uma finalidade inequívoca.

\subsubsection{Alguns apontamentos sobre a interpretação da repartição de competências legislativas e de execução no Brasil}

Feitas estes esclarecimentos acerca da interpretação da norma competencial e da qualificação competencial de leis na Alemanha, parte-se para a análise de como elas podem indicar linhas de evolução interessantes para a resolução de litígios competenciais no Brasil. Para tanto, selecionou-se uma série de casos julgados pelo Supremo Tribunal Federal que envolvem a competência da União para legislar privativamente sobre comércio exterior e interestadual (artigo 22, VIII, CF/88). ${ }^{1009}$

Trata-se de uma competência que tem sido tradicionalmente atribuída à União no Brasil, como se pode constatar do artigo 34, $5^{\circ}$, CF/1891; do artigo $5^{\circ}$, XIX, i, CF/1934; do artigo 16, VII, CF/1937; do artigo 5, XV, k, CF/1946; do artigo 8, XVII, l, CF/1967, e; do artigo 8 , XVII, 1, CF/1967-69. Ao longo dos anos, o Supremo Tribunal Federal teve a chance de julgar e de consolidar o seu entendimento em relação a alguns casos típicos submetidos à sua apreciação e que envolviam a aplicação da competência em comento. O foco desta exposição, por sua vez, reside nos casos em que uma lei estadual que pretende traçar ao menos em tese - parâmetros mais rígidos sobre meio ambiente, proteção à saúde, proteção ao consumidor, que são matérias inseridas em sua competência legislativa concorrente. Porém, os reflexos desta legislação para comércio interestadual e exterior suscitam a dúvida sobre a competência dos Estados para editar semelhante regulamentação.

Não se pretende analisar, portanto, litígios que envolvem o exercício desta competência pela União, embora se admita que eles também podem gerar questões

\footnotetext{
1008 Christian PESTALOZZA. Thesen zur kompetenzrechtlichen Qualifikation von Gesetzen im Bundesstaat. Die Öffentliche Verwaltung (DÖV), ano 25, caderno 6, março/1972, pp. 181 e ss.

1009 A fim de selecionar os acórdãos utilizados neste tópico, digitou-se a chave de busca "comércio adj interestadual" na ferramenta de busca do sítio eletrônico do Supremo Tribunal Federal (http://www.stf.jus.br/portal/jurisprudencia/pesquisarJurisprudencia.asp). A operação retornou 28 resultados, sendo que somente 11 deles guardavam efetivamente tratavam efetivamente de litígios competenciais envolvendo a competência atualmente inscrita no artigo 22, VIII, CF/88.
} 
interessantes sobre os limites da interpretação de um título competencial e sobre o correto enquadramento de uma legislação à norma de competência. Um exemplo bem conhecido desta assertiva, aliás, consiste na utilização, pela União, da chamada cláusula de comércio prevista na Seção 8.3 da Constituição Norte-Americana. Segundo este dispositivo, compete à União "regular o comércio com nações estrangeiras, e entre os diferentes Estados, e com as tribos estrangeiras", possuindo, portanto, uma redação muito parecida com as competências previstas pelas sucessivas constituições brasileiras. Não obstante isso, naquele país esta competência lastreou uma forte centralização legislativa durante o período conhecido como New Deal, o que certamente se deu em detrimento dos Estados-membros. O mais interessante, entretanto, consiste em analisar como isso começou. Quando a Suprema Corte norte-americana ainda se filiava a um paradigma de federalismo dual, ela teve que decidir a constitucionalidade de uma lei federal que proibia o comércio interestadual de produtos de fábricas de utilizavam mão-obra de trabalhadores abaixo de uma determinada idade. Como bem explica Bernard SCHWARTZ, "o objetivo do Congresso, ao aprovar tal lei, era ajudar a abolição do trabalho dos menores, negando os mercados do comércio interestadual àqueles que procuravam tirar proveito dessa exploração" ${ }^{1010}$. Em outras palavras, o objetivo da regulamentação federal era claramente desestimular o trabalho infantil, utilizando o poder de legislar sobre comércio interestadual para atingir tal mister, ainda que para o referido autor, a União tivesse atuado nos estreitos limites da sua competência $^{1011}$. Porém, neste caso a corte norte-americana entendeu pela inconstitucionalidade da legislação em comento. Foram necessários alguns anos para que ela reconhecesse a constitucionalidade da atuação da União, a qual, embora lastreada do poder de regulamentação do comércio interestadual, promovia a bem da verdade uma extensa regulamentação da economia, matéria até então inserida na competência legislativa estadual por força da X Emenda. ${ }^{1012}$

Os casos que serão abordados neste tópico colocam-se em uma relação inversa a esta problemática, pois eles versam sobre leis estaduais que parecem em um primeiro momento se lastrear em competências estaduais, mas que representam uma restrição à competência federal para disciplinar o comércio interestadual. Comecemos pela ADI 3813/RS, na qual se questionava a Lei nº 12.427/2006 do Estado do Rio Grande do Sul, cujo

\footnotetext{
${ }^{1010}$ SCHWARTZ. Direito Constitucional Americano, p. 67. O caso em questão é o Hammer v. Dagenhart, também conhecido como Child Labor Case.

${ }^{1011}$ SCHWARTZ. Direito Constitucional Americano, p. 67.

1012 Esta evolução jurisprudencial foi objeto de breves considerações no terceiro capítulo da tese. Ela também se encontra bem relatada em SCHWARTZ. Direito Constitucional Americano, pp. 208 e ss. VILHENA. Supremo Tribunal Federal, pp. 69 e ss.
} 
artigo $1^{\mathrm{o}}$ proibia a "comercialização, a estocagem e o trânsito de arroz, trigo, feijão, cebola, cevada e aveia e seus derivados importados de outros países, para consumo e comercialização" naquele Estado sem que estes tivessem "sido submetidos à análise de resíduos químicos de agrotóxicos ou de princípios ativos usados, também, na industrialização dos referidos produtos". Conforme se extrai do trecho da exposição de motivos da lei transcrito no acórdão, o objetivo supostamente perseguido pelo legislador estadual era a proteção da saúde humana - para qual ele seria competente em virtude da disposição contida no artigo $24, \mathrm{XII}, \mathrm{CF} / 88$ - representando uma reação à utilização em larga escala de agrotóxicos proibidos pela legislação brasileira nas lavouras da Argentina e do Uruguai. Asseverava-se, contudo, que tal regulamentação representava uma violação da competência privativa da União para legislar sobre comércio exterior (artigo 22, VIII, $\mathrm{CF} / 88$ ), e das competências legislativas concorrentes dos Estados e da União para legislar sobre "produção e consumo" (artigo 24, V, CF/88) e sobre "previdência social, proteção e defesa da saúde" (artigo 24, XII, CF/88). O Ministro Relator Dias Toffoli, em voto que foi acolhido pelos demais ministros, entendeu pela inconstitucionalidade da referida legislação estadual com base nos seguintes argumentos:

\footnotetext{
"De tal sorte, tendo a Lei estadual n ${ }^{\circ}$ 12.452/2006 definindo requisitos próprios e específicos para o ingresso de produtos estrangeiros no Estado do Rio Grande do Sul, invadiu ela, indubitavelmente, competência legislativa privativa outorgada à União pelo art. 22, inciso VIII, da Constituição.

É evidente, por outro lado, que não seria possível compreender a matéria como pertencente ao âmbito legislativo concorrente dos estados-membros, sob o argumento de tratar-se de legislação concernente à proteção da saúde dos consumidores (CF, artigo 24, incisos V e XII, $\S \S 1^{\circ}$ e $2^{\circ}$ ).

Primeiramente, porque, se é verdade que a questão toca, sob certo ponto de vista, em termos de competência concorrente (consumo e proteção à saúde), predominam, na hipótese, os limites da competência privativa da União para legislar sobre comércio exterior e interestadual (...)

Em segundo lugar, porque, ainda que não se tratasse de assunto de competência privativa, há legislação federal sobre o tema (Lei Federal n ${ }^{\circ} 7.802 / 1989$ e Decreto

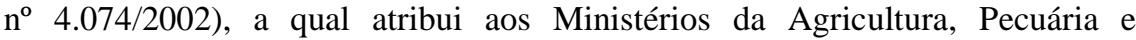
Abastecimento e da Saúde a competência para "monitorar os resíduos de agrotóxicos e afins em produtos de origem vegeral" (art. $3^{\circ}$, Decreto $\mathrm{n}^{\mathrm{o}}$ $4.074 / 2002)$, contrariamente, portanto, às disposições da lei ora impugnada"1013
}

Percebe-se do excerto transcrito que o STF não se dedica a analisar detidamente a qualificação da lei a um título específico. Ao contrário, ele parece considerar todos os efeitos possíveis da norma estadual questionada no momento de promover o seu enquadramento competencial, o que necessariamente significa a afirmação de mais de uma competência à União e aos Estados para regulamentar o caso concreto. Além do mais, a corte opta por uma análise integrada dos objetivos efetivamente propugnados pelo legislador do Estado do Rio

${ }^{1013}$ ADI 3813/RS, Relator Ministro Dias Toffoli, Pleno, julgado em 12/02/2015, pp. 6-7. 
Grande do Sul, da incidência das competências consagradas nos artigos 22, VIII e 24, V e XII, CF/88, e da conformidade da medida com o disposto nos $\S \S 1^{\circ}$ e $2^{\circ}$ do artigo $24 \mathrm{CF} / 88$. Ao término, o que parece efetivamente decidir a questão é a regra de colisão sugerida por Fernanda Dias Menezes de ALMEIDA, segundo a qual uma competência privativa deve prevalecer sobre uma competência legislativa concorrente.

Com a devida vênia, acredita-se que esta multiplicidade de critérios e argumentos serve mais para confundir do que para persuadir sobre o acerto da decisão da corte. Com efeito, o caso em questão comportava uma solução mais simples, principalmente quando se utiliza o critério da finalidade da lei. Ora, o legislador estadual invocou a necessidade de proteger a saúde da população contra o uso de agrotóxicos proibidos para fundamentar a medida questionada. Porém, uma análise mais detida da questão revela que o objetivo declarado não corresponde ao real objetivo da lei gaúcha. Há até uma pretensão de conferir a legislação contornos mais abstratos, ao se estender a proibição a todos os países. Porém, o fato de esta última compreender apenas alguns produtos (arroz, trigo, feijão, cebola, cevada e aveia) revela o viés protecionista da medida. Ora, a proibição de tais produtos não contribui de modo decisivo para a proteção da população, mas representa uma medida de proteção eficiente para alguns produtores agrícolas do Estado. Não se trata, portanto, de se defender a saúde da população, mas sim de estabelecer entraves à entrada e circulação de mercadorias estrangeiras no território gaúcho. O fato destes empecilhos afetarem sobretudo produtos argentinos e uruguaios somente agrava a situação em virtude dos acordos do MERCOSUL. De todo modo, está-se diante de uma legislação que, ainda que não de forma declarada, pretende disciplinar o comércio exterior e interestadual, representando uma usurpação da competência legislativa privativa da União prevista no artigo 22, VIII, CF/88. Deste modo, não há necessidade de se recorrer a um critério doutrinário de colisão de competências, porque efetivamente não se percebe tal colisão. Note-se que o Ministro Relator até tangencia considerações como as traçadas neste parágrafo, mas depois parte para a análise da incidência de competências legislativas concorrentes e das normas contidas nos $\S \S 1^{\circ}$ e $2^{\circ}$ do artigo $24 \mathrm{CF} / 88$.

O segundo exemplo extraído da jurisprudência do STF abrange, na verdade, um grupo de casos nos quais é questionada a constitucionalidade de leis estaduais que estabelecem a obrigatoriedade de informações em rótulos de produtos comercializados em seus respectivos territórios. O primeiro deles é a ADI n ${ }^{\circ}$ 910/RJ, no âmbito da qual se discutiu a constitucionalidade da Lei fluminense $n^{\circ} 2.089 / 1993$, cujo artigo $1^{\circ}$ estabelecia que "as bebidas em geral comercializadas no Estado do Rio de Janeiro deverão conter numeração em seus rótulos, tampinhas ou outra forma, para possibilitar maior controle de 
vendas, para efeito de arrecadação de impostos estaduais”. Estava-se, portanto, diante de uma legislação que pretendia estabelecer uma obrigação tributária acessória - enquadrandose, portanto, na competência legislativa do Estado para legislar sobre direito tributário (artigo 24, I, CF/88) - e que era questionada em face do artigo 22, VIII, CF/88, em virtude dos seus reflexos para o comércio interestadual. O Ministro Relator Maurício Corrêa entendeu que o Estado do Rio de Janeiro, ao estabelecer a obrigatoriedade da numeração inclusive para as bebidas fabricadas fora do seu território, estaria legislando sobre comércio interestadual e exterior. Além do mais, considerou que "existem normas federais em vigor que fixam os dados e informações que devem obrigatoriamente constar dos rótulos de bebidas fabricadas ou comercializadas no território nacional (Lei 8918/1994 e Decreto 2314/1997), o que afasta a possibilidade de atuação residual do Estado-membro quanto ao tema específico, havendo clara extrapolação da competência concorrente a que alude o inciso V do artigo 24 da Constituição Federal" ${ }^{1014}$. Ou seja, segundo o Ministro Relator, em posição que foi acolhida pelo Tribunal Pleno, a atuação do Estado do Rio de Janeiro não estaria respaldada pela competência legislativa concorrente da União e dos Estados para legislar sobre produção e consumo.

O segundo caso, por sua vez, consiste na ADI 3654/PR, ajuizada contra Lei paranaense $\mathrm{n}^{\circ} 14.861 / 2005$, a qual regulamentava o direito à informação assegurado pela Lei $\mathrm{n}^{\circ} 8.078 / 1990$ ao exigir que fosse informada a natureza transgênica do produto que fosse fabricado a partir de organismos geneticamente modificados. Neste caso, os argumentos relativos ao impacto de tal medida para o comércio interestadual ficam quase que subentendidos, pois o debate se centrou na incompatibilidade da lei estadual com o decreto federal que estabelecia a mesma obrigatoriedade somente em relação a produtos que contivessem mais de 1\% de OGM. Não houve, além do mais, uma preocupação com um enquadramento competencial preciso da legislação estadual, como se pode extrair do seguinte trecho do voto da Ministra Relatora Ellen Gracie:

\footnotetext{
"3. Não resta dúvida de que, seja tratando sobre consumo $(\mathrm{CF}$, art. $24, \mathrm{~V})$, seja sobre proteção e defesa da saúde (CF, art. 24, XII), busca o Diploma estadual impugnado inaugurar uma regulamentação paralela e explicitamente contraposta à legislação federal vigente, suprimindo, no âmbito do indispensável dever de informação ao consumidor, a tolerância de até um por cento de transgenia acaso existente no produto ofertado. Esta oposição ao modelo federal foi abertamente declarada nas informações prestadas pelo Governador do Estado do Paraná. Apesar de politicamente legítima tal oposição, não poderia ela se converter em atividade legislativa praticada muito além dos limites impostos pela regra constitucional de competência concorrente suplementar de que dispõem os Estados." 1015
}

\footnotetext{
${ }^{1014}$ ADI 910/RJ, Relator Ministro Maurício Correa, Pleno, julgado em 20/08/2003, p. 182.

${ }^{1015}$ ADI 3.654/PR, Relatora Ministra Ellen Gracie, Tribunal Pleno, julgada em 31/05/2006, p. 382.
} 
O terceiro e último deste bloco é a ADI 2832/PR, na qual se questionava a constitucionalidade de lei paranaense que estabelecia a obrigatoriedade de informação, nas embalagens de café comercializado no Paraná, da porcentagem de cada espécie vegetal que compõe o produto, e também: (ii) a utilização do nome "café" somente para os produtos produzidos a partir das espécies vegetais do gênero Coffea, e; (iii) a obrigatoriedade de constar nas embalagens de todo o café comercializado no Paraná um selo de qualidade emitido pela Associação Paranaense de Cafeicultores. Alegava-se, por um lado, que a referida lei violaria a competência privativa da União para legislar sobre direito comercial (artigo 22, I, CF/88) e sobre comércio interestadual (artigo 22, VIII, CF/88), além de representar uma afronta ao artigo 170, caput e inciso IV e artigo $174 \mathrm{CF} / 88$. Por outro lado, sustentava-se a possibilidade de o Estado do Paraná editar semelhante legislação "uma vez que ela pretende, tão somente, estipular regras claras com vistas à proteção do consumidor" ${ }^{1016}$. O Relator Ministro Ricardo Lewandowski, no que foi acompanhado pelos demais ministros, entendeu que não seria caso de violação da competência legislativa privativa da União inscrita no artigo 22, I e VIII, CF/88, tendo em vista que "o ato normativo impugnado tão-somente visou à proteção ao consumidor, informando sobre as características de produtos comercializados no Estado do Paraná"1017. Ao cabo, apenas declarou a inconstitucionalidade da expressão "seja comercializada no Brasil" contida no artigo $2^{\circ}$ da lei impugnada, a fim que de a norma que dispunha que a expressão "café" fosse utilizada somente para produtos produzidos somente a partir de espécies pertencentes ao gênero Coffea se aplicasse somente ao café oriundo do Paraná.

Três questões importantes podem ser extraídas destes julgados. Em primeiro lugar, os três casos analisados supra envolvem a constitucionalidade de normas que dispõem sobre a obrigatoriedade de informações nos rótulos de produtos. Olhando-os sob esta perspectiva exclusivamente seria possível até afirmar que elas pretendem disciplinar situações fáticas de um mesmo modo, produzindo os mesmos efeitos e se enquadrando nas mesmas matérias. $\mathrm{O}$ próprio Supremo Tribunal Federal parece partir desta premissa, subsumindo todas as legislações estaduais impugnadas à competência legislativa concorrente da União e dos Estados para legislar sobre produção e consumo (artigo 24, V, CF/88). Porém, ao se analisar os casos concretos com uma maior atenção, percebe-se nitidamente que as finalidades perseguidas pelas normas questionadas eram bem diferentes. Na ADI 910/RJ havia uma finalidade de promover uma melhor arrecadação tributária, consoante expresso no próprio texto do artigo $1^{\circ}$ da Lei ${ }^{\circ} 2.089 / 1993$, ainda que se possa questionar a eficácia da medida

\footnotetext{
${ }^{1016}$ ADI 2832/PR, Relator Ministro Ricardo Lawndowski, Tribunal Pleno, julgada em 07/05/2008, p. 176. ${ }^{1017}$ ADI 2832, p. 178.
} 
vis-a-vis o impacto que ela geraria no comércio de bebidas naquele Estado. Por sua vez, na ADI 3654/PR a finalidade parecia residir efetivamente na proteção do consumidor, ainda que se admita que a legislação questionada produz efeitos relevantes no comércio interestadual. Finalmente, na ADI 2832/PR, embora a finalidade declarada pelo legislador estadual seja a de conferir uma proteção adicional ao consumidor, ela parece acobertar uma finalidade real de beneficiar os produtores de café do Estado. Tal objetivo se extrai das normas que negam a denominação "café" a produtos que não se conformem aos padrões estabelecidos pela lei e, sobretudo, pela imposição de um selo de qualidade a ser conferido pela Associação Paranaense de Cafeicultores. Em outras palavras, esta legislação tem o objetivo de conformar e, em alguns casos, de restringir a circulação de produtos fabricados no Estado, mas também oriundos de outros Estados, em uma clara afronta à competência legislativa da União inscrita no artigo 22, VIII, CF/88.

Caso se considere apenas o aspecto textual das legislações que são objeto das ADIs 910/RJ, 3654/PR e 2832/PR pode-se chegar à errônea conclusão de que elas são idênticas. Quando se leva em consideração a sua finalidade, todavia, percebe-se as nuanças de cada uma delas, o que certamente introduz um fator de complexidade, mas também tende a contribuir para decisões mais acertadas. O critério da finalidade da legislação pode trazer, portanto, alguns benefícios importantes para a resolução de litígios que envolvem a repartição de competências legislativas no Brasil.

Em segundo lugar, nos três julgados analisados - e também na ADI 3813/RS, analisada mais acima - percebe-se uma tendência de se promover a qualificação competencial da legislação impugnada com base em todos os seus possíveis efeitos, o que necessariamente conduz a um enquadramento "em bloco". Deste modo, discute-se se a legislação estadual poderia ser subsumida à competência da União para legislar sobre "comércio interestadual", "direito comercial" ou então à competência da União e dos Estados para legislar concorrentemente sobre "produção e consumo", "proteção e defesa da saúde". No caso da ADI 3654/PR, a questão da correta qualificação da norma é quase relegada a uma posição flagrantemente secundária. Conforme consta da ementa do acórdão, "seja dispondo sobre consumo (CF, art. 24, V), seja sobre proteção e defesa da saúde (CF, art. 24, XII), busca o Diploma estadual impugnado inaugurar regulamentação paralela e explicitamente contraposta à legislação federal vigente" ${ }^{1018}$. Ora, ao tratar a questão da qualificação da lei “em bloco", o STF acaba por diluir uma característica fundamental da norma de competência, que é a sua função de delimitação. Como já se teve a 
oportunidade de afirmar em mais de uma oportunidade nesta tese, a competência é uma norma que seleciona uma matéria em detrimento de outras, um destinatário em detrimento de outros. A corte brasileira, ao fazer incidir tanto uma competência legislativa privativa da União quanto uma competência concorrente da União e dos Estadosmembros está a dizer que tanto União quanto Estados-membros são legitimados a atuar no caso. Trata-se de uma decisão e, ao mesmo tempo, de uma não-decisão sobre a competência de um ente federativo para legislar sobre determinada matéria. Neste contexto, passa a definir o litígio submetido à apreciação deste tribunal outra espécie de considerações, tais como a necessidade de se prestigiar o direito à informação do consumidor, ou mesmo a razoabilidade da medida impugnada.

Em terceiro lugar, o STF ainda promove uma análise conjunta da qualificação competencial de uma lei e da aplicação das normas contidas nos $\S \S 1^{\circ}$ a $4^{\circ}$ do $\operatorname{artigo} 24$ $\mathrm{CF} / 88$. É o que ocorre, de todo modo, no julgamento da ADI 3654/PR, que se baseou sobretudo na desconformidade da legislação estadual com o disposto em decreto federal. Acredita-se, contudo, que se está diante de duas questões distintas, sendo que uma questão é prejudicial em relação à outra. Antes de se aprofundar neste argumento, traz-se à apreciação um terceiro caso - na verdade, um terceiro grupo de casos - em que o STF teve que analisar a constitucionalidade de leis estaduais que proibiram a comercialização, o transporte e o trânsito de amianto em seus respectivos territórios. Ao todo, tramitam ou tramitaram nesta corte 5 ações sobre o tema: ADI 2396/MS, ADI 2656/SP, ADI 234/PRMC, ADI 3937/SP e ADI 4066. Neste tópico serão estudadas as decisões proferidas nas ADIs 2396/MS e 2656/SP, que são as únicas decididas, lembrando que o STF pode alterar o seu posicionamento nas ações que ainda se encontram pendentes de julgamento.

Na ADI 2396/MS questionava-se a constitucionalidade de lei estadual que proibia a "fabricação, o ingresso, a comercialização e a estocagem de amianto ou de produtos à base de amianto, destinados à construção civil, no território do Estado do Mato Grosso do Sul”. Já a ADI 2656/SP tinha por objeto lei paulista que estabelecia uma proibição ainda mais abrangente. Com efeito, o artigo $1^{\circ}$ da Lei no 10.813 proibia "a importação, a extração, o beneficiamento, a comercialização, a fabricação e a instalação, no Estado de São Paulo, de produtos ou materiais contendo qualquer tipo de amianto, sob qualquer forma", sendo que o seu artigo $2^{\circ}$ estendia a proibição aos "materiais de fricção e outros materiais automotivos contendo amianto" e o artigo $3^{\circ}$ aos equipamentos de proteção individual e artefatos de uso infantil, materiais escolares e giz de cera. Além do mais, a referida lei estabelecia regras sobre a presença de amianto em ambientes de trabalho no seu artigo $5^{\circ}$, sobre a retirada de amianto de determinados produtos e lugares, e assim por diante. 
Nos dois casos, discutiu-se a qualificação competencial da legislação em blocos. Assim, questionava-se a constitucionalidade da lei por usurpação de competência privativa da União inscrita no artigo 22, I e XII, CF/88. Na ADI 2396 tal argumentação restou afastada, ao passo que na ADI 2656 reconheceu-se que a legislação estadual representava uma invasão à "competência federal para legislar sobre comércio exterior, bem como acerca de minas e recursos minerais, que são bens da União (CF, artigos 20, IX e 22, VIII e XII)." ${ }^{1019}$ Por outro lado, também se discutiu o enquadramento dos atos impugnados em competências legislativas concorrentes. Nesse sentido, asseverou a Ministra Ellen Gracie, relatora da ADI 2396, que "ao determinar a proibição de fabricação, ingresso, comercialização e estocagem de amianto ou de produtos à base de amianto, destinados à construção civil, o Estado do Mato Grosso do Sil excedeu a margem de competência concorrente que lhe é assegurada para legislar sobre produção e consumo (art. 24, V); proteção ao meio ambiente e controle da poluição (art. 24, VI); e proteção e defesa da saúde (art. 24, XII)." ${ }^{1020}$ Na ADI 2656, a questão parece ter se concentrado na competência concorrente inscrita no artigo 24 , V, $\mathrm{CF} / 88$. Porém, o que efetivamente foi decisivo para a declaração da inconstitucionalidade das leis do Mato Grosso do Sul e de São Paulo foi a sua contrariedade com o direito federal, em uma aplicação dos $\S \S 1^{\circ}$ a $4^{\circ}$ do artigo $24 \mathrm{CF} / 88$.

Não se pretende repetir a crítica no que diz respeito ao que se denomina aqui de enquadramento competencial "em bloco", mas sim chamar a atenção para uma outra questão da mais fundamental importância: a aplicação das disposições sobre o exercício da competência legislativa concorrente (artigo $24, \S \S 1^{\circ}$ a $4^{\circ}, \mathrm{CF} / 88$ ) deve ser precedida da recondução, tanto da legislação federal quanto da legislação estadual, a uma mesma competência. Torna-se necessário, portanto, analisar a finalidade perseguida pelas duas legislações. Comecemos pela Lei no 9.055/1995, que trata da questão em âmbito federal. O seu artigo $1^{\circ}$ determina a proibição da "extração, produção, industrialização, utilização e comercialização da actinolita, amosita (asbesto marrom), antofilita, crociodolita (amianto azul) e da tremolita, variedades minerais pertencentes ao grupo dos anfibólios" e também a pulverização e a venda a granel de fibras em pó do amianto crisotila. $\mathrm{O}$ artigo $2^{\circ}$, por sua vez, dispõe que "o asbesto/amianto da variedade crisotila (asbesto branco), do grupo dos minerais das serpentinas, e as demais fibras, naturais e artificiais de qualquer origem, utilizadas para o mesmo fim, serão extraídas, industrializadas, utilizadas e comercializadas em consonância com as disposições desta Lei”, introduzindo, portanto, normas sobre segurança dos trabalhadores nos ambientes em que tal substância é manuseada. Do mesmo

\footnotetext{
1019 ADI 2656/SP, Relator Ministro Maurício Corrêa, Tribunal Pleno, julgada em 08/05/2003, p. 7420.

${ }^{1020}$ ADI 2396/MS, Relatora Ministra Ellen Gracie, Tribunal Pleno, julgada em 08/05/2003, pp. 7224-7225.
} 
artigo $2^{\circ}$ também se extrai, embora não se trate de algo textualmente consagrado, a permissão da utilização do amianto crisotila. Pelo menos é isso que se extrai das considerações do STF sobre a referida norma. Não obstante isso, parece-nos que a Lei n ${ }^{\circ} 9.055 / 1995$ possui duas finalidades distintas e pode, deste modo, ser subsumida a dois títulos competenciais distintos. A primeira finalidade pode ser extraída das normas contidas no artigo $1^{\circ}$ do diploma e consiste em proibir o manuseio, de qualquer tipo, de amianto do tipo anfibólio, em virtude dos seus efeitos cancerígenos sobre o corpo humano. A extração do amianto, como a de qualquer mineral, invariavelmente produz danos ao meio ambiente. Porém, é o reconhecimento dos seus malefícios à saúde humana que tem conduzido à sua proibição em vários países. O amianto crisotila é a única espécie que, supostamente, não produz malefícios, desde que manuseado corretamente e, por isso, ainda é permitido no Brasil. Porém, há quem afirme que ele é tão nocivo quanto as demais modalidades de amianto, razão pela qual se defende atualmente também a sua proibição ${ }^{1021}$. De todo modo, trata-se de uma regulamentação que pode ser reconduzida à competência concorrente da União e dos Estados-membros para legislar sobre "proteção e defesa da saúde". Já os artigos $2^{\circ}$ e seguintes da Lei $n^{\circ}$ 9.055/1995 notadamente contêm regras que visam à proteção dos trabalhadores que lidam com o amianto crisotila - conforme ressaltado, ele não tem efeitos cancerígenas quando manuseado corretamente - sendo subsumíveis, deste modo, à competência legislativa privativa da União para legislar sobre direito do trabalho. ${ }^{1022}$

Já as legislações estaduais, na parte em que elas estendem a proibição contida no artigo $1^{\circ}$ da Lei ${ }^{\circ} 9055 / 1995$ ao amianto crisotila, têm o objetivo de propiciar uma maior proteção à saúde, podendo ser reconduzida também à competência concorrente inscrita no artigo 24, XII, CF/88. Somente após esta dupla subsunção é possível cogitar a aplicação dos parágrafos do artigo $24 \mathrm{CF} / 88$. Nos julgados em comento, o STF entende que a lei estadual deve obedecer estritamente às disposições da legislação federal, por mais específica que esta última seja. Sendo assim, a legislação federal é necessariamente preservada de qualquer alegação quanto à sua constitucionalidade, ao passo que a legislação estadual resta um papel subsidiário, em alguns casos até mesmo despiciendo. Não vamos adentrar aqui nesta questão, mas sim nos deter em um outro aspecto da controvérsia. Com efeito, parece-nos que a legislação estadual neste ponto apenas reforça a legislação federal, criando um padrão de proteção à saúde superior ao estabelecido nacionalmente. Ao se considerar apenas os

\footnotetext{
1021 Nesse sentido, vide René MENDES. Asbesto (amianto) e doença: revisão do conhecimento científico e fundamentação para uma urgente mudança da atual política brasileira sobre a questão. Cadernos de Saúde Pública, Rio de Janeiro, 17 (1), jan./fev. 2001, pp. 7-29.

1022 Neste ponto considera-se a segurança do trabalho como uma parte integrante do ramo do Direito conhecido como Direito do Trabalho.
} 
aspectos textuais das normas confrontadas têm-se, de fato, a impressão de que se está diante de uma contradição. Porém, ao se considerar a finalidades de ambas, enxerga-se uma relação de complementariedade salutar entre a legislação federal e estadual. Não se está diante, assim, de uma violação ao disposto no $\S 1^{\circ}$ do artigo $24 \mathrm{CF} / 88$.

Note-se que tais considerações não afastam quaisquer alegações de inconstitucionalidade das legislações estaduais em comento, principalmente no caso da legislação do Estado de São Paulo. Com efeito, o diploma paulista contém normas que não podem ser inseridas nesta finalidade de proteção à saúde. Por exemplo, o seu artigo $5^{\circ}$, ao determinar a concentração máxima de fibra de amianto por centímetro cúbico nos ambientes de trabalho traça uma regulamentação que se destaca da matéria prevista pelo artigo 24, XII, $\mathrm{CF} / 88$, representando uma típica regulamentação de segurança do trabalho. O mesmo pode se afirmar em relação à regulamentação contida no artigo $6^{\circ}, \S 2^{\circ}$. Em outras palavras, segundo o entendimento aqui esposado, o Estado poderia proibir completamente a utilização de amianto em seu território, mas não estabelecer normas sobre como este material deve ser manuseado em ambientes de trabalho.

Há dúvidas, ademais, sobre a constitucionalidade da legislação paulista, na parte em que esta proíbe a importação de produtos contendo amianto crisotila. Este é, todavia, uma temática que será tratada com o devido aprofundamento a partir do próximo tópico. De todo modo, cumpre apenas ressaltar que todas estas discussões em torno da interpretação da norma competencial e da subsunção de uma lei a ela revelam-se especialmente importantes no caso brasileiro, em virtude de a Constituição Federal de 1988 não prever nenhuma regra geral de colisão. Exatamente por isso a afirmação da existência de leis igualmente válidas e que regulam uma mesma situação fática de forma divergente - é este, afinal, o conceito de colisão federativa de normas, conforme analisado no tópico 6.2.1 - deve ser precedida de todas as tentativas de resolver o conflito federativo por outros meios, tendo em vista que o direito constitucional positivo brasileiro não contém critérios ou disposições gerais para lidar com casos de colisão. A interpretação adequada da norma de competência e a qualificação competencial da lei, por sua vez, consistem em uma boa oportunidade de resolver um litígio competencial em um momento anterior, segundo critérios relativamente seguros, sem que seja preciso afirmar a existência de uma colisão e correr o risco de chegar a uma situação de impasse. 


\subsection{O PRINCÍPIO DA LEALDADE FEDERAL APLICADO À REPARTIÇÃO DE COMPETÊNCIAS}

O princípio da lealdade federal não é completamente estranho aos doutrinadores brasileiros. Todavia, são poucas as tentativas de abordá-lo de um ponto de vista sistemático, considerando suas possíveis implicações para as relações federativas que se desenvolvem no Brasil. Também não é possível encontrar - ao menos, com alguma facilidade - menções a este princípio em manuais e cursos de direito constitucional, ou mesmo em monografias sobre federalismo e sobre federação.

Como a lealdade federal é considerada um dos desdobramentos mais relevantes do princípio do Estado Federal (Bundesstaatsprinzip) acolhido pela Lei Fundamental de $1949^{1023}$, a presente tese não poderia deixar de abordá-la neste estudo comparativo. Optou-se por tratá-la neste sétimo capítulo, dedicado à análise de algumas questões da repartição de competências sob uma perspectiva comparada, pois se acredita que alguns litígios federativos brasileiros poderiam ser melhor equacionados pela sua incidência. Porém, como a lealdade federal possui uma abrangência ampla, considera-se importante restringir a análise a apenas uma das suas concretizações mais importantes, mais precisamente, às limitações que ela impõe ao exercício de competências pelos entes federativos. Portanto, o que se objetiva aqui é somente fornecer uma contribuição para um debate que necessariamente terá lugar, caso a intenção seja aplicar a lealdade federal na sua plenitude, ou mesmo outras concretizações suas, a conflitos federativos brasileiros.

\subsubsection{O princípio da lealdade federal na Alemanha}

Apesar da supramencionada delimitação, considera-se imprescindível expor ao menos as linhas gerais deste instituto no direito alemão. Afinal, o princípio da lealdade federal é reconhecido e aplicado no âmbito de diferentes sistemas federativos ${ }^{1024}$, mas a discussão que se pretende desenvolver aqui considera apenas a vertente alemã deste princípio. É preciso, portanto, explicar as principais características deste instituto no ordenamento jurídico alemão, com especial foco no seu fundamento jurídico, na sua definição e nas suas concretizações mais importantes.

\footnotetext{
1023 Conforme Harmut BAUER. Artikel 20 [Verfassungsprinzipien; Widerstandsrecht]. In: Horst DREIER (Hrsg.). Grundgesetz - Kommentar. Band II: Artikel 20-82. 2a Ed. Tübingen: Mohr Siebeck, 2006, p. 163.

1024 Para uma análise comparativa da lealdade federal na Alemanha, Suíça, Estados Unidos e União Europeia, vide Patrícia EGLI. Die Bundestreue: Eine rechtsvergleichende Untersuchung. Zurique: Dike, 2010.
} 
A ideia de lealdade federal é antiga na Alemanha. Desde a Constituição Imperial de 1871 os doutrinadores já se debruçavam sobre este tema, sendo que tal preocupação também era percebida sob a égide da Constituição de Weimar. ${ }^{1025}$ Não se pretende adentrar em uma análise histórica deste instituto, mesmo porque ela pouco contribuiria para o argumento aqui desenvolvido, preferindo-se concentrar a exposição nas suas implicações na Lei Fundamental de 1949. De todo modo, não se pode deixar de mencionar que foi justamente esta evolução histórica da lealdade federal que fez com que a sua adequação à constituição alemã vigente fosse questionada em um primeiro momento. Nesse sentido, em 1962 Konrad HESSE asseverava a desnecessidade de se recorrer ao referido princípio para a resolução de problemas federativos, chamando a atenção para o fato de que ele teria surgido para conferir alguma racionalidade e harmonizar as particularidades histórico-políticas dos Estados que compunham a federação alemã, representando uma "complementação útil do direito constitucional escrito inevitavelmente incompleto"1026 da Constituição Imperial de 1871. Porém, sob a égide da Lei Fundamental, não haveria como sustentar a existência deste princípio com base nas antigas particularidades histórico-políticas dos Estados-membros, tendo em vista que a constituição alemã teria efetivamente concebido uma ordem federativa completa e ampliada, bem como garantido esta última por meio de uma jurisdição constitucional de feições abrangentes. ${ }^{1027}$ Tal posicionamento encontra-se inclusive reiterado na sua conhecida obra Grundzüge des Verfassungsrechts der Bundesrepublik Deutschland. ${ }^{1028}$ No entanto, acabou prevalecendo o entendimento contrário: a lealdade federal é considerada, afinal, uma importante emanação do Estado Federal e tem sido manejada na resolução de alguns conflitos federativos emblemáticos submetidos à apreciação do Tribunal Constitucional Federal alemão, ainda que a sua fundamentação jurídica e as suas possíveis concretizações permaneçam em discussão. Comecemos pela primeira destas questões.

A existência de um princípio da lealdade federal (Bundestreue) - ou princípio da conduta federativa amistosa (Grundsatz des bundesfreundlichen Verhaltens) ${ }^{1029}$, como

\footnotetext{
1025 Para uma breve análise do princípio da lealdade federal sob a égide das Constituições de 1871 e 1919, vide HOLSTE. Der Deutsche Bundesstaat im Wandel, pp. 152-156 e 314-319. Uma visão mais aprofundada desta evolução histórica pode ser encontrada em Harmut BAUER. Die Bundestreue: Zugleich ein Beitrag zur Dogmatik des Bundesstaatsrechts und zur Rechtsverhältnislehre. Tübingen: J. C. B. Mohr (Paul Siebeck), 1992, pp. 30-102. 1026 HESSE. Der unitarische Bundesstaat, p. 8.

1027 HESSE. Der unitarische Bundesstaat, p. 9.

1028 HESSE. Grundzüge des Verfassungsrechts, p. 117.

1029 No Brasil tem-se preferido a expressão "lealdade federal" ou então "lealdade federativa", muito embora seja possível encontrar referências a um princípio da conta federativa amistosa. Neste sentido, na obra de Luiz Afonso HECK é possível encontrar menção ao "preceito constitucional da conduta amistosa" (Luiz Afonso HECK.
} 
também é conhecido - tem sido fundamentada juridicamente de diversas maneiras ao longo dos anos. Como bem ressalta Harmut BAUER, "o déficit de fundamentação que adere à lealdade federal desde o início reflete-se como antes uma multiplicidade de fundamentações jurídicas, as quais, entre outras, se estendem desde considerações federativas, passando por direito costumeiro, a 'ideia fundamental do § 242 do Código Civil', certas normas isoladas da Lei Fundamental, bem como a proibição de abuso e arbítrio, até a essência do Estado Federal e, em parte alternativa, em parte cumulativamente são chamadas à salvaguarda normativa da conduta federativa amistosa." ${ }^{1030}$ O referido autor entende, com razão, que esta multiplicidade de fundamentações jurídicas é algo que contribui mais para fragilizar o instituto do que para fortalecê-lo, defendendo a necessidade de se fundamentar a lealdade federal de modo inequívoco. Para tanto, ele recorre à ideia de boa-fé objetiva (Treu und Glauben, em uma tradução literal: lealdade e confiança), a qual atualmente se encontra positivada no $§ 242$ do Código Civil alemão, mas que teria, a bem da verdade, a envergadura de um princípio geral do Direito, sendo aplicável, deste modo, ao direito público em geral e, em especial, às relações federativas. ${ }^{1031}$ Tal fundamentação do princípio da lealdade federal é acolhida por parte da doutrina alemã, ao passo que outros preferem tratar deste princípio como uma emanação da própria ideia de Estado Federal, tão somente. ${ }^{1032}$

De nossa parte, acreditamos que o posicionamento da lealdade federal como uma aplicação do princípio da boa-fé objetiva - o qual permeia o ordenamento jurídico alemão como um princípio geral do Direito, ainda que ele seja mais conhecido pela sua positivação no âmbito do Direito Civil - é o mais convincente e também o mais útil. Note-

O Tribunal Constitucional Federal e o desenvolvimento dos princípios constitucionais: contributo para uma compreensão da Jurisdição Constitucional Federal Alemã. Porto Alegre: Sergio Antonio Fabris, 1995, pp. 255 e ss.). Na doutrina alemã, por sua vez, é possível encontrar referências a uma série de expressões, sendo que algumas delas podem ser tomadas como sinônimos, sendo que outras devem ser evitadas. Neste ponto, remete-se à leitura de BAUER. Die Bundestreue, pp. 254 e ss.

1030 BAUER. Die Bundestreue, p. 234. No original: "Die der Bundestreue von Anbeginn anhaftenden Begründungsdefizite sipiegeln sich nämlich nach wie vor in einer Vielzahl unterschliedlicher Rechtsgrundlagen wider, die u. a. von bündischen Überlegungen über Gewohnheitsrecht, den, Grundgedanken des $\S 242$ BGB', bestimmte Einzelnormen des Grundgesetzes sowie das allgemeine Missbrauchs- und Willkürverbot bis hin zum Wesen des Bundesstaates reichen und teils alternativ, teils kumulativ zur normativen Absicherung des bundesfreundlichen Verhaltens herangezogen werden."

1031 BAUER. Die Bundestreue, pp. 234 e 245-248.

1032 Relacionam expressamente lealdade federal e boa-fé objetiva Michael SACHS. Artikel 20 [Verfassungsgrundsätze; Widerstandsrecht]. In: Michael SACHS (Hrsg). Grundegesetz - Kommentar. 7a Ed. Munique: C. H. Beck, 2014, pp. 821-822 e DEGENHART. Staatsrecht I-Staatsorganisationsrecht, p. 191, muito embora estes autores também posicionem a lealdade federal como uma emanação do princípio do Estado Federal. O posicionamento da lealdade federal como uma emanação do princípio do Estado Federal, pura e simplesmente, pode ser encontrado em Karl-Peter SOMMERMANN. Artikel 20. In: Hermann von MANGOLDT, Friedrich KLEIN, Christian STARCK (Hrgs). Kommentare zum Grundgesetz. Band II: Artikel 20-82. 5a Ed. Munique: Franz Vahlen, 2005, p. 19. 
se que não há um problema em fundamentar o dever de um comportamento federativo amigável como um desdobramento típico, ou mesmo como o principal desdobramento da adoção da forma de Estado Federal. Todavia, tal opção não necessariamente atribui um conteúdo específico ao referido princípio, ao contrário do que ocorre quando a fundamentação se dá por meio da ideia de boa-fé objetiva. Neste último caso, a lealdade federativa passa a ser descrita como um dever genérico imposto aos entes federativos de proceder com lealdade em relação aos demais componentes da federação e buscar entendimento mútuo ${ }^{1033}$, e cujo desdobramento abrange inclusive o dever de levar em consideração o interesse dos outros entes federativos no momento de exercer os seus próprios direitos e deveres. A partir desta definição mais geral é possível extrair outros deveres, na grande maioria das vezes deveres acessórios às obrigações e aos encargos previstos pela própria Lei Fundamental - tal como ocorre com a boa-fé objetiva no Direito Civil, aliás. A doutrina alemã costuma tratar destes outros deveres como "concretizações da lealdade federal" (Konkretisierungen der Bundestreue), reunindo-as em grupo de casos, os quais serão objeto de maior detalhamento a seguir.

Antes, contudo, uma observação importante. Uma das características mais marcantes da lealdade federal é justamente a mutabilidade, ou a sua abertura a evoluções (Entwicklungsoffenheit), como se prefere denominar o fenômeno. De todo modo, é importante compreender que esta abertura possui duas consequências importantes, bem apontadas por Harmut BAUER. Por um lado, eventuais agrupamentos ou sistematizações dos desdobramentos da lealdade federal reconhecidos em um determinado momento histórico não podem ser considerados conclusivos, tendo em vista que se está diante de um princípio em constante evolução, sendo que o que era considerado uma concretização importante pode deixar de ser e o que era até um determinado momento considerado irrelevante pode se tornar importante em um momento futuro. Por outro lado, também não é possível elaborar uma lista de todas as possíveis concretizações da lealdade federal, a serem aplicadas a casos concretos vislumbrados e não vislumbrados de antemão. ${ }^{1034}$ Ou seja, estáse diante de um instituto marcado por uma contingência que dificulta generalizações atemporais. Por isso, sistematizações são sempre sujeitas a complementações e correções ao longo do tempo, em virtude da evolução da própria compreensão do alcance da lealdade federal e da sua aplicabilidade a casos concretos.

\footnotetext{
1033 É deste modo que Harmut BAUER delimita este princípio de um modo mais geral em BAUER. Artikel 20, p. 164.

1034 BAUER. Die Bundestreue, p. 315.
} 
Aliás, no âmbito da doutrina é possível encontrar referências a concretizações típicas da conduta federal amistosa. Nesse sentido, Michael SACHS aponta para seu o efeito limitador no exercício de competências, diante da consideração de que competências não podem ser utilizadas de modo egoístico, sem consideração aos assuntos e aos interesses dos outros entes federativos. Além do mais, o referido autor faz menção a obrigações de atuar positivamente, de adotar determinados procedimentos, além de fazer referência a concretizações da lealdade federal na celebração de contratos federativos. ${ }^{1035}$ Porém, não se trata exatamente de uma sistematização. Semelhante proposta pode ser encontrada somente em obras monográficas sobre o tema. Para os fins desta exposição, acolhe-se a proposta de Harmut BAUER de sistematização das concretizações essenciais da lealdade federal ${ }^{1036}$.

Segundo este autor, estes desdobramentos considerados principais, essenciais podem ser agrupados em três grandes grupos, os quais correspondem, por sua vez, a três grandes funções desempenhadas pelo princípio em comento. $O$ primeiro grupo seria formado pelas concretizações que estabelecem deveres aos entes federativos, subdividindo-se em deveres de cinco tipos: (i) deveres de ajuda e de apoio; (ii) deveres de informação e consulta; (iii) deveres de coordenação e de colaboração; (iv) deveres de procedimento, e; (v) outros deveres de conduta. Note-se que, segundo uma visão tradicional, a lealdade federal possuiria necessariamente um caráter acessório em relação a outros direitos e obrigações, não sendo apta para gerar, por si só, deveres aos entes federativos. Porém, em determinadas situações a lealdade federal se desprende deste caráter acessório e funda direitos e obrigações autônomos ${ }^{1037}$, como no caso de alguns dos deveres reunidos neste primeiro grupo ${ }^{1038}$. Feita esta observação, parte-se para uma breve análise de cada um dos deveres contidos neste primeiro grupo.

Os deveres de ajuda e de apoio fundamentam, como o próprio nome sugere, prestações positivas, as quais têm por objeto justamente a ajuda ou o apoio, por parte de um ente federativo, a um outro ente federativo necessitado. Os exemplos mais emblemáticos destes deveres estão no campo da constituição financeira e encontram-se disciplinados, de forma ou menos detalhada, pela própria constituição ${ }^{1039}$. Neste ponto, uma observação

\footnotetext{
1035 SACHS. Artikel 20, pp. 822-823.

1036 BAUER. Die Bundestreue, pp. 341 e ss. Tal proposta encontra-se bem resumida em BAUER. Artikel 20, pp. 166 e ss.

1037 O caráter acessório da lealdade federal é ressaltado por SACHS. Artikel 20, p. 822, SOMMERMANN. Artikel 20, p. 19, JARASS, PIEROTH. Grundgesetz, p. 504. A relativização este caráter em relação a determinadas concretizações do princípio da lealdade federal é defendida por BAUER. Die Bundestreue, pp. 335-336.

1038 Conforme ressalta BAUER. Die Bundestreue, p. 333.

1039 BAUER. Die Bundestreue, pp. 343-344.
} 
importante sobre a repartição de rendas na Alemanha: ao contrário do que ocorre no Brasil, naquele país a compensação financeira entre os entes federativos economicamente mais fortes com aqueles economicamente mais fracos e também a compensação financeira da União com os Estados não é propriamente disciplinada pela própria constituição, mas deixada a cargo do legislador federal. O modo como esta questão é regrada no plano legislativo também sofre o influxo da lealdade federal, mas nos parece que a doutrina alemã se inclina no sentido de considerar a própria ideia de que os entes federativos mais ricos devem auxiliar entes federativos mais pobres deve ser entendida como uma manifestação do princípio em comento. Outros exemplos destes deveres de ajuda e de apoio podem ser visualizados no auxílio jurídico e administrativo previsto no artigo 35 GG, e também no auxílio em caso de catástrofe previsto no mesmo dispositivo constitucional. ${ }^{1040}$ Os deveres de informação e de consulta, por sua vez, encontram-se bem resumidos no seguinte trecho da obra de Harmut BAUER:

\begin{abstract}
"Por informação devem ser entendidas notificações, avisos, informações, referências, etc; e consulta significa consulta comum, reunião, troca de ideias, manter contato e coisas semelhantes. Estes aspectos podem ser resumidos para este efeito, de forma que da lealdade federal decorre um 'dever de informação recíproca sobre propósitos e decisões, que são importantes para outros parceiros federais' e um 'dever de consultação recíproca antes de decisões que podem repercutir particularmente sobre a atuação do parceiro'. Comum a ambas concretizações é que elas não se relacionam a quaisquer eventos, mas somente a aqueles eventos que são especialmente 'dignos de conhecimento', 'significativos' ou 'importantes' para outras partes." 1041
\end{abstract}

Do excerto transcrito acima percebe-se uma relação entre lealdade federal e cooperação federativa ${ }^{1042}$, tendo em vista que consultas recíprocas e reuniões são consideradas instrumentos típicos do federalismo cooperativo, em especial da sua vertente alemã. Este relacionamento torna-se ainda mais próximo quando se analisam os deveres de coordenação e de colaboração. A coordenação, neste contexto, remete à obtenção de uma solução consensuada para problemas e que leve em consideração os interesses de todos os participantes, ao passo que a colaboração se refere a um apoio recíproco, a um trabalho

\footnotetext{
1040 BAUER. Die Bundestreue, p. 345-346.

1041 BAUER. Die Bundestreue, p. 346. No original: „Unter Information sind dabei Benachrichtigungen, Mitteilungen, Auskünfte, Hinweise usw. zu verstehen; und Konsultation bedeutet gemeinsame Beratung, Besprechung, Gedankenaustausch, Kontakthalten und ähnliches. Diese Aspekte können dahingehend zusammengefasst werden, dass aus der Bundestreue eine,Pflicht zu wechselseitiger Information über Vorhaben und Beschlüsse, die für andere, Bundesstaatspartner' wichtig sind', und eine, Pflicht zu wechselseitiger Konsultation vor Entscheidungen, die sich auf die Tätigkeit der Partner besonders auswirken können', folgt. Beiden Konkretisierungen ist gemeinsam, dass sie sich nicht auf jedwedes Vorkommnis beziehen, sondern nur auf solche Vorgänge, die für die anderen Beteiligten besonders ,wissenswert', , bedeutsam 'oder, wichtig' sind. "

1042 Karl-Peter SOMMERMANN afirma, inclusive, haver uma ligação estreita entre lealdade federal e a ideia do federalismo cooperativo, ainda que não entre em maiores detalhes sobre este relacionamento (SOMMERMANN. Artikel 20, p. 21).
} 
conjunto para a concretização de um objetivo comum ${ }^{1043}$. Obviamente, a afirmação destes deveres de forma irrestrita pode trazer prejuízos à diversidade ínsita ao Estado Federal, pois nesse contexto os Estados estariam sempre obrigados a uniformizar a sua atuação, mesmo naqueles campos em que uma ação autônoma e independente seria possível ou mesmo esperada. Por isso, defende BAUER que estes deveres devem ser aplicados em um conjunto específico de casos, por exemplo, problemas ou circunstâncias fáticas que não podem ser lidados por um ente federativo sem atingir interesses de outros componentes da federação, ou então quando um ente federativo depende da colaboração de outro. ${ }^{1044}$

Da lealdade federal também é possível extrair deveres de proceder de um determinado modo durante negociações com outros entes federativos. Nesse sentido, já decidiu o Tribunal Constitucional Federal, como bem ressalta Luís Afonso HECK, que ao Governo Federal é vedado, em negociações que devam abranger todos os Estados, tratar "de modo diferenciado os governos estaduais, de acordo com a sua orientação político-partidária, sobretudo, que convide para as suas deliberações politicamente decisivas tão-só representantes dos governos estaduais que lhe estão próximos no plano político-partidário e exclua, disso, os governos estaduais que estão próximos da oposição na Federação." 1045 Ao Bund também são impostos deveres de proceder, sobretudo um dever de oitiva do Estadomembro no caso de aquele exercer o seu direito de dar instruções no âmbito da administração estadual de leis federais sob as ordens do Bund (artigo 85 GG), ainda que não se possa extrair deste direito um dever de harmonização ou de forjar um consenso sobre questões fáticas controvertidas. ${ }^{1046}$ Finalmente, há outras obrigações que decorrem da conduta federal amistosa, embora não formem um grupo específico. Entre eles estão o dever de a União proteger os Estados nas relações com outros Estados Nacionais e também no âmbito da União Europeia. ${ }^{1047}$

O segundo grupo de concretizações fundamentais da lealdade federal é composto por limitações ao exercício de direitos. Note-se que se está diante dos desdobramentos que costumam ser mencionados com maior frequência por aqueles que se ocupam deste princípio, sendo que eles podem ser de dois tipos. Em primeiro lugar, a lealdade federal

\footnotetext{
1043 BAUER. Die Bundestreue, p. 349

1044 BAUER. Die Bundestreue, pp. 350-351.

1045 HECK. O Tribunal Constitucional Federal e o desenvolvimento dos princípios constitucionais, p. 258. Entendimento semelhante pode ser encontrado em BAUER. Die Bundestreue, p. 353, sendo que ambos refletem o posicionamento da corte constitucional alemã proferido no BVerfGE 12, 205.

1046 BAUER. Die Bundestreue, p. 354. Esta concretização da lealdade federal também é abordada em SOMMERMANN. Artigo 20, p. 20.

1047 BAUER. Die Bundestreue, pp. 354-355.
} 
pode ensejar limitações ao exercício de direitos, aplicando-se inclusive ao exercício de competências. Nesse sentido, aliás, é que se costuma falar que este princípio pode atuar como barreira ao exercício de competências (Kompetenzausübungsschranke). Como bem ressalta Michael SACHS, "competências não devem ser utilizadas de um modo egoísta, ao contrário deve-se levar em consideração interesses dos outros participantes e da totalidade, sob certas circunstâncias renunciar aos próprios objetivos"1048. Porém, não se pode esquecer que se está diante de limitações a direitos de um modo geral, o que certamente abrange competências, mas também outros direitos conferidos pela Lei Fundamental. ${ }^{1049}$ Em segundo lugar, a lealdade federal também se desdobra em uma proibição de comportamento contraditório, em uma clara manifestação do brocardo venire contra factum proprium. Deste modo, o exercício de um direito pode ser tornar proibido, caso ele se coloque em contrariedade com o comportamento anterior do ente federativo que é titular deste direito, muito embora não se trate de uma concretização que tenha sido objeto de apreciação do Tribunal Constitucional Federal alemão. ${ }^{1050}$

Finalmente, o terceiro grupo de manifestações do comportamento federal amistoso compreende algumas regras adicionais para a celebração de contratos federativos, entre elas as ideias de pacta sunt servanda e de rec sic standibus ${ }^{1051}$. Porém, há quem entenda que o pacta sunt servanda não necessita ser fundamentado na ideia de lealdade federal, ao contrário do que ocorre com a cláusula de rec sic standibus. ${ }^{1052}$

\subsubsection{O princípio da lealdade federal e suas implicações para o exercício de competências legislativas}

Desta breve exposição do conteúdo e das aplicações da lealdade federal pode-se concluir que se está diante de um princípio abrangente, que permeia, de forma explícita ou subjacente, grande parte ou mesmo a totalidade das relações federativas. Porém, o que interessa aqui são as suas implicações para o exercício de competências legislativas. Estas, por sua vez, normalmente envolvem uma limitação de direito, embora seja possível cogitar que o exercício de uma competência também possa ser conformado por alguns deveres

\footnotetext{
1048 SACHS. Artikel 20, p. 822. No original: „Kompetenzen sind nicht in egoistischer Weise zu gebrauchen, vielmehr ist Rücksicht auf Belange der anderes Beteiligten und der Gesamtheit zu nehmen, u. U. auf eigene Ziele zu verzichten".

1049 Nesse sentido, BAUER. Die Bundestreue, p. 356.

1050 BAUER. Die Bundestreue, p. 358.

1051 BAUER. Die Bundestreue, pp. 359 e ss.

1052 SACHS. Artikel 20, p. 823.
} 
positivos de conduta federativa amistosa. Ou seja, o que se pretende analisar a partir deste momento são as concretizações da lealdade federal que fornecem uma barreira ao exercício de competências. E como este item pretende ser uma continuação do que foi trabalhado no tópico 7.1, restringe-se a análise às competências legislativas. Para tanto, considera-se oportuno retomar algumas considerações feitas neste tópico.

Naquela ocasião se ressaltou a importância de se discutir como enquadrar uma determinada regulamentação legal em um título competencial. Na Alemanha, não se nota propriamente um consenso acerca do tema, embora tenha prevalecido nos últimos anos a ideia de qualificação funcional, vale dizer, a qualificação com base na finalidade perseguida pelo legislador e nos seus potenciais efeitos. Além do mais, ponderou-se sobre a necessidade de se reconduzir uma regulamentação legal a uma competência legislativa específica, ainda que esta regulamentação possua desdobramentos em outras matérias, referidas por outras competências legislativas. Em casos mais difíceis, uma lei pode promover uma ordenação que, finalisticamente, possa ser subsumida a duas ou mais competências legislativas, de titularidade de entes federativos diversos, em uma situação que se convenciona denominar de concorrência de competências. Nestes casos, propugnou-se pela aplicação do critério da ênfase da ordenação finalística, a fim de determinar a qual competência tal regulamentação legal será subsumida.

Porém, tais considerações não afastam todos os problemas que envolvem a afirmação da competência de um ente federativo para legislar sobre determinados fatos e relações jurídicas de um determinado modo. Como ressalta Tobias HERBST, o fato de se qualificar competencialmente uma lei com base na ênfase na ordenação finalística não significa que os seus efeitos passam a se restringir ao campo delimitado pela norma de competência. Ao contrário, uma transcendência de efeitos para outras matérias é normal e levada em conta pela Lei Fundamental ${ }^{1053}$. Note-se que esta transcendência pode se dar em diversos graus:

\footnotetext{
"Então ele [o efeito transcendente] pode se tratar de um efeito colateral não pretendido de pouca dimensão, que somente toca o campo alheio e não tem nenhuma consequência para a competência legislativa; ele pode se tratar de uma ordenação finalística do campo alheio, o qual, contudo, é secundário diante da ordenação finalística do próprio campo; e finalmente, a ordenação finalística do campo alheio pode até mesmo estar em primeiro plano."1054
}

\footnotetext{
1053 HERBST. Gesetzgebungskompetenzen im Bundesstaat, p. 286.

1054 HERBST. Gesetzgebungskompetenzen im Bundesstaat, p. 286. No original: „So kann es sich um eine unbeabsichtigte Nebenwirkung von geringerem Ausmaß handeln, die den fremden Sachbereich nur berührt und keine Folgen für die Gesetzgebungskompetenz hat; es kann sich um ein zweckhaftes Ordnen des fremden Sachbereichs handeln, das gegenüber dem zweckhaften Ordnen des eigenen Sachbereichs allerdings
} 
Por óbvio que este último cenário tem como resultado, segundo o critério proposto pelo referido autor e encampado por esta tese, o reconhecimento da incompetência do ente federativo para legislar sobre o referido tema. Nos demais casos, deve-se afirmar a competência do ente federativo legiferante. ${ }^{1055}$

Entretanto, é de se admitir que, em alguns casos, ainda que se admita a competência legislativa de um ente federativo para disciplinar uma determinada situação da vida, os efeitos desta regulamentação sobre os interesses e direitos dos demais entes federativos são relevantes demais para serem ignorados, ou então considerados como uma mera consequência da afirmação de uma competência legislativa em relação a um caso concreto. Competências legislativas não são, afinal, poderes a serem exercidos irrestritamente. Por isso, doutrina e jurisprudência alemãs afirmam a possibilidade de se impor barreiras ao exercício de competências, de um modo geral, e de competências legislativas, em particular. A lealdade federal fornece, por sua vez, apenas algumas destas barreiras. São importantes, mas não são as únicas é sempre bom frisar. Seja como for, diante de uma barreira ao exercício de uma competência legislativa, afirma-se a competência do ente federativo para legislar, porém se considera inadmissível a regulamentação resultante do exercício desta competência, diante dos seus efeitos. ${ }^{1056}$

Pois bem. Já se afirmou em mais de uma oportunidade que a lealdade federal impõe aos entes federativos o dever de levar em consideração os interesses dos demais no exercício dos seus poderes e direitos. Trata-se de uma relação recíproca, por meio da qual se impõe que os entes federativos considerem os interesses e os direitos uns dos outros. Esta assertiva, por sua vez, deve ser ponderada com o fato de que o exercício de um poder ou direito por parte de um ente federativo frequentemente possui desdobramentos em matérias inseridas na competência de outros entes federativos, como se teve a oportunidade de ressaltar neste tópico. Estes desdobramentos são no mais das vezes inexoráveis, ainda mais quando se está

zweitrangig ist; und schließlich kann das zweckhafte Ordnen des fremden Sachbereichs sogar im Vordergrund stehen."

1055 HERBST. Gesetzgebungskompetenzen im Bundesstaat, pp. 286-287. Interessante atentar para as considerações deste autor a esse respeito, transcritas no original: "Soweit der fremde Sachbereich durch die Regelungseinheit zweckhaft geordnet wird, kann die Regelungseinheit auch unter die Kompetenznorm subsumiert werden, die den fremden Sachbereich der anderen föderalen Ebene zugeordnet. Die entstehende Kompetenzkonkurrenz ist, wie ober ausgeführt, mit Hilfe des Kriteriums des Ordnungsschwerpunkts aufzulösen. Liegt dieser im fremden Sachbereich, dann hat die andere föderale Ebene die (alleinige) Gesetzgebungskompetenz für die Regelungseinheit; mangels eigener Kompetenz darf der Gesetzgeber eine derart hinüberwirkende Regelungseinheit nicht erlassen. Liegt jedoch der Ordnungsschwerpunkt im eigenen Sachbereich, dann hat der Gesetzgeber die Kompetenz zum Erlass der hinüberwirkenden Regelungseinheit. "

1056 É o que se extrai de HERBST. Gesetzgebungskompetenzen im Bundesstaat, pp. 286-287. 
diante do exercício de uma competência legislativa, e, por isso, não devem ser hostilizados em um primeiro momento. Os problemas surgem quando os efeitos colaterais de um ato no caso em comento, de um ato legislativo - produzem efeitos tais que efetivamente prejudiquem o exercício de poderes e direitos de outros entes federativos. A questão da viabilidade ou da inviabilidade de uma regulamentação legal reside, deste modo, na intensidade em que interesses alheios são atingidos.

No âmbito da doutrina, é possível encontrar formulações - neste ponto, retomando ou comentando decisões do BVerfG - no sentido de que o exercício de uma competência somente atenta contra a lealdade federal quando ele é abusivo (missbräuchlich) ${ }^{1057}$. Neste ponto, a corte constitucional adota um limiar de relevância (Erheblickeitsschwelle), como bem ressalta Harmut BAUER. Deste modo, a aplicação do referido princípio se daria apenas em situações excepcionais. Estas, por sua vez, se dariam quando "o titular do direito não persegue interesses autorizados ou quando interesses preponderantes dos outros participantes se contraponham e o exercício do direito poderia conduzir a uma grave perturbação da estrutura federativa" ${ }^{\text {1058. }}$. Já Tobias HERBST, em entendimento aplicável exclusivamente ao exercício de competências legislativas, defende que a ingerência de um ente federativo nos interesses de outro se coloca em contrariedade com o princípio da conduta federal amistosa quando a legislação anteriormente editada pelo outro ente se torna ineficaz na prática e, portanto, a ordenação finalística do campo delimitado pela norma de competência resta inviabilizada ${ }^{1059}$. Ou nos dizeres do referido autor:

"Uma tal influência tiraria dos outros níveis federativos (...) a possibilidade de
fazer uso da sua competência legislativa com a finalidade pretendida de forma útil
e, nesse sentido, seria uma limitação do outro nível não aceitável do ponto de vista
da lealdade federal; neste caso a fronteira do abuso seria de todo modo excedida.
Do que foi dito anteriormente resta claro que fundamentalmente uma violação da
lealdade federal enquanto barreira ao exercício de competência só vem à
consideração, se o outro nível federativo já efetuou uma regulamentação no campo
questionado. Caso não seja constatado que o outro nível federativo conformou
uma matéria, então não pode ser afirmado que tipo de consideração a lealdade
federal exige. A lealdade federal como barreira ao exercício de competência não
obriga a uma contenção legislativa, de forma que esteja aberto aos outros níveis
federativos todas as possibilidades de conformação do campo que lhe compete.
Que isso depende, de acordo com este entendimento da lealdade federativa como
barreira ao exercício de competência, da sucessão temporal de normatizações, em
que a regulamentação anterior tem um tipo de prevalência, não representa uma
quebra da ordenação de competências da Lei Fundamental, porque as barreiras ao

\footnotetext{
1057 Nesse sentido, HERBST. Gesetzgebungskompetenzen im Bundesstaat, p. 288 e BAUER. Die Bundestreue, p. 357.

1058 BAUER. Die Bundestreue, p. 357, lembrando que o autor neste ponto se refere às limitações impostas pela lealdade federal ao exercício de direitos de um modo geral, e não propriamente ao exercício de competências legislativas.

1059 HERBST. Gesetzgebungskompetenzen im Bundesstaat, pp. 289-290.
} 
exercício de competência, enquanto normas de comportamento, não são parte integrante da ordenação de competências."1060

Feitas estas considerações parte-se para o estudo das possíveis aplicações do princípio da lealdade federal no Brasil, com especial foco na repartição de competências legislativas, no item a seguir.

\subsubsection{Aplicações do princípio da lealdade federal no Brasil}

A afirmação da vigência de uma lealdade federal no ordenamento jurídico brasileiro certamente traz algumas vantagens, as quais serão brevemente mencionadas neste tópico. Antes, contudo, é preciso analisar se o modo pelo qual este princípio é fundamentado juridicamente na Alemanha também encontra respaldo no Brasil.

Viu-se que, naquele país, a conduta federal amistosa encontra seu fundamento na boa-fé objetiva, ou princípio da lealdade e confiança (Treu und Glauben), como este princípio também costuma ser denominado. Embora positivado expressamente no $§ 242$ do Código Civil alemão, há quem entenda - nesse sentido, a presente tese chamou a atenção para o argumento desenvolvido por Harmut BAUER - que a boa-fé assume na Alemanha a envergadura de um princípio geral do Direito, e como tal, aplicável também às relações federativas. No Brasil, as discussões em torno da boa-fé objetiva têm se dado sobretudo no âmbito do Direito Civil e têm se expandido para o Direito Privado como um todo, em virtude tanto da sua positivação nos artigos 113 e 422, dentre outros, do Código Civil de 2002 quanto do influxo de obras importantes como a de António MENEZES CORDEIRO ${ }^{1061}$. Não se percebem esforços em erigir o pensamento central destas disposições da legislação civil a verdadeiro princípio geral do ordenamento jurídico brasileiro, embora tal raciocínio seja

\footnotetext{
1060 HERBST. Gesetzgebungskompetenzen im Bundesstaat, p. 290. No original: „Eine solche Einwirkung würde der anderen föderalen Ebene (...) im Nachhinein die Möglichkeit nehmen, von ihrer Gesetzgebungskompetenz mit der beabsichtigten Zwecksetzung sinnvoll Gebrauch zu machen und wäre insoweit eine unter dem Gesichtspunkt der Bundestreue nicht hinzunehmende Einschränkung der anderen Ebene; in diesem Fall wäre die Missbrauchsgrenze jedenfalls überschritten. Aus dem zuvor Gesagten wird deutlich, dass grundsätzlich ein Verstoß gegen die Bundestreue als Kompetenzausübungsschranke nur dann in Betracht kommt, wenn die andere föderale Ebene in dem fraglichen Sachbereich bereits eine Regelung vorgenommen hat. Lässt sich nicht feststellen, wie die andere föderale Ebene eine Materie gestaltet, dann kann auch nicht gesagt werden, welche Art von Rücksichtnahme die Bundestreue verlangt. Die Bundestreue als Kompetenzausübungsschranke verpflichtet nicht zu einer solchen gesetzgeberischen Zurückhaltung, dass der anderes föderalen Ebene alle denkbaren Gestaltungsmöglichkeiten des ihr zustehenden Sachbereichs offengehalten werden. Dass es bei diesem Verständnis der Bundestreue als Kompetenzausübungsschranke auf die seitliche Abfolge der Normsetzungen auf den beiden föderalen Ebenen ankommt, wobei die frühere Regelung eine Art Vorrang hat, stellt keinen Brauch in der Kompetenzordnung des Grundgesetzes dar, weil die Kompetenzausübungsschranken als Verhaltensnormen kein Bestandteil der Kompetenzordnung sind."

${ }^{1061}$ Neste ponto, refere-se especificamente à seguinte obra: António MENEZES CORDEIRO. Da boa fé no Direito Civil. Coimbra: Almedina, 2013.
} 
possível, ao menos em tese. Afinal, se está diante de uma ideia que não se restringe ao Direito Privado e que encontra expressão em outros ramos do direito, inclusive no Direito Público. Nesse sentido, Maria Sylvia Zanella DI PIETRO assevera que o princípio da boa-fé começou a ser aplicado no direito administrativo brasileiro mesmo antes da sua positivação - com efeito, ele encontra previsão atualmente na lei federal de processo administrativo (Lei $\mathrm{n}^{\mathrm{o}}$ 9.784/1999) - decorrendo de outros princípios constitucionais, “especialmente do princípio da moralidade administrativa e da própria exigência de probidade administrativa que decorre de vários dispositivos constitucionais". ${ }^{1062}$ Seguindo a mesma linha de argumentação, acredita-se que a sua aplicação ao direito constitucional, em especial ao Estado Federal, não se afigura exatamente problemática. Isso só ocorreria sob um paradigma de federalismo dual, em que Estados e União competem entre si. Porém, com o advento do federalismo cooperativo, a ideia de que União e Estados devem considerar os interesses uns dos outros, além de se coordenar em torno de interesses comuns, não é exatamente estranha. Ao contrário, parece ínsito à noção de cooperação federativa o diálogo, a consideração recíproca de interesses, a renúncia de interesses egoísticos em prol de soluções coordenadas, os quais constituem, por sua vez, concretizações típicas da lealdade federal. Por este motivo, não há por que se contrapor à afirmação de que este princípio também pode informar as relações desenvolvida no âmbito do Estado Federal brasileiro. Isso posto, parte-se para a análise de suas possíveis aplicações.

De um ponto de vista mais geral, é possível afirmar que a lealdade federal seria um instituto jurídico útil para lidar com a intensa competição que marca as relações federativas brasileiras. É verdade que há tentativas por parte da União de obter a cooperação das unidades territoriais em determinadas políticas públicas. Porém, este é um esforço que se dá setorialmente, e tem o seu sucesso condicionado a uma série de fatores, entre eles a necessidade de financiamento federal para a execução de programas pelos Estados e pelos Municípios, como se teve a oportunidade de analisar no terceiro capítulo desta tese. Já o princípio da conduta federal amistosa teria um escopo mais geral, impondo deveres de consulta, de informação, e, em alguns casos, de colaboração, às relações federativas como um todo. Obviamente, não se afirma aqui que a coordenação federativa poderia prescindir dos mecanismos analisados no item 3.2.3, mas apenas que o princípio em comento poderia consistir em um arcabouço normativo importante para fomentar esta coordenação setorial. Além do mais, a ideia de lealdade federal poderia impor a realização de alguns atos preparatórios à coordenação - como, por exemplo, a troca de informações, as comunicações

1062 Maria Sylvia Zanella DI PIETRO. Direito Administrativo. 25a Ed. São Paulo: Atlas, 2012, p. 88. 
acerca de propósitos, as reuniões para tratar de problemas comuns - para áreas em que ela ainda é incipiente.

De um ponto de vista técnico-jurídico, a lealdade federal seria um instituto mais adequado para reunir e fundamentar uma série de deveres e direitos atualmente agrupados sob o rótulo de um compromisso constitucional de cooperação e outras fórmulas parecidas. Estes últimos foram tratados brevemente no tópico 1.2.3 e foram retomados em outras partes desta tese, sobretudo quando da análise do federalismo brasileiro. Com isso não se pretende exatamente declarar a inutilidade ou a inconveniência destas construções teóricas, ou mesmo a sua incompatibilidade com a ideia de lealdade federal. Neste sentido, a própria Alessandra SILVEIRA, que defende a existência de um compromisso constitucional de cooperação em Estados compostos, inclusive no Estado Federal brasileiro, também dedica páginas de sua obra à análise do que ela chama de leal cooperação, que nada mais é do que uma outra denominação do princípio da conduta federal amistosa. ${ }^{1063}$ A referida autora traça, inclusive uma ligação entre os dois institutos no seguinte trecho:

\begin{abstract}
“Ainda que a Constituição de um Estado composto não o refira expressamente, o compromisso cooperativo é sempre inferível da teleologia da regulamentação constitucional num ordenamento composto, pois para que o sistema político funcione minimamente, os governos constituídos se hão-de abster de qualquer medida susceptível de pôr causa os objectivos constitucionalmente acordados, isto é, não podem perturbar nem furtar-se a ajudar. Será precisamente ao serviço da dimensão passiva do compromisso constitucional de cooperação (é possível obrigar a cooperar passivamente, mas já não é possível obrigar a cooperar activamente, pois a cooperação activa requer atores empenhados em acções concertadas), que se formulará o princípio da lealdade federal ou leal cooperação, tendente a corrigir os eventuais descompassos da distribuição de competências e optimizar a partilha de responsabilidades prestacionais.

Diz-se que o princípio da leal cooperação evoca os estratos mais profundos do edifício constitucional dos Estados compostos: impõe uma obrigação de fidelidade ao conjunto a partir da noção de complementaridade de dois níveis que supostamse e apoiam-se mutuamente (Schwarz-Liebermann). Tal complementariedade implicaria necessariamente o dever de recíproca consideração, que conduz à abstenção de iniciativas que acarretem prejuízo aos interesses do conjunto (ou aos interesses de um ou mais associados abrangidos pela fidelidade federal), assim como o dever de promoção destes mesmos interesses (Hueck), no âmbito das atividades conduzidas por cada qual." 1064
\end{abstract}

Parece-nos, contudo, que a conduta federal amistosa, justamente por ser um princípio com concretizações típicas que podem ser identificadas inclusive em uma perspectiva comparada, fornece isoladamente parâmetros de atuação mais palpáveis aos entes federativos. Não há necessidade, assim, de se recorrer à ideia de cooperação federativa - que é mais geral e, consequentemente, mais indefinida - principalmente

\footnotetext{
1063 SILVEIRA. Cooperação e Compromisso Constitucional nos Estados Compostos, pp. 96-97 e 275 e ss. 1064 SILVEIRA. Cooperação e Compromisso Constitucional nos Estados Compostos, pp. 277-278 (grifos no original).
} 


\section{quando se considera que o fundamento jurídico da lealdade federal é a boa-fé objetiva.}

Note-se que não se está afirmando que cooperação e lealdade federativas são institutos que não se relacionam, muito pelo contrário, mas apenas que a utilização do segundo a um caso concreto deve prescindir do primeiro, até por uma questão de clareza.

Porém, o foco desta exposição reside nas implicações da lealdade federal para a repartição de competências legislativas, mesmo por uma questão de paralelismo com o que tem sido exposto até o presente momento. Por isso, são as concretizações que afetam o exercício destas competências que serão abordadas a partir deste momento, partindo-se, para tanto, de alguns julgados do Supremo Tribunal Federal sobre a constitucionalidade de leis estaduais que proíbem a comercialização do amianto tipo crisotila. No tópico 7.1.3, dois deles foram objeto de análise. Naquela ocasião foram analisadas as razões invocadas por esta corte brasileira para declarar a inconstitucionalidade da Lei estadual $n^{\circ}$ 2.210/2.001, do Estado do Mato Grosso do Sul (ADI 2.396-9/MS), e da Lei estadual no 10.813/2.001, do Estado de São Paulo (ADI 2.656-9/SP) do ponto de vista da qualificação competencial destas leis. Todavia, deixou-se em aberto pelo menos a constitucionalidade de um dos aspectos da legislação paulista contemplados pelo STF, mais precisamente, a parte em que ela proíbe a importação de amianto crisotila. Retomaremos esta questão a partir deste momento.

No seu artigo $1^{\circ}$, a referida lei paulista proíbe a "a importação, a extração, o beneficiamento, a comercialização, a fabricação e a instalação, no Estado de São Paulo, de produtos ou materiais contendo qualquer tipo de amianto". No tópico 7.1.3, analisou-se como a proibição da extração, do beneficiamento, da comercialização, da fabricação, e da instalação de produtos contendo amianto tem como finalidade a proteção e a defesa da saúde, subsumindo-se, portanto, à competência legislativa concorrente prevista no artigo 24, XII, $\mathrm{CF} / 88$. Paira dúvidas, contudo, se a proibição da importação deste mineral efetivamente se acopla à finalidade perseguida pelos demais verbos, formando com eles uma unidade de regulamentação (Regelungseinheit). Por um lado, pode-se argumentar que a importação de amianto, desde que dirigida a outros Estados da federação brasileira, não teria o condão de afetar ou mesmo prejudicar a saúde da população que vive em São Paulo. Por outro lado, é possível arrazoar que, a partir do momento em que tais produtos ingressam no território paulista, não se poderia controlar efetivamente se eles seriam dirigidos a empresas e comércios paulistas ou não. Além do mais, o próprio transporte do amianto oferece perigo, tanto que a Lei federal $n^{\circ}$ 9.055/1995 estabelece que no seu artigo 10 que "o transporte do asbesto/amianto e das fibras naturais e artificiais referidas no art. $2^{\circ}$ desta Lei é considerado de alto risco e, no caso de acidente, a área deverá ser isolada, com todo o material sendo reembalado dentro de normas de segurança, sob a responsabilidade da empresa 
transportadora". Estas duas últimas considerações, no nosso sentir, são suficientes para reconduzir também à proibição da importação de asbesto à competência concorrente para legislar sobre proteção e defesa da saúde, conforme artigo 24, XII, CF/88. Isso não significa, contudo, que São Paulo possa efetivamente editar semelhante regulamentação. Afinal, neste Estado-membro situam-se o maior porto marítimo e o maior aeroporto do Brasil. Quaisquer restrições à importação ou à exportação de produtos em seu território tende a afetar, em maior ou menor medida, outros Estados. Considerações deste tipo - que invariavelmente remetem à lealdade federal na sua vertente de limitação ao exercício de competências - serão complementadas a partir de novos desdobramentos.

Em 2007, São Paulo legislou novamente sobre o assunto. Conforme o artigo $1^{\circ}$ da Lei estadual $n^{\mathrm{o}} 12.684 / 2.007$, "fica proibido, a partir de $1^{\mathrm{o}}$ de janeiro de 2008, o uso, no Estado de São Paulo, de produtos, materiais ou artefatos que contenham quaisquer tipos de amianto ou asbesto". Trata-se, portanto, de uma proibição genérica, a qual abrange tanto as espécies já proibidas pela legislação federal quanto o amianto crisotila, como esclarece, aliás, o próprio artigo $1^{\circ}, \S 1^{\circ}$, da lei paulista. Tal iniciativa, por sua vez, ensejou a propositura de duas ações perante o STF.

A primeira delas é a ADPF 234-MC/DF, de relatoria do Ministro Marco Aurélio, sem dúvida uma das ações mais insólitas submetidas à apreciação desta corte, pelo menos no que diz respeito à repartição de competências legislativas. Com efeito, o requerente insurgia-se, a bem da verdade, contra a interpretação conferida ao artigo $1^{\circ}$ da Lei estadual $\mathrm{n}^{\mathrm{o}} 12.684 / 2007$ por agentes fiscais do trabalho, que são servidores federais ligados ao Ministério do Trabalho. Conforme relatado na petição inicial,

“a Lei Estadual em questão tem servido de instrumento para que Agentes Fiscais
do Trabalho, no Estado de São Paulo, sob a esdrúxula interpretação da referida lei
no sentido de que a proibição do uso de produtos que contenham amianto ou
asbesto no Estado de São, significa também a proibição do transporte de tais
produtos no Estado; ainda que o produto transportado seja originário de outro
Estado da Federação, onde não existe a mesma proibição, tenha como destino
outro Estado ou mesmo a exportação, proibindo assim o transporte de passagem
pelo Estado de São Paulo.
Com efeito o Estado de Goiás é o maior produtor no Brasil de asbesto/amianto da
variedade crisotila (asbesto branco) que tem a sua extração, industrialização e
comercialização expressamente permitida pela Lei Federal no 9.055 , de 01 de
janeiro de 1955, como adiante será demonstrado, vendendo este produto para os
Estados do Sul do Brasil e também para exportação via porto de Santos, hipóteses
em que o transporte do mesmo se faz pela via rodoviária, sendo obrigatória a
passagem por rodovias no Estado de São Paulo.
Muito embora a extração, utilização, industrialização e comercialização do
amianto ou asbesto branco seja uma atividade lícita e permitida em todo o Brasil,
a Lei Estadual em questão vem dando azo à prática de atos arbitrários, de
verdadeiro abuso contra empresas de transporte rodoviário de cargas associadas
da requerente, mediante a aplicação de autos de infração e interdição da atividade 
das empresas, proibindo-lhes o transporte daquele produto, ainda que de passagem pelo Estado.

Tem-se assim configurada a hipótese prevista na lei da prática de atos do Poder Público que causam lesão a preceitos fundamentais inseridos na Constituição Federal possíveis de serem evitados ou reparados como segue demonstrado." 1065

Ao término, pleiteiam-se, entre outras coisas: (i) a concessão de liminar para suspender todos os processos em andamento na Justiça do Trabalho e também todas as interdições de estabelecimento decorrentes da supramencionada interpretação; (ii) a procedência da ação para declarar inconstitucional a lei que proíbe o transporte nas rodovias do Estado de São Paulo de produtos contendo amianto, e; (iii) alternativamente, a procedência da ação para conferir à Lei Estadual interpretação conforme a Constituição Federal no sentido de conferir à proibição de uso contida no artigo $1^{\circ}$ da Lei no $12.684 / 2007$ o sentido de proibição de industrialização e comercialização, excluindo-se o transporte em rodovias do Estado.

O Ministro Marco Aurélio, ao conceder o pedido liminar, em decisão que foi acolhida pelos demais Ministros do STF, entendeu que o transporte do amianto, independentemente da competência para legislar sobre a permissão ou a proibição do uso desta substância, é matéria submetida à competência privativa da União para legislar sobre transporte e sobre comércio interestadual e internacional (artigo 22, XI e VIII, CF/88). Ressaltou ainda outras competências materiais da União, além de afirmar o direito dos cidadãos de utilizar serviços públicos federais. Finalmente, encerra com as ponderações mais relevantes, no nosso sentir, para o deslinde do caso, ao precisar o sentido dos verbos "usar" e "transportar": segundo o referido Ministro, quem usa detém o domínio sobre a coisa, ao passo que, quem transporta presta um serviço, não possuindo necessariamente a titularidade do bem; o que a lei paulista proíbe efetivamente é o uso, mas não o transporte, quando este é destinado a outros estados da Federação ou à exportação. ${ }^{1066} \mathrm{~A}$ ação ainda não foi definitivamente julgada pelo STF, mas o julgamento da medida cautelar já autoriza a elaboração de algumas observações importantes.

Em primeiro lugar, o que está em jogo nesta ação não é exatamente a competência do Estado de São Paulo para editar regulamentação tal como a contida na Lei no ${ }^{\circ}$ 2.684/2007, e sim a interpretação dada por servidores federais a esta regulamentação e a negativa de vigência que ela representa da legislação federal em vigor, a Lei federal no 9.055/1995. Além do mais, é possível questionar se os fiscais do trabalho agem nos limites de suas atribuições,

\footnotetext{
1065 Petição inicial da ADPF 234-MC/DF, Relator Ministro Marco Aurélio, itens 5-8 (o documento não possui folhas numeradas).

${ }^{1066}$ ADPF 234-MC, Relator Ministro Marco Aurélio, Tribunal Pleno, julgada em 28/09/2011, pp. 11-15.
} 
ao barrar, ainda que sob o argumento de aplicar legislação estadual, o transporte de mercadorias destinadas a outros Estados e à exportação. Não obstante isso, ele se reveste de um conflito acerca da constitucionalidade de legislação estadual, como se extrai do pedido principal formulado pela requerente em sua petição inicial. Ao invés de atacar a ilegalidade da atuação dos fiscais do trabalho, preferiu a requerente atacar o fundamento jurídico sob o pretexto do qual estes servidores praticam a ilegalidade.

Em segundo lugar, parece-nos que da proibição de uso consagrada pelo artigo $1^{\circ}$ da Lei estadual $n^{\circ} 12.684 / 2007$ não se pode extrair efetivamente uma proibição de transporte, sobretudo quando a carga, no caso o amianto, se destinar a outros Estados-membros ou à exportação. Ou seja, a atuação dos fiscais do trabalho situa-se completamente fora dos limites postos pela legislação estadual. Note-se que mesmo lei paulista anterior sobre o tema (Lei $\mathrm{n}^{\mathrm{o}}$ 10.813/2001) proibia apenas a importação, a extração, o beneficiamento, a comercialização, a fabricação e a instalação de produtos contendo qualquer tipo de amianto, silenciando-se sobre o transporte e sobre a exportação dos referidos produtos. De todo modo, apenas para dar continuidade ao argumento sobre a lealdade federal, suponha-se que a legislação paulista efetivamente proibisse a importação ou a exportação e também o trânsito de amianto em seu território, sob o argumento de que mesmo o transporte deste mineral é de alto risco e poderia comprometer a saúde da sua população. Seria de se afirmar a conformidade de tal legislação com o princípio da lealdade federal?

A resposta a este último questionamento deve ser negativa. Como já mencionado, São Paulo possui o maior porto marítimo, por onde uma parte razoável da produção do país é exportada, inclusive o amianto extraído no Estado de Goiás. Além do mais, as rodovias paulistas são estratégicas para o transporte de mercadorias para os Estados-membros que compõem a região sul ${ }^{1067}$. Tais peculiaridades recomendam, por sua vez, uma postura de contenção por parte do legislador paulista no que diz respeito a regulamentações que possam restringir o trânsito de bens e pessoas no seu território, pois elas tendem a prejudicar sobremaneira outros Estados. No caso em tela, esta postura de contenção consistiria na abstenção de proibir o trânsito de amianto crisotila destinado a outros Estados e também ao exterior, ainda que o transporte deste mineral seja considerado de alto risco e potencialmente prejudicial à saúde da população. Tal postura de contenção, por sua vez, poderia não ser exigida de Estados que

\footnotetext{
1067 Inversamente, as rodovias paulistas também são importantes para escoar a produção do sul do país para as outras regiões.
} 
não exportem ou que não representem grandes repercussões ao trânsito de amianto crisotila em âmbito nacional, como, por exemplo, o Rio Grande do Norte ou o Maranhão.

Perceba-se como não seria uma hipótese de aplicação da lealdade federal caso o Estado de São Paulo simplesmente objetivasse impor uma limitação ao tráfego de pessoas e bens, sob o pretexto de legislar sobre outra coisa. Nesta hipótese, a legislação paulista teria por finalidade regulamentar o comércio interestadual e exterior, e seria inconstitucional pela ausência de competência estadual para legislar sobre o tema. A lealdade federal entra em cena quando se chega à conclusão de que o ente federativo é, afinal, competente para editar uma determinada regulamentação legal. No nosso sentir, São Paulo deve ser considerado competente para legislar sobre a proibição do uso de amianto crisotila no âmbito do seu território, tendo em vista que se trata de uma regulamentação que objetiva a proteção da saúde de sua população, representando, neste ponto, uma complementação à proteção fornecida pelo artigo $1^{\circ}$ da Lei federal $n^{\circ} 9.055 / 1995$. Porém, caso este Estado deseje, sob o mesmo argumento, estender esta proteção a outras situações, de forma que outros Estados sejam sensivelmente prejudicados nos seus interesses, deve-se então reconhecer a inconstitucionalidade desta regulamentação, ainda que se afirme a competência do ente federativo para legislar sobre a matéria.

Finalmente, deve-se ressaltar que mais duas ADIs tramitam no STF sobre o tema: a ADI 3937/SP, em que se discute a constitucionalidade da Lei paulista $\mathrm{n}^{\circ} 12.684 / 2007$, e a ADI 4066, que tem por objeto a Lei federal no 9.055/1995. Ambos os casos caminham para uma solução que considera a adequação destas legislações a uma competência legislativa, e não a aplicação do princípio da lealdade federal. Por isso, elas não serão objeto de estudo neste tópico, pois pouco acrescentam à discussão.

\subsection{AlguMAS QUESTÕES MUNICIPAIS SOB UMA PERSPECTIVA COMPARADA}

Neste tópico derradeiro pretende-se abordar algumas questões que envolvem os Municípios em uma perspectiva comparada. Em tese, esta seria um estudo a ser desenvolvido no sexto capítulo; porém, como também se objetiva analisar a aplicabilidade da adoção de algumas regras e construções teóricas alemãs ao caso brasileiro, julgou-se oportuno postergar esta confrontação para o sétimo capítulo.

Afirma-se comumente que a grande peculiaridade do federalismo brasileiro consiste justamente no status conferido aos Municípios pela Constituição Federal de 1988, em virtude da opção de erigi-los a entes federativos, ao lado da União e dos Estadosmembros. Note-se, contudo, que o reconhecimento constitucional da importância dos 
governos locais não é uma exclusividade brasileira. Na Constituição da África do Sul, por exemplo, há um capítulo inteiro dedicado aos governos locais, sendo que há um artigo específico sobre o status das municipalidades (artigo 151). Dele se extrai a organização dos poderes executivos e legislativos em um conselho municipal, e também "o direito de governar, sob sua própria iniciativa, os assuntos de governo locais da sua comunidade, sujeito à legislação nacional e provincial". Além do mais, referido dispositivo fornece uma garantia à autonomia municipal ao prever que "o governo nacional ou um governo provincial não comprometerão ou impedirão a capacidade municipal ou o direito de exercer seus poderes ou de desempenhar as suas funções" ${ }^{1068}$. Nesse mesmo sentido, a Lei Fundamental de 1949 não só garante a existência dos Municípios, como também lhes assegura o direito de auto-administração em relação a todos os assuntos de interesse da comunidade local. Não é, portanto, a previsão de uma autonomia municipal robusta que caracteriza o federalismo brasileiro, mas sim a previsão de que os Municípios integram a federação em termos similares, ou então muito parecidos, com a União e os Estados-membros.

Certamente norteava esta opção do legislador constituinte brasileiro uma intenção de fortalecer os Municípios brasileiros, além de coroar uma longa evolução constitucional com o reconhecimento formal de que as Municipalidades realmente participavam da federação brasileira. Estas eram, por sua vez, reivindicações antigas do chamado movimento municipalista, que se encontrava muito fortalecido quando da elaboração e promulgação da Constituição Federal de 1988. Entretanto, transcorridos quase trinta anos da entrada em vigor da constituição brasileira e, principalmente, quando se compara os contornos da autonomia municipal no Brasil e na Alemanha - neste ponto, restringimos a análise somente a estas duas federações por razões óbvias - fica a dúvida de se era realmente necessário colocar os entes municipais brasileiros, do ponto de vista formal, em pé de igualdade com União e Estados-membros, a fim de que lhes fosse garantida uma margem de atuação relevante. Afinal, se a autonomia política, administrativa e financeira são requisitos imprescindíveis à existência de um ente federativo, não é preciso ser necessariamente um ente federativo para gozar destas liberdades. Neste sentido, basta recordar os contornos da garantia conferida aos Municípios alemães pelo artigo 28 II GG, a qual abrange inclusive uma presunção de competência em relação aos assuntos que não foram atribuídos expressamente ao Bund ou aos Länder, ainda que as Gemeinden alemãs sejam, do ponto de vista organizacional, apenas pessoas jurídicas de direito público integrantes da administração estadual. Isto sem

\footnotetext{
${ }^{1068}$ http://www.gov.za/documents/constitution-republic-south-africa-1996-chapter-7-local-government\#151. Acesso: 24/01/2016.
} 
mencionar a possibilidade de os Municípios fixarem alíquotas de determinados impostos, além de participarem da partilha de receitas tributárias, conforme analisado no item 2.2.3.

Por um lado, a decisão constituinte de equiparar Municípios à União e aos Estados não conduziu automaticamente a um florescimento da autonomia municipal no Brasil. Com efeito, muitos Municípios brasileiros não detêm ainda hoje capacidades administrativa, técnica e financeira mínimas, o que certamente compromete a qualidade dos serviços públicos cuja execução lhes compete. Os fatores e os condicionantes deste cenário são muitos, sendo que a sua análise certamente transcende o escopo desta tese. De todo modo, parece ser seguro afirmar que uma previsão constitucional, mesmo com toda a força normativa que lhe é inerente, não é capaz de alterar por si só a percepção de governantes e cidadãos sobre os direitos que poderão ser exercidos no âmbito de um Município. Ao contrário, a autonomia municipal parece consistir em um equilíbrio delicado entre a criação de um espaço de liberdade, garantido e propiciado pelo Estado - o que engloba, inclusive, o fomento das capacidades supramencionadas por parte da União e dos Estados-membros - e a utilização deste espaço, que passa a ser reivindicado como um exercício político, por parte dos cidadãos. Estes dois componentes parecem se combinar lentamente no Brasil, o que é natural, mas ainda assim encarado com uma certa dose de pessimismo.

Por outro lado, é de se admitir que a decisão constituinte de erigir os Municípios a entes integrantes da federação brasileira possui pelo menos um desdobramento importante. Afinal, os Municípios podem perecer com a falta de recursos, de profissionais capacitados, ou podem mesmo esbanjar estes recursos, mas não podem juridicamente ser obrigados a atuar em um determinado sentido por instâncias federativas superiores. Politicamente, a situação pode se manifestar de outro modo, pois uma determinada tarefa pode se colocar como imprescindível aos cidadãos de um Município, e neste caso a possibilidade de obtenção de recursos federais e estaduais pode induzir, por exemplo, à assunção de determinados compromissos perante os governos da União e dos Estados ou à prestação de determinados serviços. É o que ocorreu inclusive com a municipalização da saúde a partir da década de 90 do século XX. Todavia, os Municípios não podem ser obrigados juridicamente a assumir estes compromissos ou executar estes serviços. Previsões constitucionais nesse sentido constavam nos primeiros anteprojetos da Assembleia Nacional Constituinte de 1987/1988. Nesse sentido, o $§ 3^{\circ}$ do artigo $9^{\circ}$ do Anteprojeto da Subcomissão dos Municípios e Regiões determinava que "os municípios poderão prestar outros serviços e desempenhar outras atividades, mediante delegação do Estado e da União, sempre que lhes forem atribuídos os recursos necessários". Este dispositivo, em conjunto com o artigo $9^{\circ}, \S$ 
$5^{\circ}$ - segundo o qual "as particularidades locais, para efeito da variação a que se refere o $\S 1^{\circ}$ deste artigo, bem como o interesse municipal predominante mencionado nesta constituição, serão definidos em lei complementar estadual" - estabelecia uma sistemática bem parecida com a definida pela Lei Fundamental alemã de 1949. Porém, não foi essa a redação que prevaleceu, e o que se tem hoje é uma autonomia assegurada em termos que privilegiam um certo voluntarismo por parte dos Municípios ${ }^{1069}$. Não é preciso dizer como esta especial configuração do federalismo brasileiro acrescenta ainda mais complexidade à coordenação de políticas públicas importantes. O tema já foi abordado, ainda que brevemente, nos items 2.1.2 e 3.2.3 desta tese. Por ora, prossegue-se com a proposta de trabalhar algumas questões municipais sob uma perspectiva comparada, a começar por uma confrontação das tarefas desempenhadas pelos Municípios no Brasil e na Alemanha.

\subsubsection{As tarefas municipais em uma perspectiva comparada}

Conforme analisado no item 2.2.3, a Lei Fundamental de 1949 no seu artigo 28 II GG assegura aos Municípios o direito de auto-administração em relação a todos os assuntos do interesse da comunidade local. Trata-se de uma garantia institucional, dado que seus contornos são precisados pelo legislador, no caso o legislador estadual. Afinal, embora dotados de razoável autonomia, os entes municipais na Alemanha consistem em pessoas jurídicas de direito público integrantes da estrutura administrativa dos Estados-membros.

O fato de a disciplina dos Municípios na Alemanha competir em grande medida à legislação estadual, tanto constitucional quanto ordinária, fez com que surgissem uma multiplicidade de arranjos jurídicos. Tanto é assim que os manuais de direito municipal tratam apenas de grandes modelos, aos quais as legislações estaduais podem ser subsumidas, a despeito de suas particularidades. ${ }^{1070}$ Neste ponto da exposição pretende-se retomar um destes modelos doutrinários, mais especificamente aquele que distingue as tarefas municipais entre aquelas compreendidas no círculo de atuação próprio dos Municípios (Aufgaben des eigenen Wirkungskreises) e aquelas inseridas seu círculo de atuação transferido (Aufgaben des übertragenen Wirkungskreises). Em algumas obras consultadas

\footnotetext{
1069 Em sentido parecido, Fernando Luiz ABRUCIO pondera sobre a existência de um "municipalismo autárquico" no Brasil a partir de 1988, o qual "incentiva, em primeiro lugar, a 'prefeiturização', tornando os prefeitos atores por excelência do jogo local e intergovernamental. Cada qual defende seu município como uma unidade legítima e separada das demais, o que é uma miopia em relação aos problemas comuns em termos 'micro' e macrorregionais" (ABRUCIO. A coordenação federativa no Brasil, p. 48).

1070 Maiores detalhamentos podem ser encontrados nos manuais ou cursos de direito municipal que se debruçam sobre um Estado-membro específico, como curso de direito municipal da Baviera, ou então da Renânia do Norte-Westfália.
} 
estas mesmas modalidades são denominadas de tarefas de auto-administração (Selbstverwaltungsaufgaben) $\quad \mathrm{e}$ assuntos delegados (Auftragsangelegenheiten). ${ }^{1071}$ Optaremos aqui pela primeira destas terminologias, por considerá-la mais precisa.

Antes, contudo, uma observação importante. No Brasil tornou-se comum utilizar a expressão política pública (do inglês public policy) em um sentido mais amplo, para designar um programa de atuação governamental em uma determinada área. Já na literatura alemã, sobretudo na literatura jurídica alemã, percebe-se uma preferência pela expressão Aufgabe, que é traduzida aqui como tarefa. Também é possível encontrar referências a tarefas estatais em alguns textos jurídicos brasileiros, mormente daqueles autores que sofrem a influência do direito alemão, de forma que se está diante de uma expressão que não é completamente desconhecida da doutrina brasileira. De todo modo, considera-se oportuno definir o seu sentido exato, ou ao menos, o sentido com que ela será empregada nesta tese. Segundo Thorsten Ingo SCHMIDT, evocando as expressões empregadas pelo artigo 30 GG, "tarefas são os objetivos que devem ser perseguidos pelos detentores de soberania. Poderes são os meios jurídicos para a concretização destes objetivos"1072. Trata-se de uma definição forjada justamente para ser aplicada às tarefas municipais; porém, emprega-se aqui a definição proposta por Bodo PIEROTH e exposta no item 5.1 desta tese, para quem "tarefas significam as áreas materiais da atividade estatal"1073, eis que ela apresenta uma maior aderência a uma noção mais ampla de política pública, nos termos expostos neste parágrafo.

Feitas estas considerações, parte-se para a análise das tarefas municipais, a começar pelas tarefas inseridas no círculo de atuação próprio dos Municípios. Estas consistem nas típicas atividades municipais, porque abrangidas e tuteladas pela garantia inscrita no artigo 28 II GG. Elas podem dizer respeito à própria organização municipal ou então envolver prestações estatais específicas aos cidadãos, mas se caracterizam por serem assuntos de interesse da comunidade local e, como tais, geridos sob a própria responsabilidade dos Municípios ${ }^{1074}$.

O campo de atuação próprio do Município contempla tanto tarefas voluntárias quanto tarefas obrigatórias. As primeiras caracterizam-se por uma dupla discricionariedade conferida aos Municípios: em primeiro lugar, eles decidem se as tarefas

\footnotetext{
1071 Como, por exemplo, Eberhard SCHMIDT-AßMANN, Hans Christian RÖHL. Kommunalrecht. In: Eberhard SCHMIDT-AßMANN, Friedrich SCHOCH (Hrsg.). Besonderes Verwaltungsrecht. 14a Ed. Berlin: De Gruyter, 2008, p. 41.

1072 SCHMIDT. Kommunalrecht, p. 78. No original: "Aufgaben sind die von den Hoheitsträgern zu verfolgenden Ziele. Befugnisse sind die rechtlichen Mittel zur Verwirklichung dieser Ziele".

1073 JARASS, PIEROTH. Grundgesetz, p. 642.

1074 Nesse sentido, as ponderações de SCHMIDT-AßMANN, RÖHL. Kommunalrecht, p. 41.
} 
serão levadas a cabo em âmbito municipal; em segundo lugar e em caso afirmativo, os Municípios então decidirão o modo pelo qual tais tarefas serão desempenhadas. Já em relação às tarefas obrigatórias os entes municipais não detêm a liberdade sobre o "se" elas serão exercidas - tendo em vista que elas resultam de uma determinação legal - mas somente sobre o "como" esta execução se dará ${ }^{1075}$. Exemplos de atividades exercidas voluntariamente pelos Municípios são as bibliotecas e as escolas de formação para adultos (Volkshochschulen), ao passo que a elaboração do plano básico de urbanismo (Bauleitplan) e a administração de jardins de infância (Kindergärten) costumam figurar entre atividades municipais obrigatórias ${ }^{1076}$. Segundo Martin BURGI, o campo de atuação próprio do Município, como um todo, engloba pelo menos as seguintes áreas: (i) a própria administração municipal; (ii) a segurança pública; (iii) o planejamento urbanístico; (iv) a proteção dos monumentos; (v) a proteção do meio ambiente; (vi) infraestrutura de saneamento, energia e construção de vias municipais; (vii) políticas sociais; (viii) cultura e esporte, e; (ix) incentivo à economia. ${ }^{1077}$ Por óbvio que nestas matérias os entes municipais muitas vezes encontram-se vinculados, isto quando não se colocam como mero executores, da legislação federal ou estadual. Porém, ainda assim resta espaço para uma atuação autônoma por parte do Município. Nesse sentido, boa parte das ações municipais em matéria de segurança pública consiste na execução de regulamentos oriundos de outras esferas federativas, atividades estas situadas fora do círculo próprio do Município; porém, a prevenção do crime desenvolveu-se na Alemanha como uma tarefa eminentemente local. ${ }^{1078}$ A elaboração do plano de urbanismo, por outro lado, embora seja um assunto inserido na auto-administração do Município, encontra fundamento normativo em uma lei federal. ${ }^{1079}$

Percebe-se, portanto, que os entes municipais na Alemanha atuam em áreas setoriais importantes, sendo esta atividade realizada com alguma margem de autonomia, ainda que uma extensa regulamentação legal por parte da União e dos Estados possam alterar este cenário. Todavia, tais considerações não esgotam todas as tarefas levadas a cabo pelos entes locais nesta federação, pois ainda há aquelas inseridas no círculo de atuação transferido, assim definidas por Thorsten Ingo SCHMIDT:

"tarefas do círculo de atuação transferidos, ou assuntos delegados, são originalmente tarefas estatais, as quais foram transferidas às comunas e são exercidas a partir deste momento como tarefas estatais pelos órgãos comunais. Grande parte da administração imperativa constitui tais tarefas do círculo de

\footnotetext{
1075 SCHMIDT. Kommunalrecht, pp. 79-80.

1076 Exemplos retirados de SCHMIDT. Kommunalrecht, p. 80.

1077 BURGI. Kommunalrecht, pp. 56-58.

1078 BURGI. Kommunalrecht, p. 57.

1079 Como ressalta BURGI. Kommunalrecht, p. 57.
} 
atuação transferido, desde que o direito estadual não as classifique como tarefas obrigatórias de cumprimento sob instruções. Se uma comuna cumpre tarefas do círculo de atuação transferido, ela se submete tanto à supervisão jurídica quanto à supervisão técnica. Como esclarecimento é observado que as tarefas do círculo de atuação transferido são sempre atividades obrigatórias - não existem tarefas voluntárias de administração alheia! Exemplos de tais tarefas do círculo de atuação transferido são o registro de moradores e de estrangeiros e a habilitação de direção.

A transferência de tarefas estatais às comunas persegue dois objetivos: do ponto de vista estatal poupa-se a instituição de Behörden inferiores federais e estaduais, o que reduz o aparato estatal e abaixa os custos. Da perspectiva comunal, as comunas são estabelecidas como o único grau administrativo inferior e protegemse contra a concorrência da administração estatual especial de nível inferior."1080

Ou seja, em relação a estas tarefas os Municípios colocam-se como mero executores e, como tais, submetem-se a uma fiscalização mais abrangente por parte dos Estados. Notese que supervisão estadual existe em qualquer caso. Contudo, enquanto que nas tarefas do círculo próprio ela se restringe a uma supervisão jurídica, nas tarefas do círculo transferido ela abrange também uma supervisão técnica. ${ }^{1081}$

Deve-se ressaltar que esta dualidade de círculos de atuação não existe em todos os Länder, mas apenas na Baviera, Baixa-Saxônia, Renânia-Palatinado, Sarre, Saxônia-Anhalt e Turíngia; os demais - a saber, Baden-Württemberg, Brandenburgo, Hesse, MecklenburgoPomerânia Ocidental, Renânia do Norte-Westfália, Saxônia e Schleswig-Holstein - adotam o chamado sistema monista, de acordo com qual todas as tarefas municipais são executadas de forma autônoma, vale dizer, no regime estabelecido pelo artigo 28 II GG. Em outras palavras, o regime monista concebe somente um círculo de atuação, mais precisamente, o círculo de atuação próprio do Município. Porém, mesmo a legislação dos Estados que adotam este regime costuma prever "tarefas obrigatórias de acordo com instruções"

\footnotetext{
1080 SCHMIDT. Kommunalrecht, p. 80. No original: „Aufgaben des übertragenen Wirkungskreises, bzw. Auftragsangelegenheiten, sind ursprünglich staatliche Aufgaben, welche den Kommunen übertragen wurden und als weiterhin staatliche Aufgaben durch kommunale Organe wahrgenommen werden. Große Teile der Eingriffsverwaltung stellen solche Aufgaben des übertragenen Wirkungskreises dar, sofern das Landesrecht sie nicht den Pflichtaufgaben zur Erfüllung nach Weisung zuordnet. Erfüllt eine Kommune Aufgaben des übertragenen Wirkungskreises, unterliegt sie sowohl der Rechtsaufsicht als auch der Fachaufsicht. Zur Klarstellung sei angemerkt, dass die Aufgaben des übertragenen Wirkungskreises stets pflichtige Aufgaben sind - es gibt keine freiwilligen Fremdverwaltungsaufgaben! Beispiele für solche Aufgaben des übertragenen Wirkungskreises sind das Melde- und Ausländerwesen sowie die Kfz-Zulassung. Die Übertragung staatlicher Aufgaben auf die Kommunen verfolgen zwei Ziele: Aus staatlicher Sicht wird der Aufbau eigener Bundes- und Landesunterbehörden erspart, was den Verwaltungsapparat reduziert und Kosten senkt. Aus kommunale Perspektive werden die Kommunen als einzige untere Verwaltungsebene etabliert und vor der Konkurrenz staatlicher Sonderverwaltungen auf unterer Stufe bewahrt."

${ }^{1081}$ Além do mais, é se de atentar para os reflexos financeiros de tais atividades. Conforme exposto no item 2.2.3, grande parte das constituições estaduais estabelecem, no que ficou conhecido como princípio da conexão (Konnexitätsprinzip), que a transferência de tarefas sempre deverá vir acompanhada de previsão quanto aos custos. Porém, tal garantia tem demonstrado suficiente para proteger as finanças municipais, de forma que muitos Municípios se queixam do repasse insuficiente de recursos.
} 
(Pflichtaufgaben nach Weisung), as quais ficam no meio termo entre as tarefas próprias e as tarefas delegadas do sistema dualista: por um lado, a possibilidade de a atividade municipal ser conformada por instruções afasta estas tarefas obrigatórias do círculo próprio de atuação municipal; por outro lado, o fato de as instruções encontrarem fundamento e serem delimitadas pela lei acaba por retirar estas tarefas do círculo de atuação transferido ${ }^{1082}$. Seja como for, o fato é que aqui também se percebe uma dualidade da atuação municipal, ainda que se busque inseri-la como um todo dentro de um paradigma de auto-administração.

No Brasil, por sua vez, semelhante classificação ou não existe ou não conta com muitos adeptos, talvez porque a previsão da delegação de serviços estaduais aos Municípios não tenha prevalecido na versão final da Constituição Federal de 1988, conforme já ressaltado nesta tese. Não obstante isso, acredita-se que ela seja de grande serventia não só para compreender e também para melhor estruturar o papel das Municipalidades brasileiras em determinadas políticas públicas.

Comecemos pela distinção entre tarefas voluntárias e tarefas obrigatórias, tendo em vista que ela parece aplicável ao caso brasileiro sem maiores óbices. Para tanto, retoma-se algumas competências atribuídas pela Constituição Federal de 1988 aos Municípios, em especial, aquelas previstas no artigo 30, V a VII e artigo 144, $\S 8^{\circ}, \mathrm{CF} / 88$. Estabelece o artigo 30, incisos V a VIII, CF/88 a competência municipal para: (i) "organizar e prestar, diretamente ou sob regime de concessão ou permissão, os serviços públicos de interesse local, incluído o de transporte coletivo, que tem caráter essencial; (ii) "manter, com a cooperação técnica e financeira da União e dos Estados, programas de educação infantil e de ensino fundamental", e; (iii) manter, com a cooperação técnica e financeira da União e do Estado, serviços de atendimento à saúde da população". Já o artigo 144, § 8, CF/88 consagra a competência municipal para "constituir guardas municipais destinadas à proteção de seus bens, serviços e instalações, conforme dispuser a lei”. Quais destas normas estabelecem políticas que o Município deve necessariamente levar a cabo e quais delas representam apenas uma autorização para agir? A resposta a este questionamento certamente depende da interpretação dos dispositivos constitucionais supramencionados em conjunto com outros artigos da Constituição Federal de 1988. Não obstante isso, percebe-se desde já que algumas das normas selecionadas claramente estabelecem obrigações ou faculdades. $\mathrm{O}$ transporte público, por exemplo, diante da sua essencialidade, tende a ser considerado um dever, uma imposição constitucional ao Município. Já a constituição de guardas municipais parece ter sido formulada como uma mera faculdade, o que decorre não só do seu escopo

1082 Informações extraídas de BURGI. Kommunalrecht, pp. 86-93. 
limitado de atuação, mas principalmente do fato de esta instituição não ser arrolada como um órgão da segurança pública pelo caput do artigo $144 \mathrm{CF} / 88$. Já outras competências municipais supramencionadas parecem se situar em um campo cinzento. A educação infantil e o ensino fundamental, v.g., são obrigações ou são faculdades conferidas aos Municípios? Por um lado, o fato de a educação ser prevista como um direito fundamental (artigo $6^{\circ} \mathrm{CF} / 88$ ) tende a posicionar a competência municipal prevista no artigo 30, VI, CF/88, como uma obrigação. Por outro lado, o artigo 211, § 2, $\mathrm{CF} / 88$ dispõe que "os Municípios atuarão prioritariamente no ensino fundamental e na educação infantil", o que dá a entender que, embora a educação persista como um direito social - e, portanto, uma obrigação imposta ao Estado -, o Município não necessariamente figura como sujeito passivo desta obrigação. Já os serviços de interesse local, até mesmo pela sua indefinição, tendem a se posicionar como uma mera autorização conferida ao Município, a ser exercida quando as condições políticas assim o permitirem. Porém, alguns serviços tradicionalmente entendidos como de interesse local são dificilmente posicionados como uma mera faculdade. É o caso, por exemplo, dos serviços funerários municipais: como afirmar que este não é um serviço público dos mais essenciais à população, portanto, uma obrigação imposta aos Municípios?

Note-se que o exercício que se propõe aqui não é meramente teórico. O que está em jogo, afinal, é a correta interpretação de determinadas normas constitucionais. Pois, embora competências federativas normalmente sejam entendidas como faculdades franqueadas aos entes federativos, em alguns casos elas podem se colocar como verdadeiros deveres. Neste caso, é importante saber quando o Município está diante de uma obrigação ou de uma faculdade, pois em um cenário de recursos financeiros escassos os Municípios sempre deverão optar, do ponto de vista jurídico, por cumprir as suas obrigações, por mais importantes que as suas faculdades possam se afigurar politicamente.

Mas a compreensão e correta categorização das tarefas atribuídas aos Municípios brasileiros pode se tornar ainda mais complicada. Sabe-se que aos entes locais não podem ser impostas quaisquer prestações, ainda que condicionadas a uma correspondente contraprestação pecuniária. Durante os trabalhos da Assembleia Nacional Constituinte surgiram iniciativas no sentido de conferir aos Estados o poder de impor a prestação de alguns serviços aos Municípios, mas elas foram cuidadosamente retiradas da versão que restou aprovada em 1988. Nesse sentido, basta lembrar a previsão contida no artigo $9^{\circ}, \S 3^{\circ}$ do Anteprojeto da Subcomissão dos Municípios e Regiões, já mencionada supra. Também a versão do que viria a se tornar o artigo 144, $\S 8^{\circ}, \mathrm{CF} / 88$ foi alterada no decorrer dos trabalhos da Comissão de Sistematização, por iniciativa do constituinte Ibsen Pinheiro, retirando-se a previsão "além do que dispuserem as constituições estaduais", com a 
finalidade de eliminar qualquer possibilidade de ingerência dos Estados-membros sobre as atribuições das guardas municipais. ${ }^{1083}$ Isso não significa que a delegação de atribuições, desde que se restrinjam às competências de execução, resta completamente inviabilizada pela Constituição Federal de 1988, consoante se extrai da previsão contida no artigo 241 $\mathrm{CF} / 88$. Ocorre que esta delegação deve ser negociada, sendo que os Municípios sempre devem manifestar o seu consentimento.

Feitos estes esclarecimentos, parte-se para a análise da competência municipal para prestar serviços de saúde, com o auxílio técnico da União e dos Estados, nos termos do artigo 30, VII, CF/88. Esta é, por sua vez, uma disposição que deve ser lida conjuntamente com o artigo $198 \mathrm{CF} / 88$, o qual determina que a política pública de saúde deve ser estruturada em um regime único, organizado de forma descentralizada e com foco em ações preventivas. A esta previsão soma-se o artigo $196 \mathrm{CF} / 88$, que estabelece a saúde como direito de todos e dever do Estado. Extrai-se do exposto que a competência inscrita no artigo 30, VII, CF/88 não se coloca como uma mera faculdade, mas sim como um dever imposto aos Municípios. Nesse sentido, os entes locais são considerados os principais prestadores dos serviços de saúde, não só pela legislação federal subsequente, mas pelo próprio governo federal a partir de uma série de medidas tomadas durante a década de 1990 e analisadas no item 3.2.3. Porém, boa parte das iniciativas conduzidas neste período buscou justamente conformar a atuação dos Municípios a programas definidos nacionalmente, condicionando repasses federais à realização, pelos Municípios, de prestações estatais específicas. Aos Municípios restava aderir ou não às diretrizes federais, sendo que a negativa significava o não recebimento de recursos importantes, em alguns casos imprescindíveis. Falou-se à época de uma municipalização dos serviços de saúde. Não obstante isto, parece-nos que as Municipalidades se colocaram, em relação às prestações convencionadas com o governo federal, como executoras de programas federais. Certamente há espaço para ações municipais autônomas em matéria de saúde, mas no que diz respeito às prestações pactuadas com o governo federal ocorre algo muito próximo da delegação. Ainda assim, não se trata de uma delegação determinada por instâncias federativas superiores, como se dá em relação às tarefas do círculo de atuação transferido analisadas supra.

Resumindo o argumento: no Brasil não há propriamente uma definição acerca das tarefas cuja execução é franqueada, imposta ou mesmo delegada aos Municípios, tal como ocorre na Alemanha. Defende-se aqui que a adoção de semelhante classificação auxiliaria na correta interpretação - ou, ao menos, de uma interpretação

\footnotetext{
1083 O referido histórico da aprovação do artigo 144, § 8으, CF/88 foi por nós abordado em ZAGO, CARVALHO. O Estatuto Geral das Guardas Municipais, p. 174 (nota de rodapé no 9).
} 
mais apurada - de normas constitucionais que atribuem competências aos entes locais no Brasil. Por óbvio que na Alemanha as próprias leis estaduais trabalham com tal distinção. Exatamente por isso, os alemães, quando se dedicam à subsunção de determinada atividade a uma ou outra modalidade de tarefa, não estão simplesmente classificando-as doutrinariamente, mas sim interpretando o seu próprio direito positivo. No Brasil, a distinção entre tarefas voluntárias, obrigatórias e transferidas seria utilizada como uma forma de racionalizar as muitas previsões contidas na Constituição de 1988, sem que haja, ao menos em um primeiro momento, um respaldo no direito positivo. Ainda assim, acredita-se que ela forneceria uma adequada compreensão do que aos Municípios é facultado, pura e simplesmente, e do que efetivamente lhes é imposto. Além do mais, ela auxiliaria na determinação das atividades que podem ser desenvolvidas com uma maior autonomia, e aquelas atividades em que os Municípios se colocam como executores de prescrições federais e estaduais.

Porém, a presente tese vai além e advoga que a incorporação de determinadas normas jurídicas alemãs ao ordenamento jurídico pátrio prestaria um auxílio incomensurável à resolução de alguns problemas brasileiros que envolvem a delimitação das competências legislativas e de execução atribuídas ao Município. Alguns destes problemas foram expostos no decorrer desta tese, sobretudo nos tópicos 4.6 e 6.2.1; neste momento, propõe-se uma solução para estes impasses a partir de três sugestões de lege ferenda.

Em primeiro lugar, propõe-se que aos Estados-membros sejam conferidos meios jurídicos de definir o interesse local a que se refere os artigos 30, I e V, CF/88. No tópico 4.6 discutiu-se a proposta de Andreas J. KRELL, no sentido de interpretar os artigos das constituições estaduais que tratam das competências municipais de forma que "onde a Carta estadual declara os municípios a serem competentes para determinadas tarefas, o próprio estado reconhece, de maneira indireta, que tais funções - salvo raras exceções - não são de interesse predominantemente regional (estadual) e que, portanto, os municípios facultados e “exortados' a editar suas próprias legislações" ${ }^{1084}$. O que se propugna aqui é um meio mais explícito, parecido com aquele previsto no Anteprojeto da Subcomissão dos Municípios e Regiões. Segundo o artigo $9^{\circ}, \S 5^{\circ}$ deste documento, "as peculiaridades locais, para efeito da variação a que se refere o $\S 1^{\circ}$ deste artigo, bem como o interesse municipal predominante mencionado nesta Constituição, serão definidos em lei complementar estadual". Ou seja, a definição do interesse local seria, em um primeiro momento, uma decisão do legislador estadual, a exemplo do que ocorre na Alemanha. A ele competiria, portanto, delimitar quais

1084 KRELL. Diferenças do conceito, desenvolvimento e conteúdo da autonomia municipal, p. 123. 
matérias o ente local poderia legislar e quais serviços ele poderia prestar a título de interesse local. Esta legislação estadual, por sua vez, deve garantir uma margem relevante de liberdade, a fim de que os Municípios possam efetivamente exercer a sua autonomia.

Em segundo lugar, defende-se a inclusão, no texto da Constituição, de uma previsão semelhante à contida no artigo $9^{\circ}, \S 3^{\circ}$ do Anteprojeto da Subcomissão dos Municípios e Regiões. Este dispositivo já foi citado uma vez neste tópico, mas se considera oportuna a sua repetição a fim de tornar a exposição mais clara:

“ $\S 3^{\circ}$ - Os Municípios poderão prestar outros serviços e desempenhar outras atividades, mediante delegação do Estado ou da União, sempre que lhes forem atribuídos os recursos necessários"

Apenas a possibilidade de delegação da União aos Municípios não deveria ser mantida ${ }^{1085}$. Isso porque a terceira e última sugestão consiste justamente na impossibilidade de a União transferir serviços e outras atividades administrativas diretamente aos entes locais. Em situações excepcionais poder-se-ia cogitar de uma semelhante delegação. Porém, a decisão de municipalizar determinados serviços federais, em regra, não deve ser levada a cabo sem a participação dos Estados. Por isso e retomando algumas das conclusões expostas no tópico 6.2.2.1, propõe-se que, em virtude de o artigo $25, \S 1^{\circ}, \mathrm{CF} / 88$ ser a única cláusula geral em matéria de repartição de competências, todas as competências não disciplinadas expressamente pela Constituição Federal de 1988 devem ser atribuídas aos Estadosmembros. Como no Brasil a União também assume uma proeminência na repartição de competências legislação, posição esta que não se repete com a mesma intensidade na distribuição das competências de execução, admite-se que tal interpretação tem o condão de conferir aos Estados-membros mais competências de execução do que legislativas. A partir deste cenário defende-se que os Estados decidam, por meio de lei, se eles próprios executarão estas competências, se estas competências serão atribuídas ao Município para a concretização no âmbito do interesse local ou então se estas competências simplesmente terão a sua execução delegada aos Municípios.

Todas estas sugestões dependem, por sua vez, de emenda à Constituição federal. Certamente haverá quem entenda que semelhantes alterações são inconstitucionais, porque violam a autonomia conferida pela Constituição Federal de 1988 aos Municípios. Todavia,

\footnotetext{
1085 Este é, por sua vez, um ponto de vista que também é influenciado pela experiência federativa alemã. Sabese que durante muitos anos a delegação de tarefas do Bund diretamente às Gemeinden não era vedada pela Lei Fundamental de 1949, embora duramente criticada em virtude da sobrecarga financeira que semelhante previsão causava aos Municípios alemães. Finalmente, em 2006, a constituição alemã foi alterada, a fim de incluir nos seus artigos 84 e 85 GG a proibição de transferência de tarefas da União diretamente aos Municípios.
} 
é preciso olhar a questão da autonomia federativa no Brasil em perspectiva. Conforme já ressaltado em mais de uma oportunidade nesta tese, há uma certa tensão entre competências municipais - sobretudo, as competências delimitadas pelo interesse local, em virtude da sua indefinição - e a competência residual dos Estados. Caso se admita que os Municípios e somente os Municípios delimitem a sua própria competência, então a competência residual dos Estados-membros restará invariavelmente prejudicada. É preciso, portanto - e este é um ponto em que se tem insistido bastante no decorrer desta tese - conferir aos Estados mecanismos para atuar na delimitação da competência municipal, como uma forma de afirmar a sua própria competência residual.

Além do mais, as propostas aqui defendidas contribuiriam para uma melhor distribuição de competências entre Estados e Municípios. Atualmente existe uma percepção generalizada no meio jurídico brasileiro de que o Brasil não viveria de fato uma federação, o que seria evidenciado por um atrofiamento da União vis-a-vis um esvaziamento da autonomia estadual. Os Municípios permanecem, de acordo com esta visão, como entes federativos despreparados para exercer as competências que lhes foram atribuídas pela Constituição de 1988, o que em nada contribuiria para o florescimento da autonomia em âmbito local. No nosso sentir, esta especial conformação da repartição de competências no Brasil não conduz a uma descaracterização da federação brasileira enquanto tal, mas isto não significa que ela não necessite de ajustes. Uma descentralização de competências tanto legislativas quanto de execução da União aos Estados e Municípios é de todo salutar, muito embora a presente tese não formule nenhuma proposta específica neste sentido. As sugestões formuladas neste tópico têm por objetivo precípuo promover uma migração de algumas competências municipais para os Estados, ou pelo menos conferir aos últimos mecanismos para influir e coordenar o exercício de determinadas competências municipais. Não se pretende aqui somente conferir aos entes regionais brasileiros um papel relevante no que diz respeito à coordenação de certas políticas públicas. Neste ponto reside uma última contribuição do direito municipal alemão, que é justamente a percepção de que a autonomia federativa é restringida indevidamente não só pela retirada, mas também pela sobrecarga de tarefas sem a respectiva compensação financeira. Estas últimas podem ser importantes, mas quanto mais recursos municipais são despendidos com execução de políticas de outras esferas, menos espaço resta para a realização de atividades que realmente se enquadram no interesse local de uma comunidade e cujo exercício poderia se dar de forma autônoma ${ }^{1086}$. Portanto, o que se busca aqui é justamente privilegiar as

\footnotetext{
1086 Nesse sentido, DREIER. Artikel 28. In: DREIER (Hrsg.). Grundegesetz, p. 651, BURGI. Kommunalrecht, p. 61 e NIERHAUS. Artikel 28. In: SACHS (Hrsg.). Grundgesetz, p. 1060.
} 
autonomias estaduais e municipais, forjando mecanismos para que Estados recebam novas atribuições e os Municípios se desincumbam daquelas atribuições para as quais eles ainda não se afiguram capacitados.

\subsubsection{Os instrumentos políticos e jurisdicionais para assegurar a autonomia municipal}

Obviamente, os Estados poderiam extrapolar suas prerrogativas, caso as sugestões formuladas supra efetivamente fossem incorporadas pelo ordenamento jurídico brasileiro. As legislações estaduais poderiam estabelecer uma regulamentação tão detalhada, de forma que sobrasse pouco espaço para a atuação autônoma do Município, ou então estabelecer que o próprio governo estadual seria o responsável por executar grande parte dos serviços locais, o que conduziria ao mesmo resultado. É preciso, portanto, estabelecer mecanismos pelos quais os entes municipais brasileiros possam zelar pela sua autonomia, tanto antes quanto depois da aprovação da legislação que afeta os seus interesses.

Note-se que a adoção de instrumentos pelo qual os Municípios possam exercer influência sobre as esferas federativas superiores afigura-se importante mesmo no cenário atual, vale dizer, mesmo que as proposições supramencionadas não sejam colocadas em prática. Com efeito, na federação brasileira os entes locais são responsáveis pela execução de leis federais importantes, como é o caso da legislação de trânsito, e de políticas sociais cujas diretrizes são estabelecidas em âmbito federal, como ocorre com a saúde e a educação. Mesmo em políticas outrora executadas em grande parte pelos Estados-membros, os Municípios vêm adquirindo cada vez mais espaço. Este é certamente o caso das guardas municipais e o seu crescente, não obstante polêmico, papel na segurança pública, o qual motivou inclusive a elaboração e aprovação de um Estatuto federal das Guardas Municipais (Lei $\left.n^{\circ} 13.022 / 2014\right)$. Este diploma estabelece, por sua vez, uma série de normas que determinam como estes órgãos devem se organizar e quais as suas atribuições ${ }^{1087}$, ainda que admita que os Municípios permanecem com uma margem de discricionariedade importante na criação e regulamentação das suas respectivas guardas.

Não se está questionando aqui se a União detém ou não competência para editar semelhante regulamentação. ${ }^{1088} \mathrm{O}$ que se pretende afirmar apenas é que, se a União irá

\footnotetext{
1087 Cite-se, por exemplo, as disposições sobre princípios mínimos de atuação (artigo 3o), sobre competências das guardas municipais (artigo 4으) e sobre os requisitos de investidura dos seus membros (artigo 10).

1088 No caso das guardas municipais, entendemos que a União detém a competência legislativa em função do disposto no próprio artigo 144, § 8으 CF/88, o qual só pode se referir a uma lei federal, e não a uma lei
} 
legislar sobre determinados temas e a execução desta normatização competirá aos Municípios - isto quando ela efetivamente não determina a própria organização da administração municipal - a estes últimos devem ser facultados meios para influenciar o conteúdo destas legislações federais ${ }^{1089}$. No caso de as sugestões por nós formuladas serem acolhidas, estes meios deveriam ser forjados no âmbito dos poderes legislativos estaduais; atualmente, o cenário recomenda que tais meios sejam adotados no âmbito do poder legislativo federal. Por óbvio, os interesses municipais podem se articular em nível estadual e em nível federal de tal modo que a aprovação de legislações consideradas prejudiciais não seja recomendável do ponto de vista político. O que se discute aqui é adoção de instrumentos jurídicos pelos quais Municípios possam exercer sua influência sobre legislações federais e estaduais. Para tanto, lança-se novamente um olhar sobre a experiência alemã.

Como ressalta Eberhard SCHMIDT-AßMANN, "direitos de participação dos Municípios ou de confederações de municípios no processo legislativo estadual não se deixam deduzir obrigatoriamente da garantia da auto-administração, mas são parcialmente afiançadas de forma expressa nas constituições estaduais" ${ }^{1090}$. Nesse sentido, o artigo 87 III GG da constituição do Estado da Baviera prevê que "as confederações comunais devem ser ouvidas tempestivamente, antes que assuntos que digam respeito aos Municípios ou às associações de Municípios sejam disciplinados por lei ou por regulamento. O governo estadual combinará com intuito de implementar o princípio da conexão (parágrafo $3^{\circ}$ ) um procedimento de consultação com as confederações de municípios" ${ }^{1091}$. A parte final do artigo 78 III da constituição da Renânia do Norte-Westfália prevê, por sua vez, que participação das confederações comunais será regulamentada por lei. ${ }^{1092}$ Previsões parecidas

municipal, como defende parcela da doutrina. Para maiores esclarecimentos, vide ZAGO, CARVALHO. O Estatuto Geral das Guardas Municipais, p. 188).

1089 O mesmo raciocínio se aplica aos Estados, conforme analisado no item 6.3.2.1

1090 SCHMIDT-AßMANN. Kommunalrecht, p. 34. No original: "Mitwirkungsrechte der Gemeinden oder ihrer Spitzenverbände an der Landesgesetzgebung lassen sich jedoch teilw. ausdrücklich in den Landesverfassungen verbürgt“. Prossegue ainda o referido autor: „Verwaltungspolitisch kann sich die Einräumung solcher Rechte oder ihre institutionelle Ausgestaltung in einer beratenden Kommunalkammer durchaus anbieten."

1091 Documento disponível em http://gesetze-bayern.de/Content/Document/BayVerf-83 (acesso: 29/01/2016), lembrando apenas que este é o artigo que regulamenta as tarefas municipais, razão pela qual se recomenda a sua leitura integral.

1092 Disponível em:

https://recht.nrw.de/Imi/owa/br_text_anzeigen?v_id=2320020927105939563\#det250879. Acesso: 29/01/2016). 
podem ser encontradas nas constituições de Baden-Württemberg, Brandenburgo, BaixaSaxônia, Sarre, Saxônia e Turíngia. ${ }^{1093}$

Já no âmbito federal, como esclarece Thorsten Ingo SCHMIDT, não existe uma disposição constitucional que assegure a participação do Município. Porém, há previsão de oitiva das confederações comunais em assuntos que dizem respeito a interesses fundamentais dos municípios nos regulamentos dos Poderes Legislativo e Executivo ${ }^{1094}$. Nesse sentido, o $\S 69$ V do Regulamento do Parlamento Federal:

\begin{abstract}
"Caso a comissão delibere sobre um projeto a ela encaminhado, por meio do qual interesses fundamentais dos Municípios e das associações de Municípios sejam tocados, às confederações comunais existentes no nível federal deve ser dada a oportunidade de manifestar opinião antes da tomada de decisão na comissão. Isto vale em especial para os projetos de lei, que devem ser executados total ou parcialmente pelos Municípios ou associações de Municípios, que afetem as suas finanças públicas diretamente ou que influenciem a sua organização administrativa." 1095
\end{abstract}

A efetividade de tais mecanismos depende, por sua vez, em grande medida das consequências atribuídas à ausência de participação das organizações representativas dos Municípios nos processos legislativos estaduais e federal. No nível estadual, há quem entenda que a desobediência das normas que determinam a oitiva prévia das comunas não acarreta consequência alguma, haja vista se tratar de uma mera norma de organização, mas há quem defenda também que a desobediência deverá acarretar a inconstitucionalidade formal da lei estadual, pois se trata de uma norma que disciplina o próprio processo legislativo. Já no nível federal, prevalece o entendimento que se está diante de uma regulamentação interna corporis, razão pela qual a não oitiva das organizações representativas municipais não tem qualquer consequência sobre a constitucionalidade formal da legislação federal aprovada. ${ }^{1096}$

De todo modo, caso os Municípios se julguem prejudicados na sua autonomia em razão de ato legislativo federal ou estadual, eles poderão recorrer aos tribunais estaduais e também ao Tribunal Constitucional Federal. Para tanto, eles deverão manejar a chamada reclamação constitucional comunal (Kommunaleverfassungsbeschwerde) prevista no

\footnotetext{
${ }^{1093}$ Conforme ressalta SCHMIDT. Kommunalrecht, p. 34 (nota de rodapé no 29).

1094 SCHMIDT. Kommunalrecht, p. 35.

1095 No original: "Berät der Ausschuß eine ihm überwiesene Vorlage, durch die wesentliche Belange von Gemeinden und Gemeindeverbänden berührt werden, soll den auf Bundesebene bestehenden kommunalen Spitzenverbänden vor Beschlußfassung im Ausschuß Gelegenheit zur Stellungnahme gegeben werden. Dies gilt insbesondere bei Entwürfen von Gesetzen, die ganz oder teilweise von den Gemeinden oder Gemeindeverbänden auszuführen sind, ihre öffentlichen Finanzen unmittelbar betreffen oder auf ihre Verwaltungsorganisation einwirken."

1096 SCHMIDT. Kommunalrecht, pp. 34-35.
} 
artigo 93 I Nr. 4b GG. Segundo este dispositivo, a corte constitucional alemã decidirá sobre "reclamações constitucionais dos Municípios e associações de Municípios em virtude de violação por lei do direito de auto-administração conforme o artigo 28, por leis estaduais, contudo, somente à medida que uma reclamação não puder ser instaurada perante um tribunal constitucional estadual"1097. Três, portanto, são as características desta ação. Em primeiro lugar, apesar de se chamar e ser formulada como uma reclamação constitucional, ela se assemelha mais a um procedimento de controle de constitucionalidade, cujo parâmetro é principalmente o artigo 28 II GG. ${ }^{1098}$ Em segundo lugar, extrai-se da dicção do artigo 93 I Nr. 4b GG que o objeto da ação deve consistir em uma lei. Esta, por sua vez, pode ser tanto uma lei formal quanto material, oriunda do Bund ou dos Länder, abrangendo, deste modo, leis parlamentares, regulamentos e estatutos de entes municipais superiores. ${ }^{1099}$ Caso se trate de uma lei federal, o Município deve necessariamente propor ação perante o BVerfG. Porém, se a lei em questão foi estadual, então a ação deverá ser intentada perante o tribunal estadual. Somente se não houver previsão de uma reclamação constitucional em nível estadual, é que os entes municipais poderão propor ação perante a Tribunal Constitucional Federal, sendo esta a terceira característica importante a ser ressaltada: a subsidiariedade da reclamação constitucional comunal prevista no artigo 93 I Nr. 4b GG ${ }^{1100}$.

Deve-se lembrar que a garantia municipal da auto-administração é do tipo institucional, o que significa dizer que seus exatos contornos são dados pela lei, a qual se encontra sempre limitada pela previsão contida no artigo 28 II GG. Há, deste modo, uma certa tensão entre a lei e norma constitucional que não se resolve necessariamente em único sentido, dada a mutabilidade das condições políticas, econômicas e sociais dos Municípios no decorrer dos anos. Com o intuito de contemplar a complexidade inerente a tal relacionamento, o Tribunal Constitucional Federal alemão forjou a noção de núcleo ou área central (Kernbereich). O artigo 28 II GG protegeria, deste modo, apenas o núcleo da autoadministração comunal, o qual engloba, como explica Horst DREIER: (i) a presunção de competência em favor dos Municípios, na hipótese de não haver nenhuma prescrição legal que determine a atuação da União e dos Estados; (ii) a necessidade de oitiva dos Municípios

\footnotetext{
1097 No original: "Das Bundesverfassungsgericht entscheidet über Verfassungsbeschwerden von Gemeinden und Gemeindeverbänden wegen Verletzung des Rechts auf Selbstverwaltung nach Artikel 28 durch ein Gesetz, bei Landesgesetzen jedoch nur, soweit nicht Beschwerde beim Landesverfassungsgericht erhoben werden kann".

1098 É a conclusão de SCHLAICH, KORIOTH. Das Bundesverfassungsgericht, p. 108. Porém, ressaltam estes autores que esta qualificação é debatida, havendo quem entenda que se trata de fato de uma reclamação constitucional, quem se posicione no sentido de que se está diante de um procedimento de controle de constitucionalidade, e quem defenda que se trata de uma modalidade especial de reclamação constitucional. 1099 SCHMIDT. Kommunalrecht, p. 39.

${ }^{1100}$ Como se extrai de SCHLAICH, KORIOTH. Das Bundesverfassungsgericht, p. 108.
} 
em caso de alteração, inclusive alteração territorial; (iii) a proibição de regulamentações que retirem a capacidade de organização municipal, e; (iv) o nível mínimo de financiamento. ${ }^{1101}$ Note-se, portanto, que este núcleo protege o Município somente de ataques frontais à sua autonomia. A ele, contudo, soma-se o chamado princípio da divisão de tarefas (Aufgabeverteilungsprinzip), o qual determina que uma tarefa local somente seja retirada dos Municípios quando não lhes seja possível cumpri-la. Portanto, razões de economia ou de simplificação da máquina administrativa não bastam para retirar atribuições do Município, a menos que o aumento dos custos na hipótese de execução municipal seja desproporcional. ${ }^{1102}$

Já no direito brasileiro aos Municípios são conferidos meios para impugnar legislações estaduais. Nesse sentido, o artigo 90, II da Constituição do Estado de São Paulo confere legitimidade aos Prefeitos e às Mesas das Câmaras Municipais para propor ação direta de inconstitucionalidade perante o Tribunal de Justiça. Conforme o caput deste dispositivo, esta ação deverá ter objeto leis ou atos normativos estaduais e municipais, sendo que o parâmetro será a constituição estadual. Também a Constituição do Estado da Bahia autoriza os Prefeitos e as Mesas das Câmaras Municipais a proporem ação direta de inconstitucionalidade contra lei ou ato normativo estadual e municipal. Porém, deve-se admitir que tais previsões seriam suficientes somente se as sugestões por nós formuladas no tópico 7.4.1 fossem acolhidas, pois apenas neste caso os Estados realmente legislariam sobre questões que afetam diretamente os interesses municipais. No cenário atual, contudo, apenas a legislação estadual sobre regiões metropolitanas, aglomerações regiões e microrregiões têm este efeito. E mesmo assim, os julgados de maior repercussão sobre estes assuntos costumam ser discutidos e deliberados pelo STF no âmbito do controle abstrato de constitucionalidade.

\section{Por outro lado, os Municípios não dispõem de um instrumento jurisdicional} específico para fazer valer os seus interesses em âmbito federal. Com efeito, não lhes é permitido propor ações de controle abstrato de constitucionalidade, e nem mesmo suscitar conflitos federativos, tendo em vista que, nos termos do artigo 102, I, f, CF/88 estes últimos só podem se dar "entre a União e os Estados, a União e o Distrito Federal, ou entre uns e outros, inclusive as respectivas entidades da administração indireta". Aos Municípios resta, portanto, interpor o recurso extraordinário previsto no artigo 102, III, CF/88, o que pressupõe alguns anos de litígio - e, consequentemente, de espera - nas instâncias ordinárias. Por isso,

\footnotetext{
1101 DREIER. Artikel 28. In: DREIER (Hrsg.). Grundegesetz, p. 665.

1102 DREIER. Artikel 28. In: DREIER (Hrsg.). Grundegesetz, pp. 665-666.
} 
defende-se que aos Municípios sejam facultados meios para impugnar atos normativos que restrinjam indevidamente a sua autonomia federativa perante o STF. Isso não significa necessariamente a defesa de uma ampliação do rol de legitimados para a propositura de ações do controle abstrato, mesmo porque o consideramos amplo demais. $\mathrm{O}$ que se advoga aqui é a criação de um instrumento específico, cuja propositura estaria condicionada a alguns pressupostos igualmente específicos, a fim de evitar o ingresso de ações desnecessárias ou mesmo temerárias. A reclamação constitucional dos Municípios prevista pelo artigo 93 I Nr 4b GG representaria, por sua vez, um possível modelo a nortear as discussões sobre a adoção ou não de tal instrumento jurisdicional.

Não se ignora, por fim, que a sugestão aqui formulada representaria um acréscimo do número de ações julgadas pelo STF, o qual já é bem elevado. Contudo, ela representa apenas uma consequência da decisão constituinte de erigir os Municípios a entes federativos, ao lado da União e dos Estados-membros. Dado que os entes municipais integram a federação brasileira, eles também devem contar com meios adequados para fazer valer os seus interesses perante o seu grande árbitro. ${ }^{1103}$

\subsubsection{A autonomia das associações de Municípios}

No tópico 2.2.3 foram expostos os principais contornos da autonomia dos Municípios (Gemeinden) na Alemanha, com especial foco nos três níveis ou graus nos quais se desdobra a garantia de auto-administração inscrita no artigo 28 II GG. Deste modo, aos Municípios alemães seria assegurada uma garantia institucional de personalidade jurídica (institutionelle Rechtssubjektsgarantie), que é nada mais do que a garantia da sua existência como pessoas jurídicas de direito público integrantes da administração estadual. Em um segundo nível ou grau, os Municípios seriam agraciados também com uma garantia objetiva de instituição jurídica (objektive Rechtsinstitutionsgarantie), a qual se consubstancia justamente na possibilidade de regulamentar "todos os assuntos do interesse da comunidade local, nos limites da lei e sua própria responsabilidade" a que se refere o artigo 28 II GG. Finalmente, os Municípios contam também com uma garantia subjetiva de posição jurídica (subjektive Rechtsstellungsgarantie), que se traduz em uma proteção jurisdicional da garantia da auto-administração. Ou seja, caso um Município se julgue atingido em sua autonomia, ele poderá invocar a proteção jurisdicional, tanto das cortes estaduais quanto do próprio Tribunal Constitucional Federal.

${ }^{1103}$ Sobre as cortes constitucionais e a sua função de árbitro da federação, vide o item 1.6.2. 
Estas mesmas garantias são estendidas às associações de Municípios pelo artigo 28 II 2 GG. Também no item 2.2.3 ponderou-se como o fato de os entes municipais serem uma matéria afeta à regulamentação estadual fez com que surgissem uma multiplicidade de formas associativas na prática, sendo que nem todas são agraciadas com esta garantia. Ao se consultar os comentários à Lei Fundamental e também os cursos de direito municipal com uma pretensão mais geral, constata-se que há uma certa divergência sobre quais associações municipais podem ser consideradas autônomas ou quais podem ser qualificadas como meras organizações administrativas. Todas as obras, contudo, convergem no sentido de considerar os Landkreise (traduzidos aqui como circunscrições estaduais) como as associações de Municípios por excelência e, como tais, fazem jus à garantia de auto-administração inscrita no artigo 28 II 2 GG. Tanto é assim que alguns autores, comentado esta norma da Lei Fundamental de 1949, fazem expressa referência ao direito de auto-administração dos Kreise ${ }^{1104}$. Em virtude disso, neste tópico dedicado à autonomia das associações de Municípios nada mais oportuno do que tecer algumas considerações mais detidas sobre esta modalidade associativa.

Segundo Horst DREIER, os Kreise podem ser vislumbradas, a bem da verdade, como "Municípios em uma escala ampliada; o elemento associativo consiste fundamentalmente somente na contribuição devida à circunscrição"1105. Exatamente por isso, embora os Kreise congreguem normalmente entre dez e trinta Municípios menores ${ }^{1106}$, considera-se que os seus membros são as pessoas que habitam no seu território ${ }^{1107}$. Não se pode esquecer ainda que, nos termos do artigo 28 I GG, também as circunscrições devem contar com uma representação popular, que se encontra reunida normalmente em um Kreistag.

Tal como os Municípios, as circunscrições contam com um círculo de atuação próprio e, a depender do sistema adotado pelo Estado-membro, também com um círculo de atuação transferido. Isto significa, por sua vez, que estas associações executam tarefas voluntárias, tarefas obrigatórias, tarefas delegadas ou transferidas e, a depender do caso, também tarefas obrigatórias de acordo com instruções, conforme analisado no item 7.3.1. Porém, há uma distinção importante a se fazer em relação aos círculos de atuação conferidos aos Municípios propriamente ditos. O artigo 28 II GG confere a estes últimos a possibilidade de regulamentar os assuntos de interesse da comunidade local, nos limites

\footnotetext{
${ }^{1104}$ Como, por exemplo, NIERHAUS. Artikel 28. In: SACHS (Hrsg.). Grundgesetz, p. 1062.

1105 DREIER. Artikel 28. In: DREIER (Hrsg.). Grundegesetz, p. 685.

${ }^{1106}$ Conforme ressaltado no item 2.2.3.

1107 BURGI. Kommunalrecht, pp. 305-306.
} 


\section{da lei, ao passo que, em relação às associações municipais, tal dispositivo prevê somente} um campo de atuação a ser delimitado pela lei. Note-se, portanto, que a autoadministração assegurada às circunscrições estaduais é inegavelmente mais restrita do que aquela assegurada aos Municípios. E mais: tendo em vista que o campo de atuação dos Kreise é invariavelmente delimitado em detrimento das Gemeinden, tem-se que a decisão que atribui tarefas tipicamente municipais às primeiras deve se dar sempre fundamentada e com razoabilidade, de forma a preservar a atuação dos Municípios sob os assuntos de natureza local. Como ressalta Utz SCHLIESKY a partir de um julgado do Tribunal Constitucional Federal, “objetivos de simplificação da administração, de concentração de competências ou razões de diminuição de custos ou de economia não podem justificar uma 'elevação' de tarefas com caráter local relevante, mas sim o ponto de vista políticodemocrático da participação da cidadania local no cumprimento de suas tarefas públicas deve ser visto como prioritário constitucionalmente"1108

Não obstante estas ponderações, a doutrina consegue agrupar as tarefas normalmente atribuídas às circunscrições estaduais em três grandes grupos. O primeiro deles seria representado pelas tarefas supramunicipais, que se caracterizam justamente por transcenderem o território dos Municípios isoladamente. Já no segundo grupo figurariam as tarefas complementares, as quais costumam ser exercidas pelas circunscrições quando os Municípios não possuem capacidade de desempenhá-las. Finalmente, o terceiro grupo seria composto pelas tarefas niveladoras, por intermédio das quais as circunscrições apoiam os Municípios técnica, logística ou financeiramente. ${ }^{1109}$

Feitas estas considerações, deseja-se complementar a análise aqui desenvolvida com algumas considerações a respeito das Stadt-Umland-Verbände, traduzidas aqui como associações metropolitanas. ${ }^{110}$ Segundo Utz SCHLIESKY, elas se deixam definir do seguinte modo:

\footnotetext{
1108 Utz SCHLIESKY. \& 30 Stadt-Umland-Verbände. In: Thomas MANN, Günter PÜTTNER (Hsrg.). Handbuch der kommunalen Wissenschaft und Praxis. Band 1: Grundlagen und Kommunalverfassung. 3a Ed. Berlim e Heidelberg: Springer, 2007, pp. 892-893. No original: “Das Gericht hat betont, dass Ziele der Verwaltungsvereinfachung, der Zuständigkeitskonzentration oder Gründe der Wirtschaftlichkeit und Spamsamkeit allein eine, Hochzonung'von Aufgaben mit relevantem örtlichen Charakter nicht rechtfertigen können, sondern der politisch-demokratische Gesichtspunkt der Teilnahme der örtlichen Bürgerschaft an der Erledigung ihrer öffentlichen Aufgaben als verfassungsrechtlich vorrangig anzusehen ist".

1109 BURGI. Kommunalrecht, p. 310, DREIER. Artikel 28. In: DREIER (Hrsg.). Grundegesetz, p. 686 e SCHMIDTAßMANN. Kommunalrecht, pp. 117-118.

1110 Uma tradução mais literal desta expressão alemã seria algo como "associação de (municípios) vizinhos da cidade" (Stadt - cidade; Umland - vizinhança; Verband - associação). Opta-se, contudo, por traduzi-la como "associação metropolitana", por uma questão de praticidade, e mesmo porque Stadt-Umland é uma expressão
} 


\begin{abstract}
"Associação metropolitana é entendida como uma estrutura de organização, reforçada de algum modo, no âmbito de adensamento do entorno da cidade para desempenhar tarefas administrativas sob a observância da autonomia jurídica das entidades territoriais participantes. Se tal associação metropolitana representa também uma associação de Municípios no sentido do artigo 28 II 2 GG, é uma questão a ser examinada separadamente em cada caso concreto. Em alguns casos o legislador estadual, na instituição das associações metropolitanas, dispôs expressamente deste modo."1111
\end{abstract}

Percebe-se, do exposto, que as associações metropolitanas podem assumir diferentes arranjos na Alemanha, sendo que a legislação estadual será responsável por definir os seus exatos contornos. A fim de compreendê-los sob uma perspectiva sistemática, retoma-se a classificação proposta também por SCHLIESKY, a qual leva em consideração o grau de vinculação dos entes participantes e também a qualidade e quantidade de tarefas transferidas às associações. Deste modo, no grau mais alto da escala estão as associações que são organizadas como organizações territoriais autônomas e que, como tais, fazem jus à garantia da auto-administração inscrita no artigo 28 II 2 GG. Atualmente, tal modelo - que é denominado pelo autor em comento de modelo das circunscrições regionais (Regionalkreises) - é adotado por Hannover e Saarbrücken. A primeira destas cidades, aliás, consiste em um caso bem estudado, exatamente porque congrega a realização de competências da administração pública e a prestação de serviços públicos sob uma organização sólida, vale dizer, de um Kreis. Como tal, ela conta com 84 deputados eleitos pelo voto direto, além de uma assembleia regional e de presidente da região. Já o nível inferior desta mesma escala é ocupado pelo modelo das associações para propósito específico (Zweckverbände), instituídas como pessoas jurídicas de direito público para as quais são transferidas uma ou mais tarefas de direito público. É o que ocorre atualmente com a Região Stuttgart, a qual também conta com uma representação popular eleita pelo voto direto. Em um nível inferior estão as associações para o planejamento regional (Regionalplannungsverbände), as quais destinam-se, como o próprio nome sugere, ao planejamento regional. É o modelo adotado atualmente por Frankfurt am Main, depois de anos sob a forma de uma associação com atribuições mais robustas. Finalmente, o grau mais

frequentemente utilizada para designar o fenômeno de aglomeração típico de uma metrópole. Nesse sentido, fala-se em Stadt-Umland-Problematik, e assim por diante.

1111 SCHLIESKY. § 30 Stadt-Umland-Verband, p. 879. No original: „Im nachfolgend Kontext wird unter einem Stadt-Umland-Verband eine irgendwie verfestigte Organisationsstruktur in Stadt-Umland-Verdichtungsräumen zur kooperativen Erledigung von Verwaltungsaufgaben unter Wahrung der rechtlichen Eigenständigkeit der beteiligten Gebietskörperschaften verstanden. Ob derartige Stadt-Umland-Verbände dann auch Gemeindeverbände i.S.d. Art. 28 Abs. 2 S. 2. GG darstellen, ist eine im jeweiligen Einzelfall gesondert zu untersuchende Frage. In einigen Fällen haben die Ländergesetzgeber bei der Errichtung der Stadt-UmlandVerbände dies ausdrücklich angeordnet." 
baixo é ocupado por associações que assumem formas de direito privado, como na região de Karlsruhe, e também pela cooperação informação, sem qualquer base legal. ${ }^{1112}$

Por óbvio, as associações metropolitanas alemãs também enfrentam grandes problemas. Entre eles, menciona-se a necessidade de se garantir uma legitimação democrática e a concorrência de competências entre estas associações e os Municípios que a compõem. ${ }^{1113}$ Quanto a este último aspecto, atente-se para as observações feitas, mais uma vez, por Utz SCHLIESKY:

\begin{abstract}
"Precisamente na consolidação organizatória de uma associação metropolitana na forma de uma entidade (territorial) devem ser retiradas competências das entidades-membros, por meio das quais, em regra, surgem de uma atitude de negação dos protagonistas comunais. Para o sucesso de uma associação metropolitana é decisivo uma mais-valia, que se representa, na perspectiva das entidades territoriais participantes, como uma situação favorável para todos, o que, na prática, pode não se realizar. Contribui, de todo modo, decisivamente para o êxito de uma associação metropolitana, se a perda de uma competência ocorre voluntariamente e por convencimento dos efeitos de sinergia por meio de soluções cooperativas. Ao lado da vontade de todos os participantes de uma solução comum para problemas metropolitanos ajuda sobretudo uma clara delimitação de competências entre as entidades territoriais para o atingimento dos objetivos selecionados. Este foi a vantagem inicial da Região Hannover, que na sua fundação foi apoiada unanimemente pelos entes territoriais envolvidas." 1114
\end{abstract}

A partir destas considerações lança-se um olhar sobre as regiões metropolitanas brasileiras $^{1115}$, que são certamente as associações de Municípios com maior protagonismo. Atualmente, elas encontram previsão no artigo $25, \S 3^{\circ}, \mathrm{CF} / 88$, segundo o qual "os Estado poderão, mediante lei complementar, instituir regiões metropolitanas, aglomerações urbanas e microrregiões, constituídas por agrupamentos de municípios limítrofes, para integrar a

\footnotetext{
1112 SCHLIESKY. § 30 Stadt-Umland-Verband, pp. 884-885. Os exemplos de Hannover, Frankfurt am Main foram extraídos de SCHLIESKY. § 30 Stadt-Umland-Verband, pp. 886-887 e 889-890.

1113 Os problemas afetos às associações metropolitanas são discutidos em SCHIESKY. $\S 30$ Stadt-UmlandVerband, pp. 890 e ss.

1114 SCHLIESKY. \& 30 Stadt-Umland-Verband, pp. 891-892. No original: "Gerade bei der organisatorischen Verfestigung eines Stadt-Umland-Verbandes Form einer (Gebiets)Körperschaft müssen bei den Mitgliedsgebietskörperschaften Kompetenzen abgezogen werden, wodurch in der Regel automatisch eine ablehnende Haltung der kommunalen Protagonisten entsteht. Für den Erfolg eines Stadt-Umland-Verbandes wird damit ein Mehrwert entscheidend, der sich gerade auch aus Sicht der beteiligten Gebietskörperschaften als ,win-win' Situation darstellt und in der Praxis nicht einfach zu realisieren ist. Entscheidend zu dem Gelingen eines Stadt-Umland-Verbandes trägt es jedenfalls bei, wenn der Kompetenzverlust freiwillig und in der Überzeugung von Synergieeffekten durch kooperative Lösungen erfolgt. Neben dem von allen Beteiligten getragenen Willen zur gemeinsamen Lösung der Stadt-Umland-Probleme hilft vor allem eine klare Kompetenzabgrenzung zwischen den Gebietskörperschaften bei der Erreichung der gesteckten Ziele. So war es ein wesentlicher Startvorteil der Region Hannover, dass die an der Gründung beteiligten Gebietskörperschaften die Regionbildung einheilig befürworteten."

1115 A legislação estadual sobre regiões metropolitanas que será citada a seguir foi obtida, em grande parte, em http://www.emplasa.sp.gov.br/fnem/legislacao.asp. Acesso: 04/02/2016. Em alguns casos, recorreu-se à ferramenta de busca dos sítios eletrônicos das assembleias estaduais.
} 
organização, o planejamento e a execução de funções públicas de interesse comum”. Notese como as únicas imposições feitas pela Constituição Federal de 1988 consistem (i) na sua formalização por lei complementar estadual e (ii) na exigência de que os Municípios abrangidos por estas estruturas sejam limítrofes. Há ainda limitações adicionais extraídas pela doutrina, tais como a necessidade de estas regiões abrangerem mais de um município e de haver efetivamente funções públicas de interesse comum que precisem ser realizadas por meio destas organizações. ${ }^{1116}$ Sobre este último ponto, deve-se atentar apenas para o fato de que estes entes podem ser instituídos, nos termos do artigo $25, \S 3^{\circ}, \mathrm{CF} / 88$, tanto para organizar, quanto para planejar, e também para executar funções de interesse comum. Ou seja, o referido dispositivo constitucional exige que existam estas funções, conferindo ao legislador estadual um leque de possibilidades sobre como elas serão levadas a cabo no âmbito destas entidades.

Um dado importante acerca das regiões metropolitanas diz respeito à sua compulsoriedade. No âmbito da doutrina era possível encontrar defensores desta ideia, como ALAÔR CAFFÉ Alves, para quem o artigo 25, § $3^{\circ}, \mathrm{CF} / 88$ “refere-se à forma de realizar, mediante lei complementar, um agrupamento compulsório de Municípios, em razão do qual estes entes locais não teriam liberdade de isolar-se", reiterando posicionamento por ele defendido já sob a égide da Constituição Federal de 1967/1969. ${ }^{1117}$ Finalmente, a questão foi decidida pelo Supremo Tribunal Federal ao declarar inconstitucional artigo da constituição do Estado do Rio de Janeiro que condicionava a criação de uma região metropolitana à anuência dos Municípios envolvidos. ${ }^{1118}$ Ou seja, a criação ou não de uma região metropolitana permanece como uma decisão discricionária do legislador estadual, sem contudo resvalar em arbitrariedade, tendo em vista que ela sempre deve ser lastreada na existência de funções de interesse comum, conforme ressaltado no parágrafo anterior.

Aliás, em relação ao interesse comum que deve nortear a criação de uma região metropolitana, é interessante atentar para a decisão proferida em 2013 pelo STF nos autos da ADI 1842. Nesta ação questionava-se a constitucionalidade de leis complementares

\footnotetext{
${ }^{1116}$ Nesse sentido, vide ALAÔR CAFFÉ Alves. Regiões Metropolitanas, Aglomerações Urbanas e Microrregiões: Novas Dimensões Constitucionais da Organização do Estado Brasileiro. In: Eduardo C. B. BITTAR (Org). História do Direito Brasileiro: Leituras da Ordem Jurídica Nacional. São Paulo: Atlas, 2003, pp. 350 e 357.

1117 ALAÔR CAFFÉ. Regiões Metropolitanas, Aglomerações Urbanas e Microrregiões, p. 356. O posicionamento anterior, exarado a partir da sistemática estabelecida pela Constituição Federal de 1967/1969 pode ser encontrado em ALAÔR CAFFÉ Alves. Planejamento metropolitano e autonomia municipal no direito brasileiro. São Paulo: BUSHATSKY, 1981, pp. 162-172.

${ }^{1118}$ ADI 1841, Rel. Ministro Carlos Velloso, Tribunal Pleno, julgada em 01/08/2002.
} 
estaduais do Rio de Janeiro, que instituíram a região metropolitana do Rio de Janeiro e a Microrregião dos Lagos, bem como transferiram a titularidade dos serviços públicos de interesse metropolitano para o Estado do Rio de Janeiro. A Corte considerou inconstitucional esta transferência, invocando, para tanto, os seguintes motivos:

\begin{abstract}
"O estabelecimento de região metropolitana não significa simples transferência de competências para o estado.

O interesse comum é muito mais que a soma de cada interesse local envolvido, pois a má condução da função de saneamento básico por apenas um município pode colocar em risco todo o esforço do conjunto, além das consequências para a saúde pública de toda a região.

O parâmetro para aferição da constitucionalidade reside no respeito à divisão de responsabilidades entre municípios e estado. É necessário evitar que o poder decisório e o poder concedente se concentrem nas mãos de um único ente para preservação do autogoverno e da autoadministração dos municípios.

Reconhecimento do poder concedente e da titularidade do serviço ao colegiado formado pelos municípios e pelo estado federado. A participação dos entes nesse colegiado não necessita ser paritária, desde que apta a prevenir a concentração do poder decisório no âmbito de um único ente. A participação de cada Município e do Estado deve ser estipulada em cada região metropolitana de acordo com suas peculiaridades, sem que se permita que um ente tenha predomínio absoluto"1119
\end{abstract}

Da leitura deste trecho, e principalmente do voto do Ministro Gilmar Mendes - que foi o relator para o acórdão - extrai-se então que a titularidade do serviço passa para o colegiado de Municípios e do Estado formado no âmbito da região metropolitana, o qual deve ser composto de forma a garantir uma participação efetiva de todos, muito embora isto não signifique exatamente uma participação paritária. Porém, o Ministro Gilmar Mendes se abstém de analisar a questão de a região metropolitana deter ou não personalidade jurídica própria $^{1120}$, o que causa alguma perplexidade. No final das contas, a titularidade é, de fato, transferida à região metropolitana - o que pressupõe a afirmação da sua personalidade jurídica - ou ela continua a ser exercida pelos Municípios em uma espécie de titularidade difusa, por meio de um colegiado? Em outras palavras, o que está em jogo é a própria natureza jurídica da região metropolitana. Na doutrina, especificamente no pensamento de ALAÔR CAFFÉ Alves, é possível encontrar o entendimento de que a região seria uma organização de índole administrativa e não político-administrativa entre Estados e Municípios, de forma que "suas normas (administrativas) não podem impor-se aos entes políticos que integram a região, como, por exemplo, os Municípios" "1121. Porém, não se extrai destas ponderações efetivamente uma resposta para a questão de as regiões metropolitanas possuírem ou não personalidade jurídica.

\footnotetext{
1119 ADI 1842, Rel. Ministro Luiz Fux, Tribunal Pleno, julgado em 06/03/2013 (trecho citado encontra-se na ementa do acórdão)

${ }^{1120}$ ADI 1842, fls. 183-184.

${ }^{1121}$ ALAÔR CAFFÉ. Regiões Metropolitanas, Aglomerações Urbanas e Microrregiões, p. 348.
} 
Já ao analisar a legislação estadual que efetivamente instituiestes entes, percebese que o ato legislativo, pura e simplesmente, não tem o condão de criar uma nova personalidade jurídica. Enfoquemos neste ponto a exposição na legislação do Estado de São Paulo, apenas a título exemplificativo. A Lei Complementar $n^{\circ} 1.139 / 2011$, que reorganiza a Região Metropolitana da Grande São Paulo, acaba por posicioná-la como uma mera unidade regional do território estadual. $\mathrm{O}$ seu artigo $5^{\circ}$ cria, por sua vez, um Conselho de Desenvolvimento, com funções normativas e deliberativas. Nos termos do $\S 1^{\circ}$ deste dispositivo, este Conselho passará a integrar uma autarquia criada e ligada ao Estado, sendo que somente esta possuirá personalidade jurídica. Além do mais, é importante atentar para as atribuições do Conselho em comento, discriminadas no artigo $6^{\circ}$, o qual remete, por sua vez, ao artigo 13 da Lei Complementar $n^{\circ}$ 760/1994. Ao se analisar estes últimos dois dispositivos, extrai-se que o Conselho de Desenvolvimento deve promover, sobretudo, o planejamento da atuação dos Municípios englobados da região metropolitana, não possuindo nenhuma função de execução propriamente dita. Aliás, a Lei Complementar $n^{\circ}$ 1.139/2011 não atribui nenhuma competência de execução, seja à região metropolitana, seja ao Conselho de Desenvolvimento ou à autarquia prevista no artigo 17. Já as Leis Complementares $\mathrm{n}^{\mathrm{o}} 1.166 / 2012,1.241 / 2014,1.146 / 2011$ - que instituem as regiões metropolitana do Vale do Paraíba e do Litoral Norte e de Sorocaba e a Aglomeração Urbana de Jundiaí - possuem propostas muito semelhantes à da lei que reorganizou a região conhecida como Grande São Paulo. Isso, por sua vez, causa algum estranhamento, pois a uniformidade do regramento jurídico aqui certamente não corresponde à realidade destas regiões. Não há, afinal, como comparar a dimensão dos problemas enfrentados por uma megalópole como São Paulo com os problemas vivenciados por Sorocaba e as cidades do seu entorno ou então as cidades do litoral norte do Estado.

Porém, esta não é a única crítica que pode ser dirigida às regiões metropolitanas brasileiras. Ao contrário, ao se problematizar este instituto brasileiro a partir de uma perspectiva comparada, é possível encontrar uma série de problemas, atualmente não equacionados, que poderiam ser resolvidos ou mitigados por meio de uma nova interpretação do artigo $25, \S 3^{\circ}, \mathrm{CF} / 88$. Neste derradeiro tópico trataremos de apenas três questões, sendo certo que esta análise comporta ainda outros desdobramentos importantes.

Em primeiro lugar, acredita-se que não há propriamente um óbice no reconhecimento de personalidade jurídica à região metropolitana. Com efeito, esta entidade não pode ser transformada em uma simples unidade regional do Estado, pois a este último é facultado organizar o seu território em regiões administrativas. Além do mais, os fenômenos típicos e que se congregam na metrópole muitas vezes exigem uma 
autonomização dos direitos e interesses considerados comuns, e um passo importante neste sentido consiste justamente da atribuição de personalidade jurídica a esta associação de Municípios. Atualmente, percebe-se uma tendência de instituir a região metropolitana e, concomitante, autorizar a criação de uma pessoa jurídica de direito público, que pode ser uma autarquia, como ocorre no modelo paulista, ou então de um consórcio público, como é o caso da Região Metropolitana de Feira de Santana. Neste último caso, a lei instituidora (Lei Complementar n $n^{\circ} 35 / 2011$, do Estado da Bahia), prevê que no seu artigo $3^{\circ}$ que o interesse comum será exercido de modo partilhado pelos Municípios e pelos Estados no âmbito de um Conselho de Desenvolvimento. ${ }^{1122}$ Já o seu artigo $7^{\circ}$ prevê que "para a realização de ações, obras e serviços de interesse comum os Municípios poderão criar consórcios públicos". Note-se, contudo, que o ordenamento jurídico brasileiro não pró́be a criação e a formalização das regiões metropolitanas como pessoas jurídicas de direito público, tendo em vista que o artigo 41 do Código Civil arrola, como tais: (i) a União; (ii) os Estados, o Distrito Federal e os Territórios; (iii) os Municípios; (iv) as autarquias, inclusive as associações públicas e; (v) as demais entidades de caráter público criadas por lei. Ou seja, está-se diante de um rol aberto, que não se coloca em contrariedade com a ideia esposada aqui. Note-se que a criação de uma pessoa autônoma com tarefas específicas, cujos contornos são definidos por um órgão colegiado de Municípios e Estados e executadas por um órgão de feições executivas, parece ser uma forma mais simplificada de conduzir os negócios da metrópole, do que a criação de uma unidade regional, a obtenção de um consenso entre os entes federativos participantes, para somente depois cogitar a criação de um consórcio público para executar os serviços abrangidos pelo interesse comum. $^{1123}$

Em segundo lugar, tendo em vista a experiência alemã, também não se enxerga propriamente um problema em atribuir à região metropolitana, em alguns casos, o caráter de uma organização político-administrativa. Costuma-se negar esta qualidade à metrópole, sob o argumento que isto implicaria necessariamente na criação de um nível federativo entre os Municípios metropolitanos e o Estado-membro. Porém, como já se ressaltou na introdução deste tópico, se é verdade que todo ente federativo goza de autonomia política e administrativa, a recíproca não é verdadeira: ou seja, não é preciso ser necessariamente uma entidade integrante da federação para gozar de tais liberdades.

\footnotetext{
1122 Esta última informação depreende-se, apenas, do disposto no artigo 3o e no artigo 4으 da referida lei.

1123 Porém, deve-se admitir que a possibilidade de relegar a execução propriamente dita dos serviços metropolitana para um momento posterior, em que um consenso ou então uma maioria qualificada já tiver sido atingida, pode proporcionar uma congregação de esforços por parte dos entes federativos envolvidos.
} 
Os Municípios na Alemanha consistem em um bom exemplo desta nossa afirmação, conforme analisado no item 2.2.3 e também neste tópico 7.4. Portanto, não é possível afirmar que o reconhecimento de uma organização político-administrativa - o que pressupõe o acolhimento anterior, vale dizer, de que às regiões devem deter uma personalidade jurídica própria - significa necessariamente subverter a estrutura federativa instaurada pela Constituição Federal de 1988. Ao contrário, parece-nos que, em algumas hipóteses, a organização de uma região metropolitana robusta, dotada de recursos financeiros suficientes para a promoção dos serviços considerados de interesse comum e legitimada do ponto de vista democrático, pode ser a única alternativa para lidar com alguns problemas metropolitanos sensíveis. Não se afirma aqui que esta seja uma solução aplicável a todos os casos; deseja-se apenas deixar consignado de que não se vislumbra, a partir da norma contida no artigo $25, \S 3^{\circ}, \mathrm{CF} / 88$, uma proibição à sua adoção. Quem delimitará exatamente quais regiões gozarão de uma maior ou de uma menor autonomia será o legislador estadual, no momento da deliberação da lei complementar.

$\mathrm{Na}$ prática existem algumas iniciativas de incluir a sociedade civil no debate em torno dos serviços metropolitanos. Nesse sentido, a Lei Complementar no 89/2012, que dispõe sobre a região metropolitana de Belo Horizonte, prevê no seu artigo $5^{\circ}$ a participação de dois representantes da sociedade civil organizada no Conselho Deliberativo, sendo que o seu artigo $6^{\circ}$ prevê que eles serão eleitos em uma Conferência Metropolitana para um mandato de dois anos. Também a lei que institui a região metropolitana de Feira de Santana, mencionada supra, prevê a participação de representantes da sociedade civil no Conselho de Desenvolvimento, remetendo o tratamento da questão ao regulamento. Não obstante isso, considera-se que, em alguns casos específicos, a repercussão que os assuntos de interesse comum têm na vida dos cidadãos da metrópole pode recomendar a adoção de soluções mais audaciosas, inclusive por meio de realização de eleições diretas, como ocorre na Alemanha ${ }^{1124}$. De todo modo, considera-se salutar a inclusão de mecanismos de participação da sociedade civil nas regiões metropolitanas ora existentes de um modo geral, pois os assuntos deliberados nestes entes costumam ter repercussões práticas importantes na vida dos cidadãos.

Em terceiro e último lugar, ao se debruçar sobre a regulamentação das regiões metropolitanas existentes, percebe-se uma tendência em organizá-las sobretudo como associações para o planejamento conjunto. Por óbvio que há a previsão de execução de serviços de interesse comum, mas que certamente são sobrepujados justamente por estas

\footnotetext{
${ }^{1124}$ Desde que se mantenha a representação dos Municípios e dos Estados-membros, em virtude do que restou decidido na ADI 1842
} 
funções de planejamento, que costumam figurar nos objetivos, nos serviços de interesse comum ou então nas atribuições do Conselho de Desenvolvimento. Caso se faça uma comparação com o direito alemão, tem-se que as regiões metropolitanas brasileiras são algo próximo das Regionalplannungsverbände ou associações para o planejamento regional. Parece-nos que uma organização nestes moldes pode ser insuficiente para lidar com os problemas que atingem algumas regiões metropolitanas. Daí se insistir na possibilidade de se conferir a estas últimas feições de organização político-administrativa, ou então lhe atribuir a execução de serviços metropolitanos, cujos contornos serão, de todo modo, decididos por Municípios e Estados conjuntamente. Tais sugestões, por sua vez, acabam por se alinhar aos modelos mais robustos do direito alemão, como as Regionalkreise e as Zweckverbände, os quais não são exatamente vedados pelo artigo 25 , § $3^{\circ}$, CF/88, o qual prevê que as regiões, aglomerações e microrregiões poderão ser instituídas tanto para a organização e o planejamento, quanto para a execução de funções públicas de interesse comum.

Finalmente, não se pode deixar de notar um manejo um tanto quanto inadequado das regiões metropolitanas por alguns Estados-membros brasileiros. Afinal, estes entes pressupõem a existência de uma metrópole, o que simplesmente não pode ser vislumbrado em alguns casos concretos. Por exemplo, o Estado do Alagoas conta atualmente com nove regiões metropolitanas (Agreste, Caetés, Maceió, Médio Sertão, Palmeira dos Índios, São Francisco, Sertão, Vale do Paraíba e Zona da Mata) ao passo que o Estado da Paraíba possui doze regiões (Araruna, Barra de Santa Rosa, Cajazeiras, Campina Grande, Esperança, Guarabira, Itabaiana, João Pessoa, Patos, Souza, Vale do Mamanguape e Vale do Piancó). Mesmo em relação à região metropolitana do Vale do Paraíba e o Litoral Norte, em São Paulo, não consegue se vislumbrar exatamente uma metrópole, circundada por outras cidades menores. Ao se criar tantas regiões metropolitanas sem uma aderência a problemas vivenciados tipicamente em uma metrópole, acaba-se por desprestigiar o instituto em questão. 


\section{CONCLUSÃO}

A presente tese representa o resultado de um estudo comparativo da repartição de competências legislativas e de execução no Brasil e na Alemanha, com especial foco nas regras e princípios constitucionais que orientam o exercício de uma competência por um ou mais entes federativos, recorrendo-se também à jurisprudência constitucional pertinente. A pesquisa, como um todo, orientou-se no sentido de responder dois grandes questionamentos: (i) quais são as reais semelhanças e diferenças entre Brasil e Alemanha no que diz respeito ao modo pelo qual as suas respectivas constituições distribuem competências legislativas e de execução? (ii) existem soluções concebidas pela doutrina e jurisprudência alemãs para litígios que envolvem a repartição de competências federativas e que poderiam ser utilizadas para resolver alguns problemas brasileiros?

Antes de fazê-lo, contudo, foi preciso examinar outras questões menores, porém imprescindíveis tanto de um ponto de vista teórico quanto de um ponto de vista metodológico. Por isso, elaborou-se exposição dividida em duas partes. Na primeira delas, dividida em três capítulos, buscou-se expor os pressupostos teóricos da presente pesquisa, além de fornecer uma contextualização das federações brasileiras e alemã. Ao término, propôs-se uma análise comparativa preliminar, levando em consideração tanto os pressupostos discutidos anteriormente quanto as experiências federativas do Brasil e da Alemanha. Já a segunda parte, estruturada em quatro capítulos, foi dedicada ao estudo comparativo propriamente dito, com a exposição dos sistemas brasileiro e alemão de repartição de competências legislativas e de execução, a exposição das semelhanças e das diferenças entre eles e a identificação de alguns problemas brasileiros que poderiam ser mitigados por meio do transplante de alguns institutos alemães.

O primeiro capítulo da tese foi dedicado à análise dos pressupostos teóricos mais importantes da tese. Note-se, portanto, que nunca consistiu em um objetivo da tese arrolar e explicar integralmente todas as concepções teóricas que influenciam de algum modo a pesquisa, mas somente aquelas consideradas efetivamente relevantes para a verificação das hipóteses e obtenção dos resultados apresentados nos demais capítulos. Deste modo, algumas linhas foram dedicadas à exposição das noções de federalismo e de federação empregadas pela tese e à apresentação de uma das classificações mais conhecidas do federalismo, a qual contrapõe federalismo dual, de um lado, e federalismo cooperativo, de outro. Além do mais, constatou-se a existência de tendências de centralização e de descentralização no âmbito de uma mesma federação ao longo dos anos, bem como discutiram-se os modos pelos quais estas tendências podem ser identificadas e estudadas. A 
representação dos Estados-membros no âmbito federal e o papel exercido pelas cortes constitucionais em uma federação também foram temas contemplados por esta análise.

O cerne deste capítulo, todavia, consistiu nos esforços de elaboração de uma noção de competência e na exposição das classificações de competência que iriam informar a pesquisa como um todo. A primeira destas tarefas, por sua vez, só poderia ser empreendida a partir de uma compreensão das funções desempenhadas pela norma de competência em um Estado Federal, análise esta que foi empreendida no tópico 1.4 da tese a partir do pensamento de Josef ISENSEE. Segundo este autor, a competência consiste basicamente em uma medida jurídica do poder estatal, dosando-o e disciplinando-o. Por meio da ideia de competência, conflitos políticos típicos de uma federação são internalizados pelo Direito e resolvidos consoante critérios eminentemente jurídicos. Como norma, a competência deve contemplar tanto um aspecto objetivo - vale dizer, uma parte do campo de atuação do Estado, normalmente circunscrita a uma matéria - quanto um aspecto subjetivo - traduzido na escolha de um destinatário, dentre outros, de uma autorização para agir. Deste modo, concluiu-se que a competência federativa, assim definida, engloba três aspectos considerados fundamentais: (i) trata-se de uma norma que escolhe e circunscreve um campo de atuação, que corresponde somente a uma parte das atividades exercidas pelo Estado; (ii) a seguir, ela atribui a responsabilidade por esta atuação a um ou alguns possíveis destinatários, excluindo os demais; (iii) em terceiro lugar, a competência representa, em tese, somente uma autorização para que o destinatário indicado pela norma atue em relação às tarefas que lhe foram atribuídas.

No que diz respeito à classificação das competências, não se elaborou uma proposta que engloba todas as competências legislativas e de execução previstas pela Constituição Federal de 1988 e pela Lei Fundamental de 1949, mas sim que ajuda a compreender e a mitigar a complexidade inerente ao modo pelo qual estas constituições repartem competências. Após analisar brevemente as propostas de Ronald L. WATTS, JOSÉ AFONSO da Silva, Manoel Gonçalves FERREIRA FILHO e Josef ISENSEE, optou-se por trabalhar com apenas duas dicotomias: competências legislativas e de execução, de um lado, e competências privativas e concorrentes, de outro. As competências legislativas foram definidas como a autorização constitucional conferida a um ente federativo para editar lei em sentido formal sobre a matéria à qual se refere a norma. Já as competências de execução, por sua vez, foram associadas à execução de uma lei em sentido formal - em alguns casos, da própria Constituição - e que é desempenhada precipuamente pelo Poder Executivo. Naquela mesma ocasião, ponderou-se o especial relacionamento entre estas modalidades, uma vez que competências legislativas resultam normalmente na edição de uma lei em 
sentido formal, e competências de execução têm por objeto justamente as atividades, funções e instrumentos necessários à execução desta lei. Porém, isto não significa que a titularidade das competências legislativas e das competências de execução correspondentes devem coincidir, pois elas podem ser - em algumas federações, como a alemã, geralmente são atribuídas a esferas federativas diversas.

Por outro lado, as competências privativas foram delineadas como a atribuição, pela constituição, de uma matéria previamente delimitada a um ente federativo, com a exclusão dos demais. Ponderou-se, ademais, como esta noção abrange tanto competências legislativas quanto de execução e também como ela não se confunde com a competência enumerada, que consiste em uma tipologia redacional. Finalmente, as competências concorrentes foram definidas como a autorização conferida pela constituição para que níveis federativos diversos atuem em relação à matéria prevista pela norma. Trata-se, portanto, de um gênero que se subdivide em competência concorrente cumulativa, caracterizada pela ausência de limites a um ou outro ente federativo quanto à extensão da matéria regulada, e competência concorrente limitada ou não-cumulativa, que se caracteriza justamente pela presença destes limites.

Já o segundo capítulo consiste no resultado de um esforço de contextualização das federações brasileira e alemã, dando cumprimento, deste modo, a uma etapa considerada fundamental em qualquer estudo comparativo. Tratou-se, portanto, de preparar, de um ponto de vista metodológico, o estudo comparativo que foi conduzido a partir da segunda parte da tese. Porém, quando se está diante de um objeto interdisciplinar como a federação, esta análise inexoravelmente oferece dificuldades. Algumas decisões delicadas devem ser tomadas, o que decorre basicamente da constatação de que o fenômeno federativo possui tantas facetas que é impossível considerar todas em uma única abordagem. Por isso, optouse, em primeiro lugar, por uma exposição que auxiliasse na compreensão da centralização e da descentralização vivenciada pelas federações brasileira e alemã ao longo de sua história.

No caso da federação brasileira, esta investigação se iniciou com a Constituição Federal de 1967/1969, conhecida por promover uma dupla centralização, ao retirar poderes dos Estados-membros e concentrá-los na União e nas mãos do Chefe do Executivo federal em detrimento do Poder Legislativo. Já a Constituição Federal de 1988 representou, por sua vez, um movimento de descentralização em relação à ordem constitucional anterior. Porém, como se constatou no item 2.1.1.2, tratou-se de um processo levado a cabo sem grandes preocupações com o tipo de descentralização que seria realizado e o modo pelo qual isso seria feito. Ao fim, o que se observou foi uma descentralização desigual, cujos contornos foram brevemente resumidos no tópico 2.1.2 da tese. Deste modo, no plano político a 
constituição brasileira vigente representou o ápice de um movimento de descentralização iniciado ainda no período da ditadura militar, e que se consubstancia em 1988 na eleição direta dos cargos de chefe do Executivo e dos membros do Poder Legislativo em todas as esferas de governo, além da opção de erigir o Município a ente federativo. Também se verificou uma descentralização na repartição de rendas, muito embora seja esta uma tendência parcialmente revertida no decorrer da vigência da Constituição Federal de 1988. Já no plano da legislação constatou-se um novo momento de centralização em relação ao que previa o artigo $8^{\circ}$ da Constituição Federal de 1967/1969. Finalmente, no tocante à repartição de competências de execução, estabeleceu-se um movimento contraditório: por um lado, as competências privativas da União também restaram robustecidas, mas, por outro lado, o artigo 23 CF/88, ao prever um campo de competências administrativas comuns, parece possuir um viés descentralizador. Já na federação alemã esta investigação em torno da centralização e da descentralização assumiu novos contornos. O ponto de partida consistiu na federação instaurada pela Constituição imperial de 1871, marcada por uma intensa disparidade entre os Estados-membros tanto no plano jurídico quanto no plano fático. A seguir, as atenções se voltaram para a Constituição de Weimar, em que se chegou a cogitar a adoção de um Estado Unitário, mas acabou consagrando um Estado Federal de feições eminentemente centralizadas. A Lei Fundamental de 1949, na sua redação originária, significou uma nova descentralização da estrutura federativa alemã. Conforme analisado no item 2.2.1, naquele momento fundacional pretendeu-se consagrar um sistema de separação entre as atribuições da União e dos Estados. Todavia, tal configuração foi se alterando ao longo dos anos, por meio de julgados importantes do BVerfG e algumas reformas constitucionais. A primeira delas, ocorrida em 1969, introduziu na Lei Fundamental mecanismos típicos do federalismo cooperativo alemão, entre eles a ajuda financeira da União aos Estados e as chamadas tarefas comuns. Após a reunificação alemã surgiram novas demandas pela descentralização federativa, as quais culminaram com a Reforma de 1994. As Reformas de 2006 e 2009, por sua vez, também consistiram em tentativas de conferir à federação alemã feições mais descentralizadas.

No segundo capítulo foram contextualizadas as federações brasileira e alemã no que diz respeito à autonomia municipal e à representação dos Estados-membros em âmbito federal. Quanto a este primeiro aspecto, chamou-se a atenção para a decisão do legislador constituinte brasileiro de alçar os Municípios à categoria de ente federativo, conferindo um tratamento igualitário do ponto de vista formal, que em tudo contrasta com a desigualdade fática existente entre as Municipalidades brasileiras. Já na Alemanha, procurou-se situar os Municípios como titulares de uma garantia de auto-administração, a qual abrange, entre 
outras coisas, "todos os assuntos do interesse local, nos limites da lei e sob sua própria responsabilidade". Trata-se, portanto, de fórmula parecida com a empregada pela Constituição Federal de 1988, com a diferença de que a constituição brasileira delimita a competência legislativa e administrativa do Municípios aos assuntos de interesse local, ao passo que a Lei Fundamental confere um aspecto da autonomia municipal, genericamente considerado, aos interesses da comunidade local. Já no plano organizacional, os Municípios alemães permanecem como pessoas jurídicas integrantes da administração estadual, enquanto no Brasil esta vinculação não mais existe desde a promulgação da Constituição de 1988. No que diz respeito à representação dos Estados no âmbito federal, foi possível constatar que o Senado Federal brasileiro, a instância na qual os Estados em teseparticipam do processo legislativo federal, funciona na realidade como uma segunda casa legislativa, incorporando as vantagens e as desvantagens comumente atribuídas ao bicameralismo. Já o Conselho Federal alemão consiste em uma eficiente instância de representação dos governos dos Estados, o que se deve ao fato de seus membros serem pertencentes e escolhidos pelos governos estaduais e a uma ampliação (jurisprudencial) das hipóteses em que o Conselho Federal deve necessariamente aprovar projetos de lei encaminhados pelo Parlamento Federal.

O terceiro capítulo, por sua vez, foi dedicado à exposição de algumas conclusões obtidas a partir dos pressupostos teóricos enunciados no primeiro capítulo e de uma confrontação dos aspectos das federações brasileira e alemã considerados no segundo capítulo. Trata-se, portanto, de um estudo comparativo preliminar, elaborado com o intuito de obter alguns resultados que são úteis para melhor compreender o modo pelo qual Constituição Federal de 1988 e Lei Fundamental de 1949 repartem competências legislativas e de execução. Deste modo, no item 3.1 constatou-se que tanto a centralização quanto a descentralização são fenômenos inerentes ao federalismo e à federação. Em virtude disso, defendeu-se que a ocorrência de um processo de centralização, tal como o ocorrido no Estado Federal sob a égide da Constituição Federal de 1988, não conduz forçosamente e a uma descaracterização da federação brasileira enquanto tal, como assevera parcela da doutrina. Ponderou-se, ademais, como esta percepção incorre em dois equívocos: o primeiro deles consiste em ignorar que, embora se verifique no Brasil uma intensa centralização legislativa, em outras áreas operou-se uma sensível descentralização a partir de 1988; em segundo lugar, trata-se de um entendimento que parte do pressuposto de que o federalismo dual - e, em especial, a proeminência dos Estados-membros sobre a União que historicamente acompanha tal pensamento - consiste em um modelo ideal e preferencial de federação, do qual todos os outros seriam mera corruptela. A seguir, procurou-se combater uma outra 
percepção bem difundida na literatura jurídica brasileira, segundo a qual o Estado Federal no Brasil assumiria feições mais centralizadas em virtude de ser sido formada a partir do processo de desagregação de um Estado Unitário. Conforme exposto no item 3.2.1, o processo de formação da federação brasileira explica muito pouco sobre a centralização percebida nos dias atuais, sendo que algumas razões contribuem para tanto. Entre elas, destacam-se, em primeiro lugar, a impossibilidade de se estabelecer uma regra geral que relacione o processo de formação de federações e centralização federativa, bem como, em segundo lugar, o fato de que o Brasil adota a forma de Estado Federal há mais de 120 anos e, neste ínterim, outros fatores mais determinantes para a centralização entraram em cena, tais como aqueles implantados durante o Estado Novo e o Regime Militar.

Ultrapassadas estas questões de índole mais teórica, partiu-se então para uma confrontação das federações brasileira e alemã a partir de dois aspectos que lhes são fundamentais, mas que foram propositalmente postergados para o terceiro capítulo diante da constatação de que eles seriam melhor compreendidos a partir de um enfoque comparado. Deste modo, no item 3.2.2 as atenções se voltaram para a centralização. No Brasil, tal fenômeno foi abordado a partir do argumento, desenvolvido por Marta ARRETCHE, de que a centralização federativa verificada a partir da década de 1990 pode ser explicada a partir de uma continuidade decisória, tanto em relação às constituições anteriores, quanto em relação às decisões tomadas pelo legislador constituinte de 1988. Já a federação alemã também vivenciou um período de intensa centralização sob a vigência da Lei Fundamental de 1949, sendo que alguns aspectos deste fenômeno também podem ser compreendidos a partir de uma ideia de continuidade decisória. Este é certamente o caso da concentração da legislação no âmbito federal em virtude da interpretação dada pelo BVerfG aos condicionantes impostos à União pelo artigo 72 II GG em sua redação originária. Embora muitos autores entendam que tal posicionamento jurisprudencial não poderia ter sido antevisto pelo legislador constituinte alemão, o histórico da aprovação daquele dispositivo no Conselho Parlamentar foi marcado por uma pressão dos poderes aliados, à época ocupantes do território ocidental alemão, para que o dispositivo recebesse feições mais "federativas" e também por esforços, por parte de alguns políticos alemães, para que a norma contivesse expressões que limitassem a sua eficácia na prática. Olhando o entendimento do BVerfG sob esta perspectiva, percebe-se que ele também se coloca em uma relação de continuidade com decisões tomadas em 1949.

Já no tópico 3.2.3, dedicado ao estudo da cooperação federativa, observou-se a existência de fenômenos distintos no Brasil e na Alemanha, isto tanto do ponto de vista jurídico quanto político. No Brasil, o aspecto jurídico da cooperação envolve basicamente o 
reconhecimento de um compromisso constitucional de cooperação, o qual é orientado, em termos gerais, à redução das desigualdades sociais e regionais, mas que se manifesta nas chamadas políticas públicas constitucionalmente descentralizadas, como é o caso da saúde e da educação. Já na Alemanha a cooperação federativa deu origem a uma série de instrumentos jurídicos, dentre os quais figuram as reuniões e conferências interministeriais, a celebração de contratos estatais e acordos administrativos, e a transferência de competências. No plano político, a coordenação federativa no Brasil varia conforme cada política setorial, sendo que cada política permanece influenciada, em maior ou menor medida, por estruturas criadas anteriormente, em especial durante o regime militar. Além do mais, constatou-se como Estados e Municípios precisam normalmente de um incentivo para coordenar a sua atuação com os objetivos definidos nacionalmente, sendo que o sucesso da ação coordenadora da União depende, no mais das vezes, da necessidade do financiamento federal para a execução de programas pelos entes regionais e locais. Na federação alemã, por sua vez, a cooperação federativa apresenta-se intimamente relacionada com a Politikverflechtung ou a tomada de decisões conjuntas, ainda que se tratem de dois fenômenos distintos. Conforme ressaltado no tópico 3.2.3, a Politikverflechtung pode ser conceituada como uma estrutura decisória específica - por óbvio, inserida em paradigma de federalismo cooperativo - na qual os entes situados no nível estadual são obrigados a trabalhar conjuntamente, possuindo alguns elementos institucionais e históricos característicos, também analisados naquela ocasião.

Finalmente, o terceiro capítulo terminou com alguns esclarecimentos metodológicos importantes. Em primeiro lugar, diante do reconhecimento de que a federação é um fenômeno interdisciplinar, foi esclarecido o relacionamento da presente pesquisa, de índole eminentemente jurídico-dogmática, com os elementos desta forma de Estado que não são devidamente internalizados pelo Direito. Neste ponto, optou-se por uma postura intermediária, a qual prioriza questões jurídicas, mas sempre considerando os elementos extrajurídicos inerentes à federação. Em segundo lugar, situou-se a repartição de competências como a questão central da teoria jurídica do federalismo. Este, por sua vez, consistiu em um passo importante, tendo em vista que a competência e sua repartição consistem no tertium comparationis do estudo comparativo conduzido na segunda parte da tese, representando uma escolha sobre aquilo que realmente importa ser comparado em uma federação do ponto de vista jurídico.

A segunda parte da tese foi dedicada ao estudo comparativo da repartição de competências legislativas e de execução no Brasil e na Alemanha. Para tanto, foram expostas as principais características da articulação destas competências pela Constituição Federal de 
1988 e pela Lei Fundamental de 1949, o que foi efetivamente levado a cabo no quarto e no quinto capítulos.

No caso da distribuição de competências legislativas e de execução pela constituição brasileira, a análise se centrou nos artigos 21 a 25 e 30 CF/88. Como estes são dispositivos bem conhecidos e há um consenso sobre as suas principais características, procurou-se então conduzir a investigação a partir das dicotomias que informaram a presente tese de um ponto de vista teórico, o que certamente deu ensejo a conclusões interessantes. Em primeiro lugar, a constituição brasileira não promove exatamente uma correspondência no que diz respeito à titularidade das competências legislativas e de execução. Ao contrário, pôde-se constatar que, embora as competências de execução da União normalmente encontrem respaldo em uma competência legislativa também atribuída a este ente federativo, a recíproca não se mostra exatamente verdadeira: com efeito, leis federais editadas com fulcro em uma das competências arroladas no artigo 22 CF/88 são executadas por Estados e Municípios. Tal constatação também se aplica às competências comuns previstas no artigo $23 \mathrm{CF} / 88$, as quais se relacionam tematicamente tanto com competências legislativas privativas da União quanto com competências legislativas concorrentes da União e dos Estados-membros. Em segundo lugar, pôde-se compreender com maior profundidade os contornos dogmáticos da competência legislativa concorrente da União e dos Estadosmembros. Sabe-se que ela consistiu na grande aposta do legislador constituinte para promover uma descentralização gradual, após décadas de intensa centralização legislativa sob a égide da ordem constitucional anterior. Porém, atualmente predomina a percepção de que a limitação que ela impõe à atuação do Poder Legislativo federal - com efeito, o $\S 1^{\circ}$ do artigo $24 \mathrm{CF} / 88$ dispõe que a União se encontra, em relação às matérias discriminadas nos incisos deste dispositivo constitucional, adstrita à edição de normas gerais - mostrou-se ineficiente para conter o avanço da União sobre áreas cujo protagonismo legislativo deveria caber aos Estados, ao menos em tese. Tal cenário, no nosso sentir, deve-se em parte a uma indefinição sobre o próprio sentido e alcance das normas que disciplinam o exercício desta modalidade de competência legislativa pela União e pelos Estados-membros. Por isso, considerou-se oportuno trazer três subsídios para a superação de tais impasse: (i) a legislação de normas gerais da União permanece, a rigor, como uma faculdade e não como uma imposição constitucional, o que se extrai basicamente do teor dos $\S \S 3^{\circ}$ e $4^{\circ}$ do artigo 24 $\mathrm{CF} / 88$, os quais contemplam expressamente as situações de inexistência e de superveniência de legislação federal; (ii) a competência legislativa plena dos Estados, disciplinada pelo $\S 3^{\circ}$ do artigo 24 CF/88, não abrange a edição de normas gerais, pois se restringe ao território do Estado-membro, ainda que envolva a regulamentação integral de uma matéria; (iii) 
finalmente, é necessário conceber um conceito mais retristo e suficientemente delimitado de normas gerais. Neste ponto, a presente tese acolheu a proposta de Diogo de Figueiredo MOREIRA NETO, para quem normas gerais são, em primeiro plano, declarações principiológicas que estabelecem diretrizes nacionais sobre certos assuntos, dirigidas aos Estados-membros na elaboração de suas respectivas legislações. Consequentemente, são normas que devem se aplicar imediatamente às relações concretas apenas em situações excepcionais, pois este é um papel a ser exercido primordialmente pelas legislações estaduais. Finalmente, algumas linhas foram dedicadas à competência residual dos Estados prevista no artigo $25, \S 1^{\circ}, \mathrm{CF} / 88$ - competência necessariamente privativa, tanto legislativa quanto de execução - e à competência municipal para legislar e prestar serviços de interesse local. Entretanto, como a compreensão destas competências se beneficiam de um enfoque comparado, optou-se por tratá-las com maior profundidade no sexto e no sétimo capítulos da tese, optando-se no quarto capítulo apenas por uma exposição das suas principais características.

Já a exposição da repartição de competências legislativas e de execução na Alemanha assumiu contornos mais descritivos, por ser uma temática ainda pouco abordada pelos doutrinadores brasileiros. A análise concentrou-se na exposição do conteúdo dos artigos 70 a 72, 75, 83 a 87, 91a e 91b GG, os quais concentram o cerne da matéria na Lei Fundamental, procurando-se conduzir a investigação a partir das dicotomias discutidas no item 1.5.5. Note-se que esta não foi uma tarefa propriamente difícil, tendo em vista que a Lei Fundamental distingue explicitamente as competências legislativas das de execução, e as competências privativas das concorrentes. Um outro traço importante da articulação de competências promovida pela constituição alemã consiste na enunciação de algumas regras gerais. Deste modo, o artigo $30 \mathrm{GG}$ atribui aos Estados o exercício de poderes estatais e o cumprimento de tarefas estatais, salvo disposição constitucional em contrário. O artigo 70 GG, por sua vez, representa uma aplicação desta regra à repartição de competências legislativas, ao dispor que "os Estado têm o direito de legislar, à medida que esta Lei Fundamental não confira à União poderes legislativos”. Porém, em virtude da extensa enumeração de competências ao Bund, tanto privativas quanto concorrentes, esta é uma regra que se inverte na prática. Com efeito, os Länder possuem poucas competências legislativas privativas com fulcro no artigo $70 \mathrm{GG}$, muito embora elas recaiam sobre temas importantes, como segurança pública, ensino etc. No que diz respeito às competências legislativas concorrentes, embora elas sejam repartidas entre União e Estados - o que conferiria, ao menos em tese, um certo balanço entre as esferas legislativas no que diz respeito à legislação - a fragilidade dos condicionantes impostos pela Lei Fundamental à atuação do Bund 
conduziu a um avanço da legislação federal sobre os temas compreendidos por esta modalidade de competência. Após anos de uma intensa centralização legislativa, duas reformas constitucionais pretenderam reverter este cenário: a primeira delas, ocorrida em 1994, reformulou e restringiu os pressupostos de atuação da União; a segunda, realizada em 2006, criou uma nova modalidade de competência concorrente cumulativa, conhecida como legislação de divergência (Abweichungsgesetzgebung).

O artigo 83 GG consagra, por sua vez, a regra geral em matéria de competências de execução, ao prever "os Estados executam as leis federais como assunto próprio, à medida que esta Lei Fundamental não determine ou permita de outro modo". Ao contrário do que ocorre com o artigo $70 \mathrm{GG}$, neste caso a norma espelha a realidade das relações federativas na Alemanha. Com efeito, neste país os Estados-membros são os principais executores da legislação, incluindo-se a legislação federal. Porém, ao Bund são conferidos alguns instrumentos para influenciar a atuação estadual, muito embora os Länder permaneçam executando leis federais como um assunto que lhes é próprio, vale dizer, por meio de sua própria estrutura administrativa e utilizando os seus próprios recursos. Estes mecanismos de ingerência federal vêm disciplinados nos artigos 84 e 85 GG, e incluem, dentre outros, a disciplina pelo legislador federal da organização dos Behörden e do procedimento administrativo estaduais, a supervisão federal e a edição de preceitos administrativos de caráter geral. A constituição alemã também regula casos em que a legislação federal deverá ser levada executada pela própria administração federal nos artigos 86 e seguintes GG, representando uma exceção à regra contida no artigo 83 GG. Finalmente, os artigos 91a e seguintes GG consagram hipóteses de cooperação entre União e Estados na seara administrativa.

O sexto capítulo da tese foi dedicado à exposição dos resultados da atividade de confrontação dos sistemas brasileiro e alemão de repartição de competências legislativas e de execução, com a exposição das semelhanças e das diferenças observadas entre eles. Contudo, é de se admitir que o objetivo desta comparação sempre foi compreender a articulação de competências pela Constituição Federal de 1988, alinhando-se, neste ponto, a uma das possíveis finalidades do método comparativo, devidamente contemplada na introdução desta tese. Por conseguinte, as conclusões obtidas neste capítulo referem-se a problemas e características do caso brasileiro. A fim de estruturar o argumento, propôs-se uma análise a partir das duas dicotomias que informaram a pesquisa de um ponto de vista teórico -competências legislativas e de execução, de um lado, e competências privativas e de execução, de outro - acrescentando-se ainda um terceiro vetor de análise, consubstanciado nas regras gerais em matéria de repartição de competências. 
A identificação e a análise destas regras gerais se mostram imprescindíveis para interpretar a repartição de competências de um ponto de vista sistemático. A Lei Fundamental de 1949 contém muitas regras deste tipo. No tópico 6.2.1 aproveitou-se o ensejo para analisar os artigos 30 e 31 GG, que são as regras gerais por excelência ordenamento jurídico alemão, já que no quinto capítulo as atenções já haviam se voltado para os artigos 70 e 83 GG, que possuem caráter especializante em relação à norma contida no artigo 30 GG. Há, contudo, uma diferença fundamental entre o artigo 30 e o artigo 31 GG: enquanto o primeiro consagra uma regra geral de repartição de competências, o segundo prevê uma regra geral de colisão. Já a Constituição Federal de 1988 possui apenas uma regra geral a orientar a distribuição constitucional de competências: o artigo $25, \S 1^{\circ}, \mathrm{CF} / 88$. Neste ponto, atentou-se para uma evolução constitucional importante. Tradicionalmente, as constituições brasileiras enumeram competências legislativas à União e atribuem a competência residual aos Estados. As competências de execução, por sua vez, sempre seguiram a repartição de competências legislativas por expressa previsão constitucional. Porém, com o advento da Constituição Federal de 1988 desapareceu a regra que disciplinava a distribuição constitucional de competências de execução. Enquanto parte da doutrina continua a afirmar que o Brasil continua a adotar um sistema imediato de execução de serviços, a presente tese concluiu que não há no direito constitucional positivo brasileiro disposição no sentido de que a União deve executar leis federais, Estados devem executar leis estaduais e Municípios devem executar leis municipais. Portanto, às competências de execução que não recebem tratamento constitucional específico, deve ser aplicado o disposto no artigo $25, \S 1^{\circ}, \mathrm{CF} / 88$. Isto, por sua vez, significa afirmar que, na hipótese de a Constituição Federal de 1988 não disciplinar de outro modo, os Estados-membros serão os responsáveis pela atividade de execução de leis, inclusive leis federais. No mais, ao contrário do que ocorre na Alemanha, o ordenamento brasileiro não consagra nenhuma regra geral de colisão, o que invariavelmente suscita alguns problemas, tendo em vista que conflitos são normais em uma federação e sempre deve existir um mecanismo jurídico para solucioná-los. Isto não significa, todavia, que a Constituição Federal de 1988 não contenha regra de colisão alguma; ocorre que elas são bem específicas, sendo que o seu conteúdo e o seu alcance poderão ser bem compreendidos a partir da aplicação de algumas construções teóricas alemãs, como é o caso do efeito de barreira (artigos 71 e 72 GG).

No que diz respeito à repartição de competências legislativas e de execução, retomou-se uma importante característica da federação alemã, que é justamente o fato de as competências legislativas apresentarem-se concentradas na União, ao passo que as competências de execução pertencem em sua grande maioria aos Estados. Em outras 
palavras, na Alemanha os Estados-membros são os grandes responsáveis pela atividade de execução das leis, inclusive das leis federais. Por isso, ao Bund são conferidos instrumentos para influenciar a execução de suas leis pelos artigos 84 e 85 GG, ao passo que os Estados têm os seus interesses efetivamente contemplados na elaboração da legislação federal por meio do Conselho Federal. Já no Brasil também se constatou uma dissociação da titularidade das competências legislativas e da titularidade das competências de execução, em fenômeno parecido com o que ocorre no direito alemão, ainda que não na mesma intensidade. Com efeito, em algumas áreas importantes a União edita a legislação e é responsável por executála. Porém, em algumas políticas públicas relevantes - como é o caso da saúde, da educação, da segurança pública, e das políticas públicas constitucionalmente descentralizadas de um modo geral - a União é responsável pela legislação, ao passo que a execução será levada a cabo por Estados e Municípios. Tal cenário enseja, por sua vez, a existência de mecanismos pelos quais a União possa atuar sobre a execução das suas leis pelos Estados e Municípios, e estes últimos possam colaborar na elaboração da legislação federal. Atualmente, esta influência recíproca é definida setorialmente e tem o seu sucesso condicionamento a fatores múltiplos

No que diz respeito às competências privativas, constatou-se uma forte semelhança entre as disposições contidas no artigo 71 GG e no artigo 22, parágrafo único, $\mathrm{CF} / 88$, tornando viável inclusive o transplante de algumas construções teóricas alemãs para o caso brasileiro. Já na parte dedicada às competências concorrentes, a análise comparativa serviu para a identificação de quatro variáveis institucionais importantes da centralização legislativa verificada nas matérias arroladas no artigo $24 \mathrm{CF} / 88$. Em primeiro lugar, a Lei Fundamental previa até 2006 duas modalidades de competência legislativa concorrente: a primeira delas, disciplinada no artigo 72 GG e denominada de concorrente por esta constituição, é caracterizada justamente pela concorrência entre os entes federativos; já na segunda delas, prevista no artigo 75 GG, União e Estados cooperavam no sentido de forjar uma única regulamentação sobre as matérias referidas por este dispositivo constitucional. No Brasil, dado que o artigo $24 \mathrm{CF} / 88$ representa uma amálgama destas duas modalidades, é de se admitir que União, Estados e Municípios competem e cooperam em relação às mesmas matérias. Neste cenário, os limites impostos à atuação federal tendem a cair por terra e tem lugar uma competição que os Estados-membros invariavelmente perdem, em virtude da disposição contida no artigo $24, \S 4^{\circ}, \mathrm{CF} / 88$. Em segundo lugar, discutiu-se como às normas gerais da União poderia ser atribuído um sentido parecido com o que foi forjado para os preceitos-moldura do Bund (artigo 75 GG), de forma a privilegiar a autonomia estadual. Porém, reconheceu-se que a forma genérica como a limitação à atuação legiferante 
da União se encontra redigida no artigo $24, \S 1^{\circ}, \mathrm{CF} / 88$ permite ao mesmo tempo fundamentar interpretações divergentes, como a defendida nesta tese e, por outro lado, a atualmente predominante. Em terceiro lugar, a constituição brasileira não traçou nenhuma disposição específica sobre o direito federal editado antes de 1988 e que foi recepcionado como se fossem normas gerais. Em outras palavras, a Constituição Federal de 1988 não previu exatamente um mecanismo pelo qual a adequação desta legislação ao conceito de normas gerais poderia ser verificada. Tal ocorreu somente com o advento da Lei $\mathrm{n}^{\circ}$ 9.882/1999, que regulamentou a ADPF. Finalmente, a quarta variável institucional consiste na ausência de condicionantes ou pressupostos à atuação da União - ao contrário do que ocorre na Alemanha - o que significa dizer que a edição de normas gerais pela União permanece como uma decisão discricionária do legislador federal.

Finalmente, o sétimo capítulo da tese foi dedicado à análise de três institutos alemães afetos à repartição de competências legislativas e de execução e de sua aplicabilidade para a resolução de alguns conflitos federativos brasileiros. Deve-se ressaltar que a busca de soluções no direito estrangeiro também consiste em uma das finalidades comumente atribuídas à comparação jurídica, conforme analisado na introdução desta tese. No mais das vezes, tal atividade tem como o resultado o transplante de instituições jurídicas forjadas em outros ordenamentos jurídicos - em um outro contexto, portanto - para o ordenamento jurídico doméstico. É o chamado transplante jurídico, estudado por um enfoque específico do direito comparado conhecido não por outro motivo de "transplants and receptions", sendo que os seus principais contornos foram contemplados em estudo conduzido no tópico 6.1 da tese.

No tópico 7.1 as atenções se voltaram para o que a doutrina alemã costuma denominar de qualificação competencial da lei, expressão esta forjada para chamar a atenção para as especificidades que envolvem a subsunção de uma lei à norma de competência. Com efeito, lei e competência não costumam falar a "mesma língua": a lei tem por objetivo precípuo regulamentar comportamentos ou situações da vida, ao passo que a competência apenas faz referência a uma matéria em termos genéricos. Constitui tarefa do intérprete, portanto, determinar se esta regulamentação poderá ser considerada como parte integrante da matéria referida por uma norma de competência. Isso é feito, por sua vez, a partir da análise da finalidade da legislação. Ao cabo, esta atividade de subsunção da lei deve conduzir a um único resultado: em outras palavras, a regulamentação legal deverá ser reconduzida a uma única norma de competência. Ao se analisar a jurisprudência constitucional brasileira, contudo, percebeu-se uma tendência de fazer uma qualificação "em bloco". Deste modo, o STF tende a discutir a constitucionalidade de uma legislação estadual editada com fulcro na 
competência concorrente da União e dos Estados para legislar sobre "produção e consumo" e "defesa e proteção à saúde" em face da competência da União para legislar privativamente sobre "direito comercial", "comércio interestadual" e "minas e jazidas", e assim por diante. Ao fazê-lo, esta corte brasileira acaba por eliminar uma das principais funções exercidas pela competência em um Estado Federal, que é justamente a de delimitar áreas de atuação e atribuí-las a um ente federativo em detrimento de outros. Com isso, a decisão do STF passa a ser informada por outros critérios, como a razoabilidade da medida ou a necessidade de se prestigiar determinados valores, ainda que ao cabo se afirme a incompetência ou a competência do ente federativo para editar a regulamentação legal impugnada. Como uma alternativa ao modo pelo qual a jurisprudência constitucional brasileira atualmente decide, analisou-se como alguns casos julgados pelo STF poderiam ser decididos de forma mais simples e objetiva a partir da qualificação competencial da lei segundo a sua finalidade, como fazem os alemães.

No tópico seguinte, promoveu-se um estudo da lealdade federal, da forma como ela é concebido pela doutrina e pela jurisprudência alemãs. Ponderou-se como se estava diante de uma aplicação do princípio da boa-fé objetiva às relações federativas, o que serviria para lhe atribuir alguns conteúdos específicos. Entre eles figura a restrição ao exercício de um direito por um ente federativo, em consideração aos interesses de outros entes federativos, os quais poderiam ser sensivelmente prejudicados por esta atuação. A seguir, analisou-se como esta concretização da lealdade federal poderia se desdobrar em limitações à edição de uma regulamentação legal por um ente federativo, ainda que este último permaneça competente para disciplinar as relações jurídicas compreendidas por tal regulamentação. Ele só não poderá regulamentar o tema de um determinado modo, tendo em vista que interesses sensíveis de outros entes federativos são prejudicados por tal normatização. Portanto, a conduta federativa amistosa atua em um momento posterior à afirmação da competência de um ente federativo para legislar sobre uma determinada situação da vida. Feitas estas considerações, investigou-se as possíveis incidências da lealdade federal no direito brasileiro, tanto de um ponto de vista geral - vale dizer, como uma forma de mitigar a intensa competição que caracteriza às relações federativas ou então como um instrumento mais adequado para lidar com problemas enfrentados atualmente a partir da afirmação de um compromisso constitucional de cooperação - quanto de um ponto de vista específico. Quanto a este último aspecto, analisou-se como o princípio da conduta federativamente amistosa poderia auxiliar na resolução de litígios atualmente em julgamento perante o Supremo Tribunal Federal, entre eles a ADPF 234-MC/DF, restringindo a discricionariedade do ente federativo no momento de edição das suas respectivas legislações. 
O último tópico do sétimo capítulo foi dedicado ao estudo de três questões municipais sob uma perspectiva comparada. Note-se que esta é uma análise possível mesmo diante da constatação de uma diferença fundamental no que diz respeito ao status jurídico do Município no Brasil e na Alemanha. Com efeito, a Constituição Federal de 1988 eleva o Município a ente federativo ao lado da União e dos Estados, ao passo que na Alemanha os entes municipais são pessoas jurídicas de direito público integrantes da administração estadual. Não obstante isso, os dois ordenamentos jurídicos considerados contemplam aos seus entes locais uma autonomia político-administrativa em termos substanciais, o que acaba por viabilizar a sua confrontação.

Assim, no tópico 7.3.1 defendeu-se a aplicabilidade da distinção operada pela doutrina alemã - e que encontra respaldo no direito positivo de alguns Länder - entre tarefas voluntárias, obrigatórias e transferidas, como uma forma de classificar e interpretar as competências atribuídas aos Municípios pela Constituição Federal de 1988. Atualmente, não há propriamente uma definição acerca das tarefas cuja execução é apenas franqueada, imposta ou mesmo transferida aos Municípios. Isto, por sua vez, gera um problema relevante, pois não se sabe exatamente quais competências representam faculdades e quais competências representam obrigações impostas os entes municipais brasileiros. Considerase, portanto, que a recepção de tal construção alemã representaria um auxílio relevante na correta interpretação de competências municipais, especialmente aquelas que se traduzem em prestações estatais aos cidadãos. Nesta mesma oportunidade também se propôs, com base na experiência alemã e como uma decorrência das conclusões obtidas nos tópicos 4.6 e 6.2.1, duas alterações importantes na atual regulamentação constitucional do Município brasileiro. Em primeiro lugar, defendeu-se que aos Estados-membros sejam conferidos meios jurídicos para definir o interesse local a que se refere o artigo 30, I e V, CF/88, em moldes parecidos com aquele previsto pelo artigo $9, \S 5^{\circ}$ do Anteprojeto da Subcomissão dos Municípios e Regiões da Assembleia Nacional Constituinte de 1987/1988. Em segundo lugar, sugeriu-se a inclusão, no texto da Constituição, de previsão de prestação de serviços, pelos Municípios, mediante delegação do Estado, alinhando, neste ponto, à previsão contida no artigo $9^{\circ}, \S 3^{\circ}$ do referido Anteprojeto.

A seguir, foram analisados os instrumentos políticos e jurisdicioinais para assegurar a autonomia municipal na Alemanha, os quais incluem a participação das associações e das confederações de Municípios no processo legislativo federal e estadual e a possibilidade de ajuizar uma ação específica perante o Tribunal Constitucional Federal: a reclamação constitucional comunal (Kommunaleverfassungsbeschwerde). No Brasil, embora os Municípios possam ajuizar Ação Direta de Inconstitucionalidade perante os Tribunais de 
Justiça, não existem mecanismos adequados por meio dos quais eles possam valer os seus interesses perante o Supremo Tribunal Federal. Por isso mesmo, sugeriu-se a criação de um instrumento específico, cuja propositura estaria condicionada a alguns pressupostos igualmente específicos, a fim de que os Municípios pudessem se defender de violações à sua autonomia perante esta corte brasileira.

Por fim, o tópico derradeiro da tese as atenções se voltaram para a análise da autonomia das associações de Municípios na Alemanha nos termos do artigo 28 II GG. Algumas linhas também foram dedicadas à exposição dos principais contornos das chamadas Stadt-Umlände-Verbände, traduzidas nesta tese como associações metropolitanas. Com base nestas considerações, passou-se à análise das regiões metropolitanas brasileiras previstas no artigo $25, \S 3^{\circ}, \mathrm{CF} / 88$. Apesar das suas potencialidades, este instituto brasileiro permanece subutilizado. No nosso sentir, isto se deve, ao menos em parte, a um entendimento extremamente uniformizante e limitador acerca da sua estrutura, das suas funções, e da sua natureza jurídica. É corrente o entendimento, por exemplo, de que estas regiões seriam de natureza eminentemente administrativa, pois somente entes federativos poderiam gozar de autonomia político-administrativa. Porém, a análise comparativa da questão demonstra como este é um pressuposto equivocado: os próprios Municípios alemães claramente não são considerados entes federativos, mas gozam de tal autonomia nos termos do artigo $28 \mathrm{I} \mathrm{e}$ II GG. Diante disso, defendeu-se a conveniência de, em alguns casos, forjar regiões metropolitanas robustas, dotadas inclusive de autonomia político-administrativa e com jurisdição sobre tarefas tipicamente municipais, como forma de lidar com alguns problemas metropolitanos sensíveis. 


\section{BIBLIOGRAFIA}

\section{LIVROS, CAPÍTULOS DE LIVROS E PERIÓDICOS}

ABRUCIO, Fernando Luiz. A coordenação federativa no Brasil: a experiência do período FHC e os desafios do governo Lula. Revista de Sociologia e Política, Curitiba, $\mathrm{n}^{\mathbf{0}} 24$, jun/2005, pp. 41-67

redemocratização brasileira. São Paulo: Hucitec, 1998

AFFONSO, Rui. Os Municípios e os desafios da Federação no Brasil. São Paulo em Perspectiva, 10 (3), 1996, pp. 3-10

ALMEIDA, Fernanda Dias Menezes de. Comentários ao artigo 22, caput. In: CANOTILHO, J. J. Gomes; MENDES, Gilmar Ferreira; SARLET, Ingo Wolfgang; STRECK, Lenio Luiz; LEONCY, Léo Ferreira (Coord). Comentários à Constituição de Brasil. São Paulo: Saraiva, 2013, pp. 737-747

Paulo: Atlas, 2005 Competências na Constituição de 1988. $3^{\mathrm{a}} \mathrm{Ed}$. São Considerações sobre os rumos do federalismo nos Estados Unidos e no Brasil. Revista de Informação Legislativa, Brasília, ano 24, $\mathrm{n}^{\circ}$ 96, out./dez. 1987 , pp. 57-64

ALMEIDA, Maria Hermínia Tavares de. Recentralizando a federação? Revista de Sociologia e Política, Curitiba, nº 24, jun/2005, pp. 29-40

ALVES, Alaôr Caffé. Regiões Metropolitanas, Aglomerações Urbanas e Microrregiões: Novas Dimensões Constitucionais da Organização do Estado Brasileiro. In: BITTAR, Eduardo C. B. (Org). História do Direito Brasileiro: Leituras da Ordem Jurídica Nacional. São Paulo: Atlas, 2003, pp. 345-371

brasileiro. São Paulo: BUSHATSKY

Planejamento metropolitano e autonomia municipal no direito

ARAÚJO CASTRO, Raul de. A Constituição de 1937. Rio de Janeiro: Freitas Bastos, 1938

ARRETCHE, Marta Tereza da Silva. Democracia, federalismo e centralização no Brasil. Rio de Janeiro: FGV e Fiocruz, 2012

Continuidades e Descontinuidades da Federação Brasileira: De como 1988 Facilitou 1995? DADOS - Revista de Ciências Sociais, Rio de Janeiro, vol. 52, no 2, 2009, pp. 377-423 
A Centralização no Estado Federativo Brasileiro.

Tese (Livre-Docência) - Faculdade de Filosofia, Letras e Ciências Humanas. São Paulo, 2007

Federalismo e políticas sociais no Brasil: problemas de coordenação e autonomia. São Paulo em Perspectiva, 18 (2), 2004, pp. 17-26

Estado Federativo e políticas sociais: determinantes

da descentralização. Rio de Janeiro: Revan; São Paulo: FAPESP, 2000

ATALIBA, Geraldo. Normas gerais de direito financeiro e tributário e autonomia dos Estados e Municípios: Limites à norma geral - Código Tributário Nacional. Revista de Direito Público, ano 3, vol. 10, out./dez. 1969, pp. 45-80

BADURA, Peter. Staatsrecht: Systematische Erläuterung des Grundgesetzes. $5^{\mathrm{a}}$ Ed. Munique: C. H. Beck, 2012,

BANDEIRA DE MELLO, Oswaldo Aranha. Natureza jurídica do Estado Federal. São Paulo: Prefeitura do Município de São Paulo, 1948

BARACHO, José Alfredo Oliveira. Novos Rumos do Federalismo. Doutrinas Essenciais de Direito Constitucional, vol. 3, maio/2011

BARBOSA, Ruy. Commentarios à Constituição Federal Brasileira. II Volume - Arts 16 a 40 - Do poder legislativo. São Paulo: Saraiva, 1933

. Commentarios à Constituição Federal Brasileira V Volume - Arts. 63 a

72, § 23. São Paulo: Saraiva, 1934

BARROSO, Luís Roberto. Federação, transportes e meio ambiente: interpretação das competências federativas. In: TAVARES, André Ramos; LEITE, George Salomão; SARLET, Ingo Wolfgang (Org.). Estado constitucional e organização do poder. São Paulo: Saraiva, 2010, pp. 479-512

. Direito constitucional brasileiro: o problema da federação. Rio

de Janeiro: Forense, 1982

BAUER, Harmut. Artikel 20 [Verfassungsprinzipien; Widerstandsrecht]. In: DREIER, Horst (Hrsg.). Grundgesetz - Kommentar. Band II: Artikel 20-82. 2ª Ed. Tübingen: Mohr Siebeck, 2006, pp. 137-169

Die Bundestreue: Zugleich ein Beitrag zur Dogmatik des Bundesstaatsrechts und zur Rechtsverhältnislehre. Tübingen: J. C. B. Mohr (Paul Siebeck), 1992

BERCOVICI, Bercovici. "O Direito Constitucional passa, o Direito Administrativo permanece": a persistência da estrutura administrativa de 1967. In: TELES, Edson; 
SAFATLE, Vladimir (Orgs.). O que resta da ditadura: a exceção brasileira. São Paulo: Boitempo, 2010, pp. 77-90

Max Limonad, 2003

Desigualdades regionais, Estado e Constituição. São Paulo:

BINENBOJM, Gustavo. A constitucionalização do Direito Administrativo no Brasil: um inventário de avanços e retrocessos. Revista Eletrônica sobre a Reforma do Estado, $\mathrm{n}^{\circ}{ }^{13}$, março/abril/maio 2008, pp. 1-44

BLÜMEL, Willi. § 101 Verwaltungszuständigkeit. In: ISENSEE, Josef, KIRCHHOF, Paul (Hrsg). Handbuch des Staatsrechts der Bundesrepublik Deutschland. Band IV Finanzverfassung - Bundesstaatliche Ordnung. 2 ${ }^{\mathrm{a}}$ Ed. Heidelberg: C. F. Müller, 1999, pp. 857-962

BONAVIDES, Paulo. O caminho para um federalismo das regiões. Revista de Informação Legislativa, Brasília, ano 17, nº 65, jan./mar. 1980, pp. 115-126

PAES DE ANDRADE. História Constitucional do Brasil. $3^{\text {a }}$ Ed. Rio de Janeiro: Paz e Terra, 1991

BORGES, Alice Gonzalez. Aplicabilidade de normas gerais de lei federal dos Estados. Revista de Direito Administrativo, Rio de Janeiro, vol. 194, out./dez. 1993, pp. 97-106

Normas gerais nas licitações e contratos administrativos (Contribuição para a elaboração de uma lei nacional). Revista de Direito Público, ano 24, $\mathrm{n}^{\circ}$ 96, out./dez.1990, pp. 81-93

BOTHE, Michael. Federalismo - Um conceito em transformação histórica. Traduções: $o$ federalismo na Alemanha, ano 1995, $\mathrm{n}^{\circ}$ 7, pp. 3-14

BULL, Hans Peter, MEHDE, Veith. Allgemeines Verwaltungsrecht mit Verwaltungslehre.

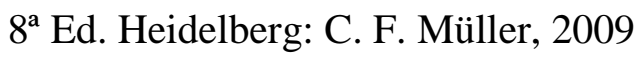

BURGESS, Michael. Comparative Federalism: Theory and Practice. Londres e Nova York: Routledge, 2006,

BURGI, Martin. Kommunalrecht. $4^{\mathrm{a}}$ Ed. Munique: C. H. Beck, 2012

. Artikel 86. In: von MANGOLDT, Hermann; KLEIN, Friedrich; STARCK, Christian (Hrsg). Kommentare zum Grundgesetz. Band III: Artikel 83-146. 6ª Ed. Munique: Franz Vahlen, 2010, pp. 109-146

BUZAID, Alfredo. O Estado Federal Brasileiro. Brasília: Ministério da Justiça, 1971

CALLIESS, Christian. Die Justitiabilität des Art. 72 Abs. 2 GG vor dem Intergrund von kooperativem und kompetitivem Föderalismus. Die öffentliche Verwaltung (DÖV), ano 50, Novembro 1997, Caderno 21, pp. 889-899 
CARVAlHO, José Murilo de. Pontos e bordados: escritos de história e política. Belo Horizonte: Editora UFMG, 2005, pp. 155-188

CASTLES, Francis G., UHR, John. Australia: Federal constraints and institutional innovations. In: OBINGER, Herbert, LEIBFRIED, Stephan, CASTLES, Francis G (Eds.). Federalism and Welfare State: New World and European Experiences. Cambridge: Cambridge University Press, 2005, pp. 51-88

CAVALCANTI, João Barbalho Uchôa. Constituição Federal brasileira (1891) [comentada]. Ed. Fac-Similar. Brasília: Senado Federal, 2002

CAVALCANTI, Themistocles Brandão. A Constituição Federal Comentada. Volume II. $2^{\mathrm{a}}$ Ed. Rio de Janeiro: José Konfino, 1952

CORWIN, Edward. The passing of dual federalism. Virginia Law Review, vol. 36, $\mathrm{n}^{\circ}$, fev/1950, pp. 1-24.

CREIFELDS, Carl. Rechtsworterbuch. $17^{\mathrm{a}}$ Ed. Munique: C. H. Beck, 2002

CRETELLA JUNIOR, José. Comentários à Constituição Brasileira de 1988. Volume III: Arts. 18 e 22. $2^{\text {a }}$ Ed. Rio de Janeiro: Forense Universitária, 1991

DANEMANN, Gerhard. Comparative Law: study of similarities or differences? In: ZIMMERMANN, Reinhard; REIMANN, Mathias (Coord.). The Oxford Handbook of comparative law. Oxford: Oxford University Press, 2006, pp. 383-419

DEGENHART, Christoph. Artikel 70 [Gesetzgebung des Bundes und der Länder]. In: SACHS, Michael (Hrsg). Grundgesetz - Kommentar. $7^{\text {a }}$ Ed. Munique: C. H. Beck, 2014, pp. 1488-1509

Artikel 72 [Konkurrierende Gesetzgebung]. In: SACHS, Michael (Hrsg.). Grundgesetz - Kommentar. $7^{\text {a }}$ Ed. Munique: C. H. Beck, 2014, pp. 15141534

- Staatsrecht I - Staatsorganisationsrecht: mit Bezügen sum

Europarecht. $28^{\mathrm{a}}$ Ed. Heidelberg: C. F. Müller, 2012

Die Neuordnung der Gesetzgebungskompetenzen durch die

Föderalismusreform. Neue Zeitschrift für Verwaltungsrecht ( $N V w Z)$, ano 25, novembro/ 2006, Caderno 11, pp. 1209 -1216

DI PIETRO, Maria Sylvia Zanella. Direito Administrativo. 25a Ed. São Paulo: Atlas, 2012

DITTMANN, Armin. Artikel 83 [Grundsatz der Länderexekutive]. In: SACHS, Michael (Hrsg.). Grundgesetz - Kommentar. $7^{a}$ Ed. Munique: C. H. Beck, 2014, pp. 1689-1695 Artikel 84 [Länderverwaltung und Bundesaufsicht]. In: SACHS, Michael (Hrsg.). Grundgesetz - Kommentar. Munique: C. H. Beck, 2014, pp. 1696-1711 
$\S 205$ Föderalismus in Gesamtdeutschland. In: ISENSEE, Josef; KIRCHHOF, Paul (Hrsg). Handbuch des Staatsrechts der Bundesrepublik Deutschland. Band IX - Die Einheit Deutschlands - Festigung und Übergang. Heidelberg: C. F. Müller, 1997, pp. 229-258

DRAIBE, Sônia Miriam. As políticas sociais do regime militar brasileiro: 1964-84. In: SOARES, Gláucio Ary Dillon; D’ARAÚJO, Maria Celina (Org.). 21 anos de regime militar: balanços e perspectivas. Rio de Janeiro: Fundação Getúlio Vargas, 1994, pp. 271-309

DÓRIA, Antônio de Sampaio. Direito Constitucional. Volume 1, Segundo Tomo. $5^{\text {a }}$ Ed. São Paulo: Max Limonad, 1962

DREIER, Horst. Artikel 28 [Homogenitätsgebot; kommunale Selbstverwaltung]. In: DREIER, Horst (Hrsg.). Grundgesetz - Kommentar. Band II: Artikel 20-82. $2^{\text {a }}$ Ed. Tübingen: Mohr Siebeck, 2006, pp. 584-694

. Artikel 31 [Vorrang des Bundesrechts]. In: DREIER, Horst (Hrsg.). Grundgesetz-Kommentar. Band II: Artikel 20 - 82. 2a Ed. Tübingen: Mohr Siebeck, 2006, pp. 736-769

DÜRIG, Günter; RUDOLF, Walter (Org). Texte zur deutschen Verfassungsgeschichte vornehmlich für den Studiengebrauch. $3^{\text {a }}$ Ed. Munique: C. H. Besk'sche Verlagsbuchhandlung, 1996

EINSENHARDT, Ulrich. Deutsche Rechtsgeschichte. $3^{\mathrm{a}}$ Ed. Munique: Beck'sche Verlagsbuchhandlung, 1999

ELAZAR, Daniel. Exploring Federalism. Tuscaloosa: The University of Alabama Press, 1987

ERBGUTH, Wilfried. Artikel 30 [Kompetenzverteilung zwischen Bund und Ländern]. In: SACHS, Michael (Hrsg.). Grundgesetz - Kommentar. $7^{\text {a }}$ Ed. Munique: C. H. Beck, 2014, pp. 1091-1103

FERREIRA, Aurélio Buarque de Holanda, DOS ANJOS, Margarida, FERREIRA, Marina Baird. Aurélio século XXI: o dicionário da língua portuguesa. $3^{\mathrm{a}} \mathrm{Ed}$. Rev. Rio de Janeiro, 1999

GARCIA DE ENTERRIA, Eduardo. El proyecto de constitución europea. Revista Española de Derecho Constitucional, ano 15, nº 45, set/dez 1995, pp. 9-29

FERRAZ, Anna Cândida da Cunha. União, Estado e Município na nova Constituição: enfoque jurídico-formal. In: A nova constituição paulista: perspectivas. São Paulo: Fundap, 1989, pp. 56-77

FERRAZ JUNIOR, Tércio Sampaio. A ciência do direito. $2^{\text {a }}$ Ed. São Paulo: Atlas, 1980 
dominação. $4^{\text {a }}$ Ed. São Paulo: Atlas, 2003

Introdução ao estudo do direito. Técnica, decisão, Normas Gerais e Competência Concorrente: Uma exegese do art. 24 da Constituição Federal. Revista Trimestral de Direito Público, ${ }^{\circ}$ 7, 1994, pp. $16-20$

FERREIRA, Gabriela Nunes. Centralização e descentralização no Império: o debate entre Tavares Bastos e visconde de Uruguai. São Paulo: Editora 34, 1999

FERREIRA FILHO, Manoel Gonçalves. Curso de Direito Constitucional. 30 ${ }^{\mathrm{a}}$ Ed. São Paulo: Saraiva, 2003

. O Estado Federal brasileiro à luz da Constituição de 1988. Revista da Faculdade de Direito da Universidade de São Paulo, vol. 86, 1991, pp. 116-129

Comentários á Constitutição Brasileira de 1988.

Volume 1: Arts. $1^{\circ}$ a 43. São Paulo: Saraiva, 1990

Comentários à Constituição brasileira: Emenda

Constitucional $n^{o} 1$, de 17 de outubro de 1969. $1^{o}$ Volume: Artigos $1^{\circ}$ a 45. $2^{\text {a }}$ Ed. São Paulo: Saraiva, 1977

Comentários à Constituição Brasileira (Emenda Constitucional $n^{o} 1$, de 17 de outubro de 1969). $1^{\circ}$ Volume - Artigos 1 a 45. São Paulo: Saraiva, 1972

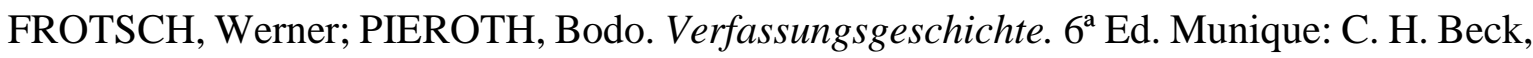
2007

GOMES, Orlando. Raízes Históricas e Sociológicas do Código Civil Brasileiro. Salvador: Livraria Progresso Editora, 1958

GRAZIADEI, Michele. Comparative Law as the study of transplants and receptions. In: ZIMMERMANN, Reinhard; REIMANN, Mathias. The Oxford Handbook of comparative law. Oxford: Oxford University Press, 2006, pp. 441-475

Legal Transplants and the Frontiers of Legal Knowledge.

Theoretical Inquiries in Law, vol. 10, 2009, pp. 693-713

GROTTI, Dinorá Adelaide Musetti. A federação brasileira como força de descentralização do poder. Cadernos de Direito Constitucional e Política, ano 5, n 18, jan/mar. 1997, pp. 130-134

Gábor HALMAI. The use of foreign law in constitutional interpretation. In: Michel ROSENFELD, András SAJÓ (Ed.). The Oxford Handbook of Comparative Constitutional Law. Oxford: Oxford University Press, 2012, pp. 1328-1348 
HAMILTON, Alexander; MADISON, James; JAY, John. O Federalista, Trad. Heitor Almeida Herrera. Brasília: Universidade de Brasília, 1984

HART, Herbert L. A.. O conceito de Direito. Trad. Antônio de Oliveira Sette-Câmara. São Paulo: Martins Fontes, 2009

HECK, Luiz Afonso. O Tribunal Constitucional Federal e o desenvolvimento dos princípios constitucionais: contributo para uma compreensão da Jurisdição Constitucional Federal Alemã. Porto Alegre: Sergio Antonio Fabris, 1995

HEINTZEN, Markus. Artikel 71. In: von MANGOLDT, Hermann; KLEIN, Friedrich; STARCK, Christian (Hrsg.). Kommentare zum Grundgesetz. Band II: Artikel 20-82. $6^{\text {a }}$ Ed. Munique: Franz Vahlen, 2010, pp. 1845-1864

HEITSCH, Christian. Die Ausführung der Bundesgesetze durch die Länder. Tübingen: Mohr Siebeck, 2001

HELLERMANN, Johannes. B. Gemeinschaftsaufgaben (Art. 91a, 91b). In: Christian STARCK (Hrsg). Föderalismusreform: Einführung. Munique: C. H. Beck, Franz Vahlen, 2007, pp. 130-144

HELY LOPES Meirelles em Direito Municipal Brasileiro. $17^{\mathrm{a}}$ Ed. São Paulo: Malheiros, 2013

HERBST, Tobias. Gesetzgebungskompetenzen im Bundesstaat: Eine Rekonstruktion der Rechtsprechung des Bundesverfassungsgerichts. Tübingen: Mohr Siebeck, 2014

HERMES, Georg. Artikel 83 [Ausführung der Bundesgesetze durch die Länder]. In: DREIER, Horst (Hrsg). Grundgesetz - Kommentar. Band III: Artikel 83-146. $2^{\mathrm{a}}$ Ed. Tübingen: Mohr Siebeck, 2008, pp. 1-30

. Artikel 84 [Länderverwaltung und Bundesaufsicht]. In: DREIER, Horst (Hrsg). Grundgesetz - Kommentar. Band III: Artikel 83-146. $2^{\text {a }}$ Ed. Tübingen, pp. 31-81 . Artikel 85 [Bundesauftragsverwaltung durch die Länder]. In: DREIER, Horst (Hrsg). Grundgesetz - Kommentar. Band III: Artikel 83-146. $2^{\mathrm{a}}$ Ed. Tübingen: Mohr Siebeck, 2008, pp. 83-123

Artikel 86 [Bundeseigene Verwaltung]. In: DREIER, Horst (Hrsg).

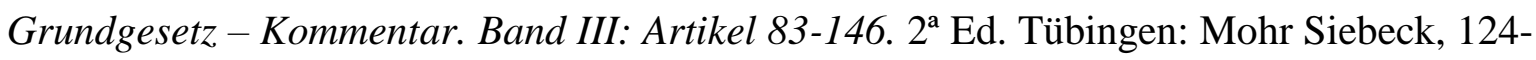
158

Artikel 87 [Gegenstände der bundeseigenen Verwaltung]. In: DREIER, Horst (Hrsg). Grundgesetz - Kommentar. Band III: Artikel 83-146. $2^{\text {a }}$ Ed. Tübingen: Mohr Siebeck, 2008, pp. 159-212 
HESSE, Joachin Jens. República Federal da Alemanha: do federalismo cooperativo à elaboração de política conjunta. Traduções: o federalismo na Alemanha, ano 1995, no 7, pp. 117-137

HESSE, Konrad. Grundzüge des Verfassungsrechts der Bundesrepublik Deutschland. 20a Ed. Heidelberg: C. F. Müller, 1999

. Elementos de Direito Constitucional da República Federal da Alemanha

(Grundzüge des Verfassungsrechts der Bundesrepublik Deutschland. Trad. Luís Afonso Heck. Porto Alegre: Sergio Antonio Fabris Editor, 1998

CAPÍTULO PRIMERO - Constitución y Derecho Constitucional. In: BENDA, Ernst; MAIHOFER, Werner; VOGEL, Hans-Joachim (Coord.). Manual de Derecho Constitucional. 2a Ed. Madrid: Marcial Pons, 2001, pp. 1-15

HERZOG, Roman. § 58 Aufgaben des Bundesrates. In: ISENSEE, Josef; KIRCHHOF, Paul (Hrsg.). Handbuch des Staatsrechts der Bundesrepublik Deutschland. $3^{\circ}$ Volume: Demokratie - Bundesorgane. $3^{\text {a }}$ Ed. Heildelberg: C. F. Müller, 2005, pp. 965-979

HEUN, Werner. Artikel 91a [Mitwirkungsbereiche des Bundes bei Länderaufgaben]. In: DREIER, Horst (Hrsg.). Grundgesetz - Kommentar. Band III: Artikel 83-146. $2^{\mathrm{a}}$ Ed. Tübingen: Mohr Siebeck, 2008, pp. 391-408

Artikel 91b [Forschungsförderung, Leistungsfähigkeit des Bildungswesens]. In: DREIER, Horst (Hrsg.). Grundgesetz - Kommentar. Band III: Artikel 83-146. 2a Ed. Tübingen: Mohr Siebeck, 2008, pp. 409-417

HOBSBAWM, Eric. Era dos Extremos: o breve século XX: 1914-1991. Trad. Marcos Santana. São Paulo: Companhia das Letras, 1995

HOFMANN, Hasso. § 9 Die Entwicklung des Grundgesetzes von 1949 bis 1990. In: ISENSEE, Josef; KIRCHHOF, Paul (Hrsg.). Handbuch des Staatsrechts der Bundesrepublik Deutschland. Band I: Historische Grundlagen. $3^{\text {a }}$ Ed. Heidelberg: C. F. Müller, 2003, pp. 355-421

HOLSTE, Heiko. Der deutsche Bundesstaat im Wandel (1867-1933). Berlin: Dunckler \& Humblot, 2002

HORTA, Raul Machado. Direito Constitucional. $5^{\text {a }}$ Ed (atualizada por Juliana Campos Horta). Belo Horizonte: Del Rey, 2010

. Organização constitucional do federalismo. Revista de Informação Legislativa. Brasília, ano 22, n. 87, jul/set. 1985, pp. 5-22 . (et. Al). Perspectivas do federalismo brasileiro. Belo Horizonte: Universidade de Minas Gerais, 1958 
HUBER, Peter M.. Artikel 31 [Vorrang des Bundesrechts]. In: SACHS, Michael (Hrsg.). Grungesetz - Kommentar. $7^{a}$ Ed. Munique: C. H. Beck, 2014, pp. 1103-1111

INFORMATIONEN ZUR POLITISCHEN BILDUNG. O Conselho Federal. Traduções: $o$ federalismo na Alemanha, ano 1995, nº 7, pp. 75-90

ISENSEE, Josef. $§ 98$ Idee und Gestalt des Föderalismus im Grundgesetz. In: ISENSEE, Josef; KIRCHHOF, Paul (Hrsg). Handbuch des Staatsrechts der Bundesrepublik Deutschland. Band IV - Finanzverfassung - Bundesstaatliche Ordnung. 2 ${ }^{\mathrm{a}}$ Ed. Heidelberg: C. F. Müller Juristischer Verlag, 1999, pp. 517-691

$\S$ 133. Die bundesstaatliche Kompetenz. In: ISENSEE, Josef; KIRCHHOF, Paul (Hrsg). Handbuch des Staatsrechts der Bundesrepublik Deutschland. Volume VI: Bundesstaat. $3^{\text {a }}$ Ed. Heidelberg: C. F. Müller, 2008, pp. 455-513

JACKSON, Vicki C.. Comparative consitutitional law: methodologies. In: ROSENFELD, Michel; SAJÓ, András (Ed.). The Oxford Handbook of Comparative Constitutional Law. Oxford: Oxford University Press, 2012 pp. 54-74

JANSEN, Nils. Comparative Law and Comparative Knowledge. In: ZIMMERMANN, Reinhard; REIMANN, Mathias (Coord.). The Oxford Handbook of comparative law. Oxford: Oxford University Press, 2006, pp. 305-338

JARASS, Hans D.; PIEROTH, Bodo. Grundgesetz für die Bundesrepublik Deutschland: Kommentar. 12a Ed. Munique: C. H. Beck, 2012

JAYME, Erik; NEUSS, Jobst-Joachim. Wörterbuch Recht und Wirtschaft. Band 2: DeutschPortugiesisch. $2^{\text {a }}$ Ed. Munique: C. H. Beck, 2013

JESTAEDT, Matthias. $§ 29$ Bundesstaat als Verfassungsprinzip. In: ISENSSE, Josef; KIRCHHOF, Paul (Hrsg). Handbuch des Staatsrechts der Bundesrepublik Deutschland. $3^{\mathrm{a}}$ Ed. Heidelberg: C. F. Müller, 2004, pp. 785-841

KELSEN, Hans. Teoria Pura do Direito. Trad. João Baptista Machado. $7^{\text {a }}$ Ed. São Paulo: Martins Fontes, 2006

Teoria Geral do Direito e do Estado. Trad. Luís Carlos Borges. São Paulo:

Martins Fontes, 2000

KING, Preston. Federalism and Federation. Baltimore: The John Hopkins University Press, 1982

KISKER, Gunter. Kooperation im Bundesstaat: Eine Untersuchung zum kooperativen Föderalismus in der Bundesrepublik Deutschland. Tübingen: J. C. B. Mohr (Paul Siebeck), 1971 
KLUTH, Winfried. Die deutsche Föderalismusreform 2006: Beweggründe - Zielsetzungen - Veränderungen. In: Winfried KLUTH (Hrsg). Föderalismusreformgesetz - Einführung und Kommentierung. Baden-Baden: Nomos, 2007

KÖBLER, Gerhard. Rechtsportugiesisch: Deutsch-portugiesisches und portugiesischdeutsches Rechtswörterbuch für jedermann. Munique: Franz Vahlen, 2007

KRELL, Andreas J.. As competências administrativas do artigo 23 da CF, sua regulamentação por lei complementar e o "poder-dever de polícia". Interesse Público, ano 5, no 20, julho/agosto 2003, pp. 53-71

Diferenças do conceito, desenvolvimento e conteúdo da autonomia municipal na Alemanha e no Brasil. Revista de Informação Legislativa, Brasília, ano 32, $\mathrm{n}^{\circ}$ 128, out/dez. 1995, pp. 107-125

KROESCHELL, Karl. Deutsche Rechtsgeschichte. Band 3: Seit 1650. $3^{\text {a }}$ Ed. Wiesbaden: Westdeutsche Verlag, 2001

KROPP, Sabine. Kooperativer Föderalismus und Politikverflechtung. Wiesbaden: VS Verlag für Sozialwissenschaften, 2010

KUGELMAS, Eduardo (Org.). José Antônio Pimenta Bueno, Marques de São Vicente. São Paulo: Editora 34, 2002

LEAL, Victor Nunes. Coronelismo, enxada e voto: o Município e o regime representativo no Brasil. $7^{\text {a }}$ Ed. São Paulo: Companhia das Letras, 2012

Leis Municipais. In: LEAL, Victor Nunes. Problemas de Direito Público. Rio de Janeiro: Forense, 1960, pp. 160-178

. Alguns problemas municipais em face da Constituição. In: LEAL,

Victor Nunes. Problemas de Direito Público. Rio de Janeiro: Forense, 1960, pp. 312-337

LOEWENSTEIN, Karl. Teoria de la Constitución. Trad. Alfredo Gallego Anabitarte. Barcelona: Ediciones Ariel, 1969

MAHONEY, James; THELEN, Kathleen. A Theory of Gradual Institutional Change. In: MAHONEY, James; THELEN, Kathleen. Explaining Institutional Change: Ambiguity, Agency, and Power. Cambridge: Cambridge University Press, 2010

MARRARA, Thiago. Do modelo municipal alemão aos problemas municipais brasileiros. Revista brasileira de Direito Municipal-RBDM, ano 9, n. 27, jan./mar. 2008, pp. 33-52

MARTINS, Leonardo. Direito Processual Constitucional Alemão. São Paulo: Atlas, 2011

MÄRZ, Wolfgang. Artikel 30. In: von MAGOLDT, Hermann; KLEIN, Friedrich; STARCK,

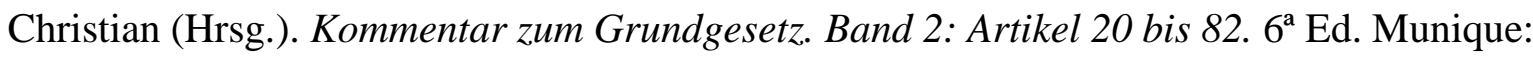
Franz Vahlen, 2010, pp. 677-711 
Artikel 31. In: von MANGOLDT, Hermann; KLEIN, Friedrich; STARCK, Christian (Hrsg.). Kommentar zum Grundgesetz. Band 2: Artikel 20 bis 82. $6^{\mathrm{a}}$ Ed. Munique: Franz Vahlen, 2010, pp. 713-760

MAURER, Harmut. Allgemeines Verwaltungsrecht. 16 ${ }^{\text {a }}$ Ed. Munique: C. H. Beck, 2006

MAZZUOLI, Valerio de Oliveira. Curso de Direito Internacional Público. $4^{\mathrm{a}}$ Ed. São Paulo: Revista dos Tribunais, 2010

MENDES, Gilmar Ferreira. Jurisdição Constitucional: o controle abstrato de normas no Brasil e na Alemanha. $5^{\text {a }}$ Ed. São Paulo: Saraiva, 2005

; COELHO, Inocêncio Mártires; BRANCO, Paulo Gustavo

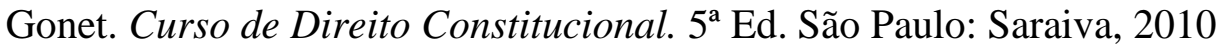

MENDES, René. Asbesto (amianto) e doença: revisão do conhecimento científico e fundamentação para uma urgente mudança da atual política brasileira sobre a questão. Cadernos de Saúde Pública, Rio de Janeiro, 17 (1), jan./fev. 2001, pp. 7-29

MENEZES DE ALMEIDA, Fernando Dias. Formação da Teoria do Direito Administrativo no Brasil. São Paulo: Quartier Latin, 2015

Comentários aos artigos 44 a 46. In:

CANOTILHO, J. J. Gomes; MENDES, Gilmar Ferreira; SARLET, Ingo Wolfgang; STRECK; LEONCY, Léo Ferreira (Coord). Comentários à Constituição de Brasil. São Paulo: Saraiva, 2013, pp. 996-999

Quartier Latin, 2012

Contrato administrativo. São Paulo: Atos administrativos normativos: algumas questões. In: MEDAUAR, Odete; SCHIRATO, Vitor Rhein (Coord.). Os caminhos do ato administrativo. São Paulo: Revista dos Tribunais, 2012, pp. 219-236

- Crítica ao tratamento constitucional do

Município como ente da federação brasileira. Doutrinas Essenciais de Direito Constitucional, v. 3, maio/2011, pp. 929 e ss

ZAGO, Mariana Augusta dos Santos. Breves considerações sobre o papel das cortes constitucionais em uma federação (no prelo)

MENEZES CORDEIRO, António. Da boa fé no Direito Civil. Coimbra: Almedina, 2013

MICHAELS, Ralf. The functional method of comparative law. In: ZIMMERMANN, Reinhard; REIMANN, Mathias (Coord.). The Oxford Handbook of comparative law. Oxford: Oxford University Press, 2006, pp. 339-382 
MOREIRA NETO, Diogo de Figueiredo. Competência concorrente limitada: o problema da conceituação das normas gerais. Revista de Informação Legislativa, Brasília, ano 25, nº 100, outubro/dezembro 1988, pp. 127-162

MUßGNUG, Reinhard. $\S 8$ - Zustandekommen des Grundgesetzes und Entstehen der Bundesrepublik Deutschland. In: ISENSEE, Josef; KIRCHHOF, Paul (Coord). Handbuch des Staatsrechts der Bundesrepublik Deutschland. Band 1: Historische Grundlagen. $3^{\mathrm{a}}$ Ed. Heidelberg: C. F. Müller, 2003, pp. 315-354

NETO LOBO, Paulo Luiz. Competência legislativa concorrente dos Estados-Membros na Constituição de 1988. Revista de Informação Legislativa, Brasília, ano 26, $\mathrm{n}^{\circ} 101$, janeiro/março 1989, pp. 87-104

NIERHAUS, Michael. Artikel 28 [Verfassungsmäßige Ordnung in den Ländern, Wahlrecht, kommunale Selbstverwaltung, Gewährleistung durch den Bund]. In: SACHS, Michael (Hrsg.). Grundgesetz - Kommentar. $7^{\text {a }}$ Ed. Munique: C. H. Beck, 2014, pp. 1032-1072

OBINGER, Herbert; LEIBFRIED, Stephan; CASTLES, Francis G.. Introduction, In: OBINGER, Herbert; LEIBFRIED, Stephan; CASTLES, Francis G. (Org.). Federalism and the Welfare State: New World and European Experiences. Cambridge: Cambridge University Press, 2005, pp. 1-48

OEBBECKE, Janbernd. § 136 - Verwaltungszuständigkeit. In: ISENSEE, Josef; KIRCHHOF, Paul (Hrsg). Handbuch des Staatsrechts der Bundesrepublik Deutschland. Band VI-Bundesstaat. $3^{\text {a }}$ Ed. Heidelberg: C. F. Müller, 2008, pp. 743-809

OETER, Stefan. Artikel 72. In: von MANGOLDT, Hermann; KLEIN, Friedrich; STARCK, Christian (Hrgs). Kommentare zum Grundgesetz. Band II: Artikel 20-82. $6^{\text {a }}$ Ed. Munique: Franz Vahlen, 2010, pp. 1865-2120

Artikel 74a. In: von MANGOLDT, Hermann; KLEIN, Friedrich; STARCK, Christian (Hrsg). Kommentar zum Grundgesetz. Band 2: Artikel 20 bis 82. $5^{\text {a Ed. }}$ Munique: Franz Vahlen, 2005, pp. 2027-2037

OLIVEIRA VIANNA, Francisco José de. O idealismo da Constituição. $2^{\text {a }}$ Ed. São Paulo, Rio de Janeiro, Recife, Porto Alegre: Companhia Editora Nacional, 1939

OSCAR VILHENA Vieira. Supremo Tribunal Federal: jurisprudência política. $2^{\text {a }}$ Ed. São Paulo: Malheiros, 2002

PAES DE BARROS, Renato. Da conceituação jurídica do Senado na Constituição de 16 de Julho. São Paulo: Revista dos Tribunaes, 1937

PERNICE, Ingolf. Artikel 30 [Kompetenzverteilung zwischen Bund und Länder]. In: DREIER, Horst (Hrsg.). Grundgesetz - Kommentar. $2^{\text {a }}$ Ed. Tübingen: Mohr Siebeck, 2006, pp. 717-737 
PESTALOZZA, Christian. Thesen zur kompetenzrechtlichen Qualifikation von Gesetzen im Bundesstaat. Die Öffentliche Verwaltung (DÖV), ano 25, caderno 6, março/1972, pp. 181192

PONTES DE MIRANDA, Francisco Cavalcanti. Comentários à constituição de 1967. Tomo III (Arts. 34-112). São Paulo: Revista dos Tribunais, 1967

. Comentários à Constituição de 1946.

Tomo II (Arts. $6^{o}$ - 72). $2^{\circ}$ Ed. Rio de Janeiro: Borsoi, 1960

POSSER, Diether. CAPÍTULO XIII - Significado del Bundesrat. In: BENDA, Ernst; MAIHOFER, Werner; VOGEL, Hans-Jochen; HESSE, Konrad, HEYDE, Wolfgang. Manual de Derecho Constitucional. Trad. Antonio López Pina. $2^{\text {a }}$ Ed. Madrid e Barcelona: Marcial Pons, 2001, pp. 677-726

RENGELING, Hans-Werner. $§ 135$ - Gesetzgebungszuständigkeit. In: ISENSEE, Josef; KIRCHHOF, Paul (Hrsg.). Handbuch des Staatsrechts der Bundesrepublik Deutschland. Band VI-Bundesstaat. $3^{\text {a }}$ Ed. Heidelberg: C. F. Müller, 2008, pp. 567-741

RIKER, William H.. Federalism. In: GREENSTEIN, Fred I. ; POLSBY, Nelson W. (Eds.). Handbook of Political Science. Volume 5: Governmental Institutions and Processes. Massachusetts: Addison-Wesley, 1975, pp. 93-172

RODDEN, Jonathan. Federalismo e descentralização em perspectiva comparada: sobre significados e medidas. Revista de Sociologia e Política, Curitiba, nº 24, junho 2005, pp. 927

ROGÉRIO, Nuno. A Lei Fundamental da República Federal da Alemanha: com um ensaio e anotações de Nuno Rogério. Coimbra: Coimbra Editora, 1996

ROVIRA, Enoch Alberti. Federalismo y Cooperación en la Republica Federal Alemana. Madrid: Centro de Estudios Constitucionales, 1986

ROZEK, Jochen. Artikel 70. In: von MANGOLDT, Hermann; KLEIN, Friedrich; STARCK, Christian (Hrgs). Kommentare zum Grundgesetz. Band II: Artikel 20-82. $6^{\text {a }}$ Ed. Munique: Franz Vahlen, 2010, pp. 1803-1843

ROZEK, Jochen. Artikel 75. In: von MANGOLDT, Hermann; KLEIN, Friedrich; STARCK, Christian (Hrgs). Kommentare zum Grundgesetz. Band II: Artikel 20-82. $5^{\mathrm{a}}$ Ed. Munique: Franz Vahlen, 2005, pp. 2039-2080

RUDOLF, Walter. $\S 141$ Kooperation im Bundesstaat. In: ISENSEE, Josef; KIRCHHOF, Paul (Hrsg.). Handbuch des Staatsrechts der Bundesrepublik Deutschland. Band VI: Bundesstaat. 5a Ed. Heidelberg: C. F. Müller, 2008, pp. 1005-1047 
SACHS, Michael. Artikel 20 [Verfassungsgrundsätze; Widerstandsrecht]. In: SACHS, Michael (Hrsg). Grundegesetz - Kommentar. $7^{\text {a }}$ Ed. Munique: C. H. Beck, 2014, pp. 798860

SALINAS, Natasha Schmitt Caccia. Reforma administrativa de 1967: a reconciliação do legal com o real. In: MOTA, Carlos Guilherme; SALINAS, Natasha Schmitt Caccia (Coord). Os juristas na formação do Estado-Nação brasileiro: 1930 - dias atuais. São Paulo: Saraiva, 2010, pp. 453-482

SARLET, Ingo Wolfgang; MARINONI, Luiz Guilherme; MITIDIERO, Daniel. Curso de Direito Constitucional. São Paulo: Revista dos Tribunais, 2012

SCHARPF, Fritz W.. Die Föderalismusreform: kein Ausweg aus der Politikverflechtungsfalle?. Frankfurt e Nova Iorque: Campus, 2009 The joint-decision trap: lessons from German Federalism and European Integration. Public Administration, v. 66, outono/1988, pp. 239-278

SCHLAICH, Klaus; KORIOTH, Stefan. Das Bundesverfassungsgericht: Stellung, Verfahren, Entscheidungen. $7^{\text {a }}$ Ed. Munique: C. H. Beck, 2007

SCHLIESKY, Utz. $\$ 30$ Stadt-Umland-Verbände. In: MANN, Thomas; PÜTTNER, Günter (Hsrg.). Handbuch der kommunalen Wissenschaft und Praxis. Band 1: Grundlagen und Kommunalverfassung. $3^{\text {a }}$ Ed. Berlim e Heidelberg: Springer, 2007, pp. 873-899

SCHMIDT, Thorsten Ingo. Kommunalrecht. $2^{\mathrm{a}}$ Ed. Tübingen: Mohr Siebeck, 2014

SCHMIDT-AßMANN, Eberhard, RÖHL, Hans Christian. Kommunalrecht. In: Eberhard SCHMIDT-AßMANN, Friedrich SCHOCH (Hrsg.). Besonderes Verwaltungsrecht. $14^{\mathrm{a}}$ Ed. Berlin: De Gruyter, 2008, pp. 9-125

SCHWARTZ, Bernard. Direito Constitucional Americano. Trad. Carlos Nayfeld. São Paulo: Ed. Forense, 1966

SELMER, Peter. Die Föderalismusreform II - Ein verfassungsrechtliches monstrum simile. Neue Zeitschrift für Verwaltungsrecht (NVwZ), 2009, pp. 1256-1262

Die Föderalismusreform - Eine Modernisierung der bundesstaatlichen Ordnung. Juristische Schulung - JUS, caderno 12, 2006, pp. 1053-1060

SILVA, José Afonso. O Constitucionalismo brasileiro: evolução institucional. São Paulo: Malheiros, 2011

Malheiros, 2009

um pouco de Direito Constitucional Comparado. São Paulo: Curso de Direito Constitucional Positivo. 24ª Ed. Malheiros: São

Paulo, 2004 
SILVA, Virgílio Afonso da. Capítulo 25 - Federalismo e articulação de competências no Brasil. In: PETERS, B. Guy, PIERRE, Jon (Orgs.). Administração Pública: Coletânea. São Paulo: UNESP; Brasilia: ENAP, 2010, pp. 549-570

. Interpretação constitucional e sincretismo metodológico. In:

SILVA, Virgílio Afonso da (Org.). Intepretação constitucional. São Paulo: Malheiros, 2005, pp. $115-143$

SILVEIRA, Alessandra. Cooperação e compromisso constitucional nos Estados Compostos: Estudo sobre a teoria do federalismo e a organização jurídica dos sistemas federativos. Coimbra: Almedina, 2007

SKIDMORE, Thomas. Brasil: de Castelo a Tancredo. Trad. Mário Salviano Silva. $8^{\text {a }}$ Ed. São Paulo: Paz e Terra, 1988

SOMMERMANN, Karl-Peter. Artikel 20. In: von MANGOLDT, Hermann; KLEIN, Friedrich; STARCK, Christian (Hrgs). Kommentare zum Grundgesetz. Band II: Artikel 2082. $5^{\text {a }}$ Ed. Munique: Franz Vahlen, 2005, pp. 1-162

SOUSA, António Francisco de. Fundamentos da tradução jurídica alemão-português. São Paulo: Saraiva, 2014

SOUZA, Celina. Federalismo: Teorias e Conceitos Revisitados. Revista Brasileira de Informação Bibliográfica em Ciências Sociais - BIB, São Paulo, nº 65, $1^{\circ}$ semestre/2008, pp. $27-48$

Federalismo, desenho constitucional e instituições federativas no Brasil pós-1988. Revista de Sociologia e Política, Curitiba, no 24, jun/2005, pp. 105-121

Federalismo e Descentralização na Constituição de 1988: Processo Decisório, Conflitos e Alianças. DADOS - Revista de Ciências Sociais, Rio de Janeiro, Vol. $44, \mathrm{n}^{\mathrm{o}} 3,2001$, pp. 513-560

Constitutional Engineering in Brazil: The Politics of Federalism and Decentralization. Basingstoke: Macmillan Press, 1997

SOUZA, Rubens Gomes de; ATALIBA, Geraldo; CARVALHO, Paulo de Barros. Comentários ao Código Tributário Nacional (Parte Geral). $2^{\mathrm{a}}$ Ed. São Paulo: Malheiros, 1985

SOUZA NETO, Cláudio Pereira de. Comentários ao artigo 144. In: CANOTILHO, J. J. Gomes; MENDES, Gilmar Ferreira; SARLET, Ingo Wolfgang; STRECK, Lenio Luiz; LEONCY, Léo Ferreira (Coord). Comentários à Constituição do Brasil. São Paulo: Saraiva, 2013, pp. 1583-1588

STARCK, Christian. 1. Teil. Einführung. In: STARCK, Christian (Hrsg). Föderalismusreform. Munique: C. H. Beck e Franz Vahlen, 2007 
STERN, Klaus. Das Staatsrecht der Bundesrepublik Deutschland. Band V: Die geschichtlichen Grundlagen des deutschen Staatsrechts. Munique: C. H. Beck'sche Verlagsbuchhandlung, 2000

. Das Staatsrecht der Bundesrepublik Deutschland. Band I: Grundbegriffe und Grundlagen des Staatsrechts, Strukturprinzipien der Verfassung. $2^{\mathrm{a}}$ Ed. Munique: C. H. Beck'sche Verlagsbuchhandlung, 1984

STETTNER, Rupert. Artikel 70 [Gesetzgebung des Bundes und der Länder]. In: DREIER, Horst (Hrsg.). Grundgesetz - Kommentar. $2^{\mathrm{a}}$ Ed. Tübingen : Mohr Siebeck, 2006, pp. 15451586

Artikel 71 [Ausschließliche Gesetzgebung des Bundes]. In: DREIER, Horst (Hrsg). Grundgesetz - Kommentar. Band II: Artikel 20-82. $2^{\text {a }}$ Ed. Tübingen: Mohr Siebeck, 2006, pp. 1587-1596

Artikel 72 [Konkurrierende Gesetzgebung des Bundes]. In:

DREIER, Horst (Hrsg.). Grundgesetz - Kommentar. Band II: Artikel 20-82. $2^{\text {a }}$ Ed. Tübingen: Mohr Siebeck, 2006, pp. 1597-1618

Artikel 75 [Rahmengesetzgebung des Bundes]. In: DREIER, Horst

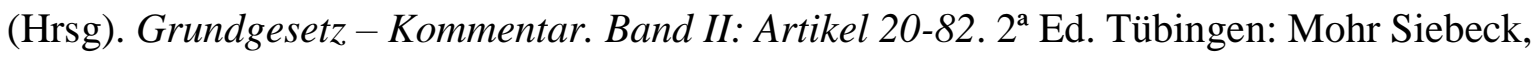
2006, pp. 1704-1724

Grundfragen einer Kompetenzlehre. Berlin: Dunckler \& Humblot,

1983

STRECK, Lenio Luiz. Jurisdição constitucional e decisão jurídica. $4^{\mathrm{a}}$ ed. São Paulo: Revista dos Tribunais, 2013

SUNDFELD, Carlos Ari. Sistema constitucional das competências. Revista Trimestral de Direito Público, no 1, 1993, pp. 272-281

TAVARES, André Ramos. Aporias acerca do "condomínio legislativo" no Brasil: uma análise a partir do STF. In: TAVARES, André Ramos; LEITE, George Salomão; SARLET, Ingo Wolfgang (Org.). Estado constitucional e organização do poder. São Paulo: Saraiva, 2010, pp. 161-191

TAVARES BASTOS, Aureliano Cândido. A Província: estudo sobre a descentralização no Brasil. Brasília: Senado Federal, 1996

TETTINGER, Peter J.; SCHWARZ, Kyrill-A.. Artikel 28. In: von MANGOLDT, Hermann; KLEIN, Friedrich; STARCK, Christian (Hrgs). Kommentare zum Grundgesetz. Band II: Artikel 20-82. 6a Ed. Munique: Franz Vahlen, 2010, pp. 567-641 
TRUTE, Hans-Heinrich. Artikel 83. In: von MANGOLDT, Hermann; KLEIN, Friedrich; STARCK, Christian (Hrgs). Kommentare zum Grundgesetz. Band III: Artikel 83-146. $6^{\mathrm{a}}$ Ed. Munique: Franz Vahlen, 2010, pp. 1-43

Artikel 84. In: von MANGOLDT, Hermann; KLEIN, Friedrich; STARCK, Christian (Hrgs). Kommentare zum Grundgesetz. Band III: Artikel 83-146. 6 a Ed. Munique: Franz Vahlen, 2010, pp. 45-83

Artikel 85. In: von MANGOLDT, Hermann; KLEIN, Friedrich; STARCK, Christian (Hrgs). Kommentare zum Grundgesetz. Band III: Artikel 83-146. $6^{\text {a }}$ Ed. Munique: Franz Vahlen, 2010, pp. 85-107

URUGUAY, Visconde do. Ensaio sobre o Direito Administrativo. Tomo II. Rio de Janeiro: Typographia Nacional, 1862

VASQUES, Denise C.. Competências Legislativas concorrentes: prática legislativa da União e dos Estados-membros e jurisprudência do Supremo Tribunal Federal. Dissertação de mestrado - Faculdade de Direito da Universidade de São Paulo (FDUSP). São Paulo, 2007

VOGEL, Juan Joaquín. CAPÍTULO XII - El régimen federal de la Ley Fundamental. In: BENDA, Ernst; MAIHOFER, Werner; VOGEL, Hans-Jochen; HESSE, Konrad; HEYDE, Wolfgang. Manual de Derecho Constitucional. Trad. Antonio López Pina. $2^{\text {a }}$ Ed. Madrid e Barcelona: Marcial Pons, 2001, pp. 613-675

$\S 22$ Die bundesstaatliche Ordnung des Grundgesetzes. In: BENDA, Ernst; MAIHOFER, Werner; VOGEL, Hans-Jochen; HESSE, Konrad; HEYDE, Wolfgang (Hrsg.) Handbuch des Verfassungsrechts der Bundesrepublik Deutschland. $2^{\circ}$ Volume. 2a Ed. Berlin: Walter de Gruyter, 1994, pp. 1041-1102

VOLKMANN, Uwe. Artikel 91a. In: von MANGOLDT Hermann; KLEIN, Friedrich; STARCK, Christian (Hrsg). Kommentar zum Grundgesetz. Band 3: Artikel 83 a 146. $5^{\mathrm{a}}$ Ed. Munique: Franz Vahlen, 2005, pp. 511-537

Artikel 91b. In: von MANGOLDT Hermann; KLEIN, Friedrich;

STARCK, Christian (Hrsg). Kommentar zum Grundgesetz. Band 3: Artikel 83 a 146. $5^{\mathrm{a}}$ Ed. Munique: Franz Vahlen, 2005, pp. 539-548

WATSON, Alan. Legal Transplants: An Approach to Comparative Law. $2^{\mathrm{a}}$ Ed. Athens e Londres: The University of Georgia Press, 1993

WATTS, Ronald L.. Comparing Federal Systems. $3^{\text {a }}$ Ed. Montreal \& Kingston: McGillQueen's University Press, 2008

WHEARE, Kenneth C.. Federal Government. Nova Iorque: Oxford University Press, 1947 
ZAGO, Mariana Augusta dos Santos. O interesse local do Município sob a égide da Constituição Federal de 1988: alguns apontamentos. Revista de Direito Administrativo Contemporâneo, ano 2, volume 9, junho/2014, pp. 177-199

; CARVALHO, Guilherme Siqueira de. O Estatuto Geral das Guardas Municipais (Lei $\mathrm{n}^{\circ}$ 13.022/2014): considerações sobre sua constitucionalidade à luz da repartição federativa de competências. Revista de Direito Administrativo Contemporâneo (ReDAC), São Paulo, ano 3, vol. 21, nov./dez. 2015, pp. 169-198

ZIMMERMAN, Joseph F.. Contemporary American Federalism: The Growth of National Power. $2^{\text {a }}$ Ed. Nova York: State University of New York Press, 2008

ZIPPELIUS, Reinhold. Kleine deutsche Verfassungsgeschichte: vom frühen Mittelalter bis zur Gegenwart. $7^{\text {a }}$ Ed. Munique: C. H. Beck, 2006

ZWEIGERT, Konrad; KÖTZ, Hein. Introduction to Comparative Law. $3^{\text {a }}$ Ed. Oxford: Clarendon Press, 1998

\section{REFERÊNCIAS ELETRÔNICAS}

Assembleia Nacional Constituinte - Subcomissão da União, do Distrito Federal e Territórios: Relatório e Anteprojeto. (http://www.camara.gov.br/internet/constituicao20anos/DocumentosAvulsos/vol-87.pdf. Acesso: 13/12/2014).

Bayern.Recht - Verfassung des Freistaates Bayern in der Fassung der Bekanntmachung vom 15. Dezember 1988 (http://gesetze-bayern.de/Content/Document/BayVerf/true. Acesso: 21/01/2016).

Bijus - Loi fondamentale / Grundgesetz (http://www.bijus.eu/?p=9663. Acesso: 09/03/2016).

Bundesministerium der Justiz und für Verbraucherschutz - Basic Law fort he Federal Republic of Germany (http://www.gesetze-im-internet.de/englisch_gg/englisch_gg.html\#p0142. Acesso: 15/07/2013)

Bundesrat $\quad-\quad$ Die Länder im (http://www.bundesrat.de/DE/bundesrat/laender/laender-node.html. Acesso: 17/03/2015).

Bundesrat - Statistik (http://www.bundesrat.de/DE/dokumente/statistik/statistik-node.html. Acesso: 28/03/2015). 
Câmara dos Deputados - Constituição Federal - Comissões e Subcomissões temáticas (http://www2.camara.leg.br/atividade-

legislativa/legislacao/Constituicoes_Brasileiras/constituicao-cidada/o-processo-

constituinte/lista-de-comissoes-e-subcomissoes. Acesso: 13/12/2014).

Câmara dos Deputados - Constituição Federal - Comissões e Subcomissões temáticas (http://www2.camara.leg.br/atividade-

legislativa/legislacao/Constituicoes_Brasileiras/constituicao-cidada/o-processo-

constituinte/lista-de-comissoes-e-subcomissoes. Acesso: 30/04/2015.)

Câmara dos Deputados - $\quad$ Lideranças e Bancadas (http://www2.camara.leg.br/deputados/liderancas-e-bancadas. Acesso: 08/10/2015).

Câmara dos Deputados - Quantos são e de que forma é definido o número de Deputados (http://www2.camara.leg.br/a-camara/conheca/quantos-sao-e-de-que-forma-e-definido-onumero-de-deputados. Acesso: 21/01/2015).

Câmara dos Deputados - Regimento interno da Assembleia Nacional Constituinte (http://www2.camara.leg.br/atividade-

legislativa/legislacao/Constituicoes_Brasileiras/constituicao-cidada/publicacoes/regimentointerno-da-assembleia-nacional/resolucao-2-1987. Acesso: 01/12/2014).

Constitution of the Republic of South Africa, 1996 - Chapter 7: Local Government (http://www.gov.za/documents/constitution-republic-south-africa-1996-chapter-7-localgovernment\#151. Acesso: 24/01/2016)

Cornell University Law School - CRS Annoted Constitution - Tenth Amendment (https://www.law.cornell.edu/anncon/html/amdt10_user.html\#amdt10_hd4. Acesso: 30/05/2015).

Curso de Estudos Europeus - Versões consolidadas do Tratado da União Europeia e do $\begin{array}{lllll}\text { Tratado sobre } & \mathrm{O} & \text { Funcionamento da União Europeia }\end{array}$ (http://www.fd.uc.pt/CI/CEE/pm/Tratados/Lisboa/tratados-TUE-TFUE-VLisboa.html\#TFUE-PARTE-III-TIT-VII-CAP-1-SECCAO-2. Acesso: 29/11/2015).

Deutscher Bundestag - Wissenschaftliche Dienste - Föderalismusreform 2006 (http://www.thueringer-landtag.de/mam/landtag/gremien-und-

rechtsgrundlagen/f_dealismusreform_2006.pdf. Acesso: 14/03/2016)

Dicionário Pons - $\quad$ "Land" (http://pt.pons.com/tradu\%C3\%A7\%C3\%A3o?q=Land\&l=dept\&in=\&lf=de. Acesso: 25/06/2015).

EMPLASA - Fórum Nacional de Entidaes Metropolitanas - Legislações (http://www.emplasa.sp.gov.br/fnem/legislacao.asp. Acesso: 04/02/2016) 
Forum of Federations - Federalism by Country (http://www.forumfed.org/countries. Acesso: 13/03/2016).

Instituto Brasileiro de Geografia e Estatística (IBGE) - Indicadores Sociais Municipais 2000 (http://www.ibge.gov.br/home/estatistica/populacao/indicadores_sociais_municipais/tabela 1a.shtm. Acesso: 07/01/2015)

Instituto Brasileiro de Geografia e Estatística (IBGE) - Indicadores sociais municipais 2010 (http://www.ibge.gov.br/home/estatistica/populacao/censo2010/indicadores_sociais_munic ipais/tabelas_pdf/tab1.pdf. Acesso: 07/01/2015).

Instituto Brasileiro de Geografia e Estatística (IBGE) - Sinopse do Censo Demográfico 2010 $\begin{array}{lrr}- & \text { Tabela } & 1.19\end{array}$ (http://www.ibge.gov.br/home/estatistica/populacao/censo2010/sinopse/sinopse_tab_brasil _zip.shtm. Acesso: 11/10/2015).

Ministério da Justiça - Conselho Nacional de Segurança Pública (CONASP) (http://portal.mj.gov.br/data/Pages/MJDE2A290DITEMID4D7BA2232A4E4DEA93D108 413FB9B62APTBRIE.htm Acesso: 10/01/2016).

Ministério da Justiça - Conselho Nacional de Segurança Pública (CONASP) - Composição (http://portal.mj.gov.br/data/Pages/MJ337926C4ITEMID53E5AC7324014DFEB2D9520E 5D7D247APTBRIE.htm. Acesso: 10/01/2016.)

Ministério do Meio Ambiente - CONAMA (http://www.mma.gov.br/port/conama/. Acesso: 10/01/2016).

Ministerium für Inneres und Kommunales des Landes Nordrhein-Westfalen - Verfassunf für das Land Nordrhein-Westfalen (https://recht.nrw.de/lmi/owa/br_text_anzeigen?v_id=2320020927105939563\#det250879. Acesso: 29/01/2016)

Senado Federal - Senadoras e Senadores em exercício (http://www.senado.gov.br/senadores/senadoresPorPartido.asp. Acesso: 08/10/2015).

Statistisches Bundesamt. Kreisfreie Städte und Landkreise nach Fläche, Bevölkerung und Bevölkerungsdichte am

31.12.2014 (https://www.destatis.de/DE/ZahlenFakten/LaenderRegionen/Regionales/Gemeindeverzeic hnis/Administrativ/Aktuell/04Kreise.html. Acesso: 21/01/2016).

Supremo Tribunal Federal - "A Constituição e o Supremo" (http://www.stf.jus.br/arquivo/cms/publicacaoLegislacaoAnotada/anexo/constituicao.PDF. Acesso: 06/03/2016). 
$\begin{array}{lllll}\text { Tribunal Superior } & \text { Eleitoral } & - & \text { Estatísticas } & \text { Eleitorais } \\ 2014\end{array}$ (http://www.tse.jus.br/eleicoes/estatisticas/estatisticas-eleitorais-2014-resultado. Acesso: 21/01/2015).

United States Senate - Constitution of the United States (http://www.senate.gov/civics/constitution_item/constitution.htm. Acesso: 08/09/2014).

Verfassungen.de - Grundgesetz für die Bundesrepublik Deutschland mit Änderungsindex (http://www.verfassungen.de/de/gg49-i.htm. Acesso: 28/03/2015)

Yale Law School - The Versailles Treaty June 28, 1919 Part VIII (http://avalon.law.yale.edu/imt/partviii.asp. Acesso: 11/02/2015). 


\section{ANEXO}

\section{Grundgesetz für die Bundesrepublik Deutschland (Lei Fundamental para a República Federativa da Alemanha) ${ }^{1125}$}

\section{Art. 28 II GG}

(2) Den Gemeinden muß das Recht gewährleistet sein, alle Angelegenheiten der örtlichen Gemeinschaft im Rahmen der Gesetze in eigener Verantwortung zu regeln. Auch die Gemeindeverbände haben im Rahmen ihres gesetzlichen Aufgabenbereiches nach Maßgabe der Gesetze das Recht der Selbstverwaltung. Die Gewährleistung der Selbstverwaltung umfaßt auch die Grundlagen der finanziellen Eigenverantwortung; zu diesen Grundlagen gehört eine den Gemeinden mit Hebesatzrecht zustehende wirtschaftskraftbezogene

Steuerquelle.

\section{Art. 28 II GG (Traduzido)}

(2) Aos municípios deve ser garantido o direito de regulamentar todos os assuntos do interesse da comunidade local nos limites da lei e sob sua própria responsabilidade. As associações de municípios também terão, nos limites das suas atribuições legais e conforme a lei, o direito à autoadministração. A garantia da autoadministração alcança também os fundamentos da sua autonomia financeira; a esses fundamentos pertencem uma fonte de impostos relacionadas à capacidade econômica com o direito de estabelecer as alíquotas respectivas.

\section{Art. 30 GG}

Die Ausübung der staatlichen Befugnisse und die Erfüllung der staatlichen Aufgaben ist Sache der Länder, soweit dieses Grundgesetz keine andere Regelung trifft oder zuläßt.

\section{Art. 30 GG (Traduzido)}

O exercício de poderes estatais e o cumprimento de tarefas estatais compete aos Estados, à medida que esta Lei Fundamental não determine ou permita outra regulamentação.

\begin{tabular}{|l|l|}
\hline Art. 31 GG & Art. 31 GG (Traduzido) \\
\hline Bundesrecht bricht Landesrecht & Direito federal revoga direito estadual \\
\hline
\end{tabular}

${ }^{1125}$ As traduções contidas neste anexo são de nossa autoria, a partir dos estudos realizados para a elaboração do quinto capítulo. Quando nos deparamos com expressões de tradução mais complexa, consultamos traduções para o português, inglês e francês obtidas nas seguintes fontes: Nuno ROGÉRIO. A Lei Fundamental da República Federal da Alemanha: com um ensaio e anotações de Nuno Rogério. Coimbra: Coimbra Editora, 1996 (português); http://www.gesetze-im-internet.de/englisch_gg/englisch_gg.html\#p0142. Acesso: 15/07/2013 (inglês); http://www.bijus.eu/?p=9663. Acesso: 09/03/2016 (francês). Já as redações dos dispositivos citados neste anexo que não estão mais vigentes foram retiradas de diversas fontes, tendo em vista não existir um sítio eletrônico de um órgão da administração pública (como http://www4.planalto.gov.br/legislacao no Brasil), ou mesmo um repositório oficial, onde elas se encontram todas sistematicamente reunidas. Por isso, recorreu-se às diversas edições dos comentários à Lei Fundamental citados no quinto capítulo, em alguns casos ao Bundesgesetzblatt, que é o equivalente ao Diário Oficial da União no Brasil. As redações anteriores e posteriores à Reforma do Federalismo de 2006 foram retiradas de um documento elaborado pelo serviço científico do Parlamento Federal alemão, e que pode ser consultado em http://www.thueringer-landtag.de/mam/landtag/gremien-undrechtsgrundlagen/f_dealismusreform_2006.pdf. (Acesso: 14/03/2016). A fim de obter uma visão cronológica das alterações, recorreu-se ao seguinte endereço: http://www.verfassungen.de/de/gg49-i.htm. Acesso: 28/03/2015. 


\section{Art. 70 GG}

(1) Die Länder haben das Recht der Gesetzgebung, soweit dieses Grundgesetz nicht dem Bunde Gesetzgebungsbefugnisse verleiht. Bund und Ländern bemißt sich nach den Vorschriften dieses Grundgesetzes über die ausschließliche und die konkurrierende Gesetzgebung.
(2) Die Abgrenzung der Zuständigkeit zwischen

\section{Art. 70 GG (Traduzido)}

(1) Os Estados têm o direito de legislar, à medida que esta Lei Fundamental não confira à União poderes legislativos.

(2) A delimitação da competência entre União e Estados rege-se pelos preceitos desta Lei Fundamental sobre a legislação privativa e concorrente.

\section{Art. 71 GG (Traduzido)}

Im Bereiche der ausschließlichen Gesetzgebung des Bundes haben die Länder die Befugnis zur Gesetzgebung nur, wenn und soweit sie hierzu in einem Bundesgesetze ausdrücklich ermächtigt werden.
$\mathrm{Na}$ área da competência privativa da União os Estados somente terão o poder de legislar se e à medida que eles são expressamente autorizados por uma lei federal.

\section{Art. 72 GG - redação originária}

(1) Im Bereiche der konkurrierenden Gesetzgebung haben die Länder die Befugnis zur Gesetzgebung, solange und soweit der Bund von seinem Gesetzgebungsrechte keinen Gebrauch macht.

(2) Der Bund hat in diesem Bereich das Gesetzgebungsrecht, wenn und soweit ein Bedürfnis nach bundesgesetzlicher Regelung besteht, weil:

1. eine Angelegenheit durch die Gesetzgebung einzelner Länder nicht wirksam geregelt werden kann oder

2. die Regelung einer Angelegenheit durch ein Landesgesetz die Interessen anderer Länder oder die Gesamtheit beeinträchtigen könnte oder

3. die Herstellung der Rechts- oder Wirtschaftseinheit, insbesondere die Wahrung der Einheitlichkeit der Lebensverhältnisse über das Gebiet eines Landes hinaus sie erfordert.

\section{Art. 72 GG - redação originária (Traduzido)}

(1) $\mathrm{Na}$ área da legislação concorrente os Estados detêm o poder de legislar, enquanto e à medida que a União não utilizar o seu poder de legislar.

(2) A União tem, neste domínio, o direito a legislar, se e à medida que existir uma necessidade de regulamentação federal, porque: 1. uma matéria não pode ser regulamentada de forma eficiente pela legislação dos Estados isoladamente ou,

2. a regulamentação de uma matéria por uma lei estadual poderia prejudicar os interesses de outros Estados ou da coletividade ou,

3. o estabelecimento da unidade jurídica e econômica, especialmente a salvaguarda da unidade das condições de vida além dos limites do território de um Estado a exigem. 


\section{Art. 72 GG - de 1994 até 2006}

(1) Im Bereich der konkurrierenden Gesetzgebung haben die Länder die Befugnis zur Gesetzgebung, solange und soweit der Bund von seiner Gesetzgebungszuständigkeit nicht durch Gesetz Gebrauch gemacht hat.

(2) Der Bund hat in diesem Bereich das Gesetzgebungsrecht, wenn und soweit die Herstellung gleichwertiger Lebensverhältnisse im Bundesgebiet oder die Wahrung der Rechtsoder Wirtschaftseinheit im gesamtstaatlichen Interesse eine bundesgesetzliche Regelung erforderlich macht.

(3) Durch Bundesgesetz kann bestimmt werden, dass eine bundesgesetzliche Regelung, für die eine Erforderlichkeit im Sinne des Absatzes 2 nicht mehr besteht, durch Landesrecht ersetzt werden kann.

\section{Art. 72 GG - a partir de 2006}

(1) Im Bereich der konkurrierenden Gesetzgebung haben die Länder die Befugnis zur Gesetzgebung, solange und soweit der Bund von seiner Gesetzgebungszuständigkeit nicht durch Gesetz Gebrauch gemacht hat.

(2) Auf den Gebieten des Artikels 74 Abs. $1 \mathrm{Nr}$. 4, 7. 11. 13. 15. 19a, 20, 22, 25 und 26 hat der Bund das Gesetzgebungsrecht, wenn und soweit die Herstellung gleichwertiger Lebenverhältnisse im Bundesgebiet oder die Wahrung der Rechts- oder Wirtschaftseinheit im gesamtstaatlichen Interesse eine bundesgesetzliche Regelung erforderlich macht.

(3) Hat der Bund von seiner Gesetzgebungszuständigkeit Gebrauch gemacht, können die Länder durch Gesetz hiervon abweichende Regelungen treffen über:

\section{Art. 72 GG - de 1994 até 2006 (Traduzido)}

(1) $\mathrm{Na}$ área da legislação concorrente, os Estados têm o poder de legislar, enquanto e à medida que a União não utilizar sua competência legislativa por meio de uma lei.

(2) A União tem, neste domínio, o direito a legislar, se e à medida que o estabelecimento de condições de vida equivalentes no território nacional ou a salvaguarda da unidade jurídica ou econômica no interesse da totalidade do Estado tornar necessária uma regulamentação por lei federal.

(3) Por meio de lei federal pode ser determinado, que uma regulamentação por meio de lei federal em relação à qual não mais subsiste a necessidade no sentido disposto pelo parágrafo $2^{\circ}$, pode ser substituída por lei estadual.

\section{Art. 72 GG - a partir de 2006 (Traduzido)}

(1) Na área da legislação concorrente, os Estados têm a competência/faculdade de legislar, enquanto e à medida que a União não utilizar sua competência legislativa por meio de uma lei.

(2) A União tem, no domínio do artigo 74, parágrafo $1^{\circ}$, números $4,7,11,13,15,19^{a}, 20$, 22, 25 e 26, o direito a legislar, se e à medida que o estabelecimento de condições de vida equivalentes no território nacional ou a salvaguarda da unidade jurídica ou econômica no interesse da totalidade do Estado tornar necessária uma regulamentação por lei federal.

(3) Se a União utilizar a competência legislativa, os Estados podem, por meio de lei, editar regulamentações divergentes sobre:

1. o regime da caça (salvo o direito das licenças de caça); 
1. das Jagdwesen (ohne das Recht der Jagdscheine);

2. den Naturschutz und die Landschaftspflege (ohne die allgemeinen Grundsätze des Naturschutzes, das Recht des Artenschutzes oder des Meeresnaturschutzes);

3. die Bodenverteilung;

4. Die Raumordnung;

5. den Wasserhaushalt (ohne stoff- oder anlagenbezogene Regelungen);

6. die Hochschulzulassung und die Hochschulabschlüsse.

Bundesgesetze auf diesen Gebieten treten frühestens sechs Monate nach ihrer Verkündung in Kraft, soweit nicht mit Zustimmung des Bundesrates anderes bestimmt ist. Auf den Gebieten des Satzes 1 geht im Verhältnis von Bundes- und Landesecht das jeweils spätere Gesetz vor.

(4) Durch Bundesgesetz kann bestimmt werden, dass eine bundesgesetzliche Regelung, für die eine Erforderlichkeit im Sinne des Absatzes 2 nicht mehr besteht, durch Landesrecht ersetzt werden kann.
2. a proteção da natureza e a preservação da paisagem natural (sem os princípios gerais da proteção da natureza, o direito da proteção das espécies ou da proteção da natureza marinha);

3. a distribuição da terra;

4. a ordenação do território;

5. o regime da água (salvo a regulamentação relacionadas às substâncias e as instalações);

6. a admissão e a conclusão em instituições de ensino superior.

Leis federações nessas matérias entram em vigor pelo menos seis meses depois da sua publicação, a menos que, com a aprovação do Conselho Federal, seja determinado de outro modo. Nas áreas do primeiro período prevalece, no relacionamento da lei federal com a lei estadual, a respectiva lei posterior.

(4) Por meio de lei federal pode ser determinado, que uma regulamentação por meio de lei federal em relação à qual não mais subsiste a necessidade no sentido disposto pelo parágrafo $2^{\circ}$, possa ser substituída por lei estadual.

\section{Art. 75 GG - redação originária}

Der Bund hat das Recht unter den Voraussetzungen des Artikels 72 Rahmenvorschriften zu erlassen über:

1. die Rechtsverhältnisse der in öffentlichen Dienste der Länder, Gemeinden und anderen Körperschaften des öffentlichen Rechtes stehenden Personen;

2. die allgemeinen Rechtsverhältnisse der Presse;

3. das Jagdwesen, den Naturschutz und die Landschaftspflege;

4. die Bodenverteilung, die Raumordnung und den Wassenhaushalt;

5. das Melde- und Ausweiswesen.

\section{Art. 75 GG - redação originária (Traduzido)}

A União tem o direito, obedecidos os requisitos do artigo 72, de editar preceitos-moldura sobre:

1. as relações jurídicas das pessoas que integram o serviço público dos Estados, Municípios e outras pessoas jurídicas de direito público;

2. o regime jurídico geral da imprensa;

3. o regime da caça, a proteção da natureza e a preservação da paisagem natural;

4. a distribuição da terra, a ordenação do território e o regime da água;

5. o regime do registro e da identificação civil. 
(1) Der Bund hat das Recht, unter den Voraussetzungen des Artikels 72 Rahmenvorschriften zu erlassen über:

1. die Rechtsverhältnisse der im öffentlichen Dienste der Länder, Gemeinden und anderen Körperschaften des öffentlichen Rechtes stehenden Personen;

1a. die allgemeinen Grundsätze des Hochschulwesens;

2. die allgemeinen Rechtsverhältnisse der Presse;

3. das Jagdwesen, den Naturschutz und die Landschaftspflege;

4. die Bodenverteilung, die Raumordnung und den Wasserhaushalt;

5. das Melde- und Ausweiswesen

(2) Rahmenvorschriften nach Absatz 1 Nr. 1 können mit Zustimmung des Bundesrates auch einheitliche Maßstäbe für den Aufbau und die Bemessung der Besoldung einschließlich der Bewertung der Ämter sowie Mindest- und Höchstbeträge vorsehen. Der Zustimmung des Bundesrates bedürfen auch Gesetze nach Artikel 73 Nr. 8, die von den nach Satz 1 getroffenen Regelungen abweichen.

(3) Absatz 2 gilt für Rahmenvorschriften nach Artikel 98 Absatz 3 Satz 2 und Gesetze nach Artikel 98 Absatz 1 entsprechend.
(1) A União tem o direito, obedecidos os requisitos do artigo 72, de editar preceitosmoldura sobre:

1. as relações jurídicas das pessoas que integram o serviço público dos Estados, Municípios e outras pessoas jurídicas de direito público;

1a. os princípios gerais do regime do ensino superior;

2. o regime jurídico geral da imprensa;

3. o regime da caça, a proteção da natureza e a preservação da paisagem natural;

4. a distribuição da terra, a ordenação do território e o regime da água;

5. o regime do registro e da identificação civil.

(2) Os preceitos-moldura do número 1 do parágrafo primeiro podem, com a aprovação do Conselho Federal, prever também parâmetros unitários para a criação e mensuração da remuneração, inclusive da avaliação dos órgãos públicos, bem como contribuições mínimas e máximas. As leis de acordo com o número 8 do artigo 73, que divergirem da regulamentação da primeira parte deste artigo, necessitam da aprovação do Conselho Federal.

(3) O parágrafo segundo vale também para os preceitos-moldura editados de acordo com o artigo 98, parágrafo $3^{\circ}$, segunda parte e com o artigo 98 , parágrafo $1^{\circ}$.

\section{Art. 75 GG - de 1971 até 1994}

(1) Der Bund hat das Recht, unter den Voraussetzungen des Artikels 72 Rahmenvorschriften zu erlassen über:

1. die Rechtverhältnisse der im öffentlichen Dienste der Länder, Gemeinden und anderen Körperschaften des öffentlichen Rechtes

\section{Art. 75 GG - de 1971 até 1994 (Traduzido)}

(1) A União tem o direito, obedecidos os requisitos do artigo 72 , de editar preceitosmoldura sobre:

1. as relações jurídicas das pessoas que integram o serviço público dos Estados, Municípios e outras pessoas jurídicas de direito 
stehenden Personen soweit Artikel 74a nicht anderes bestimmt;

1a. die allgemeinen Grundsätze des Hochschulwesens;

2. die allgemeinen Rechtverhältnisse der Presse;

3. das Jagdwesen, den Naturschutz und die Landschaftspflege;

4. die Bodenverteilung, die Raumordnung und den Wasserhaushalt;

5. das Melde- und Ausweiswesen.

(2) Rahmenvorschriften nach Absatz 1 Nr. 1 können mit Zustimmung des Bundesrates auch einheitliche Maßstäbe für den Aufbau und die Bemessung der Besoldung einschließlich der Bewertung der Ämter sowie Mindest-und Höchstbeträge vorsehen. Der Zustimmung des Bundesrates bedürfen auch Gesetze nach Artikel 73 Nr. 8, die von den nach Satz 1 getroffenen Regelungen abweichen.

(3) Absatz 2 gilt für Rahmenvorschriften nach Artikel 98 Absatz 3 Satz 2 und Gesetze nach Artikel 98 Absatz 1 entsprechend. público, à medida que o artigo 74a não disponha de outro modo;

1a. os princípios gerais do regime do ensino superior;

2. o regime jurídico geral da imprensa;

3. o regime da caça, a proteção da natureza e a preservação da paisagem natural;

4. a distribuição da terra, a ordenação do território e o regime da água;

5. o regime do registro e da identificação civil.

(2) Os preceitos-moldura do número 1 do parágrafo primeiro podem, com a aprovação do Conselho Federal, prever também parâmetros unitários para a criação e mensuração da remuneração, inclusive da avaliação dos órgãos públicos, bem como contribuições mínimas e máximas As leis de acordo com o número 8 do artigo 73, que divergirem da regulamentação da primeira parte deste artigo, necessitam da aprovação do Conselho Federal.

(3) O parágrafo segundo vale também para os preceitos-moldura editados de acordo com o artigo 98, parágrafo $3^{\circ}$, segunda parte e com o artigo 98 , parágrafo $1^{\circ}$.

\section{Art. 75 GG - de 1994 até 2006}

(1) Der Bund hat das Recht, unter den Voraussetzungen des Artikels 72 Rahmenvorschriften für die Gesetzgebung der Länder zu erlassen über:

1. die Rechtsverhältnisse der im öffentlichen Dienste der Länder, Gemeinden und anderen Körperschaften des öffentlichen Rechtes stehenden Personen, soweit Artikel 74a nichts anderes bestimmt;

1a. die allgemeinen Grundsätze des Hochschulwesens;

2. die allgemeinen Rechtsverhältnisse der Presse;

\section{Art. 75 GG - de 1994 até 2006 (Traduzido)}

(1) A União tem o direito, obedecidos os requisitos do artigo 72, de editar preceitosmoldura sobre:

1. as relações jurídicas das pessoas que integram o serviço público dos Estados, Municípios e outras pessoas jurídicas de direito público, à medida que o artigo 74a não disponha de outro modo;

1a. os princípios gerais do regime do ensino superior;

2. o regime jurídico geral da imprensa; 
3. das Jagdwesen, den Naturschutz und die Landschaftspflege;

4. die Bodenverteilung, die Raumordnung und den Wasserhaushalt;

5. das Melde- und Ausweiswesen;

6. den Schutz deutschen Kulturgutes gegen Abwanderung ins Ausland.

Artikel 72 Abs.3 gilt entsprechend.

(2) Rahmenvorschriften dürfen nur in Ausnahmefällen in Einzelheiten gehende oder unmittelbar geltende Regelungen enthalten.

(3) Erlässt der Bund Rahmenvorschriften, so sind die Länder verpflichtet, innerhalb einer durch das Gesetz bestimmten angemessenen Frist die erforderlichen Landesgesetze $\mathrm{zu}$ erlassen.
3. o regime da caça, a proteção da natureza e a preservação da paisagem natural;

4. a distribuição da terra, a ordenação do território e o regime da água;

5. o regime do registro e da identificação civil;

6. a proteção dos bens culturais alemães contra o seu envio para o exterior.

Artigo $72, \quad$ parágrafo $3^{\circ}, \quad$ aplica-se correspondentemente.

(2) Os preceitos-moldura devem, somente em casos excepcionais, descer a minucias ou conter regulamentações de aplicabilidade direta.

(3) Se a União editar preceitos-moldura, os Estados estão obrigados a editar, dentro de um prazo razoável estabelecido pela lei, as leis estaduais necessárias.

\section{Art. 83 GG}

Die Länder führen die Bundesgesetze als eigene Angelegenheit aus, soweit dieses Grundgesetz nichts anderes bestimmt oder zuläßt.

\section{Art. 83 (Traduzido)}

Os Estados excutam as leis federais como assunto próprio, à medida que esta Lei Fundamental não determine ou permita de outro modo.

\section{Art. 84 GG - até 2006}

(1) Führen die Länder die Bundesgesetze als eigene Angelegenheit aus, so regeln sie die Einrichtung der Behörden und das Verwaltungsverfahren, soweit nicht Bundesgesetze mit Zustimmung des Bundesrates etwas anderes bestimmen.

(2) Die Bundesregierung kann mit Zustimmung des Bundesrates allgemeine Verwaltungsvorschriften erlassen.

(3) Die Bundesregierung übt die Aufsicht darüber aus, dass die Länder die Bundesgesetze dem geltenden Rechte gemäß ausführen. Die Bundesregierung kann zu diesem Zwecke Beauftragte zu den obersten Landesbehörden entsenden, mit deren Zustimmung und, falls diese Zustimmung versagt wird, mit

\section{Art. 84 GG - até 2006 (Traduzido)}

(1) Caso os Estados executem as leis federais como assunto próprio, eles regulam a organização dos Behörden e o procedimento administrativo, à medida que lei federal com a aprovação do Conselho Federal não disponha de outro modo.

(2) O governo federal pode, com a aprovação do Conselho Federal, editar preceitos administrativos de caráter geral.

(3) O governo federal exerce a supervisão se os Estados executam a lei federal de acordo com o direito vigente. $\mathrm{O}$ governo federal pode, para este fim, enviar delegados para as mais altas autoridades estaduais, com o seu consentimento, e este consentimento seja denegado, mediante consentimento do 
Zustimmung des Bundesrates auch zu den nachgeordneten Behörden.

(4) Werden Mängel, die die Bundesregierung bei der Ausführung der Bundesgesetze in den Ländern festgestellt hat, nicht beseitigt, so beschließt auf Antrag der Bundesregierung oder Landes der Bundesrat, ob das Land das Recht verletzt hat. Gegen den Beschluß des Bundesrates kann das Bundesverfassungsgericht angerufen werden.

(5) Der Bundesregierung kann durch Bundesgesetz, das der Zustimmung des Bundesrates bedarf, zur Ausführung von Bundesgesetzen die Befugnis verliehen werden, für besondere Fälle Einzelweisungen $\mathrm{zu}$ erteilen. Sie sind, außer wenn die Bundesregierung den Fall für dringlich erachtet, an die obersten Landesbehörden zu richten.

\section{Art. 84 GG - após 2006}

(1) Führen die Länder die Bundesgesetze als eigene Angelegenheit aus, so regeln sie die Einrichtung der Behörden und das Verwaltungsverfahren. Wenn Bundesgesetze etwas anderes bestimmen, können die Länder davon abweichende Regelungen treffen. Hat ein Land eine abweichende Regelung nach Satz 2 getroffen, treten in diesem Land hierauf bezogene spätere bundesgesetzliche Regelungen der Einrichtung der Behörden und des Verwaltungsverfahren frühestens sechs Monate nach ihrer Verkündung in Kraft, soweit nicht mit Zustimmung des Bundesrates anderes bestimmt ist. Artikel 72 Abs 3 Satz 3 gilt entsprechend. In Ausnahmefällen kann der Bund wegen eines besonderen Bedürfnis nach bundeseinheilicher Regelung das Verwaltungsverfahren ohne Abweichungsmöglichkeit für die Länder regeln. Diese Gesetze bedürfen der Zustimmung des Bundesrates. Durch Bundesgesetz dürfen Gemeinden und Gemeindeverbänden Aufgaben nicht übertragen werden.
Conselho Federal, também para junto das autoridades subordinadas.

(4) Se o governo federal constatar que existem falhas na execução de leis federais nos Estados, e estas não forem eliminadas, então decidirá o Conselho Federal, a requerimento do governo federal ou do Estado, se este último violou o direito. Contra esta decisão do Conselho Federal pode-se provocar o Tribunal Constitucional Federal.

(5) Por meio de lei federal que necessita a aprovação do Conselho Federal, pode ser atribuído ao governo federal a faculdade de determinar instruções individuais em casos específicos. Estas instruções devem ser direcionadas às mais altas autoridades da administração estadual, salvo se o governo federal considerar o caso urgente.

\section{Art. 84 GG - após 2006 (Traduzido)}

(1) Caso os Estados executem as leis federais como assunto próprio, eles regulam a organização dos Behörden e o procedimento administrativo. Se a lei federal dispuser de outro modo, os Estados podem editar regulamentação divergente. Se um Estado editar uma regulamentação divergente no sentido do $2^{\circ}$ período desse parágrafo, regulamentação subsequente por lei federal sobre organização dos Behörden e sobre processo administrativo passará a vigorar no mínimo seis meses depois da sua publicação, desde que, com o consentimento do Conselho Federal, não tenha sido disposto de outro modo. $\mathrm{O}$ artigo 72 III vigora respectivamente. A União pode, em casos excepcionais devido a uma necessidade especial de regulamentação federal uniforme, regulamentar o procedimento administrativo sem que haja possibilidade de regulamentação divergente dos Estados. Estas leis necessitam de aprovação do Conselho Federal. Lei federal não pode transferir tarefas aos Municípios e associações de Municípios. 
(2) Die Bundesregierung kann mit Zustimmung des Bundesrates allgemeine Verwaltungsvorschriften erlassen.

(3) Die Bundesregierung übt die Aufsicht darüber aus, dass die Länder die Bundesgesetze dem geltenden Rechte gemäß ausführen. Die Bundesregierung kann zu diesem Zwecke Beauftragte $\mathrm{zu}$ den obersten Landesbehörden entsenden, mit deren Zustimmung und, falls diese Zustimmung versagt wird, mit Zustimmung des Bundesrates auch zu den nachgeordneten Behörden.

(4) Werden Mängel, die die Bundesregierung bei der Ausführung der Bundesgesetze in den Ländern festgestellt hat, nicht beseitigt, so beschließt auf Antrag der Bundesregierung oder Landes der Bundesrat, ob das Land das Recht verletzt hat. Gegen den Beschluß des Bundesrates kann das Bundesverfassungsgericht angerufen werden.

(5) Der Bundesregierung kann durch Bundesgesetz, das der Zustimmung des Bundesrates bedarf, zur Ausführung von Bundesgesetzen die Befugnis verliehen werden, für besondere Fälle Einzelweisungen zu erteilen. Sie sind, außer wenn die Bundesregierung den Fall für dringlich erachtet, an die obersten Landesbehörden zu richten.

\section{Art. 85 GG - até 2006}

(1) Führen die Länder die Bundesgesetze im Auftrage des Bundes aus, so bleibt die Einrichtungen der Behörden Angelegenheit der Länder, soweit nicht Bundesgesetze mit Zustimmung des Bundesrates etwas anderes bestimmen.

(2) Die Bundesregierung kann mit Zustimmung des Bundesrates allgemeine Verwaltungsvorschriften erlassen. Sie kann die einheitliche Ausbildung der Beamten und Angestellten regeln. Die Leiter der Mittelbehörden sind mit ihrem Einvernehmen zu bestellen.
(2) O governo federal pode, com a aprovação do Conselho Federal, editar preceitos administrativos de caráter geral.

(3) O governo federal exerce a supervisão se os Estados executam a lei federal de acordo com o direito vigente. O governo federal pode, para este fim, enviar delegados para as mais altas autoridades estaduais, com $\mathrm{o}$ seu consentimento, e este consentimento seja denegado, mediante consentimento do Conselho Federal, também para junto das autoridades subordinadas.

(4) Se o governo federal constatar que existem falhas na execução de leis federais nos Estados, e estas não forem eliminadas, então decidirá o Conselho Federal, a requerimento do governo federal ou do Estado, se este último violou o direito. Contra esta decisão do Conselho Federal pode-se provocar o Tribunal Constitucional Federal.

(5) Por meio de lei federal que necessita a aprovação do Conselho Federal, pode ser atribuído ao governo federal a faculdade de determinar instruções individuais em casos específicos. Estas instruções devem ser direcionadas às mais altas autoridades da administração estadual, salvo se o governo federal considerar o caso urgente.

\section{Art. 85 GG - até 2006 (Traduzido)}

(1) Caso os Estados executem leis federais sob as ordens da União, a organização dos Behörden permanece assunto dos Estados, desde que lei federal com a aprovação do Conselho Federal não disponha de outro modo.

(2) O governo federal pode, com a aprovação do Conselho Federal, editar preceitos administrativos de caráter geral. Ele pode regulamentar a formação uniforme dos servidores públicos e empregados. Os direitores das autoridades estatais medianas devem ser nomeados com o seu consentimento. 
(3) Die Landesbehörden unterstehen den Weisungen der Zuständigen obersten Bundesbehörden. Die Weisungen sind, außer wenn die Bundesregierung es für dringlich erachtet, an die obersten Landesbehörden $\mathrm{zu}$ richten. Der Vollzug der Weisung ist durch die obersten Landesbehörden sicherzustellen.

(4) Die Bundesaufsicht erstreckt sich auf Gesetzmäßigkeit und Zweckmäßigkeit der Ausführung. Die Bundesregierung kann zu diesem Zwecke Bericht und Vorlage der Akten verlangen und Beauftragte zu allen Behörden entsenden

\section{Art. 85 GG - após 2006}

(1) Führen die Länder die Bundesgesetze im Auftrage des Bundes aus, so bleibt die Einrichtungen der Behörden Angelegenheit der Länder, soweit nicht Bundesgesetze mit Zustimmung des Bundesrates etwas anderes bestimmen. Durch Bundesgesetz dürfen Gemeinden und Gemeindeverbänden Aufgaben nicht übertragen werden.

(2) Die Bundesregierung kann mit Zustimmung des Bundesrates allgemeine Verwaltungsvorschriften erlassen. Sie kann die einheitliche Ausbildung der Beamten und Angestellten regeln. Die Leiter der Mittelbehörden sind mit ihrem Einvernehmen zu bestellen.

(3) Die Landesbehörden unterstehen den Weisungen der Zuständigen obersten Bundesbehörden. Die Weisungen sind, außer wenn die Bundesregierung es für dringlich erachtet, an die obersten Landesbehörden zu richten. Der Vollzug der Weisung ist durch die obersten Landesbehörden sicherzustellen.

(4) Die Bundesaufsicht erstreckt sich aud Gesetzmäßigkeit und Zweckmäßigkeit der Ausführung. Die Bundesregierung kann zu diesem Zwecke Bericht und Vorlage der Akten
(3) As autoridades estaduais permanecem sob as ordens das mais altas autoridades federais. As instruções devem, exceto se o governo federal considerar o caso urgente, ser dirigidas às mais altas autoridades da administração estadual. A execução das instruções deve ser assegurada pelas mais altas autoridades públicas estaduais.

(4) A supervisão federal abrange a legalidade e a conveniência da execução. A Administração Federal pode, para este fim, exigir relatórios e apresentação de documentos e enviar delegados a todos os órgãos públicos.

\section{Art. 85 GG - após 2006 (traduzido)}

(1) Quando os Estados executam leis federais sob as ordens da União, a organização dos Behörden permanece assunto dos Estados, desde que lei federal com a aprovação do Conselho Federal não disponha de outro modo. Lei Federal não pode transferir tarefas aos Municípios e às associações de Municípios não podem

(2) O governo federal, com a aprovação do Conselho Federal, editar preceitos administrativos de caráter geral. Ele pode regulamentar a formação uniforme dos servidores públicos e empregados. Os direitores das autoridades estatais medianas devem ser nomeados com o seu consentimento.

(3) As autoridades estaduais permanecem sob as ordens das mais altas autoridades federais. As instruções devem, exceto se o governo federal considerar o caso urgente, ser dirigidas às mais altas autoridades da administração estadual. A execução das instruções deve ser assegurada pelas mais altas autoridades públicas estaduais.

(4) A supervisão federal abrange a legalidade e a conveniência da execução. A Administração Federal pode, para este fim, exigir relatórios e 
verlangen und Beauftragte zu allen Behörden entsenden

\section{Art. 86 GG}

Führt der Bund die Gesetze durch bundeseigene Verwaltung oder durch bundesunmittelbare Körperschaften oder Anstalten des öffentlichen Rechtes aus, so erlässt die Bundesregierung, soweit nicht das Gesetz Besonderes vorschreibt, die allgemeinen Verwaltungsvorschriften. Sie regelt, soweit das Gesetz nichts anderes bestimmt, die Einrichtung der Behörden. apresentação de documentos e enviar delegados a todos os órgãos públicos.

\section{Art. 86 GG (Traduzido)}

Caso a União execute as leis por meio de Administração Federal própria ou por meio de pessoas jurídicas ou entidades de direito público ligadas diretamente à União, o governo federal então editará preceitos administrativos de caráter geral, desde que a lei não disponha de modo específico. O governo federal regula, desde que a lei não disponha de outro modo, a organização administrativa.

\section{Art. 87 GG - redação originária}

(1) In bundeseigener Verwaltung mit eigenem Verwaltungsunterbau werden geführt der Auswärtige Dienst, die Bundesfinanzverwaltung, die Bundeseisenbahnen, die Bundespost und nach Maßgabe des Artikels 89 die Verwaltung der Bundeswasserstraßen und der Schiffahrt. Durch Bundesgesetz können Bundesgrenzschutzbehörden, Zentralstellen für das polizeiliche Auskunfts- und Nachrichtenwesen, zur Sammlung von Unterlagen für Zwecke des Verfassungsschutzes und für die Kriminalpolizei eingerichtet werden.

(2) Als bundesunmittelbare Körperschaften des öffentlichen Rechtes werden diejenigen sozialen Versicherungsträger geführt, deren Zuständigkeitsbereich sich über das Gebiet eines Landes hinaus erstreckt.

(3) Außerdem können für Angelegenheiten, für die dem Bunde die Gesetzgebung zusteht, selbständige Bundesoberbehörden und neue bundesunmittelbare Körperschaften und Anstalten des öffentlichen Rechtes durch Bundesgesetz errichtet werden. Erwachsen dem Bunde auf Gebieten, für die ihm die Gesetzgebung zusteht, neue Aufgaben, so können bei dringendem Bedarf bundeseigene Mittel- und Unterbehörden mit Zustimmung des

\section{Art. 87 GG - redação originária (Traduzido)}

(1) São executados pela administração federal por meio de sua própria estrutura administrativa os serviços de relações exteriores, a administração financeira federal, as ferrovias federais, o correio federal e, de acordo com artigo 89, a administração dos cursos de água federais e de navegação. Por meio de lei federal podem ser instituídos órgãos federais de proteção de fronteiras, entidades centrais para informação e comunicação policiais e para a coleta de documentação com a finalidade de proteção da constituição e para a polícia criminal.

(2) São executados por meio de corporações de direito público ligadas diretamente à União aquelas instituições de previdência social cuja jurisdição ultrapasse o território de um Estado.

(3) Além disso, podem ser instituídos, para os assuntos nos quais a União detém a competência legislativa, autoridades federais superiores independentes e novas pessoas e entes de direito público ligadas diretamente à União. Caso surjam novas tarefas em relação às quais a União detenha a competência legislativa, podem ser instituídos, no caso de necessidade urgente, órgãos federais próprios intermediários e subordinados, com a aprovação do Conselho Federal e da maioria dos membros do Parlamento Federal. 
Bundesrates und der Mehrheit der Mitglieder des Bundestages errichtet werden.

\section{Art. 87 GG - de 1972 até 1994}

(1) In bundeseigener Verwaltung mit eigenem Verwaltungsunterbau werden geführt der Auswärtige Dienst, die Bundesfinanzverwaltung, die Bundeseisenbahnen, die Bundespost und nach Maßgabe des Artikels 89 die Verwaltung der Bundeswasserstraßen und der Schifffahrt. Durch Bundesgesetz können Bundesbegrenzschutzbehörden, Zentralstellen für das polizeiliche Auskunfts- und Nachrichtenwesen, für die Kriminalpolizei und zur Sammlung von Unterlagen für Zwecke des Verfassungsschutzes und des Schutzes gegen Bestrebungen im Bundesgebiet, die durch Anwendung von Gewalt oder darauf gerichtete Vorbereitungshandlungen auswärtige Belange der Bundesrepublik Deutschland gefährden, eingerichtet werden. öffentlichen Rechtes werden diejenigen sozialen Versicherungsträger geführt, deren Zuständigkeitsbereich sich über das Gebiet eines Landes hinaus erstreckt.

(3) Außerdem können für Angelegenheiten, für die dem Bunde die Gesetzgebung zusteht, selbständige Bundesoberbehörden und neue bundesunmittelbare Körperschaften und Anstalten des öffentlichen Rechtes durch Bundesgesetz errichtet werden. Erwachsen dem Bunde auf Gebieten, für die ihm die Gesetzgebung zusteht, neue Aufgaben, so können bei dringendem Bedarf bundeseigene Mittel- und Unterbehörden mit Zustimmung des Bundesrates und der Mehrheit der Mitglieder des Bundestages errichtet werden.
(2) Als bundesunmittelbare Körperschaften des

\section{Art. 87 GG - de 1972 até 1994 (Traduzido)}

(1) São executados pela administração federal por meio de sua própria estrutura administrativa os serviços de relações exteriores, a administração financeira federal, as ferrovias federais, o correio federal e, de acordo com o artigo 89, a administração dos cursos de água federais e de navegação. Por meio de lei federal podem ser instituídos órgãos federais de proteção de fronteiras, entidades centrais para informação e comunicação policiais, para a polícia criminal e para a coleta de documentação com a finalidade de proteção da constituição e de proteção contra os esforços realizados no território federal que, por meio do emprego da violência ou de atos preparatórios nesse sentido, ponham em perigo os interesses da República Federativa da Alemanha no estrangeiro.

(2) São executados por meio de corporações de direito público ligadas diretamente à União aquelas instituições de previdência social cuja jurisdição ultrapasse o território de um Estado.

(3) Além disso, podem ser instituídos, para os assuntos nos quais a União detém a competência legislativa, autoridades federais superiores independentes e novas pessoas e entes de direito público ligadas diretamente à União. Caso surjam novas tarefas em relação às quais a União detenha a competência legislativa, podem ser instituídos, no caso de necessidade urgente, órgãos federais próprios intermediários e subordinados, com a aprovação do Conselho Federal e da maioria dos membros do Parlamento Federal.

\section{Art. 87 GG - a partir de 1994 (Traduzido)}

Art. 87 GG - a partir de 1994

(1) In bundeseigener Verwaltung mit eigenem Verwaltungsunterbau werden geführt der Auswärtige Dienst, die
(1) São executados pela administração federal por meio de sua própria estrutura administrativa os serviços de relações 
Bundesfinanzverwaltung und nach Maßgabe des Artikels 89 die Verwaltung der Bundeswasserstraßen und der Schifffahrt. Durch Bundesgesetz können Bundesgrenzschutzbehörden, Zentralstellen für das polizeiliche Auskunfts- und Nachrichtenwesen, für die Kriminalpolizei und zur Sammlung von Unterlagen für Zwecke des Verfassungsschutzes und des Schutzes gegen Bestrebungen im Bundesgebiet, die durch Anwendung von Gewalt oder darauf gerichtete Vorbereitungshandlungen auswärtige Belange der Bundesrepublik Deutschland gefährden, eingerichtet werden.

(2) Als bundesunmittelbare Körperschaften des öffentlichen Rechtes werden diejenigen sozialen Versicherungsträger geführt, deren Zuständigkeitsbereich sich über das Gebiet eines Landes hinaus erstreckt. Soziale Versicherungsträger, deren Zuständigkeit sich über das Gebiet eines Landes, aber nicht über mehr als drei Länder hinaus erstreckt, werden abweichend von Satz 1 als landesunmittelbare Körperschaften des öffentlichen Rechts geführt, wenn das aufsichtsführende Land durch die beteiligten Länder bestimmt ist.

(3) Außerdem können für Angelegenheiten, für die dem Bunde die Gesetzgebung zusteht, selbstständige Bundesoberbehörden und neue bundesunmittelbare Körperschaften und Anstalten des öffentlichen Rechtes durch Bundesgesetz errichtet werden. Erwachsen dem Bunde auf Gebieten, für die ihm die Gesetzgebung zusteht, neue Aufgaben, so können bei dringendem Bedarf bundeseigene Mittel- und Unterbehörden mit Zustimmung des Bundesrates und der Mehrheit der Mitglieder des Bundestages errichtet werden. exteriores, a administração financeira federal, e, de acordo com o artigo 89, a administração dos cursos de água federais e de navegação. Por meio de lei federal podem ser instituídos órgãos federais de proteção de fronteiras, entidades centrais para informação e comunicação policiais, para a polícia criminal e para a coleta de documentação com a finalidade de proteção da constituição e de proteção contra os esforços realizados no território federal que, por meio do emprego da violência ou de atos preparatórios nesse sentido ponham em perigo os interesses da República Federal da Alemanha no estrangeiro.

(2) São executados por meio de corporações de direito público ligadas diretamente à União aquelas instituições de previdência social cuja jurisdição ultrapasse o território de um Estado. Instituições de previdência social, cuja competência ultrapasse o território de um Estado mas que não se estenda sobre o território de mais de três Estados podem ser executadas, de forma divergente do disposto no primeiro período por meio de corporações de direito público diretamente ligadas aos Estados, se os Estados envolvidos definirem qual deles exercitará a supervisão.

(3) Além disso, podem ser instituídos, para os assuntos nos quais a União detém a competência legislativa, autoridades federais superiores independentes e novas pessoas e entes de direito público ligadas diretamente à União. Caso surjam novas tarefas em relação às quais a União detenha a competência legislativa, podem ser instituídos, no caso de necessidade urgente, órgãos federais próprios intermediários e subordinados, com a aprovação do Conselho Federal e da maioria dos membros do Parlamento Federal.

\section{Art. 91a - de 1969 até 1970 (Traduzido)}

(1) A União colabora com o cumprimento de tarefas dos Estados nas seguintes áreas, se estas

(1) Der Bund wirkt auf folgenden Gebieten bei der Erfüllung von Aufgaben der Länder mit, 
wenn diese Aufgaben für die Gesamtheit bedeutsam sind und die Mitwirkung des Bundes zur Verbesserung der Lebensverhältnisse erforderlich ist (Gemeinschaftsaufgaben):

1. Ausbau und Neubau von wissenschaftlichen Hochschulen einschließlich der Hochschulkliniken,

2. Verbesserung der regionalen Wirtschaftsstruktur,

3. Verbesserung der Agrarstruktur und des Küstenschutzes.

(2) Durch Bundesgesetz mit Zustimmung des Bundesrates werden die Gemeinschaftsaufgaben näher bestimmt. Das Gesetz soll allgemeine Grundsätze für ihre Erfüllung enthalten.

(3) Das Gesetz trifft Bestimmungen über das Verfahren und über Einrichtungen für eine gemeinsame Rahmenplannung. Die Aufnahme eines Vorhabens in die Rahmenplannung bedarf der Zustimmung des Landes, in dessen Gebiet es durchgeführt wird.

(4) Der Bund trägt in den Fällen des Absatzes 1 Nr. 1 und 2 die Hälfte der Ausgaben in jedem Land. In den Fällen des Absatzes 1 Nr. 3 trägt der Bund mindestens die Hälfte; die Beteiligung ist für alle Länder einheitlich festzusetzen. Das Nähere regelt das Gesetz. Die Bereitstellung der Mittel bleibt der Feststellung in den Haushaltplänen des Bundes und der Länder vorbehalten.

(5) Bundesregierung und Bundesrat sind auf Verlangen über die Durchführung der Gemeinschaftsaufgaben zu unterrichten.

tarefas forem significativas para a coletividade e se a colaboração da União for necessária para a melhora das condições de vida (tarefas comuns):

1. Ampliação e construção de instituições científicas de ensino superior, inclusive clínicas de instituições de ensino superior;

2. Melhoria da estrutura econômica regional;

3. Melhoria da estrutura agrária e da proteção costeira.

(2) Por meio de lei federal com a aprovação do Conselho Federal, as tarefas comuns serão reguladas em pormenores. A lei federal deve conter princípios gerais para o seu cumprimento.

(3) A lei conterá determinações sobre procedimento e sobre as instituições para um planejamento-moldura comum. A inserção de um projeto no planejamento-moldura demanda a aprovação do Estado em cujo território ele será executado.

(4) A União arcará nos casos designados no parágrafo $1^{\circ}$, Números 1 e 2 , a metade dos gastos em cada Estado. Nos casos inscritos no parágrafo $1^{\circ}$, Número 3 , a União arcará com pelo menos metade; a participação deve ser fixada de forma uniforme para todos os Estados. A lei regulará os pormenores. O fornecimento dos meios fica condicionada à inscrição nos planos orçamentários da União e dos Estados.

(5) Caso o exijam, governo federal e Conselho Federal deverão ser informados sobre a execução de tarefas comuns.

Art. 91a GG - de 1970 até 2006

(1) Der Bund wirkt auf folgenden Gebieten bei der Erfüllung von Aufgaben der Länder mit, wenn diese Aufgaben für die Gesamtheit bedeutsam sind und die Mitwirkung des Bundes zur Verbesserung der Lebensverhältnisse erforderlich ist (Gemeinschaftsaufgaben):

\section{Art. 91a GG - de 1970 até 2006 (Traduzido)}

(1) A União colabora com o cumprimento de tarefas dos Estados nas seguintes áreas, se estas tarefas forem significativas para a coletividade e se a colaboração da União for necessária para a melhora das condições de vida (tarefas comuns): 
1. Ausbau und Neubau von Hochschulen einschließlich der Hochschulkliniken,

2. Verbesserung der regionalen Wirtschaftsstruktur,

3. Verbesserung der Agrarstruktur und des Küstenschutzes.

(2) Durch Bundesgesetz mit Zustimmung des Bundesrates werden

die Gemeinschaftsaufgaben näher bestimmt. Das Gesetz soll allgemeine Grundsätze für ihre Erfüllung enthalten.

(3) Das Gesetz trifft Bestimmungen über das Verfahren und über Einrichtungen für eine gemeinsame Rahmenplannung. Die Aufnahme eines Vorhabens in die Rahmenplannung bedarf der Zustimmung des Landes, in dessen Gebiet es durchgeführt wird.

(4) Der Bund trägt in den Fällen des Absatzes 1 Nr. 1 und 2 die Hälfte der Ausgaben in jedem Land. In den Fällen des Absatzes 1 Nr. 3 trägt der Bund mindestens die Hälfte; die Beteiligung ist für alle Länder einheitlich festzusetzen. Das Nähere regelt das Gesetz. Die Bereitstellung der Mittel bleibt der Feststellung in den Haushaltplänen des Bundes und der Länder vorbehalten.

(5) Bundesregierung und Bundesrat sind auf Verlangen über die Durchführung der Gemeinschaftsaufgaben zu unterrichten
1. Ampliação e construção de instituições de ensino superior, inclusive clínicas de instituições de ensino superior;

2. Melhoria da estrutura econômica regional;

3. Melhoria da estrutura agrária e da proteção costeira.

(2) Por meio de lei federal com a aprovação do Conselho Federal, as tarefas comuns serão reguladas em pormenores. A lei federal deve conter princípios gerais para o seu cumprimento.

(3) A lei conterá determinações sobre procedimento e sobre as instituições para um planejamento-moldura comum. A inserção de um projeto no planejamento-moldura demanda a aprovação do Estado em cujo território ele será executado.

(4) A União arcará nos casos designados no parágrafo $1^{\circ}$, Números 1 e 2 , a metade dos gastos em cada Estado. Nos casos inscritos no parágrafo $1^{\circ}$, Número 3 , a União arcará com pelo menos metade; a participação deve ser fixada de forma uniforme para todos os Estados. A lei regulará os pormenores. O fornecimento dos meios fica condicionada à inscrição nos planos orçamentários da União e dos Estados.

(5) Caso o exijam, governo federal e Conselho Federal deverão ser informados sobre a execução de tarefas comuns.

\section{Art. 91a GG - após 2006}

(1) Der Bund wirkt auf folgenden Gebieten bei der Erfüllung von Aufgaben der Länder mit, wenn diese Aufgaben für die Gesamtheit bedeutsam sind und die Mitwirkung des Bundes zur Verbesserung der Lebensverhältnisse erforderlich ist (Gemeinschaftsaufgaben):

1. Verbesserung der regionalen Wirtschaftsstruktur,

\section{Art. 91a GG - após 2006 (Traduzido)}

(1) A União colabora com o cumprimento de tarefas dos Estados nas seguintes áreas, se estas tarefas forem significativas para a coletividade e se a colaboração da União for necessária para a melhora das condições de vida (tarefas comuns):

1. Melhoria da estrutura econômica regional;

2. Melhoria da estrutura agrária e da proteção costeira. 
2. Verbesserung der Agrarstruktur und des Küstenschutzes.

(2) Durch Bundesgesetz mit Zustimmung des Bundesrates werden die Gemeinschaftsaufgaben sowie Einzelheiten der Koordinierung näher bestimmt.

(3) Der Bund trägt in den Fällen des Absatzes 1 $\mathrm{Nr} 1$ die Hälfte der Ausgaben in jedem Land. In den Fällen des Absatzes $1 \mathrm{Nr} 2$ trägt der Bund mindestens die Hälfte; die Beteiligung ist für alle Länder einheitlich festzusetzen. Das Nähere regelt das Gesetz. Die Bereitstellung der Mittel bleibt der Feststellung in den Haushaltsplänen des Bundes und der Länder vorbehalten.
(2) Por meio de lei federal com a aprovação do Conselho Federal, as tarefas comuns, bem como os detalhes da cooperação, serão reguladas em pormenores.

(3) A União arcará nos casos designados no parágrafo $1^{\circ}$, Número 1 , a metade dos gastos em cada Estado. Nos casos inscritos no parágrafo $1^{\circ}$, Número 2 , a União arcará com pelo menos metade; a participação deve ser fixada de forma uniforme para todos os Estados. A lei regulará os pormenores. O fornecimento dos meios fica condicionada à inscrição nos planos orçamentários da União e dos Estados.

\section{Art. 91b GG - de 1969 até 2006}

Bund und Länder können auf Grund von Vereinbarungen bei der Bildungsplannung und bei der Förderung von Einrichtungen und Vorhaben der wissenschaftlichen Forschung von überregionaler bedeutung zusammenwirken. Die Aufteilung der Kosten wird in der Vereinbarung geregelt

\section{Art. 91b GG - de 1969 até 2006 (Traduzido)}

União e Estados podem, em razão de acordos, colaborar no planejamento do ensino e na promoção de instituições e projetos de pesquisa científica de interesse supraregional. A divisão dos custos será regulamentada no acordo.

\section{Art. 91b GG - de 2006 até 2014}

(1) Bund und Länder können auf Grund von Vereinbarungen in Fällen von überregionaler Bedeutung zusammenwirken bei der Förderung von:

1. Einrichtungen und Vorhaben der wissenschaflichen Forschung außerhalb von Hochschulen;

2. Vorhaben der Wissenschaft und Forschung an Hochschulen;

3. Forschungsbauten an Hochschulen einschließlich Großgeräten

Vereinbarungen nach Satz $1 \mathrm{Nr} .2$ bedürfen der Zustimmung aller Länder

(2) Bund und Länder können auf Grund von Vereinbarungen zur Festellung der Leistungfähigkeit des Bildungswesens im internationalen Vergleich und bei
Art. 91b GG - de 2006 até 2014 (Traduzido)

(1) União e Estados podem, em razão de acordos, colaborar em casos de importância suprarregional para a promoção de:

1. Instituições e planos de pesquisa científica fora de instituições de ensino superior;

2. Projetos de ciência e pesquisa em instituições de ensino superior;

3. Construções para a pesquisa em instituições de ensino superior, inclusive grandes equipamentos

Acordos nos termos do Nr. 2 do primeiro período necessitam da aprovação de todos os Estados.

(2) União e Estados podem, em razão de acordos para a verificação do desempenho da educação em comparação internacional e 
diesbezüglichen Berichten und Empfehlungen zusammenwirken.

(3) Die Kostentragung wird in der Vereinbarung geregelt colaborar nos relatórios e recomendações correspondentes.

(3) O custeamento das despesas será regulamentado no acordo

\section{Art. 91b GG - a partir de 2014}

(1) Bund und Länder können auf Grund von Vereinbarungen in Fällen überregionaler Bedeutung bei der Förderung von Wissenschaft, Forschung und Lehre zusammenwirken. Vereinbarungen, die im Schwerpunkt Hochschulen betreffen, bedürfen der Zustimmung aller Länder. Dies gilt nicht für Vereinbarungen über Forschungsbauten einschließlich Größgeräten

(2) Bund und Länder können auf Grund von Vereinbarungen zur Feststellung der Leistungsfähigkeit des Bildungswesens im internationalen Vergleich und bei diesbezüglichen Berichten und Empfehlungen zusammenwirken

(3) Die Kostentragung wird in der Vereinbarung geregelt

\section{Art. 91b GG - a partir de 2014 (Traduzido)}

(1) União e Estados podem, em razão de acordos em casos de importância suprarregional, colaborar para a promoção da ciência, pesquisa e ensino. Acordos, que digam respeito especialmente a instituições de ensino superior, necessitam de aprovação de todos os Estados. Isto não vale para acordos sobre construções para a pesquisa, inclusive grandes equipamentos.

(2) União e Estados podem, em razão de acordos para a verificação do desempenho da educação em comparação internacional e colaborar nos relatórios e recomendações correspondentes.

(3) O custeamento das despesas será regulamentado no acordo 